NUREG-0713

Vol. 17

\title{
Occupational Radiation Exposure at Commercial Nuclear Power Reactors and Other Facilities 1995
}

Twenty-Eighth Annual Report

Manuscript Completed: December 1996

Date Pabjished: Jannary 1997

M. L. Thormas, D. Hagemeyer"

Division of Regulatory Applications

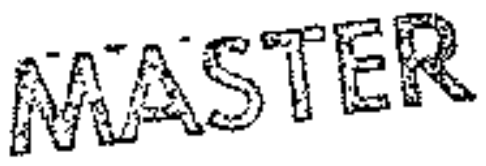

Office of Nuclear Regulatory Research

U.S. Nuclear Regulatory Commission

Washington, DC 20555-0001

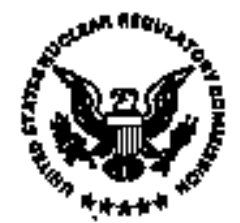

- at a

"Science Applications International Corporation 301 Laboratory Road Oak Ridge, TN 37830 


\section{PREVIOUS REPORTS IN SERIES}

WASH-1341

NLREQT-TW02

NHRECSO109

Mukte-0323

MUREC-045Z

MRREO ONOA

MUREO-0713

MURLOSTI3

NURTE-0713

NURED-0713

NURER-OT13

NUREC-O763

MUnec-0743

NDMEs-or13

NLNERATI3

NLNDR-0T13.

MURESOTIS

AURES-OT13

MURES-0713

MUREB-0713

NLRER-OTIS

NUREG-OT1S
WASH-1350R1

through

WASH-1SSOFAS

NUREO-75/100

NURRe-0119

NUREQ-0025

NUREB-04S

NURER-06es

NUREG-0714

MAREST14

MUEO-0714

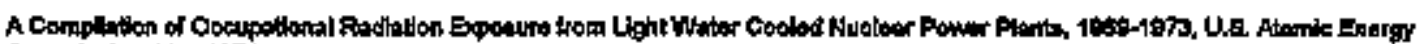
Cammisalon, why tert.

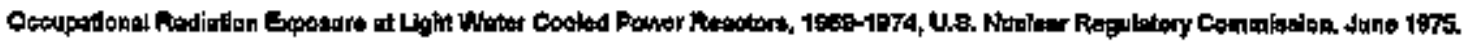

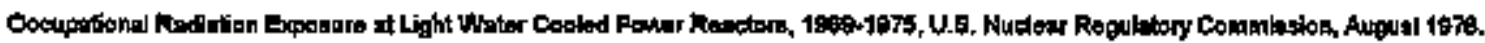

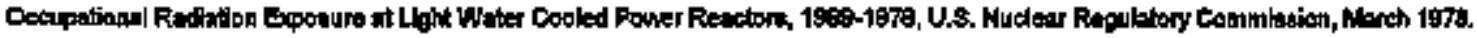

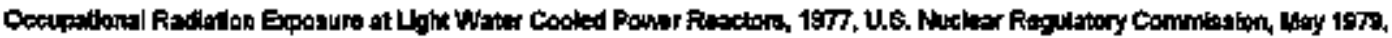

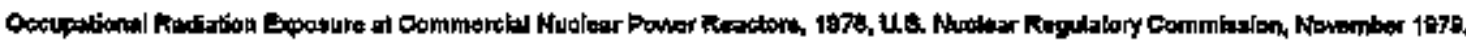

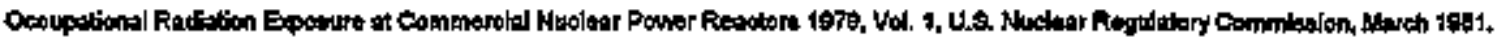

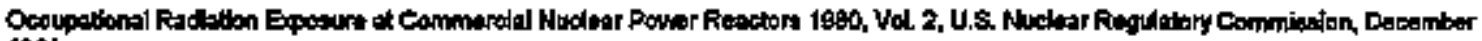
1981.

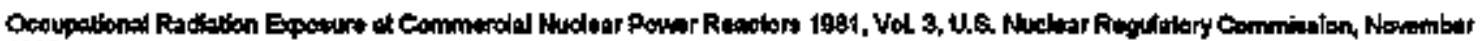
1082

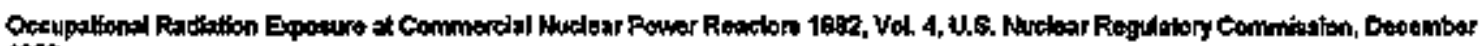
1964.

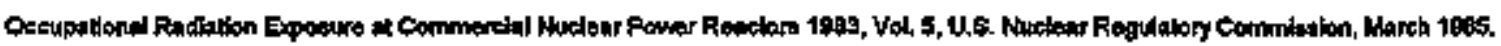

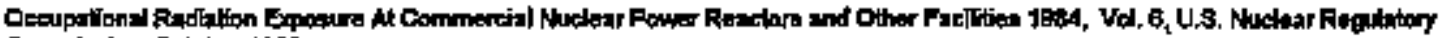

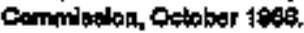

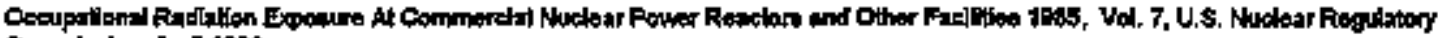
Commison, Apoll 1930.

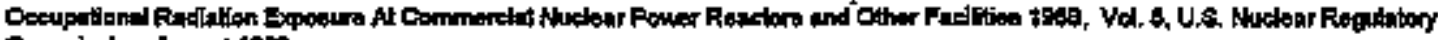
Commigion, Augrat 19\%9.

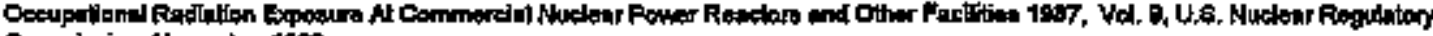
Commigaion. Alovember 1890.

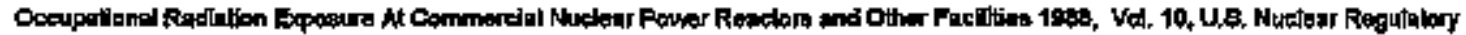
Commiation, Jubl 1991.

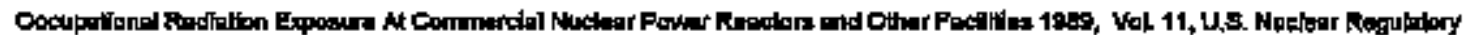
Commiluion, Aptil 1 tos?.

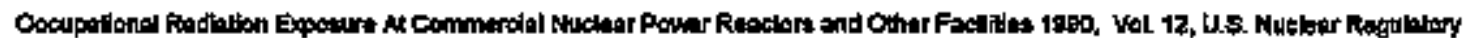
Commilision, January 1 ishs.

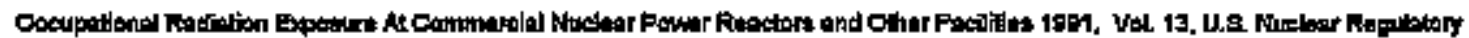
Commituilen, Juby toas.

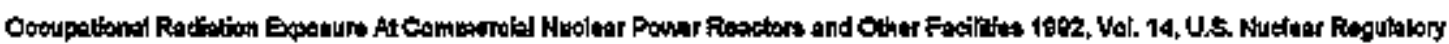
Comalaiation, Docombor 1 bess.

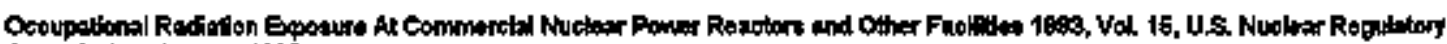
Commialion, January qees.

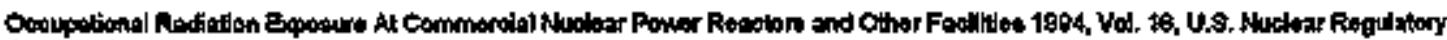

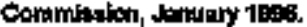

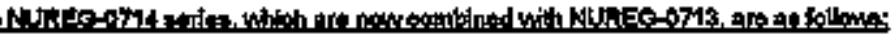

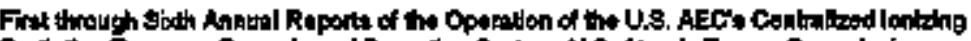

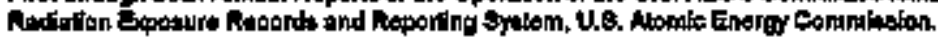

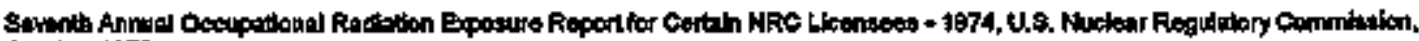
Oetober to75.

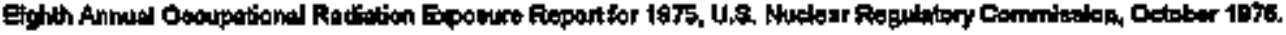

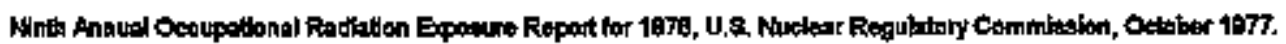

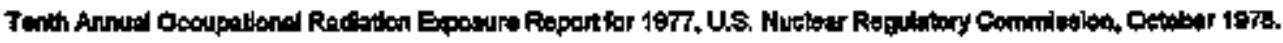

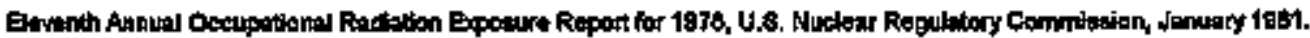

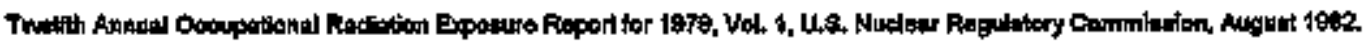

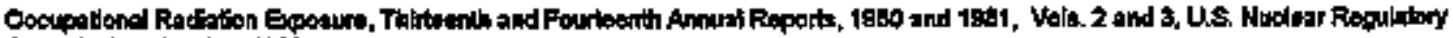
Commlosion, Datober 19as.

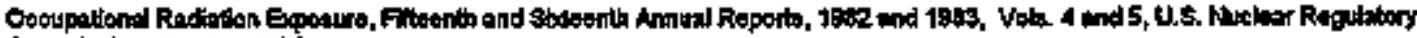
Camminston, Octobst 1stes. 


\section{DISCLAMMER}

This report was prepared as an account of work sponsored by an agency of the United States Gorernmont. Neither tho United States Government bor any agency thered, nor

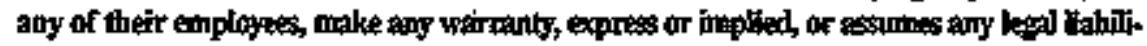

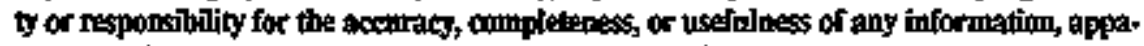

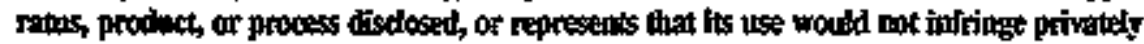

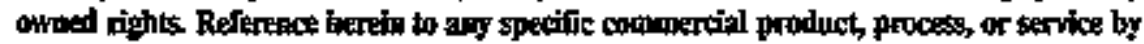

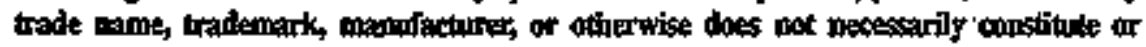

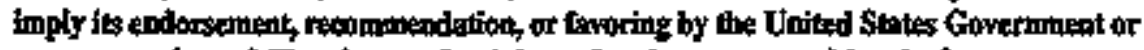
any agency thereof. The vitws and opinions of adtions expresced berein do not hecesorily state or reflect those of the United \$tates Goremment or any opeacy thereof. 


\section{DISCLAMER}

Portions of this document may be illegible in electronic image products. Inages are produced from the best available original document. 


\begin{abstract}
This report summerizes the occupational exposure data that are maintained in the U.S. Nuclear Regulatory Commission's (NRC) Radiation Exposure Information and Reporting System (REIRS). The bulk of the information contained in the report was compiled from the 1995 annual reports submitted by six of the seven cetegories ${ }^{1}$ of NRC licensees subject to the reporting requitements of 10 CFR 20.2206. Since there are no geologic repositories for high level waste currently llcensed, only six categories will be considered in this report.
\end{abstract}

Annual reports for 1995 were received from a total of 295 NRC licensees, of which 109 were operators of nuclear power reactors in commercial operation. Compilations of the reports submitted by the 295 ilcensees indicated that 143,684 individuals were monitored, 77,737 of whom received a measurable dose (Table 3.1). The collective dose incurred by these Individuals was 24,884 person-cSv (person-rem) ${ }^{2}$ whikh represents a $<0.1 \%$ decrease from the 1994 value. The number of workers receiving a measurable dose also decreased, resulting in the average measurable dose of $0.32 \mathrm{cSv}$ (rem) for 1995. The average measurable dose is defined to be the total collective dose (TEDE) divided by the number of workers receiving a measurable dose. These figures have been edjusted to account for transient reactor workers.

In 1995, the annual colective dose per reactor for light water reactor licensees (LWRs) was 199 person-cSv (person-rem). This is the same value that was reported for 1994. The annual collectve dose per reactor for boiling water reactors (BWRs) was 256 person-cSv (person-rem) and, for pressurized waler reactors (PWRs), it was 170 person-eSv (person-rem).

Analyses of translent worker data indicate that 17,153 indlwiduals completed work assignments at two or more llcensees during the monitoring year. The dose distrlbutlons are adjusted each year to account for the dupllcate reporling of transient workers by multiple licensees. In 1995. the average measurable dose calculated from reported data was $0.26 \mathrm{cSv}$ (rem). The corrected dose distribution resulted in an average measurable dose of $0.32 \mathrm{cSv}$ (rem).

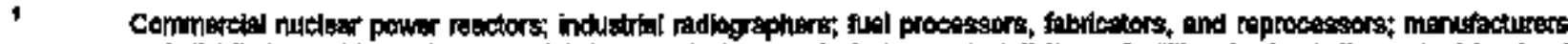

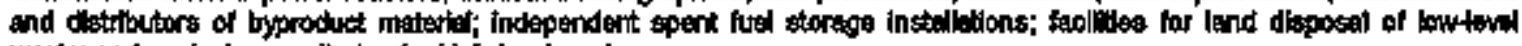

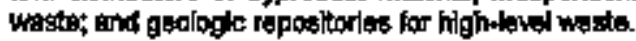
equele one rem, therefore, perretirem becomes person-cSy. 


\section{EDITOR'S NOTE}

The NRC currently has a five-year contract with Science Applications International Corporation (SAIC) to assist the NRC Slaff in the preperation of the NUREG-0713 series. Mr. Charles Hinson (NRR) assisted in the preparation of this NUREG, serving as the NRC Technical reviewer. SAIC will be suggesting changes in the presentation of certain data in these reports. Readers stould be alert to these changes, and the NRC welcomes responses, especially where these changes can be improved upon.

Comments should be difected to:

Mary L. Thomas: (301) 415-6230

E-Mail Address: mit19inic.gov

REIRS Project Manager

Office of Nuclear Regulatory Research

U.S. Nuclear Regulatory Commission

Washington, D.C. 20565 


\section{TABLE OF CONTENTS}

Page

PREVIOUS REPORTS IN SERIES

ABSTRACT

EDITOR'S NOTE v

FOREWORD $x$

PREFACE $\times$

1 INTRODUCTION. 1-1

1.1 Radlation Exposure tnformation on the Intemet.............................................1-3

2 LIMITATIONS OF THE DATA 2-1

3 ANNUAL PERSONNEL MONITORING REPORTS - 10 CFR 20.2206.

3.1 Definition of Terms and Sources of Data.

3.1.1 Statistical Summary Reports

3.1.2 Number of Monltored Workers

3.1.3 Number of Workers with Measurable Doses ..................................................3-2

3.1.4 Collective Dose..........................................................................................-2

3.1.5 Average Individual Dose........................................................................3-3

3.1.6 Average Measurable Dose ....................................................................3-3

3.1.7 Number of Licensees Reporting................................................................3-3

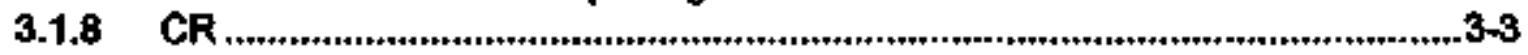

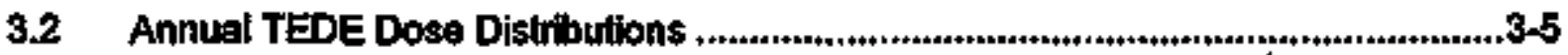

3.3 Summary of Occupational Exposure.Data By License Category ..............................3-8

3.3.1 Industrial Radiography Licenses, Single and

Mutitpla Locations.

3.3.2 Manufacturer and Distribution Licenses, TYpe "A" Broad and

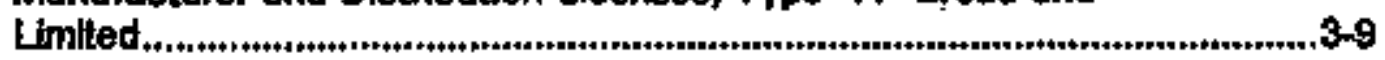

3.3.3 Low-Level Waste Disposel Licenses.........................................................3-13

3.3.4 Independent Spent Fuel Storage Instalkation Licenses . ................................3-13

3.3.5 Fuel Fabrictiotion and Reprocessing Licenses............................................3-15

3.3.6 Llght-Weler-Cooled Power Reactor (LWR) Licenses ....................................3-19

3.3.7 High-Temperature Gas-Cooled Power Reactor (HTGR) Licenses ................3-19

3.4 Summery of Intake Data by License Category ....................................................3-21 
4.1 introduction

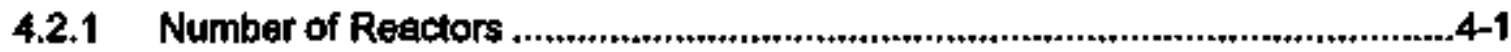

4.2.2 Electric Energy Generated ..........................................................................4-t

4.2.3 Collective Dose per Meganatt-Year ...........................................................4.5

4.2.4 Average Maximum Dependable Capacity.....................................................4-5

4.2.5 Percent of Meximum Dependeble Cepecity Achieved......................................4-5

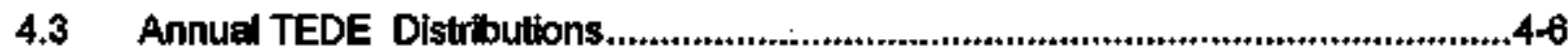

4.4 Average Annual TEDE Doses .........................................................................4-6

4.5 Plant Rankings by Collective Dase per Reactor...............................................4-13

4.6 Collective Dose by Work Function end Employee Typo.......................................4-23

4.7 Number of Personnel by Work Function and Employee Type ............................4-30

4.8 Graphical Representalion of Dose Trends in Appendix E................................4-34

4.9 Health Implications of Average Annual Doses ...................................................4-34

4.10 Estimation of Future Occupational Radlation Exposure at Commerciel Reactor Stes.

5 TRANSIENT WORKERS AT NRC LICENSED FACILITIES ..........................................6-1

5.1 Termination Reports...........................................................................................5-1

5.2 Transient Workers ak NRC Facilities ....................................................................5-1

5.3 Care日r Dose Analysls............................................................................. 5-4

6 EXPOSURES TO PERSONNEL IN EXCESS OF REGULATORY LBAITS .......................6-1

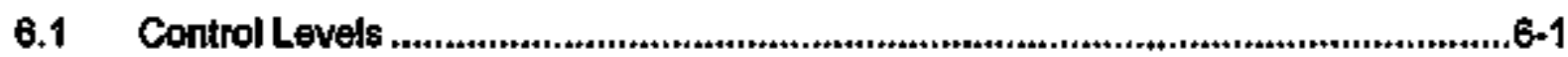

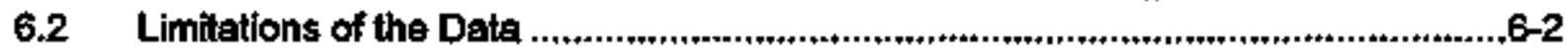

6.3 Summary of Exposures in Excess of Regulatory Limits .....................................6-3

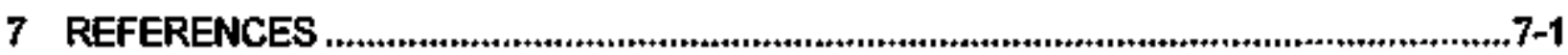

APPENDDX A - LISTING OF ANNUAL EXPOSURE DATA COMIPILED FOR CERTAIN NRC LICENSEES IN DESCENDING ORDER OF AVERAGE MEASURAELE DOSE, 1995

APPENDIX B - ANNUAL WHOLE BODY DOSES AT UCENSED NUCLEAR POWER FACILITES, 1995. 
APPENDIX C - PERSONNEL, DOSE, AND POWER GENERATION SUMMARY, 1969-1995

APPENDIX D - NUMBER OF PERSONNEL AND PERSON-REM BY WORK AND JOB FUNCTION, 1995.

APPENDIXE - GRAPHICAL REPRESENTATION OF COLLECTIVE DOSE TRENDS BY YEAR AND JOB FUNCTION FOR EACH STE, 1973-1995

APPENDIX F - SUMMARY OF ANNUAL WHOLE BODY DOSE DISTRIBUTIONS BY YEAR AND REACTOR TYPE, 1987-1995

\section{닌 OF TABLES}

Table 3.1 Annual Exposure Data for Certain Categories of Licensees 1986-1995.

Table 3.2 Distribution of Annual Collective TEDE by License Categony 1995.

Table 3.3 Summary of Annual Dose Distributions for Certain NRC Licensees 1968-1995

Table 3.4 Annual Exposure Information for Industrial Radiographers 1993-1995.

Table 3.5 Annual Exposure Information for Manufacturers and

Distributors 1993-1995

Table 3.6 Annual Exposure Informalion for Fuel Fabricators 1993-1995

Tabte 3.7 Annual Exposure Information for Fort St. Vrain 1974-1905

Table 3.8 Intakes by Licensee Type and Radionuclide Made of Intake - Ingestion 1995

Table 3.9 Intakes by Licensee Type and Radionuctide Mode of Intake - Inhalation 1995.

Table 4.1 Summary of Informalion Reported by Commercial Boiling Water Reactors 1973-1995. 
Table 4.2 Summary of Information Reported by Commercial

Pressurized Water Reactors 1973-1995

Table 4.3 Summary of Information Reported by Commercial

Light Water Reactors 1973-1995

Table 4,4 Summary DistrJbution of Annual Whole Body Doses at Commercla: Light Water Reectors 1977-1995

Table 4.5 Boiling Water Reactors Listed in Ascending Order of Collective Dase per Reactor 1991-1995

Table 4.6 Pressurized Water Reactors Listed in Ascending Order of Colective Dose per Reactor 1991-1995.

Table 4.7a Five-year Totals and Averages Listed in Ascending Order of Collective Dose per BWR 1991-1995.

Table 4.7b Five-year Totals and Averages Listed in Ascending Order of Collective Dose per PWR 1991-1995.

Table 4.8a Activities Contributing to High Collectlve Doses at Selected

Plants in 1995 - BWRs with High Collective Doses

Table 4,8b Activities Contrlbuting to High Collectlve Doses at Selected

Plents in 1995 - PWRs with High Collective Doses.

Table 4.9 Annual Collective Dose by Work Function and Personnel Type 1995

Table 4.10 Percentages of Anntual Collective Dose at LWRs by Work Function 1984-1995

Table 4.11 Annual Collective Dose by Occupation and Personne] Type 1996 $4-29$

Table 4.12 Number of Personnel by Work Function and Personnel Type 1995 4-31

Table 4.13 Number of Personnel by Occupation and Personnel Type 1995. 4-32

Table 4.14 Average Doses by Occupalion and Personnel Type 1995. 4-33

Table 4.15 Parameters Used in Collective Dose vs. Plant Age Data Model. 4-38

Table 4.16 Projected Collecthe Dose, 1996 - 2000 .40

Table 5.1 Effects of Transient Workers on Annual Stalistical Compilations, 1995 
Table 6.1 Occupalional Exposures in Excess of Regulatory Limits, 1994-1995. 6-5

Table 6.2 Occupalional Exposures in Excess of Regulatory Limits 1985-1993. 6-6

Table 6.3 Maxinum Occupalional Exposures for Each Exposure Category 1995 6-7

\section{LIST OF FIGURES}

Figure 3.1 Average Annual Values at Industrial Radiography Facilities 1973-1985

Figure 3.2 Average Annued Values at Manufacturing and Distribution Facilities 1973-1995

Figure 3.3 Average Annual Values at Low-Level Waste Disposal Facilitios 1982-1995

Figure 3.4 Average Annual Values at Independent Spent Fuel Storage Facilities 1982-1995

Figure 3.5 Average Annual Values at Fuel Fabrication and Processing Facilities 1973-1995

Figure 4.1 Average Collective Dose and Number of Workers per Reactor 1973-1995.

Figure 4.2 Number of Operating Reactors and Gross Electricity Generated 1973-1995

Figure 4.3 Average Measurable Dose per Worker and Collective Dose per Megawatt-Year 1973-1985

Figure 4.4 Average, Medlan, and Extreme Values of the Collective Dose per Reactor 1973-1996

Figure 4.5 Outage Deys, Average Dose, and Collective Dose. 4-24

Figure 4.6 Colleclive Dose by Work Function and Personnel Type 1990-1995

Figure 4.7 Average Collective Dose by Site Age 4-37

Figure 4.8 Reactor Collectlve Dose Projections 4-39 
Based on information received from 294 llcensees required to submil annual reports, collective doses decreased by less than $1 \%$ from 1994 to 1995 . The annual collective dose decreased by teas than $1 \%$ at light-water reactors from 1994 to 1995.Collective doses reported by industrial radiographers, low-level waste disposal facllities, fuel fabrication and processing facilities also showed a decrease whereas manufaclurers and distributors and independent spent fut slorage facilltes showed slight inerease.

NUREG-0713, Volume 17, summarizes the occupational exposure date for 1995 that are maintained in the U.S. Nuclear Regulatory Commission's Radiation Exposure Information Reporting System (REIRS). It does not present staff positions or requirements, However, the NRC staff believes that it cen be a useful toof in evaluating the effectiveness of an ALARA program.

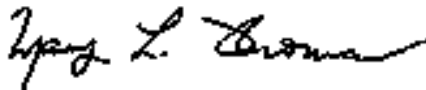 \\ Mary L. Thomas \\ Radiation Protection and Health Effects Branch \\ Division of Regulalory Applications \\ Office of Nuclear Regulatory Research
}




\section{PREFACE}

A number of NRC licensees have inquired as to how the occupational radiation exposure data that are compiled from the individual exposure reports required by $\$ 20.2206$ and the annual dose data reported by work function in accordance with Subsection 6.9.1.5 of the standard tectnical specifications for nuclear power plants are used by the NRC staff. This is a very appropriale inquiry that may be of importance to many affecled licensees. In combination with other sources of information, the principal uses of the diata are to provide facts regarding routine occupational exposures to radiation and redioactive material that occur in connection with certaln NRC-ficensed activities. These facts are used by the NRC staff as Indicated below:

1. The data permit evaluation, from the wewpoint of trends, of the effectiveness of the overall NRChicensee radiation protection and ALARA efforis by certaln ilcensees. They also provide for the identiflcation (and subsequent correction) of unlavorable trends.

2. The external dose date assist in the evaluation of the radiological risk associated with certain categories of NRC-licensed actlvities and are used for comparative analyses of radiation protection performance: USfforeign, BWRsfPWRs, civilian/military, facility/facility, nuclear industrylother industries, etc.

3. The data provide for the monitoring of transient workers who may affect dose distribution statlstics through mulifiple counting, or who may exceed regutatory limits on radiation exposure due to the accumulation of exposure at muttlple sltes per calendar guarter or calendat year.

4. The data help provide facts for evaluating the adequacy of the current risk limitation system (e.g., are individual lifetime dose limits, worker population collective dose limits, and requirements for optimization needed?).

5. The data permit comparisons of occupational radiation risks with potential publle risks when action for additional protection of the public Involves worker exposures.

6. The data are used in the establishment of prioritles for the utifization of NRC health physics resources: research, standards development, and regulatory program development.

7. The data prowde facts for answering Congressional and Administration inquiries and for responding to questions reised by public interest groups, special interest groups, tabor unions, elc.

8. The data provide information that may be used in the planning of epidemiological studies. 


\section{Occupational Radialion Exposure \\ at Commencial Nuclear Power Reactors and Other. Faclitites \\ Twenty-eighth Annual Report, 1995}

\section{INTRODUCTION}

One of the basic purposes of the Atomic Energy Act and the implementing reguiations in Thile 10. Code of Federal Reguletions, Chapter I, Part 20, Is to protect the health and safety of the publlc, inchuding the employees of the llcensees conducting operations under those regulations. Among the regulations designed to ensure thet the standards for protection against radlation set out in 10 CFR 20 are met is a requirement that llcensees provide indhituals likely to be exposed to redietion with devices to monitor their exposure. Each licensee is also required to maintain indefinitely records of the results of such monitoring. However, there was no Inittal provision that these records or any summary of them be transmilted to a central location where the deta could be retrieved and analyzed.

On November 4, 1968, the U.S. Atomle Energy Commission (AEC) published an amendment to 10 CFR 20 requiring the reporting of certaln oscupalional radiation exposure information to a central repository at AEC Headquarters. This information was required of the four categories ${ }^{3}$ of AEC licensees that were considered to involve the greatest.potential for significant occupational doses and of AEC facilities and contractors exempt from licensing. A procedure was established whereby the appropriate occupational exposure data were extracted from these reports and entered into the Commission's Radiation Exposure Information Reporting System (REIRS), a computer system that was maintained at the Oak Rldge Netians: Laboratory Computer Technology Center in Oak Ridge, Tennessee, unil" May 1990. At that time, the date were transferred to a database management system at Sclence Appllcations Imtemational Corporation (SAIC) at Oak Ridge, Tennessee. The computerization of these dala ensures that they are kept indefinitely and faciltates thelr retrieval and anelysis. The data maintained in REIRS have been summarlzed and publlshed in a report every year since 1989. Annual reports for each of the years 1969 through 1973 presented the dieta reported by both AEC flcensees and contractors and were published in sbx documents designated as WASH-1350-R1 through WASH-1350-R6.

In January 1975, with the separalion of the AEC into the Energy Research and Development Adminlstration (ERDA) and the U.S. Nuclear Regulatory Commission (NRC), each agency assumed responsibility for collecting and maintalning occupatlonal radlation exposure

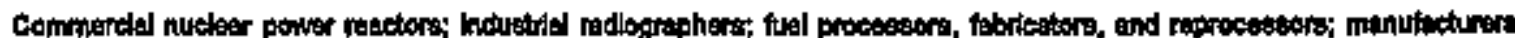

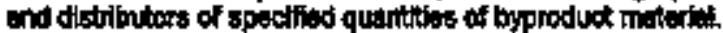


informetion reported by the facinties under its Jurisdiction. The annual reports pubrished by the NRC on occupational exposure for calender year 1974 and subsequent years to not contain informatlon pertalning to ERDA facilties or contractors. Comparable Information for facilities and contractors under ERDA, now the Department of Energy (DOE), is collected and published by DQE's Office of Health, a division of Eminonment, Safety and Health, in Gemantowm, Maryland.

In 1982 and 1983, paragraph 20.408(a) of Thtle 10 of the Code of Federal Regulations was amended to require three additional categories of NRC ficensees to submit annual slatistical exposure reports and individual termination exposure reports. The new categores are (1) geologic repositorles for high-level radioaclive waste, (2) independent spent fuel storage installations, and (3) facities for the land disposal of low-level radloactive waste. Therefore, this document presents the exposure infomation that was reported by NRC licensees representing two of these new categories. (There are no gedogic repositories for high-level waste currently ilcensed.)

This report and each of the predecessors summerizes information reported for both the current year and for previous years. More licensee-specific data for previous years, such as the annual reports submitted by each commercial power reactor pursuant to 10 CFR 20.407 and their technical speclifications, may be found in those documents Isted on the inside of the front cover of this report for the specific year desired. Additional operating data and statistics for each power reactor for the years 1973 through 1982 may be found in a series of reports, "Nuclear Power Piant Operating Experience" [Refs. 1-9]. These documents are avallable for viewing at all NRC public document rooms, or they may be purchased from the National Technical Information Servlce, es shown in the Reference section.

In May of 1991, the revised 10 CFR 20 "Standards for Protection Against Radlation; Final Rule* was published in the Federal Register. The revlsion redefined the radiatlon monitoring and reporting requirements of NRC licensees. Instead of summary annued reports (\$ 20.407) and termination reports (\$ 20.408), licensees are now requilred to submlt an annual report of the dose received by each monitored worker (\$ 20.2206). Licensees were required to implement the new requitements on or before January of 1994. This report is the second compllation of radiation exposure information collected under the revised 10 CFR 20. Certain sections of the report heve been modified to eccount for the change in the reporting of exposure Information. Readers are encouraged to comment on these charges.

Recommendations for further analysis or for different presentation of information are welcome. 


\subsection{Radiation Exposure Information on the intemet}

In May of 1995, the NRC began pursuling the disseminalion of radiation exposure information via a World Wide Wob site on the Intemet. Thls allows interested parties with the appropriate equipment to access the data electronically rather than through the published NUREG-0713 document. A web site was created for radiation exposure and Inked Into the main NRC web page. The web stte contains up-to-date informatlon on radlation exposure, as well as information and guidance on reporing radiation exposure information to the NRC. Interested parties may read the documents on-line or down-loed informalion to their systems for further analysis. Software, such as REMIT, is also avallable for downloading via the web site. There are also links io other web sites dealling with the topics of radiation and health physics. The NRC intends to continue pursuing the dlssemination of radiation exposure information via the World Wide Web and will focus more resources on the electronic distribution of information rather then the published hard copy reports.

The main web URL address for the NRC ls:

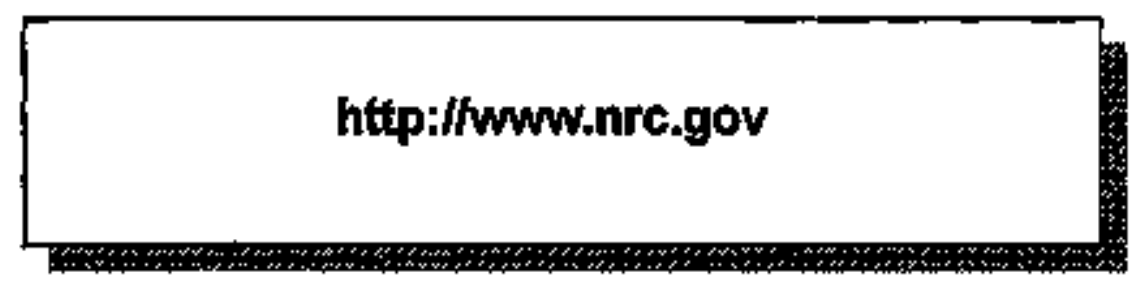

The NRC radiation exposure information web URL address is:

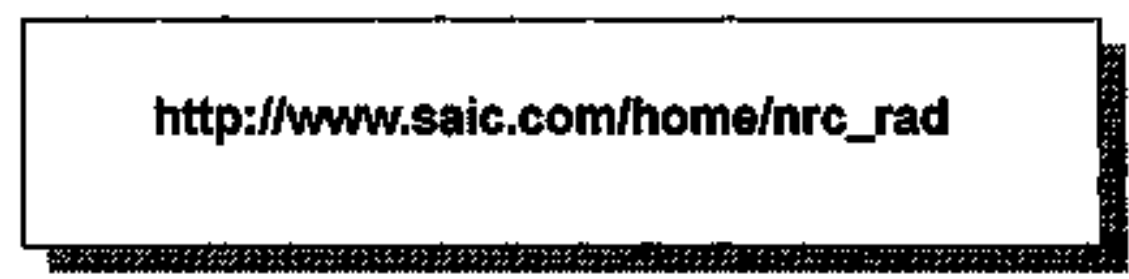

Comments on this report or the NRC's web page should be directed to:

REIRS Project Manager

Office of Nuclear Regulatory Research

U.S. Nuclear Regulatory Commission

Washington, DC 20856 


\section{LMATATIONS OF THE DATA}

All of the figures compiled in this report relating to exposures and doses are based on the results and interpretations of the readings of various types of personnel monitoring devices employed by each licensee. Thls information, obtained from routlne personnel moniloring programs, is sufficient to characterize the radiation onvironment in which individuals work and is used in evaluating the radiation protection program.

Monitoring requirements are speciffed in 10 CFR $\$ 20.1502$, whlch requires licensees to monilor individuals who receive or are likely to recelve a dose in a year in excess of $10 \%$ of the applicable limits. For most adults, the annual limit for the whole boty is 5 cSv (rem), so 0.5 cSv (rem) per year is the level above which monitoring is required. Separate dose limits have been established for minors and pregnant workers. Monikoring is required for any individual entering a high or very high radiation area. Depending on the administrative policy of each licensee. persons such as visitors and clerical workers may also be provided with monitoring devices for identification or convenience, atthough the probability of their being exposed to measurable levels of radiation is extremely small. Licensees are given the option of reporting the doses of only those individuals for whom monitoring is required, or the dose distribution of all those for whom monitoring is provided. Many licensees elect to report the katter; however, this may increase the number of individuals that one could consider to be radiafion workers. In an efitort to account for this, the number of indivlduals reported as having "no measurable exposure" has been subtracted from the total number of individuals monitored in order to calculate an average dose per individual recehing a measurable dose, as well as the average dose per monitored indlvidual (for example, see Table 3.1).

The Revised 10 CFR $\$ 20$ was published in the Federal Register on May 21, 1991. With the revision of Part 20, licensees report the monitoring results for each individual. This has eliminated the need for the staff to calculate collective dose from the statistical distributions and has Improved the accuracy of the collective dose information presented in this report. Licensees were required to implement the new reporting requirements as of January 1, 1994. Certain licensees began reporting under these new requirements during 1993, and that data has been included in the analyses presented here.

Another impact of the Revised Part 20 is the change from whole body dose to total effective dose equivalent (TEDE). The TEDE Includes both external and intemal dose. The TEDE is detemined by summing the deep dose equivalent (DDE) from extemal radiatlon exposure and the committed effective dose equivalent (CEDE) from intemal exposures. In previous reports, anly the whole body dose (equivalent to the DDE) was reported and analyzed. In the 1994 
report, the TEDE is presented and anehyzed in all graphs and tebles unless of herwise noted. Readers should be aware of this change from external whote body dose to the TEDE. For most licensed activities, the internal dose is not a signilicant contributor to the TEDE. However, workers at Fuel Fabrication facilities receive significant exposures from internal exposure. This change in reporting requirements can be seen th the 1994 and 1995 data for this licenser category. (See Section 3.3.5)

The average dose per individual, as well as the dose distributions shown for groups of licensees, also can be affected by the mulliple reporting of individuels who were monitored by two or more licensees during the year. Licensees are only required to report the doses recelved by indwiduals at their licensed facility. A dose distribution for a single licensee does not consider that some of the individuals may have received doses at other facilties. When the data are summed to determine the tolal number of individuals monitored by a group of [icensees, individuals may be counted more than once. This can also affect the distribution of doses because indriduals may be counted multiple times in the lower dose ranges rather then one time in the higher range corresponding to the actual accumulated dose for the year (the sum of the individual's dose accrued at all facilitles). This source of error has the greatest potential impact on the data reported by power reactor facilities since they employ many short-term workers. Further discussion of this point is provided in Section 5.

Another fact that should be kept In mind when examining the annual statistical data is that ail of the personnel Included in the report may not have been monitored throughout the entire year, Many licensees, such as radiography firms and nuclear power facilities, may monitor numerous individuals for periods much less than a year. The average doses calculated from these data, therefore, are less than the averege dose that an individual would recelve if involved in that ectivity for the full year.

Considerable attention should also be glven when referencing the collective totals presented in this report. The differences between the totals presented for all ticensees thet reported versus only those licensees that are requited to report should be noted. Likewise, one should pay attention to the differences between all power reactors fincluding the high temperature ges reactor (HTGR), all pressurized water reactors (PWRs), and all boiling water reactors (BWRs)]. The totals may be inclusive or exclusive of those licensees that were in commencial operation for less than one full year. These parameters vary throughout the tables and appendices of this report in order to provide the most comprehensive analysis of all the date available. The apparent discrepencies among the various tables are a necessary side-effect of this endeavor.

Also, it should again be pointed out that this report conteins informetion reported by NRC Hcensees only. Since the NRC licenses all commerciel nucleer power reactors, fuel processors, fabricators and reprocessors, end independent spent fuel storage fecilties, information shown 
for these categories reflects the U.S. experience. This is not the case, however, for the remaining categories of industrial radiography, manufacturing and distribution of specified quantities of by-product material, and low-level waste disposal. Companies that conduct these types of activities in Agreement States ${ }^{4}$ are licensed by the state and are not required to submit occupatlonal exposure reports to the NRC. Approximately twice as many facilities are licensed to Agreement States than the number licensed by the NRC. This report also does not inchude non-occupatloned exposure such as exposure due to medical x-rays, fluoroscopy, and acceleralors. Informalion shown for these categories does not reflect the total U.S. experience. 


\subsection{Defintiton of Terms and Sounces of Data}

\subsubsection{Statistical Summary Reports}

On February 4, 1974, 10 CFR 20.407 was amended to require certain categories ${ }^{5}$ of licensees to submit an annual stalistical report Indicating the distribution of the whole boty doses incurred by workers whom they monitored for exposure to radiation. Since the regulations dit not require these licensees to report the collective dose incurred by the workers shown on the statistical reports, the dose distributions were used as the basis for the stafi's calculation of the collective dose (see Section 3.1.4).

The revised 10 CFR 20 was published in the Federal Register on May 21, 1991. Section 20.2208 of the revised rule requires licensees to report the radiation exposure monitoring results for each Individuel for the monitoring yeer. All licensees were required to implement the new reporting requirements on or before Jantuary 1, 1994.

Under the new requirements, the indiwidual's total effective dose equivalent (TEDE, as defined In $\$ 20.1003$ ) is reported, so that the dose distributions may be determined directly from the indivjduel's exposure. The TEDE is summed per individual and tabulated into the appropriate dose range to generate the dose distribution for each licensee. The total collective dose is more accurate using this method, since the licensee reported the dose to each indluidual and the total collective dose was calculated from the sum of these doses and not statisticelly derived from the distribution (see Section 3.1.4). The TEDE includes the dose contribution from the committed effective dose equivalent (CEDE) for those workers who had intakes that required monitoring and reporting of intemal dose. Reports submitted under formerly applicable 10 CFR 20.407 did not Include the whole body contribution from Intemal dose.

\subsubsection{Number of Monilosed Workers}

The number of monitored workers refers to the total number of workers that the NRC licensees, who are covered by 10 CFR 20.1502, reported as being monitored for exposure to extemal and Intemal radiation during the year. This number Includes all workers for whom monltoring is required, and may inctude visitors, service representatives, contract workers, clerical workers, and any other workers for whom the licensee feels that monitoring devices should be provided.

8

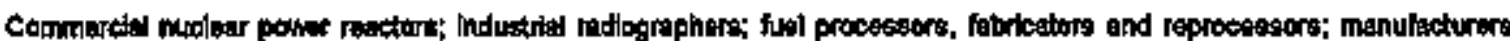

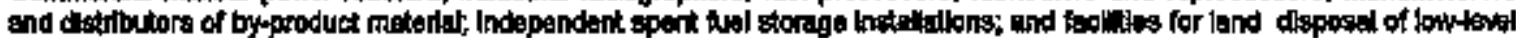
noloective mate. 
For wcensees submitting under the revised 10 CFR 20.2206, the lotal number of workers was determlned from the number of unique personal identlficalion numbers submitted per licensee. Uniqueness is defined by the combination of Identification number and identification type. [Ref. 18]

\subsubsection{Number of Workers with Measurable Doses}

Under the revised 10 CFR 20.2206, the number of workers with measurable dose includes any indlwidual with a TEDE greater than zero cSv (rem). This does not include workers with a TEDE reported as zero, not deteclable (ND), or not required to be reported (NR). [Ref. 18]

\subsubsection{Collective Dase}

The concept of collective dose is used in this report to denote the sulmmation of the TEDE recelved by all monitored workers and has the units person-cSv (person-rem). ${ }^{8}$ The revised 40 CFR 20.2206 requires that the TEDE be reported, so the collective dose is celculated by summing the TEDE for all monitored workers. The phrase "collective dose" is used throughout this report to mean the collective TEDE, unless otherwise specified.

If should be noted that the collective dose in past years was, in some cases, calculated from the dose distributions by sumrning the products abtained from multiplying the number of workers reported in each of the dose ranges by the midpoint of the corresponding dose range. This assumes that the midpoint of the range is equal to the arithmetic mean of the individual doses in the range. Past experience has shown that the actual mean dose of workers reported in each dose range is less than the midpoint of the range, and therefore the resultant calculated collective doses shown in this report for these llcensees may be about $10 \%$ higher than the sum of the actual Indhidual doses. Care should be taken when comparing the actual collective dose calculated for 1995 with the collective dose for previous years because of this change In methodology. In addition, pribr to 1994, doses only inctuded the external whole body dose. Although the contribution of internal dose to the TEDE is minimal for most Hicensees, it should be taken into consideration when comparing the 1996 collective dose with the collective dose for prior years. One noted exceptlon Is for fuel fabrication licensees where the CEDE in some cases contributes the majority of the TEDE (see Section 3.3.5.).

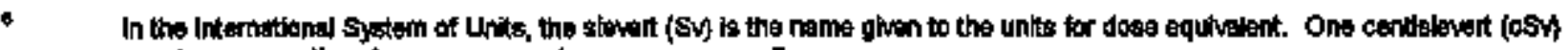
equals one fein, theretore person-rim becomes persen-osy. 


\subsubsection{Average Individual Dose}

The average individual dose is oblained by dividing the collective dose by the total number of workers reported as being monitored. This figure is usually less than the average measurable dose (see below) because it Includes the number of those workers who received zero or less than measurable doses.

\subsubsection{Average Measurable Dose}

The average measurable dose is obtained by dividing the collective TEDE by the number of workers who received a measurable dose. This is the average most commonly used in this and other reports when examining trends and comparing doses recajved by workers in various segments of the nuelear industry because it deletes those workers receiving zero or minimal doses, many of whom were monitored for conventence or Identification purposes.

\subsubsection{Number of Licensees Reporting}

The number of licensees refers to the NRC licenses issued to companies to use radioective materlal for certaln activities that would place them in one of the six categorles that are required to report pursuant to 10 CFR 20.2206. The thitd column in Table 3.1 shows the number of licensees that have filed such reports during the last 10 years. Agreement State licensees do not submit such reports to the NRC and ere not included in this report.

\subsubsection{CR}

One of the parameters thal the United Natlons Scientific Commlttee on the Effects of Atomic Redlation (UNSCEAR) recomrends be cakculated for occupational dose distributlons to aid In the comparison of exposure dala is a ralio "CR." CR is deflned to be the ratio of the annual collective dose incurted by workers whose annual doses exceed $1.5 \mathrm{cSv}$ to the total annual collective dose. One UNSCEAR report [Ref. 10] states that nomal values of CR should be between 0.05 and 0.50 . A CR of 0.50 means that $50 \%$ of the collective dose is due to indluidual doses that exceed $1.5 \mathrm{cSv}$ (rem).

Prior to 1994, the value of CR was calculated from the statistical distributions thet were submitted under 10 CFR 20.407. For this calculation, it was assumed that the doses were uniformly distributed between each dose range interval. The number of people in each dose range above $1.5 \mathrm{cSv}$ was multiplied by the midpoint of the dose range to estimate the collective dose attributed to each dose range. The collective dose of workers with doses exceeding $1.5 \mathrm{cSV}$ in the 1 to $2 \mathrm{CSV}$ range was celculated by assuming that half of the collecthe dose Incurred by workers with doses between 1 and 2 cSv was because of doses greeter than $1.5 \mathrm{cSv}$. This value was then added to the collectlve dose fincurred by workers in the higher ranges. This was known to yield a conservative CR value, but was a useful 
TABLE 3.1

ANNUAL EXPOSURE DATA FOR CERTAIN CATEGORIES OF LICENSEES

1988 - 1095

\begin{tabular}{|c|c|c|c|c|c|c|c|c|}
\hline $\begin{array}{l}\text { licenos } \\
\text { Cottegony }\end{array}$ & $\begin{array}{c}\text { Calenchar } \\
\text { Year }\end{array}$ & $\begin{array}{l}\text { Thibar of } \\
\text { Licthated } \\
\text { Repoting }\end{array}$ & $\begin{array}{l}\text { Nanibar } \\
\text { of Monitored } \\
\text { Indihiduals }\end{array}$ & 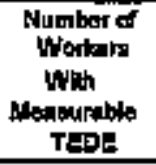 & 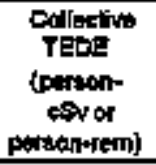 & $\begin{array}{l}\text { Aunago } \\
\text { TEDE (esv } \\
\text { or rotil }\end{array}$ & 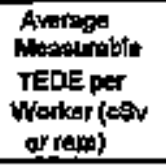 & Cark \\
\hline $\begin{array}{l}\text { hodultial } \\
\text { Radlogmphy }\end{array}$ & $\begin{array}{l}1795 \\
1904 \\
1093 \\
1902 \\
1991 \\
1000 \\
1909 \\
1908 \\
1007 \\
1803\end{array}$ & $\begin{array}{l}139 \\
139 \\
178 \\
249 \\
248 \\
258 \\
278 \\
286 \\
312 \\
395\end{array}$ & 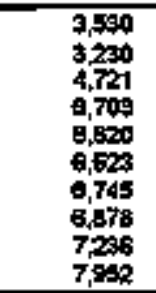 & $\begin{array}{l}2,45 \\
2,351 \\
3,007 \\
4,205 \\
4,849 \\
4,476 \\
4,352 \\
4,200 \\
4,414 \\
5,130\end{array}$ & $\begin{array}{l}1,355 \\
\$, 415 \\
1,695 \\
1,054 \\
2,190 \\
2,120 \\
2,057 \\
1,901 \\
1,095 \\
2,105\end{array}$ & $\begin{array}{l}0.36 \\
0.44 \\
0.34 \\
0.26 \\
0.39 \\
0.39 \\
0.31 \\
0.29 \\
0.25 \\
0.27\end{array}$ & $\begin{array}{l}0.54 \\
0.80 \\
0.53 \\
0.44 \\
0.49 \\
0.40 \\
0.47 \\
0.47 \\
0.41 \\
0.41 \\
\end{array}$ & $\begin{array}{l}0.40 \\
0.51 \\
0.45 \\
0.37 \\
0.40 \\
0.42 \\
0.42 \\
0.43 \\
0.39 \\
0.39\end{array}$ \\
\hline $\begin{array}{l}\text { hanmfaching } \\
\text { and } \\
\text { bialdbestion }\end{array}$ & 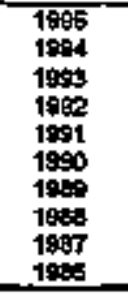 & $\begin{array}{l}30 \\
44 \\
69 \\
67 \\
59 \\
88 \\
48 \\
18 \\
24 \\
30\end{array}$ & $\begin{array}{l}2,688 \\
2,041 \\
4,013 \\
5,210 \\
4,990 \\
4208 \\
4,554 \\
2,177 \\
3,589 \\
4,042\end{array}$ & $\begin{array}{l}1,57 \\
1,251 \\
2,254 \\
2,250 \\
1,954 \\
2,279 \\
2,945 \\
504 \\
2,317 \\
2,005 \\
\end{array}$ & $\begin{array}{l}805 \\
500 \\
500 \\
704 \\
728 \\
803 \\
770 \\
348 \\
718 \\
748\end{array}$ & $\begin{array}{l}0.22 \\
0.20 \\
0.14 \\
0.15 \\
0.76 \\
0.16 \\
0.17 \\
0.16 \\
0.20 \\
0.15\end{array}$ & $\begin{array}{l}0.49 \\
0.46 \\
0.30 \\
0,35 \\
0.37 \\
0,30 \\
0.33 \\
0.40 \\
0.31 \\
0.56\end{array}$ & $\begin{array}{l}0.68 \\
0.59 \\
0.47 \\
0.54 \\
0.89 \\
0.5 \\
0.58 \\
0.82 \\
0.54 \\
0.40 \\
\end{array}$ \\
\hline $\begin{array}{l}\text { LowLeral } \\
\text { Wats } \\
\text { Dispostal }\end{array}$ & 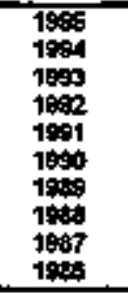 & $\begin{array}{l}2 \\
2 \\
2 \\
2 \\
2 \\
2 \\
2 \\
2 \\
2 \\
2 \\
\end{array}$ & $\begin{array}{l}212 \\
202 \\
427 \\
497 \\
908 \\
784 \\
925 \\
281 \\
717 \\
806\end{array}$ & $\begin{array}{r}8 \\
89 \\
79 \\
82 \\
147 \\
115 \\
118 \\
171 \\
173 \\
175 \\
\end{array}$ & $\begin{array}{l}8 \\
22 \\
21 \\
37 \\
30 \\
28 \\
35 \\
27 \\
24 \\
31\end{array}$ & $\begin{array}{l}0.04 \\
0.11 \\
0.05 \\
0.04 \\
0.04 \\
0.08 \\
0.04 \\
0.05 \\
0.08 \\
0.09 \\
\end{array}$ & $\begin{array}{l}0.15 \\
0.27 \\
0.27 \\
0.45 \\
0.27 \\
0.27 \\
0.26 \\
0.18 \\
0.14 \\
0.18 \\
\end{array}$ & $\begin{array}{l}0.00 \\
0.15 \\
0.27 \\
0.34 \\
0.24 \\
0.17 \\
0.17 \\
0.08 \\
0.00 \\
0.05\end{array}$ \\
\hline 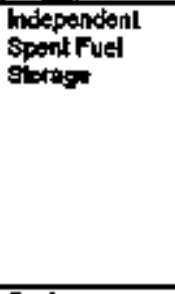 & 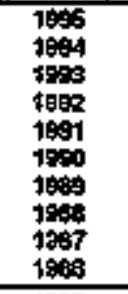 & $\begin{array}{l}1 \\
1 \\
2 \\
2 \\
2 \\
2 \\
2 \\
2 \\
2 \\
1 \\
\end{array}$ & $\begin{array}{r}104 \\
158 \\
135 \\
2 \% 0 \\
11 \\
196 \\
190 \\
217 \\
128 \\
37\end{array}$ & $\begin{array}{r}40 \\
80 \\
62 \\
45 \\
24 \\
21 \\
102 \\
57 \\
04 \\
32 \\
\end{array}$ & $\begin{array}{r}51 \\
14 \\
14 \\
11 \\
4 \\
6 \\
73 \\
75 \\
41 \\
34\end{array}$ & $\begin{array}{l}0.49 \\
0.27 \\
0.10 \\
0.04 \\
0.10 \\
0.11 \\
0.17 \\
0.12 \\
0.54 \\
1.08\end{array}$ & $\begin{array}{l}1.04 \\
0.47 \\
0.28 \\
0.13 \\
0.17 \\
0.27 \\
0.72 \\
0.44 \\
0.64 \\
1.08\end{array}$ & $\begin{array}{l}0.5 \\
0.44 \\
0.11 \\
0.00 \\
0.00 \\
0.00 \\
0.00 \\
0.27 \\
0.00 \\
0.48\end{array}$ \\
\hline $\begin{array}{l}\text { Pril } \\
\text { Pabricallon } \\
\text { and } \\
\text { Procanging }\end{array}$ & 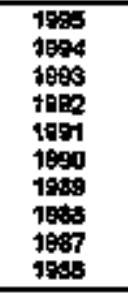 & $\begin{array}{r}8 \\
8 \\
8 \\
11 \\
11 \\
11 \\
8 \\
10 \\
10 \\
10 \\
\end{array}$ & $\begin{array}{r}4,108 \\
3,593 \\
3,649 \\
8,439 \\
14,702 \\
14,505 \\
11,608 \\
11,984 \\
10,370 \\
6,017\end{array}$ & $\begin{array}{l}2,069 \\
2,647 \\
2,611 \\
6,081 \\
9,909 \\
3,071 \\
2,090 \\
3,060 \\
3,009 \\
3,790 \\
\end{array}$ & $\begin{array}{r}1217 \\
+147 \\
339 \\
645 \\
375 \\
428 \\
248 \\
455 \\
614 \\
455 \\
\end{array}$ & $\begin{array}{l}0.30 \\
0.97 \\
0.04 \\
0.09 \\
0.05 \\
0.03 \\
0.02 \\
0.04 \\
0.08 \\
0.00\end{array}$ & $\begin{array}{l}0.41 \\
0.40 \\
0.13 \\
0.11 \\
0.10 \\
0.11 \\
0.01 \\
0.12 \\
0.13 \\
0.12 \\
\end{array}$ & $\begin{array}{l}0.39 \\
0.40 \\
0.08 \\
0.00 \\
0.01 \\
0.07 \\
0.00 \\
0.06 \\
0.07 \\
0.05\end{array}$ \\
\hline $\begin{array}{l}\text { Commorlal } \\
\text { Litit Vytar } \\
\text { Reators }\end{array}$ & 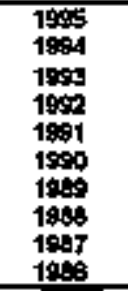 & $\begin{array}{l}109 \\
100 \\
114 \\
114 \\
115 \\
105 \\
\$ 15 \\
t 11 \\
t 08 \\
\text { tod } \\
\end{array}$ & 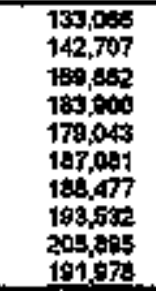 & 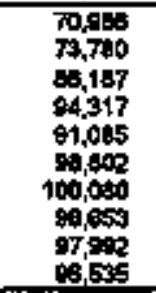 & $\begin{array}{l}21,574 \\
21,095 \\
20,346 \\
29,248 \\
28,508 \\
35,007 \\
35,900 \\
40,055 \\
30,708 \\
41,082\end{array}$ & $\begin{array}{l}0.18 \\
0.15 \\
0.18 \\
0.19 \\
0.18 \\
0.20 \\
0.19 \\
0.21 \\
0.19 \\
0.28\end{array}$ & $\begin{array}{l}0.31 \\
0.29 \\
0.31 \\
0.31 \\
0.31 \\
0.37 \\
0.36 \\
0.41 \\
0.41 \\
0.43\end{array}$ & $\begin{array}{l}0.08 \\
0.08 \\
0.28 \\
0.24 \\
0.28 \\
0.33 \\
0.33 \\
0.58 \\
0.37 \\
0.44\end{array}$ \\
\hline 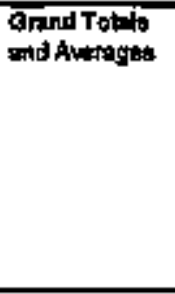 & 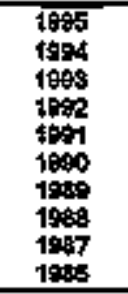 & 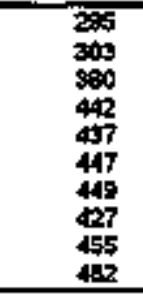 & $\begin{array}{l}143,604 \\
597,034 \\
209,712 \\
20,009 \\
200,441 \\
219,152 \\
212,474 \\
215,062 \\
227,097 \\
213,017\end{array}$ & $\begin{array}{r}77,797 \\
80,411 \\
94,187 \\
108,000 \\
104,708 \\
100,547 \\
109,900 \\
105,841 \\
108,04 \\
107,727\end{array}$ & 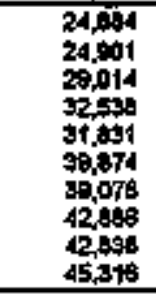 & $\begin{array}{l}0.17 \\
0.18 \\
0.15 \\
0.16 \\
0.18 \\
0.19 \\
0.110 \\
0.20 \\
0.19 \\
0.21 \\
\end{array}$ & $\begin{array}{l}0.37 \\
0.31 \\
0.31 \\
0.31 \\
0.31 \\
0.08 \\
0.38 \\
0.41 \\
0.38 \\
0.48 \\
\end{array}$ & $\begin{array}{l}0.11 \\
0.13 \\
0.24 \\
0.25 \\
0.27 \\
0.34 \\
0.34 \\
0.38 \\
0.37 \\
0.40 \\
\end{array}$ \\
\hline
\end{tabular}

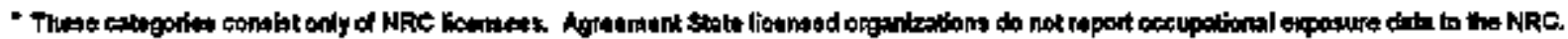

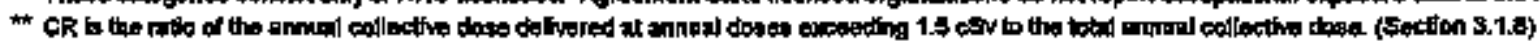

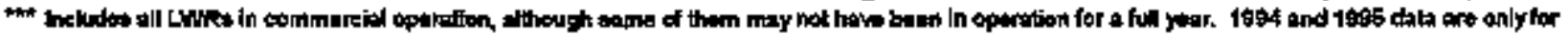

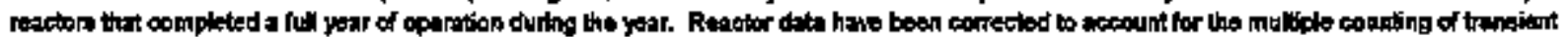
resctor workers, (uin Baction 5 )

NUREG-0713 
indicalor when consistently applied to the date from year to year.

The last column in Table 3.1 shows the values of CR for the different types of licensees. With the Implementation of the revlsed 10 CFR 20 in 1994, licensees were required to submit dose records for each individuel. This allowed the NRC to determine the CR value directly by summing the collective dose for individuals with a total TEDE greater than or equel to 1.5 cSv and divide it by the collective TEDE for the licensee. This method yiejded a large reduction in the CR for Reactors. The CR value for Reactors dropped $64 \%$ from 0.22 in 1993 to 0.08 in 1994 and to 0.06 in 1995. Using the previous melhodology, the CR value would have been calculated to be $\mathbf{0 . 2 3}$ in 1994 and $\mathbf{0 . 1 9}$ for 1995. One of the contributing factors for this. dlfference is the administrathe controls imposed at nuclear power factilties for individuals who exceed 1 cSv. This causes the dose distribution to drop off sherpy above 1 cSv with fewer exposures exceeding $1.5 \mathrm{cSv}$. Therefore, the actual CR is significantly less than the value that is calculated by assuming a uniform dose distribution.

Other licensees, such as Manufacturing and Distribution and independent Spent Fuel Storage, have experienced increases in the CR value and exceed the 0.50 value recommended by UNSCEAR. Fuel Fabricatlon doses, Including the CR value, heve increased primarily because of the inclusion of internal exposure in the TEDE for 1994 and 1995. However, the overall average CR for all licensees remained below 0.50 , and decreased to a value of 0.10 in 1995 primarily because of the decrease in CR at power reactor licensees.

\subsection{Annual TEDE Dose Distributions}

Table 3.2 is a statistical compilation of the exposure reports submitted by six categories of licensees (see Section 3.3 for a description of each licensee category). The dose distributions are generated by summing the TEDE for each individual and counting the number of individuals in each dose range. In nearly every category a large number of workers recetve doses that are less than measurable, and very few doses exceed 4 or $5 \mathrm{cSv}$ (rem). About $90 \%$ of the reported workers continue to be monitored by nuclear power facilities where they receive approximately $90 \%$ of the total collective dose.

Under the regulatory limits of the revised 10 CFR 20.1201, annual TEDE in excess of 5 CSV (rem) for occupationally exposed adults is, by definition, exposures in excess of regulatory Ilmits (see Section 6).

Table 3.3 gives a summary of the annual exposures reported to the Commission by cerlain celegories of NRC licensees as required by 10 CFR 20.2206 . Table 3.3 shows that $-96 \%$ of the exposures consistently remained <2 CSv (rem) between 1968 and 1984 . For the past 10 years the percentage of workers with $<2 \mathrm{cSv}$ (rem) has been $\geq 98 \%$. The number of workers receiving an annual exposure In excess of $5 \mathrm{cSv}$ (rem) has been $<0.01 \%$ since 1985. 


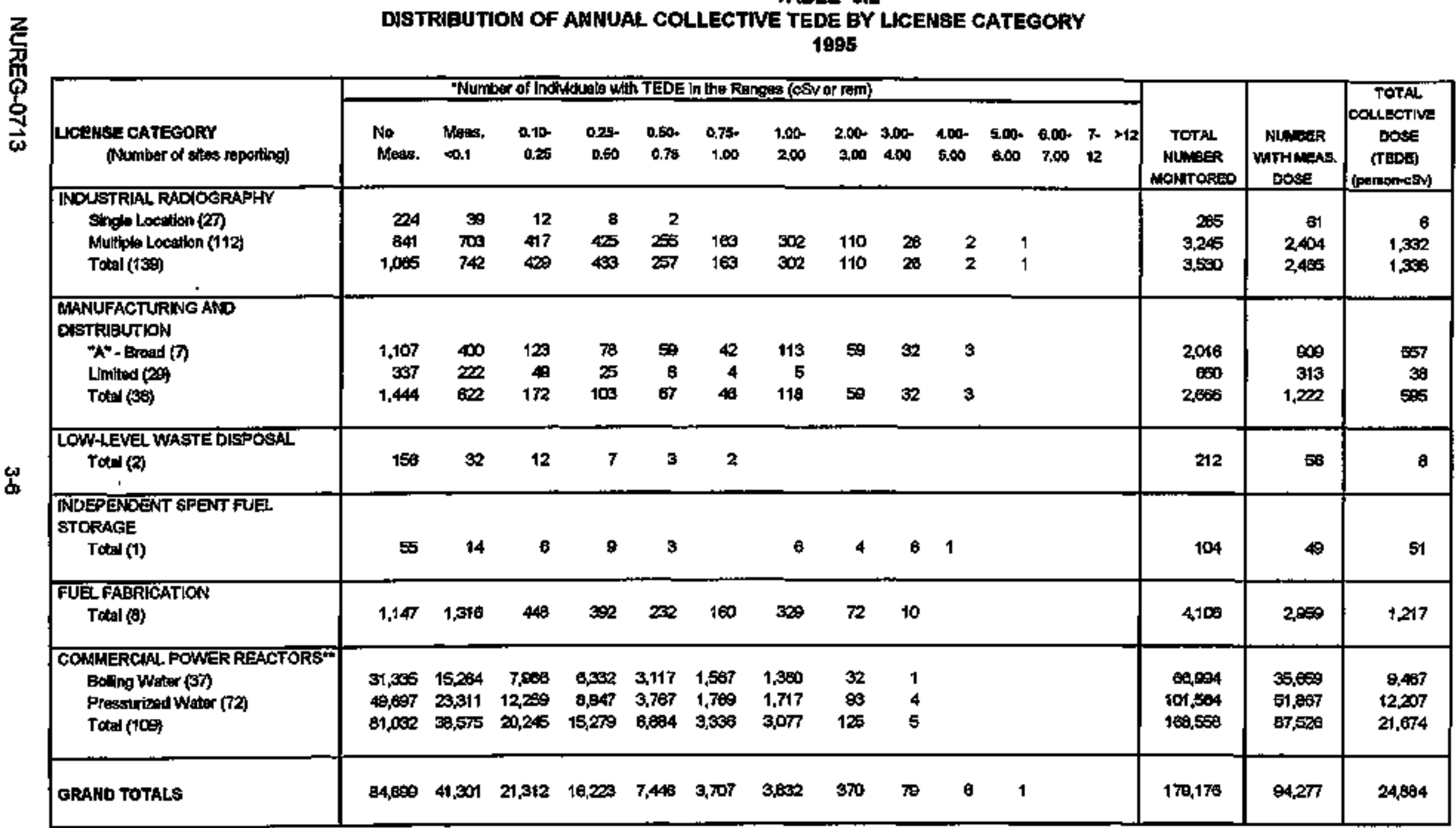

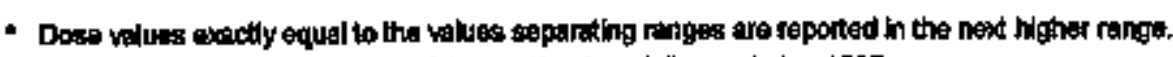

- Includes all reactors in corimerctal operation for a full year during 1005.

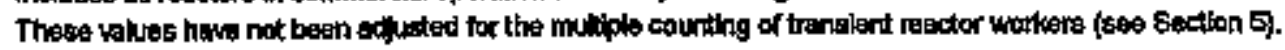


TABLE 3.3

SUMMARY OF ANNUAL DOSE DISTRIBUTIONS FOR CËRTAIN NRC LICENSEES 1968-1995

\begin{tabular}{|c|c|c|c|c|c|}
\hline \multirow[b]{2}{*}{ Year } & \multicolumn{2}{|c|}{$\begin{array}{l}\text { Total Number of } \\
\text { Monitored Persons }\end{array}$} & \multirow{2}{*}{$\begin{array}{l}\text { Percent of } \\
\text { Individuals } \\
\text { With Doses } \\
<2 \text { cSv" }\end{array}$} & \multirow{2}{*}{$\begin{array}{l}\text { Percent of } \\
\text { Individuals } \\
\text { Whth Doses } \\
<5 \text { cSv }\end{array}$} & \multirow{2}{*}{$\begin{array}{l}\text { Number of } \\
\text { Individuals } \\
\text { With Doses } \\
>12 \mathrm{cSv}^{*}\end{array}$} \\
\hline & $\begin{array}{l}\text { Reported } \\
\text { Number }\end{array}$ & $\begin{array}{l}\text { Comected } \\
\text { Number }\end{array}$ & & & \\
\hline 1968 & 36,836 & & $97.2 \%$ & $99.5 \%$ & 3 \\
\hline 1969 & 31,170 & & $90.5 \%$ & $99.6 \%$ & 7 \\
\hline 1970 & 36,164 & & $96.1 \%$ & $99.4 \%$ & 0 \\
\hline 1971 & 36,311 & & $96.3 \%$ & $99.3 \%$ & 1 \\
\hline 1972 & 44,690 & & $95.7 \%$ & $99,5 \%$ & 8 \\
\hline 1973 & 67,862 & & $95.0 \%$ & $99.5 \%$ & 1 \\
\hline 1974 & 85,097 & & $90.4 \%$ & $99.7 \%$ & 1 \\
\hline 1975 & 78.713 & & $94.8 \%$ & $99.5 \%$ & 1 \\
\hline 1976 & 92,773 & & $95.0 \%$ & $99.6 \%$ & 3 \\
\hline 1977 & 98,212 & 93,438 & $93.8 \%$ & $09.6 \%$ & 1 \\
\hline 1978 & 105,893 & 100,818 & $94.6 \%$ & $99.8 \%$ & 3 \\
\hline 1979 & 131,027 & 125,316 & $95.2 \%$ & $99.8 \%$ & $\mathbf{t}$ \\
\hline 1990 & 169.177 & 150,675 & $94.6 \%$ & $99.7 \%$ & 0 \\
\hline 1981 & 167,874 & 149,314 & $94.6 \%$ & $99.8 \%$ & 1 \\
\hline 1982 & 162,456 & 154,117 & $94.8 \%$ & $99.9 \%$ & 0 \\
\hline 1983 & 172,927 & 164,239 & $94.6 \%$ & $99.9 \%$ & 0 \\
\hline 1984 & 181,627 & 168,899 & $95.1 \%$ & $99.9 \%$ & 0 \\
\hline 1985 & 212,217 & 201,339 & $97.5 \%$ & $>99.99 \%(15)$ & 2 \\
\hline 1986 & 225,682 & 213,017 & $98.0 \%$ & $>99.99 \%(8)$ & 0 \\
\hline 1987 & 243,562 & 227,997 & $98.7 \%$ & $>99.99 \%(4)$ & 1 \\
\hline 1988 & 231,234 & 215,662 & $98.6 \%$ & $>99.99 \%(8)$ & 0 \\
\hline 1989 & 229,353 & 212,474 & $98,9 \%$ & $>99.99 \%(7)$ & 1 \\
\hline 1990 & 234,045 & 214,781 & $98,9 \%$ & $>99.99 \%(3)$ & $\theta$ \\
\hline 1991 & 219,229 & 206,732 & $99.4 \%$ & $>99.99 \%(2)$ & 0 \\
\hline 1992 & 222,728 & 205,000 & $99.4 \%$ & $>99.99 \%(1)$ & 0 \\
\hline 1993 & 209,386 & 189,711 & $99.5 \%$ & $>99.99 \%(2)$ & 0 \\
\hline 1994 & 179.803 & 152,834 & $99.5 \%$ & $>99.99 \%$ (1) & 0 \\
\hline 1995 & 179.176 & 143,684 & $99.3 \%$ & $>09.99 \%$ (1) & 0 \\
\hline
\end{tabular}




\subsection{Summary of Occupational Exposure Data by License Category}

\subsubsection{Industrial Radiography Licenses, Single and Multiple Locations}

Industrial Radiography licenses are lssued to allow the use of sealed radioactlve materials, usually in exposure devices or "cameras," that primarlly emit gamma rays for nondestructive tesling of pipeline weld joints, steel structures, bolters, aircraft and ship parts, and other high-stress alloy parts. Some firms are licensed to conduct such activities in one location, usually in a permenent facility that was designed and shlelded for radlography, and others perform radiography at multiple, temporary sites in the fleld. The radiolsotopes most commonly used are cobalt-60 and iridium-192. As shown in Table 3.1, annual reports were recelved for 139 radiography licensees in 1995 . Table 3.4 summarizes the reported data for the two types of radiography licenses for 1995 and for the previous 2 years for comparison purposes.

For the years prior to 1994, the average measureble dose for workers performing radiography at a single location ranged from 20 to $40 \%$ of the average measurable dose of workers at multiple location facirities. This is because it is more difficult for workers to avoid exposure to radiation in the field, where conditions are not opthal and may change daily. In 1994, the average measurable dose for single location radiographers was much ckoser to the value for mulliple location licensees because of high average doses at one license日, Buckeye Sleel Castings. For 1995, the average measurable dose for single localion licensees

\begin{tabular}{|c|c|c|c|c|c|c|}
\hline \multicolumn{7}{|c|}{$\begin{array}{c}\text { TABLE } 3.4 \\
\text { ANNUAL EXPOSURE INFORMATION FOR INDUSTRIAL. RADIOGRAPHERS } \\
1993-1095\end{array}$} \\
\hline \multirow[t]{2}{*}{ Year. } & Type of Ucense & $\begin{array}{c}\text { Number of } \\
\text { Licenses }\end{array}$ & $\begin{array}{c}\text { Number of } \\
\text { Monitored } \\
\text { Workers }\end{array}$ & $\begin{array}{l}\text { Workers } \\
\text { with } \\
\text { Meastrable } \\
\text { Dose }\end{array}$ & $\begin{array}{l}\text { Collective } \\
\text { Dose } \\
\text { (person- } \\
\text { csv, rem) }\end{array}$ & $\begin{array}{l}\text { Average } \\
\text { Measurable } \\
\text { Dose (c) } \\
\text { or rem) }\end{array}$ \\
\hline & single Locallon & 27 & 285 & 61 & $\theta$ & 0.10 \\
\hline \multirow[t]{3}{*}{1995} & Multiple Locations & $\$ 12$ & 3,245 & 2,404 & 1,332 & 0.55 \\
\hline & Total & 139 & 3,680 & 2,466 & 1,338 & 0.54 \\
\hline & single'Lootion & 29 & 330 & 89 & 44 & 0.60 \\
\hline \multirow[t]{3}{*}{1994} & Mutllple Localions & 111 & 2,900 & 2,262 & $1,37 t$ & 0.61 \\
\hline & Tolat & 139 & 3,230 & 2,351 & 1,415 & 0.60 \\
\hline & Single Location & 39 & 673 & 183 & 23 & 0.13 \\
\hline \multirow[t]{2}{*}{1003} & Mudtiple Locations & 137 & 4,046 & 2,824 & 1,572 & 0.58 \\
\hline & Total & 176 & 4,721 & 3,007 & 1,596 & 0.53 \\
\hline
\end{tabular}


is back down to $-20 \%$ of the average dose for multitlocation licensees. To see the contribution that each radiography licensee made to the total collective dose, a summery of the information reported by each of these licensees in 1995 is presented in Appendix A in descending order of average measurable dose.

High exposures in radiography can be directly attributable to the type and location of the radiography field work. For example, locations such as of drilling platforms and aerial tanks offer the radlographer little available shlelding. In these situations, there may not be an opportunity to use distence as a means of mininizing exposure and achieving ALARA. Atthough these licensed activitles usually result in average measurable doses that are higher than ofher licensees, they involve a relatively small number of exposed workers.

Figure 3.1 shows the number of workers with measurable dose per licensee, the total collective dose per licensee, and the average measurable dose per worker for both types of Industriat Radicgraphy facilities from 1973 through 1995.

\subsubsection{Manufacturting and Distribution Licenses, Type "A" Broad and Limited}

Manufacturer end Distributor llcenses are issued to allow the manufacture and distribution of radionuclides in verious forms for a number of diverse purposes. The products are usually distributed to persons specifically licensed by the NRC or an Agreement State. Type "A" Broad licenses are issued to larger organtzations that may use many difierent redlonucldes in many dfferent ways and that have a comprehensive radiation protection program. The Limalted licenses are usually Issued to smeller furms fequiring a more restrictive license. Some firms are medical suppliers that process, package, or distribute such products as diagnostic test kits, radioactive surgical implents, and tagged radiochemicals for use in medical research, olagnosis, and therapy. Limited firms are suppliers of industrial radionuclides and are inwolved in the processing, encepsulation, packaging, and distribution of the radionuclides that they have purchased in bulk quantifiles from production reactors and cyclotrons. Major products include gamma radlography sounces, cobatt irradiation sources, well-logging sources, sealed sources for gauges and smoke detectors, and rediochemicals for nonmedical research. However, only those NRC licensees thet possess or use at any one time specified quantities of the nuclides listed in paragraph 20.2206 (a)(7) are requared to submit reports to the NRC.

Table 3.5 presents the annual data that were reporied by the two types of licenseas for 1995 and the prewlous 2 years. Looking at the information shown separately for the Type "A" Broad and Limited licensees, it can be seen that the values of all of the parameters remain higher for the Broad licensees. However, when aftempting to examine trends in the date presented for this category of licensees, if should be noted that the types and quantities of radionuclides may fluctuate from year to year, and even during the year, so that some licensees may report dose data one year and not the next and may be included as a Broed ticensee one year and 
Average Measurable Dose per Worker (CSv)

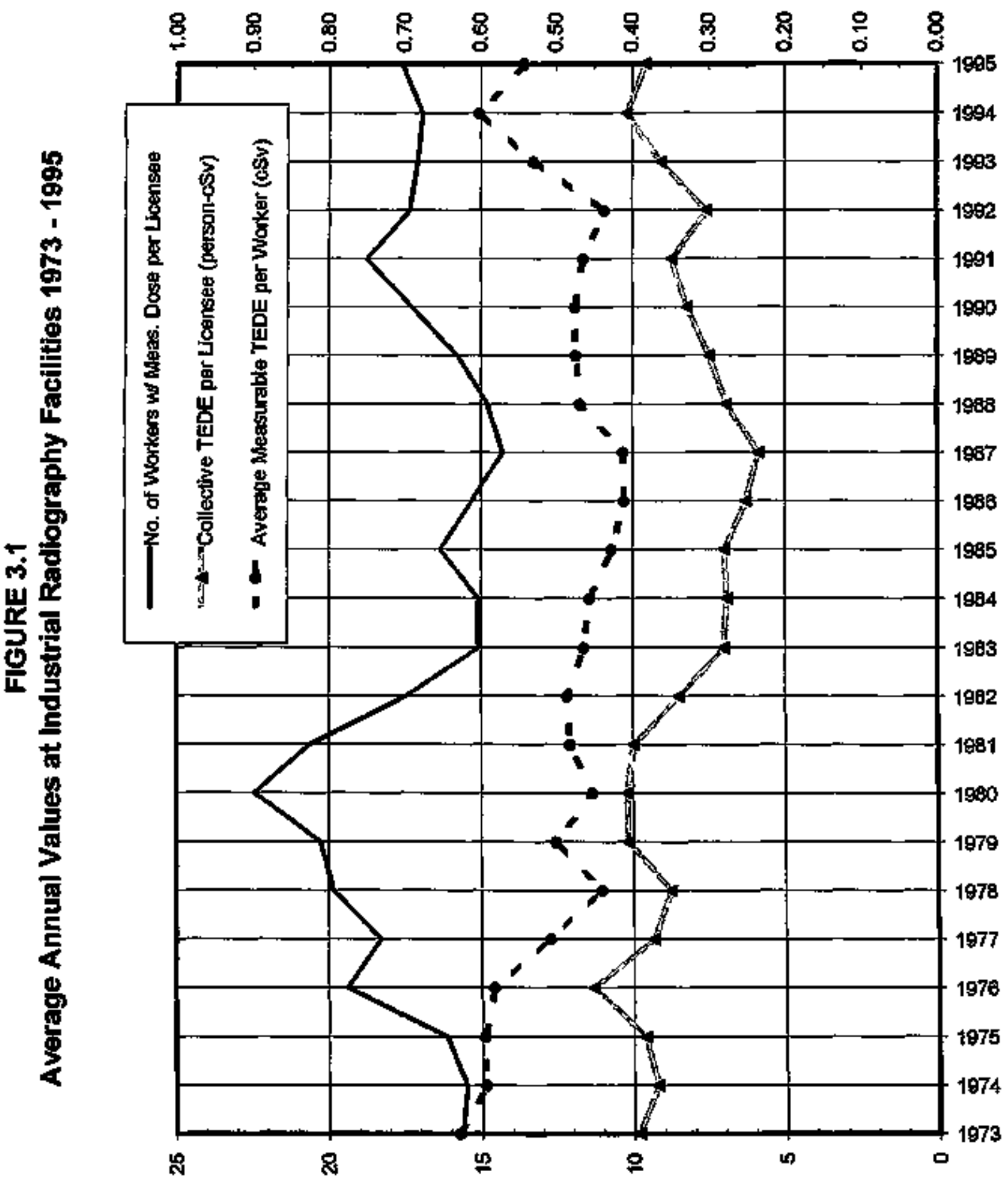

Number of Workers with Measurable Dose,

Collective TEDE per Licensee (person-cSV) 
a Limited licensee at other times. Because the number of reporting licensees is quite small, these fluctuations may have a significant impact on the vatues of the parameters.

Figure 3.2 shows the number of workers with measurable dose per licensee, the total collective dose per licensee, and the average measurable dose per worker for both Type "A" Broad and Limited Manufacturing and Distribulion facilities.

To see the contribution that each of these licensees made toward the total values of the number of workers monitored, number of workers, and collective dose, Appendix A lists the values of these parameters for each licensee in descending order of average measurable dose for 1995.

\begin{tabular}{|c|c|c|c|c|c|c|}
\hline \multicolumn{7}{|c|}{$\begin{array}{l}\text { ANNUAL EXPOSURE INFORMATION FOR MANUFACTURERS AND DISTRIBUTORS } \\
\qquad 1993-1995\end{array}$} \\
\hline Year & Type of Lcense & $\begin{array}{l}\text { Number of } \\
\text { Licenses }\end{array}$ & $\begin{array}{l}\text { Number of } \\
\text { Mon'tored } \\
\text { Workers }\end{array}$ & $\begin{array}{l}\text { Workers } \\
\text { With } \\
\text { Measumble } \\
\text { Dose }\end{array}$ & $\begin{array}{l}\text { Collective } \\
\text { Dose } \\
\text { (person- - } \\
\text { c5v, rem) }\end{array}$ & $\begin{array}{l}\text { Average } \\
\text { Measurable } \\
\text { Dose (cSv } \\
\text { or rem) }\end{array}$ \\
\hline \multirow{4}{*}{1995} & M \& D-A"Eroad & 7 & 2,016 & 909 & 557 & 0.61 \\
\hline & M \& D-Limited & 29 & 650 & $3+3$ & 38 & 0.12 \\
\hline & Total & 36 & 2,666 & 1,222 & 595 & 0.49 \\
\hline & M \& D-"A"-Eroad & 8 & 2,133 & 877 & 544 & 0.62 \\
\hline \multirow[t]{2}{*}{1994} & M \& D-Limited & 36 & 806 & 374 & 36 & 0.10 \\
\hline & Totel & 44 & 2,941 & 1,251 & 580 & 0.46 \\
\hline \multirow{3}{*}{1958} & M \& D-"*A'-Broad & 8 & 2,455 & 025 & 512 & 0.55 \\
\hline & $M \&$ D-limited & 60 & 2,458 & 1,329 & 168 & 0.13 \\
\hline & Total & 58 & 4,913 & 2,254 & 680 & 0.30 \\
\hline
\end{tabular}


Average Meas. Dose per Worker (cSv)

울

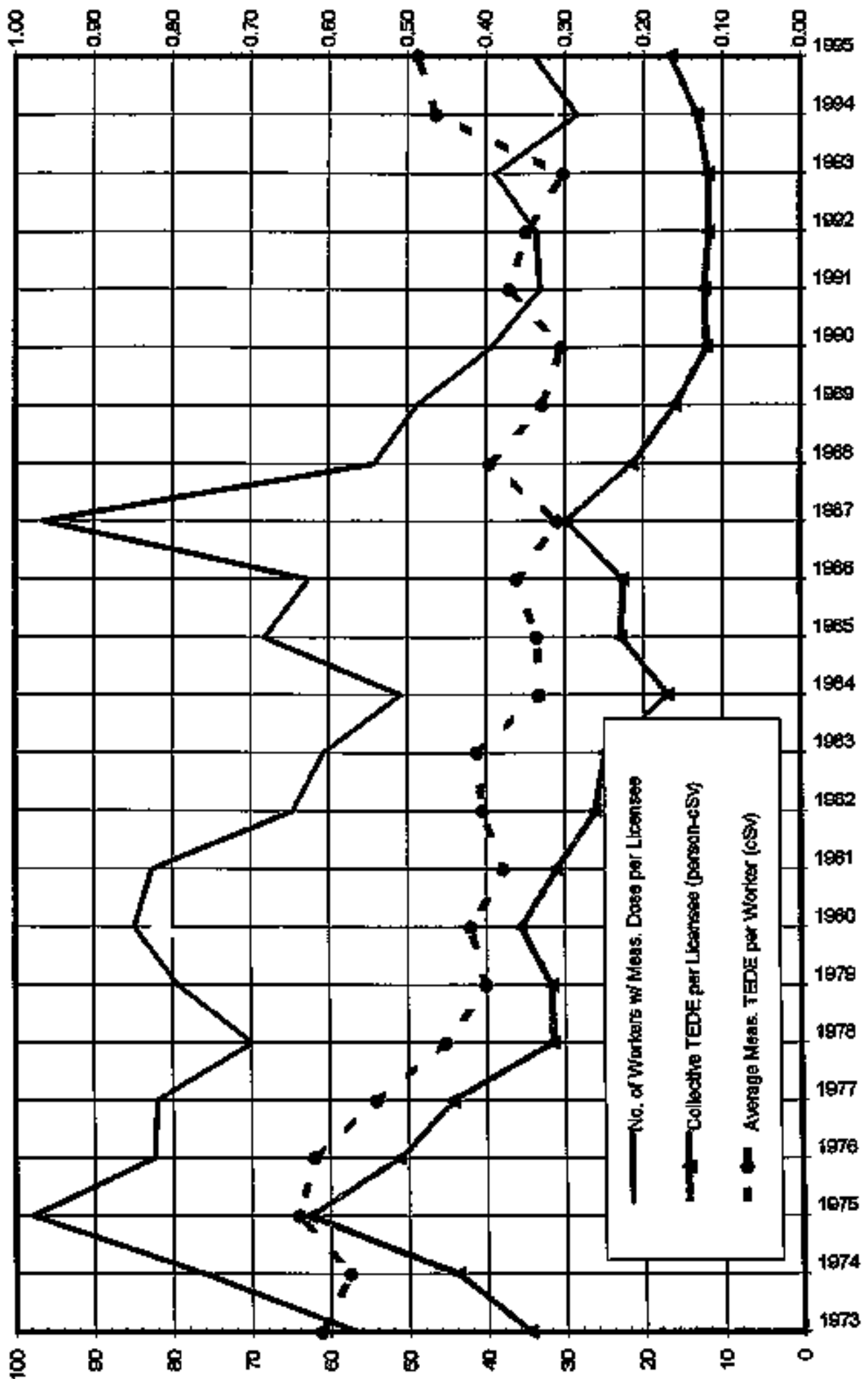

Number of Workers with Measurable Dose

Collective TEDE per Licensee (person-cSv) 


\subsubsection{Low-Level Waste Disposal Licenses}

Low-Leve] Waste Disposal licenses are Issued to allow the receipt, possession, and disposal of low-tevel radioective wastes at a land disposal facility. The licensee has the appropriate facilities to receive wastes from such places as hosplials and laboratories, store them for a short time, and dlspose of them in a properly prepared butial ground. The reensees in this category are located in and licensed by Agreement States that have primany regulatory authority over its activity. However, they also have an NRC license that covers certain speclal nuclear material they might receive. The annual dose reports submitted by these licensees include all doses recewed during the year regardless of whether they were the result of NRC or Agreement state licensed material.

The requirement for this category of NRC licensee to file annual reports became efitective in Jamuary 1983. There was only one licensee in this calegory in 1982 and 1983; however, there have been two licensees in this category since 1984. Table 3.1 summarizes the data reported for 1984 through 1995. Appendix A summarizes the exposure information reported by these two licensees in 1995.

Flgure 3.3 shows the number of workers with measurable dose per licensee, the total collective dose per licensee, and the average measurable dose per worker for Low-Level Waste Disposal facilities from 1982 through 1995. Because only two licensees have been involved in thls activity over the past 10 years, the numbers have remained fairly stable from 1984 through 1995.

\subsubsection{Independent Spent Fuel Storage Installation Licenses}

Independent Spent Fuel Storage Installation (ISFSI) licenses are issued to allow the possession of power reactor spent fuel and other associated radioactive materials for the purpose of storage of such fuel in an ISFSI. Here, the spent fuel, which has undergone at least 1 year of decery since being used as a source of energy in a power reactor, is provided interim storage, protection, and safeguarding for a limited time pending its uttimate disposal.

Eighteen licenses have been issued for these activities. Eleven are al nuclear power planis, aliowing on-site temporary storage of fuel. These licensees report the dose from fuel storage activities along with the dose from reactor operations at these siles. Out of the seven remaining licenses, only one is active and is located at a facility that is independent of a reactor site. Only this licensee is included in this analysis of ISFSI facilities for 1995. Appendix A summerizes the exposure information reported by this installetion. 
Average Meas. Dose per Worker (CSv)

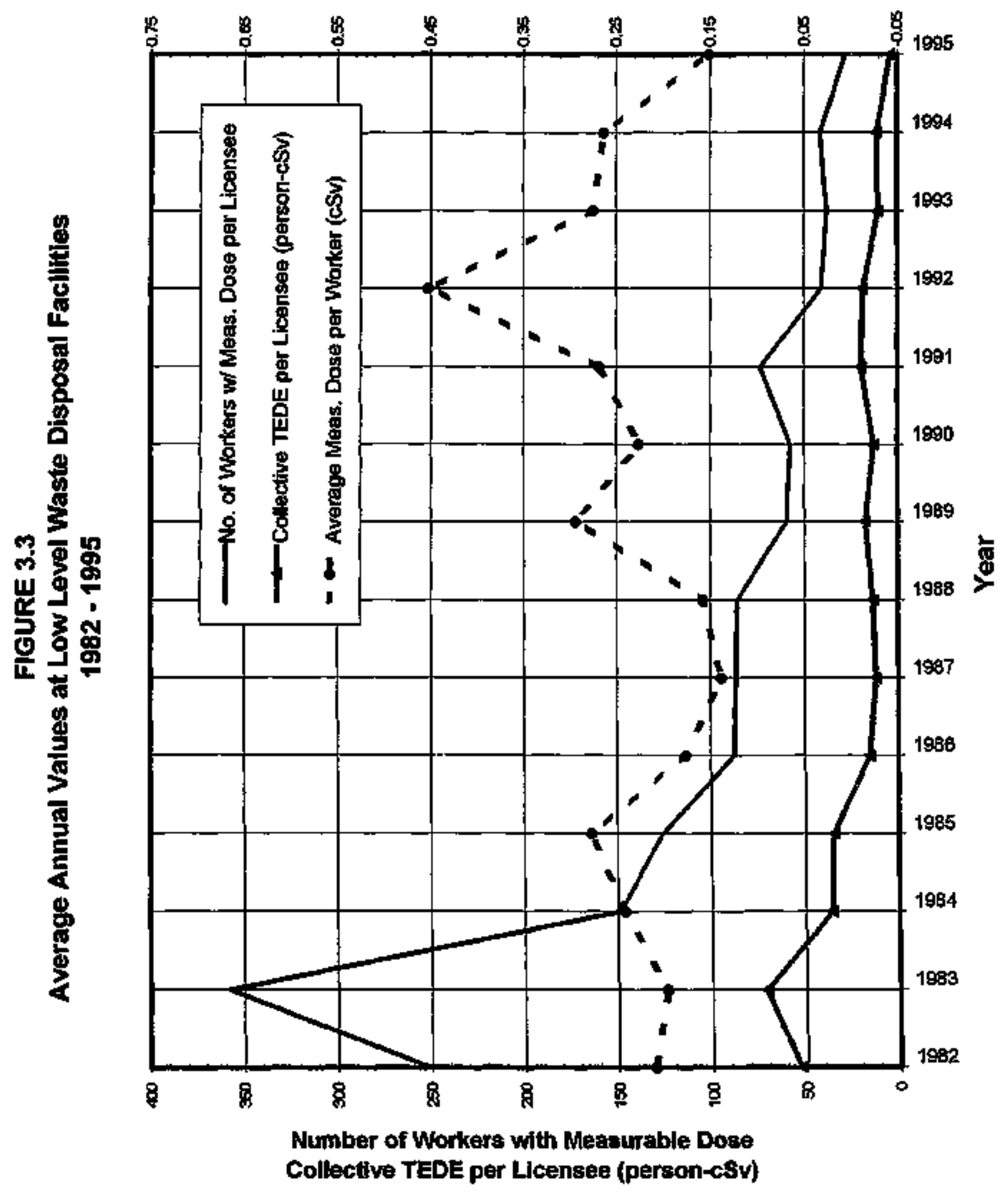


Figure 3,4 shows the number of workers with meesurable dose per llcensee, the total collectlve dose per licensee, and the average measurable dose per worker for Independent Spent Fuel Storage facilities. The large increase in the collective dose per licensee and number of workers per licensee was malnly because only one llcensee reported separately for 1994 and 1995, rather than the two ficensees that reported in prior years. The average measurable dose parameter is not based on the number of licensees and has also experienced a significant increase since 1993 .

\subsubsection{Fuel Fabrication and Processing Licenses}

The Fuel Fabrication and Processing licenses are issued to alfow the processing and fabrication of reactor fuels. In most uranium facilities where light water reactor fuels are processed, uranium hexaituoride enriched in the isotope U-235 is converted to solid uranium dioxide peilets and inserted into zirconium alloy tubes. The tubes are fabricated into fuel assemblies thal are shipped to nuclear power plants. Some facilities also perform chemical operatlons to recover the uranlum from scrap and olher off-specification materials. On a much smaller scale, fuel assemblies containing plutonitum oxide pellets can be similarly fabricated and used in reactors for experimental purposes. However, there are no NRC licensees engaged in this activily at this time.

Flgure 3.5 shows the number of workers with measurable dose per llcensee, the totel collective dose per licensee, and the average measurable dose per worker for Fuel Fabrication and Processing llcensees. In addition to the TEDE collective and average measurable dose, the Deep Dose Equivalent (DDE) collectlve dose and DDE average measurable dose are shown. Prior to 1994, only the "whole bochy" dose values were given, which were equivalent to the DDE. In 1994, the revised 10 CFR 20 went into effect, requining the calculation of the CEDE and the summation of the DDE and CEDE into the TEDE. For Fuel Fabrication facilties, the CEDE Is a signlficant contribution to the TEDE. To accurately reflect the exposure history for these facilttes, it was necessary to continue to plot the old whole body" extemal dose, now called DDE, in addition to the TEDE, which includes the CEDE contribution. The difference between the DDE and TEDE plots represents the CEDE contribution.

Appendix A lists each of the licensees reporting in 1995, with the number of workers monitored, the number of workers recoiving measurable extemal doses, and the collective dose for each licenses in descending order of everage measurable dose.

Table 3.6 shows that there were eight licensed Fuel Fabrication facilities in 1995. Several llcensees were involved in decontamination and decommissioning of their plutoniun facilities, and for several years the data for these licensees were shown in the "Decommissioning" category In Table 3.1. Because these facilities have ceased to fabricate piutonium fuel, they are not required to file annual reports and are no longer shown in the lables. 
Fuel Reprocessing licenses are issured to allow the separation of useable uranium and plutonlum from spent nuclear fuel. There was only one commerclal facility that was ever licensed to reprocess fuel, and it has been shut down since 1972. However, the licensee did some decontamination work and stored radloactive waste at the facllty for several years, and the annual report that was submitied aach year was usually grouped with those of the Fuel Fabricalors. In Febnuary 1982, the Department of Energy assumed possession and control of the reprocessing facillty to conduct waste solidificailon activities necessary for flnal decommissioning. Therefore, since 1982 the NRC Mcense hes been suspended, and no reports have been filed with the NRC.

\begin{tabular}{|c|c|c|c|c|c|c|c|c|}
\hline \multicolumn{9}{|c|}{$\begin{array}{c}\text { TABLE } 3.6 \\
\text { NNUAL EXPOSURE INFORMATION FOR FUEL FABRICATORS } \\
1998 \text { - } 1995\end{array}$} \\
\hline Year & Type of Licentse & $\begin{array}{l}\text { Number } \\
\text { of } \\
\text { Litenters }\end{array}$ & $\begin{array}{l}\text { Number of } \\
\text { Monitored } \\
\text { Workers }\end{array}$ & 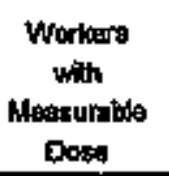 & $\begin{array}{c}\text { Codlectin } \\
\text { TEOE } \\
\text { (phront } \\
\text { OSk, rem) }\end{array}$ & 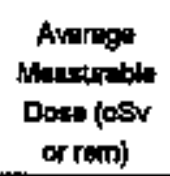 & $\begin{array}{l}\text { Collecthe } \\
\text { CEDE } \\
\text { (person-cSV, } \\
\text { rem) }\end{array}$ & $\begin{array}{l}\text { Average } \\
\text { CEDE } \\
\text { (CSY or rem) }\end{array}$ \\
\hline $195 s$ & Unantutn Fuel Fab & 8 & 4,106 & 2,959 & 1,217 & 0.41 & 990 & 0.33 \\
\hline 1994 & Urasium Fuel Fab & 8 & 3,506 & 2,847 & 1,147 & 0.40 & 867 & 0.30 \\
\hline 1993 & Uranlum Fuel Fab & $\mathbf{8}$ & 9,649 & 2,611 & 399 & 0.13 & NA & NA \\
\hline
\end{tabular}

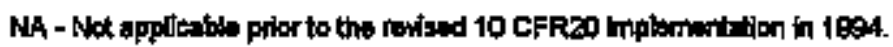


Average Meas. Dose per Worker (CSv)
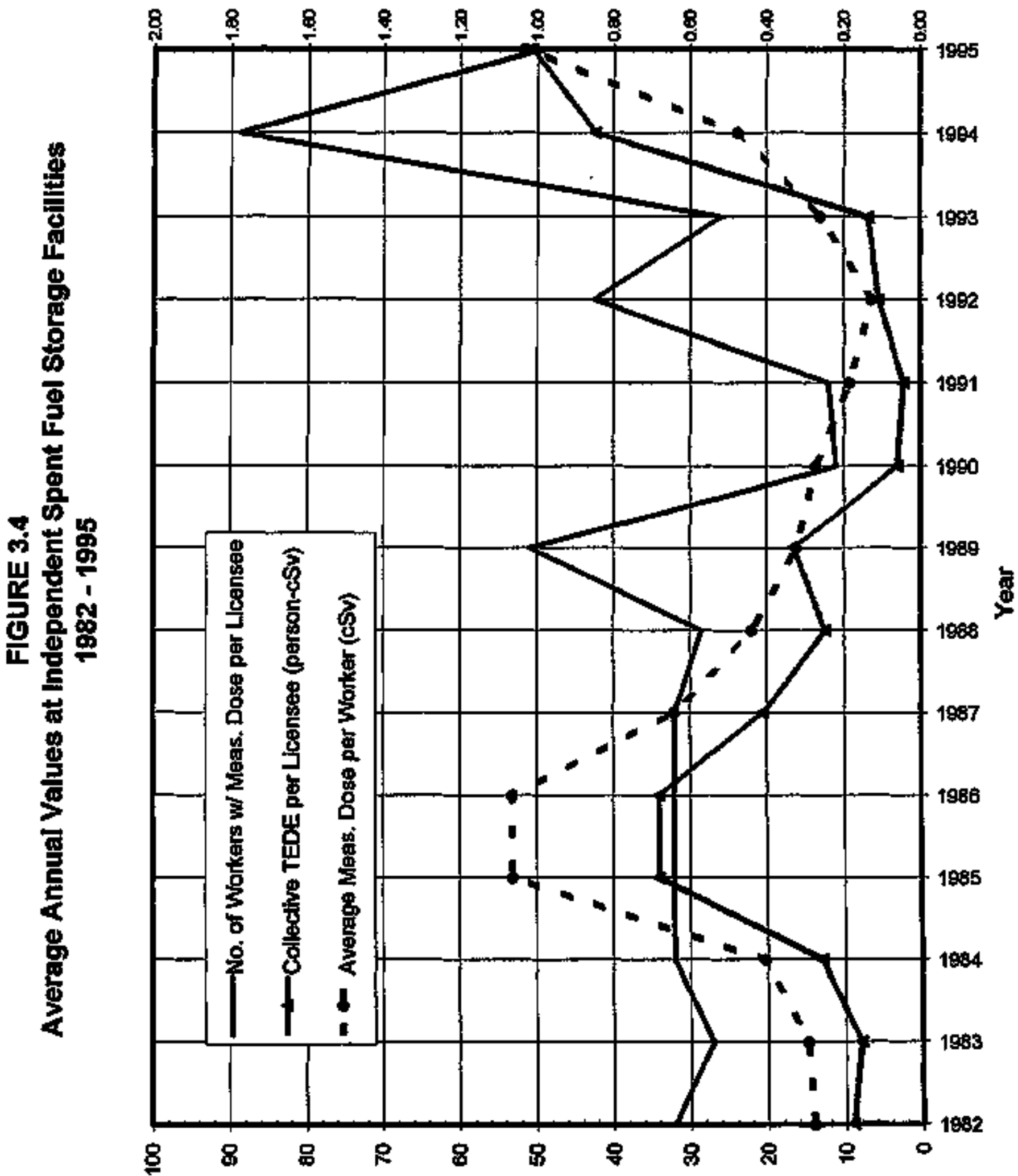

Number of Workers with Measurable Dose

Collective TEDE per Licenese (person-CSv) 
Average Meas. Dose per Worker (CSv)

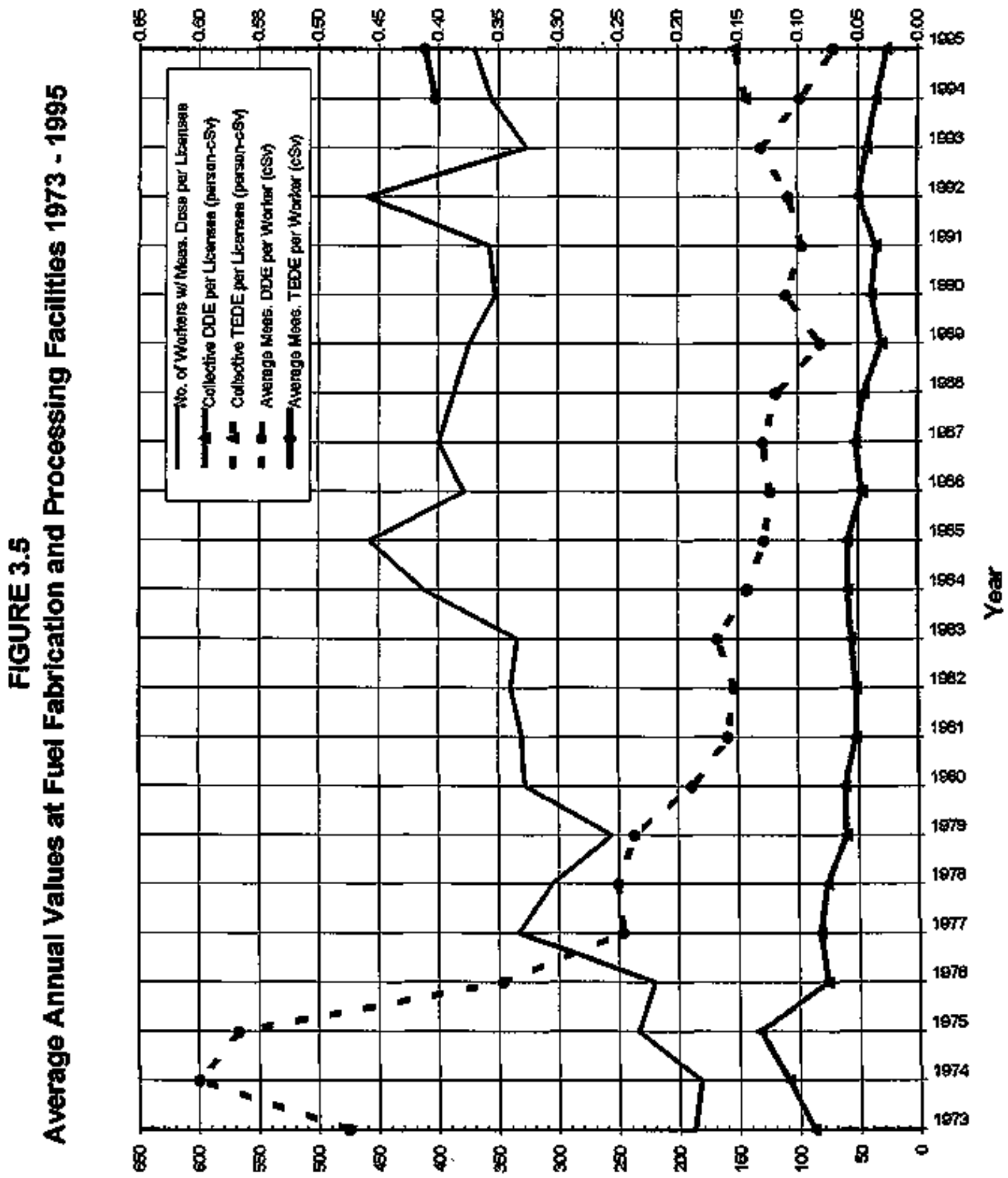

Number of Workers with Measurable Dose

Colleotive TEDE por Licensee (person-oSv) 


\subsubsection{Light-Water-Cooled Power Reactor (LWR) Licenses}

LWR licenses are issued to utilities to allow them to use special nuclear material in a reactor that produces heat to generate electriclty to be sold to consumers. There are two major types of commercial LWRs in the United States - pressurized water reactors (PWRs) and boiling waler reactors (eWRs) - each of which uses water as the primary coolant.

Table 3.1 shows the number of licensees, total number of monitored workers, the number of workers with measurable dose, the total collective dose, and average dose per worker for all reports received from reactor facilities that were in commercial operation for the years 1986 through 1995. This table includes reactors that may not have been in commercial operation for a full year. Date for 1988 through 1988 included all reactors that reported, even though some of them were shut down. Data for 1989 through 1995 do not include reactors that have been shut down. These figures have been adjusted for the multiple counting of transient workers (see Section 5). The reported dose distribution of workers monitored at each plant site is presented In alphabetlcal order by stte name in Appendix B.

More detailed presentalions and analyses of the annual exposure information reported by nuclear power facllities can be found in Sections 4 and 5.

\subsubsection{High-Temperature Gas-Cooled Power Reactor (HTGR) Licenses}

A license to operate a power reactor is issued to utilities to alkow them to use spectal nuclear material in a reactor to produce heat to generate electricity to be sold to consumers. In the HTGR, a gas, usually helium, is used as the primary coolant. Fort St. Vrain, near Greeley. Coloredo, was the only such reactor in operation in the United States. Fort St. Vrain shut down permanently in 1989. Table 3.7 shows the annual whole body doses incurred by workers al the plant. Since 1992, the doses have increased signiticantly because of decontamination and decommissioning operations. 
TABLE 3.7

ANNUAL EXPOSURE INFORMATION FOR FORT ST. VRAIN

1974 - 1995

No. of tindhickels in Ooso Ranges (csv or rem)

\begin{tabular}{|c|c|c|c|c|c|c|c|c|c|}
\hline Year & $\begin{array}{l}\text { No } \\
\text { Matas'blo } \\
\text { Dose }\end{array}$ & $\begin{array}{l}\text { Moas'ble } \\
\text { Dose } \\
<0.10\end{array}$ & $\begin{array}{l}0.10= \\
0.25\end{array}$ & $\begin{array}{l}0.25 \\
2.00\end{array}$ & $>2.0$ & $\begin{array}{l}\text { Whonber of } \\
\text { Monitorod } \\
\text { Workers }\end{array}$ & 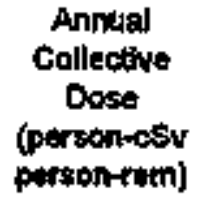 & $\begin{array}{l}\text { Gross } \\
\text { Eloctricity } \\
\text { Generatod } \\
\text { (NMW-yT) }\end{array}$ & $\begin{array}{c}\text { Average } \\
\text { Measurable } \\
\text { Dose (cSv or } \\
\text { rem) }\end{array}$ \\
\hline $\begin{array}{l}1974 \\
1975 \\
1976 \\
1977 \\
1978 \\
1979 \\
1980 \\
1981 \\
1982 \\
1983 \\
1984 \\
1985 \\
1986 \\
1987 \\
1988 \\
1989 \\
1990 \\
1991 \\
1992 \\
1998 \\
1994 \\
1995\end{array}$ & $\begin{array}{r}1,597 \\
1,263 \\
1,362 \\
946 \\
896 \\
1,149 \\
902 \\
1,056 \\
978 \\
965 \\
1,616 \\
1,929 \\
221 \\
155 \\
2388 \\
316 \\
228 \\
525 \\
520 \\
657 \\
390 \\
460\end{array}$ & $\begin{array}{r}63 \\
0 \\
25 \\
55 \\
34 \\
120 \\
57 \\
31 \\
22 \\
48 \\
62 \\
370 \\
66 \\
52 \\
24 \\
47 \\
30 \\
63 \\
144 \\
51 \\
89 \\
62\end{array}$ & $\begin{array}{r}1 \\
0 \\
0 \\
1 \\
0 \\
2 \\
1 \\
0 \\
0 \\
0 \\
8 \\
40 \\
4 \\
2 \\
0 \\
6 \\
0 \\
9 \\
36 \\
37 \\
33 \\
52\end{array}$ & $\begin{array}{r}0 \\
0 \\
0 \\
0 \\
0 \\
0 \\
0 \\
0 \\
0 \\
0 \\
0 \\
33 \\
0 \\
0 \\
0 \\
2 \\
0 \\
4 \\
34 \\
78 \\
79 \\
127\end{array}$ & $\begin{array}{l}0 \\
0 \\
0 \\
0 \\
0 \\
0 \\
0 \\
0 \\
0 \\
0 \\
0 \\
0 \\
0 \\
0 \\
0 \\
0 \\
0 \\
0 \\
0 \\
1 \\
4 \\
37\end{array}$ & $\begin{array}{r}1,661 \\
1,263 \\
1,387 \\
1,002 \\
930 \\
1,271 \\
980 \\
1,127 \\
1,000 \\
1,013 \\
1,686 \\
2,372 \\
291 \\
209 \\
262 \\
371 \\
256 \\
601 \\
734 \\
823 \\
591 \\
738\end{array}$ & $\begin{array}{r}3.3 \\
0.0 \\
1.3 \\
2.9 \\
1.7 \\
6.4 \\
3.0 \\
1.0 \\
0.4 \\
1.0 \\
3.0 \\
35.0 \\
1.8 \\
1.2 \\
0.7 \\
2.7 \\
0.6 \\
5.4 \\
25.4 \\
75.2 \\
78.0 \\
210.3\end{array}$ & $\begin{array}{r}0.0 \\
0.0 \\
2.8 \\
29.8 \\
75.7 \\
28.6 \\
83.2 \\
93.6 \\
72.6 \\
94.4 \\
10.9 \\
3.8 \\
9.7 \\
23.8 \\
81.8 \\
0.0 \\
0.0 \\
0.0 \\
0.0 \\
0.0 \\
0.0 \\
0.0\end{array}$ & $\begin{array}{l}0.05 \\
0.00 \\
0.05 \\
0.05 \\
0.05 \\
0.05 \\
0.05 \\
0.03 \\
0.02 \\
0.02 \\
0.04 \\
0.03 \\
0.03 \\
0.02 \\
0.03 \\
0.05 \\
0.02 \\
0.07 \\
0.12 \\
0.45 \\
0.39 \\
0.75\end{array}$ \\
\hline
\end{tabular}




\subsection{Summary of Intake Date by License Categony}

With the revision of 10 CFR 20 in 1994, licensees were required to report additional data to the NRC concerning intakes of radiogctive material. Licensees were required to list for each intake the radionuclide that was taken into the body, the pulmonary clearance class, Intake mode, and amount of the intake in microcurles. An NRC Form 5 report containing this information is required to be completed and submitted to the NRC under 10 CFR 20.2206.

Tables 3.8 and 3.9 summarize the intake deta reported to the NRC during 1995. The data are calegorized by licensee type and are listed in order of radionuclide and pulmonary clearance class. Table 3.8 tists the intakes where the mode of intake into the body was recorded as ingestion. Table 3.9 lists the intakes where the mode of intake was inhaletion from ambient airborne radioactive material in the workplace. The pumonary clearance cless is recorded as $D, W$, or $Y$ corresponding to its clearance half-ilme in the order of days, weeks, or years from the putmonary region of the hung Into the blood and gestrointestinal tract. The amount of material taken into the boty is given in microcurtes, $\theta$ unik of measure of the quantity of radioactive material. For each category of licensee, the maximum number of Intake records and the maximum intake is highlighted in the table in bold for ease of reference. 


\begin{tabular}{|c|c|c|c|c|}
\hline \multicolumn{5}{|c|}{$\begin{array}{c}\text { TABLE } 3.8 \\
\text { INTAKE BY LICENSEE TYPE AND RADIONUCLIDE } \\
\text { WODE OF INTAKE - WOESTION } \\
1995\end{array}$} \\
\hline Licengee Type & Progpam Code & Radlonuctide & $\begin{array}{l}\text { Nhmber of } \\
\text { Intake } \\
\text { Records* }\end{array}$ & $\begin{array}{l}\text { Intake in } \\
\text { microcinies }\end{array}$ \\
\hline Nuclear Phamacies & 02500 & TC-9eM & 25 & 17.692 \\
\hline Reactors & $\begin{array}{l}41111 \\
41111 \\
41111 \\
41111 \\
41111 \\
41111 \\
41111 \\
4111 t \\
41111 \\
41111 \\
41111 \\
41111\end{array}$ & $\begin{array}{l}C 0-58 \\
C O-60 \\
C R-51 \\
C S-134 \\
C S-137 \\
\text { I-131 } \\
M N-54 \\
N B-85 \\
\text { RU-103 } \\
\text { SB-425 } \\
\text { ZN-65 } \\
\text { ZR-95 }\end{array}$ & $\begin{array}{r}18 \\
26 \\
1 \\
1 \\
1 \\
3 \\
10 \\
11 \\
1 \\
1 \\
4 \\
10\end{array}$ & $\begin{array}{l}2.521 \\
5.216 \\
0.130 \\
0.001 \\
1.700 \\
0.026 \\
0.649 \\
0.368 \\
0.010 \\
0.065 \\
0.325 \\
0.304\end{array}$ \\
\hline
\end{tabular}

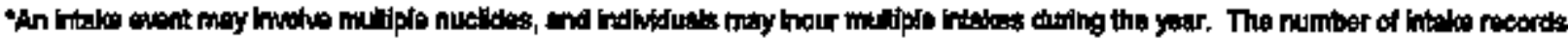

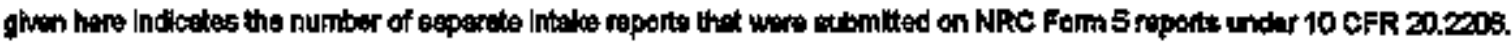




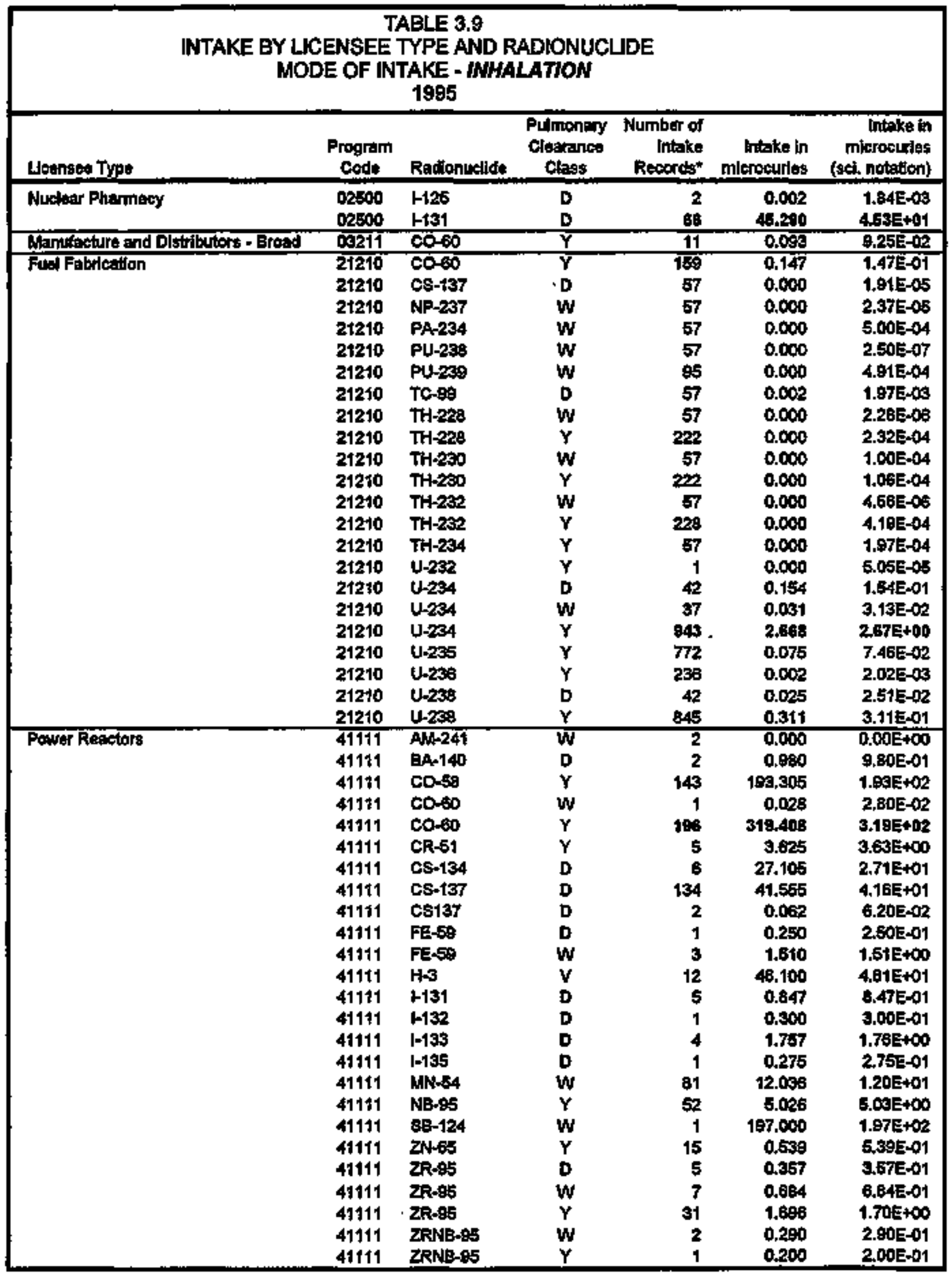

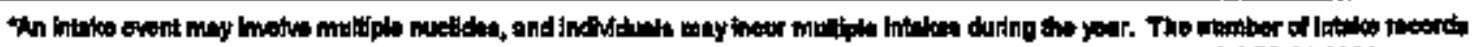

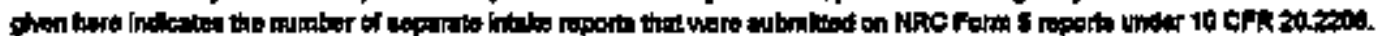




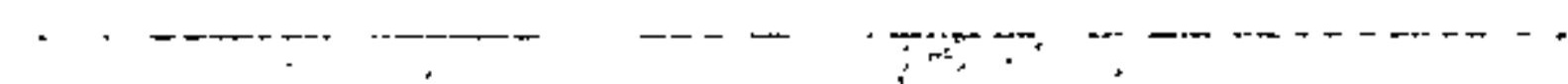




\section{COMMERCIAL LIGHT WATER REACTORS - FURTHER ANALYSIS}

\subsection{Introduction}

General trends in occupattonal radiation exposures at nuclear power reactors are best evalusted within the context of other pertinent information. In this chapter, some of the tebles and eppendices that summarize exposure data also show the type, capacily, and age of the reaction; the emount of electricity generated; the types of workers being exposed; and the sort of tasks being performed. Exposure data are then presented as a function of these dala.

\subsection{Desinition of Terms and Sources of Data}

\section{4,2.1 Number of Reactors}

The number of reactors shown in Tables 4.1, 4.2, and 4.3 is the number of BWRs, PWRs, and LWRs, respectively, that had been in commencial operation for at least 1 full year as of December 31 of each of the Indicated years. This is the number of reactors on which the average number of workers with measurable dose and average colloctive dose per reactor is based. Excluded are those reactors thet hed been in commercied operation for less than 12 months during the first year and reactors that have been permanently defueled. This yields consenative values for many of the averages shown in the tables. The dale that each reactor was dectared to be in commercial operation was taken from Reference 14.

Three Mile Istand (TMl) 2 had been included in the compllation of data for commercially operating reactors through 1988 even though the reactor hes been shut down since the 1979 accident and has been in the.process of defueling and decommissioning since that fime. TMI 2 has not been included in the deta analysis since 1988. Deta for this reactor, however, will be listed in Appendices B, C, D and E for reforence purposes.

\subsubsection{Electric Energy Generated}

The eleciric energy generated in gross megawatt-years (MW-yr) each year by each facilly is shown in Appendix $C$ and graphically represented in Appendlx $E$. This number was oblelned by dhttaing the gross megawatt-hours of elactrictily ennually produced by each facllity by 8,760 , the number of hours in the year, except for leap years when the number ls 8,784 hours. The gross electrichy generated (n megawatt-years) that is presented in Tables 4.1, 4.2, and 4.3 is the summation of electricity generated by the number of reactors Included in each year. These sums ere dwided by the number of reactors included in each year to yield the everage amount of electric energy generated per reactor, which is also stown in Tebles 4.1, 4.2, and 4.3. The number of gross megawatt-hours of electricity produced each year was found in Reference 14. 
TABLE 4.1

\begin{tabular}{|c|c|c|c|c|c|c|c|c|c|c|c|}
\hline & & Uning & INFur & TION R & $\begin{array}{r}\text { PORTED } \\
197\end{array}$ & $\begin{array}{l}\text { YY CONA } \\
-1995\end{array}$ & RCIAL B & ING W & REA & DRS & \\
\hline Year & $\begin{array}{l}\text { Nember } \\
\text { of } \\
\text { Reoters } \\
\text { netuded }\end{array}$ & 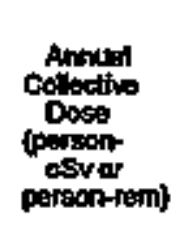 & 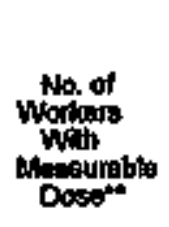 & 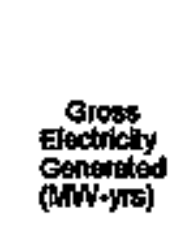 & 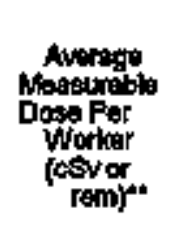 & 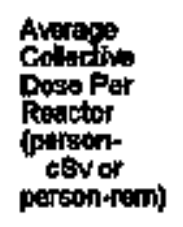 & 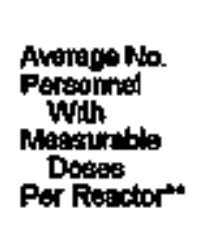 & 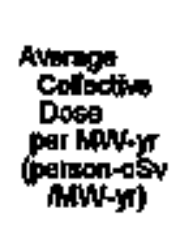 & 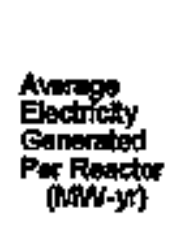 & 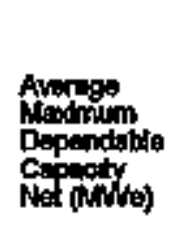 & 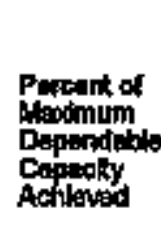 \\
\hline 1973 & 12 & 4,564 & 5,340 & $3,393,9$ & 0.85 & 390 & 445 & 1.34 & 203 & 430 & $65 \%$ \\
\hline 1974 & 14 & 7,005 & 8,769 & $4,000.2$ & 0.81 & 507 & 626 & 1.75 & 290 & 485 & $60 \%$ \\
\hline 1975 & 18 & 12,611 & 14,607 & $5,786,4$ & 0.88 & 701 & 812 & 2.18 & 321 & 595 & $54 \%$ \\
\hline 1978 & 2 & 12,300 & 16,604 & $8,137.9$ & 0.74 & 559 & 755 & 1.51 & 370 & 690 & $59 \%$ \\
\hline 1977 & $\mathbf{2 3}$ & 19,041 & 21,388 & $9,102.5$ & 0.89 & 628 & 050 & 2.09 & 396 & $6 \% 7$ & $62 \%$ \\
\hline 1978 & 25 & 16,273 & 20,276 & $11,856.0$ & 0.76 & 611 & 811 & 1.29 & 474 & 660 & $72 \%$ \\
\hline 1979 & 25 & 18,325 & 25,245 & $11,671.0$ & 0.73 & 733 & 1,010 & 1.57 & 467 & 660 & $71 \%$ \\
\hline 1990 & 26 & 29,590 & 34,094 & $10,868.2$ & 0,87 & 1,136 & 1,341 & 2.72 & 418 & 669 & $63 \%$ \\
\hline 1981 & 28 & 25,472 & 34,755 & $10,899.2$ & 0.73 & 980 & 1,397 & 2.34 & 419 & 660 & $63 \%$ \\
\hline 1882 & 26 & 24,437 & 32,295 & $10,614,6$ & 0.76 & 040 & 1,240 & 2.30 & 400 & 669 & $62 \%$ \\
\hline 1983 & 26 & 27,465 & 33,473 & $9,730.1$ & 0.82 & 1,056 & 1,287 & 2.82 & 374 & 663 & $56 \%$ \\
\hline 1984 & 27 & 27,097 & 41,105 & $10,019.2$ & 0.68 & 1,004 & 1,522 & 2.70 & 371 & 754 & $49 \%$ \\
\hline 1085 & 29 & 20,573 & 38,237 & $12,294,0$ & 0.54 & 709 & 1,319 & 1.67 & 424 & 775 & $55 \%$ \\
\hline 1988 & 30 & 19,349 & 37,928 & $12,102.1$ & 0.51 & 645 & 1,264 & 1.60 & 403 & 788 & $31 \%$ \\
\hline 1987 & 32 & 16,717 & 41,737 & $16,109.0$ & 0.40 & 522 & 1,304 & 1.11 & 472 & 832 & $57 \%$ \\
\hline 1988 & 34 & 17,903 & 40,305 & $16,635,4$ & 0.45 & 529 & 1,185 & 1.08 & 490 & 845 & $58 \%$ \\
\hline 1889 & 36 & 15,549 & 44,390 & $17,543.5$ & 0.35 & 432 & 1,202 & 0.89 & 487 & 857 & $57 \%$ \\
\hline 1990 & 37 & 15,760 & 41,577 & $21,366.1$ & 0.38 & 428 & 1,124 & 0.74 & 577 & 862 & $67 \%$ \\
\hline 1091 & 37 & 12,005 & 38,492 & $21,505,8$ & 0.31 & 324 & 1,040 & 0.58 & 681 & 860 & $68 \%$ \\
\hline 1992 & 37 & 13,309 & 42,005 & $20,592.2$ & 0.32 & 380 & 1,138 & 0.65 & 557 & 859 & $65 \%$ \\
\hline 1993 & 37 & 12,221 & 39,352 & $21,905.6$ & 0.31 & 330 & 1,084 & 0.56 & 594 & 798 & $74 \%$ \\
\hline 1994 & 37 & 12,092 & 39,108 & $22,139.0$ & 0.31 & 327 & 1,057 & 0.55 & 698 & 801 & $75 \%$ \\
\hline 1995 & 37 & 9,467 & 35,659 & $24,737.0$ & 0.27 & 256 & 964 & 0,38 & 669 & 835 & $80 \%$ \\
\hline
\end{tabular}

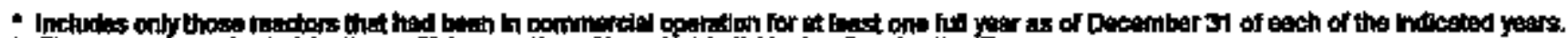

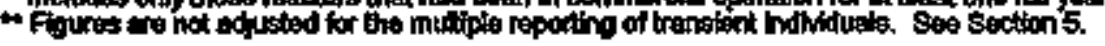


TABLE 4.2

SUMMARY OF INFORMATION REPORTED BY COMMERCIAL PRESSURIZED WATER REACTORS

1973 - 1995

\begin{tabular}{|c|c|c|c|c|c|c|c|c|c|c|c|}
\hline Year & 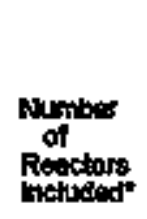 & 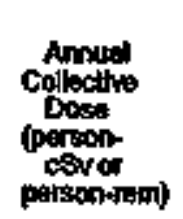 & 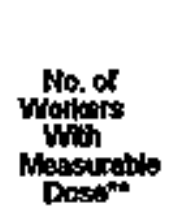 & 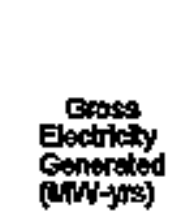 & 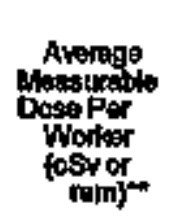 & 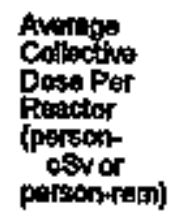 & 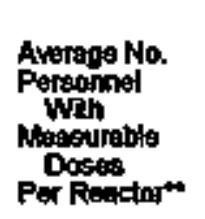 & 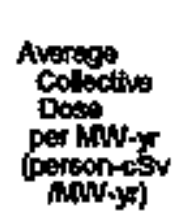 & 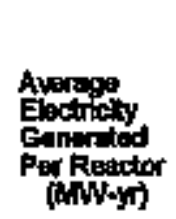 & 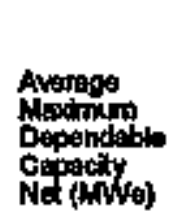 & 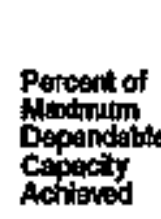 \\
\hline 1973 & 12 & 9,398 & 9,440 & $3,770.2$ & 1,00 & 783 & 787 & 2.49 & $3+4$ & 544 & $58 \%$ \\
\hline 1974 & 19 & 6,555 & 9,370 & 6.590 .7 & 0.70 & 345 & 493 & 1.00 & 344 & 591 & $58 \%$ \\
\hline 1975 & 26 & 8,266 & 10,884 & $11,982.5$ & 0.76 & 318 & 419 & 0.69 & 461 & 647 & $71 \%$ \\
\hline 1976 & 30 & 13,807 & 17,6883 & $13,325.0$ & 0.79 & 460 & 588 & 1.04 & 444 & 701 & $63 \%$ \\
\hline 1977 & 34 & 13,467 & 20,878 & $17,345,8$ & 0.65 & 396 & 614 & 0.78 & 510 & 688 & $74 \%$ \\
\hline 1978 & 39 & 16,528 & 25,700 & $19,840.5$ & 0.64 & 424 & 659 & 0.83 & 500 & 706 & $72 \%$ \\
\hline 1979 & 42 & 21,657 & 39,828 & $18,255.0$ & 0.56 & 516 & 924 & 1.19 & 435 & 746 & $58 \%$ \\
\hline 1980 & 42 & 24,267 & 46,237 & $18,280.3$ & 0.52 & 578 & 1,101 & 1.33 & 435 & 746 & $60 \%$ \\
\hline 1981 & 44 & 28,673 & 47,351 & $20,553.7$ & 0.61 & 652 & 1,076 & 1.40 & 467 & 752 & $62 \%$ \\
\hline 1982 & $4 B$ & 27,754 & 52,146 & $22,140,6$ & 0.53 & 578 & 1,096 & 1.25 & 461 & 777 & $59 \%$ \\
\hline 1983 & 49 & 29,017 & 52,173 & $28,195.5$ & 0.56 & 592 & 1,065 & 1.25 & 473 & 785 & $60 \%$ \\
\hline 1984. & s1 & 28,138 & 66,994 & $26,478.4$ & 0.49 & 552 & 1.118 & 1.08 & 519 & 600 & $64 \%$ \\
\hline 1985 & $\infty$ & 22,469 & 54,633 & $29,470,7$ & 0.41 & 424 & 1,031 & 0.76 & 656 & 820 & $66 \%$ \\
\hline 1896 & 60 & 23,032 & 62,995 & $33,593.0$ & 0,37 & 384 & 1,050 & 0.69 & 560 & 878 & $64 \%$ \\
\hline 1987 & 64 & 23,694 & 62,597 & $37,007,3$ & 0.38 & 370 & 978 & 0.64 & 578 & 900 & $64 \%$ \\
\hline 1986 & 68 & 22,760 & 62,921 & $42,929.7$ & 0.36 & 355 & 025 & 0.53 & 631 & 605 & $71 \%$ \\
\hline 1989 & 71 & 20,381 & 63,894 & $44,679.5$ & 0,32 & 287 & 900 & 0.46 & 629 & 897 & $70 \%$ \\
\hline 1990 & 73 & 20,812 & $67, \infty 81$ & $46,955.6$ & 0.31 & 285 & $\theta 1 \theta$ & 0.44 & 643 & 907 & $71 \%$ \\
\hline 1991 & 74 & 16,510 & 60,269 & $51,942,6$ & 0.27 & 223 & 814 & 0.32 & 702 & 013 & $77 \%$ \\
\hline 1992 & 73 & 15,985 & 61,048 & $59,419.8$ & 0.26 & 219 & 838 & 0.30 & 732 & 923 & $79 \%$ \\
\hline 1993 & 71 & 14,142 & 56,586 & $50,480.6$ & 0.25 & 199 & 797 & 0.28 & 711 & 945 & $75 \%$ \\
\hline 1994 & 72 & 9,6003 & 44,766 & $54,618,3$ & 0.21 & 133 & 622 & 0.18 & 769 & 1032 & B1\% \\
\hline 1995 & 72 & 12,207 & 51,867 & $55,825.1$ & 0.24 & 170 & 720 & 0.22 & 775 & 93 & $83 \%$ \\
\hline
\end{tabular}

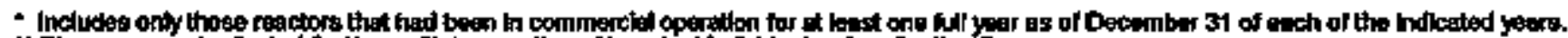

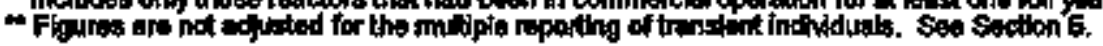


TABLE 4.3

\begin{tabular}{|c|c|c|c|c|c|c|c|c|c|c|c|}
\hline & & SUN & OF IN & MATIO: & $\begin{array}{r}\text { REPORT } \\
197\end{array}$ & $\begin{array}{l}\text { D BY CO } \\
1995\end{array}$ & AMERCIA & LIGHT WA & TER REA & TORS & \\
\hline Yat & 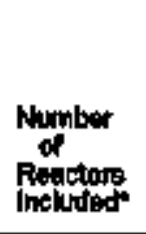 & 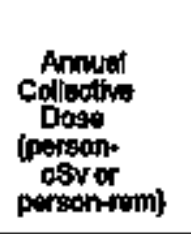 & $\begin{array}{l}\text { Na. of } \\
\text { Workere } \\
\text { Wilh } \\
\text { Mogatirable } \\
\text { Dosesen }\end{array}$ & 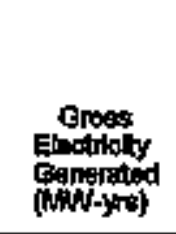 & 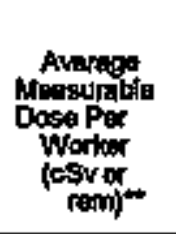 & 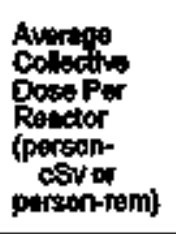 & 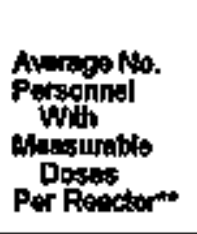 & 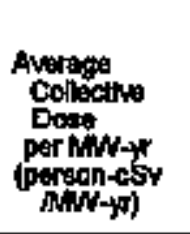 & 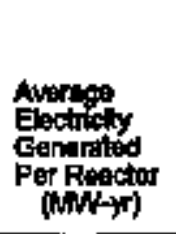 & 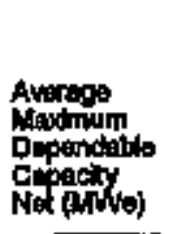 & 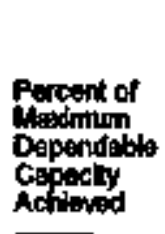 \\
\hline 1973 & 24 & 13,962 & 14,780 & $7,164.1$ & 0.94 & 682 & 616 & 1.95 & 299 & 491 & $61 \%$ \\
\hline 1974 & 33 & 13,650 & 18,139 & $10,590.9$ & 0.75 & 414 & 650 & 1.29 & 321 & 546 & $59 \%$ \\
\hline 1975 & 44 & 20,879 & 25,491 & $17,768.9$ & 0.82 & 475 & 579 & 1.18 & 404 & 628 & $65 \%$ \\
\hline 1976 & 52 & 28,107 & 34,192 & $21,462.9$ & 0.76 & 502 & 658 & 1.22 & 413 & 671 & $62 \%$ \\
\hline 1977 & 57 & 32,500 & 42,266 & $26,448.3$ & 0.77 & 570 & 742 & 1.23 & 464 & 667 & $70 \%$ \\
\hline 1978 & 64 & 31,801 & 45,978 & $31,696.5$ & 0.69 & 497 & 718 & 1.00 & 495 & 688 & $72 \%$ \\
\hline 1979 & 67 & 39,982 & 64,073 & $29,926,0$ & 0.62 & 597 & 956 & 1.34 & 447 & 714 & $63 \%$ \\
\hline 1080 & 68 & 53,797 & 80,381 & $29,157.5$ & 0.67 & 791 & 1,181 & 1.85 & 429 & 714 & $00 \%$ \\
\hline 1981 & 70 & 54,145 & 82,106 & $31,452.9$ & 0.66 & 774 & 1,173 & 1.72 & 449 & 719 & $63 \%$ \\
\hline 1982 & 74 & 52,191 & 84,381 & $32,765.2$ & 0.62 & 705 & 1,140 & 1.69 & 443 & 737 & $60 \%$ \\
\hline 1983 & 75 & 56,472 & 85,646 & $32,925.6$ & 0,66 & 753 & 1,142 & 1.72 & 439 & 743 & $59 \%$ \\
\hline 1984 & 78 & 55,235 & 98,099 & $36,497.6$ & 0.56 & 708 & 1,258 & 1.51 & 468 & 780 & $59 \%$ \\
\hline 1986 & 82 & 43,042 & 92,870 & $41,754.7$ & 0.46 & 525 & 1,133 & 1.03 & 500 & 804 & $63 \%$ \\
\hline 1986 & 90 & 42,381 & 100,023 & $45,605.1$ & 0.42 & 471 & 1,121 & 0.93 & 508 & 647 & $60 \%$ \\
\hline 1987 & 96 & 40,401 & 104,334 & $52,116.3$ & 0.39 & 421 & 1,087 & 0.78 & 543 & 877 & $62 \%$ \\
\hline 1988 & 102 & 40,769 & 103,228 & $59,596.1$ & 0.39 & 400 & 1,012 & 0.68 & 584 & $87 t$ & $67 \%$ \\
\hline 1989 & 107 & 35,900 & 109,254 & $62,223.0$ & 0.33 & 338 & 1,012 & 0.58 & 582 & 893 & $66 \%$ \\
\hline 1990 & 110 & 36,592 & 106,658 & $68,291.7$ & 0.34 & 333 & 988 & 0.54 & 621 & 892 & $70 \%$ \\
\hline 1901 & 111 & 28,515 & 98,781 & $73,448,4$ & 0.29 & 257 & 890 & 0.39 & 662 & 895 & $74 \%$ \\
\hline 1992 & 110 & 29,294 & 108,143 & 74,0120 & 0.28 & 268 & 238 & 0.40 & 673 & 901 & $75 \%$ \\
\hline 1993 & 108 & 26,363 & 95,940 & $72,476.2$ & 0.27 & 244 & 868 & 0,36 & 671 & 895 & $75 \%$ \\
\hline 1994 & 109 & 21,695 & 83,874 & $76,757.3$ & 0.26 & 199 & 769 & 0.28 & 704 & 888 & $79 \%$ \\
\hline 1995 & 100 & 21,674 & 87,526 & $80,562.1$ & 0.25 & 199 & 803 & 0.27 & 739 & 800 & $82 \%$ \\
\hline
\end{tabular}

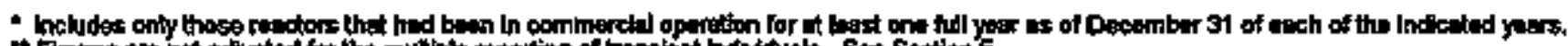

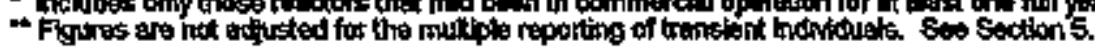




\subsubsection{Collective Dose per Megawatt-Yeer}

The number of megawatt-years of electricity genereted was used in detemining the ratio of the average value of the annual collectlve dose (TEDE) to the number of megawatt-years of electricity generated. The ratio was calculated by dividing the total collective dose in person-cSv (person-rem) by the gross electric energy generated in megawatt-years and is a measure of the dose houred by workers et power plants in relation to the gross electric energy produced. This ratio was also calculated for each reactor site and is presented in Tables 4.1, 4.2, and 4.3 and Appendtax $C$.

\subsubsection{Average Maximum Dependable Capecity}

Average maximum dependable capacity, shown in Tables 4.1, 4.2, and 4.3, was found by dividing the sum of the net maximum dependable capactles of the reactors in megawats (net MWe) by the number of reaclors Included each yoar. The net maximum dependable capacity is defined as the gross electrical output as measured at the output terminals of the lurbine generator during the most restrictlve seasonal condltions, less the normal station service bads. This "capacly" of each plant was found in Reference 14, and it is shown for each site in Appendlx C.

\section{2,5 Percent of Maximum Dependeble Capacily Achieved}

The percent of maximum dependable capscity achieved is shown for all LWRs in Table 4.3. This parameter gives an indication of the overall power generation performance of LWRs as compared to the maximum capacity that could be obtalned in a glven year. It is calculated by dviding the average electriclty generated per reactor by the average maximum dependable capacity for each year.

From 1973 to 1978 this Indicator exhlbited an increasing trend as a number of new reactors began producing power at higher efficiencies. Following the accident at Three Mile Island, reactor operations personnel concentrated on improving satety systems and complying with the new regulations for these systems. During thls time period, from 1979 to 1987 , the percent of maximum dependable capacity remained around $61 \%$. Following the completion of most of these mandated repairs, reactors have increased the percent of maximum dependable capacity from $62 \%$ in 1987 to $82 \%$ in 1995 , a gain of $20 \%$ in 8 yoars. 


\section{4,3 Annual TEDE Distributions}

Table 4.4 summarizes the distrlbution of the annuel TEDE doses received by workers at al commercial LWRs during each of the years 1977 through 1995. This distribution is the sum of the annual dose disirlbutlons reported by each licensed LWR each year. As previously mentioned, the distribution reported by each LWR site for 1995 is shown in Appendix B. Table 4.4 shows the reported dose distributions comected for the number of translent workers that were reported by more than one site (see Section 5). The total collective dose decreased by $<1 \%$ to a value of 21,674 person-csv (person-rem) in 1995. The value of CR decreased to a vakue of 0.06. The large decrease from 1993 to 1994 is primarly because of the change in methodology by which the CR value is determined (see Section 3.1.8). In 1994 and 1995, the CR value was determined directly from the individual radietion exposure records submitted under 10 CFR 20.2206 (Form 5) rather than calculeting the value indirectly from the stattstical dose distributlon summary as in prior years. This is the eleventh consecutive year that the value of CR has been $<0.50$.

\subsection{Averege Annuel TEDE Doses}

Some of the data presented in Tables 4.1, 4.2, and 4.3 are graphlcally displayed in Figure 4.1, where it can be seen that the average collective dose and average number of warkers per BWR have been higher than those for PWRs since 1974 and that the values of both parameters, in general, continued to rise at both types of facilties until 1983. Between 1983 and 1995, the average collective dose per reactor dropped by $74 \%$. In 1995, the collective dose per reactor for PWRs increased by $28 \%$ to 170 person-cSv (person-rem). The collectlve dose per reactor for BWRs decreased by $22 \%$ from 327 person-cSv (person-rem) in 1994, to 256 person-cSv (person-rem) in 1995. The overall collective dose per reactor for LWRs remained the same at 199 person-cSv (person-rem) In 1995. The number of workers with measurabte dose per reactor has decreased to 964 for BWRs but Increesed to 720 for PWRs in 1995. The overall decreasing trend in everage reactor collective doses since 1983 indicates thet licensees ere continuing to successfully implement ALARA dose reduction feetures at their faclitites.

Flgures 4.2 and 4.3 ere plots of most of the other information that is given in Tables 4.1, 4.2, and 4.3. The value for the fotal collective dose for all LWRs decreased by $<1 \%$ from a value of 21,695 person-cSv (person-rem) in 1994 to 21,674 person-cSv (person-nem) in 1995.

Together with the increase in the number of workers with measurable dose, this resulted in the average measurable dose per worker decreasing to $0.25 \mathrm{cSv}$ (rem) in 1995 . Figure 4.2 shows that in 1995 the gross electrictly generated increased to an all-time high of $80,562 \mathrm{MW}-\mathrm{yr}$. 
TABLE 4.4

SUMMARY DISTRIBUTION OF ANNUAL WHOLE BODY DOSES AT COMMERCIAL LIGHT WATER REACTORS"

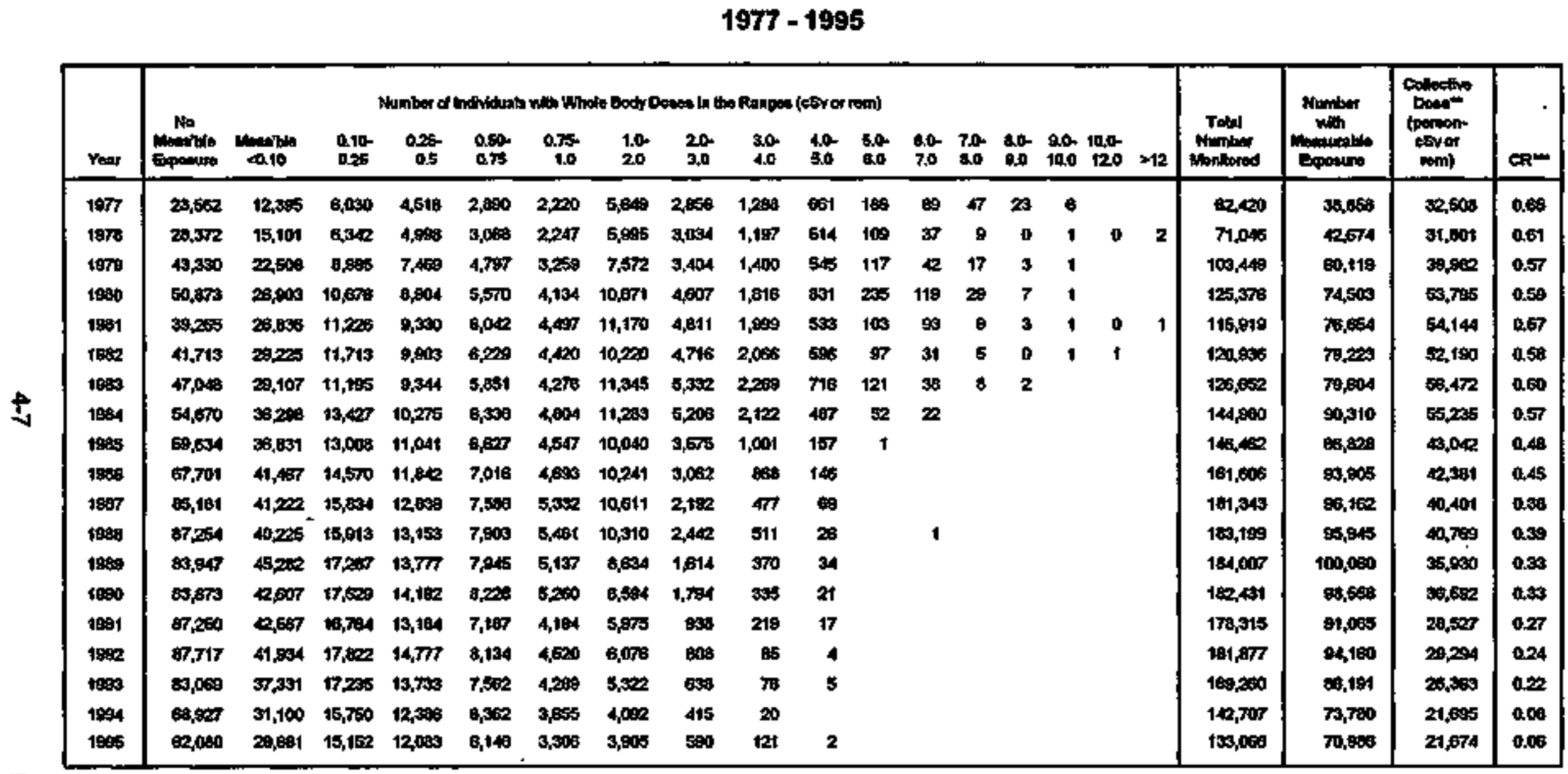

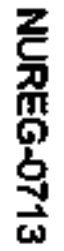

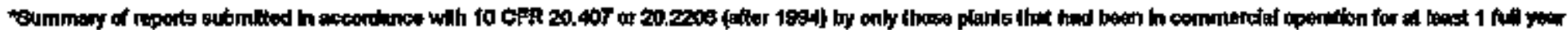

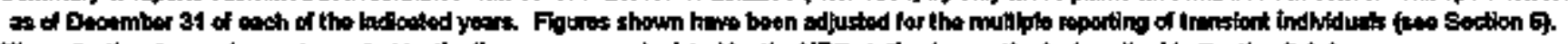

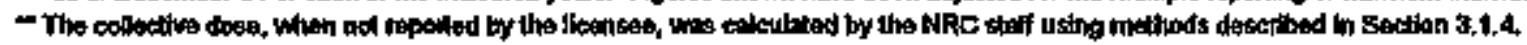

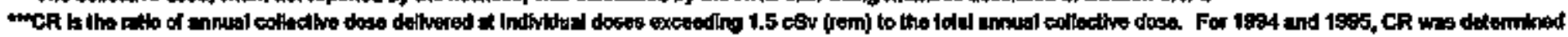

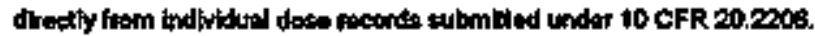




\section{Figure 4.1}

\section{Average Collocthe Dose and Number of Workers per Reactor 1973 - 1995}

\section{Avarago Anausal Collotive Dose}

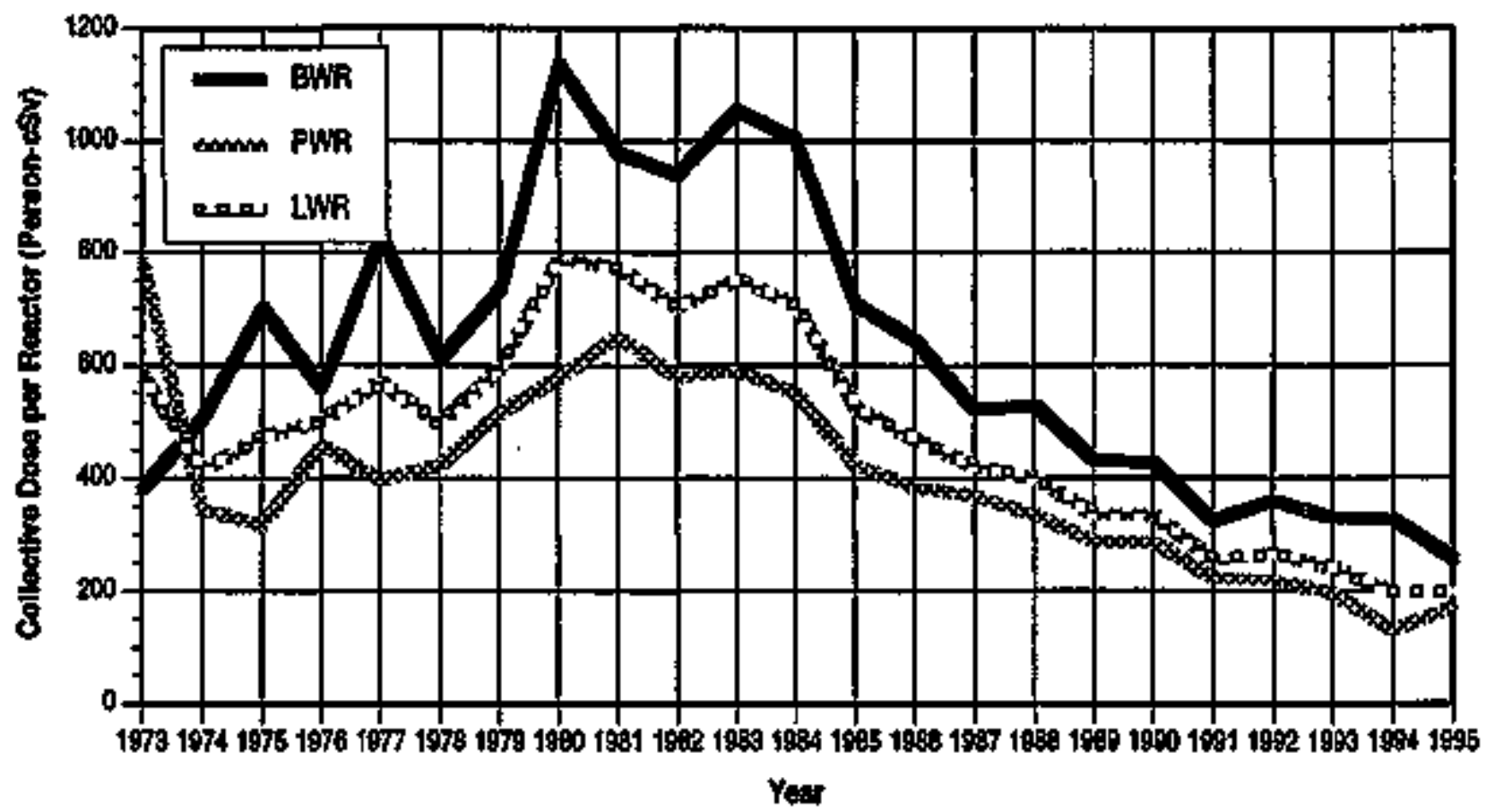

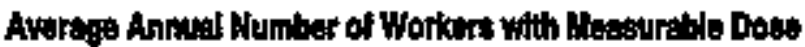

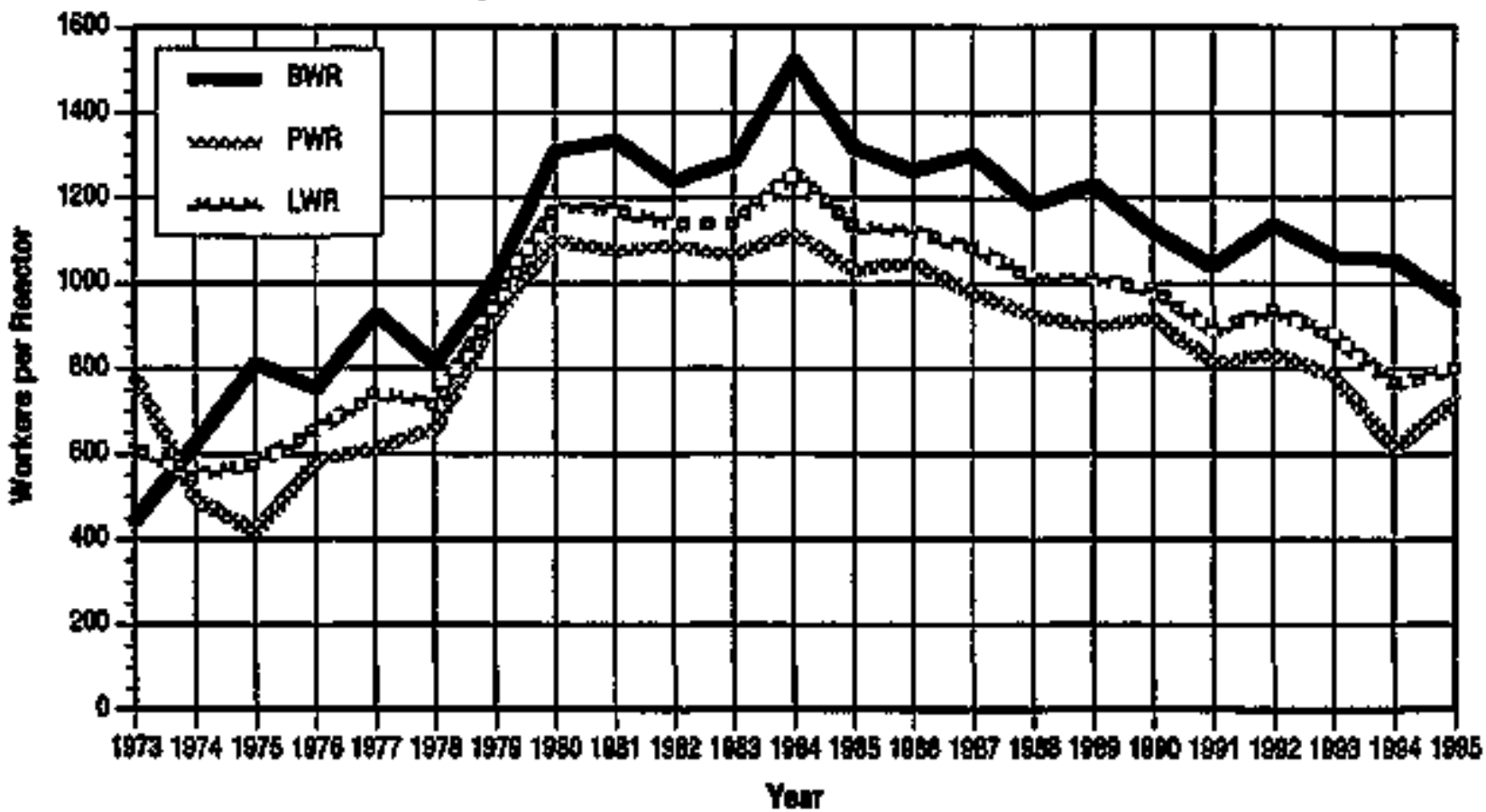

NUREG-0713 
Figure 4.2

Number of Operating Roactors and Gross Eleotrickty Generated 1973 - 1995

\section{Wunter of Opereiting Riautore}

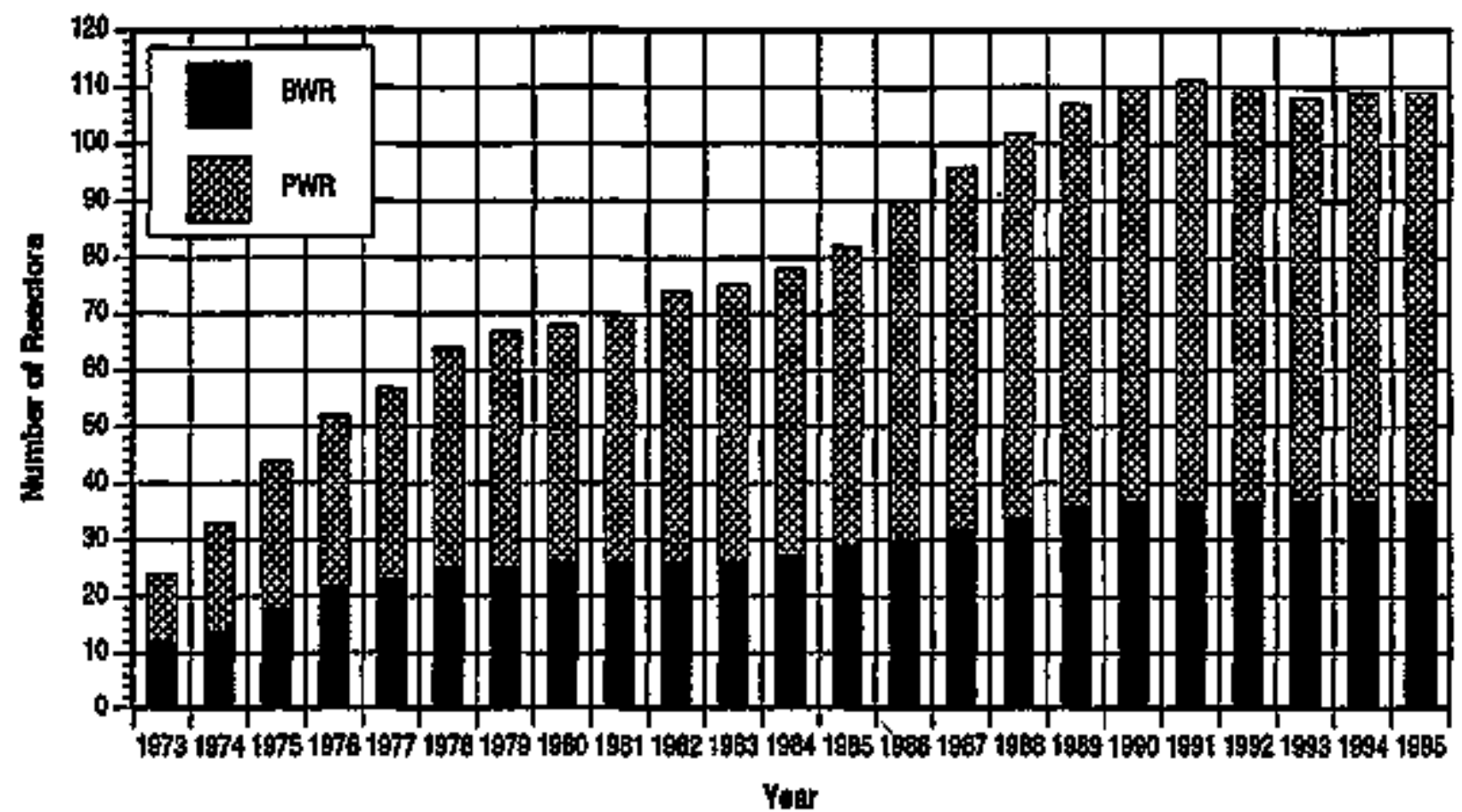

Gross Eloctelty Emorated

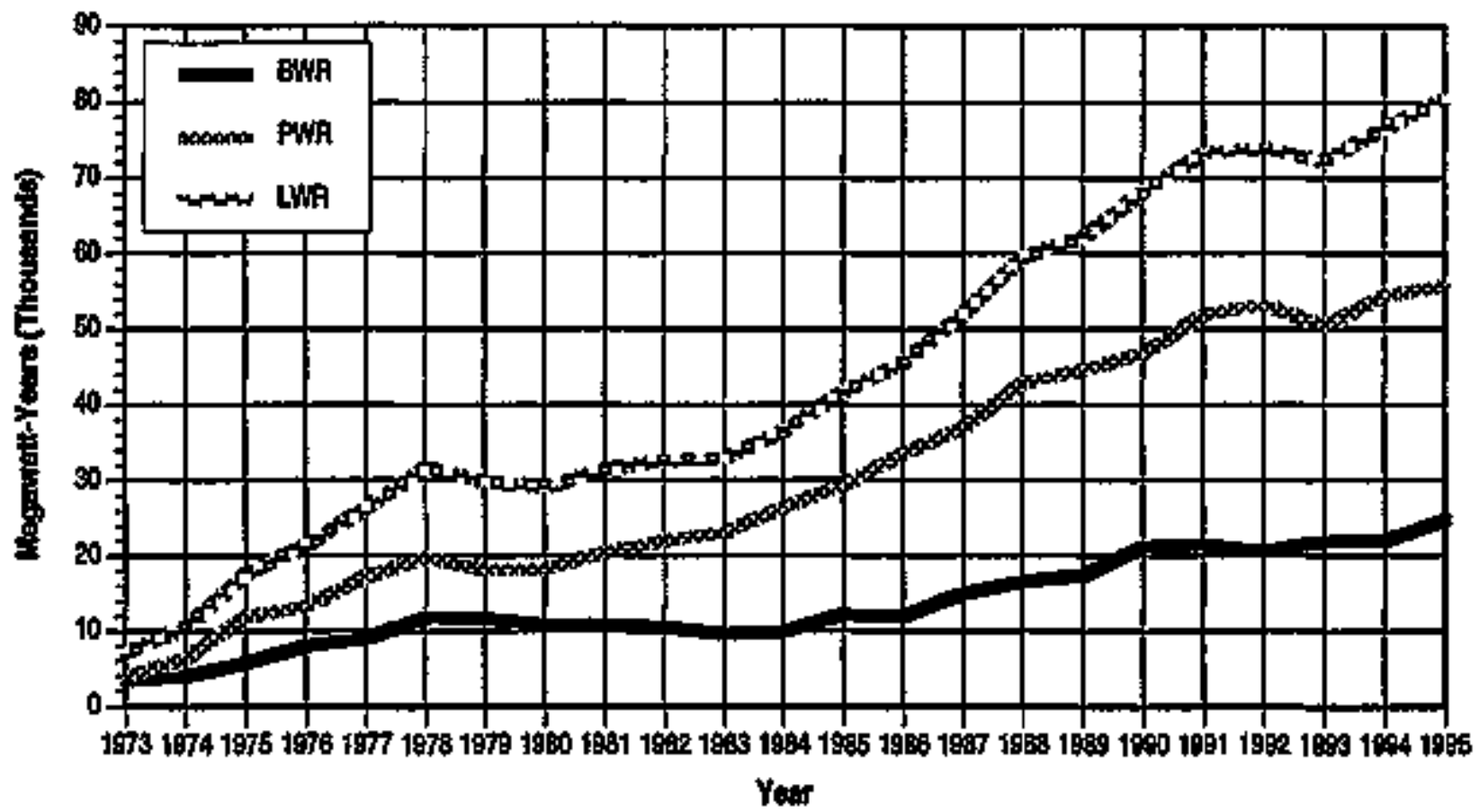


Figure 4.3

Average Measurable Dose per Worker and Coliective Dose per ilogawatt-Year 1973-1995

\section{Averags Meacureble Dowe per Worktor}

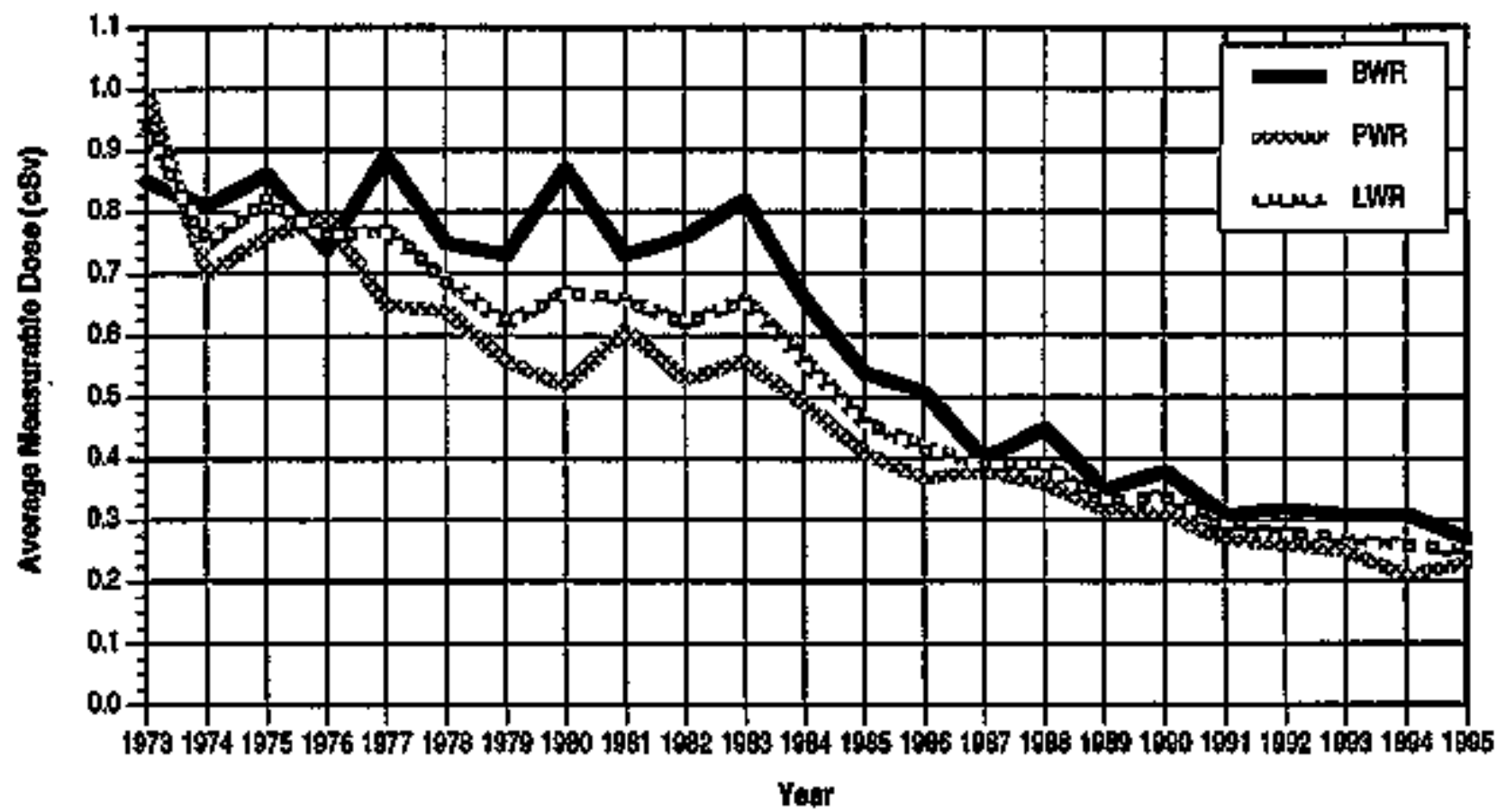

Collectlye Dose per Hegewatt-Yes

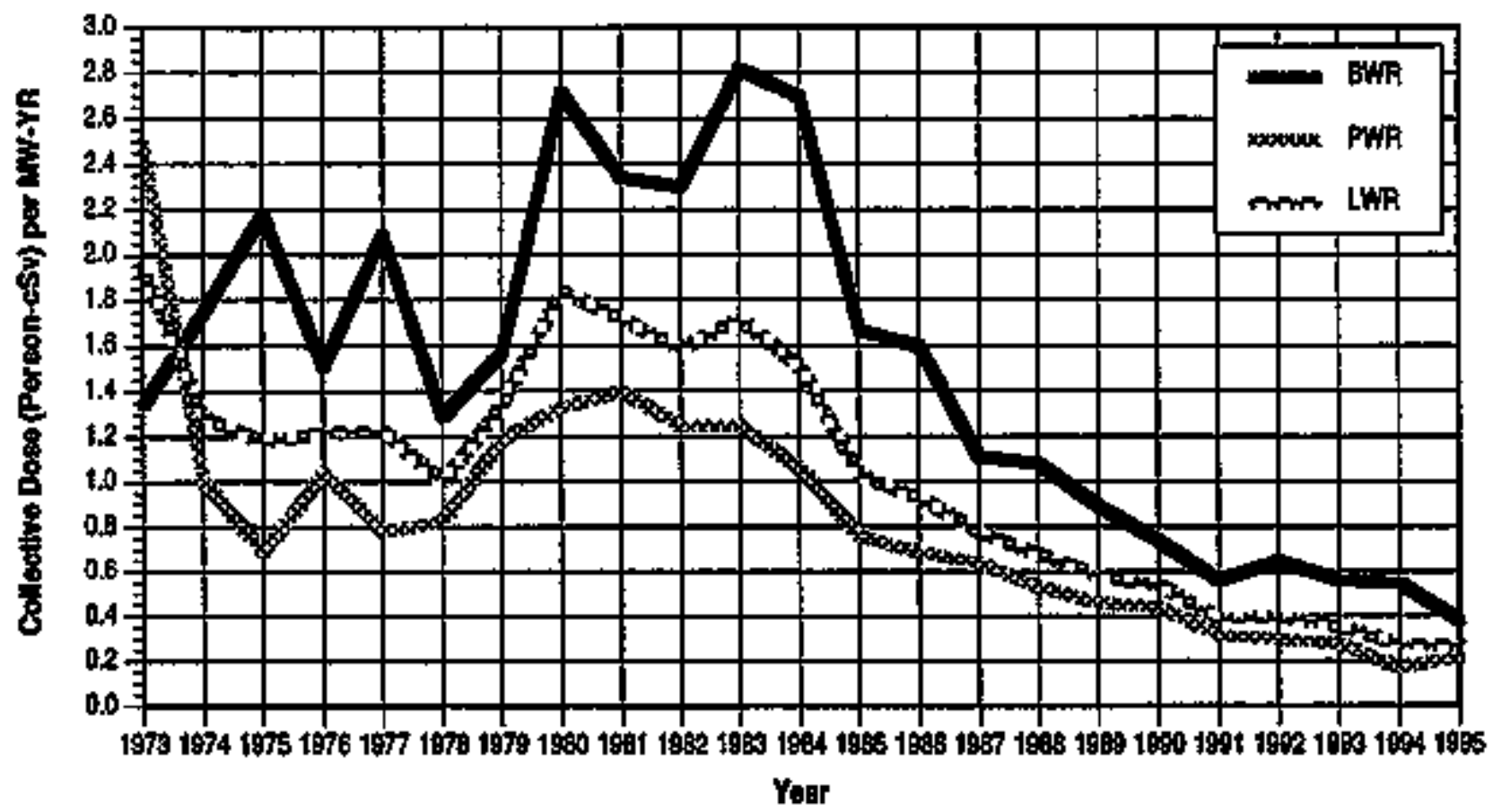


The fluctualions in the parameters for the years following the accldent at the TMI plant in 1979 may reflect some of the Impact that this incident had on the nuclear power industry. The decrease seen in dose trends since 1983 may be attribulable to several factors. Utinties have completed most of the tasks Inttlated as a result of the lessons leamed from the Three Mile Istand accident, and they are increasing efforts to avoid and reduce exposure. The importance of exposure control and the concept of keeping exposures to ALARA levels is continually being stressed, and most utllities have estebllshed programs to collect and share hofomalion relative to tasks, techniques, and expostures.

To further assist in the identificalion of any trends that might exist, Figure 4.4 displays the average and median values of the collective dose per reactor for BWRs and for PWRs for the years 1973 through 1995. The ranges of the values reported each year are-shown by the vertical thes with a small bar at each end marking the two extreme values. The rectangles Indlcate the range of values of the collective dose exhibited by those plants ranked in the twenty-fith through the seventy-fith percentiles. Since the median values usually are not as greatly affected by the extreme values of the collective doses, they do not normally fluctuate as much from year to year as do the average values. The median collectlve dose for PWRs expertenced an increase trom 135 person-cSv (person-rem) in 1994 to 146 person-cSv (person-rem) in 1995. At BWRs, the median fluctuates more from year to year, and in 1995 the median collective dose decreased to 244 persan-eSv (person-rem). Figure 4.4 also shows that, in 1995, 50\% of the PWRs reported collective doses between 102 and 207 person-cSv (person-rem) while 50\% of the BWRs reported collective doses between 136 and 357 person-c5v (person-rem). Nearly every year, the median collective dose is less than the average, which indicates that the collective dose for most plants is less than the average collective dose per reactor (the value that is widely quoled). 


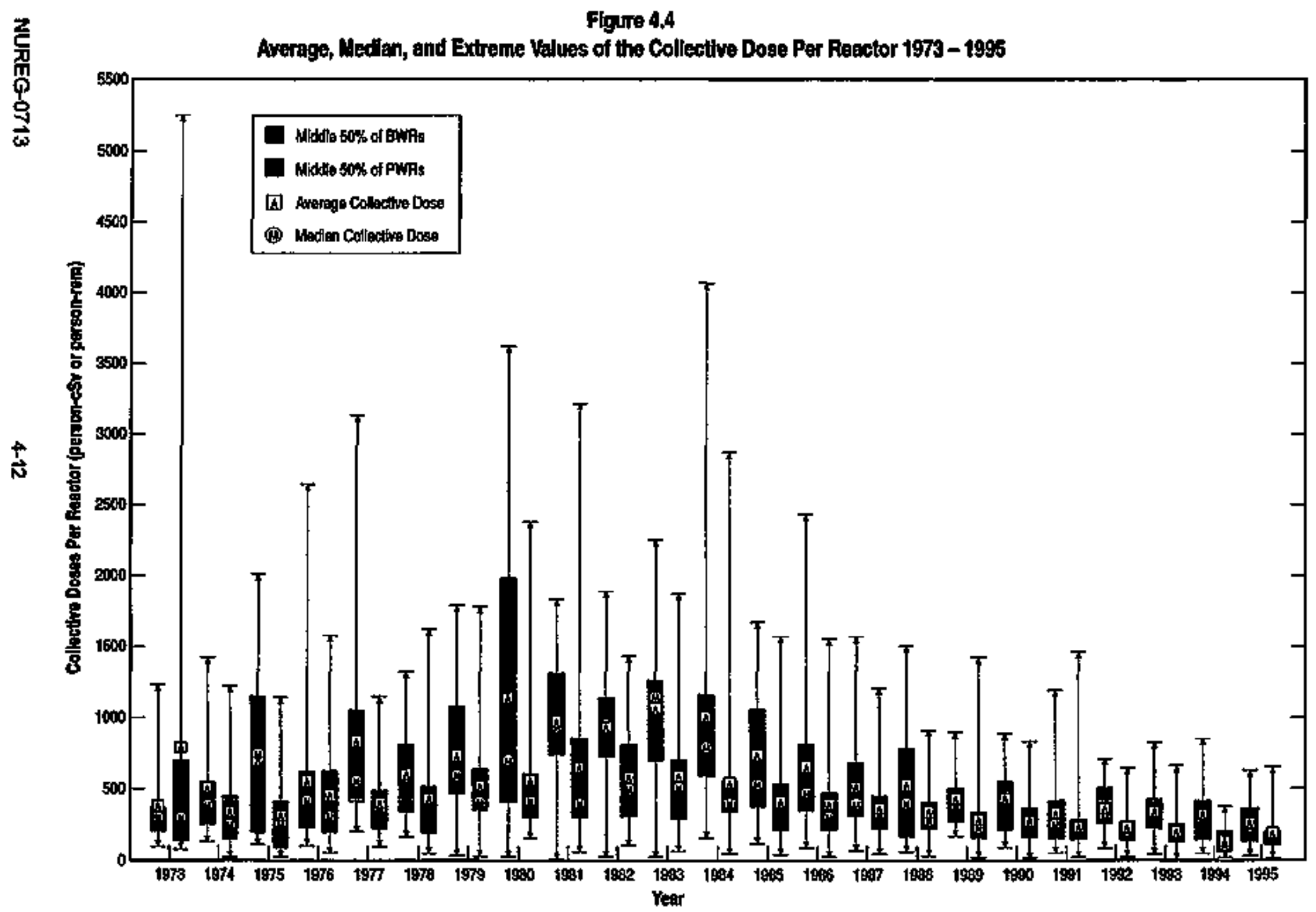




\subsection{PlaniRenklngs by Collective. Dose per Regator}

Because the number of reactors from which data have been collected is stili statistically rather smell, the information reported by a few reactors where unusual condtions or problems may have occurred could have a large impact on some of the statistics presented in this report. In an effort to identify those plants, Tables 4.5 and 4.6 list the BWRs and PWRs in ascending order of collectlve dose per reactor for each of the 5 years from 1991 through 1995. The total collecthe dose per site is listed in the tables even though the dose per reactor was used for alf ranking. Two other parameters, average measurable dose per worker and collective dose per megawatt-year, are also given for each plant. Also shown is a parameter CR, which is defined as the ratio of the annual collective dose delivered at individual doses exceeding $1.5 \mathrm{cSv}$ (rem) to the total annuel collective dose. The value of $C R$ has continued to decline for most plants, and in 1995, the CR for all the U.S. LWRs fell between 0.05 and 0.50 , the range recommended by the UNSCEAR [Ref. 10]. Note that in 1994 and 1995, the CR velue wes determined direcily from the indhidual radiation exposure records submitted under 10 CFR 20.2206 (Form 5) rather than calculating the value from the stetistical dose distribution summary (see Section 3.1,8).

In 1995, the five BWR siles with the highest collective doses all exceeded 379 person-cSV (person-rem) per reactor (Table 4.5). These reactors were Nine Mile Point 1 and 2, Dresden 2 and 3, Washington Nuclear 2, Pilgrim, and Millstone Point 1. Although the seven reactors at these five sites represented only $19 \%$ of the 37 BWRs, they contributed $34 \%$ of the total collective dase incurred at BWRs in 1995.

Some of the activitles that contributed to the collective dose accumulated at the BWR site with the highest collective dose per reactor [Millstone Point 1 with 620 person-cSv (person-rem)] were weld repeir, in-service inspection, hanger work, insulation removal and replacement, steging work, and refueling aclivities.

In 1995, the five PWR sites with the highest collective doses all exceeded 398 person-cSv (person-rem) per reactor (Table 4.6). These reactors wore Zlon 1 and 2, Haddam Neck, Palisades, Indlan Point 2, and Maine Yankee. Alhough representing $8 \%$ of the 72 PWRs included in 1995, they contributed $24 \%$ of the tolal collective dose at PWRs. Much of the collective dose accumulated at the plant with the highest dose per reactor In 1995 [Malne Yankee with 653 person-CSv (person-rem)] was attribuled to sleam generator related work (including tube sleeving, eddy current tosing, and sludge lancing), reactor coolant pump work, outage support, valve wook, decontaminatlon, refueling activities, and in-service inspection. 
TAGAE 4 S

BOILWS WATER REACTORS LESTEO WW ASCENOWG ORDER OF COLLECTNE DOSE PER REACTOR 1991 - togs

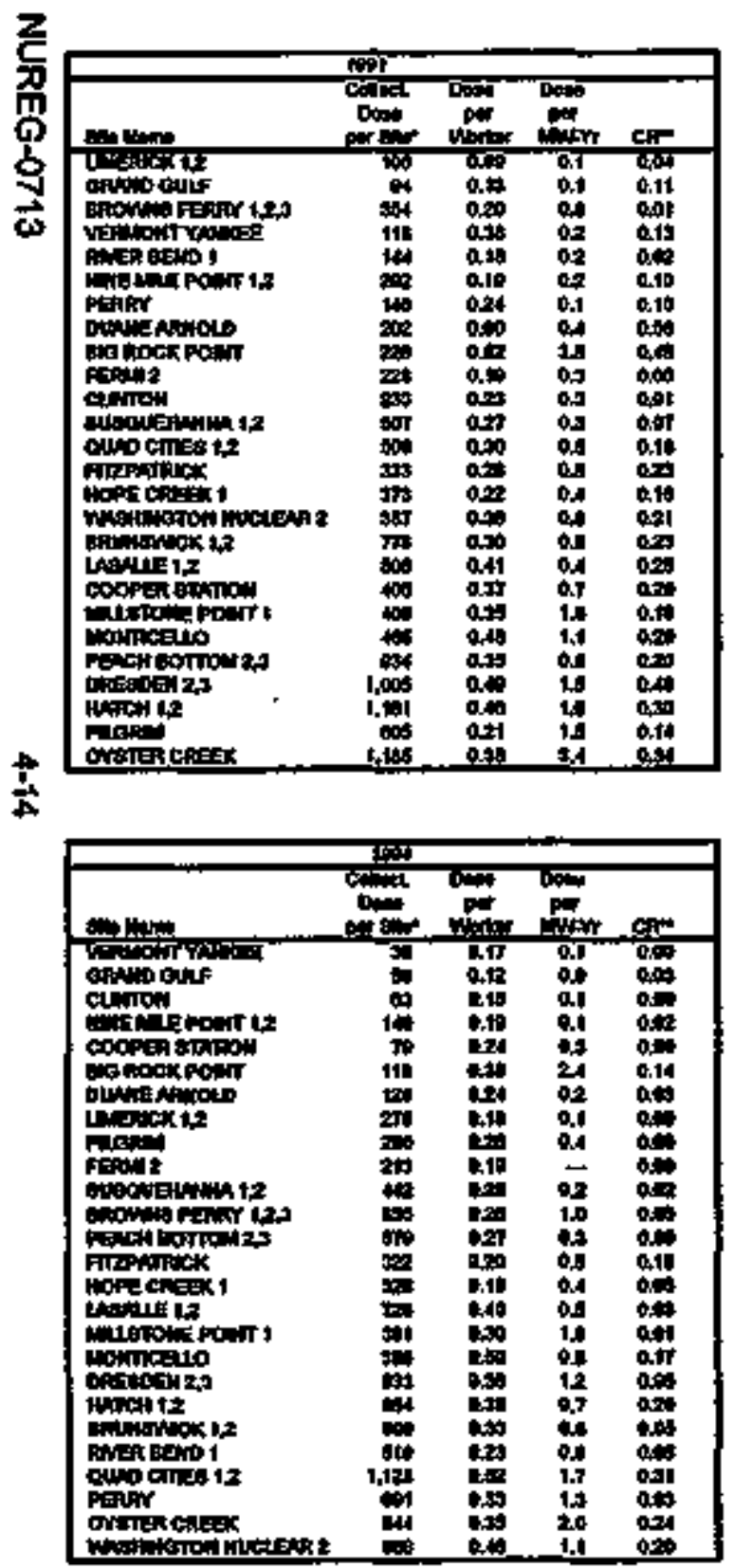

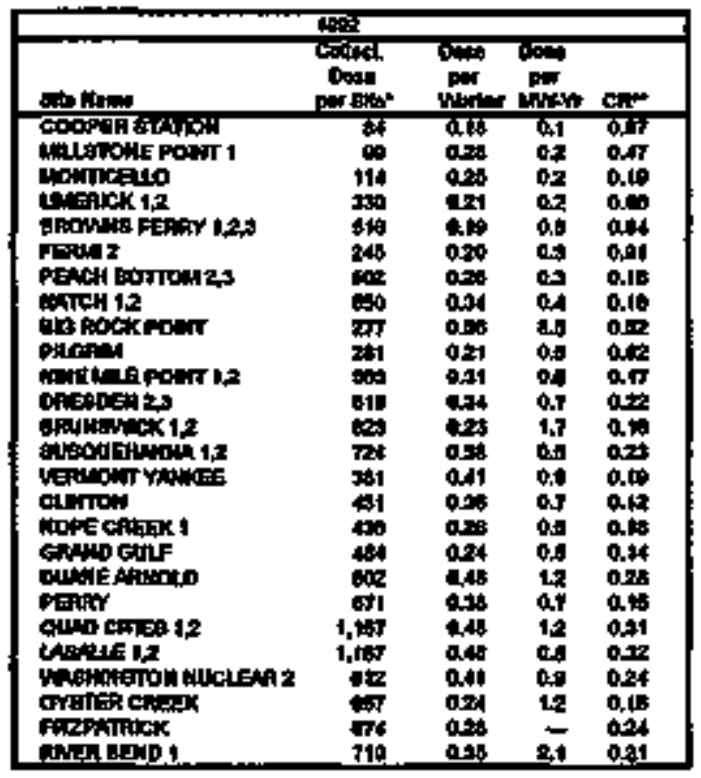

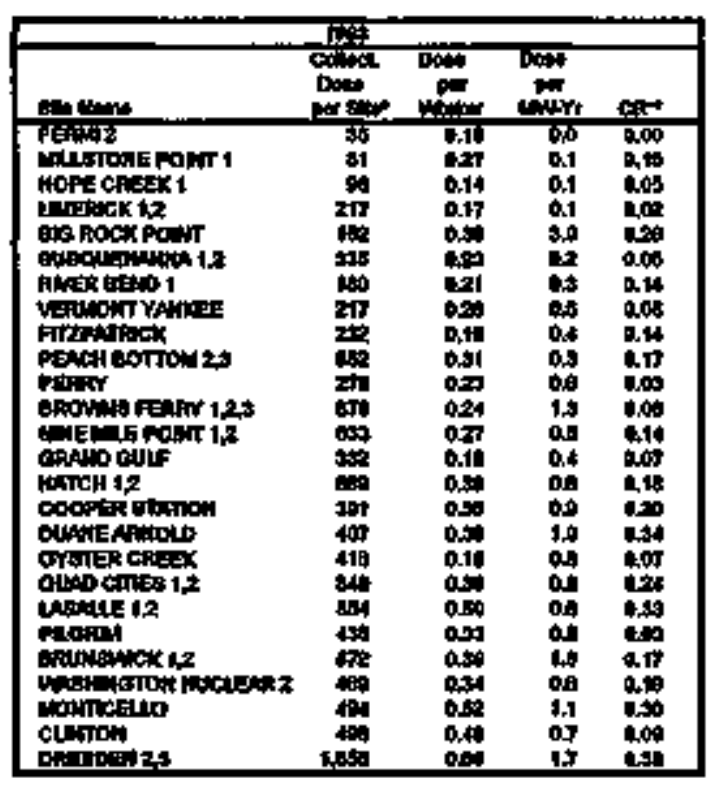

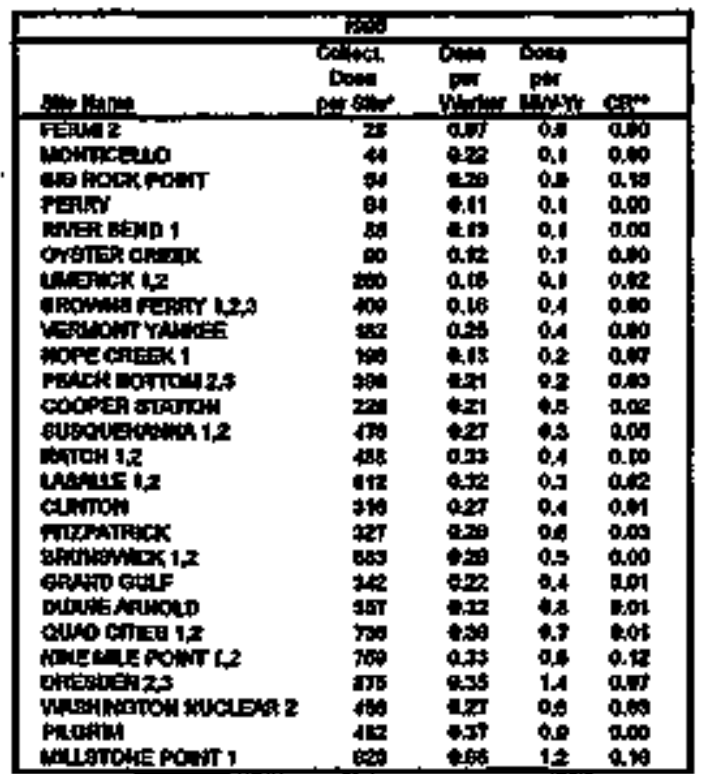

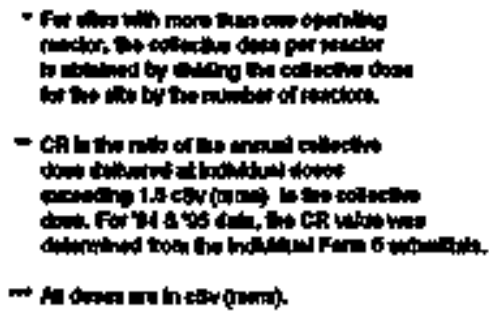


TAELE 4,6

PRESSURLED WATER REACTORS LHTEO IN ASCENDHO ORDGR OF COLLECTNE DOSE PER REACTOR 1901 - 1968

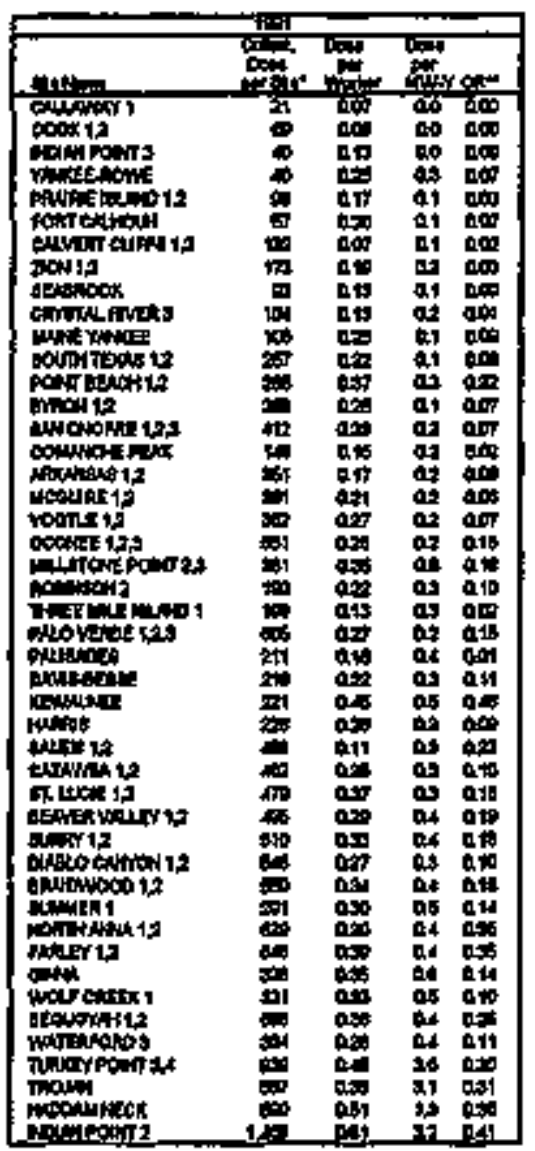

\begin{tabular}{|c|c|c|c|c|}
\hline LL. & & & Min & 5 \\
\hline 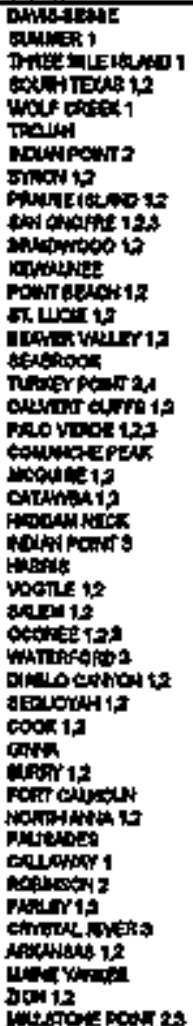 & & 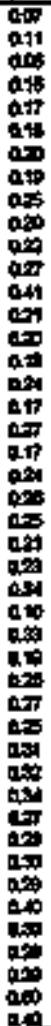 & 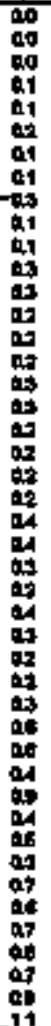 & 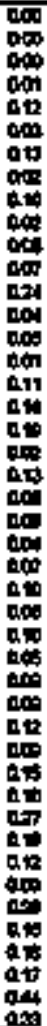 \\
\hline
\end{tabular}

\begin{tabular}{|c|c|c|c|c|}
\hline 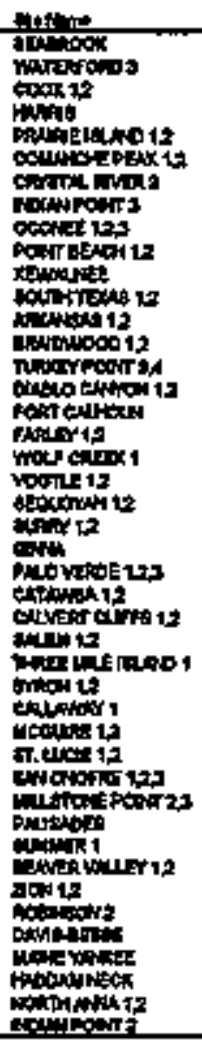 & 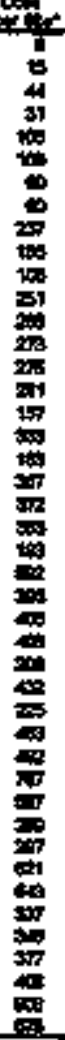 & 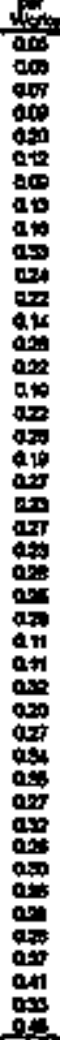 & 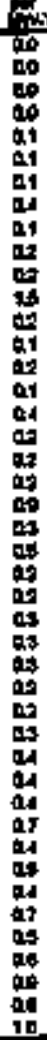 & 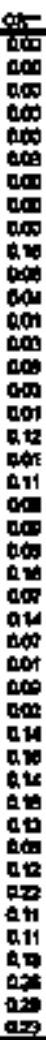 \\
\hline
\end{tabular}

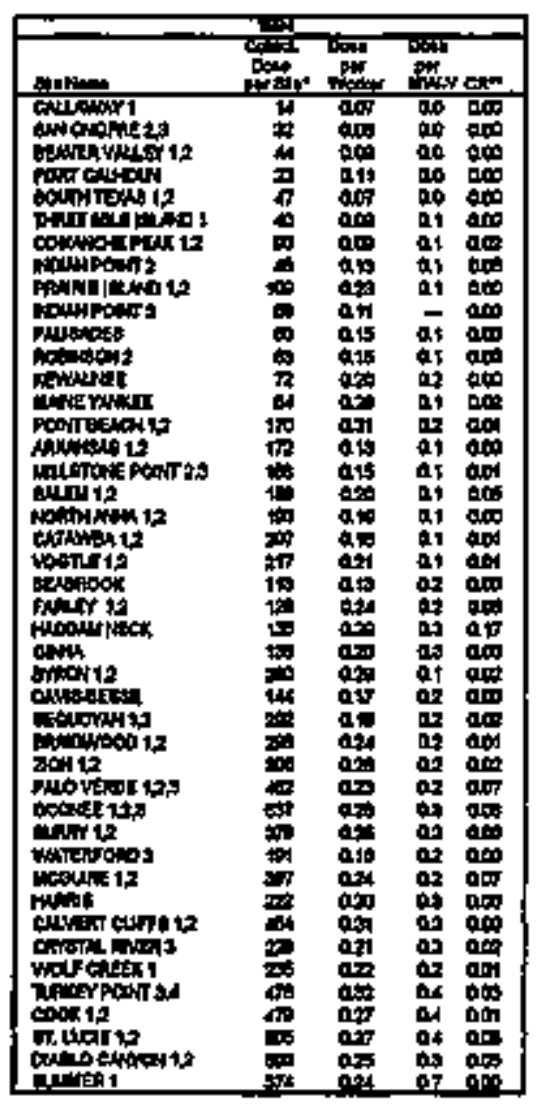

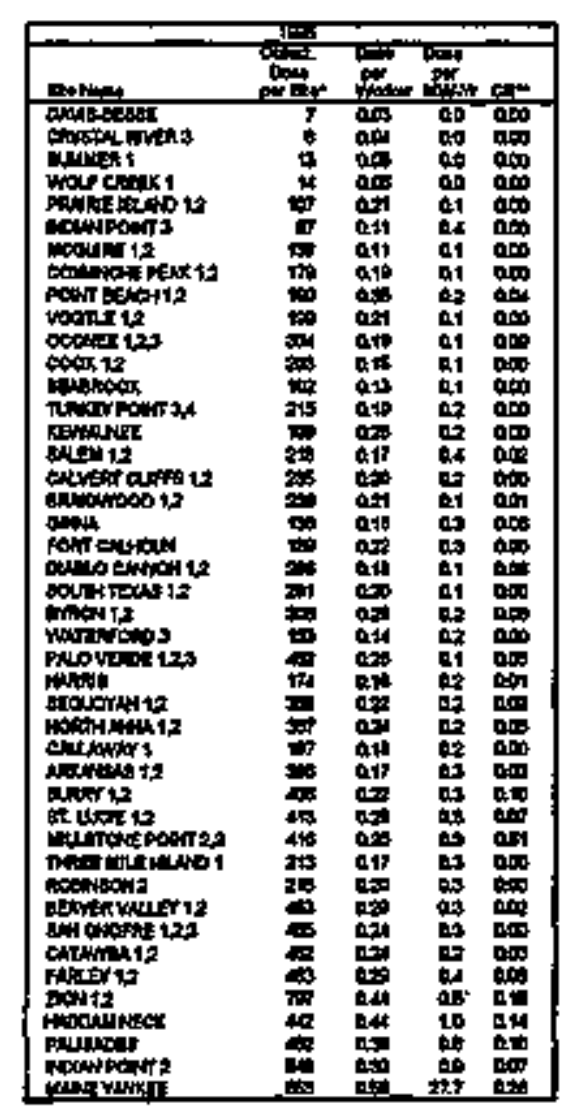

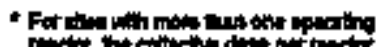

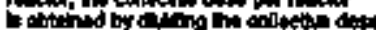

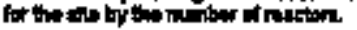

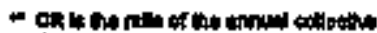

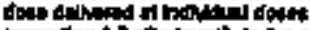

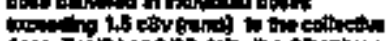

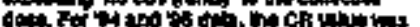

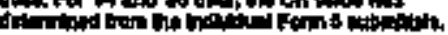

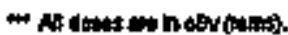


Tables 4.7a and $b$ list the sites that had been in commencial operation for at least 5 years as of December 31, 1995, and show the values of several parameters for each of the sites. They also give averages for the two types of reactors. Based on the 185 reector-years of operetion accumulated by the 37 BWRs listed, the average annuel collective dose per reactor was found to be 319 person-csv (person-sem), the average measurable dose per worker was $0.30 \mathrm{cSv}$ (rem), and the average collective dose per megawatt-year was 0.5 .

Based on the 353 reactor-years of operation at the 71 PWRs listed, the average annual collective dose per reactor, average measurable dose per worker, and average collective dose per megawett-year were found to be 190 person-c5v (person-rem), $0.25 \mathrm{cSv}$ (rem), and 0.3 person-cSvalW-yr, respectively. All of these values, at both types of facilties, are lower than those found for the 5 year period ending in 1994, with the exception of the average collective dose per silte and average collective dose per megawait-year at PWRs, which remeined the same.

In some cases, the plents having the lower values for most of the paramelers shown in Tables 4.7atb are the newer plants. Some of the older, smaller plants, such as Big Rock Point, also appear near the top of the listings because they report small collective doses. However, the ratio of collective dose to megawath-years is generally higher for these plants beceuse of their lonited power generetion capabifity.

Usually, the combination of a large annual collectlve dose and a large collectlve dose to megawatt-year ratio for a plant indicates that extenstve maintenance or modificallons were undertaken during the year. Jobs that were large contributors to BWR doses in 1995 included in-servlce inspections, valve maintenance work, refueling acthitles, shielding instaliation and removal, and area and system decontamination. At PWR facilities, the major contributors to the collective dose were steam generator related work, valve maintenance work, refueling ectivities, scaffolding and insulation, in-sorvice inspections, health physics coverage, and reactor cootant pump maintenance.

A complete breakdown of the activities contributing to the collective dose at the ten sites with the highest dose per reactor ranking in 1995 (from Tables 4.5 and 4.6) is given in Tebles 4.8a and 4.8b for BWRs and PWRs respectively. The outage dose and duration are shown as well as the collectlve dose for each activity. 


\begin{tabular}{|c|c|c|c|c|c|c|c|}
\hline \multicolumn{8}{|c|}{$\begin{array}{c}\text { TABLE 4.7a } \\
\text { 5-YEAR TOTALS AND AVERAGES LISTES IN ASCENDING } \\
\text { ORDER OF COLLECTIVE DOSE PER BWR }\end{array}$} \\
\hline Sta Name" & $\begin{array}{l}\text { Numbar } \\
\text { of } \\
\text { Rousctor } \\
\text { Years }\end{array}$ & 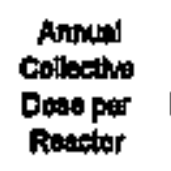 & 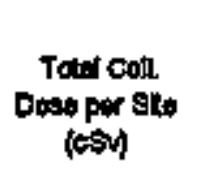 & $\begin{array}{l}\text { Workens with } \\
\text { Whas. Dosiag }\end{array}$ & $\begin{array}{l}\text { Avg. Whes. } \\
\text { Dow (oS) }\end{array}$ & 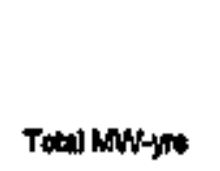 & 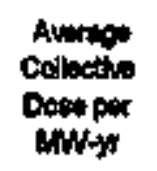 \\
\hline LMIERICK 1,2 & 10 & 118 & 1,188 & 7,121 & 0.17 & $0,367,0$ & 0.1 \\
\hline FERMII 2 & $\mathbf{5}$ & 160 & 749 & 4,316 & 0.17 & $3,215.9$ & 0.2 \\
\hline BIS ROCK POWT & 5 & 168 & 828 & 1,865 & 0.44 & 254.7 & 3,3 \\
\hline VERWONT YANKEE & $\mathbf{5}$ & 197 & $9 \$ 6$ & 3,021 & 0.31 & $2,349.3$ & 0.4 \\
\hline BROWNS FERRY $1,2,3$ & 16 & 200 & 3,004 & 13,905 & 0.22 & $4,126.0$ & 0.7 \\
\hline COOPER STATION & 5 & 237 & 1,167 & 4,120 & 0.29 & $2,482.1$ & 0.5 \\
\hline NINE MILE POINT 1,2 & 10 & 240 & 2,390 & 8,790 & 0,27 & $6,688.7$ & 0.4 \\
\hline SUSCUEKANNA 1,2 & 10 & 248 & 2,484 & 8,570 & 0.29 & $8,749.5$ & 0.3 \\
\hline CRAND GLLF & $\mathbf{s}$ & 262 & 1,308 & 6,562 & 0.20 & $5,066.7$ & 0.3 \\
\hline HOPE CREEK 1 & $\mathbf{5}$ & 286 & 1, 1, & 7,432 & 0.10 & $4,470.1$ & 0.3 \\
\hline PEACH BOTTOM 2,3 & 10 & 297 & 2,065 & 10,443 & 0.28 & $8,264,6$ & 0.4 \\
\hline MONTICELLO & 5 & 302 & 1,512 & 3,380 & 0.45 & $2,451,8$ & 0.6 \\
\hline CLINTON & 5 & 308 & $t, 541$ & 5,098 & 0.30 & $3,629.3$ & 0.4 \\
\hline DUANE ARNOLD & $\mathbf{5}$ & 398 & $1,58 B$ & 4,044 & 0.39 & $2,264.7$ & 0.7 \\
\hline MLLTONE PONT 1 & 5 & 320 & 1,600 & 4,039 & 0.40 & $2,187,4$ & 0.7 \\
\hline RWER BEND 1 & $\mathbf{5}$ & 320 & 1,653 & 6,525 & 0.25 & $3,353,6$ & 0.5 \\
\hline PERRY & 5 & 350 & 1,750 & 6,007 & 0.29 & $4,051,3$ & 0.4 \\
\hline HATCH 1,2 & 10 & 373 & 3,732 & 9,557 & 0.39 & 6,301.1 & 0.0 \\
\hline FITZPATRICK & $\mathbf{5}$ & 378 & 1,888 & 7,914 & 0.24 & $2,117.5$ & 0.0 \\
\hline BRUNSWMCK 1,2 & 10 & 30 & 3,055 & 13,003 & 0.28 & $4,479.8$ & 0.9 \\
\hline PLORIA & 5 & 401 & 2,000 & 7,646 & 0.27 & $2,400.3$ & 0.8 \\
\hline LASALLE 1,2 & 10 & 407 & 4,005 & 9.539 & 0.49 & $0,108,0$ & 0.5 \\
\hline QUAD CITIES 1,2 & 10 & 498 & 4,379 & 10,489 & 0.42 & $4,684.2$ & 0.9 \\
\hline ORESDEN 2,3 & 10 & 499 & 4,097 & 11,425 & 0.44 & $3,841.0$ & 1.3 \\
\hline WAEHINGTON NUCLEAR 2 & 5 & $\$ 58$ & $2,7 \pm 0$ & 7,520 & 0.37 & $3,669,9$ & 0.8 \\
\hline OYSTER CREEK & 5 & 638 & 3,192 & 11,663 & 0.28 & $2,486,0$ & 1.3 \\
\hline $\begin{array}{l}\text { Grand Totits and Avereses } \\
\text { Averoges Per Revator-Year }\end{array}$ & 185 & & $\begin{array}{r}50,004 \\
319\end{array}$ & $\begin{array}{r}194,705 \\
1,052\end{array}$ & 0.30 & $\begin{array}{r}110,0 \sec 8 \\
509.8\end{array}$ & 0.5 \\
\hline
\end{tabular}




\begin{tabular}{|c|c|c|c|c|c|c|c|}
\hline \multicolumn{8}{|c|}{$\begin{array}{c}\text { TABLE 4.7b } \\
\text { 5-YEAR TOTALS AND AVERAGES LISTED IN ASCENDING } \\
\text { ORDER OF COLIECTTVE DOSE PER PWR } \\
1991-1995\end{array}$} \\
\hline Ste Neamen & $\begin{array}{l}\text { Number } \\
\text { of } \\
\text { Reector } \\
\text { Yeare }\end{array}$ & $\begin{array}{l}\text { Anintal } \\
\text { Collection } \\
\text { Dose per } \\
\text { Reacter }\end{array}$ & $\begin{array}{l}\text { Totol coll. } \\
\text { Doose per sto } \\
\text { (eSt) }\end{array}$ & $\begin{array}{l}\text { Wortors With } \\
\text { Mlass. Dosses }\end{array}$ & $\begin{array}{l}\text { Awn. Mees. } \\
\text { Dese (OSV) }\end{array}$ & Totel MW-yrs & $\begin{array}{l}\text { Averagt } \\
\text { Cottective } \\
\text { Dose per } \\
\text { MWN-y }\end{array}$ \\
\hline 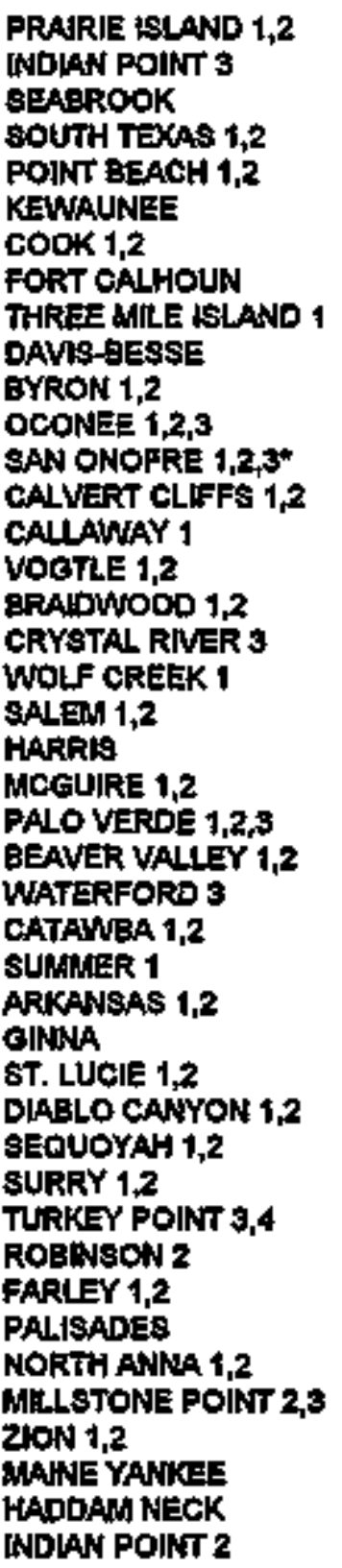 & $\begin{array}{r}10 \\
5 \\
5 \\
10 \\
10 \\
5 \\
10 \\
5 \\
5 \\
5 \\
10 \\
15 \\
13 \\
10 \\
5 \\
10 \\
10 \\
5 \\
5 \\
10 \\
5 \\
10 \\
15 \\
10 \\
5 \\
10 \\
5 \\
10 \\
5 \\
10 \\
10 \\
10 \\
10 \\
10 \\
5 \\
10 \\
5 \\
10 \\
10 \\
10 \\
5 \\
5 \\
6\end{array}$ & 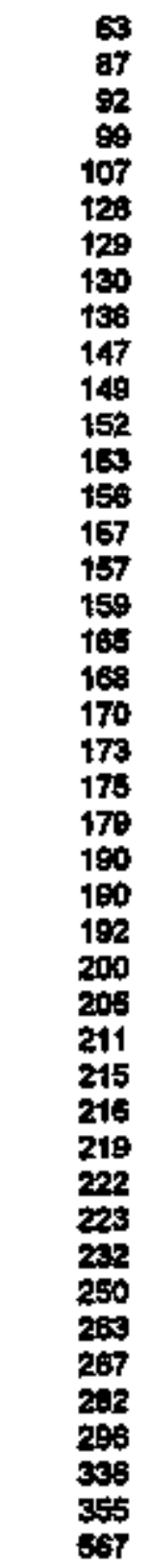 & 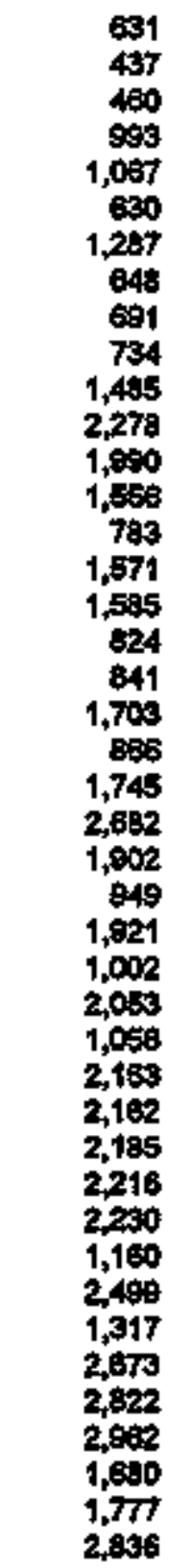 & 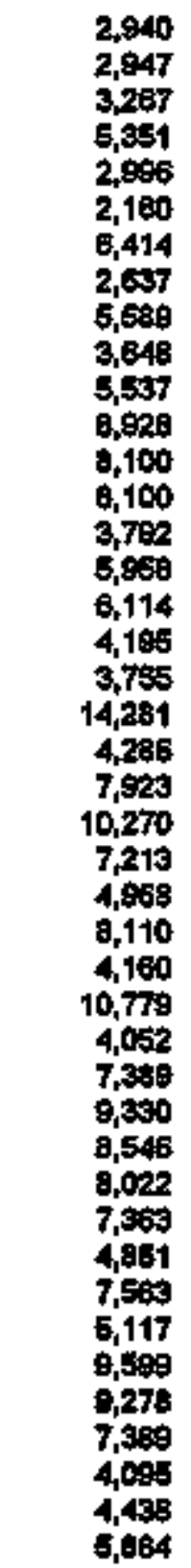 & $\begin{array}{l}0.21 \\
0.15 \\
0.14 \\
0.19 \\
0.36 \\
0.29 \\
0.20 \\
0.25 \\
0.12 \\
0.20 \\
0.27 \\
0.26 \\
0.25 \\
0.19 \\
0.21 \\
0.20 \\
0.26 \\
0.20 \\
0.22 \\
0.12 \\
0.20 \\
0.23 \\
0.26 \\
0.28 \\
0.19 \\
0.24 \\
0.24 \\
0.19 \\
0.28 \\
0.20 \\
0.23 \\
0.28 \\
0.28 \\
0.30 \\
0.24 \\
0.33 \\
0.26 \\
0.28 \\
0.30 \\
0.40 \\
0.41 \\
0.40 \\
0.48\end{array}$ & 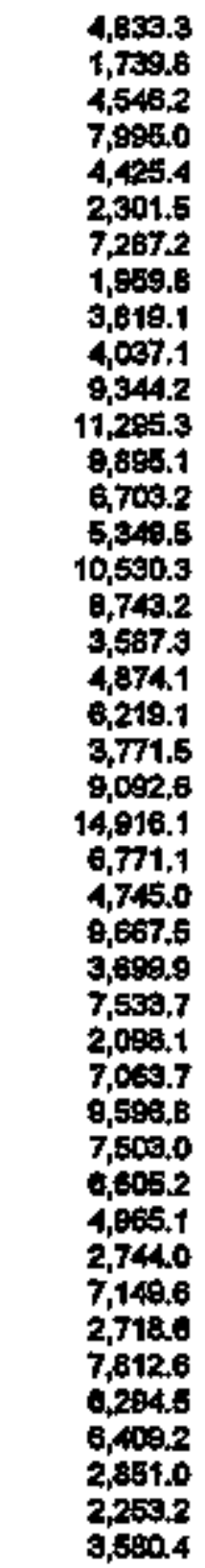 & $\begin{array}{l}0.1 \\
0.3 \\
0.1 \\
0.1 \\
0.2 \\
0.3 \\
0.2 \\
0.3 \\
0.2 \\
0.2 \\
0.2 \\
0.2 \\
0.2 \\
0.2 \\
0.1 \\
0.1 \\
0.2 \\
0.2 \\
0.2 \\
0.3 \\
0.2 \\
0.2 \\
0.2 \\
0.3 \\
0.2 \\
0.2 \\
0.3 \\
0.3 \\
0.5 \\
0.3 \\
0.2 \\
0.3 \\
0.3 \\
0.4 \\
0.4 \\
0.3 \\
0.3 \\
0.3 \\
0.4 \\
0.5 \\
0.8 \\
0.8 \\
0.8\end{array}$ \\
\hline 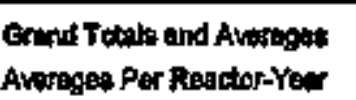 & 353 & & $\begin{array}{r}67,042 \\
190\end{array}$ & $\begin{array}{r}267,394 \\
757\end{array}$ & 0.25 & $\begin{array}{r}259,328.1 \\
734.6\end{array}$ & 0.3 \\
\hline
\end{tabular}


TABLE 4.89

ACTIVITES CONTRIBUTHLS TO HIGH COLLECTME

DOSES AT SELECTED PLANTS IN 1995

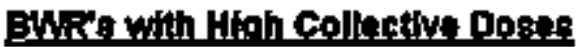

\section{WAlstone Point 1 (620 rem)}

Cutage dosedderation: 600 ramtios day.

Average delly outage dose; 0.47 bemiday

Averape detly operating doces NW

- Woild repali (drywal) (102.6 ram)

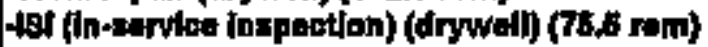

-Henger wotk (dignill) (20.6 wom)

Hawitatlon removaltreplacement (dry well) (28.4 ram)

-stoging (drywoll) (24.9 rom)

-Rohteling (12.9 rom)

-Clecoup vatwe roplocemente (dirywoli) (13.7 rem)

-8bleldiad (dinwell) (10.9 roit)

\section{Drosdon 2, 3 (876 rem)}

Outers dosefduration (U2): 696 rom/210 daye

Outage doseddaration (U3): 23 rom/127 day

Avarget drly outay dose(U2), 3.26 remidey

Aweraes dally outane doce(U3): 0.18 ramiday

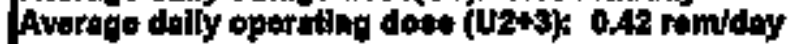

Unit 2

AfWet (ragelor wrtor olomup syctem) pipt and hat exchanger replacemant (91.1 rem]

-Valve workfreplectement (Totel of $87.6 \mathrm{rom}$ )

Two 16" Movs (motor-operatod valvest replased

- $82.2 \mathrm{rem}$

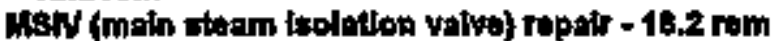

Electromagnetic and ostoty relief valve repair - 17.2 rem

-tsi (in-earvibe inspection) he dirywall (70.4 ram)

-8hisiding (Total of $47, t$ rom)

Pam. reolrouletion ring hotder ahibkine installetion

- 31.2 nem

Temporam dignall thisking inetedetionfomowal

$-18,9$ ram

Lutepe actillios aipport (Totat of 48.7 rem)

HP suppert - 292 rem

Oparationt support - $17.4 \mathrm{rom}$

Chimleal decontamingtion (reolre and RWCU) (20,7 rom)

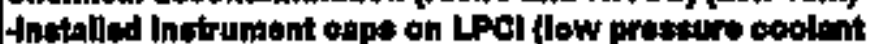

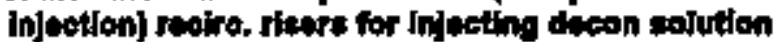
[13,7 ram]

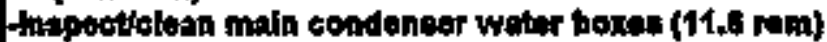

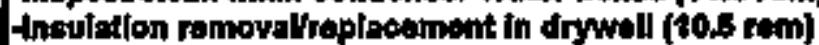

-CRo (oontrol rod driva) ramovabinatilletion (10.3 rob)

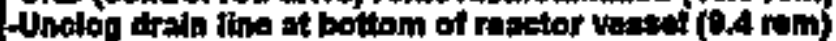

\section{Pilgrim (482 rem)}

Outbeg doweldurations $410 \mathrm{ram} / 73 \mathrm{day}$

Avwrejo delly outre dose; $\mathbf{5 , 6 2}$ remiday

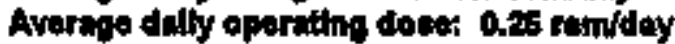

AgI (In-arvice inspection) (Dneludes dowes due to sonfrolding and (navletion) (74.5 rem)

-Roficting (Tot:l of te ritr) Renctor head ramovalifoplooentent, axvity decon

- 4he rem

Modiflostions (05.9 ram)

4OU (motor-opernted vafve) nepeintroplacoment (49.5 ruta)

Correctre maintenance (43.6 com)

-Hestith phyalos support (22,6 rem)

- Mitedilaneoue support (18.1 ram)

Shiolding (15.6 rata)

Oparations aupport [15.6 cmm)

Prewentive molittonanes (13 rem)

-Dapontamination ( $6.8 \mathrm{rom}$ )

\section{WNP 2 (456 rem)}

Ortag* dosclduration: 207 rend/49 day

Averace dally outage doet: 6.00 rem'day

Avarape delly operditing doas: 0.5 remiday

Shioldina (drywot) motallationiremoval (30 rem)

Reactor disassenblyirestsembly (Total of $28.5 \mathrm{rem}$ ) Rector rosssembly - 14.3 rem

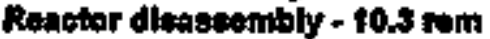

-Chomleat decoutaninifien of RWYOU (reactor water

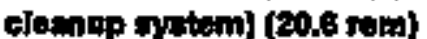

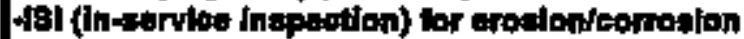
(19.5 ram)

Wali stoom rallef vatue romovalireplacement (14, rem) 
TABLE $4.8 \mathrm{a}$ (Continuted)

ACTIVTIES CONTRIBUTHNG TO HFH COLLETIVE

DOSES AT BELECTED PLANTS JN 1985

\section{EuR's with High Collective Dosegs}

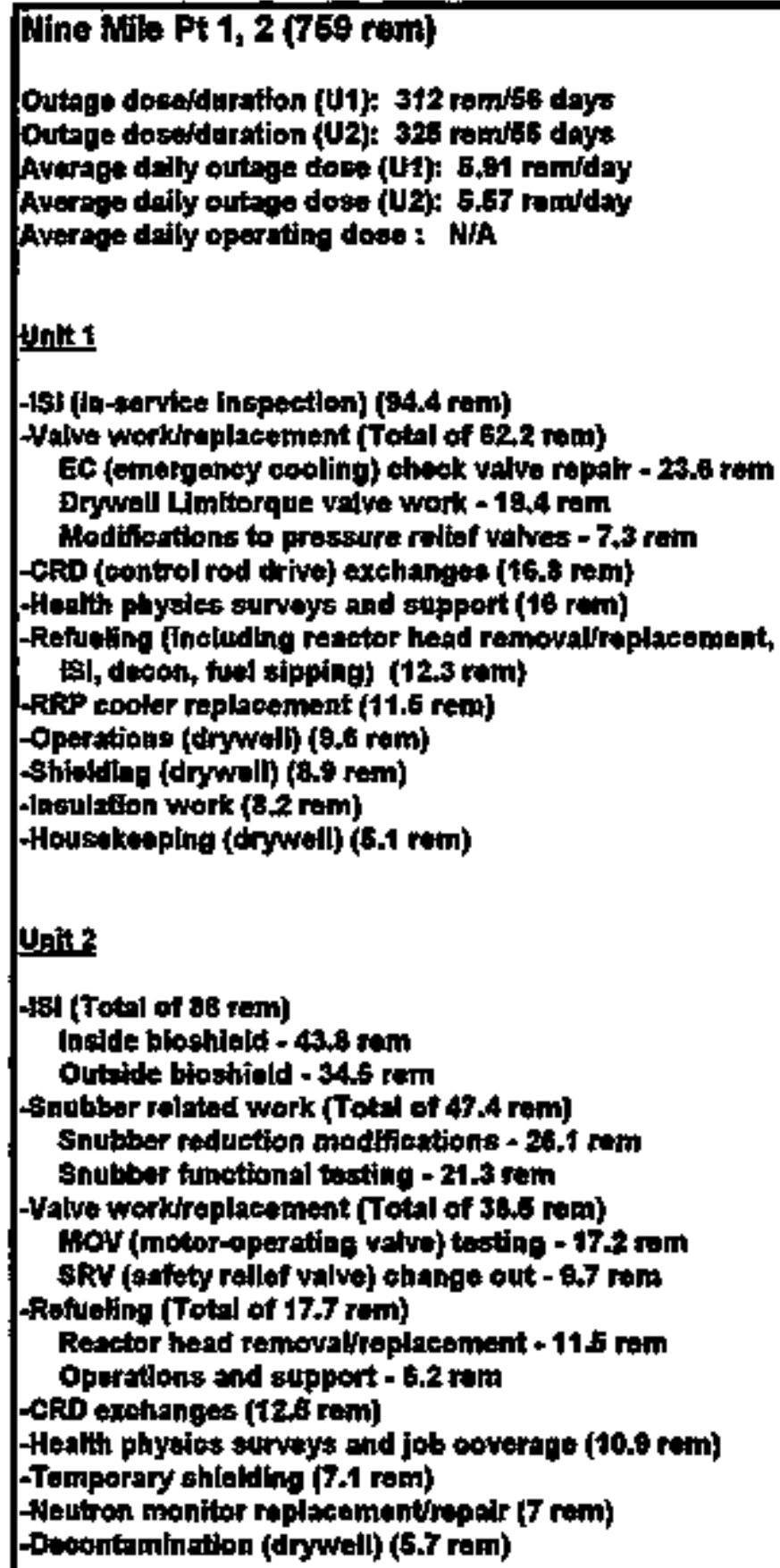


TABLE 4.Bb

ACTIVTJES CONTRIBUTING TO HIGH COLLECTIVE

DOSES AT SELECTED PLANTS IN 1995

PWR's with Hinh Collictive Dops:

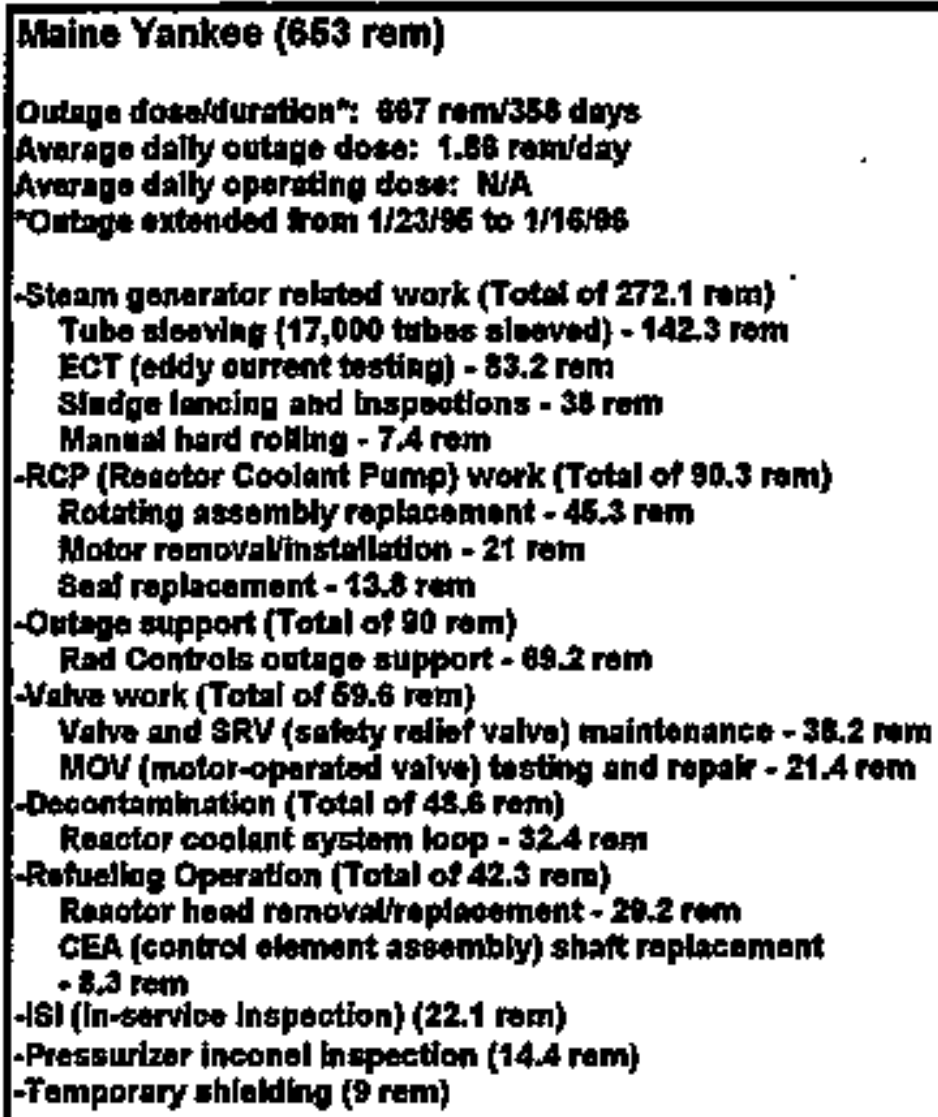

Indfan Point 2 (348 rem)

Ortage docatdoration: 499.9 remitez days

Averate dalty outage does; 4 ,1 remday Avarase daliy oparating doan 0.20 remidey Hindian Polint pariormod a full syotiom deoortentination in 1989

Floditiontrons (Total of $67.8 \mathrm{rem}$ ) stam peneratior nozzin riag lastallation - 16.3 rem Reartor vesest head split pin ropali - $14.9 \mathrm{rom}$ -Refirelling (56.7 rom)

- Maintintinos (61,2 rem)

-Radiatlon protiation (47.3 rem)

-Radwatio (40.4 ram)

-statm ganuktor work (Total of $39.8 \mathrm{rmm}$ )

Primary side (eddy aurrent tostin:) - $32.5 \mathrm{kem}$

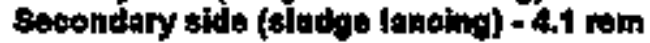

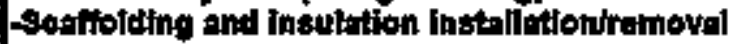
(34 ram)

-8uperviosry plant touts (33.1 $\mathrm{mm})$

-1Si (in-eervice Ingpection) (23.7 nom)

-Full syotem deconteminetson (21 rem)

RCP (Reator Coolant Pump) work (20 rem)

-Opentions [20.3 rom)

- Nov (motor-oparatad valwe) work (16.5 zam)

sonices (Bghting, air) (10.6 rem)

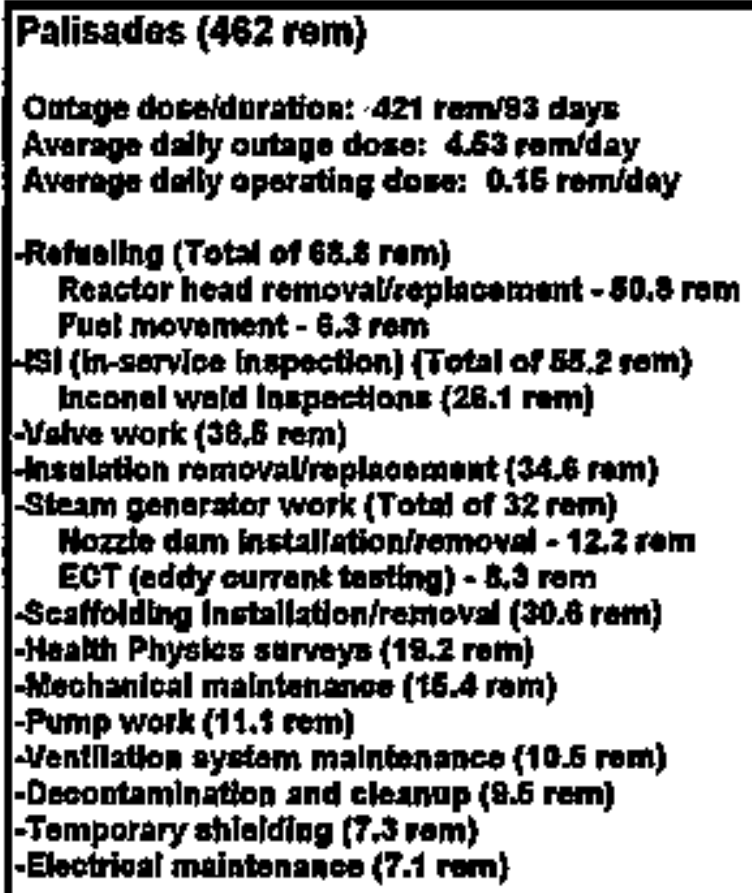




\section{TABLE 4.8b (Continuad) \\ ACTIVITES CONTREBUTINS TO HICH COLLECTIVE DOSES AT SELECTED PLANTS IN 1995}

\section{PWir's with Hirh Collective Pores}

Zion 1, 2 (7997 rem)

Outhes dogedduration (bi) 480 rem/29 diyg Outage dosedduration (tip) 167 rend103 doys Averare doily outege does (U1): 4.63 remtday Avarnge delly outage dose (U2) 1.torday Averape doily oporting doser WA

\section{thite}

Steam gentardor work (143.7 rem)

Volve work (74,1 rom)

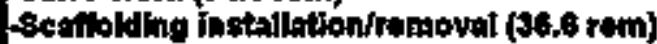

-3l (in-ivice inspection) (34,4 rom)

Fitdiation protection support (30.4 ram)

Relweling (Tetal of 24,3 rem)

Resctior heas disngeemblyasogmbly - 21 rem

Fuel shumb and inspoction - 3,3 rem

-8abberthengrt wark (23.5 rem)

-shidding (15.9 rom)

Flang work (18.4 rom)

- Resetor coofant pump work (11.2 rom)

-Operating depertment routinge (10.2 ram)

\section{Unit?}

Steam geserator work (42.7 ram)

Walwe watl (24.6 ram)

Strifiolding inotallotionfromoval (20.9 rem)

H8I (17.7 row)

-Radjation protection support (15.9 rem)

-Relueling (totw of $15.6 \mathrm{rom}$ )

Reactor houd dtanesemblyfasean'bly - 12 ram

Fusd whulite and lappection - 3,9 rem

Snubberfhanger work (13.9 rem)

Shlelding (b.7 reim)

-Roatiot cooldit punap wotk (6 rem)

\section{Faddem Nock ( 442 rem?)}

Ortage doea/duration: 464 rem/31 doys

Average dality outage doas: $6.8 \mathrm{rom} / \mathrm{day}$

Averice dally operatiag dose: o.07 rom'day

44F rem total year doese measured by TLD,

454 rem outage dost measured by pooket ion chamber

Stoam gomoretor rolated work (Total of 121.6 rem)

Eddy current and ultranonte toiting - Ak rem

Tube plugging and rearole - $3 t .5 \mathrm{rem}$

Equlpment selupftestown - 144 rem

Romoveliastall manweys - $11.2 \mathrm{ram}$

inetallfremove horale covers - $6.6 \mathrm{com}$

HP surveyejob coverage - 6.7 mom

- Valvo rolatiod work (3otel of $68.5 \mathrm{rtm}$ )

MOV (motor-operatod valve) teeting and repalre

$-24.3 \mathrm{mam}$

Mises vatve ropalr + 22,2 ram

Oote valve pressure loeking ix - 20 rem

Inspotioll end repalr of sarwies water syotom plping (B2.3 rain)

4SI (in-serviat inspeotion) (Total of 45.5 ren)

UrT (aftrasopic tostspliquid pentrant exams - 16.5 rom

inaulation removalfropfacement - $10.1 \mathrm{rom}$

Berfiolding fnatonlatlontromoval $-6.4 \mathrm{ram}$

Retreling (40.6 rem)

Oporotions (21.3 rmm)

HP covarape (19.2 rom)

Froilitios and wasta manapament (6.8 ruse)

Ghibling (7.1 rom)

ReP (Reactor Coofabt Pump) seal replacement (6.4 ram) 
Even with the use of better techniques end robotics, these tasks continue to be responsible for a major percentage of the collective dose. It should be noted that the differences in nuclear plant designs and the ages of the plants, even between plants of a given type, affect the nature of these parameters [Ref. 15]. Therefore, care should be exercised when attempting to draw conclusions from these data.

From the above analysis, one can see that the largest contribulor to the collective dose is usually associgted with outages at a site. In analyzing collective dose trends, it is useful to examine the oulage data for reactors to look for a relationship between the collective dose and the outage information for the reactors. Figure 4.5 displays the total number of outage days for BWRs and PWRs respectively. The collective dose and average measurable dose are also plotted to allow for the comparison of autage duration to collective dose.

\subsection{Collective Dose by Work Function and Emplovee Trpe}

Each plant is required by lts Technical Speciflcatlons to submit an annual statistical report that provides the collective dose of workers monitored at each plant site by employee type (plant, utility, or contractor) and by work and job functions. A copy of the report submitled for each reactor site is provided in Appendix D, and much of the data are graphicaly represented for aach sle in Appendix E. Tables 4.9 through 4.14 summarize the 1995 data for BWRs, PWRs, and LWRs. Table 4.9 shows that, at both BWRs and PWRs, about $62 \%$ of the collective dose is incurred during routine and special maintenance activities. Also, the portion of the collective dose incurred during most of the other activities is similar at the two types of plants.

One should note that the collective doses obtained from these reports are not used in any other tables in this document. This is because the Technical Specificatlons of each plant require only $80 \%$ of the plent's collective dose be accounted for, and some utillies may use the results of self-reading pocket dosimeters instead of the results of the dosimeter of record (usually themoluminescent dosimeters) In compiling the data. Also, when exarnining the number of personnet shown on these reports, thould be remembered that individuals who perform tasks in more than one categary may be counted more then once.

Table 4.10 shows that workers performing special maintenance prior to 1987 incurred the largest portion (35\%-45\%) of the collective dose and that workers performing routine maintenance activities usually incurred between $25 \%$ and $35 \%$ of the total. For the past 9 years, the percentage of collective dose attibuted to routine melntenance has been greater then that of speclat meintenance. This may be indicalive of a trend showing a reduction in TMi-related actuitles and a greater emphasis on steady-stete routine maintenence. Overell, values have been faity stable over the years with these two calegories, special maintenance 

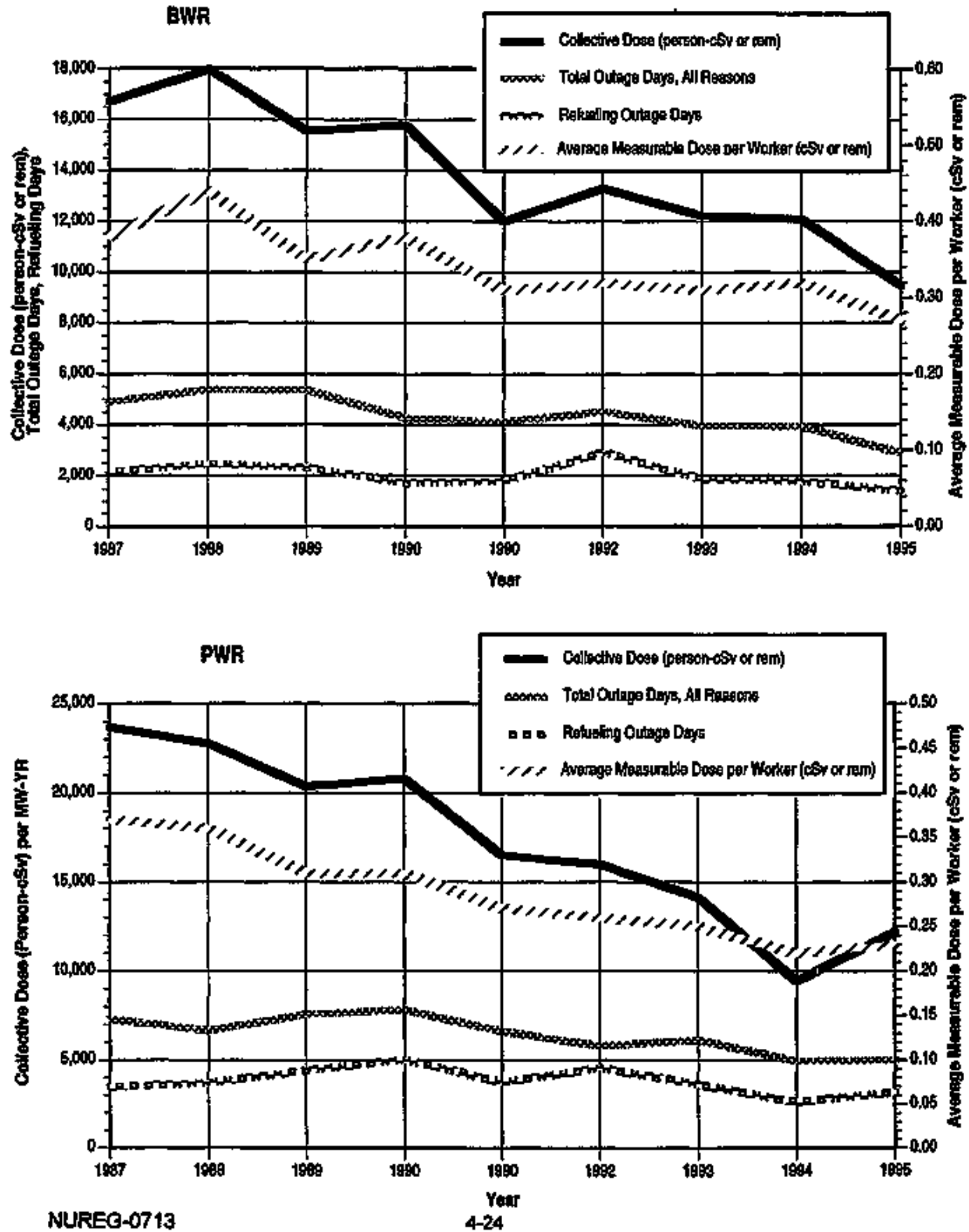
TABLE 4.9

ANNUAL COLLECTIVE DOSE

BY WORK FUNCTION AND PERSONNEL TYPE

1995

\begin{tabular}{|c|c|c|c|c|c|c|c|c|}
\hline \multirow{2}{*}{$\begin{array}{l}\text { MORK AND } \\
\text { JOB FUNCTION } \\
\text { POULWG WATER REACTOR }\end{array}$} & \multicolumn{2}{|c|}{$\begin{array}{l}\text { STATION ERPLOYEES } \\
\text { PERSON-CSV \% OF TOTAL. }\end{array}$} & \multicolumn{2}{|c|}{$\begin{array}{l}\text { UTUTY EMPLOYES } \\
\text { PERSON-CSY \% OF TOTAL }\end{array}$} & \multicolumn{2}{|c|}{$\begin{array}{l}\text { CONTRACT WORKERS } \\
\text { PERBONCSY \% OF TOTAL }\end{array}$} & \multicolumn{2}{|c|}{$\begin{array}{l}\text { TOTAL PER WORK FLWCTION } \\
\text { PERSOW-SV \% OF TOTAL }\end{array}$} \\
\hline & \multirow[b]{2}{*}{$\begin{array}{r}1,069 \\
1,623 \\
53 \\
311 \\
106 \\
150 \\
\end{array}$} & \multirow[b]{2}{*}{$\begin{array}{r}11.6 \% \\
17.6 \% \\
0.6 \% \\
3.4 \% \\
1.1 \% \\
1.6 \% \\
\end{array}$} & \multirow[b]{2}{*}{$\begin{array}{r}74 \\
425 \\
81 \\
242 \\
13 \\
64 \\
\end{array}$} & \multirow[b]{2}{*}{$\begin{array}{l}0.8 \% \\
4.6 \% \\
0.9 \% \\
2.6 \% \\
0.1 \% \\
0.7 \%\end{array}$} & \multirow[b]{2}{*}{$\begin{array}{r}499 \\
2,179 \\
627 \\
1,276 \\
58 \\
392 \\
\end{array}$} & \multirow[b]{2}{*}{$\begin{array}{r}5.4 \% \\
23.6 \% \\
6.6 \% \\
13.6 \% \\
0.6 \% \\
4.2 \% \\
\end{array}$} & \multirow[b]{2}{*}{$\begin{array}{r}1,643 \\
4,227 \\
761 \\
1,629 \\
171 \\
607 \\
\end{array}$} & \multirow[b]{2}{*}{$\begin{array}{r}17.8 \% \\
45.8 \% \\
2.2 \% \\
19.8 \% \\
1.9 \% \\
.6 .6 \% \\
\end{array}$} \\
\hline 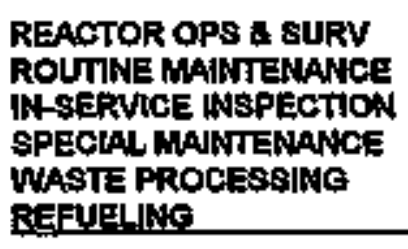 & & & & & & & & \\
\hline TOTAL & 3,313 & $35,9 \%$ & 800 & $9.7 \%$ & 5,025 & $54.4 \%$ & 9,238 & $100.0 \%$ \\
\hline \multicolumn{9}{|c|}{ PRESSURIGED WATER REACTORS } \\
\hline 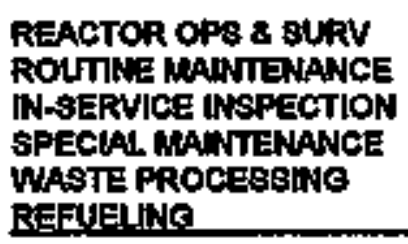 & $\begin{array}{r}687 \\
1,770 \\
114 \\
483 \\
143 \\
597 \\
\end{array}$ & $\begin{array}{r}5.5 \% \\
14.5 \% \\
0.0 \% \\
3.0 \% \\
1.2 \% \\
1.3 \% \\
\end{array}$ & $\begin{array}{r}40 \\
397 \\
199 \\
257 \\
13 \\
121 \\
\end{array}$ & $\begin{array}{l}0.3 \% \\
3.3 \% \\
1.6 \% \\
2.1 \% \\
0.1 \% \\
1.0 \%\end{array}$ & $\begin{array}{r}509 \\
2,916 \\
1,159 \\
1,419 \\
195 \\
1,255\end{array}$ & $\begin{array}{r}4.4 \% \\
23.9 \% \\
9.5 \% \\
11.6 \% \\
1.6 \% \\
10.3 \% \\
\end{array}$ & $\begin{array}{l}1,248 \\
5,083 \\
1,462 \\
2,144 \\
3,302 \\
1,098\end{array}$ & $\begin{array}{r}10.2 \% \\
41.7 \% \\
12.0 \% \\
17.6 \% \\
2.9 \% \\
15.6 \%\end{array}$ \\
\hline TOTAL & 3,684 & $30.2 \%$ & 1,019 & $8.4 \%$ & 7,481 & $61.4 \%$ & 12,184 & $100.0 \%$ \\
\hline \multicolumn{9}{|c|}{ AL!L LYGHT WATER REACTORE } \\
\hline $\begin{array}{l}\text { REACTOR OPS \& SURV } \\
\text { ROUTINE MAINTENANYCE } \\
\text { W-SERMCE INSPECTION } \\
\text { SPECIAL MANIENANCE } \\
\text { WASTE PROCESSING } \\
\text { RGUUELING. }\end{array}$ & $\begin{array}{r}1,737 \\
3,393 \\
167 \\
779 \\
249 \\
672 \\
\end{array}$ & $\begin{array}{r}6.1 \% \\
15.8 \% \\
0.8 \% \\
3.6 \% \\
1.2 \% \\
3.1 \% \\
\end{array}$ & $\begin{array}{r}114 \\
822 \\
272 \\
499 \\
27 \\
186 \\
\end{array}$ & $\begin{array}{l}0.5 \% \\
3.8 \% \\
1.3 \% \\
2.3 \% \\
0.1 \% \\
0.9 \%\end{array}$ & $\begin{array}{r}1,008 \\
5,005 \\
1,784 \\
2,695 \\
247 \\
1,647 \\
\end{array}$ & $\begin{array}{r}4.8 \% \\
23.8 \% \\
8.3 \% \\
12.6 \% \\
1.2 \% \\
7.7 \%\end{array}$ & $\begin{array}{r}2,988 \\
9,310 \\
2,223 \\
3,973 \\
5283 \\
2,505 \\
\end{array}$ & $\begin{array}{r}13.5 \% \\
43.8 \% \\
10.4 \% \\
18.5 \% \\
2.4 \% \\
11.7 \%\end{array}$ \\
\hline TOTAL & 6,997 & $32.7 \%$ & 1,919 & $9.0 \%$ & 12,505 & $58.4 \%$ & 21,422 & $100.0 \%$ \\
\hline
\end{tabular}


TAB:E 4.10

PERCENTAges of anNuAl COLlective DOSE AT LWRS BY WORK FUNCTION 1984 - 1995

\begin{tabular}{|c|c|c|c|c|c|c|c|c|c|c|c|c|}
\hline \multirow{2}{*}{ WORK FUNCTION } & \multicolumn{12}{|c|}{ PERCENTAGE OF COLIECTIVE DOSE EACH YEAR } \\
\hline & 1984 & 1965 & 1986 & 1987 & 1988 & 1969 & 1990 & 1991 & 1992 & 1993 & 1994 & 1995 \\
\hline $\begin{array}{l}\text { REACTOR OPERATIONS } \\
\text { AND SURVELLANCE }\end{array}$ & $11.4 \%$ & $12.8 \%$ & $12.8 \%$ & $11,9 \%$ & $11,0 \%$ & $12.2 \%$ & $12.3 \%$ & $14.0 \%$ & $11.6 \%$ & $11.2 \%$ & $12,8 \%$ & $13,5 \%$ \\
\hline ROUTINE MAINTENANCE & $28.9 \%$ & $34,6 \%$ & $33.2 \%$ & $35.0 \%$ & $37.7 \%$ & $36.2 \%$ & $36,5 \%$ & $36.1 \%$ & 38.7\% & $420 \%$ & $42.7 \%$ & $43.5 \%$ \\
\hline INSEERMCE INSPECTION & $6.3 \%$ & $8.6 \%$ & $8.3 \%$ & $8.0 \%$ & $8.7 \%$ & $9,5 \%$ & $8.8 \%$ & $8.9 \%$ & $9.2 \%$ & $10,8 \%$ & $8.5 \%$ & $10.4 \%$ \\
\hline SPECAAL MAINTENANCE & $45.4 \%$ & $\mathbf{3 2 . 5 \%}$ & $35.5 \%$ & $33.2 \%$ & $30.1 \%$ & $31.3 \%$ & $31.6 \%$ & $28.2 \%$ & $25.8 \%$ & $22.0 \%$ & $19.9 \%$ & $18.5 \%$ \\
\hline WASTE PROCESSHE & $3.6 \%$ & 5.1\% & $4,0 \%$ & $3.9 \%$ & $3.6 \%$ & $3.4 \%$ & $3.0 \%$ & $3.1 \%$ & $3.1 \%$ & $2.5 \%$ & $2.7 \%$ & $2.4 \%$ \\
\hline REFAEELING & $6.4 \%$ & $6.5 \%$ & $6.2 \%$ & $8.1 \%$ & 6.84 & $7.3 \%$ & $7.7 \%$ & $9.7 \%$ & $11,6 \%$ & $11.4 \%$ & $\$ 3.3 \%$ & $11.7 \%$ \\
\hline
\end{tabular}


and routine malntenance, always eccounting for the majority of the collective dose. Some of the fuctuations shown inthe percentage of the dose Incurred during refueling activities (particularly in 1992 ihrough 1995, when It increased to over 11\%) is due to the fact that some sites include doses other than those directly essockated whth fuel movement in this category.

Figure 4.6 graphically shows the trends in the collective dose by work function and type of personnel for the years 1990 through 1995 for BWRs and PWRs separately. The general decrease in collective dose is also apparent among most of these activities.

Table 4.11 presents the distribution of the collective dose for 1995 at all LWRs among five occupational categories. As in past years, maintenance personne] incumed the majority (65\%) of the colvective dose with contractor rinaintenance personnel receiving about twice as much as the station malntenance employees combined. None of the values listed chainged significantly from those found for 1987 through 1994. The collective doses shown in Tables 4.9 and 4.11 do not equal throse shown in other tables in the report because they are the sum of the doses taken from the type of annual reports shown in Appendix D rather then the collective dose that was oftalned or calculated from the annual reports that had been required to be submitted pursuant to 10 CFR 20.2206.

Another use made of the reports given in Appendix $D$ is in proportioning the collective dose obtained from the $\$ 20.407$ ennual reports into the work functions and personnel types shown in Appendix $\mathrm{C}$. This was done in the following way:

(1) The collective dose incurred by workers in the work function "Reactor Qperations and Surveiltance" on each plant's annual report submitted pursuant to their technical specifications (the first number in the last column in Appendix D) was determined.

(2) The ratio of this dose to the total collective dose (the last number in the last column in Appendix D) was calculated and multiplied by the total collective dose that had been obtained from the $\$ 20.2206$ annual reports. This product is the collective dose shown in the column headed "Operations" in Appendix $C$.

(3) The collective dose shown in the column headed "Maintenence and Others" in Appendix $C$ was determined by first summing the collective doses incurred by workers in the five remaining functions glven in Append $X \mathrm{D}$ and then calculating the fraction thet this dose is of the total collective dose. This fraction was multiplied by the total collective dose calculated from the $\$ 20.2206$ annual reports to yield the collective dose shown in this column of Appendlx $\mathrm{C}$. 
Figure 4.6

Collective Dose by Work Function and Personal Type 1990 - 1995

Boing Water ficactors

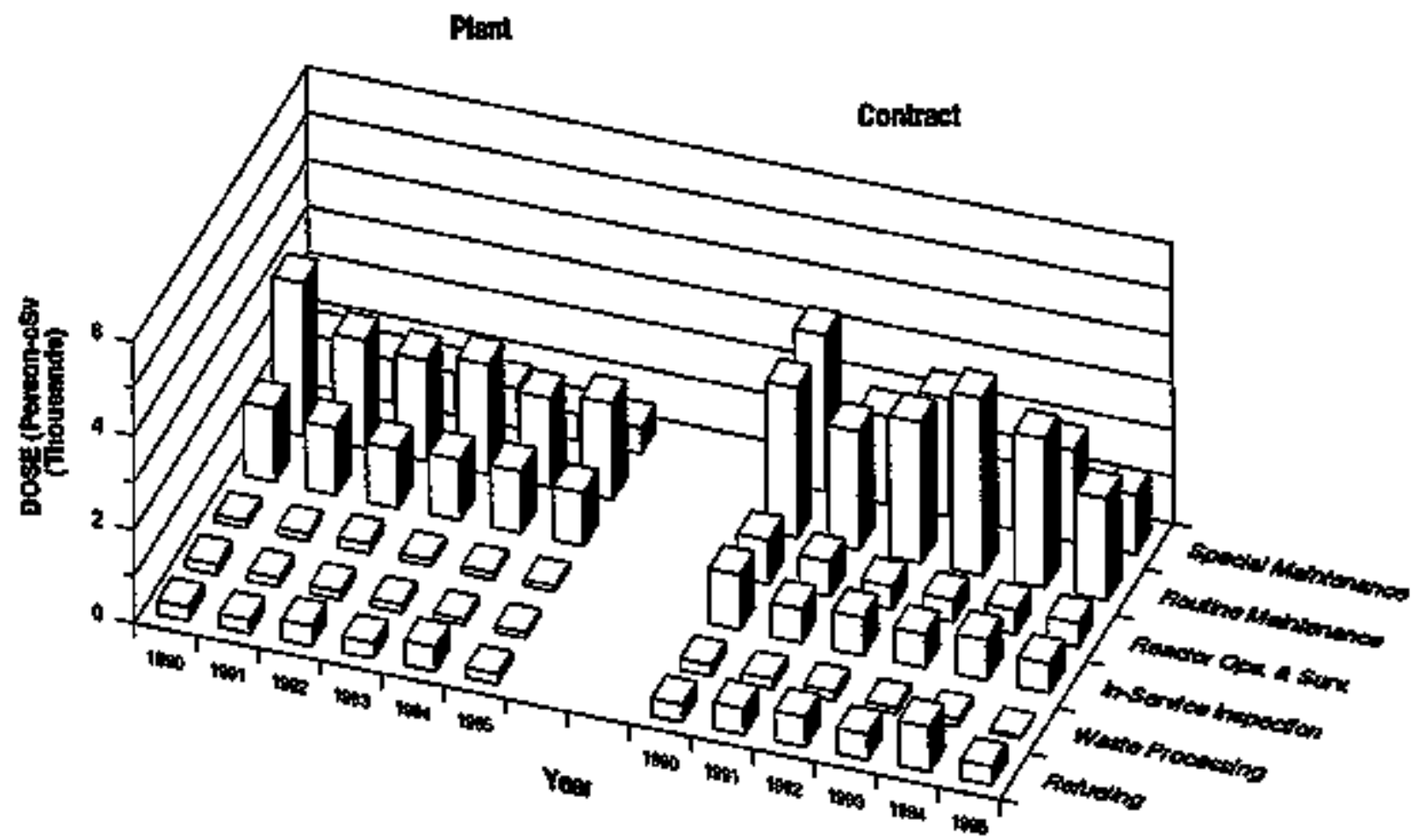

Pressurized Wailer Reactors

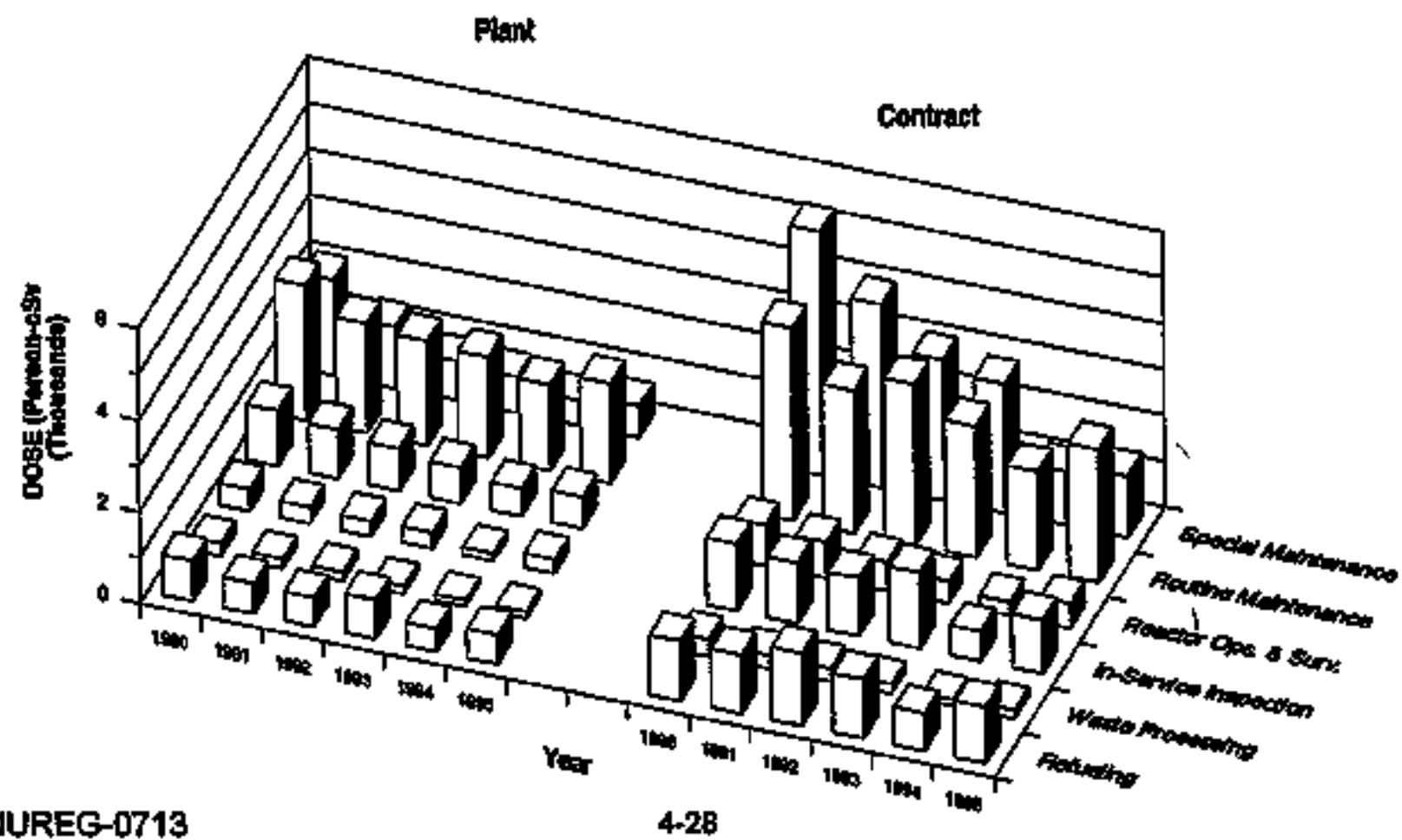


TABLE 4.11

ANNUAL COLLECTIVE DOSE

BY OCCUPATION AND PERSONNEL TYPE

1995

\begin{tabular}{|c|c|c|c|c|c|c|c|c|}
\hline OCCUPATION & \multicolumn{2}{|c|}{$\begin{array}{l}\text { STATION EMPLOYEES } \\
\text { PERSON-CSN \% OF TOTAL }\end{array}$} & \multicolumn{2}{|c|}{$\begin{array}{l}\text { UTILTY EKAPLOYEES } \\
\text { PERSON-CSY \% OF TOTAL }\end{array}$} & \multicolumn{2}{|c|}{$\begin{array}{l}\text { CONIRACT WORKERS } \\
\text { PERSON-CSN } \% \text { OF TOTAL }\end{array}$} & \multicolumn{2}{|c|}{$\begin{array}{l}\text { TOTAL PER WORK FUNCTION } \\
\text { PERSONESV \% OF TOTAL }\end{array}$} \\
\hline \multicolumn{9}{|c|}{ BOALLE WATER REACTORS } \\
\hline 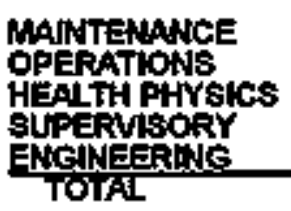 & $\begin{array}{r}1,757 \\
703 \\
502 \\
175 \\
177 \\
3,915\end{array}$ & $\begin{array}{r}19.0 \% \\
7.6 \% \\
5.4 \% \\
1.9 \% \\
1.9 \% \\
10.9 \%\end{array}$ & $\begin{array}{r}750 \\
21 \\
62 \\
6 \\
61 \\
900\end{array}$ & $\begin{array}{l}8.1 \% \\
0.2 \% \\
0.7 \% \\
0.1 \% \\
0.7 \% \\
9.7 \%\end{array}$ & $\begin{array}{r}4,074 \\
158 \\
307 \\
108 \\
378 \\
5,025 \\
\end{array}$ & $\begin{array}{r}44.1 \% \\
1.7 \% \\
3.3 \% \\
1.2 \% \\
4.1 \% \\
54.4 \%\end{array}$ & $\begin{array}{r}6,589 \\
882 \\
870 \\
289 \\
616 \\
9,2058\end{array}$ & $\begin{array}{r}71.2 \% \\
9.5 \% \\
9.4 \% \\
3.1 \% \\
6.7 \% \\
100.0 \%\end{array}$ \\
\hline
\end{tabular}

悹

RRESSURKED WATER REACTORS

- Mantenanice

optrations

TALTH PHYSICS

SUPERVISORY

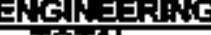

TOTAL

$\begin{array}{rr}1,655 & 15.1 \% \\ 681 & 5.6 \% \\ 720 & 5.9 \% \\ 214 & 1.0 \% \\ 234 & 1.9 \% \\ 3,684 & \text { so.2\% }\end{array}$

\begin{tabular}{rr}
885 & $7.3 \%$ \\
25 & $0.2 \%$ \\
31 & $0.3 \%$ \\
17 & $0.1 \%$ \\
53 & $0.4 \%$ \\
\hline, 019 & $6,4 \%$
\end{tabular}

$\begin{array}{ll}7.3 \% & 4,60 \\ 0.2 \% & 250 \\ 0.3 \% & 1,12 \\ 0.1 \% & 1,09 \\ 0.4 \% & 7,46\end{array}$

$\begin{array}{rr}4,604 & 37.8 \% \\ 250 & 2.1 \% \\ t, 121 & 9.2 \% \\ 425 & 3.5 \% \\ 1,092 & 0.9 \% \\ 7,465 & 61.4 \%\end{array}$

7,33
1,857
1,36
12,16

$60.2 \%$

$6 \%$

$0.2 \%$

1,0

$6,4 \%$

467

\begin{tabular}{lr}
$7.7 \%$ & 8,677 \\
$0.2 \%$ & 400 \\
$0.4 \%$ & 1,428 \\
$0.1 \%$ & 153 \\
$0.6 \%$ & 1.450 \\
\hline $8.0 \%$ & 12,506 \\
\hline
\end{tabular}

$40.5 \%$
$1.9 \%$
$6.7 \%$
$2.5 \%$
$6.8 \%$
$50.4 \%$

13,913
1,638
2,749
1,96
21,4

\begin{tabular}{rr}
9,913 & $64.9 \%$ \\
1,638 & $8.6 \%$ \\
2,742 & $12.6 \%$ \\
044 & $4.4 \%$ \\
$1,98 \%$ & $9.3 \%$ \\
\hline 1,422 & $100.0 \%$
\end{tabular}

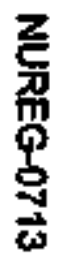

ALL LIEHT WATER REACTORS

MANTENANCE

HEALTH PHYSICS

ENethys

$6,997 \quad 32.7 \%$

1,919

(1)


(4) A simller procedure was followed in delemining the collective dose for the columns headed "Contractor" and "Stetion \& Utirty" in Appendix C.

\subsection{Number of Personnel by Work Function and Employee Type}

Hatf of the information presented in the statistical annual reports shown in Appendix D concems the number of various types of personnel that performed certain work functions. Tables 4.12 and 4.13 sum this information to show the percentege of personnel by work function and occupation. The major problem in interpreting the numbers shown in these tables Is that the same person may perform several work functions during the year so that the totel number of personnel obtained by summing those shown in the various work functions would be inflaked. However, Table 4.12 is still useful in showing the percentege of personnel associated with each of the six work functions shown. About $55 \%$ of the personnel perionmed routine or special maintenance functions, $26 \%$ were involved with reector operations and survellance, and the remalning $19 \%$ were dhided among the other three work functions.

Table 4.13 shows the percentege of personnel in each of five cocupationel categorles at BWRs, PWRs, and LWRs. The workers were slmllarly distrlbuted at BWRs and PWRs. The largest differences occurred in the maintenance and supervisory percentages for 1995. Overall, $56 \%$ of the personnel were contractors, $36 \%$ were stetion employees, and $8 \%$ were utllity employees in 1995.

Tabie 4.14 presents the average annual dose incumed by workers in the five occupational categories in 1995. These everages were celculated by dividing the collective dose reported for these groups (see Table 4.11) by the number of individuals shown in Teble 4.13. It shows that, in most instences, the maintenance and health ptysics personnel incur the highest average doses. Examination of the values of the averages given In Table 4.14 is subject to several sources of error: (1) the number of individuals may be infleted because the same plant contractor employee may work at severel plants so that the employee would be counted more than once in a summary such as Table 4.14; (2) the occupations are not clearty defined so that workers perfoming certain tasks in one plant may be clesstied as being in one occupation and be inchuded in a different one at another plant; and (3) some plants coust only those workers whose doses exceed $0.10 \mathrm{cSv}$ (rem) while other plants count all workers regardless of the dose received. Because of these mitigating factors, the usefuiness of the mumbers of individuals obtained from the reports provided in Appendix D is limited; therefore, they are not used to develop any other statistics in this document. 
TABLE 4.12

NUMBER OF PERSONNEL"*

BY WORK FUNCTION AND PERSONNEL TYPE

1995

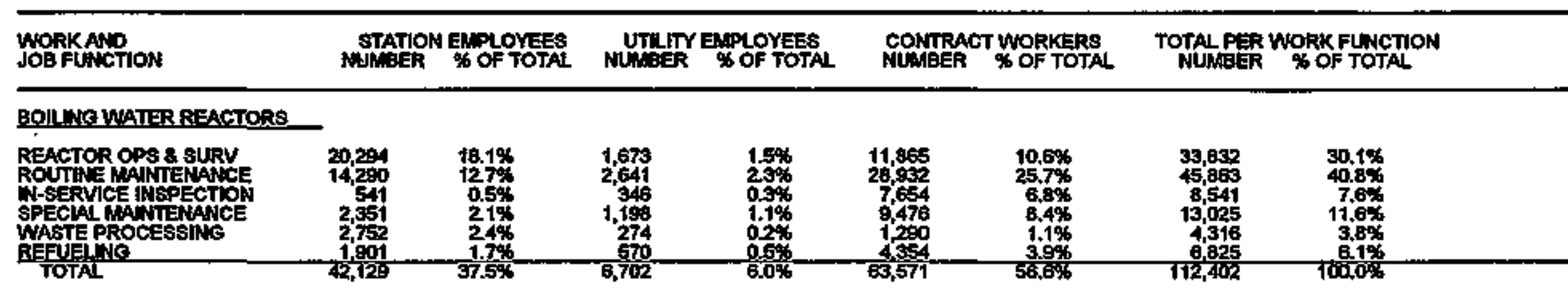

ఓ્ PRESSURZZED WATER REACTORS

\begin{tabular}{|c|c|c|c|c|c|c|c|c|}
\hline 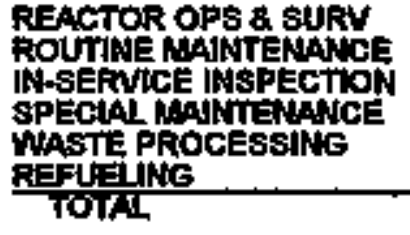 & $\begin{array}{r}9,372 \\
13,280 \\
1,130 \\
3,655 \\
1,441 \\
2,816 \\
3,1,67\end{array}$ & $\begin{array}{l}10.3 \% \\
14.7 \% \\
1.2 \% \\
4.3 \% \\
1.6 \% \\
3.1 \% \\
352 \%\end{array}$ & $\begin{array}{r}1,976 \\
4,109 \\
1,216 \\
2,399 \\
1,391 \\
1,0,117\end{array}$ & $\begin{array}{l}2.2 \% \\
4.5 \% \\
1.3 \% \\
2.6 \% \\
0.4 \% \\
1.1 \% \\
12.3 \%\end{array}$ & $\begin{array}{r}6,617 \\
18,485 \\
4,143 \\
11,074 \\
1,615 \\
5,644 \\
47,578\end{array}$ & $\begin{array}{r}7.3 \% \\
20.4 \% \\
4.6 \% \\
12 . \% 5 \\
1.5 \% \\
6.2 \% \\
525 \%\end{array}$ & $\begin{array}{r}17,965 \\
35,874 \\
6,489 \\
17,328 \\
3,450 \\
9,486 \\
90,592\end{array}$ & $\begin{array}{r}19,6 \% \\
39,6 \% \\
7,2 \% \\
19,1 \% \\
3,6 \% \\
10,5 \% \\
100,0 \%\end{array}$ \\
\hline
\end{tabular}

\section{ALL LHEHT WATER REACTORS}

\begin{tabular}{|c|c|c|c|c|c|}
\hline 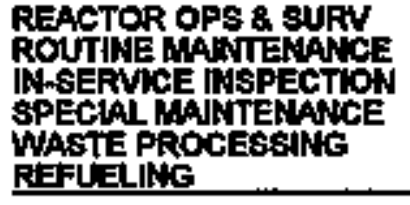 & $\begin{array}{r}29,638 \\
27,670 \\
1,671 \\
6,206 \\
4,196 \\
4717 \\
\end{array}$ & $\begin{array}{r}14.6 \% \\
13.6 \% \\
0.8 \% \\
3.1 \% \\
2.1 \% \\
2.3 \% \\
\end{array}$ & $\begin{array}{r}3,649 \\
6,760 \\
1,562 \\
3,597 \\
1,596 \\
\end{array}$ & $\begin{array}{l}1.8 \% \\
3.8 \% \\
0.8 \% \\
1.8 \% \\
0.3 \% \\
0.8 \%\end{array}$ & $\begin{array}{r}19,492 \\
47,417 \\
11,797 \\
20,550 \\
2,805 \\
9,908 \\
\end{array}$ \\
\hline TOTAL & 74,026 & $38,5 \%$ & 17,819 & $0,8 \%$ & 111,149 \\
\hline
\end{tabular}

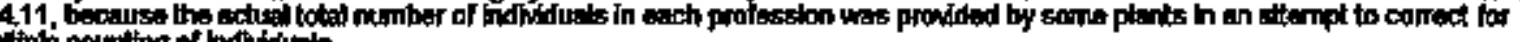


TABLE 4.13

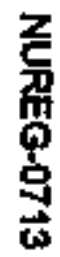

NUMBER OF PERSONNEL*

BY OCCUPATION AND PERSONNEL TYPE

1995

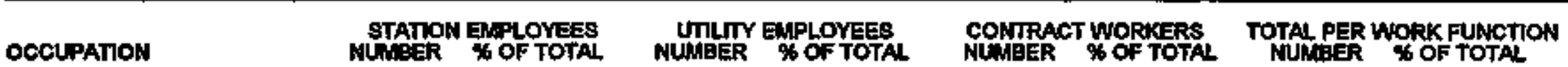

BOLLNTE WATER REACTORS

\begin{tabular}{|c|c|c|c|c|c|c|c|c|}
\hline 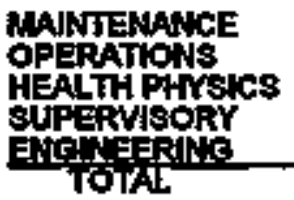 & $\begin{array}{r}12,853 \\
12,581 \\
7,187 \\
2,495 \\
5,450 \\
40,54\end{array}$ & $\begin{array}{r}11.8 \% \\
11.5 \% \\
6.6 \% \\
2.3 \% \\
5.0 \% \\
37.3 \%\end{array}$ & $\begin{array}{r}3.412 \\
527 \\
705 \\
309 \\
6, \frac{\sin }{422}\end{array}$ & $\begin{array}{l}3.1 \% \\
0.5 \% \\
0.7 \% \\
0.3 \% \\
1.3 \%\end{array}$ & $\begin{array}{r}45,414 \\
3,390 \\
4,571 \\
2,470 \\
5,991 \\
67,102\end{array}$ & $\begin{array}{r}41.7 \% \\
3.1 \% \\
4.2 \% \\
2.3 \% \\
5.5 \% \\
5.6 \%\end{array}$ & $\begin{array}{r}61,679 \\
16,481 \\
12,529 \\
6,274 \\
12,840 \\
10,797\end{array}$ & $\begin{array}{r}56.7 \% \\
16.1 \% \\
11.5 \% \\
4.8 \% \\
11.8 \% \\
100.0 \%\end{array}$ \\
\hline
\end{tabular}

A PRESSURITEO WATER REACTORS

dy

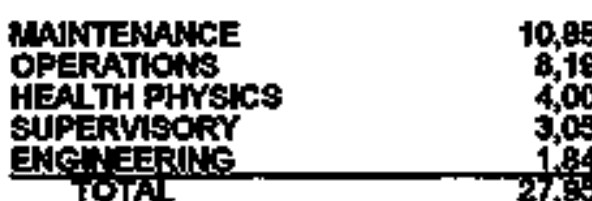

\begin{tabular}{|c|c|}
\hline $\begin{array}{l}10,054 \\
8,1005 \\
4,005 \\
3,054 \\
1,844\end{array}$ & $\begin{array}{r}13.6 \% \\
10.3 \% \\
5.0 \% \\
3.8 \% \\
2.4 \%\end{array}$ \\
\hline
\end{tabular}

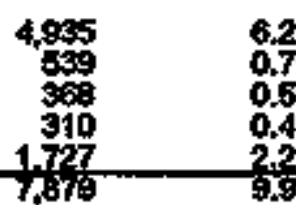

$\begin{array}{ll}6.2 \% & 23,314 \\ 0.7 \% & 2,205 \\ 0.5 \% & 7,29 \\ 0.4 \% & 5,421 \\ 2.2 \% & 5 \%\end{array}$

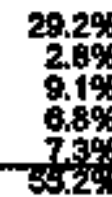

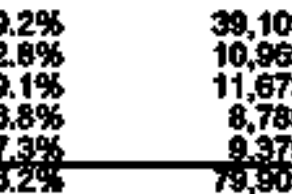

39,103
10,969
11,673
$8,7,5$
8,979

13. $13.9 \%$

14.6\%

$11.0 \%$

11.74

ALLLIGUTWATERREAGTORS

ManTENANCE

OPERATOHS

HELT PHYSIC

SUPERVISORY

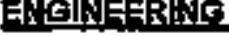

TOTAL.

\begin{tabular}{rrr}
29,707 & $12.6 \%$ & 8,347 \\
20,790 & $11.0 \%$ & 1,060 \\
11,193 & $5.9 \%$ & 1,139 \\
5,549 & $2.9 \%$ & 619 \\
7,294 & $3.9 \%$ & 3,139 \\
\hline 68,400 & $36.3 \%$ & 14,301
\end{tabular}

$\begin{array}{ll}4.4 \% & 6.72 \\ 0.6 \% & 5.6 \\ 0.6 \% & 16 \% \\ 0.5 \% & 7,8 \\ 1.7 \% & 11.7\end{array}$

$7.6 \%$

105,606

\begin{tabular}{rr}
728 & 36 \\
6780 & 6 \\
8701 & 4 \\
789 & 8 \\
\hline
\end{tabular}

$36.4 \%$
$3.0 \%$
$6.3 \%$
$4.2 \%$
$6.7 \%$

$68.1 \%$

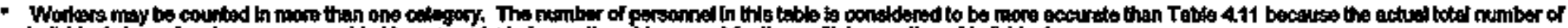

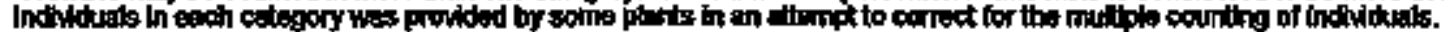


TABLE 4.14

AVERAGE DOSES BY OCCUPATION

AND PERSONNEL TYPE"

1995

\begin{tabular}{|c|c|c|c|c|c|c|c|c|c|c|c|c|}
\hline \multirow[b]{2}{*}{ OCCUPATION } & \multicolumn{3}{|c|}{ STATIN } & \multicolumn{3}{|c|}{ IITIIY } & \multicolumn{3}{|c|}{ FDNTRAGT } & \multicolumn{3}{|c|}{ TOTAL } \\
\hline & cote & DNpeger & Alve: & couse & $\begin{array}{l}\text { MMPGA OF } \\
\text { MPLOYEES }\end{array}$ & ANo. & coth & $\begin{array}{l}\text { MUNDEROF } \\
\text { EMPLOYLES }\end{array}$ & Ala & coth & Hulporof & Dose \\
\hline \multicolumn{13}{|c|}{ BOILWG_WATER REACTORS } \\
\hline 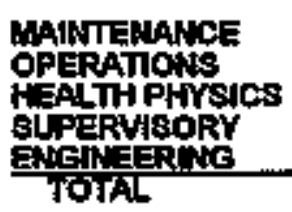 & $\begin{array}{r}1,757 \\
709 \\
502 \\
175 \\
177 \\
3,473\end{array}$ & $\begin{array}{r}12,053 \\
12,51 \\
7,197 \\
2,495 \\
5,450 \\
40,5 \% 6\end{array}$ & $\begin{array}{l}0.14 \\
0.06 \\
0.07 \\
0.07 \\
0.03 \\
0.08\end{array}$ & $\begin{array}{r}750 \\
21 \\
62 \\
6 \\
61 \\
6100\end{array}$ & $\begin{array}{r}3,412 \\
507 \\
765 \\
300 \\
4,409 \\
6,422\end{array}$ & $\begin{array}{l}0.22 \\
0.04 \\
0.08 \\
0.02 \\
0.04 \\
0.14\end{array}$ & $\begin{array}{r}4,074 \\
1,58 \\
307 \\
108 \\
3,78 \\
5,0253\end{array}$ & $\begin{array}{r}45,414 \\
3,453 \\
4,474 \\
2,770 \\
5,911 \\
61,829\end{array}$ & $\begin{array}{l}0.09 \\
0.05 \\
0.07 \\
0.04 \\
0.06 \\
0.08\end{array}$ & $\begin{array}{r}6,581 \\
682 \\
870 \\
289 \\
616 \\
9,238\end{array}$ & $\begin{array}{r}61,679 \\
18,481 \\
12,593 \\
5,274 \\
12,848 \\
108,797\end{array}$ & $\begin{array}{l}0.11 \\
0.03 \\
0.07 \\
0.03 \\
0.05\end{array}$ \\
\hline
\end{tabular}

离 PRESSLRRIZTD WATER REACTORS

\begin{tabular}{|c|c|c|c|c|c|c|c|c|c|c|c|c|}
\hline 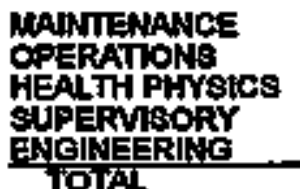 & $\begin{array}{r}1,655 \\
681 \\
720 \\
214 \\
234\end{array}$ & $\begin{array}{r}10,054 \\
8,195 \\
4,005 \\
3,154 \\
1,84 \\
7,043\end{array}$ & $\begin{array}{l}0.17 \\
0.08 \\
0.18 \\
0.07 \\
0.13 \\
0.13\end{array}$ & $\begin{array}{l}99 \\
25 \\
31 \\
17 \\
53 \\
019\end{array}$ & $\begin{array}{r}4,985 \\
509 \\
368 \\
310 \\
1,727 \\
7849\end{array}$ & $\begin{array}{l}0.18 \\
0.05 \\
0.09 \\
0.00 \\
0.00 \\
\end{array}$ & 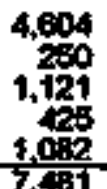 & $\begin{array}{r}20,314 \\
2,208 \\
7,298 \\
5,421 \\
6,005 \\
407\end{array}$ & $\begin{array}{l}0.20 \\
0.11 \\
0.15 \\
0.08 \\
0.19 \\
0.14\end{array}$ & $\begin{array}{r}7,352 \\
957 \\
1,872 \\
653 \\
1,368 \\
\end{array}$ & $\begin{array}{r}39,105 \\
10,869 \\
11,678 \\
6,705 \\
9,379\end{array}$ & $\begin{array}{l}0.19 \\
0.09 \\
0.16 \\
0.07 \\
0.15 \\
6.15\end{array}$ \\
\hline
\end{tabular}

\section{ALL LEEHT WATER BEACTORS}

\begin{tabular}{|c|c|c|c|c|c|c|c|c|c|}
\hline 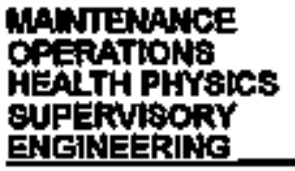 & $\begin{array}{r}3,592 \\
1,384 \\
1,221 \\
369 \\
411 \\
\end{array}$ & $\begin{array}{r}23,707 \\
20,760 \\
11,193 \\
5,549 \\
7,294\end{array}$ & $\begin{array}{l}0.15 \\
0.07 \\
0.11 \\
0.07 \\
0.03\end{array}$ & $\begin{array}{r}1,643 \\
46 \\
93 \\
23 \\
+114 \\
\end{array}$ & $\begin{array}{r}8,347 \\
1,066 \\
1,135 \\
3,136 \\
3,136 \\
\end{array}$ & $\begin{array}{l}0.20 \\
0.04 \\
0.08 \\
0.04 \\
0.04\end{array}$ & $\begin{array}{l}8,677 \\
1,428 \\
1,453 \\
1,400\end{array}$ & $\begin{array}{r}68,728 \\
5,620 \\
11,870 \\
7,891 \\
11,769 \\
\end{array}$ & $\begin{array}{l}0.13 \\
0.07 \\
0.12 \\
0.07 \\
0.12\end{array}$ \\
\hline TOTAL & 6,997 & 68,499 & 0.10 & 1,919 & 14,301 & 0.13 & 12,503 & 105,906 & 0.12 \\
\hline
\end{tabular}




\subsection{Graphical Represeriation of Dose Trends in Appendix E}

Each page of Appendix E presents two types of graphs for one site. One greph plots selected dose-performence indicators from 1973 through 1995 , and the other indicates the collective dose by job function for 1978 through 1995 . The dose and performance indicators shown in the top graph ilustrate the history of the collective dose for the site, the rofling 3-year average collective dose per reactor, and the gross electrielty generated at the site. These data are plotted, beginning with the plant's first full year of commercial oparation, and continuing through 1995. However, any data reported prior to 1973 are not Included. The 3-year average collective dose per reactor data is included because it prowdes a beiter overall indicalion of the plant's general trend in collective dose. This average is determined by summing the collective dose for the currert year and the previous 2 years and then dividing this sum by the number of reactors reporiting during those years. Date for yeers when the plant was not in commencial operation have been included when evallable. This reduces the sporadic effects on annual doses of refualing operations (usually a 2- to 3-year cycle) and occasional high-dose maintenance activities, and gives a better Idea of collective dose trends over the llfe of the plant. For sites with more than one reactor, the plot of the 3-year roling average will lie below that of the plot of the annual collective dose for the ste because it is calculated on a per-reactor basis.

The second type of graph at the bottom of each page in Appendix E displays the breakdown of collective dose by job function and employee type for the years 1978 through 1995 . The horizontal axis lists the six job functions of reactor operations, routins maintenance, in-servlce Inspectlon, special maintenence, waste menagement, and refueling operafions, and the vertical axis indlcates collective dose at each ste. This representation shows the job functions where most of the dose was accumulated as well as the division of the collective dose among plant and contract workers. The data are taken from the submitials presented In AppendlX D and therefore represent at least $80 \%$ of the collectwe dose at each ste. Only those reactors that have completed at least 1 full year of commerclel operation ere presented in Appendlix $E$.

\subsection{Heallh lmolicentions of Averang Amuai Doses}

Siudjes of populations chronlealy exposed to low levels of radlation delhered over protracted periods have not shown consistem or conchustve evidence of an associated increase in the risk of cencer. Thus, there is no evidence that the doses to workers recorded here cause ham.

The isk estimates presented bolow are based on extensive studies of Jepanese Atomic bomb survivors and other populations exposed to lerge doses of radiation delivered in short periods of time. This infomation is supplemented by animal and in vitro studies, such as iradiatlon of cell cultures. These studies have confimed that human cells have mechan'sms that repair damaged chromosomes. The existence of this repair helps to explain the finding that lower 
doses of radietion delvered at lower dose rates produce less of an effect on a cell per unt dose than high-dose, high-dose-rate iradiatlons. Thus the estimates of risks to radiation workers are likely to be conservetive.

Hez'th effects due to radiation exposure fall into three groups: carcinogenic effects, genetic effects, and mentel retardation. Mental retardation has been observed only in Japanese A-bomb sunivors exposed et 8-15 weaks gestatlonal age, and is consequently not applicable to the workplace except in the case of a pregnant female worker. Genetic effects have never been observed in man, though they have been observed in mice.

Rusk of cencer induction is known to increase with Increasing dose, bụt is hard to quantify as the risk varies wilh the site of the cancer, the age and sex of the exposed individual, the eneroy and nature of the radiation, the magnitude and duration of the dose, and exposure to other cercinogens. Since nearty $20 \%$ of all deaths in the United States occur from cancer, the estimated number of cencers atiribulable to cccupalional radiation exposure is a small fraction of the total number thet occur. (Those who do not succumb to cancer will, perforce, succumb to some other cause and in essentialy the same time frame.)

The Committee on the Blological Effects of lonizlng Radiations (BEIR) of the Nallonal Academy of Sclences (NAS) National Research Council has been conducting an ongoing study of the health efiects of lonizing radlation. Its latest report, BEIR V, was publlshed in 1990. Besed on this report, the 76,822 workers receiving the average dose of $0.32 \mathrm{cSv}$ (rem) continuously during an entire working career (working from age 18 until age 65) or the maximum accidental dose of $5.1 \mathrm{cSV}$ (rem) to the whols boty during 1995 (see Section 6 ) might expect an increased cancer death risk of about 9 chances in 1000 for the everage dose and 4 chances per 1000 for the maximum dose. ${ }^{10}$ Should a worker recelve 0.32 cSv (rem) continuously during an entire working carear (working from age 18 until ape 65), his/her lifelime risk of oying from cancer is estimated to increase by approximately $4 \%$. Since the American Cancer Soxiaty estimates that an individue's risk of dying of cancer is about $20 \%$ (one in five), the risk to an individual receiving $0.32 \mathrm{cSv}$ (rem) would be approximately $21 \%$.

The potential genetic effects from a worker populatlon recelving 24,536 person-csv (person-rem) (Teble 3.1) ere small compared to genetic dameges that nomally occur sponteneoushy in a populetion of this size. Approximalely 100,000 serious geneltic defects occur normely in one million twe biths, l.e., en average of about one serlous dofect in every ten twe births. Theoretically, the total genetic damage in the first generation chlliden of the 76,822 exposed workers would, according to NUREGFCR-4214 [Ref. 17], be an increase of

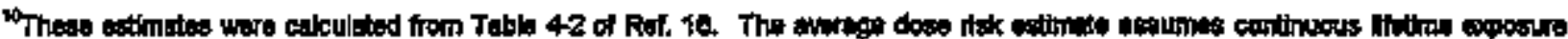

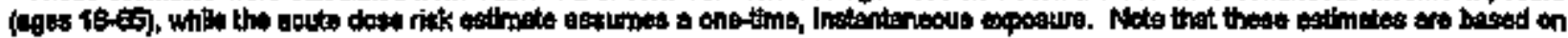

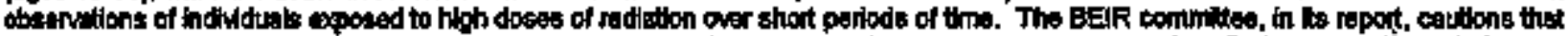

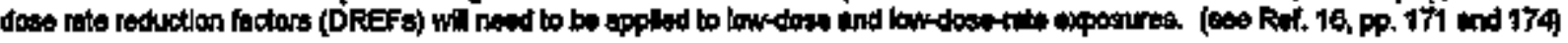


about 8 cases (approximately 0.01\%) compared to the expected 8,000 cases that occur normally. ${ }^{11}$ No significant increase In the number of genetic defects hes been observed in the chidren of individuals exposed to much hlgher levels of iontzing radlation at Hiroshima and Nagasaki, Japan.

\subsection{Estimation of Future Oceupational Radiation Exposure at Commenciel Reactor Siltes}

Date on occupetional exposure from 1973 to 1995 suggest that commercial power reactor sites show a consistent lifo-cycle exposure pettem, as ilustrated in Figure 4.7. The horizontel axis shows the average age of reactors at a site in years, while the vertical axis shows the average yearly collective dose per site in CSV (rem). The general shape of the curve supports the hypothesis that exposure increases during the startup and "shakedown" phase of operalion, and then gradually decreeses as operations become more routhe and sources of exposures are Identified and remediated. White BWR and PWR reactors show the same general pattern, the average exposure levels at PWR reactors are lower until well into the second decade of operation.

A regression model that captures this life-cycle pattem was developed based on exposures at U.S. power plants from 1973 to 1995 . The model uses information on average site age and other factors, such as type of reactor, sike capacily, and amount of power generated In a year, that can influence worker exposure. Only reactors completing a full year of commercial power operation are included. Dose information for reactors that began operation prior to 1973 are not included, so the initial years of operation for these reactors are not included in the model or reflected on the graphs. In addition, only those sites where the reactor unlt age difference is $<5$ years are included. Because the average refueling cycle is $18-24$ months, the model uses a 3-year exposure total to mininize the effect of the year-to-year differences that can occur within that cycle. The analysls summerizes dose and reactor informetion by site, because exposure data per reactor unit are not avaliable. Bata that aliow separate calculations for each reactor at a site would increase the model's accuracy. The model estlmates the collective dose in CSv (rem) at each site based on the parameters shown in Table 4.15.

n

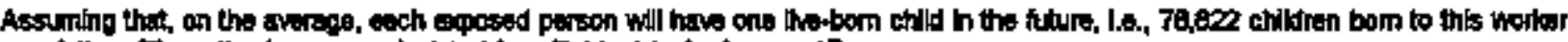

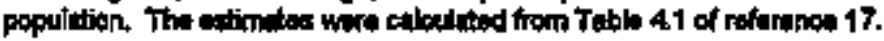


Figure 4.7 Average Collective Dose by Site Age

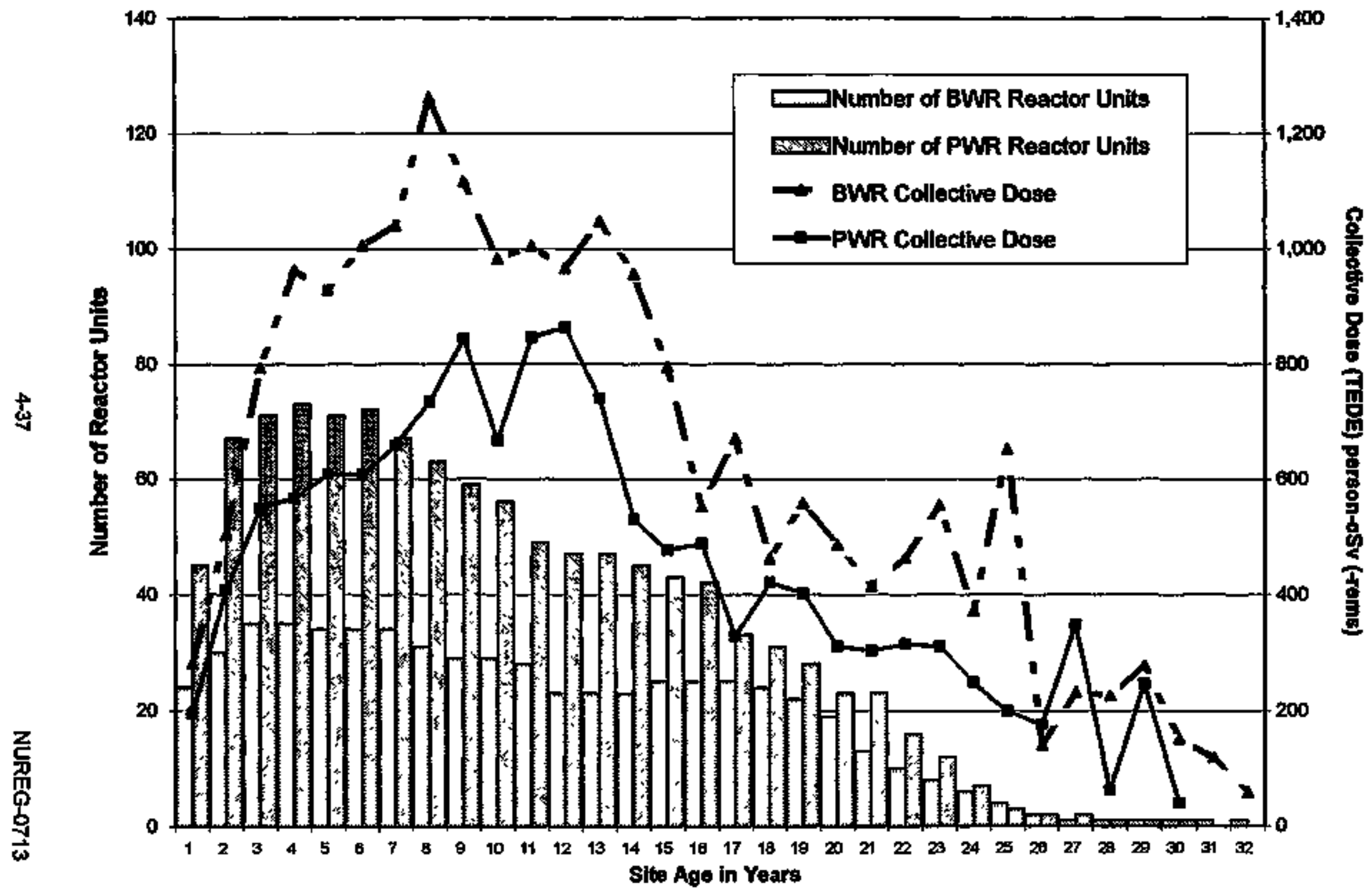




\begin{tabular}{|c|c|}
\hline \multicolumn{2}{|c|}{$\begin{array}{c}\text { Tablo 4.16 Parameters Used in Goliective Dose } \\
\text { vs. Ftant Ape Oata Model }\end{array}$} \\
\hline Peremiotar & Dessoription \\
\hline Sile Age & $\begin{array}{l}\text { Average age of reactor tunits at the ste in years. } \\
\text { Onty includes sites where reactor unit age } \\
\text { differences are < } 5 \text { years and only includes data } \\
\text { from } 1973 \text { to } 1995 \text {. }\end{array}$ \\
\hline Capacliy & Tolal capacity in meqawalts \\
\hline MWYears & $\begin{array}{l}\text { A measure of amount of power generated during } \\
\text { the year }\end{array}$ \\
\hline Reactor Type & PWR, BWR ${ }^{12}$ \\
\hline Dose Year 1 & Total dose 1 yoer ago \\
\hline Dose Year 2 & Total dose 2 years ago \\
\hline Dose Year 3 & Tofal dose 3 years ago \\
\hline$R \times \sin \theta$ & $\begin{array}{l}1 \text { If averege reactor size at sto is } \geq 1000 \mathrm{MW}_{\mathrm{t}} \\
0 \text { if less then } 1000 \mathrm{MW}\end{array}$ \\
\hline Slte Ske & $\begin{array}{l}1 \text { if capacily is } \geq 1000 \text { MW or there is more then } \\
1 \text { reactor at the site; } \\
0 \text { if the capactly is less than } 1000 \mathrm{MW}\end{array}$ \\
\hline
\end{tabular}

Because exposure levels were impacted significantly in the wake of the TMl incident, a single model will not fit the data before and after this incident. Most of the post-TMI mandated plant modificetions were completed from 1980 to 1985. Collective exposure per site dropped from $880 \mathrm{cSv}$ (rom) for 1973-1985 to $473 \mathrm{CSv}$ (rom) in 1986-1995; exposure per megenwatt rated capaclty dropped from 1.1 cSVMS (remMW) to $0.5 \mathrm{CSVMW}$ (remMM) between the two periods. The model included here uses all the avaliable data, and provides the best fit for the post-Thal period, to provide the most accurate projections for future years.

The model generates yoar-by-year estimates of expected dose that can be aggregated to estimate total U.S. worker exposure for a given year. This allows predictions to be made for the United States as a whole, while taking into account the varying ages and histories of reactors at each stte. Figure 4.8 compares the actual versus projected aggregate U.S. exposure levels for 1985-1995 ${ }^{13}$, and shows projections through 2005 . The projections (also

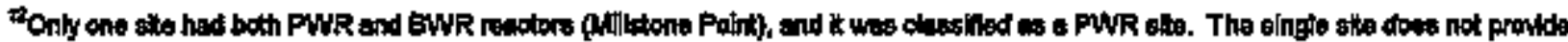

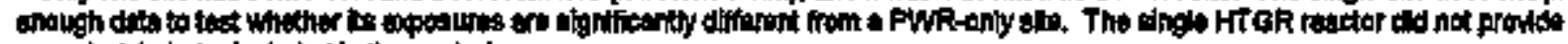

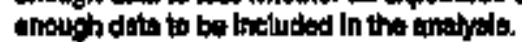

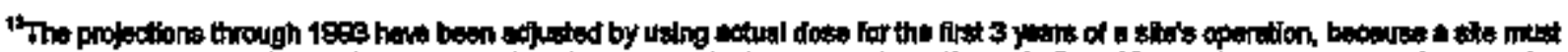

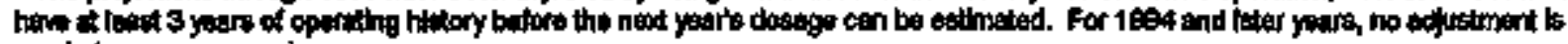
needed.
} 
Figure 4.8 Reactor Collective Dose Projections

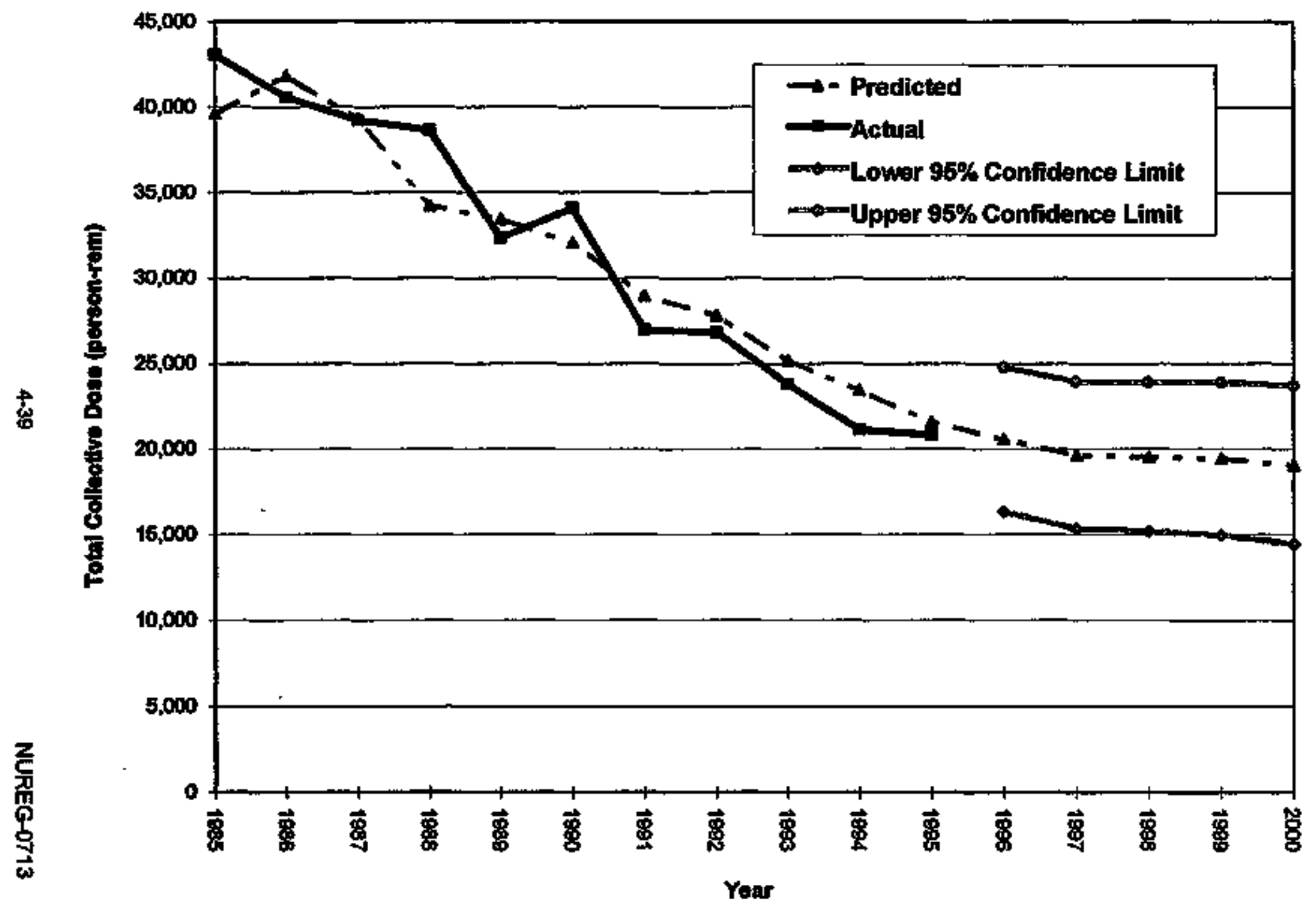


shown in Table 4.16) take into account all of the factors lsted in Tabie 4.15, the aging of the reactor population, and the scheduled closing of Big Rock Point in 2000. The actual deles of future reactor shutdowns are unknown and may be affected by petitions for plant license extensions. The modet does not take into account any exposure associated with decommissioning after these reactors ceese commercial power operetions. Because the exact emount of power generated and actuat future dosages are unknown, the most recent 3-year averages were used as values for megawatt-years and Dose Year 1 through Dose Yeer 3. The results are best used to fdently expected tronds, rather then predicting the actual exposure in any single year.

\begin{tabular}{|c|c|}
\hline \multicolumn{2}{|c|}{$\begin{array}{c}\text { Tablo 4.16 Projeoled Colleotive } \\
\text { Dose, } 1996 \text { - } 2000\end{array}$} \\
\hline Yoar & $\begin{array}{l}\text { Profotod Coliestive } \\
\text { Dose (TEDE) } \\
\text { porson-osv (rem) }\end{array}$ \\
\hline 1996 & 20,553 \\
\hline 1997 & 19,620 \\
\hline 1998 & 19,631 \\
\hline 1999 & 10,401 \\
\hline 2000 & 18,056 \\
\hline
\end{tabular}

From this analysis, it is anticipated that the total collective dose at reactor shes will continue to decreese over the next several years. Other factors, such as extended unanticlpated outages or shutdowns, may have a significant Impact on future doses. The projections are an estimation of the general trend over the next 5 years. Any glven year may have a collective dose above or below these estimated values. 


\section{TRANSIENT WORKERS AT. NRC LICENSED FACILITIES}

\subsection{Termingtion Repots}

Under the revised 10 CFR 20, licensees are required to submit NRC Form $5 s$ to the Commission for each individual who is required to be monitored at the end of the monitoring yeer or upon the individual's termination of employment at the facility. The "terminalion reports" submitted in accordance with the ofd $\$ 20.408$, Isting the individual's complete dose history during employment at the facllity, ere no longer required.

However, the Form 6s submitted to the NRC upon an individual's termination of employment serve the same function as the previous requirements with regerd to the analysis of Iransient workers at NRC-llcensed facillies. The following anatysis examines the workers who had more then one Fom 5 dose record al more than one NRC-licensed facility churing the monitoring year. These workers are defined to be translent in that they worked at more than one facllty during the montioring year.

The term "monitoring year" is used here in accondance with the definition of a year given in \$ 20.1003, which deflnes a year as "the perlod of time beginning in January used to determine compliance with the provisions of this part. The licensee may chenge the start dale of the monitoring year used to determine compliance provided that the change is made at the beginning of the monitoring/calendar year and that no day is omitted of dupliceted in consecutive years".

\subsection{Iranstent Workers at NRC Factilities}

Examination of the data reported for workers who began and terminated two or more periods of employment with two or more different tecleties wthin one monitoring year is useful in many ways. For exemple, the number and average dose for these "ennual transients" can be detemined from examining these data.

Addlfibnally, the distribution of the doses recelved by transient workers can be useful in determining the impact that the inclusion of these individuals in each of two or more licensees' annual reports has on the annual summery (as reported in Appendlces B and F) for all nucleer power facillies, and anl NRC llcensees combined (one of the problems mentioned in Section 2). Table 6.1 shows the "actual distribution" of transient worker doses as determined from the above-mentioned Form 5 termination reports and compares it with the "reported ofstribution" of the doses of these workers as they would heve eppeared in a summation of the annual reports submilted by each of the licensees. 
TABLE 5.1

EFFECTS OF TRANSIENT WORKERS ON ANNUAL STATISTICAL COMPILATIONS

1995

\begin{tabular}{|c|c|c|c|c|c|c|c|c|c|c|c|c|c|c|c|c|}
\hline \multirow[b]{2}{*}{ Lloestes Catogony } & \multicolumn{11}{|c|}{ 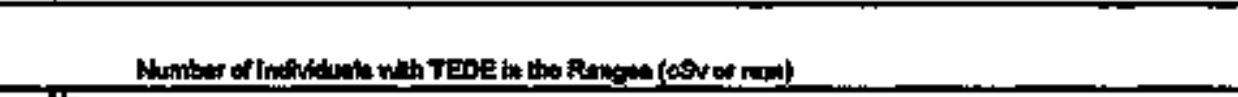 } & \multirow[b]{2}{*}{ Thomit } & \multirow{2}{*}{ 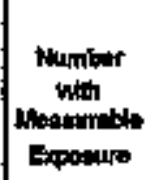 } & \multirow{2}{*}{ 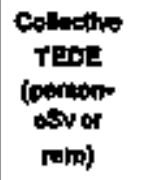 } & \multirow{2}{*}{ 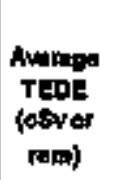 } & \multirow{2}{*}{ 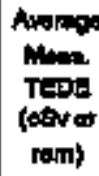 } \\
\hline & Monstos & Мimblo & $\begin{array}{l}0.10- \\
0.25\end{array}$ & $\begin{array}{c}0.25- \\
0.5\end{array}$ & $\begin{array}{l}0.60- \\
0.75\end{array}$ & $\begin{array}{c}0.76- \\
1.0\end{array}$ & $\begin{array}{l}1.0- \\
20\end{array}$ & $\begin{array}{l}20 \\
3,0\end{array}$ & $\begin{array}{l}3.0 \\
4.0\end{array}$ & $\begin{array}{l}40-= \\
5.0\end{array}$ & $\begin{array}{l}5,0 \\
0,0>0\end{array}$ & & & & & \\
\hline \multirow{2}{*}{ 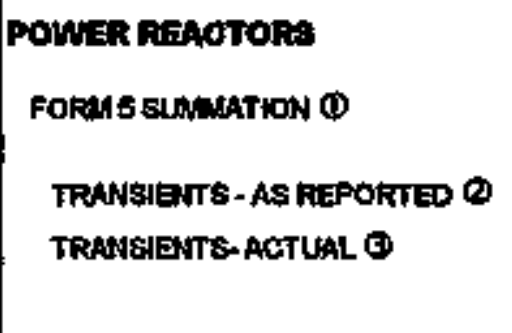 } & 부요. & 3878 & 20,245 & 15278 & 6984 & 3383 & $3,0 \pi 7$ & 125 & $\underline{\mathbf{s}}$ & & & 168, 国 & ar,ses & 21,074 & 0.13 & 0.25 \\
\hline & $\begin{array}{r}24,434 \\
5,002 \\
\end{array}$ & $\begin{array}{r}13,602 \\
4,607 \\
\end{array}$ & $\begin{array}{l}8,000 \\
2900 \\
\end{array}$ & $\begin{array}{l}6,330 \\
3,+34 \\
\end{array}$ & $\begin{array}{l}2,706 \\
2,00 \% \\
\end{array}$ & $\begin{array}{l}1,397 \\
1,307 \\
\end{array}$ & $\begin{array}{l}1,397 \\
2,165\end{array}$ & $\begin{array}{r}t 5 \\
540\end{array}$ & $\begin{array}{r}2 \\
118 \\
\end{array}$ & 2 & & $\begin{array}{l}87,084 \\
22,472 \\
\end{array}$ & $\begin{array}{l}39,810 \\
10,850 \\
\end{array}$ & $\begin{array}{l}0,008 \\
9,000\end{array}$ & $\begin{array}{l}0.18 \\
0.40 \\
\end{array}$ & $\begin{array}{l}0.27 \\
0.53 \\
\end{array}$ \\
\hline COARECTLP DISTALAUTION (1-(20) & sates & $2,0<1$ & 18,162 & 12,008 & 6,148 & $\mathbf{3}, \mathbf{3 0 0}$ & 3,806 & Bso & 121 & $\mathbf{2}$ & & 133,000 & 70,500 & 21,674 & 0.16 & ast \\
\hline \multirow{3}{*}{ 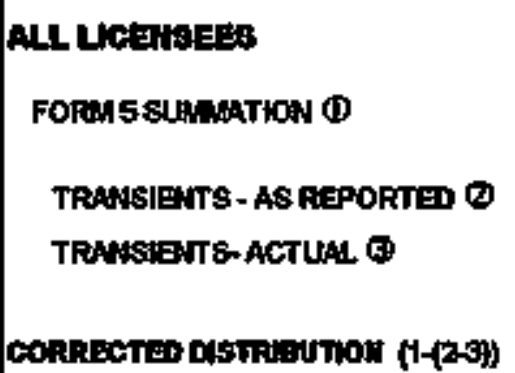 } & ed,eep & 41304 & 21,312 & 16,223 & 7,449 & 3,707 & 3,6022 & 370 & 79 & a & 1 & 17,178 & $94,2 \pi 7$ & 24801 & 0.14 & 0.28 \\
\hline & $\begin{array}{r}24,600 \\
5,442 \\
\end{array}$ & $\begin{array}{r}13,757 \\
4,627 \\
\end{array}$ & $\begin{array}{l}0,172 \\
2,999 \\
\end{array}$ & $\begin{array}{l}0,460 \\
3,160 \\
\end{array}$ & $\begin{array}{l}2,800 \\
2,050 \\
\end{array}$ & $\begin{array}{l}1,460 \\
1,394 \\
\end{array}$ & $\begin{array}{l}1,406 \\
2,205 \\
\end{array}$ & $\begin{array}{r}84 \\
554 \\
\end{array}$ & $\begin{array}{r}6 \\
124 \\
\end{array}$ & 5 & & $\begin{array}{l}50,004 \\
2205\end{array}$ & $\begin{array}{l}34,054 \\
17,100 \\
\end{array}$ & $\begin{array}{l}9,040 \\
8,09\end{array}$ & $\begin{array}{l}0.15 \\
0.40 \\
\end{array}$ & $\begin{array}{l}0.27 \\
0.53 \\
\end{array}$ \\
\hline & 1001 & $\mathbf{2 x , 1 8 1}$ & 16,110 & 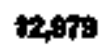 & 0,703 & stest & 408 & 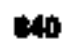 & 197 & 11 & $\mathbf{t}$ & 142,757 & $\boldsymbol{n}, \mathbf{s} \boldsymbol{6}$ & 24,884 & Q.t7 & 0.32 \\
\hline
\end{tabular}


Because $>95 \%$ of these transients are reported by nuclear power facilities, these data were considered seperately. Table 5.1 shows that the power reactor transient data consititute the vast majority of the transient worker exposure. The nonreactor licensees contribute only an additional $0.5 \%$ of the transient workforce and an additional $0.4 \%$ to the collective dose.

The following detinitions apply to Teble 5.1:

\begin{tabular}{|c|c|}
\hline Form 5 Strmmation & $\begin{array}{l}\text { The summation of the TEDE from each of the Form } 5 \text { s submitted for } \\
\text { the monitoring year. This is the summetion of eech dose record } \\
\text { grouped by licensee end individual. This distribution takes into } \\
\text { account multiple Fom 5s for an madividual at one NRC-llcensed facilly } \\
\text { but net multiple exposures at multiple licensees. }\end{array}$ \\
\hline $\begin{array}{l}\text { Translents - As } \\
\text { Reported }\end{array}$ & 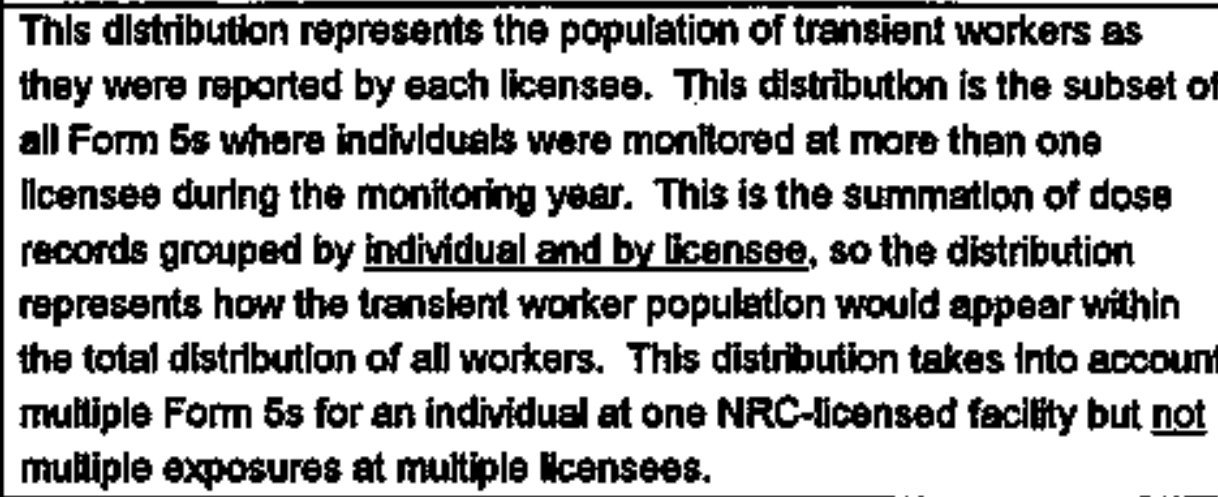 \\
\hline Transients - Actual & $\begin{array}{l}\text { Thls is the actual distribution for transient workers summed per } \\
\text { Individuel. This represents the true number of individuals and places } \\
\text { each individual in the conrect dose range. This distrlbution accounts } \\
\text { for mulliple records per intividual and muttlple Heensees. }\end{array}$ \\
\hline Corrected Dlstrïution & $\begin{array}{l}\text { Thls distribution represents the correction of the reported distribution } \\
\text { by subtracting the difference in the reported and actual distribution for } \\
\text { transient workers. This represents the most accurate dose } \\
\text { distributlon for the llcensee category and accounts for the mutiple } \\
\text { reporting of indlulduals. }\end{array}$ \\
\hline
\end{tabular}

Table 5.1 llbustrates the impact that the multiple reporting of these transient Indviduals had on the staff's summation of the exposure reports for 1995. Because each licensee reports the doses received by workers while monltored by the particular licenses during the year, one would expect thet a summation of these reports would result in Indlwiduals being counted several times In dose ranges lower than the range in which their total accumulated dose (the sum of the personnet monitoring results incurred al each facilty during the year) would actually place them. Thus, while the total collective dose would remein the same, the number of workers, their dose distrithution, and average dose would be affected by this multiple reporting. 
This was found to be true because 100 few workers were reported in the higher dose ranges. For example, in 1995, Table 5.1 shows thet the summation of annual reports for reactor licensees indicated that 130 individuels recoived doses greater then 2 CSY (rem). After accounting for those indivlduals who were reported more than once, the corrected distribution indlcated thet there were really 713 workers who received doses greater than $2 \mathrm{CSV}$ (rem). Correcting for the muttiple counting of individuals also hes a significant effect on the average measurable dose for these workers. The corrected arerage measurable dose for transient workers is twice as high as the value calculated by the summetlon of licensee records. The transient workers represent $22 \%$ of the workforce thet recelves measurable dose and increases the average measurable dose for all ilcensees by $19 \%$ from $0.26 \mathrm{cSV}$ (rem) to 0.32 cSv (rom).

One purpose of the REIRS database, which tracks occupational radiation exposures at NRClicensed faclitites, Is to identily individuels who may have exceeded the occupationel ractiation exposure imits because of multiple exposures at different facilitles throughout the year. The REIRS database stores the rediation exposure information for an individual by their unique identification number and idemification type [Ref. 18, Section 1.5] and sums the exposure for all facilities during the monitoring year. An individual exceeding the TEDE 5 CSV (rem) per year regulalory linlt would be Identified in Table 5.1 in one of the dose ranges $>5 \mathrm{rem}$. In 1995, no individual exceeded thls dose $\mathrm{lmlt}$, and since 1985, there have been no additional transient workers identified as having received a dose of >5 $\mathrm{CSV}$ (rem) that have not appeared in the annual reports received by the Commistsion. This reflects the industry's continuing concerted efforts to keep the total annual doses of all workers under $5 \mathrm{cSv}$ (rem) and shows that such reductions can be accompllshed without increasing the collective dose because the collective dose has decreased during this same time pertod. 


\section{EXPOSURES TO PERSONNEL IN EXCESS OF REGULATORY LIMITS}

\subsection{ContnolLevels}

Exposures in excess of regulatory limits are sometimes referred to as "overexposures." The phrase "exposures in excess of regulatory limits" is preferred to "overexposures" because the latter suggests that a worker has been sub]ected to an unacceptable biological risk, which may, or may not, be the case.

The implementation date for the revised 10 CFR 20 was January 1; 1994. The separate limits on intemal and extemal exposure in the old 10 CFR 20 are no longer applicable. The revised 10 CFR 20 now includes requirements for summing intemal and extemal dose equivalents to yield TEDE and to implement a similar limilation system for organs and tissues (such as the lung, liver, and bone surfaces). The dose equivalent limits for the skin of the whole body and for the extremitties have been revised, and a new limit for dose equivalent to the lens of the eye has been added. The revised 10 CFR 20.1201 limits the TEDE of workers to ionizing radletion from licensed material and other sources of radiation within the licensee's control. The revised 10 CFR 20 no longer contains quarterty exposure llmits but has reporting requirements for planned special exposures (PSEs). The annutal TEDE limit for adult workers is $5 \operatorname{csv}$ (rom).

The revised 10 CFR 20.2202 and 10 CFR 20.2203 requite that all persons licensed by the NRC submit reports of all accurrences involving personnel radiation exposures that exceed certain control levels, thus providing for Investigations and corrective actions as necessary. Besed on the magnitude of the exposure, the occurrence may be placed into one of three categorios:

(1) Category A

10 CFR 20.2202(a)(1) - a TEDE to any individual to $25 \mathrm{CSv}$ (rom) or more; an eye dose equivalent of $0.75 \mathrm{~Sv}(75 \mathrm{rem})$ or more; or a shellow-dose equivalent to the skin or extremities of $2.5 \mathrm{~Gy}(250 \mathrm{rad})$ or more. The Commission must be notified immediately of these events.

(2) Cetegory $\mathrm{B}$

10 CFR 20.2202(b)(1) - a TEDE to any individual to $5 \mathrm{CSV}$ (rem) or more; an eye dose equivalent of $0.15 \mathrm{SV}(15 \mathrm{rem})$ or more; or a shallow-dose equivalent to the skin or extremitles of $0.5 \mathrm{~Sv}(50 \mathrm{rem})$ or more in a 24-hour period. The Commission must be notified within 24 hours of these events.

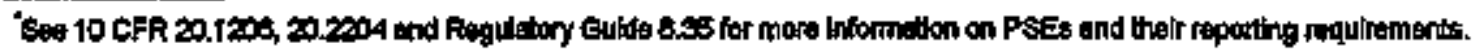


10 CFR 20.2203 - In addition to the notification required by 20.2202 (caltegory $A$ and $B$ occurrences), each licensee must subrnit a written report within 30 days after learning of any of the following occurrences: (1) Any incident for which notification is required by 20.2202 ; or (2) Doses that exceed the limits in $20.1201,20.1207,20.1208,20.1301$ (for adults, minors, the embryoffetus of a declered pregnant worker, and the public, respectively), or any applicable limit in the license; or (3) Levels of radiation or concentrations of radioective material that exceed any applicable license limit for restricled areas or that, for unresticted areas, are in excess of $\mathbf{1 0}$ times any applicable limit set forth in this pert $o r$ in the license (whether or not involving exposure of any individual in excess of the limits in 20.1301); or (4) For ticensees subject to the provisions of the Environmental Protectlon Agency's generally applicable environmental radlation standerds in 40 CFR 190, levels of radiation or releases of radioactive material in excess of those standakds, or of license conditions related to those standards.

\subsection{Limitations of the Data}

It is important to note that this summary of events includes only.

- Occupational radiation exposures in excess of regulatory timits

- Events at NRC-licensed facillties

- Final dose of record assigned to an individual

It does not include:

- Medical misadministratlons to medical patients

- Exposures in excess of regulatory limits to the general pablic

- Agreement State-licensed activities

- Other radialion-relaled violations, such as high dose rate areas or effluent fimits

- Exposures to dosimeters that, upon evaluation, have been determined to be high dosimeter readings only and are not assigned to an individual as the dose of record by the NRC

Care should be taken when comparing the summary information presented here with other reports and analyses published by the NRC or other agencies. Varlous reporis may include other types of "overexposure" events; therefore, the distinctions should be noted. 
The analysis and sumrnary of incidents presented here involving exposures in excess of regulalory limits represent the status of events as of the publication of this report. Exposure everits of this type typically undergo a kng review and evaluation process by the llcensee, the NRC inspector for the regional office, and NRC headquariers. Prellminary dose estimates submitted by licensees are often conservatively high and do not represent the final (record) dose assigned for the event. It Is therefore not uncommon for an "overexposure" event to be reassessed and the final assigned dose to be categorized as not having been in excess of the regulatory llmits. In other cases, the exposure may not be Identified until a later date, such as during the next scheduled audit or inspection of the licensee's exposure records.

For these reasons, an attempt is made to keep current the exposure events summary presented here. An event that has been reassessed and determined not to be an exposure in excess of the limits is not included in this report. In addition, events that occurred in prior years are added to the summary in the appropriate year of occurence. The reader should note that the summary presented here represents a "snapshol" of the status of events as of the publicalion date of this report. Previous or future reports may not correlate in the exact number of events because of the review cycle and reassessment of the events.

\subsection{Summary of Exposures in Excess of Regulatory Limlits}

Tabje 6.1 summarizes the occupational exposures in excess of regulatory limits as reported by Commission licensees pursuant to 10 CFR 20.2202 and 10 CFR 20.2203 from 1994 to 1995. Table 6.2 shows the data reportad under 10 CFR 20.403 and 10 CFR 20.405 for the period 1985-1993. Note that the categorization criteria changed effective with the revised 10 CFR 20. The dose reporting thresholds have been revised - the skin of the whole body and the extremilies now have the same dose limits, and a new set of dose limits has been added for the lens of the eye.

For the period 1990-1993, Table 6.2 shows the number of individuals who exceeded various limits while employed by one of several types of licensees. For the period 1985-1989, only the exposures in excess of regutatory limits reported by licensed industral radlography firms are shown separately. Most of the occurrences Included In the "Others" categary come from research facilities, universitles, and meesurting and well-logging activities.

In 1995, three workers received doses that exceeded the regulatory limit. There were no occurrences in which individuals received an exposure of the magnitude described previousty as "Category A." One "Category B" occutrence was reported.

The incident involved an individual working at a multt-bocation radiography license日 that received $5.100 \mathrm{cSV}$ (rem) during 1995. The worker received $2.670 \mathrm{cSv}$ (rem) during the first half of the year, causing the licensee to begin comective measures. The icensee counseled the worker concerning reducing hls exposure, but the Indwidual stated that personal problems 
had distracted him. Duting the third quarter the licensee limited the individual's work activities, but by the end of the year the individual exceeded the $5 \mathrm{cSv}$ (rem) TEDE annual limit. The NRC reglonal office was notified via telephone and a written report was submitted as requlred.

Two exposures to the skin in excess of the annual limit of $50 \mathrm{cSv}$ (rem) were reported in 1985. Both of these exposures were because of "hot partictes," which are small pleces of radioactive material that cen cause high doses to a localized aree of the skin of the exposed worker. Both of the exposures occurred at the same licensen, which is a manufacturer and distributor of radionucldes (Type A - Broed, see Section 3.3.2). The exposures were from Iridium-192. One individual received an estimaled absorbed dose to the skin of 230 rads in March 1995, and the other received 342 rem to the skin in September. After the first incident, the NRC issued a Notice of violation. Upon the second event the licenseg suspended all operations involving Ir-192 and the NRC began conducting a review of the licensee's hot particte procedures.

\subsection{Meximum Exposures Below the NRC Limits}

Because few exposures exceed the NRC occupational exposure llmits, certain researchers have expressed an interest In a listing of the maximum exposures recelved at NRC licensees that do not exceed the limits. This would allow an exemination of exposures that approach, but do not exceed the limits. Table 6.3 shows the meximum exposures for each dose category required to be reported to the NRC. In addition, the number of exposures in certein dose renges is shown to reflect the number of exposures thet approech the NRC llmits. 
TABLE 6.1

OCCUPATIONAL EXPOSURES IN EXCESS OF REGULATORY LIMITS

1984 - 1995

\begin{tabular}{|c|c|c|c|c|c|c|c|c|c|c|}
\hline \multirow{3}{*}{ VEAR } & \multirow{3}{*}{ 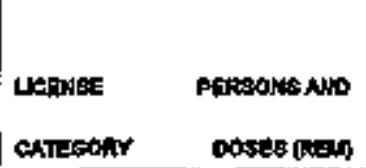 } & \multicolumn{9}{|c|}{ TYFES OF EXPOSURES AND DOSES } \\
\hline & & \multicolumn{3}{|c|}{ TEDe \{esror ran\} } & \multicolumn{3}{|c|}{ 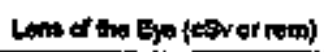 } & \multicolumn{3}{|c|}{ 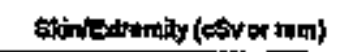 } \\
\hline & & $\Leftrightarrow$ & sest & $\mathbf{2 5}$ & $a$ & $15-76$ & 376 & $\infty$ & so-250 & $\mathbf{2 5 0} \mathrm{red}$ \\
\hline \multirow{5}{*}{ Itest } & 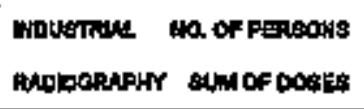 & & $\begin{array}{c}\uparrow \\
5.1\end{array}$ & & & & & & & \\
\hline & 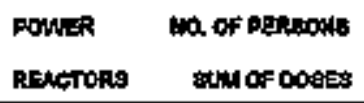 & & & & & & & & & \\
\hline & 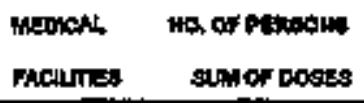 & & & & & & & & & \\
\hline & 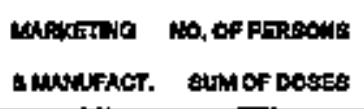 & & & & & & & & 5 & \\
\hline & 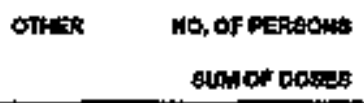 & & & & & & & & & \\
\hline \multirow{5}{*}{1994} & 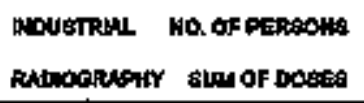 & & $\begin{array}{c}2 \\
122\end{array}$ & & & & & & & \\
\hline & 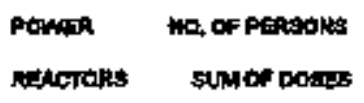 & & & & & & & $\begin{array}{l}1 \\
34\end{array}$ & & \\
\hline & 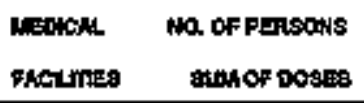 & & & & & & & & & \\
\hline & 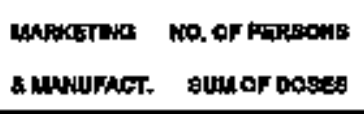 & & & & & & & & $\begin{array}{c}16 \\
180\end{array}$ & \\
\hline & $\begin{array}{l}\text { ONER NO. OF Persoms } \\
\text { Sun or OOEes }\end{array}$ & & & & & & & & & \\
\hline
\end{tabular}

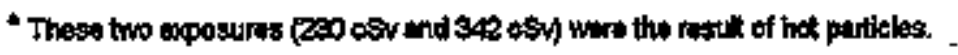

b This exposure was from a hat patticle to a kctinged aroan of the sidn. 
TABLE 6.2

OCCUPATIONAL EXPOSURES IN EXCESS OF REGULATORY LIMITS $1985-1993$

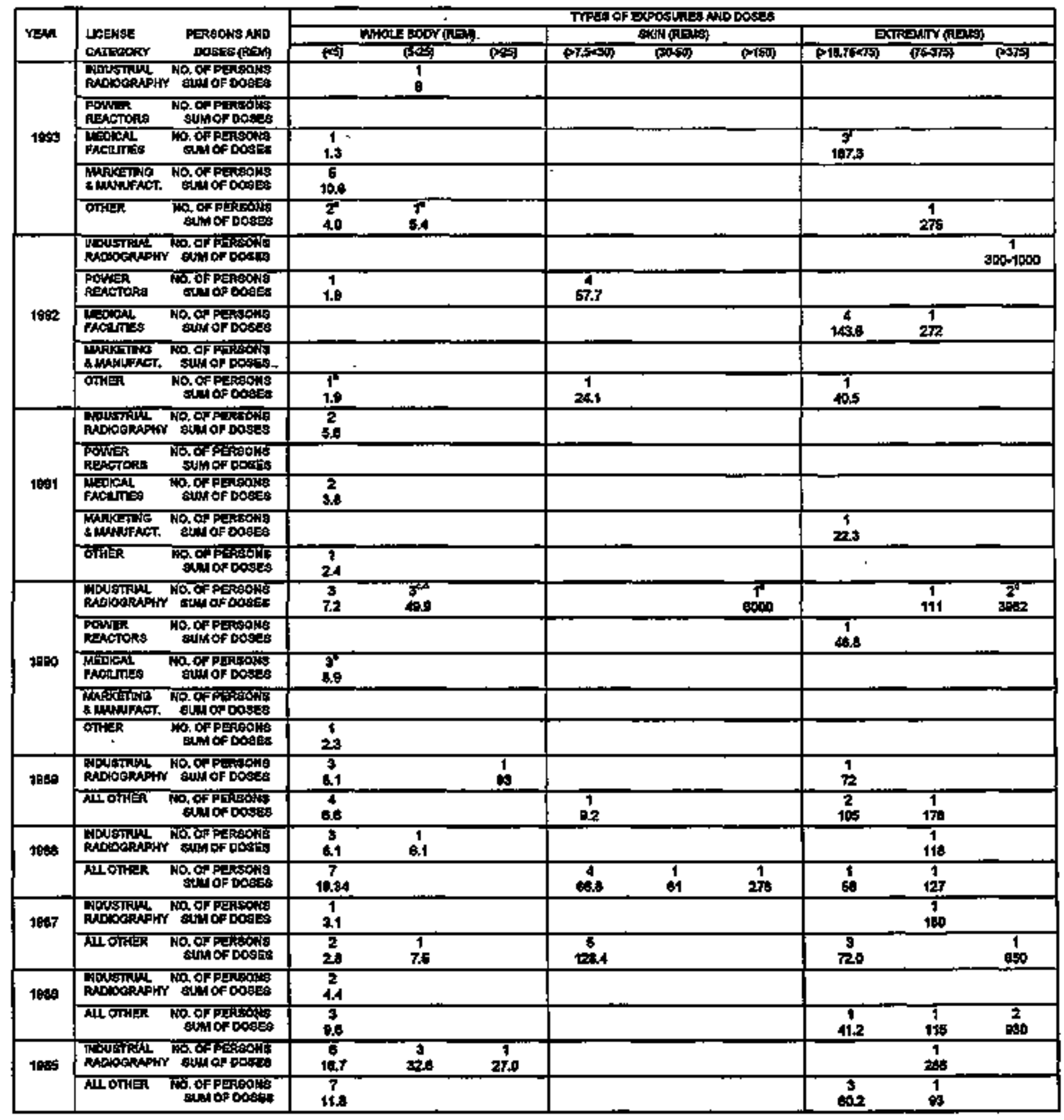

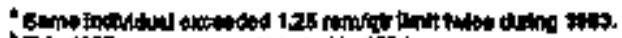

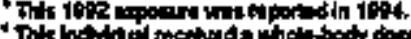

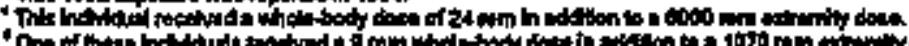

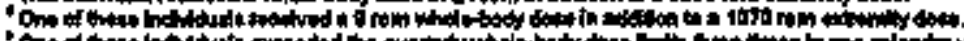

"Ore of theal in

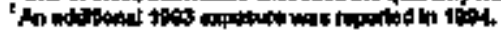


TABLE 6.3

MAXIMUN OCCUPATIOMAL EXPOSURES FOR EACH EXPOSURE CATEEORY 1995

\begin{tabular}{|c|c|c|c|c|c|c|c|}
\hline $\begin{array}{l}\text { Exposaine } \\
\text { Category }\end{array}$ & $\begin{array}{l}\text { Modmum } \\
\text { Exposure } \\
\text { Reported } \\
\text { eSv(rem) }\end{array}$ & $\begin{array}{l}\text { Max Oass } \\
\text { Percent of } \\
\text { Hxa Lhitt }\end{array}$ & $\begin{array}{c}\text { Number of } \\
\text { nolviduals with } \\
\text { Mopesureblo } \\
\text { Dose }\end{array}$ & $\begin{array}{l}\text { Numbes of } \\
\text { Indlytduals } \\
>250 \text { of } \\
\text { the Limit }\end{array}$ & $\begin{array}{l}\text { Number of } \\
\text { Indikheds } \\
>50 \% \text { of } \\
\text { the Limi }\end{array}$ & $\begin{array}{l}\text { Nomber of } \\
\text { Indriduats } \\
27 \text { of of } \\
\text { the Unk }\end{array}$ & $\begin{array}{l}\text { Nunibur of } \\
\text { Ind Natereis } \\
\text { > 65\% of } \\
\text { the Limtt }\end{array}$ \\
\hline SDEME & 41.960 & $84 \%$ & 61,245 & 112 & 18 & 2 & 0 \\
\hline SDE-WE & 22.710 & $45 \%$ & 76,967 & 1 & 0 & 0 & 0 \\
\hline LDE & 4.232 & $26 \%$ & 79,311 & 37 & 0 & 0 & o \\
\hline CEDE & $3.316^{* *}$ & $\therefore$ & 2,495 & & & 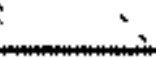 & $\therefore$ \\
\hline COE & $28,805^{* 4}$ & & 1,685 & & & $=$ & \\
\hline DDE & $5.1^{*}$ & & 76,822 & & & החקm & , \\
\hline TEDE & $5.1^{*}$ & $>11 \mathrm{mit}$ & 76,822 & 3,539 & 500 & 40 & 1 ( $>1 \| \mathrm{mlt})$ \\
\hline TODE & $28.065^{\circ+}$ & $58 \%$ & 76,622 & 463 & 3 & 0 & 0 \\
\hline
\end{tabular}

Those doses were recethed by the semo lnolikituel

"These intand doses ware received by the same indwdual

Shaded boxes represent dose categorles that do not heve spectic dose limits dofined in 10 CFR XD.

As can be seen from Table 6.3, few exposures exceed half of the NRC occupational annuad limits. Only the extremity and TEDE doses exceed $50 \%$. The only dose to come wilhin $5 \%$ of the lintt was the one exposure that exceeded the linit. 
$\cdots+\therefore \because+\quad \therefore \quad \therefore \quad-\cdots$ 


\section{REFERENCES}

1. U.S. Alomic Energy Commission, Nuclear Power Plant Operating Experience During 1973, USAEC Report OOE-ES-004, December 1974**

2. U.S. Nuclear Regulatory Commission, Nuclear Power Plant Operating Experience 1974-1975, USNRC Report NUREG-0227, April 1977:*

3. U.S. Nuclear Regulatory Commission, Nuclear Power Plant Operating Experience 1976, USNRC Report NUREG-0366, December 1977:*

4. M.R. Beebe, Nuclear Power Plant Operating Experience - 1977, USNRC Report NUREG-0483, February 1979.*

5. Nuctear Power Plant Operating Experience - 1978, USNRC Report NUREG-0618, December 1979.*

6. Nuclear Power Plant Operating Experience - 1979, USNRC Report NUREG/CR-1496, May 1981.*

7. Nuclear Power Plant Operating Experience - 1980, USNRC Report NUREG/CR-2378, ORNLNSIC-191, October 1982."

8. Nuclear Power Plant Operating Experience - 1987, USNRC Report NUREG/CR-3430, ORNLNSIC-215, Vot. 1, December 1983.*

9. Nuclear Power Plent Operating Experience - 1982, USNRC Report NUREG/CR-3430, ORNLNSIC-215, Vol. 2, January 1985.*

10. United Natlons, Report of the Scientific Committee on the Effacts of Atomic Radiation, Annex H, General Assembly of Official Records, United Nations, New York, 1982.

11. A. Brodsky, R. Specht, B. Brooks, et al., Log-Normal Distributions of Occupational Exposure in Medicine and industry. Presented at the 9th Midyear Topical Symposium of the Health Physies Society, 1976.

12. S. Kumazawa and T. Namakunai, A New Theoreticel Anelysis of Occupational Dose Distributions indicating the Effect of Dose Limits, Health Physics, Vol. 41, No. 3, 1981."

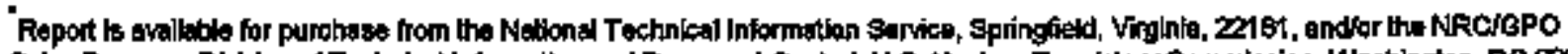

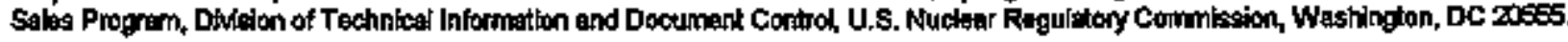


13. S. Kumazawa and T. Namakunal, A Msthod for implementation of ALARA for Occupational Exposure Using the Hybrid Lagnormal Model. Presented at the 271h Annual Meeting of the Heatth Physics Society. July 1, 1982.

14. Licensed Operating Reactors, Status Summary Report, USNRC Report NUREG-0020, Vol. 20, No. 1. Data for 1995 provided on diskette by D. Hartíald, USNRC Office of Information Resources Management, Systems Development Branch.

15. LA. Cross and A.P. Cross, Trends in Nuclear Power Plant Man-Rem Per Megawatt-Year. Presented to American Nuckear Society European Nuctear Society International Conference, Washington, DC, November 17-20, 1980.

16. National Research Council, Health Effects of Exposure to Low Levels of Ionizing Radlefion: BEIR V, Committee on the Biological Effects of tonizing Radiations, 1990. Avallable from the National Academy Press, 2101 Constitution Avenue NW., Washinglon, DC 20418.

17. Health Effects Models for Nuclear Power Plant Accident Consequence Analysis, Part II: Scientific Basis for Health Effects Models, USNRC Report NUREG/CR-4214, May 1989.

18. Instructions for Recording and Reporting Occupational Raciation Exposure Data, USNRC Regulatory Gulde 8.7. Rev. 1, June 1992. 
APPENDIXA

Llsting of Annuas Expoture Data Compilted for Certain NRC Llcentees

in Descending Order of Avorage Mesariable Dose

1995 


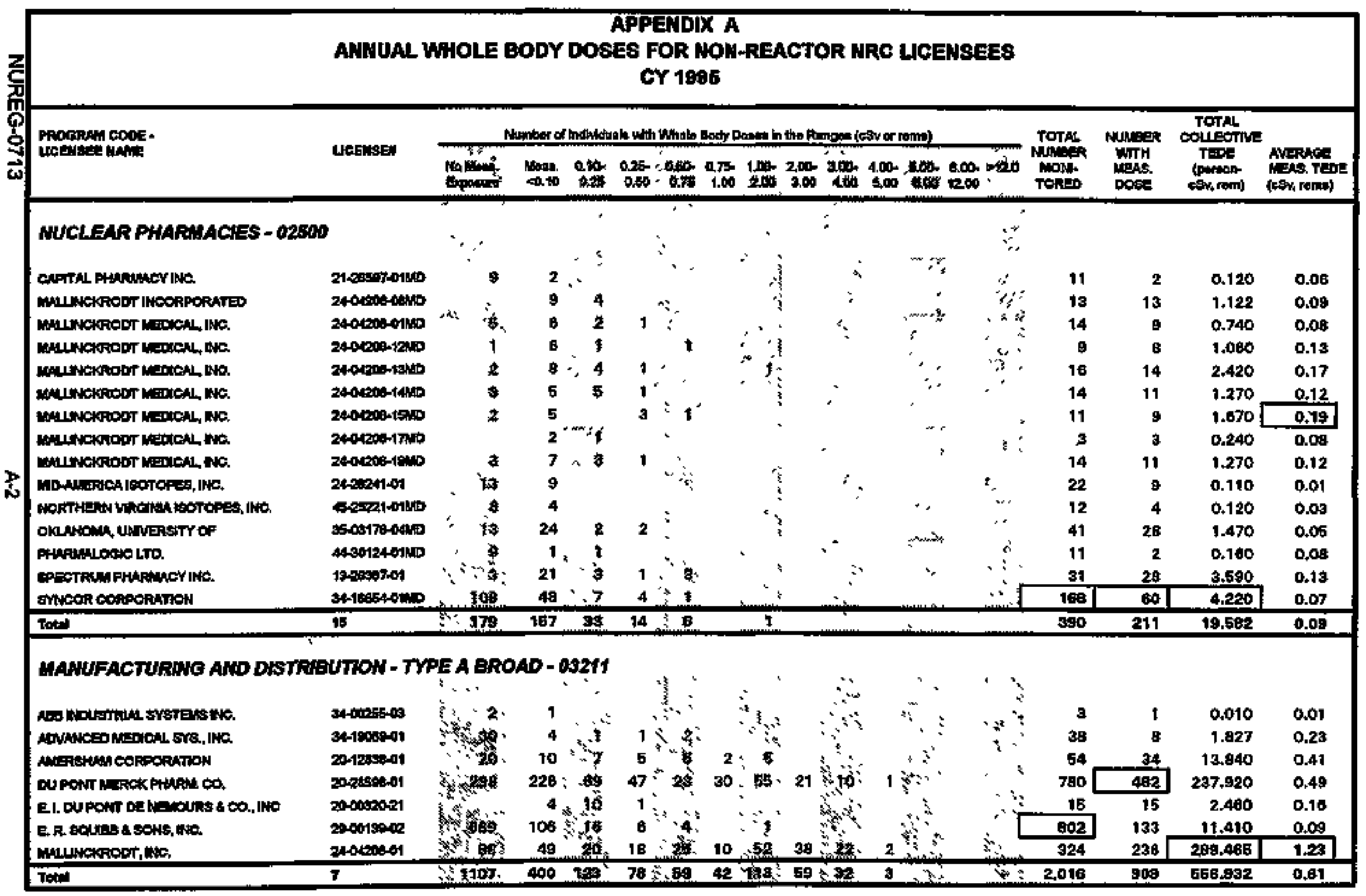




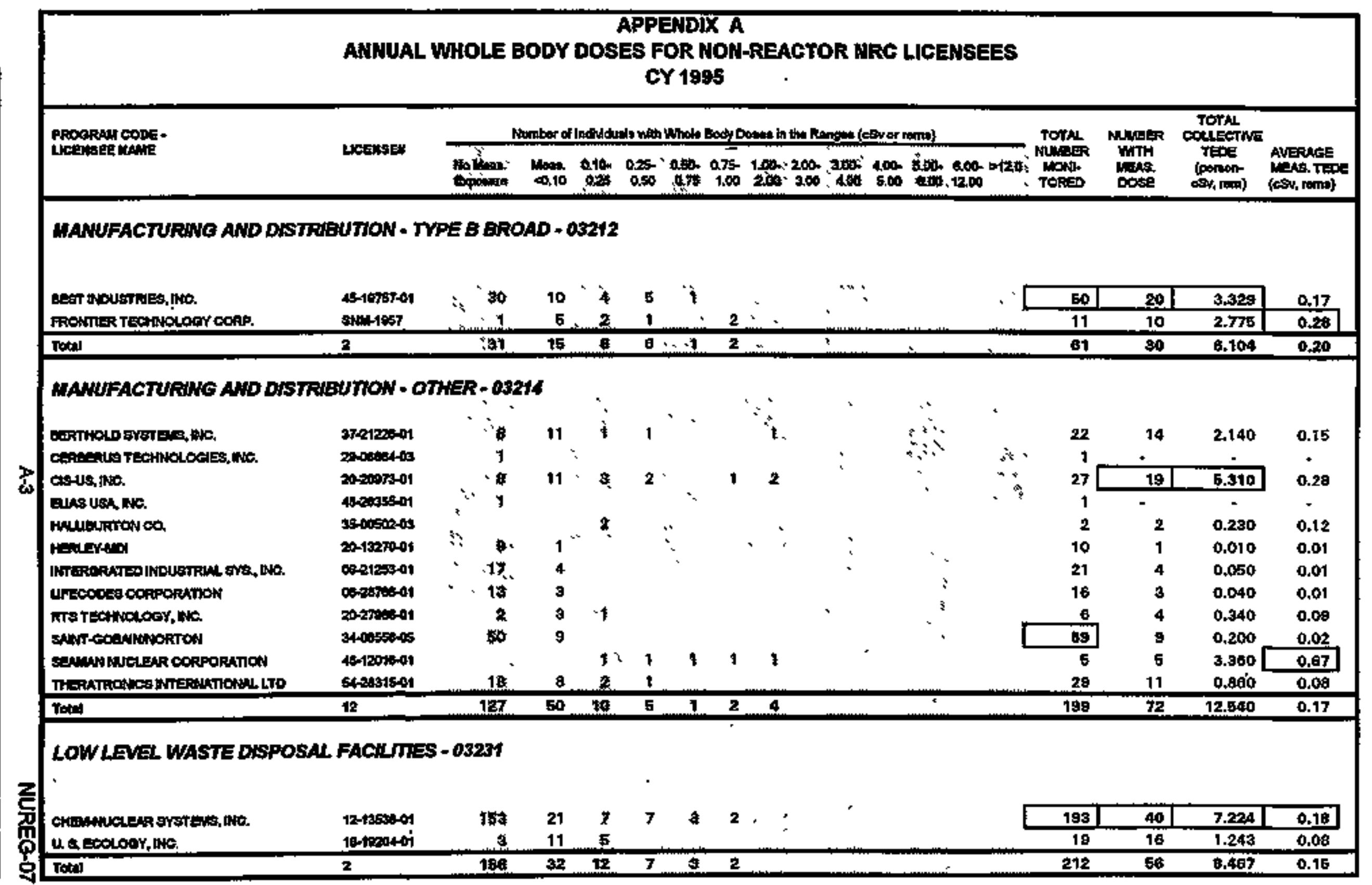




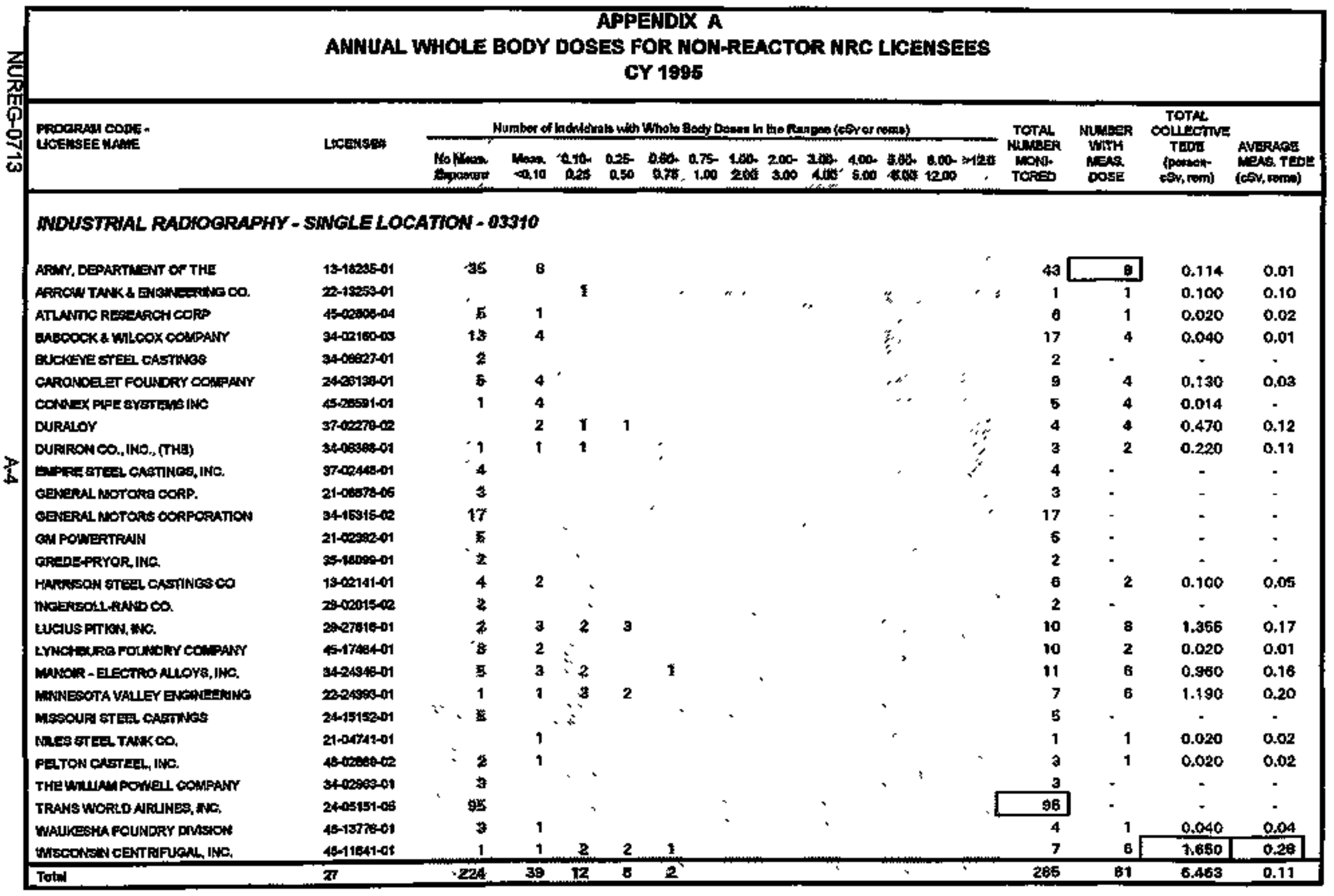




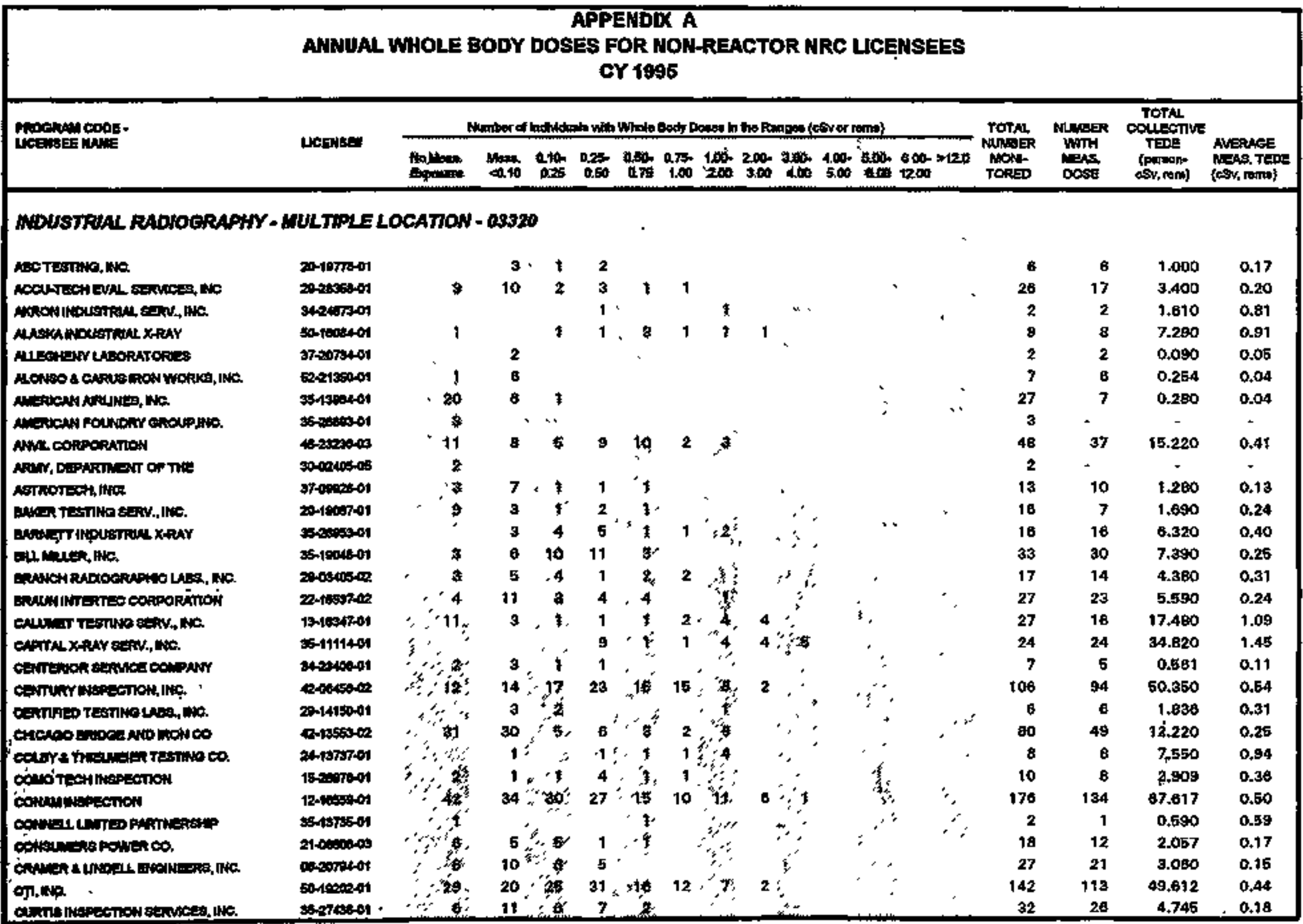




\begin{tabular}{|c|c|c|c|c|c|c|c|c|c|c|c|c|c|c|c|c|c|}
\hline \multirow{3}{*}{$\begin{array}{l}\text { PROCRAM CODE. } \\
\text { LOEMSEE HAHE }\end{array}$} & \multicolumn{13}{|c|}{$\begin{array}{l}\text { APBEADX A } \\
\text { ANHUAL WHOLE BODY DOSES FOR NOW-REACTOR MRC LCENSESS } \\
\text { CY } 1995\end{array}$} & \multirow{3}{*}{$\begin{array}{l}\text { TOTAL } \\
\text { NLWBER } \\
\text { MONA* } \\
\text { TOFED }\end{array}$} & \multirow{3}{*}{ 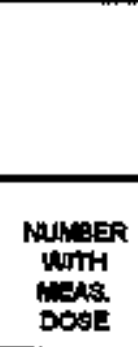 } & \multirow{3}{*}{ 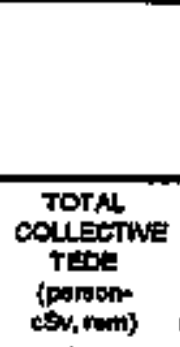 } & \multirow[b]{3}{*}{$\begin{array}{l}\text { AVERAGE } \\
\text { MEAS. TEDE } \\
\text { (CAN, namo) }\end{array}$} \\
\hline & \multirow{2}{*}{ LtCE:HSE: } & \multicolumn{12}{|c|}{ 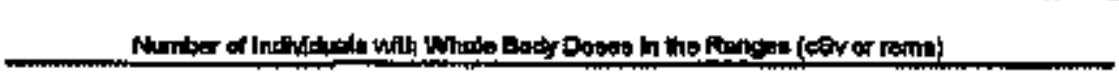 } & & & & \\
\hline & & 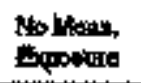 & $\ln 2.10$ & $\begin{array}{l}0,14 \\
0.25\end{array}$ & a.25- & b.t. & 0.700 & $\frac{134}{2010}$ & $\begin{array}{l}2,000 \\
3.00\end{array}$ & 400 & 5.00. & s.0. & - - - & & & & \\
\hline MDUSTRAL RADIOCRAFH & WTHPE & ATHOH & 032 & $b \boldsymbol{c o}$ & ntine & & & & & & & & & & & & \\
\hline DAYTONX-MAY CO & $34-00940-01$ & $\mathbf{z}$ & 2 & 4 & 7 & 4 & 2 & 4 & & & & & 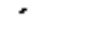 & 25 & 23 & 11.710 & 0.51 \\
\hline 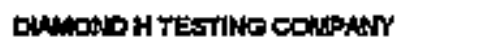 & 172731509 & 2 & 2 & 4 & 3 & & $2^{2}$ & 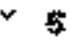 & & & & & & 18 & 16 & 9,936 & 0.67 \\
\hline EASTERN TESTINS \& INSFECTION, LNC. & 200014-04 & 5 & $\mathbf{l}$ & 3 & 1 & 3 & 1 & $*$ & & & & $m$ & $\cdot$ & 16 & 11 & 5.810 & 0.53 \\
\hline COWARDS FWERNE TESTNS, WNC. & $35-20183-01$ & 2 & 21 & 24 & 39 & 25 & 20 & 17 & & & & & & 148 & 146 & 74.646 & 0.51 \\
\hline EO \& O MORON, WNC., DOC-005 & $0921233-01$ & 20 & 8 & & & & & & & & & & & 37 & $\mathbf{8}$ & 0.190 & 0,02 \\
\hline 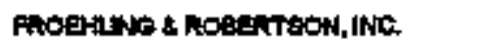 & $45-00000-01$ & 8 & 7 & $t$ & 2 & & & & & & & & & 16 & to & 1.220 & 0.12 \\
\hline 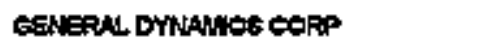 & $080178,-09$ & & 23 & 10 & 4 & & & & & & & & & 43 & 49 & 4.991 & 0.11 \\
\hline 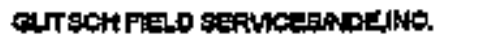 & $34+14071 \cdot 01$ & 2 & 18 & $\theta$ & $\mathbf{B}$ & $\mathbf{4}$ & 2 & a & & & & & , & 40 & 38 & 10.260 & 0.27 \\
\hline GLOEX X RAY SURV., INC. & $35-95194-01$ & 4 & 1 & 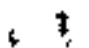 & $\mathbf{5}$ & 4 & 2 & 4 & 4 & $\mathbf{s}$ & 1 & t & & 30 & 26 & 40.770 & 1.57 \\
\hline GREAT LAKES TESTIND, INC. & $40-28494-01$ & 、 & 1 & á & $2^{\prime}$ & & & 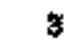 & & & & & & 9 & $\mathbf{9}$ & 5.742 & 0.64 \\
\hline GRAKWELL CORPORATION & se-28750001 & $\boldsymbol{\theta}$ & 3 & 7 & 1 & ‘ & & & & & & & & 8 & 5 & 0.620 & 0.10 \\
\hline HAO INGFECTXON COUPANY, NKC. & $42 \pi 00001$ & 1 & & $\$$ & 2 & $\mathbf{t}$ & 1 & 6 & 2 & & & & 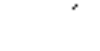 & 18 & 16 & 16.200 & 1.09 \\
\hline H. R INSPEETION SERV., NC. & $16-0 \cos 000 t$ & $\mathbf{z}$ & 1 & 2 & 2 & & & 4 & & & & & & 11 & 9 & 7,590 & 0.84 \\
\hline HCH WOUNTANINSP. EERV, INOC. & $48-2800002$ & $\cdot 2$ & $\mathbf{2}$ & $\mathbf{8}$ & 2 & & & . & & & & & & $\theta$ & 7 & 1.390 & 0.20 \\
\hline 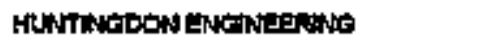 & $2201370-02$ & 5 & 4 & 6 & 2 & 1 & 2 & a & 2 & & & & & 27 & 22 & 16,450 & 0.75 \\
\hline HUNTWETON TESTHE \& TECH & $47-20076-01$ & 1 & 2 & 7 & 8 & 8 & $\mathbf{2}$ & 8 & s & & & $r$ & & 38 & $\mathbf{3 5}$ & 31.100 & 0.89 \\
\hline HUTCHASON TECHIACAL COULESE & $22-1656401$ & 317 & 6 & .7 & & & & & & & & - & & 124 & 7 & 0.240 & 0.03 \\
\hline INDUSTFIAL NOT $\infty .$, NAC. & SPaduestot & 1 & 3 & $\sqrt{4}$ & 3 & 1 & 1 & 当 & 2 & & & & & 19 & 14 & $\$ 0.370$ & 0.74 \\
\hline 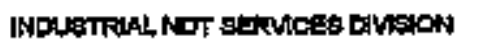 & t3-otertat-04 & 1 & 7 & 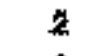 & 1 & $\uparrow$ & & 2 & & & & & & 14 & 13 & 3.520 & 0.27 \\
\hline INGFECTLON WANNEEMENT CORP & $35-204: 4-01$ & 1 & 3 & $\cdot 2$ & 1 & 7 & & 2 & 2 & $\neq$ & 1 & & & 14 & 13 & 20.960 & 1,60 \\
\hline INTERANONTNN TESTINO CO. & $05-0707201$ & & 3 & 2 & 5 & $\mathbf{3}$ & 4 & 6 & 5 & & & & & $2 B$ & 28 & 28,361 & 1.01 \\
\hline JNWXRAY EERVCES, ING. & $2+16500-01$ & & 3 & $\$$ & $10^{\circ}$ & 8 & 8 & $\rightarrow$ & $\uparrow$ & $t$ & & & 、 & 46 & 46 & 36.500 & 0.79 \\
\hline MAGPACHEK, INC. & 29-19151-02 & $\sqrt{2}$ & $\mathbf{5}$ & \pm & & & & & & & & $\because$ & & 8 & 6 & 0.220 & 0.04 \\
\hline MWRYLW EOLABORATORIEB, INC. & To-28:at-01 & .5 & $\mathbf{2}$ & 2 & 2 & 2 & & 3 & & & & $\checkmark$ & & 16 & 11 & 5.890 & 0.53 \\
\hline MASSACHUSETTS MATEFJALSRES. & $07-0117800$ & $\therefore 2$ & 2 & 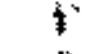 & 2 & $\$$ & & 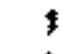 & & & & & & $\mathbf{9}$ & 7 & 3.220 & 0.46 \\
\hline MATEFAL TESTINE LALS. INC. & $45-17151-01$ & 7 & 3 & $\mathbf{f}$ & 2 & & & \pm & & 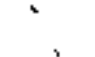 & & & & 14 & 7 & 2.790 & 0.40 \\
\hline MATTINELY TESTINK SERWAES, AK. & $25-21470-01$ & $=$ & 5 & & 3 & $\$$ & 1 & 莫 & & ' & & & & 11 & 11 & 4.205 & 0,39 \\
\hline 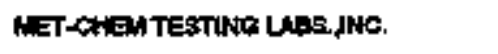 & $43073=2-01$ & $\mathbf{5}$ & 4 & 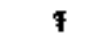 & 4 & 4 & & 2 & 2 & $\mathbf{t}$ & & & & 23 & 18 & $15, a 14$ & 0.85 \\
\hline 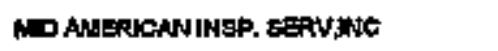 & $21-25000-01$ & 、 & & & 1 & 2 & $\mathbf{3}$ & a & $\mathbf{2}$ & & & & & 11 & 11 & 13.870 & 1.28 \\
\hline MOWEST INDUSTRAL X-NAY, MNC. & $3,-274<7-01$ & 3 & 1 & & 1 & 2 & 1 & 4 & 3 & & & & & 15 & 12 & 14.890 & 1.24 \\
\hline
\end{tabular}




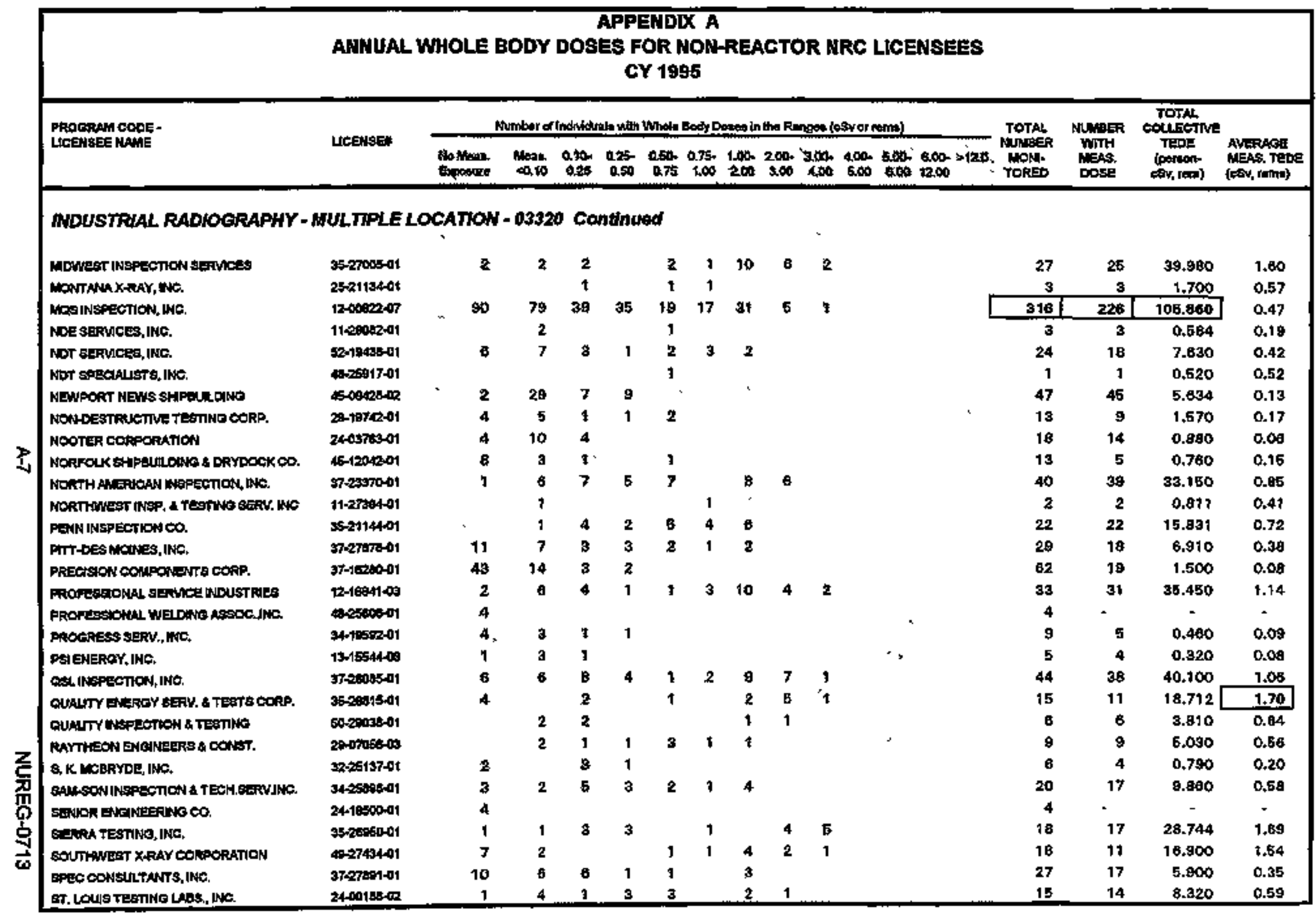




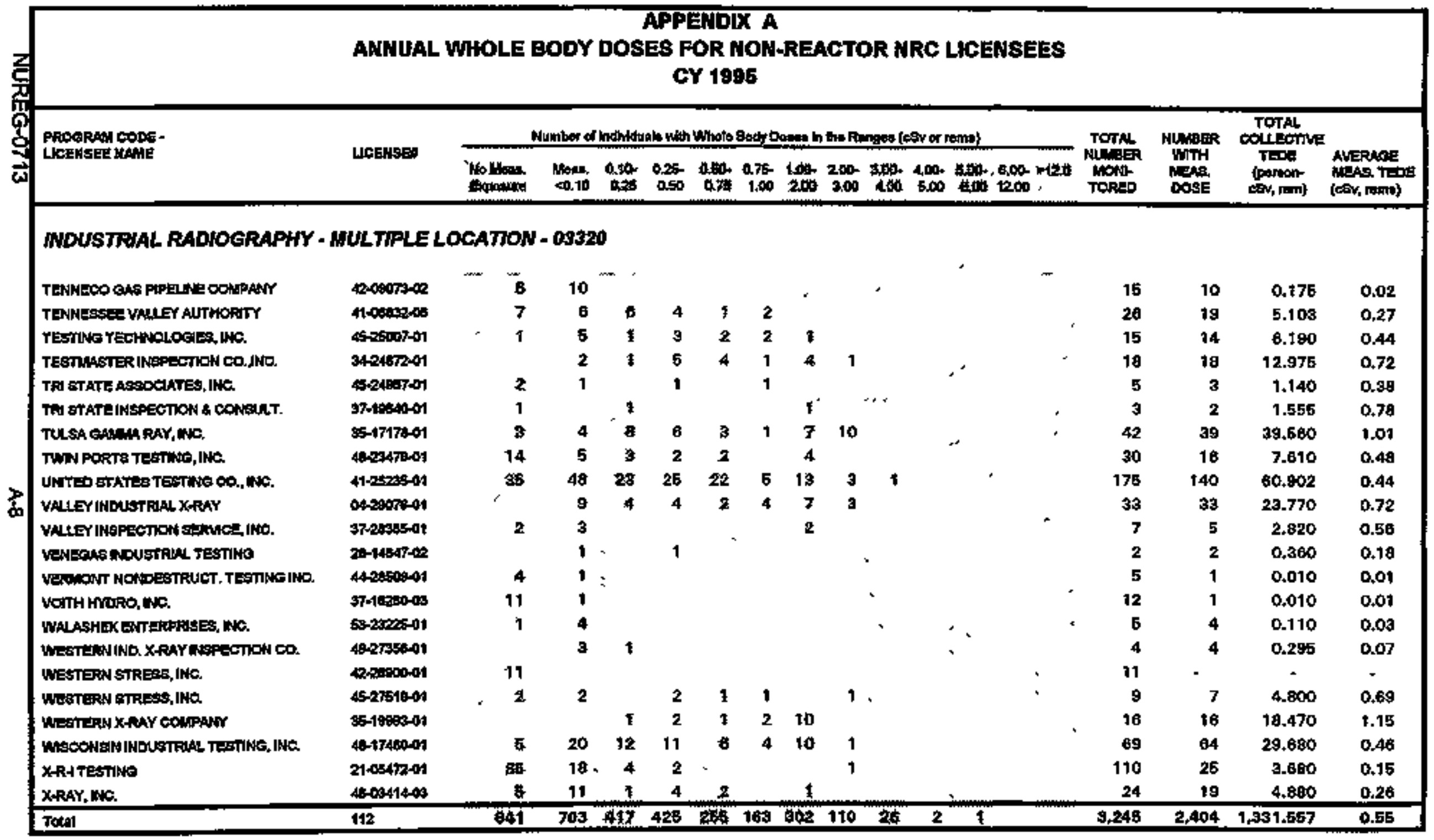




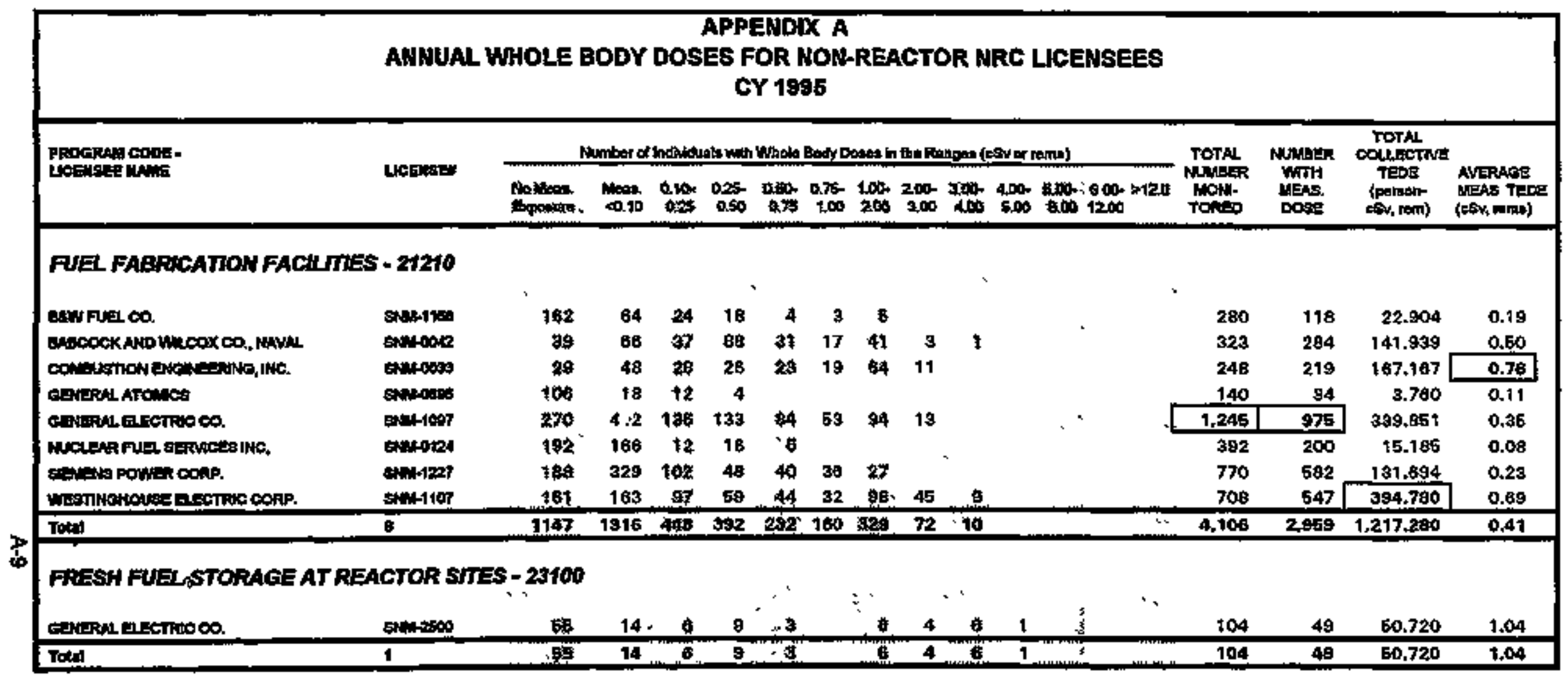




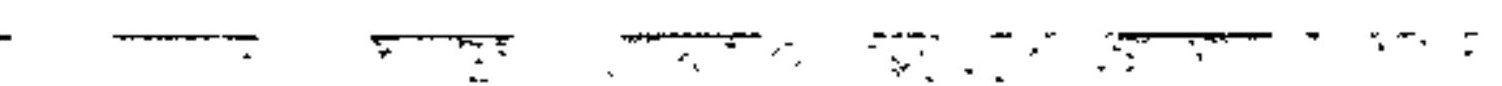


APPENOIX $\mathrm{B}$

Annual Whole Body Doses at Licensed Nuclaar Power Factitties

1998

B-1

NUREG-0713 
APPENDIX B

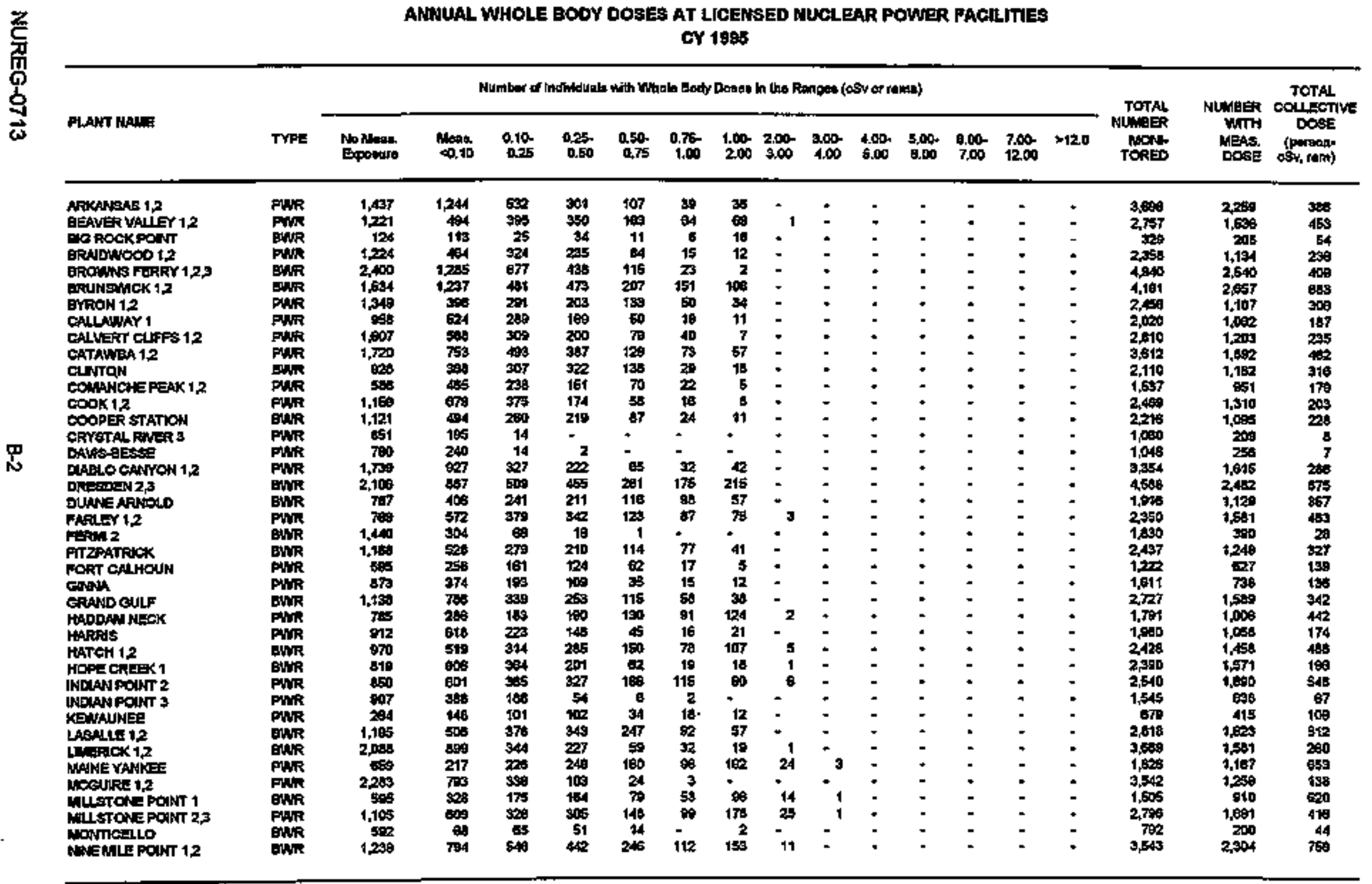


APPENDIX B (Continaod)

ANNUAL WHOLE BODY DOSES AT LICENSED NUCLEAR POWER FACILITIES CY 1995

\begin{tabular}{|c|c|c|c|c|c|c|c|c|c|c|c|c|c|c|c|c|c|c|}
\hline \multirow{2}{*}{ MLAST RAdE } & \multirow[b]{2}{*}{ TYFE } & \multicolumn{14}{|c|}{ 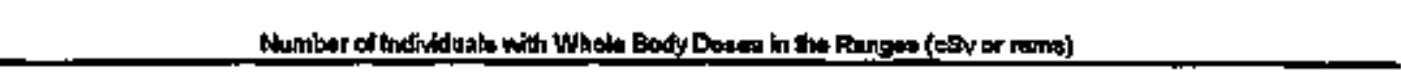 } & \multirow{2}{*}{$\begin{array}{c}\text { TOTAL } \\
\text { Numer } \\
\text { MON, } \\
\text { Toreo }\end{array}$} & \multirow{2}{*}{ 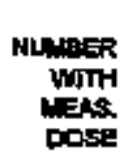 } & \multirow{2}{*}{$\begin{array}{c}\text { TOTAL } \\
\text { COUESTINE } \\
\text { DOSE } \\
\text { (porwont } \\
\text { efr, reip) }\end{array}$} \\
\hline & & $\begin{array}{l}\text { No Hoopa } \\
\text { Eposure }\end{array}$ & $\operatorname{mon}$ & $\begin{array}{l}0.10- \\
0.25\end{array}$ & $0.25-$ & $0.50-$ & $\begin{array}{l}0.75 \\
1.00\end{array}$ & $\begin{array}{l}1.00 \\
200\end{array}$ & 200. & $\frac{3.00}{400}$ & $\begin{array}{l}4.00 \\
5.00\end{array}$ & $\begin{array}{l}5.00 \\
5.00\end{array}$ & $\begin{array}{l}6.00 \\
7.00\end{array}$ & $\begin{array}{l}7.00 \\
1200\end{array}$ & $3=12.0$ & & & \\
\hline 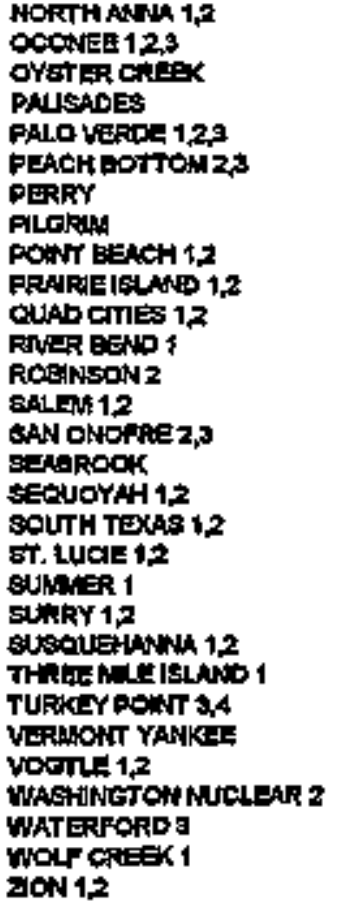 & 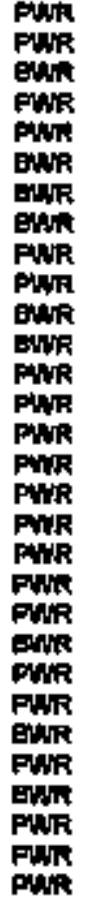 & 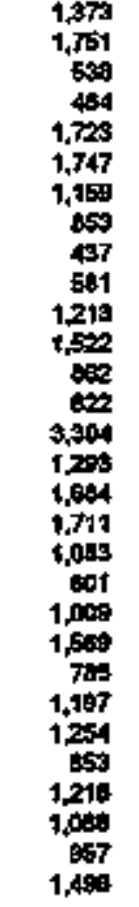 & 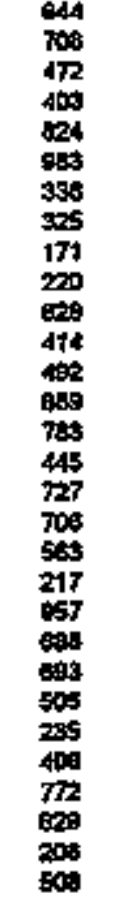 & 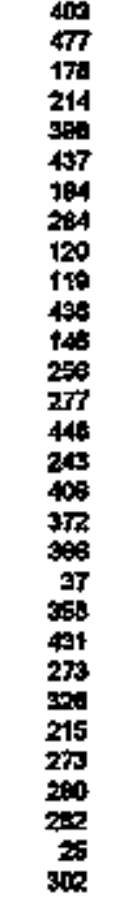 & 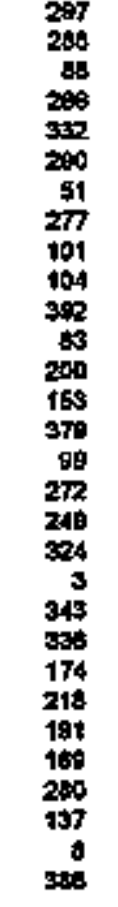 & $\begin{array}{r}113 \\
74 \\
15 \\
140 \\
181 \\
420 \\
4 \\
224 \\
78 \\
43 \\
273 \\
14 \\
75 \\
47 \\
200 \\
13 \\
139 \\
94 \\
114 \\
0 \\
119 \\
109 \\
57 \\
67 \\
71 \\
75 \\
191 \\
20 \\
1 \\
225\end{array}$ & 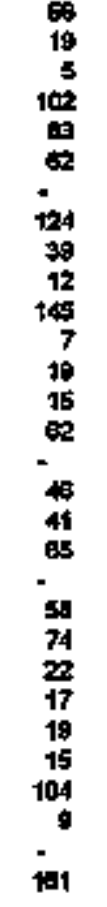 & 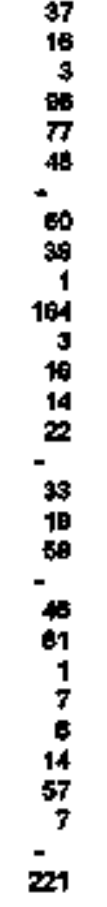 & 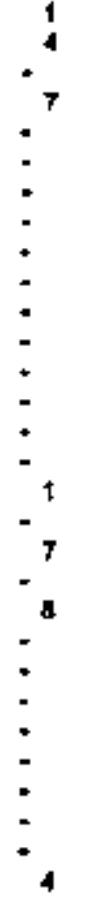 & 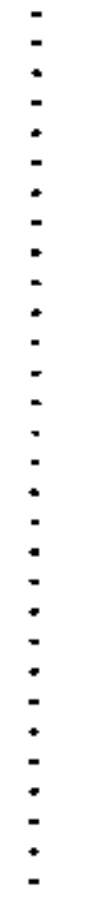 & $\begin{array}{l}- \\
: \\
: \\
: \\
: \\
: \\
: \\
: \\
: \\
: \\
: \\
: \\
: \\
: \\
: \\
: \\
: \\
: \\
:\end{array}$ & 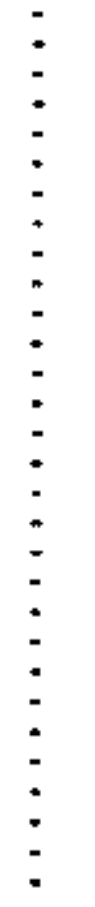 & 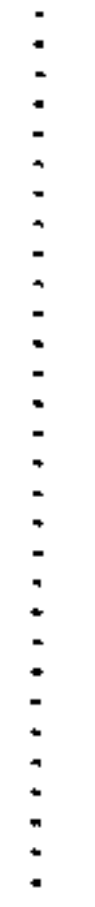 & 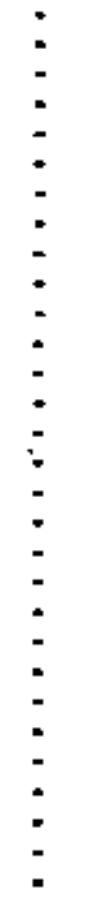 & $\begin{array}{l}: \\
: \\
: \\
: \\
: \\
: \\
: \\
: \\
: \\
: \\
: \\
: \\
: \\
: \\
: \\
:\end{array}$ & 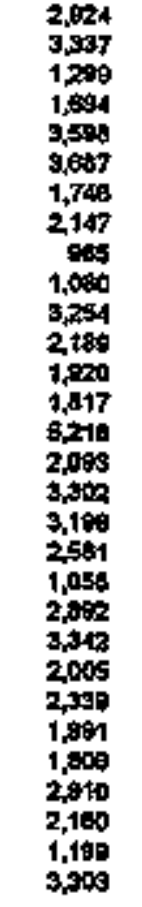 & 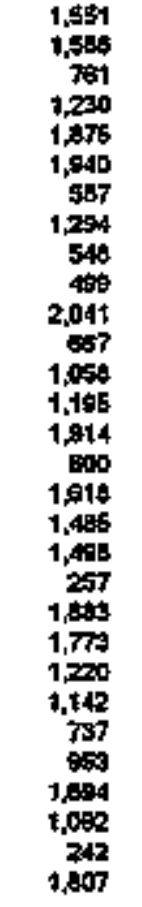 & 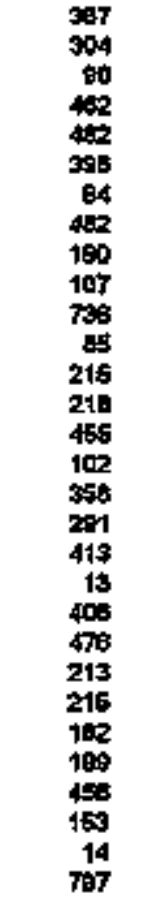 \\
\hline 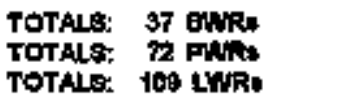 & & $\begin{array}{l}M 1,345 \\
1,097 \\
1,092\end{array}$ & $\begin{array}{l}16,264 \\
23,311 \\
38,676\end{array}$ & $\begin{array}{r}7,060 \\
12,760 \\
202,245\end{array}$ & $\begin{array}{r}0,332 \\
0,947 \\
15,2 \pi\end{array}$ & $\begin{array}{l}3,517 \\
3,767 \\
\text { e,as4 }\end{array}$ & $\begin{array}{l}1,507 \\
1,709 \\
3,360\end{array}$ & $\begin{array}{l}1,360 \\
1,717 \\
3,077\end{array}$ & $\begin{array}{r}32 \\
93 \\
125\end{array}$ & $\begin{array}{l}1 \\
4 \\
6\end{array}$ & $\dot{-}$ & : & $\vdots$ & $:$ & $\dot{-}$ & $\begin{array}{r}68,984 \\
10 t, 584 \\
104,558\end{array}$ & $\begin{array}{l}95,659 \\
81,887 \\
97,509\end{array}$ & $\begin{array}{r}9,467 \\
12,207 \\
21,074\end{array}$ \\
\hline
\end{tabular}


APPEHDAX B (Continued)

공

ANNUAL WHOLE BODY DOSES AT LICEESED NUCLEAR POWER FACILTIES

FACLITIES NOT W OPERATION OA IN OPERATIOH LESS THAN ONE YEAR

CY 1984

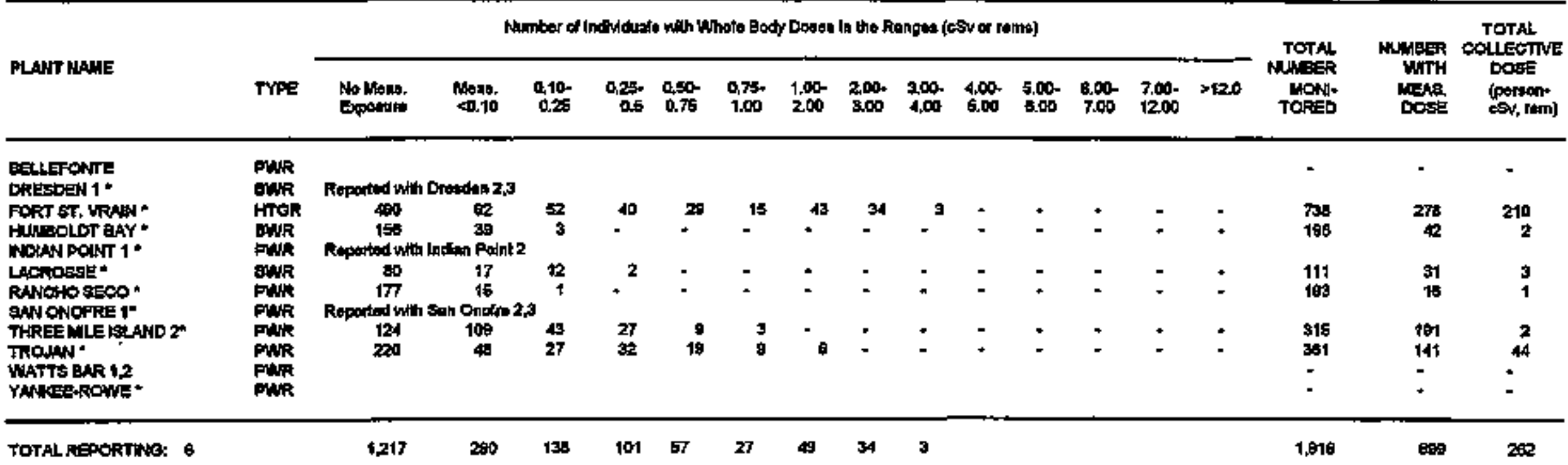




\section{APPENDIX $\mathrm{C}^{n}$}

Personnel, Dose, and Power Generation Summary

1969-1996

"A dlscussion of the methods used to collect and calculate the information contained in this Appendix is given in Sectlon 2.1 
곡

APPENDIX C

PERSONNEL, DOSE AND POWER GENERATION SUMMARY

\begin{tabular}{|c|c|c|c|c|c|c|c|c|c|c|c|}
\hline \multirow[b]{3}{*}{ Roparting Organizolion } & \multirow[b]{3}{*}{ Yosar } & \multirow[b]{3}{*}{$\begin{array}{l}\text { Megawatt } \\
\text { Years } \\
\text { MNYR }\end{array}$} & \multirow[b]{3}{*}{$\begin{array}{l}\text { Unit } \\
\text { Avaluaboty } \\
\text { Factor }\end{array}$} & \multirow[b]{3}{*}{$\begin{array}{c}\text { Jotal Personnel } \\
\text { With Measurable } \\
\text { Doses }\end{array}$} & \multicolumn{5}{|c|}{ Person-a $\$$ v (-rems) } & \multirow{3}{*}{$\begin{array}{l}\text { Average } \\
\text { Measuratle } \\
\text { Dops } \\
\text { (cSvor } \\
\text { roms) }\end{array}$} & \multirow{3}{*}{$\begin{array}{c}\text { Persont } \\
\text { csw } \\
\text { (-tisns) } \\
\text { Mon-yr }\end{array}$} \\
\hline & & & & & & Rerleks & inition & PerPerse & y trine & & \\
\hline & & & & & $\begin{array}{c}\text { Collective } \\
\text { Dose }\end{array}$ & $\begin{array}{l}\text { Opera. } \\
\text { lons }\end{array}$ & $\begin{array}{c}\text { Maint } \\
\text { Others }\end{array}$ & $\begin{array}{l}\text { Can- } \\
\text { tractor }\end{array}$ & $\begin{array}{l}\text { Slallon } 8 \\
\text { Utility }\end{array}$ & & \\
\hline 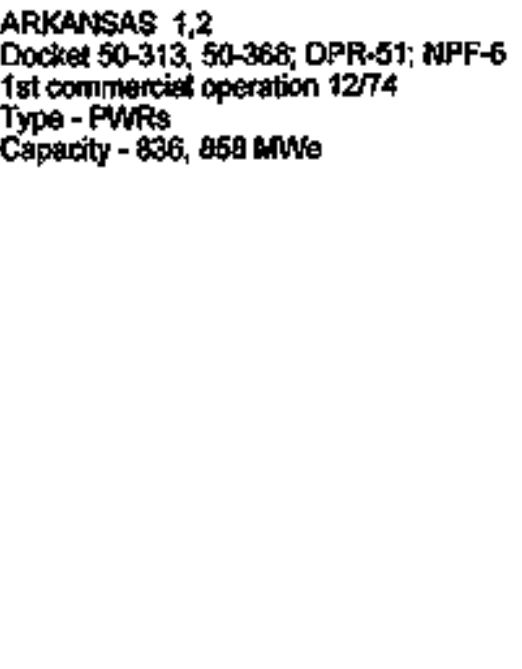 & $\begin{array}{l}1975 \\
1976 \\
1977 \\
1978 \\
1979 \\
1980 \\
1991 \\
1992 \\
1993 \\
1994 \\
1995 \\
1986 \\
1987 \\
1988 \\
1989 \\
1990 \\
1991 \\
1992 \\
1993 \\
1994 \\
1995\end{array}$ & $\begin{array}{r}596.0 \\
464.6 \\
610.3 \\
627.2 \\
397.0 \\
452.8 \\
1,104.7 \\
905.4 \\
915.0 \\
1,289.1 \\
1,192.3 \\
1,070.3 \\
1,366.1 \\
1,070.3 \\
1,066.3 \\
1,361.9 \\
1,516.8 \\
1,352.1 \\
1,606.0 \\
1,662.8 \\
1,397.0\end{array}$ & $\begin{array}{l}76.5 \\
56.6 \\
76.8 \\
77.5 \\
56.3 \\
6.7 \\
64.3 \\
54.6 \\
54.7 \\
77.4 \\
73.6 \\
66.9 \\
68.9 \\
69.4 \\
72.0 \\
64.2 \\
68.4 \\
77.4 \\
91.3 \\
93.6 \\
82.7\end{array}$ & $\begin{array}{r}147 \\
476 \\
601 \\
7,22 \\
1,321 \\
1,203 \\
2,226 \\
1,606 \\
2,109 \\
1,742 \\
1,262 \\
2,135 \\
1,123 \\
2,421 \\
2,063 \\
2,493 \\
2,064 \\
3,114 \\
1,961 \\
1,301 \\
2,259\end{array}$ & $\begin{array}{r}21 \\
269 \\
256 \\
169 \\
969 \\
342 \\
1,402 \\
1803 \\
1,397 \\
906 \\
2968 \\
1,141 \\
392 \\
1,397 \\
711 \\
782 \\
351 \\
876 \\
288 \\
172 \\
393\end{array}$ & $\begin{array}{r}27 \\
28 \\
32 \\
34 \\
81 \\
130 \\
97 \\
96 \\
99 \\
62 \\
194 \\
92 \\
139 \\
36 \\
32 \\
35 \\
21 \\
9 \\
60 \\
34\end{array}$ & $\begin{array}{r}262 \\
228 \\
157 \\
316 \\
261 \\
972 \\
708 \\
1,301 \\
717 \\
224 \\
947 \\
290 \\
1,249 \\
675 \\
730 \\
316 \\
463 \\
259 \\
91 \\
362\end{array}$ & $\begin{array}{r}100 \\
111 \\
109 \\
262 \\
213 \\
843 \\
505 \\
1,145 \\
533 \\
148 \\
631 \\
205 \\
1,094 \\
832 \\
625 \\
242 \\
719 \\
194 \\
122 \\
273\end{array}$ & $\begin{array}{r}189 \\
145 \\
80 \\
147 \\
129 \\
259 \\
298 \\
252 \\
273 \\
138 \\
260 \\
177 \\
293 \\
189 \\
137 \\
109 \\
157 \\
74 \\
49 \\
113\end{array}$ & $\begin{array}{l}0.14 \\
0.61 \\
0.43 \\
0.26 \\
0.28 \\
0.26 \\
0.50 \\
0.50 \\
0.63 \\
0.46 \\
0.23 \\
0.53 \\
0.34 \\
0.57 \\
0.34 \\
0.34 \\
0.17 \\
0.28 \\
0.14 \\
0.13 \\
0.17\end{array}$ & $\begin{array}{l}0.0 \\
0.6 \\
0.4 \\
0.3 \\
0.9 \\
0.8 \\
9.0 \\
0.9 \\
1.5 \\
0.6 \\
0.2 \\
1.1 \\
4.3 \\
1.3 \\
0.7 \\
0.5 \\
0.2 \\
0.6 \\
0.2 \\
0.1 \\
0.3\end{array}$ \\
\hline
\end{tabular}

BEAVER VALLEY 1,2

DPR-65 NPF-73 1 st commercidi operation $1076,11,97$

Type - FWirs

Capacity - 810, 820

\begin{tabular}{|c|c|}
\hline $\begin{array}{l}1977 \\
1978 \\
1979 \\
1960 \\
1981 \\
1942 \\
1983 \\
1984 \\
1995 \\
1938 \\
1987 \\
1988 \\
1989 \\
1990 \\
1998 \\
1090\end{array}$ & $\begin{array}{r}355.6 \\
304.2 \\
221.0 \\
39.8 \\
573.4 \\
326.7 \\
561.2 \\
576.7 \\
717.7 \\
581.3 \\
684.1 \\
1,396.1 \\
1,017.4 \\
1,271.0 \\
1,267.6 \\
1,441.9\end{array}$ \\
\hline
\end{tabular}

331
648
704
1,617
1,297
1,755
1,485
1,393
1,619
1,575
1,262
2,344
1,675
1,669
1,414

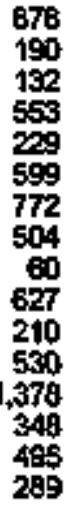

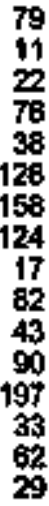

79
11
22
78
38
128
158
124
17
82
43
90
197
33
62
29

29
151
67
477
142
481
615
302
12
456
137
438
1,151
268
325
203

$\begin{array}{ll}0.26 & 0.2 \\ 0.29 & 0.6 \\ 0.19 & 0.6 \\ 0.30 & 13.9 \\ 0.19 & 0.4 \\ 0.34 & 1.8 \\ 0.32 & 1.4 \\ 0.36 & 0.9 \\ 0.10 & 0.1 \\ 0.40 & 1.1 \\ 0.16 & 0.3 \\ 0.30 & 0.4 \\ 0.59 & 1.4 \\ 0.21 & 0.3 \\ 0.29 & 0.4 \\ 0.20 & 0.2\end{array}$


APPENDIX C (continued)

PERSONNEL, DOSE AND POWER GENERATION SUMMARY

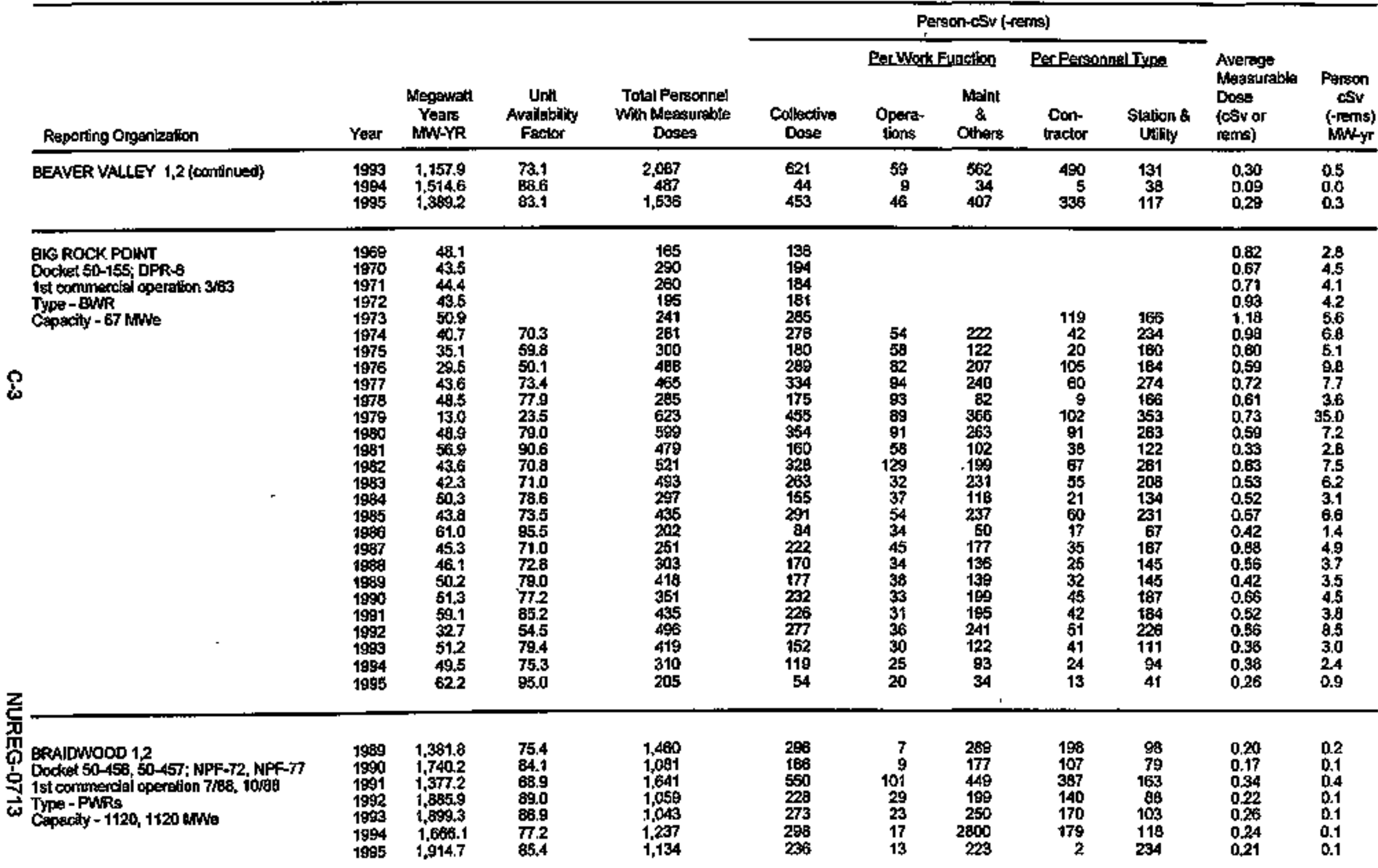




\begin{tabular}{|c|c|c|c|c|c|c|c|c|c|c|c|}
\hline \multirow{4}{*}{ 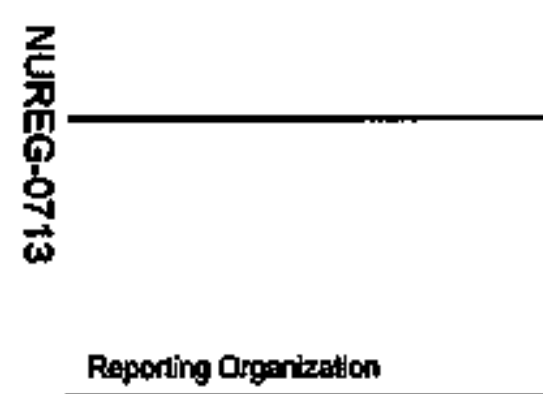 } & \multirow[b]{4}{*}{ Yest } & \multicolumn{8}{|c|}{$\begin{array}{l}\text { APPENDX C (continued) } \\
\text { PERSONNEL, DOSE AND POWER GENERATION SUM:LARY }\end{array}$} & \multirow{4}{*}{$\begin{array}{l}\text { Average } \\
\text { Measurabie } \\
\text { Dose } \\
\text { (cSvor } \\
\text { rems) }\end{array}$} & \multirow{4}{*}{$\begin{array}{l}\text { Person } \\
\text { c5s } \\
(-1 t e m s) \\
\text { WW-yr }\end{array}$} \\
\hline & & \multirow[b]{3}{*}{$\begin{array}{l}\text { Megrwatt } \\
\text { Yeare } \\
\text { Am-YR }\end{array}$} & \multirow[b]{3}{*}{$\begin{array}{l}\text { Unit } \\
\text { Aveliability } \\
\text { Factor }\end{array}$} & \multirow[b]{3}{*}{$\begin{array}{l}\text { Toted Personnel } \\
\text { Wilh Mioasurable } \\
\text { Doses }\end{array}$} & \multicolumn{5}{|c|}{ Penson-csv (-rems) } & & \\
\hline & & & & & \multicolumn{3}{|c|}{ Per work Function } & \multicolumn{2}{|c|}{ Ber.refsonneityre } & & \\
\hline & & & & & $\begin{array}{c}\text { Collective } \\
\text { Dose }\end{array}$ & $\begin{array}{c}\text { Open- } \\
\text { tians }\end{array}$ & $\begin{array}{l}\text { Walnt } \\
\text { \& } \\
\text { Ohers }\end{array}$ & $\begin{array}{c}\text { Can- } \\
\text { Ifactor }\end{array}$ & $\begin{array}{c}\text { Stalion \& } \\
\text { Utillyy }\end{array}$ & & \\
\hline 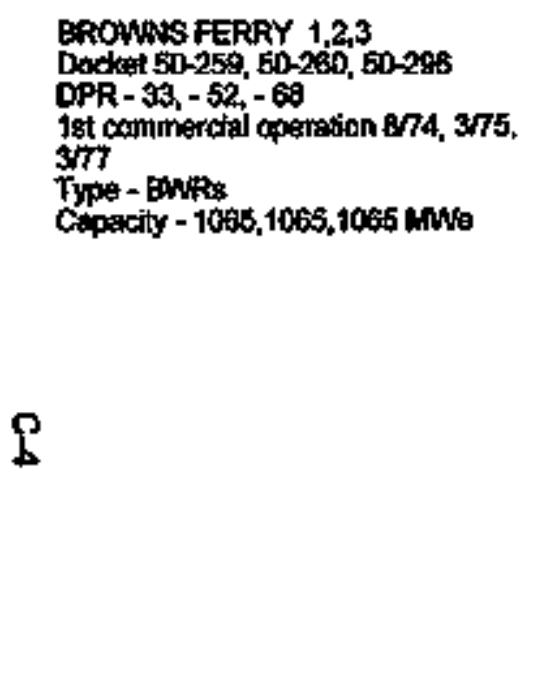 & 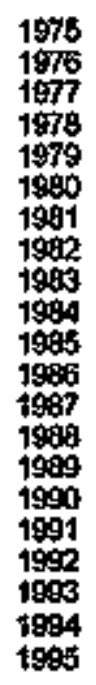 & $\begin{array}{r}161.7 \\
397.6 \\
1,327.5 \\
1,992.1 \\
2,393.0 \\
2,182.1 \\
2,132.9 \\
2,026.4 \\
1,641.0 \\
1,431.9 \\
369.2 \\
0.0 \\
0.0 \\
0.0 \\
0.0 \\
0.0 \\
44.0 \\
979.9 \\
675.1 \\
860.2 \\
1,165.0\end{array}$ & $\begin{array}{l}17.8 \\
25.9 \\
73.7 \\
73.5 \\
79.1 \\
73.6 \\
69.5 \\
67.6 \\
54.3 \\
54.2 \\
11.9 \\
0.0 \\
0.0 \\
0.0 \\
0.0 \\
0.0 \\
17.7 \\
32.2 \\
6.8 \\
83.4 \\
93.6\end{array}$ & $\begin{array}{l}2,300 \\
2,207 \\
1,859 \\
2,376 \\
2,699 \\
2,712 \\
3,379 \\
3,277 \\
3,302 \\
2,962 \\
2,755 \\
3,003 \\
3,115 \\
3,324 \\
2,663 \\
2,717 \\
1,815 \\
2,656 \\
3,694 \\
3,299 \\
2,540\end{array}$ & $\begin{array}{r}325 \\
234 \\
863 \\
1,792 \\
1,667 \\
1,926 \\
2,394 \\
2,220 \\
3,368 \\
1,940 \\
1,169 \\
1,050 \\
1,181 \\
1,156 \\
656 \\
1,310 \\
354 \\
516 \\
870 \\
855 \\
409\end{array}$ & $\begin{array}{r}60 \\
4 \\
0 \\
4 \\
190 \\
191 \\
276 \\
290 \\
201 \\
196 \\
187 \\
234 \\
97 \\
64 \\
134 \\
84 \\
78 \\
64 \\
64\end{array}$ & $\begin{array}{r}805 \\
1,768 \\
1,657 \\
1,620 \\
2,260 \\
2,039 \\
3,067 \\
1,711 \\
968 \\
854 \\
994 \\
994 \\
569 \\
1,246 \\
220 \\
491 \\
792 \\
800 \\
345\end{array}$ & $\begin{array}{l}249 \\
261 \\
289 \\
50 \\
404 \\
317 \\
909 \\
541 \\
300 \\
343 \\
220 \\
109 \\
131 \\
69 \\
121 \\
289 \\
600 \\
649 \\
284\end{array}$ & $\begin{array}{r}614 \\
1,531 \\
1,378 \\
1,776 \\
1,976 \\
1,903 \\
2,454 \\
1,399 \\
953 \\
707 \\
959 \\
1,046 \\
525 \\
1,242 \\
239 \\
217 \\
270 \\
205 \\
129\end{array}$ & $\begin{array}{l}0.14 \\
0.11 \\
0.46 \\
0.75 \\
0.62 \\
0.67 \\
0.70 \\
0.68 \\
1.02 \\
0.65 \\
0.42 \\
0.35 \\
0.38 \\
0.35 \\
0.24 \\
0.48 \\
0.20 \\
0.19 \\
0.24 \\
0.28 \\
0.16\end{array}$ & $\begin{array}{l}2.0 \\
0.7 \\
0.7 \\
0.9 \\
0.7 \\
0.8 \\
1.1 \\
1.1 \\
2.0 \\
1.4 \\
3.1 \\
= \\
= \\
= \\
\overline{0.8} \\
0.5 \\
1.3 \\
0.9 \\
0.4\end{array}$ \\
\hline 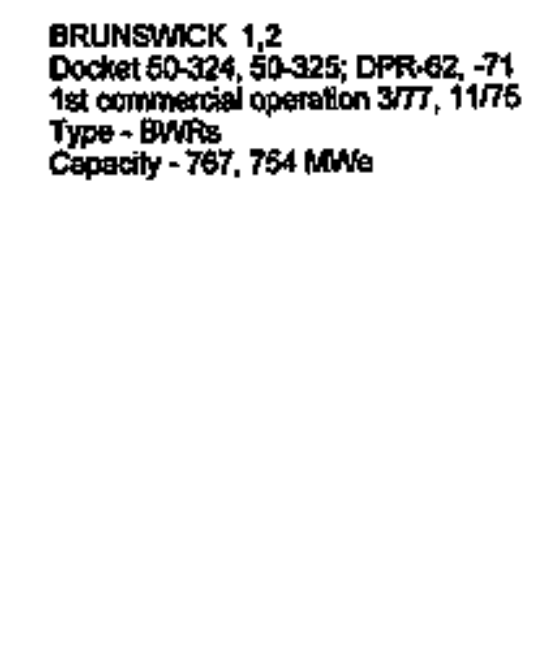 & $\begin{array}{l}1976 \\
1977 \\
1978 \\
1979 \\
1960 \\
1961 \\
1962 \\
1963 \\
1984 \\
1985 \\
1986 \\
1987 \\
1998 \\
1989 \\
1980 \\
1991 \\
1992 \\
1993 \\
1954 \\
1995\end{array}$ & $\begin{array}{r}297.2 \\
290.1 \\
1,173.1 \\
610.0 \\
687.2 \\
925.2 \\
540.3 \\
636.7 \\
761.3 \\
822.2 \\
1,051.3 \\
1,152.4 \\
990.8 \\
990.9 \\
991.6 \\
952.8 \\
375.9 \\
470.0 \\
1,269.4 \\
t, 411.7\end{array}$ & $\begin{array}{l}56.0 \\
65.7 \\
83.7 \\
60.1 \\
52.2 \\
56.9 \\
50.3 \\
44.3 \\
51.5 \\
58.4 \\
69.1 \\
80.6 \\
70.1 \\
65.8 \\
67.8 \\
64.5 \\
27.9 \\
33.8 \\
83.1 \\
92.9\end{array}$ & $\begin{array}{l}1,265 \\
1,512 \\
1,456 \\
2,891 \\
3,784 \\
3,954 \\
4,957 \\
6,609 \\
5,046 \\
4,057 \\
3,370 \\
3,052 \\
2,643 \\
3,944 \\
3,192 \\
2,683 \\
2,690 \\
2,921 \\
3,049 \\
2,657\end{array}$ & $\begin{array}{l}336 \\
1,120 \\
1,004 \\
2,602 \\
3,870 \\
2,618 \\
3,792 \\
3,475 \\
3,265 \\
2,904 \\
1,909 \\
1,419 \\
1,747 \\
1,795 \\
1,548 \\
778 \\
623 \\
672 \\
992 \\
693\end{array}$ & $\begin{array}{r}15 \\
48 \\
99 \\
97 \\
111 \\
159 \\
162 \\
162 \\
143 \\
120 \\
97 \\
144 \\
219 \\
181 \\
152 \\
120 \\
95 \\
110 \\
122 \\
101\end{array}$ & $\begin{array}{r}311 \\
1,071 \\
905 \\
2,505 \\
3,759 \\
2,479 \\
3,690 \\
3,523 \\
3,117 \\
2,684 \\
1,912 \\
1,275 \\
1,528 \\
1,605 \\
1,396 \\
659 \\
528 \\
754 \\
676 \\
582\end{array}$ & $\begin{array}{r}222 \\
782 \\
695 \\
2,074 \\
3,088 \\
1,990 \\
2,841 \\
2,429 \\
2,363 \\
2,077 \\
1,273 \\
8,961 \\
1,051 \\
1,295 \\
1,156 \\
451 \\
464 \\
645 \\
720 \\
402\end{array}$ & $\begin{array}{r}104 \\
337 \\
309 \\
528 \\
772 \\
748 \\
851 \\
1,047 \\
897 \\
727 \\
636 \\
358 \\
696 \\
491 \\
392 \\
327 \\
159 \\
227 \\
278 \\
201\end{array}$ & $\begin{array}{l}0.26 \\
0.74 \\
0.69 \\
0.90 \\
1.02 \\
0.68 \\
0.76 \\
0.62 \\
0.65 \\
0.69 \\
0.57 \\
0.46 \\
0.66 \\
0.46 \\
0.49 \\
0.30 \\
0.23 \\
0.30 \\
0.33 \\
0.26\end{array}$ & $\begin{array}{l}1.1 \\
3.8 \\
0.9 \\
3.2 \\
5.6 \\
2.9 \\
7.0 \\
5.5 \\
4.3 \\
3.4 \\
1.8 \\
1.2 \\
1.8 \\
1.8 \\
1.6 \\
0.8 \\
1.7 \\
1.9 \\
0.7 \\
0.5\end{array}$ \\
\hline
\end{tabular}


APPENDIX C (continued)

PERSONNEL, DOSE AND POWER GENERATION SUMMARY

\begin{tabular}{|c|c|c|c|c|c|c|c|c|c|c|c|}
\hline \multirow[b]{3}{*}{ Reporting Organization } & \multirow[b]{3}{*}{ Year } & \multirow[b]{3}{*}{$\begin{array}{l}\text { Megowat } \\
\text { Years } \\
\text { MNKYR }\end{array}$} & \multirow[b]{3}{*}{$\begin{array}{l}\text { Unit } \\
\text { Availebility } \\
\text { Factor }\end{array}$} & \multirow[b]{3}{*}{$\begin{array}{c}\text { Total Personitel } \\
\text { Wilh Measurable } \\
\text { Dosess }\end{array}$} & \multicolumn{5}{|c|}{ Person-csv (-rents) } & \multirow{3}{*}{$\begin{array}{l}\text { Average } \\
\text { Measturable } \\
\text { Dose } \\
\text { (c) or } \\
\text { rems) }\end{array}$} & \multirow{3}{*}{$\begin{array}{l}\text { Person } \\
\text { cSY } \\
\text { (rems } \\
\text { whint }\end{array}$} \\
\hline & & & & & & \multicolumn{2}{|c|}{ BarworkFunction } & \multicolumn{2}{|c|}{ BarParsomelType } & & \\
\hline & & & & & $\begin{array}{l}\text { Collective } \\
\text { Dose }\end{array}$ & $\begin{array}{c}\text { Opera } \\
\text { tigns }\end{array}$ & $\begin{array}{l}\text { Maint } \\
\& \\
\text { Others }\end{array}$ & Con- & $\begin{array}{l}\text { Slation \& } \\
\text { UJtînty }\end{array}$ & & \\
\hline 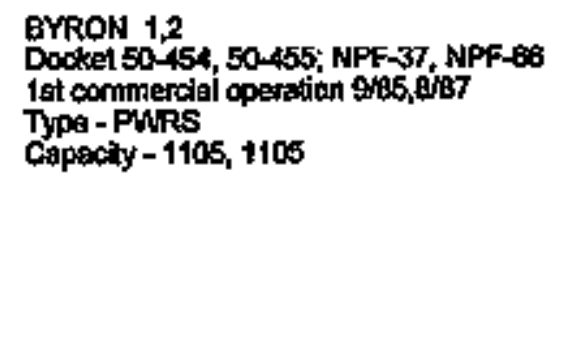 & $\begin{array}{l}1985 \\
1987 \\
1989 \\
1999 \\
1980 \\
1991 \\
1992 \\
1993 \\
1994 \\
1995\end{array}$ & $\begin{array}{r}894.5 \\
650.9 \\
1,534.7 \\
1,812.6 \\
1,567.3 \\
1,816.3 \\
1,8684 \\
1,7866 \\
1,963.3 \\
1,900.6\end{array}$ & $\begin{array}{l}98.6 \\
70.9 \\
86.3 \\
90.2 \\
78.9 \\
89.9 \\
90.1 \\
83.5 \\
90.7 \\
85.5\end{array}$ & $\begin{array}{r}1,081 \\
1,026 \\
1,222 \\
1,109 \\
1,396 \\
1,077 \\
1,021 \\
1,370 \\
0 \times 2 \\
1,107\end{array}$ & $\begin{array}{l}76 \\
769 \\
459 \\
172 \\
434 \\
269 \\
199 \\
432 \\
280 \\
306\end{array}$ & $\begin{array}{c}12 \\
11 \\
0 \\
21 \\
39 \\
42 \\
43 \\
57 \\
17 \\
1\end{array}$ & $\begin{array}{l}64 \\
756 \\
459 \\
151 \\
396 \\
228 \\
156 \\
375 \\
262 \\
395\end{array}$ & $\begin{array}{l}47 \\
667 \\
333 \\
165 \\
265 \\
159 \\
118 \\
248 \\
164 \\
183\end{array}$ & $\begin{array}{r}29 \\
102 \\
126 \\
67 \\
168 \\
110 \\
81 \\
184 \\
115 \\
123\end{array}$ & $\begin{array}{l}0.07 \\
0.42 \\
0.38 \\
0.15 \\
0.31 \\
0.25 \\
0.19 \\
0.32 \\
0.29 \\
0.28\end{array}$ & $\begin{array}{l}0.1 \\
1.2 \\
0.3 \\
0.1 \\
0.3 \\
0.1 \\
0.1 \\
0.2 \\
0.1 \\
0.2\end{array}$ \\
\hline $\begin{array}{l}\text { CALLAWAY 1 } \\
\text { Docket 50-483; NPF-30 } \\
\text { 1st cemmercial operalion 121294 } \\
\text { Type-PWR } \\
\text { Cepacity - } 1115 \text { whe }\end{array}$ & $\begin{array}{l}1965 \\
1965 \\
1987 \\
1988 \\
1989 \\
1990 \\
1991 \\
1982 \\
1993 \\
1994 \\
1995\end{array}$ & $\begin{array}{r}967.4 \\
8652 \\
7590 \\
1,0692 \\
1,000.3 \\
960.7 \\
1.199 .1 \\
967.5 \\
1,002.9 \\
1,196.4 \\
969.6\end{array}$ & $\begin{array}{r}90.0 \\
81.3 \\
71.7 \\
98.4 \\
85.4 \\
84.1 \\
99.7 \\
83.0 \\
86.4 \\
100.0 \\
84.7\end{array}$ & $\begin{array}{r}964 \\
1,052 \\
1,082 \\
353 \\
1,055 \\
1,134 \\
200 \\
1,133 \\
1,126 \\
191 \\
1,062\end{array}$ & $\begin{array}{r}36 \\
225 \\
393 \\
27 \\
283 \\
442 \\
21 \\
336 \\
225 \\
14 \\
187\end{array}$ & $\begin{array}{r}16 \\
53 \\
89 \\
12 \\
46 \\
50 \\
9 \\
52 \\
73 \\
6 \\
30\end{array}$ & $\begin{array}{r}20 \\
172 \\
304 \\
45 \\
237 \\
392 \\
12 \\
284 \\
152 \\
7 \\
157\end{array}$ & $\begin{array}{r}7 \\
129 \\
249 \\
2 \\
191 \\
332 \\
2 \\
244 \\
157 \\
0 \\
118\end{array}$ & $\begin{array}{r}29 \\
96 \\
144 \\
25 \\
92 \\
110 \\
19 \\
92 \\
68 \\
13 \\
69\end{array}$ & $\begin{array}{l}0.04 \\
0.21 \\
0.38 \\
0.08 \\
0.27 \\
0.39 \\
0.07 \\
0.30 \\
0.20 \\
0.07 \\
0.18\end{array}$ & $\begin{array}{l}0.0 \\
0.3 \\
0.5 \\
0.0 \\
0.3 \\
0.5 \\
0.0 \\
0.3 \\
0.2 \\
0.0 \\
0.2\end{array}$ \\
\hline 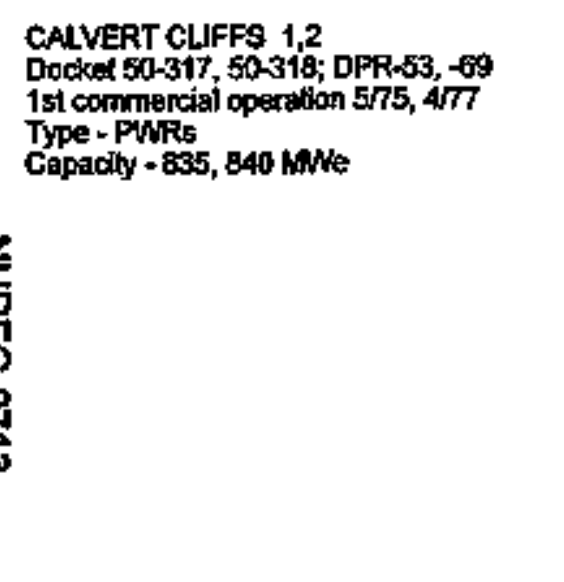 & $\begin{array}{l}1976 \\
1977 \\
1976 \\
1979 \\
1960 \\
1981 \\
1908 \\
1983 \\
1984 \\
1985 \\
1988 \\
1997 \\
1988 \\
1989 \\
1990 \\
1999 \\
1998 \\
1993\end{array}$ & $\begin{array}{r}753.4 \\
683.0 \\
1,168.5 \\
1,161.0 \\
1,309.9 \\
1,379.7 \\
1,238.3 \\
1,3972 \\
1,399.4 \\
1,189.8 \\
1,690.0 \\
1,207.3 \\
1,397.7 \\
333.8 \\
161.1 \\
1,095.0 \\
1,271.2 \\
1,462.1\end{array}$ & $\begin{array}{l}95.2 \\
72.1 \\
75.8 \\
74.0 \\
64.1 \\
63.1 \\
73.7 \\
81.6 \\
79.3 \\
68.4 \\
87.2 \\
71.8 \\
81.0 \\
20.7 \\
11.0 \\
64.7 \\
73.9 \\
83.9\end{array}$ & $\begin{array}{l}507 \\
2,265 \\
1,391 \\
1,428 \\
1,496 \\
1,595 \\
1,805 \\
1,915 \\
1,359 \\
1,598 \\
1,296 \\
1,364 \\
1,296 \\
1,768 \\
2,019 \\
1,974 \\
1,979 \\
1,402\end{array}$ & $\begin{array}{r}74 \\
547 \\
500 \\
605 \\
677 \\
607 \\
1,057 \\
666 \\
479 \\
694 \\
347 \\
412 \\
291 \\
346 \\
304 \\
132 \\
330 \\
405\end{array}$ & $\begin{array}{l}28 \\
33 \\
13 \\
13 \\
15 \\
16 \\
29 \\
84 \\
5 \\
61 \\
69 \\
29 \\
29 \\
30 \\
11 \\
12 \\
25 \\
35 \\
13\end{array}$ & $\begin{array}{l}46 \\
511 \\
, 497 \\
773 \\
662 \\
578 \\
973 \\
663 \\
418 \\
625 \\
345 \\
333 \\
261 \\
335 \\
299 \\
107 \\
295 \\
392\end{array}$ & $\begin{array}{r}8 \\
224 \\
143 \\
426 \\
402 \\
370 \\
402 \\
143 \\
79 \\
144 \\
101 \\
110 \\
90 \\
216 \\
203 \\
70 \\
228 \\
299\end{array}$ & $\begin{array}{r}68 \\
323 \\
357 \\
379 \\
275 \\
229 \\
655 \\
525 \\
400 \\
550 \\
246 \\
302 \\
201 \\
130 \\
101 \\
62 \\
102 \\
106\end{array}$ & $\begin{array}{l}0.15 \\
0.24 \\
0.36 \\
0.58 \\
0.45 \\
0.39 \\
0.69 \\
0.35 \\
0.35 \\
0.43 \\
0.27 \\
0.30 \\
0.22 \\
0.19 \\
0.15 \\
0.07 \\
0.17 \\
0.23\end{array}$ & $\begin{array}{l}0.1 \\
0.9 \\
0.4 \\
0.7 \\
0.5 \\
0.4 \\
0.9 \\
0.5 \\
0.3 \\
0.6 \\
0.2 \\
0.3 \\
0.2 \\
1.0 \\
1.9 \\
0.1 \\
0.3 \\
0.3\end{array}$ \\
\hline
\end{tabular}




\begin{tabular}{|c|c|c|c|c|c|c|c|c|c|c|c|}
\hline \multirow[b]{4}{*}{ Reperting Organtzalion } & \multirow[b]{4}{*}{ Yeler } & \multicolumn{8}{|c|}{$\begin{array}{l}\text { APPENDIX C (continued) } \\
\text { PERSONNEL, DOSE AND POWER GENERATION SUMHMARY }\end{array}$} & \multirow{4}{*}{$\begin{array}{l}\text { Average } \\
\text { Mesasurable } \\
\text { Dase } \\
\text { (csvor } \\
\text { rems) }\end{array}$} & \multirow{4}{*}{$\begin{array}{c}\text { Peroon } \\
\text { c } \$ v \\
\text { (-rems) } \\
\text { Nin-yr }\end{array}$} \\
\hline & & \multirow[b]{3}{*}{$\begin{array}{l}\text { Megawalt } \\
\text { Years } \\
\text { MW-YR }\end{array}$} & \multirow[b]{3}{*}{$\begin{array}{l}\text { Unit } \\
\text { Augilability } \\
\text { facilor }\end{array}$} & \multirow[b]{3}{*}{$\begin{array}{l}\text { Total Perisonnel } \\
\text { Whin Measturatote } \\
\text { Doses }\end{array}$} & \multicolumn{5}{|c|}{ Person-civ (-rems) } & & \\
\hline & & & & & \multicolumn{3}{|c|}{ Perwodk Function } & \multicolumn{2}{|c|}{ PerPersonned Tre } & & \\
\hline & & & & & $\begin{array}{l}\text { Collective } \\
\text { Dose }\end{array}$ & $\begin{array}{c}\text { Opera. } \\
\text { tions }\end{array}$ & $\begin{array}{l}\text { Maint } \\
\text { \& } \\
\text { Ohers }\end{array}$ & $\begin{array}{l}\text { Con* } \\
\text { toactor }\end{array}$ & $\begin{array}{c}\text { Slation } 8 \\
\text { Utllity }\end{array}$ & & \\
\hline CALVERT CLIFFS 1,2 (conlinued) & $\begin{array}{l}1994 \\
1995\end{array}$ & $\begin{array}{l}1,342.1 \\
1,542.8\end{array}$ & $\begin{array}{l}79.4 \\
89.9\end{array}$ & $\begin{array}{l}1,482 \\
1.203\end{array}$ & $\begin{array}{l}454 \\
235\end{array}$ & $\begin{array}{l}30 \\
29\end{array}$ & $\begin{array}{l}424 \\
208\end{array}$ & $\frac{9133}{174}$ & $\begin{array}{r}121 \\
61\end{array}$ & $\begin{array}{l}0.31 \\
0.20\end{array}$ & $\begin{array}{l}0.3 \\
0.2\end{array}$ \\
\hline 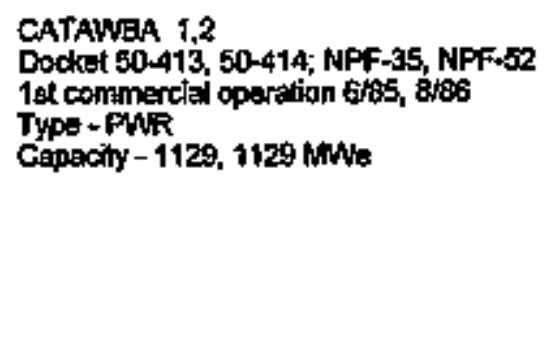 & $\begin{array}{l}1996 \\
1997 \\
19889 \\
1989 \\
1990 \\
1991 \\
1992 \\
1993 \\
1994 \\
1995\end{array}$ & $\begin{array}{r}638.9 \\
1,651.2 \\
1,675.2 \\
1,733.6 \\
1,616.3 \\
1,691.5 \\
1,962.6 \\
1,896.1 \\
2,105.2 \\
2,011.9\end{array}$ & $\begin{array}{l}49.9 \\
75.9 \\
77.2 \\
79.5 \\
70.8 \\
74.8 \\
83.9 \\
81.5 \\
90.2 \\
85.3\end{array}$ & $\begin{array}{l}1,724 \\
1,865 \\
2,009 \\
1,660 \\
2,174 \\
1,871 \\
1,515 \\
1,584 \\
1,258 \\
1,892\end{array}$ & $\begin{array}{l}286 \\
449 \\
556 \\
334 \\
609 \\
402 \\
414 \\
396 \\
207 \\
462\end{array}$ & $\begin{array}{l}27 \\
32 \\
71 \\
46 \\
58 \\
50 \\
52 \\
29 \\
35 \\
62\end{array}$ & $\begin{array}{l}269 \\
417 \\
485 \\
286 \\
751 \\
412 \\
362 \\
367 \\
172 \\
400\end{array}$ & $\begin{array}{r}68 \\
161 \\
200 \\
110 \\
292 \\
141 \\
92 \\
59 \\
47 \\
83\end{array}$ & $\begin{array}{l}218 \\
288 \\
356 \\
224 \\
517 \\
321 \\
322 \\
337 \\
160 \\
378\end{array}$ & $\begin{array}{l}0.17 \\
0.24 \\
0.28 \\
0.20 \\
0.37 \\
0.25 \\
0.27 \\
0.25 \\
0.16 \\
0.24\end{array}$ & $\begin{array}{l}0.4 \\
0.3 \\
0.3 \\
0.2 \\
0.5 \\
0.3 \\
0.2 \\
0.2 \\
0.1 \\
0.2\end{array}$ \\
\hline $\begin{array}{l}\text { CLINTON } \\
\text { Oocket 50-461; NPF-62 } \\
\text { 1st cemminercid cperdion 11/67 } \\
\text { Type - BNR } \\
\text { Capacity - } 930 \text { NoWe }\end{array}$ & $\begin{array}{l}1998 \\
1999 \\
1990 \\
1991 \\
1999 \\
1993 \\
1994 \\
1995\end{array}$ & $\begin{array}{l}701.3 \\
348.3 \\
435.8 \\
722.7 \\
569.7 \\
701.5 \\
883.3 \\
731.1\end{array}$ & $\begin{array}{l}84.2 \\
48.5 \\
65.4 \\
80.8 \\
68.6 \\
79.6 \\
94.8 \\
63.0\end{array}$ & $\begin{array}{r}769 \\
1,196 \\
1,390 \\
1,010 \\
1,195 \\
1,253 \\
109 \\
1,182\end{array}$ & $\begin{array}{l}130 \\
372 \\
653 \\
233 \\
431 \\
499 \\
63 \\
316\end{array}$ & $\begin{array}{r}48 \\
91 \\
497 \\
202 \\
63 \\
49 \\
1 \\
25\end{array}$ & $\begin{array}{r}82 \\
281 \\
143 \\
11 \\
368 \\
450 \\
62 \\
291\end{array}$ & $\begin{array}{r}64 \\
261 \\
438 \\
143 \\
287 \\
367 \\
7 \\
202\end{array}$ & $\begin{array}{r}66 \\
111 \\
115 \\
90 \\
144 \\
131 \\
56 \\
\$ 14\end{array}$ & $\begin{array}{l}0.17 \\
0.31 \\
0.40 \\
0.23 \\
0.36 \\
0.40 \\
0.15 \\
0.27\end{array}$ & $\begin{array}{l}0.2 \\
1.1 \\
1.3 \\
0.3 \\
0.7 \\
0.7 \\
0.0 \\
0.4\end{array}$ \\
\hline 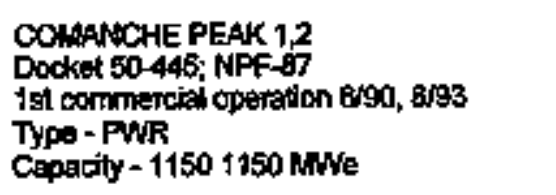 & $\begin{array}{l}1991 \\
1992 \\
19993 \\
1994 \\
1995\end{array}$ & $\begin{array}{r}644.4 \\
890.8 \\
853.8 \\
1,750,0 \\
2,022,6\end{array}$ & $\begin{array}{l}62.2 \\
84.0 \\
91.2 \\
93.7 \\
92.5\end{array}$ & $\begin{array}{r}995 \\
1,128 \\
945 \\
970 \\
951\end{array}$ & $\begin{array}{r}148 \\
188 \\
109 \\
90 \\
179\end{array}$ & $\begin{array}{l}13 \\
29 \\
25 \\
22 \\
21\end{array}$ & $\begin{array}{r}135 \\
180 \\
84 \\
68 \\
158\end{array}$ & $\begin{array}{r}111 \\
158 \\
92 \\
75 \\
154\end{array}$ & $\begin{array}{l}37 \\
30 \\
17 \\
15 \\
25\end{array}$ & $\begin{array}{l}0.15 \\
0.17 \\
0.12 \\
0.09 \\
0.19\end{array}$ & $\begin{array}{l}0.2 \\
0.2 \\
0.1 \\
0.1 \\
0.1\end{array}$ \\
\hline 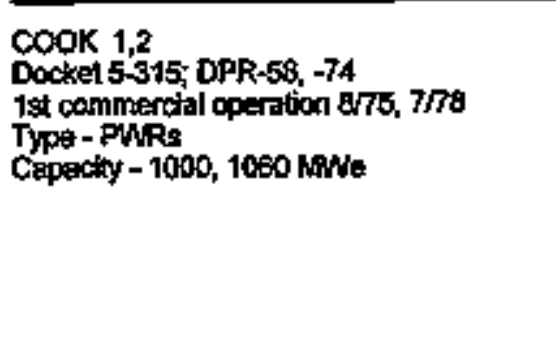 & $\begin{array}{l}1976 \\
1977 \\
1978 \\
1999 \\
19800 \\
19911 \\
1968 \\
1998 \\
1994 \\
1985\end{array}$ & $\begin{array}{r}807.4 \\
573.0 \\
744.8 \\
1,373.0 \\
1,552.4 \\
1,557.3 \\
1,461.6 \\
1,456.5 \\
1,526.0 \\
925.4\end{array}$ & $\begin{array}{l}83.1 \\
76.1 \\
73.8 \\
65.3 \\
74.1 \\
73.4 \\
69.8 \\
71.2 \\
75.3 \\
47.6\end{array}$ & $\begin{array}{r}395 \\
602 \\
778 \\
1,445 \\
1,345 \\
1,341 \\
1,527 \\
1,418 \\
1,559 \\
1,984\end{array}$ & $\begin{array}{l}116 \\
300 \\
336 \\
718 \\
493 \\
656 \\
699 \\
659 \\
762 \\
945\end{array}$ & $\begin{array}{l}13 \\
21 \\
49 \\
45 \\
46 \\
48 \\
67 \\
50 \\
43 \\
92\end{array}$ & $\begin{array}{l}103 \\
278 \\
287 \\
673 \\
447 \\
609 \\
632 \\
609 \\
799 \\
853\end{array}$ & $\begin{array}{l}71 \\
138 \\
139 \\
454 \\
323 \\
443 \\
472 \\
467 \\
597 \\
758\end{array}$ & $\begin{array}{l}45 \\
161 \\
197 \\
264 \\
170 \\
213 \\
227 \\
191 \\
165 \\
187\end{array}$ & $\begin{array}{l}0.29 \\
0.37 \\
0.43 \\
0.50 \\
0.37 \\
0.49 \\
0.46 \\
0.48 \\
0.49 \\
0.48\end{array}$ & $\begin{array}{l}0.1 \\
0.5 \\
0.5 \\
0.5 \\
0.3 \\
0.4 \\
0.5 \\
0.5 \\
0.5 \\
1.0\end{array}$ \\
\hline
\end{tabular}


APPENDIX C (confinued)

PERSONNEL, DOSE AND POWER GENERATION SUMMARY

\begin{tabular}{|c|c|c|c|c|c|c|c|c|c|c|c|}
\hline \multirow[b]{2}{*}{ Reporting Organization } & \multirow[b]{2}{*}{ Year } & \multirow[b]{2}{*}{$\begin{array}{l}\text { Megewralt } \\
\text { Years } \\
\text { MW-YR }\end{array}$} & \multirow[b]{2}{*}{$\begin{array}{l}\text { Unik } \\
\text { Avatabitity } \\
\text { Factor }\end{array}$} & \multirow[b]{2}{*}{$\begin{array}{c}\text { Total Personnel } \\
\text { With Measurabte } \\
\text { Doses }\end{array}$} & \multicolumn{5}{|c|}{ Person-cSv (-rems) } & \multirow[b]{2}{*}{$\begin{array}{l}\text { Average } \\
\text { Measurabla } \\
\text { Dose } \\
\text { (csis or } \\
\text { nems) }\end{array}$} & \multirow[b]{2}{*}{$\begin{array}{c}\text { Person } \\
\text { cSt } \\
\text { (-rems) } \\
\text { MaN-yr }\end{array}$} \\
\hline & & & & & $\begin{array}{l}\text { Collective } \\
\text { Dose }\end{array}$ & $\begin{array}{l}\text { Opera } \\
\text { tons }\end{array}$ & $\begin{array}{l}\text { Funcion } \\
\text { Maint } \\
\text { Others }\end{array}$ & $\begin{array}{l}\text { Perpetis: } \\
\text { Con- } \\
\text { tractor }\end{array}$ & $\begin{array}{c}\text { Stalion \& } \\
\text { Utithy }\end{array}$ & & \\
\hline $\operatorname{coOK} 1,2$ (conlinued) & $\begin{array}{l}1986 \\
1987 \\
1988 \\
1989 \\
1990 \\
1991 \\
1998 \\
1998 \\
1994 \\
1905\end{array}$ & $\begin{array}{r}1,307.1 \\
1,199.5 \\
1,160.4 \\
1,433.1 \\
1,318.5 \\
1,937.4 \\
760.9 \\
1,927.7 \\
1,105.2 \\
1,656.0\end{array}$ & $\begin{array}{l}73.4 \\
70.2 \\
63.5 \\
72.8 \\
67.9 \\
90.2 \\
50.8 \\
98.5 \\
65.2 \\
92.1\end{array}$ & $\begin{array}{r}1,774 \\
1,695 \\
2,466 \\
1,575 \\
1,051 \\
815 \\
1,954 \\
597 \\
1,748 \\
1,310\end{array}$ & $\begin{array}{r}745 \\
685 \\
457 \\
493 \\
5806 \\
69 \\
492 \\
44 \\
479 \\
203\end{array}$ & $\begin{array}{l}64 \\
79 \\
52 \\
50 \\
87 \\
29 \\
60 \\
10 \\
26 \\
29\end{array}$ & $\begin{array}{r}681 \\
587 \\
815 \\
443 \\
493 \\
41 \\
432 \\
34 \\
453 \\
174\end{array}$ & $\begin{array}{r}585 \\
525 \\
762 \\
421 \\
504 \\
48 \\
416 \\
29 \\
362 \\
142\end{array}$ & $\begin{array}{r}160 \\
141 \\
105 \\
72 \\
76 \\
21 \\
76 \\
15 \\
117 \\
61\end{array}$ & $\begin{array}{l}0.42 \\
0.39 \\
0.38 \\
0.31 \\
0.34 \\
0.08 \\
0.25 \\
0.07 \\
0.27 \\
0.15\end{array}$ & $\begin{array}{l}0.6 \\
0.6 \\
0.7 \\
0.3 \\
0.4 \\
0.0 \\
0.6 \\
0.0 \\
0.4 \\
0.1\end{array}$ \\
\hline $\begin{array}{l}\text { COOPER STATION } \\
\text { Docket 50-298; DPR-46 } \\
\text { 1st commercial operation } 7 / 74 \\
\text { Type-BWR } \\
\text { Capecity - } 764 \text { MWe }\end{array}$ & $\begin{array}{c}1975 \\
1976 \\
1977 \\
1978 \\
1979 \\
1960 \\
1981 \\
1982 \\
1983 \\
1984 \\
1965 \\
1985 \\
1997 \\
1988 \\
1989 \\
1990 \\
1991 \\
1992 \\
1993 \\
1994 \\
1995\end{array}$ & $\begin{array}{l}450.4 \\
433.3 \\
538.2 \\
576.0 \\
591.0 \\
448.3 \\
467.1 \\
622.3 \\
396.6 \\
411.8 \\
127.3 \\
480.0 \\
652.3 \\
493.4 \\
564.3 \\
602.0 \\
566.3 \\
731.0 \\
436.1 \\
262.2 \\
486.5\end{array}$ & $\begin{array}{l}93.8 \\
75.5 \\
96.2 \\
91.0 \\
07.6 \\
71.2 \\
71.2 \\
94.8 \\
63.3 \\
67.2 \\
21.5 \\
74.7 \\
96.2 \\
67.9 \\
76.2 \\
79.4 \\
79.8 \\
93.4 \\
59.4 \\
35.1 \\
66.8\end{array}$ & $\begin{array}{r}\$ 79 \\
763 \\
315 \\
297 \\
426 \\
795 \\
935 \\
743 \\
1,383 \\
1,593 \\
1,980 \\
895 \\
549 \\
1,942 \\
1,202 \\
1,174 \\
1,099 \\
463 \\
1,130 \\
333 \\
1,095\end{array}$ & $\begin{array}{r}117 \\
350 \\
199 \\
158 \\
221 \\
859 \\
579 \\
542 \\
1,293 \\
799 \\
1,353 \\
320 \\
103 \\
251 \\
343 \\
379 \\
405 \\
64 \\
391 \\
79 \\
228\end{array}$ & $\begin{array}{l}30 \\
39 \\
50 \\
40 \\
50 \\
71 \\
63 \\
66 \\
57 \\
46 \\
49 \\
49 \\
26 \\
40 \\
40 \\
34 \\
50 \\
16 \\
33 \\
24 \\
31\end{array}$ & $\begin{array}{r}87 \\
311 \\
147 \\
118 \\
171 \\
788 \\
516 \\
476 \\
1,236 \\
753 \\
1,284 \\
271 \\
77 \\
211 \\
303 \\
345 \\
355 \\
68 \\
358 \\
55 \\
197\end{array}$ & $\begin{array}{r}19 \\
210 \\
66 \\
58 \\
90 \\
644 \\
384 \\
381 \\
1,081 \\
635 \\
1,104 \\
115 \\
11 \\
118 \\
228 \\
265 \\
255 \\
16 \\
245 \\
7 \\
137\end{array}$ & $\begin{array}{r}98 \\
140 \\
131 \\
100 \\
131 \\
215 \\
197 \\
181 \\
212 \\
164 \\
229 \\
205 \\
92 \\
133 \\
115 \\
114 \\
150 \\
68 \\
146 \\
72 \\
91\end{array}$ & $\begin{array}{l}0.20 \\
0.46 \\
0.63 \\
0.53 \\
0.52 \\
1.09 \\
0.62 \\
0.73 \\
0.93 \\
0.50 \\
0.67 \\
0.36 \\
0.14 \\
0.27 \\
0.29 \\
0.32 \\
0.37 \\
0.19 \\
0.36 \\
0.24 \\
0.21\end{array}$ & $\begin{array}{r}0.3 \\
0.0 \\
0.4 \\
0.3 \\
0.4 \\
1.9 \\
1.3 \\
0.9 \\
3.3 \\
\mathbf{1 . 9} \\
\mathbf{t} 0.5 \\
0.7 \\
0.2 \\
0.5 \\
0.6 \\
0.6 \\
0.7 \\
0.1 \\
0.9 \\
0.9 \\
0.3 \\
0.5\end{array}$ \\
\hline $\begin{array}{l}\text { CRYSTALRIVER } 3 \\
\text { Docket 50-302; DPR-72 } \\
\text { 1st commordal operation } 377 \\
\text { Type - FWR } \\
\text { Capachy - 618 MWe }\end{array}$ & $\begin{array}{c}1978 \\
1979 \\
1980 \\
1981 \\
1992 \\
1993 \\
1984 \\
1985\end{array}$ & $\begin{array}{l}311.5 \\
453.0 \\
404.1 \\
490.4 \\
589.8 \\
452.1 \\
774.2 \\
344.2\end{array}$ & $\begin{array}{l}\mathbf{4 1 . 4} \\
58.9 \\
53.2 \\
62.2 \\
76.0 \\
58.8 \\
94.5 \\
47.6\end{array}$ & $\begin{array}{r}643 \\
1,150 \\
1,063 \\
1,120 \\
1,780 \\
1,720 \\
1,949 \\
1,976\end{array}$ & $\begin{array}{r}321 \\
495 \\
625 \\
406 \\
177 \\
562 \\
49 \\
689\end{array}$ & $\begin{array}{r}8 \\
29 \\
24 \\
18 \\
9 \\
71 \\
16 \\
44\end{array}$ & $\begin{array}{r}313 \\
466 \\
601 \\
390 \\
168 \\
481 \\
39 \\
645\end{array}$ & $\begin{array}{r}244 \\
346 \\
392 \\
236 \\
119 \\
353 \\
22 \\
424\end{array}$ & $\begin{array}{r}77 \\
149 \\
243 \\
772 \\
61 \\
199 \\
27 \\
265\end{array}$ & $\begin{array}{l}0.50 \\
0.43 \\
0.59 \\
0.36 \\
0.23 \\
0.32 \\
0.09 \\
0.35\end{array}$ & $\begin{array}{l}1.0 \\
1.1 \\
1.5 \\
0.8 \\
0.3 \\
1.2 \\
0.1 \\
2.0\end{array}$ \\
\hline
\end{tabular}


孞

APPENDIX C (continued)

PERSONNEL, DOSE AND POWER GENERATION SUMMARY

\begin{tabular}{|c|c|c|c|c|c|c|c|c|c|c|c|}
\hline \multirow[b]{2}{*}{ Reporting Organization } & \multirow[b]{2}{*}{ Year } & \multirow[b]{2}{*}{$\begin{array}{l}\text { Megenwatt } \\
\text { Years } \\
\text { MiN-YR }\end{array}$} & \multirow[b]{2}{*}{$\begin{array}{l}\text { Unil } \\
\text { Availability } \\
\text { Factor }\end{array}$} & \multirow[b]{2}{*}{$\begin{array}{c}\text { Total Personinel } \\
\text { Wilh Measurable } \\
\text { Doses }\end{array}$} & \multicolumn{5}{|c|}{ Person-cSv (-rems) } & \multirow[b]{2}{*}{$\begin{array}{l}\text { Average } \\
\text { Neasturebli } \\
\text { Dose } \\
\text { (osv or } \\
\text { rems) }\end{array}$} & \multirow[b]{2}{*}{$\begin{array}{c}\text { Person } \\
\text { csisy } \\
\text { (-rems }) \\
\text { Wh'tyt }\end{array}$} \\
\hline & & & & & $\begin{array}{c}\text { Collecthe } \\
\text { Dose }\end{array}$ & $\begin{array}{c}\text { Opera- } \\
\text { tors }\end{array}$ & $\begin{array}{l}\text { todion } \\
\text { Maink } \\
\text { Obers }\end{array}$ & $\begin{array}{c}\text { Con- } \\
\text { tractor }\end{array}$ & $\begin{array}{c}\text { Station } 8 \\
\text { Unlity }\end{array}$ & & \\
\hline CRYSTAL RTVER 3 (continued) & $\begin{array}{l}1968 \\
1967 \\
1988 \\
1999 \\
1990 \\
1991 \\
1992 \\
1993 \\
1994 \\
1995\end{array}$ & $\begin{array}{l}319.5 \\
435.0 \\
690.2 \\
352.6 \\
497.8 \\
654.6 \\
632.1 \\
722.4 \\
711.9 \\
650.0\end{array}$ & $\begin{array}{r}41.8 \\
60.9 \\
84.0 \\
48.6 \\
63.8 \\
62.0 \\
75.1 \\
65.0 \\
84.3 \\
100.0\end{array}$ & $\begin{array}{r}1,057 \\
1,384 \\
569 \\
980 \\
1,441 \\
1,401 \\
1,403 \\
683 \\
1,079 \\
209\end{array}$ & $\begin{array}{r}472 \\
498 \\
64 \\
234 \\
476 \\
716 \\
424 \\
60 \\
228 \\
6\end{array}$ & $\begin{array}{r}26 \\
49 \\
2 \\
5 \\
8 \\
8 \\
7 \\
4 \\
7 \\
1\end{array}$ & $\begin{array}{r}447 \\
439 \\
62 \\
229 \\
468 \\
904 \\
417 \\
56 \\
221 \\
7\end{array}$ & $\begin{array}{r}298 \\
302 \\
17 \\
128 \\
318 \\
59 \\
333 \\
31 \\
156 \\
1\end{array}$ & $\begin{array}{r}174 \\
106 \\
47 \\
106 \\
158 \\
57 \\
91 \\
29 \\
72 \\
7\end{array}$ & $\begin{array}{l}0.45 \\
0.35 \\
0.11 \\
0.27 \\
0.33 \\
0.14 \\
0.30 \\
0.09 \\
0.21 \\
0.04\end{array}$ & $\begin{array}{l}1.5 \\
1.1 \\
0.1 \\
0.7 \\
1.0 \\
0.2 \\
0.7 \\
0.1 \\
0.3 \\
0.0\end{array}$ \\
\hline 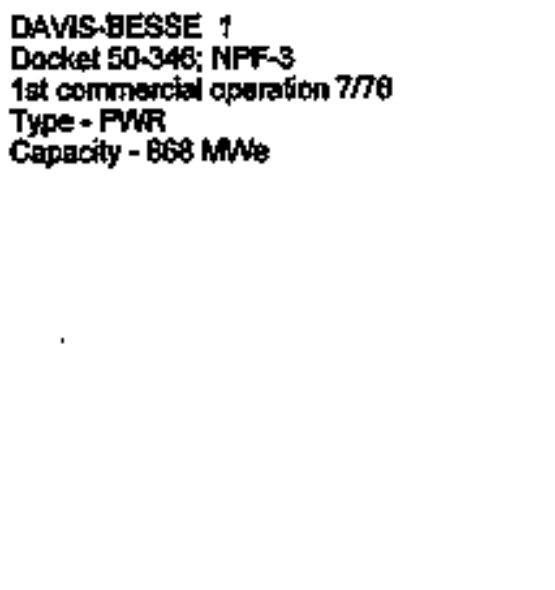 & $\begin{array}{l}1979 \\
1979 \\
1980 \\
1991 \\
1998 \\
1963 \\
1964 \\
1965 \\
1968 \\
1987 \\
1968 \\
1989 \\
1990 \\
1991 \\
1998 \\
1993 \\
1994 \\
1995\end{array}$ & $\begin{array}{r}326.4 \\
381.0 \\
256.4 \\
531.4 \\
390.8 \\
592.1 \\
518.5 \\
238.3 \\
3.3 \\
618.0 \\
744.1 \\
680.0 \\
500.0 \\
703.6 \\
915.2 \\
729.5 \\
768.4 \\
920.4\end{array}$ & $\begin{array}{r}48.7 \\
67.0 \\
36.2 \\
67.4 \\
51.5 \\
73.0 \\
52.5 \\
34.2 \\
1.3 \\
89.0 \\
27.1 \\
99.0 \\
56.7 \\
64.8 \\
100.0 \\
63.4 \\
88.0 \\
100.0\end{array}$ & $\begin{array}{r}421 \\
304 \\
1,285 \\
578 \\
1,350 \\
718 \\
1,006 \\
718 \\
991 \\
625 \\
1,183 \\
1,304 \\
1,377 \\
1,000 \\
1,287 \\
1,244 \\
851 \\
256\end{array}$ & $\begin{array}{r}48 \\
30 \\
154 \\
58 \\
164 \\
46 \\
177 \\
71 \\
124 \\
47 \\
307 \\
39 \\
489 \\
216 \\
79 \\
349 \\
144 \\
7\end{array}$ & $\begin{array}{r}13 \\
6 \\
4 \\
1 \\
12 \\
6 \\
10 \\
5 \\
22 \\
11 \\
36 \\
5 \\
54 \\
38 \\
10 \\
12 \\
28 \\
2\end{array}$ & $\begin{array}{r}35 \\
22 \\
150 \\
57 \\
152 \\
74 \\
167 \\
66 \\
102 \\
36 \\
271 \\
33 \\
475 \\
176 \\
9 \\
336 \\
116 \\
5\end{array}$ & $\begin{array}{r}14 \\
5 \\
121 \\
32 \\
139 \\
46 \\
122 \\
44 \\
105 \\
27 \\
255 \\
5 \\
414 \\
169 \\
0 \\
209 \\
69 \\
0\end{array}$ & $\begin{array}{l}34 \\
26 \\
33 \\
26 \\
25 \\
34 \\
55 \\
27 \\
21 \\
20 \\
52 \\
33 \\
75 \\
57 \\
19 \\
79 \\
75 \\
7\end{array}$ & $\begin{array}{l}0.11 \\
0.10 \\
0.12 \\
0.10 \\
0.12 \\
0.11 \\
0.16 \\
0.10 \\
0.13 \\
0.09 \\
0.26 \\
0.09 \\
0.38 \\
0.22 \\
0.07 \\
0.28 \\
0.17 \\
.03\end{array}$ & $\begin{array}{l}0.1 \\
0.1 \\
0.5 \\
0.1 \\
0.4 \\
0.1 \\
0.3 \\
0.3 \\
37.6 \\
0.1 \\
2.1 \\
0.0 \\
1.0 \\
0.3 \\
0.0 \\
0.5 \\
0.2 \\
0.0\end{array}$ \\
\hline 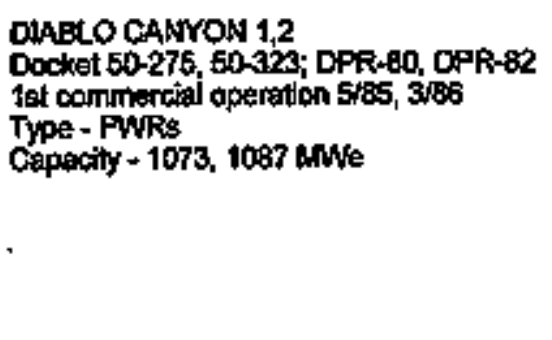 & $\begin{array}{l}1996 \\
1987 \\
1988 \\
1989 \\
1990 \\
1994 \\
1992 \\
1993 \\
1994 \\
1995\end{array}$ & $\begin{array}{r}641.5 \\
1,689.6 \\
1,386.1 \\
1,899.0 \\
1,962.6 \\
1,609.6 \\
1,905.7 \\
2,008.6 \\
1,032.6 \\
4,950.3\end{array}$ & $\begin{array}{l}80.6 \\
83.0 \\
67.6 \\
87.5 \\
91.0 \\
63.8 \\
90.9 \\
91.4 \\
83.3 \\
90.0\end{array}$ & $\begin{array}{l}1,260 \\
1,170 \\
1,0 \% 5 \\
1,640 \\
1,441 \\
2,040 \\
1,850 \\
1,608 \\
2,317 \\
1,615\end{array}$ & $\begin{array}{l}304 \\
395 \\
877 \\
465 \\
323 \\
546 \\
459 \\
281 \\
590 \\
283\end{array}$ & $\begin{array}{l}4 \\
5 \\
4 \\
3 \\
1 \\
1 \\
0 \\
0 \\
1 \\
2\end{array}$ & $\begin{array}{l}300 \\
331 \\
873 \\
462 \\
322 \\
545 \\
459 \\
281 \\
589 \\
284\end{array}$ & $\begin{array}{l}206 \\
226 \\
599 \\
329 \\
220 \\
377 \\
300 \\
182 \\
399 \\
189\end{array}$ & $\begin{array}{r}99 \\
110 \\
284 \\
130 \\
103 \\
169 \\
156 \\
99 \\
191 \\
97\end{array}$ & $\begin{array}{l}0.24 \\
0.29 \\
0.49 \\
0.28 \\
0.22 \\
0.27 \\
0.25 \\
0.19 \\
0.26 \\
0.18\end{array}$ & $\begin{array}{l}0.5 \\
0.2 \\
0.6 \\
0.2 \\
0.2 \\
0.3 \\
0.2 \\
0.1 \\
0.3 \\
0.1\end{array}$ \\
\hline
\end{tabular}




\begin{tabular}{|c|c|c|c|c|c|c|c|c|c|c|c|}
\hline \multirow[b]{2}{*}{ Reporting Orgar'zation } & \multirow[b]{2}{*}{ Yeer } & \multirow[b]{2}{*}{$\begin{array}{l}\text { Meganalt } \\
\text { Yeans } \\
\text { MNAYR }\end{array}$} & \multirow[b]{2}{*}{$\begin{array}{l}\text { Unit } \\
\text { Avaliablity } \\
\text { Eachor }\end{array}$} & \multirow[b]{2}{*}{$\begin{array}{c}\text { Total Personnel } \\
\text { With Meastirible } \\
\text { Doses }\end{array}$} & \multicolumn{5}{|c|}{ Person-cSv (trems) } & \multirow[b]{2}{*}{$\begin{array}{l}\text { Awarage } \\
\text { Adeasurable } \\
\text { bose } \\
\text { (osvor } \\
\text { refos) }\end{array}$} & \multirow[b]{2}{*}{$\begin{array}{c}\text { Person } \\
\text { cSN } \\
\text { (rrems) } \\
\text { NiN-yr }\end{array}$} \\
\hline & & & & & $\begin{array}{c}\text { Collective } \\
\text { Dose }\end{array}$ & $\begin{array}{c}\text { Qpera- } \\
\text { tons }\end{array}$ & $\begin{array}{l}\text { Monction } \\
\text { Otherg } \\
\text { Other }\end{array}$ & $\begin{array}{l}\text { Rer Perso } \\
\text { Con- } \\
\text { tractor }\end{array}$ & $\begin{array}{c}\text { Station } \\
\text { Utily }\end{array}$ & & \\
\hline 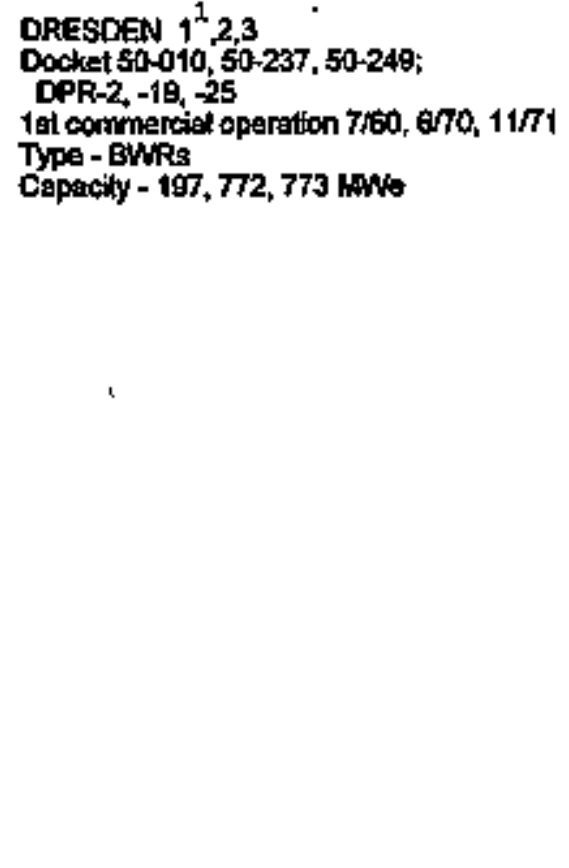 & $\begin{array}{l}1969 \\
1970 \\
1971 \\
1972 \\
1973 \\
1974 \\
1975 \\
1976 \\
1977 \\
1978 \\
1979 \\
1980 \\
1981 \\
1982 \\
1983 \\
1984 \\
1985 \\
1985 \\
1997 \\
1989 \\
1999 \\
1990 \\
1991 \\
1992 \\
1993 \\
1994 \\
1995\end{array}$ & $\begin{array}{r}99.7 \\
163.1 \\
394.5 \\
1,243.7 \\
1,112.2 \\
842.5 \\
700.1 \\
1,127.2 \\
1,132.4 \\
1,248.2 \\
1,013.0 \\
1,074.4 \\
1,035.7 \\
1,085.3 \\
913.6 \\
799.8 \\
909.4 \\
740.5 \\
933.9 \\
1,014.7 \\
1,184.2 \\
1,107.8 \\
675.2 \\
972.4 \\
960.1 \\
690.2 \\
643.1\end{array}$ & $\begin{array}{l}64.9 \\
54.6 \\
60.8 \\
77.0 \\
79.5 \\
74.7 \\
55.0 \\
51.5 \\
77.9 \\
65.6 \\
55.3 \\
64.5 \\
52.6 \\
74.0 \\
75.8 \\
83.1 \\
76.6 \\
60.7 \\
75.4 \\
66.5 \\
51.7 \\
49.6\end{array}$ & $\begin{array}{l}1,341 \\
1,594 \\
2,340 \\
1,746 \\
1,662 \\
1,946 \\
2,407 \\
2,717 \\
2,331 \\
2,572 \\
2,854 \\
2,251 \\
2,817 \\
3,111 \\
2,052 \\
2,414 \\
2,259 \\
2,235 \\
2,044 \\
t, 812 \\
2,751 \\
2,336 \\
2,482\end{array}$ & $\begin{array}{r}286 \\
143 \\
715 \\
728 \\
939 \\
1,662 \\
3,423 \\
1,680 \\
1,694 \\
1,529 \\
1,600 \\
2,105 \\
2,602 \\
2,923 \\
3,582 \\
1,774 \\
1,686 \\
2,686 \\
1,145 \\
1,409 \\
1,131 \\
1,400 \\
1,005 \\
619 \\
1,655 \\
833 \\
875\end{array}$ & $\begin{array}{r}149 \\
271 \\
271 \\
398 \\
359 \\
191 \\
236 \\
120 \\
136 \\
176 \\
153 \\
474 \\
268 \\
241 \\
215 \\
154 \\
176 \\
166 \\
128 \\
125 \\
93 \\
69\end{array}$ & $\begin{array}{r}790 \\
3,188 \\
1,452 \\
1,377 \\
1,170 \\
1,609 \\
1,869 \\
2,682 \\
2,767 \\
3,406 \\
1,621 \\
1,212 \\
2,400 \\
1,194 \\
1,976 \\
1,224 \\
859 \\
491 \\
1,530 \\
740 \\
606\end{array}$ & $\begin{array}{r}344 \\
57 \\
2,252 \\
749 \\
693 \\
619 \\
641 \\
1,093 \\
1,600 \\
1,731 \\
2,127 \\
815 \\
679 \\
2,009 \\
599 \\
6009 \\
641 \\
753 \\
433 \\
272 \\
1,116 \\
517 \\
2\end{array}$ & $\begin{array}{r}595 \\
1,606 \\
1,171 \\
931 \\
1,000 \\
1,529 \\
1,159 \\
1,092 \\
952 \\
1,192 \\
1,456 \\
959 \\
807 \\
659 \\
552 \\
604 \\
489 \\
647 \\
572 \\
347 \\
539 \\
316 \\
873\end{array}$ & $\begin{array}{l}0.70 \\
1.04 \\
1.48 \\
0.98 \\
0.91 \\
0.79 \\
0.75 \\
0.77 \\
1.20 \\
1.14 \\
1.26 \\
0.79 \\
0.60 \\
0.86 \\
0.56 \\
0.56 \\
0.50 \\
0.63 \\
0.49 \\
0.34 \\
0.60 \\
0.36 \\
0.35\end{array}$ & $\begin{array}{l}2.9 \\
0.9 \\
1.8 \\
0.6 \\
0.8 \\
2.0 \\
4.8 \\
1.5 \\
1.6 \\
1.2 \\
1.8 \\
2.0 \\
2.7 \\
2.7 \\
3.9 \\
2.2 \\
1.9 \\
3.6 \\
1.2 \\
1.4 \\
1.0 \\
1.3 \\
1.5 \\
0.7 \\
1.7 \\
1.2 \\
1.4\end{array}$ \\
\hline $\begin{array}{l}\text { DLANE ARNOLD } \\
\text { Docitet 60-331; DPR-49 } \\
\text { 1st commercial operation } 275 \\
\text { Type - BWR } \\
\text { Capacity - } 515 \text { MNW }\end{array}$ & $\begin{array}{l}1976 \\
1977 \\
1978 \\
1979 \\
1990 \\
1981 \\
1982 \\
1983 \\
1984 \\
1985\end{array}$ & $\begin{array}{l}305.2 \\
353.8 \\
149.2 \\
358.0 \\
339.1 \\
277.7 \\
278.5 \\
283.0 \\
329.4 \\
236.2\end{array}$ & $\begin{array}{l}78.0 \\
78.9 \\
33.2 \\
78.0 \\
73.3 \\
69.8 \\
74.7 \\
62.9 \\
72.9 \\
53.8\end{array}$ & $\begin{array}{r}350 \\
538 \\
1,112 \\
757 \\
1,100 \\
1,286 \\
624 \\
1,496 \\
611 \\
1,414\end{array}$ & $\begin{array}{r}105 \\
299 \\
974 \\
275 \\
671 \\
790 \\
229 \\
1,135 \\
189 \\
1,112\end{array}$ & $\begin{array}{l}14 \\
36 \\
59 \\
35 \\
32 \\
58 \\
18 \\
42 \\
28 \\
49\end{array}$ & $\begin{array}{r}91 \\
263 \\
915 \\
240 \\
634 \\
734 \\
211 \\
1,093 \\
161 \\
1,063\end{array}$ & $\begin{array}{r}62 \\
220 \\
932 \\
219 \\
570 \\
598 \\
175 \\
1,016 \\
117 \\
954\end{array}$ & $\begin{array}{r}43 \\
79 \\
42 \\
56 \\
1101 \\
192 \\
54 \\
119 \\
72 \\
158\end{array}$ & $\begin{array}{l}0.30 \\
0.56 \\
0.89 \\
0.36 \\
0.61 \\
0.61 \\
0.44 \\
0.77 \\
0.31 \\
0.79\end{array}$ & $\begin{array}{l}0.3 \\
0.8 \\
6.5 \\
0.8 \\
2.0 \\
2.8 \\
0.8 \\
4.0 \\
0.6 \\
4.7\end{array}$ \\
\hline
\end{tabular}

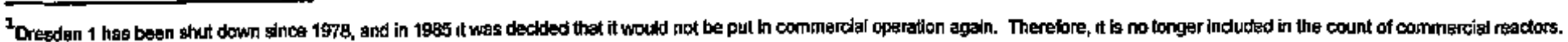




\begin{tabular}{|c|c|c|c|c|c|c|c|c|c|c|c|}
\hline \multirow{4}{*}{ 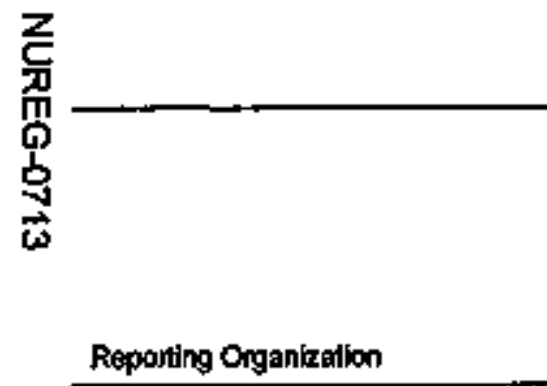 } & \multirow[b]{4}{*}{ Year } & \multirow{4}{*}{$\begin{array}{c}\text { PERSO| } \\
\\
\text { Meggarall } \\
\text { Yeare } \\
\text { MNW-YR }\end{array}$} & \multirow[b]{4}{*}{$\begin{array}{l}\text { Unit } \\
\text { Availebility } \\
\text { Factor }\end{array}$} & \multirow[b]{4}{*}{$\begin{array}{c}\text { Tolal Perschinel } \\
\text { With Measurabte } \\
\text { Dosses }\end{array}$} & \multirow{2}{*}{\multicolumn{5}{|c|}{ Person-cSv (-nems) }} & \multirow{4}{*}{$\begin{array}{l}\text { Average } \\
\text { Magsultale } \\
\text { Dose } \\
\text { (cSy or } \\
\text { rems) }\end{array}$} & \multirow[b]{4}{*}{$\begin{array}{c}\text { Person } \\
\text { OSv } \\
\text { (-vems) } \\
\text { WWN-yr }\end{array}$} \\
\hline & & & & & & & & & & & \\
\hline & & & & & \multirow[b]{2}{*}{$\begin{array}{l}\text { Collective } \\
\text { Doses }\end{array}$} & \multicolumn{2}{|c|}{ Per Wiak Functlon } & \multicolumn{2}{|c|}{ Per Personingl Tye } & & \\
\hline & & & & & & $\begin{array}{c}\text { Opere- } \\
\text { tions }\end{array}$ & $\begin{array}{c}\text { Meint } \\
\text { Others } \\
\text { Other }\end{array}$ & $\begin{array}{c}\text { Con- } \\
\text { Iractor }\end{array}$ & $\begin{array}{c}\text { Station E } \\
\text { Utility }\end{array}$ & & \\
\hline DUANE ARNOLO (cominued) & $\begin{array}{l}1988 \\
1987 \\
1980 \\
1989 \\
1990 \\
1991 \\
1992 \\
1993 \\
1984 \\
1995\end{array}$ & $\begin{array}{l}385.5 \\
308.4 \\
386.5 \\
388.5 \\
367.4 \\
503.7 \\
416.5 \\
393.4 \\
498.6 \\
452.5\end{array}$ & $\begin{array}{l}82.0 \\
64.7 \\
75.2 \\
79.0 \\
75.8 \\
94.5 \\
81.9 \\
79.5 \\
94.0 \\
83.8\end{array}$ & $\begin{array}{r}476 \\
1,094 \\
1,136 \\
426 \\
1,460 \\
338 \\
1,043 \\
1,043 \\
493 \\
1,129\end{array}$ & $\begin{array}{l}197 \\
697 \\
614 \\
194 \\
861 \\
201 \\
602 \\
407 \\
120 \\
367\end{array}$ & $\begin{array}{r}49 \\
241 \\
71 \\
49 \\
126 \\
34 \\
123 \\
86 \\
14 \\
39\end{array}$ & $\begin{array}{l}138 \\
426 \\
543 \\
145 \\
735 \\
168 \\
378 \\
321 \\
106 \\
318\end{array}$ & $\begin{array}{r}94 \\
478 \\
416 \\
58 \\
644 \\
43 \\
276 \\
299 \\
24 \\
217\end{array}$ & $\begin{array}{r}98 \\
189 \\
198 \\
196 \\
217 \\
159 \\
226 \\
106 \\
98 \\
140\end{array}$ & $\begin{array}{l}0.39 \\
0.61 \\
0.54 \\
0.45 \\
0.59 \\
0.60 \\
0.48 \\
0.39 \\
0.24 \\
0.32\end{array}$ & $\begin{array}{l}0.5 \\
2.2 \\
1.6 \\
0.5 \\
2.3 \\
0.4 \\
1.2 \\
1.0 \\
0.2 \\
0.8\end{array}$ \\
\hline 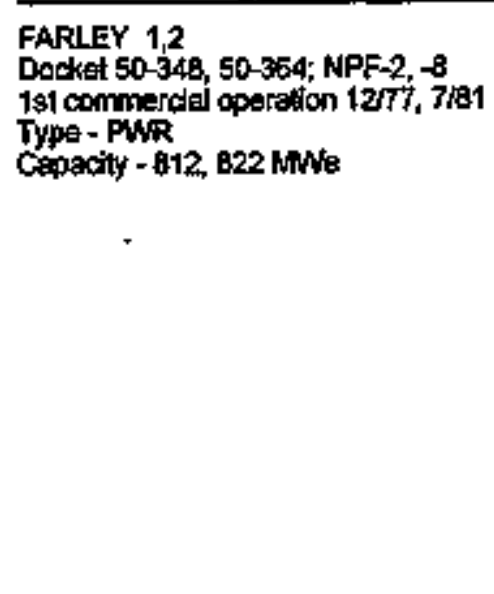 & $\begin{array}{l}1978 \\
1979 \\
1980 \\
1991 \\
1998 \\
1993 \\
1994 \\
1995 \\
1996 \\
1997 \\
1998 \\
1999 \\
1900 \\
1991 \\
1992 \\
1993 \\
1994 \\
1995\end{array}$ & $\begin{array}{r}713.8 \\
211.0 \\
557.3 \\
310.2 \\
1,271.5 \\
1,353.5 \\
1,447.0 \\
1,368.2 \\
1,409.4 \\
1,368.7 \\
1,567.7 \\
1,402.9 \\
1,464.0 \\
1,464.0 \\
1,331.7 \\
1,455.5 \\
1,587.2 \\
1,311.2\end{array}$ & $\begin{array}{l}86.5 \\
28.6 \\
69.3 \\
41.4 \\
79.2 \\
83.0 \\
86.0 \\
81.1 \\
89.8 \\
84.7 \\
98.3 \\
84.6 \\
86.7 \\
88.1 \\
81.8 \\
88.3 \\
93.5 \\
83.8\end{array}$ & $\begin{array}{r}527 \\
1,227 \\
1,330 \\
1,331 \\
1,453 \\
1,938 \\
2,046 \\
2,551 \\
2,314 \\
1,871 \\
1,840 \\
2,206 \\
1,700 \\
1,645 \\
2,048 \\
1,284 \\
1,035 \\
1,574\end{array}$ & $\begin{array}{r}108 \\
643 \\
435 \\
512 \\
4184 \\
1,021 \\
902 \\
799 \\
858 \\
598 \\
552 \\
749 \\
457 \\
648 \\
805 \\
333 \\
250 \\
460\end{array}$ & $\begin{array}{r}39 \\
108 \\
106 \\
96 \\
155 \\
241 \\
179 \\
158 \\
148 \\
105 \\
74 \\
89 \\
47 \\
106 \\
121 \\
22 \\
29 \\
60\end{array}$ & $\begin{array}{r}69 \\
535 \\
329 \\
416 \\
329 \\
780 \\
724 \\
641 \\
710 \\
493 \\
478 \\
661 \\
410 \\
542 \\
684 \\
311 \\
221 \\
400\end{array}$ & $\begin{array}{r}34 \\
460 \\
165 \\
270 \\
196 \\
479 \\
505 \\
442 \\
454 \\
347 \\
340 \\
516 \\
342 \\
498 \\
570 \\
224 \\
150 \\
307\end{array}$ & $\begin{array}{r}74 \\
183 \\
250 \\
242 \\
268 \\
542 \\
397 \\
357 \\
394 \\
251 \\
212 \\
233 \\
115 \\
150 \\
235 \\
109 \\
100 \\
553\end{array}$ & $\begin{array}{l}0.20 \\
0.52 \\
0.39 \\
0.38 \\
0.33 \\
0.53 \\
0.44 \\
0.31 \\
0.37 \\
0.32 \\
0.340 \\
0.34 \\
0.27 \\
0.39 \\
0.40 \\
0.26 \\
0.24 \\
0.29\end{array}$ & $\begin{array}{l}0.2 \\
3.0 \\
0.8 \\
1.7 \\
0.4 \\
0.8 \\
0.6 \\
0.6 \\
0.6 \\
0.4 \\
0.4 \\
0.5 \\
0.3 \\
0.4 \\
0.6 \\
0.2 \\
0.2 \\
0.4\end{array}$ \\
\hline 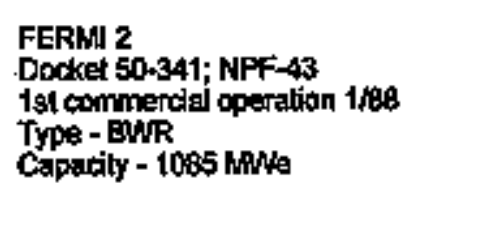 & $\begin{array}{l}1989 \\
1990 \\
1991 \\
1992 \\
1993 \\
1994 \\
1905\end{array}$ & $\begin{array}{r}624.0 \\
848.2 \\
739.0 \\
874.3 \\
984.3 \\
0.0 \\
618.3\end{array}$ & $\begin{array}{r}68.5 \\
84.7 \\
77.0 \\
81.3 \\
92.9 \\
2.2 \\
80.9\end{array}$ & $\begin{array}{r}1,270 \\
462 \\
1,223 \\
1,213 \\
360 \\
1,130 \\
390\end{array}$ & $\begin{array}{r}255 \\
83 \\
228 \\
245 \\
35 \\
213 \\
28\end{array}$ & $\begin{array}{l}35 \\
34 \\
53 \\
60 \\
23 \\
58 \\
21\end{array}$ & $\begin{array}{r}220 \\
52 \\
175 \\
195 \\
12 \\
145 \\
7\end{array}$ & $\begin{array}{r}182 \\
14 \\
151 \\
151 \\
7 \\
159 \\
10\end{array}$ & $\begin{array}{l}73 \\
69 \\
77 \\
94 \\
28 \\
60 \\
18\end{array}$ & $\begin{array}{l}0.20 \\
0.18 \\
0.19 \\
0.20 \\
0.10 \\
0.19 \\
0.07\end{array}$ & $\begin{array}{l}0.4 \\
0.1 \\
0.3 \\
0.3 \\
0.0 \\
0.0\end{array}$ \\
\hline
\end{tabular}


APPENDDX C (continued)

PERSONNEL, DOSE AND POWER GENERATION SUMMARY

\begin{tabular}{|c|c|c|c|c|c|c|c|c|c|c|c|}
\hline \multirow[b]{2}{*}{ Reporting Organtzalion } & \multirow[b]{2}{*}{ Year } & \multirow[b]{2}{*}{$\begin{array}{l}\text { Mogganalt } \\
\text { Years } \\
\text { Mherk }\end{array}$} & \multirow[b]{2}{*}{$\begin{array}{l}\text { Unit } \\
\text { Avaliablity } \\
\text { Fantor }\end{array}$} & \multirow[b]{2}{*}{$\begin{array}{c}\text { Total Personnel } \\
\text { Wth Megsurable } \\
\text { Doses }\end{array}$} & \multicolumn{5}{|c|}{ Person-asv (-1ems) } & \multirow[b]{2}{*}{$\begin{array}{l}\text { Average } \\
\text { Mtequsurabla } \\
\text { Dose } \\
\text { (CSv tr } \\
\text { rems) }\end{array}$} & \multirow[b]{2}{*}{$\begin{array}{l}\text { Persont } \\
\text { cSv } \\
\text { (-rems) } \\
\text { Mint-yt }\end{array}$} \\
\hline & & & & & $\begin{array}{c}\text { Collecthe } \\
\text { Dose }\end{array}$ & $\begin{array}{l}\text { Peryor: } \\
\text { Opers- } \\
\text { tons }\end{array}$ & $\begin{array}{l}\text { unction } \\
\text { Mzint } \\
8 \\
\text { Others }\end{array}$ & $\begin{array}{l}\text { Be:Pers: } \\
\text { Con- } \\
\text { trator }\end{array}$ & $\begin{array}{c}\text { Station \& } \\
\text { UL'lly }\end{array}$ & & \\
\hline $\begin{array}{l}\text { FITPATRICK } \\
\text { Docket } 50-333 \text {; DPR-59 } \\
\text { 1st commercial operation } 7 / 75 \\
\text { Typh - BdVR } \\
\text { Capacity - } 774 \text { hive }\end{array}$ & $\begin{array}{l}1976 \\
1977 \\
1978 \\
1979 \\
1980 \\
1981 \\
1982 \\
1983 \\
1984 \\
1985 \\
1990 \\
1997 \\
1998 \\
1999 \\
1990 \\
1991 \\
1992 \\
1993 \\
1994 \\
1995\end{array}$ & $\begin{array}{l}469.0 \\
460.5 \\
497.0 \\
349.0 \\
509.5 \\
562.9 \\
583.6 \\
540.2 \\
576.2 \\
492.3 \\
711.2 \\
496.2 \\
514.0 \\
727.5 \\
543.0 \\
599.7 \\
0.0 \\
569.6 \\
688.4 \\
569.8\end{array}$ & $\begin{array}{l}71.6 \\
6.6 .4 \\
721 \\
50.8 \\
70.3 \\
74.7 \\
75 . \mathrm{J} \\
70.6 \\
76.8 \\
63.7 \\
90.6 \\
70.3 \\
69.0 \\
92.3 \\
72.6 \\
53.4 \\
0.0 \\
81.7 \\
63.2 \\
74.5\end{array}$ & $\begin{array}{r}600 \\
1,390 \\
904 \\
650 \\
2,056 \\
2,490 \\
2,322 \\
1,715 \\
1,810 \\
1,645 \\
1,185 \\
1,578 \\
1,553 \\
1,027 \\
1,536 \\
1,269 \\
2,374 \\
1,427 \\
1,595 \\
1,249\end{array}$ & $\begin{array}{r}202 \\
1,060 \\
909 \\
859 \\
2,040 \\
1,425 \\
1,190 \\
1,090 \\
971 \\
1,051 \\
411 \\
940 \\
760 \\
377 \\
864 \\
333 \\
674 \\
232 \\
322 \\
327\end{array}$ & $\begin{array}{r}14 \\
166 \\
169 \\
118 \\
197 \\
136 \\
158 \\
82 \\
85 \\
81 . \\
164 \\
162 \\
58 \\
92 \\
48 \\
70 \\
33 \\
276 \\
292\end{array}$ & $\begin{array}{r}1,065 \\
743 \\
690 \\
1,922 \\
1,239 \\
1,054 \\
932 \\
889 \\
986 \\
330 \\
776 \\
624 \\
319 \\
792 \\
285 \\
604 \\
199 \\
45 \\
35\end{array}$ & $\begin{array}{r}937 \\
597 \\
539 \\
1,809 \\
1,072 \\
863 \\
567 \\
467 \\
718 \\
168 \\
616 \\
506 \\
194 \\
557 \\
127 \\
476 \\
81 \\
141 \\
151\end{array}$ & $\begin{array}{l}143 \\
312 \\
321 \\
232 \\
353 \\
327 \\
423 \\
504 \\
330 \\
243 \\
304 \\
280 \\
186 \\
327 \\
208 \\
199 \\
151 \\
181 \\
176\end{array}$ & $\begin{array}{l}0.34 \\
0.78 \\
1.01 \\
1.01 \\
0.99 \\
0.57 \\
0.51 \\
0.64 \\
0.60 \\
0.57 \\
0.35 \\
0.60 \\
0.51 \\
0.37 \\
0.58 \\
0.26 \\
0.28 \\
0.16 \\
0.20 \\
0.26\end{array}$ & $\begin{array}{l}0.4 \\
2.3 \\
1.8 \\
2.5 \\
4.0 \\
2.5 \\
2.0 \\
2.0 \\
1.7 \\
2.1 \\
0.6 \\
1.9 \\
1.5 \\
0.5 \\
1.5 \\
0.8 \\
0.4 \\
0.4 \\
0.5 \\
0.6\end{array}$ \\
\hline 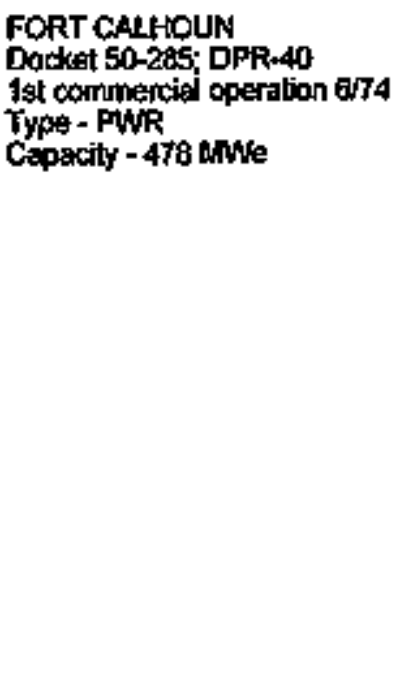 & $\begin{array}{c}1976 \\
1976 \\
1977 \\
1978 \\
1979 \\
1989 \\
1981 \\
1982 \\
1989 \\
1994 \\
1989 \\
1994 \\
1987 \\
1988 \\
1989 \\
1990 \\
1991 \\
1992 \\
1993 \\
1994 \\
1995\end{array}$ & $\begin{array}{l}252.3 \\
265.9 \\
351.8 \\
342.3 \\
440.0 \\
242.3 \\
260.9 \\
419.0 \\
350.4 \\
279.2 \\
367.0 \\
431.8 \\
368.0 \\
315.5 \\
395.7 \\
290.0 \\
391.1 \\
349.4 \\
369.7 \\
492.8 \\
4028\end{array}$ & $\begin{array}{l}67.4 \\
69.5 \\
79.4 \\
7.4 .1 \\
99.7 \\
60.4 \\
72.3 \\
89.7 \\
73.1 \\
59.9 \\
73.7 \\
94.3 \\
76.4 \\
74.1 \\
89.2 \\
64.2 \\
91.7 \\
65.9 \\
80.8 \\
99.6 \\
83.2\end{array}$ & $\begin{array}{r}469 \\
516 \\
535 \\
596 \\
451 \\
891 \\
622 \\
604 \\
6050 \\
913 \\
982 \\
756 \\
1,247 \\
1,594 \\
1,210 \\
760 \\
284 \\
602 \\
713 \\
211 \\
627\end{array}$ & $\begin{array}{r}294 \\
313 \\
297 \\
410 \\
126 \\
889 \\
456 \\
217 \\
433 \\
590 \\
373 \\
74 \\
396 \\
272 \\
93 \\
290 \\
57 \\
272 \\
157 \\
23 \\
139\end{array}$ & $\begin{array}{r}28 \\
35 \\
59 \\
19 \\
38 \\
61 \\
46 \\
66 \\
91 \\
54 \\
26 \\
76 \\
74 \\
31 \\
30 \\
14 \\
59 \\
16 \\
5 \\
16\end{array}$ & $\begin{array}{r}265 \\
284 \\
351 \\
107 \\
630 \\
397 \\
172 \\
367 \\
472 \\
319 \\
46 \\
310 \\
198 \\
56 \\
260 \\
43 \\
213 \\
141 \\
18 \\
123\end{array}$ & $\begin{array}{r}92 \\
38 \\
72 \\
151 \\
47 \\
425 \\
254 \\
102 \\
205 \\
313 \\
231 \\
30 \\
225 \\
173 \\
50 \\
160 \\
25 \\
154 \\
137 \\
6 \\
62\end{array}$ & $\begin{array}{r}202 \\
275 \\
225 \\
259 \\
79 \\
242 \\
204 \\
115 \\
229 \\
250 \\
142 \\
44 \\
162 \\
99 \\
43 \\
130 \\
32 \\
118 \\
70 \\
17 \\
77\end{array}$ & $\begin{array}{l}0.63 \\
0.61 \\
0.56 \\
0.09 \\
0.28 \\
0.75 \\
0.58 \\
0.38 \\
0.50 \\
0.62 \\
0.38 \\
0.10 \\
0.31 \\
0.17 \\
0.08 \\
0.38 \\
0.20 \\
0.34 \\
0.22 \\
0.11 \\
0.22\end{array}$ & $\begin{array}{l}1.2 \\
1.2 \\
0.8 \\
1.2 \\
0.3 \\
2.8 \\
1.8 \\
0.5 \\
1.3 \\
2.0 \\
1.0 \\
0.2 \\
1.1 \\
0.9 \\
0.2 \\
1.0 \\
0.1 \\
0.9 \\
0.4 \\
0.0 \\
0.3\end{array}$ \\
\hline
\end{tabular}




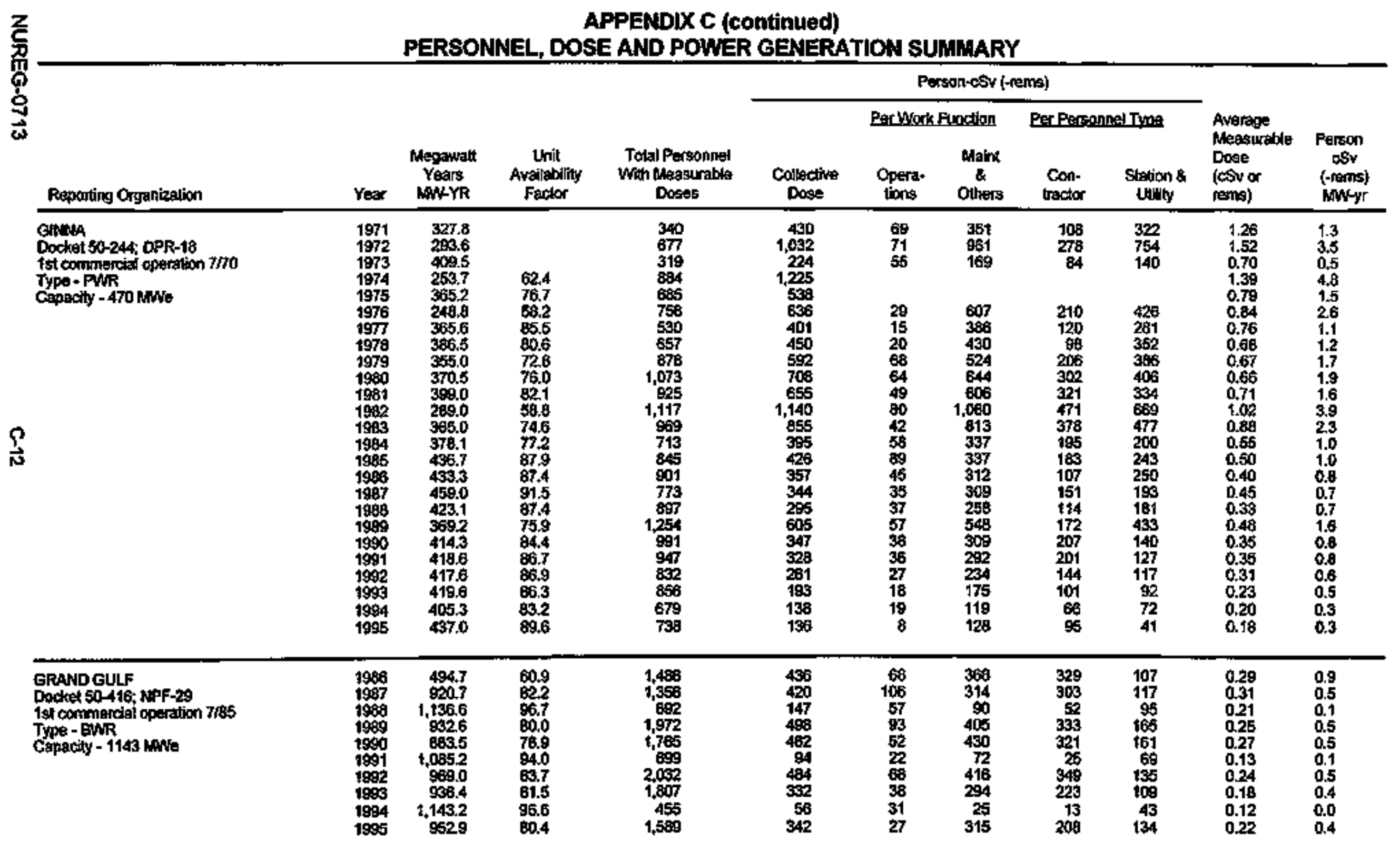


APPENDIX C (continued)

PERSONNEL, DOSE AND POWER GENERATION SUMMARY

\begin{tabular}{|c|c|c|c|c|c|c|c|c|c|c|c|}
\hline \multirow[b]{2}{*}{ Reparting Oryarization } & \multirow[b]{2}{*}{ Year } & \multirow[b]{2}{*}{$\begin{array}{l}\text { Megawat } \\
\text { Years } \\
\text { MM-YR }\end{array}$} & \multirow[b]{2}{*}{$\begin{array}{c}\text { Un'̀ } \\
\text { Availablllty } \\
\text { Factor }\end{array}$} & \multirow[b]{2}{*}{$\begin{array}{c}\text { Total Personnel } \\
\text { With Measurable } \\
\text { Doses }\end{array}$} & \multicolumn{5}{|c|}{ Person-csv (-Rems) } & \multirow[b]{2}{*}{$\begin{array}{l}\text { Average } \\
\text { Messurabie } \\
\text { Dose } \\
\text { (cSivor } \\
\text { rems) }\end{array}$} & \multirow[b]{2}{*}{$\begin{array}{l}\text { Person } \\
\text { CSV } \\
\text { (reqms) } \\
\text { MW-yr }\end{array}$} \\
\hline & & & & & $\begin{array}{c}\text { Collective } \\
\text { Dose }\end{array}$ & $\begin{array}{c}\text { Opers } \\
\text { tions }\end{array}$ & $\begin{array}{c}\text { Manction } \\
\text { Mainl } \\
\text { Others } \\
\end{array}$ & $\begin{array}{l}\operatorname{con} * \\
\text { tractior }\end{array}$ & $\begin{array}{c}\text { STlation } \\
\text { Utility }\end{array}$ & & \\
\hline 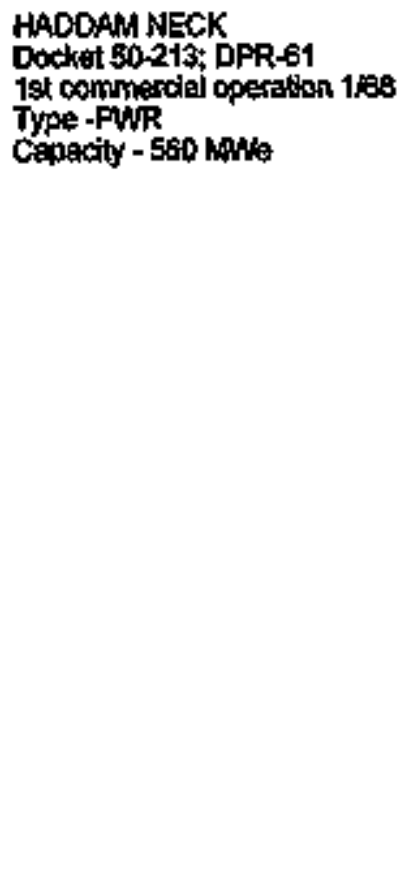 & $\begin{array}{l}1969 \\
1970 \\
1971 \\
1972 \\
1973 \\
1974 \\
1975 \\
1976 \\
1977 \\
1978 \\
1979 \\
1980 \\
1961 \\
1962 \\
1963 \\
1984 \\
1965 \\
1904 \\
1967 \\
1996 \\
1996 \\
19904 \\
1991 \\
1992 \\
1993 \\
1994 \\
1996\end{array}$ & 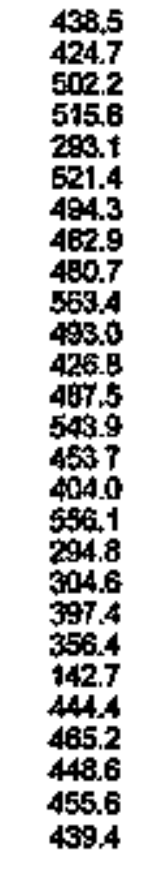 & $\begin{array}{l}91.2 \\
89.8 \\
825 \\
63.9 \\
99.6 \\
97.6 \\
75.0 \\
84.3 \\
93.4 \\
77.8 \\
71.7 \\
99.4 \\
53.6 \\
54.0 \\
70.3 \\
67.2 \\
32.2 \\
76.4 \\
80.1 \\
81.6 \\
77.7 \\
77.7\end{array}$ & $\begin{array}{r}138 \\
734 \\
289 \\
365 \\
951 \\
950 \\
795 \\
644 \\
694 \\
216 \\
1,208 \\
1,660 \\
1,554 \\
1,559 \\
1,445 \\
1,430 \\
1,94 \\
1,945 \\
1,763 \\
1,755 \\
1,456 \\
1,979 \\
1,168 \\
7997 \\
1,094 \\
4693 \\
1,006\end{array}$ & $\begin{array}{r}106 \\
689 \\
342 \\
325 \\
325 \\
697 \\
201 \\
703 \\
449 \\
641 \\
117 \\
1,162 \\
1,353 \\
1,036 \\
126 \\
1,384 \\
1,216 \\
101 \\
1,567 \\
750 \\
237 \\
696 \\
421 \\
690 \\
202 \\
406 \\
136 \\
442\end{array}$ & $\begin{array}{r}20 \\
5 \\
59 \\
25 \\
74 \\
175 \\
174 \\
46 \\
197 \\
154 \\
21 \\
179 \\
99 \\
43 \\
68 \\
75 \\
80 \\
28 \\
42 \\
0 \\
74\end{array}$ & $\begin{array}{r}683 \\
444 \\
392 \\
98 \\
1,068 \\
1,178 \\
962 \\
60 \\
1,277 \\
1,062 \\
80 \\
1,398 \\
651 \\
194 \\
526 \\
346 \\
510 \\
174 \\
356 \\
0 \\
368\end{array}$ & $\begin{array}{r}27 \\
463 \\
168 \\
134 \\
544 \\
\\
253 \\
440 \\
18 \\
783 \\
1,076 \\
609 \\
22 \\
1,022 \\
803 \\
22 \\
1,274 \\
553 \\
107 \\
472 \\
268 \\
463 \\
129 \\
312 \\
0 \\
348\end{array}$ & $\begin{array}{c}79 \\
226 \\
176 \\
144 \\
153 \\
\\
196 \\
196 \\
99 \\
979 \\
277 \\
227 \\
104 \\
3502 \\
413 \\
79 \\
293 \\
197 \\
130 \\
124 \\
153 \\
127 \\
73 \\
96 \\
0 \\
94\end{array}$ & $\begin{array}{l}0.77 \\
0.94 \\
1.18 \\
0.91 \\
0.73 \\
0.37 \\
0.88 \\
0.70 \\
0.72 \\
0.64 \\
0.95 \\
0.73 \\
0.67 \\
0.23 \\
0.84 \\
0.65 \\
0.28 \\
0.81 \\
0.43 \\
0.32 \\
0.41 \\
0.43 \\
0.54 \\
0.25 \\
0.41 \\
0.29 \\
0.44\end{array}$ & $\begin{array}{l}0.2 \\
1.6 \\
0.7 \\
0.6 \\
2.4 \\
0.4 \\
1.4 \\
0.8 \\
1.3 \\
0.2 \\
2.4 \\
3.2 \\
2.1 \\
0.2 \\
3.1 \\
3.0 \\
0.2 \\
5.3 \\
2.5 \\
0.6 \\
1.7 \\
3.0 \\
1.3 \\
0.4 \\
0.9 \\
0.3 \\
1.0\end{array}$ \\
\hline 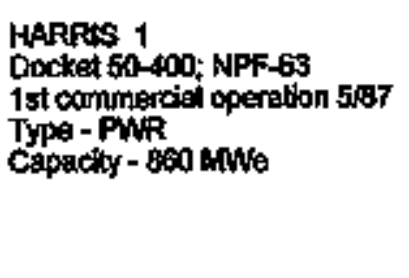 & $\begin{array}{l}1988 \\
1999 \\
1990 \\
1991 \\
1998 \\
1993 \\
1994 \\
1995\end{array}$ & $\begin{array}{l}652.9 \\
690.6 \\
776.4 \\
724.8 \\
661.8 \\
913.0 \\
740.8 \\
731.1\end{array}$ & $\begin{array}{l}75.0 \\
79.5 \\
89.6 \\
61.6 \\
74.9 \\
89.7 \\
82.7 \\
83.6\end{array}$ & $\begin{array}{r}721 \\
929 \\
453 \\
872 \\
930 \\
327 \\
1,089 \\
1,068\end{array}$ & $\begin{array}{l}169 \\
156 \\
85 \\
228 \\
213 \\
31 \\
222 \\
174\end{array}$ & $\begin{array}{r}29 \\
32 \\
13 \\
27 \\
34 \\
9 \\
22 \\
11\end{array}$ & $\begin{array}{r}140 \\
124 \\
72 \\
199 \\
179 \\
20 \\
200 \\
163\end{array}$ & $\begin{array}{r}118 \\
95 \\
97 \\
970 \\
134 \\
10 \\
167 \\
121\end{array}$ & $\begin{array}{l}51 \\
71 \\
38 \\
76 \\
79 \\
21 \\
35 \\
53\end{array}$ & $\begin{array}{l}0.23 \\
0.17 \\
0.19 \\
0.26 \\
0.23 \\
0.09 \\
0.20 \\
0.18\end{array}$ & $\begin{array}{l}0.3 \\
0.2 \\
0.1 \\
0.3 \\
0.3 \\
0.0 \\
0.3 \\
0.2\end{array}$ \\
\hline
\end{tabular}


롱

APPENDIX C (continued)

PERSONNIEL, DOSE AND POWER GENERATION SUMMARY

\begin{tabular}{|c|c|c|c|c|c|c|c|c|c|c|c|}
\hline \multirow[b]{2}{*}{ Reporting Organizalion } & \multirow[b]{2}{*}{ Year } & \multirow[b]{2}{*}{$\begin{array}{c}\text { Meganath } \\
\text { Yoars } \\
\text { MuYYR }\end{array}$} & \multirow[b]{2}{*}{$\begin{array}{l}\text { Unia } \\
\text { Avallabitity } \\
\text { Factor }\end{array}$} & \multirow[b]{2}{*}{$\begin{array}{c}\text { Total fersonned } \\
\text { Whu Heasurable } \\
\text { Doses }\end{array}$} & \multicolumn{5}{|c|}{ Persen-csv (-rens) } & \multirow[b]{2}{*}{$\begin{array}{l}\text { Averiegs } \\
\text { Measirible } \\
\text { Dose } \\
\text { (cSv or } \\
\text { rems) }\end{array}$} & \multirow[b]{2}{*}{$\begin{array}{c}\text { Person } \\
\text { csy } \\
\text { (rems) } \\
\text { AnN-yr }\end{array}$} \\
\hline & & & & & $\begin{array}{l}\text { Collective } \\
\text { Dose }\end{array}$ & $\begin{array}{l}\text { Rerwoik } \\
\text { Opera- } \\
\text { tons }\end{array}$ & $\begin{array}{l}\text { Malntiont } \\
8 \\
\text { Others }\end{array}$ & $\begin{array}{l}\text { Rerperes } \\
\text { Con- } \\
\text { tractor }\end{array}$ & $\begin{array}{c}\text { Sta: } 5 \text { on \& } \\
\text { Utill'y }\end{array}$ & & \\
\hline $\begin{array}{l}\text { HATCH 1,2 } \\
\text { Docket 50-321, 50-366; DPR-57; } \\
\text { PPF_s5 } \\
\text { 1sl commenclat operailon 1275, 9r9 } \\
\text { Type - BWRs } \\
\text { Capactly - 74t, } 765 \text { ante }\end{array}$ & $\begin{array}{l}1976 \\
1977 \\
1978 \\
1979 \\
1990 \\
1891 \\
1982 \\
1993 \\
1984 \\
1985 \\
1986 \\
1987 \\
1988 \\
1989 \\
1904 \\
1991 \\
1992 \\
1997 \\
1994 \\
1995\end{array}$ & $\begin{array}{r}496.3 \\
446.0 \\
513.0 \\
401.0 \\
1,008.7 \\
870.9 \\
768.0 \\
934.7 \\
658.6 \\
1,211.0 \\
1,872.0 \\
1,265.4 \\
1,001.4 \\
1,271.1 \\
1,289.0 \\
1,152.4 \\
1,293.8 \\
1,189.6 \\
1,289.0 \\
1,376.3\end{array}$ & $\begin{array}{l}93.6 \\
60.3 \\
72.8 \\
54.6 \\
70.9 \\
64.3 \\
68.6 \\
68.6 \\
47.3 \\
79.6 \\
64.8 \\
69.7 \\
70.4 \\
87.1 \\
63.5 \\
77.4 \\
88.6 \\
65.5 \\
87.1 \\
60.6\end{array}$ & $\begin{array}{r}1300 \\
1,303 \\
1,304 \\
2,131 \\
1,980 \\
2,999 \\
3,418 \\
3,428 \\
4,110 \\
2,941 \\
3,486 \\
2,202 \\
2,509 \\
1,350 \\
2,902 \\
2,504 \\
1,615 \\
1,733 \\
2,243 \\
1,458\end{array}$ & $\begin{array}{r}134 \\
465 \\
248 \\
582 \\
449 \\
1,337 \\
1,460 \\
1,294 \\
2,248 \\
818 \\
1,497 \\
816 \\
1,401 \\
566 \\
1,455 \\
1,161 \\
550 \\
669 \\
864 \\
488\end{array}$ & $\begin{array}{r}79 \\
96 \\
89 \\
85 \\
143 \\
200 \\
218 \\
253 \\
311 \\
182 \\
347 \\
207 \\
275 \\
154 \\
224 \\
195 \\
119 \\
139 \\
169 \\
85\end{array}$ & $\begin{array}{r}55 \\
349 \\
180 \\
497 \\
306 \\
1,137 \\
1,242 \\
1,040 \\
1,907 \\
646 \\
+, 150 \\
609 \\
1,126 \\
402 \\
1,231 \\
965 \\
431 \\
530 \\
696 \\
400\end{array}$ & $\begin{array}{r}4 \\
220 \\
52 \\
381 \\
153 \\
702 \\
1,034 \\
651 \\
1,861 \\
508 \\
1,107 \\
435 \\
927 \\
305 \\
1,074 \\
799 \\
294 \\
339 \\
659 \\
240\end{array}$ & $\begin{array}{l}130 \\
245 \\
196 \\
201 \\
285 \\
545 \\
306 \\
448 \\
367 \\
310 \\
390 \\
381 \\
474 \\
251 \\
381 \\
365 \\
256 \\
270 \\
305 \\
248\end{array}$ & $\begin{array}{l}0.21 \\
0.36 \\
0.19 \\
0.27 \\
0.23 \\
0.46 \\
0.43 \\
0.38 \\
0.54 \\
0.29 \\
0.43 \\
0.37 \\
0.56 \\
0.41 \\
0.50 \\
0.46 \\
0.34 \\
0.39 \\
0.39 \\
0.33\end{array}$ & $\begin{array}{l}0.3 \\
1.0 \\
0.5 \\
1.5 \\
0.4 \\
t .5 \\
1.9 \\
1.4 \\
3.4 \\
0.7 \\
1.7 \\
0.5 \\
1.4 \\
0.4 \\
1.1 \\
1.0 \\
0.4 \\
0.5 \\
0.7 \\
0.4\end{array}$ \\
\hline $\begin{array}{l}\text { HOPE CREEK } 1 \\
\text { Docket 50-354; NaPF-57 } \\
\text { Ist commencial aperotion } 1286 \\
\text { Type - BWR } \\
\text { Capaciky - } 1001 \text { MNA }\end{array}$ & $\begin{array}{l}1997 \\
1998 \\
1999 \\
1990 \\
1991 \\
1992 \\
1999 \\
1994 \\
1995\end{array}$ & $\begin{array}{r}609.2 \\
832.7 \\
791.1 \\
966.4 \\
892.5 \\
841.9 \\
1,049.2 \\
652.0 \\
844.5\end{array}$ & $\begin{array}{l}86.4 \\
60.7 \\
77.8 \\
91.6 \\
64.2 \\
80.8 \\
97.8 \\
61.2 \\
79.8\end{array}$ & $\begin{array}{r}589 \\
1,734 \\
1,879 \\
1,394 \\
1,700 \\
1,694 \\
689 \\
1,779 \\
1,571\end{array}$ & $\begin{array}{r}117 \\
287 \\
465 \\
195 \\
373 \\
435 \\
98 \\
326 \\
193\end{array}$ & $\begin{array}{r}21 \\
38 \\
40 \\
20 \\
11 \\
9 \\
22 \\
34 \\
27\end{array}$ & $\begin{array}{r}46 \\
249 \\
425 \\
170 \\
362 \\
427 \\
76 . \\
292 \\
169\end{array}$ & $\begin{array}{r}40 \\
163 \\
292 \\
89 \\
249 \\
304 \\
9 \\
194 \\
101\end{array}$ & $\begin{array}{r}77 \\
124 \\
178 \\
107 \\
124 \\
132 \\
90 \\
132 \\
95\end{array}$ & $\begin{array}{l}0.20 \\
0.17 \\
0.25 \\
0.14 \\
0.22 \\
0.26 \\
0.14 \\
0.18 \\
0.12\end{array}$ & $\begin{array}{l}0.1 \\
0.3 \\
0.6 \\
0.2 \\
0.4 \\
0.5 \\
0.1 \\
0.3 \\
0.2\end{array}$ \\
\hline 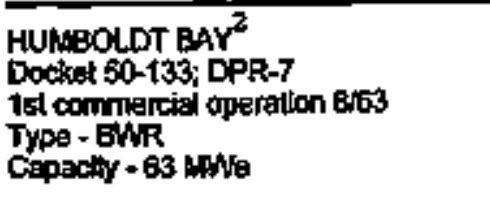 & $\begin{array}{l}1939 \\
1970 \\
1971 \\
1972 \\
1973 \\
1974\end{array}$ & $\begin{array}{l}44.6 \\
49.3 \\
39.6 \\
43.1 \\
50.1 \\
43.4\end{array}$ & 83.8 & $\begin{array}{l}125 \\
115 \\
140 \\
127 \\
210 \\
296\end{array}$ & $\begin{array}{l}164 \\
209 \\
292 \\
253 \\
266 \\
318\end{array}$ & $\begin{array}{r}69 \\
130 \\
114 \\
61 \\
60 \\
103\end{array}$ & $\begin{array}{l}95 \\
79 \\
178 \\
172 \\
208 \\
215\end{array}$ & $\begin{array}{l}12 \\
37 \\
65 \\
67\end{array}$ & $\begin{array}{l}152 \\
172 \\
227 \\
198\end{array}$ & $\begin{array}{l}1.34 \\
1.82 \\
2.09 \\
1.99 \\
1.27 \\
1.07\end{array}$ & $\begin{array}{l}3.7 \\
4.2 \\
7.4 \\
5.2 \\
5.3 \\
7.3\end{array}$ \\
\hline
\end{tabular}

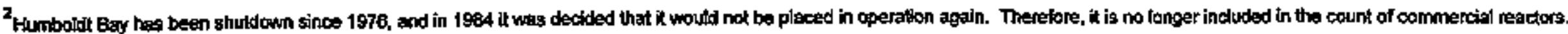




\section{APPENDIX C (continued) \\ PERSONNEL, DOSE AND POWER GENERATION SUMMARY}

\begin{tabular}{|c|c|c|c|c|c|c|c|c|c|c|c|}
\hline \multirow[b]{2}{*}{ Reporting Organkation } & \multirow[b]{2}{*}{ Year } & \multirow[b]{2}{*}{$\begin{array}{l}\text { Meganotit } \\
\text { Years } \\
\text { MN-YR }\end{array}$} & \multirow[b]{2}{*}{$\begin{array}{l}\text { Undt } \\
\text { Avallability } \\
\text { Factor }\end{array}$} & \multirow[b]{2}{*}{$\begin{array}{c}\text { Tobol Personnel } \\
\text { With Measurable } \\
\text { Doses }\end{array}$} & \multicolumn{5}{|c|}{ Parson-csv (-rems) } & \multirow[b]{2}{*}{$\begin{array}{l}\text { Average } \\
\text { Measurable } \\
\text { Doses } \\
\text { (cSv or } \\
\text { retis) }\end{array}$} & \multirow[b]{2}{*}{$\begin{array}{c}\text { Person } \\
\text { cSv } \\
(-r e m s) \\
\text { MHWy }\end{array}$} \\
\hline & & & & & $\begin{array}{l}\text { Collective } \\
\text { Dase }\end{array}$ & $\begin{array}{c}\text { Opere- } \\
\text { tions }\end{array}$ & $\begin{array}{c}\text { Cuprition } \\
\text { Maint } \\
\& \\
\text { Others }\end{array}$ & $\begin{array}{c}\text { Con- } \\
\text { tractor }\end{array}$ & $\begin{array}{l}\text { Station \& } \\
\text { Lutilty }\end{array}$ & & \\
\hline HUMBCLDT BAY ${ }^{3}$ (ContInUed) & $\begin{array}{l}1975 \\
1978 \\
1977 \\
1978 \\
1979 \\
1990 \\
1981 \\
1988 \\
1999 \\
1993 \\
1994 \\
1995\end{array}$ & $\begin{array}{c}45.3 \\
23.5 \\
0.0 \\
0.0 \\
0.0 \\
0.0 \\
0.0 \\
0.0 \\
0.0 \\
0.0 \\
0.0 \\
0.0\end{array}$ & $\begin{array}{l}a 3,9 \\
46.4 \\
0.0 \\
0.0 \\
0.0 \\
0.0 \\
0.0 \\
0.0 \\
0.0 \\
0.0 \\
0.0 \\
0.0\end{array}$ & $\begin{array}{r}265 \\
523 \\
1,083 \\
320 \\
135 \\
142 \\
76 \\
71 \\
84 \\
24 \\
21 \\
42\end{array}$ & $\begin{array}{r}339 \\
683 \\
1,905 \\
335 \\
31 \\
22 \\
9 \\
19 \\
17 \\
1 \\
1 \\
2\end{array}$ & $\begin{array}{r}131 \\
37 \\
24 \\
13 \\
11 \\
10 \\
3 \\
5 \\
4 \\
0 \\
0 \\
4\end{array}$ & $\begin{array}{r}200 \\
646 \\
1,860 \\
322 \\
20 \\
12 \\
5 \\
14 \\
13 \\
0 \\
0 \\
0\end{array}$ & $\begin{array}{r}112 \\
50 \\
973 \\
145 \\
2 \\
3 \\
3 \\
0 \\
0 \\
0 \\
0 \\
0\end{array}$ & $\begin{array}{r}227 \\
633 \\
931 \\
990 \\
29 \\
19 \\
6 \\
19 \\
17 \\
0 \\
0 \\
\ldots\end{array}$ & $\begin{array}{l}1.28 \\
1.31 \\
1.79 \\
1.05 \\
0.23 \\
0.15 \\
0.12 \\
0.77 \\
0.20 \\
0.04 \\
0.05 \\
0.05\end{array}$ & $\begin{array}{r}7.5 \\
= \\
= \\
= \\
= \\
= \\
=\end{array}$ \\
\hline 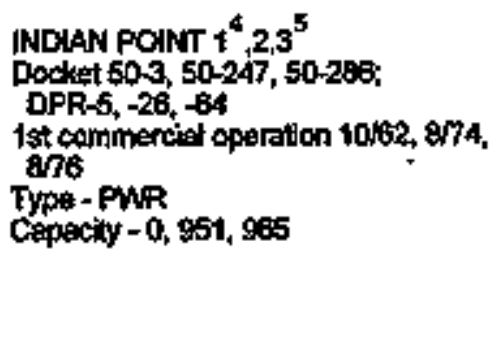 & $\begin{array}{l}1969 \\
1970 \\
1971 \\
1972 \\
1973 \\
1974 \\
1975 \\
1976 \\
1977 \\
1978\end{array}$ & $\begin{array}{r}205.2 \\
49.3 \\
194.0 \\
142.3 \\
0.0 \\
556.1 \\
584.4 \\
273.9 \\
1,279.3 \\
1,172.3\end{array}$ & $\begin{array}{l}. \\
59.4 \\
74.8 \\
34.8 \\
75.3 \\
67.8\end{array}$ & $\begin{array}{l}2,998 \\
1,019 \\
1,591 \\
1,590 \\
1,909\end{array}$ & $\begin{array}{r}298 \\
1,639 \\
768 \\
967 \\
5,462 \\
910 \\
705 \\
1,950 \\
1,070 \\
2,006\end{array}$ & $\begin{array}{l}709 \\
165 \\
164 \\
169 \\
260\end{array}$ & $\begin{array}{r}4,553 \\
5996 \\
1,796 \\
1,741 \\
1,746\end{array}$ & $\begin{array}{r}2,847 \\
47 \\
172 \\
393 \\
759\end{array}$ & $\begin{array}{r}2,415 \\
658 \\
1,778 \\
687 \\
1,247\end{array}$ & $\begin{array}{l}1.76 \\
0.89 \\
0.79 \\
1.23 \\
0.77 \\
1.05\end{array}$ & $\begin{array}{r}1.4 \\
37.8 \\
5.0 \\
6.8 \\
1.6 \\
1.2 \\
7.1 \\
0.8 \\
1.7\end{array}$ \\
\hline MOAAN POINT $1^{5}, 2$ & $\begin{array}{l}1979 \\
1980 \\
1991 \\
1982\end{array}$ & $\begin{array}{l}574.0 \\
510.8 \\
367.5 \\
532.4\end{array}$ & $\begin{array}{l}71.4 \\
64.8 \\
46.0 \\
65.4\end{array}$ & $\begin{array}{l}1,349 \\
1,577 \\
2,595 \\
2,144\end{array}$ & $\begin{array}{r}1,279 \\
971 \\
2,731 \\
1,635\end{array}$ & $\begin{array}{l}209 \\
304 \\
297 \\
343\end{array}$ & $\begin{array}{l}1,070 \\
667 \\
2,494 \\
1,292\end{array}$ & $\begin{array}{r}612 \\
6 \\
1,595 \\
885\end{array}$ & $\begin{array}{r}667 \\
965 \\
1,136 \\
752\end{array}$ & $\begin{array}{l}0.95 \\
0.62 \\
1.05 \\
0.76\end{array}$ & $\begin{array}{l}2.2 \\
1.9 \\
7.4 \\
3.1\end{array}$ \\
\hline
\end{tabular}




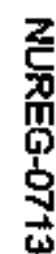

APPENDIX C (continued)
PERSONNEL, DOSE AND POWER GENERATION SUMMARY

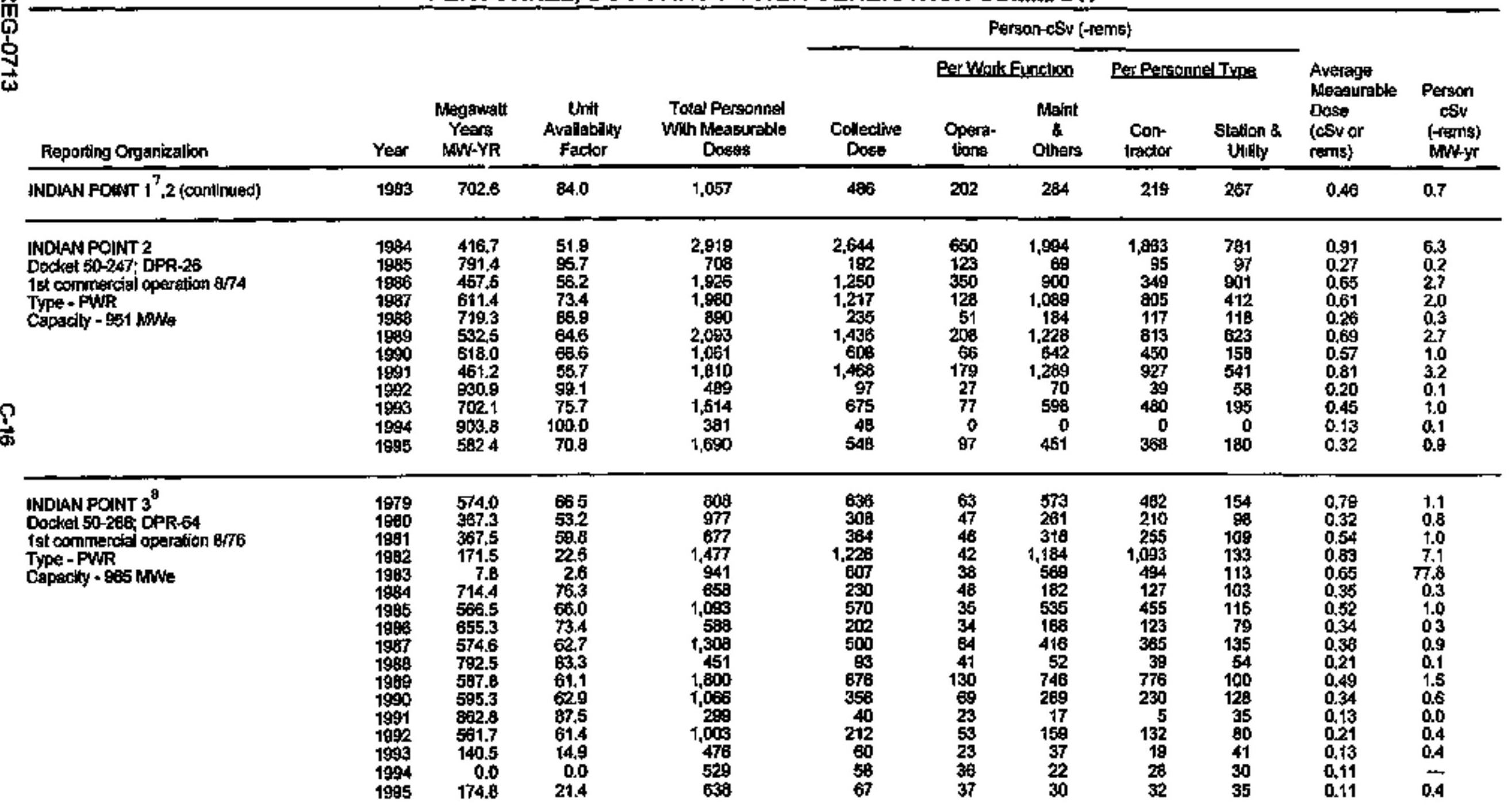

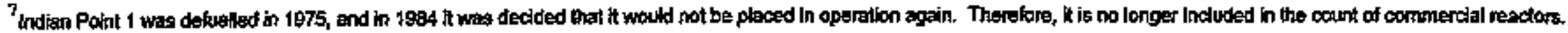

8Indian Point 3 was punchesed by a different utility and now reports separately. 
PERSONNEL, DOSE AND POWER GENERATION SUMMARY

\begin{tabular}{|c|c|c|c|c|c|c|c|c|c|c|c|}
\hline \multirow[b]{3}{*}{ Repporting Organizzation } & \multirow[b]{3}{*}{ Year } & \multirow[b]{3}{*}{$\begin{array}{l}\text { Megowalt } \\
\text { Years } \\
\text { MW-YR }\end{array}$} & \multirow[b]{3}{*}{$\begin{array}{c}\text { Unik } \\
\text { Avallabitity } \\
\text { Factor }\end{array}$} & \multirow[b]{3}{*}{$\begin{array}{c}\text { Total Personnel } \\
\text { With Measurable } \\
\text { Doses }\end{array}$} & \multicolumn{5}{|c|}{ Person-c5v (-rems) } & \multirow{3}{*}{$\begin{array}{l}\text { Average } \\
\text { Measurable } \\
\text { Dose } \\
\text { (asv or } \\
\text { rems) }\end{array}$} & \multirow{3}{*}{$\begin{array}{c}\text { Person } \\
\text { cos } \\
(-1 \in \pi s) \\
N W-y I\end{array}$} \\
\hline & & & & & & \multicolumn{2}{|c|}{ Percilork Function } & \multicolumn{2}{|c|}{ Per Personnel Type } & & \\
\hline & & & & & $\begin{array}{c}\text { Collective } \\
\text { Dose }\end{array}$ & $\begin{array}{c}\text { Opera- } \\
\text { tions }\end{array}$ & $\begin{array}{l}\text { Maint } \\
\& \\
\text { Others }\end{array}$ & $\begin{array}{l}\text { Con* } \\
\text { tractor }\end{array}$ & $\begin{array}{c}\text { Stestion \& } \\
\text { Utitiky }\end{array}$ & & \\
\hline 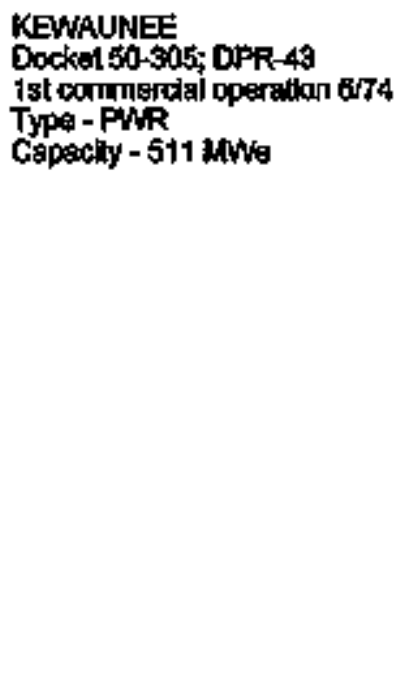 & $\begin{array}{l}1975 \\
1976 \\
1977 \\
1979 \\
1979 \\
1990 \\
1991 \\
1992 \\
1993 \\
1994 \\
1995 \\
1986 \\
1987 \\
1988 \\
1969 \\
1980 \\
1991 \\
1992 \\
1993 \\
1994 \\
1995\end{array}$ & $\begin{array}{l}401.9 \\
405.9 \\
425.0 \\
465.6 \\
412.0 \\
433.8 \\
455.6 \\
468.4 \\
444.1 \\
455.3 \\
443.1 \\
48.7 \\
440.0 \\
487.5 \\
449.1 \\
468.6 \\
441.8 \\
471.4 \\
457.1 \\
475.6 \\
455.6\end{array}$ & $\begin{array}{l}88.2 \\
78.9 \\
79.9 \\
69.5 \\
79.0 \\
92.1 \\
88.7 \\
87.6 \\
6.7 \\
85.7 \\
82.4 \\
85.8 \\
89.7 \\
88.3 \\
84.9 \\
87.9 \\
89.4 \\
89.0 \\
86.8 \\
89.8 \\
87.8\end{array}$ & $\begin{array}{l}104 \\
931 \\
312 \\
335 \\
343 \\
491 \\
393 \\
353 \\
445 \\
482 \\
519 \\
502 \\
755 \\
705 \\
700 \\
490 \\
495 \\
450 \\
436 \\
364 \\
415\end{array}$ & $\begin{array}{c}29 \\
270 \\
140 \\
154 \\
127 \\
165 \\
141 \\
101 \\
165 \\
139 \\
176 \\
169 \\
226 \\
210 \\
239 \\
145 \\
221 \\
122 \\
106 \\
72 \\
109\end{array}$ & $\begin{array}{r}1 \\
16 \\
6 \\
11 \\
6 \\
7 \\
7 \\
7 \\
5 \\
10 \\
7 \\
9 \\
8 \\
8 \\
5 \\
10 \\
5 \\
4 \\
3 \\
2 \\
2 \\
3 \\
3\end{array}$ & $\begin{array}{r}27 \\
254 \\
131 \\
143 \\
121 \\
158 \\
134 \\
96 \\
155 \\
132 \\
167 \\
161 \\
218 \\
204 \\
229 \\
140 \\
217 \\
119 \\
104 \\
70 \\
106\end{array}$ & $\begin{array}{r}12 \\
193 \\
76 \\
89 \\
79 \\
103 \\
94 \\
51 \\
119 \\
89 \\
114 \\
111 \\
173 \\
165 \\
179 \\
112 \\
189 \\
89 \\
65 \\
39 \\
71\end{array}$ & $\begin{array}{l}16 \\
77 \\
63 \\
65 \\
48 \\
62 \\
47 \\
60 \\
40 \\
60 \\
62 \\
68 \\
63 \\
45 \\
60 \\
33 \\
33 \\
34 \\
41 \\
34 \\
36\end{array}$ & $\begin{array}{l}0.27 \\
0.71 \\
0.45 \\
0.45 \\
0.37 \\
0.41 \\
0.37 \\
0.29 \\
0.37 \\
0.29 \\
0.34 \\
0.34 \\
0.30 \\
0.30 \\
0.42 \\
0.30 \\
0.45 \\
0.27 \\
0.24 \\
0.20 \\
0.26\end{array}$ & $\begin{array}{l}0.1 \\
0.7 \\
0.3 \\
0.3 \\
0.3 \\
0.4 \\
0.3 \\
0.2 \\
0.4 \\
0.3 \\
0.4 \\
0.4 \\
0.5 \\
0.4 \\
0.5 \\
0.3 \\
0.5 \\
0.3 \\
0.2 \\
0.2 \\
0.2\end{array}$ \\
\hline 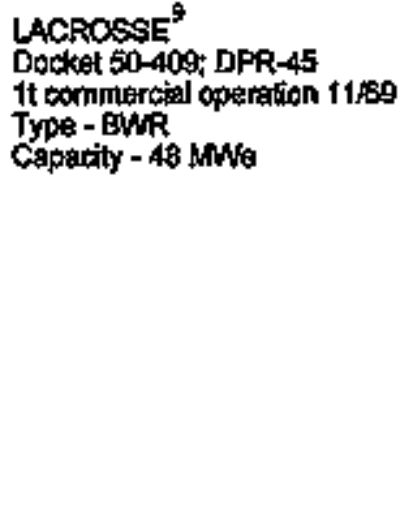 & $\begin{array}{l}1970 \\
1971 \\
1972 \\
1973 \\
1974 \\
1976 \\
1976 \\
1977 \\
1978 \\
1979 \\
1980 \\
1981 \\
1983 \\
1983 \\
1984 \\
1935\end{array}$ & $\begin{array}{r}15.3 \\
323.1 \\
29.2 \\
24.4 \\
37.9 \\
32.0 \\
21.2 \\
11.3 \\
21.6 \\
24.0 \\
26.4 \\
29.6 \\
17.2 \\
24.8 \\
38.5 \\
39.2\end{array}$ & $\begin{array}{l}81.0 \\
69.6 \\
47.6 \\
33.7 \\
62.0 \\
71.6 \\
68.5 \\
76.0 \\
44.6 \\
59.7 \\
80.5 \\
86.7\end{array}$ & $\begin{array}{l}115 \\
165 \\
118 \\
141 \\
162 \\
153 \\
124 \\
187 \\
149 \\
160 \\
289 \\
373\end{array}$ & $\begin{array}{l}111 \\
158 \\
151 \\
157 \\
139 \\
234 \\
110 \\
225 \\
164 \\
186 \\
218 \\
123 \\
205 \\
313 \\
252 \\
173\end{array}$ & $\begin{array}{r}172 \\
221 \\
89 \\
40 \\
40 \\
60 \\
69 \\
65 \\
63 \\
62 \\
65 \\
103 \\
141 \\
76\end{array}$ & $\begin{array}{r}50 \\
71 \\
764 \\
96 \\
121 \\
155 \\
61 \\
840 \\
210 \\
111 \\
97\end{array}$ & $\begin{array}{r}6 \\
6 \\
6 \\
8 \\
6 \\
21 \\
11 \\
3 \\
16 \\
31 \\
5 \\
22\end{array}$ & $\begin{array}{l}138 \\
105 \\
216 \\
168 \\
165 \\
207 \\
120 \\
189 \\
282 \\
247 \\
151\end{array}$ & $\begin{array}{l}0.72 \\
1.14 \\
1.41 \\
1.21 \\
1.42 \\
0.93 \\
1.60 \\
0.90 \\
1.22 \\
1.76 \\
0.66 \\
1.39 \\
1.96 \\
0.68 \\
0.46\end{array}$ & $\begin{array}{r}7.2 \\
4.8 \\
6.9 \\
9.4 \\
3.7 \\
7.3 \\
5.2 \\
19.9 \\
7.6 \\
7.6 \\
8.3 \\
4.2 \\
11.9 \\
12.6 \\
6.5 \\
4.4\end{array}$ \\
\hline
\end{tabular}

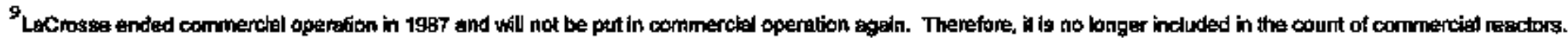




\begin{tabular}{|c|c|c|c|c|c|c|c|c|c|c|c|}
\hline \multirow{4}{*}{ 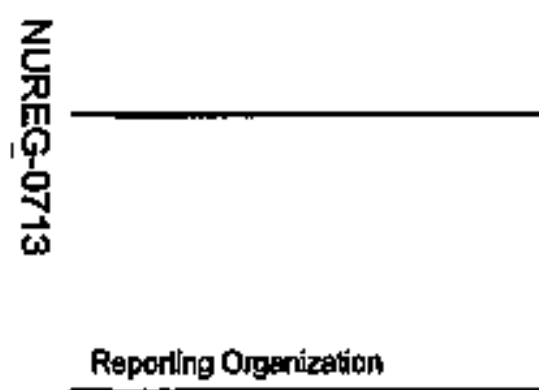 } & \multicolumn{9}{|c|}{$\begin{array}{c}\text { APPENDIX C (continued) } \\
\text { PERSONNEL, DOSE AND POWER GENERATION SUMMARY }\end{array}$} & \multirow{4}{*}{$\begin{array}{l}\text { Average } \\
\text { Measuratele } \\
\text { Dose } \\
\text { (cSvor } \\
\text { rents) }\end{array}$} & \multirow{4}{*}{$\begin{array}{l}\text { Person } \\
\text { csv } \\
\text { (rems) } \\
\text { WW-yr }\end{array}$} \\
\hline & \multirow{3}{*}{\multicolumn{2}{|c|}{$\begin{array}{l}\text { Megawatt } \\
\text { Years } \\
\text { MN-YR }\end{array}$}} & \multirow[b]{3}{*}{$\begin{array}{l}\text { Uhit } \\
\text { Availabitity } \\
\text { Factor }\end{array}$} & \multirow[b]{3}{*}{$\begin{array}{l}\text { Total Persennel } \\
\text { With Measurable } \\
\text { Doses }\end{array}$} & \multicolumn{5}{|c|}{ Penson-osv (-trams) } & & \\
\hline & & & & & \multicolumn{3}{|c|}{ Eercusark Function } & \multicolumn{2}{|c|}{ Per Personne: Type } & & \\
\hline & & & & & $\begin{array}{c}\text { Collective } \\
\text { Dose }\end{array}$ & $\begin{array}{c}\text { Opera- } \\
\text { tons }\end{array}$ & $\begin{array}{c}\text { Maint } \\
\& \\
\text { Others }\end{array}$ & $\begin{array}{l}\text { Con- } \\
\text { tractor }\end{array}$ & $\begin{array}{c}\text { Station \& } \\
\text { Uirity }\end{array}$ & & \\
\hline LACROSSE ${ }^{10}$ (continued) & $\begin{array}{l}1986 \\
1987 \\
1993 \\
1994 \\
1998\end{array}$ & $\begin{array}{l}19.6 \\
0.0 \\
0.0 \\
0.0 \\
0.0\end{array}$ & $\begin{array}{l}40.1 \\
0.0 \\
0.0 \\
0.0 \\
0.0\end{array}$ & $\begin{array}{r}280 \\
127 \\
46 \\
65 \\
31\end{array}$ & $\begin{array}{r}290 \\
68 \\
8 \\
8 \\
3\end{array}$ & $\begin{array}{r}42 \\
0 \\
3 \\
-14\end{array}$ & $\begin{array}{r}26 \\
0 \\
5 \\
+\end{array}$ & $\begin{array}{r}2 \\
0 \\
4 \\
-\pi\end{array}$ & $\begin{array}{r}66 \\
0 \\
4 \\
4\end{array}$ & $\begin{array}{l}1.12 \\
0.64 \\
0.17 \\
0.12 \\
0.10\end{array}$ & $\frac{14,6}{=}$ \\
\hline 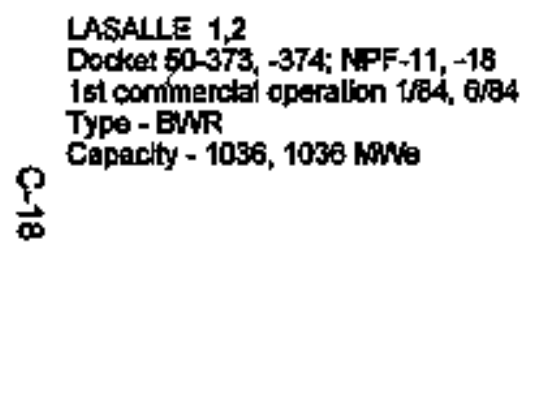 & $\begin{array}{l}1964 \\
1985 \\
1896 \\
1997 \\
1988 \\
1999 \\
1990 \\
1991 \\
1992 \\
1993 \\
1994 \\
1895\end{array}$ & $\begin{array}{r}677.8 \\
987.9 \\
929,6 \\
1,030.0 \\
1,317.6 \\
1,503,6 \\
1,764.3 \\
1,837.0 \\
1,447.4 \\
1,542.0 \\
1,580.0 \\
1,696.6\end{array}$ & $\begin{array}{l}77.8 \\
53.0 \\
50.6 \\
59.3 \\
71.6 \\
73.1 \\
64.6 \\
68.7 \\
72.0 \\
76.0 \\
77.6 \\
8.4\end{array}$ & $\begin{array}{l}1,245 \\
1,695 \\
1,614 \\
1,744 \\
2,734 \\
2,475 \\
1,690 \\
1,985 \\
2,413 \\
1,701 \\
1,812 \\
1,629\end{array}$ & $\begin{array}{r}252 \\
685 \\
898 \\
1,396 \\
2,471 \\
1,396 \\
949 \\
908 \\
1,167 \\
954 \\
726 \\
612\end{array}$ & $\begin{array}{r}29 \\
88 \\
143 \\
217 \\
253 \\
138 \\
130 \\
161 \\
195 \\
204 \\
105 \\
98\end{array}$ & $\begin{array}{r}223 \\
597 \\
795 \\
1,179 \\
2,218 \\
1,248 \\
616 \\
645 \\
972 \\
650 \\
621 \\
414\end{array}$ & $\begin{array}{r}66 \\
420 \\
827 \\
809 \\
1,978 \\
853 \\
503 \\
427 \\
648 \\
387 \\
426 \\
270\end{array}$ & $\begin{array}{l}164 \\
265 \\
371 \\
407 \\
493 \\
533 \\
445 \\
379 \\
519 \\
467 \\
300 \\
242\end{array}$ & $\begin{array}{l}0.20 \\
0.42 \\
0.50 \\
0.80 \\
0.90 \\
0.50 \\
0.52 \\
0.41 \\
0.49 \\
0.50 \\
0.40 \\
0.32\end{array}$ & $\begin{array}{l}0.4 \\
0.7 \\
1.0 \\
1.4 \\
1.9 \\
0.9 \\
0.5 \\
0.4 \\
0.8 \\
0.6 \\
0.5 \\
0.3\end{array}$ \\
\hline 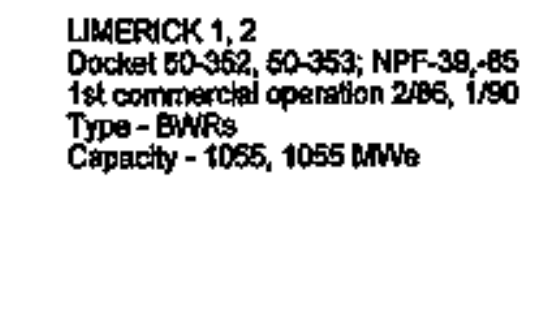 & $\begin{array}{l}1997 \\
1989 \\
1989 \\
1990 \\
\mathbf{1 9 9 1} \\
1992 \\
1993 \\
1994 \\
1995\end{array}$ & $\begin{array}{r}636.1 \\
794.9 \\
628.4 \\
1,527.7 \\
1,870.9 \\
1,741.4 \\
1,913.2 \\
1,944.4 \\
1,967.1\end{array}$ & $\begin{array}{l}70.2 \\
66.5 \\
66.0 \\
78.2 \\
86.8 \\
84.8 \\
91.6 \\
94.9 \\
93.0\end{array}$ & $\begin{array}{r}2,156 \\
950 \\
1,818 \\
1,422 \\
1,159 \\
1,559 \\
1,287 \\
1,543 \\
1,691\end{array}$ & $\begin{array}{l}174 \\
62 \\
266 \\
175 \\
106 \\
330 \\
217 \\
276 \\
260\end{array}$ & $\begin{array}{r}7 \\
20 \\
70 \\
37 \\
24 \\
23 \\
33 \\
44 \\
136\end{array}$ & $\begin{array}{c}167 \\
32 \\
198 \\
138 \\
62 \\
307 \\
184 \\
231 \\
124\end{array}$ & $\begin{array}{r}114 \\
23 \\
158 \\
78 \\
52 \\
182 \\
113 \\
161 \\
134\end{array}$ & $\begin{array}{r}60 \\
29 \\
110 \\
97 \\
54 \\
149 \\
104 \\
114 \\
124\end{array}$ & $\begin{array}{l}0.08 \\
0.05 \\
0.15 \\
0.12 \\
0.09 \\
0.21 \\
0.17 \\
0.18 \\
0.16\end{array}$ & $\begin{array}{l}0.3 \\
0.1 \\
0.4 \\
0.1 \\
0.5 \\
0.2 \\
0.1 \\
0.1 \\
0.1\end{array}$ \\
\hline 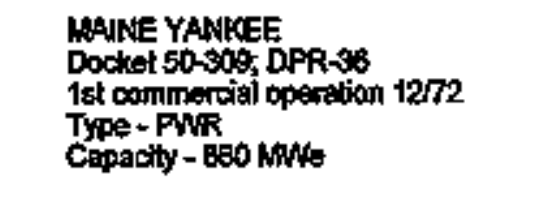 & $\begin{array}{l}1973 \\
1974 \\
1975 \\
1976 \\
1977 \\
1978\end{array}$ & $\begin{array}{l}409.7 \\
432.6 \\
542.9 \\
712.2 \\
617.6 \\
642.7\end{array}$ & $\begin{array}{l}68.7 \\
79.9 \\
95.0 \\
62.2 \\
64.1\end{array}$ & $\begin{array}{l}782 \\
619 \\
440 \\
244 \\
508 \\
638\end{array}$ & $\begin{array}{r}117 \\
420 \\
319 \\
85 \\
245 \\
429\end{array}$ & $\begin{array}{l}64 \\
15 \\
27 \\
46 \\
54\end{array}$ & $\begin{array}{r}356 \\
304 \\
58 \\
199 \\
366\end{array}$ & $\begin{array}{r}59 \\
188 \\
181 \\
28 \\
112 \\
262\end{array}$ & $\begin{array}{r}59 \\
232 \\
138 \\
59 \\
133 \\
158\end{array}$ & $\begin{array}{l}0.45 \\
0.66 \\
0.72 \\
0.35 \\
0.48 \\
0.63\end{array}$ & $\begin{array}{l}0.3 \\
1.0 \\
0.8 \\
0.1 \\
0.4 \\
0.7\end{array}$ \\
\hline
\end{tabular}

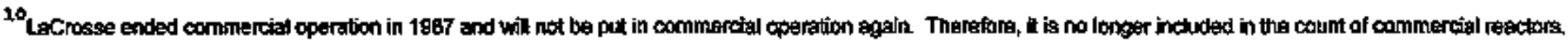




\begin{tabular}{|c|c|c|c|c|c|c|c|c|c|c|c|}
\hline \multirow[b]{2}{*}{ Reporting Oganizalton } & \multirow[b]{2}{*}{ Yos } & \multirow[b]{2}{*}{$\begin{array}{l}\text { Meganatt } \\
\text { Years } \\
\text { MWVR }\end{array}$} & \multirow[b]{2}{*}{$\begin{array}{l}\text { Unit } \\
\text { Aveilability } \\
\text { Feclor }\end{array}$} & \multirow[b]{2}{*}{$\begin{array}{c}\text { Total Personinel } \\
\text { With Measurable } \\
\text { Doses }\end{array}$} & \multicolumn{5}{|c|}{ Person-chy (-rems) } & \multirow[b]{2}{*}{$\begin{array}{l}\text { Avorage } \\
\text { Neasurable } \\
\text { Dose } \\
\text { (cSv or } \\
\text { rems) }\end{array}$} & \multirow[b]{2}{*}{$\begin{array}{c}\text { Person } \\
\text { wsy } \\
\text { (-remins) } \\
\text { MiN-y }\end{array}$} \\
\hline & & & & & $\begin{array}{l}\text { Collective } \\
\text { Dose }\end{array}$ & $\begin{array}{l}\text { Operb- } \\
\text { Hons }\end{array}$ & $\begin{array}{l}\text { Inctilon } \\
\text { Main } \\
\text { Others }\end{array}$ & $\begin{array}{c}\text { Cort- } \\
\text { tractor }\end{array}$ & $\begin{array}{c}\text { Station } 8 \\
\text { Utitity }\end{array}$ & & \\
\hline MANE YANKEE (coni'nued) & $\begin{array}{l}1979 \\
1990 \\
1991 \\
1992 \\
1998 \\
1994 \\
1996 \\
1996 \\
1997 \\
1998 \\
1999 \\
1990 \\
1991 \\
1992 \\
1993 \\
1994 \\
1995\end{array}$ & $\begin{array}{r}537.0 \\
527.0 \\
624.2 \\
542.5 \\
677.1 \\
605.7 \\
635.4 \\
737.6 \\
478.1 \\
591.9 \\
819.2 \\
573.0 \\
738.1 \\
631.7 \\
674.8 \\
782.8 \\
23.6\end{array}$ & $\begin{array}{r}68.4 \\
72.2 \\
78.2 \\
69.1 \\
83.6 \\
74.4 \\
79.2 \\
67.8 \\
6.3 \\
79.1 \\
93.7 \\
71.0 \\
86.6 \\
79.1 \\
79.8 \\
80.8 \\
3.7\end{array}$ & $\begin{array}{r}393 \\
735 \\
1060 \\
1,295 \\
592 \\
1,260 \\
1,009 \\
495 \\
1,100 \\
1,058 \\
375 \\
1,359 \\
426 \\
1,199 \\
1,016 \\
297 \\
1,167\end{array}$ & $\begin{array}{r}154 \\
462 \\
424 \\
619 \\
165 \\
884 \\
700 \\
100 \\
722 \\
725 \\
99 \\
692 \\
105 \\
461 \\
377 \\
84 \\
653\end{array}$ & $\begin{array}{r}70 \\
117 \\
11 \\
33 \\
41 \\
9 \\
54 \\
34 \\
39 \\
52 \\
38 \\
146 \\
27 \\
67 \\
74 \\
16 \\
116\end{array}$ & $\begin{array}{r}84 \\
345 \\
413 \\
588 \\
124 \\
875 \\
640 \\
66 \\
693 \\
673 \\
61 \\
546 \\
78 \\
374 \\
393 \\
68 \\
537\end{array}$ & $\begin{array}{r}26 \\
277 \\
306 \\
462 \\
72 \\
702 \\
529 \\
14 \\
531 \\
576 \\
25 \\
547 \\
45 \\
360 \\
309 \\
57 \\
533\end{array}$ & $\begin{array}{r}128 \\
185 \\
116 \\
157 \\
93 \\
162 \\
171 \\
66 \\
191 \\
149 \\
74 \\
135 \\
99 \\
101 \\
69 \\
27 \\
120\end{array}$ & $\begin{array}{l}0.39 \\
0.63 \\
0.49 \\
0.48 \\
0.28 \\
0.70 \\
0.69 \\
0.20 \\
0.66 \\
0.69 \\
0.26 \\
0.50 \\
0.25 \\
0.39 \\
0.37 \\
0.28 \\
0.56\end{array}$ & $\begin{array}{c}0.3 \\
0.9 \\
0.7 \\
1.1 \\
0.2 \\
1.5 \\
1.1 \\
0.1 \\
1.5 \\
1.2 \\
0.1 \\
1.2 \\
0.1 \\
0.7 \\
0.6 \\
0.1 \\
27.7\end{array}$ \\
\hline 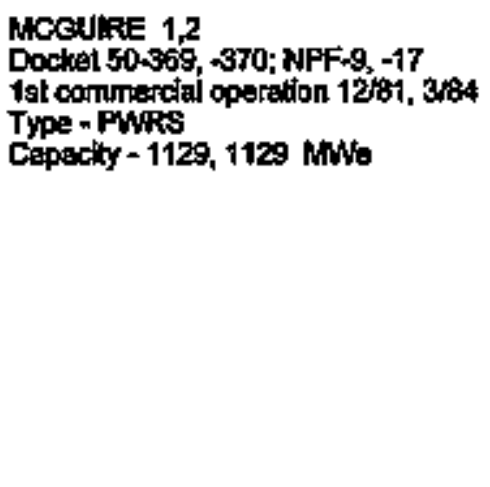 & $\begin{array}{l}1982 \\
1983 \\
1984 \\
1985 \\
1986 \\
1987 \\
1998 \\
1999 \\
1996 \\
1991 \\
1992 \\
1993 \\
1994 \\
1995\end{array}$ & $\begin{array}{r}524.9 \\
568.3 \\
764.1 \\
608.4 \\
1,390.0 \\
1,774.7 \\
1,830.7 \\
1,610.2 \\
1,340.3 \\
1,945.1 \\
1,686.8 \\
1,470.4 \\
1,846.0 \\
2,132.3\end{array}$ & $\begin{array}{l}80.4 \\
55.4 \\
68.5 \\
77.0 \\
60.1 \\
79.2 \\
80.2 \\
80.8 \\
61.3 \\
85.0 \\
74.4 \\
66.2 \\
80.2 \\
98.9\end{array}$ & $\begin{array}{l}1,500 \\
1,751 \\
1,663 \\
2,217 \\
2,300 \\
2,805 \\
2,006 \\
1,994 \\
2,289 \\
1,723 \\
1,619 \\
1,695 \\
1,657 \\
1,259\end{array}$ & $\begin{array}{r}169 \\
521 \\
507 \\
771 \\
1,015 \\
1,043 \\
1,104 \\
620 \\
727 \\
361 \\
418 \\
463 \\
397 \\
138\end{array}$ & $\begin{array}{r}28 \\
35 \\
35 \\
92 \\
47 \\
38 \\
65 \\
44 \\
63 \\
18 \\
38 \\
16 \\
7 \\
7\end{array}$ & $\begin{array}{r}143 \\
496 \\
472 \\
679 \\
908 \\
1,005 \\
1,039 \\
576 \\
604 \\
343 \\
390 \\
447 \\
390 \\
131\end{array}$ & $\begin{array}{r}29 \\
123 \\
106 \\
277 \\
389 \\
510 \\
592 \\
252 \\
268 \\
111 \\
114 \\
63 \\
80 \\
29\end{array}$ & $\begin{array}{l}140 \\
393 \\
401 \\
494 \\
626 \\
553 \\
512 \\
398 \\
439 \\
.260 \\
304 \\
390 \\
317 \\
109\end{array}$ & $\begin{array}{l}0.11 \\
0.30 \\
0.30 \\
0.35 \\
0.44 \\
0.36 \\
0.39 \\
0.31 \\
0.32 \\
0.21 \\
0.26 \\
0.27 \\
0.24 \\
0.11\end{array}$ & $\begin{array}{l}0.3 \\
0.9 \\
0.7 \\
1.0 \\
0.7 \\
0.6 \\
0.6 \\
0.3 \\
0.5 \\
0.2 \\
0.2 \\
0.3 \\
0.2 \\
0.1\end{array}$ \\
\hline 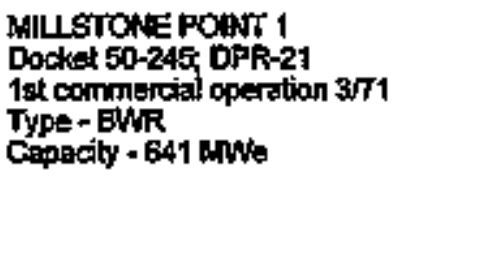 & $\begin{array}{l}1972 \\
1973 \\
1974 \\
1976 \\
1976 \\
1977 \\
1978 \\
1979\end{array}$ & $\begin{array}{l}377.6 . \\
255.1 \\
430.3 \\
455.4 \\
449.8 \\
575.7 \\
556.6 \\
505.0\end{array}$ & $\begin{array}{l}79.1 \\
75.6 \\
76.1 \\
69.6 \\
67.6 \\
77.3\end{array}$ & $\begin{array}{r}612 \\
1,184 \\
2,477 \\
2,647 \\
1,387 \\
1,076 \\
1,391 \\
2,001\end{array}$ & $\begin{array}{r}693 \\
663 \\
1,430 \\
2,022 \\
1,194 \\
394 \\
1,416 \\
1,795\end{array}$ & $\begin{array}{r}50 \\
125 \\
\\
54 \\
113 \\
160 \\
198\end{array}$ & $\begin{array}{r}546 \\
534 \\
1,140 \\
274 \\
1,256 \\
1,597\end{array}$ & $\begin{array}{r}340 \\
422 \\
\\
955 \\
150 \\
1,036 \\
1,327\end{array}$ & $\begin{array}{c}256 \\
241 \\
. \\
239 \\
233 \\
390 \\
468\end{array}$ & $\begin{array}{l}0.97 \\
0.86 \\
0.56 \\
0.76 \\
0.86 \\
0.37 \\
1.02 \\
0.90\end{array}$ & $\begin{array}{l}1.6 \\
2.9 \\
3.3 \\
4.3 \\
2.7 \\
0.7 \\
2.5 \\
3.6\end{array}$ \\
\hline
\end{tabular}




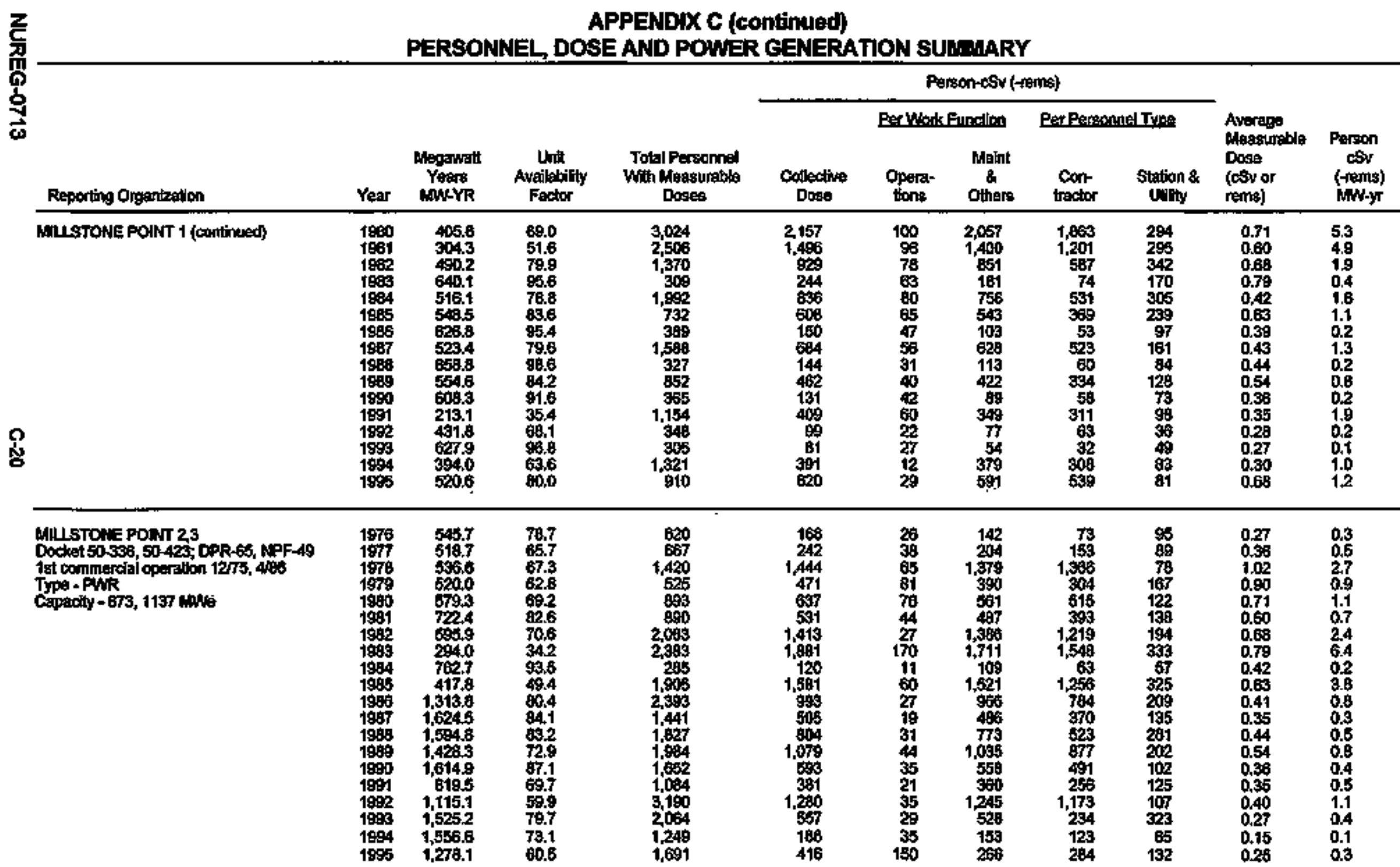


APPENDIX C (continued)

PERSONNEL, DOSE AND POWER GENERATION SUMHARY

\begin{tabular}{|c|c|c|c|c|c|c|c|c|c|c|c|}
\hline \multirow[b]{3}{*}{ Reporting Orgenization } & \multirow[b]{3}{*}{ Year } & \multirow[b]{3}{*}{$\begin{array}{l}\text { Aloganett } \\
\text { Years } \\
\text { MNKLYR }\end{array}$} & \multirow[b]{3}{*}{$\begin{array}{l}\text { Unit } \\
\text { Avalubility } \\
\text { Factor }\end{array}$} & \multirow[b]{3}{*}{$\begin{array}{c}\text { Total Persornel } \\
\text { Wilh Measutialtile } \\
\text { Dosess }\end{array}$} & \multicolumn{5}{|c|}{ Person-cory (-8gn) } & \multirow{3}{*}{$\begin{array}{l}\text { Average } \\
\text { Measuratile } \\
\text { Dose } \\
\text { (cSv or } \\
\text { rems) }\end{array}$} & \multirow{3}{*}{$\begin{array}{l}\text { Person } \\
\text { CSv } \\
\text { (rems) } \\
\text { mav-yr }\end{array}$} \\
\hline & & & & & & \multicolumn{2}{|c|}{ PestworkEunction } & \multicolumn{2}{|c|}{ Eer Pessonged Type } & & \\
\hline & & & & & $\begin{array}{l}\text { Collective } \\
\text { Dose }\end{array}$ & $\begin{array}{l}\text { Operer- } \\
\text { fons }\end{array}$ & $\begin{array}{l}\text { Maint } \\
\text { \& } \\
\text { Others }\end{array}$ & $\begin{array}{l}\text { Con. } \\
\text { tractor }\end{array}$ & $\begin{array}{c}\text { Stalion \& } \\
\text { Utolity }\end{array}$ & & \\
\hline 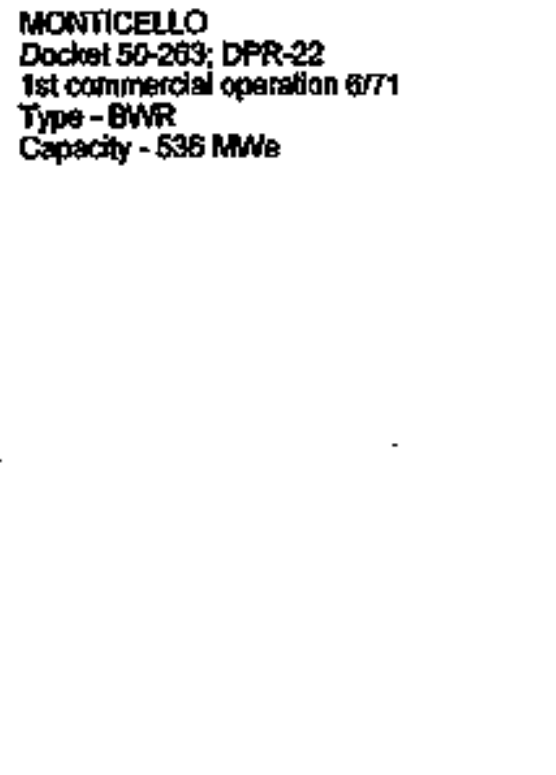 & $\begin{array}{l}1972 \\
1973 \\
1974 \\
1975 \\
1976 \\
1977 \\
1978 \\
1979 \\
1980 \\
1981 \\
1982 \\
1983 \\
1984 \\
1965 \\
1966 \\
1967 \\
1968 \\
1969 \\
1990 \\
1991 \\
1992 \\
1983 \\
1994 \\
1995\end{array}$ & $\begin{array}{l}424.4 \\
3198.5 \\
349.3 \\
344.8 \\
476.4 \\
425.6 \\
459.4 \\
522.0 \\
411.8 \\
389.3 \\
291.1 \\
494.6 \\
33.7 \\
509.8 \\
402.7 \\
422.5 \\
542.5 . \\
319.2 \\
538.0 \\
429.4 \\
529.3 \\
459.1 \\
471.3 \\
504.7\end{array}$ & $\begin{array}{r}74.9 \\
72.2 \\
91.5 \\
79.9 \\
93.2 \\
97.6 \\
79.2 \\
77.6 \\
83.3 \\
93.3 \\
91.2 \\
91.7 \\
79.1 \\
81.9 \\
99.8 \\
77.2 \\
96.9 \\
80.8 \\
97.5 \\
84.4 \\
87.0 \\
100.0\end{array}$ & $\begin{array}{r}99 \\
401 \\
842 \\
1,353 \\
325 \\
860 \\
679 \\
372 \\
1,114 \\
1,446 \\
1,307 \\
416 \\
1,872 \\
586 \\
896 \\
941 \\
376 \\
1,102 \\
3356 \\
964 \\
454 \\
934 \\
786 \\
200\end{array}$ & $\begin{array}{r}61 \\
176 \\
349 \\
1,353 \\
263 \\
1,000 \\
375 \\
157 \\
531 \\
1,004 \\
993 \\
121 \\
2,462 \\
327 \\
596 \\
566 \\
110 \\
507 \\
94 \\
455 \\
114 \\
494 \\
395 \\
44\end{array}$ & $\begin{array}{r}40 \\
49 \\
\\
59 \\
59 \\
135 \\
62 \\
62 \\
82 \\
104 \\
130 \\
57 \\
208 \\
97 \\
94 \\
102 \\
40 \\
99 \\
42 \\
102 \\
46 \\
118 \\
63 \\
27\end{array}$ & $\begin{array}{r}21 \\
128 \\
\\
204 \\
204 \\
635 \\
313 \\
95 \\
449 \\
903 \\
863 \\
64 \\
2,254 \\
240 \\
502 \\
466 \\
70 \\
409 \\
52 \\
363 \\
66 \\
376 \\
312 \\
17\end{array}$ & $\begin{array}{r}1 \\
67 \\
91 \\
52 \\
56 \\
661 \\
166 \\
50 \\
249 \\
756 \\
780 \\
23 \\
927 \\
47 \\
114 \\
115 \\
10 \\
113 \\
11 \\
101 \\
10 \\
94 \\
102 \\
3\end{array}$ & $\begin{array}{r}50 \\
109 \\
258 \\
212 \\
359 \\
210 \\
105 \\
283 \\
249 \\
233 \\
98 \\
1,535 \\
290 \\
492 \\
453 \\
100 \\
394 \\
83 \\
354 \\
104 \\
400 \\
293 \\
41\end{array}$ & $\begin{array}{l}0.62 \\
0.44 \\
0.41 \\
1.00 \\
0.81 \\
1.16 \\
0.56 \\
0.42 \\
0.48 \\
0.69 \\
0.76 \\
0.29 \\
1.32 \\
0.56 \\
0.57 \\
0.60 \\
0.29 \\
0.46 \\
0.29 \\
0.49 \\
0.25 \\
0.52 \\
0.50 \\
0.22\end{array}$ & $\begin{array}{c}0.1 \\
0.5 \\
1.0 \\
3.9 \\
0.6 \\
2.3 \\
0.8 \\
0.3 \\
1.3 \\
2.6 \\
3.4 \\
0.2 \\
73.1 \\
0.6 \\
1.5 \\
1.3 \\
0.2 \\
1.6 \\
0.2 \\
1.1 \\
0.2 \\
1.1 \\
0.8 \\
0.1\end{array}$ \\
\hline 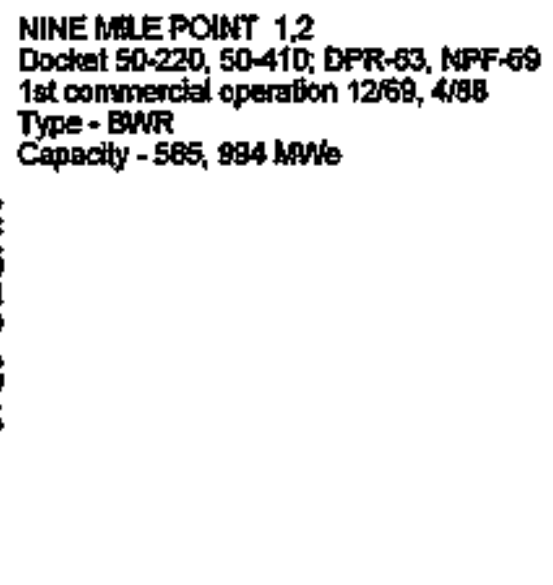 & $\begin{array}{l}1970 \\
1971 \\
1972 \\
1973 \\
1974 \\
1975 \\
1976 \\
1977 \\
1979 \\
1979 \\
1980 \\
1991 \\
1988 \\
1963 \\
1984 \\
1985 \\
1983 \\
1997\end{array}$ & $\begin{array}{l}227.0 \\
346.5 \\
381.8 \\
411.0 \\
335.9 \\
359.0 \\
484.6 \\
347.4 \\
527.7 \\
354.0 \\
533.9 \\
336.2 \\
133.5 \\
329.8 \\
426.8 \\
590.8 \\
374.0 \\
542.6\end{array}$ & $\begin{array}{l}70.5 \\
721 \\
86.2 \\
59.2 \\
95.1 \\
68.1 \\
92.3 \\
68.0 \\
91.4 \\
58.2 \\
71.9 \\
98.4 \\
65.3 \\
93.3\end{array}$ & $\begin{array}{r}821 \\
1,006 \\
735 \\
650 \\
740 \\
649 \\
352 \\
1,093 \\
561 \\
1,326 \\
1,174 \\
2,029 \\
1,350 \\
1,405 \\
1,530 \\
1,007 \\
1,978 \\
1,190\end{array}$ & 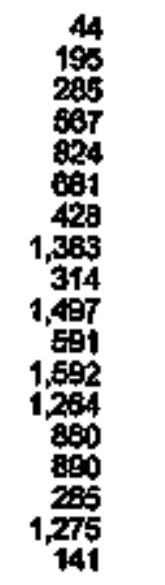 & $\begin{array}{r}12 \\
43 \\
59 \\
139 \\
42 \\
49 \\
52 \\
41 \\
59 \\
106 \\
75 \\
744 \\
149 \\
60 \\
163 \\
164 \\
69 \\
39 \\
35\end{array}$ & $\begin{array}{r}32 \\
182 \\
225 \\
428 \\
782 \\
613 \\
378 \\
1,342 \\
255 \\
1,391 \\
516 \\
1,446 \\
1,201 \\
810 \\
727 \\
1204 \\
1,237 \\
100\end{array}$ & $\begin{array}{r}17 \\
63 \\
28 \\
118 \\
279 \\
203 \\
229 \\
298 \\
28 \\
28 \\
940 \\
251 \\
1,064 \\
944 \\
576 \\
372 \\
43 \\
730 \\
39\end{array}$ & $\begin{array}{l}27 \\
132 \\
257 \\
449 \\
545 \\
478 \\
199 \\
500 \\
238 \\
553 \\
340 \\
528 \\
320 \\
264 \\
519 \\
222 \\
545 \\
102\end{array}$ & $\begin{array}{l}0.05 \\
0.19 \\
0.30 \\
1.03 \\
1.11 \\
1.05 \\
1.69 \\
1.27 \\
0.56 \\
1.13 \\
0.50 \\
0.78 \\
0.93 \\
0.61 \\
0.58 \\
0.26 \\
0.63 \\
0.12\end{array}$ & $\begin{array}{l}0.2 \\
0.6 \\
0.7 \\
1.4 \\
2.1 \\
1.9 \\
0.9 \\
4.0 \\
0.6 \\
4.2 \\
1.1 \\
4.1 \\
0.5 \\
2.8 \\
2.1 \\
0.5 \\
3.4 \\
0.3\end{array}$ \\
\hline
\end{tabular}




\begin{tabular}{|c|c|c|c|c|c|c|c|c|c|c|c|}
\hline \multirow{4}{*}{ 旁 } & \multirow[b]{4}{*}{ Year } & \multicolumn{8}{|c|}{$\begin{array}{l}\text { APPENDIX C (continued) } \\
\text { PERSONNEL, DOSE AND POWER GENERATION SUMNARY }\end{array}$} & \multirow{4}{*}{$\begin{array}{l}\text { Average } \\
\text { Measurable } \\
\text { Dose } \\
\text { (cSv or } \\
\text { rems) }\end{array}$} & \multirow{4}{*}{$\begin{array}{c}\text { Person } \\
\text { cSi } \\
\text { (-rems } \\
\text { WWW-yr }\end{array}$} \\
\hline & & \multirow[b]{3}{*}{$\begin{array}{l}\text { Megawatt } \\
\text { Years } \\
\text { WWK YR }\end{array}$} & \multirow[b]{3}{*}{$\begin{array}{l}\text { Unit } \\
\text { Availability } \\
\text { Factor }\end{array}$} & \multirow[b]{3}{*}{$\begin{array}{l}\text { Total Persionel } \\
\text { With Alessurable } \\
\text { Doses }\end{array}$} & \multicolumn{5}{|c|}{ Person-csviv (-rems) } & & \\
\hline & & & & & \multicolumn{3}{|c|}{ Ber Mork Finnilyon } & \multicolumn{2}{|c|}{ Per Persomel Type } & & \\
\hline & & & & & $\begin{array}{c}\text { Collective } \\
\text { Dose }\end{array}$ & Opere- & $\begin{array}{l}\text { Maint } \\
\& \\
\text { Others }\end{array}$ & $\begin{array}{l}\text { Con- } \\
\text { tractor }\end{array}$ & $\begin{array}{c}\text { Stetion \& } \\
\text { Utity }\end{array}$ & & \\
\hline NINE MHE POINT 1,2 (conlinued) & $\begin{array}{l}1988 \\
1989 \\
1990 \\
1991 \\
1992 \\
1993 \\
1994 \\
1915\end{array}$ & $\begin{array}{r}0.0 \\
527.5 \\
658.2 \\
1,250.8 \\
885.9 \\
1,380.2 \\
1,588.6 \\
1,382.2\end{array}$ & $\begin{array}{r}0.0 \\
29.7 \\
48.6 \\
79.7 \\
61.8 \\
64.6 \\
95.9 \\
62.5\end{array}$ & $\begin{array}{l}2,626 \\
2,737 \\
2,405 \\
1,543 \\
1,600 \\
2,352 \\
800 \\
2,304\end{array}$ & $\begin{array}{l}864 \\
564 \\
699 \\
292 \\
565 \\
635 \\
149 \\
759\end{array}$ & $\begin{array}{r}33 \\
53 \\
35 \\
72 \\
102 \\
90 \\
960 \\
97\end{array}$ & $\begin{array}{r}821 \\
611 \\
614 \\
200 \\
461 \\
549 \\
93 \\
672\end{array}$ & $\begin{array}{r}509 \\
382 \\
467 \\
94 \\
184 \\
427 \\
52 \\
579\end{array}$ & $\begin{array}{r}345 \\
182 \\
252 \\
198 \\
379 \\
200 \\
97 \\
180\end{array}$ & $\begin{array}{l}0.33 \\
0.21 \\
0.29 \\
0.18 \\
0.31 \\
0.27 \\
0.19 \\
0.33\end{array}$ & $\begin{array}{l}1.1 \\
1.1 \\
0.2 \\
0.6 \\
0.5 \\
0.1 \\
0.5\end{array}$ \\
\hline 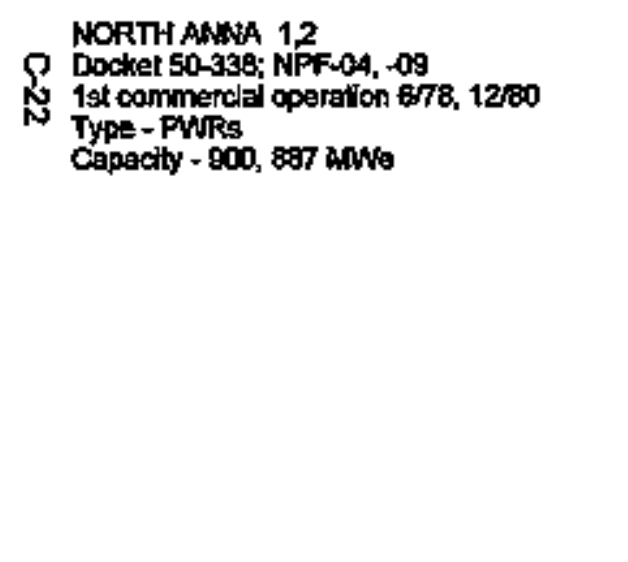 & $\begin{array}{l}1979 \\
1990 \\
1991 \\
1992 \\
1983 \\
1994 \\
1985 \\
1996 \\
1987 \\
1986 \\
1989 \\
1980 \\
1991 \\
1992 \\
1993 \\
1994 \\
1995\end{array}$ & $\begin{array}{r}507.0 \\
691.9 \\
1,241.9 \\
777.7 \\
1,338.4 \\
1,021.3 \\
1,516.9 \\
1,494.5 \\
1,112.8 \\
1,772.7 \\
1,226.8 \\
1,590.4 \\
1,597.5 \\
1,403.2 \\
1,428.4 \\
1,717.1 \\
1,626.4\end{array}$ & $\begin{array}{l}61.7 \\
61.5 \\
71.5 \\
45.8 \\
76.1 \\
58.6 \\
85.1 \\
83.0 \\
67.8 \\
96.7 \\
72.5 \\
90.5 \\
88.6 \\
84.1 \\
80.1 \\
95.9 \\
90.8\end{array}$ & $\begin{array}{l}2,025 \\
2,086 \\
2,416 \\
2,672 \\
2,228 \\
3,062 \\
2,436 \\
2,831 \\
2624 \\
998 \\
2,861 \\
2,161 \\
2,085 \\
2,159 \\
2,769 \\
1,030 \\
1,551\end{array}$ & $\begin{array}{r}449 \\
218 \\
680 \\
1,915 \\
685 \\
1,945 \\
638 \\
722 \\
1,521 \\
112 \\
1,471 \\
590 \\
629 \\
576 \\
909 \\
193 \\
367\end{array}$ & $\begin{array}{r}78 \\
129 \\
198 \\
78 \\
129 \\
155 \\
141 \\
111 \\
60 \\
28 \\
35 \\
12 \\
19 \\
15 \\
12 \\
17 \\
9\end{array}$ & $\begin{array}{r}371 \\
90 \\
492 \\
1,837 \\
536 \\
1,790 \\
697 \\
811 \\
1,461 \\
84 \\
1,435 \\
578 \\
610 \\
581 \\
886 \\
176 \\
358\end{array}$ & $\begin{array}{r}190 \\
85 \\
343 \\
1,207 \\
296 \\
1,417 \\
501 \\
343 \\
1,075 \\
19 \\
1,159 \\
453 \\
461 \\
413 \\
711 \\
93 \\
193\end{array}$ & $\begin{array}{l}259 \\
133 \\
337 \\
708 \\
369 \\
528 \\
337 \\
379 \\
446 \\
93 \\
312 \\
157 \\
168 \\
163 \\
197 \\
100 \\
174\end{array}$ & $\begin{array}{l}0.22 \\
0.10 \\
0.28 \\
0.67 \\
0.30 \\
0.64 \\
0.34 \\
0.26 \\
0.58 \\
0.11 \\
0.51 \\
0.27 \\
0.30 \\
0.27 \\
0.33 \\
0.19 \\
0.24\end{array}$ & $\begin{array}{l}0.9 \\
0.3 \\
0.5 \\
2.5 \\
0.5 \\
1.9 \\
0.6 \\
0.5 \\
1.4 \\
0.1 \\
1.2 \\
0.4 \\
0.4 \\
0.4 \\
0.6 \\
0.1 \\
0.2\end{array}$ \\
\hline 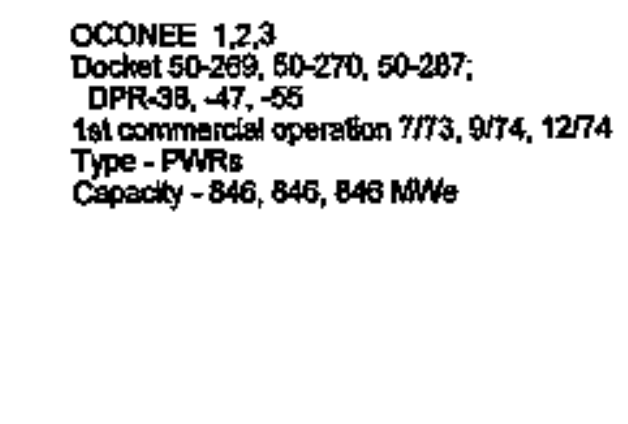 & $\begin{array}{l}1974 \\
1975 \\
1978 \\
1977 \\
1978 \\
1979 \\
1980 \\
1981 \\
1962 \\
1983 \\
1934 \\
1935 \\
1986\end{array}$ & $\begin{array}{r}650.6 \\
1,638.3 \\
1,651.4 \\
1,556.4 \\
1,909.0 \\
1,708.0 \\
1,703.7 \\
1,661.5 \\
1,293.1 \\
2,141.5 \\
2,242.9 \\
2,036.3 \\
1,995.6\end{array}$ & $\begin{array}{l}60.1 \\
75.5 \\
63.0 \\
65.9 \\
75.8 \\
67.7 \\
70.1 \\
66.8 \\
52.5 \\
82.2 \\
25.7 \\
80.5 \\
79.0\end{array}$ & $\begin{array}{r}844 \\
929 \\
1,215 \\
1,595 \\
1,638 \\
2,100 \\
2,124 \\
2,445 \\
2,445 \\
1,902 \\
2,085 \\
2,729 \\
2,499\end{array}$ & $\begin{array}{r}517 \\
497 \\
1,026 \\
1,329 \\
1,393 \\
1,001 \\
1,055 \\
1,211 \\
1,792 \\
1,207 \\
1,106 \\
1,304 \\
1949\end{array}$ & $\begin{array}{r}18 \\
72 \\
65 \\
244 \\
179 \\
123 \\
117 \\
113 \\
97 \\
89 \\
63 \\
144 \\
30\end{array}$ & $\begin{array}{r}499 \\
425 \\
981 \\
1,084 \\
1,214 \\
976 \\
938 \\
1,098 \\
1,095 \\
1,119 \\
1,043 \\
1,160 \\
913\end{array}$ & $\begin{array}{r}144 \\
90 \\
219 \\
294 \\
340 \\
191 \\
162 \\
275 \\
384 \\
316 \\
260 \\
378 \\
264\end{array}$ & $\begin{array}{r}373 \\
407 \\
807 \\
1,034 \\
1,053 \\
820 \\
893 \\
936 \\
1,428 \\
891 \\
846 \\
926 \\
688\end{array}$ & $\begin{array}{l}0.61 \\
0.60 \\
0.84 \\
0.53 \\
0.85 \\
0.48 \\
0.50 \\
0.50 \\
0.73 \\
0.63 \\
0.53 \\
0.40 \\
0.38\end{array}$ & $\begin{array}{l}0.8 \\
0.3 \\
0.7 \\
0.8 \\
0.7 \\
0.6 \\
0.6 \\
0.7 \\
1.4 \\
0.6 \\
0.5 \\
0.6 \\
0.5\end{array}$ \\
\hline
\end{tabular}


APPENDXC (continued)

PERSONNEL, DOSE AND POWER GENERATION SUMMARY

\begin{tabular}{|c|c|c|c|c|c|c|c|c|c|c|c|}
\hline \multirow[b]{3}{*}{ Reporting Ogarization } & \multirow[b]{3}{*}{ Yeяr } & \multirow[b]{3}{*}{$\begin{array}{l}\text { Megawntl } \\
\text { Yegrs } \\
\text { MWK-YR }\end{array}$} & \multirow[b]{3}{*}{$\begin{array}{l}\text { Uni: } \\
\text { Availability } \\
\text { Factor }\end{array}$} & \multirow[b]{3}{*}{$\begin{array}{l}\text { Total Personmel } \\
\text { Witi Mitesurabla } \\
\text { Doees }\end{array}$} & \multicolumn{5}{|c|}{ Persan-osv (-1ems) } & \multirow{3}{*}{$\begin{array}{l}\text { Average } \\
\text { Measuratile } \\
\text { Dose } \\
\text { (CSv or } \\
\text { rems) }\end{array}$} & \multirow{3}{*}{ 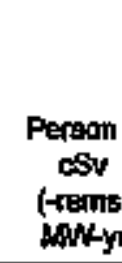 } \\
\hline & & & & & & \multicolumn{2}{|c|}{ PermankFindicon } & \multicolumn{2}{|c|}{ 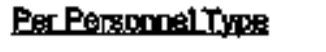 } & & \\
\hline & & & & & $\begin{array}{c}\text { Collective } \\
\text { Dopese }\end{array}$ & $\begin{array}{l}\text { Opera- } \\
\text { tons }\end{array}$ & $\begin{array}{l}\text { Haint } \\
\& \\
\text { Others }\end{array}$ & $\begin{array}{c}\text { Con- } \\
\text { tractor }\end{array}$ & $\begin{array}{c}\text { Station \& } \\
\text { Ufifity }\end{array}$ & & \\
\hline OCONEE $1,2,3$ (continued) & $\begin{array}{l}1987 \\
1988 \\
1989 \\
1990 \\
1991 \\
1992 \\
1998 \\
1994 \\
1996\end{array}$ & $\begin{array}{l}1,962.6 \\
2,228.9 \\
2,188.6 \\
2,405.2 \\
2,275.0 \\
2,110.7 \\
2,399.2 \\
2,144.3 \\
2,365.1\end{array}$ & $\begin{array}{l}82.4 \\
87.2 \\
85.4 \\
91.4 \\
86.7 \\
82.0 \\
91.3 \\
62.2 \\
89.5\end{array}$ & $\begin{array}{l}2,672 \\
2,672 \\
2,205 \\
1,948 \\
1,966 \\
1,964 \\
1,499 \\
1,923 \\
1,586\end{array}$ & $\begin{array}{r}1,142 \\
871 \\
694 \\
404 \\
559 \\
612 \\
237 \\
637 \\
304\end{array}$ & $\begin{array}{l}51 \\
51 \\
53 \\
36 \\
46 \\
60 \\
23 \\
40 \\
31\end{array}$ & $\begin{array}{l}1,091 \\
620 \\
691 \\
368 \\
505 \\
552 \\
214 \\
497 \\
273\end{array}$ & $\begin{array}{r}373 \\
317 \\
200 \\
132 \\
143 \\
166 \\
43 \\
114 \\
63\end{array}$ & $\begin{array}{l}765 \\
854 \\
494 \\
272 \\
408 \\
446 \\
194 \\
423 \\
241\end{array}$ & $\begin{array}{l}0.43 \\
0.33 \\
0.31 \\
0.21 \\
0.28 \\
0.31 \\
0.16 \\
0.28 \\
0.19\end{array}$ & $\begin{array}{l}0.6 \\
0.4 \\
0.3 \\
0.2 \\
0.2 \\
0.3 \\
0.1 \\
0.2 \\
0.1\end{array}$ \\
\hline 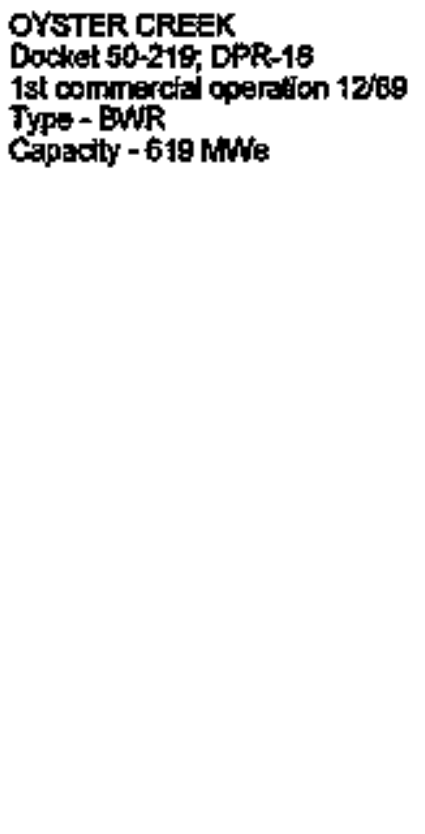 & $\begin{array}{l}1970 \\
1971 \\
1972 \\
1973 \\
1974 \\
1975 \\
1976 \\
1977 \\
1976 \\
1979 \\
1980 \\
1981 \\
1991 \\
1983 \\
1964 \\
1995 \\
1998 \\
1967 \\
1968 \\
1989 \\
1990 \\
1991 \\
1992 \\
1993 \\
1994 \\
1995\end{array}$ & $\begin{array}{r}\$ 13.6 \\
449.9 \\
315.0 \\
424.6 \\
444.5 \\
373.6 \\
468.6 \\
395.7 \\
491.0 \\
541.0 \\
232.9 \\
314.8 \\
242.7 \\
27.9 \\
37.1 \\
446.1 \\
157.3 \\
371.0 \\
419.6 \\
287.5 \\
511.6 \\
351.6 \\
536.3 \\
561.9 \\
431.7 \\
615.4\end{array}$ & $\begin{array}{c}70.4 \\
73.3 \\
79.3 \\
70.1 \\
74.3 \\
85.9 \\
41.4 \\
59.8 \\
62.5 \\
11.5 \\
0.6 \\
89.4 \\
31.5 \\
64.2 \\
65.9 \\
57.3 \\
69.1 \\
60.5 \\
85.9 \\
97.8 \\
70.8 \\
97.4\end{array}$ & $\begin{array}{r}95 \\
249 \\
339 \\
762 \\
935 \\
1,210 \\
1,562 \\
1,673 \\
1,414 \\
842 \\
1,966 \\
1,689 \\
1,270 \\
2,303 \\
2,369 \\
2,342 \\
3,740 \\
1,932 \\
2,975 \\
2,395 \\
1,941 \\
3,089 \\
2,771 \\
2,860 \\
2,382 \\
761\end{array}$ & 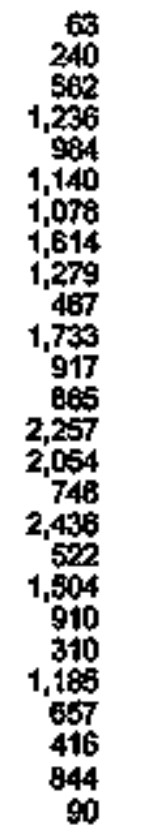 & $\begin{array}{c}21 \\
50 \\
150 \\
195 \\
168 \\
189 \\
70 \\
76 \\
134 \\
95 \\
97 \\
49 \\
33 \\
65 \\
134 \\
116 \\
269 \\
112 \\
135 \\
138 \\
76 \\
151 \\
70 \\
600 \\
56 \\
21\end{array}$ & 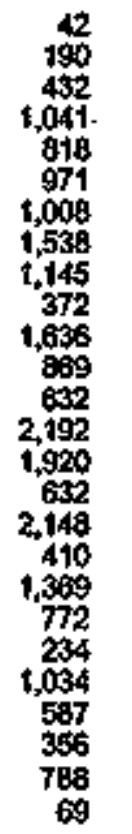 & $\begin{array}{r}11 \\
92 \\
167 \\
683 \\
163 \\
271 \\
587 \\
1,048 \\
696 \\
135 \\
1,183 \\
479 \\
491 \\
1,963 \\
1,537 \\
318 \\
1,924 \\
211 \\
1,238 \\
5683 \\
131 \\
938 \\
438 \\
238 \\
238 \\
621 \\
17\end{array}$ & $\begin{array}{l}52 \\
149 \\
418 \\
553 \\
022 \\
869 \\
491 \\
566 \\
593 \\
332 \\
550 \\
438 \\
374 \\
394 \\
517 \\
430 \\
512 \\
311 \\
272 \\
344 \\
179 \\
247 \\
219 \\
178 \\
223 \\
73\end{array}$ & $\begin{array}{l}0.68 \\
0.96 \\
1.72 \\
1.58 \\
1.05 \\
0.94 \\
0.68 \\
0.96 \\
0.91 \\
0.55 \\
0.88 \\
0.54 \\
0.69 \\
0.98 \\
0.87 \\
0.32 \\
0.65 \\
0.27 \\
0.52 \\
0.38 \\
0.15 \\
0.39 \\
0.24 \\
0.16 \\
0.35 \\
0.12\end{array}$ & $\begin{array}{l}0.1 \\
0.6 \\
1.1 \\
2.9 \\
2.3 \\
3.1 \\
2.4 \\
4.2 \\
3.0 \\
0.9 \\
7.4 \\
2.9 \\
3.6 \\
80.9 \\
55.4 \\
1.7 \\
15.5 \\
1.4 \\
3.6 \\
3.2 \\
0.6 \\
3.4 \\
1.2 \\
0.8 \\
2.0 \\
0.1\end{array}$ \\
\hline
\end{tabular}


点

APPENDIX C (continued)

PERSONNEL, DOSE AND POWER GENERATION SUMMARY

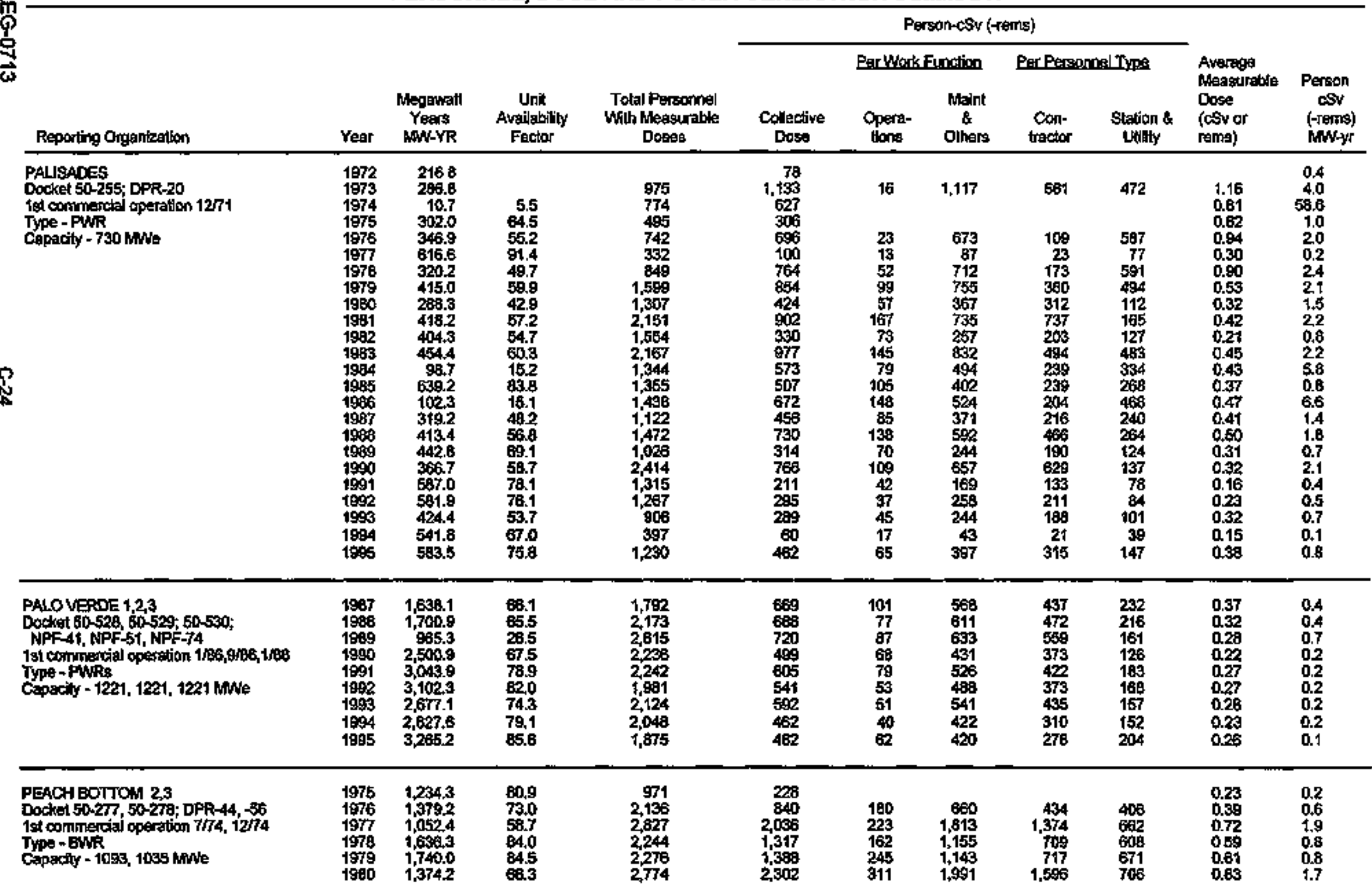


APPENDIX C (continued)

PERSONNEL, DOSE AND POWER GENERATION SUMMARY

\begin{tabular}{|c|c|c|c|c|c|c|c|c|c|c|c|}
\hline \multirow[b]{3}{*}{ Repporting Organtzation } & \multirow[b]{3}{*}{ Year } & \multirow[b]{3}{*}{$\begin{array}{c}\text { Meganatl } \\
\text { Yesis } \\
\text { MW-YR }\end{array}$} & \multirow[b]{3}{*}{$\begin{array}{l}\text { Unit } \\
\text { Avoitability } \\
\text { Factor }\end{array}$} & \multirow[b]{3}{*}{$\begin{array}{c}\text { Totel Personnel } \\
\text { With Measurgale } \\
\text { Doses }\end{array}$} & \multicolumn{5}{|c|}{ Persen-tsv (-rems) } & \multirow{3}{*}{$\begin{array}{l}\text { Average } \\
\text { Measurable } \\
\text { Dose } \\
\text { (c) or } \\
\text { tems) }\end{array}$} & \multirow[b]{3}{*}{$\begin{array}{l}\text { Person } \\
\text { osv } \\
\text { (-reans) } \\
\text { Muryyr }\end{array}$} \\
\hline & & & & & \multicolumn{3}{|c|}{ Perwork Function } & \multicolumn{2}{|c|}{ Per Personoed Tyes } & & \\
\hline & & & & & $\begin{array}{l}\text { Collective } \\
\text { Dose }\end{array}$ & $\begin{array}{c}\text { Opere- } \\
\text { tions }\end{array}$ & $\begin{array}{l}\text { Maink } \\
\& \\
\text { Others }\end{array}$ & $\begin{array}{l}\text { Cont } \\
\text { Iractor }\end{array}$ & $\begin{array}{c}\text { Stalion \& } \\
\text { Utitity }\end{array}$ & & \\
\hline PEACH BOTTOM 2,3 (comlinued) & $\begin{array}{l}1981 \\
1962 \\
1063 \\
1964 \\
1965 \\
1986 \\
1967 \\
1968 \\
1969 \\
1990 \\
1991 \\
1992 \\
1993 \\
1994 \\
1995\end{array}$ & $\begin{array}{r}1,161.8 \\
1,583.3 \\
924.7 \\
1,165.8 \\
692.7 \\
1,395.0 \\
385.7 \\
0.0 \\
491.0 \\
1,684.0 \\
1,210.9 \\
1,546.6 \\
1,6554.0 \\
1,927.4 \\
1,958.9\end{array}$ & $\begin{array}{r}58.0 \\
76.0 \\
41.0 \\
57.5 \\
37.5 \\
71.7 \\
20.3 \\
0.0 \\
35.0 \\
85.7 \\
62.3 \\
78.7 \\
81.9 \\
93.8 \\
95.1\end{array}$ & $\begin{array}{l}2,857 \\
2,734 \\
3,107 \\
3,313 \\
4,209 \\
2,454 \\
4,363 \\
4,204 \\
2,301 \\
1,585 \\
2,702 \\
1,911 \\
1,757 \\
2,133 \\
1,940\end{array}$ & $\begin{array}{r}2,506 \\
1,977 \\
2.963 \\
2,450 \\
3,354 \\
1,080 \\
2,195 \\
2,327 \\
729 \\
377 \\
934 \\
502 \\
655 \\
579 \\
308\end{array}$ & $\begin{array}{r}273 \\
313 \\
331 \\
225 \\
385 \\
294 \\
178 \\
114 \\
243 \\
99 \\
137 \\
121 \\
135 \\
97 \\
118\end{array}$ & $\begin{array}{r}2,233 \\
1,664 \\
2,632 \\
2,225 \\
2,959 \\
786 \\
2,017 \\
2,243 \\
485 \\
278 \\
797 \\
3381 \\
417 \\
482 \\
280\end{array}$ & $\begin{array}{r}1,160 \\
1,348 \\
2,422 \\
2,4045 \\
2,727 \\
671 \\
1,712 \\
2,025 \\
357 \\
179 \\
610 \\
255 \\
282 \\
374 \\
226\end{array}$ & $\begin{array}{l}626 \\
629 \\
541 \\
405 \\
627 \\
409 \\
483 \\
302 \\
371 \\
196 \\
324 \\
246 \\
260 \\
265 \\
172\end{array}$ & $\begin{array}{l}0.86 \\
0.72 \\
0.95 \\
0.74 \\
0.80 \\
0.44 \\
0.50 \\
0.55 \\
0.32 \\
0.24 \\
0.35 \\
0.28 \\
0.31 \\
0.27 \\
0.21\end{array}$ & $\begin{array}{l}2.2 \\
1.2 \\
3.6 \\
2.1 \\
4.9 \\
0.8 \\
6.0 \\
1.5 \\
0.2 \\
0.8 \\
0.3 \\
0.3 \\
0.3 \\
0.2\end{array}$ \\
\hline $\begin{array}{l}\text { PERRY } \\
\text { Docket 50-440; NFF.58 } \\
\text { 1At commercial operation 11/87 } \\
\text { Type- BWR } \\
\text { Capady - 1166 MWo } \\
.\end{array}$ & $\begin{array}{l}1998 \\
1999 \\
1990 \\
1991 \\
1992 \\
1993 \\
1994 \\
1995\end{array}$ & $\begin{array}{r}869.3 \\
642.2 \\
702.7 \\
1,074.2 \\
846.2 \\
478.2 \\
550.8 \\
1,090.9\end{array}$ & $\begin{array}{l}79.0 \\
67.0 \\
67.1 \\
91.9 \\
75.6 \\
48.2 \\
50.2 \\
85.6\end{array}$ & $\begin{array}{r}788 \\
1,883 \\
1,637 \\
600 \\
1,487 \\
1,225 \\
2,098 \\
587\end{array}$ & $\begin{array}{r}1015 \\
767 \\
638 \\
146 \\
571 \\
278 \\
691 \\
64\end{array}$ & $\begin{array}{r}34 \\
113 \\
51 \\
24 \\
28 \\
30 \\
71 \\
13\end{array}$ & $\begin{array}{r}71 \\
654 \\
587 \\
122 \\
543 \\
248 \\
620 \\
51\end{array}$ & $\begin{array}{r}36 \\
604 \\
194 \\
50 \\
440 \\
106 \\
529 \\
17\end{array}$ & $\begin{array}{r}69 \\
163 \\
144 \\
66 \\
131 \\
172 \\
162 \\
47\end{array}$ & $\begin{array}{l}0.13 \\
0.41 \\
0.42 \\
0.24 \\
0.38 \\
0.23 \\
0.33 \\
0.11\end{array}$ & $\begin{array}{l}0.1 \\
1.2 \\
0.1 \\
0.1 \\
0.7 \\
0.6 \\
1.3 \\
0.1\end{array}$ \\
\hline $\begin{array}{l}\text { PILGRIM 1 } \\
\text { Docket 50-293; DPR-35 } \\
\text { 1st cormmercial operalion } 1272 \\
\text { Type - BWTR } \\
\text { Copacty - } 670 \text { MWe }\end{array}$ & $\begin{array}{l}1973 \\
1974 \\
1975 \\
1975 \\
1977 \\
1978 \\
1979 \\
1990 \\
1981 \\
1982 \\
1983 \\
1984 \\
1985 \\
1996 \\
1987 \\
1998\end{array}$ & $\begin{array}{r}484.0 \\
234.1 \\
301.1 \\
2887.8 \\
311.8 \\
519.5 \\
574.0 \\
360.3 \\
40.3 \\
369.9 \\
555.5 \\
1.4 \\
587.3 \\
12.9 \\
0.0 \\
0.0\end{array}$ & $\begin{array}{r}39.2 \\
71.3 \\
60.7 \\
61.4 \\
83.1 \\
89.4 \\
56.2 \\
63.9 \\
63.9 \\
87.2 \\
0.4 \\
91.5 \\
19.8 \\
0.0 \\
0.0\end{array}$ & $\begin{array}{r}230 \\
454 \\
473 \\
1,317 \\
1,875 \\
1,697 \\
2,458 \\
3,549 \\
2,803 \\
2,854 \\
2,326 \\
4,542 \\
2,209 \\
2,635 \\
4,710 \\
2,073\end{array}$ & $\begin{array}{r}128 \\
415 \\
798 \\
2,648 \\
3,142 \\
1,327 \\
1,015 \\
3,626 \\
1,836 \\
1,639 \\
1,162 \\
4,062 \\
8963 \\
674 \\
1,579 \\
392\end{array}$ & $\begin{array}{r}49 \\
142 \\
68 \\
145 \\
187 \\
130 \\
207 \\
70 \\
314 \\
296 \\
647 \\
13 \\
110 \\
99 \\
63\end{array}$ & $\begin{array}{r}77 \\
656 \\
2,582 \\
2,996 \\
1,170 \\
685 \\
3,419 \\
1,758 \\
1,225 \\
836 \\
3,435 \\
880 \\
764 \\
1,480 \\
334\end{array}$ & $\begin{array}{r}412 \\
2,270 \\
2,176 \\
895 \\
516 \\
3,076 \\
1,418 \\
1,094 \\
3,76 \\
3,767 \\
739 \\
718 \\
1,465 \\
213\end{array}$ & $\begin{array}{l}396 \\
376 \\
966 \\
435 \\
499 \\
550 \\
418 \\
445 \\
386 \\
315 \\
154 \\
158 \\
94 \\
174\end{array}$ & $\begin{array}{l}0.55 \\
0.94 \\
1.69 \\
2.04 \\
1.69 \\
0.60 \\
0.41 \\
1.02 \\
0.66 \\
0.54 \\
0.50 \\
0.90 \\
0.40 \\
0.33 \\
0.34 \\
0.19\end{array}$ & $\begin{array}{r}0.3 \\
1.8 \\
2.6 \\
9.2 \\
9.9 \\
2.6 \\
1.8 \\
10.1 \\
4.5 \\
3.9 \\
2.1 \\
15.7 \\
1.5 \\
7.2 \\
=\end{array}$ \\
\hline
\end{tabular}




\begin{tabular}{|c|c|c|c|c|c|c|c|c|c|c|c|}
\hline \multirow{4}{*}{ 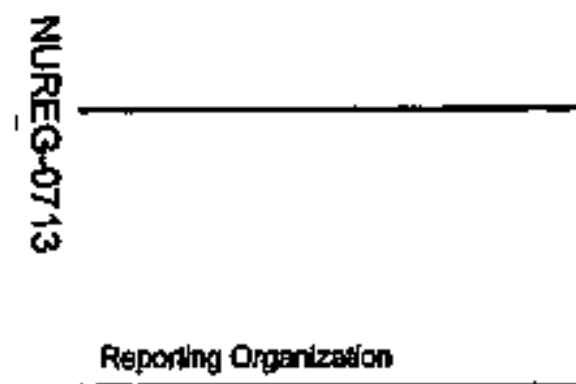 } & \multicolumn{9}{|c|}{$\begin{array}{l}\text { APPENDIX C (continued) } \\
\text { PERSONNEL, DOSE AND POWER GENERATION SUMPARY }\end{array}$} & \multirow{4}{*}{$\begin{array}{l}\text { Average } \\
\text { Measurable } \\
\text { Dose } \\
\text { (c5v ar } \\
\text { rams) }\end{array}$} & \multirow[b]{4}{*}{$\begin{array}{l}\text { Person } \\
\text { cSW } \\
(-1 \mathrm{~m} 8) \\
\text { hin-yr }\end{array}$} \\
\hline & & \multirow[b]{3}{*}{$\begin{array}{l}\text { Megawat } \\
\text { Years } \\
\text { MWK-YR }\end{array}$} & \multirow[b]{3}{*}{$\begin{array}{l}\text { Unit } \\
\text { Awallablily } \\
\text { Fackor }\end{array}$} & \multirow[b]{3}{*}{$\begin{array}{c}\text { Total Personnet } \\
\text { With Heasurable } \\
\text { Doses }\end{array}$} & \multicolumn{5}{|c|}{ Person-csv (-nems) } & & \\
\hline & & & & & \multicolumn{3}{|c|}{ Per Work Function } & \multicolumn{2}{|c|}{ Peq Personnel Type } & & \\
\hline & Year & & & & $\begin{array}{c}\text { Collieclive } \\
\text { Dose }\end{array}$ & $\begin{array}{l}\text { Opera- } \\
\text { tions }\end{array}$ & $\begin{array}{c}\text { Maint } \\
\& \\
\text { Others }\end{array}$ & $\begin{array}{c}\text { Con. } \\
\text { frastor }\end{array}$ & $\begin{array}{c}\text { Stalion \& } \\
\text { Ulitiky }\end{array}$ & & \\
\hline PILGRIM 1 (continued) & $\begin{array}{l}1989 \\
1990 \\
1991 \\
1992 \\
1993 \\
1994 \\
1995\end{array}$ & $\begin{array}{l}204.6 \\
\mathbf{5 0 3 . 5} \\
\mathbf{4 0 6 . 3} \\
\mathbf{5 5 1 . 0} \\
\mathbf{5 1 3 . 7} \\
\mathbf{4 5 3 . 6} \\
\mathbf{5 3 1 . 7}\end{array}$ & $\begin{array}{l}64.1 \\
82.1 \\
65.8 \\
86.4 \\
80.9 \\
71.4 \\
80.7\end{array}$ & $\begin{array}{r}1,797 \\
1,698 \\
2,636 \\
1,332 \\
1,328 \\
758 \\
1,294\end{array}$ & $\begin{array}{l}207 \\
225 \\
605 \\
281 \\
435 \\
200 \\
482\end{array}$ & $\begin{array}{c}137 \\
112 \\
113 \\
50 \\
54 \\
41 \\
55\end{array}$ & $\begin{array}{r}70 \\
113 \\
492 \\
231 \\
381 \\
159 \\
427\end{array}$ & $\begin{array}{r}40 \\
68 \\
410 \\
122 \\
283 \\
79 \\
297\end{array}$ & $\begin{array}{l}167 \\
157 \\
195 \\
159 \\
152 \\
121 \\
185\end{array}$ & $\begin{array}{l}0.12 \\
0.12 \\
0.21 \\
0.21 \\
0.93 \\
0.26 \\
0.37\end{array}$ & $\begin{array}{l}t .0 \\
0.4 \\
1.5 \\
0.5 \\
0.8 \\
0.4 \\
0.9\end{array}$ \\
\hline 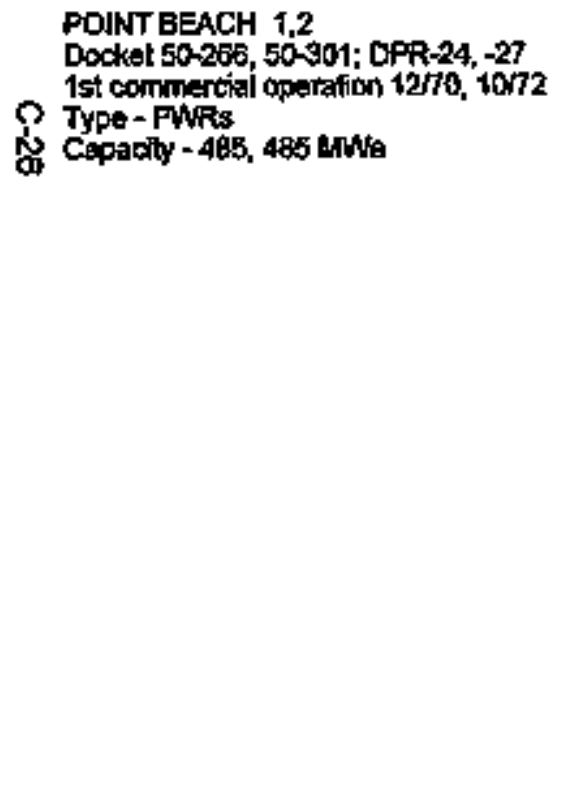 & $\begin{array}{l}1971 \\
1972 \\
1973 \\
1974 \\
1975 \\
1976 \\
1977 \\
1978 \\
1979 \\
1980 \\
1991 \\
1982 \\
1963 \\
1994 \\
1985 \\
1966 \\
1987 \\
1998 \\
1989 \\
1990 \\
1991 \\
1992 \\
1993 \\
1994 \\
1995\end{array}$ & 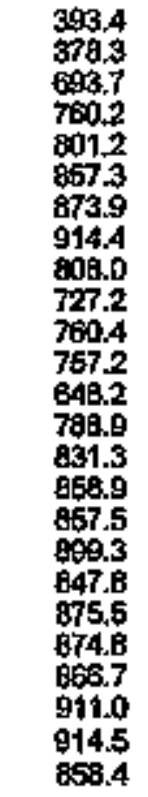 & $\begin{array}{l}91.3 \\
82.9 \\
86.7 \\
97.3 \\
90.9 \\
80.8 \\
82.5 \\
83.6 \\
84.3 \\
72.7 \\
78.6 \\
82.5 \\
85.7 \\
85.5 \\
86.6 \\
85.5 \\
86.5 \\
87.1 \\
85.8 \\
80.0 \\
91.2 \\
86.1\end{array}$ & $\begin{array}{r}501 \\
400 \\
339 \\
313 \\
417 \\
336 \\
510 \\
831 \\
773 \\
767 \\
1702 \\
1,372 \\
571 \\
564 \\
720 \\
734 \\
736 \\
817 \\
724 \\
617 \\
559 \\
548 \\
549\end{array}$ & $\begin{array}{r}164 \\
580 \\
588 \\
295 \\
459 \\
470 \\
370 \\
430 \\
320 \\
644 \\
598 \\
596 \\
609 \\
1.403 \\
789 \\
492 \\
402 \\
554 \\
410 \\
504 \\
378 \\
265 \\
256 \\
486 \\
170 \\
\mathbf{7 9 0}\end{array}$ & $\begin{array}{c}72 \\
70 \\
58 \\
58 \\
71 \\
71 \\
65 \\
60 \\
63 \\
72 \\
61 \\
121 \\
71 \\
50 \\
55 \\
64 \\
77 \\
53 \\
42 \\
39 \\
28 \\
34 \\
29\end{array}$ & $\begin{array}{r}516 \\
225 \\
312 \\
312 \\
350 \\
249 \\
579 \\
598 \\
513 \\
537 \\
1.322 \\
668 \\
411 \\
352 \\
499 \\
346 \\
427 \\
325 \\
223 \\
217 \\
160 \\
136 \\
161\end{array}$ & $\begin{array}{r}81 \\
107 \\
212 \\
111 \\
440 \\
420 \\
364 \\
375 \\
1,184 \\
457 \\
242 \\
219 \\
339 \\
235 \\
284 \\
164 \\
134 \\
148 \\
53 \\
75 \\
92\end{array}$ & $\begin{array}{l}214 \\
263 \\
217 \\
209 \\
196 \\
178 \\
232 \\
234 \\
219 \\
332 \\
240 \\
183 \\
185 \\
175 \\
220 \\
217 \\
131 \\
139 \\
123 \\
85 \\
98\end{array}$ & $\begin{array}{l}1.17 \\
0.74 \\
1.35 \\
1.18 \\
1.03 \\
0.95 \\
1.06 \\
1.07 \\
0.77 \\
0.79 \\
0.82 \\
0.58 \\
0.72 \\
0.61 \\
0.7 \\
0.56 \\
0.69 \\
0.61 \\
0.37 \\
0.41 \\
0.33 \\
0.31 \\
0.35\end{array}$ & $\begin{array}{l}0.4 \\
1.5 \\
0.8 \\
0.4 \\
0.6 \\
0.4 \\
0.5 \\
0.3 \\
0.8 \\
0.8 \\
0.8 \\
0.8 \\
2.2 \\
1.0 \\
0.5 \\
0.5 \\
0.6 \\
0.5 \\
0.8 \\
0.4 \\
0.3 \\
0.3 \\
0.2 \\
0.2 \\
0.2\end{array}$ \\
\hline 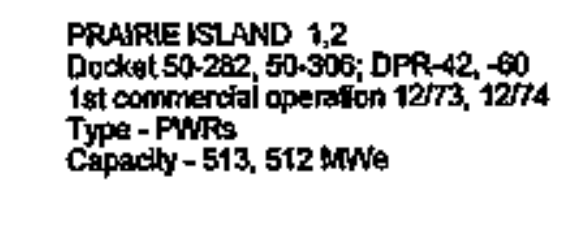 & $\begin{array}{l}1974 \\
1975 \\
1975 \\
1977 \\
1978 \\
1979 \\
19190\end{array}$ & $\begin{array}{l}181.9 \\
630.0 \\
725.2 \\
922.9 \\
941.1 \\
865.0 \\
800.7\end{array}$ & $\begin{array}{l}43.9 \\
83.3 \\
76.6 \\
87.2 \\
92.2 \\
88.0 \\
79.9\end{array}$ & $\begin{array}{l}150 \\
477 \\
818 \\
718 \\
546 \\
694 \\
983\end{array}$ & $\begin{array}{r}18 \\
123 \\
447 \\
300 \\
221 \\
180 \\
363\end{array}$ & $\begin{array}{l}69 \\
73 \\
49 \\
29 \\
40\end{array}$ & $\begin{array}{l}379 \\
227 \\
178 \\
131 \\
353\end{array}$ & $\begin{array}{r}5 \\
235 \\
60 \\
48 \\
49 \\
141\end{array}$ & $\begin{array}{r}13 \\
212 \\
240 \\
173 \\
131 \\
212\end{array}$ & $\begin{array}{l}0.12 \\
0.26 \\
0.85 \\
0.42 \\
0.40 \\
0.30 \\
0.38\end{array}$ & $\begin{array}{l}0.1 \\
0.1 \\
0.6 \\
0.3 \\
0.2 \\
0.2 \\
0.4\end{array}$ \\
\hline
\end{tabular}


APPENDIX C (continued)

PERSONNEL, DOSE AND POWER GENERATION SUMNIARY

\begin{tabular}{|c|c|c|c|c|c|c|c|c|c|c|c|}
\hline \multirow[b]{3}{*}{ Raporting Organizalion } & \multirow[b]{3}{*}{ Year } & \multirow[b]{3}{*}{$\begin{array}{l}\text { Megawalt } \\
\text { Years } \\
\text { MWYYR }\end{array}$} & \multirow[b]{3}{*}{$\begin{array}{l}\text { Whit } \\
\text { Avaliabily } \\
\text { Fector }\end{array}$} & \multirow[b]{3}{*}{$\begin{array}{c}\text { Total Personnef } \\
\text { Whth Weasuratide } \\
\text { Doses }\end{array}$} & \multicolumn{5}{|c|}{ Person-ssv (-rems) } & \multirow{3}{*}{$\begin{array}{l}\text { Average } \\
\text { Neasurable } \\
\text { Dose } \\
\text { (cSv or } \\
\text { rems) }\end{array}$} & \multirow{3}{*}{$\begin{array}{c}\text { Persen } \\
\text { Siv } \\
\text { (-1ems) } \\
\text { hin-yr }\end{array}$} \\
\hline & & & & & & \multicolumn{2}{|c|}{ PerrWorkFunction } & \multicolumn{2}{|c|}{ 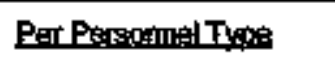 } & & \\
\hline & & & & & $\begin{array}{l}\text { Collectitio } \\
\text { Dose }\end{array}$ & $\begin{array}{c}\text { Opera } \\
\text { thons }\end{array}$ & $\begin{array}{c}\text { Meint } \\
\text { \& } \\
\text { Others }\end{array}$ & $\begin{array}{c}\text { Cort } \\
\text { tractor }\end{array}$ & $\begin{array}{c}\text { Station \& } \\
\text { Llithy }\end{array}$ & & \\
\hline PRAIREE ISLAND 1,2 (COKAnLOEd) & $\begin{array}{l}1981 \\
1982 \\
1983 \\
1984 \\
1985 \\
1965 \\
1987 \\
1968 \\
1969 \\
1990 \\
1991 \\
1998 \\
1993 \\
1994 \\
1995\end{array}$ & $\begin{array}{r}844.9 \\
944.9 \\
921.1 \\
972.4 \\
882.6 \\
930.6 \\
969.6 \\
932.0 \\
1,001.8 \\
925.4 \\
1,029.3 \\
811.6 \\
978.3 \\
996.9 \\
1,023.2\end{array}$ & $\begin{array}{l}80.5 \\
90.4 \\
95.8 \\
91.7 \\
84.0 \\
90.3 \\
91.6 \\
89.1 \\
94.7 \\
89.2 \\
95.6 \\
76.2 \\
90.7 \\
91.5 \\
93.9\end{array}$ & $\begin{array}{r}838 \\
645 \\
654 \\
548 \\
1,082 \\
818 \\
593 \\
732 \\
475 \\
737 \\
585 \\
845 \\
532 \\
478 \\
499\end{array}$ & $\begin{array}{r}329 \\
229 \\
293 \\
147 \\
416 \\
255 \\
135 \\
199 \\
99 \\
198 \\
98 \\
211 \\
105 \\
109 \\
107\end{array}$ & $\begin{array}{c}37 \\
30 \\
14 \\
18 \\
31 \\
18 \\
9 \\
17 \\
10 \\
8 \\
10 \\
12 \\
5 \\
17 \\
11\end{array}$ & $\begin{array}{r}292 \\
199 \\
219 \\
129 \\
385 \\
237 \\
126 \\
182 \\
69 \\
180 \\
68 \\
189 \\
101 \\
92 \\
96\end{array}$ & $\begin{array}{r}728 \\
68 \\
73 \\
52 \\
136 \\
80 \\
51 \\
62 \\
28 \\
74 \\
28 \\
72 \\
32 \\
41 \\
40\end{array}$ & $\begin{array}{r}201 \\
161 \\
160 \\
95 . \\
280 \\
175 \\
84 \\
137 \\
71 \\
114 \\
72 \\
139 \\
74 \\
68 \\
67\end{array}$ & $\begin{array}{l}0.39 \\
0.36 \\
0.36 \\
0.27 \\
0.39 \\
0.34 \\
0.23 \\
0.27 \\
0.21 \\
0.28 \\
0.17 \\
0.25 \\
0.20 \\
0.23 \\
0.21\end{array}$ & $\begin{array}{l}0.4 \\
0.2 \\
0.3 \\
0.2 \\
0.5 \\
0.3 \\
0.1 \\
0.2 \\
0.1 \\
0.2 \\
0.1 \\
0.3 \\
0.1 \\
0.1 \\
0.1\end{array}$ \\
\hline 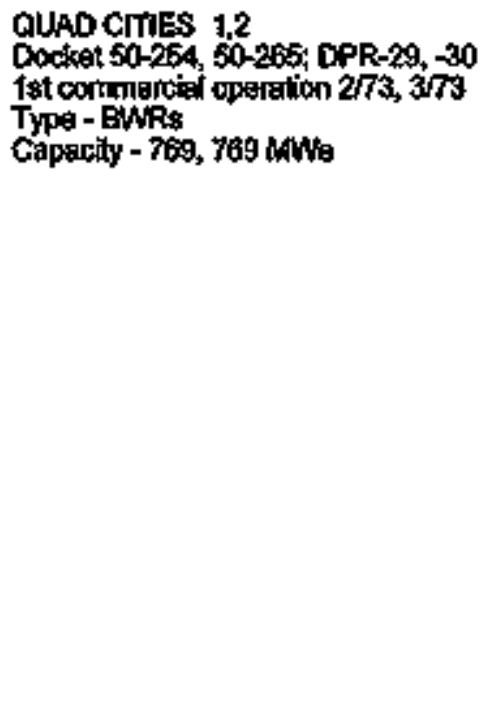 & $\begin{array}{l}1974 \\
1975 \\
1978 \\
1977 \\
1978 \\
1979 \\
1990 \\
1981 \\
1992 \\
1989 \\
1984 \\
1935 \\
1986 \\
1997 \\
1988 \\
1999 \\
1990 \\
1991 \\
1992 \\
1993 \\
1994 \\
1995\end{array}$ & $\begin{array}{r}959.1 \\
933.6 \\
951.2 \\
970.1 \\
1,124.5 \\
1,075.0 \\
806.9 \\
1,166.9 \\
1,018.7 \\
1,086.5 \\
994.6 \\
1,268.0 \\
1,093.2 \\
1,426.6 \\
1,173.7 \\
1,196.3 \\
1,148.9 \\
1,044.5 \\
960.8 \\
974.9 \\
681.5 \\
1,0025\end{array}$ & $\begin{array}{l}72.3 \\
68.4 \\
73.1 \\
84.0 \\
89.6 \\
84.6 \\
84.4 \\
81.1 \\
76.0 \\
79.2 \\
65.7 \\
82.7 \\
71.0 \\
75.3 \\
84.1 \\
65.9 \\
77.8 \\
73.2 \\
68.0 \\
67.0 \\
48.7 \\
70.4\end{array}$ & $\begin{array}{r}678 \\
1,083 \\
1,225 \\
9,907 \\
1,207 \\
1,698 \\
3,089 \\
2,245 \\
2,914 \\
1,002 \\
1,678 \\
1,184 \\
1,481 \\
1,429 \\
1,486 \\
1,721 \\
2,186 \\
1,722 \\
2,413 \\
2,150 \\
2,163 \\
2,041\end{array}$ & $\begin{array}{r}489 \\
1,610 \\
1,651 \\
1,031 \\
1,618 \\
2,159 \\
4,039 \\
3,146 \\
3,757 \\
2,491 \\
1,979 \\
990 \\
950 \\
720 \\
627 \\
900 \\
1,028 \\
509 \\
1,157 \\
849 \\
1,128 \\
730\end{array}$ & $\begin{array}{l}114 \\
269 \\
106 \\
358 \\
215 \\
291 \\
190 \\
177 \\
168 \\
122 \\
172 \\
128 \\
79 \\
135 \\
143 \\
193 \\
107 \\
168 \\
131 \\
144 \\
101\end{array}$ & $\begin{array}{l}1,504 \\
1,302 \\
923 \\
1,260 \\
t, 943 \\
4,547 \\
3,046 \\
3,690 \\
2,323 \\
1,467 \\
818 \\
822 \\
641 \\
691 \\
757 \\
845 \\
402 \\
999 \\
719 \\
984 \\
655\end{array}$ & $\begin{array}{r}36 \\
692 \\
648 \\
373 \\
729 \\
1,250 \\
3,657 \\
2,623 \\
2,653 \\
1,996 \\
1,075 \\
27 \\
656 \\
435 \\
645 \\
616 \\
713 \\
292 \\
754 \\
491 \\
799 \\
441\end{array}$ & $\begin{array}{r}446 \\
926 \\
1,003 \\
659 \\
1,618 \\
909 \\
1,181 \\
503 \\
1,904 \\
593 \\
504 \\
903 \\
392 \\
285 \\
282 \\
284 \\
315 \\
217 \\
403 \\
358 \\
339 \\
295\end{array}$ & $\begin{array}{l}0.71 \\
1.49 \\
1.35 \\
1.14 \\
1.34 \\
1.28 \\
1.67 \\
1.40 \\
1.82 \\
1.38 \\
0.94 \\
0.84 \\
0.65 \\
0.50 \\
0.58 \\
0.52 \\
0.47 \\
0.30 \\
0.48 \\
0.39 \\
0.52 \\
0.36\end{array}$ & $\begin{array}{l}0.5 \\
1.9 \\
1.7 \\
1.1 \\
1.4 \\
2.0 \\
5.6 \\
2.7 \\
9.7 \\
2.3 \\
1.6 \\
0.8 \\
0.9 \\
0.6 \\
0.7 \\
0.8 \\
0.9 \\
0.5 \\
1.2 \\
0.9 \\
1.7 \\
0.7\end{array}$ \\
\hline
\end{tabular}




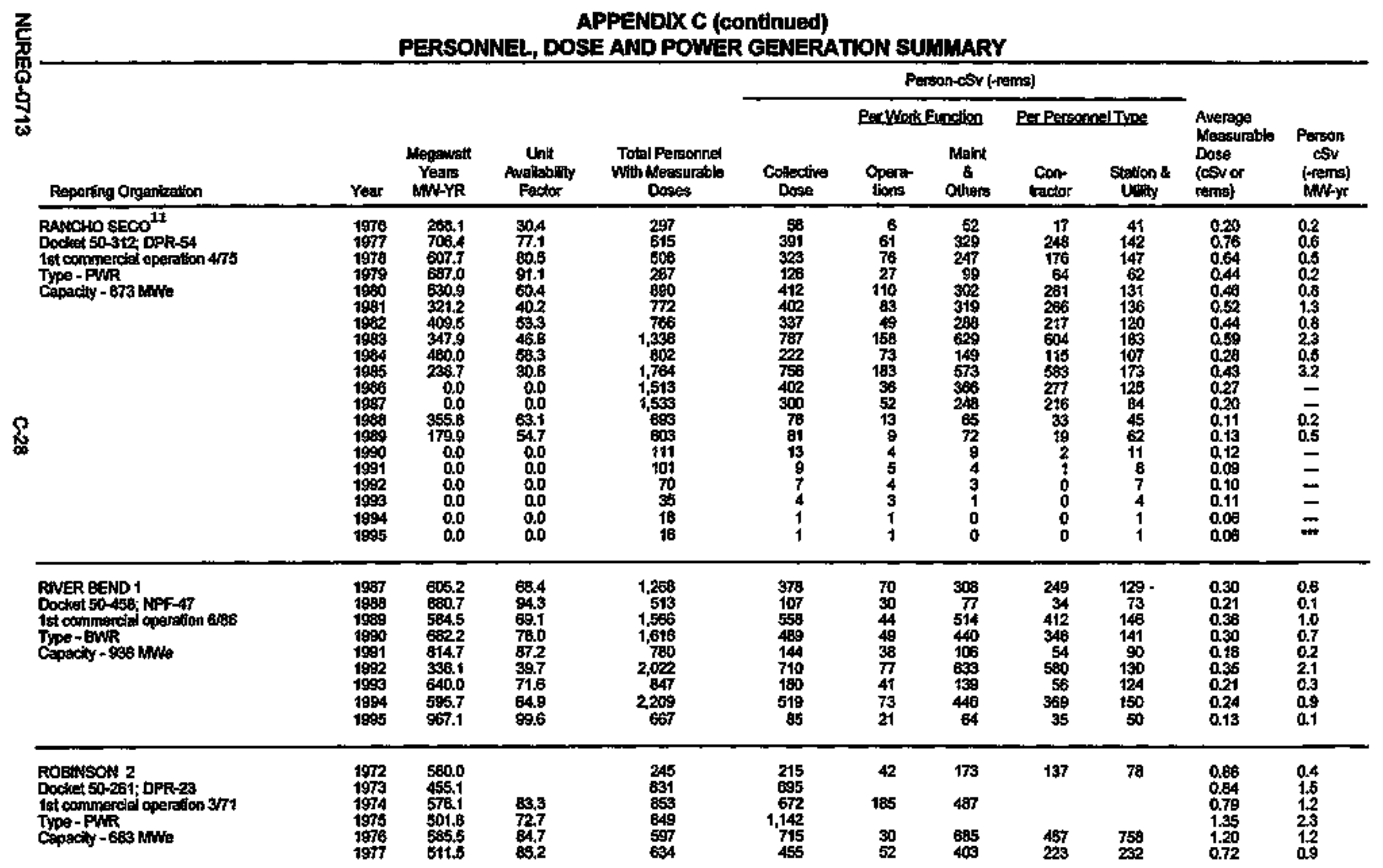

${ }^{11}$ Rancino sees hes been permanenty studidown. 
APPENDIX C (continued)

PERSONNEL, DOSE AND POWER GENERATION SUMMAARY

\begin{tabular}{|c|c|c|c|c|c|c|c|c|c|c|c|}
\hline \multirow[b]{3}{*}{ Reperting Orgenization } & \multirow[b]{3}{*}{ Year } & \multirow[b]{3}{*}{$\begin{array}{l}\text { Meagumatt } \\
\text { Years } \\
\text { MW-YR }\end{array}$} & \multirow[b]{3}{*}{$\begin{array}{l}\text { Init } \\
\text { Avaliablity } \\
\text { Factor }\end{array}$} & \multirow[b]{3}{*}{$\begin{array}{c}\text { Total Personined } \\
\text { With Measurable } \\
\text { Dusess }\end{array}$} & \multicolumn{5}{|c|}{ Persorasv (-rems) } & \multirow{3}{*}{$\begin{array}{l}\text { Average } \\
\text { Mersurable } \\
\text { Dose } \\
\text { (civ or } \\
\text { reng) }\end{array}$} & \multirow{3}{*}{$\begin{array}{l}\text { Person } \\
\text { esv } \\
\text { (trems) } \\
\text { MAN-yr }\end{array}$} \\
\hline & & & & & & \multicolumn{2}{|c|}{ Per Whotk Function } & \multicolumn{2}{|c|}{ Per Persennter Types } & & \\
\hline & & & & & $\begin{array}{l}\text { Collective } \\
\text { Doses }\end{array}$ & $\begin{array}{c}\text { Opera- } \\
\text { tions }\end{array}$ & $\begin{array}{c}\text { Meint } \\
\& \\
\text { Others }\end{array}$ & $\begin{array}{l}\text { Con- } \\
\text { tractor }\end{array}$ & $\begin{array}{c}\text { Stalion \& } \\
\text { U:IIty }\end{array}$ & & \\
\hline ROBINSON 2 (continued) & 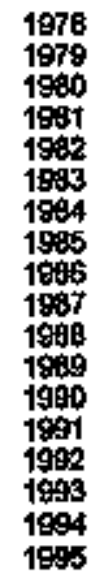 & 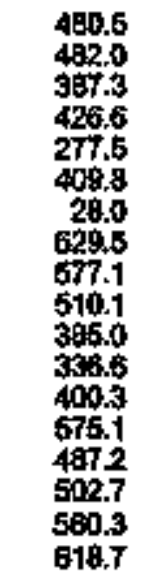 & $\begin{array}{l}72.0 \\
70.8 \\
692 \\
73.0 \\
49.9 \\
75.5 \\
7.0 \\
97.9 \\
80.9 \\
72.5 \\
69.9 \\
49.7 \\
64.9 \\
81.4 \\
66.9 \\
70.7 \\
79.5 \\
84.7\end{array}$ & $\begin{array}{r}943 \\
1,454 \\
2,009 \\
1,462 \\
2,019 \\
2,244 \\
4,127 \\
1,378 \\
1,671 \\
1,379 \\
1,351 \\
1,098 \\
1,626 \\
685 \\
1,267 \\
1,221 \\
420 \\
1,058\end{array}$ & 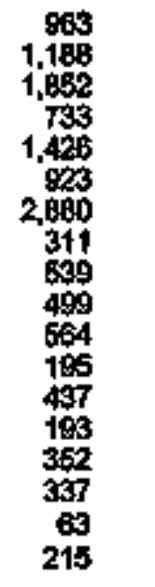 & $\begin{array}{c}63 \\
80 \\
79 \\
45 \\
128 \\
96 \\
196 \\
52 \\
46 \\
54 \\
44 \\
31 \\
33 \\
31 \\
51 \\
13 \\
99 \\
12\end{array}$ & $\begin{array}{r}900 \\
1,128 \\
1,773 \\
683 \\
1,298 \\
827 \\
2,684 \\
259 \\
493 \\
445 \\
620 \\
164 \\
404 \\
162 \\
301 \\
324 \\
54 \\
203\end{array}$ & $\begin{array}{r}529 \\
794 \\
1,379 \\
513 \\
945 \\
628 \\
2.549 \\
164 \\
340 \\
313 \\
370 \\
38 \\
356 \\
139 \\
260 \\
246 \\
17 \\
111\end{array}$ & $\begin{array}{l}434 \\
394 \\
473 \\
220 \\
481 \\
295 \\
331 \\
147 \\
199 \\
188 \\
194 \\
107 \\
81 \\
54 \\
92 \\
91 \\
46 \\
104\end{array}$ & $\begin{array}{l}1.02 \\
0.82 \\
0.92 \\
0.50 \\
0.71 \\
0.41 \\
0.70 \\
0.23 \\
0.34 \\
0.36 \\
0.42 \\
0.18 \\
0.27 \\
0.22 \\
0.28 \\
0.28 \\
0.16 \\
0.20\end{array}$ & $\begin{array}{r}2.0 \\
2.5 \\
4.8 \\
1.7 \\
5.1 \\
2.3 \\
102.9 \\
0.5 \\
0.9 \\
1.0 \\
1.5 \\
0.6 \\
1.1 \\
0.3 \\
0.7 \\
0.7 \\
0.1 \\
0.3\end{array}$ \\
\hline 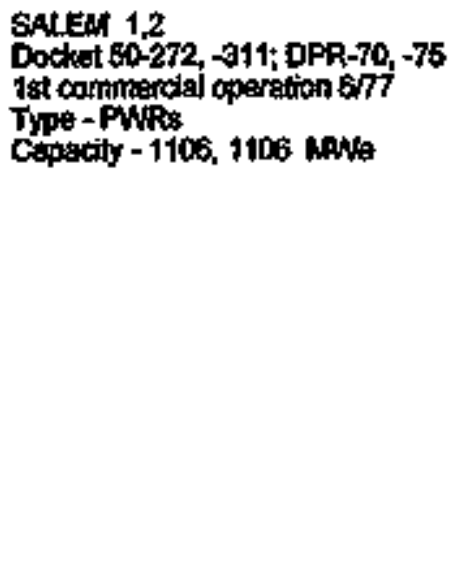 & $\begin{array}{l}1978 \\
1979 \\
1990 \\
1981 \\
1992 \\
1993 \\
1994 \\
1995 \\
1996 \\
1997 \\
1998 \\
1989 \\
1999 \\
1991 \\
1999 \\
1999 \\
1994 \\
1995\end{array}$ & $\begin{array}{r}546.4 \\
250.0 \\
590.6 \\
743.0 \\
1,440.4 \\
742.0 \\
650.1 \\
1,657.7 \\
1,434.3 \\
1,478.2 \\
1,591.6 \\
1,675.4 \\
1,362.6 \\
1,726.4 \\
1,200.9 \\
1,365.3 \\
1,367.4 \\
558.1\end{array}$ & $\begin{array}{l}55.6 \\
25.5 \\
69.2 \\
70.1 \\
72.6 \\
30.5 \\
31.9 \\
75.8 \\
70.4 \\
73.3 \\
73.6 \\
70.5 \\
65.1 \\
70.3 \\
61.1 \\
65.4 \\
73.1 \\
29.3\end{array}$ & $\begin{array}{r}574 \\
1,488 \\
1,704 \\
1,652 \\
3,228 \\
2,, 763 \\
1,395 \\
1,112 \\
3,564 \\
2,543 \\
1,609 \\
2,944 \\
3,636 \\
4,201 \\
4,376 \\
3,569 \\
950 \\
1,196\end{array}$ & $\begin{array}{r}122 \\
584 \\
449 \\
254 \\
1,203 \\
581 \\
681 \\
204 \\
599 \\
500 \\
603 \\
538 \\
372 \\
463 \\
431 \\
408 \\
198 \\
219\end{array}$ & $\begin{array}{r}28 \\
100 \\
55 \\
4 \\
66 \\
10 \\
10 \\
59 \\
10 \\
8 \\
1 \\
4 \\
6 \\
18 \\
16 \\
11 \\
2 \\
4\end{array}$ & $\begin{array}{r}94 \\
484 \\
394 \\
250 \\
1,137 \\
571 \\
671 \\
145 \\
589 \\
598 \\
508 \\
334 \\
266 \\
443 \\
415 \\
397 \\
186 \\
214\end{array}$ & $\begin{array}{l}32 \\
359 \\
281 \\
152 \\
846 \\
463 \\
469 \\
54 \\
459 \\
439 \\
329 \\
309 \\
169 \\
365 \\
340 \\
348 \\
122 \\
147\end{array}$ & $\begin{array}{r}90 \\
225 \\
169 \\
102 \\
357 \\
118 \\
212 \\
150 \\
140 \\
167 \\
174 \\
129 \\
84 \\
82 \\
91 \\
90 \\
65 \\
71\end{array}$ & $\begin{array}{l}0.21 \\
0.39 \\
0.28 \\
0.15 \\
0.37 \\
0.24 \\
0.49 \\
0.18 \\
0.17 \\
0.24 \\
0.31 \\
0.11 \\
0.07 \\
0.11 \\
0.10 \\
0.11 \\
0.20 \\
0.18\end{array}$ & $\begin{array}{l}0.2 \\
2.3 \\
0.7 \\
0.3 \\
0.8 \\
0.8 \\
1.0 \\
0.1 \\
0.4 \\
0.4 \\
0.3 \\
0.2 \\
0.2 \\
0.3 \\
0.4 \\
0.3 \\
0.1 \\
0.4\end{array}$ \\
\hline
\end{tabular}




\begin{tabular}{|c|c|c|c|c|c|c|c|c|c|c|c|}
\hline \multirow[b]{2}{*}{ Reporting Organization } & \multirow[b]{2}{*}{ Yạar } & \multirow[b]{2}{*}{$\begin{array}{l}\text { Megawatt } \\
\text { Years } \\
\text { MW-YR }\end{array}$} & \multirow[b]{2}{*}{$\begin{array}{l}\text { Unlt } \\
\text { Autilatility } \\
\text { Factor }\end{array}$} & \multirow[b]{2}{*}{$\begin{array}{c}\text { Tolal Personnel } \\
\text { Wiun Messuratle } \\
\text { Doses }\end{array}$} & $\begin{array}{l}\text { inwed) } \\
\text { ENERA }\end{array}$ & $\frac{\operatorname{TON} \mathrm{SL}}{\mathrm{P}}$ & $\frac{1.1 \mathrm{ARY}}{\operatorname{son} \cdot \operatorname{csv}(4)}$ & m5) & & \multirow[b]{2}{*}{$\begin{array}{l}\text { Average } \\
\text { Measurable } \\
\text { Dose } \\
\text { (cov or } \\
\text { rens) }\end{array}$} & \multirow[b]{2}{*}{$\begin{array}{c}\text { Person } \\
\text { esy } \\
\text { (-rems) } \\
\text { MAn-yr }\end{array}$} \\
\hline & & & & & & $\begin{array}{l}\text { Periphis } \\
\text { Opero- } \\
\text { thons }\end{array}$ & $\begin{array}{c}\text { hetnt } \\
\text { \& } \\
\text { Others }\end{array}$ & $\begin{array}{c}\text { Con- } \\
\text { tristor }\end{array}$ & $\begin{array}{l}\text { sidestion \& } \\
\text { UAtity }\end{array}$ & & \\
\hline 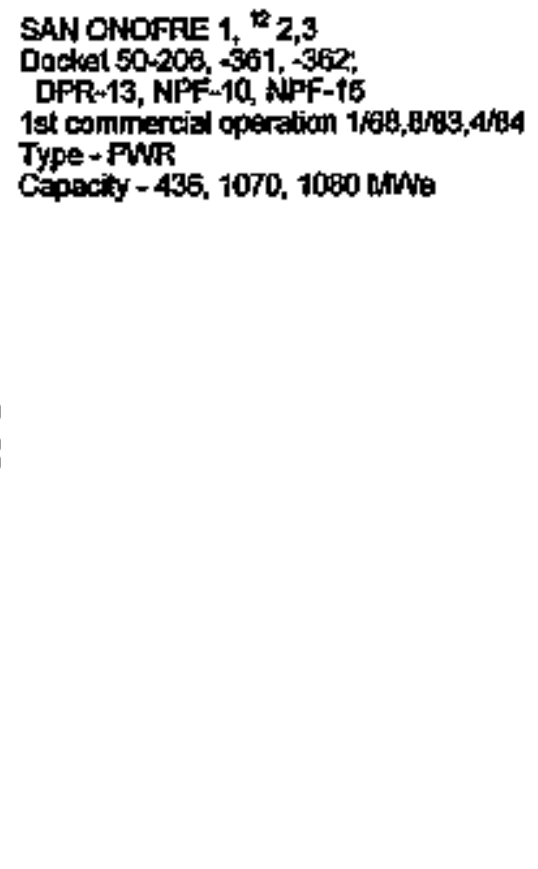 & $\begin{array}{l}1979 \\
1970 \\
1971 \\
1972 \\
1973 \\
1974 \\
1975 \\
1976 \\
1977 \\
1978 \\
1979 \\
1980 \\
1981 \\
1982 \\
1983 \\
1964 \\
1986 \\
1985 \\
1987 \\
1986 \\
1989 \\
1990 \\
1996 \\
1992 \\
1993 \\
1994 \\
1995\end{array}$ & $\begin{array}{r}314.1 \\
365.9 \\
362.1 \\
338.5 \\
273.7 \\
377.8 \\
389.0 \\
297.9 \\
291.2 \\
323.2 \\
401.0 \\
97.3 \\
95.9 \\
61.6 \\
0.0 \\
670.4 \\
1,381.9 \\
1,698.2 \\
1,989.0 \\
1,982.3 \\
1,940.8 \\
1,980.6 \\
1,967.6 \\
2,228.6 \\
1,771,3 \\
2,220,7 \\
1,686.9\end{array}$ & $\begin{array}{r}88.1 \\
87.4 \\
70.2 \\
63.7 \\
80.2 \\
90.2 \\
22.3 \\
28.7 \\
15.7 \\
0.0 \\
68.3 \\
132.9 \\
61.1 \\
79.8 \\
69.4 \\
69.9 \\
69.1 \\
76.3 \\
87.1 \\
79.9 \\
100.0 \\
79.1\end{array}$ & $\begin{array}{r}123 \\
251 \\
121 \\
328 \\
570 \\
219 \\
424 \\
1,390 \\
985 \\
764 \\
521 \\
3,063 \\
2,902 \\
3,055 \\
1,701 \\
7,614 \\
5,742 \\
3,604 \\
2,139 \\
2,324 \\
2,247 \\
2,224 \\
1,914 \\
1,651 \\
2,193 \\
529 \\
1,914\end{array}$ & $\begin{array}{r}42 \\
155 \\
50 \\
256 \\
353 \\
71 \\
292 \\
890 \\
947 \\
401 \\
139 \\
2,396 \\
3,223 \\
932 \\
155 \\
935 \\
722 \\
924 \\
996 \\
791 \\
647 \\
845 \\
412 \\
324 \\
767 \\
32 \\
455\end{array}$ & $\begin{array}{r}10 \\
13 \\
12 \\
29 \\
40 \\
\\
147 \\
77 \\
25 \\
23 \\
219 \\
100 \\
81 \\
31 \\
105 \\
16 \\
86 \\
113 \\
99 \\
23 \\
109 \\
43 \\
5 \\
89 \\
7 \\
0\end{array}$ & $\begin{array}{r}32 \\
142 \\
39 \\
227 \\
313 \\
\\
733 \\
770 \\
376 \\
116 \\
2.767 \\
3.123 \\
751 \\
124 \\
681 \\
173 \\
738 \\
685 \\
662 \\
644 \\
775 \\
339 \\
319 \\
676 \\
25 \\
455\end{array}$ & $\begin{array}{r}5 \\
59 \\
3 \\
117 \\
168 \\
\\
829 \\
451 \\
234 \\
65 \\
2,017 \\
3,104 \\
730 \\
113 \\
831 \\
181 \\
574 \\
499 \\
518 \\
397 \\
699 \\
269 \\
239 \\
599 \\
10 \\
301\end{array}$ & $\begin{array}{r}37 \\
96 \\
47 \\
139 \\
185 \\
\\
251 \\
396 \\
167 \\
74 \\
369 \\
119 \\
102 \\
42 \\
155 \\
39 \\
260 \\
289 \\
263 \\
250 \\
192 \\
123 \\
93 \\
169 \\
22 \\
154\end{array}$ & $\begin{array}{l}0.34 \\
0.62 \\
0.41 \\
0.79 \\
0.62 \\
0.32 \\
0.69 \\
0.66 \\
0.86 \\
0.52 \\
0.27 \\
0.78 \\
1.17 \\
0.27 \\
0.09 \\
0.27 \\
0.24 \\
0.24 \\
0.33 \\
0.34 \\
0.25 \\
0.40 \\
0.23 \\
0.20 \\
0.35 \\
0.00 \\
0.24\end{array}$ & $\begin{array}{r}0.1 \\
0.4 \\
0.1 \\
0.8 \\
1.3 \\
0.2 \\
0.0 \\
3.0 \\
3.0 \\
1.2 \\
0.3 \\
24.5 \\
33.6 \\
13.5 \\
1.5 \\
1.5 \\
1.5 \\
1.1 \\
0.4 \\
0.4 \\
0.3 \\
0.4 \\
0.2 \\
0.1 \\
0.4 \\
0.0 \\
0.3\end{array}$ \\
\hline 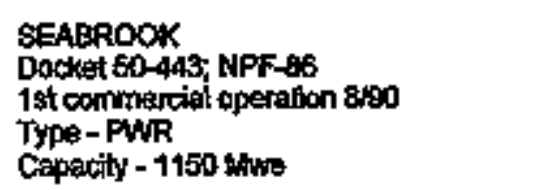 & $\begin{array}{l}1991 \\
1992 \\
1993 \\
1994 \\
1996\end{array}$ & $\begin{array}{r}910.4 \\
932.4 \\
1.071 .5 \\
736.4 \\
9 \$ 5.5\end{array}$ & $\begin{array}{l}76.9 \\
81.3 \\
82.6 \\
63.5 \\
67.5\end{array}$ & $\begin{array}{l}699 \\
600 \\
110 \\
962 \\
600\end{array}$ & $\begin{array}{r}92 \\
147 \\
6 \\
113 \\
102\end{array}$ & $\begin{array}{r}2 \\
0 \\
0 \\
28 \\
2 \\
2\end{array}$ & $\begin{array}{r}90 \\
147 \\
6 \\
85 \\
100\end{array}$ & $\begin{array}{r}49 \\
129 \\
6 \\
87 \\
70\end{array}$ & $\begin{array}{r}49 \\
19 \\
6 \\
26 \\
26\end{array}$ & $\begin{array}{l}0.13 \\
0.18 \\
0.05 \\
0.13 \\
0.13\end{array}$ & $\begin{array}{l}0.1 \\
0.2 \\
0.0 \\
0.2 \\
0.1\end{array}$ \\
\hline 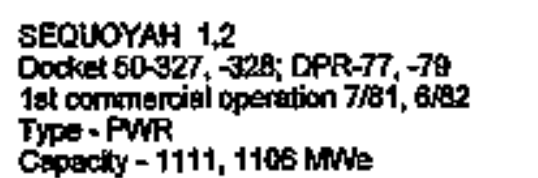 & $\begin{array}{l}1982 \\
1983 \\
1984 \\
1985 \\
1986\end{array}$ & $\begin{array}{r}583.5 \\
1,003.7 \\
1.481 .9 \\
1.151 .3 \\
0.0\end{array}$ & $\begin{array}{l}52.8 \\
75.1 \\
59.0 \\
51.3 \\
0.0\end{array}$ & $\begin{array}{l}1,905 \\
1,772 \\
2,373 \\
1,854 \\
1,736\end{array}$ & $\begin{array}{r}570 \\
491 \\
1.117 \\
1,071 \\
526\end{array}$ & $\begin{array}{r}73 \\
74 \\
152 \\
118 \\
101\end{array}$ & $\begin{array}{l}497 \\
417 \\
965 \\
953 \\
425\end{array}$ & $\begin{array}{r}61 \\
46 \\
111 \\
243 \\
70\end{array}$ & $\begin{array}{r}509 \\
445 \\
1,005 \\
628 \\
465\end{array}$ & $\begin{array}{l}0.29 \\
0.28 \\
0.47 \\
0.58 \\
0.30\end{array}$ & $\begin{array}{l}1,0 \\
0.3 \\
0.8 \\
0.9 \\
-\end{array}$ \\
\hline
\end{tabular}

12 Sen Onofie 1 was sher down $11 / 92$ and is no longer included in the count of commercial reactors. 
APPENDIX C (continued)

PERSONNEL, DOSE AND POWER GENERATION SUMMARY

\begin{tabular}{|c|c|c|c|c|c|c|c|c|c|c|c|}
\hline \multirow[b]{3}{*}{ Reporting Orgarization } & \multirow[b]{3}{*}{ Year } & \multirow[b]{3}{*}{$\begin{array}{l}\text { Megawalt } \\
\text { Ysers } \\
\text { MNE-YR }\end{array}$} & \multirow[b]{3}{*}{$\begin{array}{l}\text { Unit } \\
\text { Aveikability } \\
\text { Factor }\end{array}$} & \multirow[b]{3}{*}{$\begin{array}{c}\text { Total Personnel } \\
\text { With Meresurable } \\
\text { Doses }\end{array}$} & \multicolumn{5}{|c|}{ Person-cSv (-remt) } & \multirow{3}{*}{$\begin{array}{l}\text { Averitge } \\
\text { Measurable } \\
\text { Dose } \\
\text { (csiror } \\
\text { nems) }\end{array}$} & \multirow{3}{*}{ 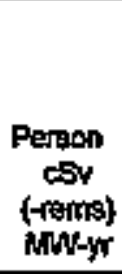 } \\
\hline & & & & & \multicolumn{3}{|c|}{ Fervorkfunction } & \multicolumn{2}{|c|}{ Per Rerronentroes } & & \\
\hline & & & & & $\begin{array}{l}\text { Colleclive } \\
\text { Doses }\end{array}$ & $\begin{array}{c}\text { Opera } \\
\text { bons }\end{array}$ & $\begin{array}{c}\text { Maink } \\
\text { \& } \\
\text { Others }\end{array}$ & $\begin{array}{l}\text { Cont } \\
\text { tracter }\end{array}$ & $\begin{array}{l}\text { Station \& } \\
\text { Utilty }\end{array}$ & & \\
\hline SEQUOVAH 1,2 (continted) & $\begin{array}{l}1987 \\
1988 \\
1999 \\
1990 \\
1991 \\
1992 \\
1993 \\
1994 \\
1995\end{array}$ & $\begin{array}{r}0.0 \\
490.8 \\
1,951.7 \\
1,662.8 \\
1,985.4 \\
1,849.0 \\
405.7 \\
1,418.7 \\
1,664.2\end{array}$ & $\begin{array}{r}0.0 \\
31.8 \\
85.7 \\
77.2 \\
68.0 \\
85.4 \\
21.8 \\
66.3 \\
60.1\end{array}$ & $\begin{array}{l}2,060 \\
2,439 \\
2,007 \\
2,934 \\
1,928 \\
1,714 \\
1,629 \\
1,657 \\
1,618\end{array}$ & $\begin{array}{r}420 \\
678 \\
657 \\
1,678 \\
699 \\
465 \\
372 \\
292 \\
358\end{array}$ & $\begin{array}{r}55 \\
73 \\
71 \\
102 \\
379 \\
39 \\
329 \\
29 \\
18 \\
28\end{array}$ & $\begin{array}{r}365 \\
605 \\
586 \\
1,576 \\
659 \\
433 \\
343 \\
274 \\
300\end{array}$ & $\begin{array}{l}101 \\
115 \\
140 \\
352 \\
299 \\
343 \\
272 \\
210 \\
250\end{array}$ & $\begin{array}{r}319 \\
563 \\
517 \\
1,326 \\
399 \\
122 \\
100 \\
62 \\
100\end{array}$ & $\begin{array}{l}0.20 \\
0.28 \\
0.33 \\
0.57 \\
0.36 \\
0.27 \\
0.23 \\
0.19 \\
0.22\end{array}$ & $\begin{array}{l}\overline{1.4} \\
0.4 \\
1.0 \\
0.4 \\
0.3 \\
0.9 \\
0.2 \\
0.2\end{array}$ \\
\hline 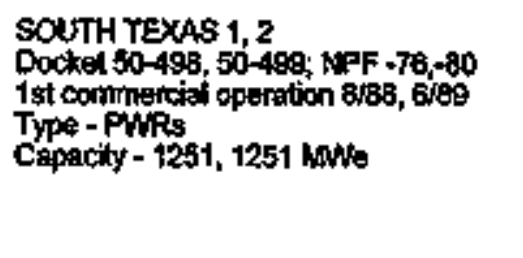 & $\begin{array}{l}1999 \\
1990 \\
1091 \\
1692 \\
1993 \\
1994 \\
1995\end{array}$ & $\begin{array}{r}769.3 \\
1,604.1 \\
1,741.8 \\
2,098.0 \\
163.1 \\
1,700.2 \\
2,294.2\end{array}$ & $\begin{array}{r}65.6 \\
65.9 \\
72.4 \\
89.4 \\
8.9 \\
70.6 \\
69.9\end{array}$ & $\begin{array}{r}989 \\
1,136 \\
1,144 \\
023 \\
1,138 \\
661 \\
1,495\end{array}$ & $\begin{array}{r}181 \\
206 \\
267 \\
147 \\
251 \\
47 \\
291\end{array}$ & $\begin{array}{c}10 \\
18 \\
38 \\
9 \\
12 \\
11 \\
15\end{array}$ & $\begin{array}{l}181 \\
189 \\
219 \\
139 \\
239 \\
36 \\
276\end{array}$ & $\begin{array}{r}114 \\
125 \\
172 \\
91 \\
197 \\
26 \\
209\end{array}$ & $\begin{array}{l}47 \\
60 \\
65 \\
56 \\
54 \\
21 \\
83\end{array}$ & $\begin{array}{l}0.16 \\
0.18 \\
0.22 \\
0.16 \\
0.22 \\
0.07 \\
0.20\end{array}$ & $\begin{array}{l}0.2 \\
0.1 \\
0.1 \\
0.1 \\
1.5 \\
0.0 \\
0.1\end{array}$ \\
\hline 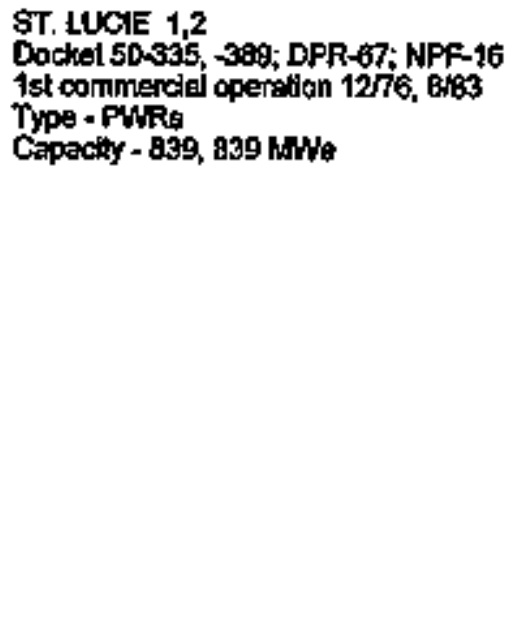 & $\begin{array}{l}1977 \\
1979 \\
1979 \\
1980 \\
1981 \\
1982 \\
1983 \\
1984 \\
1985 \\
1986 \\
1997 \\
1989 \\
1989 \\
1990 \\
1991 \\
1992 \\
1993 \\
1994 \\
1995\end{array}$ & $\begin{array}{r}849.1 \\
606.4 \\
5920 \\
627.9 \\
599.1 \\
816.8 \\
290.3 \\
1,193.0 \\
1,445.8 \\
1,588.6 \\
1,407.9 \\
1,639.7 \\
1,493.1 \\
1,186.4 \\
1,692.8 \\
1,511.9 \\
1,227.6 \\
1,424.8 \\
1,306.6\end{array}$ & $\begin{array}{l}84.7 \\
78.5 \\
74.0 \\
77.5 \\
72.7 \\
94.0 \\
15.4 \\
69.6 \\
82.5 \\
69.1 \\
91.9 \\
93.0 \\
86.1 \\
70.0 \\
90.8 \\
67.3 \\
77.7 \\
85.0 \\
76.0\end{array}$ & $\begin{array}{r}445 \\
797 \\
907 \\
1,074 \\
1,473 \\
1,045 \\
2,211 \\
2,090 \\
1,971 \\
1,279 \\
2,072 \\
1,446 \\
1,414 \\
1,876 \\
1,282 \\
1,261 \\
1,462 \\
1,693 \\
1,488\end{array}$ & $\begin{array}{r}152 \\
337 \\
438 \\
533 \\
929 \\
272 \\
1,204 \\
1,263 \\
1,344 \\
491 \\
951 \\
611 \\
496 \\
777 \\
479 \\
264 \\
492 \\
505 \\
413\end{array}$ & $\begin{array}{r}26 \\
15 \\
26 \\
62 \\
20 \\
17 \\
5 \\
40 \\
294 \\
81 \\
1 \\
84 \\
24 \\
83 \\
98 \\
29 \\
36 \\
24 \\
20\end{array}$ & $\begin{array}{r}126 \\
322 \\
413 \\
450 \\
909 \\
253 \\
1,198 \\
1,223 \\
1,050 \\
410 \\
950 \\
557 \\
471 \\
694 \\
441 \\
235 \\
456 \\
491 \\
393\end{array}$ & $\begin{array}{c}92 \\
140 \\
209 \\
195 \\
556 \\
105 \\
924 \\
807 \\
610 \\
322 \\
569 \\
371 \\
299 \\
482 \\
303 \\
153 \\
304 \\
302 \\
197\end{array}$ & $\begin{array}{l}60 \\
197 \\
229 \\
337 \\
373 \\
187 \\
290 \\
456 \\
534 \\
169 \\
391 \\
240 \\
197 \\
295 \\
176 \\
111 \\
186 \\
203 \\
216\end{array}$ & $\begin{array}{l}0.34 \\
0.42 \\
0.49 \\
0.50 \\
0.03 \\
0.26 \\
0.54 \\
0.60 \\
0.68 \\
0.38 \\
0.47 \\
0.42 \\
0.35 \\
0.41 \\
0.37 \\
0.21 \\
0.34 \\
0.27 \\
0.28\end{array}$ & $\begin{array}{l}0.2 \\
0.6 \\
0.7 \\
0.8 \\
1.3 \\
0.3 \\
4.1 \\
1.1 \\
0.9 \\
0.3 \\
0.7 \\
0.4 \\
0.3 \\
0.7 \\
0.3 \\
0.2 \\
0.4 \\
0.4 \\
0.3\end{array}$ \\
\hline
\end{tabular}




\begin{tabular}{|c|c|c|c|c|c|c|c|c|c|c|c|}
\hline \multirow[b]{4}{*}{ Reporting Organizalion } & \multicolumn{9}{|c|}{$\begin{array}{l}\text { APPENDIX C (continued) } \\
\text { PERSONNEL, DOSE AND POWER GENERATION SUHALARY }\end{array}$} & \multirow{4}{*}{$\begin{array}{l}\text { Averrige } \\
\text { Measurable } \\
\text { Dose } \\
\text { (cSv or } \\
\text { rems) }\end{array}$} & \multirow{4}{*}{$\begin{array}{l}\text { Person } \\
\text { c5v } \\
\text { (rems) } \\
\text { MON-yr }\end{array}$} \\
\hline & \multirow{3}{*}{\multicolumn{2}{|c|}{$\begin{array}{c}\text { Megawalt } \\
\text { Years } \\
\text { Year } \quad \text { WW-YR }\end{array}$}} & \multirow[b]{3}{*}{$\begin{array}{l}\text { Unit } \\
\text { Avaibabllity } \\
\text { Factor }\end{array}$} & \multirow[b]{3}{*}{$\begin{array}{l}\text { Total Persomnt } \\
\text { With Heasubablo } \\
\text { Doses }\end{array}$} & \multicolumn{5}{|c|}{ Perbon-cSv (rrams) } & & \\
\hline & & & & & \multicolumn{3}{|c|}{ Pesinkork Funation } & \multicolumn{2}{|c|}{ Ber,Personnedy Iys } & & \\
\hline & & & & & $\begin{array}{c}\text { Collective } \\
\text { Dose }\end{array}$ & $\begin{array}{c}\text { Optrat } \\
\text { thons }\end{array}$ & $\begin{array}{c}\text { Maink } \\
\text { \& } \\
\text { Others }\end{array}$ & $\begin{array}{c}\text { Con- } \\
\text { troctar }\end{array}$ & $\begin{array}{l}\text { Suation \& } \\
\text { Utotidy }\end{array}$ & & \\
\hline 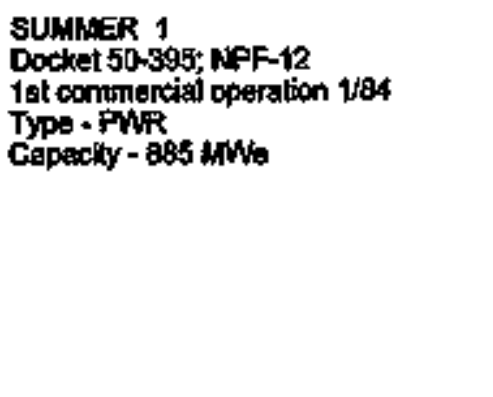 & $\begin{array}{l}1984 \\
1965 \\
1986 \\
1967 \\
1988 \\
1969 \\
1990 \\
1991 \\
1992 \\
1993 \\
1994 \\
1996\end{array}$ & $\begin{array}{l}504.6 \\
627.7 \\
859.7 \\
618.7 \\
605.3 \\
652.4 \\
730.0 \\
642.5 \\
892.6 \\
728.3 \\
\$ 36.7 \\
899.6\end{array}$ & $\begin{array}{l}91.1 \\
71.0 \\
95.3 \\
71.0 \\
69.1 \\
83.1 \\
89.9 \\
92.0 \\
97.4 \\
94.0 \\
69.5 \\
97.2\end{array}$ & $\begin{array}{r}1,120 \\
1,201 \\
392 \\
1,075 \\
1,127 \\
374 \\
1,000 \\
984 \\
249 \\
1,121 \\
1,548 \\
257\end{array}$ & $\begin{array}{r}295 \\
379 \\
23 \\
560 \\
511 \\
52 \\
376 \\
291 \\
27 \\
297 \\
374 \\
13\end{array}$ & $\begin{array}{r}29 \\
74 \\
5 \\
34 \\
35 \\
11 \\
29 \\
21 \\
6 \\
11 \\
27 \\
3\end{array}$ & $\begin{array}{r}288 \\
305 \\
10 \\
528 \\
476 \\
41 \\
347 \\
270 \\
21 \\
286 \\
347 \\
10\end{array}$ & $\begin{array}{r}202 \\
241 \\
12 \\
454 \\
403 \\
27 \\
322 \\
253 \\
12 \\
259 \\
334 \\
4\end{array}$ & $\begin{array}{r}83 \\
138 \\
11 \\
108 \\
108 \\
25 \\
54 \\
39 \\
15 \\
44 \\
40 \\
9\end{array}$ & $\begin{array}{l}0.26 \\
0.32 \\
0.06 \\
0.52 \\
0.45 \\
0.14 \\
0.34 \\
0.30 \\
0.11 \\
0.28 \\
0.24 \\
0.06\end{array}$ & $\begin{array}{c}0.6 \\
0.6 \\
0.08 \\
0.9 \\
0.8 \\
0.1 \\
0.5 \\
0.5 \\
0.0 \\
0.4 \\
0.7 \\
0.0\end{array}$ \\
\hline 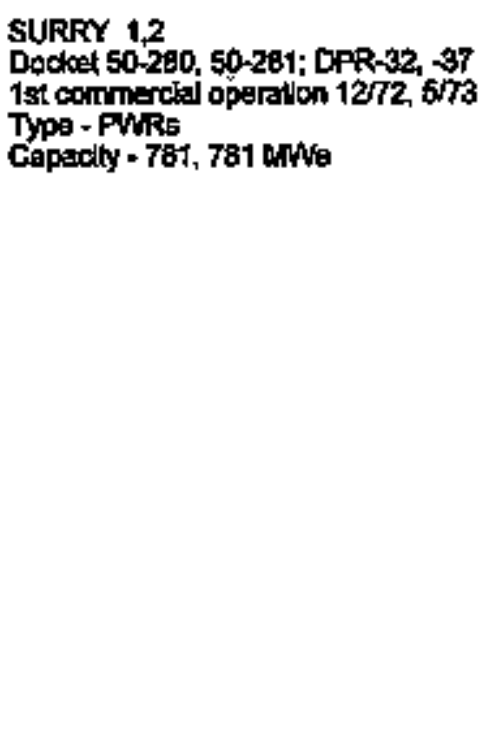 & $\begin{array}{l}1973 \\
1974 \\
1975 \\
1976 \\
1977 \\
1978 \\
1979 \\
1980 \\
1991 \\
1982 \\
1993 \\
1984 \\
1995 \\
1989 \\
1997 \\
1998 \\
1999 \\
1990 \\
1994 \\
1999 \\
1998 \\
1994 \\
1995\end{array}$ & $\begin{array}{r}420.8 \\
717.4 \\
1,079.0 \\
930.7 \\
1,139.0 \\
1,210.6 \\
343.0 \\
568.2 \\
907.6 \\
1,323.3 \\
916.2 \\
1,026.7 \\
1,160.4 \\
1,090.5 \\
1,132.7 \\
750.4 \\
469.3 \\
1,236.4 \\
1,274.9 \\
1,396.3 \\
1,283.1 \\
1,320.9 \\
1,333.0\end{array}$ & $\begin{array}{l}48.8 \\
70.8 \\
60.4 \\
72.2 \\
77.2 \\
42.3 \\
40.3 \\
59.3 \\
89.5 \\
61.3 \\
71.0 \\
78.2 \\
69.0 \\
72.7 \\
30.0 \\
33.0 \\
89.8 \\
84.5 \\
89.8 \\
84.6 \\
85.2 \\
84.2\end{array}$ & $\begin{array}{r}938 \\
1,715 \\
1,948 \\
2,753 \\
1,980 \\
2,203 \\
5,065 \\
5,317 \\
3,753 \\
1,678 \\
2,754 \\
3,198 \\
3,206 \\
3,763 \\
2,675 \\
3,194 \\
3,100 \\
1,947 \\
1,547 \\
1,690 \\
1,402 \\
1,590 \\
1,683\end{array}$ & 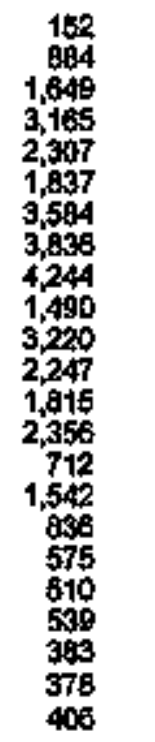 & $\begin{array}{r}72 \\
27 \\
444 \\
348 \\
530 \\
173 \\
353 \\
428 \\
399 \\
571 \\
558 \\
599 \\
430 \\
192 \\
66 \\
27 \\
53 \\
45 \\
108 \\
72 \\
66 \\
60\end{array}$ & $\begin{array}{r}912 \\
1,622 \\
2,721 \\
1,959 \\
1,307 \\
3,411 \\
3,493 \\
3,616 \\
1,091 \\
2,849 \\
1,711 \\
1,306 \\
1,926 \\
5520 \\
1,474 \\
6009 \\
5522 \\
445 \\
431 \\
311 \\
312 \\
346\end{array}$ & $\begin{array}{r}1,065 \\
1,873 \\
1,380 \\
1,240 \\
2,975 \\
3,117 \\
3,040 \\
506 \\
1,768 \\
1,575 \\
1,232 \\
1,677 \\
1,325 \\
1,117 \\
330 \\
389 \\
311 \\
383 \\
241 \\
254 \\
246\end{array}$ & $\begin{array}{r}584 \\
1,292 \\
927 \\
589 \\
609 \\
719 \\
1,204 \\
964 \\
1,434 \\
672 \\
583 \\
679 \\
387 \\
425 \\
306 \\
186 \\
199 \\
158 \\
142 \\
124 \\
160\end{array}$ & $\begin{array}{l}0.16 \\
0.52 \\
0.95 \\
1.15 \\
1.24 \\
0.83 \\
0.71 \\
0.72 \\
1.13 \\
0.79 \\
1.17 \\
0.70 \\
0.57 \\
0.63 \\
0.27 \\
0.48 \\
0.27 \\
0.30 \\
0.33 \\
0.32 \\
0.27 \\
0.25 \\
0.28\end{array}$ & $\begin{array}{r}0.4 \\
1.2 \\
1.5 \\
3.4 \\
2.0 \\
1.5 \\
10.4 \\
6.8 \\
4.7 \\
1.1 \\
3.5 \\
2.2 \\
1.6 \\
2.2 \\
0.6 \\
2.1 \\
1.7 \\
0.5 \\
0.4 \\
0.4 \\
0.3 \\
0.3 \\
0.3\end{array}$ \\
\hline
\end{tabular}


APPENDIX C (contioued)

PERSONNEL, DOSE AND POWER GENERATION SUMMARY

\begin{tabular}{|c|c|c|c|c|c|c|c|c|c|c|c|}
\hline \multirow[b]{2}{*}{ Reporting Orgarizalion } & \multirow[b]{2}{*}{ Year } & \multirow[b]{2}{*}{$\begin{array}{c}\text { Megaswalt } \\
\text { Yeers } \\
\text { MWS-YR }\end{array}$} & \multirow[b]{2}{*}{$\begin{array}{l}\text { Unik } \\
\text { Avallabillty } \\
\text { Factor }\end{array}$} & \multirow[b]{2}{*}{$\begin{array}{c}\text { Total Persomel } \\
\text { With Measurable } \\
\text { Doses }\end{array}$} & \multicolumn{5}{|c|}{ Person-cSv (-rems) } & \multirow[b]{2}{*}{$\begin{array}{l}\text { Awerage } \\
\text { Nifessurable } \\
\text { Dage } \\
\text { (cSv or } \\
\text { rems) }\end{array}$} & \multirow[b]{2}{*}{$\begin{array}{c}\text { Person } \\
\text { cSs } \\
\text { (-rems) } \\
\text { MiN-yr }\end{array}$} \\
\hline & & & & & $\begin{array}{l}\text { Colloctive } \\
\text { Dose }\end{array}$ & $\begin{array}{c}\text { Opert- } \\
\text { thons }\end{array}$ & $\begin{array}{c}\text { Maint } \\
\text { \& } \\
\text { Othors }\end{array}$ & $\underset{\text { tractor }}{\text { Con. }}$ & $\begin{array}{l}\text { Slation } 8 \\
\text { Utitiy }\end{array}$ & & \\
\hline 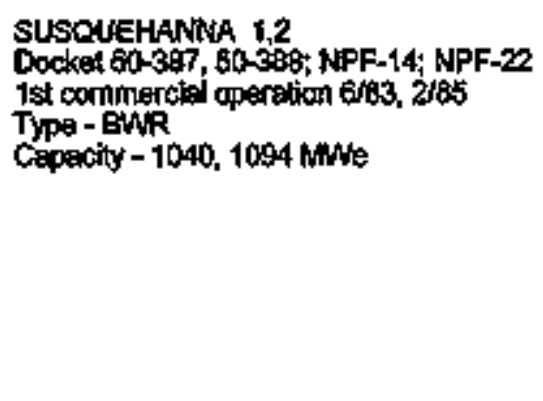 & $\begin{array}{l}1984 \\
1985 \\
1986 \\
1987 \\
1989 \\
1909 \\
1990 \\
1991 \\
1992 \\
1993 \\
1994 \\
1905\end{array}$ & $\begin{array}{r}719.9 \\
1,45.2 \\
1,344.6 \\
1,749.5 \\
1,691.0 \\
1,572.5 \\
1,746.9 \\
1,978.0 \\
1,604.2 \\
1,602.1 \\
1,814.4 \\
1,850.8\end{array}$ & $\begin{array}{l}72.6 \\
76.4 \\
67.0 \\
85.3 \\
83.5 \\
77.1 \\
85.4 \\
89.8 \\
79.7 \\
77.3 \\
88.4 \\
85.3\end{array}$ & $\begin{array}{l}2,827 \\
3,669 \\
2,996 \\
2,548 \\
1,904 \\
2,063 \\
1,691 \\
1,844 \\
1,885 \\
1,488 \\
1,580 \\
1,773\end{array}$ & $\begin{array}{r}308 \\
1,106 \\
828 \\
521 \\
516 \\
704 \\
440 \\
507 \\
724 \\
335 \\
442 \\
476\end{array}$ & $\begin{array}{l}74 \\
79 \\
50 \\
35 \\
52 \\
32 \\
30 \\
44 \\
29 \\
19 \\
20 \\
54\end{array}$ & $\begin{array}{r}234 \\
1,029 \\
778 \\
595 \\
464 \\
672 \\
410 \\
463 \\
695 \\
316 \\
427 \\
422\end{array}$ & $\begin{array}{l}127 \\
796 \\
412 \\
341 \\
291 \\
342 \\
179 \\
251 \\
356 \\
172 \\
246 \\
176\end{array}$ & $\begin{array}{l}181 \\
346 \\
426 \\
280 \\
236 \\
372 \\
261 \\
256 \\
366 \\
163 \\
168 \\
300\end{array}$ & $\begin{array}{l}0.11 \\
0.30 \\
0.28 \\
0.24 \\
0.27 \\
0.34 \\
0.28 \\
0.27 \\
0.38 \\
0.28 \\
0.28 \\
0.27\end{array}$ & $\begin{array}{l}0.4 \\
0.8 \\
0.6 \\
0.4 \\
0.3 \\
0.4 \\
0.3 \\
0.3 \\
0.5 \\
0.2 \\
0.2 \\
0.3\end{array}$ \\
\hline 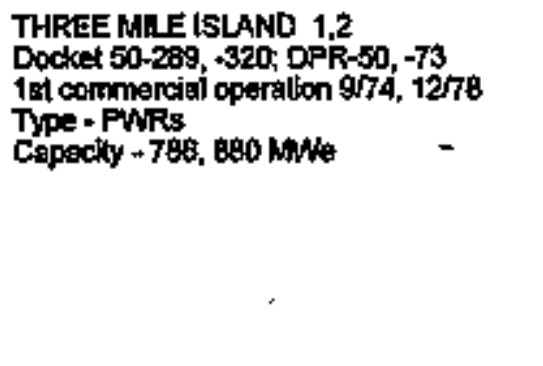 & $\begin{array}{l}1975 \\
1976 \\
1977 \\
1970 \\
1979 \\
1980 \\
1964 \\
1998 \\
1983 \\
1984 \\
1985\end{array}$ & $\begin{array}{r}675.9 \\
530.0 \\
654.5 \\
690.0 \\
288.0 \\
0.0 \\
0.0 \\
0.0 \\
0.0 \\
0.0 \\
103.6\end{array}$ & $\begin{array}{r}82.2 \\
65.4 \\
80.9 \\
85.1 \\
21.9 \\
0.0 \\
0.0 \\
0.0 \\
0.0 \\
0.0 \\
10.6\end{array}$ & $\begin{array}{r}131 \\
819 \\
+122 \\
1,929 \\
3,975 \\
2,328 \\
2,103 \\
2,123 \\
1,592 \\
1,079 \\
1,890\end{array}$ & $\begin{array}{r}73 \\
296 \\
360 \\
504 \\
1,392 \\
394 \\
376 \\
1,004 \\
1,159 \\
686 \\
857\end{array}$ & $\begin{array}{r}23 \\
15 \\
32 \\
197 \\
29 \\
50 \\
62 \\
65 \\
50 \\
230\end{array}$ & $\begin{array}{r}263 \\
344 \\
472 \\
1,195 \\
365 \\
328 \\
942 \\
1,074 \\
638 \\
627\end{array}$ & $\begin{array}{r}18 \\
69 \\
128 \\
236 \\
907 \\
239 \\
190 \\
433 \\
633 \\
330 \\
266\end{array}$ & $\begin{array}{l}55 \\
217 \\
231 \\
269 \\
485 \\
155 \\
186 \\
571 \\
526 \\
360 \\
591\end{array}$ & $\begin{array}{l}0.56 \\
0.35 \\
0.32 \\
0.26 \\
0.36 \\
0.17 \\
0.18 \\
0.47 \\
0.73 \\
0.64 \\
0.45\end{array}$ & $\begin{array}{l}0.1 \\
0.5 \\
0.5 \\
0.7 \\
5.2 \\
= \\
= \\
= \\
8.3\end{array}$ \\
\hline 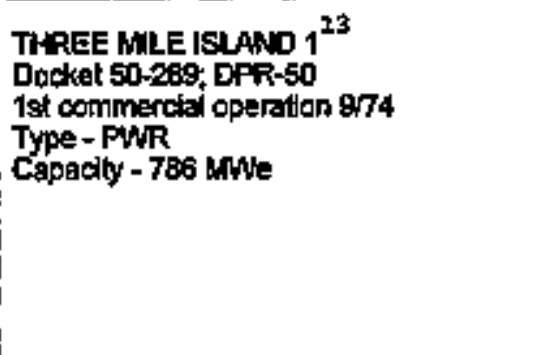 & $\begin{array}{l}1983 \\
1987 \\
1998 \\
1989 \\
1990 \\
1991 \\
1992 \\
1993 \\
1994 \\
1995\end{array}$ & $\begin{array}{l}585.2 \\
610.7 \\
661.0 \\
671.3 \\
645.5 \\
688.7 \\
836.8 \\
722.0 \\
798.7 \\
772.9\end{array}$ & $\begin{array}{r}70.9 \\
73.6 \\
77.8 \\
100.0 \\
84.6 \\
86.4 \\
100.0 \\
98.5 \\
95.5 \\
90.6\end{array}$ & $\begin{array}{r}1,360 \\
1,260 \\
1,012 \\
670 \\
1,310 \\
1,642 \\
558 \\
1,835 \\
434 \\
1,220\end{array}$ & $\begin{array}{r}213 \\
149 \\
210 \\
54 \\
264 \\
108 \\
34 \\
206 \\
40 \\
213\end{array}$ & $\begin{array}{l}44 \\
40 \\
40 \\
20 \\
53 \\
47 \\
15 \\
53 \\
19 \\
31\end{array}$ & $\begin{array}{r}169 \\
109 \\
170 \\
32 \\
211 \\
151 \\
19 \\
153 \\
21 \\
182\end{array}$ & $\begin{array}{r}89 \\
50 \\
89 \\
3 \\
121 \\
99 \\
5 \\
110 \\
1 \\
120\end{array}$ & $\begin{array}{r}124 \\
99 \\
122 \\
51 \\
143 \\
99 \\
29 \\
96 \\
39 \\
97\end{array}$ & $\begin{array}{l}0.16 \\
0.12 \\
0.21 \\
0.08 \\
0.20 \\
0.13 \\
0.06 \\
0.11 \\
0.09 \\
0.17\end{array}$ & $\begin{array}{l}0.4 \\
0.2 \\
0.3 \\
0.1 \\
0.4 \\
0.3 \\
0.0 \\
0.3 \\
0.1 \\
0.3\end{array}$ \\
\hline
\end{tabular}

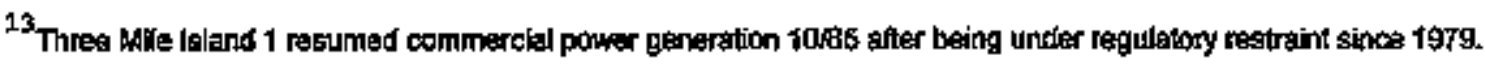




\begin{tabular}{|c|c|c|c|c|c|c|c|c|c|c|c|}
\hline \multirow{4}{*}{ 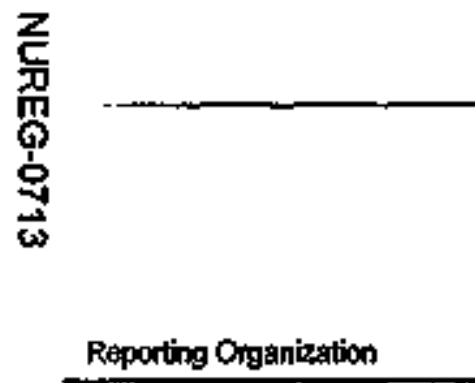 } & \multirow[b]{4}{*}{ Year } & \multirow{4}{*}{\multicolumn{3}{|c|}{ 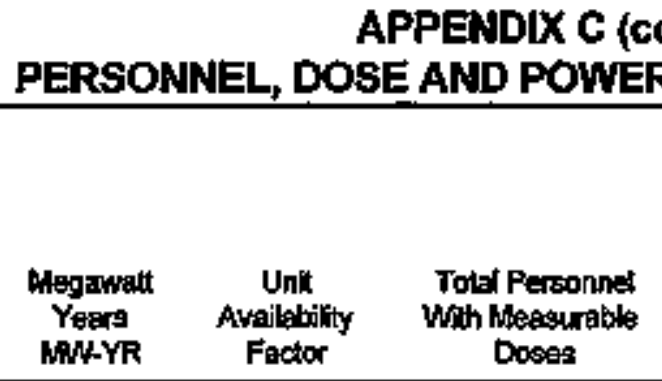 }} & \multirow{2}{*}{\multicolumn{5}{|c|}{ Person-csv (-rems) }} & \multirow{4}{*}{$\begin{array}{l}\text { Average } \\
\text { Mesesurable } \\
\text { Cose } \\
\text { (cSv ar } \\
\text { rems) }\end{array}$} & \multirow{4}{*}{ 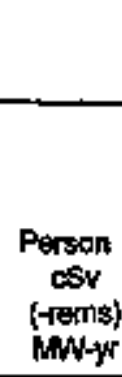 } \\
\hline & & & & & & & & & & & \\
\hline & & & & & \multicolumn{3}{|c|}{ Pertwonk Finction } & \multicolumn{2}{|c|}{ Per Persomal Trpe } & & \\
\hline & & & & & $\begin{array}{l}\text { Collective } \\
\text { Dose }\end{array}$ & $\begin{array}{l}\text { Opera- } \\
\text { llors }\end{array}$ & $\begin{array}{c}\text { Meint } \\
\mathbf{8} \\
\text { Others }\end{array}$ & $\begin{array}{l}\text { Con- } \\
\text { tractor }\end{array}$ & $\begin{array}{l}\text { Stetion } 5 \\
\text { Undity }\end{array}$ & & \\
\hline 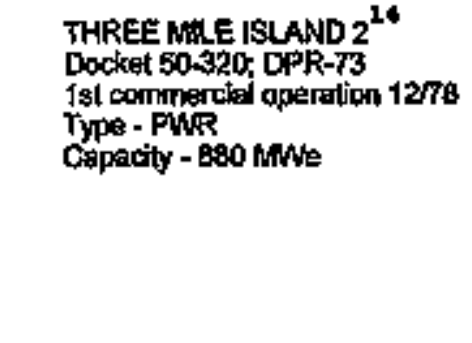 & $\begin{array}{l}1986 \\
1987 \\
1988 \\
1969 \\
1990 \\
1991 \\
1998 \\
1993 \\
1994 \\
1995\end{array}$ & $\begin{array}{l}0.0 \\
0.0 \\
0.0 \\
0.0 \\
0.0 \\
0.0 \\
0.0 \\
0.0 \\
0.0 \\
0.0\end{array}$ & $\begin{array}{l}0.0 \\
0.0 \\
0.0 \\
0.0 \\
0.0 \\
0.0 \\
0.0 \\
0.0 \\
0.0 \\
0.0\end{array}$ & $\begin{array}{r}1,497 \\
1,378 \\
1,247 \\
1,014 \\
484 \\
153 \\
316 \\
167 \\
259 \\
181\end{array}$ & $\begin{array}{r}915 \\
977 \\
917 \\
639 \\
136 \\
37 \\
157 \\
33 \\
7 \\
2\end{array}$ & $\begin{array}{c}97 \\
90 \\
26 \\
88 \\
25 \\
1 \\
7 \\
4 \\
0 \\
1\end{array}$ & $\begin{array}{r}816 \\
887 \\
891 \\
581 \\
111 \\
36 \\
160 \\
32 \\
7 \\
1\end{array}$ & $\begin{array}{r}615 \\
697 \\
691 \\
382 \\
50 \\
3 \\
99 \\
19 \\
2 \\
0\end{array}$ & $\begin{array}{r}300 \\
290 \\
206 \\
257 \\
86 \\
34 \\
58 \\
14 \\
5 \\
2\end{array}$ & $\begin{array}{l}0.61 \\
0.71 \\
0.74 \\
0.63 \\
0.28 \\
0.24 \\
0.50 \\
0.20 \\
0.09 \\
0.04\end{array}$ & $\begin{array}{l}= \\
= \\
= \\
= \\
= \\
\cdots\end{array}$ \\
\hline 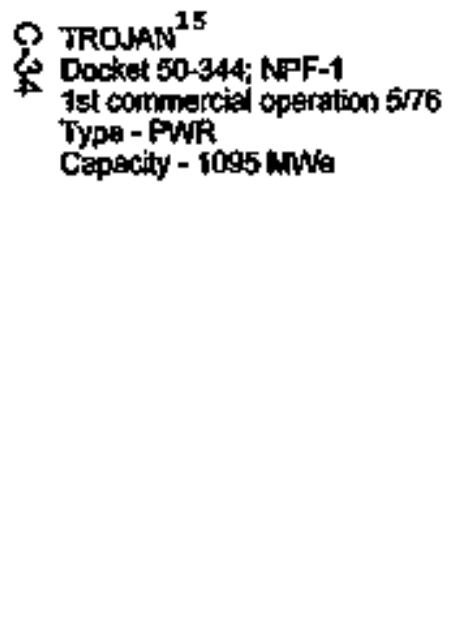 & $\begin{array}{c}1977 \\
1978 \\
1979 \\
1990 \\
1981 \\
1992 \\
1993 \\
1994 \\
1995 \\
1998 \\
1987 \\
1998 \\
1999 \\
1990 \\
1991 \\
1992 \\
1993 \\
1994 \\
1995\end{array}$ & $\begin{array}{r}792.0 \\
205.5 \\
631.0 \\
727.5 \\
775.6 \\
579.5 \\
494.2 \\
567.0 \\
629.1 \\
852.4 \\
525.5 \\
758.6 \\
668.8 \\
732.4 \\
181.6 \\
553.9 \\
0.0 \\
0.0 \\
0.0\end{array}$ & $\begin{array}{r}92.6 \\
20.6 \\
58.1 \\
72.5 \\
74.1 \\
60.8 \\
62.4 \\
54.4 \\
76.7 \\
79.7 \\
64.0 \\
67.5 \\
61.9 \\
66.3 \\
16.1 \\
68.4 \\
68.4 \\
0.0 \\
0.0\end{array}$ & $\begin{array}{r}591 \\
711 \\
738 \\
1,159 \\
1,311 \\
977 \\
969 \\
1,042 \\
862 \\
1,327 \\
1,209 \\
1,406 \\
1,690 \\
1,169 \\
1,496 \\
647 \\
54 \\
61 \\
141\end{array}$ & $\begin{array}{r}174 \\
319 \\
258 \\
421 \\
609 \\
419 \\
307 \\
439 \\
369 \\
391 \\
304 \\
401 \\
421 \\
259 \\
567 \\
84 \\
21 \\
9 \\
44\end{array}$ & $\begin{array}{r}30 \\
63 \\
74 \\
77 \\
113 \\
76 \\
35 \\
41 \\
31 \\
45 \\
66 \\
106 \\
37 \\
9 \\
17 \\
8 \\
3 \\
2 \\
4\end{array}$ & $\begin{array}{r}144 \\
236 \\
184 \\
344 \\
496 \\
345 \\
272 \\
392 \\
392 \\
345 \\
297 \\
248 \\
364 \\
249 \\
550 \\
76 \\
18 \\
7 \\
4=6\end{array}$ & $\begin{array}{r}105 \\
125 \\
113 \\
305 \\
363 \\
168 \\
129 \\
230 \\
210 \\
274 \\
286 \\
311 \\
317 \\
185 \\
475 \\
52 \\
12 \\
6 \\
4\end{array}$ & $\begin{array}{r}69 \\
194 \\
145 \\
116 \\
243 \\
251 \\
178 \\
209 \\
153 \\
107 \\
97 \\
90 \\
104 \\
73 \\
92 \\
32 \\
9 \\
3 \\
40\end{array}$ & $\begin{array}{l}0.29 \\
0.45 \\
0.35 \\
0.38 \\
0.46 \\
0.43 \\
0.32 \\
0.42 \\
0.43 \\
0.29 \\
0.30 \\
0.26 \\
0.31 \\
0.22 \\
0.38 \\
0.15 \\
0.39 \\
0.18 \\
0.31\end{array}$ & $\begin{array}{l}0.2 \\
1.6 \\
0.4 \\
0.6 \\
0.8 \\
0.7 \\
0.6 \\
0.8 \\
0.4 \\
0.4 \\
0.7 \\
0.5 \\
0.8 \\
0.4 \\
3.1 \\
0.2 \\
-2 \\
-.7 \\
.4\end{array}$ \\
\hline
\end{tabular}

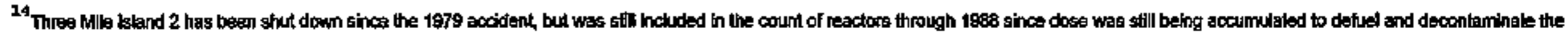
un't during thts time period

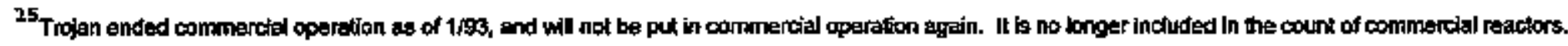


APPENDIX C (continued)

PERSONNEL, DOSE AND POWER GENERATION SUMMARY

$\$$

\begin{tabular}{|c|c|c|c|c|c|c|c|c|c|c|c|}
\hline \multirow[b]{3}{*}{ Reporting Organizstikn } & \multirow[b]{3}{*}{ Year } & \multirow[b]{3}{*}{$\begin{array}{l}\text { Megenwat } \\
\text { Years } \\
\text { MWNYR }\end{array}$} & \multirow[b]{3}{*}{$\begin{array}{l}\text { Unit } \\
\text { Availebilly } \\
\text { Factor }\end{array}$} & \multirow[b]{3}{*}{$\begin{array}{c}\text { Total Pergonnel } \\
\text { With Hessurable } \\
\text { Doses }\end{array}$} & \multicolumn{5}{|c|}{ Person-csy (-rems) } & \multirow{3}{*}{$\begin{array}{l}\text { Average } \\
\text { dersurahe } \\
\text { Dose } \\
\text { (c) of or } \\
\text { rems) }\end{array}$} & \multirow{3}{*}{$\begin{array}{l}\text { Person } \\
\text { cSs } \\
\text { herns } \\
\text { Mansy }\end{array}$} \\
\hline & & & & & & \multicolumn{2}{|c|}{ Per Work Fumetion } & \multicolumn{2}{|c|}{ PerPessomelal Type } & & \\
\hline & & & & & $\begin{array}{l}\text { Collective } \\
\text { Dose }\end{array}$ & $\begin{array}{c}\text { Opera } \\
\text { tions }\end{array}$ & $\begin{array}{c}\text { Maint } \\
\& \\
\text { Othess }\end{array}$ & $\begin{array}{c}\text { Cort- } \\
\text { treator }\end{array}$ & $\begin{array}{c}\text { Station \& } \\
\text { Uticty }\end{array}$ & & \\
\hline 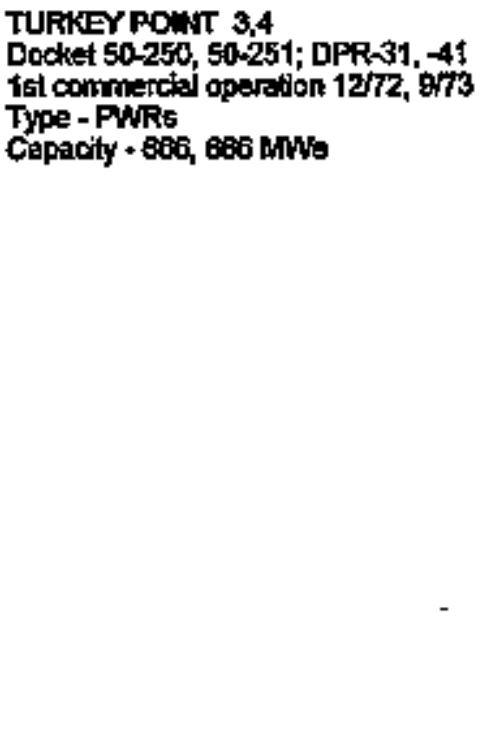 & $\begin{array}{l}1973 \\
1974 \\
1975 \\
1976 \\
1977 \\
1978 \\
1979 \\
1980 \\
1994 \\
1982 \\
1983 \\
1984 \\
1985 \\
1986 \\
1997 \\
1998 \\
1960 \\
1990 \\
1991 \\
1992 \\
1993 \\
1994 \\
1905\end{array}$ & $\begin{array}{r}401.9 \\
953.6 \\
1.003 .7 \\
974.2 \\
979.5 \\
1,000.2 \\
911.0 \\
990.6 \\
654.0 \\
915.7 \\
878.4 \\
946.7 \\
1,034.9 \\
754.1 \\
431.3 \\
809.8 \\
6989.9 \\
934.1 \\
255.2 \\
964.9 \\
1,24.8 \\
1,972.9 \\
1,320.3\end{array}$ & $\begin{array}{l}74.9 \\
71.2 \\
72.1 \\
78.8 \\
62.4 \\
73.6 \\
46.8 \\
65.2 \\
62.8 \\
68.5 \\
74.7 \\
54.9 \\
30.6 \\
59.5 \\
50.6 \\
69.0 \\
21.0 \\
75.5 \\
91.0 \\
97.2 \\
94.6\end{array}$ & $\begin{array}{r}444 \\
794 \\
1,176 \\
1,647 \\
1,319 \\
1,336 \\
2,002 \\
1,903 \\
2,932 \\
2,956 \\
2,930 \\
2,010 \\
1,905 \\
1,808 \\
1,906 \\
1,941 \\
1,625 \\
2,099 \\
2,097 \\
1,374 \\
1,271 \\
1,489 \\
1,142\end{array}$ & $\begin{array}{r}78 \\
454 \\
876 \\
1,184 \\
1,096 \\
1,032 \\
1,690 \\
1,651 \\
2,251 \\
2119 \\
2,691 \\
1,255 \\
1,253 \\
946 \\
1,371 \\
738 \\
493 \\
730 \\
939 \\
325 \\
275 \\
476 \\
218\end{array}$ & $\begin{array}{r}88 \\
270 \\
69 \\
94 \\
90 \\
290 \\
232 \\
274 \\
197 \\
272 \\
217 \\
91 \\
71 \\
79 \\
18 \\
25 \\
140 \\
105 \\
32 \\
6 \\
0 \\
0\end{array}$ & $\begin{array}{r}366 \\
606 \\
1,095 \\
942 \\
942 \\
1,391 \\
1,419 \\
1,977 \\
1,922 \\
2,409 \\
1,038 \\
1,162 \\
975 \\
1,292 \\
720 \\
409 \\
590 \\
634 \\
293 \\
269 \\
476 \\
216\end{array}$ & $\begin{array}{r}202 \\
559 \\
668 \\
582 \\
546 \\
997 \\
1.219 \\
1,654 \\
1,656 \\
2.119 \\
676 \\
817 \\
716 \\
987 \\
523 \\
281 \\
475 \\
685 \\
173 \\
164 \\
231 \\
102\end{array}$ & $\begin{array}{l}252 \\
317 \\
316 \\
514 \\
486 \\
699 \\
433 \\
397 \\
463 \\
562 \\
379 \\
438 \\
230 \\
394 \\
215 \\
152 \\
258 \\
264 \\
152 \\
111 \\
245 \\
113\end{array}$ & $\begin{array}{l}0.18 \\
0.57 \\
0.74 \\
0.72 \\
0.79 \\
0.77 \\
0.84 \\
0.92 \\
0.77 \\
0.72 \\
0.92 \\
0.62 \\
0.68 \\
0.62 \\
0.69 \\
0.40 \\
0.27 \\
0.35 \\
0.45 \\
0.24 \\
0.27 \\
0.32 \\
0.19\end{array}$ & $\begin{array}{l}0.2 \\
0.5 \\
0.9 \\
1.2 \\
1.1 \\
1.0 \\
2.1 \\
1.7 \\
3.4 \\
2.3 \\
3.1 \\
1.3 \\
1.2 \\
1.3 \\
3.2 \\
0.9 \\
0.6 \\
0.8 \\
3.6 \\
0.3 \\
0.2 \\
0.4 \\
0.2\end{array}$ \\
\hline 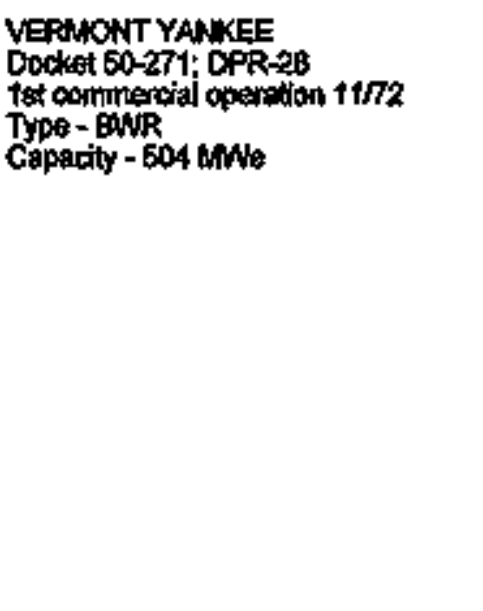 & $\begin{array}{l}1973 \\
1974 \\
1975 \\
1976 \\
1977 \\
1978 \\
1979 \\
1980 \\
1981 \\
1988 \\
1983 \\
1984 \\
1985 \\
1986 \\
1987 \\
1988 \\
1989 \\
1990 \\
1991\end{array}$ & $\begin{array}{l}222.1 \\
302.5 \\
429.0 \\
399.6 \\
423.5 \\
337.5 \\
414.0 \\
357.8 \\
429.1 \\
501.0 \\
346.1 \\
396.1 \\
361.4 \\
249.1 \\
42.6 \\
498.1 \\
432.8 \\
433.1 \\
492.3\end{array}$ & $\begin{array}{l}87.8 \\
77.1 \\
85.1 \\
75.9 \\
82.1 \\
71.5 \\
84.6 \\
96.0 \\
99.3 \\
79.0 \\
71.8 \\
48.9 \\
84.2 \\
95.7 \\
84.7 \\
85.9 \\
94.3\end{array}$ & $\begin{array}{r}244 \\
357 \\
262 \\
615 \\
641 \\
934 \\
1,220 \\
1,443 \\
1,264 \\
484 \\
1,316 \\
654 \\
1,392 \\
1,399 \\
827 \\
379 \\
632 \\
849 \\
310\end{array}$ & $\begin{array}{r}85 \\
216 \\
153 \\
411 \\
258 \\
339 \\
3,170 \\
1,338 \\
731 \\
205 \\
1,627 \\
626 \\
1,051 \\
1,148 \\
303 \\
124 \\
288 \\
307 \\
118\end{array}$ & $\begin{array}{r}24 \\
70 \\
36 \\
83 \\
78 \\
546 \\
141 \\
121 \\
660 \\
215 \\
43 \\
163 \\
44 \\
37 \\
27 \\
43 \\
37 \\
19\end{array}$ & $\begin{array}{r}192 \\
83 \\
375 \\
175 \\
261 \\
624 \\
1,197 \\
610 \\
145 \\
1,312 \\
543 \\
698 \\
1,144 \\
266 \\
97 \\
245 \\
270 \\
99\end{array}$ & $\begin{array}{r}103 \\
63 \\
246 \\
90 \\
158 \\
642 \\
926 \\
908 \\
408 \\
80 \\
787 \\
318 \\
989 \\
1.091 \\
228 \\
67 \\
220 \\
238 \\
66\end{array}$ & $\begin{array}{c}113 \\
80 \\
165 \\
189 \\
191 \\
528 \\
412 \\
323 \\
125 \\
740 \\
306 \\
153 \\
97 \\
77 \\
57 \\
66 \\
71 \\
52\end{array}$ & $\begin{array}{l}0.35 \\
0.61 \\
0.54 \\
0.50 \\
0.40 \\
0.38 \\
0.96 \\
0.93 \\
0.59 \\
0.43 \\
1.16 \\
0.66 \\
0.76 \\
0.86 \\
0.37 \\
0.33 \\
0.35 \\
0.36 \\
0.38\end{array}$ & $\begin{array}{l}0.4 \\
0.7 \\
0.4 \\
1.1 \\
0.6 \\
0.9 \\
2.8 \\
3.7 \\
1.7 \\
0.4 \\
4.4 \\
1.6 \\
2.9 \\
4.6 \\
0.7 \\
0.3 \\
0.7 \\
0.7 \\
0.2\end{array}$ \\
\hline
\end{tabular}




\begin{tabular}{|c|c|c|c|c|c|c|c|c|c|c|c|}
\hline \multirow{4}{*}{ 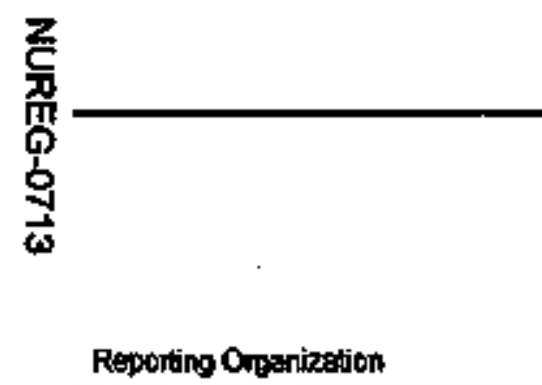 } & \multirow[b]{4}{*}{ Year } & \multirow{4}{*}{$\begin{array}{c}\text { PERSOL } \\
\begin{array}{c}\text { Megawatt } \\
\text { Yasis } \\
\text { MM-YR }\end{array}\end{array}$} & \multirow[b]{4}{*}{$\begin{array}{c}\text { Unit } \\
\text { Avallebility } \\
\text { Factor }\end{array}$} & \multirow[b]{4}{*}{$\begin{array}{c}\text { Total Persomel } \\
\text { Wilti Measurablolo } \\
\text { Doses }\end{array}$} & \multirow{2}{*}{\multicolumn{5}{|c|}{ PEson-chN (-rams) }} & \multirow{4}{*}{$\begin{array}{l}\text { Average } \\
\text { Masurable } \\
\text { Dose } \\
\text { (cSv or } \\
\text { reins) }\end{array}$} & \multirow{4}{*}{$\begin{array}{c}\text { Person } \\
\text { cosv } \\
(-10 m s) \\
M\end{array}$} \\
\hline & & & & & & & & & & & \\
\hline & & & & & \multirow[b]{2}{*}{$\begin{array}{l}\text { Collective } \\
\text { Dose }\end{array}$} & \multicolumn{2}{|c|}{ Perthonk Eimction } & \multicolumn{2}{|c|}{ Eer-Pareoneliture } & & \\
\hline & & & & & & $\begin{array}{c}\text { Opera- } \\
\text { tions }\end{array}$ & $\begin{array}{c}\text { Maint } \\
\& \\
\text { Others }\end{array}$ & $\begin{array}{c}\text { Con- } \\
\text { tractor }\end{array}$ & $\begin{array}{c}\text { Station \& } \\
\text { Utifty }\end{array}$ & & \\
\hline VERMNONT YANKEE (comtinUHd) & $\begin{array}{l}1992 \\
1993 \\
1994 \\
1995\end{array}$ & $\begin{array}{l}446.8 \\
402.3 \\
515.8 \\
462.1\end{array}$ & $\begin{array}{l}88.1 \\
80.1 \\
96.7 \\
87.0\end{array}$ & $\begin{array}{l}821 \\
833 \\
220 \\
737\end{array}$ & $\begin{array}{r}381 \\
217 \\
38 \\
182\end{array}$ & $\begin{array}{l}59 \\
41 \\
24 \\
47\end{array}$ & $\begin{array}{r}323 \\
178 \\
14 \\
135\end{array}$ & $\begin{array}{r}319 \\
186 \\
18 \\
161\end{array}$ & $\begin{array}{l}62 \\
51 \\
20 \\
31\end{array}$ & $\begin{array}{l}0.41 \\
0.26 \\
0.17 \\
0.25\end{array}$ & $\begin{array}{l}0.9 \\
0.5 \\
0.1 \\
0.4\end{array}$ \\
\hline 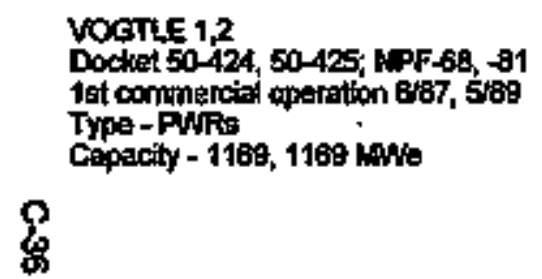 & $\begin{array}{l}1989 \\
1999 \\
1990 \\
1991 \\
1992 \\
1993 \\
1994 \\
1995\end{array}$ & $\begin{array}{r}820.4 \\
1,045.8 \\
1,710.9 \\
1,966.5 \\
2,047.9 \\
2,060.4 \\
2,170.4 \\
2,285.4\end{array}$ & $\begin{array}{l}77.7 \\
96.0 \\
82.7 \\
89.2 \\
90.0 \\
89.3 \\
91.3 \\
95.2\end{array}$ & $\begin{array}{r}1,108 \\
427 \\
1,602 \\
1,357 \\
1,262 \\
1,398 \\
1048 \\
853\end{array}$ & $\begin{array}{r}138 \\
32 \\
466 \\
362 \\
460 \\
369 \\
247 \\
199\end{array}$ & $\begin{array}{r}13 \\
7 \\
89 \\
50 \\
51 \\
34 \\
8 \\
13\end{array}$ & $\begin{array}{r}125 \\
25 \\
377 \\
312 \\
375 \\
333 \\
209 \\
186\end{array}$ & $\begin{array}{r}107 \\
14 \\
323 \\
286 \\
310 \\
251 \\
120 \\
94\end{array}$ & $\begin{array}{r}31 \\
18 \\
143 \\
66 \\
116 \\
116 \\
97 \\
105\end{array}$ & $\begin{array}{l}0.12 \\
0.07 \\
0.29 \\
0.27 \\
0.34 \\
0.27 \\
0.21 \\
0.21\end{array}$ & $\begin{array}{l}0.2 \\
0.0 \\
0.3 \\
0.2 \\
0.2 \\
0.2 \\
0.1 \\
0.1\end{array}$ \\
\hline 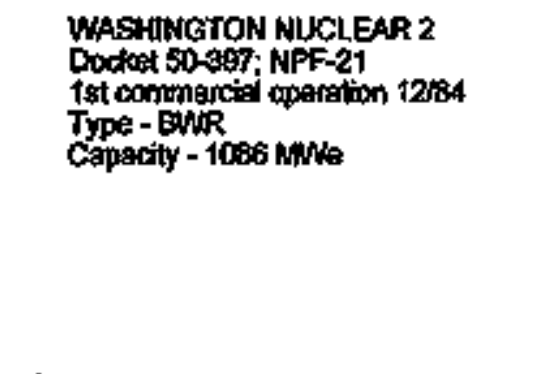 & $\begin{array}{l}1986 \\
1986 \\
1998 \\
1989 \\
1989 \\
1990 \\
1991 \\
1992 \\
1993 \\
1994 \\
1995\end{array}$ & $\begin{array}{l}616.0 \\
616.0 \\
639.0 \\
797.7 \\
727.2 \\
684.7 \\
508.5 \\
692.3 \\
849.6 \\
609.8 \\
824.7\end{array}$ & $\begin{array}{l}87.6 \\
74.4 \\
70.8 \\
71.8 \\
78.3 \\
67.5 \\
50.3 \\
65.6 \\
79.5 \\
75.2 \\
8 \$ .8\end{array}$ & $\begin{array}{r}755 \\
1,013 \\
1,201 \\
1,050 \\
1,299 \\
1,348 \\
1,088 \\
1,489 \\
1,385 \\
1,670 \\
1,694\end{array}$ & $\begin{array}{l}119 \\
202 \\
400 \\
353 \\
492 \\
536 \\
357 \\
612 \\
469 \\
656 \\
456\end{array}$ & $\begin{array}{r}42 \\
56 \\
95 \\
81 \\
161 \\
121 \\
88 \\
11 \\
1 \\
108 \\
91\end{array}$ & $\begin{array}{l}77 \\
168 \\
311 \\
272 \\
331 \\
415 \\
299 \\
601 \\
468 \\
758 \\
306\end{array}$ & $\begin{array}{r}42 \\
70 \\
143 \\
99 \\
216 \\
209 \\
149 \\
307 \\
207 \\
468 \\
219\end{array}$ & $\begin{array}{r}77 \\
152 \\
268 \\
260 \\
276 \\
327 \\
244 \\
305 \\
262 \\
398 \\
237\end{array}$ & $\begin{array}{l}0.16 \\
0.22 \\
0.34 \\
0.34 \\
0.38 \\
0.40 \\
0.36 \\
0.41 \\
0.34 \\
0.48 \\
0.27\end{array}$ & $\begin{array}{l}0.2 \\
0.4 \\
0.6 \\
0.5 \\
0.7 \\
0.8 \\
0.8 \\
0.9 \\
0.6 \\
1.1 \\
0.6\end{array}$ \\
\hline 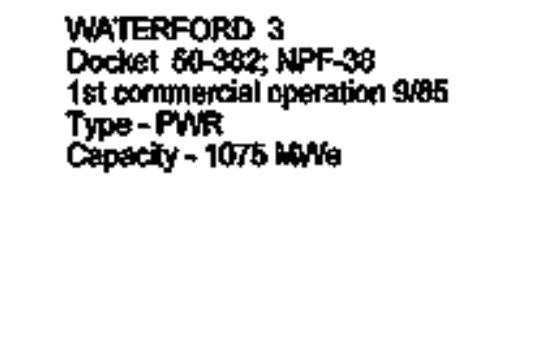 & $\begin{array}{l}1986 \\
1967 \\
1966 \\
1969 \\
1990 \\
1991 \\
1992 \\
1993 \\
1994 \\
1995\end{array}$ & $\begin{array}{r}875.7 \\
891.8 \\
784.3 \\
909.8 \\
1,027.9 \\
870.6 \\
909.6 \\
1,0099.3 \\
949.1 \\
927.4\end{array}$ & $\begin{array}{l}79.1 \\
22.5 \\
75.4 \\
02.6 \\
92.8 \\
79.8 \\
83.2 \\
99.4 \\
87.0 \\
29.4\end{array}$ & $\begin{array}{r}1,244 \\
959 \\
1,246 \\
1,308 \\
432 \\
1,304 \\
1,213 \\
195 \\
1,167 \\
1,092\end{array}$ & $\begin{array}{r}223 \\
156 \\
259 \\
285 \\
47 \\
384 \\
226 \\
15 \\
194 \\
153\end{array}$ & $\begin{array}{r}62 \\
33 \\
79 \\
70 \\
0 \\
101 \\
52 \\
3 \\
47 \\
2\end{array}$ & $\begin{array}{r}151 \\
123 \\
180 \\
195 \\
47 \\
263 \\
174 \\
12 \\
144 \\
151\end{array}$ & $\begin{array}{r}178 \\
100 \\
207 \\
231 \\
24 \\
207 \\
177 \\
6 \\
143 \\
93 \\
93\end{array}$ & $\begin{array}{l}45 \\
50 \\
52 \\
34 \\
23 \\
57 \\
49 \\
10 \\
48 \\
60\end{array}$ & $\begin{array}{l}0.18 \\
0.16 \\
0.21 \\
0.20 \\
0.11 \\
0.28 \\
0.19 \\
0.08 \\
0.16 \\
0.14\end{array}$ & $\begin{array}{l}0.3 \\
0.2 \\
0.3 \\
0.3 \\
0.0 \\
0.4 \\
0.2 \\
0.0 \\
0.2 \\
0.2\end{array}$ \\
\hline
\end{tabular}


APPENDIX C (contīnued)

PERSONNEL, DOSE AND POWER GENERATION SUMMARY

\begin{tabular}{|c|c|c|c|c|c|c|c|c|c|c|c|}
\hline \multirow[b]{2}{*}{ Reporting Organization } & \multirow[b]{2}{*}{ Year } & \multirow[b]{2}{*}{$\begin{array}{l}\text { Meggawatt } \\
\text { Years } \\
\text { MM-YR }\end{array}$} & \multirow[b]{2}{*}{$\begin{array}{c}\text { Unit } \\
\text { Awallability } \\
\text { Factor }\end{array}$} & \multirow[b]{2}{*}{$\begin{array}{c}\text { Total Personnel } \\
\text { With Measurable } \\
\text { Doses }\end{array}$} & \multicolumn{5}{|c|}{ Parsor-csv (-rems) } & \multirow[b]{2}{*}{$\begin{array}{l}\text { Average } \\
\text { Measurable } \\
\text { Dose } \\
\text { (cSvor } \\
\text { rems) }\end{array}$} & \multirow[b]{2}{*}{$\begin{array}{c}\text { Person } \\
\text { tSu } \\
\text { f-renns) } \\
\text { MwN-yr }\end{array}$} \\
\hline & & & & & $\begin{array}{l}\text { Collective } \\
\text { Dose }\end{array}$ & $\begin{array}{c}\text { Oper- } \\
\text { lians }\end{array}$ & $\begin{array}{l}\text { unction } \\
\text { Mtaint } \\
\& \\
\text { Others }\end{array}$ & $\begin{array}{l}\text { Con- } \\
\text { tractor }\end{array}$ & $\begin{array}{c}\text { Stailion \& } \\
\text { Utility }\end{array}$ & & \\
\hline $\begin{array}{l}\text { WOLF CREEK I } \\
\text { pocket 50-492; NPF-42 } \\
\text { 1st cominercial operation } 9865 \\
\text { Type - PWN } \\
\text { Capactly - 1160 whe }\end{array}$ & $\begin{array}{l}1989 \\
1997 \\
1998 \\
1999 \\
1990 \\
1991 \\
1992 \\
1999 \\
19994 \\
1995\end{array}$ & $\begin{array}{r}832.8 \\
778.8 \\
794.7 \\
1,109.4 \\
940.2 \\
707.6 \\
1,010.8 \\
940.5 \\
1,017.2 \\
1,198.0\end{array}$ & $\begin{array}{l}73.3 \\
74.1 \\
70.7 \\
99.5 \\
81.0 \\
74.9 \\
86.7 \\
80.8 \\
86.8 \\
98.7\end{array}$ & $\begin{array}{r}699 \\
675 \\
1,010 \\
186 \\
796 \\
1,010 \\
446 \\
975 \\
1,082 \\
242\end{array}$ & $\begin{array}{r}143 \\
139 \\
297 \\
19 \\
195 \\
331 \\
79 \\
193 \\
235 \\
14\end{array}$ & $\begin{array}{l}27 \\
26 \\
62 \\
4 \\
29 \\
37 \\
17 \\
31 \\
36 \\
5\end{array}$ & $\begin{array}{r}116 \\
112 \\
235 \\
14 \\
160 \\
294 \\
91 \\
152 \\
199 \\
9\end{array}$ & $\begin{array}{r}78 \\
82 \\
177 \\
8 \\
130 \\
244 \\
42 \\
117 \\
170 \\
2\end{array}$ & $\begin{array}{r}65 \\
56 \\
120 \\
10 \\
65 \\
87 \\
36 \\
66 \\
65 \\
12\end{array}$ & $\begin{array}{l}0.21 \\
0.20 \\
0.29 \\
0.10 \\
0.24 \\
0.33 \\
0.17 \\
0.19 \\
0.22 \\
0.06\end{array}$ & $\begin{array}{l}0.2 \\
0.2 \\
0.4 \\
0.0 \\
0.2 \\
0.5 \\
0.1 \\
0.2 \\
0.2 \\
0.0\end{array}$ \\
\hline 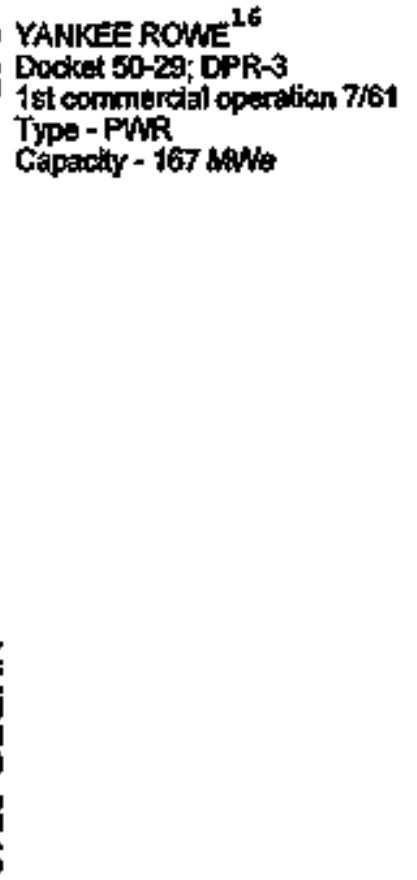 & $\begin{array}{l}1969 \\
1970 \\
1971 \\
1972 \\
1973 \\
1974 \\
1975 \\
9976 \\
9977 \\
1976 \\
1979 \\
1980 \\
1991 \\
1962 \\
1983 \\
1984 \\
1995 \\
1986 \\
1967 \\
1968 \\
1989 \\
1990 \\
1991 \\
1992 \\
19923 \\
1994 \\
1995\end{array}$ & $\begin{array}{r}138.3 \\
146.1 \\
173.5 \\
78.7 \\
127.1 \\
111.3 \\
145.1 \\
152.2 \\
124.6 \\
145.0 \\
149.0 \\
35.6 \\
109.0 \\
108.6 \\
163.5 \\
124.8 \\
144.3 \\
169.7 \\
139.7 \\
138.4 \\
159.4 \\
101.1 \\
121.2 \\
0.0 \\
0.0 \\
0.0 \\
0.0\end{array}$ & $\begin{array}{l}82.4 \\
89.8 \\
73.9 \\
81.0 \\
91.6 \\
22.04 \\
74.4 \\
73.4 \\
91.4 \\
71.4 \\
86.3 \\
96.0 \\
82.7 \\
85.2 \\
92.9 \\
61.5 \\
72.3 \\
0.0 \\
0.0 \\
0.0 \\
0.0\end{array}$ & $\begin{array}{r}193 \\
355 \\
155 \\
282 \\
133 \\
243 \\
249 \\
152 \\
725 \\
565 \\
441 \\
502 \\
515 \\
814 \\
395 \\
654 \\
653 \\
384 \\
593 \\
736 \\
496 \\
702 \\
162 \\
324 \\
313 \\
2222 \\
0\end{array}$ & $\begin{array}{r}215 \\
255 \\
90 \\
255 \\
99 \\
205 \\
116 \\
59 \\
356 \\
282 \\
127 \\
213 \\
302 \\
474 \\
683 \\
348 \\
214 \\
45 \\
217 \\
227 \\
64 \\
246 \\
40 \\
94 \\
163 \\
156 \\
0\end{array}$ & $\begin{array}{r}83 \\
90 \\
46 \\
63 \\
\\
52 \\
17 \\
28 \\
24 \\
16 \\
6 \\
8 \\
7 \\
19 \\
15 \\
17 \\
20 \\
37 \\
35 \\
20 \\
32 \\
11 \\
10 \\
8 \\
4 \\
0\end{array}$ & $\begin{array}{r}132 \\
1065 \\
44 \\
192 \\
\\
64 \\
42 \\
429 \\
3258 \\
111 \\
207 \\
294 \\
467 \\
500 \\
333 \\
194 \\
25 \\
180 \\
192 \\
42 \\
244 \\
29 \\
84 \\
155 \\
152 \\
0\end{array}$ & $\begin{array}{r}78 \\
158 \\
19 \\
148 \\
47 \\
99 \\
66 \\
4 \\
174 \\
96 \\
52 \\
90 \\
136 \\
215 \\
7 \\
141 \\
81 \\
2 \\
126 \\
149 \\
19 \\
170 \\
16 \\
59 \\
153 \\
137 \\
0\end{array}$ & $\begin{array}{c}133 \\
97 \\
71 \\
109 \\
50 \\
106 \\
50 \\
560 \\
182 \\
187 \\
75 \\
139 \\
166 \\
269 \\
619 \\
207 \\
130 \\
43 \\
99 \\
79 \\
43 \\
77 \\
24 \\
35 \\
10 \\
19 \\
0\end{array}$ & $\begin{array}{l}1.11 \\
0.72 \\
0.58 \\
0.90 \\
0.74 \\
0.84 \\
0.47 \\
0.39 \\
0.49 \\
0.50 \\
0.29 \\
0.42 \\
0.59 \\
0.59 \\
0.17 \\
0.53 \\
0.32 \\
0.72 \\
0.37 \\
0.31 \\
0.12 \\
0.35 \\
0.25 \\
0.29 \\
0.52 \\
0.70 \\
0.00\end{array}$ & $\begin{array}{l}1.6 \\
1.7 \\
0.5 \\
3.2 \\
0.8 \\
1.8 \\
0.8 \\
0.4 \\
2.9 \\
1.9 \\
0.9 \\
6.0 \\
2.8 \\
4.4 \\
0.4 \\
2.8 \\
1.5 \\
0.3 \\
1.6 \\
1.7 \\
0.4 \\
2.4 \\
0.3 \\
= \\
= \\
=\end{array}$ \\
\hline
\end{tabular}

\footnotetext{
${ }^{15}$ Yankee Rowe onded commencial operation as of 10/91, and will not be put in cormmercial operation apain. It is no longer included in the coumt of commerciat reactors
} 


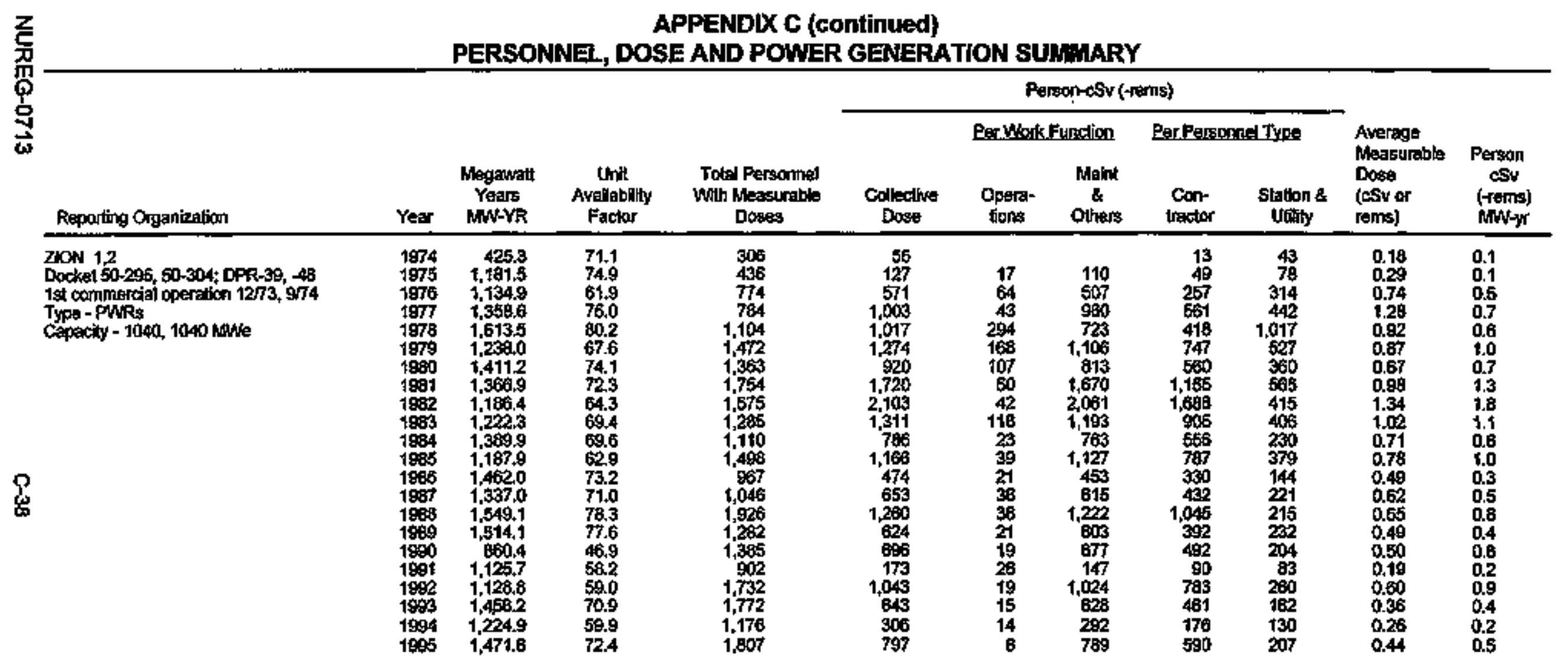




\section{APPENDIX 0}

Number of Personnel and Person-rem by Work and Job Function 1995

NOTE: Appendix D contains data on oparating plants as well as plants which are no longer in commerclal operation.

D-1 
WORKAND JOB FUNCTION

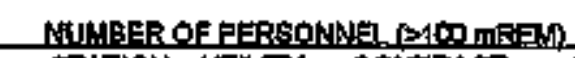
STATHN UTLTY CONTRACT TOTAL
TOTAL PERESONLREM

STATION UTIUTY CONTRACT TOTAL

REACTOR CPE \& SURV MAINTENANCE FERSONNG OPERATIONSPERSONWEL

HEALTH FHYSICS PER SONNIE SUPERVISORY PERSONWE ENGINEERING PERSONNEL TOTAL

ROUTWE MAINTENANCE MAINTENANKE PERSONNEL OPERATIONS PERSONNEL HEALTH PHYSICS PERSONNEL SLPERVISORY PERSONME ENGINEERING PERSONNEL TOTAL

1
1
30
0
1
33

1
1
1
0
0
3

32
0
41
1
0
44

34
2
42
1
1
80

0.200
0.101
0.884
0.000
0.240
7.425

\section{5}

\subsection{0}

0.160

0.000

0.079

7.425

MLSERYICE JNSEECTION MAINTENANCEPERSONWEL OPERATIONS PERSONNEL HEALTH PHY\&CS PERSONNEL BUPERVISORY PERSONNEL DNGINEERING PERSONNEL TOTAL

SPECIALLMALNTENANCEE MAINTENANCEEPERSONNNEL OPERATIONS FERSONNEL HEALTH PHYSICS PERSONWEL SUPERVISORY PERSONNEL ENGINEERING PERSONNNEL TOTAL

WASTEPROCESSING MANTENANCEPERSONNEL OPERATIONS PERSONNAE HEALTH PHYSICS PERSONEVE SUPERMSORY PERSONNEL ENGINEERNA PERSONNEL TOTAL

\section{REFUE:|NG}

MANTENANCE PERSONNEL OPERATIONS PEREONWEL HEALTH FHYSTCS PERSONNEL SUPERVISORY PERSONNEL UNEINEERING PERSONNEL TOTAL

TOTAL EY JOR EUNCTION MANTENANCE PERSONNEE OPERATIONS PERSONNEI. HEALTH PHTYSICS PERBONNEL SUPERVISORY PERSONN희. ENCNEERING PERSONNE

$\mathbf{5}$
$\mathbf{0}$
0
$\mathbf{0}$
$\mathbf{0}$
$\mathbf{5}$

5

0

0

o

$\begin{array}{rr}38 & 38 \\ 0 & 0 \\ 0 & 3 \\ 1 & 1 \\ 9 & \frac{11}{53}\end{array}$

\subsection{0}

0.000

0.000

0.000

000

0.000

\section{0,000}

0.000

0.614

0000

acx

0.914

208

14
103

3

7

132

$\frac{2}{5}$

289

15015

1.39

T.4.5

0.511

1.44

2580

o

a

3

0

$\frac{1}{4}$

$\begin{array}{ll}0 & 0 \\ 0 & 0 \\ 0 & 1 \\ 0 & 0 \\ 0 & 1 \\ 0 & \frac{1}{2}\end{array}$

0

4

0

B

0.000

0,00

0.570

0,000

0.117

0.037

311
23
91
10
40
485

23.022

4.611

13.482

3.51

45.522

68

30

23

15

$\infty$

1034

0.000
0.000
0.000
0.000
0.000
0.000

\section{0,294}

0.270

0.234

0,000

0000

0.788

14.077
0.000
2182
0.128
0.000
10.069

15.272

D.27

D.155

0.129

0.240

25.107

0.694

0.000

0.000

0000

$\mathrm{BOOO}$

0.694

0.694

0.000

0.000

0.000

000

0.654

$\begin{array}{lrr}0.000 & 13.705 & 13.705 \\ 0.000 & 0.000 & 0.000 \\ 0.000 & 0.000 & 0.614 \\ 0.000 & 0.670 & 0.5 \% \\ 0.000 & 1.97 & 2.071 \\ 0.000 & 1.265 & 17.189\end{array}$

49.128

0.174

12649

0.000

요

62015

84,427

1.841

xase

0.511

2.112 .

8.279

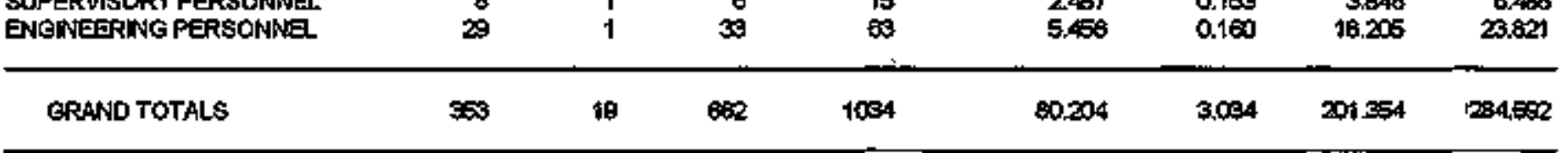

"Workers may be countad in frore then ane category. 
REACTOR OPS \& SURV

MANTENANCE PERSONNER

OPERATIONS PERSONWEI

HEELTH FHYSICS PERSONWE

SUPERVISORY PERSONNHE

ENGWEERNG PERSONNEL TOTAL

ROUTINE MARTTENANCE

MANTENANCE PERSONMVZ

OPERATIONS PERSONNEL

HEALTH PHYSICS PERSONNNEL

EUPERMSORY PERSONNEL

ENBNEERING PERSONNEE TOTAL

M-SFRVICEINGPECTION

MAINTERANGE PERSONNEL

OFERATIONS PEASSONNEE

HEALTH PHYSICS PERSONNEI

SUPERVISORY PERSONNEL

ENGINEERANE PERSONNEL TOTAL

11
69
29
15
3121

0
0
0
0
0
0

12
6
27
4
0
49

23
69
56
19
170
$\frac{3}{30}$
stamor

$\begin{array}{rrr}165 & 0 & 262 \\ 2 & 0 & 0 \\ 13 & 0 & \frac{0}{15} \\ 15 & 0 & 11 \\ 5 & 0 & 10 \\ 200 & 0 & 130\end{array}$

427
2
88
28
15
58

2.521
18.110
7.000
3.784
0.545
29.950
UTUTY CONTRACT TOTAL

geEC|ALLMAINTENANCE MAINTENANCE PERSONNEL OPERATIONS PERSONINE. HEALTH PHYYSHCS PERSONNEL SUPERVISORYPERSONNEL, ENEINEERINO PERSONNEI TOTAL

$\begin{array}{lll}4 & 0 & 16 \\ 0 & 0 & \\ 0 & 0 & \\ 0 & 0 & 11 \\ 1 & 0 & 21\end{array}$

170
0
35
10
200

67.009
0.005
2765
3.678
1.005
7.203

0.000
0.000
0,000
0.000
0.000
0.000

3.400
0.845
10.549
0.806
0160
18.749

$$
\begin{array}{r}
8.901 \\
18.055 \\
17.078 \\
4500 \\
0.056 \\
48.739
\end{array}
$$

18.749

WASTE PROCESSING MAINTENANCE PERSONNNEL OPERATIONS PERBONNEL HEALTH FH HYSHCS PERSONNEL. SUPERVISORY PERSONNEL ENGINEEFANO PERBONONEL

$$
\text { TOTAL }
$$

$\begin{array}{ll}0 & 0 \\ 0 & 0 \\ 0 & 0 \\ 0 & 0 \\ 0 & 0 \\ 0 & 0\end{array}$

$\begin{array}{ll}0 & 0 \\ 0 & 0 \\ 0 & 0 \\ 0 & 0 \\ 0 & 0 \\ 0 & \\ 0\end{array}$

\section{REFUELING}

MAINTENANCE PERSONNEL OPERATIONS PERBONWEI HEALTH PHYSICS PERSONNEL SUPERVISORYPERSONNE. ENAEUNEERING PERSONNEI TOTAL

$\begin{array}{ll}1 & 0 \\ 4 & 0 \\ 2 & 0 \\ 1 & 0 \\ 0 & 0 \\ 8 & 0\end{array}$

$a$
0
0
0
0
12

0.000
0.000
0.000
0.000
0.000
0.000

110.496

0.000

32547

5,850

2090

177.507

0.695

35312

9,680

4005

$\begin{array}{rr}160 & 170 \\ 0 & 3 \\ 31 & 90 \\ 217 & 200\end{array}$

2.140
0.000
0.005
4.990
0.150
7.375

0.000
0.000
0.000
0.000
0.000
0.000

101.000

0.000

15.297

8,500

G.3\%7

128.113

104079

0.050

15.52

13.430

0.077

$\begin{array}{ll}0 & 0 \\ 0 & \\ 0 & 0 \\ 0 & 0 \\ 0 & 0\end{array}$

0.113

0,000

0,000

0,075

0,000

0.150

\subsection{0}

0.000

0.000

0,000

D.000

0,000

2068

0,000

0.148

o.oro

0,000

2247

2201

0.000

0.154

0.085

0000

2440

039

0900

0.450

0.35

0000

2.102

0,000

0.000

0,000

0.000

cor.000

0,000

0,570

0,000

3.400

0,000

0,000

4000

0907

aseo

3800

o.ss

0,000

$\frac{2000}{6.122}$

$\begin{array}{rrrr}7 & 0 & 59 & \\ 2 & 0 & 0 & \\ 0 & 0 & 20 & \\ 9 & 0 & 3 & \\ 2 & 0 & 8 & \\ 17 & 0 & 90 & 10\end{array}$

2284

0.000

37894

0.000

0.081

Do10

3.817

요워

0000

0.000

0,000

1.240

260

0.000

50.845

40.178

1.110

9.091

5.057

$31 \%$

50.56

TOTAL RY JOAFUNCTION

MANTERANCE PERSONNAE

OPERATONS PERSONLEA

HEALTH PHIYSICS PERSONNEL

SLIPERVISORY PEREONNIE.

ENGINEERING PERSONNEL

$\begin{array}{rrr}185 & 0 & 500 \\ 71 & 0 & \\ 44 & 0 & 16 \\ 45 & 0 & 2 \\ 11 & 0 & 7\end{array}$

500
8
79

$\begin{array}{rrr}0.000 & 759.389 & 333.853 \\ 0.000 & 0.945 & 19.770 \\ 0.000 & 71.062 & 81.547 \\ 0.000 & 18.508 & 39.128 \\ 0.000 & 6.157 & 8.477\end{array}$

$0,000 \quad 253469 \quad 47850$


REACTOR OPS \& SILRV MANTENANCE PERSONNEE OPERATIONS PERSONNEL HEALTH PHYSICSPERSONWE SUPERVISORY PERSONNEL ENEWEEER' PERSONNEL TOTAL

ROUTINE MALTENANCE MANTENANCE PERSONME OPERATIONS PERSONNAL HEALTH PHYSICS PERSONNE SUPERVISORY PERSONNA ENCONEERINB FERSONNEL TOTAL

M-SGRVICINSPECTICN MANTE WANCE PERSONWE OPERATIONS PERSONNEI HEALTHPHYSICS PERSONWEL SUFERVBORY PERSONWE ENGNEERING FERSONNEI. TOTAL

SPECIAL MANTENANCE MAINTENANCE PERSONNE OPERATHNS PERSONNE HEALTH PHYSCS PERSCNNEL SUPERUSORY PERSONNEL ENGNEERINSPERBONNEI TOTAL

$\begin{array}{rr}0 & 0 \\ 35 & 0 \\ 10 & 0 \\ 0 & 0 \\ 2 & 0 \\ 45 & 0\end{array}$

0
0
2
0
0
2

0
89
12
0
2
47

0.180 13.900 3.870

0.387

0.850

19.247

$\begin{array}{rl}19 & 1 \\ 1 & 0 \\ 7 & 0 \\ 0 & 0 \\ 3 & 0 \\ 30 & 9\end{array}$

\begin{tabular}{l}
4 \\
0 \\
2 \\
1 \\
0 \\
\hline 7
\end{tabular}

24
1
6
1
3
38

5.040

0.340

1.895

0051

0.820

6.886

0

0

0

뭉

\section{WASTEPROCESSINA}

MAINTE EMANCE PERSONINEL OPERATIONS PERSONNEL HEALTH PHYSICS PERSONNEI SUPERVSORY PERSONNEL

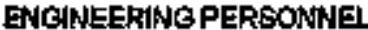
TOTAL.

1
11
0
14

$\begin{array}{ll}0 & 5 \\ 0 & 0 \\ 0 & 0 \\ 0 & 1 \\ 0 & 0 \\ 0 & 8\end{array}$

5
0
0
1
0
8

$\begin{array}{ll}0 & 0 \\ 0 & 0 \\ 0 & 0 \\ 0 & 0 \\ 1 & 0 \\ 0 & 0\end{array}$

BEFUEANG

MAWTENANCE PERSONNEL OPERATIONS PERSONNES HEALTH PAYSICS PERSONN트 SUPERMSORY PERSONNEL DNGINEERING PER\&ONNEL TOTAL

0
0
0
0
0
0

0
0
0
0
0
0
0

0
0
0
0
0
0

$\begin{array}{ll}0 & 0,000 \\ 0 & 0.000 \\ 0 & 0,000 \\ 0 & 0.00\end{array}$

nocos

o.tosi

0.000

a.o12

0,007

0.085

$\begin{array}{ll}1 & 1 \\ 0 & 0 \\ 1 & 8 \\ 0 & 0 \\ 0 & 1 \\ 2 & 11\end{array}$

5
1
11
1
2
2

0.297

0.390

6.121

0.01

0.518

7.57

0.000
0.008
0.002
0.018
0.010
0.000

$\begin{array}{lr}0.006 & 0.187 \\ 0.003 & 13.97 \% \\ 0.770 & 4.642 \\ 0,220 & 0.000 \\ 0.0027 & 0.897 \\ 1.028 & 20.911\end{array}$

0.040
0.000
0.008
0.009
0.06
0.396

1.158

0,000

0.46

0.294

0,000

1.86

7.456

0.340

2311

0.371

11.149

TOTAL BY VOB FLNCTION MAINTENANCEPEREONANEL OPERATLONS PERSONNE. HEALTH PHYBICS FERSONNA STIPERVISOFY PERSONNEL ENININEERING PERSONNEL

19
35
39
0
8

10
0
2
0

\begin{tabular}{|c|c|c|c|c|}
\hline $\begin{array}{l}0 \\
0 \\
0 \\
0 \\
0 \\
0\end{array}$ & $\begin{array}{l}0,000 \\
0,000 \\
0,000 \\
0,000 \\
0,000 \\
0,000\end{array}$ & $\begin{array}{l}0.000 \\
0.000 \\
0.000 \\
0.000 \\
0.000 \\
0.000\end{array}$ & $\begin{array}{l}0,000 \\
0,000 \\
0,000 \\
0,000 \\
0.000 \\
0.000\end{array}$ & $\begin{array}{l}0,000 \\
0,000 \\
0,000 \\
0,000 \\
0,000 \\
0,000\end{array}$ \\
\hline $\begin{array}{r}30 \\
56 \\
41 \\
2 \\
8\end{array}$ & $\begin{array}{r}0.491 \\
14,920 \\
17,057 \\
0.525 \\
2164\end{array}$ & $\begin{array}{l}0.346 \\
0.008 \\
0.010 \\
0.094 \\
0.032\end{array}$ & $\begin{array}{l}.7202 \\
0.000 \\
1.002 \\
1.425 \\
0.051\end{array}$ & 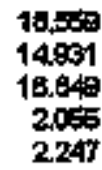 \\
\hline
\end{tabular}

ocose

otost

0.000

0.012

0007

$\frac{0,007}{0.009}$

B. +29

0.000

0.165

0.910

ofoiso

8.219

a.401

a.sog

6.286

0.:81

0.594

\begin{tabular}{|c|c|c|}
\hline $\begin{array}{l}0.0 \% 8 \\
0.169 \\
5.151 \\
0.054 \\
0.579 \\
5.505\end{array}$ & $\begin{array}{l}0, \infty 00 \\
0,000 \\
0,000 \\
0,0 \infty 0 \\
0,0,0 \\
0,0 \infty 0\end{array}$ & $\begin{array}{l}0.455 \\
0.000 \\
0.2063 \\
0.007 \\
0.002 \\
0.057\end{array}$ \\
\hline
\end{tabular}

8

1

17

118

41.937

0.490

12.914

Workere may be counted h more than one categary. 
REACTOR OPS A SURV

MAINTENALCEPERBONNEL OPERATLNNG PERSONNEI HEALTH PHYECS PERSONNEL SUPERVISORYPERSONNEL ENCENNEERING PERSONNEL

TOTAL

12
38
15
44
139
139

0
27
4
6
0
37

\section{2}

144

28

o

ROUTINEMAINTENANCE

MANTENANGE PERSONN1E OPERATIONS PERSONNEI HEALTH PHYYSTC\& PERSONNEI SUPERVSORY PER8OND: ENONEERING PERSONWEL TOTAL

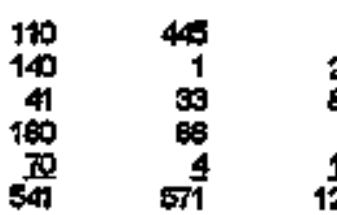

$\begin{array}{rr}9 & 564 \\ 20 & 164 \\ 85 & 180 \\ 1 & 206 \\ 10 & 84 \\ 125 & 1237\end{array}$

MLEFFMACEINGPECTION MAINTENANEEEPERSONNEL OPERATIONS PERSONNEL HEALTH PHYSICS PERSONNEL SUPERVISORY PERSONNEI ENGINEEFING PERSONANEL TOTAL

$\begin{array}{rrr}0 & 112 \\ 0 & \\ 0 & \\ 0 & \\ 18 & \\ 18 & 11\end{array}$

112

0

1

$11 \frac{1}{\frac{1}{5}}$

0
0
5
1
1
7

112

0

2

18

138

EPECIALMANTENANCE MAINTENANGE PERSONNEI OPERATIONLS PEREONNES.

HEALTH PYMSICS FERSONNE. STIPERVISORY PERSONNEL. ENCINETRWG PERSONNEL TOTAL

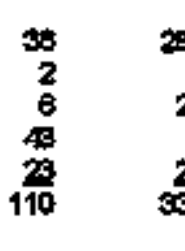

WASTEPROCSESENC MANTENANCE PERGONNE OPERATIONSPERSONWE

HEALTH FHYSTCS PERSONME. SUPERVISORY PERSONNE ENGINEERNG PERBONNEE. TOTAL

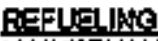

MANTIUUNANCE PERSONNEE OPERATIONS PERBONNNEI

HEALTH PHYSICS PERBONNEL, GLPERVISORY PERSONNEI ENONNEERING PERSONNAI TOTAL

TOTALEY JOA FUNCTION MAINTENANCE FERSONARE OPERATIONS PERBONNEI. HEALTH PHYEICS PERSONNEL SLPERVISORY PERSONYYI ENGINEERING PERSONNE.

$\begin{array}{rrr}0 & 29 & \\ 4 & 145 & \\ 2 & 0 & 10 \\ 2 & 0 & \\ 0 & 0 & \\ 6 & 174 & 11\end{array}$

10
28
20
2

327

2

58

43

2it

$\operatorname{css}$

$0 \quad 2$

$\underset{100}{20}$

2

$11 \quad 193$

$\begin{array}{rrr}12 & 11 \\ 10 & 0 \\ 1 & 0 & \\ 17 & 0 & \\ 0 & 0 & \end{array}$

$\begin{array}{rr}6 & 29 \\ 0 & 10 \\ 23 & 24 \\ 1 & 18 \\ 0 & 9 \\ 30 & 90\end{array}$
$10 \quad 1200.417$

2400

3.737

3370

1.381

p.ps

11.50

000

0.150

0.756

0.103

o.cm

1068

22495

14509

8.971

5,000

134

52624

700.02

0.005

5.8es

1.694

nods

Ps

0.000

0.000

0,000

0.011

axs

D.506

17.875

0.000

0.165

0,000

0.여도

18.075

0.002

254

0.065

0,000

0.000

0.000

344

4100

1.487

0 도연

12605

7380

1.315

1.348

0.45?

10.643

44514

0.000

4.117

0.110

0.284

49.405

$0.5 \%$

0.119

0.526

0,00

Q.17.

$1,0 \%$

94,005

14,463

15.180

7.344

1,452

132.444

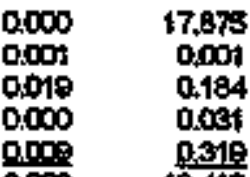

TB்ATO

0.005
0.417
0.001
0.074
0.091
0.48

4.543

0.637

0.01

0.000

p,op

5,381

0.013

52007

0.143

0.200

0,000

0.011

0.879

1.459

D.T.

60.924

$29 \quad 2.890$

2.68

0.165

0,842

0.177

1.785

0.00

0.002

0.00

a.0.9

1.847

0,000

0.004

poss

0,00

acong

0.042

4.543

1.25

0.040

0.074

0.001

5.921

4.502

34.75

19.70

13.622

e,014

14.100
0.905
10.984
1.000

0.320

0.54

4.5\%

$1,0=0$

0.285

0.088

000

0.542

요고

0,000

o.ses

2689

80165

$1.597 \quad 178.404$

$0.273 \quad 20.063$

0.613 25\%5

$0000 \quad 10.014$

$0.077 \quad 3.272$

Workars may be counted in more thas ons octegory. 
WORKAND

JOB FUNCTION

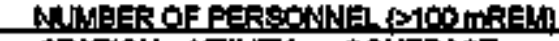
STATION UTILITY
TOTALPERSON-REM STATION UTILTY CONTRACT TOTAE
REACTOR OPS

MAINTENANGE PERSONBGL OFERATION8 PERSONNEL

HEALTH FHYSUCS PERSONWE

SUPCRVSORY PERSONWG.

ENBNEERING PERSONNEL TOTAL

\section{ROLTINH MANTENANCE}

MANTENANCE FEFSONWIEL

OPERATIONS PERSONNEL

HEALTH PHNSGCS PERSONNE.

SUPERVISORY PERSONNEL

ENGINEERING FERSONNEEL TOTAL

\section{N-SERMCE INSPECTION}

MANTENANGE PERSONNEL

OPERATIONS PERSONNEL

HEALTH PHYSCS PERBONNEL

SLIPERVISORY PERSONNEL

GNGNEEERNA PERSONMEI TOTAL

EPECIAL MAINTE ENANCE

MABTENANCE PERSONNEI.

OPERATIONS PERSCNNEL

HEALTH PHYSICS PERSONNEL

SUPERVSORY PERSONNEL

ENGINEERING PEREONNEL TOTAL

123
+08
54
50
340

$\begin{array}{rr}21 & 30 \\ 3 & 2 \\ 6 & 1 \\ 0 & 51 \\ 1 & 30\end{array}$

$\begin{array}{rr}304 & 48 \\ 2 & 113 \\ 1 & 91 \\ 51 & 81 \\ 30 & \text { 寊 }\end{array}$

its

86

22

$\frac{24}{537}$

$\begin{array}{rrr}25 & 00 & 404 \\ 3 & 9 & 108 \\ 0 & 1 & 63 \\ 2 & 09 & 98 \\ 4 & 400 & 1200\end{array}$

104
108
63
98
$\frac{70}{100}$

3
0
0
0
0
0

3
0
0
0
0
0

138

5

5

$\frac{15}{2 \% 9}$

$\begin{array}{rr}24 & 73 \\ 2 & 3 \\ 6 & 1 \\ 2 & 71 \\ 1 & 49 \\ 35 & 98\end{array}$

808
61
60
62
69
1169

$\begin{array}{rl}18 & 1 \\ 10 & 0 \\ 10 & 0 \\ 3 & 0 \\ 0 & 0 \\ 41 & 9\end{array}$

13
1
9
0
14
TOTAL

REFEUEAING

MANTENANCEPERSONNEL OPERATTONS PERSONNEL

HEALTH FHYSICS FERSONNH. SUPERVISOFY PERSONNEL ENNEINEERINZ PERSONNEL TOTAL

$\begin{array}{rr}0 & 0 \\ 13 & 0 \\ 1 & 0 \\ 1 & 0 \\ 0 & 0 \\ 15 & 0\end{array}$

7
0
0
1
0
8

7
13
1
2
0
26

$\begin{array}{rr}446 & 7 \\ 703 & \\ 65 & \\ 62 & 6\end{array}$

$\begin{array}{rrr}71 & 17 \% 5 & 229 \\ 8 & 15 & 30 \\ 18 & 3 & 196 \\ 4 & 192 & 261 \\ 6 & 150 & 100\end{array}$

11.484

1,20

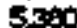

0.242

oros

19.271

0.279

0.754

0,133

0,090

$0,0 \times$

1.229

0,000
0.074
0,002
0,001
0,000
0.077

3.311

0.104

1.04

0.058

$0 \mathrm{con}$

4.5te

0.023

0.00

$0, \infty 00$

0.000

0,00

0,028

$0 \infty 0$

0.000

0,000

0.000

0,000

0,000

51,200

30.43

22,493

5805

4403
8.371

0.612

2268

0.27

osto
127209

0.668

0,01

0.002

$55 \times$

141.580

005

0.292

0,000

0,000

0,000

0.350

0011

0.000

0,000

0.015

nows

0.029

245.455

3.505

0.272

18.867

Dess 2000s

21.829

11278

0314

3.440

6.714

141.764

Q.e⿰亻

7.163

10,227

4739

173547

0.041

0.000

$0+\infty 00$

0000

0000

0.041

142014

2027

0.424

6.3.2

오교

165.35

ENGINEERING PERSONNEL 
APPENDIX D (Continued)

NUMBER OF PERBOHNEL AND PERBON-REM

BY WORK AND JOB FUNGTION

TYFE: BWR

TOTALREFSOMN=REM

STATION UTILTY CONTRACT TOTAL
1905

PLANT: HBRUNBWCK 1,2
WORKAND

JOB FLNCTION
NUMAER OF PERSONN]EL_OFQM mR:EM

STATION UTITY CONTRACT TOTAL
BEACTOR OPSA S SURV

MAINTENANCE PERSONNEL

OPERATIONS PERSONNEI

HEALTH FHYSHCS PERSONWE-

SUPERVISORY PERSONUE.

ENGINEERWNG PERSONWEI

TOTAL

ROUTME MANTIENANCE

MAINTENANCEPERRSONNEL

OPERATIONS PERSONNNEI.

HEALTH PHYSICS PERSONNEI

GUPERVISORY PERSONNE

ENGINEEFRNG PERSONNEE

TOTAL

N-SERVMEINSPECTNN

MAISTENANCE PERSONNNEL

OPERATIONS FERSONNEI

HEALTH PHYSICS PERSONME

SUPERVISORY FERSONNET

ENGINEERNAG PGRSONNE.

TOTAL

SPFCIAILMAINTIENANKCE

HAINTENANGE PERSOWNEL OPERATIONS PERSONNE

HEALTH PHYSICS PERSONNEL

ELPERVISORY PERSONWEI

ENGINEERING PERSONWE

TOTAL

11
79
64
14
5
173

2
0
0
1
0
3

\section{9}

120

93

17

7

171

$\stackrel{2}{20}$

240

413

15

7

$\frac{128}{54}$

3

4

植

o 18

00

to

$\frac{14}{32}$

0

0
10

10
3

5

19

10

3

0

14

ENCANEEFING PERSONNEL

TOTAL.

\section{REFUEANG}

MANTENANCEPERSONNEL

OPERATIONS PERSONNEL

HEALTH PHYSICS PERSONNER

SLPERVISORYPERSONNEL

ENGNEERTNG PEREONNEI TOTAL

TOTAL BY, JOB FINETION

MANT EMANCEPERECNNEL

OPERATION8 PERSONNEL

HEALTH PHYSICS PERSONNEL

SUPERVISORY PERSONNEL

ENEINEERNG PERSONNEI (n)

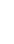

\begin{tabular}{|c|c|c|c|c|c|c|}
\hline \multirow{2}{*}{$\begin{array}{l}\text { YORKAND } \\
\text { OB FLNCTION }\end{array}$} & \multicolumn{4}{|c|}{ 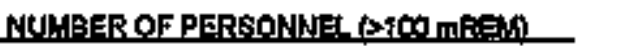 } & & TQMALRE \\
\hline & STATIN & பTபTY & CONTRACT & TOTAL & & STATION \\
\hline 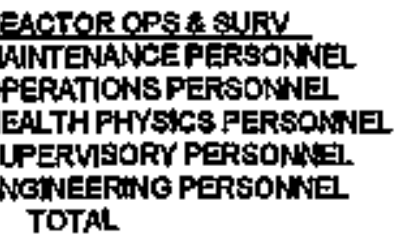 & $\begin{array}{r}11 \\
79 \\
64 \\
14 \\
5 \\
113\end{array}$ & $\begin{array}{l}2 \\
0 \\
0 \\
1 \\
0 \\
3\end{array}$ & $\begin{array}{r}9 \\
4 \\
29 \\
2 \\
2 \\
80\end{array}$ & $\begin{array}{r}19 \\
120 \\
93 \\
17 \\
7 \\
206\end{array}$ & & 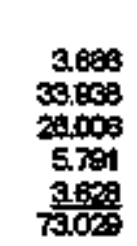 \\
\hline 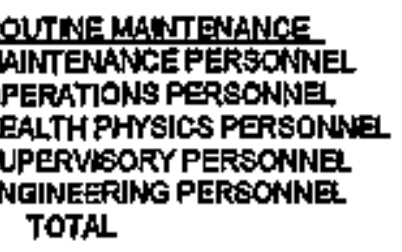 & $\begin{array}{r}171 \\
0 \\
22 \\
11 \\
240\end{array}$ & $\begin{array}{l}1 \\
0 \\
0 \\
0 \\
1 \\
2\end{array}$ & $\begin{array}{r}413 \\
1 \\
15 \\
7 \\
128 \\
584\end{array}$ & $\begin{array}{r}585 \\
1 \\
37 \\
18 \\
168 \\
600\end{array}$ & & $\begin{array}{r}72.743 \\
0.652 \\
6.577 \\
5.057 \\
16397 \\
101.368\end{array}$ \\
\hline 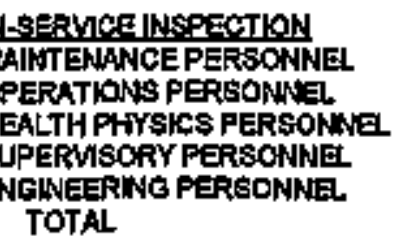 & $\begin{array}{r}3 \\
4 \\
1 \\
1 \\
7 \\
16\end{array}$ & $\begin{array}{l}0 \\
0 \\
0 \\
0 \\
0 \\
0\end{array}$ & $\begin{array}{r}18 \\
0 \\
0 \\
0 \\
14 \\
32\end{array}$ & $\begin{array}{r}21 \\
4 \\
1 \\
1 \\
4 \\
4 \\
43\end{array}$ & & $\begin{array}{l}0.012 \\
1.877 \\
0.228 \\
0.289 \\
1.091 \\
5.252\end{array}$ \\
\hline 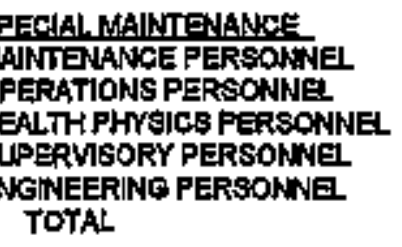 & $\begin{array}{r}0 \\
0 \\
10 \\
3 \\
5 \\
18\end{array}$ & $\begin{array}{l}7 \\
0 \\
0 \\
0 \\
1 \\
8\end{array}$ & $\begin{array}{r}289 \\
2 \\
17 \\
5 \\
57 \\
324\end{array}$ & $\begin{array}{r}290 \\
2 \\
7 \\
0 \\
208\end{array}$ & & $\begin{array}{l}1.240 \\
0.044 \\
2197 \\
1.005 \\
1.590 \\
0.124\end{array}$ \\
\hline 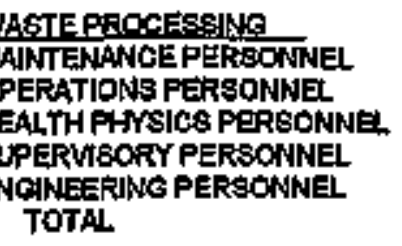 & $\begin{array}{r}10 \\
0 \\
3 \\
0 \\
1 \\
14\end{array}$ & $\begin{array}{l}0 \\
0 \\
0 \\
0 \\
0 \\
0\end{array}$ & $\begin{array}{r}20 \\
0 \\
1 \\
1 \\
4 \\
2\end{array}$ & $\begin{array}{l}30 \\
0 \\
4 \\
1 \\
5 \\
4\end{array}$ & $\cdot$ & $\begin{array}{l}4472 \\
0000 \\
0.08 \\
0.150 \\
0.48 \\
5650\end{array}$ \\
\hline 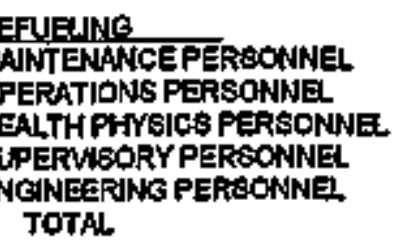 & $\begin{array}{r}8 \\
0 \\
0 \\
1 \\
5 \\
12\end{array}$ & $\begin{array}{l}2 \\
0 \\
0 \\
0 \\
0 \\
2\end{array}$ & $\begin{array}{r}30 \\
0 \\
1 \\
2 \\
44 \\
77\end{array}$ & $\begin{array}{r}53 \\
0 \\
1 \\
3 \\
49 \\
01\end{array}$ & & $\begin{array}{l}1.704 \\
0.000 \\
0007 \\
0.589 \\
1.54 \\
3.684\end{array}$ \\
\hline 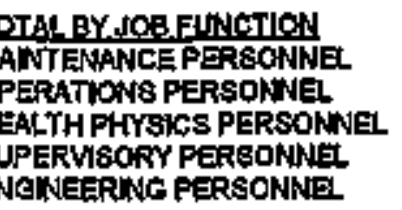 & $\begin{array}{r}201 \\
800 \\
90 \\
02\end{array}$ & $\begin{array}{r}12 \\
0 \\
0 \\
1 \\
2\end{array}$ & $\begin{array}{r}73 \\
44 \\
63 \\
17 \\
206\end{array}$ & $\begin{array}{r}986 \\
127 \\
183 \\
48 \\
275\end{array}$ & & 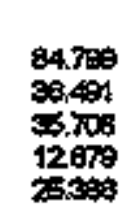 \\
\hline
\end{tabular}

\begin{tabular}{|c|c|c|c|c|c|c|}
\hline \multirow{2}{*}{$\begin{array}{l}\text { YORKAND } \\
\text { OB FLNCTION }\end{array}$} & \multicolumn{4}{|c|}{ 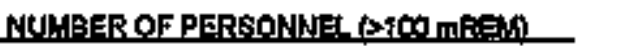 } & & TQMALRE \\
\hline & STATIN & பTபTY & CONTRACT & TOTAL & & STATION \\
\hline 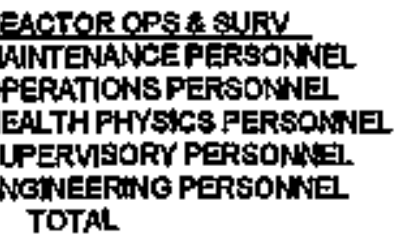 & $\begin{array}{r}11 \\
79 \\
64 \\
14 \\
5 \\
113\end{array}$ & $\begin{array}{l}2 \\
0 \\
0 \\
1 \\
0 \\
3\end{array}$ & $\begin{array}{r}9 \\
4 \\
29 \\
2 \\
2 \\
80\end{array}$ & $\begin{array}{r}19 \\
120 \\
93 \\
17 \\
7 \\
206\end{array}$ & & 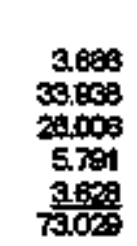 \\
\hline 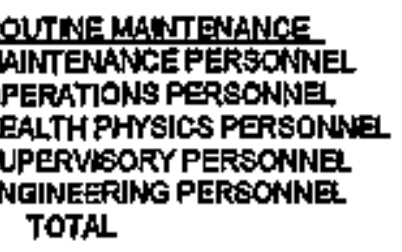 & $\begin{array}{r}171 \\
0 \\
22 \\
11 \\
240\end{array}$ & $\begin{array}{l}1 \\
0 \\
0 \\
0 \\
1 \\
2\end{array}$ & $\begin{array}{r}413 \\
1 \\
15 \\
7 \\
128 \\
584\end{array}$ & $\begin{array}{r}585 \\
1 \\
37 \\
18 \\
168 \\
600\end{array}$ & & $\begin{array}{r}72.743 \\
0.652 \\
6.577 \\
5.057 \\
16397 \\
101.368\end{array}$ \\
\hline 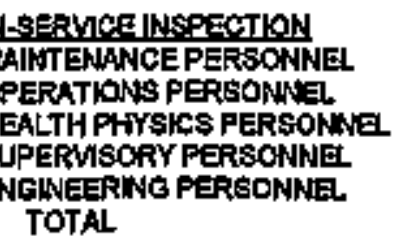 & $\begin{array}{r}3 \\
4 \\
1 \\
1 \\
7 \\
16\end{array}$ & $\begin{array}{l}0 \\
0 \\
0 \\
0 \\
0 \\
0\end{array}$ & $\begin{array}{r}18 \\
0 \\
0 \\
0 \\
14 \\
32\end{array}$ & $\begin{array}{r}21 \\
4 \\
1 \\
1 \\
4 \\
4 \\
43\end{array}$ & & $\begin{array}{l}0.012 \\
1.877 \\
0.228 \\
0.289 \\
1.091 \\
5.252\end{array}$ \\
\hline 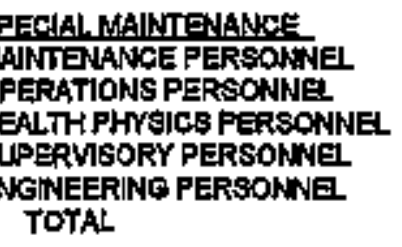 & $\begin{array}{r}0 \\
0 \\
10 \\
3 \\
5 \\
18\end{array}$ & $\begin{array}{l}7 \\
0 \\
0 \\
0 \\
1 \\
8\end{array}$ & $\begin{array}{r}289 \\
2 \\
17 \\
5 \\
57 \\
324\end{array}$ & $\begin{array}{r}290 \\
2 \\
7 \\
0 \\
208\end{array}$ & & $\begin{array}{l}1.240 \\
0.044 \\
2197 \\
1.005 \\
1.590 \\
0.124\end{array}$ \\
\hline 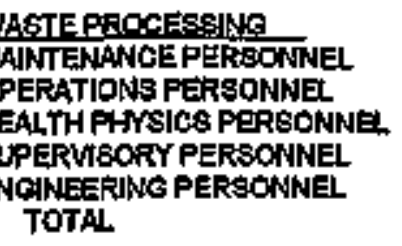 & $\begin{array}{r}10 \\
0 \\
3 \\
0 \\
1 \\
14\end{array}$ & $\begin{array}{l}0 \\
0 \\
0 \\
0 \\
0 \\
0\end{array}$ & $\begin{array}{r}20 \\
0 \\
1 \\
1 \\
4 \\
2\end{array}$ & $\begin{array}{l}30 \\
0 \\
4 \\
1 \\
5 \\
4\end{array}$ & $\cdot$ & $\begin{array}{l}4472 \\
0000 \\
0.08 \\
0.150 \\
0.48 \\
5650\end{array}$ \\
\hline 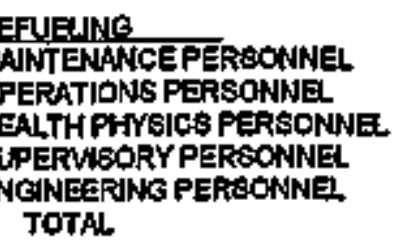 & $\begin{array}{r}8 \\
0 \\
0 \\
1 \\
5 \\
12\end{array}$ & $\begin{array}{l}2 \\
0 \\
0 \\
0 \\
0 \\
2\end{array}$ & $\begin{array}{r}30 \\
0 \\
1 \\
2 \\
44 \\
77\end{array}$ & $\begin{array}{r}53 \\
0 \\
1 \\
3 \\
49 \\
01\end{array}$ & & $\begin{array}{l}1.704 \\
0.000 \\
0007 \\
0.589 \\
1.54 \\
3.684\end{array}$ \\
\hline 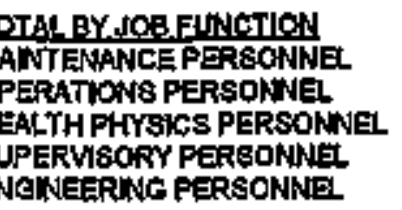 & $\begin{array}{r}201 \\
800 \\
90 \\
02\end{array}$ & $\begin{array}{r}12 \\
0 \\
0 \\
1 \\
2\end{array}$ & $\begin{array}{r}73 \\
44 \\
63 \\
17 \\
206\end{array}$ & $\begin{array}{r}986 \\
127 \\
183 \\
48 \\
275\end{array}$ & & 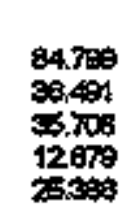 \\
\hline
\end{tabular}

0 o

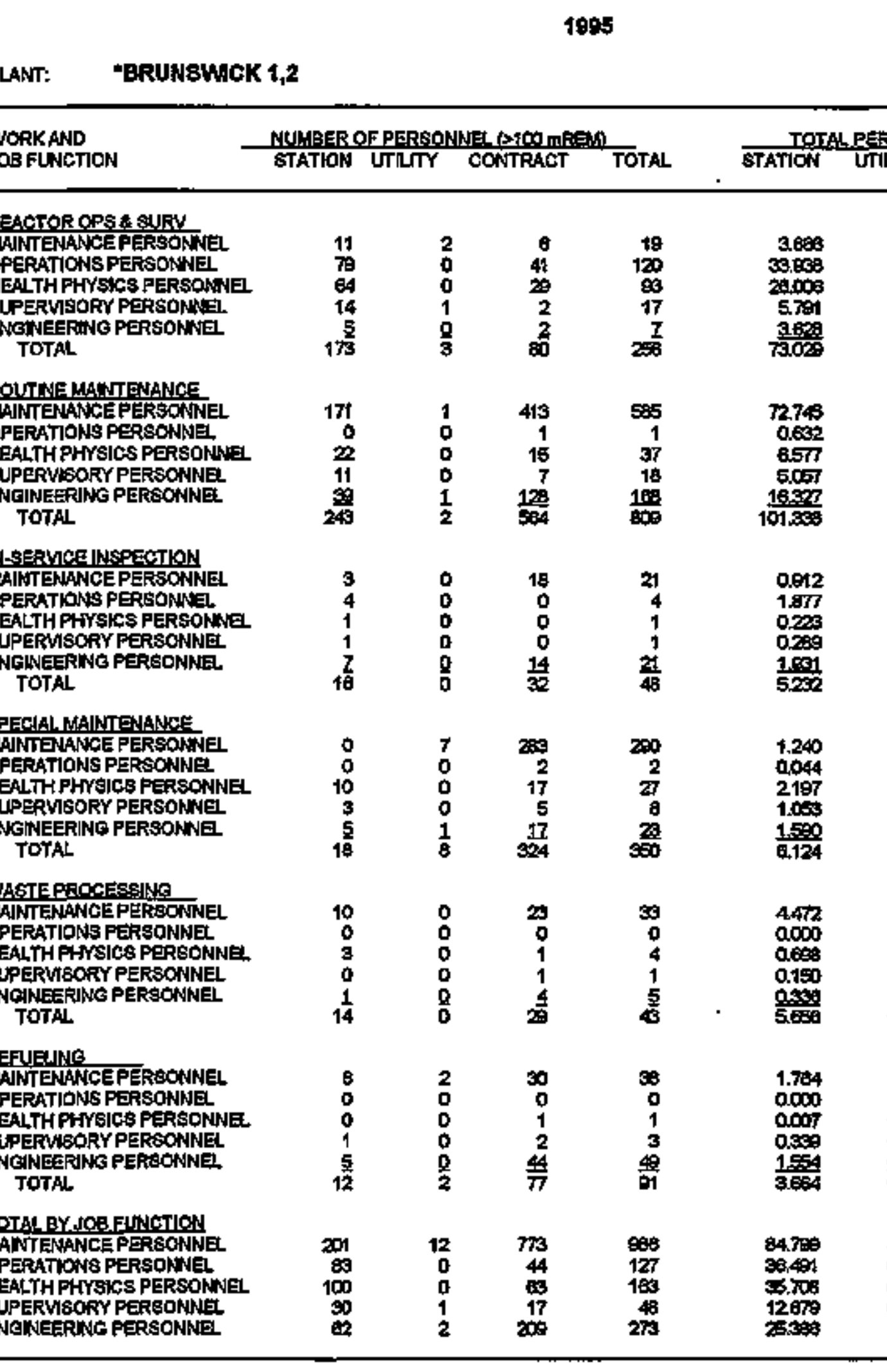

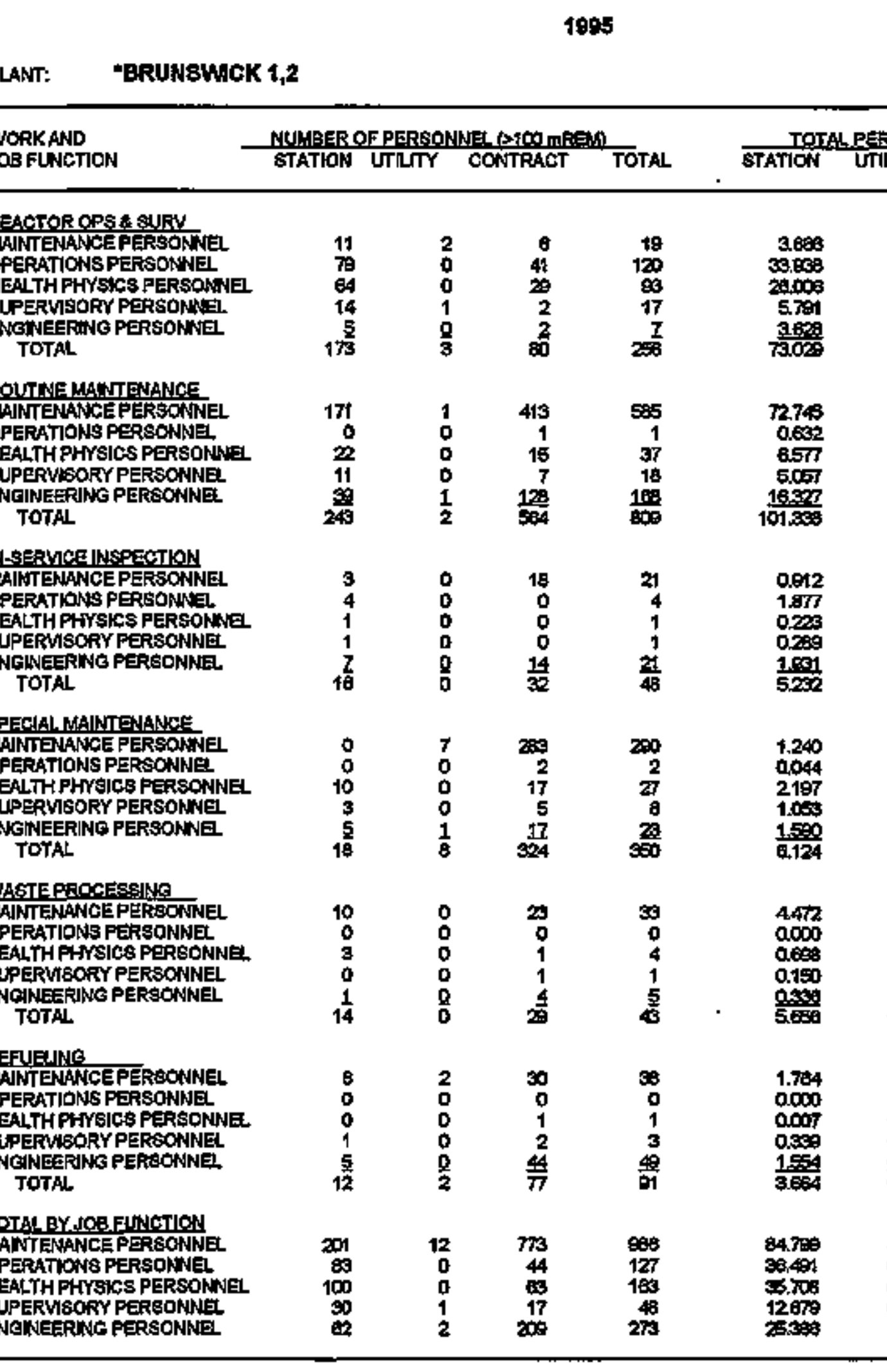

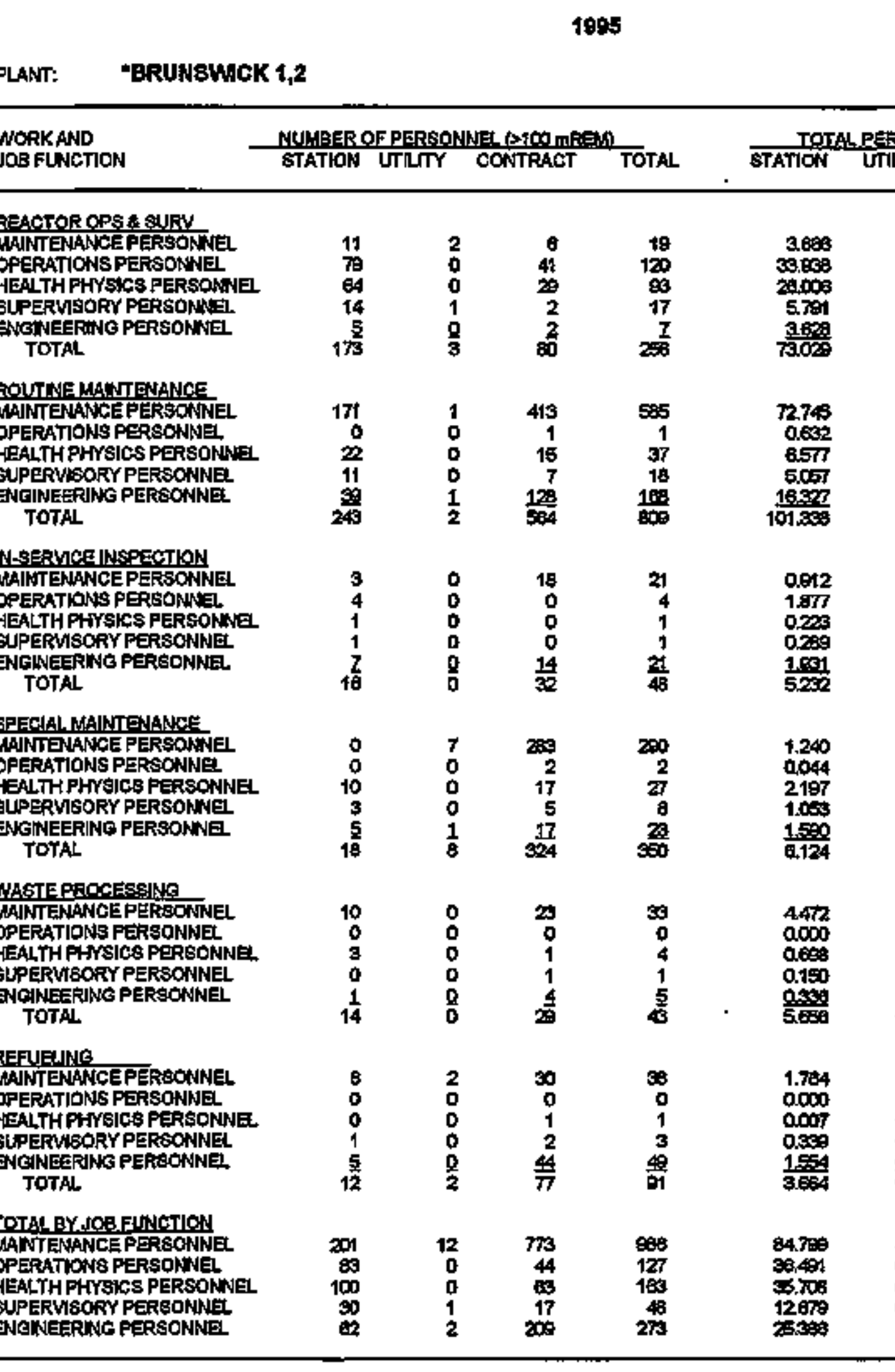

GRAND TOTALS $\quad 479$

Workers may be counted In mers than one category. 
WOFKAND JOS FUNHCTION
Nuls STATION UTILITY CONTRACT TOTAL
TOTALPERSON-RES!

STATION UTILITY GONTRACT TOTAL
REACTOR OFS \& SURY

MAINTENANCE PERSONNAE OPERATIONS PERSONNE!

HEALTH PHYSCS PERSONNNEL

SLPERVISORY PERSONWNEL

GMOINEERING PERSONNEZ TOTAL

ROUTME MANTIENANCE

MAINTE KANICE PERSONNEL

OPERATIONS PERSONNEL

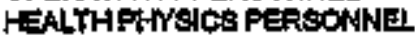

SUPERVISORY PERSONNEL

DNGNEERING PERSONWEL TOFAL

N.SERYCE INLSECTION MANTI JANGE PERSONNDI OPERATIONS PERSONNIE HEALTH PHYSGCA PERSONNEI BLPERVEORY PERSONNEI ENGNEERING PERBONNEL TOTAL

SEECCIA!MMNTERANCE MADNTENANCE PERECNNEL OPERATHON'S PERSOMNEL HEALTH FHYSICS PERSONWI. SUPERVBORY PERSONNEI ENGINEENING PERSONNEL TOTAL

$\begin{array}{ll}0 & 0 \\ 0 & 0 \\ 0 & 0 \\ 0 & 0 \\ 0 & 0\end{array}$

$\begin{array}{ll}0 & 1 \\ 0 & 0 \\ 0 & 0 \\ 0 & 3 \\ 0 & 0 \\ 0 & 4\end{array}$

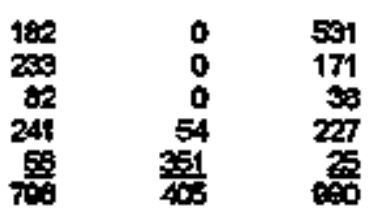

713
404
118
522
494
219

1
0
0
3
0
4

1
0
0
0
0
4

0,000
0,000
0,000
0,000
0.000

-1.

\section{0}

$\begin{array}{rr}0 & 0 \\ 0 & 0 \\ 0 & 0 \\ 0 & 0 \\ 1 & 34 \\ 1 & 40\end{array}$

187
0
0
0
$18 \frac{8}{6}$

187
0
0
0
209

2852
21.558
64522
15.000
14.182
117.611

0.000
0.000
0,000
0.000
0.000
0.000

4.190
0,000
0.000
0.000
0.172
4.371

CONTRACT

NASTE PROCESSNG

MANT ENANAE PERSONNE. OPERATIONS PERSONNEE

HEALTH PHYESCS PERSONNEL

SUPERVISORY PERSONW

ENQTNEERNG PERSONNIEI

$$
\text { TOT시 }
$$

$\begin{array}{ll}0 & 0 \\ 0 & 0 \\ 0 & 0 \\ 0 & 0 \\ 0 & 0 \\ 0 & 0\end{array}$

0
0
0
0
0
0

0
0
0
0
0
0

0.028
0.000
0.118
0.000
0.000
0.146

$\begin{array}{rrr}0.401 & 0.072 & 0.501 \\ 0.000 & -0.000 & 0.000 \\ 0.000 & 27.150 & 27.749 \\ 0.000 & 0.000 & 0.000 \\ 0.019 & 0.000 & 0.019 \\ 0.400 & 27.202 & 27.760\end{array}$

REFIJELIVIE

MANNTENANCE PERSONNEL OPERATIONS PEREONNEI

HEALTH PHYBACS PERSONNEL SUPERVSORY PERSONNG. ENGDEERING FERSONNEL TOTAL

0
1
0
0
1

$\begin{array}{rr}0 & 0 \\ 0 & 11 \\ 0 & 0 \\ 0 & 0 \\ 0 & 0 \\ 0 & 11\end{array}$

$\begin{array}{rl}0 & \\ 11 & 1 \\ 0 & \\ 0 & 0 \\ 11 & 0\end{array}$

0
12
0
0
0
12

0.013
0.011
0.057
0.000
0.007
0.000

0005

0,000

$0 \infty 0$

0.000

omong

000

$\begin{array}{ll}0.000 & 0.019 \\ 0.000 & 0.017 \\ 0.014 & 0.071 \\ 0.000 & 0.000 \\ 0.000 & 0.007 \\ 0.014 & 0.107\end{array}$

$\begin{array}{ll}0 & 0 \\ 0 & 0 \\ 0 & 0 \\ 4 & 0 \\ 0 & 0 \\ 4 & 0\end{array}$

0
0
0
0
0
0

$\begin{array}{lllll}0 & 0.00 & 0.000 & 0.000 & 0.000 \\ 0 & 0.000 & 0.000 & 0.000 & 0.040 \\ 0 & 0.114 & 0.000 & 0.000 & 0.114 \\ 4 & 0.009 & 0.000 & 0.000 & 0.003 \\ 0 & 0.189 & 0.000 & 0.000 & 0.189 \\ 4 & 0.000 & 0.000 & 0.344\end{array}$

\section{TOTALBYJOB FLNCTION}

MAINTENANCE PERSONNNEL OPERATIONS PERSONNEL HEALTH FHYEICB PERSONNEL SUPERVISORV PERSONVEI ENGWEERING PERSONME

$\begin{array}{rrr}182 & 0 & 719 \\ 234 & 0 & 182 \\ 84 & 0 & 350 \\ 240 & 60 & 200 \\ 50 & 50 & 30\end{array}$

719

416

118

ECS

477

21.408

15.751

14.380
DO1 2004
0.001
0.005
0.004
0.081
0.081
0.082

0.001

$0, \infty$

0.000

$0 \infty 0$

p.000

D.001

0.00

0.000

0.000

o.107

요을

0.107

exto1s

$\begin{array}{rrr}4.009 & 0,300 & 7.010 \\ 0,000 & 4.853 & 29.244 \\ 0.000 & 104,250 & 168.097 \\ 0.000 & 1.823 & 17.574 \\ 0.19 t & 72000 & 8.044\end{array}$

GRAND TOTALS

902

445

1200

2447

118271

4.797

183.27

scoses

Workes moy be coutted in more then one eqtegary. 
REACTOR OPS A.SHEY MAINTENANCEPERSONNDZ OPERATHONS PERSONNEL HEALTH PHYYSICS PERSONEVI. SUPERVISORY FERSONNE ENGINEGERNA PURBCNNEㄴ. TOTAL

$\begin{array}{rr}0 & 0 \\ 24 & 0 \\ 39 & 0 \\ 4 & 0 \\ 2 & 1\end{array}$

1
0
35
1
97

1
24
74
5
9
107

8

ROUT|NEMANTENANGE MANT GTANCE PERSONWE OPERATIONS PERSONNEL HEALTH FHYSICSPERBONWEL BJPERVISCRY PERSONR를 TOTAL

$\begin{array}{rr}97 & 1 \\ 2 & 0 \\ 1 & 1 \\ 2 & 0 \\ 9 & 0 \\ 111 & 2\end{array}$

0
0
0
1
0

194
2
2
2
10
210

20
0
0
0
2
43

$\begin{array}{r}37 \\ 0 \\ 9 \\ 0 \\ \text { g } \\ \hline 9\end{array}$

IN.8ERUTCE NEPEFCTION

MANT ENAKCE PERSONDNE OPERATIONS PERSONNEL

HEALTH PHYEACS FERSONNEL SUPERVISORY PERSONWNI ENGNEERNG PERSONM그. TOTAL

SPECIALMAINTENANCE MANTENANCEPERBONNEL OPERATIONIS PERSONNEI. HEALTHPHYSICS PERSONNEL SLFERUISORY PERSONWNEL TOTAL

$\begin{array}{ll}1 & 0 \\ 0 & 0 \\ 4 & 0 \\ 0 & 0 \\ 1 & 0\end{array}$

$\begin{array}{rrr}11 & 0 & 8 \\ 0 & 0 & \\ 1 & 0 & \\ 2 & 0 & \\ 14 & 0 & \\ 30 & 0 & 8\end{array}$

84
0
2
0
2
89

102
0
3
2
18
17

$\begin{array}{rr}0 & 0 \\ 0 & 0 \\ 12 & 0 \\ 0 & 0 \\ 0 & 0 \\ 12 & 0\end{array}$

$\begin{array}{ll}0 & 0 \\ 0 & 0 \\ 0 & 0 \\ 0 & 0 \\ 0 & 0 \\ 0 & 0\end{array}$

0
0
0
0
0
0

0
0
12
0
0
12

0
0
0
1
$\mathbf{9}$
$\mathbf{9}$

$\begin{array}{ll}0 & 27 \\ 0 & \\ 0 & 0 \\ 1 & 0\end{array}$

$\begin{array}{ll}27 & \\ 10 & 10 \\ 0 & \\ 0 & \end{array}$

\section{7}

10

1

4

219

$\begin{array}{ll}1 & 2 \\ 0 & \\ 1 & \\ 2 & \end{array}$

$\begin{array}{rr}244 & \\ 10 & \\ 42 & 10 \\ 1 & \\ 3 & \end{array}$

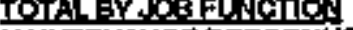
MAINTENANCE PERSONNE HEALTHPHYSICS PERSONNEL SLPERWBORY PERSONINEL ENGANEERINS PERSONNNEL ENGINEERNG PERSONMELL. ENGINEERING PERSONNEL

\begin{tabular}{|c|c|c|c|}
\hline $\begin{array}{l}0.144 \\
5.000 \\
0.470 \\
2248 \\
1.254 \\
18.212\end{array}$ & $\begin{array}{l}0,000 \\
0.000 \\
0.057 \\
0,069 \\
0.541 \\
0.446\end{array}$ & $\begin{array}{r}0.698 \\
0.000 \\
10.054 \\
0.284 \\
0.051 \\
11.077\end{array}$ & 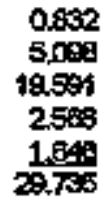 \\
\hline
\end{tabular}

\begin{tabular}{|c|c|c|c|}
\hline $\begin{array}{l}25.971 \\
0.917 \\
1.400 \\
1.009 \\
2.79 \\
1.807\end{array}$ & $\begin{array}{l}0.124 \\
0.000 \\
0.194 \\
0.004 \\
0.099 \\
0.054\end{array}$ & $\begin{array}{r}31.387 \\
0.000 \\
0.841 \\
0.148 \\
0.297 \\
32675\end{array}$ & $\begin{array}{r}57.078 \\
0.817 \\
2.455 \\
1.152 \\
6.142 \\
64.555\end{array}$ \\
\hline
\end{tabular}

\begin{tabular}{|c|c|c|}
\hline $\begin{array}{l}0.178 \\
0.000 \\
1.008 \\
0.102 \\
0.467 \\
1.778\end{array}$ & $\begin{array}{l}0.000 \\
0000 \\
0.000 \\
0012 \\
0.002 \\
0.012\end{array}$ & $\begin{array}{r}17.063 \\
0.000 \\
1.870 \\
0.000 \\
0.954 \\
20.007\end{array}$ \\
\hline
\end{tabular}

\begin{tabular}{|c|c|c|}
\hline $\begin{array}{l}5.628 \\
0.058 \\
0.687 \\
0.557 \\
3.146 \\
10.253\end{array}$ & $\begin{array}{l}0,000 \\
0,000 \\
0.085 \\
0,000 \\
0,000\end{array}$ & $\begin{array}{r}38.004 \\
0.000 \\
1.044 \\
0.000 \\
0.015 \\
39.753\end{array}$ \\
\hline
\end{tabular}

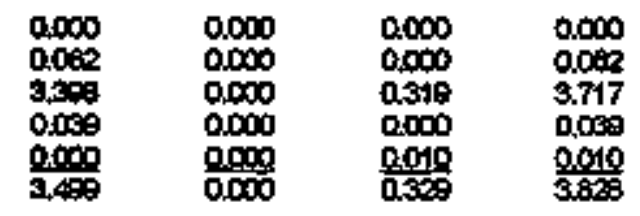

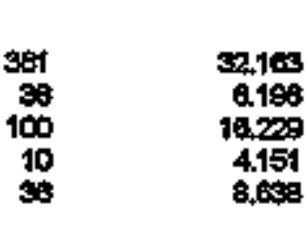

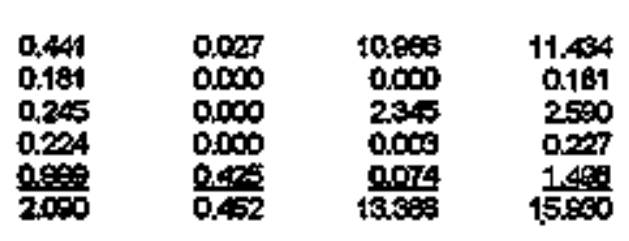

\section{7}

$4 \quad 302$

$302 \quad 543$

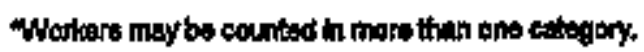


WORKAND JOB FUACTHON
NWWAER QF PEROONHEL S 100 mREW STATION UTLT'Y CONTRACT
TOTALPERSONHEH

STATION UTUTY CONTRACT TOTAL

REACTOR OPL R SULW

9

62

7

TOTAL

33
0
81
0
0
116

MANTENANACE PERSONNEL

OPERATIONS PEREONNE

HEALTH PHYSICS PERSONNEL

SUPERVISORY PERSONNEL

ENGNEERNA PERSONWEL

TOTAL

$\begin{array}{rl}20 & 0 \\ 0 & 0 \\ 10 & 0 \\ 0 & 0 \\ 0 & 0 \\ 45 & 0\end{array}$

ROUTINE MAINTTANANE

MAINTENANCEPERSONNEL

OPERATIONS PEREONNEL

HEAL,TH PHYSICS PERSONNEL

SUPERIISORY PERSONNAL

ENGINEEFING PERSONWEL TOTAL

0
0
0
0
0

$\begin{array}{ll}1 & 5 \\ 0 & 0 \\ 0 & 0 \\ 0 & 0 \\ 0 & 0 \\ 1 & 5\end{array}$

M-5ERVICEINIBEECTION MALNTENANCE PERSONNEL

OPERATIONS PERSONNEL

HEALTH PHNEUSCS FERSONNNEL

SUIFERUISORY PERSOANNE

ENGINEERINO PERSONNEL TOTAL

2
0
2
1
5

$\begin{array}{ll}0 & 6 \\ 0 & 0 \\ 0 & 8 \\ 0 & 0 \\ 0 & 0 \\ 0 & 78\end{array}$

68
0
9
0
0
75

SPECIAL-HADTERANGE

MANTENANCE PERSONNE OPERATLONS PERSONNEI

HEALTH PHYSICS PERSONNEL

SUPERVISORY PERSONNEL

ENGLNESRNG PERSONNEI TOTAL

$\begin{array}{rrr}74 & 24 & 150 \\ 3 & 0 & 2 \\ 7 & 0 & 48 \\ 1 & 0 & 1 \\ 4 & 0 & 4 \\ 69 & 24 & 255\end{array}$

6
0
0
0
0
6

69

0

0

1

80

150
2
48
1
4
25

248
$\frac{5}{3}$
$\frac{2}{6}$
398

0
0
10
0
0
10

TOTAL

\section{REFUE!UNE}

MAINTENANCE PERSONNEL

OPERATIONS PERSONNEL

HEALTH FHYSICS PERSONNEL

SUPERVEORY PERSONNEב

ENGNEFRNG FERSONNAE TOTAL

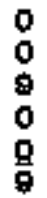

0
0
1
0
0
1

TOTAL BY JOB FUNCTION MAINIENANCE PERSONNEL OPERATIONS PERSONNEL HEALTH PHYSICS PERSONNEL SUPERVISOFY PERSONAE ENGINEERNG PERSONNE

$\begin{array}{rrrrr}109 & (89) & 25 & 03 & 31 \\ 6 & (35) & 0 & (0) & \\ 42 & (36) & 0 & (0) & 14 \\ 1 & (4) & 0 & (0) & \\ 6 & (9) & 0 & (1) & \end{array}$

(9) 0 (1)

$\begin{array}{rrr}7 & 0 & 80 \\ 3 & 0 & 1 \\ 5 & 0 & 20 \\ 0 & 0 & 1 \\ 0 & 0 & 5 \\ 15 & 0 & 107\end{array}$

87

4

1

$12 \frac{5}{2}$

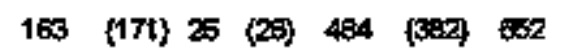

(257) 4

3
4
2

(3) 444 (57)

(19)

(145)

(3) 3

(i) 14

3500
0.000
3.012
0.000
0.000
7.500

0.000

0,000

0000

0,000

000

0.000

1.203

0.000

12.019

$0, \infty 0$

0.000

13.52

4820

0.000

1503

0000

20.754

0.000

0,000

0.000

0,000

D.0.9.

0.000

0.114

0.000

$0 \infty \infty$

0,000

D.0.9.

0.114

0.854

0.000

0.000

0.000

0,000

0,654

0.769

0.000

0.000

0,000

000

$\frac{0.08}{0.768}$

0.404

0.000

0.350

0000

0.154

0.000

000

0.00

0.000

0.000

0.000

0000

15.727

0.000

1.400

0,000

0.009

17,127

16.131

0.00

1.750

0.000

Q.154

18.065

20.300

6.538

39.409

68.537

0.498

0.960

0.113

0.6si

$20 \times$

0,000

0,000

$0, \infty \infty$

0,000

$-5.58$

0.400

8.344

0.100

0.7종

4.104

0.000

9307

0.219

I.ti1

8,172

$\begin{array}{llll}0,000 & 0,000 & 0.000 & 0,000 \\ 0.000 & 0,000 & 0.000 & 0.000 \\ 1.450 & 0.000 & 0.112 & 1.562 \\ 0.000 & 0.000 & 0.000 & 0.000 \\ 0.000 & 0.000 & 0.000 & 0.000 \\ 1.450 & 0.000 & 0.112 & 1.502\end{array}$

GRAND TOTALS

(19)
2319
050
1.319
0.000
no.
3965

\section{2}

0843

7.004

0.113
0.815

0.113
0.81E

\subsection{0}

0,000

0.000

0.000

n.0.0.

0.000

33.627

0.594

5.074

0.050

2889

42.820

35945

0.734

eses

C, ENO

28:88

4 \&.8B

$a+\infty$
0,00
0,000
0,00

80.740

0.784

28.949

0.55

3.043

124,002

1.67\%

34.943

1.

4,41

Workers may be pounted in more then one category. Numbers In parentheses are totel numbers of knthduals. 
REACTOR OPSA SURV MANTENANCE PERSONNAL OPERATIONS PERSONNEL HEALTH PHYSICS PERSONNEL SUPERVISORYPERSONWEI ENGNEEFANG PERSONNEI TOTAL

171
63
29
4
808
300

ROUTNE MANTENANCE MAINTENANCE PERSONNEI OPERATIONS PERSONNEL HEALTH PHYSICS PERSONNE. SLPERVISORYPERSONNEL ENGANEEFANG PERSONANEL

TOTAL

M-SERMCE ILASPECTHNN MAINTENANCE PERSONNNEL DPERATIONS PERSONNEL MEALTH PHYSICS PEREONNEL SUPERVISORY PERSONNEI. ENGINEERING PERSONNNEL TOTAL

$\begin{array}{rrr}170 & 532 & 7 \\ 53 & 0 & 3 \\ 28 & 1 & 8 \\ 3 & 2 & \\ 7 & 1 & 189\end{array}$

72
85
80
1
189

74
88
109
6
9
06

$\begin{array}{rrr}115 & 400 & 77 \\ 14 & 0 & 1 \\ 10 & 0 & 40 \\ 1 & 2 & 0 \\ 1 & 11 & 3 \\ 141 & 411 & 130\end{array}$

$\infty$
15
5
3
5

SEECJAL MAINTEMANCEE MADVTENANCE PERSONNE OPERATLONS PERSONNELL HEALTH PHYSICS PERBONNEE. SLPERVISORYPERSONNEL ENGINEERNAG PERSONNEE. TOTAL.

$\begin{array}{rrr}124 & 472 & 6 \\ 75 & 0 & 2 \\ 18 & 1 & 7 \\ 2 & 2 & \\ 82 & 1 & \\ 227 & 476 & 16\end{array}$

$\begin{array}{rr}04 & 60 \\ 25 & 100 \\ 73 & \\ 1 & 11 \\ 165 & 869\end{array}$

660
100
02
5
11
669

WAETE PROCESSING MANTENANCE PEREOTNNEL OPERATIONS PERSONWEL HEALTH PHYSICS PERSONNEL SUPERUISORY PERSONNEC. ENGWEERTNG FERSONWEL TOTAL

REFU리NG

MAN NGNANCE PEREONNII OPERATIONS PERSONNEL HEALTH PHYSUCS PERSONNEL SUPERYIBORY FERSONNAE ENGNEERING PERBGNNE. TOTAL

$\begin{array}{rrr}12 & 28 & \\ 6 & 0 & 31 \\ 14 & 0 & 2 \\ 0 & 0 & 1 \\ 0 & 0 & 5 \\ 32 & 23 & 5 \\ 108 & 320 & 50 \\ 52 & 0 & 50 \\ 0 & 0 & 3 \\ 1 & 3 & 0 \\ 180 & 320 & \end{array}$

$\begin{array}{rr}2 & 4 \\ 31 & 3 \\ 21 & 3 \\ 1 & \\ 0 & \end{array}$

TOTAL BY JOF FUNCTION MADNT NANCE PERSONNAE OPERATIONE PEREONINEL HEALTH PHYAOS PERSONNEL SLPERVISORY PERSONWEL ENGNEERING PERSONNE.

(113) 3408
(29) 450
(2) 400
(6)

$\begin{array}{rr}50 & 48 \\ 37 & 4 \\ 0 & \\ 017 & \end{array}$

484
02
45
4
1
626

$\min _{107}^{\infty}$

107

11

23
(17)

$\begin{array}{rrrr}(20) & 0 & (0) & 156 \\ (4) & 12 & (1) & 80 \\ (3) & 5\end{array}$

(a) 3 (1) $\infty 0$

(घ) 5

(2) 12

$\begin{array}{rr}5.099 & 11.705 \\ 20081 & 0.000 \\ 3.194 & 0.018 \\ 0.274 & 0.018 \\ 0.041 & 0.064 \\ 34.609 & 11.605\end{array}$

1.196

3841

9.801

0.000

0000

14000

17.999

29.872

13.073

0.296

0,15

61.37

38.76

2040

0.404

o.ras

43.20

8725

0.000

0,003

0.107

Dopts

87.473

11.967

6.172

7,102

acos

Q001

200

137.05

7.028

10.168

0.569

0.3쪽

156.113

\begin{tabular}{|c|c|c|c|}
\hline $\begin{array}{l}8.768 \\
1.487 \\
0.234 \\
0.004 \\
0.000 \\
10.503\end{array}$ & $\begin{array}{r}107.300 \\
0.000 \\
0.000 \\
0.209 \\
0.001 \\
107.800\end{array}$ & $\begin{array}{r}11.0003 \\
0.005 \\
7.131 \\
0.000 \\
0.044 \\
19.789\end{array}$ & $\begin{array}{r}127,405 \\
1.472 \\
7.355 \\
0,300 \\
0.555 \\
137.130\end{array}$ \\
\hline
\end{tabular}

\subsection{4}

0.417

osses

0.04

1,218

a.037

37.747

0,000

0.197

0.000

0.000

37,940

$4 \pi 72$

2354

$1, \mathrm{E} 8 \mathrm{~B}$

0,000

0.315

6.107

48.473

277

2.129

0.17

1,53

55,084

\begin{tabular}{|c|c|c|c|}
\hline $\begin{array}{l}0.018 \\
0.503 \\
1.1333\end{array}$ & $\begin{array}{l}0.031 \\
0.000 \\
0.00\end{array}$ & $\begin{array}{l}0,000 \\
0,096 \\
3,16\end{array}$ & $\begin{array}{l}0.050 \\
0.00 \\
500\end{array}$ \\
\hline 0,000 & 0.000 & 0.002 & 0,000 \\
\hline 000 & 0.000 & 0,000 & $\frac{0,000}{5700}$ \\
\hline
\end{tabular}

3.497

0.197

osza

0.021

$\frac{0.015}{4252}$

0.000

0,000

0.028

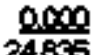

\subsection{0}

3.840

31.528

$0000 \quad 2750$

00000018

$\frac{0.397}{39.424}$

GRANDTOTALS

$1147 \quad 300 \% 377(002) \quad 06$

(2क) 4422 (1156)

$(302)$

02100

29271

8.362

0.827

1.58

20.116

0,000

32.20

16.53

31.55

303.48

0.249

0.423

0.140

40.577

0.148

0.900

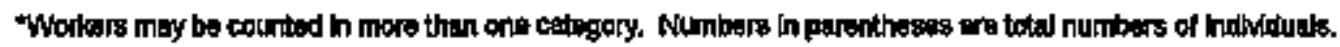


1095

WOFK AND

JOB FUNCT TON

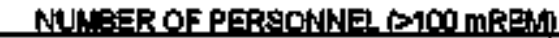 STATION UTLTY CONTRACT TOTAL}

TOTALPERSONLREM STATION UTIUTY CONTRACT TOTAL
REACTOR DFS \& SURV

MANTENANCE PERSONNEL

OPERATHONS PERSONNA

HEALTH PHYSKS PERSONNEL

SUPERVISORY PERSONNEL

ENENEETNG PERSONNETOTAL.

$\begin{array}{rr}175 & 1 \\ 67 & 0 \\ 40 & 0 \\ 18 & 0 \\ 15 & 0 \\ 256 & 1\end{array}$

197
10
44
1
7
200

203
77
44
70
22

ROUTMEMAMTENANCE

MANTENANCE PERSONNIL

OPERATIONS PERSONNEE

HEALTH PHYSICS PERSONYE.

SUPERVISORY PERSONNE

ENGINESRING PERSONNE TOTAL

$\begin{array}{rrr}30 & 0 & 23 \\ 3 & 0 & 0 \\ 15 & 0 & 2 \\ 0 & 0 & 0 \\ \mathbf{2} & 0 & 0 \\ 50 & 0 & 25\end{array}$

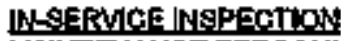

MAINTENANCE PERSORWVZ

OPERATIONS PERSONNEL

HEALTH PHYSACS PERSONNEL.

SUPERVISORY PEREOWNEL

ENBNEERIS FERSONNEL

TOTAL

7
2
1
1
4
15

0
0
0
0
0
0

$\operatorname{sen}$

11

0

具

$\begin{array}{rr}3 & 59 \\ 0 & 3 \\ 2 & 17 \\ 0 & 0 \\ 0 & 7 \\ 5 & 75\end{array}$

5

37

$\frac{0}{75}$

SEECHALMA!NTENANCE

MANTENANGE PERSOHNEL

OFERATIONS PERSONNEL

HEALTH PHYSICS PERSONNEE.

SLPERVISORY PERSONNAEL

ENGCNNEERNNG PERSONNE

$$
\text { Toral }
$$

$\begin{array}{rrrr}153 & 3 & 374 & 50 \\ 77 & 1 & 11 & 84 \\ 50 & 0 & 40 & 96 \\ 75 & 0 & 4 & 20 \\ 319 & 0 & 4 & 762\end{array}$

WASTE PROCESSNNG

MAINTENANCE PERSONNEL

OPERATIONS FERSONNE

HEALTH PHYSICS PERSONNEL

SUPERMSORY PERSONNEI.

ENGNEERING PERSONNNE

TOTAL

REFUAHNL

MANTENANCEPERSONNEL

OPERATIONS PERSONNEL

HEALTH PHYSICS PERSONNE.

SUPERVISORY PERSONNEL

ENEANEERINE PERSONNEL

TOTAL

IOTAL BY JOE FLANCTION

MALNTENANCE PERSONNEL

OPEERATIONS PERSONHAL

HEALTH PHYSKS PERSONNEL

SLWERYMSORY PERSONNEL.

ENGGINEERING PERSONNAE

7
0
15
1
0
21
0
0
0
0
0
0

1
3
0
0
0
4

8
3
13
1
0
25

$\$ 52$

122

32

18

11

3
0
0
0
0
3

477

76

44

3

21

暲

444

204

151

63

St

$\begin{array}{rr}900 & 143 \\ 32 & 237 \\ 147 & 29 \\ 8 & 71 \\ 23 & 7\end{array}$

4318
5.901
2857
0.629
14.200

0.044
0.000
0.000
0.000
0.004
0.044

\section{5}

0.25

5.600

opes

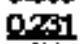

0.740

7,007

\subsection{6}

B.다

0.097

D.eA?

24004

Dese

0.008

Q.179

o.

0.14

D.747

on

0.000

0,00

0.000

0.00.

0.000

0.713

0.00

0.020

0.000

0000

0.735

1.200

0,00

0.100

0,00

0014

1.480

D.199

0.000

0,000

0,000

0.002

0.188

D.231

0.000

0 no

0.000

\subsection{1}

0,000

0.092

0.000

$$
219
$$

iens

4,620

0.010

0004

0.188

2478

7.520

41.245
12.259
11.320
2.104
2.548
6.475

abs

0.015

0.000

0,000

0.00

0.659

168.78

0.512

4.789

0.166

ots

114.627

180,879

12786

11.100

2.300

2017

184741

$\begin{array}{llll}0.058 & 0,000 & 0.382 & 0.320 \\ 0.000 & 0,000 & 0.545 & 0.545 \\ 0.787 & 0.000 & 0.000 & 0.287 \\ 0.001 & 0.000 & 0.000 & 0.001 \\ 0.000 & 0.000 & 0.000 & 0.010 \\ 0.328 & 0.000 & 0.527 & 1.153\end{array}$

GRAND TOTALS

93

$8 \quad 1189$

2110

1439
237
298
71
73

12580
4.150
1.660
1.048
1.475
24.615

0.215
0.000
0.000
0.000
0.000
0.215

53.687

1.361

3.756

0,327

0,324

50.48

es.282

5513

5.416

2275

1 .7\%

81.265

58.726
22329
11.405
4.887
4.734

0.892
0.016
0.000
0.000
0.000

$17 t 560$

2.00

14.917

0502

201.17

25009

30.722

5.45

$3.119 \quad 7.853$

Workers may be couted in more than one contogry. 
APPENDXX D (Continued)

NUMBER OF PERSONNEL AND PERBON-REM

BY WORK AND JOB FUNCTKON

1895

PLANT: "COMANCHE PEAK 1,2

TYPE: PWR

WOFK AND

JOB FUNGTION

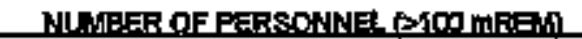

STATTOA UTILITY DONTRACT TOTAL,

TOTAL PERSOHERE:

SFATION UTLITY CONTRACT TOTAL

REACTOR OPS \& SURV

MANTERANGEPERBONNEL

OPERATIONS PERSONNEL

HEALTH PHYSICS PERBONWE

SUPERWISORY PERBONNEL

ENCEINEERINE PERSONNEL

TOTAL

$\begin{array}{rr}0 & 0 \\ 13 & 0 \\ 11 & 0 \\ 0 & 0 \\ 2 & 0 \\ 2 & 0\end{array}$

9
2
29
0
1
40

8

15

0

3

ROUTINE MANTIENANCE

NALTENANCE PERSONNEL

OPERATLONS FERSONNEL

HEALTH FHYSICS PERSOHMEL

SUPERWISORY PERSONNEL

GN이르N PERSONNEL

TOTAL

23
3
2
0
1

$\begin{array}{ll}0 & 17 \\ 0 & \\ 0 & \\ 0 & \\ 0 & \\ 0 & 18\end{array}$

$172 \quad 185$

皇

5

18

7

7
7

NLSERVLE MSPECTLN

MANTENANCE PERSONH:ב

OFERATIONS PERBONWEL

HEALTH PHYBICS PERSONNEI.

SUPERVISORY FERSONME

ENGNEERING PERSONWE

TOTAL.

$\begin{array}{rr}125 & 12 \\ 7 & \\ 8 & \\ 0 & \\ 140 & \end{array}$

SPECOALALHAlNTENANCE

MAINTENANCE PERSONWE

OPERATIONE PERBONNEL

HEALTH PHYSICS PERSONNEL

SLFURVISORY PERSONHNEL

ENCINEERING PERSONNEL

TOTA

$\begin{array}{ll}1 & \\ 0 & \\ 4 & \\ 0 & 0 \\ 5 & \end{array}$

$\begin{array}{rr}0 & 125 \\ 0 & 7 \\ 0 & 8 \\ 0 & 0 \\ 0 & 0 \\ 0 & 140\end{array}$

129
7
72
0
0
148

0.462

0.143

1.003

0,00

0,25I

t.

0000

0.070

0.071

0,000

a.cos

0.144

e.7:0

0.601

o,or

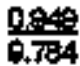

\section{5}

0

o

0

0

모․

0

0

是

음

17
0
0
0
0
17

$0 . \cos$

0.034

0001

$\mathbf{0 , \infty}$

000

0.73

0.000
0.000
0.000
0.000
0.045
0.045

\section{7}

1.038

7.488

0.153

0.21

11.077

2100

,

10.29

0.184

140

MASTEPROCESSINC

MAINTENANCEPERSONWEI OP닥ATIONLS PERSONNEL

HEALTH PTYYSICS PERBONNEL

SUPERVISORY PERSOANNEL.

ENCANEERING PERSONNEL

TOTAL

REFUELLING

MAINTENATCE FERSONNEL OPERATIONS FERSONNIEL

HEALTH PHY'ICS PERSONNE

SUPERVISORYPERSOHNEL

ENㄷNNEERWNO PERBCNNAL

TOTAL

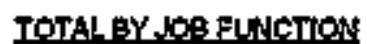

MANTENANCEPERBONNEL OPERATIONH FERBONNE HEALTH PAHSICS PERSONNE. SUPERVISORY PERSONNEI DNGINEERING PERSONNEL

0
4
0

$\begin{array}{lll}0 & 0 & \\ 0 & 1 & \\ 0 & 1 & \\ 0 & 0 & \\ 0 & 0 & \\ 0 & 2 & \end{array}$

0
2
5
0
0
7

\begin{tabular}{|c|c|c|c|}
\hline $\begin{array}{l}0.698 \\
0.004 \\
0.001 \\
0,000 \\
0.000 \\
0.70\end{array}$ & $\begin{array}{l}0,000 \\
0.000 \\
0,000 \\
0.000 \\
0.000 \\
0,000\end{array}$ & $\begin{array}{l}7,578 \\
0.171 \\
0,043 \\
0000 \\
0.177 \\
7.900\end{array}$ & $\begin{array}{l}8.276 \\
0.205 \\
0.044 \\
0.000 \\
0.177 \\
8.702\end{array}$ \\
\hline $\begin{array}{l}0.013 \\
0.076 \\
0.779 \\
0.000 \\
0.071 \\
1.1503\end{array}$ & $\begin{array}{l}0.000 \\
0,000 \\
0.005 \\
0.000 \\
0,00 \\
0,005\end{array}$ & $\begin{array}{l}0.377 \\
0.774 \\
0.740 \\
0.060 \\
0.000 \\
1.847\end{array}$ & $\begin{array}{l}0.340 \\
1.450 \\
1.614 \\
0.000 \\
0.071 \\
3.475\end{array}$ \\
\hline
\end{tabular}

$\begin{array}{ll}\mathbf{1} & 0 \\ \mathbf{6} & \\ \mathbf{0} & \\ \mathbf{6} & \end{array}$

$\begin{array}{rr}0 & 42 \\ 0 & 0 \\ 0 & 6 \\ 0 & 0 \\ 0 & 1 \\ 0 & 49\end{array}$

4
4
6
0
54

0.349
0.720
0.703
0.000
0.143
1.45

$\begin{array}{lrr}0.000 & 45.224 & 48.790 \\ 0.000 & 2.679 & 2.25 \\ 0.000 & 2.543 & 3.574 \\ 0.000 & 0.000 & 0.000 \\ 0.000 & 1.514 & 1.755 \\ 0.000 & 5.530 & 54.450\end{array}$

$\begin{array}{rr}54.200 & 91.010 \\ 1.503 & 2796 \\ 2019 & 2.020 \\ 0.001 & 0.002 \\ 1.818 & 2.010 \\ 14.000 & 6.48\end{array}$

\begin{tabular}{|c|c|c|c|c|c|c|c|}
\hline $\begin{array}{r}27 \\
21 \\
21 \\
0 \\
3\end{array}$ & $\begin{array}{l}0 \\
0 \\
0 \\
0 \\
0\end{array}$ & $\begin{array}{r}362 \\
18 \\
49 \\
0 \\
.11\end{array}$ & $\begin{array}{r}309 \\
37 \\
70 \\
0 \\
14\end{array}$ & $\begin{array}{l}8.545 \\
8.741 \\
5.544 \\
0.052 \\
2.507\end{array}$ & $\begin{array}{l}0.000 \\
0.070 \\
0.160 \\
0.000 \\
0.04=\end{array}$ & $\begin{array}{r}128.414 \\
6.700 \\
15.121 \\
0.154 \\
4.003\end{array}$ & $\begin{array}{r}136.749 \\
15.034 \\
20.831 \\
0.180 \\
0.583\end{array}$ \\
\hline
\end{tabular}

GRAND TOTALS

72

$\mathbf{0}$

489

$\$ 0$

2015

9.784

155015

170958

Workers may be counted in more then one extegory. 
REAGTOR OPS \& SURV

MANTTENANCE PERSOMNEL

OPERATHONS PERSONNEI

HEALTH PHYSICS PERSONINEL

SUPERYRSORY PERSONNEI

ENGANEEAING PERSONNEL TOTALL

ROLTINEMAINTENANCE

MAINTENANCE PERSONNEL

OPERATIONS PERSONNEI

HEALTH FHYSICS PERSONNEL

SUPERVISORY PERSONNE

GNEINEERINO PERSONNEL TOTAL

INSERMCE MUSPECTKON

MAINTENANCE PERSONNEZ

OPERATHONS PERSOHWEI

HEAL.TH PHYSKSS PERSONWEI

SUPERVISORY PERSONNE.

ENGBNEERNG PERSONNEA TOTAL.

$\begin{array}{rr}6 & 0 \\ 18 & 1 \\ 25 & 0 \\ 1 & 0 \\ 0 & 0 \\ 0 & 9\end{array}$
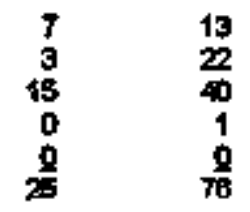

13

22

1

72

7

1

$\frac{11}{29}$

$\begin{array}{lr}0 & 253 \\ 1 & 31 \\ 0 & 40 \\ 0 & 2 \\ 0 & 2 \\ 1 & 310\end{array}$

507
51
63
3
13
437

$\mathbf{2}$
5
0
0
1
31

TOTAL

MASTEPROCESSINHB

MAINTENANCE PERSONNNEL

OPERATKONS PERSONNEI

HEALTH PHYSICS PERSONNE.

SUFERVIORY PERSONNEI

ENGINEEFING PERBONWEI TOTAL

REFUEUNG

MAINTENANCE PERSONNEL

OPERATIONS FERSONNEL

HEALTH PHIYSICS PERSONNAI

SUPERVISCRY FERSONNEI.

ENOINEERING PERSONNEE

TOTAL

TOTAL PY JOB FLINCTON

MANTE ENANCE PERSOINER.

OPERATKONS PERGONANEL

HEALTH PHYYSICS PERSONNAE.

SUPERVISORY FERSONNEL

ENGINEERING PERSONNEI

$\begin{array}{rrr}1 & 0 & 24 \\ 0 & 1 & 0 \\ 0 & 0 & 0 \\ 0 & 0 & 0 \\ 0 & 4 & 0 \\ 1 & 5 & 24\end{array}$

25

1

0

30

0.420

0.105

0.015

0,000

0.445

o.004

1
0
1
0
0
$\frac{0}{2}$

1

2

$\frac{0}{3}$

어여

0.000

0.130

0.000

0.97

0.170

$\begin{array}{rr}27 & 31 \\ 0 & 14 \\ 0 & 1 \\ 0 & 0 \\ 0 & 0 \\ 35 & 43\end{array}$

1.205

2140

0.747

0.005

0.0용

4.707

$\begin{array}{rrr}00 & 0 & 312 \\ 40 & 3 & 44 \\ 0 & 0 & 58 \\ 2 & 0 & 2\end{array}$

$\begin{array}{rrr}\text { 60 } & 0 & 312 \\ 43 & 3 & 44 \\ \mathbf{5 0} & 0 & 58 \\ 2 & 0 & 2 \\ 11 & 4 & 3\end{array}$

402

114

23.548

17.268

1505

0628

5.72
VTILTTY

CONTRACT

TOTAL
7.402
7.091
0.050
3.715
38.490

1.725

0,001

0.130

0.000

ong7

273

\begin{tabular}{|c|c|}
\hline $\begin{array}{l}0,004 \\
0.134 \\
0,002 \\
0,000 \\
0.091 \\
0.231\end{array}$ & $\begin{array}{r}4044 \\
1.809 \\
5.244 \\
0.018 \\
0.249 \\
12118\end{array}$ \\
\hline
\end{tabular}

0.169

a.t7

0.013

ofor

Q.728

0.747

89.048

13.845

12800

030

1,483

117.023

100.497

21.654

20.602

0.64

5.438

154806

0.000

0,20

0.016

$0 \infty 0$

gete?

0.175

6.160

O.545

0.117

$0.0 \%$

D.24

7890

1.106

0271

o.cos

10040

tom

0.141

O.t소

0,00

$1.2 \times 3$

1,300

B. 000

0.027

0.000

0,0 te

00:

8.742

9008

0.273

o.tost

0.016

$\frac{17.77}{14.125}$

n,000

0000

0,00

0.000

000

000

0388

0.014

0.202

0.000

이런

0,025

0.404

0.014

0335

0,000

20:8

De01

ano

7.194

5.480

0.000

0.000

2133

4.273

0.000

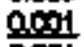

0 어요

ams

0.000

0.001 9522

13.70
0.17

0572

004

0.000

1.751
$\$ 8.603$

$18 .+5$

0.488

2060
141.81日

36.443

30.830

1,054 956 
APPENDIX D (Continued)

NUMBER OF PERSONNEL AND PERSON-REM

BY WORK AND JOB FUNCTION

1996

PLANT: "COOPER STATIOH

TYPE: BWR

WORK ANP

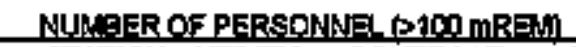

STATION UTUTY CONTRACT TOTAL

TOTAL PERSONLREM

JOB FUNCTION

STATKON UTHTY

REACTOR OPS \& 언.

TILITY

CONTRACT TOTAL

MAINTENAHCE PERSOHME

CFERATIONS PERSONWEL

HEAL,TH PHVSACS PERSONNEL

SUPERVISORY PERSONNEL

ENGINEERING PERSONNEL TOTAL

54
41
30
6
$1 \frac{19}{50}$

$\begin{array}{rr}2 & 65 \\ 0 & 0 \\ 0 & 3 \\ 0 & 2 \\ 3 & 17 \\ 4 & 117\end{array}$

$\begin{array}{rr}65 & 124 \\ 0 & 41 \\ 3 & 69 \\ 2 & 8 \\ 17 & 87 \\ 117 & 271\end{array}$

124

ROLTNEMANTENANEE

MANTENANOE PERBOWNEL

OPERATHONS PERSONNEL

HEALTH PHYSICS PERBONNEE.

stJPERMSORY PERSONNE:

ENGUNEERINE PERSONDNEI

$$
\text { TOTAL. }
$$

$\begin{array}{rrr}76 & 2 & 37 \\ 42 & 0 & \\ 33 & 0 & 35 \\ 7 & 0 & \\ 17 & 3 & 3\end{array}$

$\begin{array}{rr}320 & 40 \\ 0 & 4 \\ 3 & 11 \\ 19 & 4\end{array}$

$\begin{array}{rr}401 & 34.616 \\ 42 & 7.704 \\ 68 & 11.834 \\ 11 & 1.278 \\ 51 & 2852 \\ 562 & 58.281\end{array}$

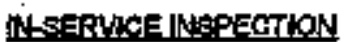

WANTENANCE PZRSONNE

OPERATIONS PEREOHWVI

HEALTH PHYSICS PERSONNVE

SUPERVISORY PERSONNEL

ENGINGERL忙 PERSONNEL TOTAL

8
12
1
52

$\begin{array}{ll}0 & 15 \\ 0 & \\ 0 & \\ 0 & \\ 1 & \\ 1 & 14\end{array}$

137
0
5
1
1
145

145
6
18
2
7
173

0.246
0.088
0.254
0.148
0.329
0.067

1,2606
2.407
7.305
0.505
1.380
18,743

0.056

0.000

0,000

$0, \infty 0$

0.008

0.119

0.897

0.000

7.42

0.379

0.545

9,243

2219

6.407

14,807

14.807

1.909

GPECCAALAMINTENANCE

MANTEUANEE PERSONNE

OPGRATIONS PERSONNEI.

HEALTH FHYEACS PERSONMaL

SUPERUISORY PERSOANE

ENGNEERNG PERSONNE. TOTAL

$\begin{array}{rll}18 & 1 & 8 \\ 2 & 0 & \\ 9 & 0 & 10 \\ 1 & 0 & \\ 1 & 2 & \\ 31 & 3 & \end{array}$

$\begin{array}{rr}80 & 59 \\ 0 & 2 \\ 10 & 19 \\ 0 & 4 \\ 3 & 67\end{array}$

$0, \cos$

0.134

0.117

0.005

Q.0.1

$0 \times 81$

0.00

69002

0000

6.788

0,000

070

1.289

0.358

2859

73.887

99.119

7.701

18.622

1.636

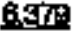

133.457

WAETE PROCESS!NT-

MNNTENANCEPERSONNEL

OPERATIONS PERSONNEL

HEALTH PHYSICS PERSONNALL.

SUPERMSORY PERSONNEI

ENICNEENANG PERSONINEL TOTAL.

$\begin{array}{ll}0 & 5 \\ 0 & 0 \\ 0 & 6 \\ 0 & 0 \\ 0 & 0 \\ 0 & 11\end{array}$

22
20
20
0
0

0.044

0.774

a540

0.001

0,009

0.000

39100

38378

0,000

0.000

0,000

000

$\frac{0.006}{0.06}$

0.000

0.519

0.001

0032

38712

0.058

0.77

0.149

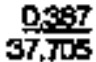

REFUE1NG

MANTEKANCEPERSONNEL

OPERATKONS PERSONNEL

HEALTH PHYSSES PERSONNEL

SUPERVISORY PERSONNE

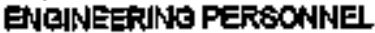
TOTAL

$\begin{array}{rrr}1 & 0 & 1 \\ 5 & 0 & \\ 2 & 0 & \\ 1 & 0 & \\ 1 & 0 & \\ 10 & 0 & 1\end{array}$

$\begin{array}{rr}10 & 17 \\ 0 & \\ 0 & \\ 0 & \\ 17 & \\ 17 & 2\end{array}$

17
5
2
1
27
27

\section{D.0.01}

0.000

0.000

0.000

o.s.9.

0.110

3508

0.000

0.004

0.000

0.019

4,249

0.134
0.211

0,005

0.199

4798

TOTA: BY JOB FNCTON

MANTENANCE PE ESONNA-

OPERATIONS PERSONNEL

HEALTH PHYSICS FERSONNEL

SUPERVISORY PERSONNEL

ENGNEERING PERSONNEL

$\begin{array}{lll}174 & (70) & 5 \\ 122 & (42) & 0 \\ 100 & (55) & 0 \\ 17 & (7) & 0 \\ 40 & (20) & 0\end{array}$

(द) 628

(35) 805

(D) 0

(i) $8 \mathrm{a}$

(4i) 122

(4) 38.005

(42) 17.307

(t) 1.753

(20)

(4)

4600

$0, \infty 0$

0.000

0.000

$0 . \infty 00$

opos

0.000

0.007

0.000

0,062

0,00

0.000

ô.0\%

0031

0,774

acos.

noos

acon

\begin{tabular}{|c|c|c|}
\hline $\begin{array}{l}0.001 \\
0.250 \\
0.004 \\
0.004 \\
0.097 \\
0.374\end{array}$ & $\begin{array}{l}0,000 \\
0,000 \\
0,000 \\
0,000 \\
0.000 \\
0.000\end{array}$ & $\begin{array}{l}0.800 \\
0.000 \\
0.000 \\
0.000 \\
0.002 \\
0.852\end{array}$ \\
\hline
\end{tabular}

SRANDTOTALS

450) (178) 13

(9) 762

(416) 1234

(5))

80.673

1.584

$\begin{array}{rrr}0.068 & 105.434 & 142,897 \\ 0.000 & 0.000 & 17.307 \\ 0.000 & 14.855 & 35,019 \\ 0,000 & 0.738 & 2.476 \\ 0.058 & 3.417 & 8.972\end{array}$

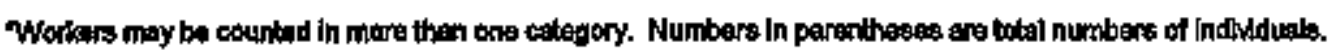


REACTOR OPS \& SLRV

MANTENANCE FERSONNE. OPERATIONS PERSONNEL HEALTH PHYSICS PERSONNESUPERVISORY PERSONNEIENGNEERWG PERSONNEC TOTAL

$\begin{array}{ll}0 & 0 \\ 1 & 0 \\ 0 & 0 \\ 0 & 0 \\ 0 & 0 \\ 1 & 0\end{array}$

0
0
0
0
0
0

0
1
0
0
0
1

0.010
0.076
0.000
0.000
0.097
0.000

0,000
0,000
0,000
0,000
0,000
0,000

$\begin{array}{ll}0.000 & 0.010 \\ 0,000 & 0.870 \\ 0.000 & 0.000 \\ 0.000 & 0.000 \\ 0.000 & 0.017 \\ 0.000 & 0.006\end{array}$

ROUTINEMAINTENANCE MAUNTENANCE PERSONNAL OPERAT|ONS PERSONDE. HEALTH PHYSICS PERSONWEl. SUPERVISORY PERSONNE ENGINEERING PEREONNA TOTAL

$\begin{array}{ll}1 & 0 \\ 7 & 0 \\ 0 & 0 \\ 0 & 0\end{array}$

$\begin{array}{ll}0 & 0 \\ 0 & 0 \\ 0 & 0 \\ 0 & 0 \\ 0 & 0 \\ 0 & 0\end{array}$

1
7
0
0
0

1.707
0.684
2.135
0.209
0.172
5.007

D.7892

0.000

0,00

0.152

0.287

0.681

\subsection{4}

0.000

$0, \infty 00$

0,378

0.000

0,758

2.463

0.684

2.133

0.749

$0,4 \leq 5$

\section{N-SERMCE INSPECTION} MANTENANCE FERSONNEL OPERATIONS PERSONNEI HEALTH PHYSICS PERSONNEL SUPERVISORY FERSONNEL ENGIHEERING PERSONNE TOTAL

$\begin{array}{ll}0 & \\ 0 & \\ 0 & \\ 0 & 0 \\ 0 & \end{array}$

0
0
0
0
0
0

$\begin{array}{llll}0,000 & 0,000 & 0,000 & 0,000 \\ 0,000 & 0.000 & 0.000 & 0.000 \\ 0,000 & 0.000 & 0.000 & 0.000 \\ 0,000 & 0.000 & 0.000 & 0.000 \\ 0,000 & 0.000 & 0.000 & 0.000 \\ 0.000 & 0.000 & 0.000 & 0.000\end{array}$

SPECALAMAINTENANDE MANTENANCE PERSONWEL OPERATICNS PERSONNEL HEALTH PHYSICS PERSONNEL SUPERVISORY PERSONNEL ENCINEEFINE PERSONANEL TOTAL

$\begin{array}{ll}0 & \\ 0 & 0 \\ 0 & 0 \\ 0 & 0 \\ 0 & 0\end{array}$

$\begin{array}{ll}0 & 0 \\ 0 & 0 \\ 0 & 0 \\ 0 & 0 \\ 0 & 0 \\ 0 & 0\end{array}$

\section{WASTERROCESSIYM}

MAINTENANCE PERSONNEI OPERATIONS PERSONNEL HEALTH PHYSICS PERSONNEL BUPERVIBORY PERBONNEL ENGINEERING PERSONNEL TOTAL

$\begin{array}{lll}0 & 0 & 0 \\ 2 & 0 & 0 \\ 0 & 0 & 0 \\ 1 & 0 & 0 \\ 0 & 0 & 0\end{array}$

$\begin{array}{ll}0 & 0 \\ 0 & 2 \\ 0 & 0 \\ 0 & 1 \\ 0 & 0 \\ 0 & 3\end{array}$

0
0
0
0
0
0

0,000
0,000
0,000
$0, \infty$
0,000
0,00

0,000

0.000

0.000

0,000

0,000

0,000

\subsection{0}

$\mathbf{0 . 0 0 0}$

0.000

$0, \infty$

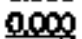

a)

$0, \infty$

0.000

0.000

0,000

o.m.

0.000

\section{REFUELLNIS}

MANTENANCE PERSONNEL OPERATIONS PERSONNEL HEALTH PHYSICB PERSONNEC SUPERVISORY PERSONNEL ENEINEERING PERSONNEL TOTAL

$\mathbf{0}$
$\mathbf{0}$
$\mathbf{0}$
$\mathbf{0}$
$\mathbf{0}$
$\mathbf{0}$

$\begin{array}{ll}0 & 0 \\ 0 & 0 \\ 0 & 0 \\ 0 & 0 \\ 0 & 0\end{array}$

0
2
0
1
0
3

0.009
0.024
0.018
0.148
0.008
0.701

0,000 0,000

0.00

0.000

0.000

0,000

$0 \infty$

$0, \infty$

a.d

$0, \infty$

Q,mon

0,000

0.624

0.018

0,143

0.000

के⿻心

0, 苚1

$\begin{array}{ll}0 & \\ 0 & \\ 0 & 0 \\ 0 & 0 \\ 0 & 0\end{array}$

0
0
0
0
0

0,00
0.000
0.000
0.00
0.00
0000

\subsection{0}

\subsection{0}

0.000

0,000

a.to

0.000

0000

0.000

0.000

0.000

0,000000

0,000 0.000

TOTAL BY VOB FLNCTION MANTENANCEPERSONWEL OPERATIONS PERSONNEL HEALTH PHYSICS PERSONNEL SUPERVISORYPERBONNEL ENGINEERING PERSONNEL

$\begin{array}{lll}1 & 0 & 0 \\ 4 & 0 & 0 \\ 7 & 0 & 0 \\ 1 & 0 & 0\end{array}$

0
0
0
0

$\begin{array}{ll}1 & 1 \\ 7 & 218 \\ 1 & 0\end{array}$

\begin{tabular}{llll}
1.810 & 0.282 & 0.394 & 2.476 \\
2104 & 0.000 & 0.000 & 2.164 \\
2.151 & 0.000 & 0.000 & 2.151 \\
0.597 & 0.137 & 0.378 & 0.097 \\
0.189 & 0.267 & 0.000 & 0.480 \\
\hline 0.791 & 0.681 & 0.762 & 8.144
\end{tabular}

Workers may be counted in more than one cortegory. 
1996

PLANT:

WOFKAND JOB FUNCTKN
NUM, BER OF PERSONNEL $\$ 100$, mREM STATION UTILITY CONTEACT TOTAL
TOTALPERSON-REM STATION UTLITY CONTRACT TOTAL
REACTOR OES \& SIJRY

MANTTENANCEPERSONNEL

OPERATIDNS PERSONNEL

HEALTHFHYSFOS PERSONNEL.

8LPERNASORY PERBONNEI

ENGINEERING PERSONNEL TOTAE

ROUTMEMANTIENANGE

MAINTENANCE PZRSONNEL

OPERATLONS PERSONNE

HEALTH PHYSICS PERSONNEE

SUPERMISORY PERSONNEL

ENIENNEERNHO PERSONNEL TOTAL

NLESTRICE INIE:PECTHON MANTENANCE PERSONNVI OPERATHONS PERSONNEL

HEALTH PHYSICS PERSOMNE.

SUPERUSORY PERSONNEL

ENGINEERNG FERBONNE.

TOTAL

EPECHÁL MALNTENANCE

MANTE ENANCE PERSONIES

OPERATICNS PERSONNEL

HEALTHA PHYSCA PERSONWNEL

SUPERYISORY PERSONNA

BHGWEERING FERBONNAE

$$
\text { TOTAL }
$$

WAETTERROCESSINO

MANTENANCE PERSONNEL OPERATIONS PERSONNEL.

HEALTHPHYEICS PERSO'NNEL

SUPERVISORY PERSONDEL

ENICNNEERANB PERSONNAEL TOTAL

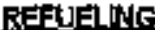

MAINTEKANCE PERSONNEL

OPERATIONS FERSONNEL

HEALTH PHYBICS PERSONNEL

SUTPERVISORY PERSONNN1

ENGNEERING PERBONNNEI.

TOTAL

TOTAL BX VOB FLNCTION

MAINTEMANCE PERSONNEL

OPERATIONS PEREONNEI

HEALTH PHYSIOS PERSONNEL

SUPERVISORYPERSONWEI

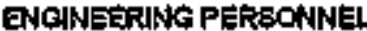

$\begin{array}{ll}0 & 0 \\ 0 & 0 \\ 0 & 0 \\ 0 & 0 \\ 0 & 0 \\ 0 & 0\end{array}$

0
0
0
0
0
0

0
0
0
0
0
0

0.001
1.110
0.020
0.007
0.099

0,00
0.000
0.00
$0,0 \infty$
0.00
0.00

$\begin{array}{ll}0,00 & 0.011 \\ 0.009 & 1.113 \\ 0.000 & 0.600 \\ 0,001 & 0.008 \\ 0.000 & 0.001 \\ 0.014 & 1.811\end{array}$

0

0
0
0
0

0
0
0
0
0
0

0
0
0
0
0
0

0
0
0
0
0
0

1220

0.005

0.031

0.005

0.143

1.402

000

0.14

1.811

0

$\mathbf{0}$

$\stackrel{9}{0}$

0

0

o

0

0

욤

0
0
0
0
0
0

0.001

0.000

0.000

0000

0,000

ठक्ष

0.000

$0, \infty$

0000

0.000

0,00

0000

0.016

0.000

0.000

0.000

0,000

1.298

0,005

0,031

0.000

0.143

0.016

1.446

$\begin{array}{ll}2 & 0 \\ 1 & 0 \\ 2 & 0 \\ 0 & 0 \\ 0 & 0 \\ 5 & 0\end{array}$

0
0
0
0
0
0

2
1
2
0
0
5

\begin{tabular}{l}
0.055 \\
0.011 \\
0.704 \\
0.011 \\
0.009 \\
\hline 2.087
\end{tabular}

0.000

0,000

0.000

0000

omo

0.00

0,000

0,00

anon

0,000

0.000

no00

0.000

0,000

0,000

0.000

a,

0.001

$\begin{array}{lll}0,00 & 0,000 & 0.535 \\ 0,00 & 0.000 & 0.311 \\ 0,00 & 0,000 & 0.784 \\ 0,00 & 0.000 & 0.011 \\ 0,00 & 0.000 & 0.078 \\ 0,000 & 0,000 & 2367\end{array}$

0
0
0
0
0
0

$\begin{array}{ll}0 & 0 \\ 0 & 0 \\ 0 & 0 \\ 0 & 0 \\ 0 & 0 \\ 0 & 0\end{array}$

tor

0.002

0.58

0,000

000

0.8T6

$\begin{array}{lll}0,000 & 0.009 & 0.098 \\ 0.000 & 0.000 & 0.02 \\ 0,000 & 0.000 & 0.008 \\ 0.000 & 0.000 & 0.003 \\ 0.000 & 0.00 & 0.00 \\ 0.000 & 0.000 & 0.675\end{array}$

0
0
0
0

$\begin{array}{ll}0 & 0 \\ 0 & 0 \\ 0 & 0 \\ 0 & 0 \\ 0 & 0 \\ 0 & 0\end{array}$

0.004

0.004

0.050

0,00

$\frac{0.012}{0.000}$

$\begin{array}{lll}0.000 & 0.070 & 0.074 \\ 0,000 & 0.000 & 0.004 \\ 0.000 & 0.000 & 0.000 \\ 0.000 & 0.000 & 0.000 \\ 0.000 & 0.007 & 0.019 \\ 0.000 & 0.077 & 0.130\end{array}$

2
1
2
0
0

$\begin{array}{ll}0 & 0 \\ 0 & 0 \\ 0 & 0 \\ 0 & 0\end{array}$

\begin{tabular}{|c|c|c|c|c|c|}
\hline $\begin{array}{l}0 \\
0 \\
0 \\
0 \\
0\end{array}$ & $\begin{array}{l}2 \\
1 \\
2 \\
0 \\
0\end{array}$ & $\begin{array}{l}2.188 \\
1.752 \\
2009 \\
0.024 \\
0.249\end{array}$ & $\begin{array}{l}0,000 \\
0,000 \\
0,000 \\
0,000 \\
0,000\end{array}$ & $\begin{array}{l}0.150 \\
0.000 \\
0.000 \\
0.001 \\
0.007\end{array}$ & $\begin{array}{l}2345 \\
1.75 \\
20020 \\
0.003 \\
0.250\end{array}$ \\
\hline 0 & 5 & B.268 & 0,000 & 0.168 & 6.402 \\
\hline
\end{tabular}

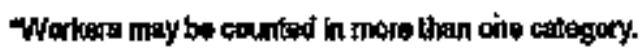


WORKAND JOE FUNCTKON

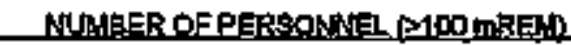
STATION UTILTY GONTRACT TÖTAL
TOTAL, EERSON-REM STATION UTILTY CONTRACT TOTAL
RHACTOR OPS BURY MANATENANCE PERSONWE OPERATIONS PERSONNEL HEALTH PHYSICS PERSONNEI. SUPERVISORY PERSONNE ENGNEERING PERSONWEL TOTAL

1
33
23
0
0
57

ROLTITE MANTENANCE MAINTENANGE PERSONNEL OPERATIONS PERSONNEL HEALTH PHYSICS PERSONNEL SUPERVISORY PERSONNAI ENGINEERINO PERBONWEL

$$
\text { TOTAL }
$$

N-SERYCE UNSPECTHN MANTENANCE PERSONNEL OPERATKNS PERSONME. HEALTH PHYSICS PERSONNEI. SUPERUSORY PERSONNEL ENCNNEERINB PERSONNEI.

TOTAL

\section{SEECIAL MANTENANCE}

MAINTENANCE PEREONNEL OPERATIONS PERSONHEL HEALTH PHY'SICS PERSONREL SUPERVSOFY PERSONNEL ENGINEERING PERSONNEL. TOTAL

WASTE PROCESENG MANTENANCE PERSONNVL OPERATIONS PERSONNIL HEALTH PHYSICS PERSONWEI. SUPERVISORY PERSONNEL ENGGWEERWG PERSONNEI

TOTAL

REFUE ING

MANTENANCE PERSONNE OPERATONS PERSONNEL HEALTH PHYSICS PERSONNEL SUPERVISORY PERSONN르. ENGINEARING PERSONNEL

TOTAL

TOTAL GYJOR FUNGTION MANTENANCE PERSONNEL OPERATIONS PERSONNEL HEALTH PHYSICS PERSONNEL \&UPERVISORY PERSONN1E. ENGINEERING PERSONNE

25

15

24

0

64

$$
\begin{aligned}
& 2 \\
& 1 \\
& 3 \\
& 0 \\
& 0 \\
& \mathbf{6}
\end{aligned}
$$

1
0
0
0
1
2

4
34
26
0
1
65

0.065

1.5728

0.288

0,000

0.000

1.876

$\begin{array}{rl}69 & \\ 17 & \\ 38 & 14 \\ 130 & \end{array}$

$\begin{array}{rr}30 & 168 \\ 0 & 5 \\ 14 & 17 \\ 0 & 0 \\ 4 & 10 \\ 4 & 103\end{array}$

234
22
69
0
21
378

\subsection{5}

0.388

3074

0,000

0.29

8.300

$\begin{array}{rr}4 & 19 \\ 5 & 0 \\ 6 & 5 \\ 0 & 0 \\ 0 & 0 \\ 15 & 96\end{array}$

32
3
3
0
3
41

47
8
14
0
$\frac{3}{72}$

0.882

2.T70

0.117

0.000

0.000

$38 \times 9$

$\begin{array}{rr}01 & 20 \\ 14 & 0 \\ 30 & 21 \\ 0 & 0 \\ 4 & 2 \\ 109 & 48\end{array}$

281
7
24
1
9
292

357
21
75
15
440

6
1
5
0
0
12

13
9
5
0
0
99

44
17
34
0
0
es

$\begin{array}{rr}7 & 39 \\ 53 & 1 \\ 40 & 30 \\ 0 & 0 \\ 8 & \frac{4}{74}\end{array}$

$3 \$ 4$
8
31
0
312
$3 \times 5$

400
62
101
0
24
617

10.712
0.682

4,838

0.000

0.071

18.20

$0.0 \infty$

0.082

4.148

0,000

anon

4.050

$\begin{array}{rrrr}230 & 113 & \pi 7 & 1120 \\ 137 & 3 & 24 & 194 \\ 161 & 78 & 80 & 316 \\ 0 & 0 & 1 & 1 \\ 19 & 10 & 30 & 64\end{array}$

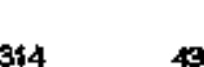

21.

6.694

0,410

0.000

1.50

35.927

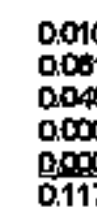

Domo

0.001

004

poog

0.117

1.484

$\mathbf{0 . 0 0 0}$

0.700

$0, \infty 0$

0,077

2169

2981

000

0.09

0000

n.000

3.072

1.788

0,000

3081

0000

$\frac{0.114}{4001}$

0.071

0002

0,000

octo

$0+78$

0.884

5,232

1 . पा

0.824

80.433

\begin{tabular}{lr}
5.680 & 11.502 \\
0.047 & 0.430 \\
0.500 & 4.252 \\
0.000 & 0.000 \\
1.024 & 1.319 \\
\hline 7.154 & 17.626
\end{tabular}

7.508

0.768

0.423

0.000

1.008

8789

11.59

$35 \mathbf{6}$

0.634

0,000

$10 \%$

$1 \longdiv { 6 2 9 }$

9.734

1.520

13.151

$1.2 \mathrm{~T}$

$\frac{1,009}{111.007}$

0,07

0002

1.50

0.400

noon

1,690

0.729

0,083

5.783

0.000

o.0.0

6.507

B.645

0.043

5.209

0,00

0.45

12.47

84.637

2108

7002

0.000

1.450

15.227

120585

0.045

18.749

0.000

3.202

123581

$\begin{array}{rrrrr}1120 & 38.259 & 12525 & 180.106 & 211.270 \\ 104 & 12317 & 0.103 & 3.797 & 18.210 \\ 318 & 18.684 & 9279 & 14.70 & 42.353 \\ 1 & 0.000 & 0.000 & 1.277 & 1.277 \\ 64 & 1.648 & 0.564 & 4.397 & 6.619\end{array}$

GRAND TOTALS

$\mathbf{x + 3}$

204

97

1674

71,008

22804

184327

279.900

Workers may be counted in moxe then one celegery. 
APPENDIX D (Continthed)

MUMBER OF PERSONHEL AND PERSON-REH

BY WORK AND JOB FUNCTION

1995

PLANT: *DRESDEN 2,3

TYPE: $\quad$ BWR

\begin{tabular}{|c|c|c|}
\hline WORK AND & 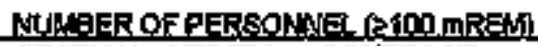 & $A-R E$ EL \\
\hline
\end{tabular}

BEACTOR OPS \& STINY

MANTENANCE PERSONNAT.

OPERATTON8 PERSONHEL

HESLTH PHYSICS PERSONBNEL

SUPERVSORY PEREONNEL

EN헤 NESRING PERSOFNEL

TOTAL.

$\begin{array}{rr}10 & 34 \\ 143 & 44 \\ 30 & 4 \\ 127 & 139 \\ 808 & \frac{10}{401}\end{array}$

34

4

20

ROUTINEMANTENANCE

MANTENANCE PERSONHED

OPERATIONS PERSONNEL

HEALTH FHYSTCS PER\&ONNEL

SUPERVISORY PERSONWEL

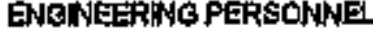
TOTAL

$\begin{array}{rr}394 & 860 \\ 162 & 62 \\ 40 & 100 \\ 192 & 12 \\ 116 & 200 \\ 100 & 142\end{array}$

5
0
107
0
0
142

1329

24

253

204

40

$247 \theta$

$\begin{array}{rr}0 & 228 \\ 0 & 0 \\ 133 & 134 \\ 0 & 10 \\ 0 & 37 \\ 130 & 413\end{array}$

228
0
134
10
313
413

624

37 .

8

74

ENSS1NEEANNO PERSOANEL TOTAL

\section{WASTEPROCESSING}

MANTENANCEPERBONNAE.

OPERATIONS PERSONNE:

HEALTH PHYSUCS PERSONNEI.

GUPERVISORY PERSONNEL

ENGINEER|NG PERSONNEI. TOTAL

REFUELLNG

MANTENANCE PERSONNEL

OPERATIONS PERSONNEA.

HEALTH PHNझCB PERSONNEL

SUPERVISORY PERSONTIEL

ENGINEERINK PERSONANEL TOTAL

TOTALEY JOB FUNCTLN

MAINTENANCE PERSONNNEL

OPERATIONS PERSONNEL

HEALTH PHYEICS PERSONNEl.

SUPERVISORY PERSONNEL

ENGINEEAING PERSONNEL

$\begin{array}{rr}7 & 617 \\ 2 & 7 \\ 1 & 28 \\ 8 & 0 \\ 10 & 84 \\ 2 & 718\end{array}$

0
0
8
0
0
8

$\begin{array}{rr}0 & 4 \\ 11 & 68 \\ 5 & 0 \\ 5 & 0 \\ 0 & 0 \\ 21 & 72\end{array}$

0
0
0
0
0
0

16

3

2

8

6

$\begin{array}{rr}7 & 9 \\ 2 & 1 \\ 4 & 0 \\ 8 & 0 \\ 3 & 8 \\ 21 & \end{array}$

$\begin{array}{rr}4 & 0.003 \\ 70 & 1.734 \\ 5 & 1.610 \\ 5 & 0.291 \\ 0 & 0.001 \\ 03 & \end{array}$

0.000
0.000
0.019
0.005
0.911
1.018

0.000

0.294

0.092

1.179

70.714

2.275
0.286
0.372
0.447
0.678
4.056

$1 \mathrm{gB} 50 \mathrm{~F}$

0.488

e.ces

0.00

3.373

201.176

1.271
4.035
0.000
0.000
0.009
5.360

0.000

0.000

0,000

0.000

0,000

0,000

pono

0.000

0.000

pogo

Q4ST

13.853

25.907

10.714

8.112

gogs

68.699

2.208
0.349
0.200
0.444
0.254
3.469

2815

D.075

0.044

0.00:

1705

4.640

0,001

0.000

0,002

0.000

0,000

0.003

ex149

$0, \infty$

0.744

0.128

2140

72101

\begin{tabular}{|c|c|c|c|c|c|c|c|}
\hline $\begin{array}{l}509 \\
523 \\
84 \\
340 \\
232\end{array}$ & $\begin{array}{r}1650 \\
182 \\
133 \\
161 \\
492\end{array}$ & $\begin{array}{r}30 \\
0 \\
0 \\
0 \\
0\end{array}$ & $\begin{array}{l}2247 \\
505 \\
612 \\
501 \\
724\end{array}$ & $\begin{array}{c}117.198 \\
51.000 \\
24500 \\
19.501 \\
15.270\end{array}$ & $\begin{array}{r}565.018 \\
11.022 \\
42.645 \\
0.9 \overline{85} \\
25 . \mathrm{B19}\end{array}$ & $\begin{array}{l}0,474 \\
0,000 \\
1,288 \\
0,000 \\
0,000\end{array}$ & $\begin{array}{r}682.600 \\
62628 \\
69.529 \\
20.543 \\
41.009\end{array}$ \\
\hline 1383 & 2818 & $4 \times 5$ & 4589 & 28378 & $645,4=0$ & 1.762 & 875476 \\
\hline
\end{tabular}

Workels mey be counted in more then one category. 
MAINTENAWCEPERBONNEL

OPERATKNA PERECNND.

HEALTH PHYACS PERSONNEL.

BUPERVISORY PERSONNE1

DNGINEERING PERSONNEL TOTAL

$$
\text { STATION UTLITY CONTRAT TOTAL }
$$

$\begin{array}{ll}15 & 0 \\ 25 & 0 \\ 10 & 0 \\ 0 & 0 \\ 7 & 0 \\ 68 & 0\end{array}$

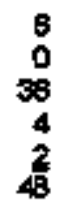

$\begin{array}{ll}0 & 8 \\ 0 & 0 \\ 0 & 8 \\ 0 & 4 \\ 0 & 8 \\ 0 & 4\end{array}$

21

25

48

13

$11 \frac{4}{4}$
132

MANTENANCE PERSONNE

OPERATKONS PERSONNEL

HEALTH PHYSSICS FERSONNEL

SUPERVISORY PERSONNEI

ENGIVEERNG PERSONNEL TOTAL

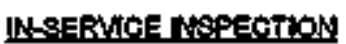

MAINEENANHCE FERSCWNVE

OPERATTONS PERSONNEL

HEALTH PHYYGICS PERSONMEL

SUPERVISORY PERSONNE

ENGNEERNG PERSONNEL TOTAL

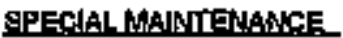

MAINTENANGE PERSONWEL

OPERATICNIS PERSONNEL

HEALTH PHYSICS PERBONNEL

SUPERMSORY PERSONNEI

ENGNEERING PERSONWE TOTAL

WASTE PROCESSIHE

MAINTENANCE PERSONNEL

OPERATIONIS PERSONNEH

HEALT H PHYSYCS PERSONNEL

BUPERRVIEORY PERSONNNEL

EACINEERINS PERSONWEL TETAL

REFu로№

MANFTENANCE PERSONNEL

OPERATLNS PERSONWEL

HEALTH PHYSBCS PERSONNEㄴ.

SUPEFVSORY PERSONNEL

ENCINEERINO PERSONNNEL TOTAL.

TOTALBY VOE ELNCTION

MAINTEKANCEPEREONNE:

OPERATIONS PERSONNDE

HEALTH FHYSSICS PERSONNNEL

SUPERMSORY PERSONNEL

ENGWNEERING PERSONNEL.

200

15

18

12

20

$\begin{array}{rr}0 & 2 \\ 0 & 15 \\ 1 & 18 \\ 0 & 12 \\ 1 & 249\end{array}$

20
0
1
0
20
$\frac{20}{9}$

125

3

3
1
3

1

44

$\begin{array}{rr}0 & 100 \\ 0 & 0 \\ 0 & 4 \\ 0 & 3 \\ 0 & 17 \\ 0 & 1 \frac{130}{30}\end{array}$

$\begin{array}{rrr}8 & 0 & 1 \\ 0 & 0 & 1 \\ 2 & 0 & 1 \\ 0 & 0 & 2 \\ 0 & 0 & 5 \\ 17 & 0 & 10\end{array}$

200

30

17

12
334

24

27

32

457

st

0

1

송

100

1

4

to7

7

10

3

2

27

30
0
13
0
14
10

0.48

0.48

0.000

ops?

$12 \pi$

1,300
2.57
0.844
0,000
0,000
5,000

0,000

0,000

0.000

000

acto

0.000
0,000
0.000
0.000
0.000

s5.61e

0.000

0.600

0,862

5.54

42.742

0,458

0.600

0.112

0.443

1.474

3.160

0,00

0,000

0.000

0.000

0,000

0.000

1277

0.000

1,77

0.000

s.144

19.700

1.657

3.447

0,860

0.446

1.474

0.100

13.287

0,000

2245

0000

5,443

Des

\begin{tabular}{|c|c|c|c|c|c|c|c|}
\hline $\begin{array}{r}191 \\
68 \\
26 \\
18 \\
38\end{array}$ & $\begin{array}{l}0 \\
0 \\
0 \\
1 \\
0\end{array}$ & $\begin{array}{r}402 \\
3 \\
60 \\
27 \\
6\end{array}$ & $\begin{array}{r}508 \\
71 \\
94 \\
43 \\
108\end{array}$ & $\begin{array}{r}79.378 \\
2.168 \\
7.884 \\
4.84 \\
7.044\end{array}$ & $\begin{array}{l}0,000 \\
0000 \\
0000 \\
0.185 \\
0.000\end{array}$ & $\begin{array}{r}155893 \\
1.048 \\
18.709 \\
5.971 \\
20.667\end{array}$ & $\begin{array}{r}215.274 \\
24704 \\
26573 \\
11,160 \\
35941\end{array}$ \\
\hline 341 & 1 & 688 & 910 & 12248 & 0.185 & 180.499 & $\$ 13.152$ \\
\hline
\end{tabular}

Workers mey be counted in more then one category. 


\section{WORK AND}

JOS FUNCTION

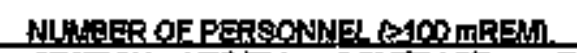
STATION UTIET COWIRACT TOTAL
TOTAL PERSOHLREM

STATIN UTLITY CONTRACT TOTAL,

\section{REACTOROPSR S sUEV}

MAINT ENANCE PERSONNEL

OPERATIONS PERSONNEL

HEALTH PHYSICS PERSONNEL,

SUPERVISORY PERSONNEL

ENGINEERANG PERSONNEL. TOTAL

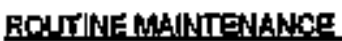
MAINTENANCE PERBONDNEL OPERATIONHS PERSONNEL HEALTH PHYSICSS FERSONNE. \$UPERVISORY PERSONNEL

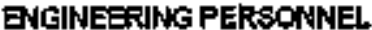
TOTAL

ILLERRMGE WEPECTION MANTENANCE PERRONNE OPERATIONA PERSONWEI HEALTH PHYSICS PERSONWE SUPERVISORY PERkCNNEL ENGWNEERNG PERSONNE TOTAL

SPECIAL MANDTAYANCE

MANTTEANOE PGRSONNEL OPERATIONSPERSONWEL

HEALTH PHYACS PERSONNE. SUPERVISORY FERSONNEL ENBNEEERING PERSONNE. - TOTAL

\section{WASTE PROCESSINT}

MANTENANCE PERSOLRH OPERATIONS PERBONNEL

HEALTH PHYYSOS PERSONNEL QUPERVISRRY PERSONNE. ENGINEERINO PERSONME TOTAL

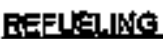

MANTENANCE PERSONWIEL OPERATIONS PERSONNEL HEALTH PHYSICS PERBONNEL SLLEFVISORY PERSONMEL ENOWNEEFNNC PERSONNAE TOTAL

TOTAL BY JoA Flutcton MANTENANCE PERBONNEL OFERATIONSPERSOANNEL. HEALTH PHYESCS PERSONNEI SLPERVISORY PERSONMEL ENONEERING PERSDNNE

$\begin{array}{rl}1 & 0 \\ 74 & 0 \\ 33 & 0 \\ 0 & 0 \\ 0 & 0 \\ 10 \hat{0} & 0\end{array}$

0
0
77
2
82
82

1
74
110
2
3
180

0.317
21.207
10.040
0.494
0.795
3.479

0.007
0.000
0.000
0.113
0.184
0.504

atso 0.000 2425 ass $\frac{1.004}{2.715}$

7.454

$\begin{array}{rr}13 & 0 \\ 0 & 0 \\ 2 & 0 \\ 0 & 0 \\ 0 & 0 \\ 15 & 0\end{array}$

0
0
0
0
0
0

13
0
2
0
0
15

0229

Q515

0 to

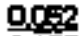

a, 27

$\begin{array}{rrr}0 & 0 & 61 \\ 0 & 0 & 0 \\ 0 & 0 & 1 \\ 0 & 0 & 1 \\ 0 & 0 & -\frac{9}{7} \\ 0 & 0 & 170\end{array}$

01
0
1
1
1
13

0.222

0.00

o.ta1

0,002

1 1.9.

1.7107

$\begin{array}{rrr}16 & 1 & 979 \\ 8 & 0 & 0 \\ 4 & 0 & 23 \\ 2 & 0 & 3 \\ 05 & 0 & 51\end{array}$

57
17
7
5
60
6.5.591
4.205
17.TE2
0.418
$3 \mathrm{cms}$
a

$0, \infty \infty 0$
0,000
0,000
$0, \infty 00$
0,001

0.974

0.00

0.000

0.000

olong

1.000

0,494

21.207

34.871

0.845

1.083

50,409

8.429
0.200
0.515
0.027
0.079
0.276

0.278

$\begin{array}{rll}8 & 0 & \\ 8 & 0 & \\ 28 & 0 & \\ 0 & 0 & \\ 0 & 0 & 0\end{array}$

4

9
6
32
0
47

1,400

1.492

10,208

0.100

cons

13,348

\begin{tabular}{|c|c|}
\hline $\begin{array}{l}0.019 \\
0.000 \\
0.00 \\
0.021 \\
0.121 \\
0.151\end{array}$ & $\begin{array}{r}39.500 \\
0.003 \\
0.504 \\
1.627 \\
31.51 \\
3.735\end{array}$ \\
\hline
\end{tabular}

$\begin{array}{lll}0 & 0 & 0 \\ 5 & 0 & 11 \\ 0 & 0 & 0 \\ 2 & 0 & 0 \\ 0 & 0 & 0\end{array}$

15

0
0
2
2
0
0
0

0.007
1.758
0.116
0.368
0.158
2,403

0.100
0.000
0.000
0.000
0.008
0.210

167.850

2.805

6.652

0002

1 1사요

199,231

244558

7,898

24604

1,477

20.87

291.52

$\begin{array}{llr}0.000 & 1.057 & 2.457 \\ 0.000 & 0.241 & 1.750 \\ 0.00 & 2.200 & 12580 \\ 0.000 & 0.013 & 0.121 \\ 0.000 & 0.013 & 0.019 \\ 0.000 & 0.00 & 16.907\end{array}$

0.000

Bros

16.807

\begin{tabular}{|c|c|c|c|c|c|c|c|}
\hline $\begin{array}{r}174 \\
02 \\
112 \\
4 \\
14\end{array}$ & $\begin{array}{l}1 \\
0 \\
0 \\
0 \\
0\end{array}$ & $\begin{array}{r}40 \\
21 \\
105 \\
6 \\
1+1\end{array}$ & $\begin{array}{r}011 \\
113 \\
217 \\
10 \\
128\end{array}$ & $\begin{array}{r}70.011 \\
20.710 \\
30.009 \\
1.412 \\
5.574\end{array}$ & $\begin{array}{l}0.132 \\
0.021 \\
0.000 \\
0.255 \\
0.370\end{array}$ & $\begin{array}{r}210019 \\
6.475 \\
34,845 \\
2.979 \\
52.241\end{array}$ & $\begin{array}{r}289.161 \\
36.200 \\
74580 \\
4.620 \\
58,101\end{array}$ \\
\hline
\end{tabular}

\section{ORAND TOTALS}

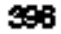

1

675

1076

150915

0.704 cors

3.328

0.68

D.015

0 . 4

4.392

0.085

5.10

o.eos

0.402

b.4.8

6,880

Workals may be courted in mere than ons cetegory. 
APPENOIX 0 (Continued)

NUMBER OF PERSONNEL AND PERBOHAREM

BY WORK AND JOB FUMCTION

1995

FLANT:

TFERMI 2

TYPE:

BWR

WORKANB

JOB FLENCTION

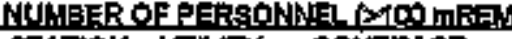
STATION UTILTY CONTRACT TOTAL
TOTAL RERSOH-REM

STATION UTILTY CONTRACT

TOTAL,

REACTOR CPS R ENJPY

MANTENANCEPERSONNEL OPERATIONS PERSONNNEL

HEALTH PHYSICS PERSONANL

SUPERVISORY PERSONMEL

ENGNEEFNA PERBONNEL TOTAL

ROUTREMATTEFANCE MAINTEKANCEPERBONWEL OPERATIONS PERSONNEL HEALTH PHYSICS PERSONNE. SLPERVISORY PERSONNEL ENCANEEANNT PERSONNEL TOTAL

N-SYERVICEN15EECTION MAINTENANCEPERSONNEL OPERATLONS PERSONNEI HEALTH PHYSICS FERSONNE. SUPERVISORY PERSONNEI GNCINESENNB PERSONNEI. TOTAL

SPECCALMANTENANCE MANTENANCE PERSONRTEL OFERATTONS PERSONNEI. HEALTH PHYSCS PERSONNEL SLPERVISORY PERSONNAal ENGINEERNAG PERSONNEI TOTAL

WASTERROCES:Nㅐ MANTENANSEE PERSONNEL QPERATIONS PERSONNE. HEALTH PHYSICS PERSONNNEL SUPERVISORY PERSONINEL ENCINEERING PERSONNEE TOTAL.

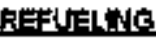

MAINTENAWICEPERSONNEI. OPERATIONS PERSONNEL HEALTH PHYSICS PERSONWEZ SUPERVISORY PERSONNEL

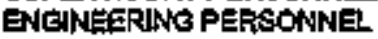
TOTAL

\section{TOTA: BY IOA FUNCTICN}

MAINTENANICE PERSONNEL OPERATIONS PERSONNW HEALTH PHYSKCS PERSONNA SUPERVISORY PERSONNEL, ENGANEERANG PERBONNAL

$\begin{array}{rr}143 & 2 \\ 169 & 1 \\ 31 & 0 \\ 110 & 15 \\ 121 & 2 \\ 514 & 20\end{array}$

$\begin{array}{rr}85 & 270 \\ 24 & 134 \\ 2 & 38 \\ 128 & 250 \\ 0 & 120 \\ 200 & \end{array}$

4.624
5.631
2.446
1.759
1.294
1.854

0.005
0.000
0.000
0.010
0.000
0.015

2,199

3912

0 ans

0977

$\mathrm{con}$

7.299

6.825

0.743

2047

2748

$1,30 t$

$\begin{array}{ll}5 & 0 \\ 0 & 0 \\ 0 & 0 \\ 0 & 0 \\ 0 & 2 \\ 5 & 2\end{array}$

1
0
0
0
0
1

0
0
0
0
2
8

0.58

$0, \infty$

0000

$0+\infty$

0,000

0559

0.000

0,00

0.000

0,000

0.000

0.000

0.132

0,00

0.000

a,

ogon

0.132

2326

$\begin{array}{ll}0 & 0 \\ 0 & 0 \\ 3 & 0 \\ 0 & 0 \\ 0 & 0 \\ 3 & 0\end{array}$

0
0
0
1
0
1

0.171

0.00

0.475

0,000

o,

0.640

0,000

0.000

0.000

0000

0,009

0.000

1.725

0.00

0,75

0.516

o.0.4

2000

0.000

000

0.000

0.000

g.0.0

000

0,00

$0, \infty$

0.000

doest

0,00

002

0.491

0.000

0.000

0,000

$000 \mathrm{r}$

0.491

17

1,427

0.10

Roto

1.815

0.95

3384

0171

0.000

0.475

0.03

0.0009

3.152

0.189

0.755

$2 \mathrm{SOH}_{1}$

Q.017

B.44
0000

0,000

0,00

axs

o.pon

025

0.000

0.000

0.000

0000

poon

0.000

0.017

0.150

0000

D.045

모요

어2

000

0,000

0,000

0000

oncon

0.000

0,000

0,000

0.000

$0, \infty 00$

0,000

0.000

0,000

0.00

o,

000

0,000

0,000

0.017

0.150

0,000

0.340

ㅁ. 0.03

0.507

0,100

0.000

$\mathbf{0 . 0 0}$

0.000

0.000

0.000

168
114
41
119
120

$\begin{array}{rr}2 & 15 \\ 1 & \\ 15 & 1 \\ 4 & \end{array}$
$135 \quad 3$

143

43

$\sin$

134
B.979

5911

3 .

267

1.208
0.005

$0, \infty$

0.000

0.010

0.000
3.772

4.171

0.201

2660

0.000
10.658

toos?

3857

5.443

$\mathbf{t . 3 1 8}$

ses

2

300

847

20014

0.015

11.087

31 재

Warkars may be counted in more than one cotegary. 
APPENDIX $D$ (Continusd)

MUMEER OF PERSONNEL AND PERSON-REM

BY WORK AND JOB FUNCTION

1895

PLANT: WFITZPATRICK

TYPE: BWR

WORKAND
JOB FUNCTION

JOB FUNCTION

STATION UTHTY CONTRACT TOTAL

UTITY CONTRACT

BFACTCR OPB B. BLAY

MANTENANCE PER8ONNII

OPERATIONS PERSONAEL

FEALTH PHYSICS PERSONNEL

SUPERVISORY PERSONNEL

GN헤NEERING PERSONNEI

TOTAL.

109
74
52
74
12
241

$\begin{array}{rr}0 & 517 \\ 0 & 15 \\ 0 & 25 \\ 0 & 23 \\ 0 & 0 \\ 6 & 380\end{array}$

428
8
77
37
27

61.00

40.75

21250

3.500

3270

15000

ROUTINE MAHTELYNACE

MANT ENAKHCE PERSONNE

OPERATIONS PERSONNEL

HEALTH FHYSICS PERSOMNE

SUPERVISORY PERSONNE

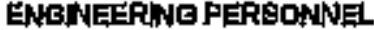

TOTAL

4
0
0
0
0
4

0
0
0
0
0
0

$\mathbf{2}$
$\mathbf{0}$
$\mathbf{0}$
$\mathbf{0}$
$\mathbf{p}$
$\mathbf{2}$

3.410

0,000

0,000

$0 \mathrm{non}$

3.490

1
1
2
0
0
4

0
0
0
0
0
0

0
0
0
0
0
0

0.270

0.720

0.700

0.000

0.00

1.720

$\begin{array}{rr}11 & 11 \\ 0 & 1 \\ 1 & 2 \\ 0 & 0 \\ 0 & 0 \\ 12 & 14\end{array}$

0.000

0.000

0.050

$\cos$

D.mon

atos

TOTAL

WAETERROCFB에은

MANNTENANCE PEFSONNEL

OPERATIONS PERSONNEL

HEALTHPHYVICS PERSONNEL

SUPERVISORY PERSONNE.

ENCINEERINSPERBONNEL TOTAL.

13

13
2

7

0

量

$\begin{array}{rr}30 & 9 \\ .0 & 8 \\ 3 & 10 \\ 1 & 1 \\ 0 & 9 \\ 40 & 6\end{array}$

9
8
10
1
8
6

11.500

1.440

3,400

0,000

popos

$0, \infty$

0.000

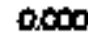

0,000

oden

0.000

$\begin{array}{rr}110.600 & 172.400 \\ 4.700 & 4240 \\ 6.770 & 29.020 \\ 5.730 & 9.280 \\ 2.780 & 0.000 \\ 130.700 & 261.970\end{array}$

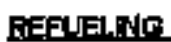

MANTENANCEPERSONNEL OPERATIONS PEREONNDLL HEALTH PHYEIOS FERSONNEL. SUPPERUSORY PERSONNEI ENGNNEERINO PERBONNEL

$$
\text { TOTAL }
$$

5
3
1
10

$\begin{array}{ll}0 & 0 \\ 0 & \\ 0 & 0 \\ 0 & 0\end{array}$

$\begin{array}{lr}0 & 1 \\ 1 & 0 \\ 2 & 5 \\ 0 & 1 \\ 0 & 0 \\ 3 & 15\end{array}$

0.000
2.700
0.000
0.000
0.000
4.410

0.000
0.000
0.000
0.00
0.000
0.000

$\begin{array}{ll}0.050 & 4000 \\ 0.000 & 0.000 \\ 0.000 & 0.000 \\ 0.000 & 0.000 \\ 0.000 & 0.000 \\ 0.650 & 4000\end{array}$

TOTALEY NOB FUNATION

MAINTENANCE PERSONNEL OPERATIONS PERSONWEI HEALTH PHAYSICS PERSONNE. SUPERVISORV PEREONNEE. ENGINZERTNG PERBONNEL

128
62
12
12

\begin{tabular}{|c|c|c|c|c|c|c|}
\hline $\begin{array}{l}0 \\
7 \\
0 \\
0 \\
0\end{array}$ & $\begin{array}{r}308 \\
28 \\
31 \\
24 \\
8\end{array}$ & $\begin{array}{c}494 \\
111 \\
98 \\
\infty \\
\infty\end{array}$ & $\begin{array}{l}78.120 \\
4.600 \\
28.610 \\
3500 \\
3270\end{array}$ & $\begin{array}{l}0.000 \\
0.740 \\
0.000 \\
0.000 \\
0.000\end{array}$ & $\begin{array}{r}114.400 \\
4.960 \\
7.840 \\
5.700 \\
2760\end{array}$ & $\begin{array}{r}192.650 \\
61.820 \\
34.450 \\
9.280 \\
0.000\end{array}$ \\
\hline
\end{tabular}

ENAND TOTALS

502

$7 \quad 451 \quad 760$

157.120

$\begin{array}{llr}0.00 & 1.200 & 13.150 \\ 0.000 & 0.170 & 1,610 \\ 0.000 & 0.670 & 4260 \\ 0.000 & 0.000 & 0.000 \\ 0.000 & 0.000 & 0.000 \\ 0.000 & 2000 & 1.000\end{array}$

$\begin{array}{lll}0.000 & 0.000 & 0.000 \\ 0.000 & 0.000 & 2.750 \\ 0.000 & 0.310 & 1,300 \\ 0.00 & 0.000 & 0.000 \\ 0.000 & 0.000 & 0.000 \\ 0.000 & 0.310 & 4,720\end{array}$

$\begin{array}{ll}0.000 & 0.770 \\ 0.00 & 0.720 \\ 0.00 & 0.790 \\ 0.000 & 0.000 \\ 0.000 & 0.000 \\ 0.00 & 1.70\end{array}$

$\begin{array}{ll}20040 & 2,040 \\ 0.000 & 0.020 \\ 0.000 & 0.140 \\ 0.000 & 0.000 \\ 0.000 & 0.000 \\ 2140 & 2.000\end{array}$

Workers may be counted in mote then ene cetepory. 
WORK AND

JOB FENCTION

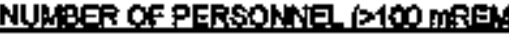
STATON UTIJTY CONTRACT TOTAL
TOTAL PGRSON-REM

STATION UTILITY CONTRACT TOTAL
REACTOR OPS \& SURV

MANTENANCEPERSONWEL OPERATIONS PERSONNEL

HEALTH PHYSCS PERSONNEL

SUPERVISORY PERSONNEI

ENGINEEFING PERSONNEL

TOTAL

ROUTINE MAINTENANCE

MAINTERAAWEPERSONWEL

OPERATIONIS PERSONNEEI

HEALTH PITYSICS PERSONNEL

SUPERVISORY PERSONWEL

ENCINEEENANG PERSONIA툐 TOTAL

1
32
17
2
54

0
0
0
0
0
0

0
0
14
0
0
14

1
32
31
2
2

assog

8.434

a.005

0.75

$\frac{0.790}{16.95}$

16.463

$\begin{array}{rrr}54 & 19 & 45 \\ 0 & 0 & 0 \\ 20 & 0 & 27 \\ 7 & 0 & 0 \\ 11 & 1 & 1 \\ 92 & 10 & 73\end{array}$

117

47

7

$\frac{13}{184}$

IN-SERUGEINSPECTLON

MANTENANCE PERSONNEL

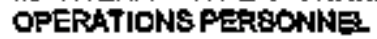

HEALTH PHYSICS PERSONNE.

SUIFERVISORY PERSONNEL

ENGINEEFNNB PERSONNER TOTAL

$\begin{array}{rr}15 & 14 \\ 0 & \\ 3 & \\ 0 & \\ 24 & \end{array}$

$\begin{array}{rr}14 & 7 \\ 0 & 0 \\ 0 & 17 \\ 0 & 0 \\ 0 & 3 \\ 14 & \end{array}$

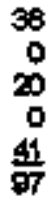

SPEGIALMANTIENANCE

MALTTENANCE PERßONNEL OPERATIONS PERSONNEI.

HEALTH PHYBJCS PERSONWEL

SUPERVSORYPERSONNE.

ENALMEERING PERSONNEL TOTAL

\section{1}

0

J

o

14
0
0
0
20
20

10
0
0
0
眆

WASTE FROCESSINT

MANTENANCE PERSONMEZ

OFERATLONS PERSONNEL

HEALTH PHYSACS PERSONNEL

SUPERVIBORY FERSONDU1

ENGINEERING PERSONNG TOTAL

\section{REFUELMO}

MANTENANCEPERSONME

OPERATIONS PERSONNEL

HEALTH PHYSICS PERSONNNEL

SUPERVISORY PERSOFWE

ENGINEERING PERSONNEL TOTAL

$\begin{array}{ll}0 & 0 \\ 0 & 0 \\ 8 & 0 \\ 0 & 0 \\ 8 & 0\end{array}$

$\begin{array}{ll}0 & 0 \\ 0 & 0 \\ 0 & 0 \\ 0 & 0 \\ 0 & 0\end{array}$

0
0
0
0
0
3

0
0
11
0
0
11

$\begin{array}{rr}35 & 21 \\ 0 & 0 \\ 5 & 0 \\ 2 & 0 \\ 8 & 0 \\ 50 & 21\end{array}$

8
0
24
0
5
57

64
0
2
2
13
108

IOTAL EY JOR FUNCTION MANNTENANCE FERSONNEL OFERATIONS PERSONNEL HEALTH PHYSICSS PERSONNEL SUPERVISORY PERSONHE ENGLEERDAG PERSONINE.

\begin{tabular}{|c|c|c|c|c|c|c|c|c|}
\hline 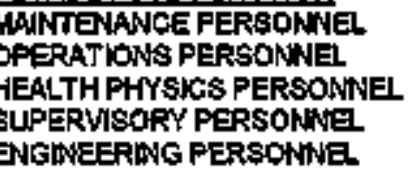 & $\begin{array}{r}105 \\
32 \\
53 \\
11 \\
30\end{array}$ & $\begin{array}{r}54 \\
0 \\
0 \\
0 \\
1\end{array}$ & $\begin{array}{r}74 \\
0 \\
85 \\
0 \\
47\end{array}$ & $\begin{array}{r}234 \\
32 \\
138 \\
11 \\
78\end{array}$ & $\begin{array}{r}34.671 \\
10.655 \\
10.398 \\
4.994 \\
1.841\end{array}$ & $\begin{array}{l}10.731 \\
0.000 \\
0.000 \\
0.014 \\
0.000\end{array}$ & $\begin{array}{r}20.203 \\
0.023 \\
20.722 \\
1.670 \\
24535\end{array}$ & $\begin{array}{r}92.605 \\
10.687 \\
40.091 \\
6.078 \\
34.083\end{array}$ \\
\hline GRAND TOTALS & 232 & 茊 & $\mathbf{2 0}$ & 403 & 75,900 & 20.354 & 78.190 & 174,474 \\
\hline
\end{tabular}

50.013

0,404

$\begin{array}{llll}6.050 & 0.000 & 7.721 & 13.771 \\ 2.01 & 0.014 & 1.103 & 3.378\end{array}$

$\begin{array}{llll}6.050 & 0.000 & 7.721 & 13.771 \\ 2.01 & 0.014 & 1.103 & 3.378\end{array}$

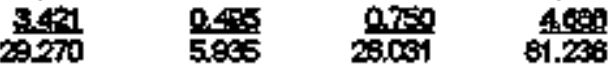

\begin{tabular}{|c|c|c|c|}
\hline $\begin{array}{l}4.040 \\
0.000 \\
0.849 \\
0.059 \\
1.584 \\
6.048\end{array}$ & $\begin{array}{l}4,072 \\
0,000 \\
0,000 \\
0,000 \\
0,014 \\
4,000\end{array}$ & $\begin{array}{r}2127 \\
0.017 \\
4500 \\
0.200 \\
17.68 \\
24568\end{array}$ & $\begin{array}{r}10.259 \\
0.100 \\
5.179 \\
0.259 \\
19.478\end{array}$ \\
\hline
\end{tabular}

\begin{tabular}{|c|c|c|}
\hline $\begin{array}{l}0.159 \\
0.000 \\
0.189 \\
0.084 \\
0.748 \\
1.514\end{array}$ & $\begin{array}{l}0.344 \\
0.000 \\
0.000 \\
0.000 \\
0.000 \\
0.344\end{array}$ & $\begin{array}{r}5.007 \\
0.000 \\
1.122 \\
0.050 \\
4.008 \\
10.280\end{array}$ \\
\hline
\end{tabular}

\begin{tabular}{|c|c|c|}
\hline $\begin{array}{l}0.014 \\
0,000 \\
1.814 \\
0,004 \\
0,001 \\
1 B 2\end{array}$ & $\begin{array}{l}0,005 \\
0,0 \infty \\
0,0 \infty \\
0, \infty 00 \\
0,000 \\
0.005\end{array}$ & $\begin{array}{l}0,008 \\
0.000 \\
1.500 \\
0.000 \\
0.002 \\
1.510\end{array}$ \\
\hline
\end{tabular}

$4.696 \quad 27.049$

$\begin{array}{llll}1.749 & 0.000 & 0.000 & 1.740\end{array}$

$\begin{array}{llll}1.372 & 0.000 & 5.442 & 0.814\end{array}$

$\begin{array}{llll}1.290 & 0.000 & 0.288 & 1.088\end{array}$

$\frac{3.314}{20.199} \quad \frac{0.100}{121000} \quad \frac{1.704}{42,374}$

\footnotetext{
Worksis mary ba counted in more then one cedegory.
} 
BEACTOR OPE : SURV

MANNJDAANCE PERSONWEL

OPERATIONS PEREONNEA

HEALTH PHYEICS PERSONNEL

SLPERVISORY PERSONNEL

ENBINEERING PERSONNE1. TOTAL

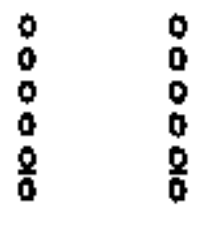

\section{RQIJTNE MANTENANCE}

MALNTENANCE PERBDNMEL OPERATIONS PERSONNEL

HEALTH PHYYICS PERSONNEL

QUPERVISORY PERSONNEL

EVGNEERING PERSONNEL TOTAL.

$\begin{array}{ll}0 & 0 \\ 0 & 0 \\ 0 & 0 \\ 0 & 0 \\ 0 & 0 \\ 0 & 0\end{array}$

MESERMCEIMSPECTION MAINTENANCE PERSONNEL OPERATIONB FERSONNEL. HEALTH PHYUICS PERSONINE BUPERYSSORY PERSONNEL ENGINEERING PERBONNEI TOTAL

$\begin{array}{ll}0 & 0 \\ 0 & 0 \\ 0 & 0 \\ 0 & 0 \\ 0 & 0 \\ 0 & 0\end{array}$

\section{SPECIALMAINTENANGE}

MAINTENANCE PERSONNEL OPERATIONS PERSOMMEL HEALTH PHYSICS FERSONWE SLPERVISORY PERSONNEI ENGMEERTG PEREONNER. TOTAL

$\begin{array}{lll}0 & 0 & 1 \\ 0 & 0 & \\ 0 & 0 & \\ 0 & 0 & \\ 2 & 0 & \\ 2 & 0 & 21\end{array}$

0
0
0
0
0
0

0
0
0
0
0
0
STATION जTLTY CONIRACT

TOTAL

\section{WASTE RROCESSNG}

MAINTENANCE PERSONALEL OPERATIONB PERSONNEI

HEALTH PHYSTCS PERSONNAEL SUPERVIORY PERSONNEL ENGINEERNG PERSONNES TOTAL

$\begin{array}{ll}0 & 0 \\ 0 & 0 \\ 0 & 0 \\ 0 & 0 \\ 0 & 0 \\ 0 & 0\end{array}$

REFUㄴ.MG

HAINTENANCE PERSONWE OPERATIONS PERSONNEL HEALTH PHYEICS PERSONNEL SUPERVISORY PERSONNG. ENGINEERING PERSONNE

$$
\text { TOTAL }
$$

$\begin{array}{ll}0 & 0 \\ 0 & 0 \\ 0 & 0 \\ 0 & 0 \\ 0 & 0 \\ 0 & 0\end{array}$

0
0
0
0
0
0

TOTAL BY JOB FUNCTION MAINTENANGE PERSONWNEL OPGRATIONS PERSONNEL HEALTH PHYBICS PERSONNEL SUPERVISORY PERSONWUEl ENGINEERINE PERSONNEI

\begin{tabular}{|c|c|c|c|c|c|c|c|}
\hline $\begin{array}{l}0 \\
0 \\
0 \\
0 \\
2\end{array}$ & $\begin{array}{l}0 \\
0 \\
0 \\
0 \\
0\end{array}$ & $\begin{array}{r}163 \\
0 \\
58 \\
\theta \\
.8\end{array}$ & $\begin{array}{r}163 \\
0 \\
36 \\
9 \\
7\end{array}$ & $\begin{array}{l}0.000 \\
0.000 \\
0.000 \\
0.000 \\
0,00\end{array}$ & $\begin{array}{l}0.000 \\
0.000 \\
0.000 \\
0.000 \\
0, \infty \infty\end{array}$ & $\begin{array}{r}187.690 \\
0.000 \\
13.348 \\
4.767 \\
1.476\end{array}$ & $\begin{array}{r}197,880 \\
0,600 \\
12,346 \\
4,767 \\
1,694\end{array}$ \\
\hline 2 & 0 & 213 & 215 & 0203 & 0.000 & 207.418 & 207.677 \\
\hline
\end{tabular}

Workers may be counted in more than one ontegary. 
WORKAND JOB FUNCTION
NLMA. STATION UTLTY
TOTALPRERSONAER STATHON UTUTY CONTRACT

TOTAL
REACTOK OPS \& sURV

MAINTENANCE PERSONNEL OPERATLNIS PERSONNEL HEALTH PHYSTCS PERSONNEL SUPERVISORY PERSONNEL RNGNEERING PERSONNEL TOTAL

\section{ROUTRE MAINT ENANCE} WANTERANCE PERSONNEL OPERATIONS PERSONNE HEALTH PHYSICS FERSOHNEL SUPERVISORY PERSONNEL ENCINEERING PERSONNEL TOTAL

W-SERVGE MNPECTION MAINTENANCE PERSONNE! OPERATLN'S PERSONW: HEALTH PHYSICS PER\&ONNE. SUPERWISORY FERSONNEA ENGINEEENHG PERSONNEL TOTAL

SPECIALMANTENANCE

MANTENANDE PERSONNE OPERATIONS PERSONWAI. HEALTH PHYSICS PERSONWE SUPERV SORY PERSONNEA ENGINEERING PERSONNEE TOTAL.

\section{WASTE PROGESSING}

MANTENANCE PERSONNAL OPERATIONS PERSONNEI HEALTH PHYSICS PERBONNEL SUPERVISORY PERSONNAE

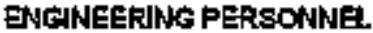
TOTAL.

$\begin{array}{rr}490 & 174 \\ 3168 & \\ 878 & \\ 6 & \\ 123 & 1 \\ 4844 & 3\end{array}$

$\begin{array}{rr}174 & 214 \\ 1 & 28 \\ 0 & 1980 \\ 0 & 0 \\ 189 & \frac{204}{3408}\end{array}$

857
3185
273
8
915
7413

9000

815

1000

료

푸오

$\begin{array}{rr}81 t & 1545 \\ 4 & 06 \\ 0 & 0 \\ 0 & 3749 \\ 489 & 718 \\ 1060 & 6107\end{array}$

52036
018
6
4009
1754
+22023

1

13

0

B

$\infty$
0
0
0
20

$\begin{array}{r}50 \\ 0 \\ 2 \\ 0 \\ 188 \\ \hline 74\end{array}$

657

105

11

等

$\begin{array}{rr}801 & 2087 \\ 0 & 0 \\ 0 & 980 \\ 0 & 1 \\ 92 & 2007 \\ 800 & 5709\end{array}$

60

1092

12

2184

748

$\begin{array}{rr}29 & 5 \\ 3 & 0 \\ 35 & 0 \\ 0 & 0 \\ 70 & \frac{18}{20}\end{array}$

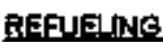

MANTENANCEFERBONNE OPERATIONS PEROONREI HEALTH PHYSICS PERSONNAE SUPERVISORY PERSONNE ENGNEERING PERSCNNEL TOTAL

TOTAL BY JOA FUWOTION MANTENANCE FERSONNG OPERATLNSPERSONNAEL HEALTH PHYSICS PERSONNEL SUPERVISORY PERSONNE ENGINEERING PERSONNEI

5
0
0
0
18
23

$\begin{array}{rr}6 & 40 \\ 0 & 6 \\ 100 & 221 \\ 0 & 0 \\ 2 & 20 \\ 204 & 207\end{array}$

$\begin{array}{rr}88 & 45 \\ 113 & 25 \\ 5 & 0 \\ 0 & 0 \\ 0 & 21\end{array}$
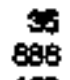

12

7

$\frac{11}{91}$

1000

139

1024

1Z7

D

1303

\begin{tabular}{|c|c|c|}
\hline $\begin{array}{r}4292 \\
4234 \\
100 \\
1079 \\
210\end{array}$ & $\begin{array}{r}1850 \\
30 \\
0 \\
0 \\
1014\end{array}$ & $\begin{array}{l}4502 \\
1009 \\
3169 \\
3700 \\
3505\end{array}$ \\
\hline
\end{tabular}

\subsection{4 \\ 0.003 \\ 0.000 \\ o.mo \\ c.440}

000

$\begin{array}{ll}0.355 & 0.057 \\ 3.751 & 0.000 \\ 1.772 & 0,000 \\ 0.001 & 0.000 \\ 0.055 & 0.288 \\ 5.974 & 0.345\end{array}$

0.040

0.000

2004

0.000

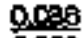

2820

D.A92

3.751

4,498

0.001

0.429

9.439

$\begin{array}{ll}2.008 & 0.684 \\ 1.149 & 0.00 \\ 0.105 & 0.000 \\ 1.273 & 0.000 \\ 0.159 & 0.458 \\ 4.734 & 1.140\end{array}$

$\$ .127$

3879

0.006

0,000

10.684

0.424

12.241

1. IES

0.103

11.00

$\frac{1.99}{18.115}$

0.172

0.000

0.000

0.000

1287

1.45

0. 451

0,000

0.000

0000

1,598

1807

0.623

0.484

0.008

0.000

2829

3.683

5.000
0.283
1.838
0.139
0.148
7.458

20.50

0,000

0,000

0,000

$171^{8}$

28.849

51.927

0,000

axso

0283

0,000

44568

$8.2 \times$

0.138

2716

48,458

107.029

4000

0.000

0.017

0.000

Doton

0.027

0.000

0.000

0.000

0.000

000

0.005

0.000

0,000

D.81日

0,00

ond

0.510

0.010

0,000

0.003

0,000

ㅇo장

1.684

0954

0,07a

Q.618

0.545

0,000

0.594

$15 \% 00$

0,00

$0, \infty$

$\frac{0.510}{1.673} \quad \frac{0.174}{16519}$

2043

16.782

0,776

0,0

268

0.000

a.egd

20.688

Q.21

6.57

3.612

1.414

22529

0.545

0.000

27.831

50.67

15,289

10304

10.084

22405

0.340

0.000

46.803

12008

12088
51.412

\begin{tabular}{|c|c|c|c|c|c|c|c|c|}
\hline CRAND TOTALS & 10001 & 2700 & 15758 & 2000 & 24.354 & 2733 & 11090 & 159.606 \\
\hline
\end{tabular}

Workers may be counted in more than one cotegory. 
1.000

1.169

13.315

0.75

0.172

TOTAL

TOTAL

$\begin{array}{rrr}157 & 75 & 417 \\ 59 & 0 & 11 \\ 29 & 1 & 8 \\ 11 & 1 & 17 \\ 11 & 0 & 2 \\ 27 & 27 & 4\end{array}$

417
11
8
17
2
4

ENO

69

37

18

SLPERVISORY PERSONNEL TOTAL

$\begin{array}{rrr}0 & 0 & 04 \\ 0 & 0 & 0 \\ 0 & 0 & 0 \\ 3 & 0 & 31 \\ 2 & 0 & 0 \\ 5 & 0 & 05\end{array}$

M-SERMGE INSPECTION MAINTENANCE PERSONNEL OPERATIONS PERSONNEE. HEALTH PHYSICS PERSONNII SLPERVISORY PERBONNAL ENGANEERING PERSONNEL TOTAL

\section{SPEGIALMANITENANCE}

MAINTE KANCE PERSONNEI OPERATIONS FERSONNEL HEALTH PHYSICS PERSONNEL SUPERVISORY PERSONNEL ENCINEERING PERSONNIES TOTAL.

\section{WASTEPROCESSNG}

MANTE AANCE PERSONNEI OPERATIONS PERSONNEI

HEALTH PHYSICS PERSONNEL SUPERVISORY PERSCNNEL ENGINEEERING PERSONNE TOTAL

REEUECING

MAWTENANCE PERSONWEI OPERATIONS PERSONNEL

HEALTH FHYYSICS PERSONNEL SUPERVISORY FERSONNEL ENGNNERRNG PERSONEL TOTAL

TOTALBY JGB FUMCTION

MANTTENANCE PGRSOKNAEL OPERATIONS PERSONNEI HEALTH FHYSICS PERSONNEG SUPERVISORY PERSONNE. ENGINEERING PERSONNEL

64
0
0
31
0
0

64
0
0
34
100

0
0
0
0
0
0

0
0
0
0
0
0

0.004

0.000

0.018

1.094

0.871

0.000

0.000

0000

0,000

o.pog

$\begin{array}{ll}0 & 0 \\ 0 & 0 \\ 0 & 0 \\ 0 & 0 \\ 0 & 0 \\ 0 & 0\end{array}$

0
0
0
0
0
0

0
0
0
0
0
0

0,000

0,000

0,000

0.000

0,000

161
60
56
15
18

70.723
25.609
9.606
3.383
6.199
115.002

\begin{tabular}{l}
0,003 \\
0,000 \\
2,200 \\
0,000 \\
0,000 \\
\hline 2.212
\end{tabular}

\subsection{7}

0.009

10.278

0.015

0.009

10.673

\begin{tabular}{|c|c|c|}
\hline $\begin{array}{l}6.009 \\
0.002 \\
0.428 \\
0.386 \\
0.011\end{array}$ & $\begin{array}{r}159.983 \\
7.547 \\
2793 \\
4177 \\
0.989 \\
169.417\end{array}$ & $\begin{array}{r}232,790 \\
33,252\end{array}$ \\
\hline
\end{tabular}

0,000
0,000
0,000
0,008
0.001
0,0000

24.248

0.023

0.004

9003

0.05

33.724

0.000

0,000

0.000

0,000

0.000

0.000

0,000

0,000

0.000

0.000

0.000

0.000

24.330

0,026

0.025

10513

0.427

3532

0.000

0.000

0.000

0,000

0000

0.000

0.000

0.000

0.000

0.000

D.0.00

0,000

D.000

0,000

0.000

0,000

0.000

0.000

0.000

0,000

0.00

0.000

0.000

$\begin{array}{rrrrrrrr}0 & 0 & 38 & 38 & 0118 & 0.000 & 11.142 & 11.260 \\ 1 & 0 & 2 & 3 & 0.453 & 0.000 & 0.534 & 0.987 \\ 0 & 0 & 0 & 0 & 0.002 & 0.000 & 0.070 & 0.092 \\ 0 & 0 & 2 & 2 & 0.347 & 0.007 & 0.401 & 0.75 \\ 0 & 0 & 0 & 0 & 0.416 & 0.000 & 0.000 & 0.418 \\ 1 & 0 & 42 & 40 & 1.356 & 0.007 & 12147 & 13.510\end{array}$

$\begin{array}{rrr}521 & 73 \\ 13 & 89 \\ 50 & 69 \\ 2 & 2\end{array}$

$\pi 7$
73
6
20

T2015

27319

20.021

5.054

7.151

134560

11.169

8.098

0.002

2.640

0.419

B.110

13.145

49800

200.859

35.431

38.605

19.48

8.208
GRAND TOTALS

310

34

6zi

9os

Workers may be counted la mora then ane catagory. 
1995

WORKAND
JOB FUNCTION

\section{EPACTOR OPS : S1MEV} MANTENANDE PERSONNAL OPERATIONS PERSONNEL. HEALTH PHYSSIC PERSONANZL SUPERVISORY PQRSONNE. ENGINEERING PERSONNEL TOTAL. STATKW UTUரT CONTRACT TOTAL

51
44
10
2
15
1510

$\begin{array}{rr}15 & 205 \\ 0 & 0 \\ 0 & 40 \\ 1 & 1 \\ 20 & 291\end{array}$

271
44
64
4
498

ROUTINE MAAINTEENALCE MAINTENANCE PGRSOONNII OPERATIONS PERSONANEI. HEALTH PHHYSICS PERSONNE SUIPERVISORY PERSONNEL GNGINETERING PERSONNEL TOTAL.

6.142
25.250
4.500
0.310
1.569
s.3.9.9

\begin{tabular}{|c|c|c|}
\hline $\begin{array}{l}0.061 \\
0.000 \\
0,000 \\
0.000 \\
0.370 \\
1,391\end{array}$ & $\begin{array}{r}2.812 \\
0.000 \\
0.087 \\
0.000 \\
0,040 \\
30,075\end{array}$ & $\begin{array}{r}34,015 \\
25,250 \\
14,174 \\
0,549 \\
2,519 \\
77,005\end{array}$ \\
\hline
\end{tabular}

LSPMVE INSPECTHN

5
21
to
2
15

$\begin{array}{ll}37 & 3 \\ 0 & \\ 1 & \\ 5 & 17 \\ 4 & 54\end{array}$

$\begin{array}{rr}325 & 49 \\ 0 & 2 \\ 4 & \\ 174 & 194 \\ 344 & 409\end{array}$

$\begin{array}{rr}495 & 17.697 \\ 21 & 0.805 \\ 67 & 2443 \\ 4 & 0.065 \\ 194 & 1.055 \\ 608 & 22.453\end{array}$

4.760

0.000

0.000

0.000

Q. $\mathrm{cP7}$

8,100

37.410

5060

$0.000 \quad 0.680$

$0.811 \quad 3.254$

$00 \%$

0.180

11.199

1P.895

$\rightarrow, 4=0$

77,079 MANATENANCE PERSONNE OPERATKONS PERSONNA HEALTH PHYSICS PERSONAEE SUPERVISORY PERSONNNE. ENGNEERNG PERSONNEL TOTAL

18

4

0

是

6
0
0
1
4
13

$\frac{1}{104}$

257
4
35
$\frac{17}{470}$

7.494

0.015

0.45

$0, \infty$

0,768

8,700

0.56

0.000

0.00

0.00

Q405

1.081

SPECIAL MANTIENANCE

$\begin{array}{rr}39 & 2 \\ 3 & 0 \\ 5 & \\ 1 & \\ 12 & 2 \\ 84 & 2\end{array}$

$\begin{array}{rr}24 & 14 \\ 0 & \\ 0 & \\ 1 & \\ 2 & 17 \\ 24 & 17\end{array}$
MAINTENANCE PERSONINEL OPERATIONS PERLONMEl HEALTH PHYSICS PERSONNEL SUPERVSORY PERSONNEE ENGINEERING PERSONNE. TOTAL

\subsection{7}

0.290

0.185

0.010

0.805

7.391

WASTE PROCESEINC

MANTENANCE PERSONNE. OPERATLONS PERSDNEYE. HEALTH FHTYSLS PERSONWEI SUPERVISORY PER8ONNE. ENEINESRING PERSONNEL TOTAL

3
0
17
1
1
2

REFUUELWNG

MANTENANCE FERSONNEL OPDRATIONS PERSONWEL HEALTH PHYSICS PERSONKRE. BUPERVISORY PERSONNEL GNEINIFERINO PERSONNEE

TOTAL

TOTAL BY.UOB FUNCTION MAINTENANCE PERSONNEL OPERATONB PEREONNE HEALTH PHYSICS PERSONMEI SUPERVISORY PERSONNEL. ENGINEERING PERSONNEL

$\begin{array}{rrr}4 & 14 & 21 \\ 0 & 0 & 5 \\ 0 & 34 & 51 \\ 0 & 0 & 5 \\ 0 & 5 & 51 \\ 4 & 51 & 7\end{array}$

16
2
4
0
4
29

3
0
0
0
0
0

$\begin{array}{rr}0 & 2 \\ 0 & 2 \\ 9 & 15 \\ 1 & 1 \\ 2 & 0 \\ 21 & 110\end{array}$

21
0
61
1
4
7

0,005

0,000

4.39

0.145

D, op

4.491

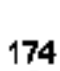

$174 \quad 8$

$88 \quad 9$

$0 \quad 0$

12

1249

74

24

41.780

0.
4,55

0000

0.000

0.005

$\frac{0.560}{5.012}$

Bsise

0.000

0.43

0,057

12209

21233

배요

0.015

600 o.tr

124.54

Dis.10

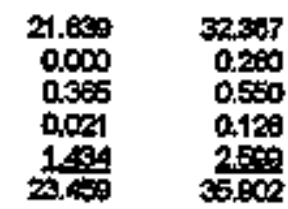

0.005

0.00

0.000

000

0.000

D.sis

0.088
0.000
12.211
0.000
0.078
12327

0,308

0,000

16.552

0.165

Q0요

17.121

\begin{tabular}{|c|c|c|c|}
\hline $\begin{array}{r}83 \\
2 \\
13 \\
1 \\
0 \\
110\end{array}$ & $\begin{array}{l}2000 \\
0,003 \\
0.005 \\
0,000 \\
0.200 \\
2000\end{array}$ & $\begin{array}{l}0.100 \\
0.00 \\
0.000 \\
0.000 \\
0.000 \\
0.100\end{array}$ & $\begin{array}{r}30.070 \\
0.00 \\
0.390 \\
0.142 \\
0.200 \\
50.008\end{array}$ \\
\hline
\end{tabular}

11.318

0000

193574

0000

3a127

b.781

0,200

1.442

1)

251.699

28,400

44.04

1,018

\begin{tabular}{|c|c|c|c|c|c|c|c|c|}
\hline GRAND TOTALS & 876 & 107 & 1543 & 2003 & 85074 & $128=3$ & 384820 & 402857 \\
\hline
\end{tabular}

Whis

1 t wite y in more than one wategory.

NUREG-0713 
REAGTDRORS \& S1RY

MANTENANCE PERTONMGL OPERATIONS PERSOANEL HEALTH PHYSTCS PERSONWEI SUPERVISORY PERSONNEL ENGNEERNG PERSONNE TOTAL

$\begin{array}{rr}2 & 0 \\ 1 & 0 \\ 19 & 0 \\ 0 & 0 \\ 0 & 0 \\ 22 & 0\end{array}$

2
0
0
0
0
8

4
1
2
0
0
0

0.402 $23 \pi$

$4 \$$

0.100

0372

8.158

ROUTMEMAINTIENANCE. MANNTENANCE PERSONNEL OPERATIONS PECSONNEL HEALTH PHYSICB PERSONNEL SUPERVISORY PERSONNEL. ENCUNEEFINE PERSONNEI TOTAL

$\begin{array}{ll}0 & 0 \\ 0 & 0 \\ 0 & 0 \\ 0 & 0 \\ 0 & 0 \\ 0 & 0\end{array}$

3
0
0
0
0
3

3
0
0
0
0
3

1.775

0.162

0.0

0.013

$0 \% 7$

284

$\begin{array}{ll}2 & 0 \\ 0 & 0 \\ 0 & 0 \\ 0 & 0 \\ 0 & 0 \\ 2 & 0\end{array}$

0
0
0
0
0
0

2
0
0
0
0
2

0.044 MAINTENANCEPERSONNEI OPERATIONS PERSONNVE HEALTH PHYSICS PERSONNEL SLPERISORY PERSONNEL TOTAL

SPECIALMAINTENANCE MANTEEAANCE PERSONNEL OPERATIONS PERBONNE. HEALTH FHYSICS PERSONWEL SUP ERVISORY PERSONNA. ENGWEERTNG PERSONNEL TOTAL

$\begin{array}{rrr}19 & 0 & 37 \\ 1 & 0 & 0 \\ 10 & 0 & 0 \\ 0 & 0 & 0 \\ 1 & 0 & 0 \\ 25 & 0 & 5\end{array}$

37
0
0
0
2
30

50
1
10
0
3
04

0.000

0.002

0.00

Q0.84

$\begin{array}{lll}1 & 0 & 0 \\ 0 & 0 & 0 \\ 2 & 0 & 0 \\ 0 & 0 & 0 \\ 0 & 0 & 1 \\ 3 & 0 & 1\end{array}$

1
0
2
0
1
4

a.ti

\section{WASTE PROCGSSSINE}

MAWTENANCE PERBONNE PERATIONS PERSONNEI SUPERVISORY PERSONHWE ENGMEERTNG FERSONHE. TOTAL

REFU:A MNG MAINTENANCEFERSONNEL. OPERATION'S PERSONWNEL HEALTH PHYEICS PERSONNEI BLPERVIORY FERBONAML ENGWNEEFANG PERSONDAEL TOTAL

$\begin{array}{rrr}47 & 4 & 10 \\ 12 & 0 & 1 \\ 17 & 0 & 20 \\ 0 & 0 & \\ 15 & 0 & 120 \\ 91 & 4 & 2\end{array}$

$\begin{array}{rr}102 & 1 \\ 20 & 120 \\ 200 & 1\end{array}$

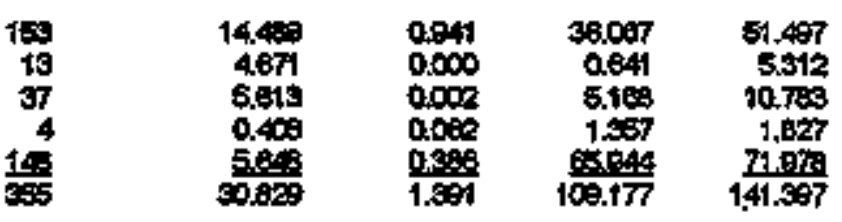

TOTAL PY JOA FUNCTION MAIN GNANCE PGRSONNEL OPERATIONG PERSONNEE HESLTH PHYESCS PEREOMNEL SUPGRVISORY PERSONWEI ENCNNEERTNG PERSONWE-

$\begin{array}{rrrr}93 & 4 & 144 & 219 \\ 14 & 0 & 1 & 1 \\ 40 & 0 & 29 & 74 \\ 0 & 0 & 4 & \\ 10 & 0 & 190 & 152\end{array}$

5.72

acer

2851

Q.018

0.481

0.417

$\begin{array}{lrr}0.000 & 10.778 & 18.504 \\ 0.000 & 0.050 & 0.481 \\ 0.000 & 0.006 & 2.046 \\ 0.000 & 0.000 & 0.018 \\ 0.011 & 0.418 & 0.000 \\ 0.001 & 11.371 & 20,790\end{array}$

0.460

0.06

1.400

0.000

D.019

2027

0.000

0.000

0.000

0,000

0,009

0000

0.259

0.000

0.072

0.00

0.189

0,500

0.70

0.00

1.402

0,000

욜

20

GRANDTOTALS

143

4

311

488
Ex.680

$26.26 \%$
7.671
15.475
0.545
6.791

\section{1,002}

0,000

0.034

0,005

0.416

1.517

$\begin{array}{rr}4.649 & 73.057 \\ 0.04 & 8.603 \\ 7.417 & 22099 \\ 1.584 & 1.964 \\ 0.797 & 70.064\end{array}$

128.191

Works may be courted h more then one category. 
EEAGTOR OPS s SUNV

MANTENANCEPERSONINEI

OPERATIONS PERSONNE

HERLTH PHYSICS PERSONNEL

SLPakVISORY PERSONNEI.

ENG'NEERING PERSONNEL TOTAL

ROUTNEMAINTINANCE

MANTENANCEPERSONNEL

OPERATIONS FERSONTEL

HEALTH PHYYSICS PERSONNE

SUPERVISORY PERBONNIEL

ENGANEEANG PERSONNE. TOTAL

$\begin{array}{cc}32 & 0 \\ 87 & 0 \\ 62 & 4 \\ 10 & 0 \\ 2 & 0 \\ 175 & 4\end{array}$

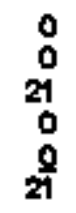

$\begin{array}{rr}179 & 13 \\ 10 & 0 \\ 14 & 1 \\ 25 & 0 \\ 11 & 0 \\ 20 & 14\end{array}$

13
0
1
0
0
14

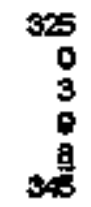

$\begin{array}{rr}4 & 0 \\ 17 & 0 \\ 7 & 3 \\ 0 & 0 \\ 0 & 0 \\ 29 & 3\end{array}$

24
17
2
0
1
67

$\begin{array}{ll}2 & 0 \\ 0 & 0 \\ 1 & 0 \\ 3 & 0 \\ 0 & 0 \\ 33 & 0\end{array}$

0
0
0
0
50

82
0
1
3
3
89

32
67
67
10
18

514
10
19
34
19
19

NCE NSEECTIN

MANTENANCE PERSONhE

HEALTH PHYSTCS PERBONNEI

ENGINERTG PERSONIE

$$
\text { TOTAL }
$$

SPECHAL MANTENANCE.

MANF WNANCE PERSOKNIE

HEALTH PHYSACS PERSONNEL

SUPERVISORY PERSONNEL

$$
\text { TOTAL }
$$

WASTE PROCEE\&NG

MANTERANCE PERBONNEL

OPERATIONS PERSONNEL

HSALTH PHNSICS PERSONNE⿱

SLFERVISORY PERSONNEL

ENGANEENNA PERSONNEI

$$
\text { TOTAL }
$$

REPUEING

MANNTENANTCEPERSONNEL

OPERATIONS PERSONHE.

HEALTH PHVSTCS PERSONNEL

SLFERVISORY PERSONNEL

ENGINEERNE PERSONNE1. TOTAL

$\begin{array}{ll}4 & 0 \\ 1 & 0 \\ 2 & 2 \\ 1 & 0 \\ 0 & 0\end{array}$

$\begin{array}{ll}0 & 0 \\ 0 & 0 \\ 2 & 3 \\ 0 & 0 \\ 0 & 0 \\ 2 & 3\end{array}$

$\begin{array}{lll}0 & 0 & 50 \\ 0 & 0 & 0 \\ 0 & 0 & 0 \\ 1 & 0 & 0 \\ 0 & 0 & \frac{4}{2} \\ 1 & 0 & 72\end{array}$

50
0
0
0
$\frac{4}{72}$

6
0
9
1
4
79

$\begin{array}{rr}457 & 715 \\ 0 & 96 \\ 51 & 147 \\ 9 & 49 \\ 16 & 28\end{array}$

TOTAL BY NOS FLNCTION

MANTENANCEPERSONHE.

OPERATHON'S PERSONtWEI

HEALTH PHYSICS PERSONWE

BUPERVISOAY PERSONNL

ENCINEERING PERSONNEI.

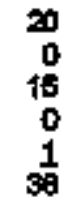

OFERATIONS PERSONNEL

4
1
7
1
0
13

12002
34.640
20.705
4.044
$1.16 \mathrm{~g}$
73.443

112200

3.719

4.221

12.431

scos?

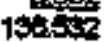

0.77
4328
3088
0.050
0.148

8834

14.507
0.248
0.616
2007
0.048
17.600

0.008

1.3501
0.000
6.735
0.040
0.079
22565

16.290

4,at?

11.854

0.078

0.62

3.200

245
85
86
40
13

19
0
10
0
0

0,000

0.028

$0, \infty$

0,000

otsin

1.52
0.597
1.378
0.500
0.008
3.608

0.000

0.00

0.355

0.000

acpar

0.325

31.405
0.400

oto

1 .

35108

$$
\begin{aligned}
& 0,200 \\
& 0.000 \\
& 1,846 \\
& 0.002 \\
& 0.051 \\
& 1.009
\end{aligned}
$$

48,06

0.248

1.111

2110

\begin{tabular}{|c|c|c|c|}
\hline $\begin{array}{l}0.025 \\
0.56 \\
0.008 \\
0.252 \\
0.100 \\
1.028\end{array}$ & $\begin{array}{l}0.007 \\
0.000 \\
0.013 \\
0.000 \\
0.000 \\
0.050\end{array}$ & $\begin{array}{r}16,507 \\
0,000 \\
2,502 \\
0,071 \\
1,449 \\
20,550\end{array}$ & $\begin{array}{r}1859 \\
0.83 \\
2411 \\
0.523 \\
1.593 \\
21.491\end{array}$ \\
\hline
\end{tabular}

1,6

4.208

1.792

口然

2349.

Dosis

0000

590

141.782
44.648
50658
10.25
5396

3.568
0.00
3.341
0.102

210.097

copo

19.700

505.44

44083

5ser7

$\begin{array}{lll}0.102 & 3.718 & 23.054 \\ 0.144 & 6.200 & 11.713\end{array}$

\section{CRAND TOTALS}

479

20

5

1005

241.100

7.1历

29.715

487.879

\footnotetext{
Workers may bo counted in more than one cetegory.
} 

UTEITY

CONTIACT

TOTAL

MANTEAANCE PEREONNE

OPERATIONS PERSONNEI

HEALTH PHYSTS PERSOMNE.

EUPERVIBORY PERSONWEI

ENGNEERING PEREONWE

$$
\text { TOTAL }
$$

BOITINEMAINTENANGE

MANNTENANCE PERSONNEl

OFEFATIONS PERSONNEA

HEALTH PHVSICS PEREONNEI

SUPERVISORY PERSONNEL.

ENGINEERANO PERSONNEL TOTAE

$\begin{array}{ll}17 & 1 \\ 41 & 0 \\ 18 & 0 \\ 0 & 0 \\ 0 & 0 \\ 76 & 1\end{array}$

$\begin{array}{ll}5 & 2 \\ 0 & \\ 1 & \\ 0 & \\ 0 & \end{array}$

$\begin{array}{rr}23 & 5.324 \\ 41 & 12724 \\ 19 & 3.604 \\ 0 & 0.064 \\ 0 & 0.417 \\ 04 & 21.7152\end{array}$

\subsection{7}

0.403

0.017

0,008

0.008

1,403

1.962

$15 x$

0.06

0.142

oros

420

7.913

14725

4.214

0.173

0.20

27.20

$\begin{array}{rl}11 & 0 \\ 3 & 0 \\ 0 & 0 \\ 0 & 0 \\ 0 & 0 \\ 14 & 0\end{array}$

1
0
0
0
0
1

12

3

0

3.470

0006

0,494

0.001

0.102

5053

0.120

0.00

0,000

0.002

$0,0 x$

0.419

0.350

0.116

0.003

0.00

o.por.

0504

3.858

1.170

1.170

0.003

M-SERMCEINHFEGTION

MANTENANCE PERSONNEL

OPERATIONS PEREONNDL

HEALTH FHYSICS PERSONWE.

BLPERWISORY PERSONNEL.

ENGNEERWV PERSONNNEL TOTAL.

$\begin{array}{ll}0 & 2 \\ 0 & 2 \\ 0 & 0 \\ 0 & 0 \\ 0 & 1 \\ 0 & 5\end{array}$

4

20

nosis

0.108

0.125

$0, \infty$

0.040

Desa

0.544

0.568

0000

0,000

Q65:

1.487

13.097

10,868

otoss

0.293

0.116

2535

nozs

5.

SPFCIALMHANTENANCE

MANTENANCE PEREONNEE

OPERATHONS PERSONAEL.

HEATTH PHYBIGS PERSONNIE

SUPERVISORY PERSOKNEL

ENONEERING PERECNNAL TOTAE

$\begin{array}{rrr}96 & 7 & \\ 27 & 3 & \\ 27 & 0 \\ 134 & 0 & \\ 2 & 12 & 12\end{array}$

50.48\%

7.692

seca

o.04s

03:8

$445 \%$

2180

29.109

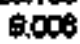

1,370

0.25

0,070

0.017

Q.887

0.189

30.80

14596

11.597

0.19

0

0.511

WABTE PROCEESS!NR

MANTEVARCE PERSONNEL

OPERATIONSPERSONNEL

HEALTH PHYSICS PERSONNE.

SUPERVISORY PERSONNEL

ENG NOER|NG PGRSCNNEI TOTAL.

0
9
0
0
18

0
0
1
0
0
1

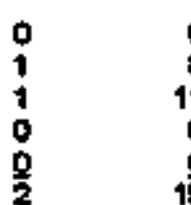

a200

1,

3045

0.000

oms

425

4.077

\section{0,144}

0.008

0.25

0.000

0.1\%9

0.571

\subsection{0}

0.592

0.200

0.000

000

axp

55.759

17.025

7.456

0.209

$\frac{1.78}{8263}$

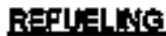

MANTENANEEPERSONNEL

OPERATIONS PERSONNEL

HEALTH PHY

SUPERUISORY PERSONNE.

ENGUNESRINA PERSONWEL TOTAL

$\begin{array}{rrr}2 & 4 & 6 \\ 6 & 1 & \\ 13 & 0 & \\ 0 & 0 & \\ 0 & 0 & \\ 21 & 5 & 12\end{array}$

$\begin{array}{rr}62 & 6 \\ 51 & \\ 0 & \\ 12 & \end{array}$

6
58
28
0
14

1.28

1.495

0.511

0.000

0.009

4.451

0.031

0 ogit

0,089

17.891

14053

9.647

0.137

‥15

0.433

1.051

3500

0.00

0.159

EOSP

TOTAL BY NOS FLMCTKON

MAINTENANCEPERSONINEL

OPERATIONS PERSONNEL

FEALTH PHYALCS PERSONNEL.

SUPERVISORY PERSONNEL

GNGINEERNNG PERSOTNEL

116
76
67
0
2

$\begin{array}{rr}14 & 160 \\ 6 & 109 \\ 5 & \end{array}$

$\begin{array}{rr}160 & 328 \\ 109 & 18 \\ 15 & 7 \\ 3 & \end{array}$

\begin{tabular}{|c|c|c|c|c|}
\hline $\begin{array}{r}323 \\
189 \\
08 \\
9 \\
7\end{array}$ & $\begin{array}{c}40.82 \\
20,3=6 \\
17,715 \\
0,101 \\
0,730\end{array}$ & $\begin{array}{l}5,040 \\
2891 \\
0.569 \\
0.059 \\
1,558\end{array}$ & $\begin{array}{r}57.312 \\
38.953 \\
5.057 \\
0.510 \\
0.45\end{array}$ & $\begin{array}{r}103.153 \\
04270 \\
23091 \\
0.944 \\
2,754\end{array}$ \\
\hline
\end{tabular}

20504

16.902

gos:

0.174

axs

35.604000
GRAND TOTALS

25

Watkers may be counled in mere than one oategory. 
REACTOR OPS\& SURV MAINTENANACE PERSONNEL OPERATIONS PERSONNEI HEALTH PHYACS PERSONNEL SUFERVISORY PERSONNEL ENGANEERING PERSONANEL TOTAL

\section{ROITLNE MAINTENANCE}

MAINTENANCE PERSONNTL OPERATIONS PERSONNE HEALTH PIYEICS PERSONNEL SSUFERVISORY PERBONNEL ENGNEERANG PERSONNEL TOTAL

IN-SERVICE LISPEGTION MAINTE NANCE PERSONANEL OPERATIONS PERSONNEL HEALTH PHYSICS PERSONNEI SLPERVISORY PERSONAEL ENGINEENNNG PERSONNEI TOTAL.

$\begin{array}{rrr}48 & 41 & 100 \\ 73 & 0 & 3 \\ 25 & 3 & 94 \\ 12 & 11 & 11 \\ 17 & 7 & 21 \\ 17 & 6 & 25\end{array}$

100
3
94
11
21
20.9

$\begin{array}{rrr}74 & 110 & 138 \\ 7 & 0 & 2 \\ 3 & 0 & 5 \\ 3 & 2 & 7 \\ 8 & 4 & 12 \\ 8 & 110 & 184\end{array}$

$\begin{array}{rrr}10 & 27 & 40 \\ 4 & 0 & 1 \\ 4 & 0 & 16 \\ 2 & 3 & 0 \\ 9 & 1 & 5 \\ 2 & 31 & 69\end{array}$

SPPECLAL MANTENANCE MAINTENANCEPERSONNEL. OFERATIONS PEREONNEZ HEALTH PHIYSICS PERSONWEL SUPERWISORY PERSONNZL. ENCINEEFANG PERSONNEL TOTAL

$\begin{array}{rr}63 & 181 \\ 28 & 0 \\ 25 & 0 \\ 6 & 11 \\ 19 & 10 \\ 101 & 207\end{array}$

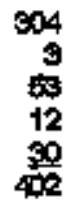

$\begin{array}{rrr}20 & 20 & 108 \\ 3 & 0 & 0 \\ 18 & 0 & 25 \\ 4 & 0 & 5 \\ 1 & 5 & 7\end{array}$

WASTEEROCESSNG

MAINTENANCE PERSORWE OPERATHNS PER'ONNEI

HEALTH FHYSICS PERSONNEL SUPERVISORY PERSONMEL ENGNNEERNG PERSONNEL TOTAL

\section{BEFUEINA}

MAINTENANCE PERBONNAE OPERATIONS PERSONNEL HEALTH PHYSAGS PERSONNE. SUPERVISORY PERSONWVE

ENSWEERRNG FERSONNEL TOTAL

\section{TOTAR BY IOB EUNCTION}

MANTENANCE PERSONNA OPERATTONS PERSONNEI HEALTH PHTYSKS PERSOMNEL SUPERVISORY PURSONNEI ENCINEERNG PERSONAE

$\begin{array}{rrr}03 & 80 & 30 \\ 10 & 0 & 3 \\ 7 & 0 & 50 \\ 11 & 7 & 14 \\ 17 & 7 & 29 \\ 108 & 04 & 412\end{array}$

302

125 (74) व (0) 12

32 (15) 34 (12)

72 (26) 32 (13) 104
$105 \quad 210$

3

43

7

$\frac{14}{274}$

4 it

13

37

하

배뇨

412

187
76
128
34
4
484

1.935

23,190

日.485

1.540

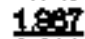

400

32
6
12
370
370

5.733

0,004

0.107

0,00

n.438

83
5
20
15
153

coson

0.130

0017

0.162

an:

1.57

563
31
78
29
59
753

15.141
0.819
1.749
0.494
4.184
2.350

74.432

0,000

0,000

4,015

4.473

82का
2470

0.014

1.040

0348

o.0y

3.975

2004

1.918

0343

s.8ed

노116

12007
3.032

0.000

0,000

0.000

0007

3.00

7 aye

0.000

0.000

1.30

D.554

1007

80.251

0.000

1.388

7.297

6.088

$\begin{array}{rr}3.042 & 7,159 \\ 0.271 & 29.481 \\ 50.564 & 60.37 \\ 1.169 & 4.651 \\ 0.890 & 3.565 \\ 5.878 & 104.012\end{array}$

1517

멱

0.040

0094

n.19

1899

1교

0.141

0283

0.000

thas:

2 eas

10250

1.275

8845

1.875

BAg?

121.110

$0.2 \times 3$

0.109

0.147

0.107

$\frac{0.728}{10.321}$

2.617

0.271

0.340

0.180

$\frac{10 \mathrm{OP}}{4.491}$

195.

2001

10.58

6,580

16504

220300

$\begin{array}{rr}44015 & 50.117 \\ 0.000 & 0.014 \\ 5.503 & 0.573 \\ 0.398 & 0.754 \\ 0.017 & 0.875 \\ 00.701 & 58.283\end{array}$

149.122

$0.5 \times 2$

1.500

32as

Ge00

10. 000

159002

2511

2.148

B.14

11,879

1874

(4) 137 178

(17) 119 (44)

(43) 206
$27 x$

11.72

6.155

11.300
$301.825 \quad 416001$

$67.065 \quad 80.172$

B.007 20.200

$15 \mathrm{EO} \quad 32371$
$2001 \quad 32,454$

GRAND TOTALS

시 (2x)

(674) 2624 (1121)

83.314

104,852

393.941

507,207

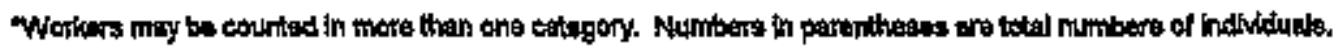




\begin{tabular}{|c|c|c|c|c|c|c|c|c|c|}
\hline \multirow{2}{*}{$\begin{array}{l}\text { WORKAND } \\
\text { JOA FUNCTION }\end{array}$} & \multicolumn{5}{|c|}{ 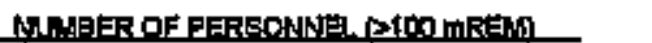 } & \multicolumn{3}{|c|}{ TOTAE PESGgNLREY } & \multirow[b]{2}{*}{ TOTAL } \\
\hline & STATION & UTLTY & & CONTRACT & TÓTAL & BTATHON & UTस्पY & CONTRAGT & \\
\hline 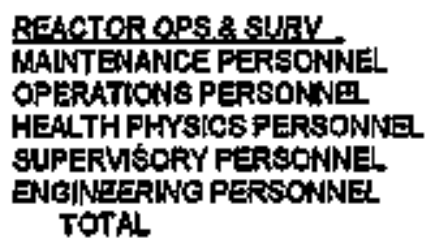 & $\begin{array}{r}17 \\
37 \\
19 \\
6 \\
4 \\
82\end{array}$ & & $\begin{array}{l}0 \\
0 \\
0 \\
0 \\
1 \\
1\end{array}$ & $\begin{array}{r}30 \\
5 \\
7 \\
0 \\
1 \\
43\end{array}$ & $\begin{array}{r}47 \\
42 \\
20 \\
5 \\
6 \\
120\end{array}$ & $\begin{array}{l}2.570 \\
8,400 \\
5.400 \\
0,770 \\
0.000 \\
18,000\end{array}$ & $\begin{array}{l}0,000 \\
0000 \\
0000 \\
0.000 \\
0.110 \\
01100\end{array}$ & $\begin{array}{l}5.170 \\
0.060 \\
0.960 \\
0.000 \\
0.100 \\
7.110\end{array}$ & $\begin{array}{l}7.740 \\
7.200 \\
6.400 \\
0.700 \\
1.010 \\
20.240\end{array}$ \\
\hline 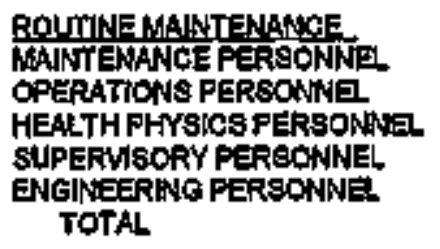 & $\begin{array}{l}0 \\
0 \\
0 \\
0 \\
0 \\
0\end{array}$ & & $\begin{array}{l}0 \\
0 \\
0 \\
0 \\
0 \\
0 \\
0\end{array}$ & $\begin{array}{l}0 \\
0 \\
0 \\
0 \\
0 \\
0\end{array}$ & $\begin{array}{l}0 \\
0 \\
0 \\
0 \\
0 \\
0\end{array}$ & $\begin{array}{l}0, \infty \infty \\
0, \infty 00 \\
0,000 \\
0, \infty \infty \\
0,00 \\
0, \infty 00\end{array}$ & $\begin{array}{l}0.000 \\
0.000 \\
0.000 \\
0,000 \\
0.000 \\
0.000\end{array}$ & $\begin{array}{l}0,000 \\
0,000 \\
0,000 \\
0,000 \\
0,000 \\
0,000\end{array}$ & $\begin{array}{l}0,000 \\
0,000 \\
0,000 \\
0,000 \\
0,000 \\
0,000\end{array}$ \\
\hline 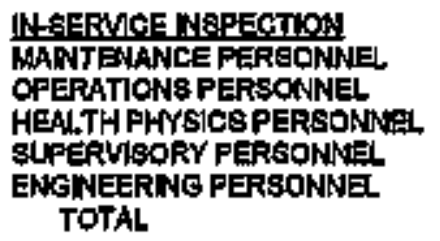 & $\begin{array}{l}0 \\
0 \\
0 \\
0 \\
0 \\
0\end{array}$ & & $\begin{array}{l}0 \\
0 \\
0 \\
0 \\
0 \\
0 \\
0\end{array}$ & $\begin{array}{l}0 \\
0 \\
0 \\
0 \\
0 \\
0\end{array}$ & $\begin{array}{l}0 \\
0 \\
0 \\
0 \\
0 \\
0 \\
0\end{array}$ & $\begin{array}{l}0,000 \\
0,000 \\
0,000 \\
0,000 \\
0,000 \\
0,000\end{array}$ & $\begin{array}{l}0.000 \\
0.000 \\
0,000 \\
0.000 \\
0.000 \\
0.000\end{array}$ & $\begin{array}{l}0,000 \\
0,000 \\
0,000 \\
0,000 \\
0,000 \\
0,000\end{array}$ & $\begin{array}{l}0.000 \\
0.000 \\
0,000 \\
0.000 \\
0.000 \\
0.000\end{array}$ \\
\hline 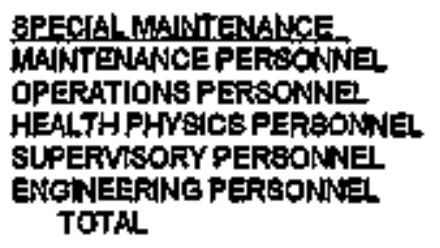 & $\begin{array}{r}23 \\
0 \\
0 \\
4 \\
1 \\
28\end{array}$ & & $\begin{array}{l}0 \\
0 \\
0 \\
0 \\
0 \\
0\end{array}$ & $\begin{array}{r}6 \\
4 \\
0 \\
0 \\
0 \\
72\end{array}$ & $\begin{array}{r}91 \\
4 \\
0 \\
4 \\
1 \\
100\end{array}$ & $\begin{array}{l}\mathbf{5 . 1 1 0} \\
0.000 \\
0.000 \\
0.610 \\
0.109 \\
\mathbf{5 . 0 2 0}\end{array}$ & $\begin{array}{l}0.000 \\
0,000 \\
0.000 \\
0.000 \\
0.000 \\
0.000\end{array}$ & $\begin{array}{r}123 \pi \\
0,800 \\
0.000 \\
0.000 \\
0.000 \\
13.170\end{array}$ & $\begin{array}{r}17.480 \\
0.800 \\
0.000 \\
0.910 \\
0.100 \\
19.000\end{array}$ \\
\hline 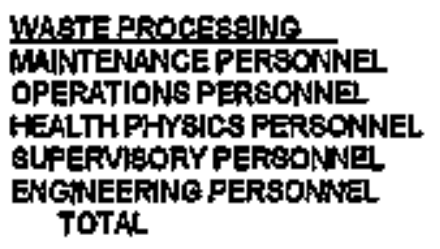 & $\begin{array}{l}0 \\
1 \\
0 \\
0 \\
0 \\
1\end{array}$ & & $\begin{array}{l}0 \\
0 \\
0 \\
0 \\
0 \\
0\end{array}$ & $\begin{array}{l}0 \\
0 \\
0 \\
0 \\
0 \\
0\end{array}$ & $\begin{array}{l}0 \\
1 \\
0 \\
0 \\
0 \\
1\end{array}$ & $\begin{array}{l}0.000 \\
0.110 \\
0.000 \\
0.000 \\
0.000 \\
0.110\end{array}$ & $\begin{array}{l}0,000 \\
0,000 \\
0,000 \\
0,000 \\
0,000 \\
0,000\end{array}$ & $\begin{array}{l}0,000 \\
0,000 \\
0.000 \\
0,000 \\
0,000 \\
0.00\end{array}$ & $\begin{array}{l}0,000 \\
0.110 \\
0,000 \\
0,000 \\
0.000 \\
0.1110\end{array}$ \\
\hline 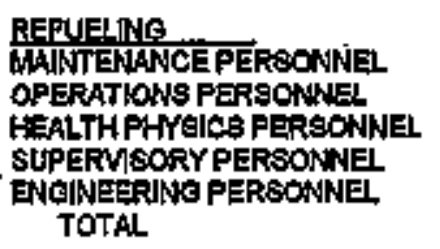 & $\begin{array}{l}0 \\
0 \\
0 \\
0 \\
0 \\
0\end{array}$ & & $\begin{array}{l}0 \\
0 \\
0 \\
0 \\
0 \\
0\end{array}$ & $\begin{array}{l}0 \\
0 \\
0 \\
0 \\
0 \\
0\end{array}$ & $\begin{array}{l}0 \\
0 \\
0 \\
0 \\
0 \\
0\end{array}$ & $\begin{array}{l}0.000 \\
0.000 \\
0.000 \\
0.000 \\
0.000 \\
0,000\end{array}$ & $\begin{array}{l}0,000 \\
0.000 \\
0.000 \\
0,000 \\
0.000 \\
0,000\end{array}$ & $\begin{array}{l}0.000 \\
0.000 \\
0.00 \\
0.000 \\
0.000 \\
0.000\end{array}$ & $\begin{array}{l}0.000 \\
0.000 \\
0.000 \\
0.000 \\
0.000 \\
0.000\end{array}$ \\
\hline 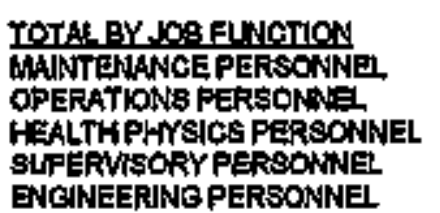 & $\begin{array}{r}40 \\
3 \\
16 \\
6 \\
6\end{array}$ & & $\begin{array}{l}0 \\
0 \\
0 \\
0 \\
1\end{array}$ & $\begin{array}{l}88 \\
0 \\
7 \\
0 \\
1\end{array}$ & $\begin{array}{r}139 \\
47 \\
29 \\
9 \\
7\end{array}$ & $\begin{array}{l}7.400 \\
6.540 \\
5.4 \% 0 \\
1.380 \\
0 \% 00\end{array}$ & $\begin{array}{l}0,000 \\
0.000 \\
0,000 \\
0,000 \\
0.110\end{array}$ & $\begin{array}{r}17.500 \\
1.6 \infty \\
0.800 \\
0.000 \\
0.100\end{array}$ & $\begin{array}{r}25,200 \\
8.200 \\
6,400 \\
1.300 \\
1.110\end{array}$ \\
\hline GRAND TOTALS & 111 & & 1 & 115 & 227 & 21.480 & 0.110 & 20200 & 42340 \\
\hline
\end{tabular}

Worlers may be cotnted a more than onta cedegry. 
APPENDIX D (Continued)

NUMBER OF PERSONHEL AND PERSONAREM

BY WORK AND JOB FUNCTION

1996

PLANT: KEWAUNEE

TYPE: PWR

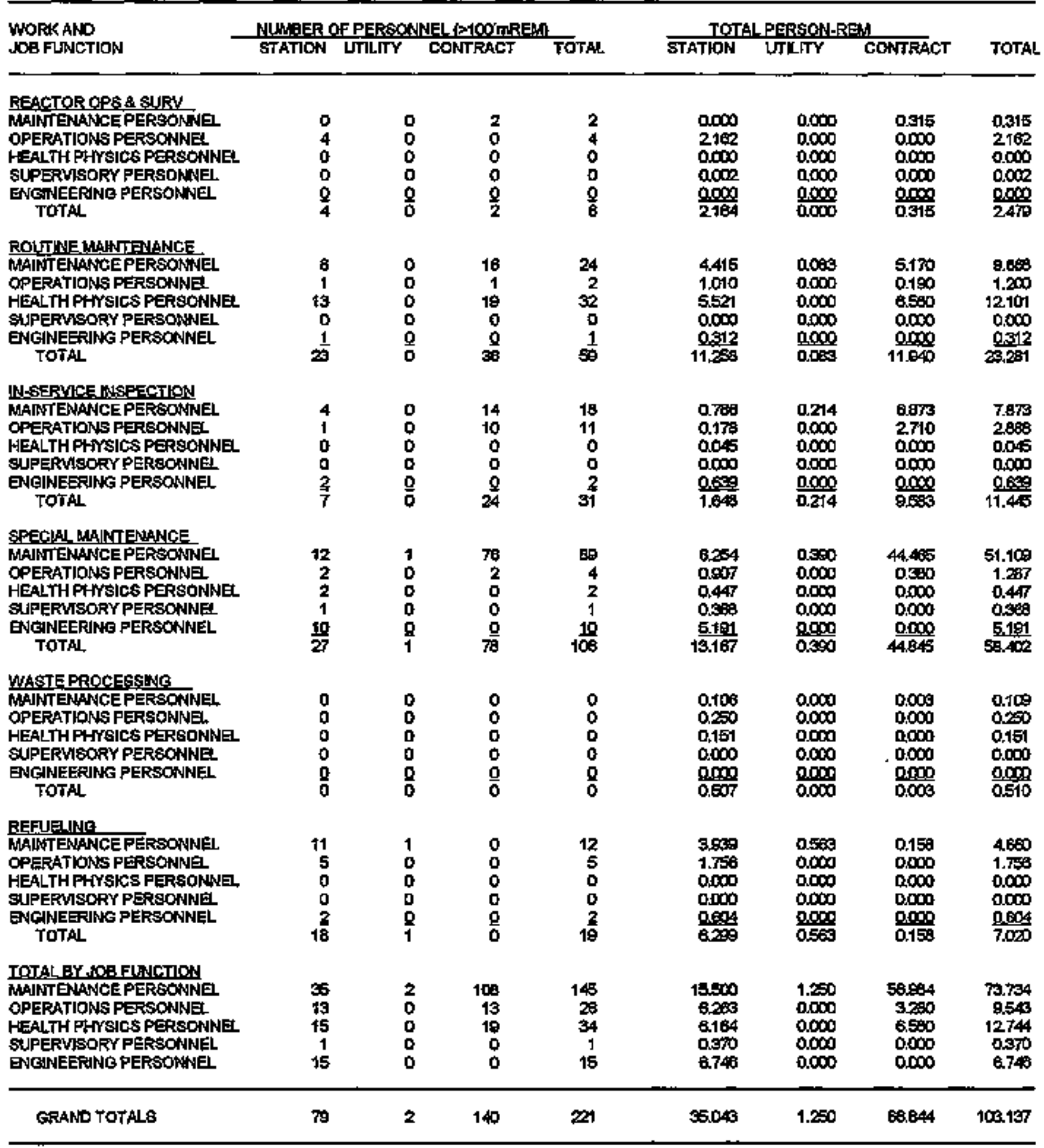

Workors moy be cournted in more than ond cotegory. 
1695

PLANT:

*LASALLE 1,2

TYPE:

BWR

WORK AND

IOA FUYCTLON

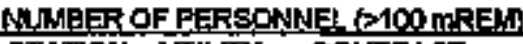

STATION UTILITY CONTRACT TOTAL.
TOTALPERSON-RET:

STATKN UTILITY CONTRACT TOTAL
BEACTOR OPS \& SURV

MANTEVANCE PERSONNEL

OPERATIONS PERBONNEL

HEALTH PHYYSKS PERSONNEI

SUPERVISORY PERSONNEL

ENGINEEANNQ PERSONNNEL

TOTAL

ROUTINE MAINTIENANCE

MANTENANCE PERSONNEL

OPERATIONS PERSONNEL

HEALTH PYYYSICS PERSONWE

SUPERVISORY PERSONNA

ENCUNEERRIS PERSONNEL

TOTAL

$\begin{array}{rr}34 & 1 \\ 132 & 0 \\ 43 & 123 \\ 100 & 0 \\ 73 & 0 \\ 34 & 124\end{array}$

18
115
7
64
5
259

53
247
173
164
81
718

18002

34.419

17.000

B.818

B.275

62534

$\begin{array}{rr}209 & 22 \\ 19 & 0 \\ 38 & 149 \\ 147 & 0 \\ 57 & 9 \\ 488 & 160\end{array}$

$\begin{array}{rr}040 & 097 \\ 0 & 19 \\ 29 & 211 \\ 0 \% & 216 \\ 01 & 148 \\ 010 & 1491\end{array}$

108.542
4.718
14.754
10.453
8.053
14.650

240
0
250
304
344

\section{oos4}

0042

0.268

D.365

요용

1,670

43
0
2
10
4
50

1.023

0.121

0.450

0257

Q.475

2029

HEALTH FHYSICS PERSOMNE

SUPERVISORY PERsONNa.

ENGINEERNG PERSONNEL TOTAL

REFUEATHG

MANTENANCE PERSONNE.

OPERATIONS PERSONNEI.

HEALTH PHY'A]CS PERSONNAE

SUPERVISORY PERSDHNEL

ENONEERLNG PERGONNEL TOTAL

TOHAL_AY_JOB_FUNCTION

MAINTENANCE PERSONNEL

OPERATIONS PERSONWEL

HEALTH PHYSICS PERSONNEL

SUPERVISORY PERSONNEL

ENGHEERING PERSONNEL
13

10

3

4

1

2

$\frac{0}{7}$

a

4

$\stackrel{0}{45}$

$\begin{array}{rr}0 & 42 \\ 0 & 0 \\ 10 & 2 \\ 0 & 3 \\ 0 & 57 \\ 13 & 104\end{array}$

$\begin{array}{rr}42 & 45 \\ 0 & 7 \\ 2 & 19 \\ 3 & 21 \\ 57 & 58 \\ 104 & 150\end{array}$

1267

0.000

oseo

o.115

0.028

2146

1.241

1.872

1.591

1,214

$\frac{0,110}{6,03}$

0.000

0.000

0.114

0.000

0.000

o.t4

129.148

41,162

$33 \mathrm{BS8}$

18.945

15.827

\begin{tabular}{|c|c|c|}
\hline $\begin{array}{l}1.270 \\
0.000 \\
2.596 \\
0.000 \\
0.000\end{array}$ & $\begin{array}{r}189.696 \\
7277 \\
14349 \\
4394 \\
83.872\end{array}$ & $\begin{array}{r}319.105 \\
49.625 \\
50,629 \\
20.337 \\
60.600\end{array}$ \\
\hline
\end{tabular}

GRAND TOTALS

sto

$3 t 5$

1504

2018

238557

3.85

209577

Sit.3e0

Workere may be counted th more than ane axtigoryt 


305
224
43
10
$\frac{101}{713}$

REACTOR QPSB SURV MANTENANCE PERSONNE OPERATIONS PERSONNEL HEALTT PHYSCS PERSONNEL SLFERVISORY PERRONNEI. ENCANEERINGPERSONNEL TOTAL

ROUTINE MALTENANCE MAINTENANCEPERSONWII OPERATIONS PER6ONNEL. HEALTH PHYYISS PEROONNEL SUPERMSORY PERSONWNEL ENCINEERING PERSONNEL TOTAL

H.SER VHEE INSPECTION MAIKT ENANCE PERSONNNEI. OPERATIONS PERSONNEL HEALTH P'HYSICS PERSONNE. SUPERVSORY PERSONNEL ENGNEERINS PERSONNELL TOTAL

SPECIALMAINTENANCE MANT ENANCE FERSONNEE. OPERATWNS PERSONNEL HEALTH PHYBWCS PERSONNEI. SUPERVISORY PERSONNEL GNONEERING PERSONNG TOTAL

139
101
30
39
310

$\begin{array}{rr}81 & 287 \\ 15 & 317 \\ 2 & 1 \\ 0 & \\ 118 & \\ 110 & 34\end{array}$

$\begin{array}{rr}287 & 507 \\ 31 & 147 \\ 17 & 49 \\ 6 & 8 \\ 5 & \frac{61}{77} \\ 346 & 772\end{array}$

262

100

1

2

$0 \quad 0$

$\frac{\mathbf{n}}{2}$

用

12

11

100

WASTE PROCESSSWC

MANTENANCE PERSONWE OPERATIONSPERSONNEL

HEALTH FHY IICS PERSONNEL.

SLPERVISORY PERSOKME

ENGNEERING PERSONWVZ TOTAL

76
2
1
0
4
6

70
29
16
0
0
113

$\begin{array}{rr}49 & 78 \\ 29 & 4 \\ 18 & 1 \\ 1 & 0 \\ 10 & 1 \\ 107 & 69\end{array}$

$\begin{array}{rr}75 & 39 \\ 4 & 31 \\ 1 & 14 \\ 0 & 0 \\ 1 & 0 \\ 64 & 8\end{array}$

$\begin{array}{rr}39 & 165 \\ 31 & 04 \\ 14 & 39 \\ 0 & 1 \\ 0 & \frac{11}{5}\end{array}$

MANTENANCE PERSONHEL OPERATIONS PERSONNEL

HEALTH PHYSICS PERSONNEL

SUPERVISORY PERSONAVI

ENGNEERING PERSONWVZ TOTAL

TOTAL BY JOB FUNGTION

MANTE NANCE PERSONNEL OPERATIONSPERSONNEI HEALTH FHYSICS PERSONNEI. SUPERVISORY PERSOHWe ENGNEERTG PERSDNNE.
18

18
11
14
2
$\frac{6}{49}$

$\begin{array}{rr}\infty & 67 \\ 6 & 4 \\ 1 & 10 \\ 0 & \\ 1 & \end{array}$

$\operatorname{tas}$

378

125

184 (foo) (294)

(48) 9 (日) 88 (4) 232 (101)

(蛇 $3<17$

(15) 100 (195)

24 (75) 40 (110) $\frac{1}{64}$

64

1

2

1

205

42

4

13

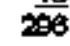

20.908
15.468
7.009
0.278
5.508
3.208

7.537
3.978
1.591
0.026
0.945
13.947

0.000

0,0

0.010

0.000

$0, \infty$

0.045

4529

oseo

0.914

o.co1

Q:xOs

8,310

$\begin{array}{rr}179 & 0.250 \\ 5 & 0.158 \\ 25 & 0.538 \\ 3 & 0.027 \\ 15 & 0.040 \\ 270 & 0.008\end{array}$

8.202

$1, \overline{3}$

D.969

0.001

0.519

0.416

41 (119) sot (4\%)
47,488
21,845
11,357
0.364
7,390
11.579

1.612

0.744

0,018

1015

15.868

3.612

0.211

0.008

0,000

0.782

4.098

0.17

0,000

0.000

a.000

0,00

0.177

\subsection{9}

0,088

0.027

0.000

0.100

6.004

1.250

0.160

0.050

0,000

요우

220

47.037

89ta

4.374

0.240

0.1858

02202

47.482

0,07

0.779

0005

오?

4 4.51

1380

0.000

0.110

000

and

13.974

3.484

O.810

0.628

0.000

0,000

S.002

0.192

O.836

0.397

a,oon

0,000

1387
6391

0.024

0.080

0.00

0.075

6.510

1.376

1.770

0.532

Do01

D.077.

3.705

28,844

2008

0.972

0.018

3.60 $\begin{array}{rr}141,337 & 169,697 \\ 14.446 & 39.299 \\ 0.790 & 19.489 \\ 0.209 & 0.651\end{array}$

0.7011 .44

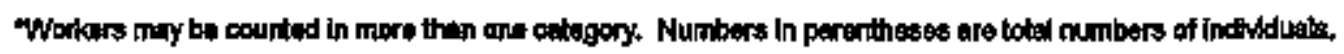


1996

REACTOR OPS R RURVI.

MANTENANCE PERBONNAEL

OPERATIONS PERSONNE

HEALTHPHYSHCS PURSONNIEL

SUPERMSORY PERSONNEI

ENGNNEERNG PERSONNEL TOTAL.

ROUTREMAINTINANCE

MANTENANCE PEREONNEL

OPERATIONS PERSONWE.

HEALTH PHYSKCS PERSONNEL

SUPERUISORY PERSONNEL

ENIENNEEERINO PERSONNEL TOTAL

5
43
2
1
4
10

$\begin{array}{rr}0 & 8 \\ 0 & 18 \\ 0 & 120 \\ 0 & 2 \\ 0 & 1 \\ 0 & 149\end{array}$

13
61
142
5
5
224

1.600
18.057
13.379
0.458
2.79
30104

0.00
$0, \infty$
0,00
$0,0 \infty$
0.00
0,00

4.07
10.084
69.780
0.800
4.850
0.670

248
59
60
40
504

3.602

10008

6.300

4.710

g, (1)

6.747

$$
\text { . }
$$

\section{ILSERMCE RSSPECTKN}

MALNTENANCE PERSOWNIEL

OPERATIONS PERSONWEL

HEALTH FHYSICS PERSONNEL

sUPERVISORY PERECNNJL

ENGINEERNG FERSONNE TOTAL

\section{SPECIAL MAINTENANCE}

MANT ENANCE PURSDNNE

OPERATICNS PERSONNEL

HEALTH PHVEICE PERSONNEL

SUPERVBOFY PERBONHEL

EMG NEERANG PERSONNiG TOTAL

$\begin{array}{lll}0 & 0 & 2 \\ 0 & 0 & 0 \\ 0 & 0 & \\ 0 & 0 & 10 \\ 2 & 0 & 2\end{array}$

21
0
6
10
$\frac{30}{67}$

0.005

0.00

0,000

a.oes

0.55

0.75

0,oo

0,000

$\mathbf{0} \infty \mathbf{0}$

atom

pogo

6,

$\begin{array}{r}52377 \\ 0.58 \\ 28.576 \\ 16.940 \\ 174.920 \\ \hline 57.450\end{array}$

\begin{tabular}{|c|c|}
\hline $\begin{array}{l}0.000 \\
0.000 \\
0,000 \\
0.000 \\
0.000 \\
0.000\end{array}$ & $\begin{array}{r}11.005 \\
0.005 \\
3.700 \\
8.600 \\
12137 \\
3.657\end{array}$ \\
\hline
\end{tabular}

$\begin{array}{rrr}0 & 0 & 24 \\ 0 & 0 & 4 \\ 1 & 0 & 3 \\ 0 & 0 & 3 \\ 3 & 0 & 89 \\ 10 & 0 & 130\end{array}$

85
4
4
107
109

2.006

0.00

$0.2 \times 5$

0,556

1.529

5.404

0.000

0.000

0.000

ato

900

ond

\begin{tabular}{rr}
8.170 & 10.770 \\
0.702 & 1.392 \\
1.439 & 1.673 \\
1.815 & 2.370 \\
8.487 & e..75 \\
\hline 74.52 & 79.950
\end{tabular}

WABTE PROCgEgsiNR WNNTENANGE PERBONNE OPERATIONS PERSONNEI HEALTHPHYSICS PERSONNEL SUTPERVISORY PERSONWEL ENGNEERING PERSONNEL TOTAL.

$\begin{array}{ll}2 & 0 \\ 2 & 0 \\ 3 & 0 \\ 2 & 0 \\ 0 & 0\end{array}$

REFU EING

MANTTEHANCE PERSONNIEL OPERATIONS FEREONNIEFEALTH PHYYICS PERSONNEL BUPEFMSORY PERSONNEL ENENNEBRNNO PERSONNALL TOTAL

$\begin{array}{lll}\infty & 0 & 11 \\ 20 & 0 & \\ 6 & 0 & 5 \\ 5 & 0 & 17 \\ 7 & 0 & 211\end{array}$

TOTAL BYLOBELNCTION MNNTENANCE PERSONNEL OPERATIONS PERSONWE. HEALTHPHY'SICS PERSONNEE SUPERUSOORY PERSONNEL'

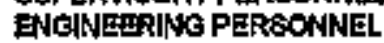

\begin{tabular}{|c|c|c|c|c|c|c|c|}
\hline $\begin{array}{l}80 \\
80 \\
40 \\
22 \\
32\end{array}$ & $\begin{array}{l}0 \\
0 \\
0 \\
0 \\
0\end{array}$ & $\begin{array}{r}\cos \\
43 \\
211 \\
02\end{array}$ & $\begin{array}{r}458 \\
133 \\
257 \\
84 \\
387\end{array}$ & $\begin{array}{r}53.76 a \\
3.542 \\
2208 \\
9.444 \\
14.468\end{array}$ & $\begin{array}{l}0,000 \\
0,000 \\
0,000 \\
0,000 \\
0,000\end{array}$ & $\begin{array}{r}158.000 \\
28.071 \\
118.804 \\
38.200 \\
274.501\end{array}$ & $\begin{array}{r}211.865 \\
67,213 \\
141.102 \\
45.500 \\
280.769\end{array}$ \\
\hline 27 & 0 & 1040 & $1319^{\circ}$ & 138.901 & 0,000 & E18.108 & 754.490 \\
\hline
\end{tabular}

Workers may ba counted in mare then one category. 
REAGTOR OPS \& SURV MANTENANCE PERSONDEE OPERATIONS PERSONNEI HEALJHPHYEICS PEREONNEI SLFERVISORY PERSONWNEI ENCINEERING PEREONNEL TOTAL

ROSTINE MAINTENANAE MAINTENANACEPERSONNEL OPERATIONS PERSONNEL HEALTH PHYSICS PGRSONNEL EUIPERVISORYPERSONNEL ENGINEERING PERSONNEL TOTAL

tes

0

$\mathbf{0}$

部

$\begin{array}{rr}108 & 20 \\ 23 & \\ 18 & \\ 1 & \\ 105 & \end{array}$

IN-SERACE MSEECTION MANTENANCE PEREONNE OPERATIONS PERSONWEI HEALTH PHYBICS PERSONWEL SUPERVISORY PERSONNEL ENGINEERING PERSONNE1 TOTAL

SPFECAAM MaINTENANGE MAINTENANCZ PERSONDVI OPERATICNSPERSONNEI HEALTH PHYSTCS PERSONNEL SLPERVISORY PERSONWEL ENGNEEFING PERSONWEL TOTAL

\section{WASTE PROCESSING}

MAINTENANQE PERSOTNEL OPEKATIONS PERSONNE. HEALTH PHYSICS PERSONNEL SUPERVEOORY PERSONNEL DNGINFEFING PERSONNNEL TOTAL

\section{REEUEANTE}

MAINTENANGEPERSONNEL OPERATIONS PERSONNE HEALTH PHYSICS PERSONNER SUPERMSORY PERSONNEL ENIEINEERING PERSONNEL TOTAL.

TOTAL BY IOB FUNKTION MANTENANCE PERSONHEZ OPERATIONS PERSONNEL HEALTH PHYETCS PERSONNEL SUPERVISORYPERSONNE: ENEINESRNG PEREONNEI

$\begin{array}{ll}45 & \\ 0 & \\ 3 & \\ 0 & \\ 0 & \\ 4 & \end{array}$

$\begin{array}{rr}44 & 29 \\ 2 & 0 \\ 9 & 9 \\ 0 & 0 \\ 1 & 0 \\ 53 & 23\end{array}$

$\begin{array}{rr}103 & \\ 25 & \\ 18 & \\ 1 & \\ 18 & \end{array}$

$\begin{array}{rr}17 & 0 \\ 0 & 0 \\ 0 & 4 \\ 0 & 0 \\ 0 & 0 \\ 17 & 12\end{array}$

$$
\begin{array}{r}
0 \\
4 \\
4 \\
0 \\
0 \\
17
\end{array}
$$

$\begin{array}{rr}62 & 371 \\ 16 & 42 \\ 10 & 37 \\ 0 & 1 \\ 0 & 8 \\ 07 & 48\end{array}$

309
67
3
6
6

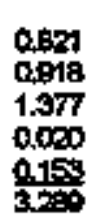

1,000
0,000
0,000
0,000
0,057
1.148

2.68

acto

2544

0.000

0.718

$\mathbf{5 0 . 4 4 5}$

44280

0,000

0.00

0,000

0,370

44.50

0.817

0.000

0.014

0,000

nomp

D.651

$0.7 \%$

0.000

0.000

0,000

now.

0.76

1.010
0.044
0.316
0.000
0.000
1.375

0.586

0.000

0.000

0.000

poge

Doss

0,000

0.000

and

0,000

noper

apon

0,000

0.000

D.00

0.000

o.000

0,000

$\begin{array}{ll}0.00 & 0.010 \\ 0.000 & 0.000 \\ 0,00 & 0.000 \\ 0.00 & 0.000 \\ 0.00 & 0.000 \\ 0.000 & 0.010\end{array}$

0.010

0.60

0.010

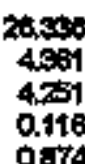

49,420

0.000

0,000

0,000

0.427

0,000

0,50

0.453

0.000

000

$0 \mathrm{ar}$

1, pos

$1.27 \mathrm{f}$

1800

0.020

ontin

B.577

1435

2887

2470

0.000

0.00

19,022

82279

6.280

406

0.000

1068

9469

0,300

0.000

0.009

0,000

a.cos

0.499

1.94

0,000

0.043

0,000

p.gog

1 tes

1.179

2524

cotos

0.044

0.000

$\mathrm{no00}$

1.251

0.113

0.390

0000

0009

3000

a,on

0.174

0,00

0.000

o.con

0.174

0.000

0.174

ODo

0.000

Doto

0.174

$0+\infty$

0,000

o.so

0,000

$0,000 \quad 0,000$

n.000 $\quad 0,000$

$0.000 \quad 0.010$

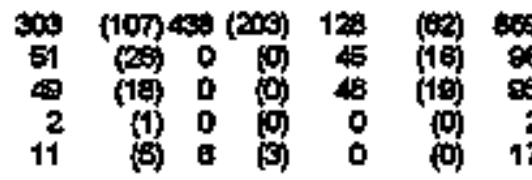

15868

3.403

2049

0.00

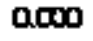

88.701

7.844

7.200

0.516

1.501 EFAND TOTALS

$410 \quad(157) 444(200) \quad 218$

(87) 1078

(4) 35,408

40.650

22300

105.102

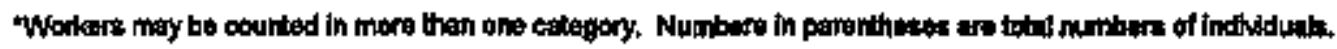


APPENDX D (Continued)

MUMBER OF PERSOHNEL AND PERSON-REM

BY WORK AND JOB FUNCTION

1995

PLANT: MILLSTONE PONN 1

TYFE: BWR

WORK AND

JOB FUNCTION
NUR, BER GF PEREONH

STATKN UTIUY CONTRACT TOTAL
TOTAL PERSON-REM

STATION UTILITY CONTRACT TOTAL
REACTOR OPS \& 원

MANTENANCE PERSONWNEL

OPERATIONIS PERSONNEL

HEALTH PHYSICS PERSONNEL

SUPERVEORY PERSONNEL

ENOINIEERANG PERSONWEL TOTAL

\section{ROUTHEMANTENANCE}

MANTIENAWCEFERSOTNNEL

OPERATIONAS PERSONNEI

HEALTH PHYSICS PERSONNEL

SLPERVISORY PERSONNEL

ENGANEERING PERSONNEI TOTAL

$\begin{array}{rrr}50 & 24 & 58 \\ 60 & 1 & 20 \\ 47 & 5 & 5 \\ 1 & 0 & 0 \\ 13 & 10 & 15 \\ 171 & \frac{10}{40} & 270\end{array}$

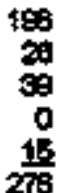

272
87
01
1
489

2140

11 ots

4.179

0.121

0.24

17.7:7

$\begin{array}{rrr}108 & 68 & 52 \\ 16 & 1 & 0 \\ 23 & 3 & 20 \\ 3 & 0 & 6 \\ 118 & 20 & 50\end{array}$

64
23
40
9
98
040

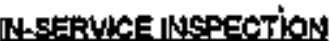

MANTENANCE FERSONNEL

OPERATIONS PERSOMNEI

HEALTH PHYSTCS PERBONAEL

SHPEFVISORY PERSONNFE.

ENNGNEERING PERSONNEL TOTAL.

\section{epgCIAL ManTENANCE}

MANTTENANCE PURSONWZL

OPERATIONS PERSONNEL,

HEALTH PHYSICE PERSON

ELPERVSORY PERSONNE

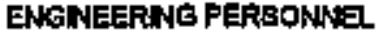
TOTAL

$\begin{array}{ll}0 & 0 \\ 0 & 0 \\ 2 & 0 \\ 0 & 0 \\ 1 & 1\end{array}$

$\begin{array}{ll}0 & 5 \\ 0 & 0 \\ 0 & 0 \\ 0 & 0 \\ 1 & 4 \\ 1 & 5\end{array}$

5
0
2
0
6
13

$\begin{array}{rr}86 & 6 \\ 37 & \\ 42 & 19 \\ 168 & 18\end{array}$

e) 6

125

38

$\frac{18}{8}$

sit?

841
63
8
6
800

$7.8 \%$

O.0T2

0,771

001

ㅁ.823

ofos

000

$0.0 \times 0$

0.007

0.000

oms

0.007

11.850

3.714

6.416

0.024

2375

24391

WASTE RROCESS!ML

MANTE ENANICE PERSONNNEL, OPERATIONS PERSONNE

HEALTH AHYSICS PERSONWEI.

SUPERVISORY PERSONNE.

ENGNEERNG FEREONN브. TOTAL

$\begin{array}{rr}45 & 37 \\ 24 & \\ 2 & \\ 2 & 9\end{array}$

$\begin{array}{rr}37 & 205 \\ 0 & 11 \\ 1 & 18 \\ 0 & 0 \\ 0 & 7 \\ 58 & 37\end{array}$

$\begin{array}{rr}34 & 13 \\ 23 & \\ 0 & \\ 74 & 2\end{array}$

32120

TALT

OPERATKONS PERSOKNEL

SITPERMIORY PERSONNEL

ENCNNEFRING PERSONNEL
189

8
317

16

43

387

$\begin{array}{rrr}13 & 163 & 210 \\ 0 & 3 & 14 \\ 1 & 8 & 32 \\ 0 & 2 & 2 \\ 7 & 11 & 24\end{array}$

210
14
32
2
24
24
$209 \quad 1812 \quad 250$

37

$13 \quad 123$

$\mathbf{2 9 7}$

144

58 1.43t

0.007

0.679

0.20

0,000

2200

1.122

$1=34$

1.452

0.00

ofse

4531
20

200

\subsection{5 \\ 0,000 \\ a.316 \\ 0,000 \\ Dors \\ 0978}

\subsection{1}

1.301

o.072

0,00

이용

0,00

4209

12410

$10 \times 3$

․ㅓㄱㅕ

Dos?

$\begin{array}{rrr}1,014 & 10.320 & 19.703 \\ 0.002 & 0.000 & 0.074 \\ 0,002 & 1.344 & 2.117 \\ 0.000 & 0216 & 0.227 \\ 0.521 & 1.073 & 2.417 \\ 2.159 & 12.056 & 24.601\end{array}$

$\begin{array}{lll}0.000 & 0.015 & 0.015 \\ 0.000 & 0.000 & 0.000 \\ 0.000 & 0.000 & 0.007 \\ 0.000 & 0.000 & 0.000 \\ 0.004 & 0.074 & 0.068 \\ 0.004 & 0.050 & 0.050\end{array}$

10.578

a.teo

0,070

0,00

2895

407.60

7.805

orse

1.679

애엉

450

420.783

11,580

16.067

1.702

$\frac{35699}{47 \%}$ erta

278 24164 버녀

버녀

\subsection{4 \\ 0,000 \\ 0,000 \\ $\lim _{0 \infty}$ \\ 0.000 \\ 0.003}

$\begin{array}{ll}0.370 & 4.041 \\ 0.591 & 0.909 \\ 1.040 & 1.600 \\ 0.000 & 0.223 \\ 0.000 & 0.003 \\ 4.810 & 7.134\end{array}$

\begin{tabular}{|c|c|c|}
\hline $\begin{array}{l}0.895 \\
0.000 \\
0.010 \\
0.000 \\
1.078 \\
1.094\end{array}$ & $\begin{array}{l}2.205 \\
0.001 \\
0.684 \\
0.006 \\
2.48 \\
23.054\end{array}$ & $\begin{array}{r}24.502 \\
1.258 \\
2.108 \\
0.009 \\
4.100 \\
31.789\end{array}$ \\
\hline
\end{tabular}

GRAKD TOTALS

Workess may be counted in more then ene cotepory. 
APPENOX D (Continued)

NUWBER OF PERSONNELAND PERSON-REN

BY WORK AND JOB FUNCTION

1995

PLANT: *NILSTONE POINT 2,3

TYPE: PWR

WORKAND

JOB FLINGTION

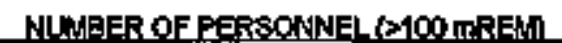

STATION UTILITY CONTRACT TOTAL
TOTAL PERSON*REM

STATKN UTLITY CONTRACT TOTAL

\section{EEACTOR OPS RIDV}

MANTENANCEPERSONNEL

OPERATIONS PERSONNEL

HEALTH PHYSICS FERSONNE.

SUFERVISORY PERSONNEL

ENIGINEERINGG PERSONNEL TOTAL

$\begin{array}{rr}200 & 111 \\ 04 & \\ 4 & \\ 4 \pi & \end{array}$

$\begin{array}{rrr}111 & 1158 & 1478 \\ 6 & 51 & 138 \\ 7 & 83 & 184 \\ 0 & 9 & 13 \\ 78 & 98 & 104 \\ 187 & 1358 & 1019\end{array}$

138

194

102

ROATINEMAINTENANCE

MAINTERAAKCE PERSONNEL

OPERATIONS PERSONHEL

HEALTH PHYSIGS PERSCNEE,

SUPERVISORY PERSONNEL

ENGINEERING PERSONNEL TOTAL

105
52
43
487

$\begin{array}{rr}7 & 75 \\ 3 & 29 \\ 2 & 41 \\ 0 & 6 \\ 19 & \frac{35}{10}\end{array}$

NHSESTICE INSPECTION

MAINTENANCE PERSONNNEL

OFERATIONS PERSONNEL

BEALTH PHYSICS PERSONNE:

SLPZRVISORY PERBONNEI

ENENEERNAG PERSONNEL TOTAL

40
11
25
1
16
183

$\begin{array}{rr}57 & 394 \\ 1 & 3 \\ 2 & 34 \\ 0 & 2 \\ 21 & \frac{4}{81} \\ 81 & 463\end{array}$

932
84
88
10
17
1256

431

15

3

78

SPECIAL MANTENANCE

MANTENANCE PERSONNE

OPERATIONS FERSONMVL

HEALTH PHYSICS PERSONW

SUPERVISORY PERSONNEI

ENGINEERNAG PERSONNEL TOTHAL

\section{WASTE PROCESSING}

MANTTENANCE PERSONNEL

OPERATLON'S PERSONNEI

HEALTH PHYSHCS PERSONNEL

EUPERVISORY PERBONNEL

ENGNEERNG PERSONNEL TOTAL

\section{REFUE:ULNG}

MANTE HANCE PERSONNEE

OPERATIONS FERSONHEL

HEALTH PHYSEKS PERSCKNE

SUPERVISORY PERSONWE.

ENEINEERNA PGRSONM포 TOTAL

19
2
6
0
10
39

7
0
1
0
6
4

5
2
4
1
2
6

7

13

4

18

$\begin{array}{rrr}119 & 74 & 370 \\ 24 & 3 & 31 \\ 68 & 1 & 50 \\ 4 & 0 & 0 \\ 15 & 3 & 15 \\ 20 & 61 & 484\end{array}$

572
58
178
4
39
75

120

34

4

$\frac{13}{216}$

$\begin{array}{rr}79 & 6 \\ 5 & 24 \\ 5 & 49 \\ 0 & 3 \\ \frac{11}{94} & \frac{39}{772}\end{array}$

858

69

8

1082

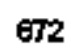

20T2

284

10

297

$397 \quad 3370$

MANTENANCE PERBONNE

HEALTH PHYYSICS PERSONNE

BUPERVISORY PER\&ONNE.

ENGNEERING PERSONNAE
104

18.070
17.790
10.735
0.002
1.701
4.807

5.292

0.441

$0.5 \pm 3$

0.000

0.57

1505

7.97\%
$27.0 \% 8$
1,255
3.609
0.145
074
33512

3.005

0.062

0.00

0.000

0.47

3567

\subsection{7}

0.267

0.073

0.480

0.134

000

0.78

2544

0,00

058

1.62

0.200

0.002

0.077

000

우요

oto?

0.044

0.000

0.917

0,00

0.15

0.210

0.008

0,000

0.000

0.000

0.19

0234

e.10s

1.820

1.078

$0,2 \%$

0.000

0.10 ?

3.262

11,000

1.788

0.910

0.000

1.751
0.59

11.16

0.181

18 s.

6.718

58.320

0,300

2547

0.216

‥658

0.049

$\$ 5.702$

0.000

0.551

0.014

15905

Toxz

0.170

0.000

0.116

0,000

ons

0,318

4.740

0000

1.173

0,000

o연

34.673

0,005

4,258

0,002

0.740

$\$ 9.700$

97.352

16.740

22428

0.213

3947

142000

89.022

1.097

6.145

$0.3 \times 1$

1872

0.147

55.518

0.737

1.t58

0.074

16714

$74 \mathrm{xm}$

0.483

0.002

0.210

0,000

0.747

1.442

0.027

0,382

281

0001

0.244
12355

50.699

3500

7.748

0.009

1,388

由.709

$27.585 \quad 302108$

1012 25006

$20.213 \quad 40.618$

$0.445 \quad 0.748$

18.80 24287
GRAND TOTALS

1278

521

3987

5784

109583

13.459

297.792

302804

Wartaces may be counted in more than one ontugory. 
1895

MORKAND

JOP FUNCTTON
MLNAFR OF PFRSO

STATKON UTILTY CONTRACT TOTAL
TOTAL PERSONAREH

STATKON UTILIY CONTRACT TOTAL

EEACTOR OPS.8 BUTY MANTENANCE PERTONTIZ, OPERATIONS PERSDNN티.

HEALTH PHYSICS PERSOHNEL SUPERVISOFY PERSONNE ENGIERTNG PERSONNG TOTAL

24
31
10
7
8

$\begin{array}{ll}4 & 2 \\ 0 & 0 \\ 3 & 2 \\ 0 & 1 \\ 9 & 9 \\ 7 & 5\end{array}$

$\begin{array}{ll}2 & 30 \\ 0 & 31 \\ 2 & 21 \\ 1 & 5 \\ 0 & 8\end{array}$

$\begin{array}{ll}30 & 4091 \\ 31 & 2 \% 9 \\ 21 & 4009 \\ 8 & 2810 \\ 8 & 2090 \\ 83 & 2000\end{array}$

18

ROLTINE MANTIENANCE MANTENANCE PERSONWEL OPERATTON'S PERSONNEL

HEALTH PHYSIC8 PERSONNEL SUPERVISORY FERBONWEL ENGNESRNG FERSONWE. TOTAl.

10
0
1
0

7
0
5
0
0
12

2
0
1
0
0
0

27
0
0
1
0
37

3.750
0.70
0.800
0384
$0.18 \%$
5.150

2
0
0
0
0
2

4
0
0
1
0
5

0.00
0.00
0000
0.016
0.006
0.016

7

MANTENANCEPERSONNEL OPERATIONS PERSONNEL

HEALTTH FHNOICS PERSONNEE

SUPERUISORY PERSONNEA.

ENG|NEEERINC PERSONNEL TOTAL

\section{WASTEPROCESEING}

MAIHTENANCE PERSONNEL OPERATIONS PERSONHEL HEALTH PHYYICS FERSONNEL SUFERVISORY PERBONNEL ENGINEERING PERSONNEI, TOTAL

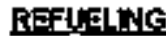

MANTENATCEPERSONWEL OPERATIONS PERSONNOI HEALTH PHMEICS PERSONNEL SUFERVISORY PERSONNEI ENGINEERING PERSONNNEL TOTAL

TOTAI. AY JOS FLNCTIOX MANTENANGE PERBONDN⿴囗 OPERATIONS PERSONNEL HEALTH PHYSICS PERSONNEL. BUPERVISORY PERSONNEL ENGANEERANG PERSONNNEI

$\begin{array}{ll}0 & 2 \\ 0 & 0 \\ 0 & 0 \\ 0 & 1 \\ 0 & 0 \\ 0 & 3\end{array}$

$\begin{array}{ll}0 & 6 \\ 0 & 0 \\ 0 & 0 \\ 0 & 0 \\ 0 & 0 \\ 0 & 8\end{array}$

1
0
0
0
0
1

\begin{tabular}{ll}
0 & 4 \\
1 & 0 \\
1 & 0 \\
0 & 0 \\
0 & 0 \\
\hline 2 & 4
\end{tabular}

$$
\begin{aligned}
& 0 \\
& 0 \\
& 1 \\
& 0 \\
& 0 \\
& 1
\end{aligned}
$$

0
0
0
0

$\begin{array}{ll}0 & 0 \\ 0 & 0 \\ 0 & 0 \\ 0 & 0 \\ 0 & 0 \\ 0 & 0\end{array}$

$\begin{array}{ll}0 & \\ 0 & \\ 0 & 0 \\ 0 & 0 \\ 0 & 0\end{array}$

$\underset{32}{3}$

73
0
7
0

7
0
1
0

\begin{tabular}{|c|c|c|c|c|}
\hline $\begin{array}{l}0 \\
0\end{array}$ & $\begin{array}{l}0,00 \\
0,00 \\
0,000 \\
0,00 \\
0,000 \\
0,000\end{array}$ & $\begin{array}{l}0,0 \infty \\
0,0 \infty \\
0,0 \infty \\
0,0 \infty \\
0,000 \\
0,0 \infty\end{array}$ & $\begin{array}{l}0.000 \\
0.000 \\
0.000 \\
0,000 \\
0.00 \\
0,000\end{array}$ & $\begin{array}{l}0,00 \\
0.000 \\
0.000 \\
0.00 \\
0.00 \\
0,000\end{array}$ \\
\hline
\end{tabular}

\begin{tabular}{lllllllll}
\hline GRANDTOTALB & 110 & 32 & 12 & 154 & 50.172 & 10.611 & 3.515 & 44.208 \\
\hline
\end{tabular}

Workals mby be courted in more than ono bategry. 
MAINTENANCE PERSONYNEL OPERATIONS PERSONNEL

HEALTH PHYSTCS PERSONNEI

SUPERUSORY FERSONNEL

ANENNETRNG PERSONNE

$$
\text { TOTAL }
$$

2041
205
500
1004
13727

ROUTINE MANTENANCE

KANTE EANCE PERSONNEL

OPERATIONS PERSONNEL

HEALTH FHYSICS PERSONNEI

SUPERVSORY PERSONWEL

ENGNEERING PERSONNVE TOTAL

N.SERVICEINSEECTION

MAINTENANACE PERSONNEL

OPERATIONS PERSONNE.

HEALTH PHYSICS PERSONNEL

SUPERVISORY PERSONNEL

ENGINEERING PERSONWEL TOTAL

SPECIAL MaNNTENALCEE

MANTENANTCE PERSONINEL

OPERATIONS PERSONNEL

HEALTH PHYSIICS PERSONNEL

SUPERVSORY PERSONNEL

ENGINEERING PERSONINEL TOTAL

\section{WASTEPROCESSINLC}

MAINTENANGE PERSONNEL

OPERATIONS PERSONNEI

HEALTH FHYSICS PERSONWLE

SUPERN

ENGINEERING PERSONNE: TOTAL

REFUELINS

MAINTENANCE PERSONNEL

OPERATIONS PERSONNEL

HEALJH PHYSICS PERSONNEE

SUPERVISORY PERSONNEI

ENGANEERING PERSONNEL

$$
\text { TOTAL. }
$$

TOTAL BY JOB FUNCTION

MAINTENANCE PERSONNE

OPERATIONS FERSONNE-

HEALTH PHYSICS PERSONNEL

SUTFERVISORY PERSSONNEL

ENGINEERING PERSONNEI

\section{1}

$\begin{array}{ll}0 & 3000 \\ 0 & 780 \\ 0 & 968 \\ 4 & 281 \\ 20 & 480 \\ 20 & 5482\end{array}$

5197
7003
5004
605
2198
19205

3050

320

1799

$\frac{1504}{7105}$

\begin{tabular}{rr}
0 & 15840 \\
0 & 808 \\
0 & 1749 \\
23 & 388 \\
72 & 1479 \\
\hline 50 & 2009
\end{tabular}

15840

1749

1479

2000
19473
1134
3539
6
3012
$2 \operatorname{rans}$

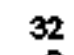

2

18

호ㄱㅗㅗ

112

110

12

15

을

\begin{tabular}{rr}
0 & 4112 \\
0 & 1 \\
0 & 25 \\
1 & 150 \\
1 & 1320 \\
\hline 2 & 5820
\end{tabular}

4144

3

178

137

$\frac{154}{5734}$

3541

$\begin{array}{rr}0 & 354 \\ 0 & 74 \\ 0 & 17 \\ 1 & 174 \\ 11 & 909 \\ 12 & 4700\end{array}$

3857

83
84

84
180

978

495

135

1460

108

31

1743

$\begin{array}{lr}0 & 134 \\ 0 & 200 \\ 0 & 22 \\ 0 & 0 \\ 0 & \frac{112}{564}\end{array}$

270

130

31

$\frac{121}{207}$

\section{7}

16

216

27

$\frac{17}{67}$

$\begin{array}{rr}0 & 1600 \\ 0 & 47 \\ 0 & 165 \\ 0 & 3 \\ 0 & 180 \\ 0 & 1040\end{array}$

1697

209

381

s08

$2 \frac{x 08}{203}$

\section{trat}

8620

$\$ 174$

seo

3494

\section{a $29128 \quad 34978$}

24t

$1 \pi \mathrm{r}$

790

32

4400
- $1990 \quad 10500$

\section{9 \\ 30285 \\ 10.445 \\ 1.510 \\ $4+5$}

63042

57.481

3.054

15.290

4275

9.724

690

0.45

0.003

0.000

0.483

ㅇ.sts

1.802

2013

0.070

0.291

0001

1.113

3549

1.502

5.322

0.454

0,087

이료

7.1 䧑

1.739

i.195

1266

0,822

140

65x

73.721

48019

27.731

7258

17205

0.000

0.000

0.000

0,000

0.00

0.000

2000

$0.3 \times 2$

1.102

0,007

1.762

2.134

0.00

0.000

0.00

0.145

0.680

455,702

6756

24,900

0.505

77.568

500.425

52677

52.741

17.024

esoss

Workers may be courtedi in more than one categary. 
WORKAND JOB FUNCTION

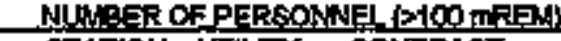
STATKN UTIUTY CONTRACT
TOTAL PERSON-REM

STATION UI'IUTY CONTRACT TOTAL
REACTOROPE

MAINT ENANCE PERSOAREAL OPERATIONS PERSONWNEL

HEALTH FHYSTCS PERSONANEl.

SUPURVISORY PERSONWEL

ENGWNERING PERSONNEL

TOTAL

ROLTINIE MAINTENANGE

MANTENANCE PERSONNEL

OFERATIONS PERSONNNEL

HEALTH PHYETCS PERSONNEL

SLPERVISORV FERSONMEL

ENGANEERNG PERSONWEL

TOTAL

41
91
19
39
10
194

$\begin{array}{ll}0 & \\ 0 & \\ 0 & 12 \\ 0 & \\ 0 & \end{array}$

$\begin{array}{rr}0 & 41 \\ 0 & 91 \\ 12 & 31 \\ 0 & 30 \\ 2 & 12 \\ 14 & 206\end{array}$

0.480
4688
0.243
0.121
0.408
5.5 .3

20;

210

65

78

111

IN.8ERVICEINEFECTION

WAWTENANCE PERSONNEL

OPERATIONS PERSONNE.

HEALTH PHY\&ICS PERSONNEL

SLPERVISORY PERSONWII

ENG NEERING PERBONNEL,

TOTAL

SPGCIALMAI:STENANCE

MAINTENANGEPERSOKNEL

OPERATIONS PERSONNEI.

HEALTH PHYSICS PERSONNEL

SUPERWISORY PERSONNEL

ENGNEERING PERSONNEI

TOTAL

$\begin{array}{rr}0 & 48 \\ 84 & 4 \\ 4 & 24 \\ 1 & \\ \frac{10}{60} & 8\end{array}$

409
40
241
9
843

725
340
340
89
109
1670

$52 \pi 97$

1.4 is

11.703

0.623

20.5is

69.149

15

17

10

1

量

0
0
0
0
0
0

$\begin{array}{rr}44 & 50 \\ 0 & 17 \\ 11 & 24 \\ 1 & 2 \\ 21 & 55 \\ 82 & 134\end{array}$

1.497

1.504

0.088

0,000

1.509

4.545

$\begin{array}{rrr}0 & 88 & 170 \\ 50 & 24 & 185\end{array}$

0 58

131

co

s7

쇼

soto

1

WASTEPROCESSINC

MAINT ENANCE PERSONN NEI,

OPERATIONS FERSONNEL

HEALTH PHYSICB PERSONNEA,

SLPERVISORY PERSONNEI

ENICINEERING PERSONNEL

TOTAL.

89
14
39
8
117

$\begin{array}{rr}0 & 32 \\ 1 & 0 \\ 0 & 8 \\ 0 & 0 \\ 0 & 9 \\ 1 & 40\end{array}$

88
15
48
8
1
+58

REFLELLNG

MAINTENANCEPERSONNWEL

OPERATIONS FERSONNEI

HEALTH PHYEICS PERSONNE

SUPERVISORY PERSONNEL ENGINEENINS PERSONNEL TOTAL

104
61
23
18
$21 \frac{3}{2}$

$\begin{array}{ll}0 & 6 \\ 7 & \\ 0 & \\ 0 & \\ 0 & 11\end{array}$

$\begin{array}{rr}61 & 16 \\ 1 & 6 \\ 51 & 18 \\ 124 & 34\end{array}$

162
69
77
18
$\frac{17}{340}$

\section{0,892}

\section{e.685}

0.400

0.693

$1.7 \%$

10.255

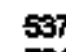

537

MAINTENANCE PERSONNEL OPERATIDNS PERSONNE.

HEALTH PHYSICS PERSOHNIEL

SUPERMSORY PERSONNEL

NNㅌN르레№ PERSONNEL

0
122
4
1
11

$\begin{array}{rr}714 & 1251 \\ 71 & 717 \\ 379 & 607 \\ 13 & 190 \\ 95 & 307\end{array}$

\begin{tabular}{|c|c|c|}
\hline $\begin{array}{l}0.000 \\
0.000 \\
0.000 \\
0,000 \\
0.000 \\
0.000\end{array}$ & $\begin{array}{l}0,000 \\
0,000 \\
0,034 \\
0,000 \\
0,0,8 \\
0.057\end{array}$ & $\begin{array}{l}0.460 \\
4.666 \\
0.277 \\
0.121 \\
0.128 \\
5.600\end{array}$ \\
\hline
\end{tabular}

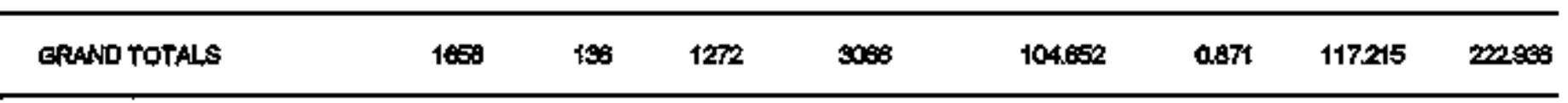

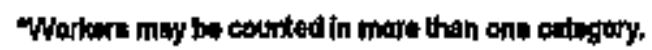


REACTOR OPS \& STRV MANTENANCE FERSONNEL OPERATIONS PERSONANE HEALTH PHYSTCS PERSONNEL SUPERVISORY PERSONME ENGINEERNG PERSONNEI TOTAL

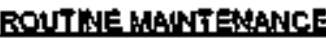
MANTENANCE PERSONNIE OPERATIONS PERSONNEI HEALTH PHYSICSPERSONNEL SLPERVISORY PERSONWFI ENGWNEERING PERSONMEI TOTAL

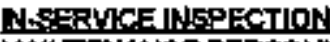
MAINTENANCE PERSONANE OPERATICNS PERSONNEI. HEALTH PHYSICS PERSONNEL SLPERVISORY PERSONWN ENGWEERNG FERSONME TOTAL

SPECIAL MALTEENANGE MANTJEANCE PERSONWEL OPERATICNS PERSONNNEL HEALTH PHYEICS PERSONNEL SUPERVSORY PERSONNEL ENGINEERING PERSONNEL TOTAL

\section{WASTE PROCESS NO}

MAINTENANCE PERSONNEI OPERATIONS PERSONNII HEALTH PHYSICS PERSCNNEL SUPERMSORY PERSONNEI ENCNNEEFIND PERBONWEL TOTAL.

REFUELING

MANNTENANCE PERSONNEL OPERATIONS FERSONNEL HEAL.TH PHYSICS PERBONNEI SUPERVISORY PERSONNEL ENANNEERING PERSONNEI TOTAL

IOTAE BY JOG FUNCTION MAINTENANCE PERSONINEL OPERATIONS PERSONNEL HEALTH PHYECS PERSONNE. SUPERVISORY PEFSONNEL ENSWNEERING PERSONNELL

$\begin{array}{rrr}100 & 375 & \\ 78 & 0 & 27 \\ 30 & 0 & \\ 5 & 1 & \\ 1 & 1 & \\ 313 & 37 & 104\end{array}$

89
27
74
0
104

$\begin{array}{rr}054 & 4.992 \\ 105 & 15.000 \\ 113 & 1.720 \\ 6 & 1.063 \\ 0 & 0.000 \\ 884 & 29.405\end{array}$

$\begin{array}{rrr}190 & 370 & 84 \\ 59 & 0 & 43 \\ 37 & 0 & 75 \\ 4 & 1 & 0 \\ 1 & 0 & 2\end{array}$

$0 \times 0$
102
112
5
3
972

450

2200

4280

0.720

0.278

52554

\begin{tabular}{rr}
4 & 119 \\
1 & 0 \\
5 & 0 \\
0 & 0 \\
1 & 0 \\
\hline 5 & 119
\end{tabular}

55
0
0
0
70

202
1
44
0
3
200

2037

0000

0.005

$0, \infty$

0,000

2070

1.762
0.000
0.000
0.000
0.001
1.763

0.217

D.s.5

3.287

0.000

Q.004

$4,52 t$

Q.977

16,3:0

4.097

1,060

20.48

$\begin{array}{rrr}24 & 204 & 4 \\ 11 & 0 & 1 \\ 20 & 0 & 44 \\ 2 & 1 & \\ 1 & 1 & \\ 128 & 200 & 10\end{array}$

$\begin{array}{rr}45 & 343 \\ 13 & 24 \\ 44 & 64 \\ 0 & 3 \\ 1 & 3 \\ 103 & 407\end{array}$

कo.418

0,00

0,000

02

oco

90668

8.200

16.287

11.20

0.000

000

3.78

14ses

18.507

15.834

0801

0.314

179011

$$
\begin{array}{r}
15.505 \\
0.000 \\
0.000 \\
0.000 \\
0.000 \\
15.005
\end{array}
$$

0.217

0.00

3.207

0.000

0.004

4.521

17896

0.03

3500

0.000

0004

21후웅

5.403

20.750

0.000

0.00

0.397

0.000

noon

5.866

0,000

0.150

0.185

21.074

6.813

s5.049

0.6110 .681

20412023

$0.000 \quad 0.162$

$0.11 \mathrm{~B} \quad$ Q.tog

12583 s95x

$\begin{array}{rr}35 & 10 \\ 27 & \\ 30 & \\ 9 & \\ 9 & \end{array}$

$\begin{array}{rr}10 & 1 \\ 0 & 34 \\ 0 & 1 \\ 0 & 0 \\ 0 & 0 \\ 10 & 38\end{array}$

48
61
31
3
0
147

0.879

2802

1.870

0.210

요음

$\operatorname{coses}$

2,000

0000

0,000

p.0.9.9.

0,003

0.00

1,009

0.013

0,000

o.cro

1.102

0,002

3,021

1.863

a.210

p.om

6.918

$\begin{array}{rrr}23 & 0 & 13 \\ 0 & 0 & 15 \\ 12 & 0 & 24 \\ 1 & 0 & 0 \\ 1 & 0 & 0 \\ 37 & 08 & 52\end{array}$

104

104
15

1.007

0.000

B.e.5

0.561

0.181

10.200

0.021

0.00

0.454

0.000

ormo

o.041

0.000

8.025

1.183

a.s

0.014

$\frac{0041}{10.84}$

$\begin{array}{rrrrr}580 & (160) & 152 & (378) & 26 \\ 178 & (80) & 0 & (0) & 13 \\ 143 & (30) & 0 & (0) & 25 \\ 15 & (5) & 3 & (1) & 0 \\ 5 & (1) & 2 & (1) & \end{array}$
(B) 190

(BS1)

50.420

20.02

8.209

2009

0.350
137.124
0.000
0,000
0.411
0,186

19.008

19834

20.00

215.549

0.000

40.486

28.57

0.162

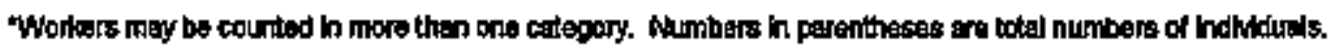


APPENOIX D (Continued)

NUMEER OF PERSONNEL AND PERSON-REM

BY WORK AND JOB FUNCTION

1998

PLANT: \#OYSTER CREEK

TYPE: BWR

WORK AND
JOB FLNCTION
REACTORORE REUTH

OPERATIOHS PERSONANEL

HEALTH PHYSCS PERSONWN

SUPERVISORY PERSONNEL

ENGNEEFING PERSONNEL

TOTAL

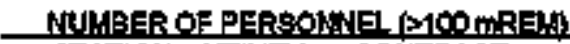

STATION UTILIY CONTRAGT TOTAL

100
108
38
7
9
203

$\begin{array}{rr}0 & 14 \\ 0 & 0 \\ 0 & 0 \\ 0 & 0 \\ 9 & 1 \\ 0 & 15\end{array}$

117
100
38
7
10
278

TOTALPERSOW-REM

STATION UTILITY CONTRACT TOTAL
MANTENANCE PERSONHE

ROUTISE MANTENANCE

MANNTENANCEPERSONNEL

OPERATIONS PEASONNEL

HEALTH PHYSCS PERSONNEL.

SLPERVISORY PERSONNEL

ENGNEERING PERSONNNEL

TOTAL.

1N-5ERMCE INSPECTION

MAINTENANGE PEKSONNEL

OPERATIONS PERSONNEL

HEALJH PHYSICS PERSONNEI

SLFERVIORY PERSONQNEL

ENGINEERING PERSONNEL

TOTAL.

SPECIAL_MANITEXANGE

MANTENANGE PURSONNE

OPERATIONS FERSONMU.

HEALTH PHYSICS PER'OHDHE:

SUPERVISORY PERSONNEL

GNGIMERNHG PERSONNEL

TOTAL.

5.189
11.413
2.259
0.200
0.214
19.250

$0, \infty$

0,000

0,000

0.000

무요

0,000

2773

0.000

and

0,000

axpan

2973

7.001

11.413

272

165

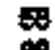

119

119

$\begin{array}{rr}6 & 156 \\ 0 & 9 \\ 1 & 0 \\ 3 & 13 \\ 2 & 17 \\ 12 & 17\end{array}$

414

184

如

139

139

20sed

5.041

1.601

0000

2푸오

30015

39

17

17

옥

0
0
0
0
1
1

9
0
0
0
0
8

44
17
2
$\frac{7}{73}$

2818

0255

0k8.

0.545

어빈

148

148
51

51

8

ㄱ.

20

$\begin{array}{rr}0 & 108 \\ 0 & 2 \\ 0 & 1 \\ 0 & 1 \\ 0 & 110\end{array}$

25

5

10

호

WASTEPROCESSWC

MANTEAANCE PERSONNLEL

OPERATIONS PERBONWEL

HEALTH PHYSACS PERSONNID

SUPERVISORY PERSONNE:

ENEINEERNO PERSCNNEL

TOTAL

5
43
34
3
1
145

$\begin{array}{rrr}0 & 14 & 73 \\ 0 & 1 & 49 \\ 0 & 0 & 34 \\ 0 & 0 & 3 \\ 1 & 1 & 3\end{array}$

73
49
34
3
16

REFUEUNM

MANTENANCEPERSONANE

OPERATIONS PERSONNEI

HEALTH PHYSTCS PERSONNEI.

SUPERVISORV PERSONNEL

ENBINEERTNG PERSONNAE

TOTAL

TOTA!_EY JOG FuNCTION

MANTENANCE PERSONNE OPERATIONS PEREONNIEL HEALTH PHYSICS PERSONNAE. SUPERVISORY PER8ONN크. ERKingerino PERSONNEL

11
21
7
0
1
4

0
0
0
0
0
0

13
21
7
9
1
51

$\begin{array}{rrr}62 & 294 & 12 \\ 417 & (24) & 0 \\ 214 & \text { (a1) } & 1 \\ 10 & (74) & 3 \\ 103 & (12) & 4\end{array}$

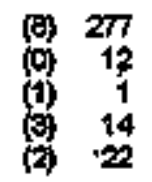

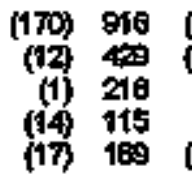

1258

$1+48$

6.384

0.083

041

25.203

a.e87

D.49

0.684

0.108

thast

1.904

1.041

0.25

0.019

0.052

noot

0.50

$$
\begin{aligned}
& 0.100 \\
& 0.000 \\
& 0.000 \\
& 0.009 \\
& 0.004 \\
& 0.170
\end{aligned}
$$

1.502

0.002

a.o

0.003

075

1,83

2370

0.20

연ㄷㄴ

22.20

GRAND TOTALE

1519

(eco) 20

(14) 326

(214) $180 \mathrm{~s}$ (10si)

$\begin{array}{rr}452) & 41.607 \\ 14302 \\ (193) & 11.700 \\ \text { (191) } & 1.022 \\ \text { (140) } & 3.325\end{array}$

0.000
0.000
0.000
0.000
0.001

1.162

0,000

0.00

axpos

1.162

27.091

5005

1 se1

0.971

2758

32.874

$\begin{array}{llr}0.347 & 0.857 & 10.491 \\ 0.000 & 0.187 & 2.055 \\ 0.000 & 0.053 & 6.397 \\ 0.000 & 0.012 & 0.005 \\ 0.009 & 0.724 & 1.139 \\ 0.347 & 7.027 & 29.507\end{array}$

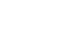

\subsection{0}

0,000

0.000

ion

0.000

\subsection{9}

1.563

0,000

0.000

ales:

3679

2648

\section{2}

0,884

0.100

0236

5.673

Wertere may be cotrited in more than one categery. Numbers h parentheses are toted numbers of indikidala.

\subsection{2}

075

$\begin{array}{lll}0.000 & 0.000 & 0.019 \\ 0.000 & 0.000 & 0.002\end{array}$

00000000001

$0,000 \quad 0.0010$

$\begin{array}{lrr}0.516 & 14.50 & 56.603 \\ 0.000 & 1.774 & 21.073 \\ 0.000 & 0.053 & 11.758 \\ 0.0 \times 3 & 0.050 & 1.956 \\ 0.008 & 1.318 & 4.643\end{array}$

0.524

17.6\%5

ใดิ108 


$\begin{array}{rr}1 & 0 \\ 31 & 0 \\ 8 & 0 \\ 82 & 0\end{array}$

$\begin{array}{lr}0 & 4 \\ 0 & 0 \\ 0 & \\ 0 & 0 \\ 0 & 11 \\ 0 & 0\end{array}$

$\begin{array}{r}4 \\ 5 \\ \hline\end{array}$

11 TOTAL

$\begin{array}{rr}75 & 21 \\ 12 & 0 \\ 47 & 0 \\ 5 & 0 \\ 147 & 2\end{array}$

21
0
0
0
2
2

$\begin{array}{rr}171 & 257 \\ 5 & 17 \\ 27 & 74 \\ 2 & 7 \\ 27 & 52 \\ 227 & 357\end{array}$

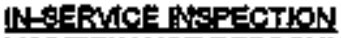

MANTENANCE PERSONNE

OPERATTONS PERSONNEL

HEALTH PHYSICS PERSONWE.

SUPERVISORY PERSONNEI

ENIBINEE ERING PERSONNEE. TOTAL

$\begin{array}{rr}1 & 4 \\ 0 & 0 \\ 2 & 0 \\ 1 & 0 \\ 1 & 0 \\ 5 & 12 \\ & \\ 4 & 32 \\ 0 & 0 \\ 6 & 0 \\ 2 & 1 \\ 1 & 3 \\ 12 & 3\end{array}$

82
0
11
0
128

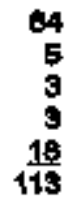

TOTAR

\section{WABTE PROCESSINL}

MANTENANCE PERSONNEL

OPERATIONIS PEREONNEI

HEALTHPHYSICS PERSONNEL

BUPERUtBORY PERSONNEL

ㅌNㅌNㅌE저NASPERBONNEL TOTAL

$\begin{array}{ll}0 & 0 \\ 0 & 0 \\ 5 & 0 \\ 1 & 0 \\ 0 & 0 \\ 0 & 0\end{array}$

REEUEINTR

MANTERANCEFETSONNEL

OPERATINS PERSONNAE.

MEALTHPHYSHCS PERSONNEL.

SUPERMSORY PERSONNEI

ENGNNEERING PERSONNEL TOTAL

$\begin{array}{rrr}15 & 2 & 2 \\ 17 & 0 & \\ 1 & 0 & \\ 5 & 0 & \\ 8 & 1 & 1 \\ 40 & 3 & 5\end{array}$

28.

32

CONATRAC

TOTAL
87
0
93
1
42
140

어1

0.120

0.717

0.45

0.47

2,300

120
5
9
6
23
19

20

8

107

1.70

0.000

0,000

o,

6.842

8.452
1.494

0.393

2001

0.720

0.85

5.423

o.of

0,084

3,377

0.491

이도

उ.जि

10.352

0.000

0,000

0.1日9

$0,2=0$

11.751

6.481

6.016

0.151

1.445

2449

16.560

48.904

23,165

2.45s

7.417

10.218

0.448

0,000

0000

0,00

요독

abos

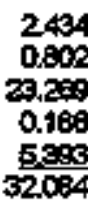

4034

14.673

32.78

2579

ㅁ.670

63614

91.979

2309

8.780

0.751

720

100.250

134.297

5.128

10,480

2723

11.969

1735

\begin{tabular}{rr}
57.163 & .568 \\
0.000 & 0.200 \\
3.031 & 3.748 \\
0.000 & 0.445 \\
15.204 & 27.298 \\
\hline 5.500 & 66.252
\end{tabular}

29076

41.404

1.370

1.560

1.70

3551

2000

8.9.8

40.518

619

$\begin{array}{lll}0,318 & 0.398 & 0.677 \\ 0.000 & 0.070 & 0.104 \\ 0.000 & 0.002 & 3.409 \\ 0.000 & 0.001 & 0.492 \\ 0.015 & 0.058 & 0.084 \\ 0.353 & 0.455 & 4.728\end{array}$

28.006

0.014

2497

4,713

19,940

52.70

$\cos 2$

$6,6 \times 0$

28.8

a.161

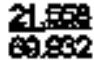

\begin{tabular}{|c|c|c|c|c|}
\hline $\begin{array}{r}524 \\
78 \\
100 \\
29 \\
143\end{array}$ & $\begin{array}{r}48.904 \\
23,165 \\
2.465 \\
7,417 \\
10.218\end{array}$ & $\begin{array}{l}19,371 \\
0.045 \\
0,000 \\
0.200 \\
8.900\end{array}$ & $\begin{array}{r}207.408 \\
5.276 \\
37.150 \\
6.753 \\
53.911\end{array}$ & $\begin{array}{r}273.773 \\
28.496 \\
65.594 \\
14.570 \\
73.027\end{array}$ \\
\hline$\$ 04$ & 11ㅎ.129 & 2524 & Mo:s7 & 40 \\
\hline
\end{tabular}

TOTAL EY JOE FVNLTION MAINTENANCE PERSONIN OPERATIONS PERSONWEL HEALTH PHYYICS PERSONWWH SUPERMSORY PERSONNEL ENIENNEEERANE PERSONNEI.

$\begin{array}{rrr}83 & 50 & 36 \\ 65 & 0 & 1 \\ 20 & 0 & 8 \\ 20 & 1 & 10\end{array}$

Workers may be counted in more than one cetegory. 
REACTOROPS \&.SURV

MAINT NANCE PERSOMMEI OPERATIONS PERSONNEL

HEALTH PHYSICS PERSONNEL SUPERMSORY PERSONNEI. ENBINEERINIS PERSONNEE TOTAL

STATKN UTLTY GONTRACT TOTAL STATION UTIVTY CONEACT TOTAL

ROITMEMAINTENANCE, MAINTENASCE PERSONINEL OPERATIONS PERBCNNEL HEALTH PHYYSICS PEREONNE. SUPERVISORY PERBONNND ENGINEERING PERSONNEL. TOTAL

10
37
5
6
120

$\begin{array}{ll}0 & 20 \\ 0 & 0 \\ 0 & 50 \\ 0 & 0 \\ 0 & 1 \\ 0 & 86\end{array}$

42
37
114
6
7
200

5.062
12569
14.015
2.375
3.270
39.191

0.000
0.000
0.000
0.000
0.000
0.000

$\begin{array}{rr}7.454 & 13.416 \\ 0.432 & 12.701 \\ 18.063 & 30.848 \\ 0.044 & 2449 \\ 0.608 & 3.876 \\ 24.669 & 6.060\end{array}$

\section{N-GERVICE ILEPECTION}

MNINTENANCEPERSONINE OPERATIONS PERSONNEL HEALTH FH YSICS PERSONNEL SUPERMSORY PERSONNNEI ENGEINEERING PERSONNE! TOTAL

SEECIAL MANTENANCE MANTENANCE PERSONNEOPERATLNS PERBONWEL HEALTH PHYSICS PERSONNEL SUPERVISORY PERSONNG ENEINEERING PERSONNEI TOTAL

\begin{tabular}{|c|c|}
\hline $\begin{array}{r}175 \\
55 \\
58 \\
25 \\
25 \\
316\end{array}$ & $\begin{array}{l}0 \\
0 \\
0 \\
0 \\
0 \\
0\end{array}$ \\
\hline
\end{tabular}

\begin{tabular}{|c|c|c|c|}
\hline $\begin{array}{r}506 \\
10 \\
142 \\
28 \\
54\end{array}$ & $\begin{array}{r}78.694 \\
15.497 \\
27.79 t \\
8.975 \\
15.403 \\
137.730\end{array}$ & $\begin{array}{l}0.000 \\
0.000 \\
0.00 \\
0.00 \\
0.000 \\
0.000\end{array}$ & $\begin{array}{r}169.970 \\
1.300 \\
2.670 \\
0.078 \\
9000 \\
20.908\end{array}$ \\
\hline
\end{tabular}

\section{WASTE PROCEQSANR}

WAINTENANCE PERSONA OPERATIONS PERSONNEL HEALTH PHYECS PERSONNEL EUPERVISORY PERSONNEL ENSINERRNA PERSONNEI TOTAL

$\begin{array}{ll}1 & 0 \\ 1 & 0 \\ 0 & 0 \\ 1 & 0 \\ 1 & 0 \\ 4 & 0\end{array}$

$\mathbf{2}$
1
0
0
3
31

27
2
0
1
5
35

0.05
0.520
0.027
0.125
0.094
1.451

$\begin{array}{rrr}0.000 & 9.267 & 9.552 \\ 0.000 & 0.549 & 0.8 \% 9 \\ 0.000 & 0.304 & 0.351 \\ 0.000 & 0.000 & 0.125 \\ 0.000 & 2.800 & \mathbf{3 5 3 4} \\ 0.000 & 13.000 & 14.451\end{array}$

$\begin{array}{lll}0 & 0 & 34 \\ 0 & 0 & 0 \\ 0 & 0 & 0 \\ 0 & 0 & 1 \\ 1 & 0 & 3 \\ 1 & 0 & 30\end{array}$

34
0
0
1
39

\section{REFUELING}

MANTEENANGE PERSONANE1. OPERATIONSS PEREONNES

HEALTH PHYSICS PERSONNEL SLPERUESORY PERSONNEI ENGINESRINB PERSONNEL

$$
\text { TOTAL }
$$

$\begin{array}{rrr}1 & 0 & 1 \\ 0 & 0 & 1 \\ 10 & 0 & 8 \\ 0 & 0 & 0 \\ 0 & 0 & 0 \\ 11 & 0 & 10\end{array}$

2
1
18
0
2
21

0.177
0.070
0.125
0.000
0.008
0.000

$\begin{array}{rrr}0.000 & 12975 & 13,152 \\ 0.000 & 0.000 & 0.070 \\ 0.000 & 0.400 & 0.605 \\ 0.000 & 0.662 & 0.682 \\ 0.000 & 0.510 & 0.818 \\ 0.000 & 14.627 & 15.507\end{array}$

\section{IOTAL EY NOE FLNCTION} MAINTEKAANGE PERSOONNEL OPERATIONS PERSONWEL HEAETH PHYSICS PERSONNEI SUPERMSORY PERSONNEL

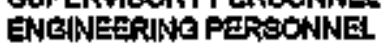

$\begin{array}{rrr}42 & 0 & 20 \\ 4 & 0 & 0 \\ 5 & 0 & 12 \\ 11 & 0 & 0 \\ 4 & 0 & 2 \\ 0 & 0 & 45\end{array}$

20
0
12
0
2
4

\begin{tabular}{|c|c|c|c|}
\hline $\begin{array}{r}68 \\
4 \\
17 \\
11 \\
11 \\
111\end{array}$ & $\begin{array}{r}17.818 \\
1.006 \\
1.921 \\
3.406 \\
1.384 \\
25.926\end{array}$ & $\begin{array}{l}0.000 \\
0.000 \\
0.000 \\
0.000 \\
0.000 \\
0.000\end{array}$ & $\begin{array}{r}9.252 \\
0.020 \\
4.447 \\
0.000 \\
1.828 \\
15.57\end{array}$ \\
\hline
\end{tabular}

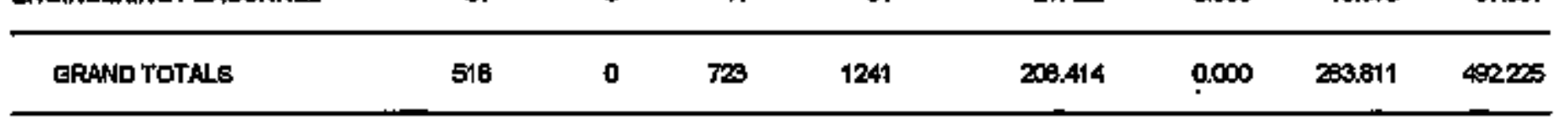

Whators may bo coultod in mber then one category. 
REACTIRR OPS \& tuRV

MAINTENANCE PERSON"ED

OPERATIONS PERSONNEI

HEALTH FHYSICS PERSONNEI.

SUPERVIBORY PEREONNEI

ENGNEERNG FERSONWEL

TOTAL

$\begin{array}{rrrr}442 & 310 & 1005 & 175 \\ 105 & 30 & 100 & 241 \\ 22 & 4 & 19 & 45 \\ 10 & 8 & 29 & \\ 64 & 84 & 39 & 24\end{array}$

STATION UTIUTY

CONTRACT

TOTAL

ROLTLNE MANTENANCE

MAINTENANCE PERSONNVE.

OPERATIONS PERSONNEL

HEALTH PHYYACS PERSONNEL

SLPERUSORY PERSONNEI.

ENGINEERING PERGONNEL

TOTAL.

\begin{tabular}{rr|r}
114 & 111 \\
5 & \\
2 & \\
0 & \\
2 & \\
123 & 124
\end{tabular}

111200

62

04

1

3xis

1757
241
45
241
2141

4.669
2.424
2.394
0.045
0.634
4.036

14.589

0.202

0.024

0.009

15.654

47.820
3.570
1.593
0.245
0.163
59.422

$105.2 \%$

0.045

6.284

4014

$11 \frac{1.729}{7.252}$

\section{NESERMCEEINAPECTION}

MAINTENANCEPERSONNEL

OPERATIONS PERSONNEL.

HEALTH PHYSICS PERSONNEI

SUPERVISORY PERSONREI

ENGENEERING PERSONNAE

TOTAL

$\begin{array}{rr}17 & 13 \\ 0 & \\ 0 & \\ 0 & \\ 17 & \\ 17 & 1\end{array}$

13
3
0
0
0
16

$\begin{array}{rr}314 & 344 \\ 4 & 7 \\ 0 & 0 \\ 1 & 1 \\ 2 & 2 \\ 2 & 2\end{array}$

10.547

0.182

7.713

20.67

0.008

0.105

0.000

0.094

10.65

$0, \infty$

0,0

Q0094

1.042

0.040

0.105

0.041

7.860

2.105

42137

1.20

0.143

0.106

0.159

43.829

EPECIAL MAINIENANCE

MAANTENANCE PERSONWNEI

OPERATIONS PERSONNEL.

HEALTH PHYSICS PERSONNEL

SUPERVISORY PERSONANEI

ENGINEERING PERSONINEL

TOTAL

$\begin{array}{rr}155 & 12 \\ 12 & \\ 7 & \\ 0 & \\ 185 & 19\end{array}$

0,485

0.45

44.165

48.400

0.000

0.057

0.744

0.781

0,000

0.000

0,000

$0 \mathrm{mo}$

0.007

2.018

0.007

0.430

44054

40.200

WASTE PROCESSNMNG

MAAINTE NANCE PERSONNNEL

OPERATIONS PERSONNEL

HEALTH PHHSICS PERSONNEI

SUPERUISORY PERSONNEL

ENGINEEFING PERBONNIEL

TOTAL

12
0
0
0
0
12

$\begin{array}{rr}121 & 35 \\ 8 & 27 \\ 0 & 3 \\ 2 & 1 \\ 19 & 10 \\ 149 & 408\end{array}$

821
47
10
3
37
718

\subsection{8}

0.300

0.568

0.000

0.09

0,582

10.821

8.019

0.052

0.000

32724

$4.28 ?$

0.272

48.698

0,007

0.140

ases

0.409

4.642

$0.8 \times 3$

0.178

0.487

54.744

BEEUUITING

MANTENANCE PERSONNEL

OPERATIONS PERSONNEL

HEALTH PHYSICS PERSONNEL

SUPERVISORY PERBONNNEI

ENGINEERING PERSONNEI

TOTAL

$\begin{array}{lll}2 & 15 \\ 0 & & \\ 0 & & \\ 0 & & \\ 2 & 1\end{array}$

$\begin{array}{rr}15 & 2 \\ 1 & \\ 0 & \\ 0 & \\ 0 & \\ 16 & 9\end{array}$

29
1
0
0
0
30

0.289
0.000
0.000
0.000
0.000
0.206

0.000

0,000

0,000

0.000

a, 000

0,000

0.491

0.920

$0.001 \quad 0.001$

0,000

0.000

0.000

0,000

0.000

0.009

$\begin{array}{rr}223 & 274 \\ 43 & 2 \\ 14 & \\ 3 & \\ 35 & 3\end{array}$

$\begin{array}{rrr}274 & 612 & 1314 \\ 20 & 44 & 107 \\ 2 & 15 & 31 \\ 2 & 9 & 14 \\ 32 & 15 & 73 \\ 300 & 15 & 1542\end{array}$

TOTAL BY NOB,FUNGTON

MAINTENANCE PERSONNEL

OPERATONS PERSONNNEL

HEALTH PHYSICS PERSONNEL

SLIPERVISORY PERSONNNEL

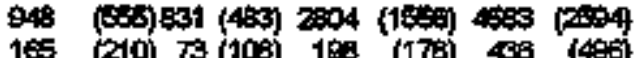

165 (210) 73 (108) 198 (178) 438 (496)

45 (4) 1 (D) 40 (27) 91 (25)

13

(18) 12 (18)

(es) 121 (184)

$\begin{array}{rrrr}44 & (96) & \text { 由 } & (13 \%) \\ 69 & (66) & 273 & (377)\end{array}$

19.640

2101

1.607

43.041

1,002

0.776

0,009

2.989

$18 \times$

57.1832

3.268

120.619

8.301

$1.572 \quad 3.258$

$0.857 \quad 1.12$

$\frac{0.98}{64128}$

GNGNNEEFINO PERBONNEI

84

1256

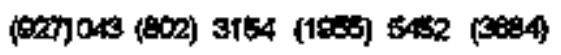

6.202

77.172

25.809

30000

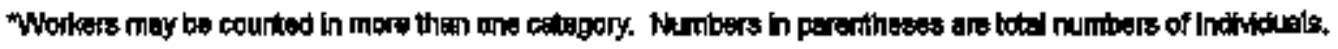




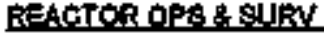

MANTENANGE PERSONANEL OPERAT KONS PERSONNEL

HEALTH FHYYSOS PERSONNEL

SUPERVISORY PURBONNEL ENG'NEERINE PERBONHES TotAl

$\begin{array}{rr}147 & 33 \\ 228 & 21 \\ 69 & 12 \\ 3 & 4 \\ 49 & 90 \\ 400 & 160\end{array}$

145
17
45
52
40

\section{5}

268

120

6

169

ROATNFMANLENANGE

MANTENANGEPER6ONNEL

OPERATIONS PARSONNE,

FEALTH PHYEKCS PEREONNAZ,

BUPERVIEORY PERSONNEL

ENENNEERING PERSONWWL TOTAL

$\begin{array}{rrr}216 & 81 & 378 \\ 524 & 49 & 44 \\ 60 & 15 & 02 \\ 4 & 4 & 40 \\ 58 & 174 & 68 \\ 600 & 313 & 592\end{array}$

075
417
143
48
$7 \% 0$
1573

075

143

40

1573

$\begin{array}{rr}2 & 0 \\ 5 & 2 \\ 6 & 0 \\ 0 & 0 \\ 0 & 7 \\ 15 & 9\end{array}$

4
0
0
0
2
5

3
7
9
0
50

$\begin{array}{rr}91 & 12 \\ 65 & 3 \\ 32 & 5 \\ 0 & 0 \\ 8 & 16 \\ 199 & 30\end{array}$

48
5
10
0
2
05

151
76
47
0
20
300

$\begin{array}{rr}74 & 28 \\ 79 & 5 \\ 40 & 14 \\ 13 & 17 \\ 214 & \frac{12}{60}\end{array}$

WASTE PROAFESHLG

MANTENAWCE PERSONNEL

OPERATIONS PEREONNEL

HEALTH PHYACA PERSONNEL

SUFERVISORY PERSONWEL

ENGINEERING PERSONWEL

$$
\text { TOTAR }
$$

$\begin{array}{lll}0 & 0 & 0 \\ 0 & 0 & 0 \\ 0 & 0 & 0 \\ 0 & 0 & 0 \\ 0 & 0 & 0 \\ 0 & 0 & 0\end{array}$

$\begin{array}{rr}30 & 138 \\ 11 & 04 \\ 3 & 09 \\ 4 & 5 \\ 4 & 59\end{array}$

RPEI,EIMG

MANTENANCEPERSONNEL.

OPERATIONIS PERSONNEL

HEALTHAHYSCS PEREONNEL

SLPERULSORY PERSOWWE

ENCNNEERANG PERBONNEL

$$
\text { TOTAL }
$$

TOTHLY BO

MAINTENANCE PERSONNEL

OPERATHONS FERSONNEZ

HEALTH PHYSIOS PERSONNEL

SUPERUSORY PERSONNEL

\begin{tabular}{|c|c|c|c|c|c|c|c|}
\hline $\begin{array}{r}500 \\
708 \\
216 \\
718\end{array}$ & $\begin{array}{r}154 \\
80 \\
48 \\
9 \\
289\end{array}$ & $\begin{array}{r}611 \\
77 \\
150 \\
00 \\
116\end{array}$ & $\begin{array}{r}1295 \\
800 \\
414 \\
112 \\
523\end{array}$ & $\begin{array}{r}16.350 \\
13.794 \\
8.012 \\
0.002 \\
0.881\end{array}$ & $\begin{array}{l}4.409 \\
0.389 \\
1.324 \\
0.17 \\
1.563\end{array}$ & $\begin{array}{r}12780 \\
0.780 \\
3.398 \\
0.289 \\
0.978\end{array}$ & $\begin{array}{r}35.519 \\
14,460 \\
11.490 \\
0.300 \\
3.493\end{array}$ \\
\hline 47 & 570 & 1050 & $\operatorname{sen} 4$ & $\sec 619$ & 0.003 & 17.584 & 65 2 \\
\hline
\end{tabular}

ENGINEERING PERSONWEL

Workers may be canted in moke then ons cetcogory. 
WORK AND

JOB FUNCTION

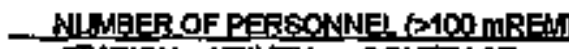

STATION UTILTY CONTRAGT TOTAL
TOTAL PEREONEEM

STATKN UTLITY COWTRACT TOTAL
REACTOR OES \& EUTR
MAINTENIANCE PERSONNEL

OPERATLN

HEALTH PHYSICS PERSONNE.

SUPERVSORY PER SONNEL

ENEMNEERWG PERSONNEI TOTAL.

170
126
41
120
176
583

13718

200

110

54

132

144

SUPERVISORY PERSONNEL

GNNEINEERWG PERSONNEL TOTAL

L-SERHCE NSPECTHN

MANTENANCE PERSONNEZ

OPERATIONS PERSONREL

HEALTH PHYSICS PERSONNE

SUPERVISORY PERSONNET

ENGINEERTNGG PER\&ONNEL TOTAL

SFECIAL MANTEAANCE

MAINTENANCE PERSONMEI

OPERATIONS PERSONNEL

HEALTH FHYSICS PERSONNEL

SUPERVISORY PERSONRE

ENGWNEERING PERSONNEL TOTAL

6

19

15

20

135

38

3

2

13

WASTEFROCESSNG

MAINT ENANCE PERBONWE

OPERATIONS PERBONHEI.

HEALTH PHYSICS PERSONWD

SUPERVISORY PERSONNE

ENGNEERNG PERSCNNEL TOTAL

50
43
29
16
7
144

128

48

35

274

60

340

174

$3 \boldsymbol{3}$

356

MAINTENANCEPERSOHME

OPERATIONS PERBONNEI.

SUPERVISORY PERSONDNEL
10

15

7

64

$\begin{array}{rrr}38 & 708 & 10 \\ 4 & 168 & 28 \\ 3 & 44 & 104 \\ 18 & 108 & 254 \\ 78 & 1171 & 19\end{array}$

1050
290
104
254
298
199

208

\begin{tabular}{rr}
2 & 208 \\
0 & 10 \\
0 & 8 \\
4 & 13 \\
3 & 2 \\
\hline & 319
\end{tabular}

358

17

25

3y

401

500

3
2
0
0
0
0

28

1

2

3

$\begin{array}{rr}10 & 163 \\ 2 & 25 \\ 0 & 12 \\ 4 & 18 \\ 2 & 17 \\ 18 & 237\end{array}$

168

25

18

$2 \frac{77}{37}$

$\begin{array}{rr}609 & 3683 \\ 210 & 29.410 \\ \pi & 3.788 \\ 227 & 2854 \\ 109 & 3.850 \\ 1009 & 4250\end{array}$

$\mathbf{3 6 8 3}$

3.788

3,802

40560

71.091

9.450

1929

12034

8.854

12212

3552

0.028

0.207

0.164

0.514

$4 \sqrt{35}$

1.67s

0287

0.007

000 r

opers

2.198

0.852

6384

2.114

a.下

0.79단

10.891

183

301

70

40

58

529

Q.176

2524

2125

2004

0.704

16.620

B) 220

18 284

78

53

\section{0,913}

49.064

27.500

14.837
0.230
0.100
0.436
0.550
0.009
1.997

7.808

1.507

5.587

1.132

$0 \times 82$

13816

14.761

31.000

9,791

4518

5.213

62365

6.004
0.251
0.000
0.715
0.838

6.5

200.870
9.914
7.154
8.026
2.508
232000

278.305

10,615

20552

71,675

19628

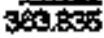

\begin{tabular}{|c|c|c|}
\hline $\begin{array}{l}0,003 \\
0.000 \\
0.000 \\
0,020 \\
0.049\end{array}$ & $\begin{array}{r}23.583 \\
0.312 \\
0.133 \\
0.416 \\
0.210 \\
24.590\end{array}$ & $\begin{array}{r}29,80 \\
0,538 \\
0,400 \\
0,600 \\
0,7 \% 0 \\
28,980\end{array}$ \\
\hline
\end{tabular}

0.000

0.000

0.000

0.000

o.t.4

0.027

14.041

0.579

0.009

0,314

오어도

15.68

1674

a.e68

0.018

a315

1.141

17.891

0,00

0,624

0.000

0.000

$\log$

0.72

0,019

0.104

0.110

0,000

0.017

1,044

1869

6.992

227

0.77

0.811

12.447

0348

o.001

0,000

0.012

0.519

0.678

38,200

2814

2085

sises

1 st:4

48.040

47821

5.300

4208

5.445

2 B⿺辶4

0.347

ENGINEERING PERSONNEL

1873

180

3018

5071

7.604

205.516

393.433

0.978

4000

16078

13.227

1279

10.250

43.191

33.110

1.004

199.499

1229

$\operatorname{sed} 00$

gendes 
REACTOR OPR S.SUEV

MANTTENANCE PERSONNEL

OPERATIONSPERSONNE

HEMTTH PHYEICS PERSONNEL

SUPERVISORY PERSONNEL

ENGINEERING PERSONNEL TOTAL

ROUTNE MAINTENANCE

MAINTENANCE PERSONNEL

OPERATIONS PERSONNEL

HEALTH PHYSICS PEFSONNEL

SLPERVISORY PERSONNEL

ENGINEERING PERSONNEI TOTAL

W.SERUICE MLPPECTION

MAINT ENANCE PERBONNEL,

DPERATIONS FERSONNEL

HEALTH PHYSKS PERSONWVZ

SLPERUSORY PEREONNEL.

ENGINEERING PERSONNEL TOTAL,

BPECLAL MARTEENANGE

MAINT ENANCE PEREONNE.

OPERATLNS PERSONHEI

FEALTH FHYSICS PEREONNA

SUPERVISORY PERSONNE-

ENGWEERNG PERSONNEL TOTAL

$\begin{array}{rr}0 & 0 \\ 49 & 0 \\ 27 & 0 \\ 10 & 0 \\ 8 & 10 \\ 53 & 10\end{array}$

0
0
0
0
0
0

0
43
27
10
18
103

0.000
11.210
10.400
9.700
1.700
27.000

$\begin{array}{rr}52 & 40 \\ 0 & 0 \\ 0 & 0 \\ 0 & 0 \\ 0 & 0 \\ 50 & 40\end{array}$

0
0
0
0
0
0

02
0
0
6
0
0

24380

0.000

0.000

0.860

$\underline{0,000}$

25200

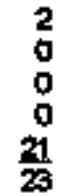

2

o

0

o

0

$\frac{1}{1}$

4

$\frac{21}{23}$

52

0

0

魚

5

$\begin{array}{rr}0 & 55 \\ 0 & 0 \\ 0 & 57 \\ 0 & 2 \\ 0 & 09 \\ 0 & 150\end{array}$

WASTE PROCESSSNG

MANTENANCE PERSONNAL

OPERATIONS PERSONWVE

HEALTH PHYSICS PERSONME,

SUPERVISORY PERSONNAL

DNENEERING PERSONNEL TOTAL

$\begin{array}{rr}0 & 0 \\ 48 & 0 \\ 27 & 0 \\ -1 & 0 \\ 0 & 0 \\ 76 & 0\end{array}$

$\begin{array}{rr}7 & 7 \\ 0 & 48 \\ 2 & 29 \\ 0 & 1 \\ \text { D } & 0 \\ 9 & 0\end{array}$

REFUTLINR

MANTENANCEPERSONNEL OPERATIONS PERSONWEL

HEALTH PHYSICS PERSONNE.

SUPERYISORY PERSONNEL

ENGWEERING PERSONNEE. TOTAL,

TOTAL EY, WOG FLNCTION

MANTTENANCE PERBONNEI

OPERATIONS PERSONWEL

HEALTH PHYSICS FERSONNEL

SUPERVISORY PERSONNEL

ENENEERTNG PERBONNNEI

0.000

0.000

0.000

0,000

DS70

$\frac{0.50}{0.0}$

3810

0,000

0000

0.110

0000

3900

0.000

0,160

0.400

0.210

0.000

$0.7 \times$
41.890

12720

10.840

5.090

$2 \%$

$\begin{array}{rr}52 & 40 \\ 48 & 0 \\ 0 & 0 \\ 13 & 0 \\ 0 & 0 \\ 113 & 40\end{array}$

$\begin{array}{rr}0 & 92 \\ 0 & 48 \\ 0 & 0 \\ 0 & 13 \\ 0 & 0 \\ 0 & 153\end{array}$

150

144

(52) 80 (40)

(48) 0 (0) 0

$\$ 4$ (27) 0 (D) 3

36 (3) 0 (0) 2

(क) 14 (14) 8
(62) 290

(D) 144

(अ)

(2) 38

(ib) 112
0.000

0,000

0,000

0.000

11.050

0.000

0.000

0,000

0,000

1.500

$\frac{1.500}{1.560}$

0.000

0.000

0000

0.000

0,003

0.000

27.120

0000

11.778

2470

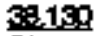

39.499

0,000

0,000

0.000

0.000

0.000

0,000

1.270

0.000

0.850

0.000

0,000

2120

1.270

0.150

1.250

0.210

0.000

2.880

$\begin{array}{rrrr}13.760 & 10.940 & 0.000 & 24.700 \\ 1.350 & 0.000 & 0.000 & 1,380 \\ 0,000 & 0.000 & 0.000 & 0.000 \\ 0.750 & 0.000 & 0.000 & 0.790 \\ 0.000 & 0.000 & 0.000 & 0.000 \\ 15.910 & 10.840 & 0.000 & 20.550\end{array}$

GRAND TOTALS

*a (174) $94 \quad$ (54) 19

(t82)
22000

0.000

0.000

0.000

2660
29.700

0.040

12 E29

$24 \pi$

48.000
9260

12700

20,420

5.150

so,toro

Woskers may be counted In mose than one oxtegory. Numbers in parentheses aro total numbers of indwiduala. 
WORK AND JOE FUNCTION
NLABER OF PGRSOANE $(100 \mathrm{MRF}$ STATION UTRTY CONTRACT TOTAL
TOTAL PERSONHEM

STATHON UTLRY CONTRACT TOTAL.
REACTOR OPS \& suRV MAINTENANCE PERSONNEL OPERATLONS PERSONNE HEALTH PHYSSICS PERSONNEE. SUPERWIORY PERSONNEI ENGINIEERDG PERSONNEL TOTAL

ROUTINEMAINTENAMCE MANTIENANCE FERSONNEL OPERATIONS PERSONNLEI HEALTH FHYSICS PERSONWE SUPERVISCRY PERSONN트 ENGIKEERING PERSONNE,

TOTAL

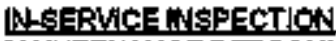
MANTENANCE PERSONNE OPERATIONSPERSONWEL HEALTH FHYSICS FERSCNNEL SUPERVISORY PERSONNA. ENREINELERING PERSONNEI TOTAL

SPECIALMANTENANCE MANT GNAACE PERSONNE OPERATIONS PERSONNEI HEALTH FHYSICS PERSONNEL SUPERVISORYPERSONNEL ENGNNEERING FERSONNE TOTAL

WASTE PROCESSU|NIE MANTENANCEPERSONNEL OPERATIONS PERSONNEL HEALTH PHYSICS PERSONNEL SUPERVISORY PERSONWE ENGANEERANG PERSONWEL TOTAL

REFUELING

MAINTENANCE PERSONNEL OPERATHONB PERSONNEL HEALTH PHYSICS PERSONNEL SLPERMISORY PERSONNEL ENGINEERNHG PERSONANEL TOTAL.

TOTAL BY JQA FUNCTION MANTENANCE PERSONNEL OPERATIONS PERSONNEL HEALTH PHYSCS PERSONNEL. GLPERVISORY PERSONNEL ENGNEERING PERSONNEI,

2
4
6
3
15

$\begin{array}{lr}0 & 0 \\ 0 & 0 \\ 0 & 10 \\ 0 & 1 \\ 0 & 0 \\ 0 & 11\end{array}$

0
0
10
1
0
11

2
4
18
4
0
28

1,044

2.709

1.524

1.208

0.27

6.872

$\begin{array}{rr}24 & 23 \\ 1 & 0 \\ 0 & 0 \\ 3 & 0 \\ 0 & 0 \\ 34 & 20\end{array}$

2
0
0
0
0
10

49
1
0
11
67
67

5.669

0.131

0.189

1.463

1527

9.144

1,281

0.017

0.273

0.489

g.000

2000

0.711
0.000
0.000
0.143
0.000
0.057

0.003

0.000

2622

0.324

0.00

3.152

7 그섯

0,000

0.000

$0.2 \%$

000

7.964

O.8T3

0.000

0.212

2813

0,000

3.806

1.781

$27 \%$

4,348

1,005

0.27

1 ầ81

$\begin{array}{ll}5 & 22 \\ 0 & 0 \\ 0 & 0 \\ 1 & 0 \\ 0 & 0 \\ 0 & 32\end{array}$

11.190

0.000

0.000

0.044

o.0.9.

11234

$2 \times 92$

0.000

1,278

7.739

0.120

11.729

14.423

0.131

0.401

4.494

1.577

20.976

$\begin{array}{ll}4 & 5 \\ 0 & 0 \\ 0 & 0 \\ 1 & 0 \\ 8 & 5\end{array}$

$\begin{array}{rr}5 & 10 \\ 0 & 0 \\ 0 & 3 \\ 0 & 20 \\ 0 & 0 \\ 5 & 36\end{array}$

1.095

0005

0.098

0.08

0.487

2648

2205

0000

0.000

0.102

0.000

2397

4040

0,000

0,00

13.898

0,000

16.869

15.063

0.017

1.581

B. 271

0.170

25002

$\begin{array}{ll}1 & 0 \\ 0 & 0 \\ 1 & \\ 0 & 0 \\ 0 & 0\end{array}$

0.000

0.000

0.216

0.110

0.000

0,094

0.075

0.000

0.000

0.005

0,000

0.114

0,000

0.000

0.002

0,000

0000

0,002

7390

0.028

1.000

14.002

0.467

$23.8 \mathrm{Bz}$

6.723

0.208

D.22

0.584

0.227

8.000

$11.34 \mathrm{~g}$

0.00

0.000

0.119

0000

11.460

0.000

$\$, 000$

0.162

0.483

우오

000

0.093

0.000

0.248

0.149

0.000

4.140

28$$
7 \frac{1}{4}
$$

184

0

21

57
0

16.897
3.241
2592
4.761
2496

39.251

7,811

0.000

5.497

25.201

D.120

18.071

0,208

0.444

1.171

ㅁ.227

20.121

0,00

0.723

0,000

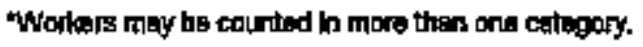


REACTOR OPS E FUNY MANTENANCE PERSONAEl OPERATTONS PERSONNNEL HEALTH PHYSICS PERBOWNEL SUPERVISORY PERSONWEI ENGNERING PERSONW TOTAL

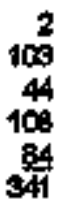

ROUTINEMANTENANCE

MANTENAMCE FERBONNEL

OPERATIONS PERBONNEL

HEALTH PHYSICE PERSONNEL

SUPERVISORY PERSONNEL.

ENGNEER|NG PERSONNE. TOTAL

MN-SERMCE HWIPECTION

MANTENANCE PERSONNEL

OPERATIONS PERSONNE

HEALTH PHYYICS PERSCNNEL

SUPERVISORY PERSONNEL

ENONNEERNG PERSONMETOTAL

\section{EPECIAL MANTEKLANGE}

WAINTENANICEPERSONNEL

OPERATYONS PERSONWEL

HEALTH PHYYSFCS PERSONNEL.

SUPERMSORY PEREONNEI

ENGGNNEERING PERSONNEL TOTAL

$\begin{array}{rrrr}154 & 0 & 844 & 98 \\ 27 & 0 & 0 & \\ 28 & 109 & 59 & 170 \\ 147 & 0 & 139 & 280 \\ \frac{68}{422} & 100 & 1078 & 170\end{array}$

$\begin{array}{rr}1 & 0 \\ 1 & 0 \\ 1 & 18 \\ 2 & 0 \\ 13 & 0 \\ 18 & 19\end{array}$

$\begin{array}{rrr}5 & 0 & 407 \\ 3 & 0 & 1 \\ 5 & 19 & 29 \\ 12 & 0 & 01 \\ \frac{31}{50} & 7 & 68\end{array}$

WASTEFROCESBHAG

MANTT NANEE PERSONNEL

OPERATHONS PERSONNEL

HEALTH PHYSICS PERSONNEL

SUPERVISORY PEREONNEI

ENGINEERING PERSONNEL TOTAL

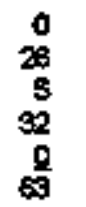

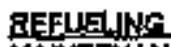

MANTENANCE PERSONNEL OPERATIONS PERSONNEL

HEALTH PHYSICS PEREONNIE

SUPERVISORY PERSONNEL.

ENGINEERING PERSONNELTOTAL

TOTAL. BY.JOB FUNCTION

MANTENANICEPERSONNE.

OPERATLNE PERSONNEL

HEALTHPHYSICS PERSCNNE-

QUPERVISORY PERSONNE

ENGINEERING PERSONNEL

$\begin{array}{rrr}12 & 0 & 5 \\ 13 & 0 & 0 \\ 5 & 27 & 0 \\ 17 & 0 & 1 \\ 50 & 0 & 3\end{array}$

17
13
30
18
8
80

174
173
88
318
189

$\begin{array}{rrr}0 & 1390 & 157 \\ 0 & 187 & 360 \\ 210 & 86 & 38 \\ 0 & 25 t & 58 \\ 8 & 134 & 36\end{array}$

$\begin{array}{rr}0 & 16 \\ 0 & 175 \\ 37 & 17 \\ 0 & 26 \\ 1 & 11 \\ 25 & 215\end{array}$

56
278
86
134
83
894

1.044

39058

21.711

108es

5.80

903
27
176
285
175
1009

17.588
0.477
14081
14305
170.245

123

122
0
3
7
$1 \frac{19}{45}$

1
22
9
28

18

$\begin{array}{rr}0 & 5 \\ 0 & 11 \\ 0 & 0 \\ 0 & 0 \\ 0 & 0 \\ 0 & 16\end{array}$

412
4
53
93
108
$\frac{68}{608}$

\section{0}

0.20

$0.5 \%$

0.200

$\frac{\text { angs }}{2440}$

4178

1.172

2779

1.150

$2+184$

11.495

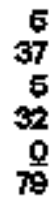

\subsection{2}

9.178

2306

3.002

a.pe

14094

\subsection{0 \\ 0.00 \\ 0.300 \\ 0,00 \\ ocks \\ D䑻}

4270

13.750

4.743

1.273

0.700

24.

\begin{tabular}{|c|c|}
\hline $\begin{array}{l}0,000 \\
0,000 \\
1.143 \\
0.000 \\
0.000 \\
1.148\end{array}$ & $\begin{array}{r}229.978 \\
0.090 \\
10.586 \\
6.516 \\
250.750\end{array}$ \\
\hline
\end{tabular}

0

0.000

0.185

0,000

$\frac{0.000}{0.185}$

36.00

000

0.853

0.350

0818

33.624

a200

1.503

0.539

1.704

0.18

\begin{tabular}{|c|c|c|}
\hline $\begin{array}{l}0.000 \\
0.000 \\
0.198 \\
0.000 \\
0.005 \\
0.251\end{array}$ & $\begin{array}{r}110.755 \\
0.095 \\
8.165 \\
3.919 \\
4.180 \\
127.008\end{array}$ & $\begin{array}{r}114.563 \\
1.257 \\
11.140 \\
5.033 \\
138.792\end{array}$ \\
\hline
\end{tabular}

\section{$\$ .000$}

0000

0,008

0.000

0,000

0.000

1.220

0.834

0.050

0.010

0000

2132

162:

10012

2.359

3072

oxprs

17.000

\begin{tabular}{|c|c|c|}
\hline $\begin{array}{r}9.401 \\
4.501 \\
1.350 \\
1.704 \\
0.569 \\
17.352\end{array}$ & $\begin{array}{l}0,00 \\
0, \infty \\
0.28 \\
0,0 \infty \\
0,0 \times \\
0.28\end{array}$ & $\begin{array}{l}1.529 \\
0.008 \\
0.072 \\
0.001 \\
0.175 \\
\$ .043\end{array}$ \\
\hline
\end{tabular}
1575
360
34
301

60.608

42800

30.63

14.176

0.000
0.000
2218
0.000
0.041

30.684

14.720

24.458

12.152

$9.4 \pi$

524.497

75328

c0.489

$+143$

29.64

2079

$\$ 247$

292451

220

441.471

739,161

Horkers may be counted In mare thon one category. 
WORK AND JOE FUNCTION

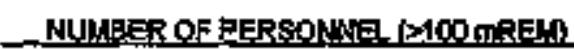
STATION UITLTY CONTRACT TOTAL
TOTAL PERSON-REN

STATION UTILTY CONTRAGT TOTAL
REACTOR OPS S SURV

MAINTENANCE PERSONWNEL

OPERATIONS PERSONNEL

HEALTHPHYSICS PERSONNEL

BUPERVSORY PERSONNEL

ENGINEEANG PERSONNEL

TOTAL

ROUTHE MANTENANGE

MANTEKANICE PERSONNEI

OPERATIONS PERSONh:I.

HEALTH PHYSICS PERSONNE

SUPERVISOFY PERSONNEL

ENGWEERNG PERSCNNEL

TOTAL

INSSERMCE NSPECTLN MAINTENANCE PETSONNEL OPERAT!ONS PERSQNMVI. HEALTH PHYSTCS PERBONWEL SUPEXVISORY PERSONNE ENOWEERNG PERSONNEL. TOTAL

SPECALAMANTENANCE MANT ENANCE PERSONNEL OPERATIONS FERSONNEL HEALTH PHYSICS PERSONNEL SUPERVISORY PERSONNEL

ENGWEEFNG PERSONHEL

TOTAL.

\section{WASTE PROCESSINE}

MAINTENANCEPERSONNEL OPERATLNS PERSONNAL HEALTH PHYSICS PERSONNE. SUPERUISORY PERSONWEI ENCANEERINO PERBONWNEL TOTAL

6
49
22
13
10
100

5
5
3
5
10
20

12
50
20
19
70
700

28

10

8

5

to

o

0

0

0

응

0
0
0
0
0
0

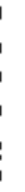

$\begin{array}{ll}0 & 0 \\ 0 & 0 \\ 0 & 0 \\ 0 & 0 \\ 0 & 0 \\ 0 & 0\end{array}$

$\begin{array}{rr}10 & 0 \\ 5 & 0 \\ 5 & 0 \\ 0 & 0 \\ 0 & 0 \\ 2 & 0\end{array}$

0
0
0
0
0
0

$\begin{array}{rr}3 & 13 \\ 0 & 5 \\ 1 & 5 \\ 0 & 0 \\ 0 & 0 \\ 4 & 24\end{array}$

프리대는

MAWTENANCE PERSONNE OPERATLNS PERSONNEI HEALTH PHYSICS PERSONWEL. SUPERVISORY PERSONNE. ENGINEEFING PERSONNEL TOTAL

TGTAL BY VOB FINACTION MALNTENANCE PERSONNE OPERATIONS PERSONNEL HEALTH PHYSICS PERSONNE. SUPERVISORY PERSONNEL

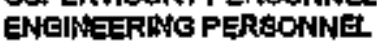

$\begin{array}{rr}1 & \\ 10 & \\ 2 & \\ 1 & 0\end{array}$

0
0
0
0
0

0
0
1
0
0
1

$\begin{array}{r}48 \\ 14 \\ 8 \\ 5 \\ 10 \\ \hline 55\end{array}$

0.274

0,010

0.012

0005

o.0.5

0512

0

0

0,000

0.000

0.000

0.000

0.000

0.000

0,000

$0, \infty$

a.tod

0.000

t.m.

0.000

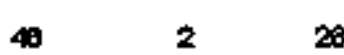

40
75
15

2
1
1
1
0

\section{8}

74

7

5

1
10
3
0
1
15

0.016

0.010

0.087

$0 . \infty$

0,000

0.115.

000

0.00

0.000

0,000

gom

0011

74
82
4
24
31

025

0.25

0.00

0.010

0.00

204

1.509

0.000

$\begin{array}{lll}0,000 & 0.000 & 0.000 \\ 0.000 & 0,000 & 0.003 \\ 0,000 & 0.000 & 0.003 \\ 0,0 \infty & 0.000 & 0.00 \\ 0.000 & 0.00 & 0.000 \\ 0.000 & 0.00 & 0.011\end{array}$

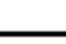

Whatkers may be coutited in mant that one netegory. 
APPENOLX D (Continued)

HUMEER OF PEKSONNEL AND PERSOHAREM

BY WORK AND JOB FUNCTION

1995

PLANT: FIVER BEND 1

TYPE: BWR

WORKAND

NULAER DE PERSONNEL $\$ 100$ mREFAP

TOTALPEREON-REH:

JOE FUNCTION

STATHON UTILIT COWTRACT TOTAL

ETATION UTILITY

CONTRACT

TOTAL

REACTORCPS \& BNRV

MAINTENANCE PERSONNEL

OPERATIONS PERSONNIE.

HEALTH PHYGCS PERSOMNEL

SUPERVASORY PERSONNEL

ENGNEERING PERSONNEL TOTAL.

$\begin{array}{rr}3 & 0 \\ 38 & 0 \\ 18 & 1 \\ 0 & 0 \\ 4 & 1 \\ 61 & 2\end{array}$

3
0
3
1
1
8

6
36
22
1
$\frac{0}{71}$

0.50
8.268
4.543
0.009
0.522
13.890

0,009

000

0.40

0.000

1.028

224573

0.005

0.42

0,000

0.055

ling

p.os

8.274

71

$13 . \operatorname{asc}$

0.202

$0.05 \%$

o. $\arg$

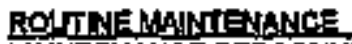

MANTENANCE PEREONNEI

OPERATHNS FERSCNW בZ.

HEALTHFHYSICS PEREONNEL

SUPERVIEORY PERSONNEL

ENCINEERING PERSONNEL TOTAL

$\begin{array}{rl}11 & 1 \\ 0 & 0 \\ 0 & 0 \\ 0 & 0 \\ 1 & 0 \\ 12 & 1\end{array}$

1
0
0
0
0
1

13

1570

0.214

0.000

0.256

0008

4000

$\cos 0$

0.244

$0, \infty 00$

noit

0.979

15.014

\section{NSEERICE NASPEGTLN}

MANNTENANCEPEREONNEE

OPFRATIONS PERSONNEI

HEALTH PHY'SLS PERSONNEE

BUPERVIEORY PERSONNEE

ENGINEERANG FERSONNEI TOTAL

$\begin{array}{ll}0 & 1 \\ 2 & 0 \\ 0 & 0 \\ 0 & 0 \\ 0 & 1 \\ 11 & 2\end{array}$

$\begin{array}{ll}4 & 14 \\ 0 & \\ 0 & \\ 3 & \end{array}$

14
2
0
0
4

4.141

0.058

0,049

0,000

a.0.5

5228

ars

$\begin{array}{ll}0.109 & 1.009 \\ 0.000 & 0.258 \\ 0.000 & 0.069 \\ 0.005 & 0.005 \\ 0.055 & 0.200 \\ 0.019 & \frac{2072}{207}\end{array}$

SPECCIALMANITENANCE

MANTENANCE PERSCHNA

OPERATIONS PERSONNE!

HEALTH FHYSACS PERSONNEI

SUPERVISORY PERSONNG.

ENGNEERING PERSONHELL TOTAL

$\begin{array}{rr}24 & 2 \\ 1 & 0 \\ 1 & 0 \\ 0 & 0 \\ 1 & 1 \\ 27 & 3\end{array}$

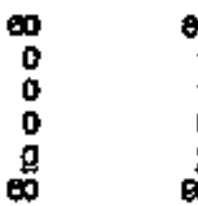

03
1
1
0
2
00

10235

0201

1,350

o.ton

$\frac{0.343}{12189}$

0.217
0.000
0.000
0.000
0.105
0.322

1.168

5.549

0.000 0.063

$0.012 \quad 0.031$

$0.017 \quad 0.017$

Q.834 0.874

WASTERROGESSING

MAINTENALCEE PERSONN NEL.

OPERATIONS PERSONNEL

HEALTHPHYY'UES PERSONNEL

SUPERUISORY PEREONNEI

EMGSNEERING PERSONMED TOTAL

0
0
2
0
0
2

$\begin{array}{ll}0 & 2 \\ 0 & \\ 0 & \\ 0 & \\ 0 & \\ 0 & 2\end{array}$

$\begin{array}{rr}22 & 2 \\ 0 & \\ 1 & \\ 0 & \\ 23 & \end{array}$

22
0
3
0
0
25

12.180

$\begin{array}{lrr}0.200 & 14.592 & \mathbf{5 . 1 1 4} \\ 0.000 & 0.0 \% 3 & 0.481 \\ 0.006 & 0.314 & 1.712 \\ 0.000 & 0.107 & 0.107 \\ 0.167 & 0.009 & 0.719 \\ 0.472 & \mathbf{1 5 . 4 7 5} & \mathbf{2 . 1 5 3}\end{array}$

BEFIJALW.NS

MANTENANCEPERSONNEL

OPERATIONHS PERGONNEI

HEALTHPHYSICS PER6ONNEL

SUPERMSORY PERSONNEL

ENGINEEPING PERBONNEL

TOTAL.

$\begin{array}{ll}3 & 0 \\ 0 & 0 \\ 1 & 0 \\ 0 & 0 \\ 0 & 0 \\ 4 & 0\end{array}$

\section{1}

\section{4}

0

1

量

0.002

$0 . \infty$

0.797

0.000

poos

0.74

$\begin{array}{lll}0.000 & 5.408 & 5.496 \\ 0.000 & 0.065 & 0.005 \\ 0.003 & 0.054 & 1.424 \\ 0.000 & 0.000 & 0.000 \\ 0.000 & 0.000 & 0.005 \\ 0.003 & 0.215 & 0.002\end{array}$

TOTAL BY_OBFLNCGION

MAINTENANCE PERSONNIEI

OPERATIONS FERSONWE

HERLTHPHYSICS PERSONINEL

SUPERYSORY PERSONNEL

ENGINEE⿱㇒木NANG PERSONNEL

$\begin{array}{ll}50 & 4 \\ 30 & 0 \\ 0 & 1 \\ 0 & 0\end{array}$

$\begin{array}{llll}0.100 & 0.000 & 0.085 & 0.189 \\ 0.004 & 0.000 & 0.000 & 0.004 \\ 0.001 & 0.000 & 0.011 & 0.072 \\ 0.000 & 0.000 & 0.000 & 0.000 \\ 0000 & 0.000 & 0.000 & 0.000 \\ 0.108 & 0.000 & 0.0003 & 0.234\end{array}$

$\begin{array}{rr}145 & 16.029 \\ 39 & 8.700 \\ 27 & 6.790 \\ 1 & 0.000 \\ 13 & 1.109\end{array}$

$\begin{array}{lll}0.600 & 20029 & 39357 \\ 0.000 & 0.324 & 10,005 \\ 0.134 & 1.412 & 8.330 \\ 0.000 & 0.164 & 0.164 \\ 0.391 & 0.946 & 2506\end{array}$

$\begin{array}{llll}34.327 & 1.224 & 24.975 & 00.420\end{array}$

Workers may be counted in moro than one rodegry. 
REACTOR OPS \& SLYH

MAINE GNAWHE PERSDNNEL

OPERATIONS PEREONNNEL.

HEALTH PHYS|CS PERSONWEL

SUPERVISORY PERSONNE

GNGNEERING PERSONWETOTAL

$\begin{array}{rr}6 & 0 \\ 14 & 0 \\ 15 & 0 \\ 0 & 0 \\ 0 & 0 \\ 35 & 0\end{array}$

6
14
15
0
0
35

2160

$4.2 \times 5$

4,520

0.121.

우요

11.058

0.007
0.000
0.005
0.01
0.013
0.024

0.084

0.112

0,002

0.193

0.407

\section{1}

ROUTWE MAINTENANCE

MANTE UAKCE PERSONNEL

OPERATIONS PERSONNEL

HEALTHPHYSIOS PERSONNEL

SUPERUISORY PERSONNEL

ENGINEERING PERSONNE

$$
\text { TOTAL }
$$

2
0
0
0
0
2

0
0
0
0
0
0

1.271

0,000

0.079

0.003

0,047

1.394

0.021

0.00

$0, \infty$

0.00

C.cos

ONon

1,050

0,005

0,000

0.012

0,009

1.002

$4.3 \%$

0.124

$\frac{1.105}{12297}$

1LSERUICEJNSEECTICN

MANTENANCE PERSONNEL

OPERATIONS PERSONNEI

HEALTH PHYSHSS PERSONNEL

SUPERVISORY PERBONNEL

ENGINEERING FERSONWEL TOTAL

$\begin{array}{ll}0 & 0 \\ 0 & 0 \\ 1 & 0 \\ 0 & 0 \\ 1 & 0 \\ 2 & 0\end{array}$

\section{0}

0.052

0.000

0.419

0.001

0.479

0.551

0000

0000

0.000

0.000

0.000

a.000

0.052

0.000

0.000

0.000

0.141

$0.1 \mathrm{BS}$

2008

o.oos

0.073

0015

ong?

2513

GPECIAL-MANTIENANCE

MAINTENANCE PERSONNEL

OPERATLNS PERSONNE

HEALTHPHYSICS PERSONMEL

SUPERVISCRY PERSONNEL

ENIBINEERING PERSONN티 TOTAL

38
0
4
0
2
42

a.t.2

0.140

$\uparrow .042$

0.068

1.015

a341

0000

0.000

0,00

o.n.g.

2.621

0.005

0.034

0,000

0,24

0.104

0,000

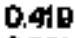

0.001

QB.5\%

1.144

\section{WAETE PROCESSHAG}

MANTENANCE PERSONNE

OFERATIONS PERSONNEL

HEALTH PHYSJCS PERSONNE

SUPERVISORY PERSONRA

ENONEERING PERSONNG TOTAL

0
0
$\mathbf{5}$
0
0
$\mathbf{0}$

0
0
0
0
0
0

0.00

0.000

1.436

0.000

$\mathrm{g}, 03$

1.:DO

0.58

11.034

0.15

1. 1878

0.068

1279

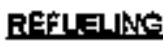

MAINTENANCE PERSONNE.

OPERATIONS PERSONNEL

HEALTH PHYSICS PERBONNEL

SUPERVISORY PERSONNE

ENGINEERWG PERSOANUE

TOTAL

80
38
14
194

$\begin{array}{rrr}27 & 16 \\ 0 & \\ 0 & \\ 0 & \\ 0 & & \end{array}$

0,000

000

0.00

0.000

Q.000

0000

0,009

0,000

0.017

0.000

o. 0 \%

0.009

0.068

0.000

$1.4 \times 3$

0.000

0.109

TOTAL BY JOB EUNXTLON

MA NT GNANCE PERSONWEL OPERATIONS PERSONNEL

HEALTH FHYSICB PERSONWEL,

SUPERVISORY PERSONNEL

ENGINEERNG PERBONAE

NEL 13

$\begin{array}{rr}27 & 17 \\ 0 & \\ 0 & \\ 1 & \end{array}$

$\begin{array}{rr}160 & 28 \\ 0 & 3 \\ 35 & \\ 54 & \\ 200 & \end{array}$

40,582

10.400

a.res

3ast

7345

6.070

0,304
0.000
0.000
0.120
0.05
0.029

69,024

0.527

11.50

2240

38.130

109.782

107.910

10730

18,340

A.s.

4960

186861

$\begin{array}{rr}178 & \\ 0 & \\ 5 & 6 \\ 54 & 11\end{array}$

$\begin{array}{rrrr}52.710 & 0.673 & 62050 & 124.489 \\ 14.841 & 0.000 & 0.414 & 15.265 \\ 14.875 & 0.003 & 11.718 & 28.390 \\ 4.155 & 0.121 & 2.257 & 6.55 \\ 9.248 & 0.284 & \$ 8.715 & 46.827\end{array}$

GRAND TOTALS

278

28

302

+os

\$2.280

10,001

113.154

279504

Workers mesy be counted h more than ond categary. 
MORK AND

JOB FUNCTION

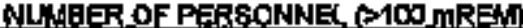
\$TATION UTILITY COWTRACT TOTAL
TOTALPERSONEREN

STATIDN UTLITY CONTRACT

TOTAL
REACTOR ORS \& SURV

AANTENANCEFERSONNEL OPERATIONS PERSONNE

HEALTH PHYSICS PERSONNEL SLPERVISORY PERSONNEI

ENGNEERNA FERSONNEL.

TOTAL

ROUTIIE MANTENANCE

MAINTEWANCEPERSONNEL

OPERATIONS PERSONNEL

HEALTH PHYSICS PERSONNEI

SUFERVISORY PERBONNEI

ENGINEERANG PERSONNEL

TOTAL

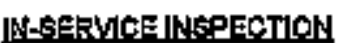

MAINTENANCEFERSONNEL

OPERATIONS PERSONNEL

MEALTH PHYSICS PERSONNEL

SUPERVISORY PERSONNEL

ENCNNEERINB PERSONNEL

TOTAL.

3
2
4
0
9

$\begin{array}{ll}1 & 0 \\ 0 & 0 \\ 0 & 0 \\ 0 & 0 \\ 9 & 0 \\ 1 & 0\end{array}$

4
2
4
0
9
10

1.240

0.756

1.300

0.012

․․명

3.55

15

11

17

0

14

1
1
0
0
0
2

7
0
0
0
0
7

2

12

17

0

1

6.17

$\mathbf{3 1 2}$

0.112

에요

18,422

b

$0 \quad 1$

0

웅

SPECIALMANTENANCE MAINTERANCEPERSONNEL OPERATIONS PERSONNA HEALTH PHYYSICS FERSONNEL SUPERVISORY PERSONNEL ENCINEERINO PERSONNEL TOTAl.

WASTEPROCESSNG MANTIENANCE PERSONNEL OPERATHONS FERSONWE HEALTH PHYSICS PERSONNEI, EUPERVISORY PERSONNEL ENEINEERLNG PERSONNE. TOTAL.

REFUETNG

MALTENANCEPERRONNEL OFERATLONS PERBONNEL HEALTH PHYYKICS PERBONWEL, SUPERVISORY PERSONNEI ENALNEERNO PERSONNEL TOTAL

TOTAL aY JOA FuJATION

NANTENANCEFER8ONNEL OPERATIONS PERSOAHEE HEALTH PHYYSICS PERSONHEL SUPERVISORY PERSONNEL

ENGINEEERDG PERSONNEI

$\begin{array}{ll}1 & 3 \\ 1 & 1 \\ 0 & 0 \\ 0 & 0 \\ 0 & 0 \\ 2 & 4\end{array}$

4
2
0
0
0
8

0,129

0.130

0.018

0,000

$0, \cos$

0 s02

3.728

Q,498

0,50

0.105

0.067

4.74

\begin{tabular}{l}
0.165 \\
0.150 \\
0,000 \\
0.004 \\
0.085 \\
\hline 0.371
\end{tabular}

nots

anes

0.004

0000

0,000

$\overline{0000}$

1.4\%8

0.00

1.305

0.018

0.050

3.778

5
0
0
0
0
5

$\begin{array}{ll}1 & 22 \\ 0 & 1 \\ 0 & 0 \\ 0 & 0 \\ 0 & 0 \\ 1 & 20\end{array}$

$\begin{array}{lll}1 & 0 & 1 \\ 0 & 0 & 0 \\ 0 & 0 & 0 \\ 0 & 0 & 0 \\ 0 & 0 & 0 \\ 1 & 0 & 1\end{array}$

\begin{tabular}{l}
2 \\
0 \\
0 \\
0 \\
0 \\
\hline
\end{tabular}

0.350
0.034
0.024
0.000
0.008
1.345

2.094
0.958
0.184
0.087
0.58
3.757

5.305

1.197

0.418

0.124

0214

$7,2+3$

15.560

8.50

4034

0.273

1.178

20.491

\begin{tabular}{|c|c|}
\hline $\begin{array}{l}1.075 \\
0.568 \\
0.028 \\
0.000 \\
0.285 \\
1.854\end{array}$ & $\begin{array}{l}1.800 \\
0.502 \\
0.180 \\
0.051 \\
0007 \\
2.720\end{array}$ \\
\hline
\end{tabular}

$\begin{array}{llr}0.092 & 7.000 & 11.433 \\ 0.131 & 0.708 & 1.307 \\ 0.000 & 0.041 & 0.397 \\ 0.009 & 0.001 & 0.114 \\ 0.005 & 0.007 & 0.079 \\ 0.039 & 7.500 & 13.404\end{array}$

$\begin{array}{rr}24 & 7 \\ 4 & 0 \\ 2 & 0 \\ 0 & 0\end{array}$

$\begin{array}{rr}7 & 217 \\ 0 & 38 \\ 0 & 44 \\ 0 & 3 \\ 0 & 0 \\ 7 & 302\end{array}$

249
42
03
3
0

11.74

5312

gess

0.171

nass

0.706

0.004

0,180

0.000

o.ten

0.200

0.249

0.20

1.082

0,000

000

1.56

C.684

0.248

2158

0.000

pops

3.174

$\begin{array}{rrr}43 & 11 & 250 \\ 17 & 2 & 40 \\ 43 & 0 & 44 \\ 0 & 0 & 3 \\ 1 & 0 & 0\end{array}$

$\begin{array}{rr}200 & 509 \\ 40 & 5 \\ 3 & \end{array}$

$\begin{array}{rr}309 & 23.59 \\ 58 & 12010 \\ 87 & 16,060 \\ 3 & 0.40 \\ 1 & 089\end{array}$

\begin{tabular}{lr}
5.080 & 83.195 \\
0.765 & 21.851 \\
0.179 & 17.700 \\
0.099 & 2403 \\
0.897 & 0.293 \\
\hline 6.897 & 125002
\end{tabular}

9.973

27.07

27.814

2.605

1.400

Z7.

$\begin{array}{rrr}9.122 & 97.684 & 1322012 \\ 2577 & 24.589 & 40.076 \\ 0.515 & 19.431 & 38.014 \\ 0.000 & 2689 & 3.157 \\ 1.802 & 0.521 & 3.215\end{array}$

109

13

357

40

5.5.674

$140 \div$

144854

214.994

Wortors may be counted In more then ane category. 
17

MANTENANCE PERSONN OPERATIONIS PERSONNII

HEALTH PHYSICS FERSONNE. SUPERVISORY PERSONNEL ENGINEERWG PERSONNE

TOTAL

ROUTINE MALLTENANCE.

MATINTENANCE PERSONNNA

OPERATIONS PERSONNEI

HEALTH PHYSICS PERSONVE-

SLFERVISORV PERSONNE

ENGNEERNG PERSONHEI

TOTAL

HLSERMCE ANSPECTON

MAINTENANCE PERSONNE

OFERATONS PERBONNEI.

HEALTH PHYSTCS PERSONNEL

SLFERVISORY PERSONNEL

GNCINEERING PERSONMVE

TOTA시

SPECIAL MAINTENANACE.

MAINTENANCE PERSONNEL,

OPERATONS PERSONNEL

HEALTH PHYEICS PEROONNEL

SLFERVISORY PERSONNEL,

ENGINEERING PERSONMEL

TOTAL.

2
0
0
0
0
2

23
0
11
0
2
39

45
3
13
1
10
72
STATION UTILTY

CONTRACT

TOTAL

$\begin{array}{rr}23 & 617 \\ 25 & 12 \\ 2 & 12 \\ 0 & 800\end{array}$

$\begin{array}{rr}617 & 848 \\ 10 & 83 \\ 125 & 202 \\ 8 & 13 \\ 42 & 122 \\ 800 & 120\end{array}$

0.178
0.027
0.003
0.009
0.112
0.334

0.002
0.060
0.000
0.000
0.000
0.000

\subsection{8}

0.000

0.115

0.000

0.000

0.234

0.206

0.027

0.123

0,000

ans

0.570

82.152
0.724
30.004
1.051
10.59
134.180

11.192

6.100

0289

0.000

2114

248.507

1.047

38.643

2898

1229

19.704

301.454

$\operatorname{scos51}$

1680

4003

4019

24.983

450

22
3
10
1
8
44

$\begin{array}{rr}22 & 10 \\ 0 & \\ 3 & \\ 117 & 16\end{array}$

107
4
35
4
15
$1 \frac{15}{65}$

0.583

0.054

0.043

0.018

0.37

1.071

\subsection{8}

0.001

0.000

0000

0.000

0.887

1.412

2001

0,000

0.017

0,129

$\frac{0.117}{1.075}$

0.05

0,000

0.147

0.40

2839

64
13
37
1
124
124

81
1
14
4
4
104

14
20
51
5
15
240

0.752

0.180

0.065

$\mathbf{0 2 7 2}$

1.400

0.140

0.060

0.000

0.000

$0 \mathrm{0rga}$

0.240

2256

0.000

0.084

0.139

0.195

3.176

0,137

0,264

024

0 닥

MAETE PROCESEINR

MALNIENANCE PERSONNEL

OPERATIONS PERSONNEL

HEALTH PHYSICS PERBONNEL.

10

3

$\$ 3$

20
15
63
0
0
104

37
21
97
0
1
158

oses

1.527

7540

0,000

000

2035

0.282

1,03

$0.0 \%$

0.000

$\frac{0.241}{1.621}$

2077

4,320

$$
\text { TOTAL }
$$

49
5
1
17
80

$\begin{array}{rr}3 & 129 \\ 3 & 4 \\ 1 & 11 \\ 0 & 3 \\ 3 & 7 \\ 10 & 154\end{array}$

160
12
21
4
24
244

16000

0.259

$1.34 \mathrm{~B}$

0.028

1378

19860

\subsection{0 \\ 0.141 \\ a.00 \\ 0.000 \\ 0.372}

1020

osts

6,799

17360

0.000

이요

24.672

$1, \operatorname{tas}$

i.s.0

24.973

0.000

0.291

30.98

TOTAL BY JOP FUNCTION MAINIENANCE PERSONWEL OPERATIONS PERSONNEL HEALTH PHYSICS PERSONNEI SUPER VISORY PERSONNEL ENGNEERING PERSONME

$\begin{array}{rlr}302 & (201) & 41 \\ 72 & (40) & 30 \\ 105 & (74) & 4 \\ 9 & (5) & 0 \\ 77 & \text { (35) } & 11\end{array}$
(28) 89
(6) 1334
(2) 36
(17) 145
(0) 18
(8) 27
(i) 62 (40) 160

$\begin{array}{rr}\text { (158) } & 101.155 \\ \text { (97) } & 11.699 \\ \text { (21) } & 3211 \\ \text { (15) } & 1.791 \\ \text { (a) } & 12650\end{array}$

13.114

7.334

0 oss

0,000

2777

38.541

se.84

$0.045 \quad 0.457$

0.02321 .579

$0.005 \quad 0.096$

0 os 2000

40.172 91.084

GRAND TOTALS

6es (380) 84

(E0) 1327

(832) $2100(1254) \quad 168,462$

zast

$\begin{array}{rr}249.357 & 400.603 \\ 7.092 & 26.065 \\ 30.409 & 80.008 \\ 4.201 & 5.052 \\ 12.005 & 28.408\end{array}$

Woikers may be courted ln morathes one categary. Numbers in parentheses ere tctal numbers of individuals. 
1995

PLANT:

REACTOR OPB R SUTRV

MANT GNANCE PERSONWE

CFERATIONS PERSONNEL

HEALTH FHYSACS PERSONNEL

SUPERVISORY PERSONNEL

ENONEERNG PERSONNEL

$$
\text { TOTAF. }
$$

$\begin{array}{rr}2 & 0 \\ 14 & 0 \\ 2 & 0 \\ 0 & 1 \\ 0 & 0 \\ 10 & 1\end{array}$

$\begin{array}{rr}0 & 2 \\ 1 & 15 \\ 0 & 2 \\ 0 & 1 \\ 0 & 0 \\ 1 & 20\end{array}$

15

2

量

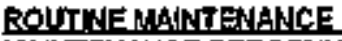
MANTENANGE PERSONNEE OPERATIONS PERSONNER

HEALTTHPHYYSOS PERSONNEL SLPERVISORY PERSONWEL

EXGGNEERING PERSONWEL TOTAL

$\begin{array}{rrrr}30 & 3 & 147 & 160 \\ 23 & 6 & 7 & 30 \\ 10 & 0 & 49 & 65 \\ 2 & 6 & 9 & 5 \\ 0 & 2 & 97 & 39\end{array}$

$\begin{array}{rr}165 & 6.900 \\ 30 & 2008 \\ 65 & 4.054 \\ 8 & 0.000 \\ 39 & 0.000 \\ 330 & 13.452\end{array}$

N-SERVCEINSPECTKN WNINTENANCE PERSONNEL OPERATIONS PERSONNEl

HEALTH PHYSICS PERSONNNE SUPERWISORY PARSONNEL ENGINEERING PERSONNEL TOTAL

$\begin{array}{ll}0 & 1 \\ 0 & 1 \\ 2 & 0 \\ 0 & 1 \\ 0 & 1\end{array}$

SPECIALMANTESSANCE

MANTENANCE PERSONNEL

OPERATIONS PERSONNEL

HEALTH PHYSTCS PERSONNEL

SUPERVISORV PERSONNEL

ENGINEERING PERSONNEL TOTAL

WASTEPROCESSING

MANTENANCE PERSONN主

OPERATIONS PERSONNEI

HEALTH FHYSTCS PERSONNE!

SUPGRVISORY PERSONWVE

ENGWNEERING FERBONDEEL TOTAL

REFUENAG

MANT UNANCE PERSONNIEL

OFERATIONS PERSONNEL

HEALTH FHYB|CS PERSONNEL

SUPERVISORY FERSON"NEL

ENGWEERING PERSONNEL TOTAL.

$\begin{array}{ll}1 & 0 \\ 0 & 0 \\ 1 & 0 \\ 0 & 0 \\ 0 & 0 \\ 2 & 0\end{array}$

$\begin{array}{ll}0 & 3 \\ 0 & 1 \\ 0 & 1 \\ 0 & 0 \\ 0 & 0 \\ 0 & 6\end{array}$

4
1
2
0
0
7

$\begin{array}{rr}5 & 1 \\ 3 & 0 \\ \mathbf{3} & 0 \\ 0 & 0 \\ 0 & 0 \\ 16 & 1\end{array}$

1
0
0
0
0
1

17
1
18
0
1
37

23
4
26
0
1
54

0.000

0.000

0.012

0.00

ocm

0.012

0.000

0,000

0.002

0,000

0,000

0.002

$\begin{array}{rr}28 & \\ 8 & \\ 1 & \\ 2 & \\ 0 & \\ 37 & 1\end{array}$

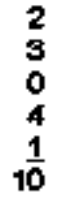

75
3
17
0
24
110

105

14

18

10

0.468

0.152

0,30

0,000

gogo

0.94

$\begin{array}{rr}6 & 7 \\ 48 & 10 \\ 30 & 0 \\ 4 & 12 \\ 0 & 4\end{array}$

$\begin{array}{rr}242 & 318 \\ 13 & 71 \\ 80 & 110 \\ 0 & 10 \\ 02 & 60\end{array}$

TOTAL BY JOA FUNCTION MANTENANCE PERSONNES OPERATICNS PERSONNEI HEALTH PHYSCS PERSONNEL EUPERVISORY PERSONNE ENGNEERNG FERSONNEL

$\begin{array}{rr}7 & 2 \\ 10 & 1 \\ 0 & \\ 12 & \\ 4 & \end{array}$

$\begin{array}{lll}0.000 & 0.000 & 0.138 \\ 0.000 & 0.007 & 1.415 \\ 0.000 & 0.000 & 0.000 \\ 0,00 & 0.000 & 0.000 \\ 0.00 & 0.009 & 0.000 \\ 0,000 & 0.097 & 1.57\end{array}$

\begin{tabular}{|c|c|c|c|c|}
\hline $\begin{array}{r}318 \\
71 \\
110 \\
16 \\
6\end{array}$ & $\begin{array}{l}9.501 \\
3802 \\
4.009 \\
0.584 \\
0.000\end{array}$ & $\begin{array}{l}0.650 \\
1.349 \\
0.000 \\
1.009 \\
0.357\end{array}$ & $\begin{array}{r}35.857 \\
1.587 \\
11.211 \\
0.000 \\
14.181\end{array}$ & $\begin{array}{r}45.008 \\
6.797 \\
15.910 \\
1.682 \\
14.51 d\end{array}$ \\
\hline 57 & $18.5 \%$ & 3.403 & 620038 & 84.805 \\
\hline
\end{tabular}

Workers mey be counted h more than one celegery. 
TOTALPGREON-REM

REACTOR OPS \& SWFY

MADYTEAANCE PERSONDE

OPERATTONS PERSONNEL

HEALTH PHYYSICS PERSONREE

SUPERVISCRY FERSONNE

ERHGINEERING PERSONNEZ TOTAL

$\begin{array}{ll}90 & 2 \\ 63 & 3 \\ 58 & 3 \\ 13 & 6 \\ 24 & 6 \\ 238 & 20\end{array}$

$\begin{array}{rr}2 & 159 \\ 3 & 7 \\ 3 & 55 \\ 8 & 0 \\ 6 & 9 \\ 2 & 257\end{array}$

$\begin{array}{rr}159 & 248 \\ 7 & 60 \\ 55 & 116 \\ 0 & 19 \\ 9 & \text { 望 } \\ 25 & 485\end{array}$

387

113

MAINTEKANCE PERSONNE

OPERATTONS PERSONNEL

HEALTH PHYSICS PERSONW:Z

SUPERVISORY PERSONNE

ENGNEERNG FERSONNEI

TOTAL

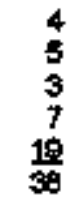

9
00
0
000

484

60

137

110

203

19

48

$\begin{array}{rr}16 & 0 \\ 6 & 1 \\ 23 & 4 \\ 2 & 5 \\ 7 & 20 \\ 7 & 53\end{array}$

48
4
38
0
109
199

84
11
70
701
709

2.427

MAINTENANCE PERSONHE-

OPERATKONS PERSONNEL

FEALTH PHYYICS FERBONM:日.

SUPERMSORY PERSONNE

$$
\text { TOTAL }
$$

33

MAINTENANCE FERSONINA

OPERATTONS PERSONNEL

HEALTH PHYSICS PERSONNEL

SUPERVISCRY PERSONNA

ENGINEERING PERSONNEL TOTAL

WASTE PROCESSNG

MANT ENANCE FERSONNEE

OPERATIONS PERSONNEL

HEALTH PHYSICS PERSONNEL

SUPERVISORY PERSONNVI

ENGINEERING PERSONNZR TOTAL

$\begin{array}{rr}3 & 250 \\ 2 & 10 \\ 1 & 19 \\ 5 & 2 \\ 5 & 72 \\ 16 & 90\end{array}$

371
45
72
18
88
85

$\begin{array}{rr}0 & 19 \\ 0 & 1 \\ 0 & 17 \\ 0 & 0 \\ 0 & 1 \\ 0 & 38\end{array}$

27

$\begin{array}{rl}0 & 0 \\ 0 & 0 \\ 34 & 0 \\ 0 & 0 \\ 0 & 0 \\ 42 & 0\end{array}$

10
1
17
0
1
38

51

51

80

2,001

0,073

0.78?

9.,005

29.103
1.606
20.400
3.365
3.242
0.1689

पTILIT

CONTRAC

TOTAL

REFUEUNG

MANT ENANCE PERSONNE

OPERATIONS PERSONNAEL

HEALTH PHYSICS PERSONWEL

SUPERVISORV PERSONIJE

ENENNEERING PERSONNEL TOTAL

10
1
7
5
3
28

0
1
0
0
3

$\begin{array}{rr}21 & 3 \\ 3 & \\ 8 & 15 \\ 0 & 21 \\ 36 & 2\end{array}$

$\begin{array}{rl}3 & 0.450 \\ 5 & 0.078 \\ 15 & 0.04 \\ 5 & 1.5 \% \\ 20 & 0.17 \\ 82 & 200\end{array}$

7.729
0.829
2604
0.487
1.808
19444

$0 \operatorname{ses}$

0.334

0.008

0.245

0.242

1.48

\begin{tabular}{|c|c|c|}
\hline $\begin{array}{l}0.682 \\
0.145 \\
0083 \\
0.158 \\
0.818\end{array}$ & $\begin{array}{r}0.708 \\
1.197 \\
7.288 \\
0.000 \\
\text { B.368 }\end{array}$ & $\begin{array}{r}50.499 \\
2690 \\
28.77 \\
3540 \\
12.48\end{array}$ \\
\hline & 8 & 145.131 \\
\hline
\end{tabular}

$0, \infty$

a.ton

11.47

0.126

0.810

102

0.079

8.50

0.918

0.000

$11.5 \%$

51.757

69.42

note

E4970

TOTAL EY JOB FUNCTIDN

MANTENANCE PERSONMEI

OPERATTONS PERSONNEL

HEAL.TH PHYSICS DERBONNEI.

SLIPERMSORY PERSONNEI

ENGINEERINO PERSONNEL

$\begin{array}{ll}209 & \\ 145 & 12 \\ 203 & 11 \\ 66 & 29\end{array}$

9
12
11
23
6

$\begin{array}{rr}807 & 1175 \\ 34 & 169 \\ 197 & 461 \\ 2 & 74 \\ 27 & 413\end{array}$

41,658

10.830

34.253

$6.2 \times$

a.sie

0.187

0.000

3.20

0.000

0,000

$\frac{0.000}{3.453}$

\begin{tabular}{rr}
60.078 & 60.404 \\
1.253 & $24 \times 8$ \\
0.549 & 3.251 \\
0.282 & 0.804 \\
18549 & 20.447 \\
\hline 0.709 & 65.581
\end{tabular}

0,000

0,000

0.000

0,00

omo

0म00

0.405

0.79

0.39

0,0

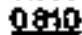

25

0.502

0739

3.65

0,000

OAd

5,606

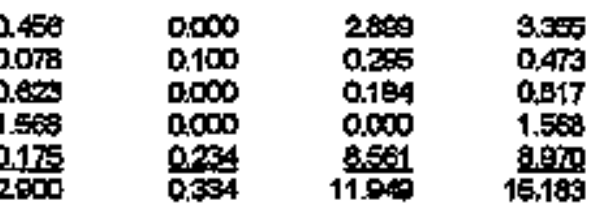

CRAMP TOTALS

832

110

$13 \%$

2314

90507

1300

145398

3.004

188.356

1.165

0.800

24917

0.20

15,0005

5xes4

1.446

89083

7.397

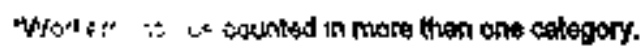


WORK AND Jos Futction
NLMBER OF PERSONNIL OACO mREN STATION UTILITY CONTRACT TOTAL
TOTALPEREONLREY

STATION UFLTY CONTRACT TOTAL

REACTCR OPS \& SIIRY

MANTENANCE PERSONNEI OPERATHON'S PERSONNEL

HEALTH FHYSIKS PERSONNE

S्GUPERVISORY PERSONN]

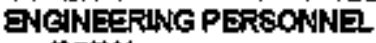
TOTAL

ROUT:NE MA|lSTENANCE

MANT GHANCE PERSCNNEL OPERATIONS PERSONNEL

HEALTH FHYSTCHS PERSONNEI

SUPERVISORY PERSONWE.

ENGINEERING FERSONNE. TOTAL

IN-SESEMLE INSPECTION MAINTENANCE PERSONWEL OPERATIONSPERSONNEL HJALTH PHYSICS PERSONNEL SUPERVISORY PERSONWG. ENCINESRNG PERSONNE TOTAL

SPECHAL WANTENAKCE MANTENANCEE PERSONNEL DPERATIONS PERSONNEE HEALTHA PHYSIOS PERSONNEL \$LYPERVISORY PERSONNEL. ENGNNEENMG PERSONNEI TOTAL

WASTEPROCESSWN MAWTENANCE PERSONNEL OPERATIONS PERSONNEL

HEALTH FHY'ICS PERSONNEL SUPERVISORY PERSONNEL ENCINEERNNE PEREONNEL TOTAL

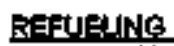

MANTENANCEPERSONNEL OPERATHONS PERSONNEL

HEALTH PHYSICS PERSOANAE. BUPERVISCRY PERSONDVZ ENCINEERNO PERSONNAL TOTAL

IOTALRY JOB FuNCTIN MANTENANCE PERSONWEL OPERATHONS PERSONNEL HEALTH PHYSICS PERSONNEL SUPERVISOFY PERㅇNN토. ENGINERRIG PERSONNEL

5
5
0
0
50

0
2
0
0
4

1
2
2
0
0
5

8
44
7
0
2
5

2172
11.291
1.207
0.009
0.000
14809

\subsection{7}

\subsection{7}

0.002

0,00

13 ing

2004

263

28

55

1

녹

3
8
0
0
7
18

234
86
97
0
0
414

40

130

142

7

$\begin{array}{ll}1 & 0 \\ 0 & 5 \\ 0 & 0 \\ 0 & 0 \\ 0 & 0 \\ 1 & 5\end{array}$

$\begin{array}{rrr}69 & 0 \\ 1 & 0 \\ 00 & 0 \\ 0 & 0\end{array}$

1
0
14
0

0
1
0
0
0
1

0
6
0
0
0
12

7
11
0
0
0
18

DATP

\subsection{1}

0.068

0.00

nom

0.988

100
2
22
0
125

\section{3 \\ 0.400 \\ 6.005 \\ 0,00 \\ nom \\ 2802}

0
1
14
0
2
20

1200

0.10

5228

o.to

$0 \times 0$

6.67

$0.7 \mathrm{te}$

3.770

0.002

0.000

2509

1.POT

ops

1.288

aspo

0,00

ans

2761

3.165

13.244

1.928

ocos

1.318

1964

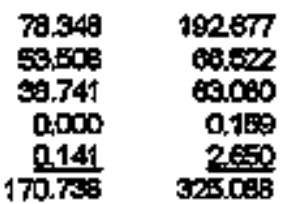

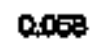

1.005

0.000

0.000

gerg

1.75

1.85

1.960

0.002

000

0,044

3.841

2.212

3.400

0.070

0,000

0.034

6.309

\begin{tabular}{|c|c|}
\hline $\begin{array}{l}0.003 \\
0.063 \\
0.000 \\
0.00 \\
0.00 \\
0.03\end{array}$ & $\begin{array}{r}11.681 \\
0.495 \\
0.945 \\
0.000 \\
0.089 \\
13.187\end{array}$ \\
\hline
\end{tabular}

\subsection{8}

0,012

0.000

0.000

0.779

0.800

\subsection{8}

0.35

0.65

0,000

pose

2678

2.804

0560

Soss

0.000

0.871

估傮

$\begin{array}{llll}1.157 & 0.000 & 0.311 & 1.488 \\ 1.097 & 0.113 & 0.021 & 2.021 \\ 0.020 & 0.000 & 0.003 & 0.028 \\ 0.000 & 0.000 & 0.000 & 0.000 \\ 0.000 & 0.141 & 0.000 & 0.141 \\ 3.064 & 0.254 & 0.003 & 3.050\end{array}$

$\begin{array}{rrrrrrr}305 & (267) & 3 & (3) & 280 & (271) & 588 \\ 0 & (73) & 10 & (9) & 103 & (10) & 190 \\ 03 & (50) & 0 & (0) & 92 & (92) & 185 \\ 1 & (1) & 0 & (0) & 0 & (0) & 1 \\ 0 & (0) & 13 & (13) & 0 & (0) & 13\end{array}$

$\begin{array}{rr}(541) & 169.274 \\ (1105) & 20.476 \\ (151) & 35.946 \\ (1) & 0.168 \\ \text { (13) } & 0.000\end{array}$

$0.8 \times$

5.770

0.004

0,000

5.647

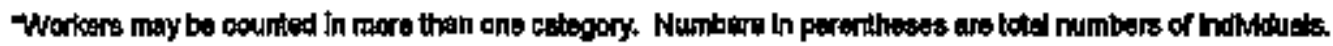


REACTOR ORS \& SINRV

MANTENANCE PERTONN

OPERATIONS PERSONWEL

HEALTH FHYSYCS PERSONWEL

SUPERVISORY PERSONNEI

ENOWEERING PERSONNEL

TOTAL.

$\begin{array}{ll}0 & 0 \\ 0 & 0 \\ 0 & 0 \\ 0 & 0 \\ 0 & 0 \\ 0 & 0\end{array}$

0
1
0
0
0
1

0
1
0
0
0
1

0.052
0.800
0.634
0.051
0.110

0.000
0.000
0.000
0.000
0.000
0.000

0.056

0.106

0

o.

$\begin{array}{ll}0 & 0 \\ 0 & 0 \\ 0 & 0 \\ 0 & 0 \\ 0 & 0 \\ 0 & 0\end{array}$

0
0
0
0
0
0

0
0
0
0
0
0

1. 107

1.30

0.257

0.052

0.001

do.t.

1.892

TOTAL

N-SERVCE INSPESTION

MAINTENANCE PERSONNEI

OPERATIONS FERSONNEL

HEALTH PHYSICS PERSONNAL

SUPERWISORYPERSONNEI

ENGINEERTNO PERSONINEL

TOTA!

SEECIALMAINTENANCE

MAINTENANCE PERSONNEL

OPERATIONS PERSONNAE

HEALTH FHYSICS PERSONNNEL

SLLPERVISORY PERSONNAEL

ENGWEERING PERSONANE

TOTAL

\section{WASTE PROCESGING}

MAINTENANCE FERSONNA

OFERATIONS PERSONNEI

HEALTH PHYEICS PERSONNEL

SLPERVISORY PERSONNEL.

EMGNEEFING PERSONWEL

TOTAL

0
0
0
0
0

0
0
0
0
0
0

0
0
0
0
0
0

0,000

0.000

0.000

a,

0.000

0.000

0,001
0,000
0,000
0,000
0,000
0,001

0.778

0.044

0.031

0.013

E.500

1.016

0.678

0,062

0.198

2007

\section{Refuglune}

MAINTENANCE PERBONWEL

OPERATIONS PERSONNEL

HEALTH PHYSICS PERSONNEL,

SLIPERVISORY PERSONNEL

ENGINEEFING PERSONMNEL

TOTAL

$\begin{array}{ll}3 & 0 \\ 0 & \\ 0 & 0 \\ 0 & 0 \\ 0 & 0 \\ 0 & 0\end{array}$

2
0
0
0
0
2

1.480

0.342

0349

0.060

0.080

$250 \%$

0,000
0.000
0.000
0.000
0.000
0.000

0,400

0.000

0,009

1.274

2167

0.723

0.272

0.067

a.0.5

3,207

$\begin{array}{ll}0 & 0 \\ 0 & 0 \\ 1 & 0 \\ 0 & 0 \\ 0 & 0 \\ 1 & 0\end{array}$

0
0
0
0
0
0

o.0.s

0.070

0.579

0.001

o.cos

0.000

0.000

0,000

0,000

0,000

0.000

0.000

0.000

0.000

o.cos

0,000

0.000

0.000

0.000

$0 \times 000$

0.000

TOTAL BY JOS FLMCTION MAINTENANCE PERSONWEI OPERATIONS PERSONNEL HEALTH PHYSICS PERSONNEL SUPERVISORY PERSONNAL

ENGANEEFUNB PERSONNEI

$\begin{array}{ll}0 & \\ 0 & 0 \\ 0 & 0 \\ 0 & 0 \\ 0 & 0\end{array}$

$$
\begin{aligned}
& 0 \\
& 0 \\
& 0 \\
& 0 \\
& 0 \\
& 0
\end{aligned}
$$

0.000

0.000

0.000

0,00

0.000

0.000

0.000

0,000

0,000

0,000

0.000

0.000

1052

0.205

0.017

0.000

$\frac{0.151}{1.486} \quad \frac{0.734}{3801}$

2,512

0.637

0.35

$0.0 \pm 0$

GRAND TOTALS 4

\footnotetext{
Workats mey be counted in more then ane cetegory.
} 
WORK AND

JOB FUNCTRON
NLMABER OF PEREONNEL PAOOMREYN STATHON UTILITY CONTRACT TOTAL
TOTAL PERSONHREM STATHON UTIUTY CONTRACT TOTAL
REACTOR OPSB SLEV

MAINTENANCE PERSONNEI. OPERATIONS PERBONNAZ

HEALTH PHYYSICS PERSONNEL

STJPERVISORY PERSONNEI

ENGEINEERNNO PERSONNIEL TOTAL

ROUTIN= MAINTEMANCE

MANTENANCE PERSCNNE

OPERATIONS FERBCNNE

HEALTH PHYSICS PERSONNEL

SUPERWISORY PERSONNEL

ENGINEERING PERSONNE. TOTAL.

\section{MASSRWCE MEPECTION}

MANTENANCE PERSONNEL

OPERATIONS FERSONNAZ

HEALTH PHYYSFS PERSONMEL

SUPERVISORY PERSONNEL

ENGINEERING PERSONNEL TOTAL.

201
312
80
128
108
800

\begin{tabular}{rr}
4 & 338 \\
54 & 43 \\
1 & 207 \\
8 & 29 \\
8 & 14 \\
\hline 5 & 13
\end{tabular}

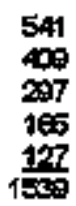

215

281

58

$\frac{89}{700}$

11
44
0
3
10
63

$\begin{array}{rr}11 & 851 \\ 44 & 28 \\ 0 & 162 \\ 3 & 50 \\ 15 & 11 \frac{38}{68}\end{array}$

1077

303

240

122

$1 \frac{126}{895}$

$\infty 9$
50
37
25
$1 \frac{13}{197}$

$\begin{array}{rr}0 & 294 \\ 1 & 4 \\ 0 & 57 \\ 1 & 8 \\ 1 & 37 \\ 3 & 30\end{array}$

$\cos$

58

. 84

34

$\frac{48}{85}$

SPECIAL MAINUENANCE

MANNTENANCE PERSondue

OPERATIONS PERSONNEL

HEALTH PHYSICS PERSONNEL

SLFERVISORY PERSONNEL

ENGINEERING PERSONWVב

TOTAL

44
24
19
11
113

\section{9}

$\begin{array}{ll}1 & 291 \\ 3 & 13\end{array}$

$0 \quad 20$

a 1

$\frac{1}{4} \quad 390$

358
46
51
34
18
477

MASTEPROCEBS웨닌

MAINTENANCE PERSONNEL

OPERATIONS PERSONNEL

HEALTH PHYSICS PERSONNEL

SIPERMSORY PERSONNEL

ENGTNEERING PERSONNAI

$$
\text { TOTAL }
$$

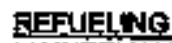

MANT ENAKCE PERSONWEL OFERATIONS PERSONNEL

HEALTH PHYSICS PERSONNEL

SLFERVISORY PERSONNEL

ENGINEERING PERSONNEL TOTAL

TOTAL BY JOS FUNGTON

MANNTENANCE PERSONNEL

OPERATIONS PERBONNEL

HEALTH PHYSICS PERSONNEI

SLFERVISORY PERSONNEL

ENCINEERINE PERSONNAEL

$\begin{array}{rr}44 & 0 \\ 30 & 70 \\ 14 & 9 \\ 3 & 9\end{array}$

$\begin{array}{lr}0 & 5 \\ 7 & 3 \\ 0 & 13 \\ 0 & 1 \\ 0 & 0 \\ 7 & 25\end{array}$

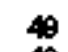

40

5

15

$19 \frac{3}{0}$

$\begin{array}{ll}20 & \\ 31 & 14 \\ 23 & \\ 17 & 0 \\ 3 & \\ 94 & 14\end{array}$

$\begin{array}{rr}14 & 4 \\ 0 & 39\end{array}$

0

14

109

BS

49

18

213

$\begin{array}{rrr}500 & 13 & 1845 \\ 711 & 123 & 95\end{array}$

206

294

250
06

4.133
21.628
10.272
2.481
0.758
30.238

0.017
0.056
0.001
0.001
0.005
0.000

70.140

5.911

13.278

5.570

$34 \%$

104271

$4.8+3$

0.191

1.778

$0 \times 91$

154

$15 A$

7.823

1.279

0.55

0.405

0.122

020

2644

$$
\begin{aligned}
& 1.377 \\
& 0.383 \\
& 0.000 \\
& 0,012 \\
& 0.098 \\
& 1.870
\end{aligned}
$$

\begin{tabular}{|c|c|}
\hline $\begin{array}{l}0,000 \\
0,020 \\
0,000 \\
0,000 \\
0,000 \\
0,002\end{array}$ & $\begin{array}{r}44.079 \\
0.285 \\
2.557 \\
3.572 \\
10.451 \\
64.584\end{array}$ \\
\hline
\end{tabular}

CNIRACT

ong

0.013
0.032
0.000
0.000
0.000
0.045

13.891

acos

0.437

0.717

$0,0 \mathrm{~s}$

$15 . \cos$

15.150

D.642

0.842

D.809

0.272

17.748

\begin{tabular}{llll}
0.078 & 0.000 & 0.009 & 0.115 \\
0.454 & 0.050 & 0.005 & 0.509 \\
0.432 & 0.000 & 0.144 & 0.576 \\
0.130 & 0.000 & 0.000 & 0.130 \\
0.001 & 0.000 & 0.009 & 0.091 \\
\hline 1.003 & 0.050 & 0.188 & 1.531
\end{tabular}

\subsection{4}

1,344

0.43

0.034

nocs

2008 .

$$
\begin{aligned}
& 0.000 \\
& 0.116 \\
& 0.000 \\
& 0.000 \\
& 0.000
\end{aligned}
$$

\begin{tabular}{|c|c|c|c|c|c|c|c|c|}
\hline $\begin{array}{l}\text { HEALTH PHYSICB PERSONNEI } \\
\text { SLFERVISORY PERSONNEL } \\
\text { ENEINEERINE PERSONINEL }\end{array}$ & $\begin{array}{l}298 \\
284 \\
280\end{array}$ & $\begin{array}{r}1 \\
12 \\
19\end{array}$ & $\begin{array}{r}580 \\
102 \\
63\end{array}$ & $\begin{array}{l}797 \\
398 \\
318\end{array}$ & $\begin{array}{l}2000 \\
9206 \\
0027\end{array}$ & $\begin{array}{l}0.001 \\
0.013 \\
0.103\end{array}$ & $\begin{array}{r}49.714 \\
7.708 \\
14.606\end{array}$ & $\begin{array}{l}75.724 \\
16.000 \\
20.790\end{array}$ \\
\hline
\end{tabular}

2546

$$
0.658
$$

0.638

006

0,000

3,808

3.140

2118

1 . 131

0.590

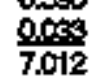

Workers moy be counted in more then one category. 
TOTAL

REACTOR OFS R EUIVY MAINTENANCE PERSONNEL OPERATIONS PERSONNEL. HEALTHIPHYGCS PERSONNEL SUPERVISORY PERSONNEL. ENENNEERNO PERSONNEL TDTAL

1
5
32
2
1

$\begin{array}{ll}0 & 0 \\ 1 & \\ 0 & 0 \\ 0 & 0\end{array}$

$\begin{array}{rr}0 & 1 \\ 0 & 55 \\ 38 & 71 \\ 0 & 2 \\ 0 & 1 \\ 30 & 130\end{array}$

0.159

13.754

13.802

0.477

0.316

$3 \times 428$

$\begin{array}{rrrr}318 & 19 & 151 & 40 \\ 10 & 0 & 0 & 10 \\ 50 & 0 & 34 & 64 \\ 10 & 0 & 4 & 14 \\ 21 & 4 & 5 & 90 \\ 400 & 23 & 194 & 620\end{array}$

142953

4505

18.521

2063

471

170.700

118

10

3

137

SUPERVISORY PERSONME

ENGINESRNG PEREONNE1. TOTAL

$\begin{array}{rr}21 & 3 \\ 0 & 0 \\ 0 & 0 \\ 1 & 1 \\ 0 & 0 \\ 22 & \frac{0}{4}\end{array}$

94
0
10
1
111

B.915

0.000

0.000

0.134

0,000

0.049

$\begin{array}{rr}47 & 1 \\ 0 & 0 \\ 0 & 0 \\ 0 & 0 \\ 0 & 0 \\ 47 & 1\end{array}$

\section{5}

MAINTENANKE PERSONWE

OPERATIONS PERSONNEL

HEALTH PHYSICS PERSONME

SUPERVISORY PERSONNEI

ENGINEERNG PERSONNE TOTAL

MASTE RROCERSINB

MAINTENANCE PERSONNAEL

OPERATIONS PEREONNEI

HEALTH PHY ICS PERSONNEL,

SUPERVISORY PERSONNE

ENGNEER'N PERSONNAE TOTAL

$\begin{array}{ll}1 & 0 \\ 0 & 0 \\ 8 & 0 \\ 0 & 0 \\ 0 & 0 \\ 0 & 0\end{array}$

28.733

0.000

0.000

0.000

ond

28.335

$$
60
$$$$
10 \frac{8}{2}
$$

\subsection{0 \\ 0,000 \\ 0.104 \\ 0.000 \\ 0.000 \\ 0.104}

\subsection{0}

0,000

12400

0,000

ondon

1249

0.119

18.714

20.405

0.477

0.3요

48.091

BEFI.EW W.

MAINTENANCE PERSONNE

OPERATIONS PERSONNNEI,

HEALTH PHYSICS PERSONWNEL

SLPERVISORY PERSONNE

ENGNEERING PERSONNEL TOTAL

$\begin{array}{rr}0 & 0 \\ 11 & 0 \\ 0 & 0 \\ 1 & 0 \\ 0 & 0 \\ 12 & 0\end{array}$

TOTALBY NOEFINCTION

MAINTENANCE PERSONNEI.

OPERATIONS PER\&ONNEL

HEALTH PI YYEICS PETESONNEL

SUPERVISORY PERSONNEL

ENGDNEERING PERSONWEL

\begin{tabular}{|c|c|c|c|c|c|c|c|}
\hline $\begin{array}{l}395 \\
70 \\
87 \\
14 \\
22\end{array}$ & $\begin{array}{r}23 \\
0 \\
1 \\
1 \\
4\end{array}$ & $\begin{array}{r}280 \\
1 \\
85 \\
5 \\
19\end{array}$ & $\begin{array}{r}707 \\
77 \\
175 \\
20 \\
45\end{array}$ & $\begin{array}{r}178.824 \\
24.972 \\
31.677 \\
2821 \\
8.027\end{array}$ & $\begin{array}{r}12357 \\
0.000 \\
0.104 \\
0.152 \\
0.688\end{array}$ & $\begin{array}{r}114.376 \\
1.310 \\
2.173 \\
1.177 \\
4020\end{array}$ & $\begin{array}{r}505517 \\
20.282 \\
60509 \\
4.130 \\
10.015\end{array}$ \\
\hline
\end{tabular}

\begin{tabular}{lllllllll} 
GRANDTUTALS & 697 & 29 & 40 & 1002 & 243,521 & 13,201 & 150,841 & 407.453 \\
\hline
\end{tabular}

Workars may be counted h more than one category. 
APPENOIX $D$ (Continated)

NUMBER OF PERSONNEL AND PERSON-REM

BY WORK AND JOB FUNCTION

1998

PLANT: TTHREE RAILE ISLAND 1

TYPE: PWR

WORK AND

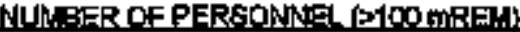

TOTAI.PERSON-REM

DOB FUNGTION

STAT|ON UTLVY GONTRAGT TOTAL STATION UTILTY CONTRACT

TOTAL

REACTOR OPSR SURV

MANTENANCE PERSONNEL

OPERATIONS PERSONNET

HEALTH PATYSCS PERSONNEL

SUPERUISORY PEFSONNEL

ENBNEERING PERSONNE TOTAL

ROUTINE MANTENANCE

MAINTENAKCE PERSONNEL

OPERATIONS PERSONNEL

HEALTH PHYSICS PAESONNEL

SUPERVISORY PERSONNEL

ENGANEERING PERBONNEL TOTAL

108

100

70

167

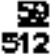

54

139

se

197

75

498

NEESHUCE INLPECTION MANTENANCE PERSONNEL OPERATOMS PERSONNEL

HEALTH PHYSICS FERSONNEL SUPERVI\$ORY PERSONNEL ENGG|NEER|NG PERSONIETOTAL.

SPECIALMAINTENANCEE

MANNTENANCE PERSONNEL

OPERATIONS PERSONNEL

HEALTH PHYSICS PERSONNEL

SLPEERVISORY PERSONNEL

ENGANEERING PERSONWEL TOTAL

31
5
19
9
70

125

50

74

$\frac{45}{43}$

WASTEPROCESSWG

MANTENANCE PERSONNEL

OPERATIONS PERSONNEI

HEALTH PHYSICS PEREONNEL

SUPERVISORY PERSONNEL

ENGINEERING PERSONNEL

TOTAL

REFUE:ING

MANTENANCE PERSONNA OPERATIONS PERSONNEL

HEALTH PHYSICS PERSONNEI BUPERVISORY PERSONNNEL ENEINEERING PERSONNEL TOTAL

TOTA! BY JOB FUNCTION

MANTENANCE FERSONNE

OPERATIONLS PGRSONNEI

HEALTH OHYSICS PERSONNEL

SUPERVSORY PERSONNA.

ENGINEERANG PERSONWNEL

\section{4}

3

13

13

$\begin{array}{rr}56 & 1 \\ \mathbf{6 3} & 0 \\ 34 & 1 \\ 35 & 4 \\ 6 & 4 \\ 106 & 10\end{array}$

5
1
4
37
7
54

$\infty$
0
20
20
14

203
109
97
243
715
715

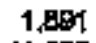

11,605

B.564

3507

1587

27

$\begin{array}{rr}507 & 50 \\ 4 & 60 \\ 1 & 50 \\ 37 & 200 \\ 18 & 104 \\ 400 & 1024\end{array}$

10264

1.043

0.278

2211

0.803

14097

0.880

0.101

0.052

1.009

nog

2163

11.874

3.742

3907

3579

226

25.415

1210

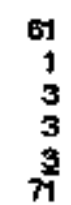

118
64
38
42
15
$\frac{15}{77}$

1.189

8.446

0.674

1.542

opio

11.811

$\begin{array}{rrr}91 & 1 & 193 \\ 85 & 0 & 0 \\ 17 & 3 & 5 \\ 40 & 5 & 11 \\ 15 & 4 & 20 \\ 25 & 13 & 209\end{array}$

205
25
62
42
496

5736

4047

0.705

$2 \cos 2$

0516

13086

50 (150) 28 (19) 1569

300 (116) 5 (ज) 8

194 (71) 10 (6) 51

538 (स) 89 (R) 138

214 (102) 39 (26) 84
(4) 394 [1\%)

(26) 255 (100)

(7iv) 708 (390)

(57) 357 (18)
(65) 2147 (1004)

0.081
0.028
0.358
0.277
0.119
0.259

2.97\%

0,000

1.058

1.280

0.178

8008

4943

$11.72 t$

10568

5.000

34284

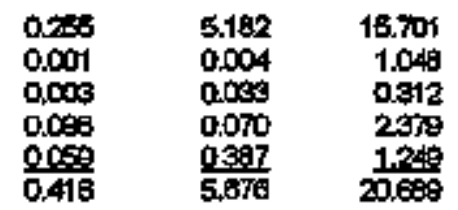

\subsection{8 \\ 0.04 \\ 0.000 \\ 0.00 \\ Q0720 \\ 0.170}

\section{5}

\subsection{0}

0.014

0.025

0.104

3.248

3.630

0.310

0.06

1.217

$0.15 \%$

$\frac{0.152}{351}$

0.020

E2545

0.000

0.327

0.134

non:

0.62

0.370

3.255

5.907

$5.7 \times 9$

108.447

10450

4.121

a.100

9.620

ging

$134,4=0$

0.107

0,000

0,000

0.000

0.000

000

3791

\subsection{0}

6.5.5

0.731

1.542

0.010

15.124

1.02

10.478

$\begin{array}{rrr}0.004 & 10.478 & 16.218 \\ 0.000 & 0.000 & 4.047\end{array}$

$0.006 \quad 0.232 \quad 0.963$

$0.142 \quad 0.603 \quad 2.800$

0.107

2818

3.44

a.70

27.49

$\begin{array}{rrrr}31.637 & 0.459 & 117.178 & 149.472 \\ 2.074 & 0.070 & 0.670 & 29.820 \\ 14.468 & 0.712 & 5.809 & 20.779 \\ 14.000 & 0.744 & 7.897 & 22.691 \\ 5.607 & 0.393 & 9.550 & 15.240\end{array}$

Workers may be coumted in more than one cetegory. Numbers in parentheses ara total numbers of indkiduab. 
APPENDIX D (Continued)

NUMBER OF PERBONNEL AND PERSON-REM

BY WORK AND JOE FUNCTION

1995

PLANT: MTHREE MILE ISLAND 2

TYPE: PWR

\begin{tabular}{|c|c|c|c|c|c|c|c|c|c|c|c|c|}
\hline \multirow{2}{*}{ 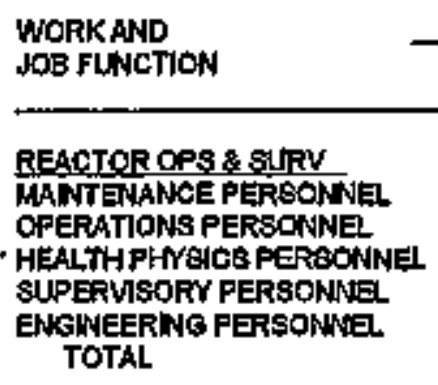 } & \multicolumn{8}{|c|}{ 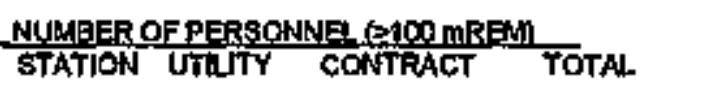 } & \multicolumn{3}{|c|}{ TOTALPERSONAREM } & TOTAL \\
\hline & 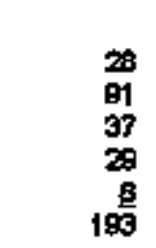 & & $\begin{array}{l}1 \\
0 \\
1 \\
3 \\
\frac{1}{6}\end{array}$ & & $\begin{array}{r}15 \\
0 \\
5 \\
8 \\
0 \\
28\end{array}$ & & $\begin{array}{r}44 \\
94 \\
49 \\
38 \\
9 \\
25\end{array}$ & & $\begin{array}{l}0.252 \\
0.255 \\
0.468 \\
0.212 \\
0.004 \\
\$ .160\end{array}$ & $\begin{array}{l}0,000 \\
0.000 \\
0.000 \\
0000 \\
0.000 \\
0,001\end{array}$ & $\begin{array}{l}0.002 \\
0.000 \\
0.009 \\
0.000 \\
0.000 \\
0.011\end{array}$ & $\begin{array}{l}0.234 \\
0.225 \\
0.451 \\
0.213 \\
0.044 \\
1.194\end{array}$ \\
\hline 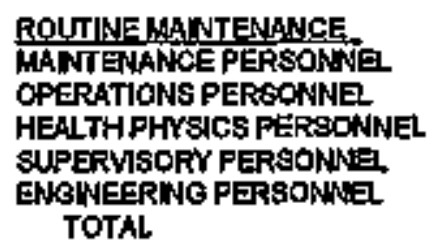 & $\begin{array}{r}57 \\
6 \\
9 \\
4 \\
2 \\
78\end{array}$ & & $\begin{array}{l}0 \\
0 \\
0 \\
0 \\
0 \\
0\end{array}$ & & $\begin{array}{l}\mathbf{s} \\
0 \\
0 \\
0 \\
0 \\
5\end{array}$ & & $\begin{array}{r}82 \\
6 \\
9 \\
4 \\
2 \\
20\end{array}$ & & $\begin{array}{l}0.008 \\
0.000 \\
0.005 \\
0.000 \\
0.004 \\
0.014\end{array}$ & $\begin{array}{l}0,000 \\
0,000 \\
0,000 \\
0,000 \\
0,000 \\
0.000\end{array}$ & $\begin{array}{l}0.000 \\
0.00 \\
0.000 \\
0.000 \\
0.000 \\
0.000\end{array}$ & $\begin{array}{l}0.006 \\
0.000 \\
0,000 \\
0.000 \\
0.001 \\
0.014\end{array}$ \\
\hline $\begin{array}{l}\text { INLSERMCE NSEECTION } \\
\text { MANTENANCE PERSONNEL } \\
\text { OPERATIONS PERSONNEI. } \\
\text { HEALTHPHWEICS PERSONNEL } \\
\text { SLFERVBORY PERSONNEL } \\
\text { ENGINEERNG PERSONWEL } \\
\text { TOTAL }\end{array}$ & $\begin{array}{r}4 \\
1 \\
3 \\
2 \\
90 \\
10\end{array}$ & & $\begin{array}{l}0 \\
0 \\
0 \\
0 \\
0 \\
0\end{array}$ & & $\begin{array}{l}0 \\
0 \\
0 \\
0 \\
0 \\
0\end{array}$ & & $\begin{array}{r}4 \\
1 \\
3 \\
2 \\
0 \\
0\end{array}$ & & $\begin{array}{l}0.343 \\
0.000 \\
0.298 \\
0.096 \\
0.090 \\
0.729\end{array}$ & $\begin{array}{l}0.000 \\
0.000 \\
0.000 \\
0.000 \\
0.000 \\
0.000\end{array}$ & $\begin{array}{l}0.000 \\
0.000 \\
0.000 \\
0.000 \\
0.000 \\
0.000\end{array}$ & $\begin{array}{l}0.340 \\
0.000 \\
0.200 \\
0.000 \\
0.000 \\
0.720\end{array}$ \\
\hline 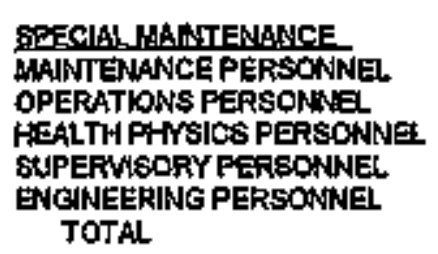 & $\begin{array}{r}8 \\
5 \\
3 \\
0 \\
0 \\
16\end{array}$ & & $\begin{array}{l}0 \\
0 \\
0 \\
0 \\
0 \\
0\end{array}$ & & $\begin{array}{l}0 \\
0 \\
0 \\
0 \\
0 \\
0\end{array}$ & & $\begin{array}{r}\mathbf{\theta} \\
\mathbf{5} \\
\mathbf{3} \\
\mathbf{8} \\
\mathbf{0} \\
\mathbf{1 0}\end{array}$ & & $\begin{array}{l}0,000 \\
0.000 \\
0.000 \\
0.000 \\
0.000 \\
0.000\end{array}$ & $\begin{array}{l}0.000 \\
0.000 \\
0.000 \\
0.000 \\
0.000 \\
0.000\end{array}$ & $\begin{array}{l}0.000 \\
0.000 \\
0.000 \\
0,000 \\
0.000 \\
0.000\end{array}$ & $\begin{array}{l}0,000 \\
0,000 \\
0,000 \\
0,000 \\
0,000 \\
0,000\end{array}$ \\
\hline 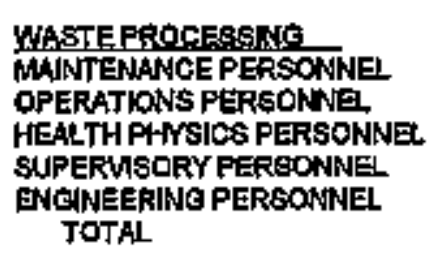 & $\begin{array}{l}1 \\
7 \\
0 \\
0 \\
0 \\
0\end{array}$ & & $\begin{array}{l}0 \\
0 \\
0 \\
0 \\
0 \\
0\end{array}$ & & $\begin{array}{l}1 \\
0 \\
0 \\
0 \\
0 \\
1\end{array}$ & & $\begin{array}{l}2 \\
7 \\
0 \\
0 \\
0 \\
0\end{array}$ & & $\begin{array}{l}0.017 \\
0.060 \\
0.000 \\
0.000 \\
0.000 \\
0.097\end{array}$ & $\begin{array}{l}0,000 \\
0,000 \\
0,000 \\
0,000 \\
0,000 \\
0,000\end{array}$ & $\begin{array}{l}0,000 \\
0,000 \\
0,000 \\
0,000 \\
0,000 \\
0,000\end{array}$ & $\begin{array}{l}0,017 \\
0,080 \\
0.000 \\
0.000 \\
0.000 \\
0.009\end{array}$ \\
\hline 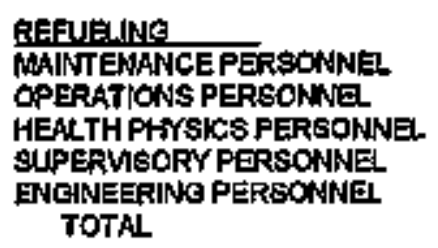 & $\begin{array}{l}0 \\
0 \\
0 \\
0 \\
0 \\
0\end{array}$ & & $\begin{array}{l}0 \\
0 \\
0 \\
0 \\
0 \\
0\end{array}$ & & $\begin{array}{l}0 \\
0 \\
0 \\
0 \\
0 \\
0 \\
0\end{array}$ & & $\begin{array}{l}0 \\
0 \\
0 \\
0 \\
0 \\
0\end{array}$ & & $\begin{array}{l}0.000 \\
0.000 \\
0.000 \\
0.000 \\
0.000 \\
0.000\end{array}$ & $\begin{array}{l}0.000 \\
0,000 \\
0,000 \\
0.000 \\
0.000 \\
0.000\end{array}$ & $\begin{array}{l}0.000 \\
0.000 \\
0.000 \\
0.000 \\
0.000 \\
0.000\end{array}$ & $\begin{array}{l}0.000 \\
0.000 \\
0.000 \\
0.000 \\
0.000 \\
0.000\end{array}$ \\
\hline $\begin{array}{l}\text { TOTALEY JOB FUNGTION } \\
\text { MAINTENANCE PERSONNEL } \\
\text { OPERATONOS PERSONNE } \\
\text { HEALTH PHYYSICS PERSONWWEL } \\
\text { SUPERVSORY PEREONNEL } \\
\text { ENGINEERING PERBONNEL }\end{array}$ & $\begin{array}{r}90 \\
110 \\
52 \\
35 \\
10\end{array}$ & $\begin{array}{l}(71) \\
(35) \\
(30) \\
(33) \\
(10)\end{array}$ & $\begin{array}{l}1 \\
0 \\
1 \\
3 \\
1\end{array}$ & $\begin{array}{l}\text { (1) } \\
(9) \\
\text { (1) } \\
\text { (3) } \\
\text { (1) }\end{array}$ & $\begin{array}{c}21 \\
0 \\
5 \\
0 \\
0\end{array}$ & $\begin{array}{c}(20) \\
(0) \\
(9) \\
(0) \\
(0)\end{array}$ & $\begin{array}{r}120 \\
110 \\
59 \\
44 \\
11\end{array}$ & $\begin{array}{l}(98) \\
(89) \\
(48) \\
(42) \\
(11)\end{array}$ & $\begin{array}{l}0.600 \\
0.355 \\
0.784 \\
0.305 \\
0.005\end{array}$ & $\begin{array}{l}0,000 \\
0.000 \\
0.000 \\
0.001 \\
0.000\end{array}$ & $\begin{array}{l}0.000 \\
0.000 \\
0.009 \\
0.000 \\
0.00\end{array}$ & $\begin{array}{l}0.002 \\
0.356 \\
0,770 \\
0.306 \\
0.005\end{array}$ \\
\hline GRAND TOTALS & 305 & (248) & 6 & (a) & 32 & $(31)$ & 343 & (28) & 2.000 & 0.001 & 0.011 & 2021 \\
\hline
\end{tabular}

Workers may be counted in more then one ceategory. Numbers in pertitheses ane totet numbers of ind'widuals. 

STATION UTILTY

CONTRACT

TOTAL

REACTOR OES S SURY

0
0
0
0
0
0

0
0
0
0
0
0
MARITENANCEPERSONNEL OPERATIONS PERSONNEI. HEALTH PHMSUCS PER'SONNEE SUPERVISORY PERSONNAL TOTAL

$\begin{array}{rrr}141 & 4 & 147 \\ 32 & 0 & 2 \\ 42 & 0 & 5 \\ 5 & 0 & 2 \\ 16 & 9 & 0 \\ 236 & 4 & 200\end{array}$

$\begin{array}{rr}147 & 292 \\ 2 & 34 \\ 5 & 97 \\ 2 & 7 \\ 3 & 19 \\ 309 & 499\end{array}$

0,000

0,060

0.144

0.000

0,05

0.201

ROUTINE MAINTENANCE

MANTENANCE PERSONNEL

OPERTTONS PERSONNEL

HEALTH PHYEFCS PERBONNEL

SUPERVISORY PERSONNNEL

ENGENEERING PERSONWEL TOTAL

$\begin{array}{rrr}\mathbf{5} & 1 & \mathbf{6 7} \\ \mathbf{0} & 0 & 0 \\ 0 & 0 & 7 \\ 0 & 9 & \mathbf{5 6} \\ \mathbf{1 1} & 9 & 1 \\ \mathbf{1 6} & \mathbf{2} & 139\end{array}$

IN-SERMCE INEPRCTION

MANTTENANCE PERSONNE.

OPERATIONS PERSONNEI

HEALTH PLHYSICS PERSONNEL.

SUPERVISORY PERSONINEL

ENCINEEFANG PERSONNEL TOTAL

SEFCIAL MANTENANCE

MAINTENANCE PERSONNAE

OPERATIONS PERSONNEL

HEALTH FHYS|CS PERSONNEL

SUPERVISORY PERSONN검

ENGINEERNG PERSONNEI. TOTAL

WASTE PROCESSING

MAINT ENANCE PERSONNEL

OPERATIONS PERSONNNEL.

HEALTH PHYSICS PERSONNEC

SUPERVISORY PERSONNEL

ENSWEERNG PERSONNAL TOTAL

REFUANRS

MAINTENANCE PERSONNAL

OPERATIONS PERSONNEL

HEALTH PHYSICS PERSONWE.

SLPERVISORY PERSONNVE

ENGINEERNG PERSONNAE. TOTAL

$\begin{array}{rrr}7 & 0 & 11 \\ 0 & 0 & 0 \\ 1 & 0 & 0 \\ 2 & 0 & 0 \\ 2 & 1 & 0 \\ 12 & 1 & 11\end{array}$

$\begin{array}{rr}11 & 18 \\ 0 & 0 \\ 0 & 1 \\ 0 & 2 \\ 0 & \frac{3}{11} \\ 11 & 24\end{array}$

$\begin{array}{lll}0 & 0 & 0 \\ 0 & 0 & 0 \\ 0 & 0 & 4 \\ 0 & 0 & 0 \\ 0 & 0 & 0 \\ 0 & 0 & 4\end{array}$

0
0
4
0
0
4

$\begin{array}{rrr}62 & 0 & 3 \\ 2 & 0 & 1 \\ 1 & 0 & 7 \\ 1 & 0 & 0 \\ \frac{4}{10} & 0 & 0 \\ 11\end{array}$

6
3
6
4
4
81

TOTAL BY NOA FUNCTION MAINTENANCE PERSONNEL OPERATIONS PERBONNEL HEALTH FHYSICS PERSOMNEI. SUPERVISORY PERSONNA ENGINEERWE PERSONNEI

$\begin{array}{rrrrr}215 & (173) & 5 & (5) & 228 \\ 34 & (34) & 0 & (9) & 3 \\ 44 & (42) & 0 & (0) & 73 \\ 8 & (9) & 1 & (1) & 5 \\ 33 & (39) & 1 & (1) & 4\end{array}$

0.000
0.000
0.000
0.000
0.000
0.000

0.000

0.000

0,000

0,000

0,000

0.000

0.000

0000

0.144

0.000

0.057

0.2.

41.697
10.520
13.974
1.717
0.60
74.096

0.804

0,000

0.000

0.083

orर्1

$\mathbf{1 . 1 5 6}$

36.75

0.691

11.857

1.297

1.287

61887

39.226

11.194

25.09

3087

7.78

127.141

1.194
0.452
0.449
0.031
3059
5059

0.169

21.570

20:11

c.too

0,000

0.128

0.082

0.000

1,400

23074

0,311

46.480

0.552

1945

23281

3.45

B1.04

18

205

0.065

$0.5 \%$

0.258

0.45

4.201

0001

0.000

0.000

0.000

0.167

0.248

2000

0.000

0.163

0.015

0,00

$3, \cos$

5850

0.065

0.731

0.255

D.A42

7.547

0400

0.106

0.250

0.005

a.001

0.776

0.000

0.000

0.000

0.000

0.009

01000

0.004

0,05

0.668

0.012

0.000

0.0s

0.412

0.162

1.124

0.017

p.0.1

28.719

1,689

0,202

3,119

2.517

0.000

0,00

2527

2062

0.260

0.003

0.011

0.20

0.05

ong

$3 \frac{1278}{3574}$

$\frac{1.139}{31.6 \% 0}$

0,071

4.820

gRANDTOTALS

394 (287) 7 (7) 300

$\begin{array}{rr}(189) & 448 \\ (3) & 37 \\ (71) & 117 \\ (58) & 67 \\ (4) & 38\end{array}$

(364)

(37)

(113)

(64)

73145

14.040

15.819

1.053

62987

137.124

0,000

1.019

15 bos

0.017

17,000

32.645

2250

0.206

24378

28684

13.159

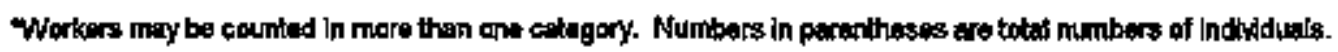


REACTOR DRS : SURV

MAINTENANCEPERSONWEL

OPERATIONS PERSONNEL

HEALTH PHYEICS PERSONNEL

SUPERVISORYPERSONNEL

DNCINEERING PERSONNEL

TOTAL

ROUTINEMALTENAHCE.

NALNTENANCE PERSONNEL

OPERATIONS PERSONNE

HEALTH PHYSICS PERSONNE.

SUPERVISORY PEFSONNEL

ENGINEERINO PERECNNEL

TOTAL

IN-8ERVLFE NSFECTION

MATNTEMANCE FERSONNA

OPERATIONS PERSONTEI

HEALTH PHYSICS PERSOHMU.

GLPRRVISORY PERSONNEL

ENGSNEEFUNG FERBONWEl.

TOTAL

SPECIALWMAINTENASYCE

MAINTENANCEPERSONWNEL

OPERATIONS PERBONNEI

HEALTH PHYSCS PERSONINEL

SLFERVISORY PERBONWNEL.

ENCINEERING PERSONNEL

TOTAL

WASTE PROCESS이을

MANTENANCEPERSONNEL

OPERATIONS PERSONNEL

HEALTH PHYEICS PERSONNEL

BUPERVEORY PERSONINEL

ENENEEFNG PERSONNEL

TOTA

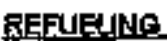

MANTENANCEPEREONNEL

OPERATIONH PERSONNE

HEALTH PHNSICS PERSONNEL

SUPERVISORY PERSONNEA

ENIGNNEERING PERSONNEL

TOTAL

TOTAL, BY JOP FUNACTION

MAINTENANGEPERSONNEL OPERATHWNS PERSONNEI

HEALTH FHYYSICS PERSONNDL.

SUPERVISORY PERSONNEI

ENCINEERNNG PERSONNEL

22
25
12
0
0
5

0
0
0
0
0
0

65
1
19
0
0
05

87
23
31
0
0
144

5.124
7.484
4.422
0.000
0.189
17.500

20

$\boldsymbol{2}$

2

8

2

20
2
8
2
0
0

20
0
0
0
1
200

2
4
2
1
305

\section{7.}

1.450

3.65

0.2

Rozas

130k

$\begin{array}{rr}54 & 84 \\ 0 & 0 \\ 2 & 2 \\ 0 & 0 \\ 0 & 0 \\ 50 & 5\end{array}$

0.072

0.015

00 ot

0.000

00

0.158

0
0
0
0
0
0

0,000

0,000

0.000

0.000

0,000

다을

$0, \infty$
0,000
$0, \infty \infty$
$0, \infty \infty$
0,00

0.000

0,000
0,000
0,000
0,000
0,000

20.009
0.430
5.414
0.011
0.000
20.400

28.732

7.732

9.638

0.101

ㅁ.18:

294

4.772

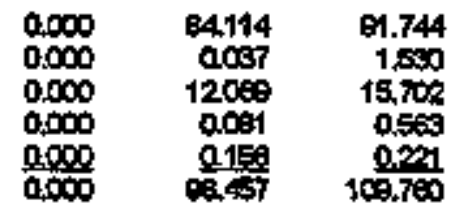

27

$\begin{array}{ll}2279 & 22589 \\ 0.002 & 0.017 \\ 0.750 & 0.51 \\ 0.009 & 0.000 \\ 0.000 & 0.010 \\ 20.053 & 20216\end{array}$

\subsection{0}

0.000

0.000

0.000

0,009

$0,0 \times 0$

$\begin{array}{ll}0.553 & 0.053 \\ 0.000 & 0.000 \\ 0.000 & 0.000 \\ 0.000 & 0.000 \\ 0.000 & 0.000 \\ 0.003 & 0.053\end{array}$

0
0
0
0

$\begin{array}{lll}0 & 0 & \\ 0 & 0 & \\ 0 & 1 & \\ 0 & 0 & \\ 0 & 0 & 0 \\ 0 & 1\end{array}$

0
0
1
0
0
1

0.267
0.007
0.107
0.002
0.007
0.307

$$
\begin{aligned}
& 0,000 \\
& 0.000 \\
& 0.000 \\
& 0000
\end{aligned}
$$

$\begin{array}{ll}0.305 & 0.652 \\ 0.000 & 0.007\end{array}$

$0.287 \quad 0.394$

$0.000 \quad 0.000$

now 000

0.682

$\begin{array}{ll}0 & \\ 0 & \\ 0 & \\ 0 & 0\end{array}$

$\begin{array}{ll}0 & 0 \\ 0 & 0 \\ 0 & 0 \\ 0 & 0 \\ 0 & 0 \\ 0 & 0\end{array}$

000

0.157

مer

0.00

not

0.000
0.000
0.000
0,000
0.000
0.000

ators

0.004

0,002

0,000

nom.

0.161

0.002

0,000

우요

0.252

\begin{tabular}{|c|c|c|c|}
\hline $\begin{array}{r}13.152 \\
8.159 \\
8.223 \\
0.574 \\
0.287\end{array}$ & $\begin{array}{l}0 ., \infty 0 \\
0,0 \infty 0 \\
0.000 \\
0.0 \infty \\
0.000\end{array}$ & $\begin{array}{r}151.000 \\
0.470 \\
18.562 \\
0.101 \\
0.150\end{array}$ & $\begin{array}{r}144.153 \\
9.562 \\
28.723 \\
0.675 \\
0.425\end{array}$ \\
\hline
\end{tabular}

45
27
2
0

$\begin{array}{ll}0 & 3 \\ 0 & \\ 0 & \\ 0 & \end{array}$

$\begin{array}{rr}348 & \\ 1 & 2 \\ 0 & 8 \\ 1 & \end{array}$

203
28
2
1

04

$\mathbf{0}$

412

803

31.572

0.000

0.000

150501
191.673

Workers may be counted In more then ans cotegory. 
TOTAL.PERBONEAGM

28

sis

101.984

3379

$\operatorname{seg} 2$

Whorkers may be counted in more then ont ettegory. 


WORK AND
JOB FUNCTION

REAGTOR OPB 8 NㅐV. MAINTENANCEPERSONNEL OPERATLONB PERSONNE HEALTHFHYSIGS FERBONNEL BUPERVISORY PERSONNEL ENCINEERING PERSONNEL TOTAL

ROMTINE HAINTEMANKCE MALTTENANCE PERSONNE OPERATIONSPERSONNEL HEALTH FHYSSICS PERSONWEL SUPERVISORY PERSONNEI ENGLEERNG PERSONNLE †OTAL

98
47
14
11
200

$\begin{array}{rr}5 & 48 \\ 1 & 1 \\ 1 & 55 \\ 4 & 2 \\ 3 & \frac{11}{97}\end{array}$

148
49
74
20
47
378

$\begin{array}{rr}241 & 942 \\ 0 & 2 \\ 21 & 27 \\ 5 & 11 \\ 37 & 57 \\ 299 & 434\end{array}$

|lLEERMCE INSFECTION HANTENANCE PERBONNE OPERATIONS PERSONNEL HEALT'H PHYSTCS PERSONNE․ SUPERVIBORY PERSONWLI ENEINEERNG FERSCNNEL TOTAL.

8
2
6
4
4
118

$\begin{array}{ll}3 & 24 \\ 0 & \\ 2 & 2 \\ 19 & \\ 10 & 25\end{array}$

0
0
0
0
2
2

$\begin{array}{rr}0 & 35 \\ 0 & 0 \\ 0 & 0 \\ 0 & 1 \\ 2 & 18 \\ 2 & 52\end{array}$

SPECIAL MAINTENANCE MANTT GNANCE PERSONME OPERATIONS PERSONNEI HEALTH PHYSIGS PERSONNNEL SUPERVISORY FERSONWEL ENGTNEERING PERBONNUEL, TOTAL

WASTIE PROCESOIKL

MAINTENANCEPERSONNEL OFERATIONE PERSONNEI MEALTH PHYEICS PERSONNEL SUPERVISORY PERSONNEI ENAGINEERINO PERSONNEI TOTAL.

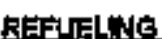

MANTENANCE PERSONWEL OPERATIONS PERSONNEL HEALTH PHYSICS PERSONNEL. BSPERVTORY PERSOANNEL ENGINEERING PERSONNEL TOTAL

$\begin{array}{lll}0 & \\ 0 & & 0 \\ 0 & 0 & 0\end{array}$

a

35
0
0
10
50

\begin{tabular}{|c|c|c|c|}
\hline $\begin{array}{l}0.522 \\
0.002 \\
0.202 \\
0.000 \\
1.027 \\
1.643\end{array}$ & $\begin{array}{l}0.004 \\
0.000 \\
0,000 \\
0.006 \\
2512 \\
2510\end{array}$ & $\begin{array}{r}10.944 \\
0,000 \\
0.157 \\
0.564 \\
10.157 \\
2.054\end{array}$ & $\begin{array}{r}58.500 \\
0.002 \\
0.419 \\
0.384 \\
13.679 \\
34.013\end{array}$ \\
\hline
\end{tabular}

0

0

0

0

0.000

0.00

D.000

t.ong

0.000

0.000

0.000

0.000

0,000

o.fers

0.000

$\begin{array}{ll}0,000 & 0,000 \\ 0,00 & 0,000 \\ 0, \infty \infty & 0,000 \\ 0,00 & 0,000 \\ 0,00 & 0,000 \\ 0.000 & 0.000\end{array}$

0
0
1

0
0
0

$\begin{array}{ll}0 & 0 \\ 0 & 0 \\ 4 & 6 \\ 0 & 0 \\ 0 & 0\end{array}$

0
0
6
0
0
0

0.949

0.400

0,000

Dono

0.678

0,00

0.000

0.07

1.612

0.01k

0.471

$\begin{array}{ll}0.017 & 1.424 \\ 0.000 & 0.010 \\ 1.000 & 2.58 \\ 0.000 & 0.071 \\ 0.009 & 0.017 \\ 1.007 & 4.006\end{array}$

$\begin{array}{rrrr}15 & 0 & 14 & 2 \\ 2 & 0 & 0 & 2 \\ 1 & 0 & 14 & 15 \\ 2 & 0 & 1 & 5 \\ 2 & 4 & 5 & 11 \\ 2 & 4 & 34 & 6\end{array}$

29
2
15
$\frac{11}{60}$

TOTAL BY vas Functon MAINTENANCEPERSONANEL OPERATIONS FERSONNE. HEALTH PHY 어CS PEREONNEL SUTERVISORY PERSONNEI GNIㅈNEERING PERSONNEL

IEL

\begin{tabular}{|c|c|c|c|c|c|c|c|}
\hline $\begin{array}{l}203 \\
51 \\
43 \\
20 \\
23\end{array}$ & $\begin{array}{r}8 \\
1 \\
1 \\
6 \\
3\end{array}$ & $\begin{array}{r}398 \\
1 \\
74 \\
9 \\
63\end{array}$ & $\begin{array}{r}58 \\
53 \\
118 \\
55\end{array}$ & $\begin{array}{r}114,205 \\
32618 \\
22015 \\
8.865 \\
7.026\end{array}$ & $\begin{array}{r}4.607 \\
0.255 \\
0.105 \\
1.207 \\
13.815\end{array}$ & $\begin{array}{r}140255 \\
0.173 \\
25.021 \\
1.775 \\
21.503\end{array}$ & $\begin{array}{r}29.095 \\
30.278 \\
48.00 t \\
41.947 \\
42347\end{array}$ \\
\hline 343 & 5 & 4 & 983 & 185,000 & 19980 & 189678 & $394, \overline{456}$ \\
\hline
\end{tabular}

Worlere may be colrted in more than one categay. 
REACTOROPSB STLPY MANTENANCE PERSONNE. OPERATIONS PERSONNEL HEALTH FHYSTCS PERSONENEL SUPERVISORY PERSONNE ENGINEERING PERSONWEL TOTAL

$\begin{array}{ll}0 & 0 \\ 1 & 0 \\ 0 & 0 \\ 0 & 0 \\ 0 & 0 \\ 1 & 0\end{array}$

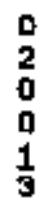

0
3
0
0
1
4

11

MANTENANCE PERSONWV OPERATIONS PERSONANEL HEALTH FHYSICS PERSONWE. SUPERVISCRY PERSONNEE ENGINEERING PERSONNEI TOTAL

\section{N-SERVICE 1 NESECTICN}

MAINTIENANCE PERBONNEI.

OPERATIONS PERSONNEL

HEALTH PHYSTCS PERBONNEI

SUPERVISORY PERBONNEL

ENCNEERING PERSONNEL TOTAL

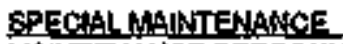

MAINTENANGE PERSONNEL

OPERATIONSPERSONNEL

HEALTH PHY

SUFERVISORY PERSONNEI.

ENGINEERING PERSONNEL

$$
\text { TOTAL. }
$$

$\begin{array}{ll}11 & 1 \\ 12 & 1 \\ 5 & 3 \\ 3 & 0 \\ 1 & 9 \\ 3 & 5\end{array}$

\section{WASTEPROCERSNNG}

MAINTENANTCE PERSONNEL

OPERATIONS PERSONNEE

HEALTH FHYSICS PERSONNEL

SUFERVISORY PERBONNEL

ENGINEERING PERSONNEL TOTAL

\section{REFUELING}

MANTENANCE PERSONINEL

OPERATINS PERSONNEL

HEALTH PAHYSICS PERSONNEL

SUPERVISORY PERSONNEL

ENIEINEERING PERSONNNEL TOTAL.

TOTAL BY VOB FLNCTION MAINTENANCE PERSCNNEL OPERATIONLS PERSONNEL HEALTH PHYSICS FERSONNEL SUPERVISORY PERSONNEL ENGANEERANG PERSONNEE

23
3
3
$\frac{1}{3}$

$\begin{array}{rr}6 & 0 \\ 32 & 0 \\ 15 & 7 \\ 1 & 0 \\ 1 & 0 \\ 1 & 7\end{array}$

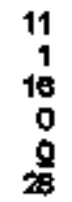

\section{7}

30

1

1

39
14
17
9
105

104

14

2

$13^{2}$

$\begin{array}{rrr}11 & 0 & 24 \\ 5 & 0 & 1 \\ 1 & 0 & 1 \\ 4 & 0 & 0 \\ 3 & 0 & 21\end{array}$

$\begin{array}{ll}4 & 0 \\ 1 & 0 \\ 2 & 0 \\ 0 & 0 \\ 0 & 0\end{array}$

$\begin{array}{rrrr}56 & 2 & 142 & 18 \\ 54 & 1 & 16 & 71 \\ 27 & 10 & 40 & 77 \\ 10 & 0 & 6 & 16 \\ 0 & 0 & 47 & 59\end{array}$

0.008
0,002
0.012
0.003
0.170
0.703

0.005
0.000
0.000
0.000
0.000
0.005

atse

0,351

$0,0 \infty$

n, $\infty$

0.391.

1.068

0.477

0.743

마2

acts

0.190

Q솜

1.77

\subsection{2}

4.727

1.843

口ots

$\frac{0.79}{15.294}$

T.343

1.574

1.어요

D.67

ㅁ. $4 \pi$

$100 \%$

0.138

0.465

0.000

0.013

1.24

14.350

0.157

2916

1.840

secos

20.727

20.400

$5 \times 3$

5.414

2813



0.600

0.091

0.108

0000

Q000

0600

24504

32.600

3,09

3.65

0002

$\underline{0,111}$

32008

$5 \mathrm{SOH}$

4.77

0,50

0588

43,837

4172

7.102

4908

$0.5 \% 5$

0.78

17.572

0.207

0.000

1.384

D.000

0,000

1.00

6.243

aess

3.09 ?

000

아오

12504

12052

7.78

10070

0.565

매:4 4

3भ. 910

3.410

0,002

0009

0.057

$\$ 000$

0.284

1.058

onges

$0.00 \mathrm{~s}$

0.321

0.579

0.319

0.001

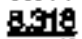

15.537

0.733

1.000

0.60

1,059

$\frac{1,312}{2613}$

1.004

0.600

0518

0.078

0.000

2.400

$0.0 \mathrm{~s}$

0.00

0.004

0.00

a.mo

0.000

0.048

0,075

0.882

000

0,000

1.000

1,168

0.875

1.404

0,000

0,000

23.10

$15, \mathrm{Bg}$

1.101

olst

5.000

5,402

77.100

8.613

3254

2207

11,469

0.000

1.600

17.624

21.917

200

20.75

\begin{tabular}{lllllllll}
\hline GRANN TOTALS & 152 & 13 & 201 & 416 & 60,057 & 3.861 & 69.147 & 148.965 \\
\hline
\end{tabular}

Workere may be counted in mone than ons category. 


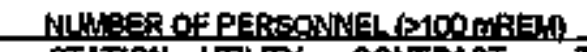

STATION UTLITY CONTRACT TOTAL

TOTAL EERSONLREM

BTATION UTEITY CONIRACT TOTAL

MAINTENANCE PERSONNEL

OPERATIONS PERSONNEI

HEALTH PHYSTCS PERSONNEL

SUPERVISORY PERRSONNEL.

ENESHEEFING PERSONNEL

TOTAL

ROUTWF MANTENANCE

MAINTENANCEE PERSONNEL

OPERATIONS PERSONNEL

HEALTH PHYEICS PERSONNEL

SLPERVISORY PERSONNEL

ENGANEERINO PERBONNEL

TOTAL

0
0
8
1
0

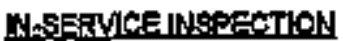
MAINTENANCE PERSONNEL OPERATIONS PERSONNEE. HEALTH PHYSICS PERSONNEL SUPERVLORY PERSONNEL ENGINEERING PEREONNEL TOTAL

SERCMAL MANTENANCE WANTENANCE PERSONNE OPERATIONHS PERSONNA HEALTH PYATSICS PERSONDEI SAPERVISORY PERBONNE ENGNEERNG PERSONNE. TOTAL

WASTE PROCESSING

MANTE NANCE PERSONWWEL OPERATIONS PERSONME HEALTH PHYSICS PERBONNEI SUPERVISORY PERSONHEI ENGMEERNG PERSONNE TOTAL

REFU⿴囗十⺝MG

MANTENANCEFERSONNEL OPCRATHONS PERSONNE

HEALTH PHYSICS PERSONNEL SUPERVISORY PERSONNAE던INEERMG PERSONNE. TOTAL

TOTAL BY JOB FUNCTION MATSTENANCE PERSONINE. OPERATIONS FERSONNAE HEALTH PHTSICS PERSONRVE SUPERVISORY PERSONNA. ENGINEERINO PERSONNEI

$\begin{array}{ll}0 & 0 \\ 0 & 0 \\ 1 & 0 \\ 0 & 0 \\ 0 & 0 \\ 1 & 0\end{array}$

0
0
0
1
0
10

\subsection{0}

0.895

3.002

0.409

0.892

4,684

0

$\stackrel{0}{0}$

0

$\mathbf{0}$

$\begin{array}{ll}0 & 0 \\ 0 & 0 \\ 0 & 0 \\ 0 & 0 \\ 0 & 0 \\ 0 & 0\end{array}$

0
0
0
0
0
0

1.172

0.149

0.20

0.591

o.s.7.

278

o.ors

0.002

0.160

0.027

매을

0.24

o.esi

0.000

0206

000

thas

1.021

0.274

0.416

1 . 912

acos

a.9.8

$2 \pi 00$

0,0053

0.057

0,017

0.040

pos4

a.21

2500

1,300

6.848

1.314

1.120

\section{0,000 \\ 0.120 \\ 0.124 \\ 0.075 \\ nodg \\ 0.338}

0.134

acon

000

0.042

Qmi1

0.178

0.440
0.608

3.185

O.61

gas

$\begin{array}{lll}0.018 & 0.275 & 1.482 \\ 0.018 & 0.000 & 0.167 \\ 0.063 & 0.00 & 0.328 \\ 0.001 & 0.181 & 0.749 \\ 0.015 & 0.043 & 0.845 \\ 0.037 & 0.40 & 3.359\end{array}$

o.08z

0.000

0,000

0.000

0.000

$0.0 \mathrm{~m}$

0.000

0.000

0.00

0.000

0.000

Dons

0.07

0.078

0.002

0.100

0.007

oces

0.331

\begin{tabular}{|c|c|}
\hline $\begin{array}{l}0.092 \\
0.000 \\
0.013 \\
0.000 \\
0.0 .44 \\
0.100\end{array}$ & $\begin{array}{l}0,05 \\
0,00 \\
0,000 \\
0,00 \\
0,00 \\
0,05\end{array}$ \\
\hline
\end{tabular}

0,000

0.00

0.014

0,000

p.000

0.017

to.016

0,047

0.000

poco

0,000

boes

0.28

0.46

1.500

0.088

o018

2.790

$\begin{array}{rr}1 & 0 \\ 1 & 0 \\ 12 & 1 \\ 1 & 0 \\ 0 & 0\end{array}$

$\begin{array}{ll}0 & 4 \\ 0 & 0 \\ 1 & 0 \\ 0 & 0\end{array}$

$\begin{array}{lll}0.000 & 0.000 & 0.053 \\ 0.000 & 0.000 & 0.057 \\ 0.001 & 0.000 & 0.019 \\ 0.000 & 0.000 & 0.040 \\ 0.000 & 0.002 & 0.048 \\ 0.001 & 0.002 & .0 .214\end{array}$

0.107
0.141
0.155
0.078
0.003

\begin{tabular}{ll}
1.306 & 4011 \\
0.048 & 1.49 \\
0.000 & 5.631 \\
0.273 & 1.613 \\
0,000 & 1.218 \\
\hline
\end{tabular}

GRAND TOTALS

15

1

4

$\mathbf{2 0}$

11.900

\footnotetext{
whincers may be counted In mort then ano category.
} 
WORK AND

JOE FUNCTION

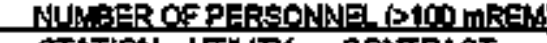
STATION UTUTY CONTRACT TOTAL
TOTALPERSON-REM

STATION UTHTY CONTRACT TOTAL

REACTOR OPS \& SURY

MANTENANCE PERSONNE

OPERATLNA' PERBONNEL

HEALTH PHYSICS PERSONWE

SUFERVISORY PERSONNEL

ENGSWEERING PERSONNEI TOTAL

ROUTINE MAIGTENANCE

MANTTENANCE PERSONNEL

OPERATIONS PERSONWEL

HEALTH PHYSKCS PERSONAE

SUPERVISORY PERSONWEI

ENGINEERNG PERSONNAี TOTAL

$\begin{array}{ll}\mathbf{0} & 0 \\ \mathbf{2} & 0 \\ \mathbf{0} & 0 \\ \mathbf{0} & 0 \\ \mathbf{0} & \end{array}$

o

$\mathbf{0}$

0

$\frac{\mathbf{0}}{3}$

$\stackrel{0}{0}$

3

$\frac{9}{3}$

TOTAL

T.

0
2
3
0
0
5

$\begin{array}{lll}4 & 0 & 19 \\ 0 & 0 & \\ 0 & 4 & 2 \\ 0 & 0 & 0 \\ 0 & 1 & 0 \\ 7 & 5 & 4\end{array}$

$\begin{array}{rr}19 & 23 \\ 1 & 1 \\ 28 & 33 \\ 0 & 0 \\ 0 & 1 \\ 48 & 50\end{array}$

HWSERRACE NSPECTHON MANTENANCE PERSONNE OPERATIONS PERSONWEL

HEALTH PHYSICS PERSONNIE SUPERVISORY PURSONNE ENGWEERING PERSONNEL TOTAL

$\begin{array}{ll}0 & 0 \\ 0 & 0 \\ 0 & 0 \\ 0 & 0 \\ 0 & 0 \\ 0 & 0\end{array}$

0
0
0
0
0
0

0
0
0
0
0
0

SPECIAL MANRTENANCE.

MANTENANCE PERSONNEL

OPERATIONS PERSONNEL

HEALTH PHYSACS PERSONNEL

SLPERVISORY PERSONNEL

ENGNEERING PERSONN크 TOTAL

$\begin{array}{lll}2 & 0 & 3 \\ 0 & 0 & 0 \\ 0 & 0 & 5 \\ 0 & 0 & 0 \\ 0 & 0 & 0 \\ 2 & 0 & 5\end{array}$

$\begin{array}{ll}32 & 34 \\ 0 & 0 \\ 5 & 5 \\ 9 & 0\end{array}$

\section{WASTE EROCESSLLG}

MAINTE NANCE PERSON"NEL

OPERATIONS PERSONNE⿱

HEALTH PHYSICS PERSONNEL

SUPERVISORY PERSONNEL

ENGINEFRING PERSONNE TOTAL

$\begin{array}{rrr}2 & 0 & \text { eo } \\ 0 & 0 & 1 \\ 1 & 1 & 20 \\ 0 & 0 & 0 \\ 0 & 0 & 1 \\ 3 & 1 & 84\end{array}$

$\begin{array}{rr}60 & 71 \\ 1 & 1 \\ 20 & 25 \\ 0 & 0 \\ 1 & 8\end{array}$

71
1
25
0
1
$8 \frac{1}{8}$

REEIYFINGG

MANNTENAKCEPERSONNEL

OFERATIONS PERSONNE

HEALTH PHYSICS PERSONNEL

SUPERVISORY PERSOMNEL

ENGNEERIG PERSONNEI TOTAL

$\begin{array}{ll}0 & 0 \\ 0 & 0 \\ 0 & 1 \\ 0 & 0 \\ 0 & 0\end{array}$

$\begin{array}{ll}0 & 1 \\ 0 & 0 \\ 1 & 1 \\ 0 & 0 \\ 0 & 0 \\ 1 & 2\end{array}$

1
1
0
a
2

$\begin{array}{ll}1 & 0,050 \\ 0 & 0.010 \\ 2 & 0,000 \\ 0 & 0,000 \\ 0 & 0,000 \\ 3 & 0.045\end{array}$

0.010
0.040
0.005
0,000
0,000
0,05

0.000
0.000
0.000
0.000
0.000

D.760

0,008

0,000

nogs

0.5

0.015
0.000
0.005
0.000
0.005
0.005

14.978

0.010

1.000

0.000

0.005

16.973

0.170

0.020

a.do 0

0,000

0.20

\begin{tabular}{|c|c|c|}
\hline $\begin{array}{l}0.800 \\
0.200 \\
0.460 \\
0.000 \\
0.000 \\
1,300\end{array}$ & $\begin{array}{l}0,050 \\
0,000 \\
0.380 \\
0,000 \\
0.280 \\
0.675\end{array}$ & $\begin{array}{r}29.615 \\
0.001 \\
10.409 \\
0.000 \\
0.000 \\
40,425\end{array}$ \\
\hline
\end{tabular}

TOTAL BY_RO FUNCTLON

MAINT ENANCE PERSONANEL OPERATIONS PERSONNEL HEALTH PHYSICS PERSONNEL SUPERVISORY PERSONNEL

$\begin{array}{lll}8 & 0 & 12 \\ 2 & 0 & \\ 4 & 6 & \\ 0 & 0 & \\ 0 & 1 & \end{array}$

$\begin{array}{rr}121 & 12 \\ 2 & \\ 58 & 6 \\ 0 & \end{array}$

\begin{tabular}{rrrrr}
129 & 2.005 & 0.155 & 5.453 & 15.265 \\
4 & 1.000 & 0.010 & 1.551 & 2621 \\
63 & 1.070 & 2005 & 27.459 & 30.604 \\
0 & 0.005 & 0.000 & 0.085 & 0.060 \\
2 & 0.110 & 0.005 & 0.445 & 1.550 \\
\hline
\end{tabular}

\begin{tabular}{lllllllll} 
GRAND TOTALS & 14 & 7 & 162 & 203 & 4.900 & 3.2505 & 81.943 & 80.000 \\
\hline
\end{tabular}

Workers may be counted in more then one extegory.
0.000

0.200

0.000

Q

0,180

ㅇ․어응

0.400

0.000

0000

0.25

0.020

0,000

000

0.825 


\section{APPENDIX D (Continued)}

NUMBER OF PERSONNEL AND PERSON-REM

BY WORK AND JOB FUNCTION

1995

PLANT: KZION 1,2

TYPE: PWR

WORK AND
JOB FUNCTION

TOTAL.

BEACTOR,OESRSSINRY

MAINTENANCE PERSONNEL

OPERATIONSPERSONNEL

HEALTH PHYSTCS PERSONWII

SUPERVISORY PERSONNE

ENGINEERNG PERSONNER

TOTAL

ROUTINEMAINTENANCE.

MAINTENANCE PERSONNEL

OPERATIONAS PERSONINE

HEALTH PHISSICS FERSONNEI.

SUPERVISORY PERSONNA

ENGWEERING PERSONNE

TOTAL

0
0
0
0
0
0

164
148
69
277

277

17

ats

a

WANTENANCE FEREONNA

OFERATTONS PERBONNEL

HEALTH PHYSTCS PERSONNE

SUPERVVISOFY PERSONNA1

ENGINEERNG PERSONNEL

TOTAL.

SPECAAL MANATIENANGE

HANTENANCE PERBONNEL

OPERATIONS PEREONNEL

HEALTH PHYEGCS PERSONNEL

SLPERMSORY PERSONNEI

ENB|NEERING PERSONNEL

TOTAL

WASTE PROCESSINO

MAINTENANCE PERRONNEL OPERATIONS PERSONNNEL

HEALTH PHYSICS PERSONNNEL

SLPERVIBORY PERSONNEI

ENGINEERING PERSONNEL.

TOTAL

REDIFING

MAINTELANYE PERSONWEL

OFERATIONS PERSONNEL

HEALTH PHYEICS PERSONNEL

SLPERVISORY PERSONWEI

ENGINEERING PERSONNEL

TOTAL

TOTAL, GY JOB FLNCTION

MAINTENANCE PERSONWEL

OPERATIONS PERSONNEL

HEALTH PHYSICS PERSONNEL

SUPERVISORY PERSONWEL

ENG|NEERING PERSONNA-

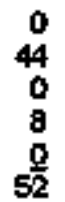

\section{0}

$\circ$

o

0
44
0
8
9
52

0.009
7,491
0.000
0.725
0.009
8.494

0,000

0,000

0.000

0.000

0,000

$\overline{0.00}$
2007
24.892
23.450
25.194
1358
160.457

141

$\begin{array}{rr}11 & 1258 \\ 0 & 164 \\ 127 & 83 \\ 0 & 324 \\ 0 & 38 \\ 130 & 1868\end{array}$

310

278

ots

제1

1865

2831

1,000
0,000
1,367
0,000
0,000

3.265

127

127

108

$\frac{7}{8}$

1

89

$\underline{40}$

2
1
0
1
4
5

\section{1}

1

0

4

17

0.100

0,009

0.001

0.091

0.484

0.721

0.000

0.000

0,000

0,000

0,000

0,000

0.917

0.150

0.018

0,087

$08 \mathrm{mon}$

1,480

0.000

0.000

0.000

0.000

0000

0.000

0.024

$0 \infty 0$

0.000

0.008

ogon

acos

0.203

7.491

000

0.733

어오

8.4.58

$\begin{array}{rr}457.947 & 52.812 \\ 0.162 & 25.144 \\ 35.320 & 60.197 \\ 28073 & 50.287 \\ 2217 & 15.781 \\ 503718 & 707.141\end{array}$

$46.415 \quad 48.521$

0.000

0.000

7.648

1.909

sised

0.009

0.040

7.700

250

53009

0

0
0

0.058

0.872

1.078

0.210

nong

$22 m$

0.000

0,000

0.000

0,000

0,0

0.005

$\mathbf{3 1 4 1}$

0,00

0.00

0.67

$0 \mathrm{ngs}$

3.672

4.059

0.150

0.018

0.784

D.534

5,357

站

3203

3,207

$0 . \infty$

1.170

0.672

2200

$0.027 \quad 0.207$

0.003

$4.449 \quad 6.66$

505

10

35

22

호

a.122

5.544

0.040

1.698

D. 270

㧤的要

0.000

0.000

0.372

0,000

0000

0.351

1000

0,000

0002

0217

Doot

207

4970

5.544

0.484

1.000

0.271

13.179

1.877

0,000

$5+250$

0.162

ㅂ11.915

3005

1.751

3054

39.218

27900

0,000

32,670

6280

701

14.650

0.000

4.161

\begin{tabular}{lllllllll}
\hline GRAND TOTALS & 966 & 174 & 2150 & 3200 & 205.733 & 3.628 & 500.112 & 797.473
\end{tabular}

Workars mey be counted in more than one cetegory. 


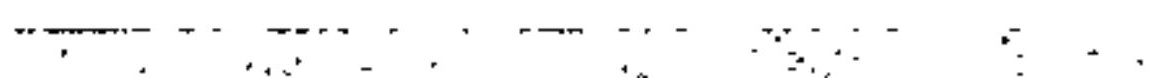




\section{APPENDIXE \\ Graphlcal Representation of Collective Dose Trends by Year and Job Function for Each Site \\ 1973-1985}

NOTE: Appendlix E contsins data on operathing plants as well as plants whlch are no longer in cormmerclel operation. 


\section{APPENDXX E}

ARKANSAS 1,2

Dose-Performance indicators

PWR

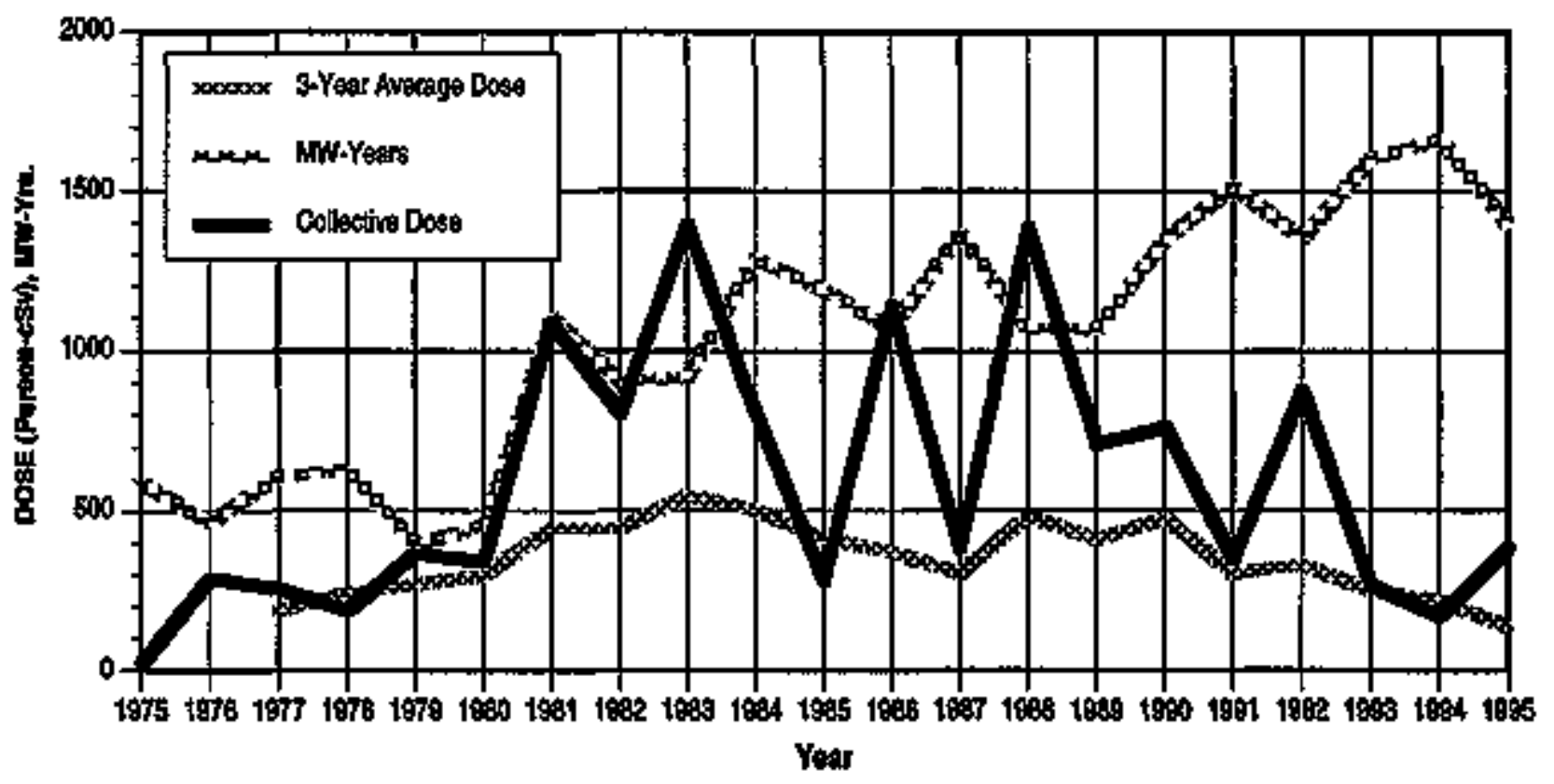

Brealkdown by Job Function

Plant

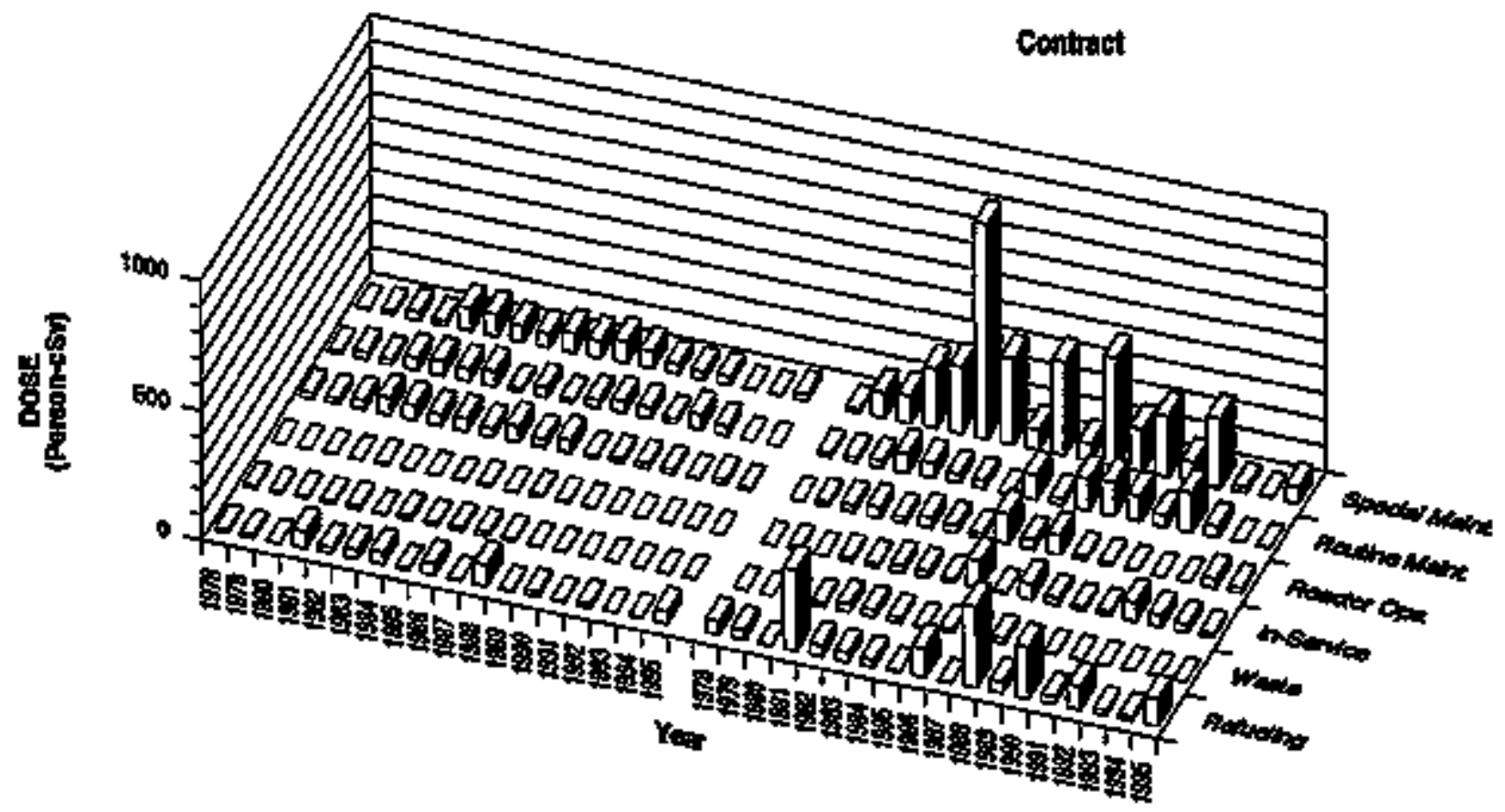

NUREG-0713 


\section{APPENDIX E (continued)}

BEAVER YALLEY 1,2

Dose Peformance ladicators

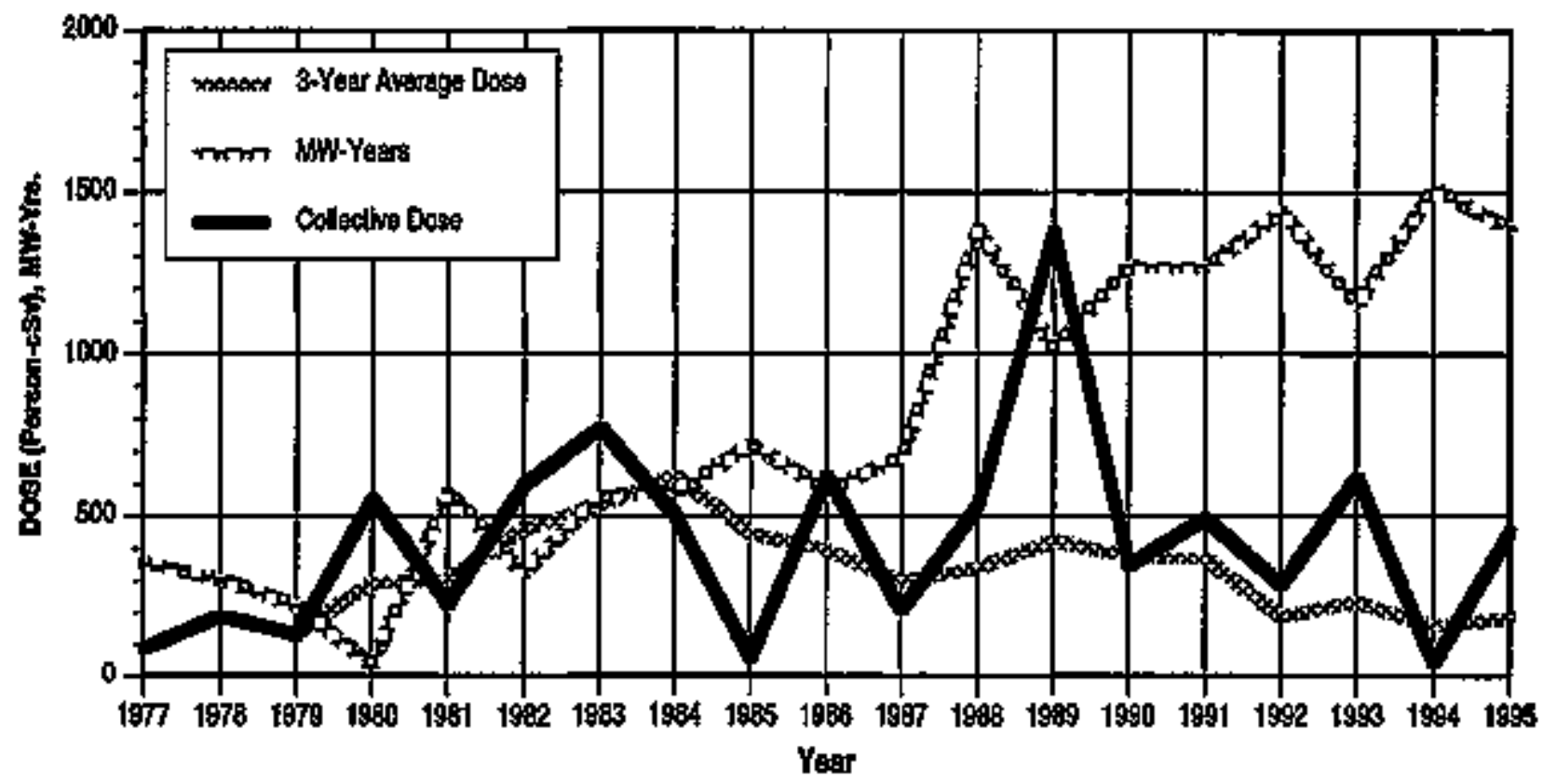

Breakdown by dob Funetion

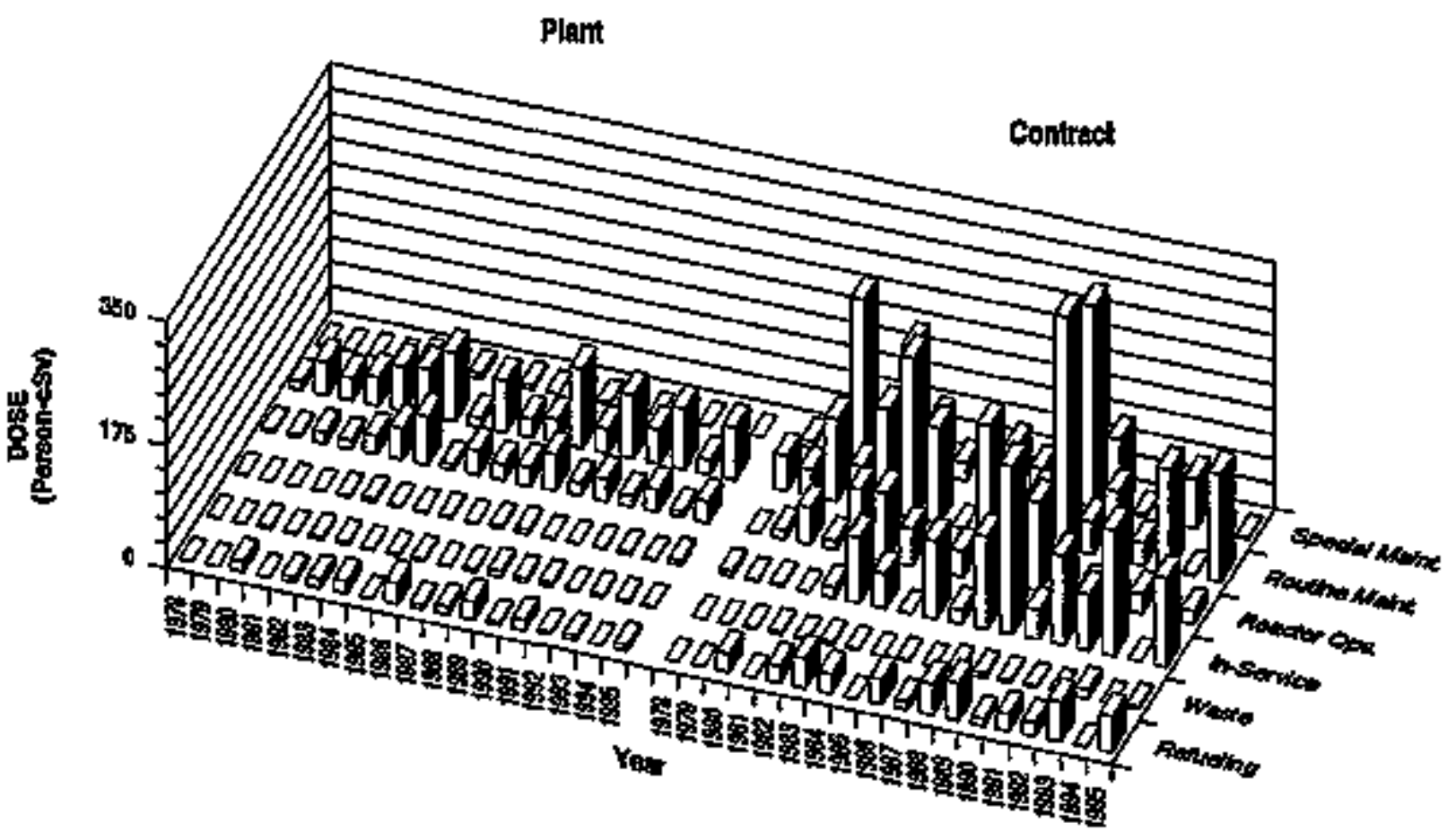




\section{APPENDIX E (continued) \\ BIG ROCK POWT}

Dose-Paiformance Indicators

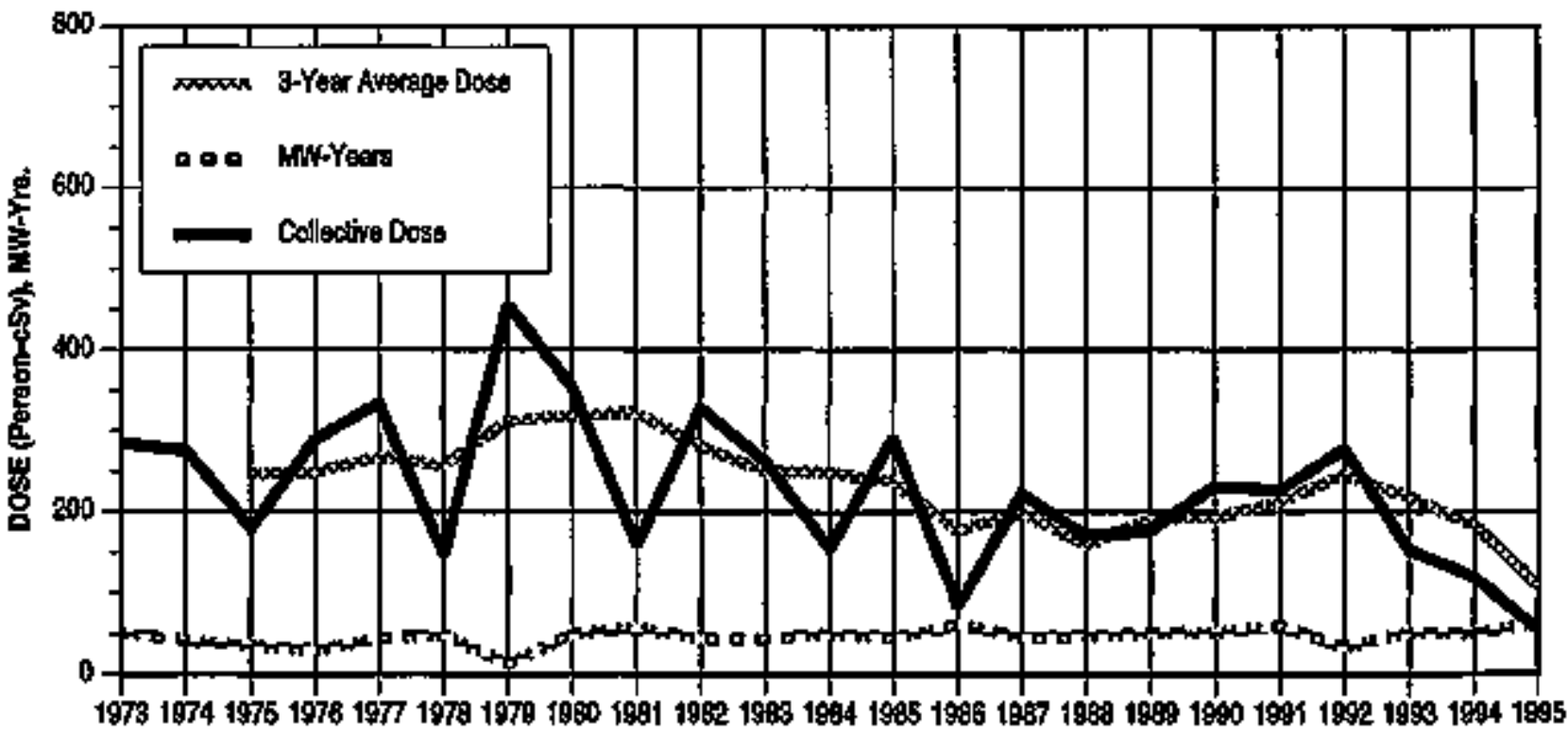

Year

Breakdown by Job Funstion

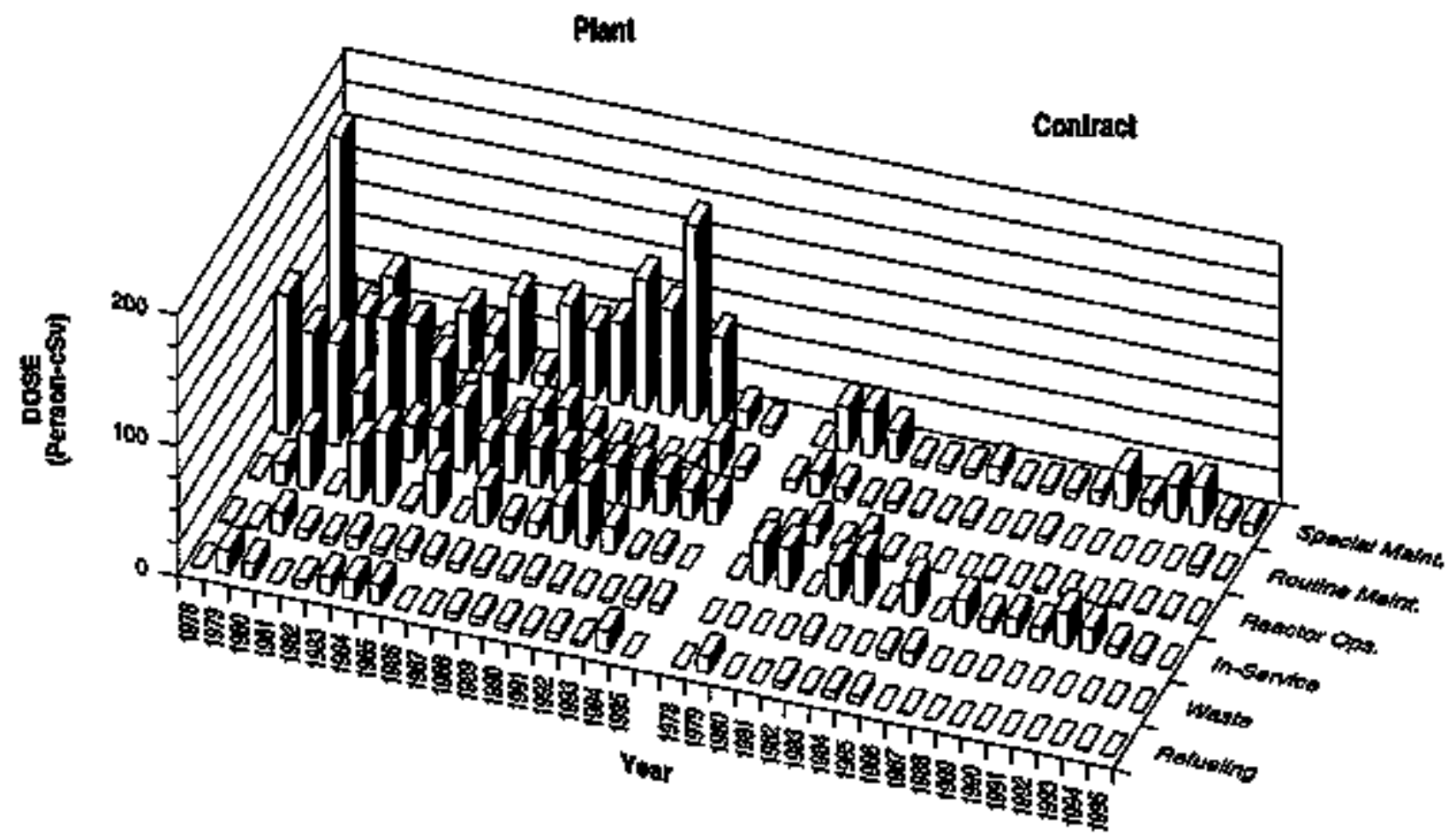




\section{APPENDXX E (continued) \\ BRADWOOD 1,2}

Dose-Periormance indicatars

PWR

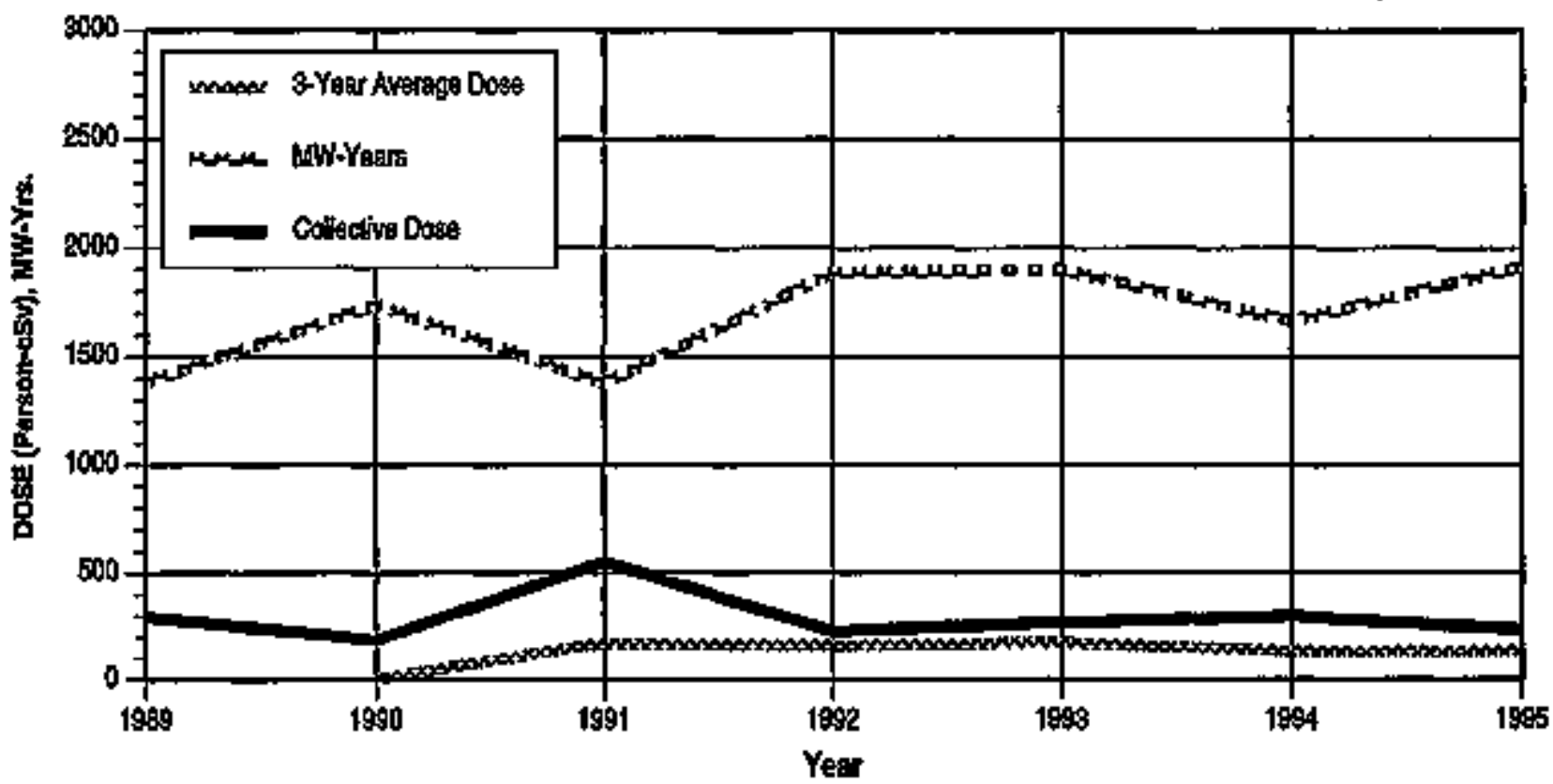

Breaktown by Job Function

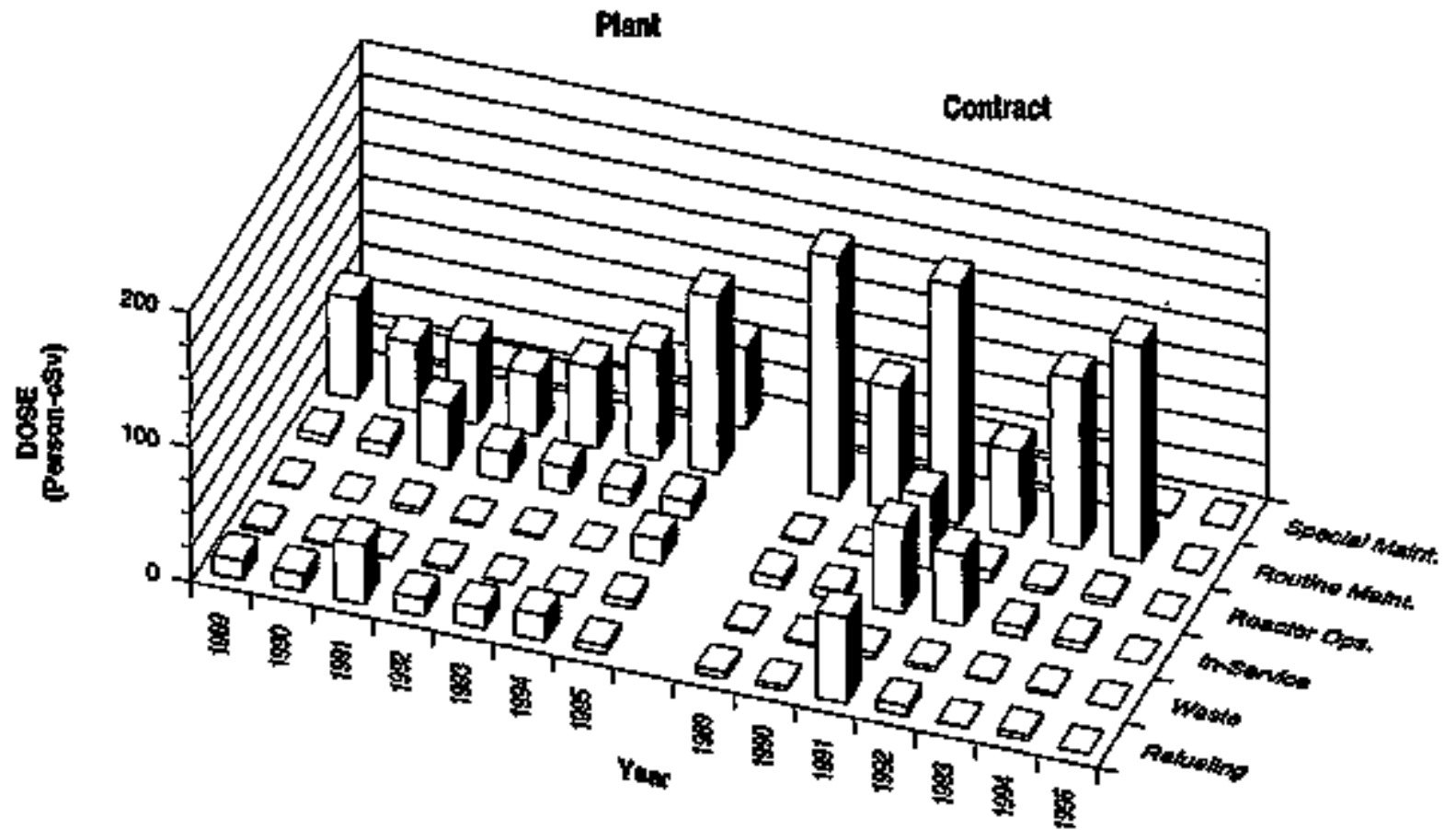




\section{APPENDIX E (continued)}

BROWWS FERRY 1, 2, 3

Dose Perfornance indicators

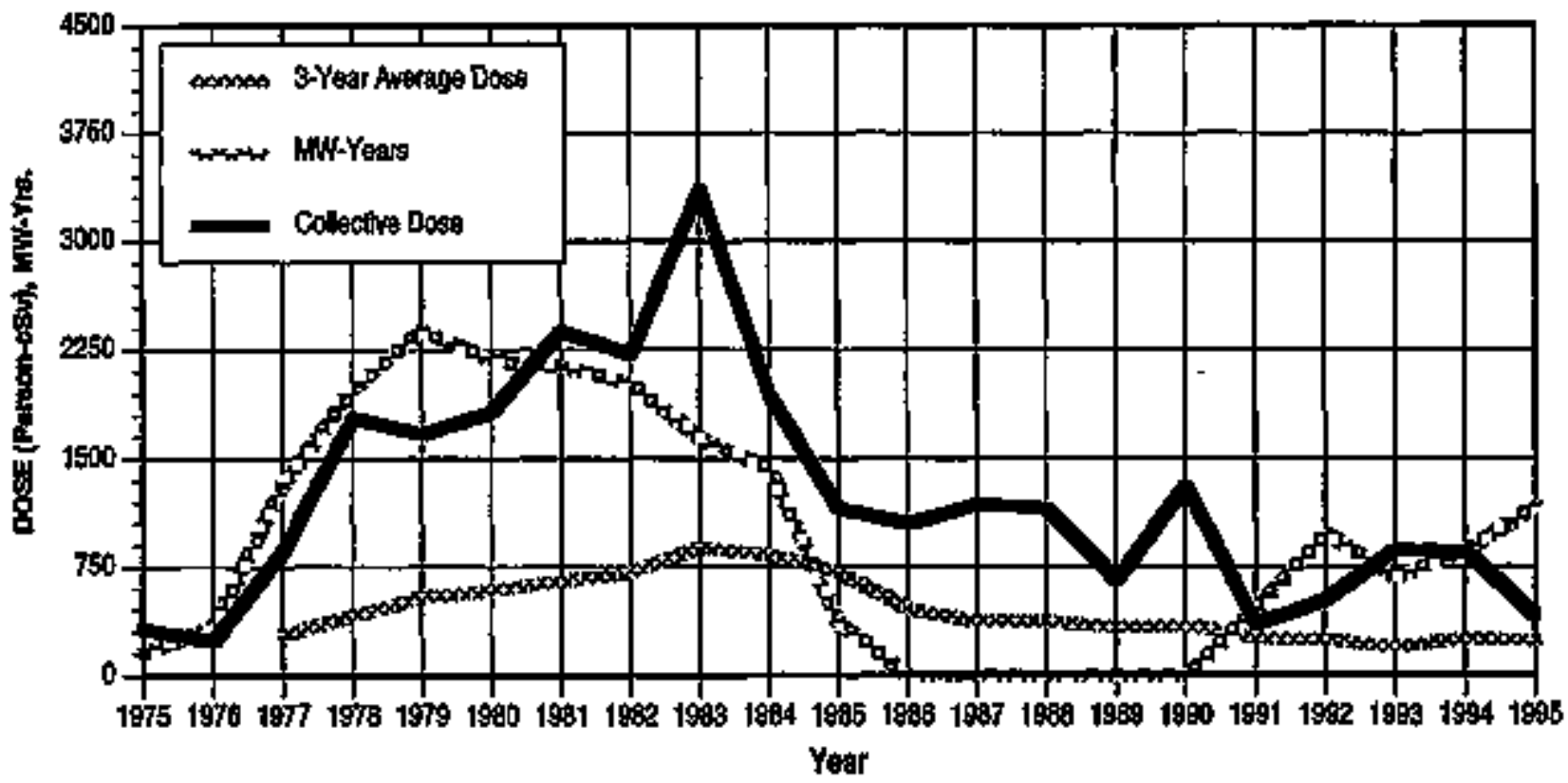

Breakdown by Job Function

Piant

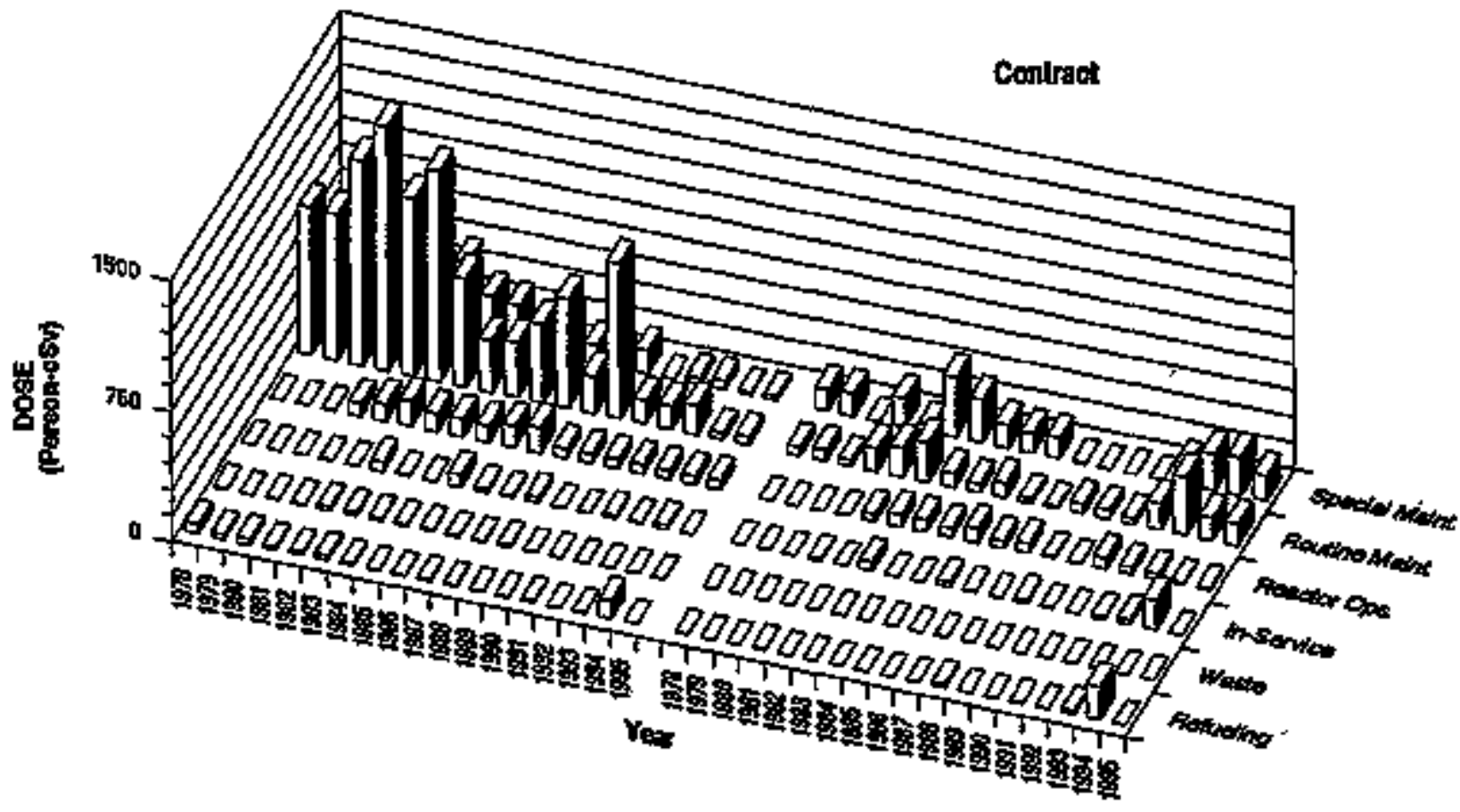




\section{APPENDIX E (continued) \\ BRINSWICK 1,2}

Dose-Pertomencen Infilioators

BWR

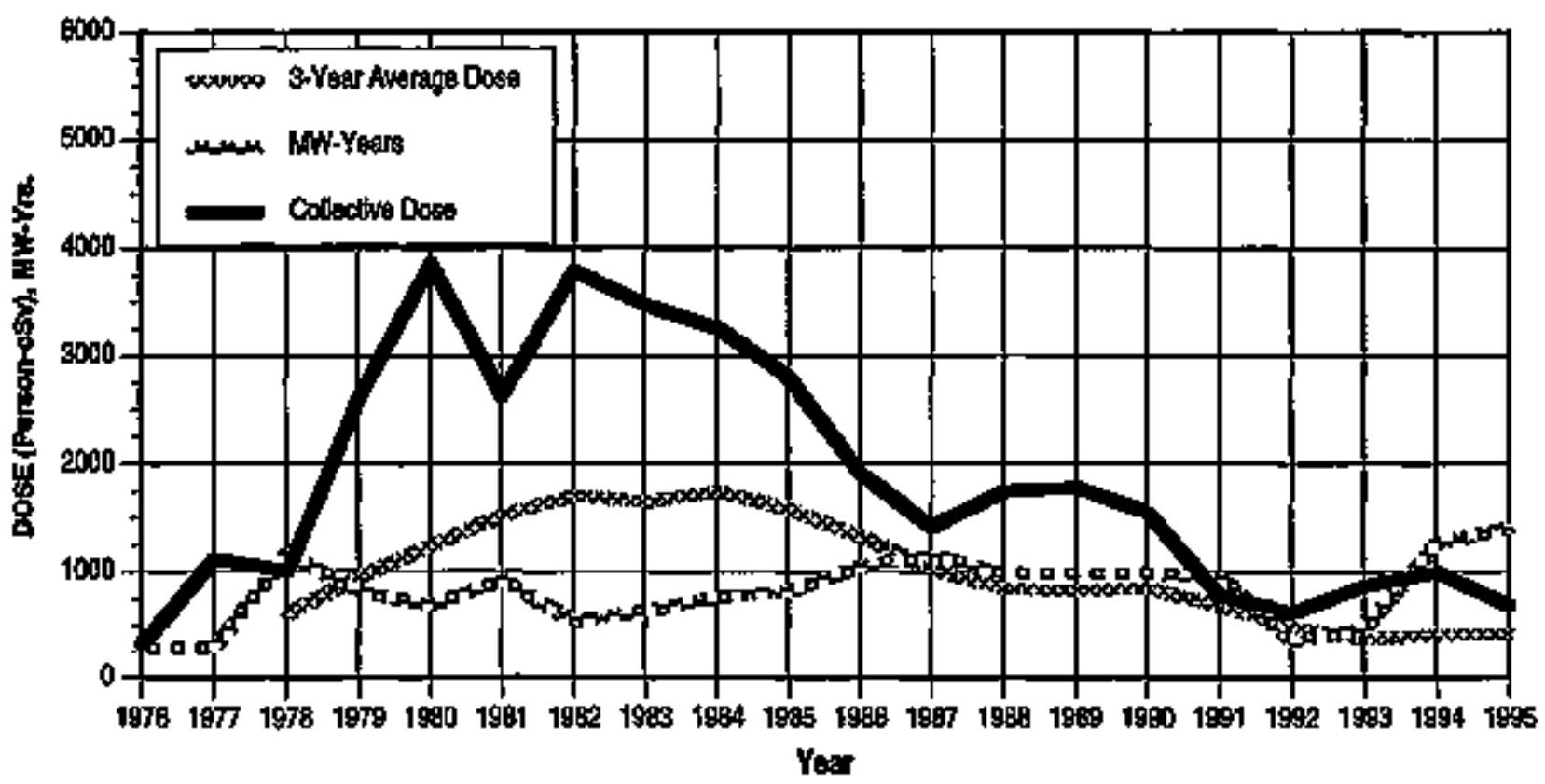

Breakdoum by tob Function

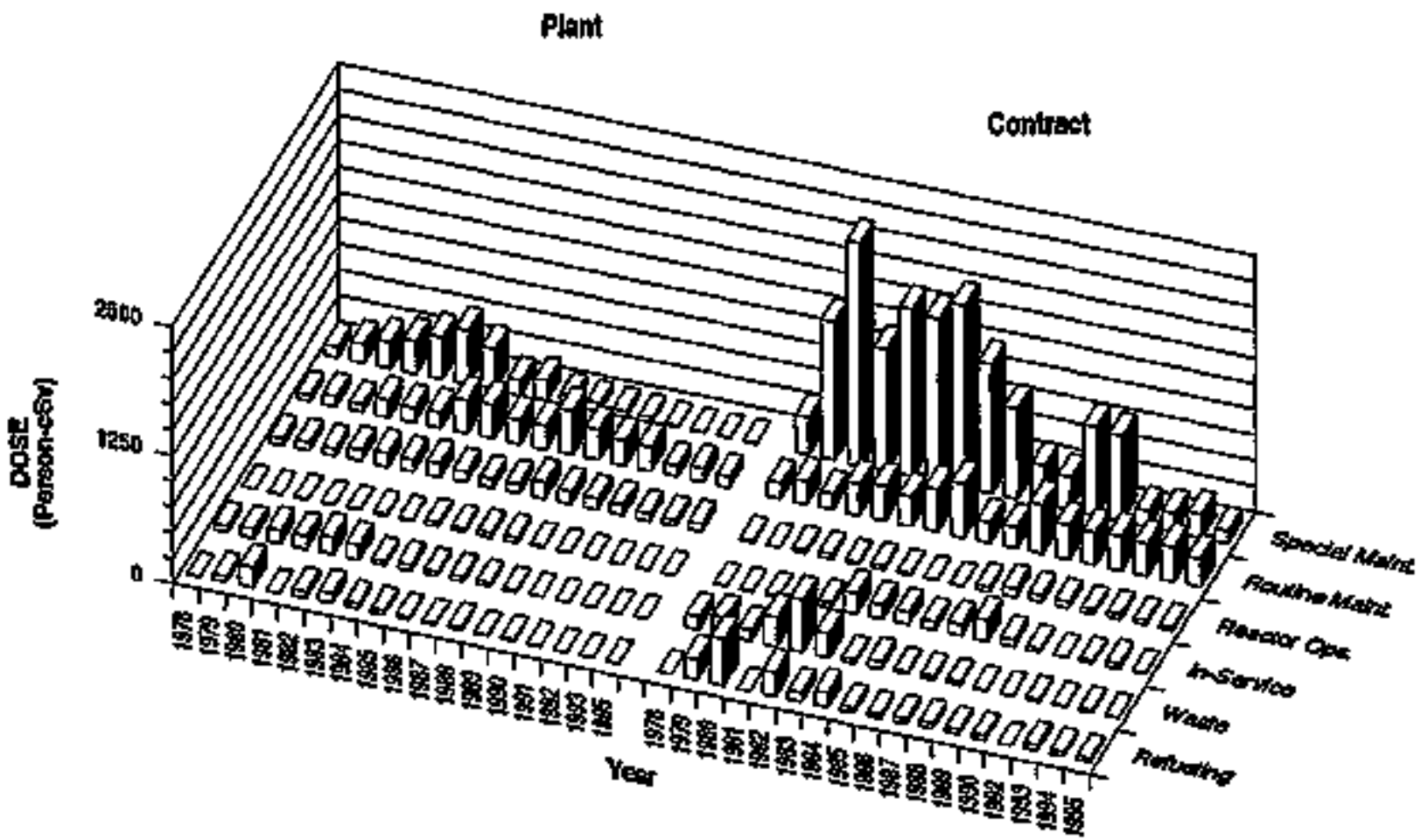




\section{APPENDIX E (continued) \\ BYAON 1,2}

Dose-Performanos Indioalors

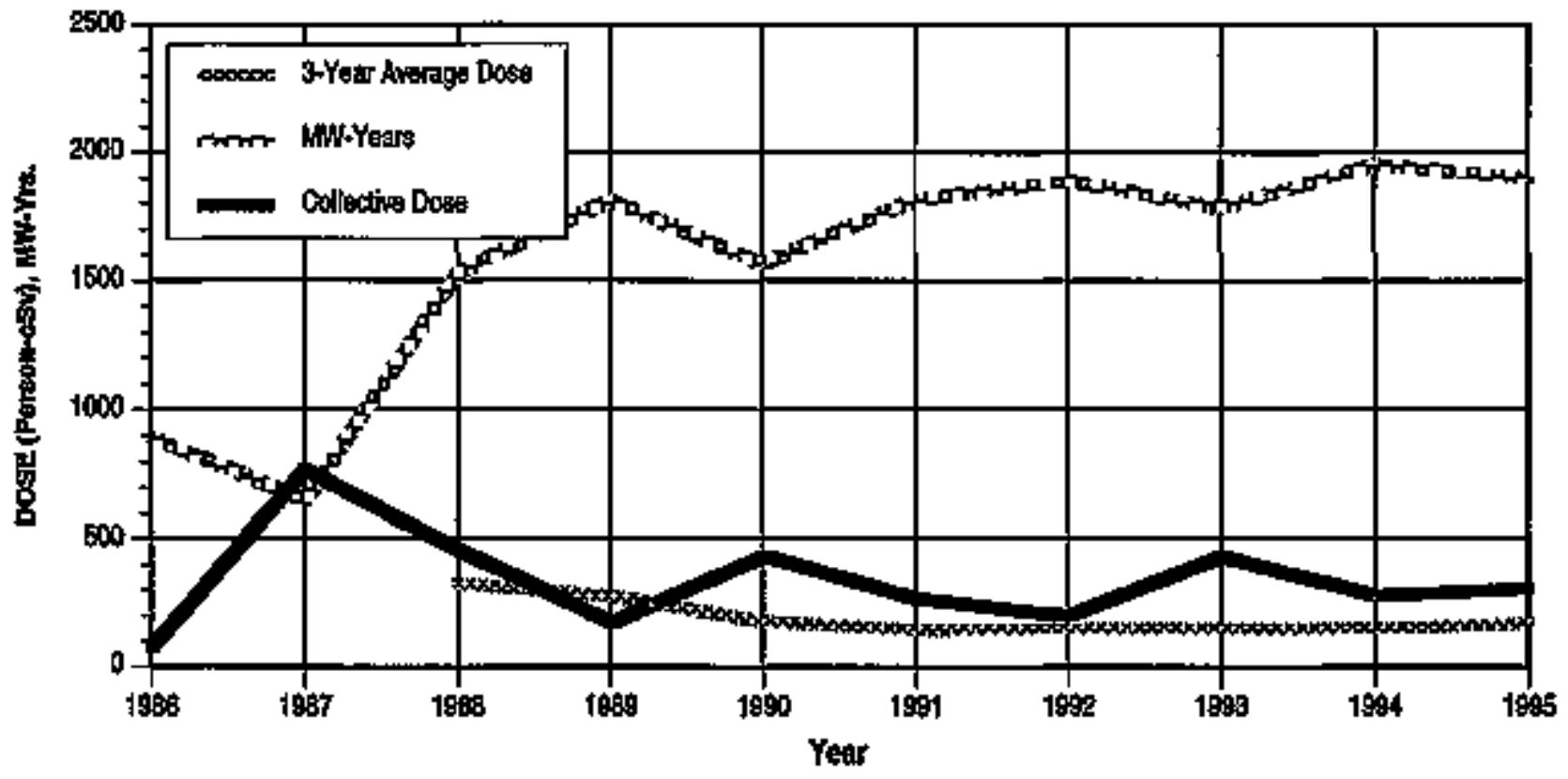

Brakdoun by dob Function

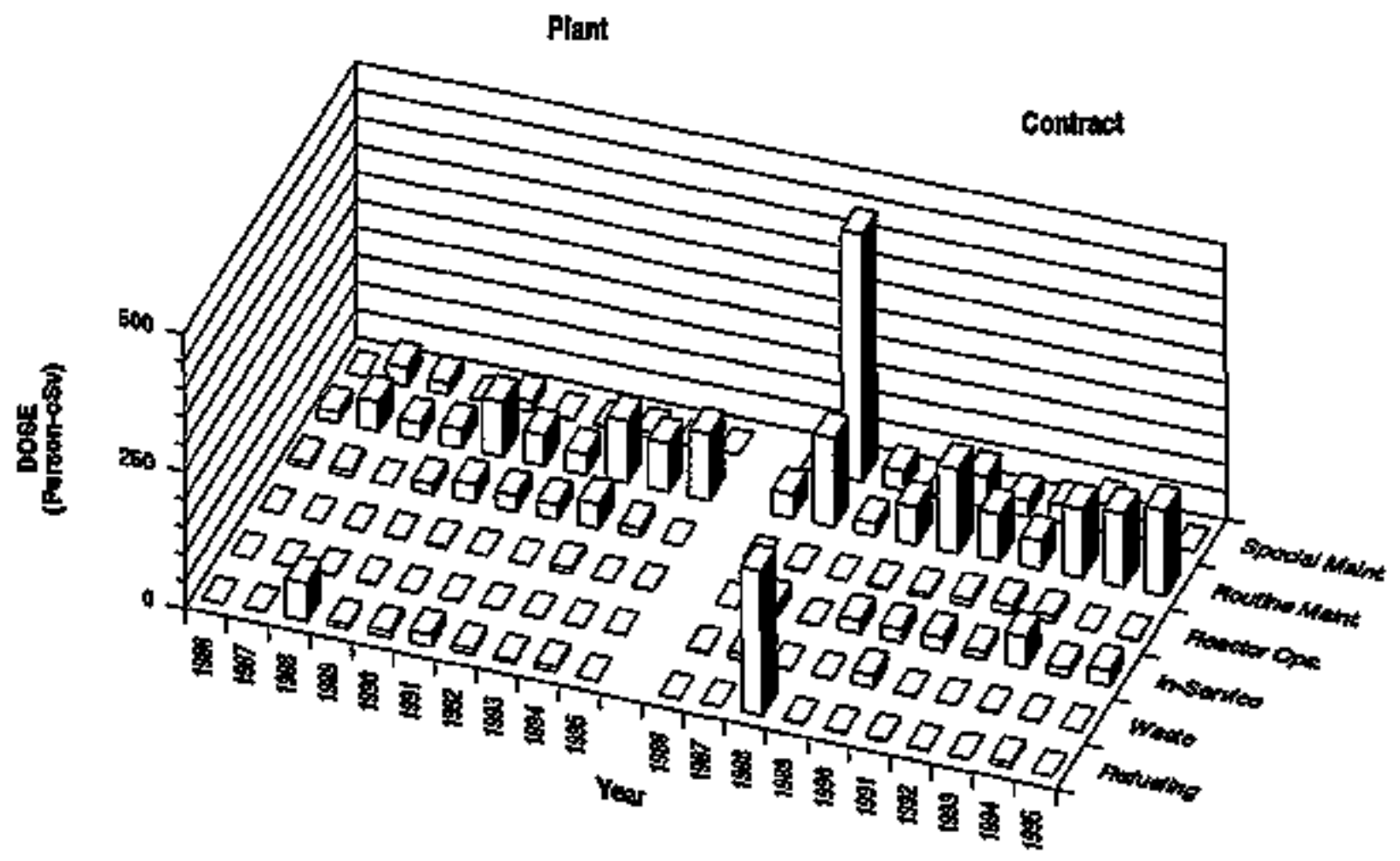




\section{APPENDIX E (continued) \\ CALLAWAY 1}

Dosa-Peeformante hodicaiors

PWR

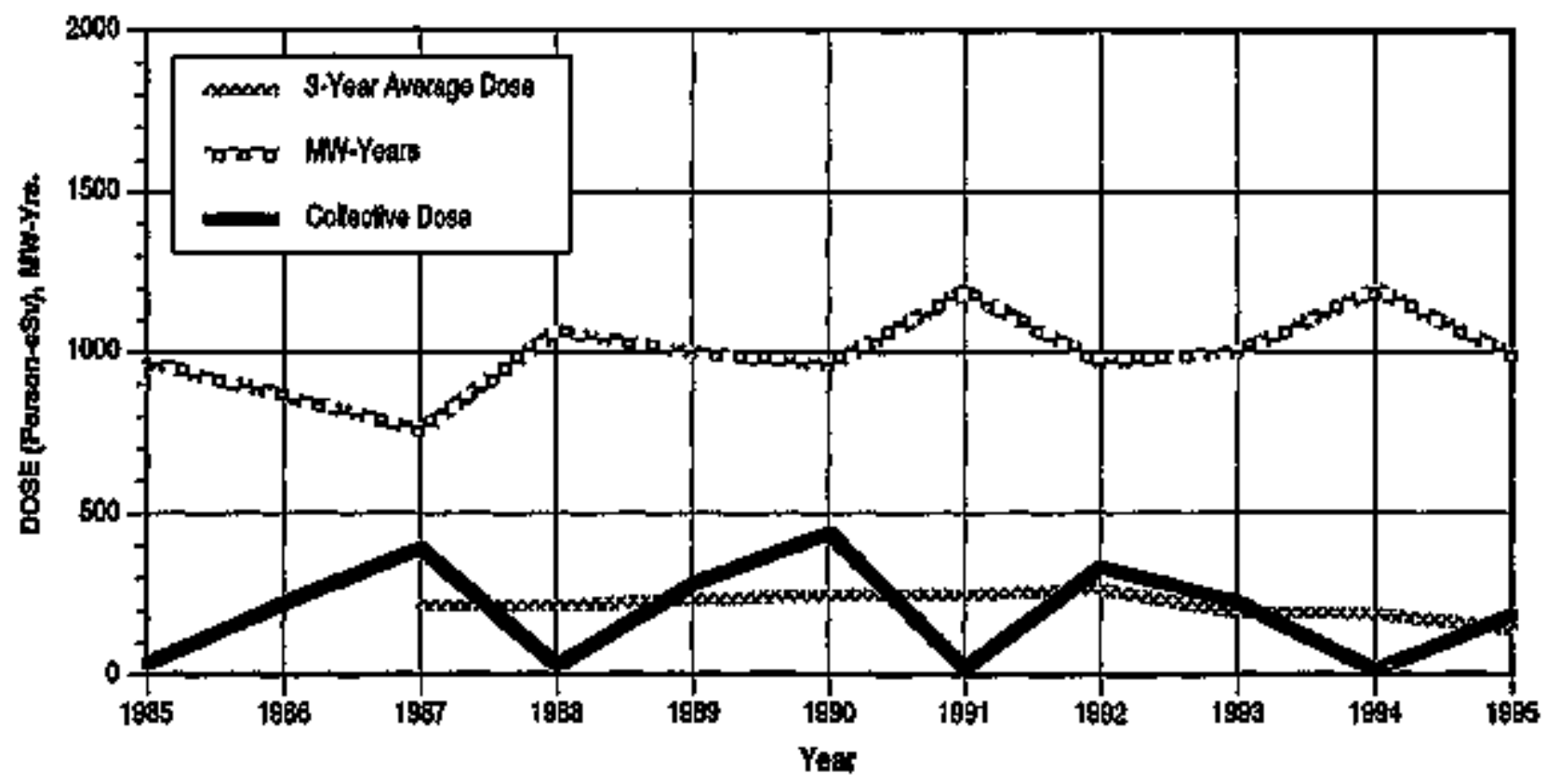

Breakdown by Job Functian

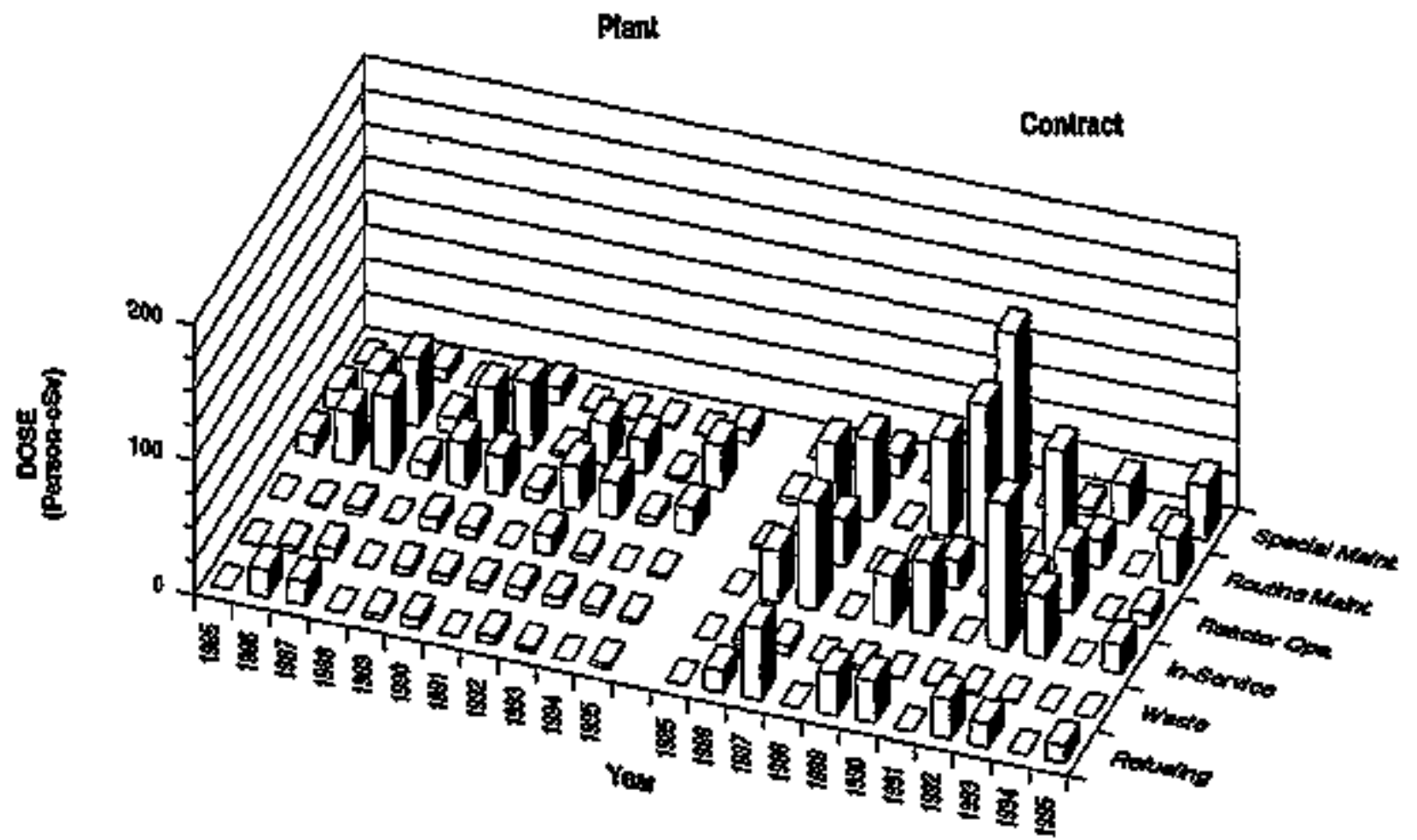


APPENDX E (continued)

CALVERT CLIFFS 1, 2

Dosefartomence Irdicators

PWR

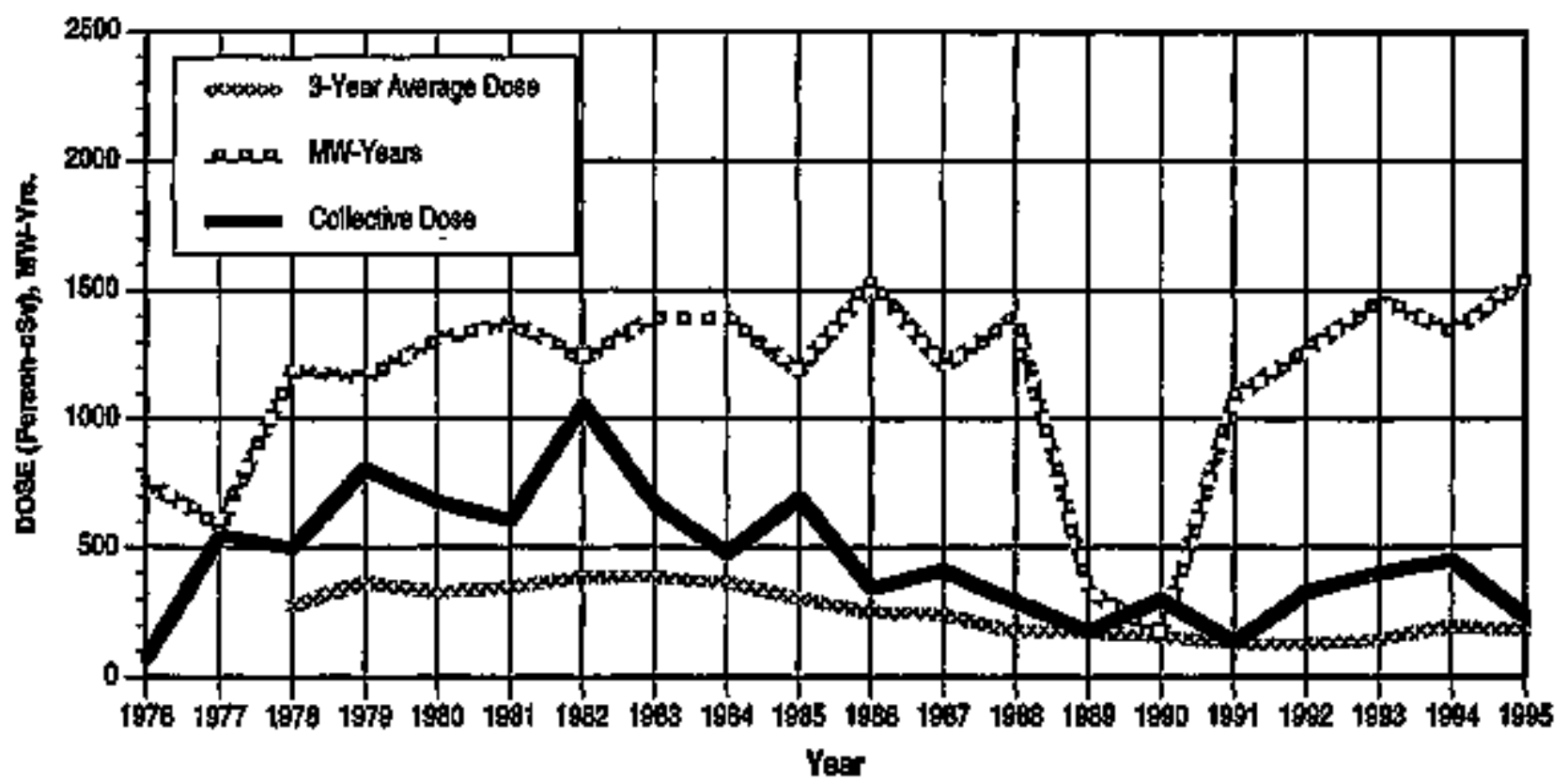

Brakdown by lob Funntion

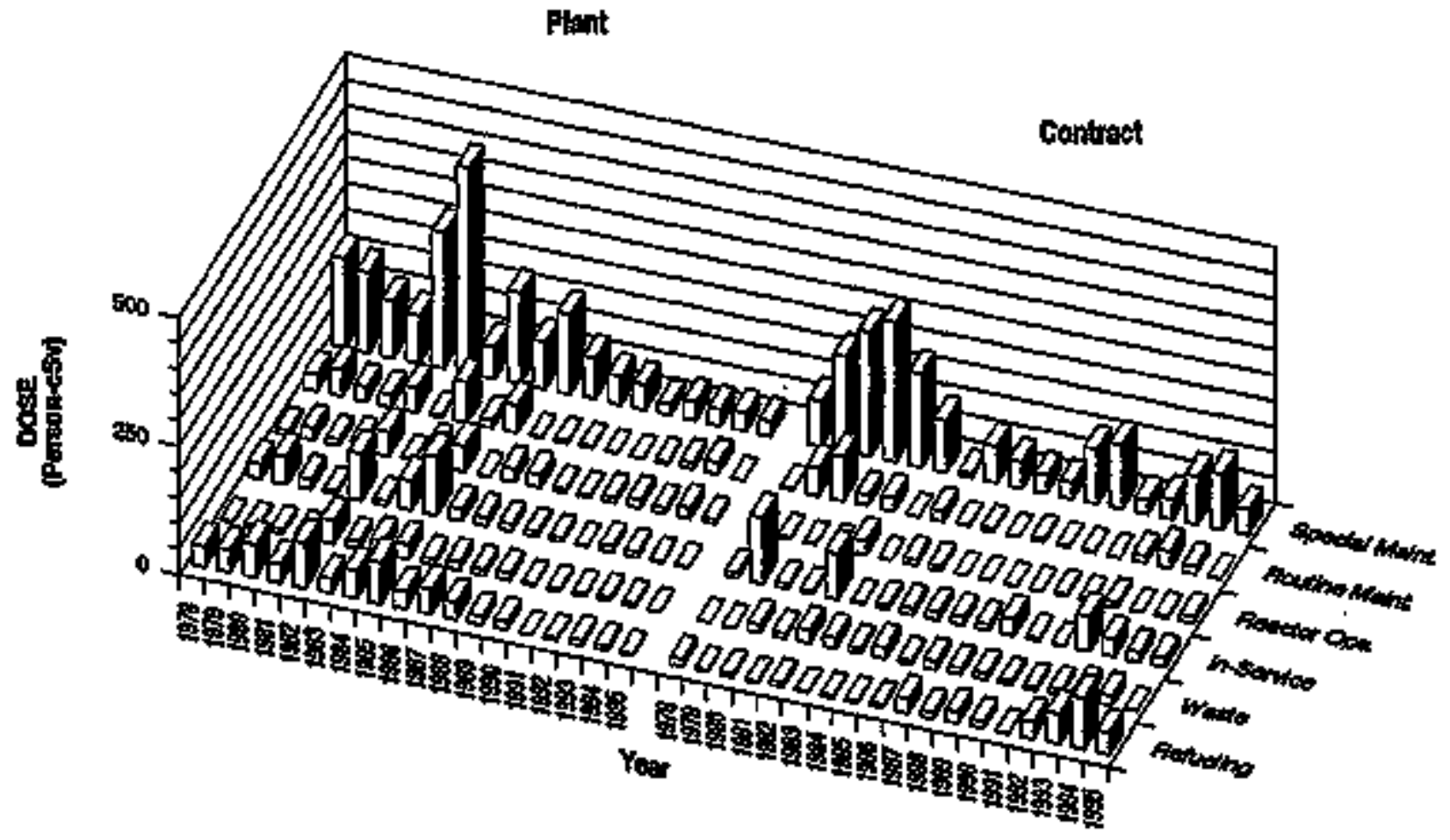

NUREG-0713

E-10 


\section{APPQ日NDXX E (continued) \\ CATAWBA 1,2}

Dose-Performanca hrdicators

PWR

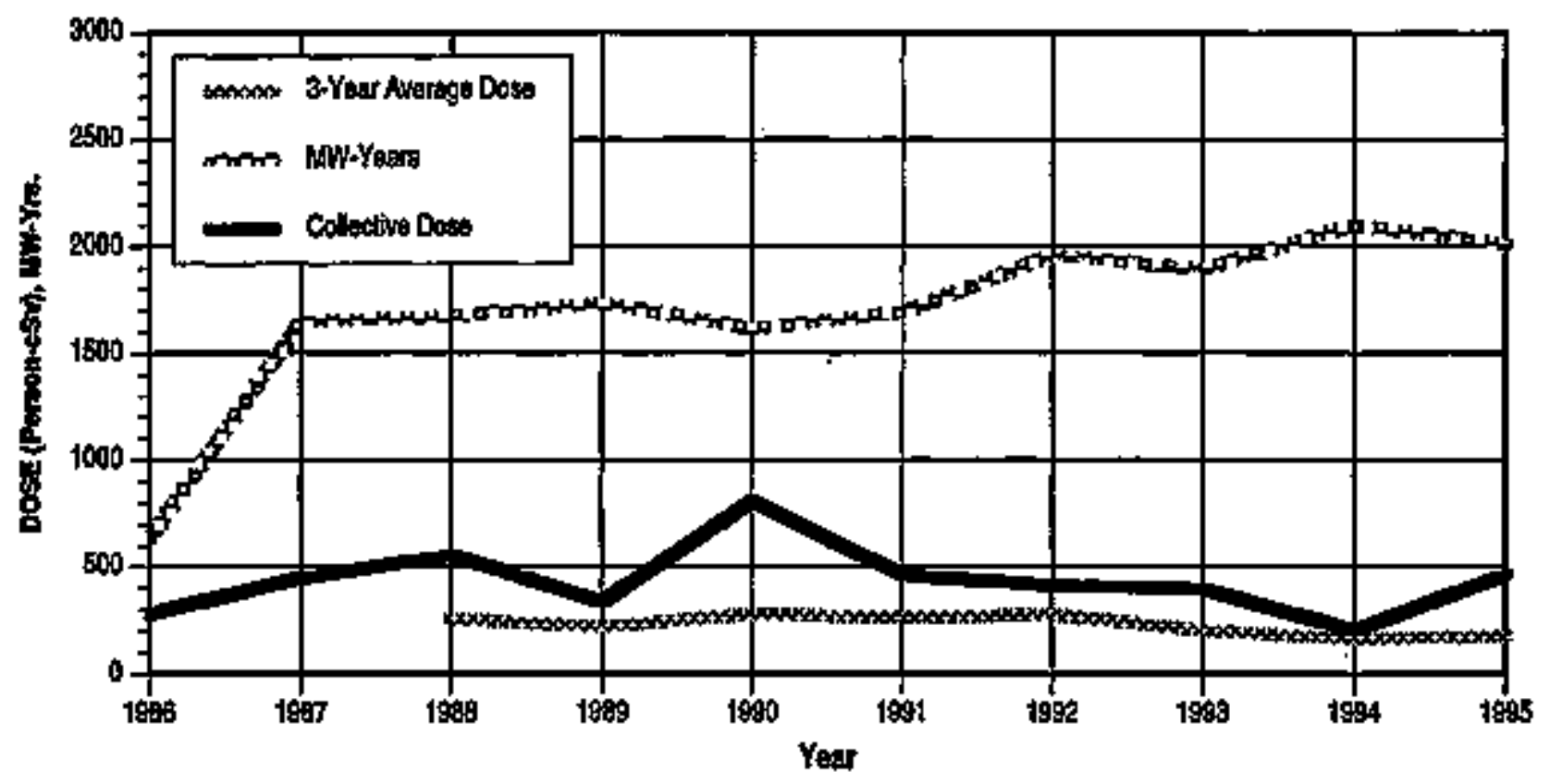

Breakcionn by Job Function

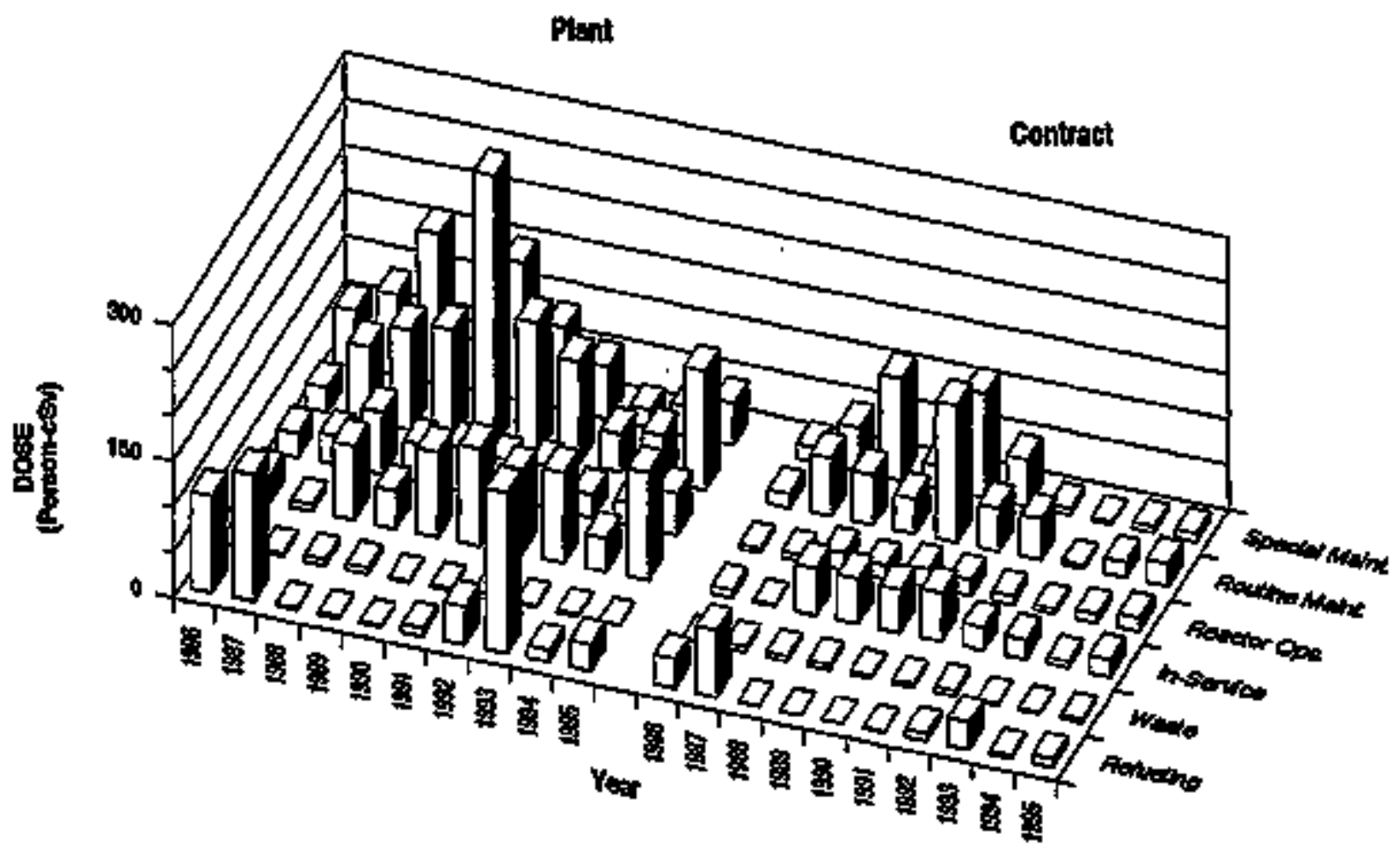




\section{APPENDXX E (continued) \\ CLINTON}

Dose-Poffomanco Inticators

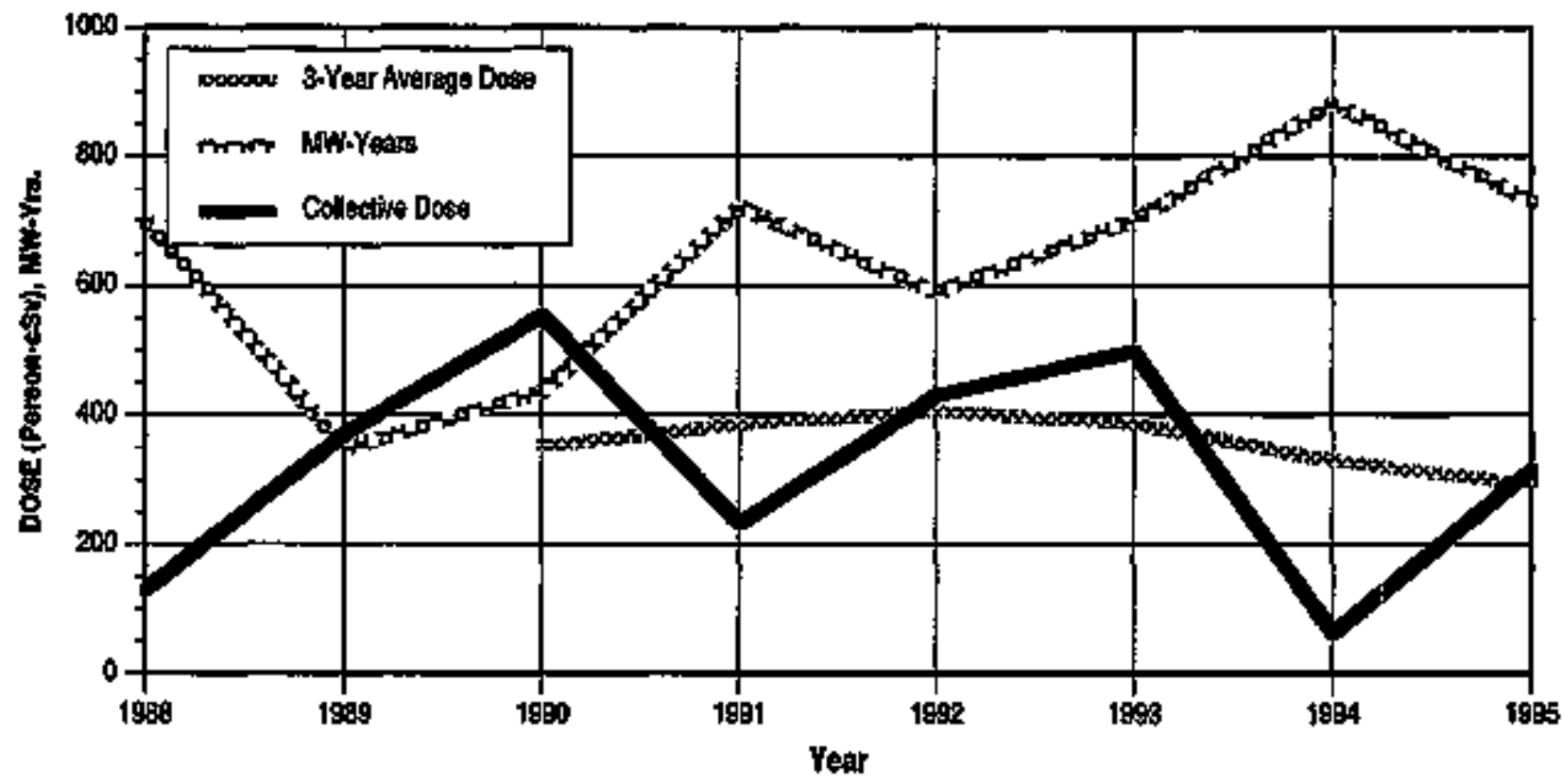

Breakdown by dob Function

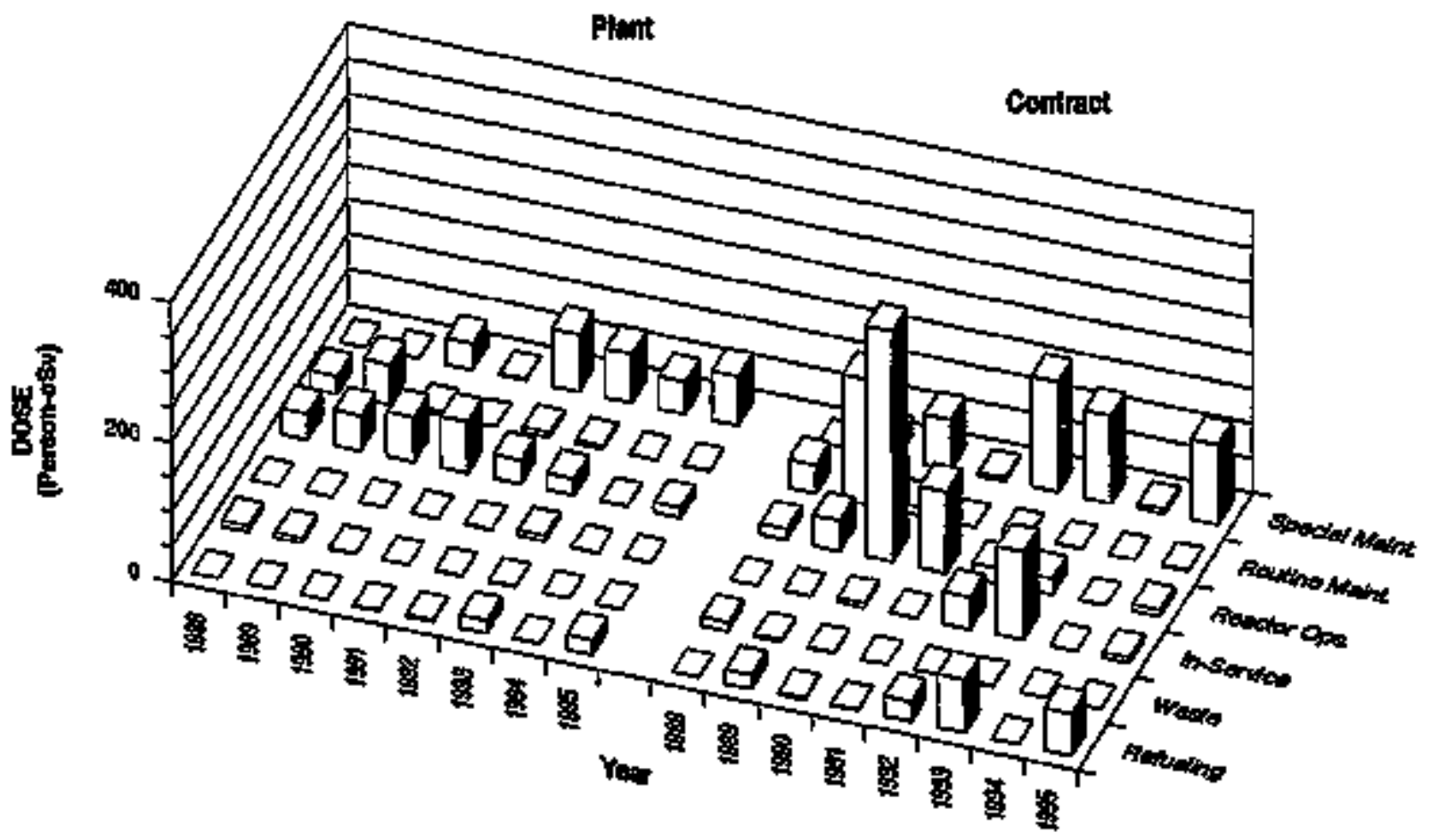


APPENDXX E (continued)

COMANCHE PEAK 1, 2

Dose-Periomance Indicators

PWR

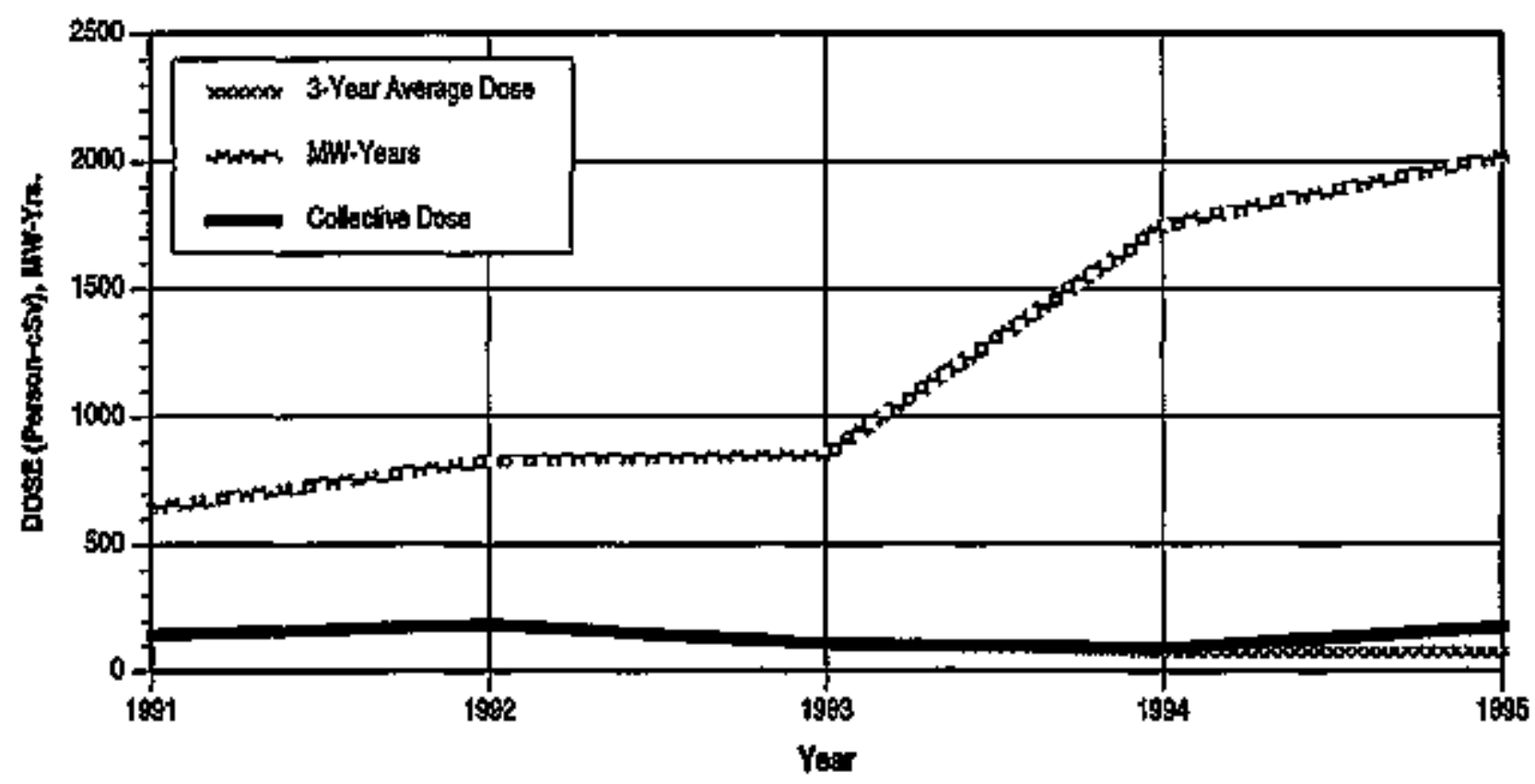

Breakdiown by Job Function

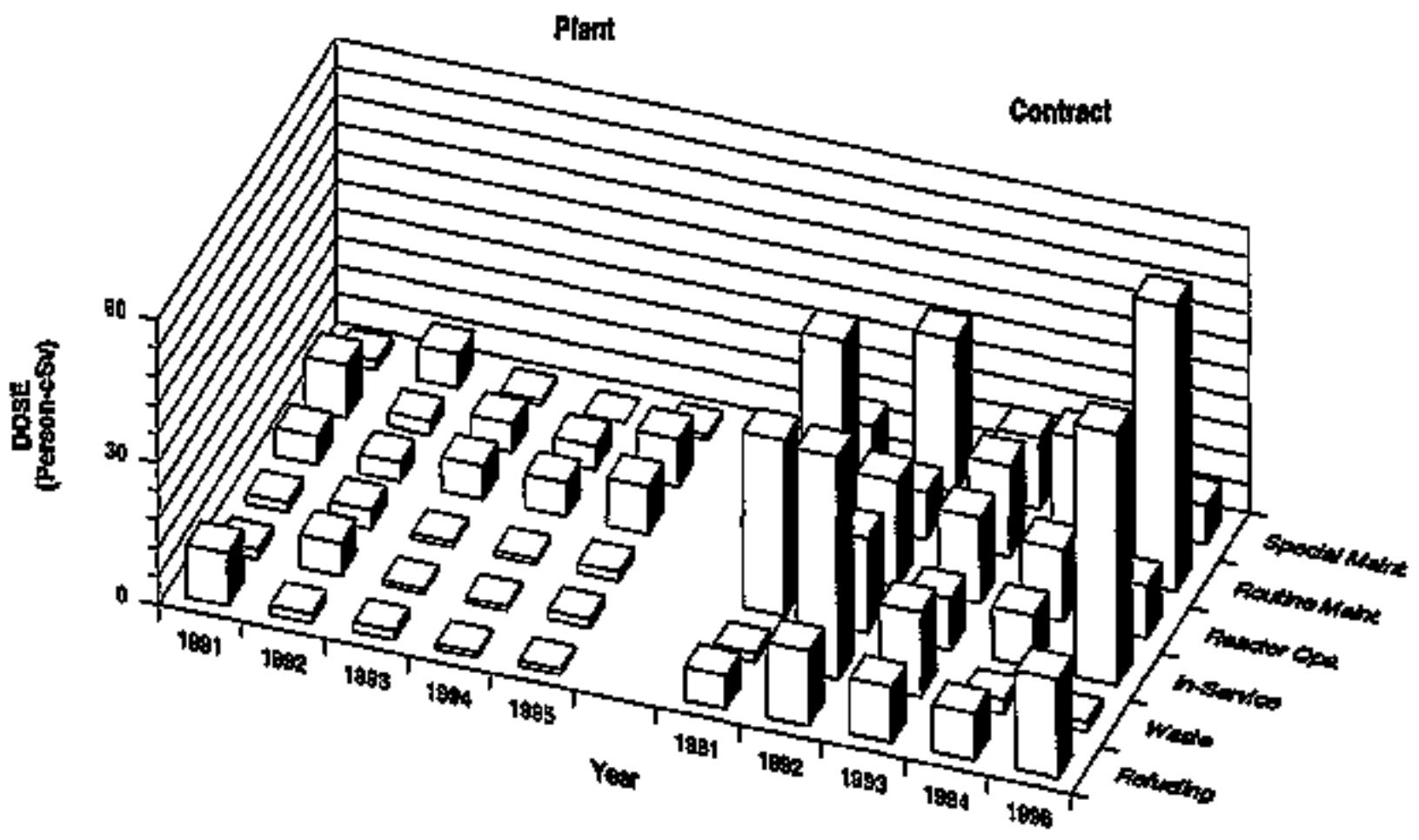

E-13

NUREG-0713 
APPENDLX E (continued)

COOK 1,2

Dosefertormance Indicators

PWA

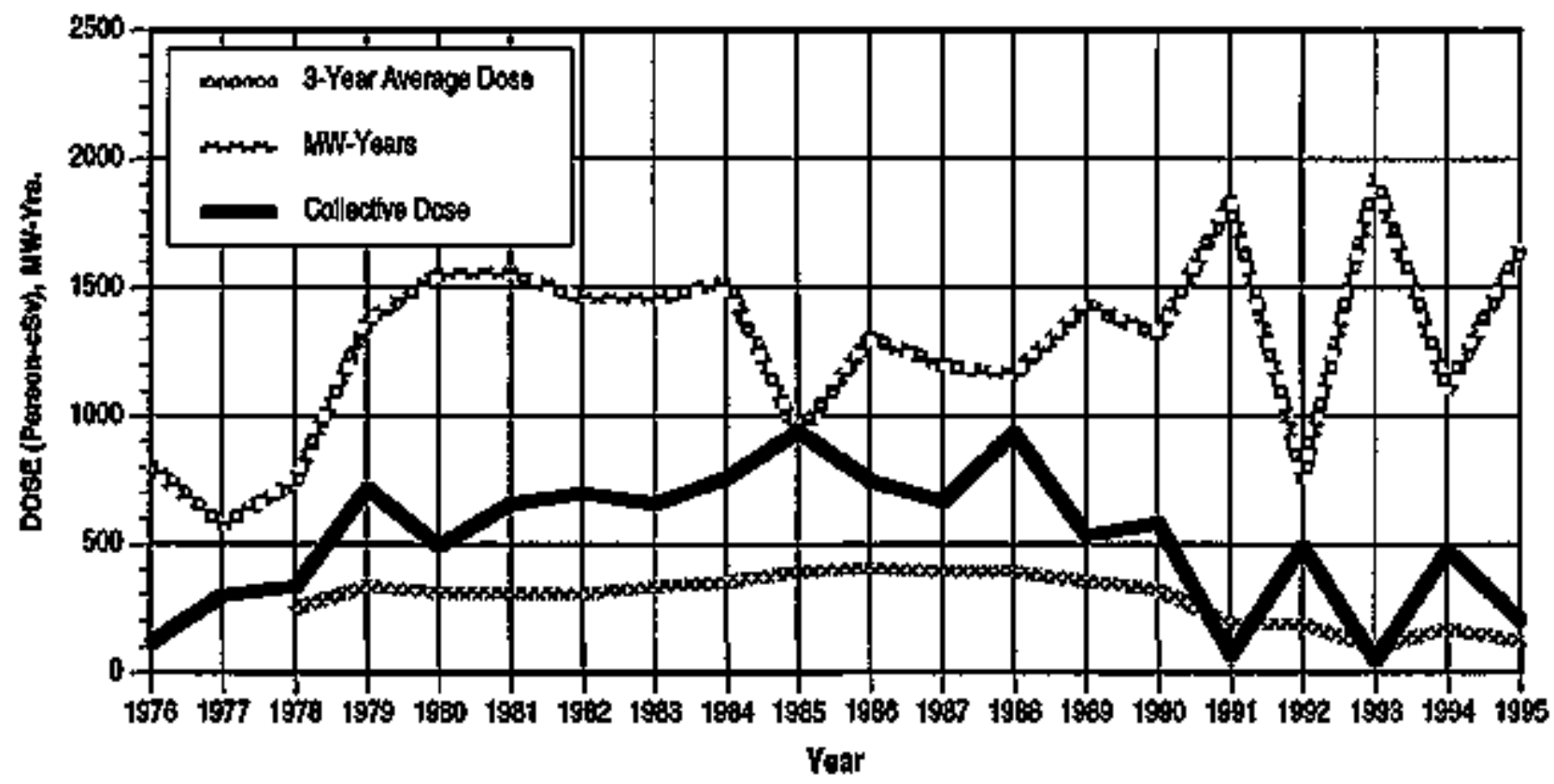

Breakdowat by Job Futction

Plent

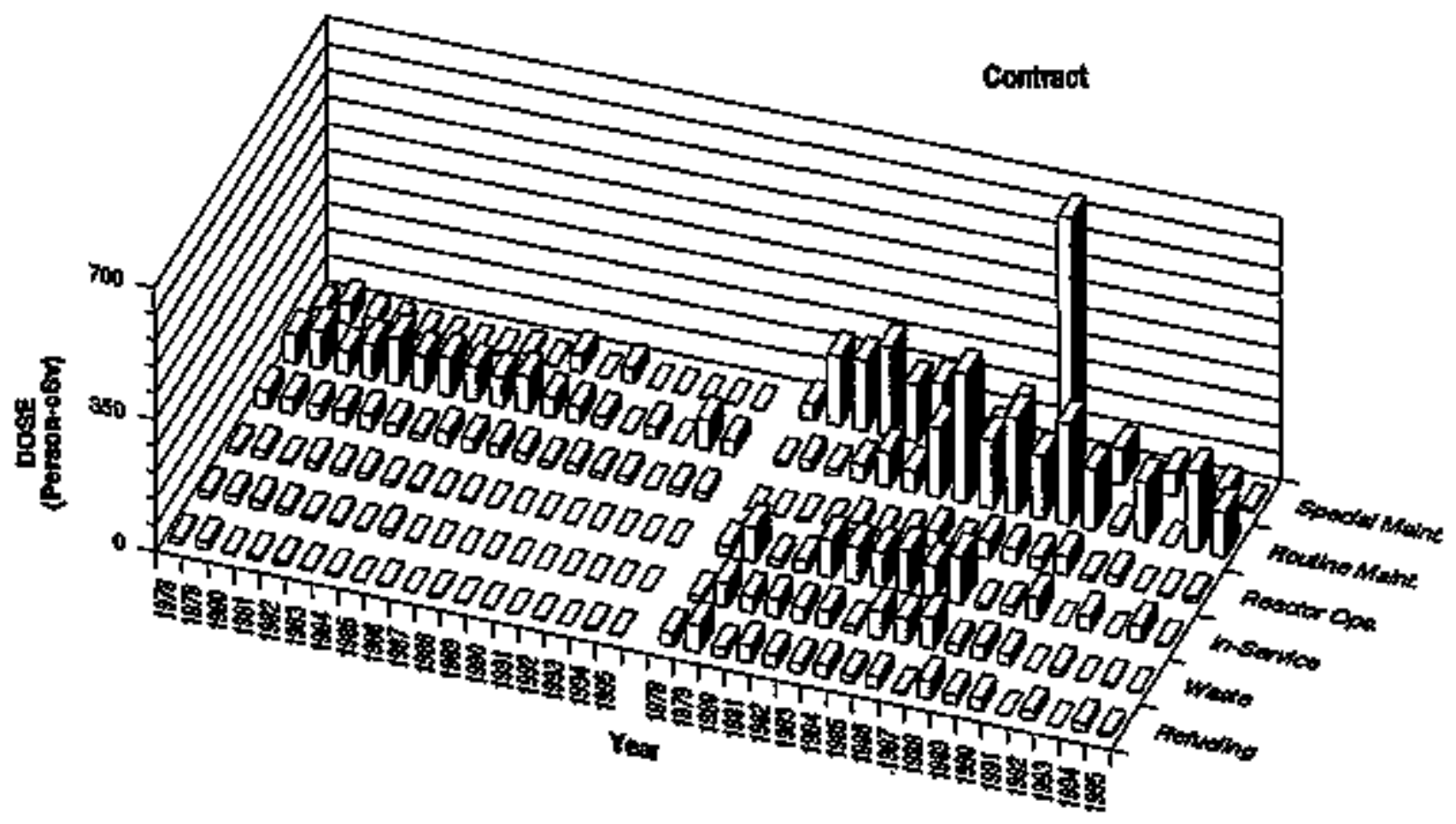




\section{APPENDIX E (continued) \\ COOPER STATION}

Dose Peformance Indioaloss

BWR

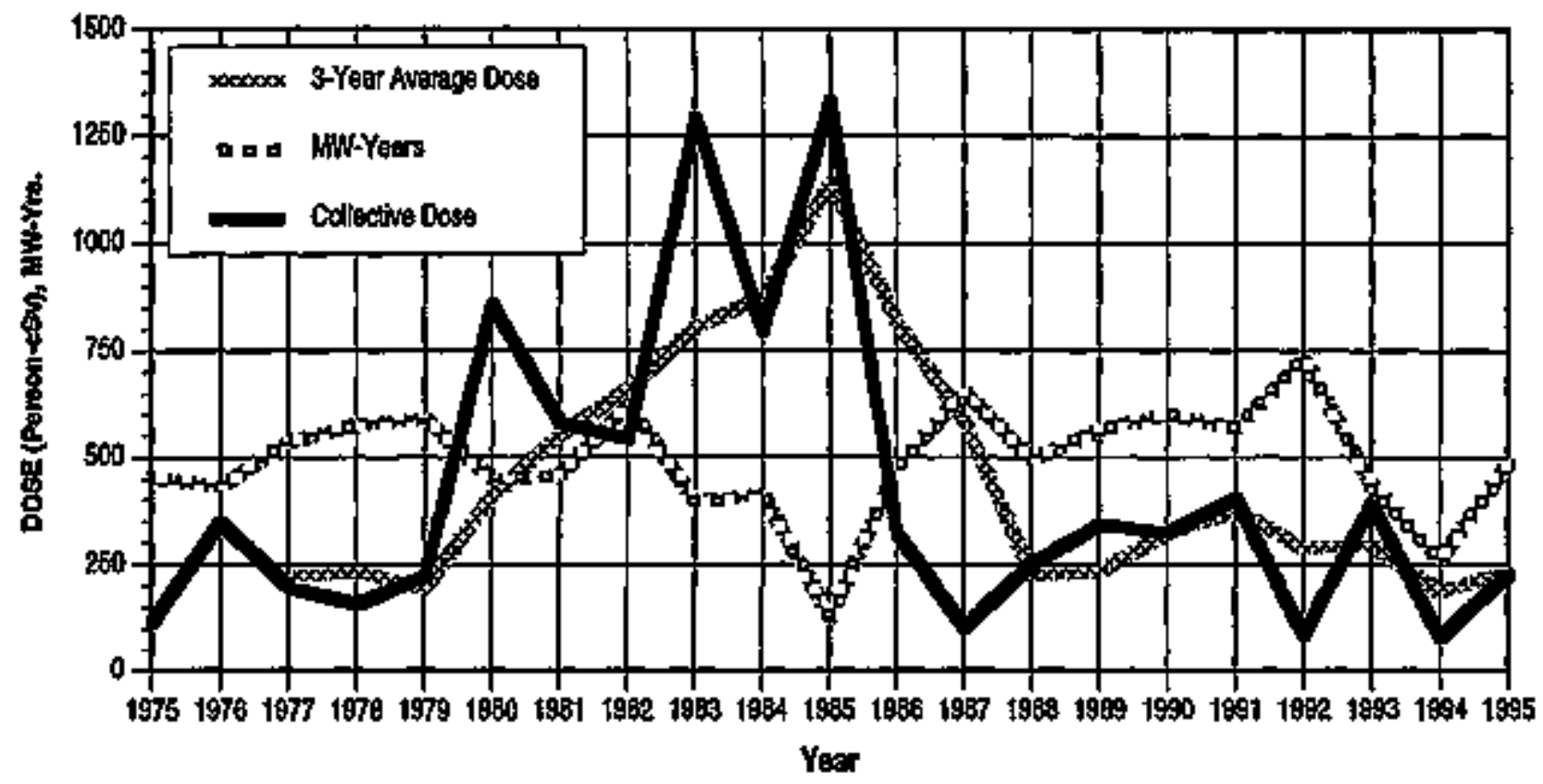

Breaktown by Job Function

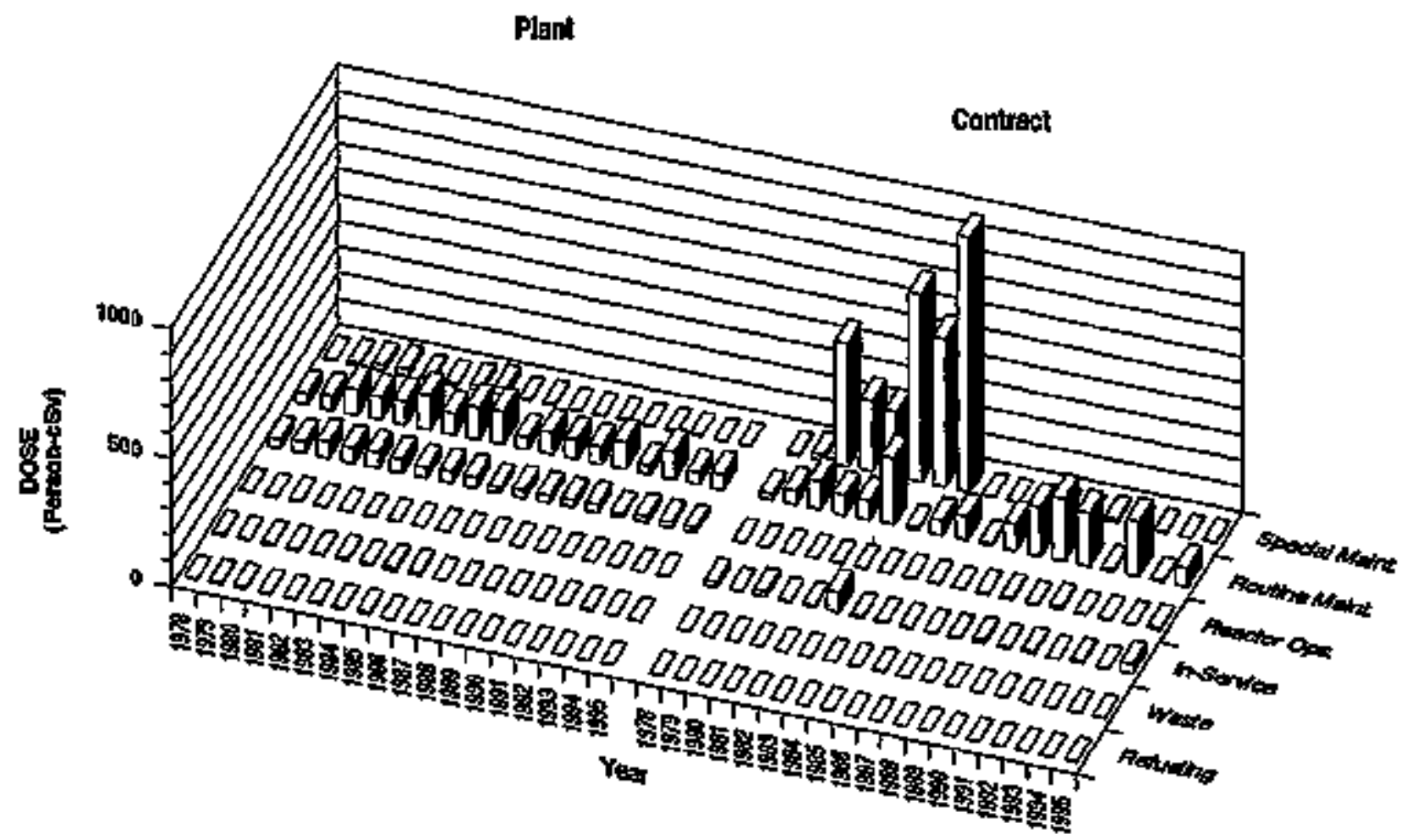




\section{APPENDXX E (continuad) \\ CRYSTAL RIVER 3}

Dose-Perlomence Indleators

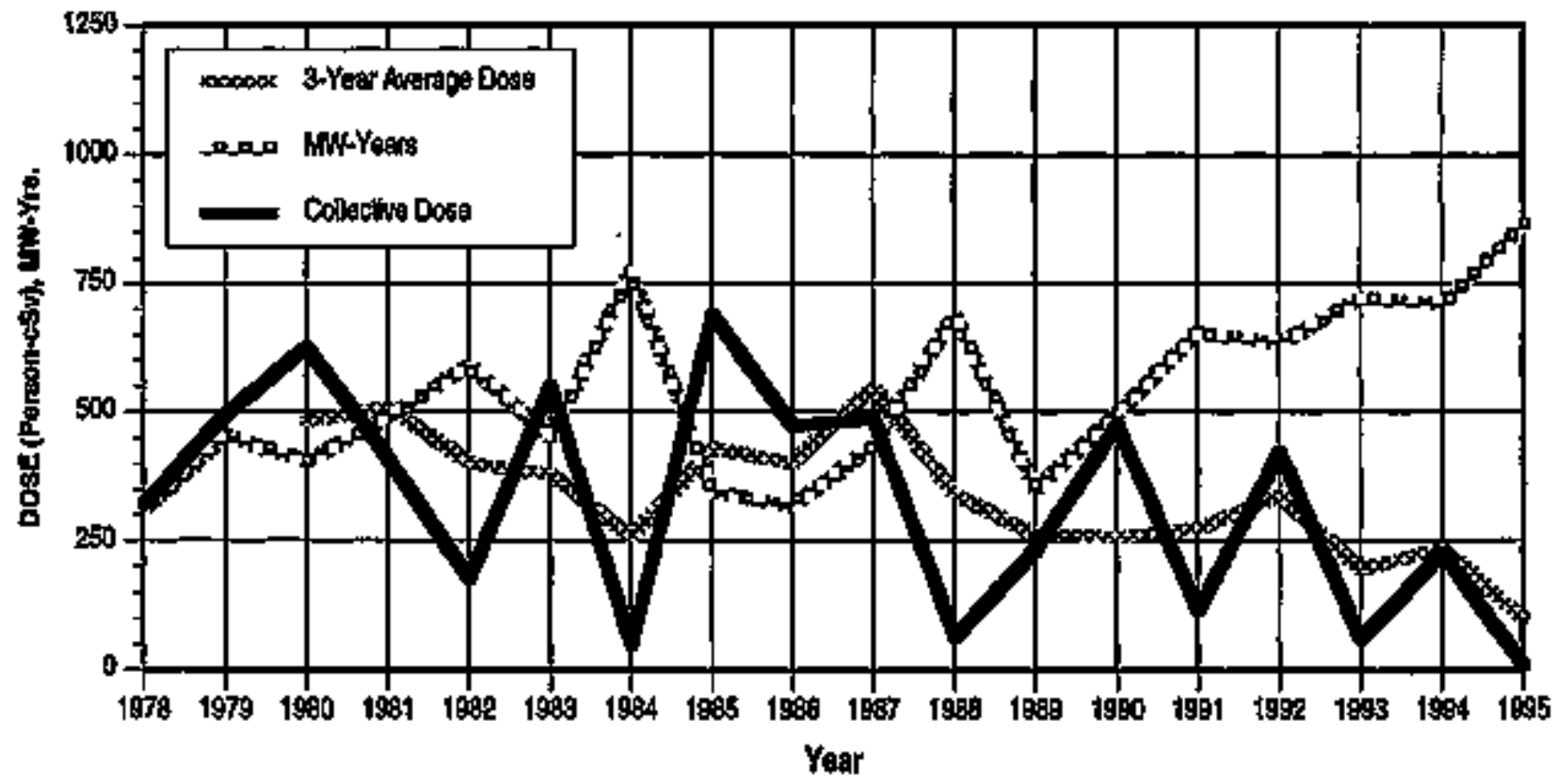

Greakdown by Job Function

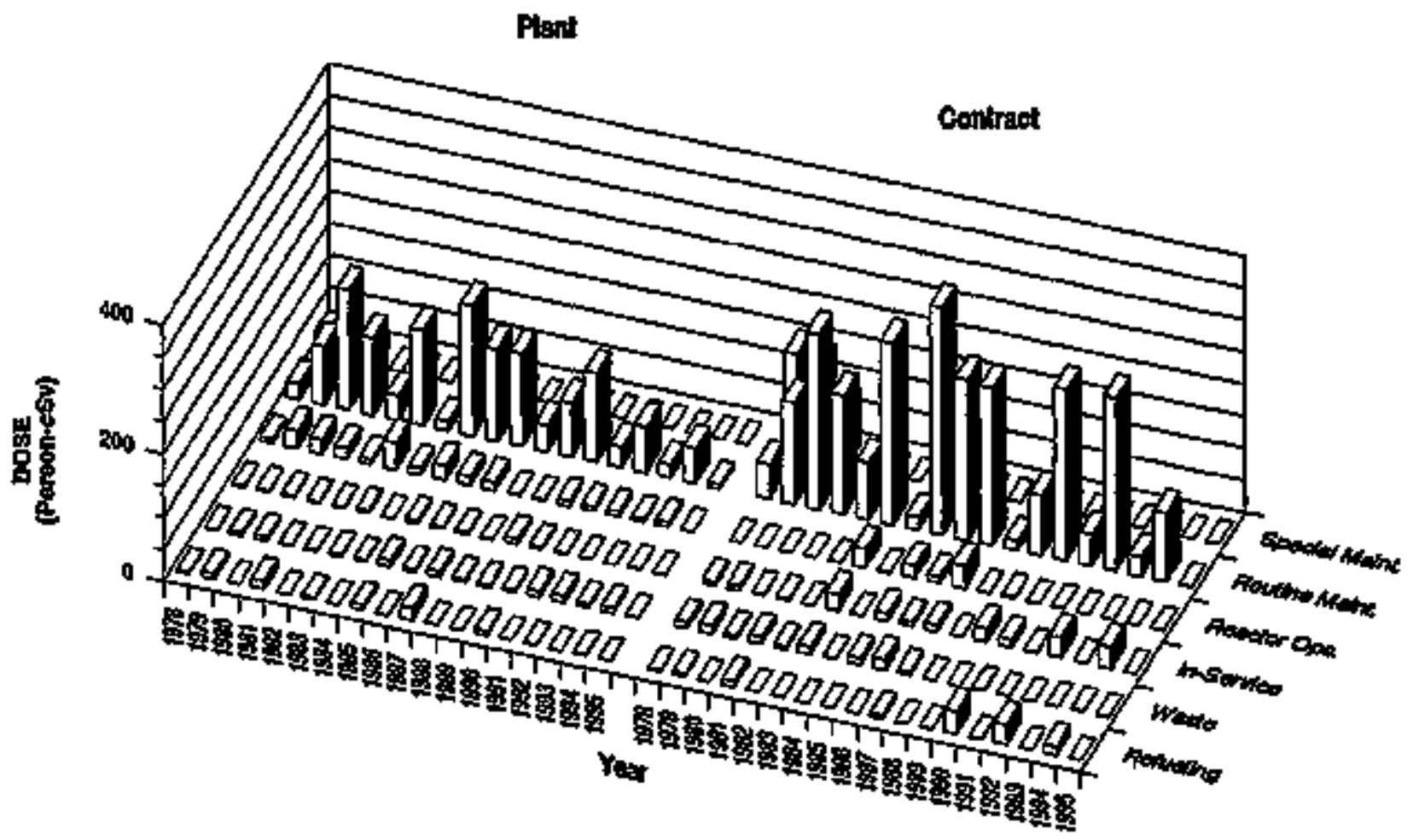




\section{APPENDIX E (continued) \\ DAVIS-BESSE \\ Dose-Periormance hdicalors}

PWR

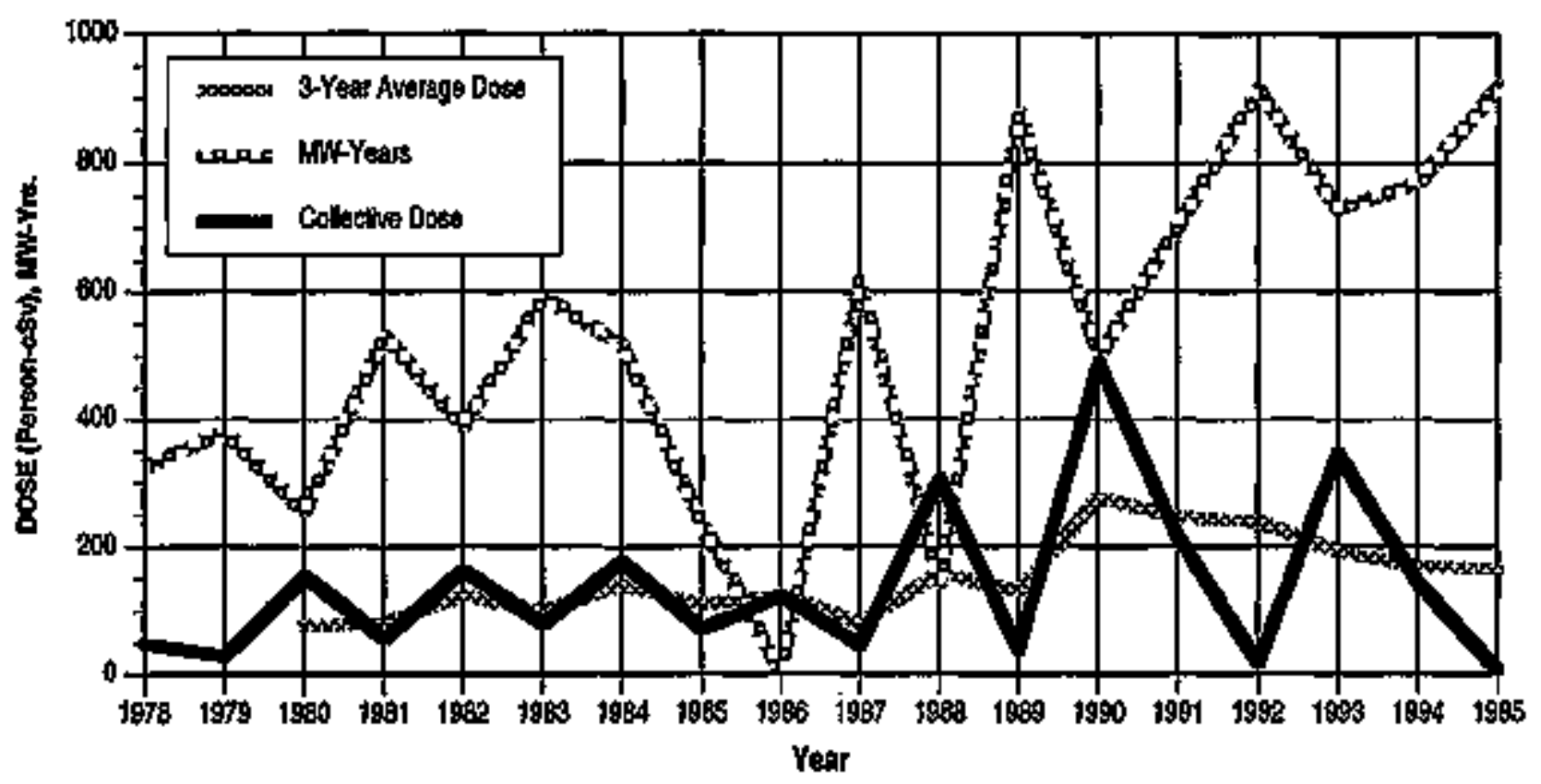

Breakdorm by Job Function

Flant

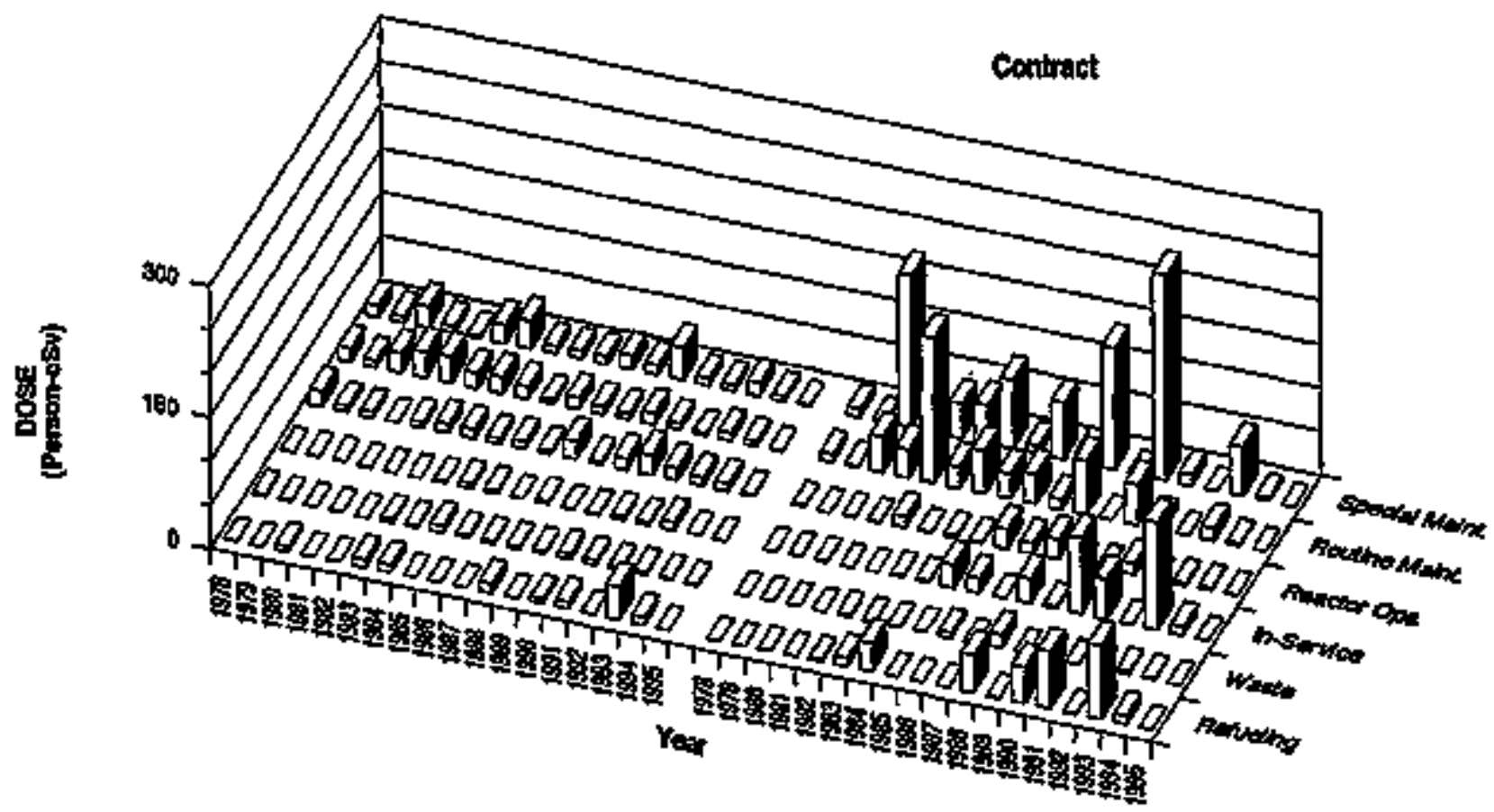


APPENDIX E (continued)

DJABLO CANYON 1,2

Dogeferformance Indicators

PWR

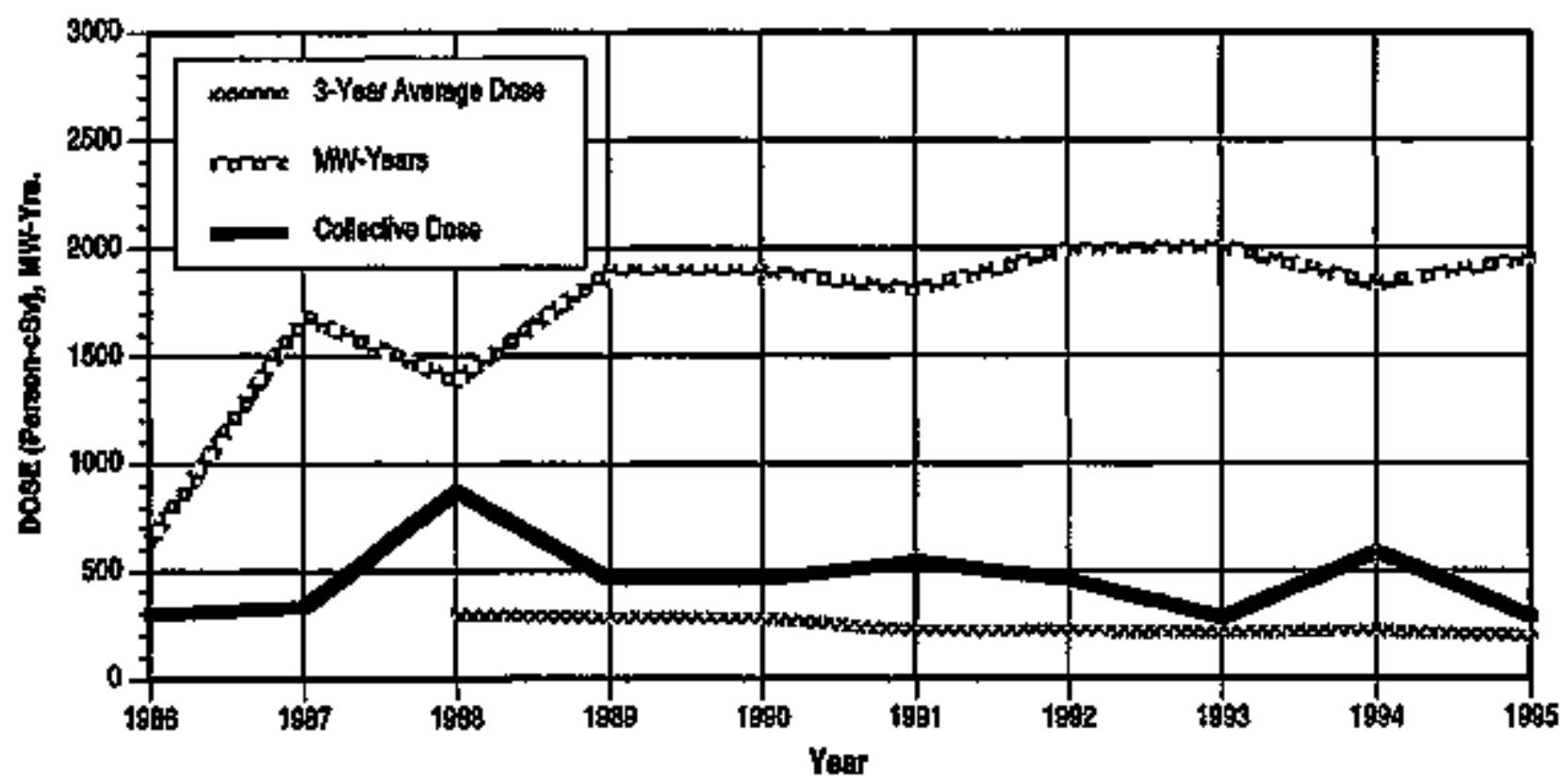

Braakdown by Job Function

Flent

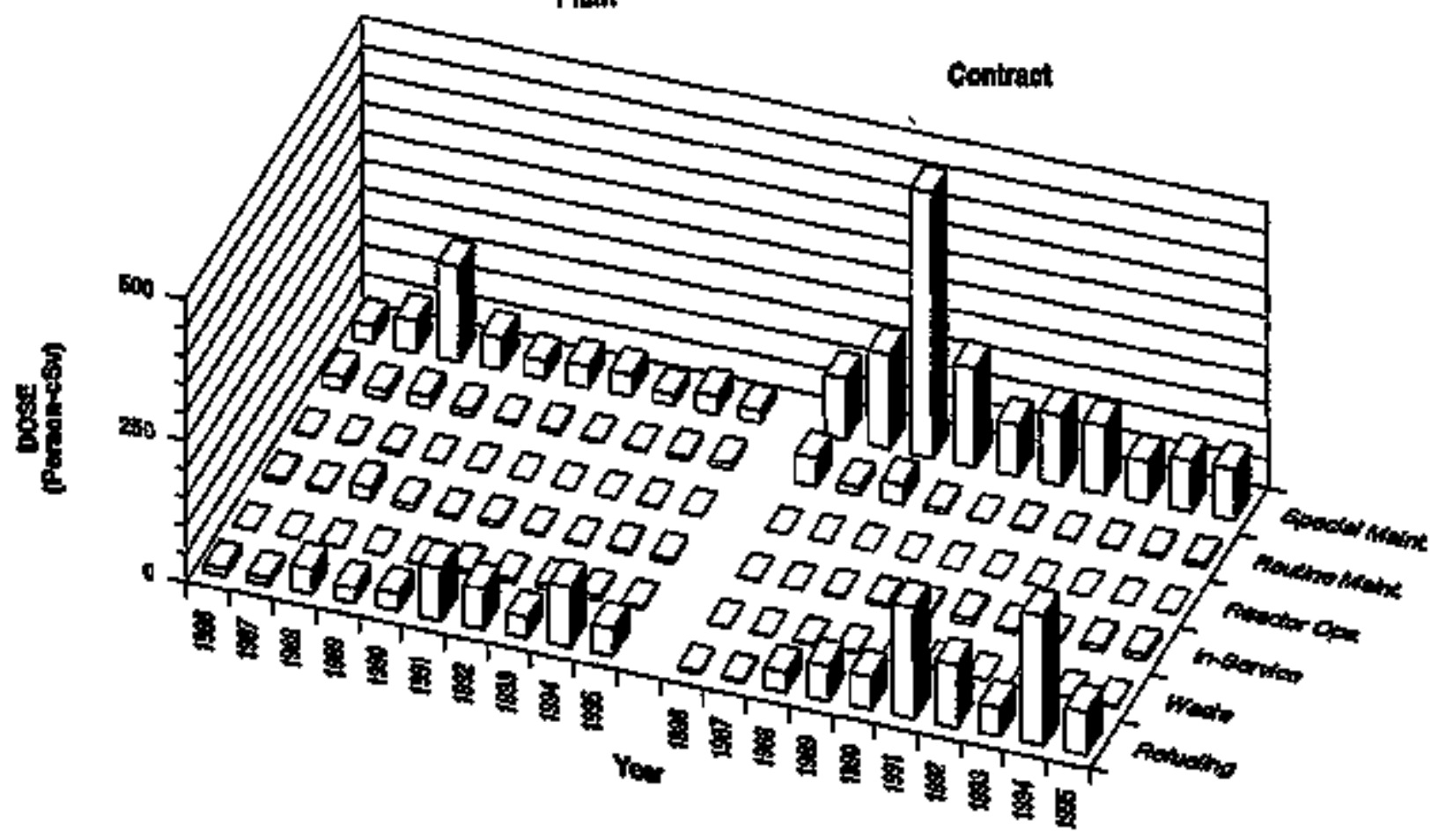




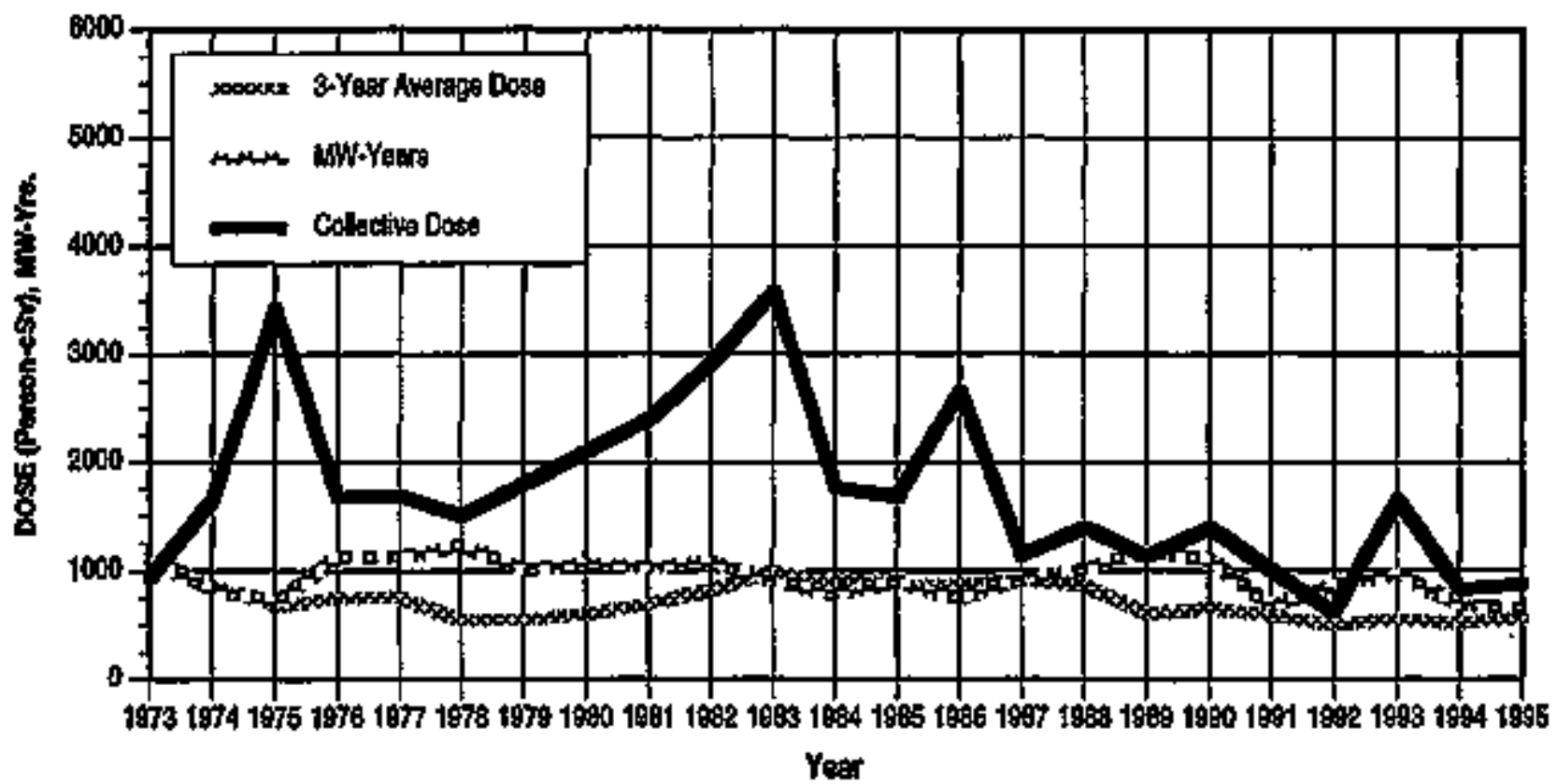

Breakcown by Job Function

Fient

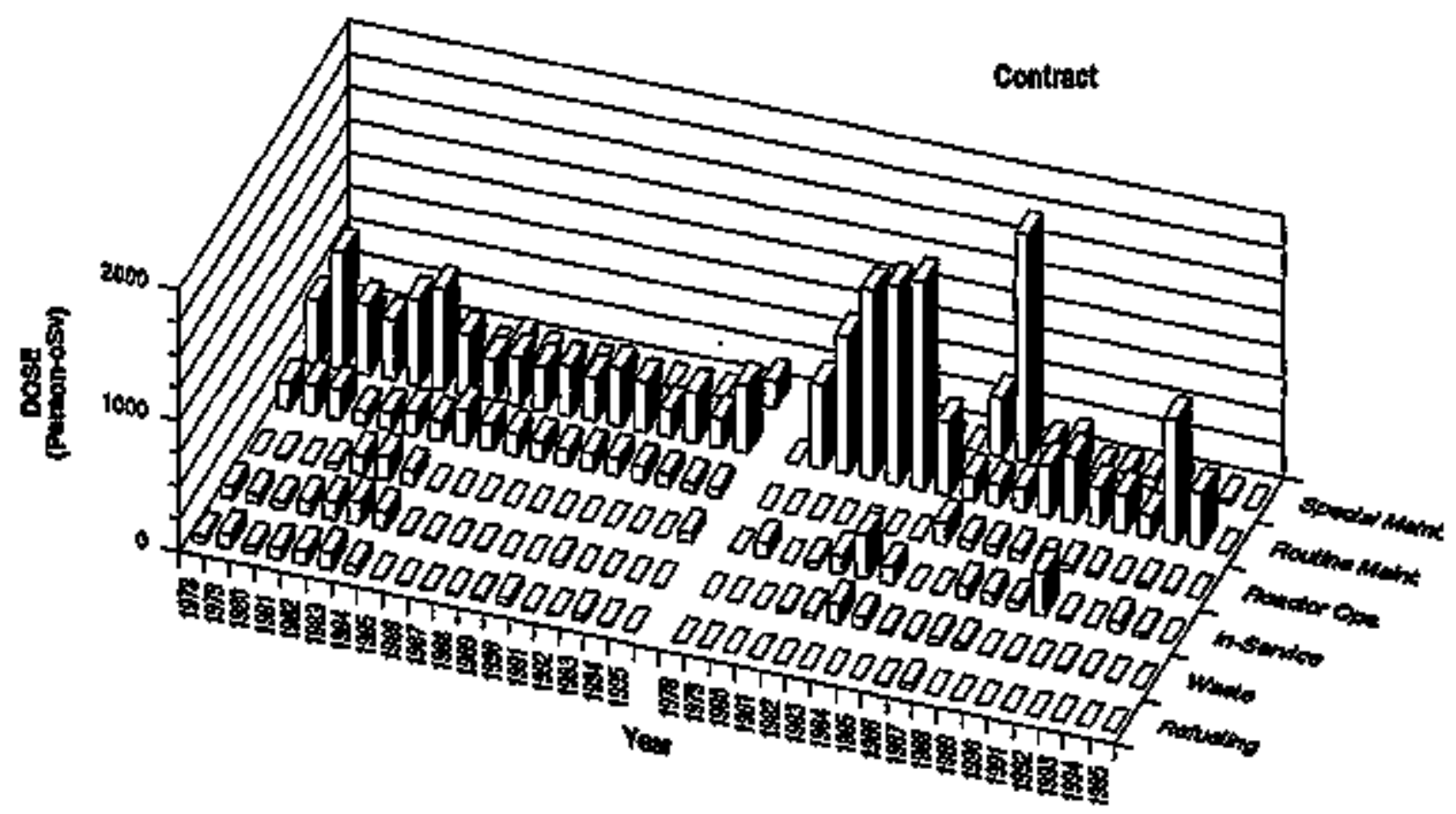




\section{APPENDIX E (continued) \\ GUARE ARNOLD}

Dose-Performanco hdicators

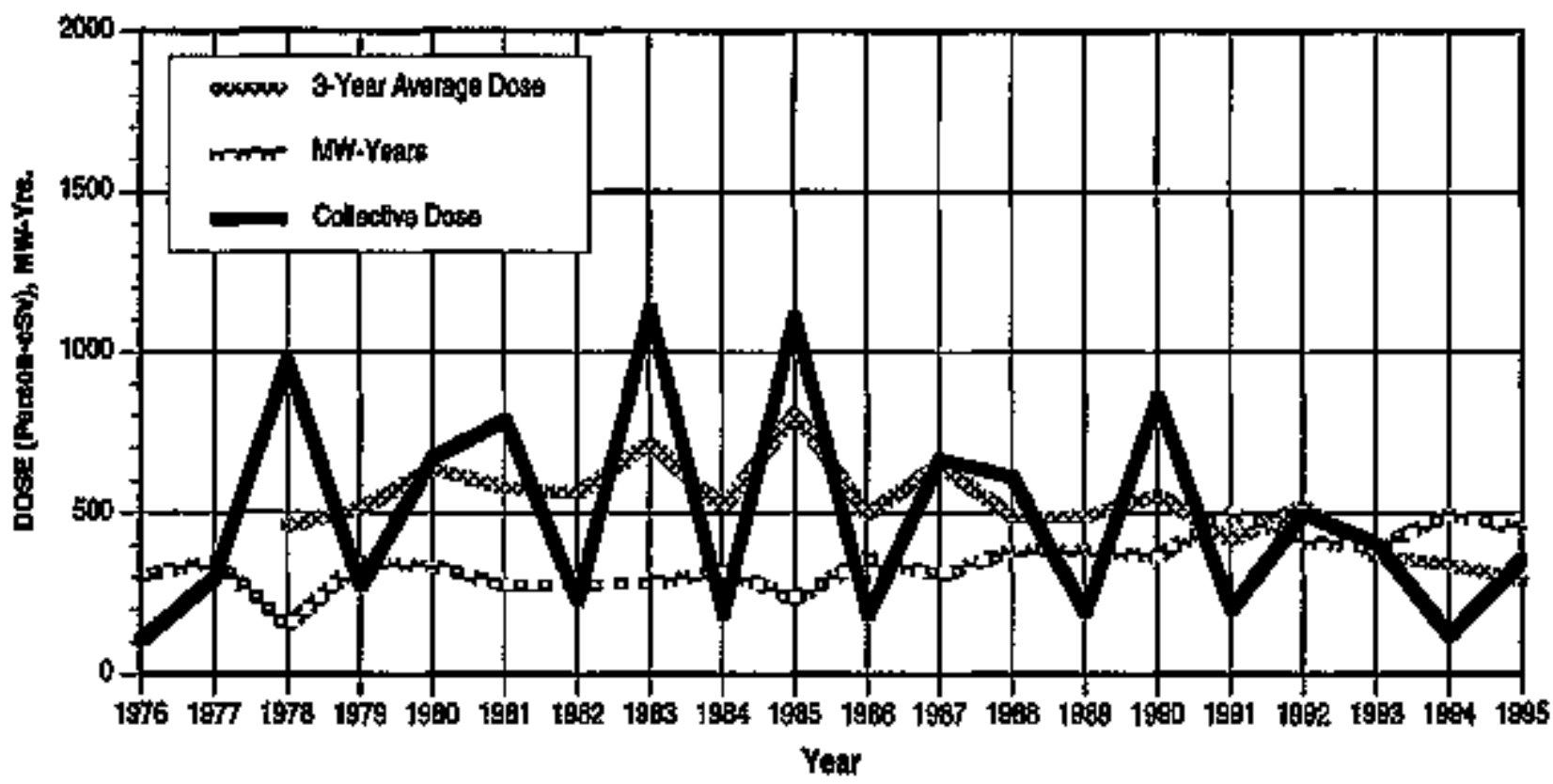

Breakdown by dab Funcition

Plant

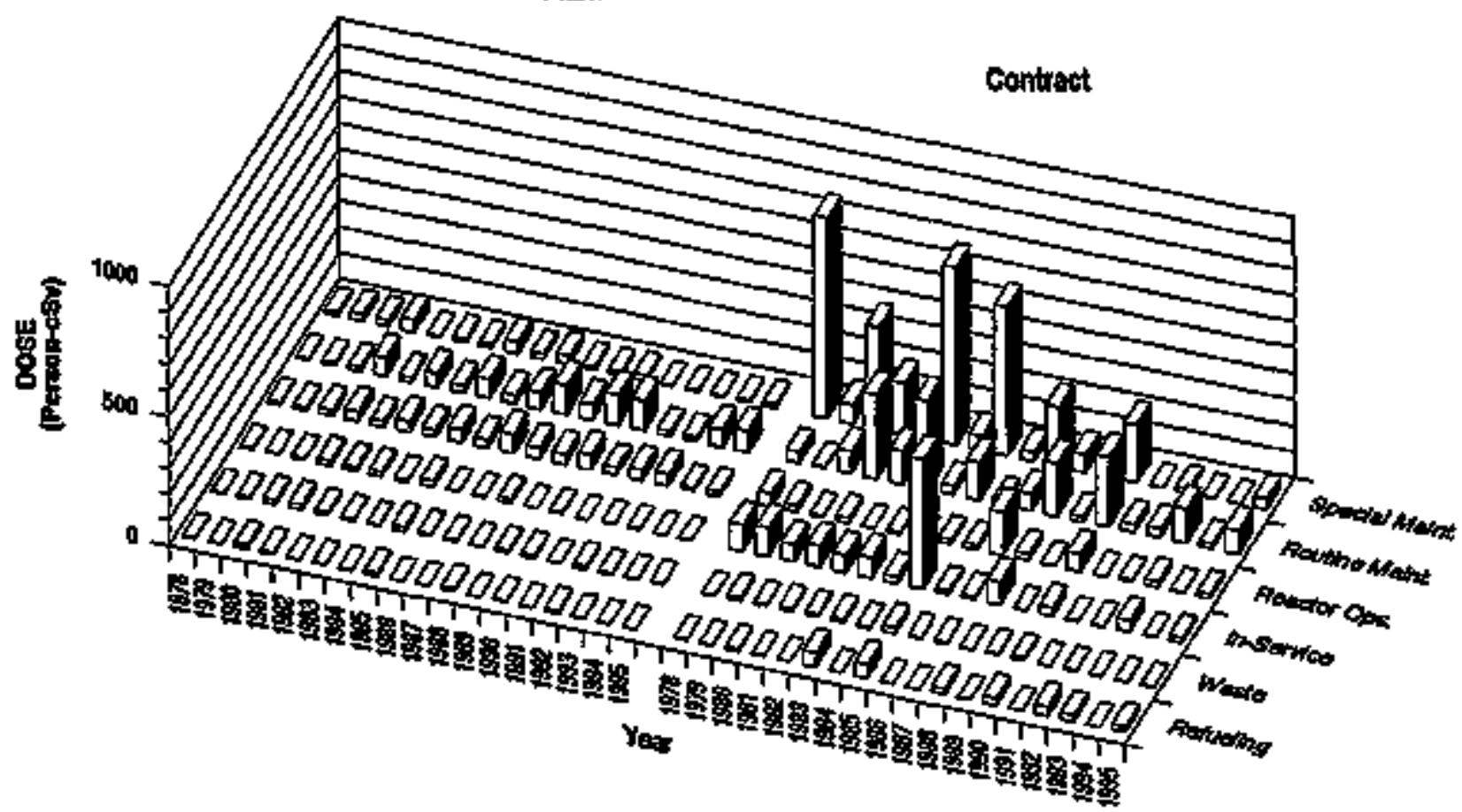




\section{APPENDIX E (continued)}

FARLEY 1,2

Dose-Pertomance Indieators

PWR

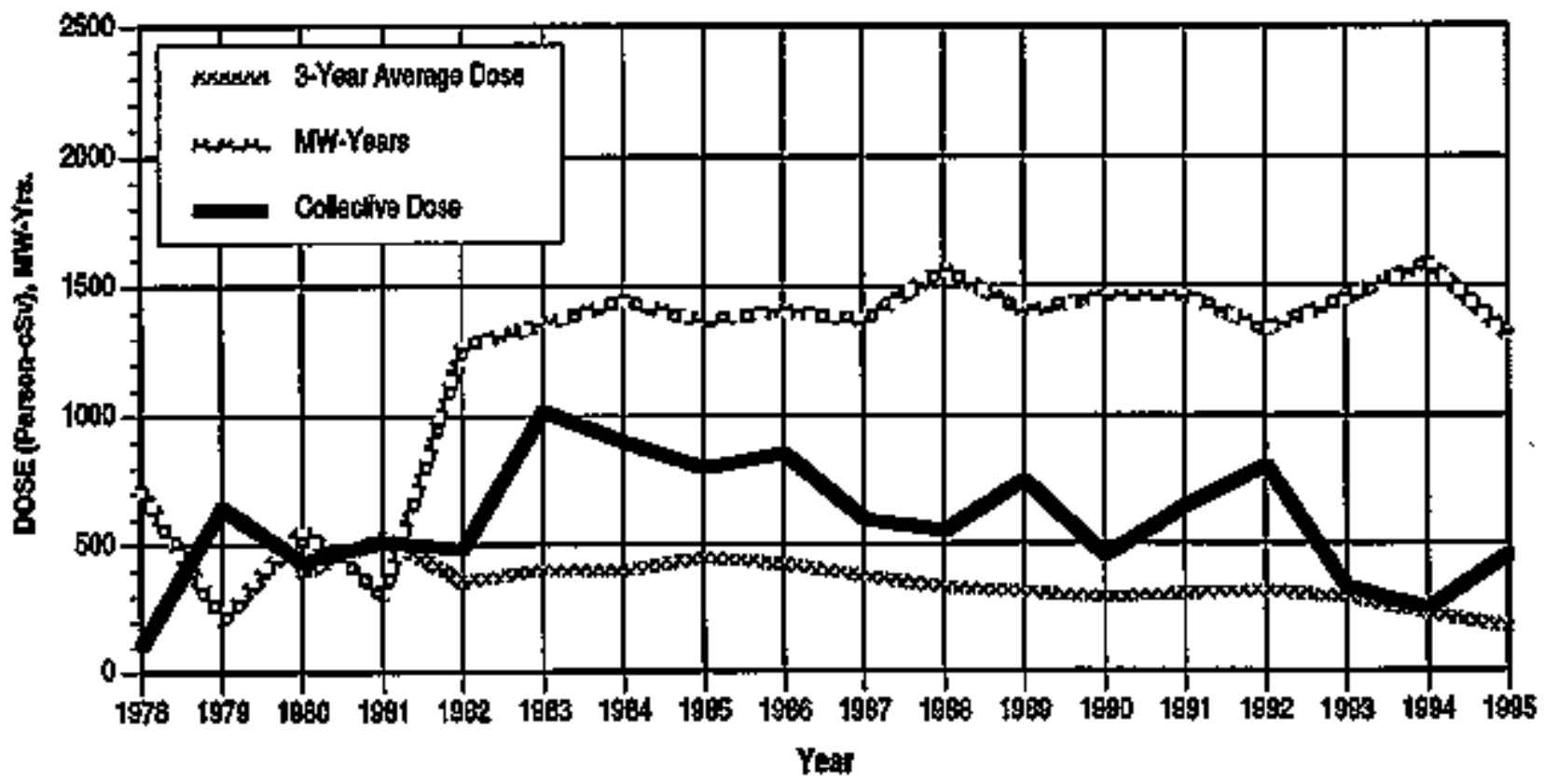

Breaktom by Job Function

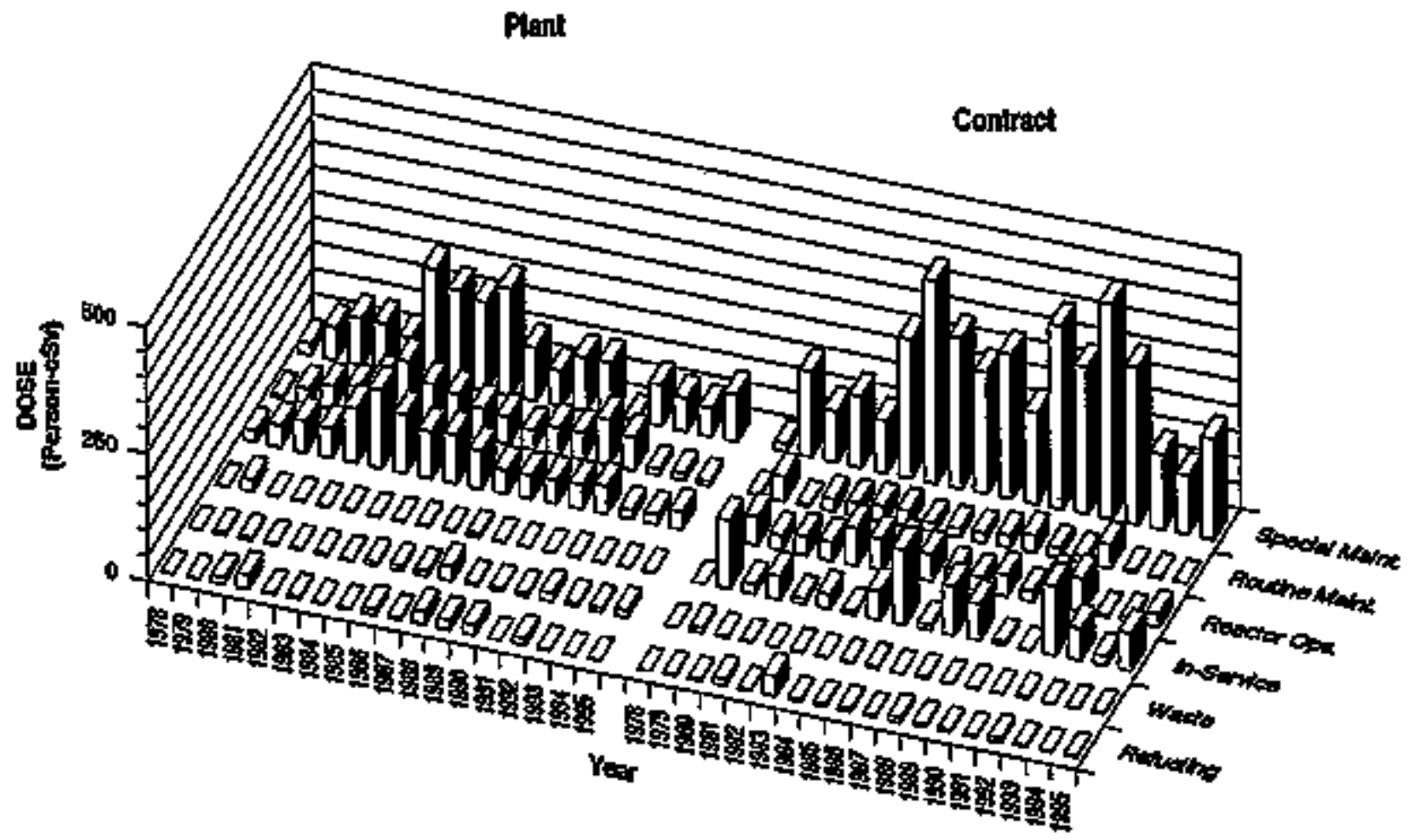




\section{APFENDIX E (continued)}

FERAl 2

Dose-Peffommance Inticators

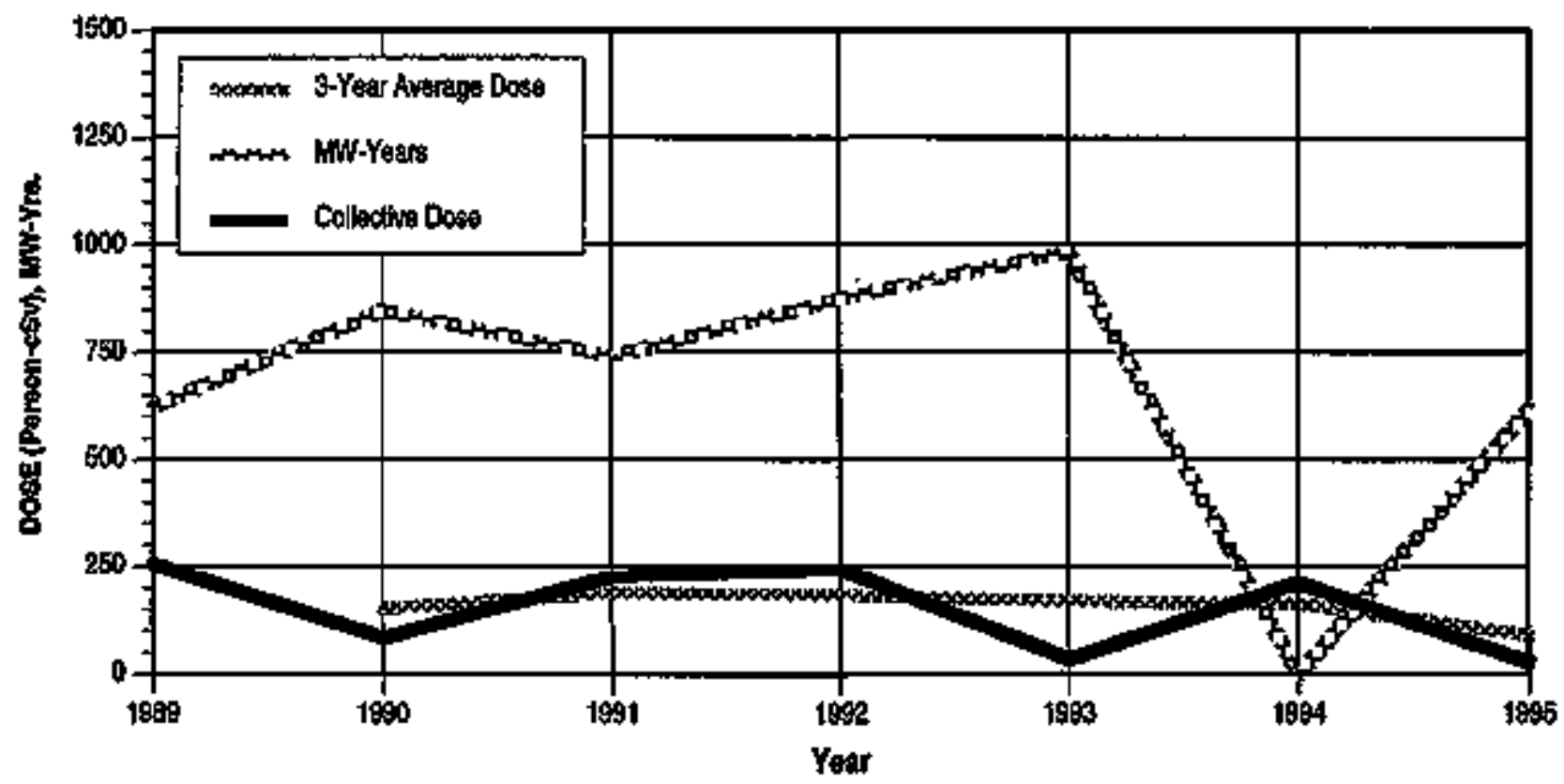

Braakdown by dob Function

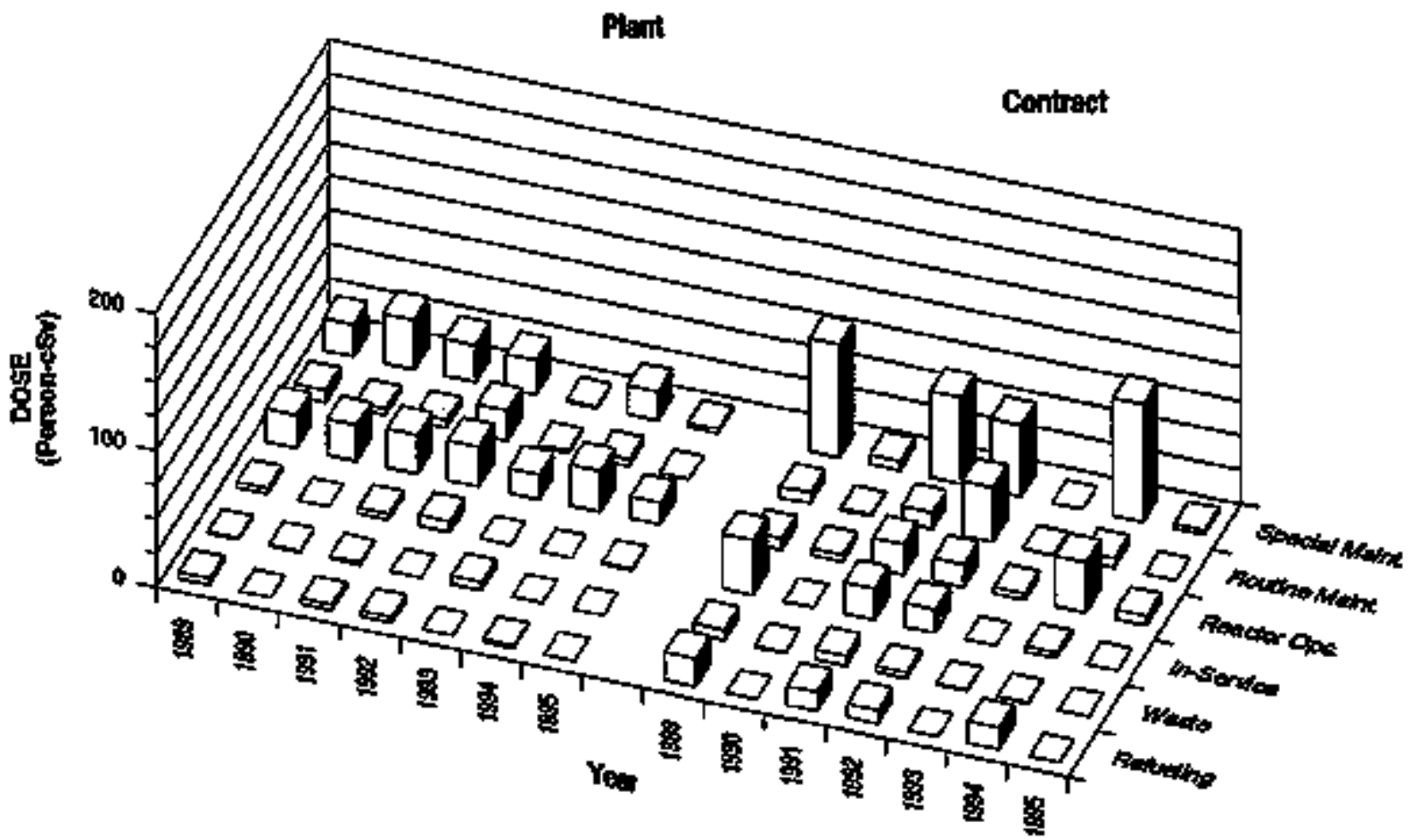


APPENDIX E (continured)

\section{FIZPATRICK}

Dose-Perifemance indipalors

BWR

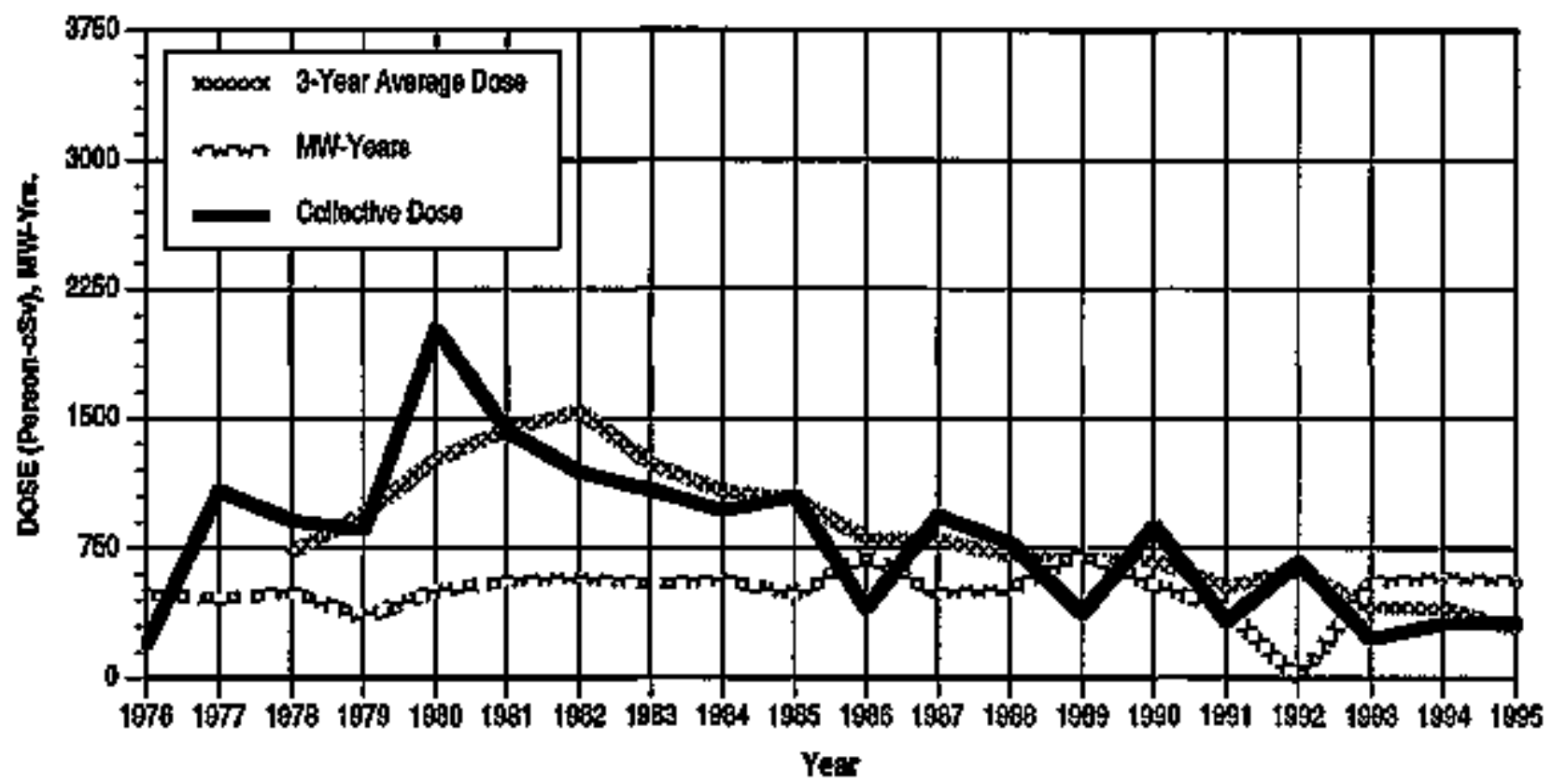

Breakdown by Job Finclion

Plant

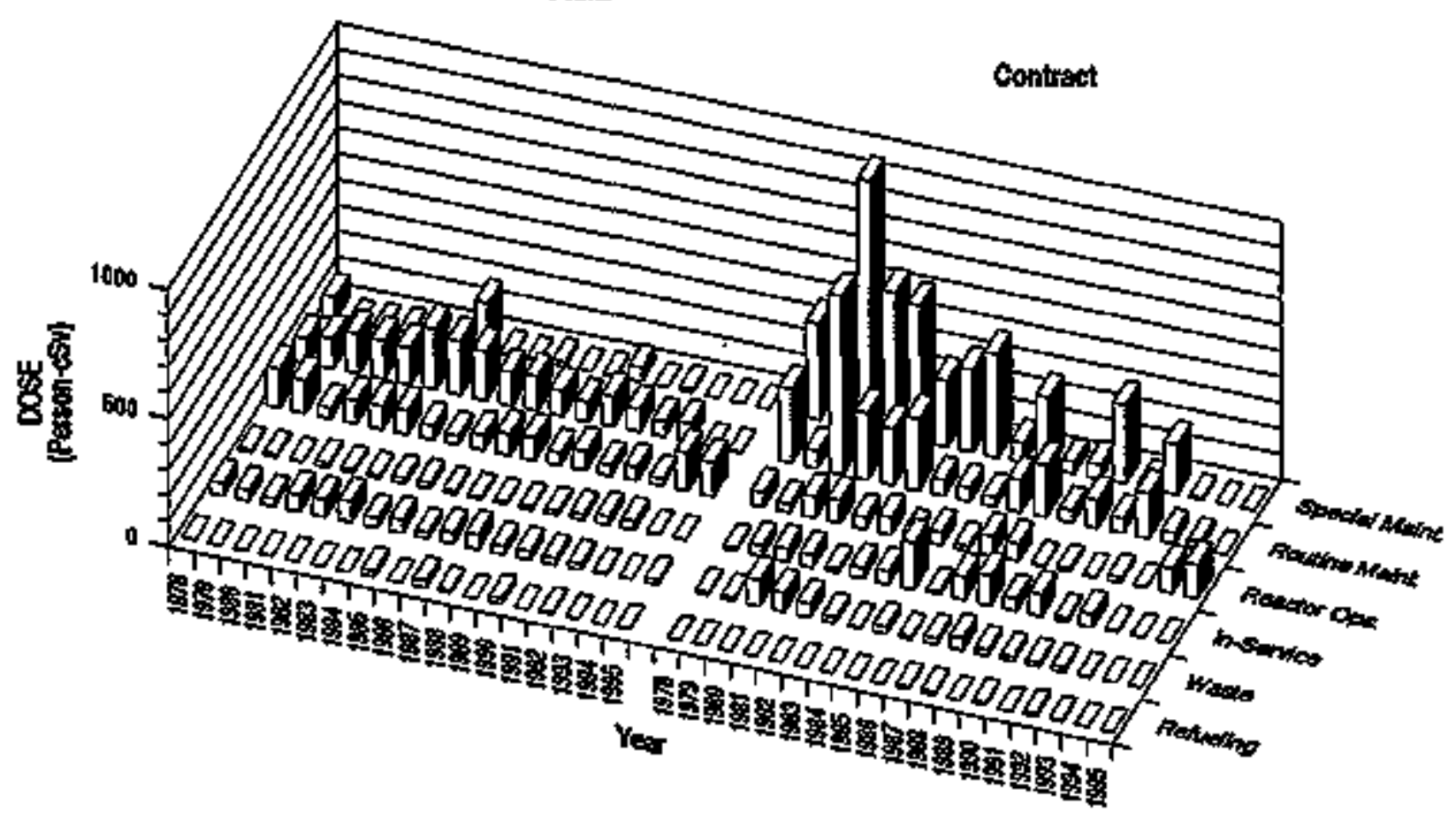




\section{APPENDIX E (conthued) \\ FORT CALHOUN}

Dosa-Parlomance Indloators

PWh

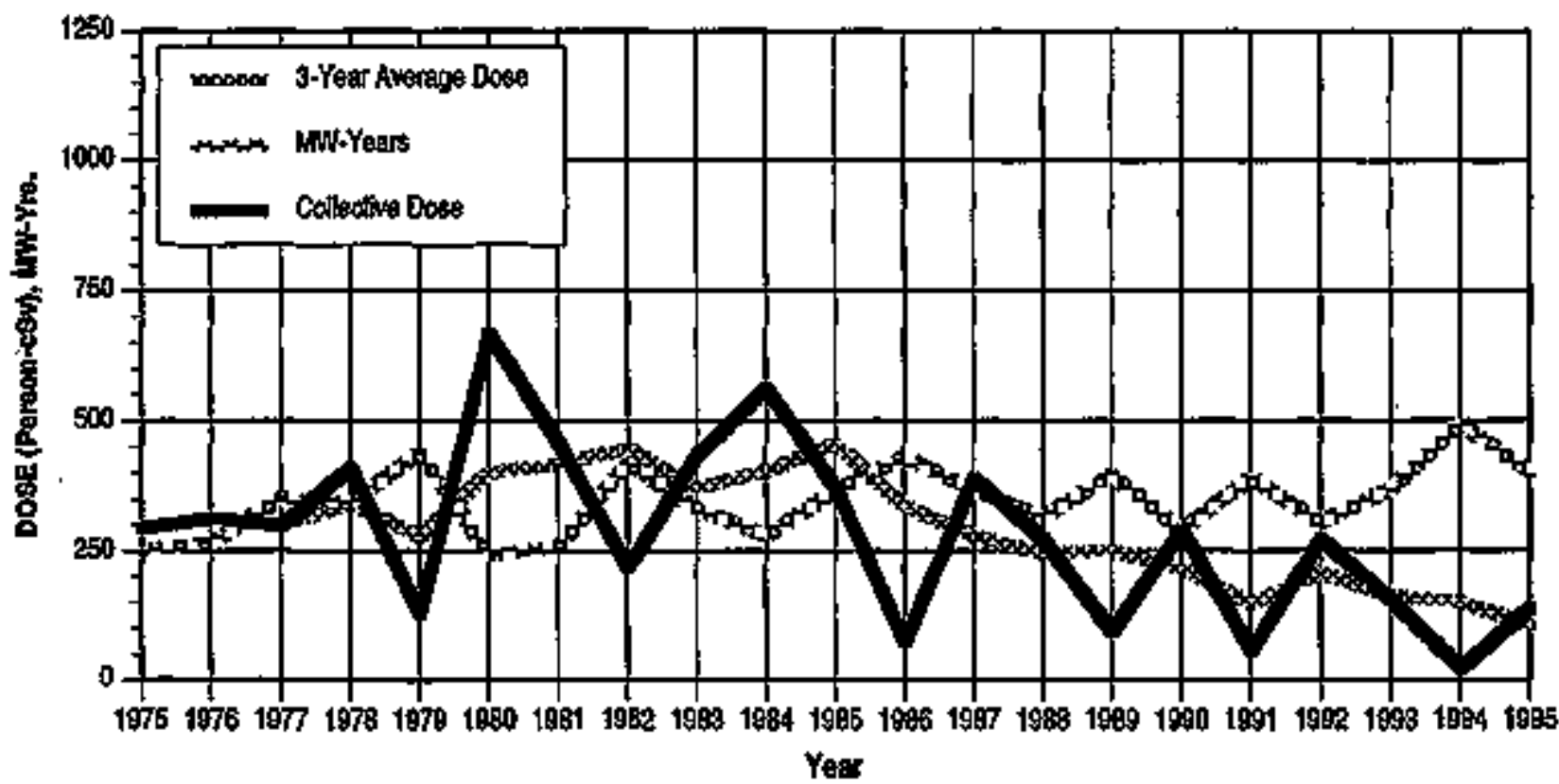

Breakdoun by dob Funation

Plant

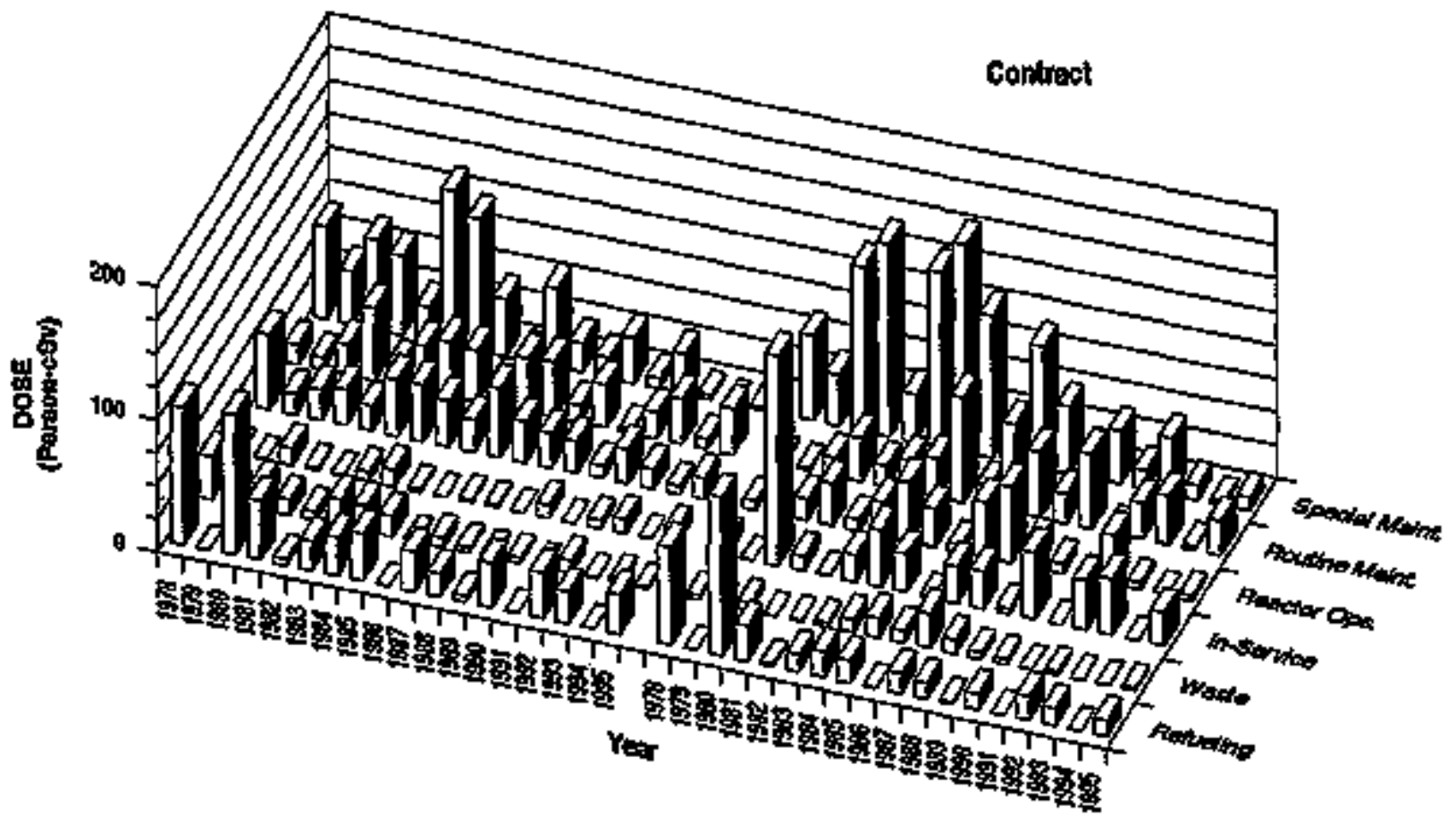




\section{APPENDIX E (continued)}

FORT ST. VRAIN

Dose-Periomanoe indicalors

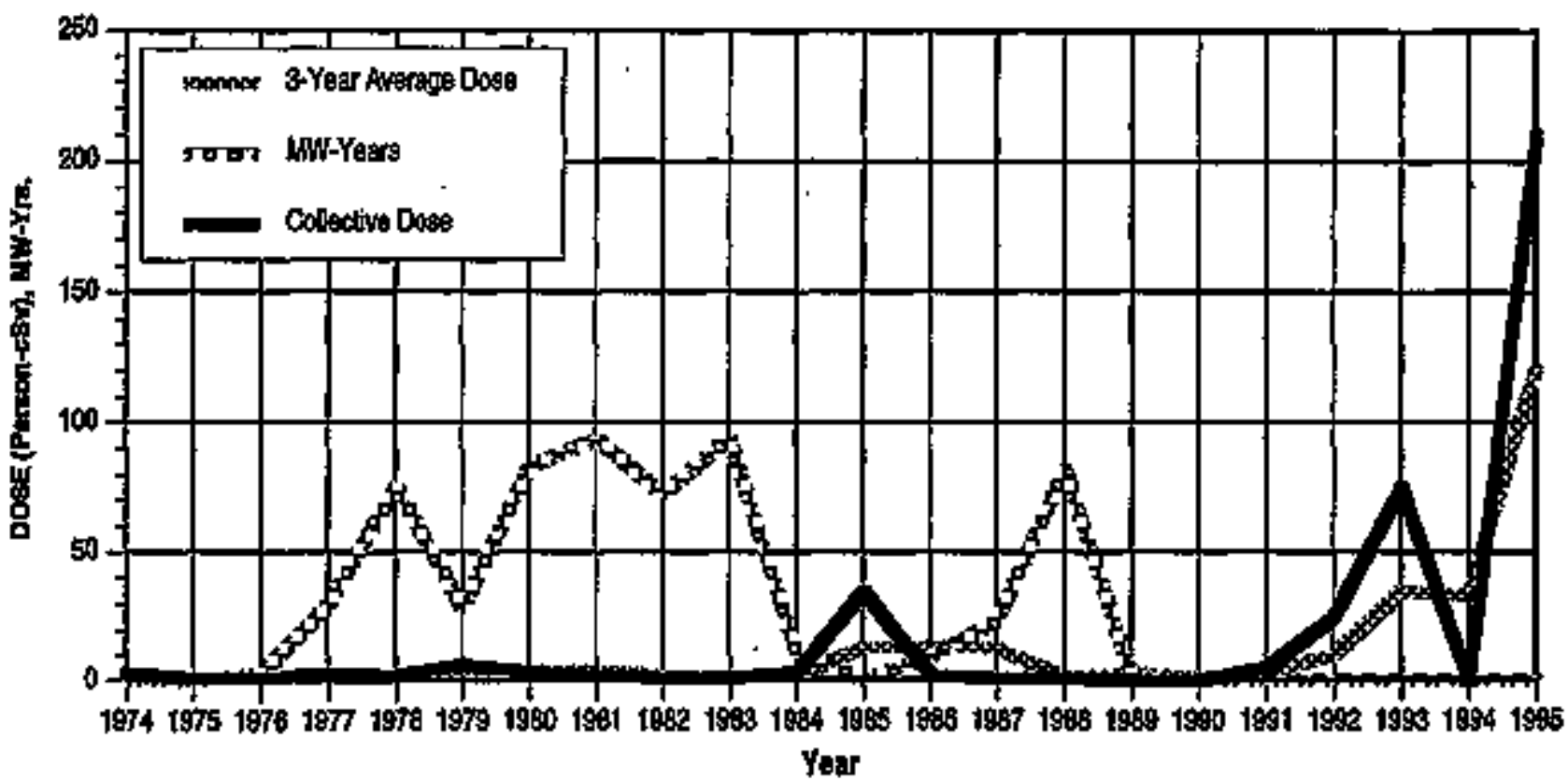

Brakkdown by Job Function

PJant

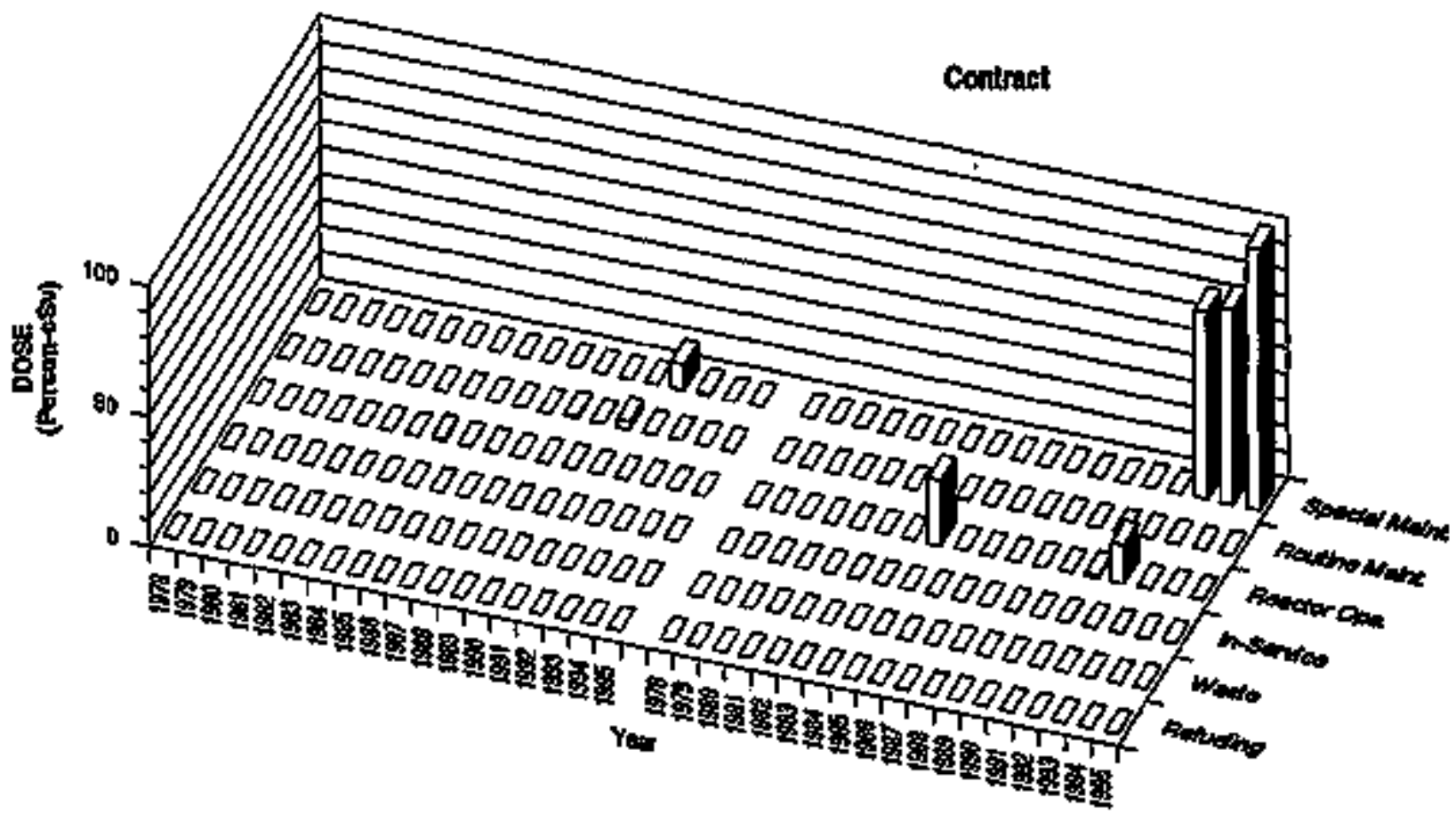




\section{APPENDIX E (oontinued)}

GIINA

Dose-Perfomance Indicators

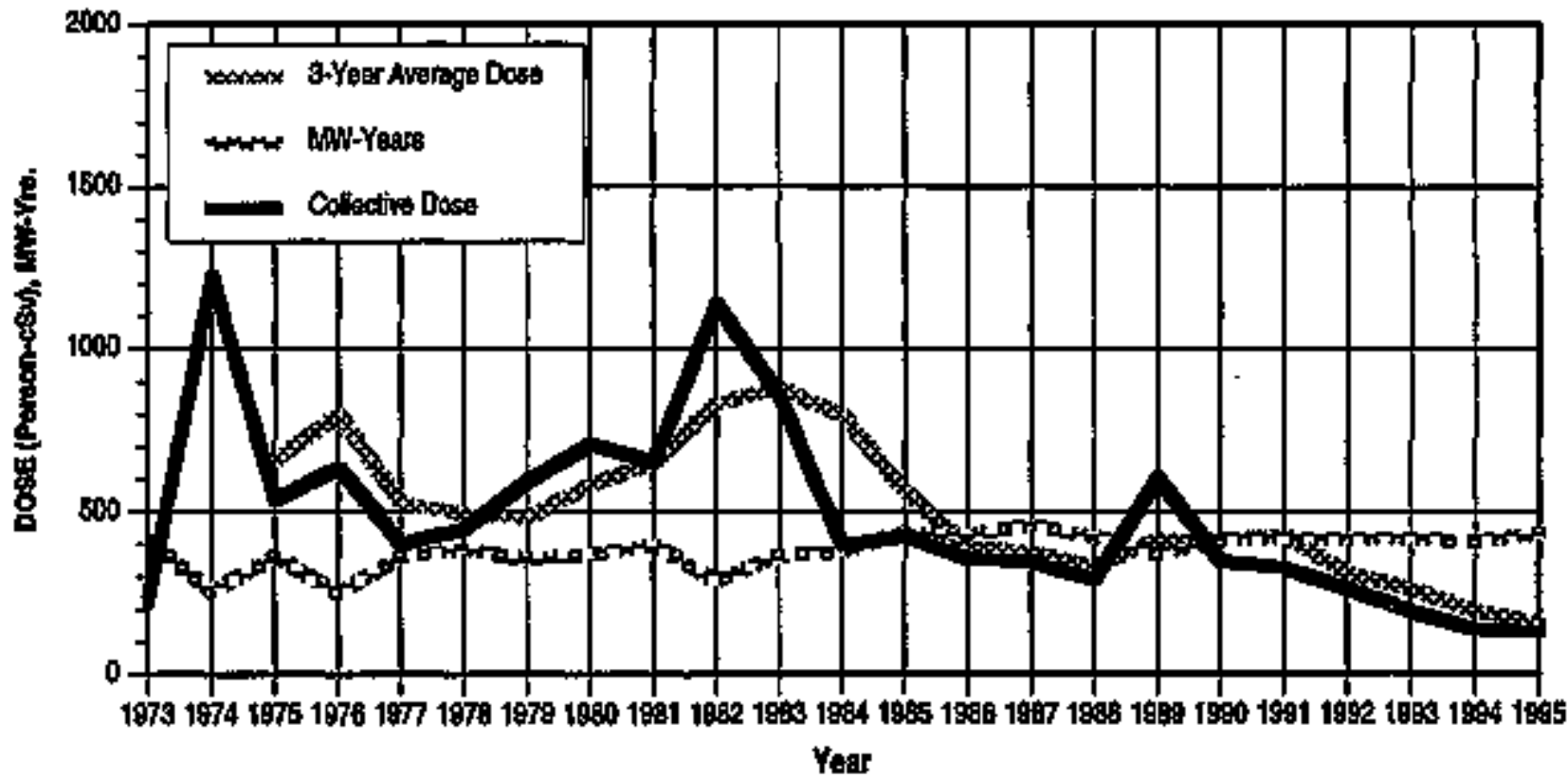

Bradktoun by Job Function

Plent

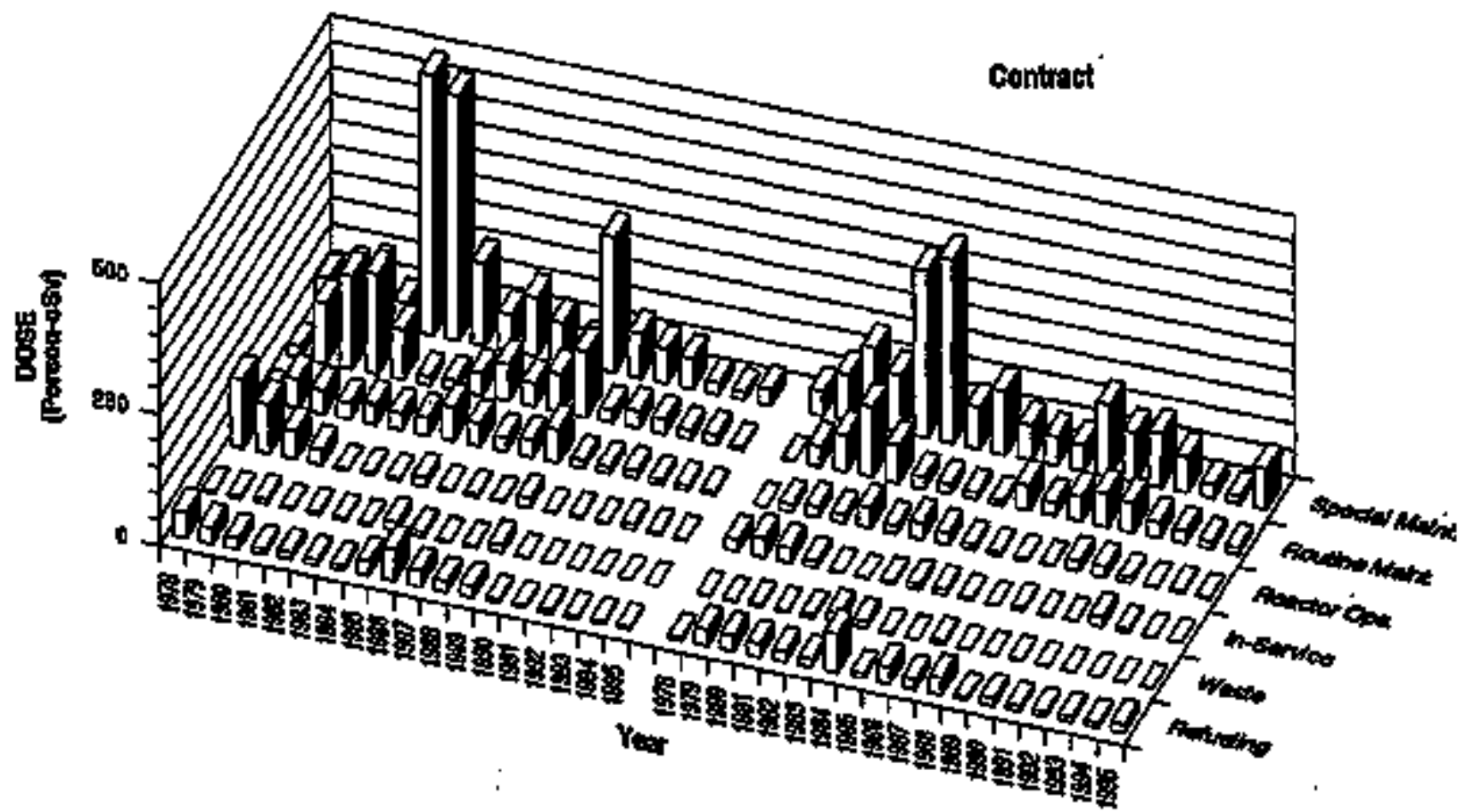


APPENDAX E (continued)

GRAND GULF

Dose-Perfomance Indicators

BWR

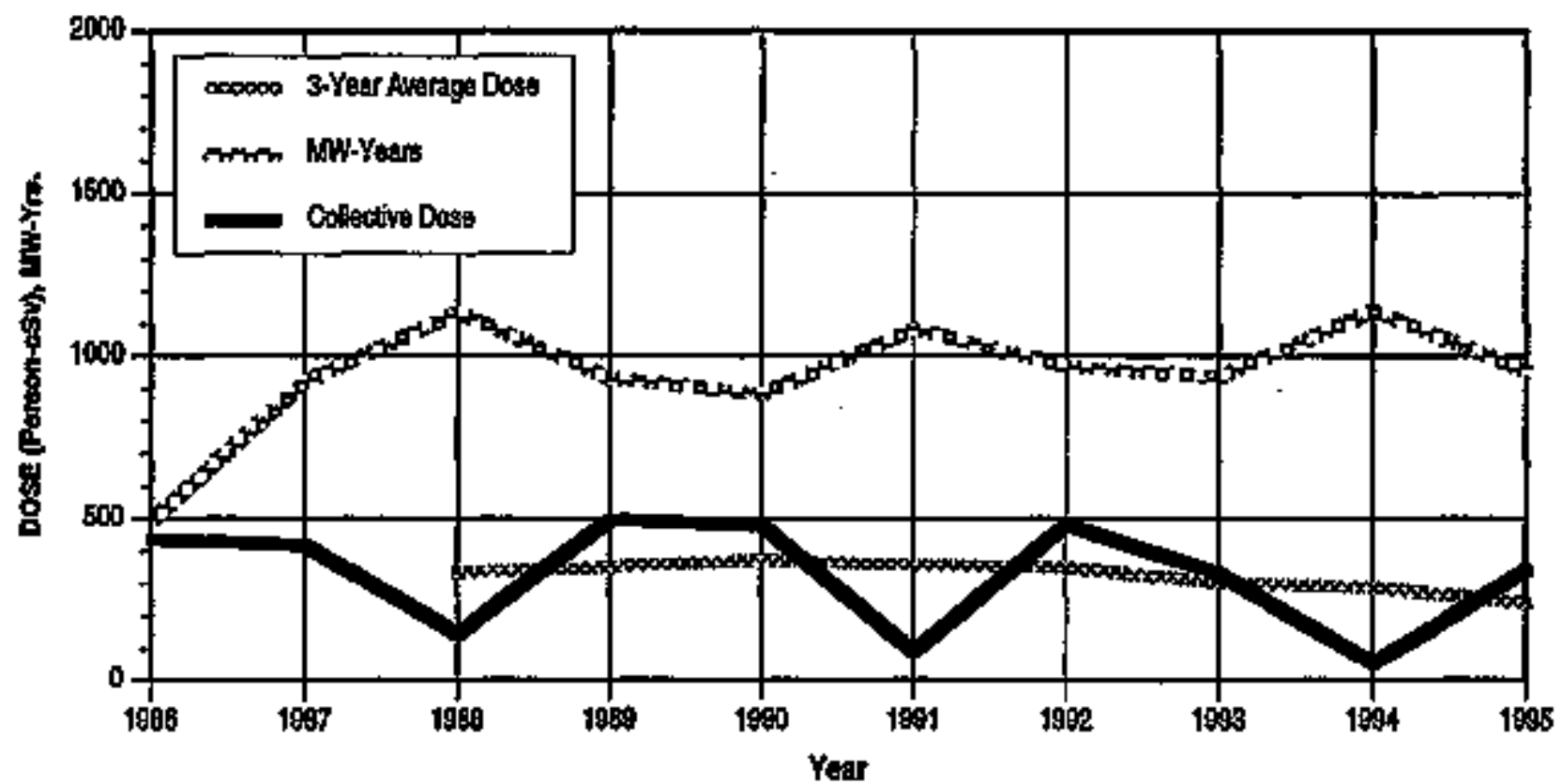

Breakdown by Jah Funotion

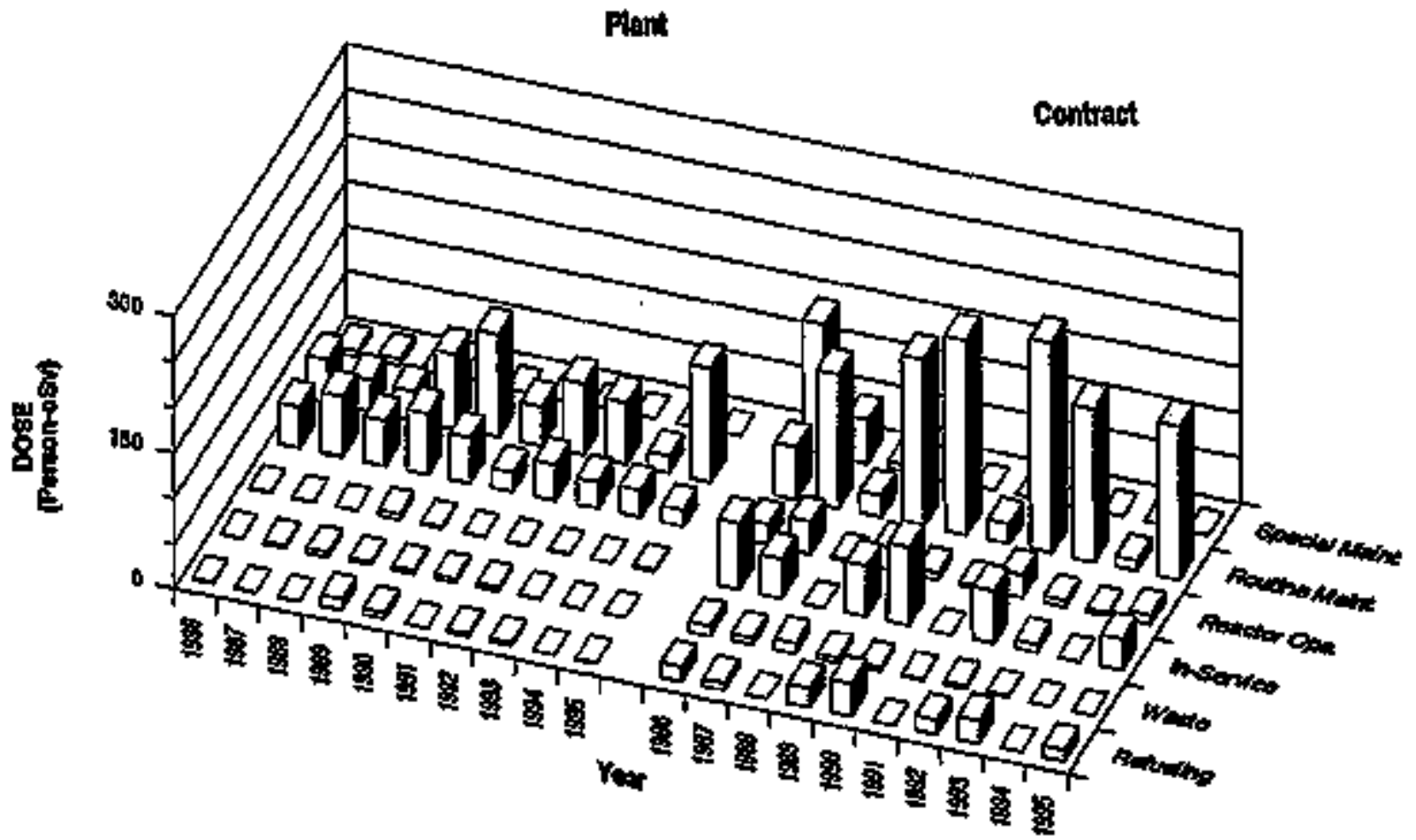


APPENDIX E (continued)

HADDAMNECK

Dose-Perionmance Indicators

PUWR

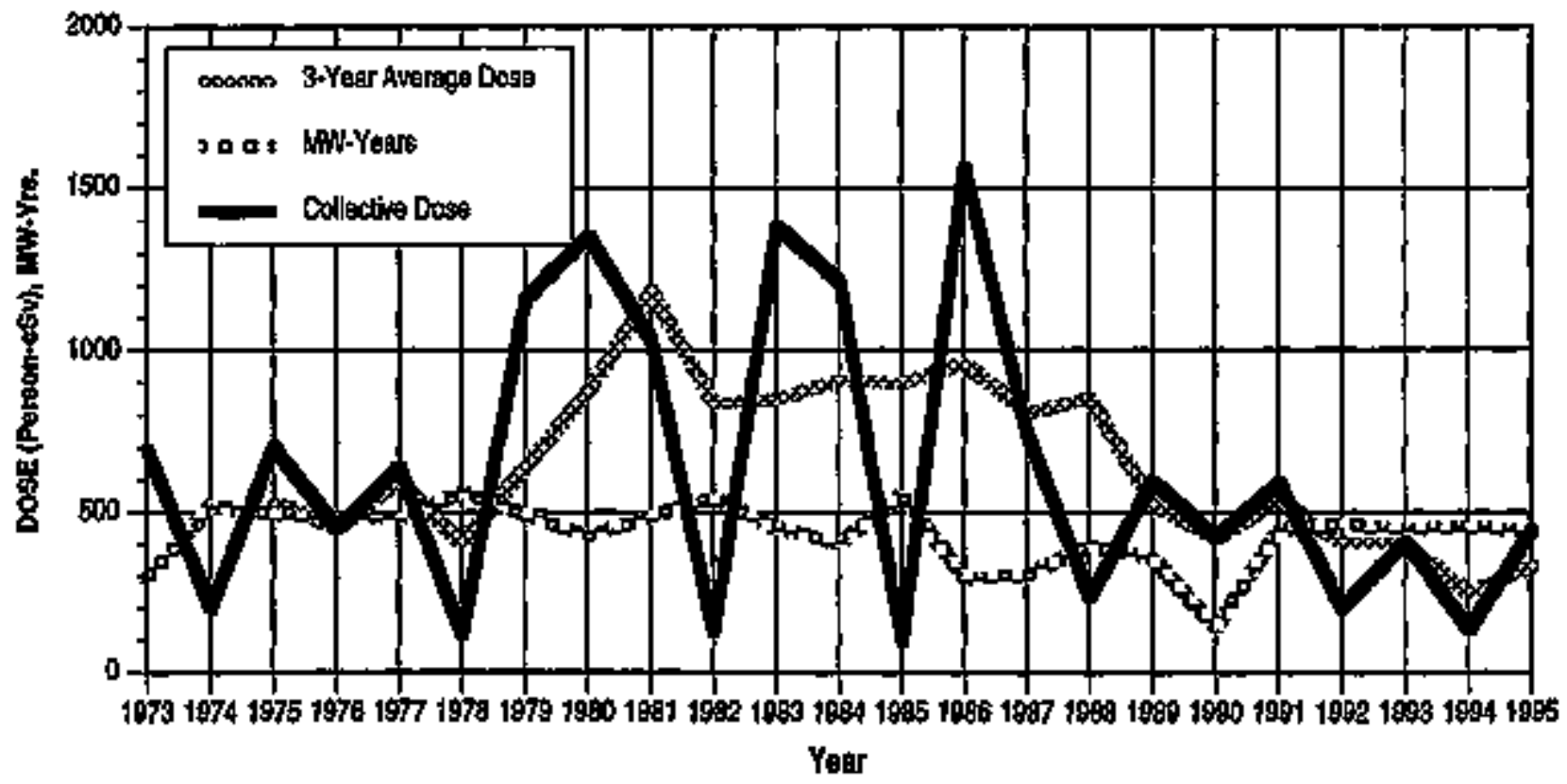

Brakadown by Job Function

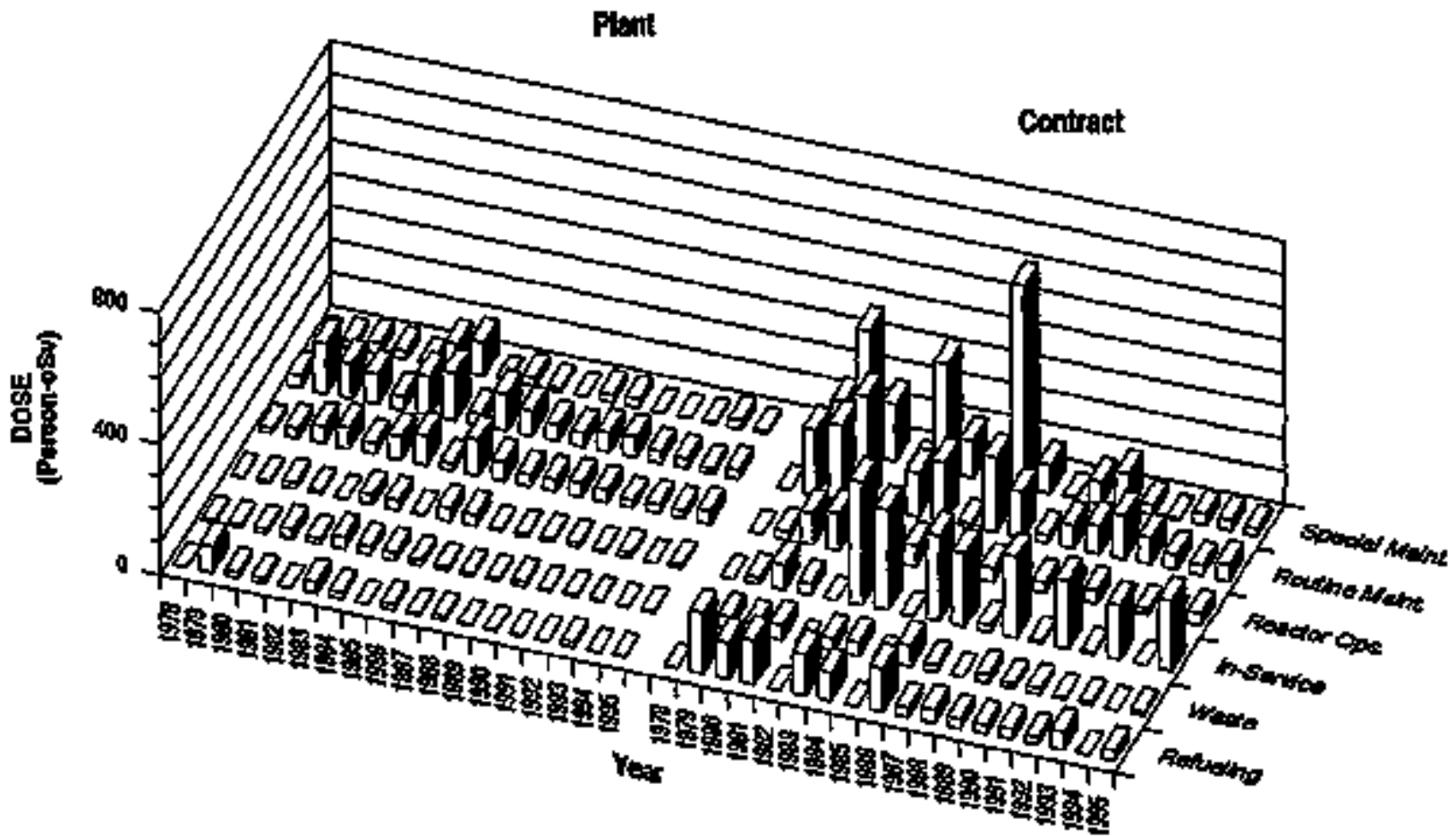




\section{APPENDIX E (continued) \\ HABRIS}

Dose Pritomence Indicators

PWR

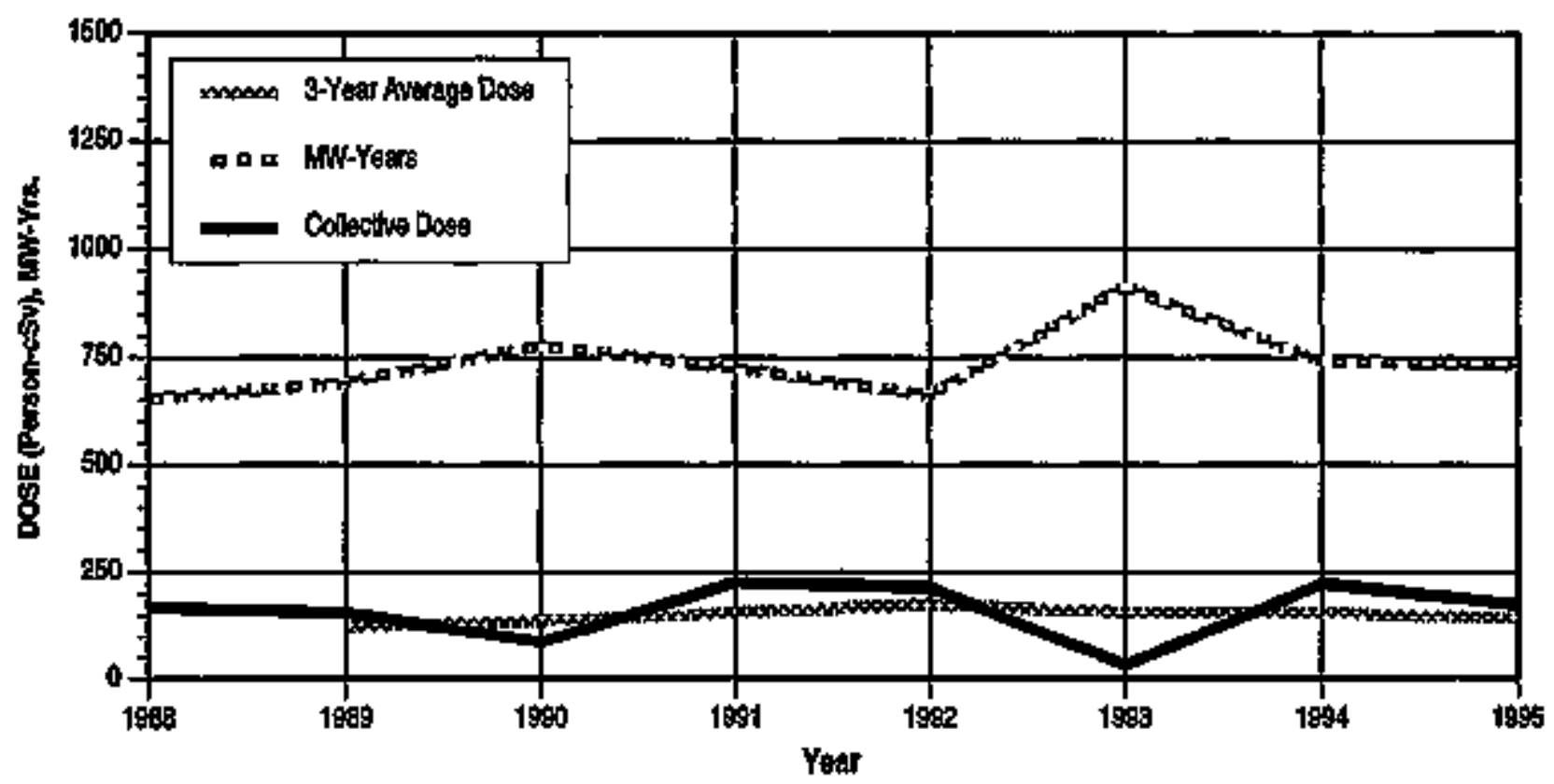

Breakdown by Job Funation

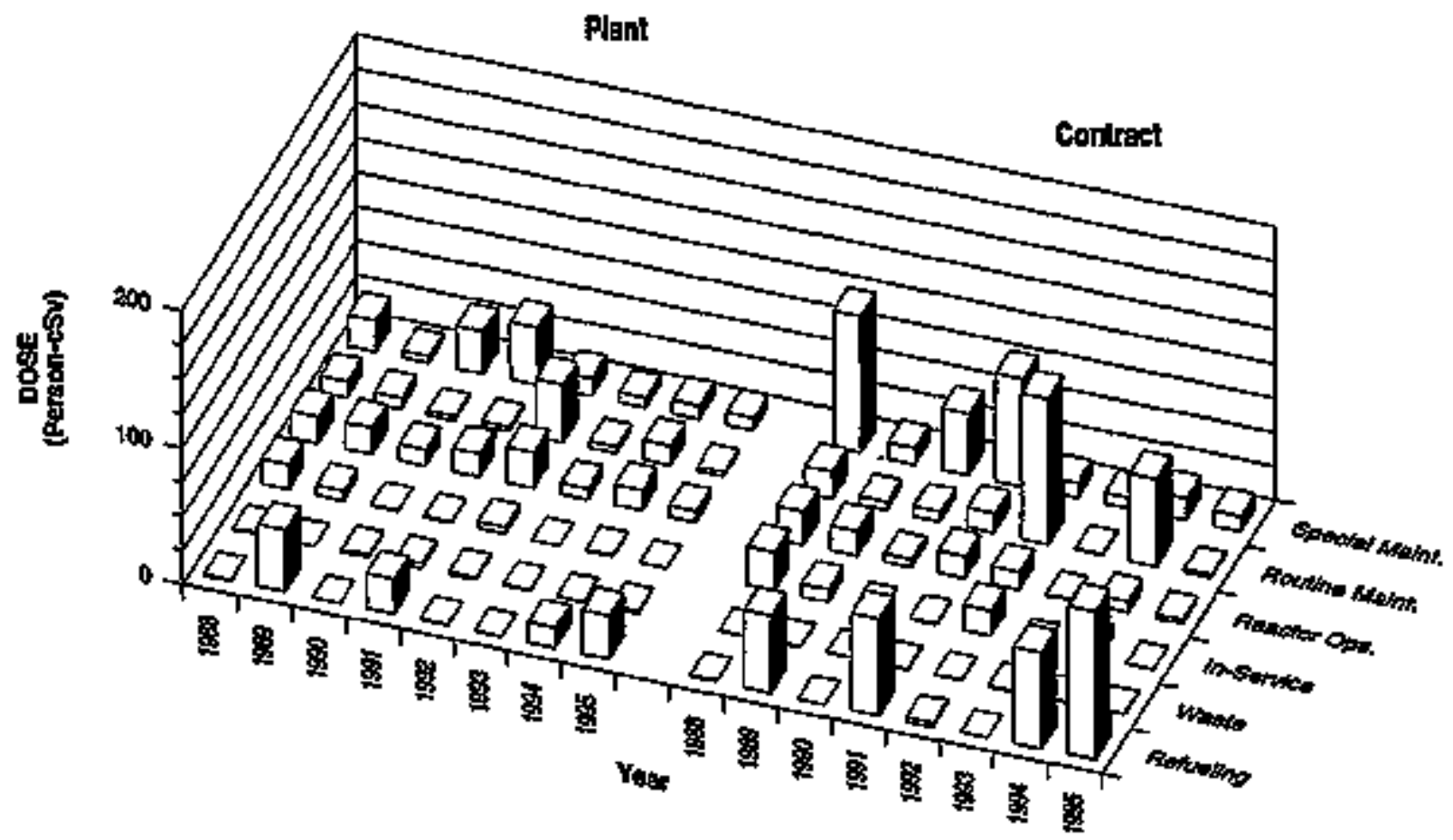


APPENDIXE (continued)

HATCH 1,2

Dose-Periormance ind cators

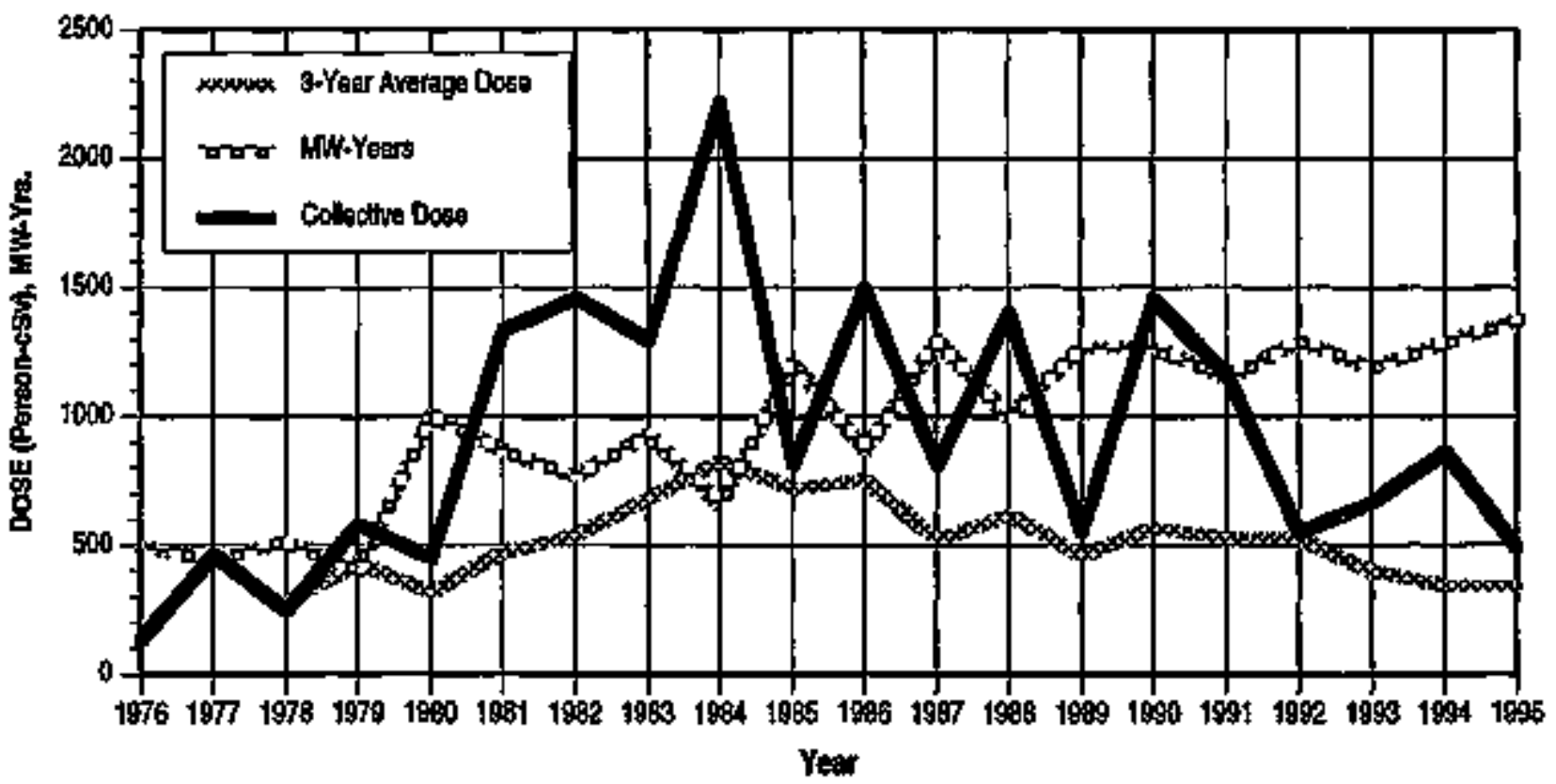

Braakdown by Job Funcotion

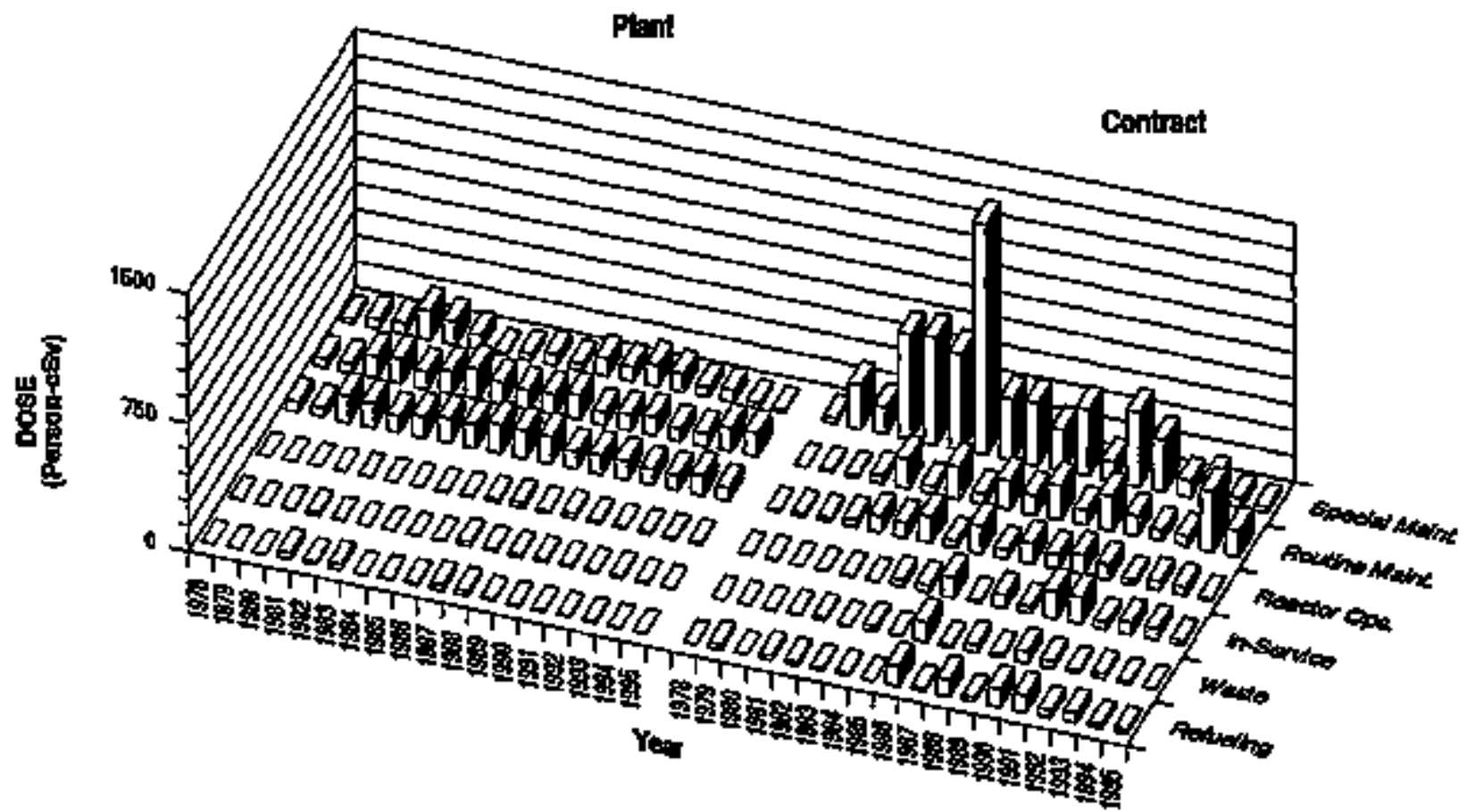




\section{APPENDIX E (contlnugd) \\ HOPE CREEK 1}

Dose-Perfomance indicators

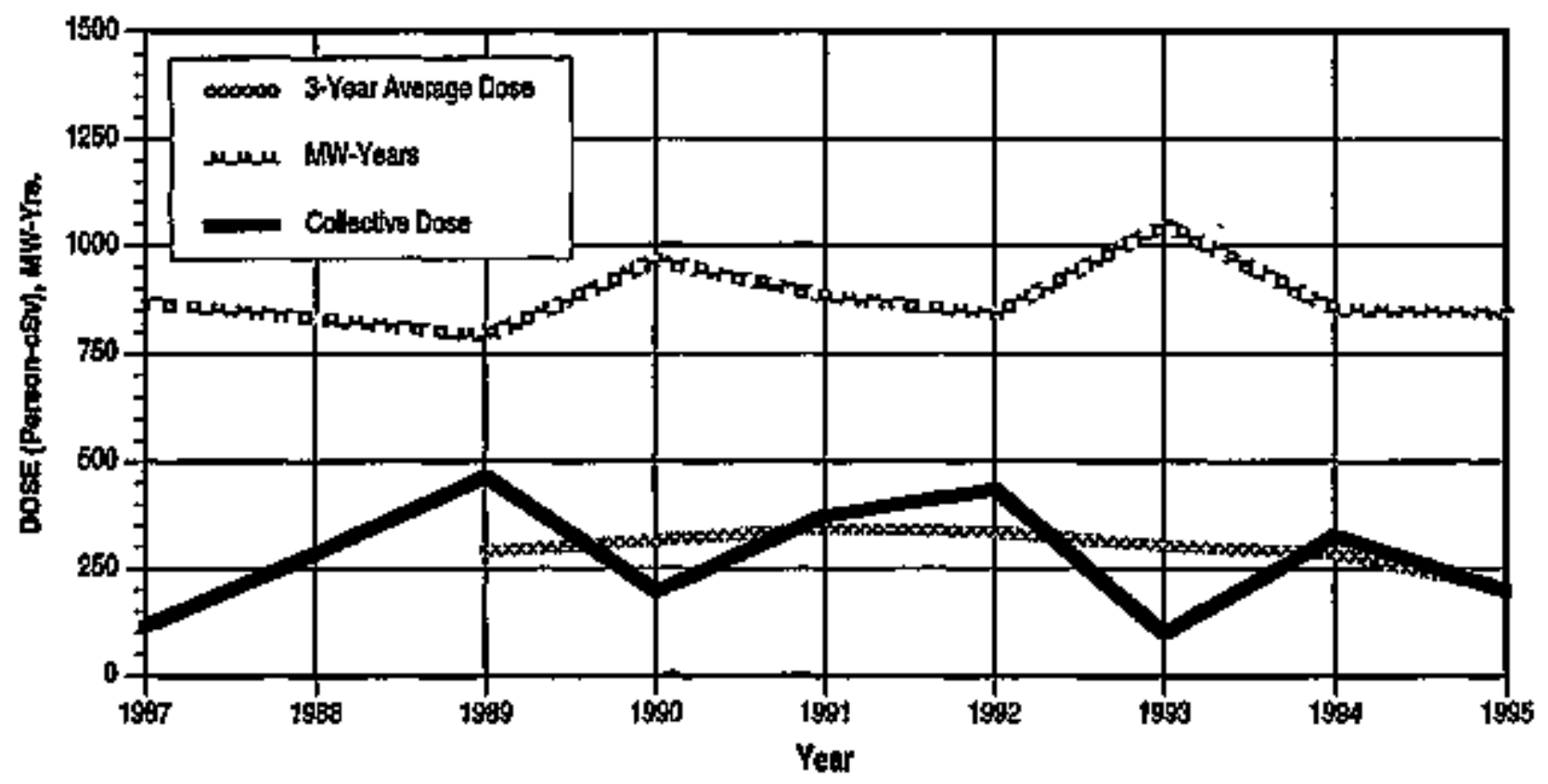

Brakdomin by Jat Funolion

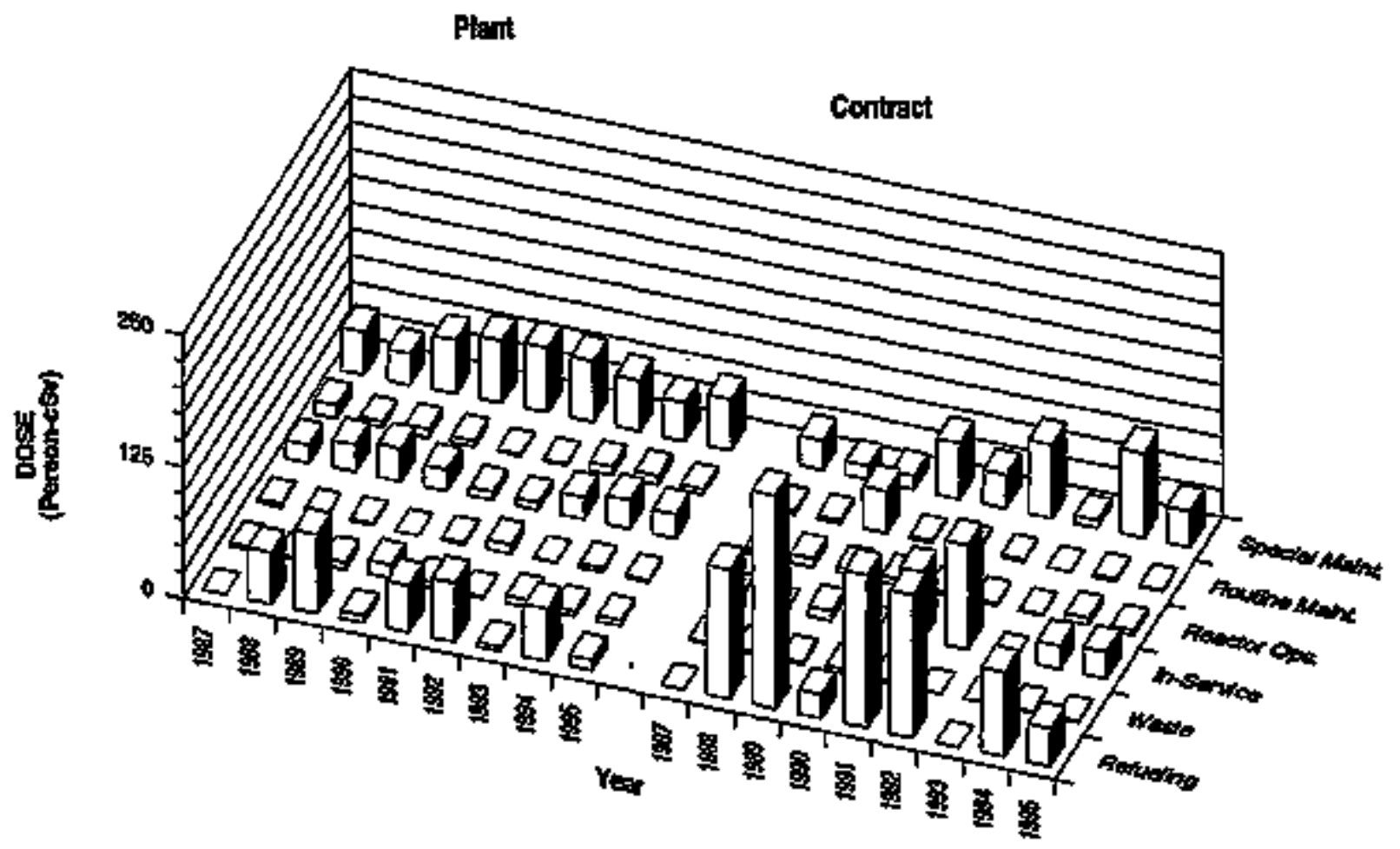


APPENDIX E (continued)

IADIAN POINT 2

Dose-Perfomance Indleators

PWA

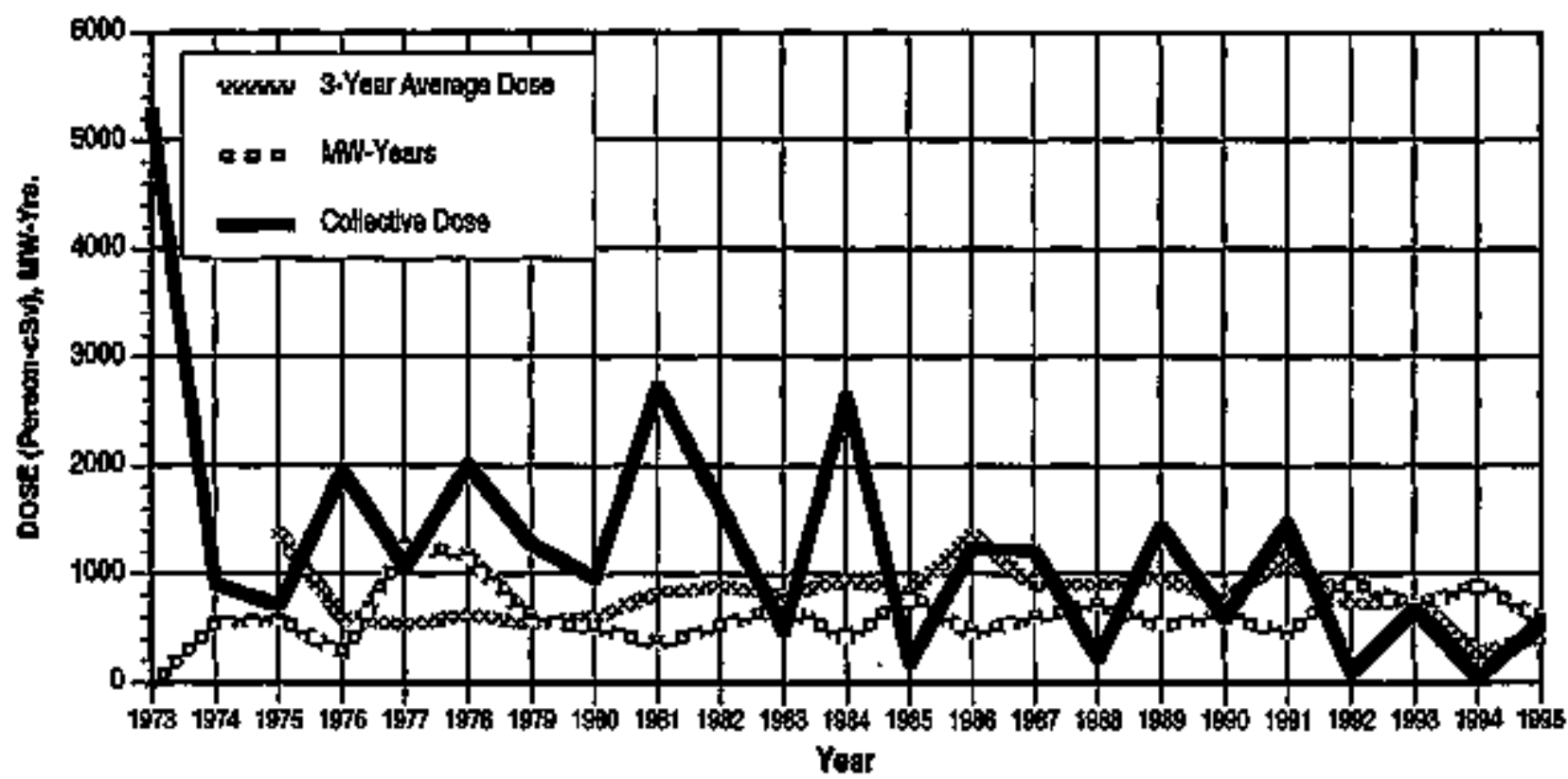

Broakdown by Job Fumclion

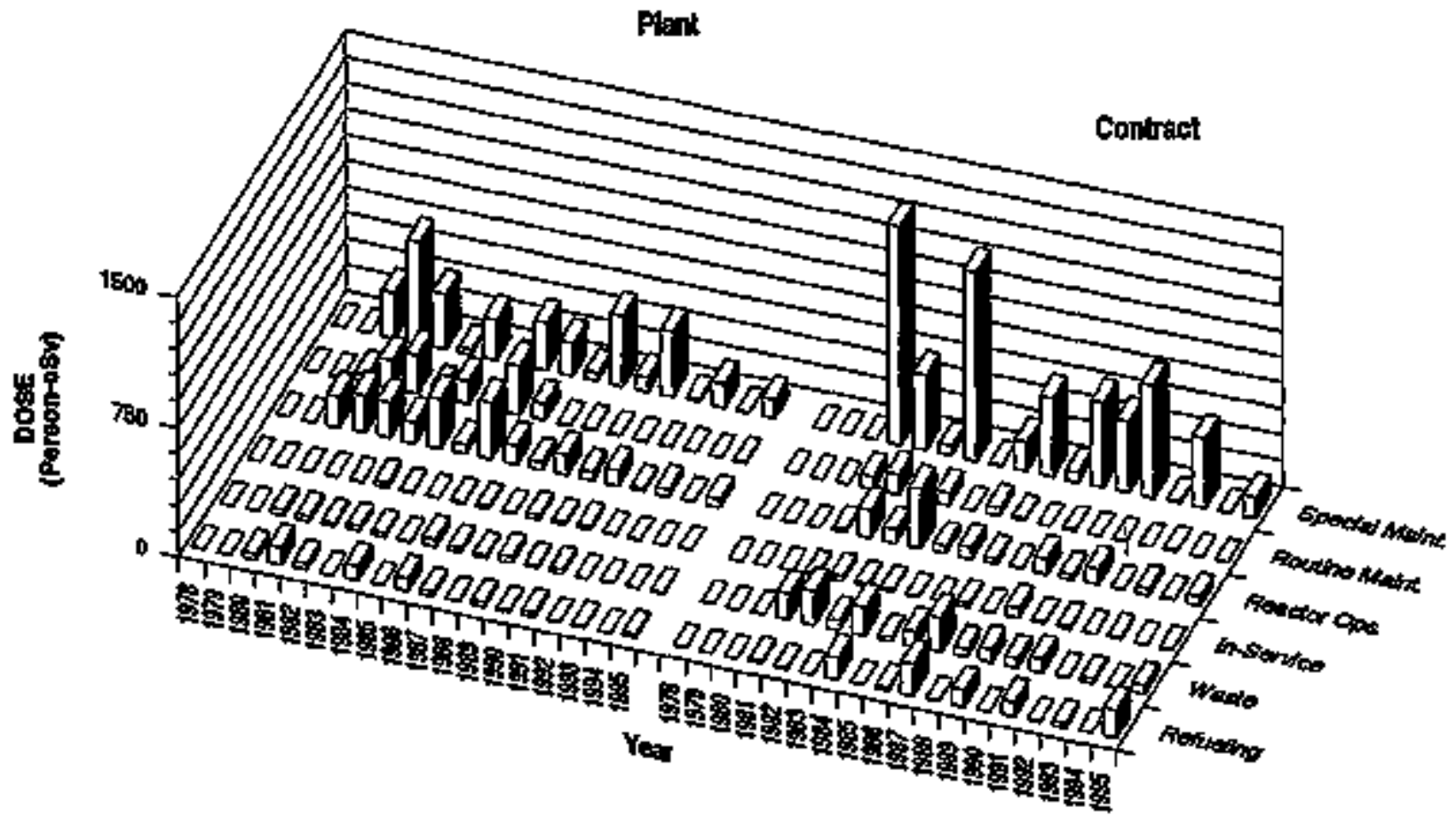

NUREG-0713

E-32 


\section{APPENDIX E (continued) \\ INDIAN POINT 3}

Dose-Pertomance Indicators

PWR

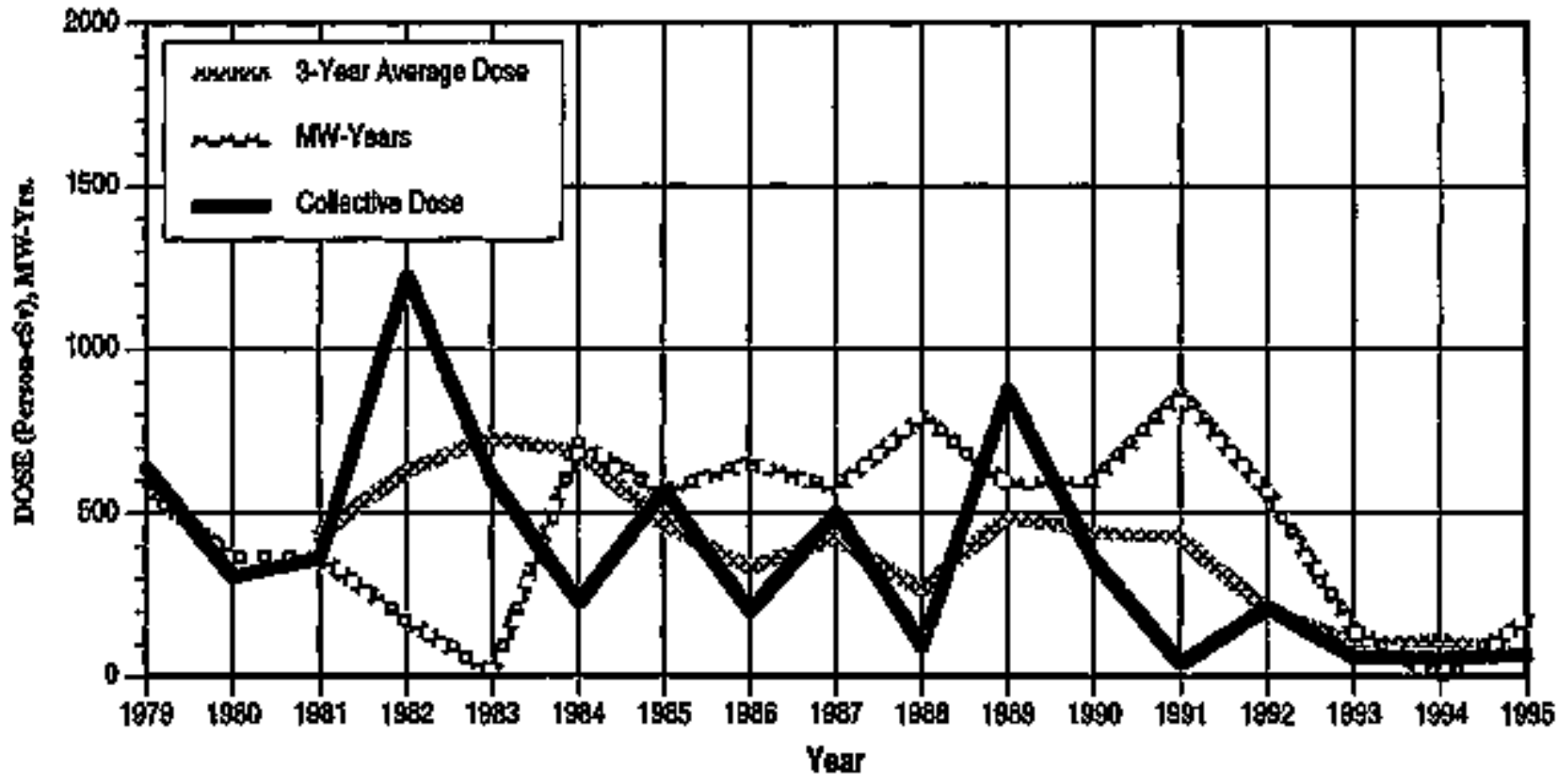

Brakdoun by lob Function

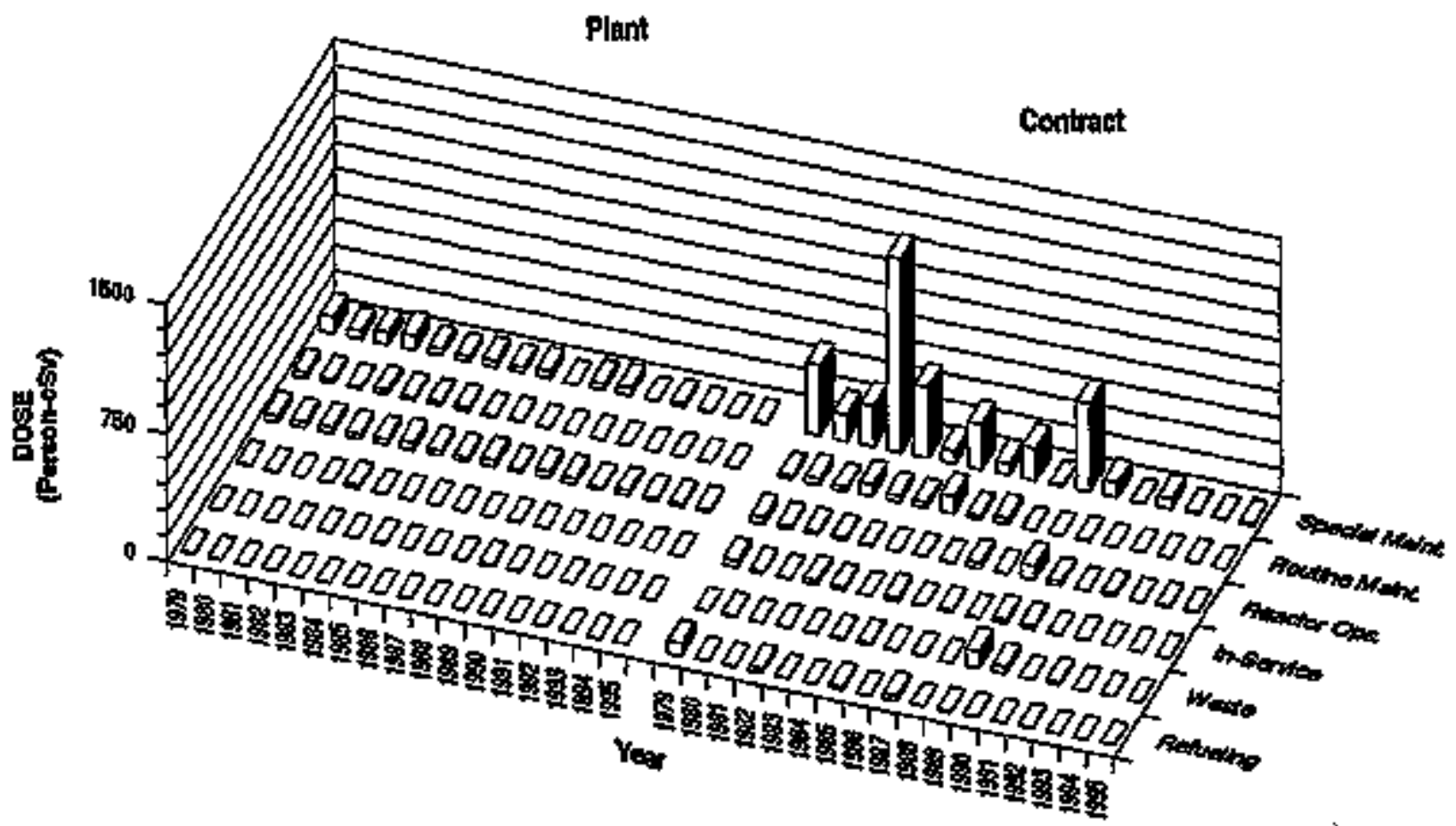


APPENDIX E (conthnued)

KENAUNEE

Dose-Pendintence indicators

PuA

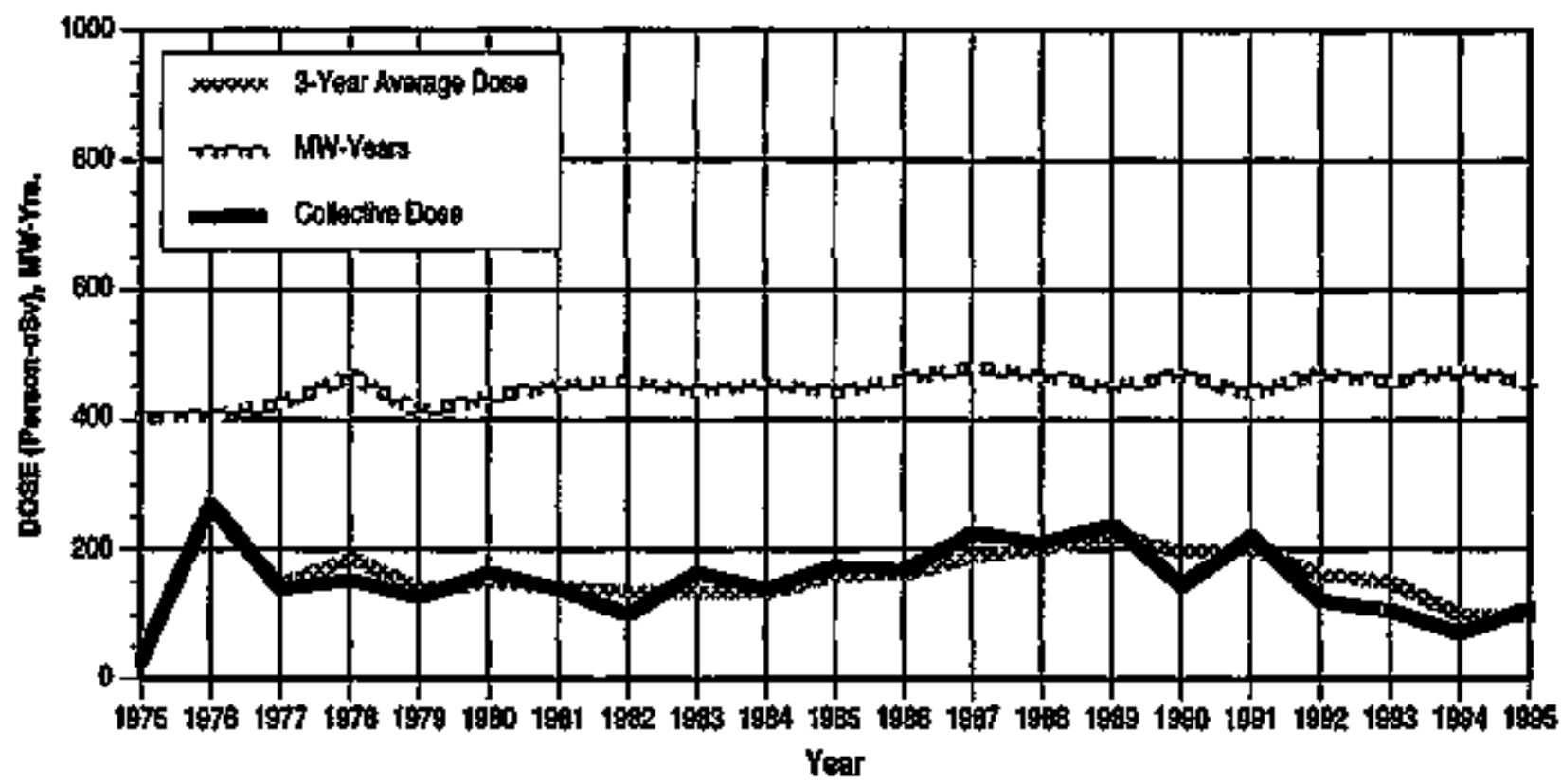

Breakdoun by sob Funetion

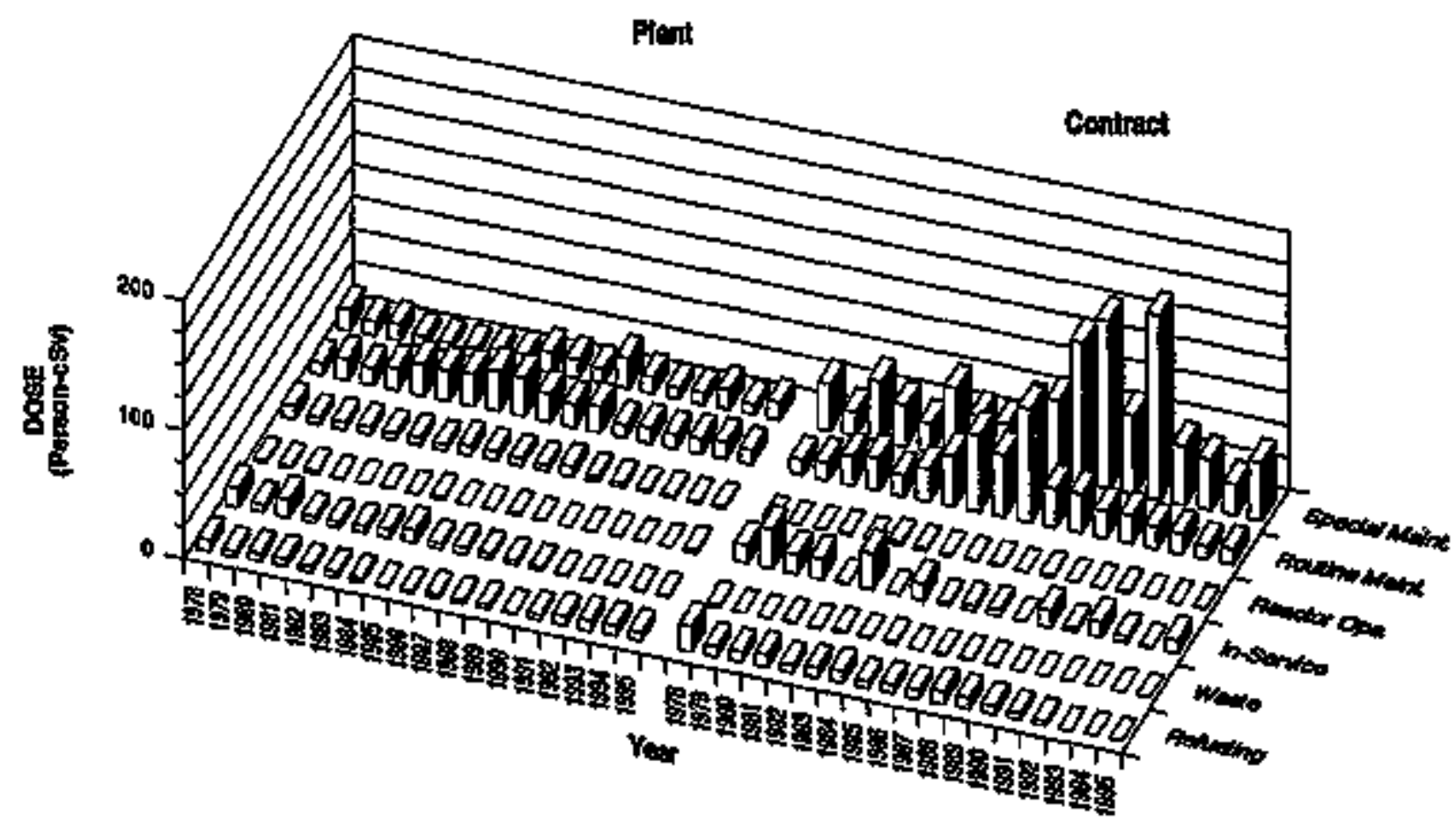




\section{APPENDX E (continued) \\ LASALE 1,2 \\ Dose-Periormance hdicators}

BWHA

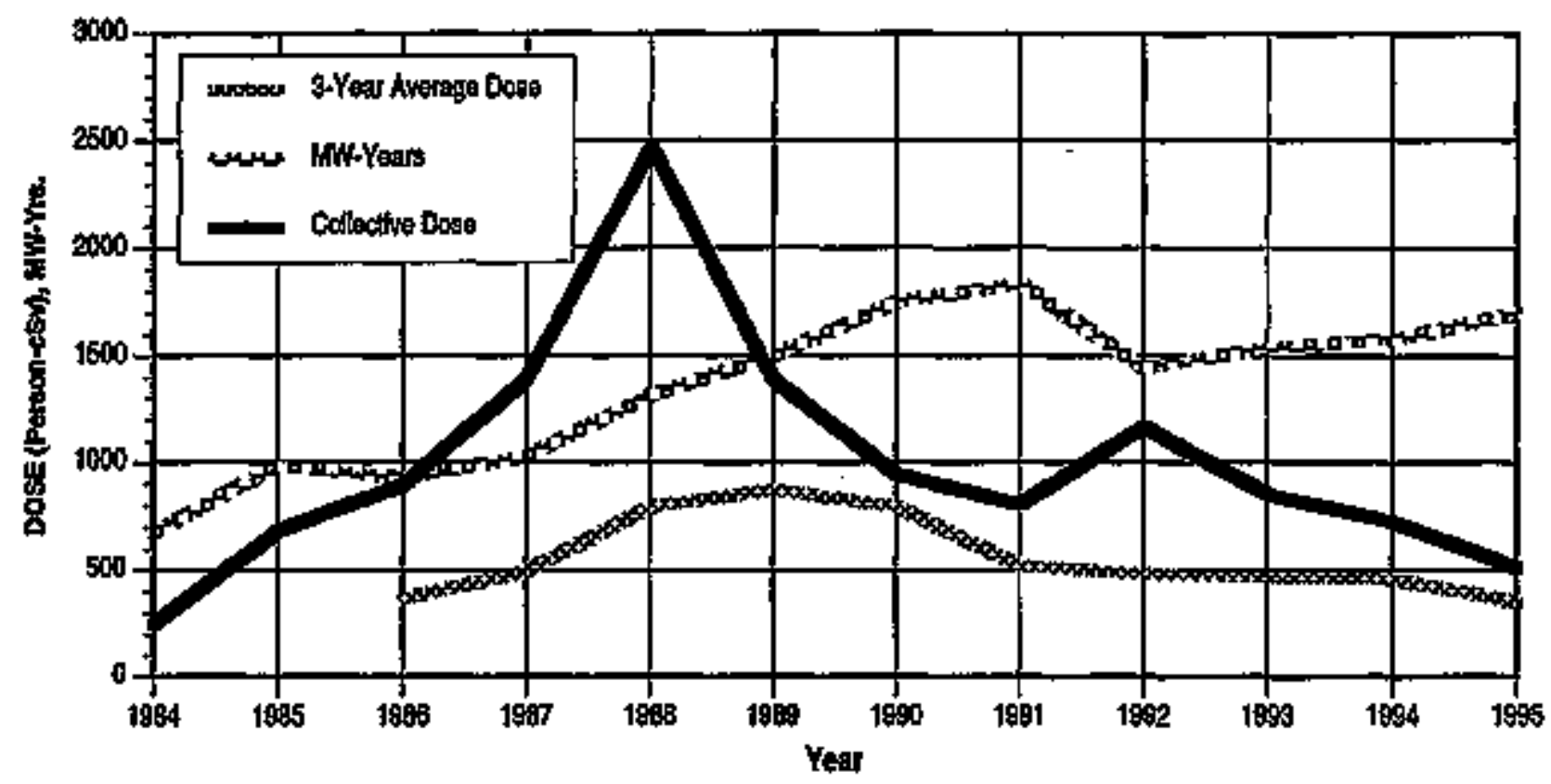

Breakdom by Job Function

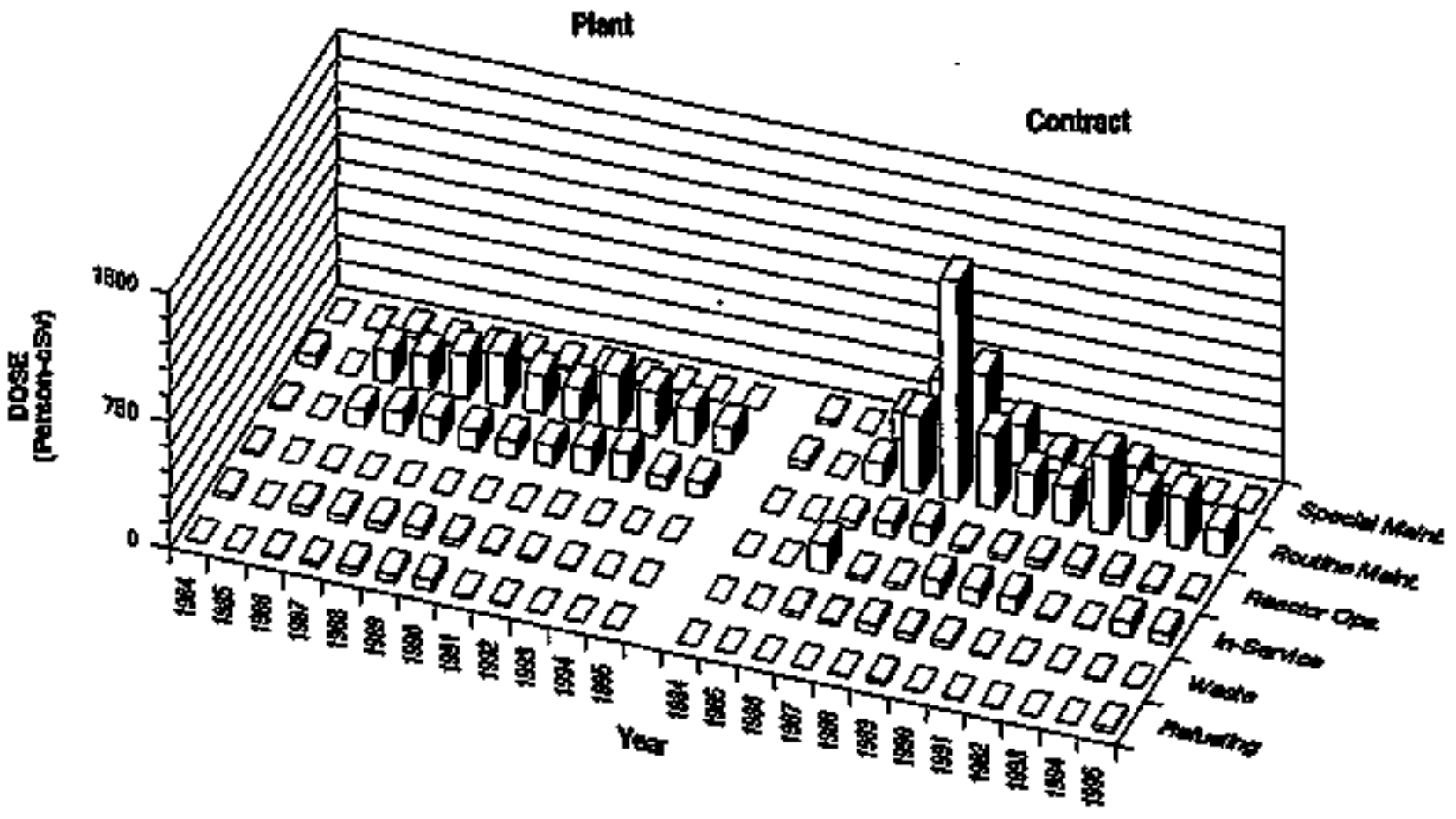




\section{APPENDIX E (continued) \\ LIIAEFiCK 1, 2 \\ Doseperformance hidicators}

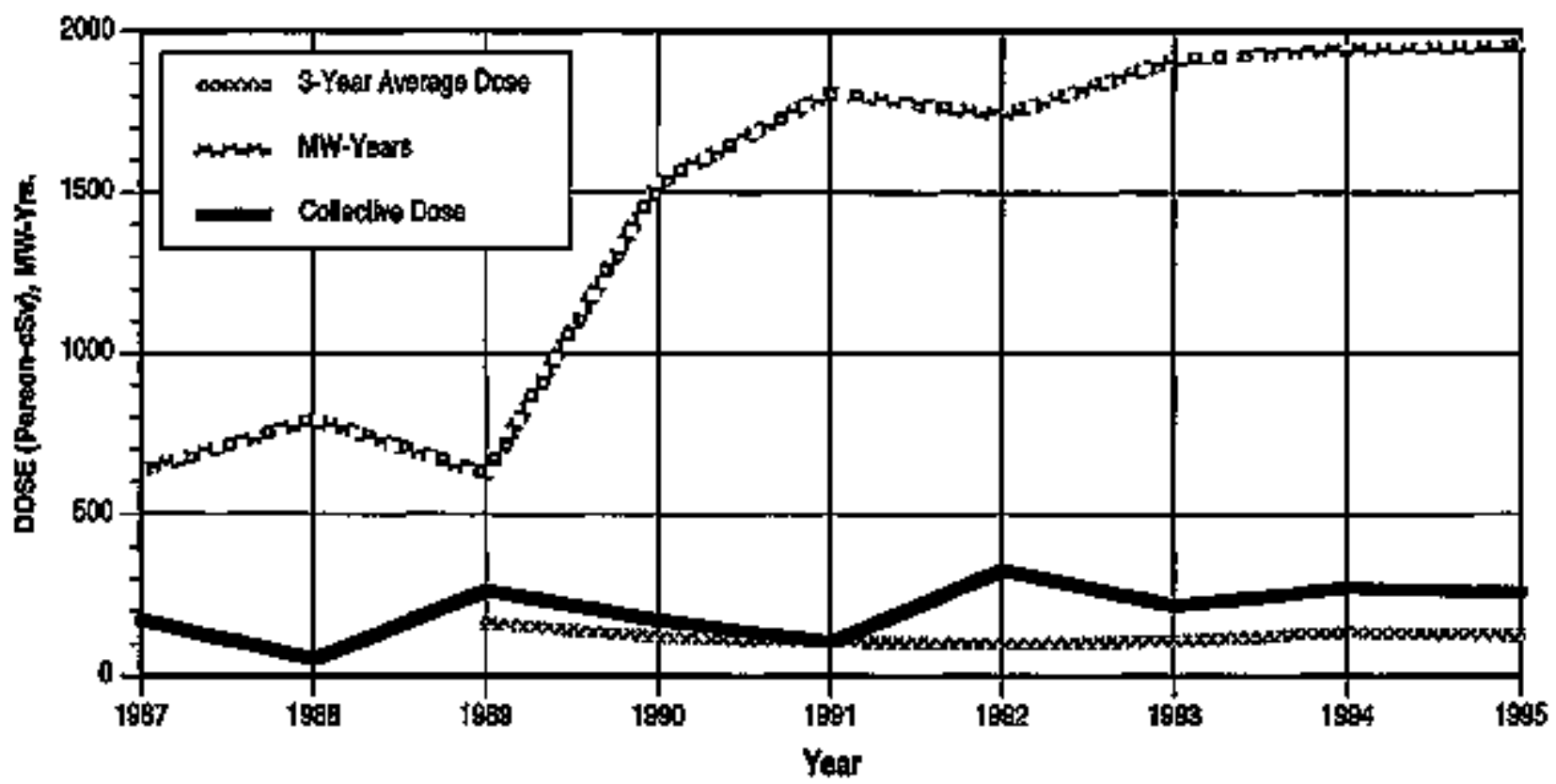

Brakdown by Job Function

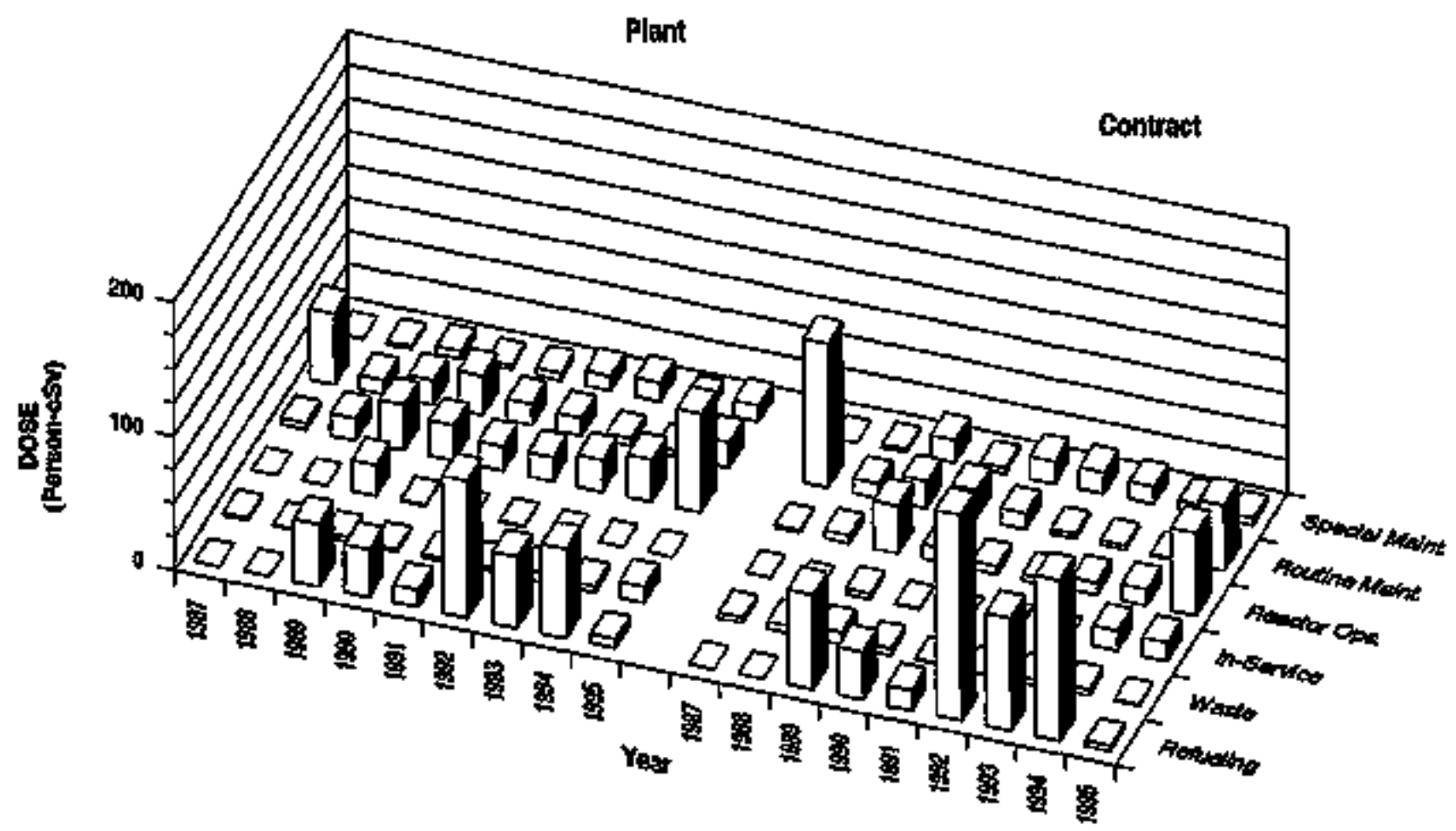


APPENDXX E (continued)

maINE YaNKeE

Dose-Pariomance Indicators

PIV

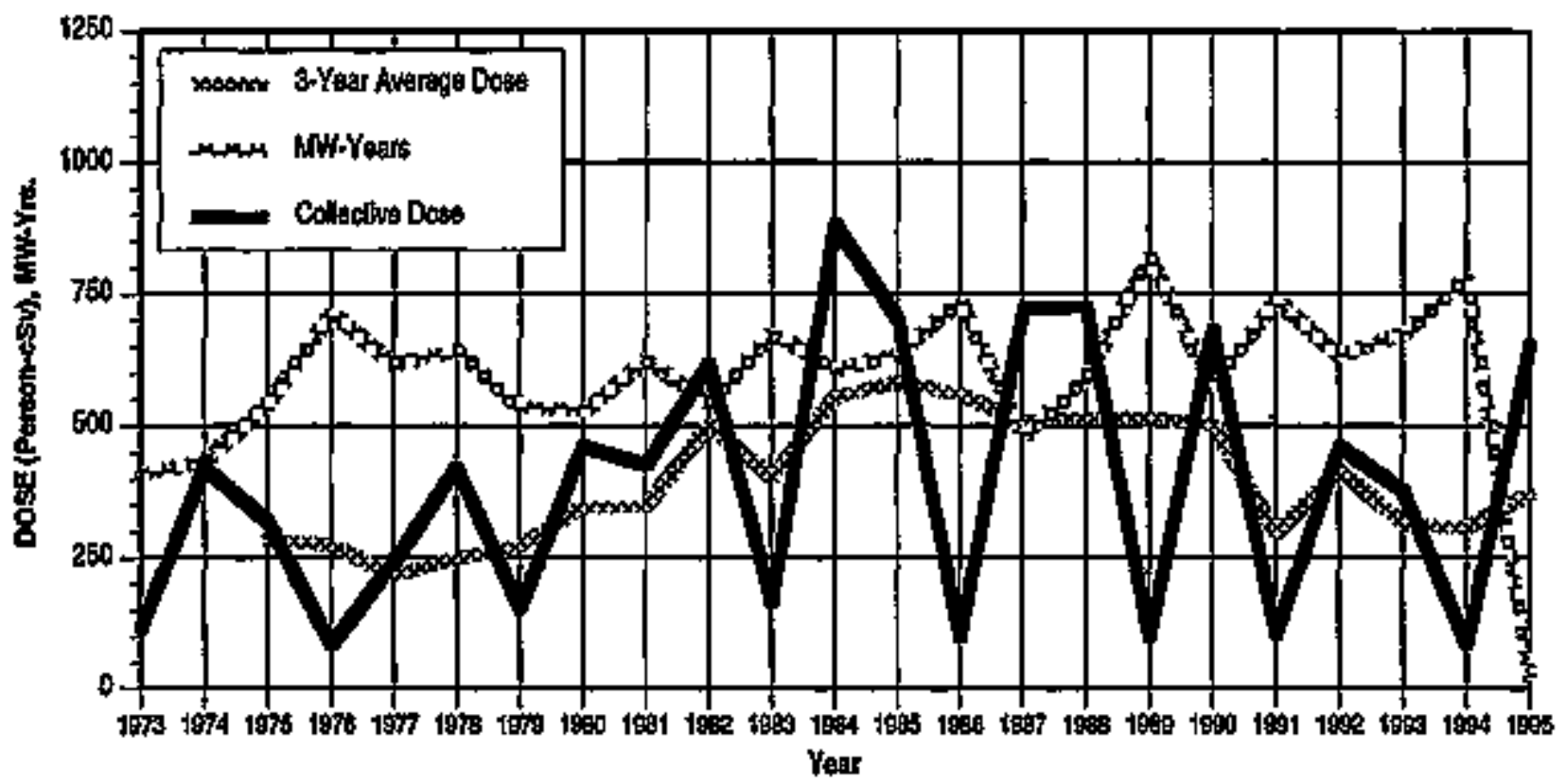

Breakdown by dob Function

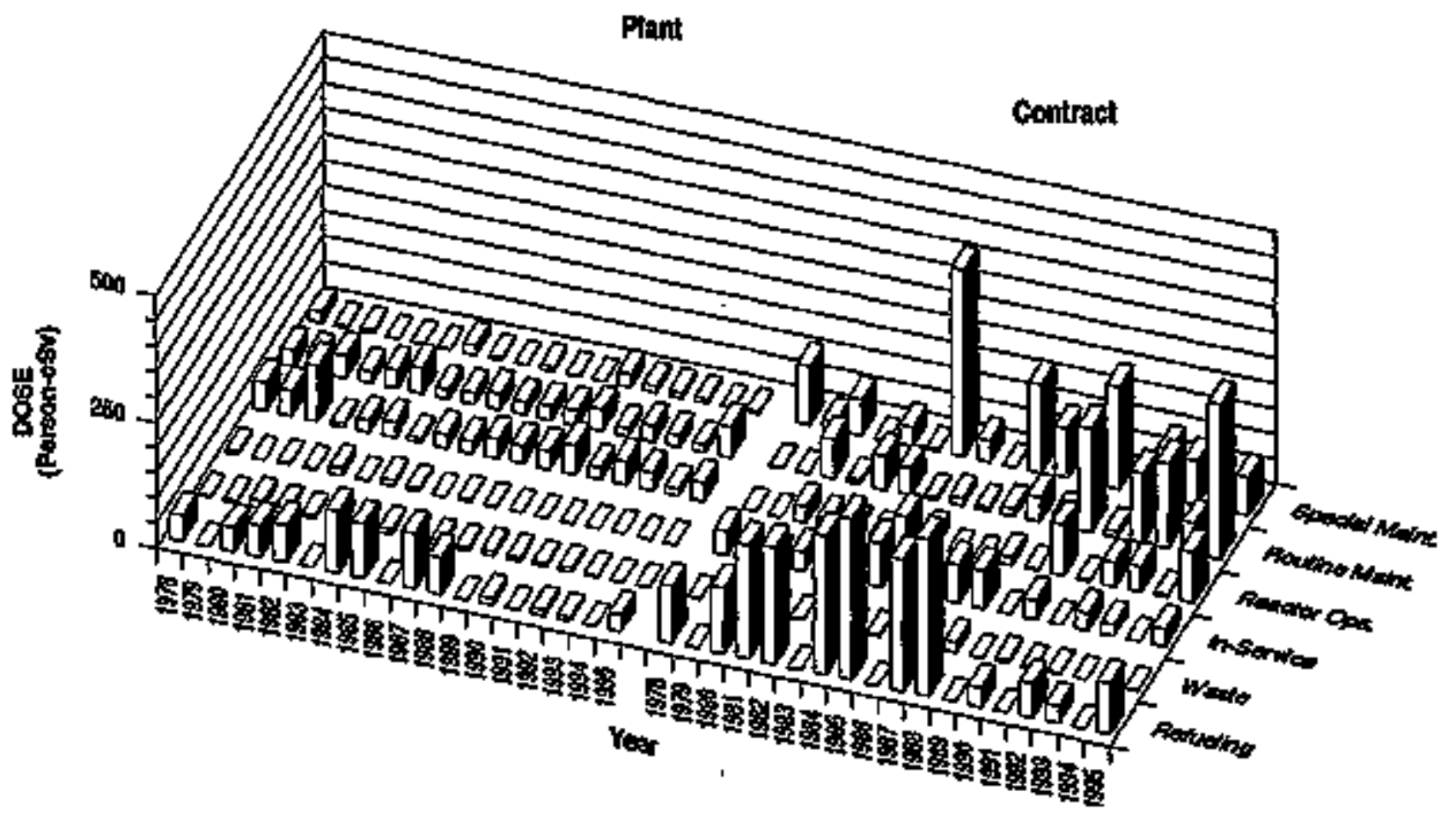


APPENDIX E (continued)

MCCAJRE 1, 2

Dose:Pertormanice Indicators

PNR

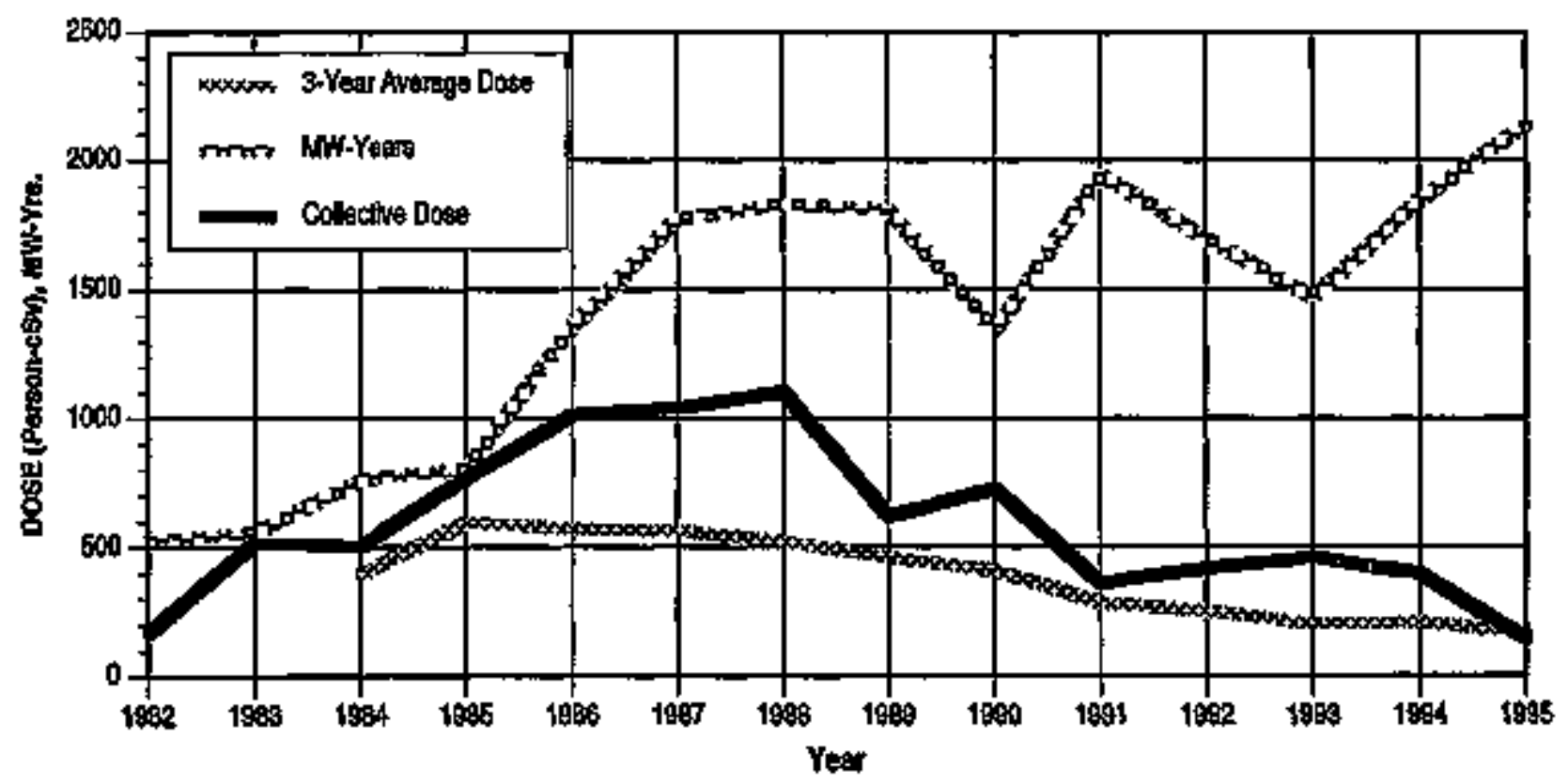

Brakidoun by Job Funection

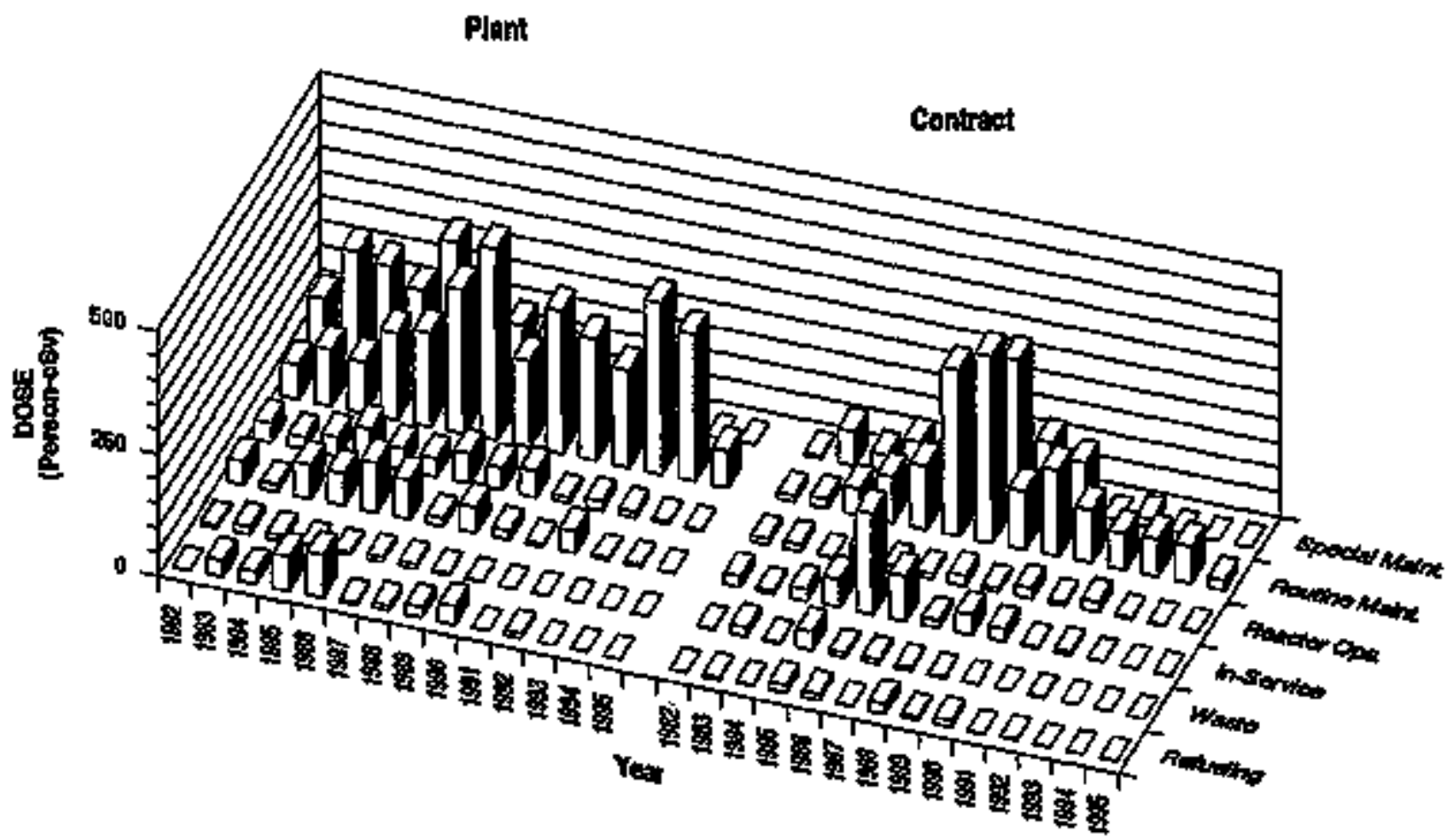




\section{APPENDIX E (continued)}

\section{MLLSTONE POINT 1}

Dose-Peiformanea hdlealors

BWR

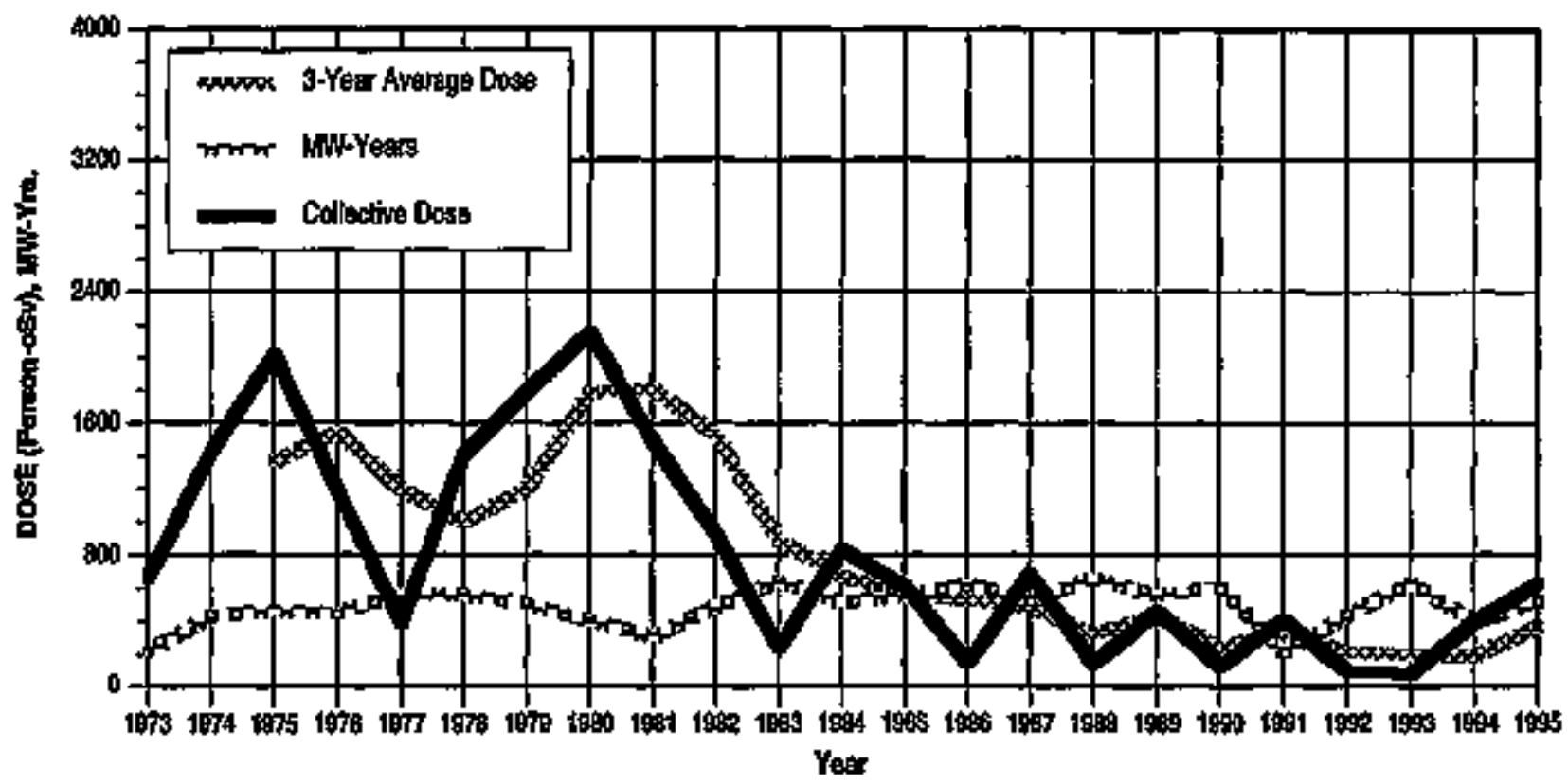

Breakdown by Jab Function

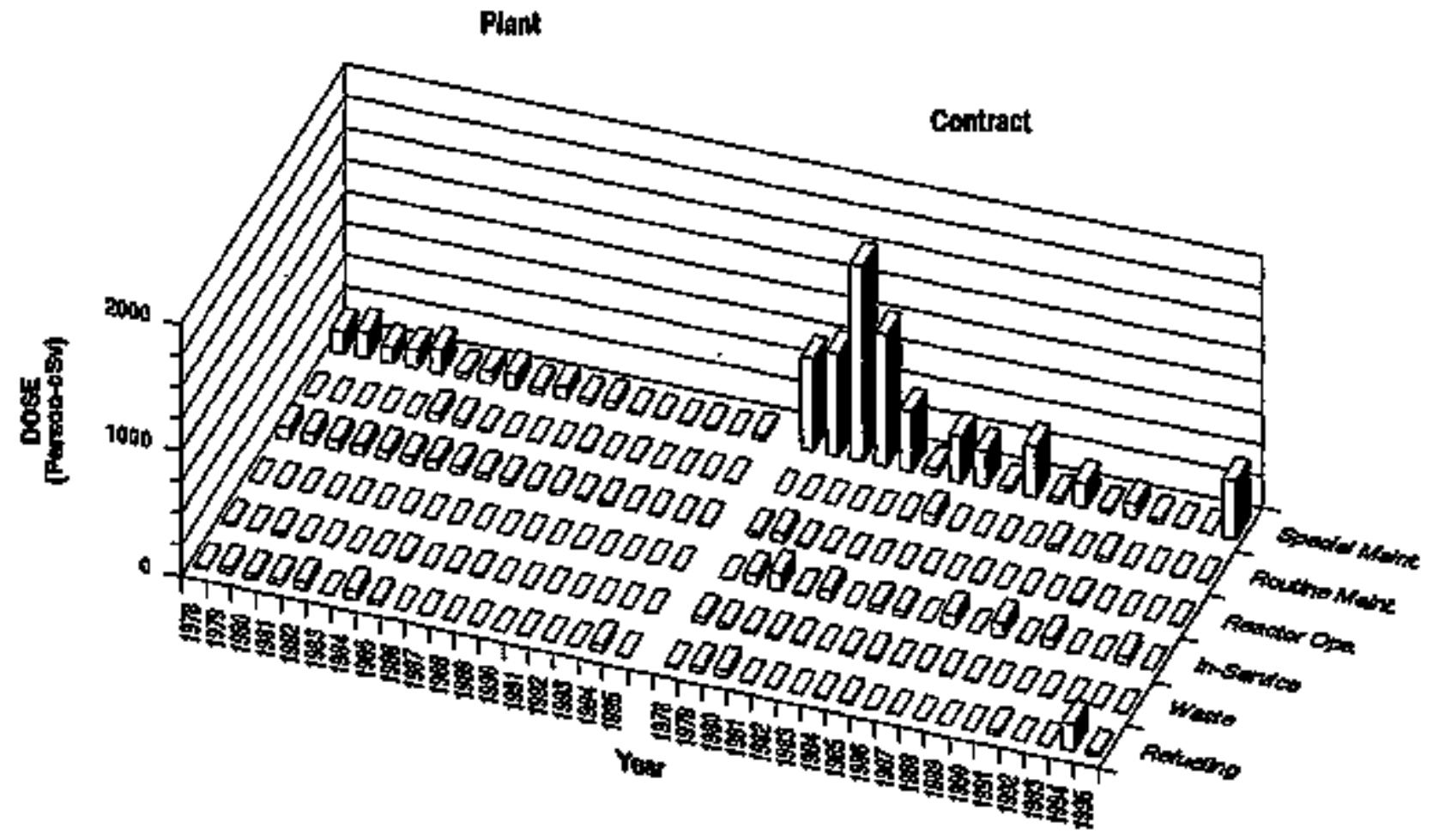


APPENOX E (continued)

MLLSTONE PONT 2,3

Dose-Parkomenco Indleaters

PWR

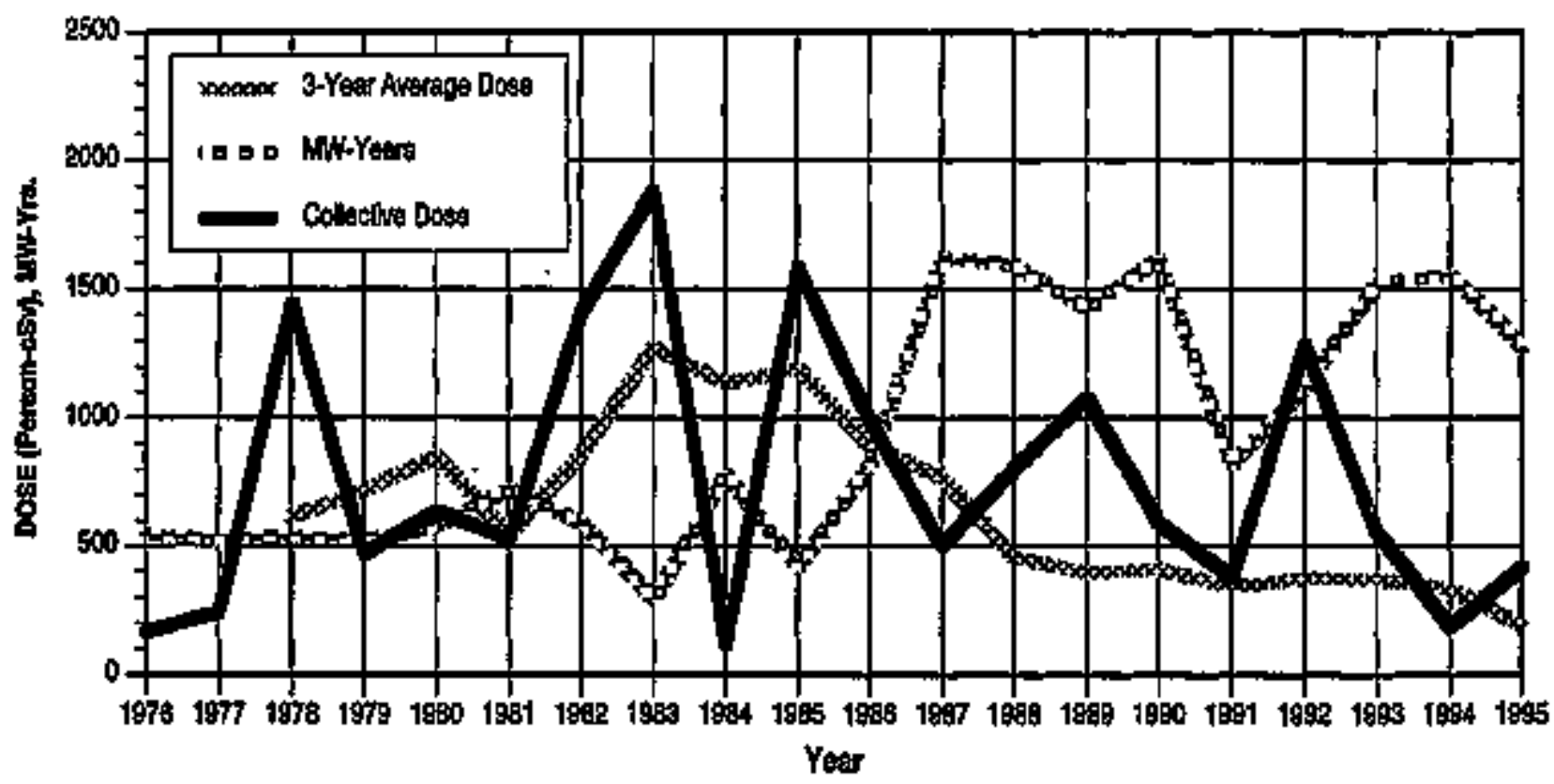

Brakdoun by lab Function

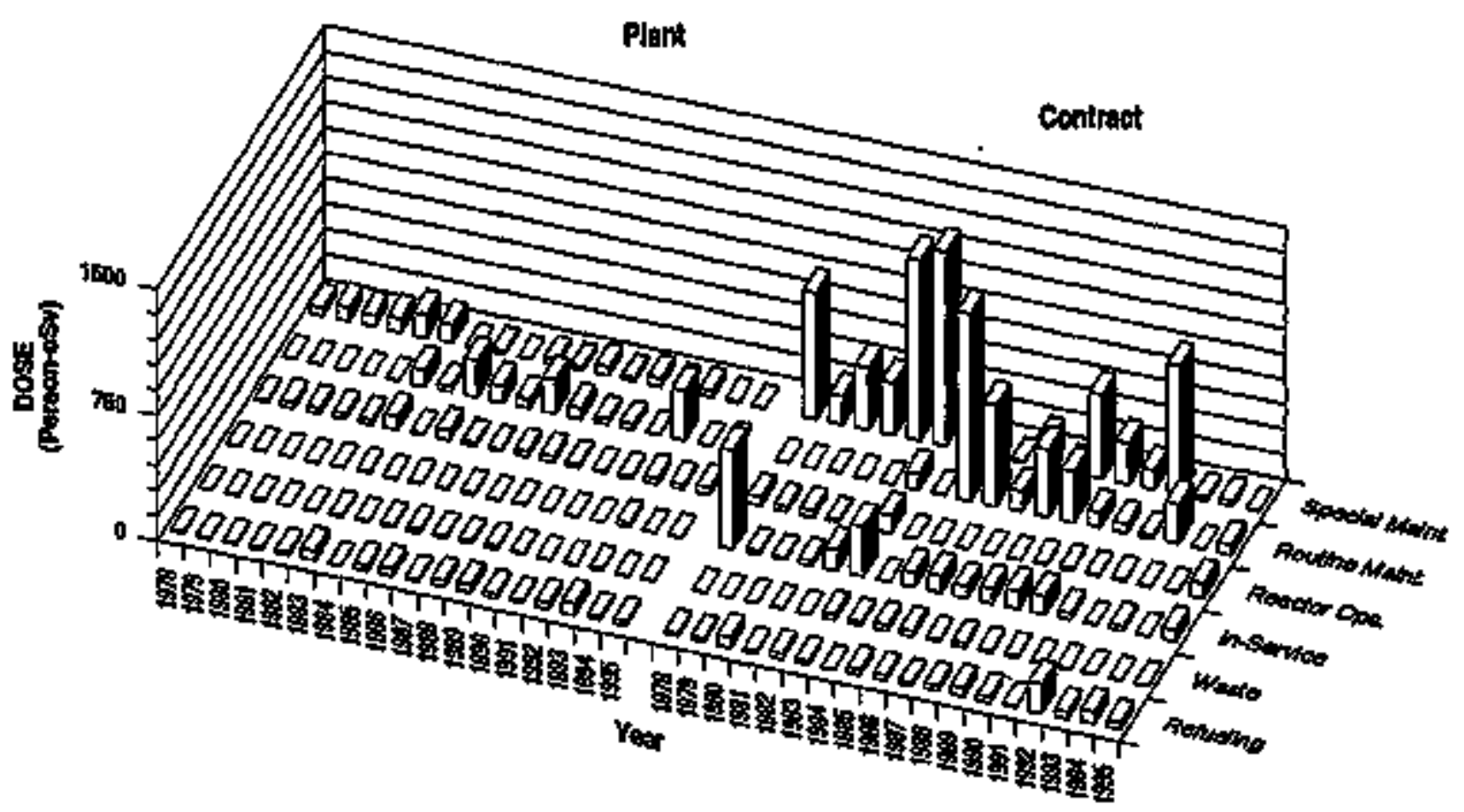


APPENDIX E (continued)

MONTICELLO

Dose-Performance inditcstors

BWA

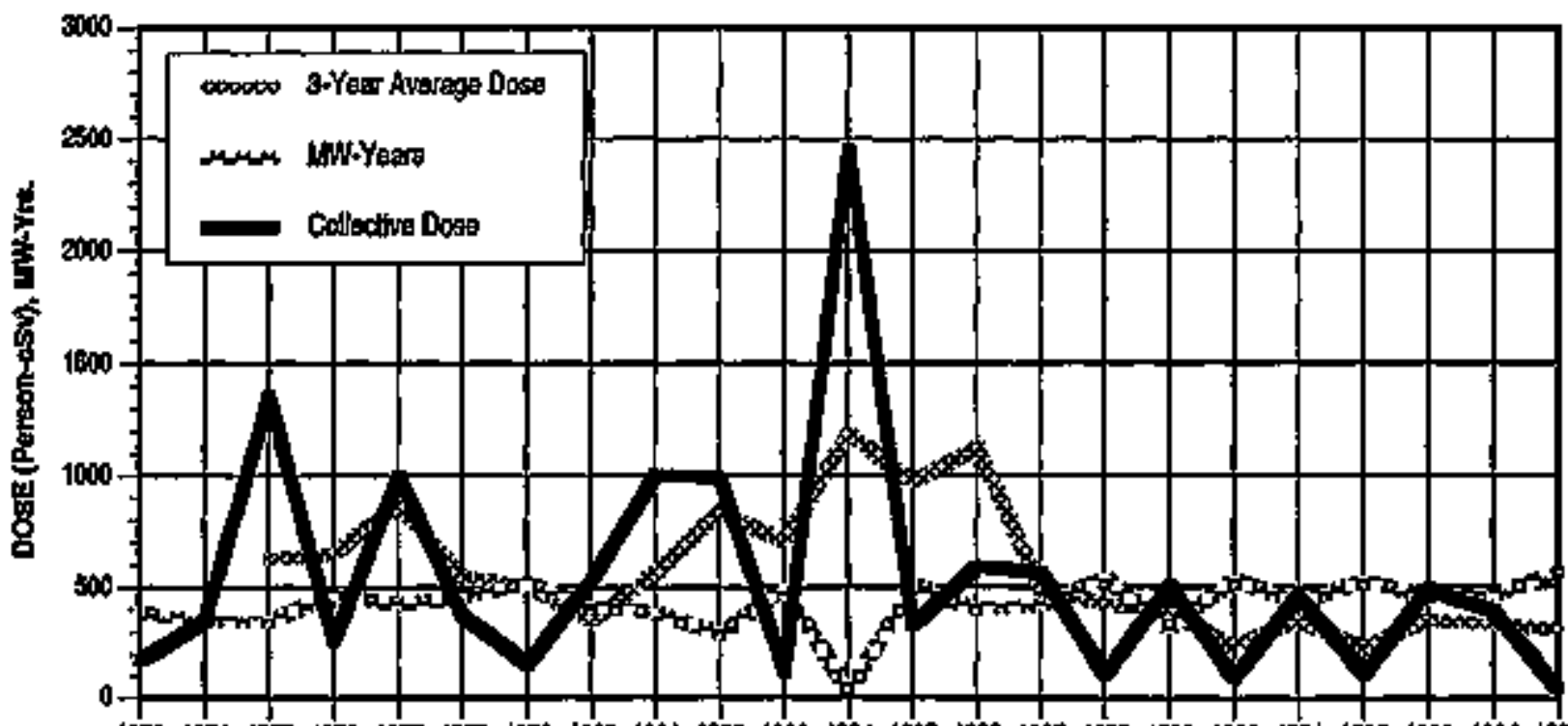

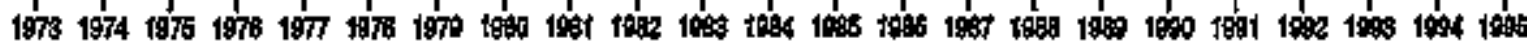
Yair

Ersakdown by uob Finetion

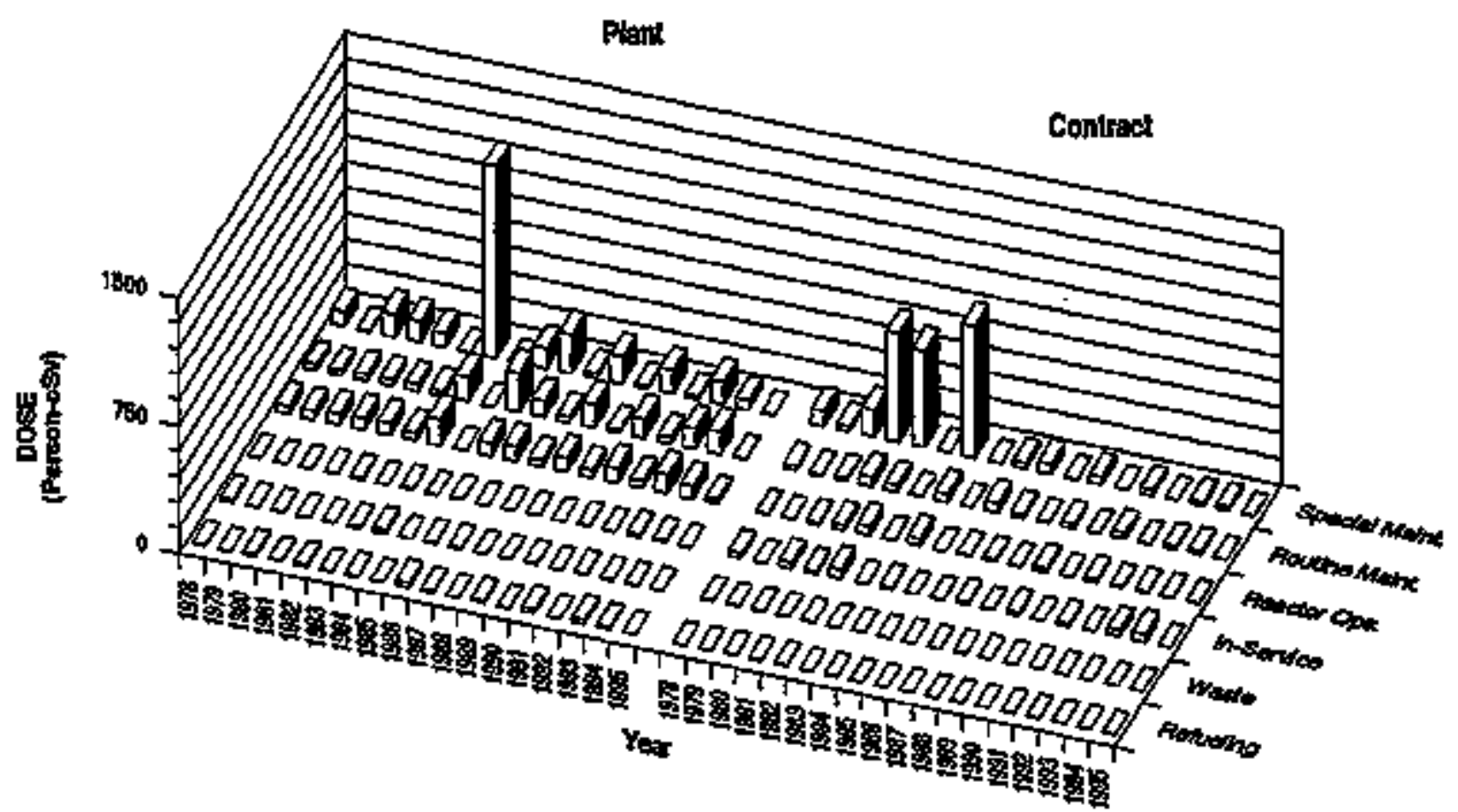


APPENDIX E (continued)

MINE MIE POINT 1,2

Dose-Peitormance Inticators

BWR

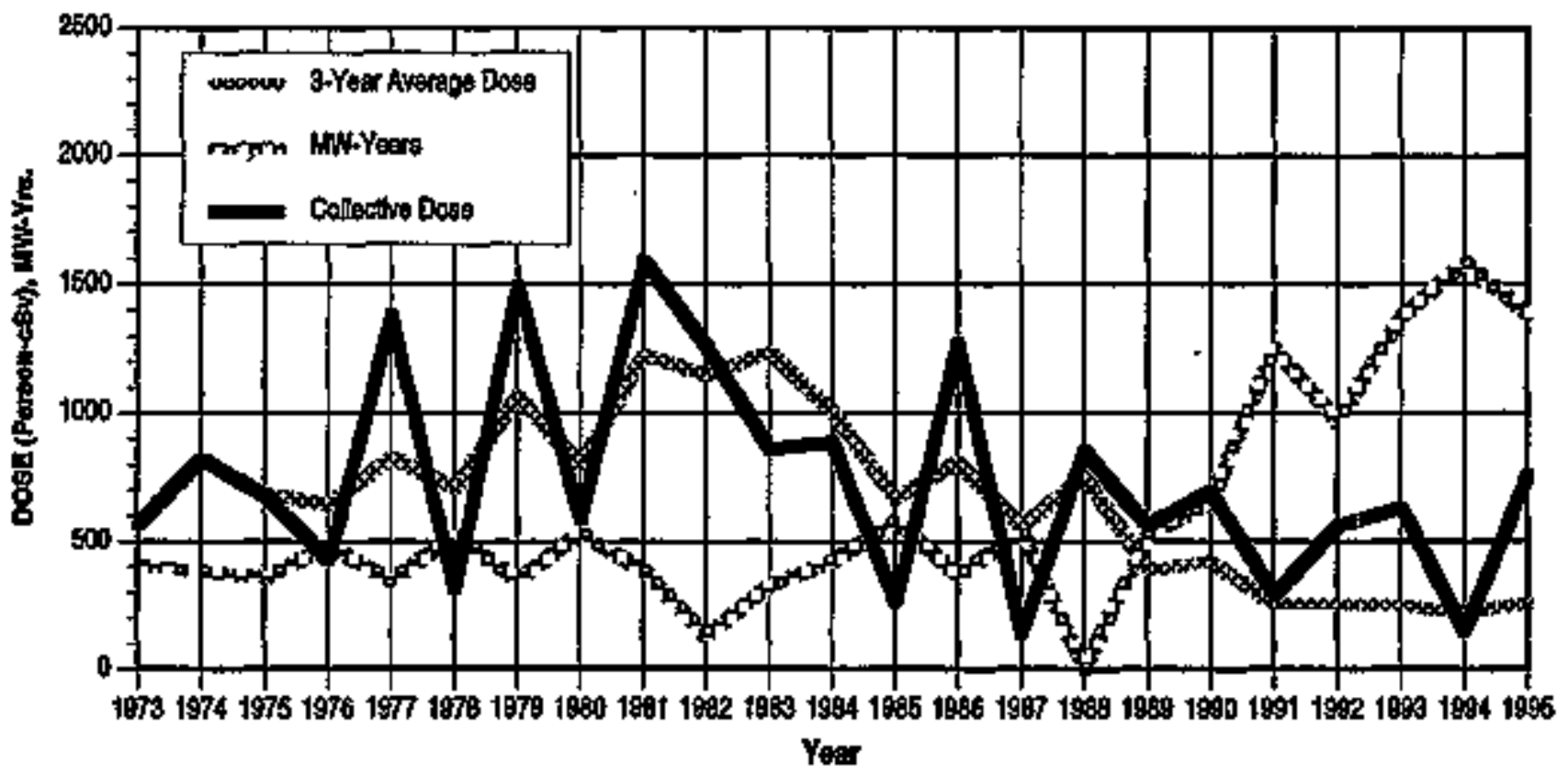

Broekdown by job Function

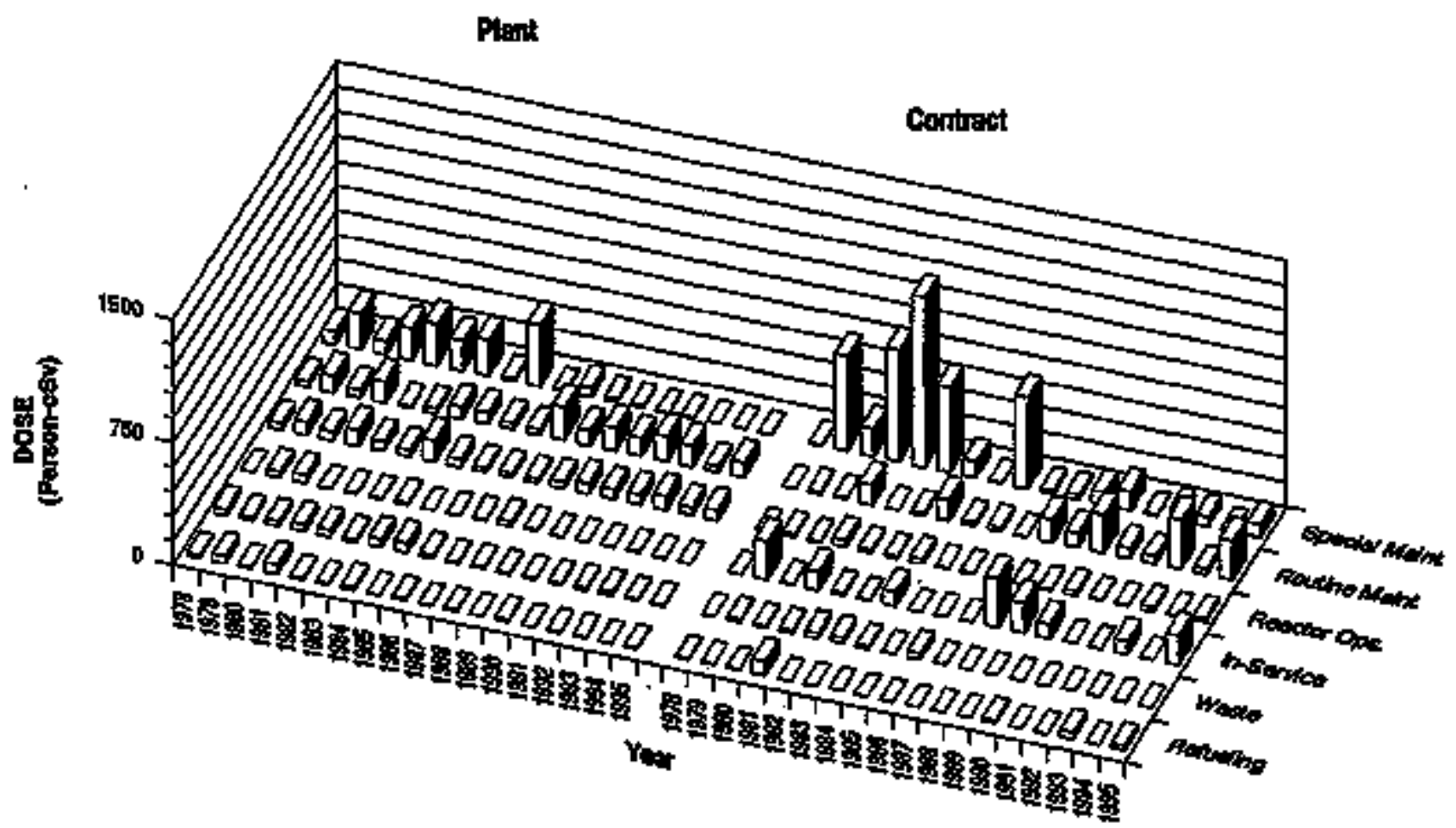


APPENDIX E (continued)

NORTH ANDA 1, 2"

Dose-Pexformance hdícators

PWR

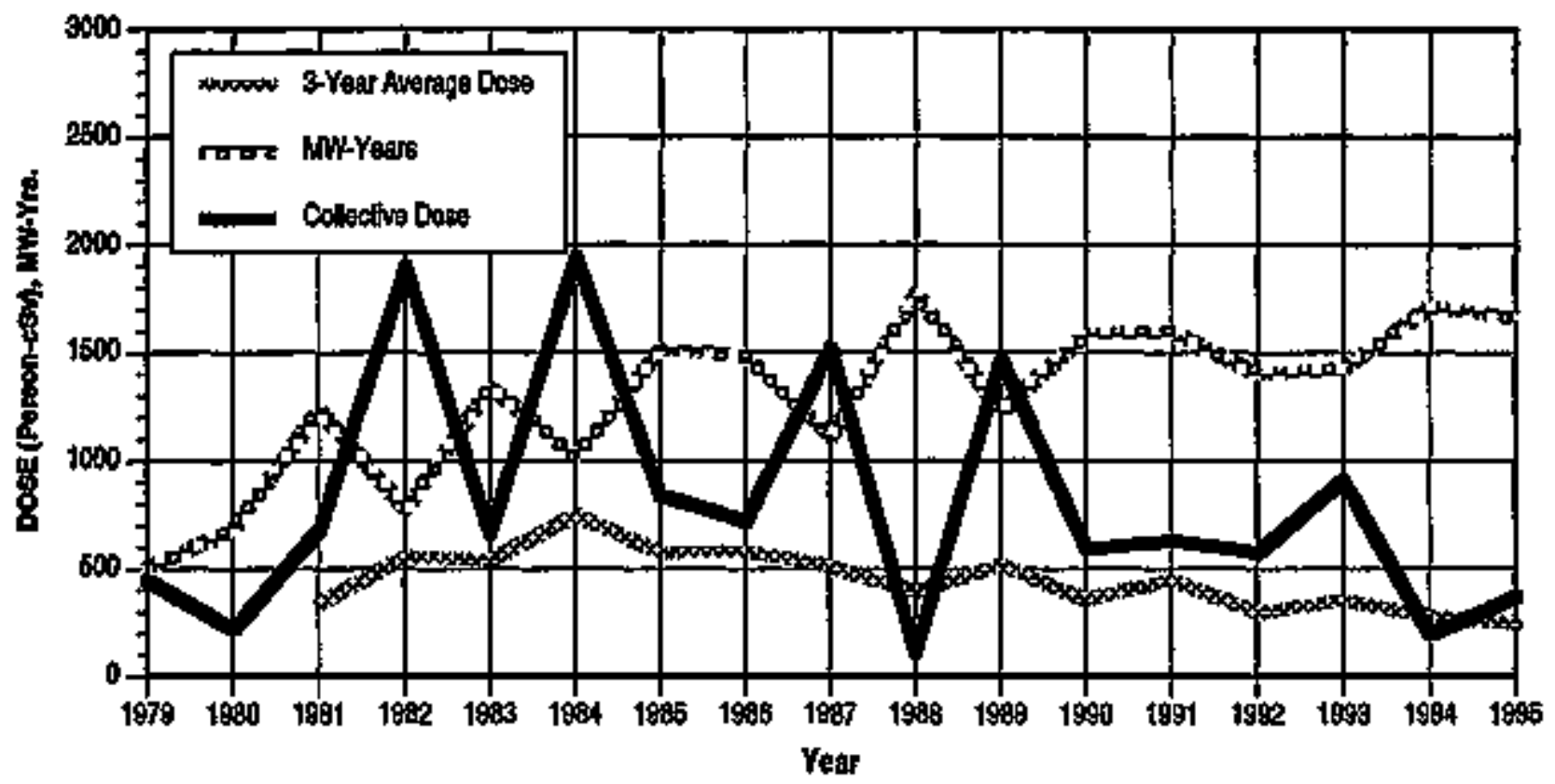

Broakdorn by Job Function

Plant

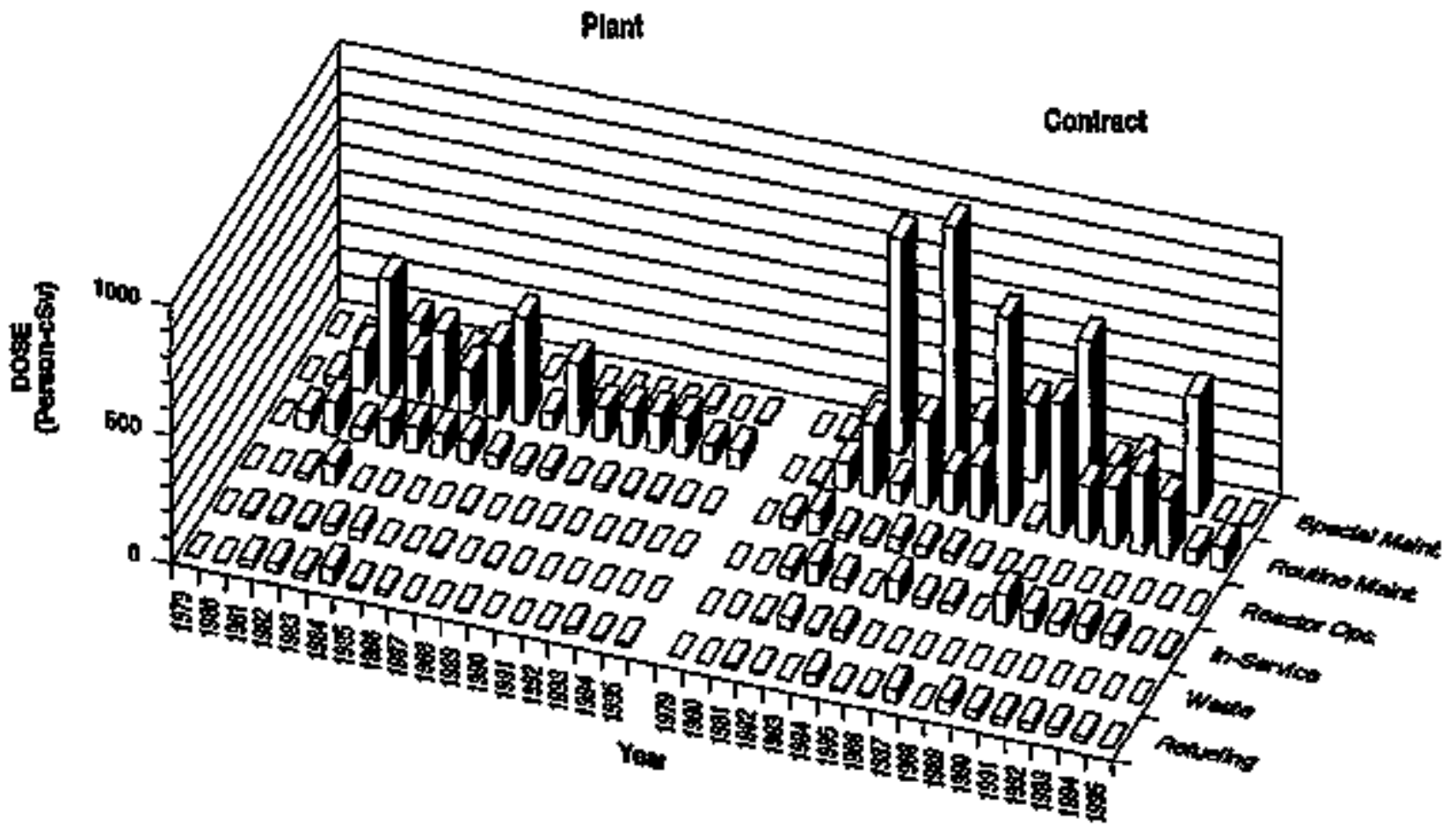




\section{APPENDIX E (continued)}

OCONEE $1,2,3$

Dose-Pexformance hollcators

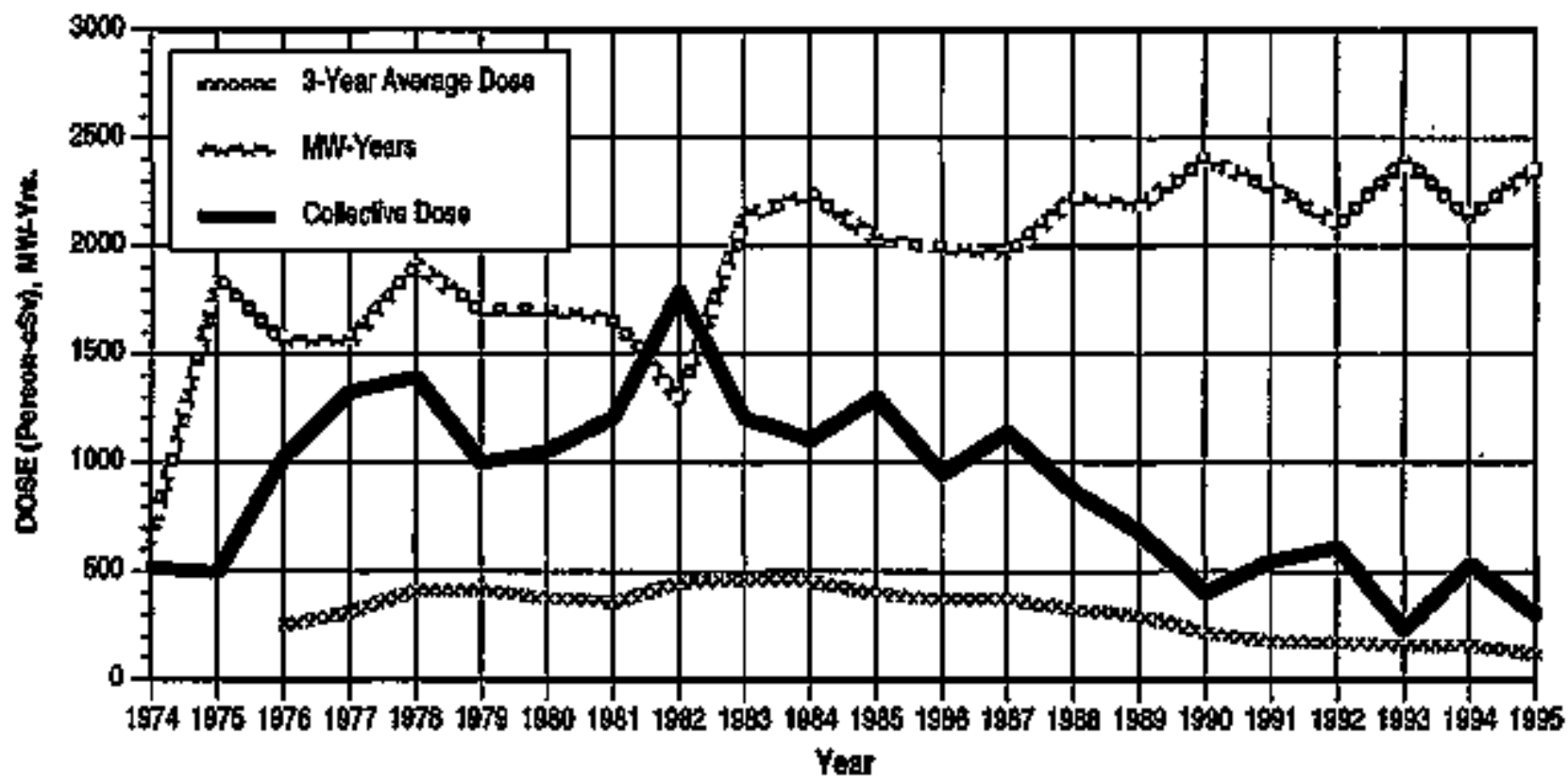

Breakdown by Job Funetion

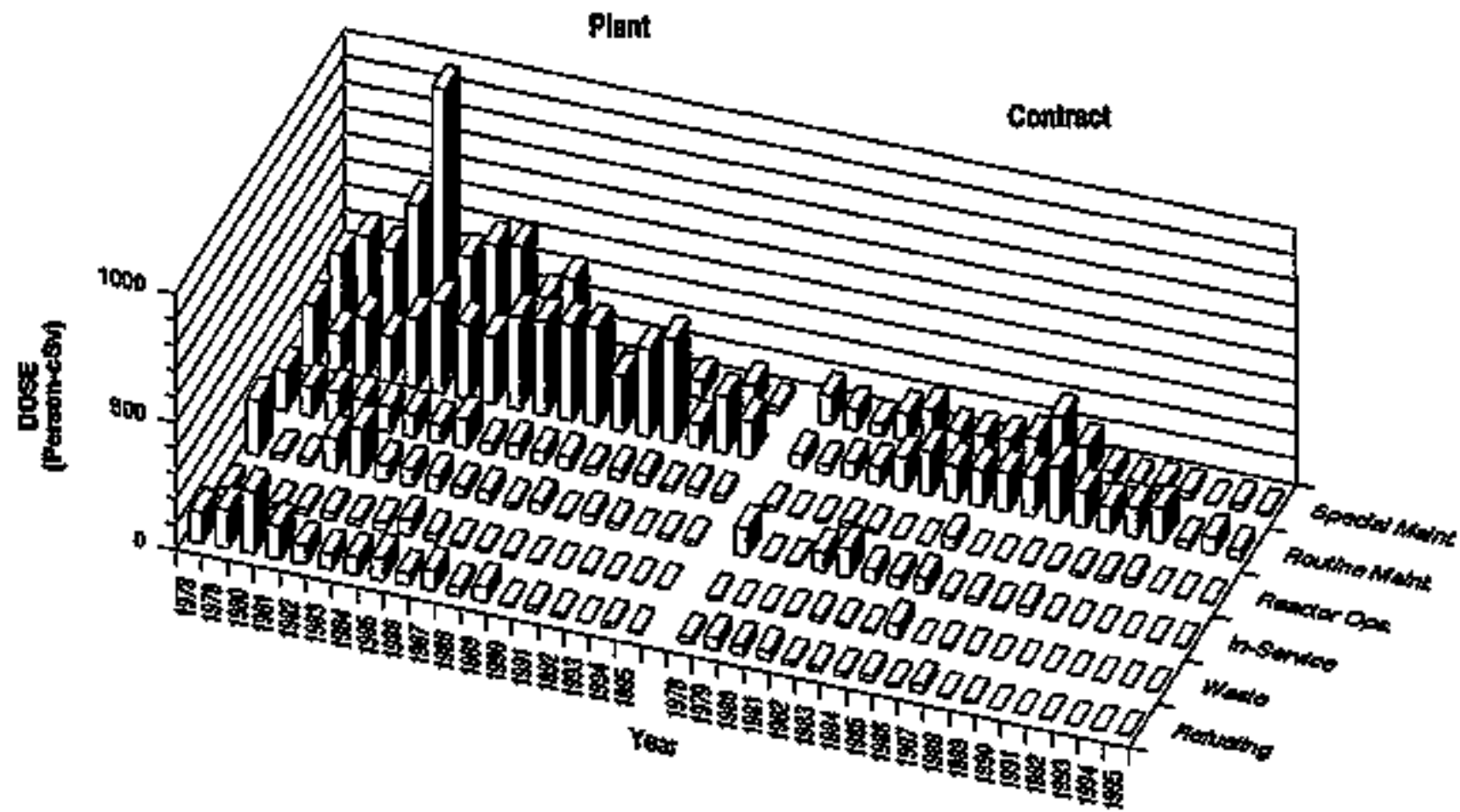

NUREG-0713 
APPENDIX E (continued)

OYSTER CREEK

Dose-Pertormance holicelors

BWR

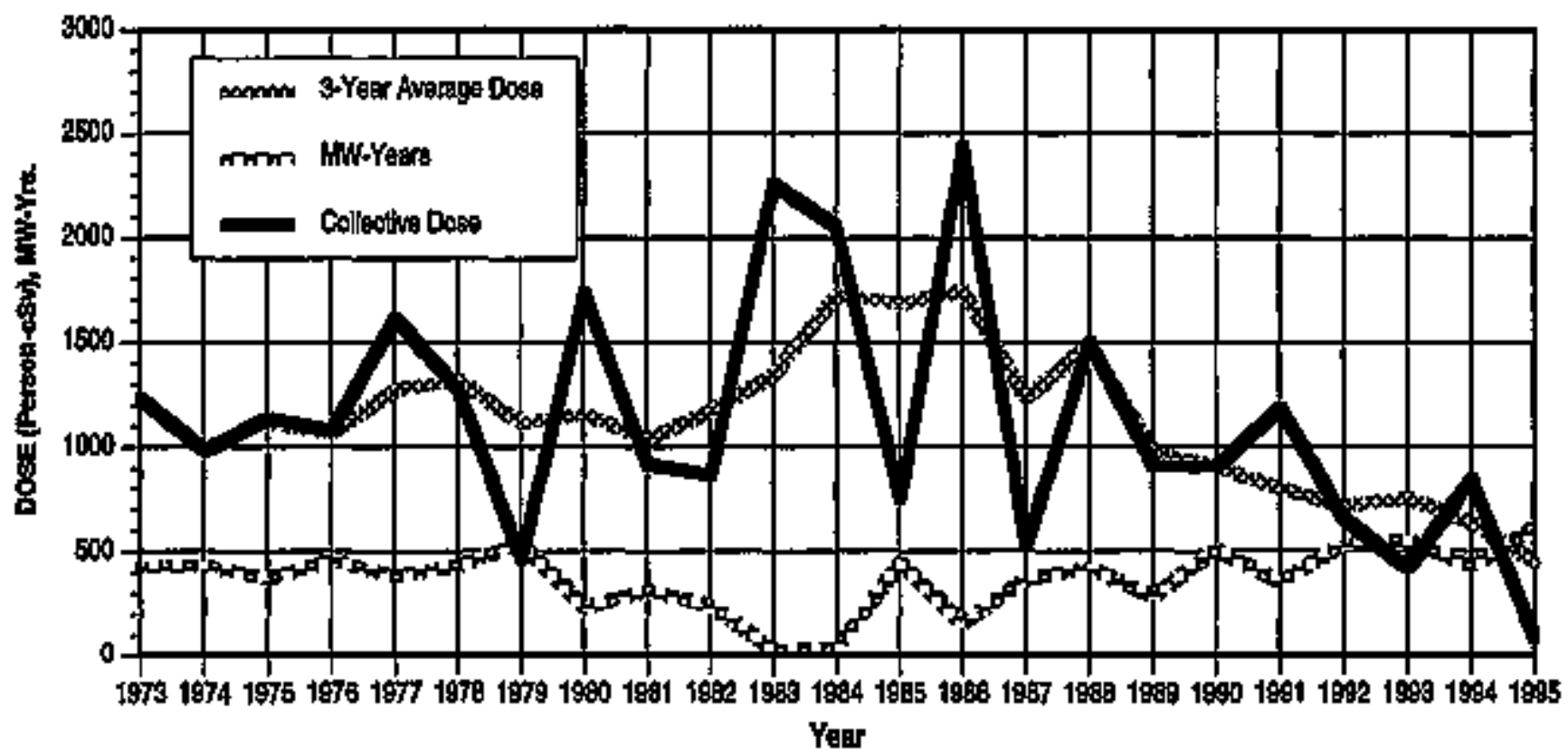

Ersakdom by uob Funclion

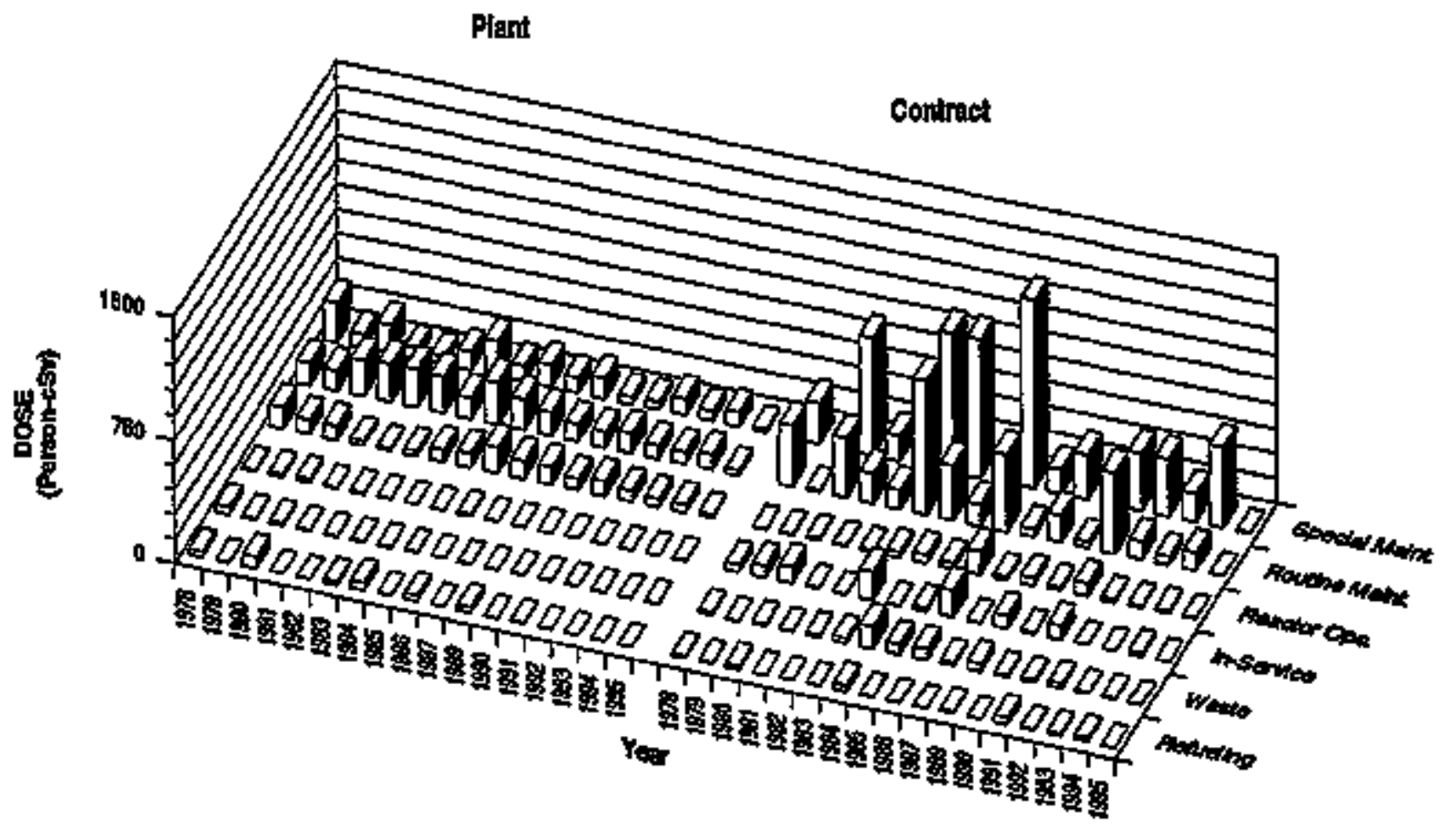




\section{APPENDIX E (continued) \\ PALISADES}

Dose-Perfomance Indicators

PWR

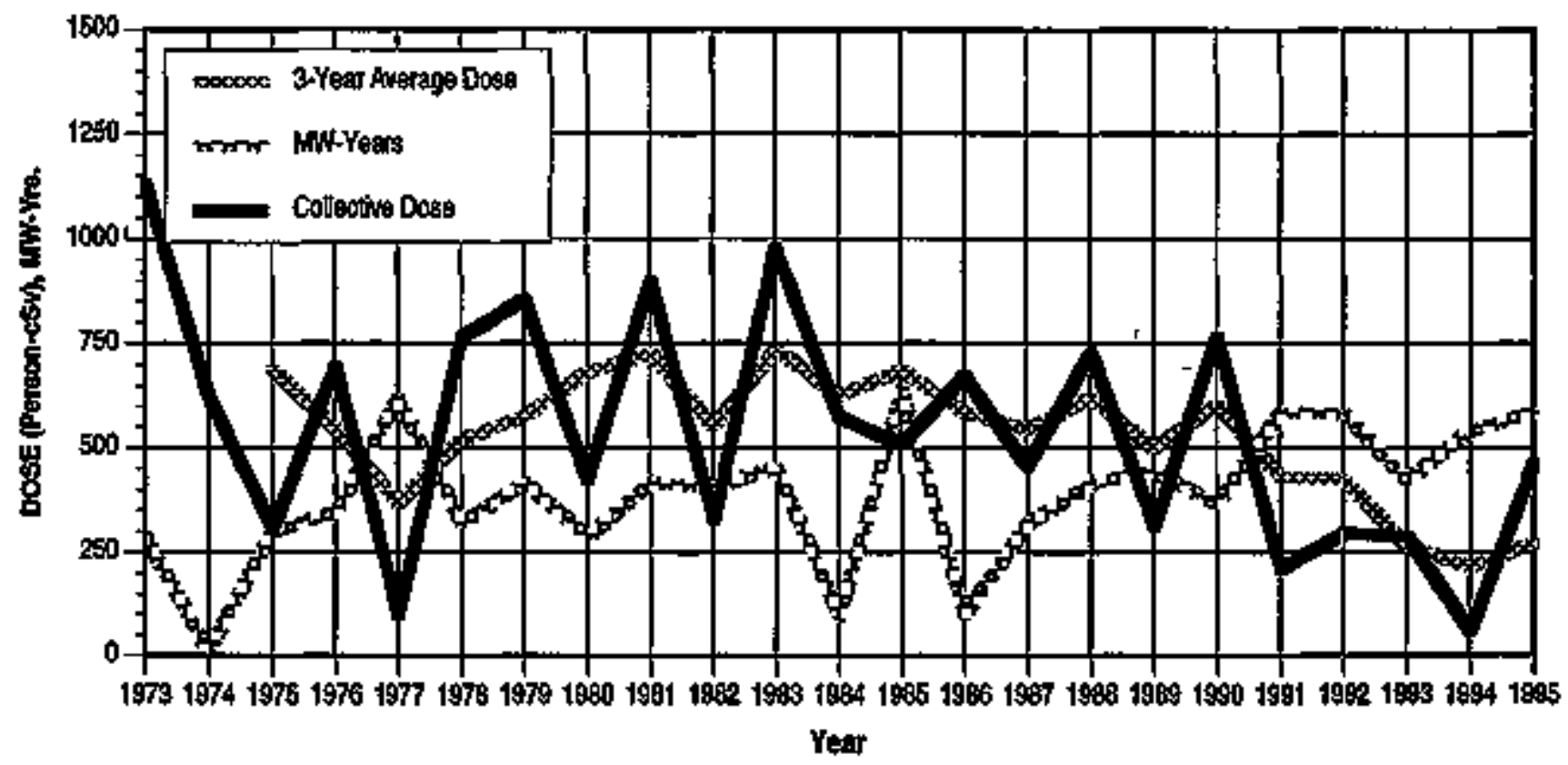

Breakdown by Job Function

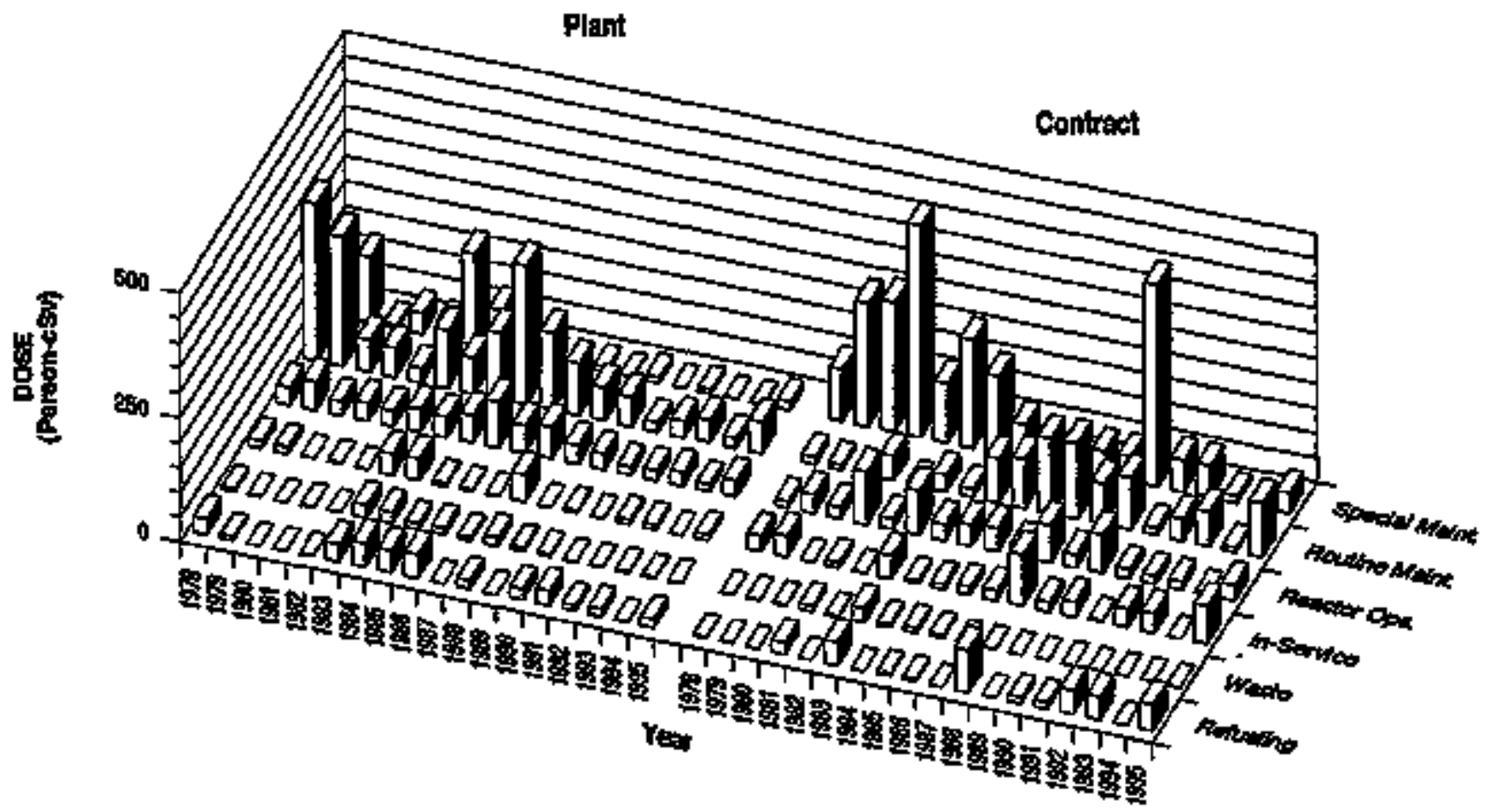

NUREG-0713 


\section{APPENDIX E (continued)}

PALO VERDE $1,2,3$

DosePariormance indlcators

PWR

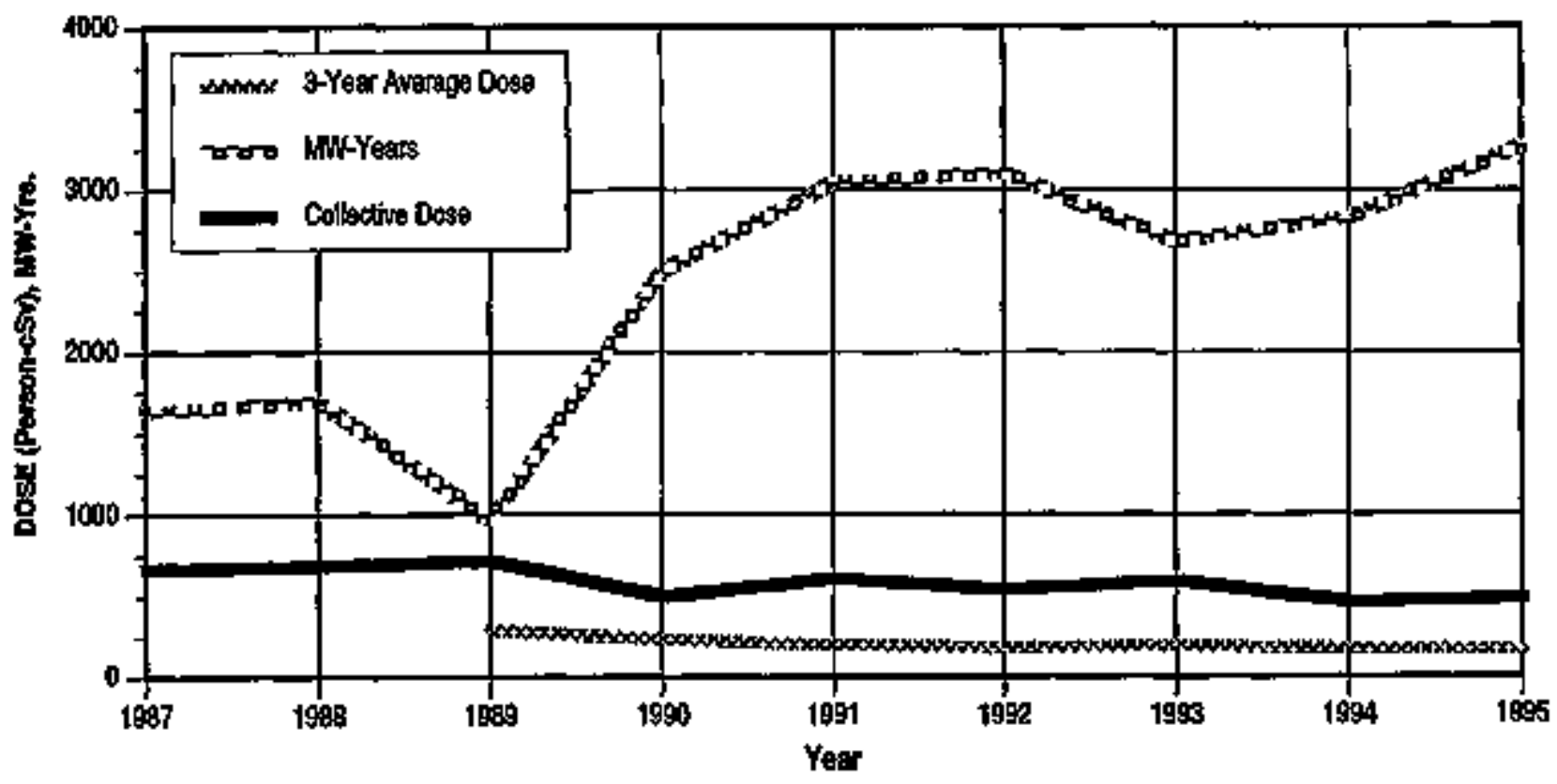

Breakdown by Jab Function

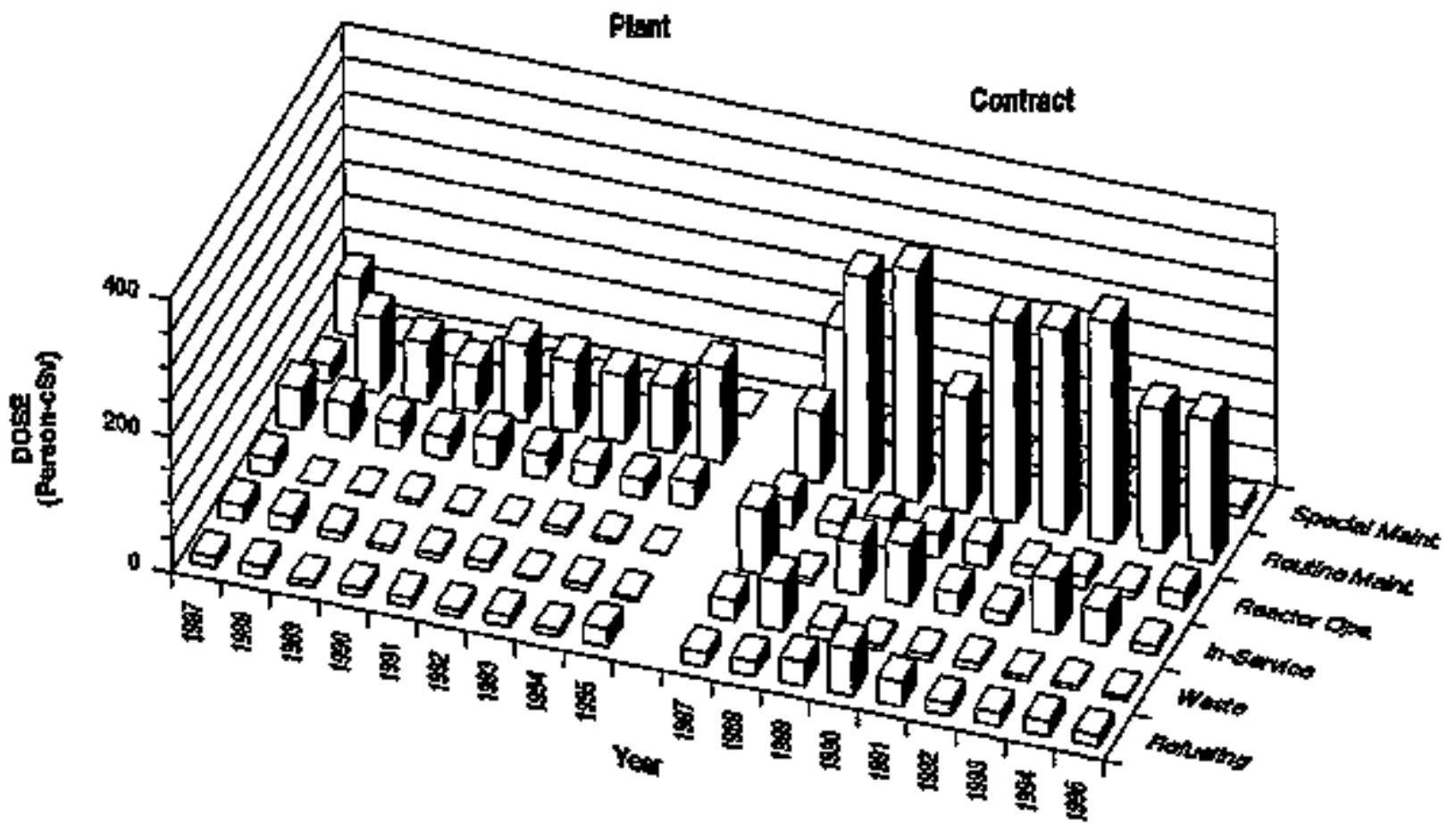




\section{APPENDDX E (continued)}

PEACH BOTTOH 2,3

Dose-Performance indicators

BWh

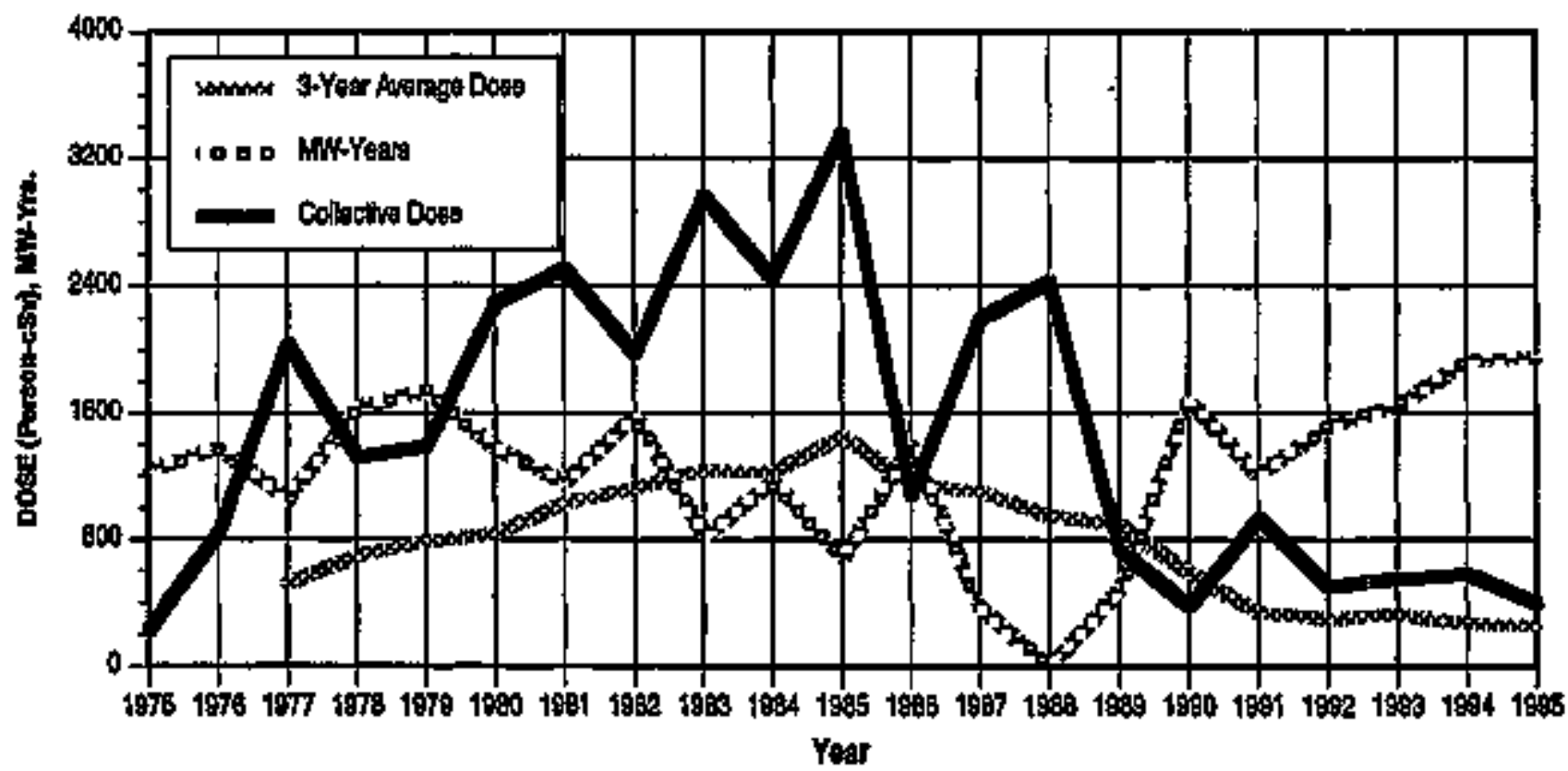

Brgakdamin by lob Funation

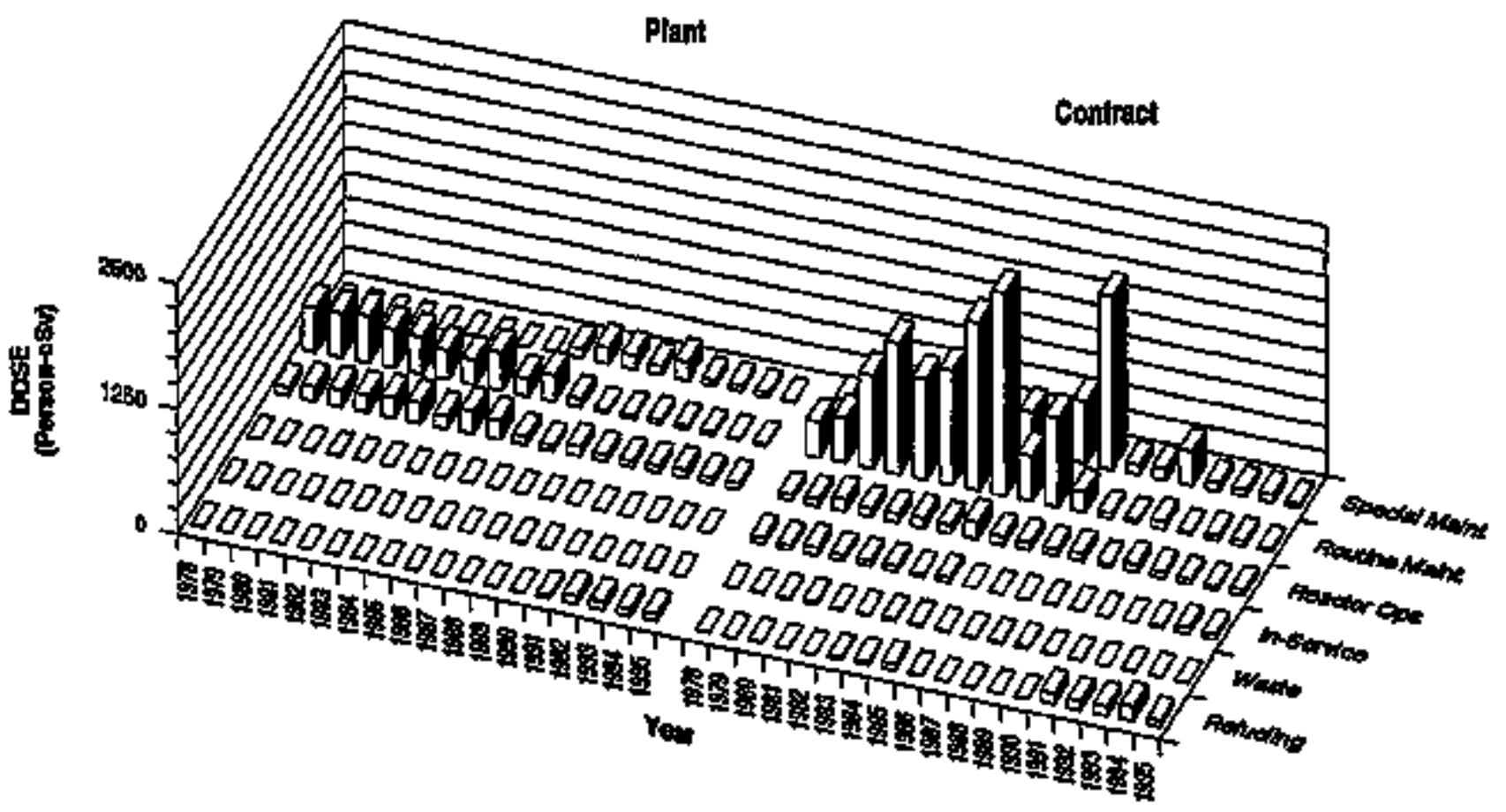


APPENDIX E (continued)

PERAY

DosepPertormance indicaloris

BWR

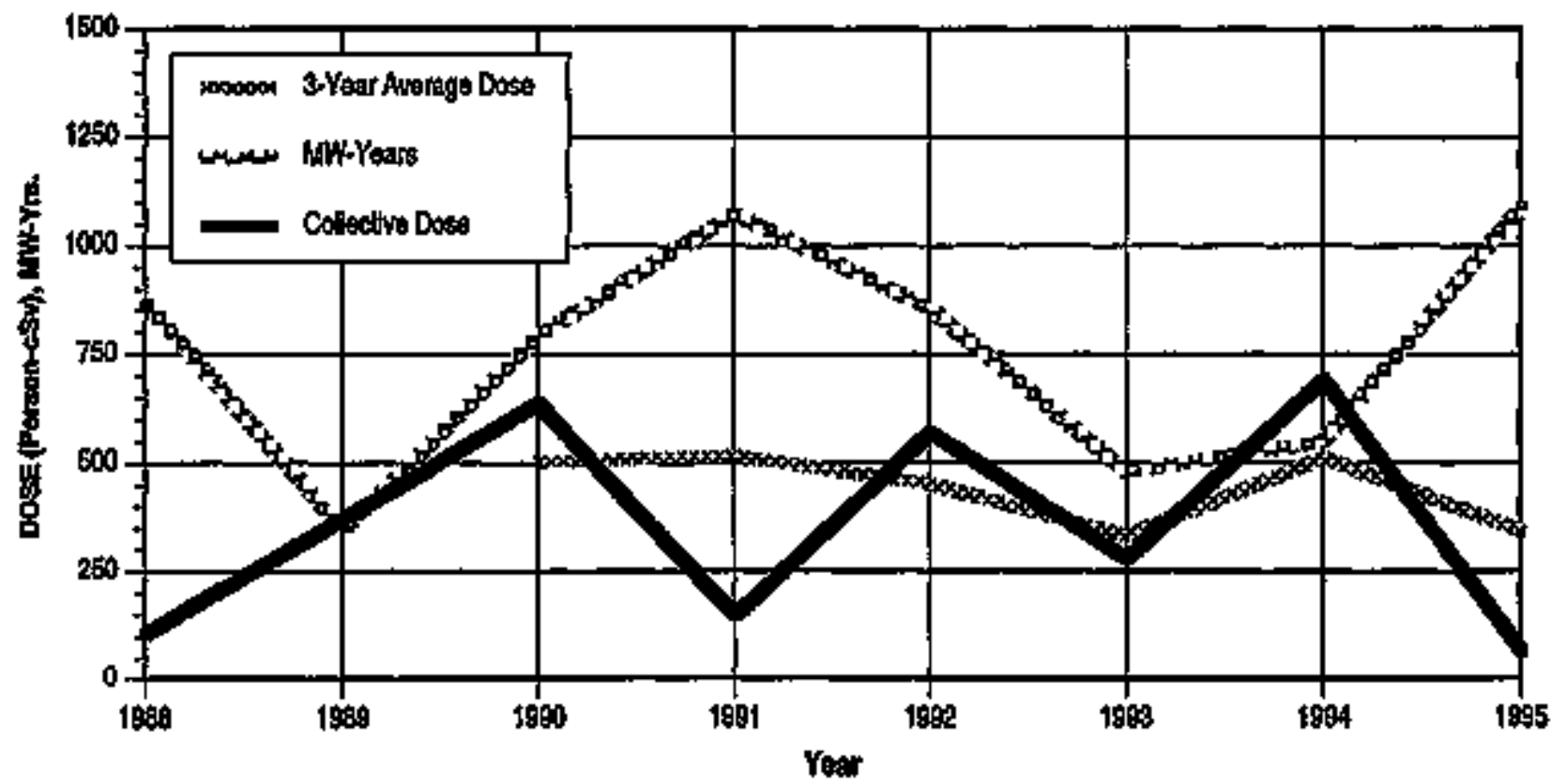

Breakdown by Job Function

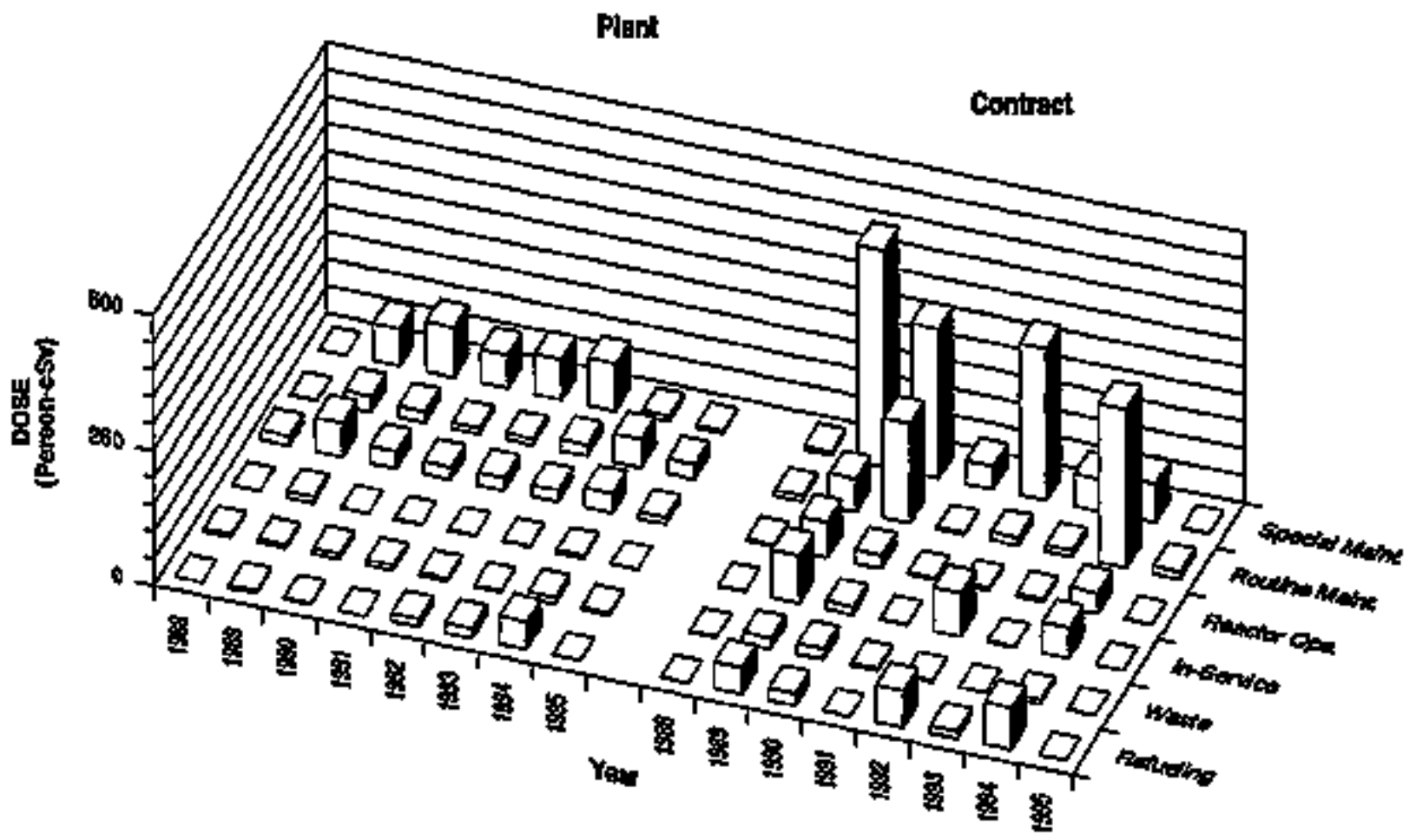




\section{APPENDXX E (continued)}

\section{PILCBili}

Dosepertomance ind calors

BWA

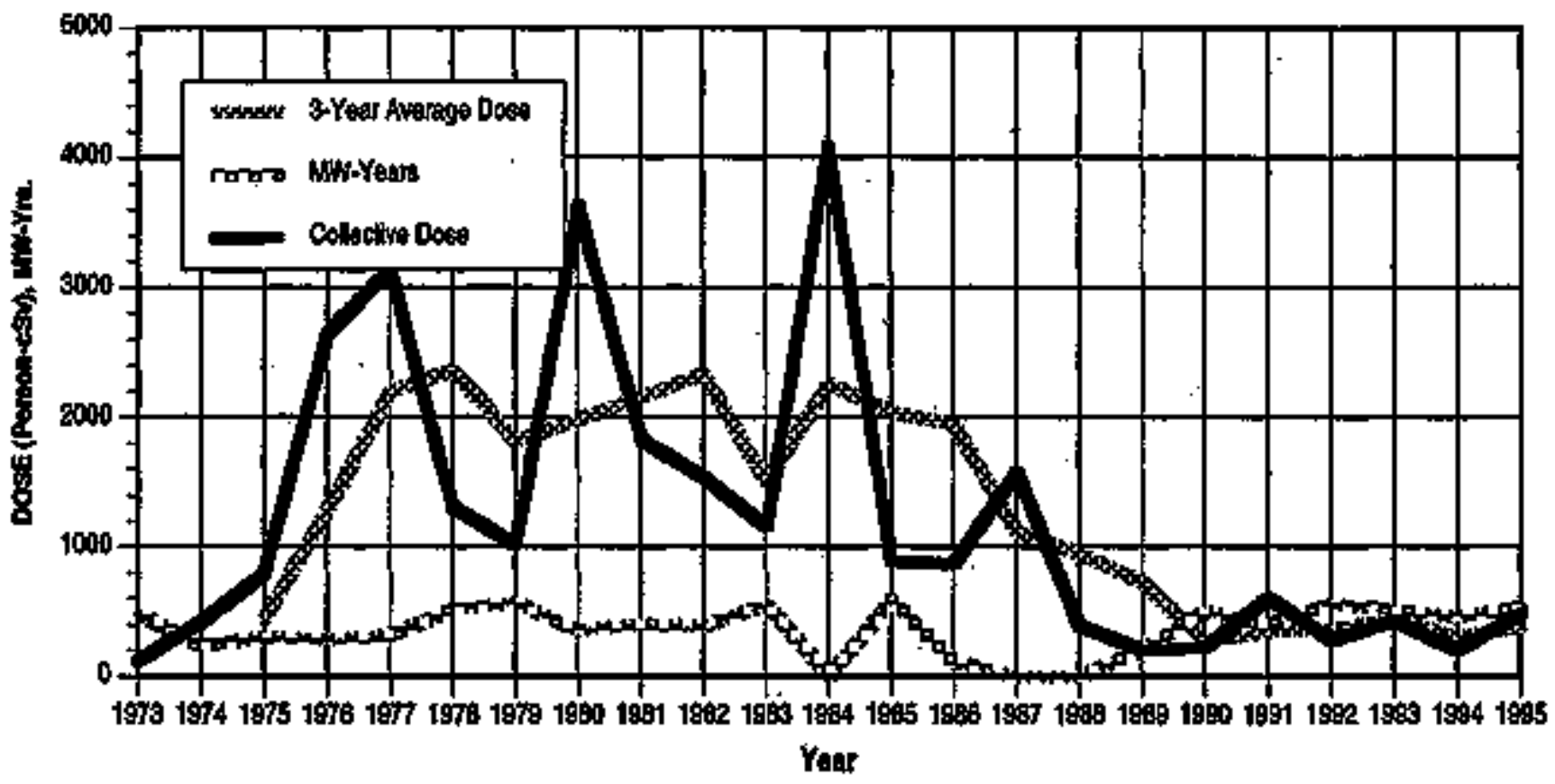

Breakdown by Job Function

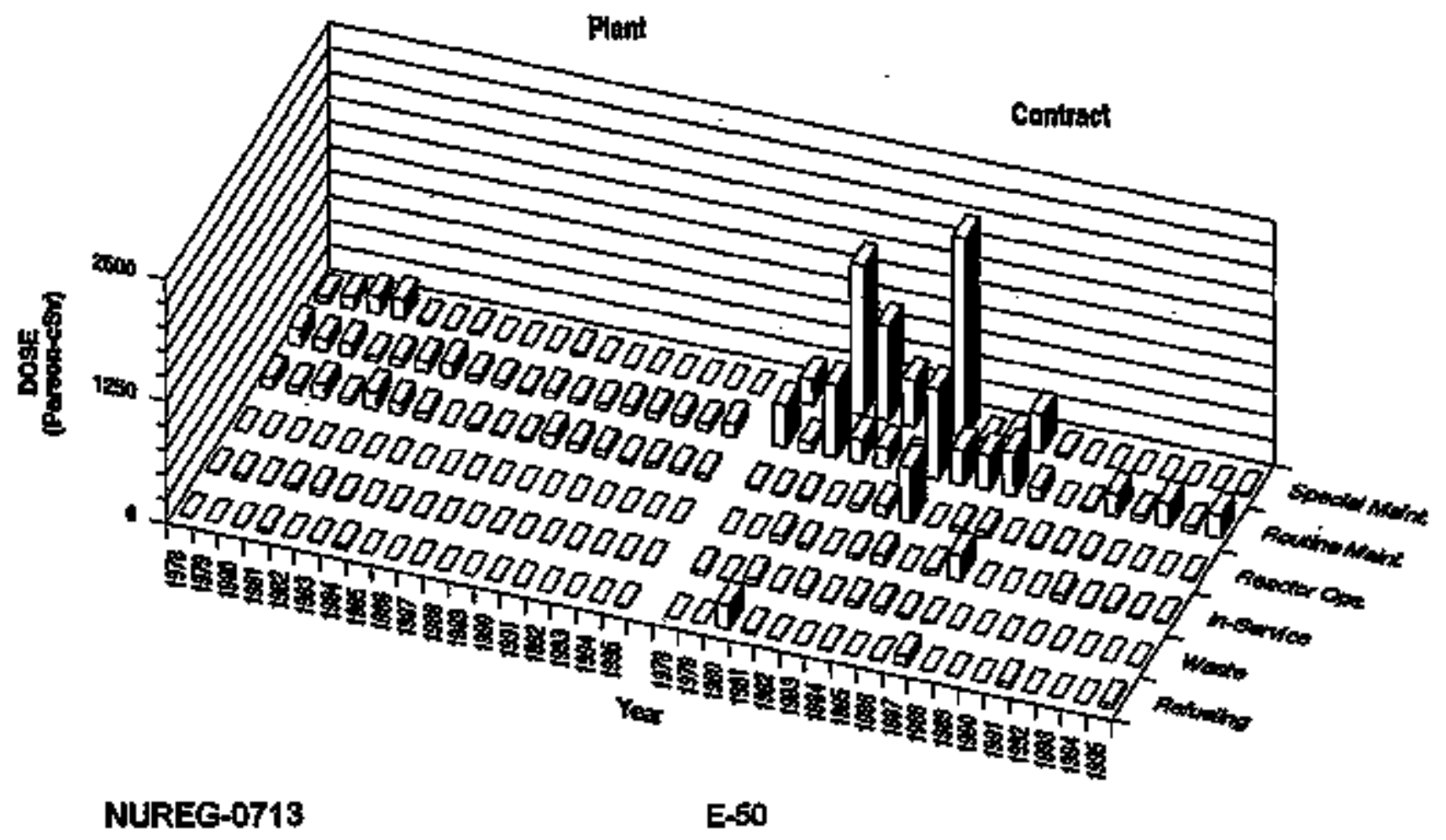




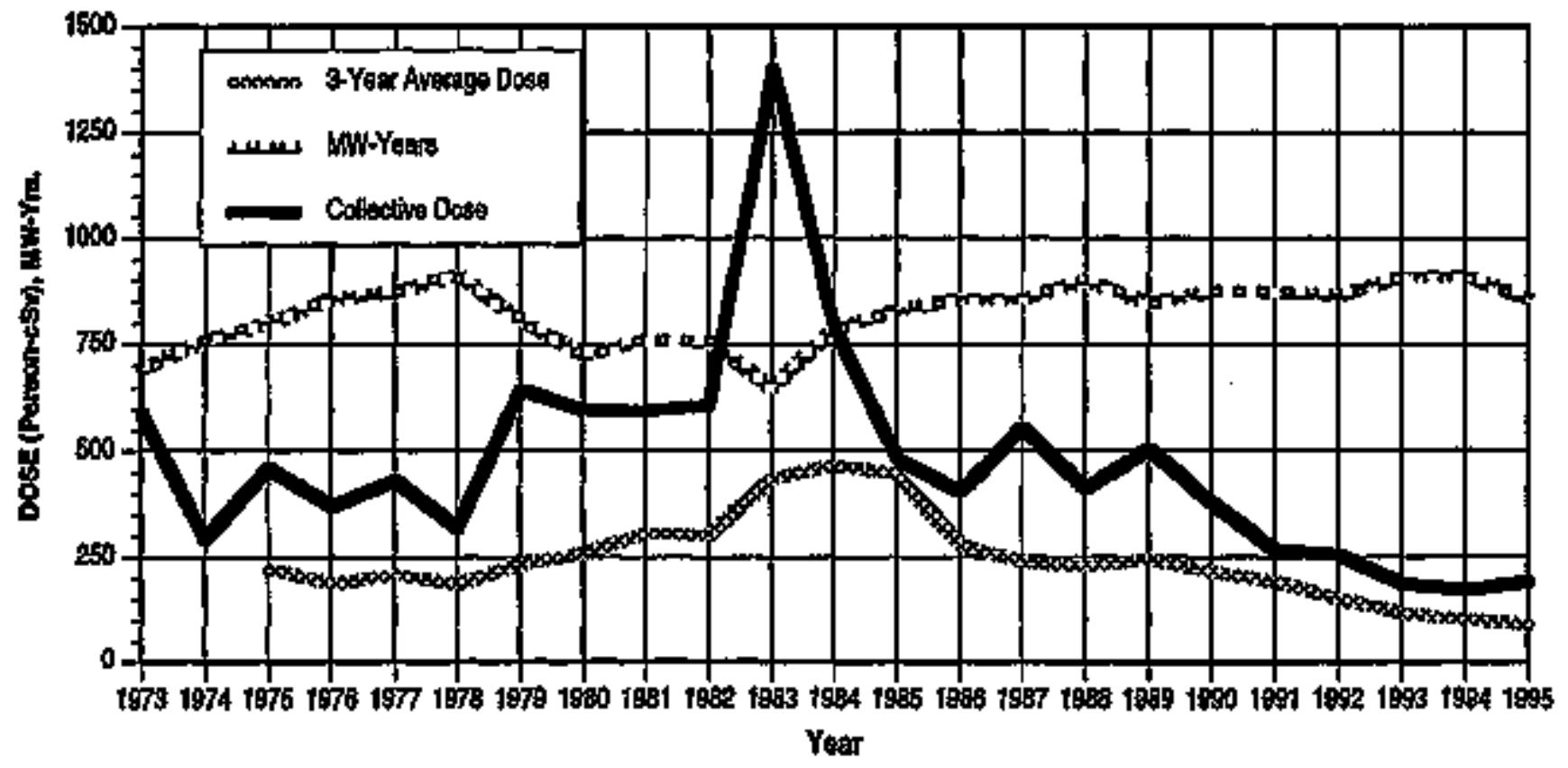

Breakdown by Job Functon

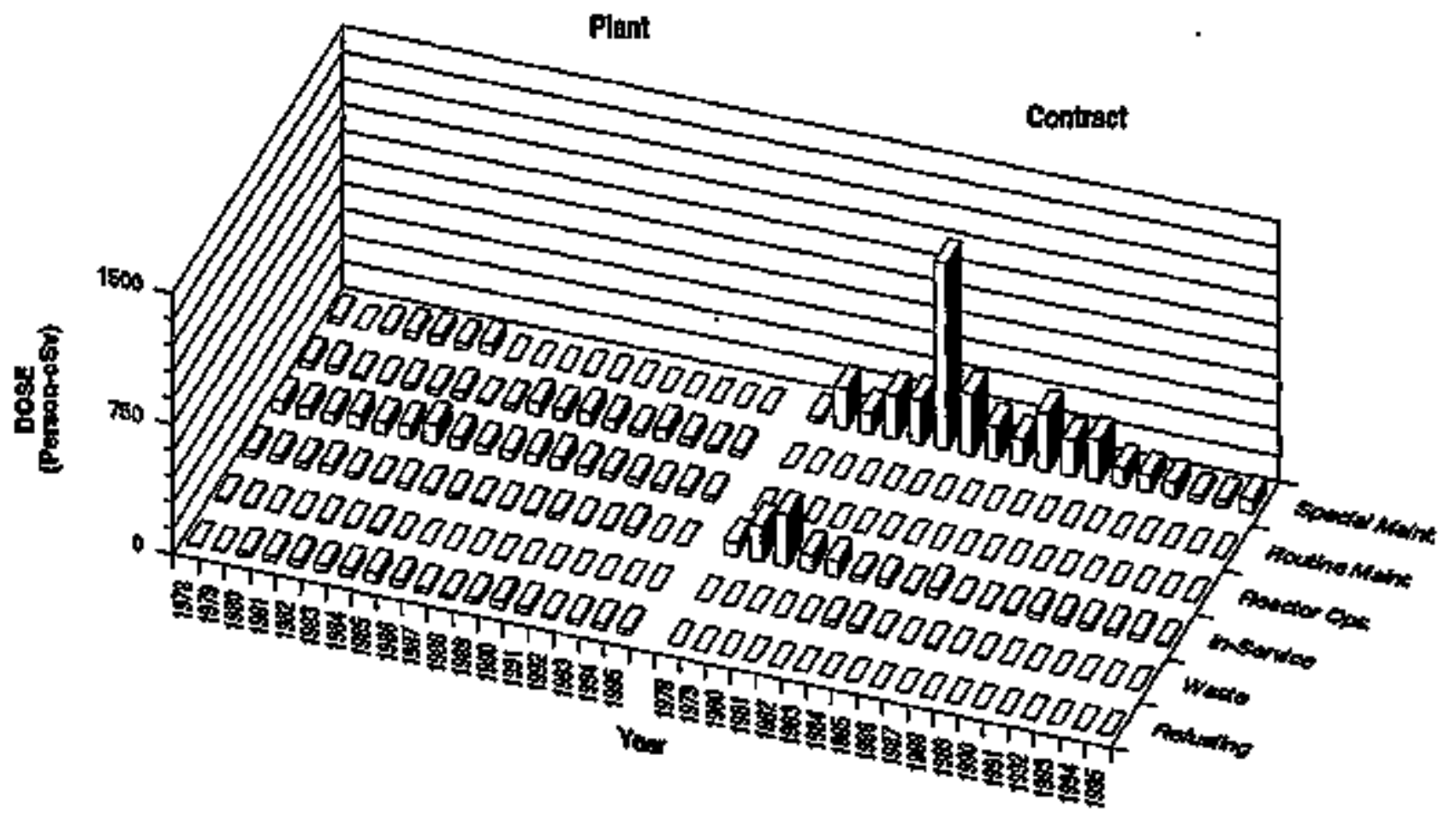


APPENDIX E (continued)

PRAIRIE ISLAND 1, 2

Dose-Perfomeance Indicators

PWR

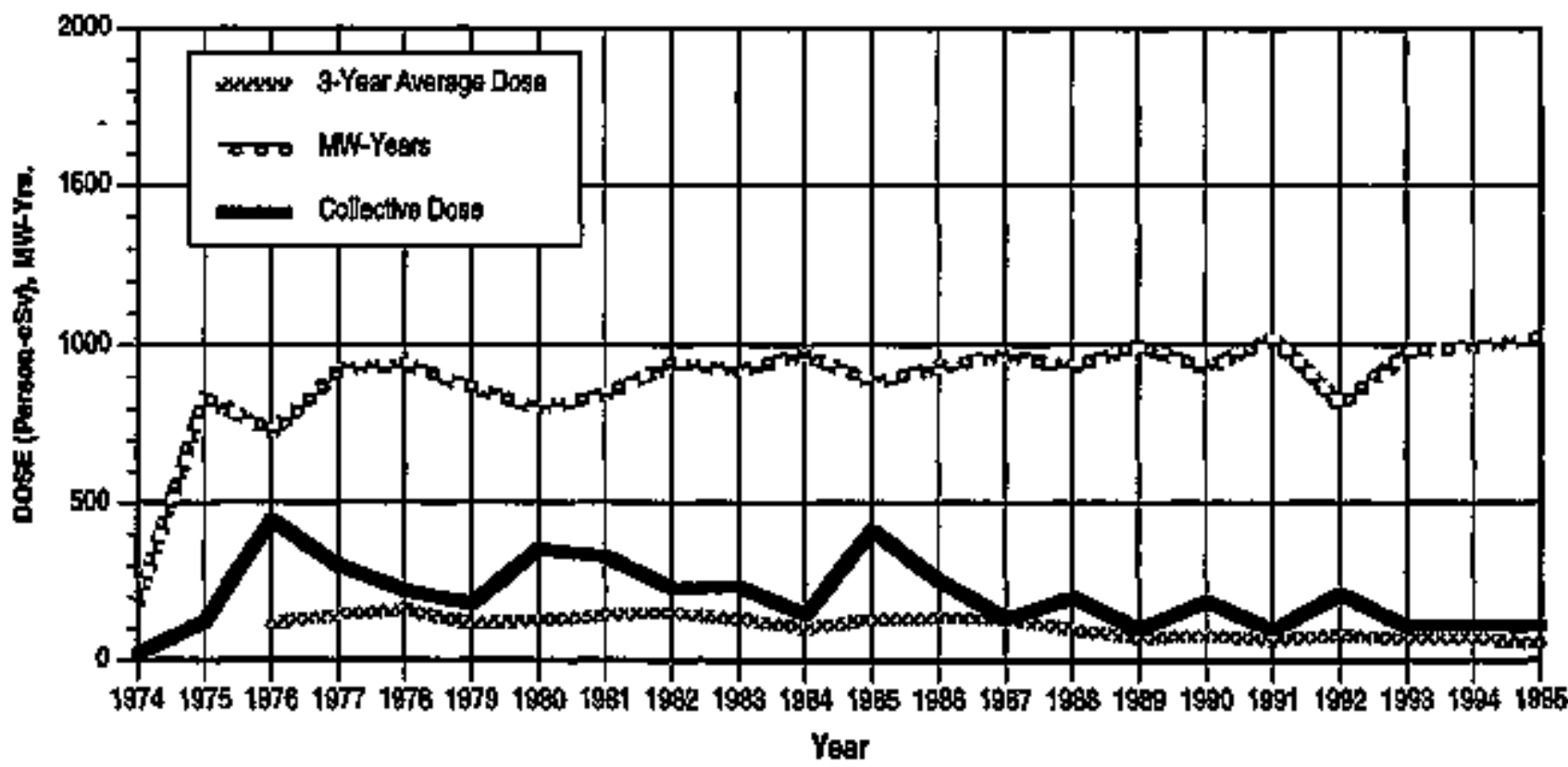

Breakdomn by Job. Funcion

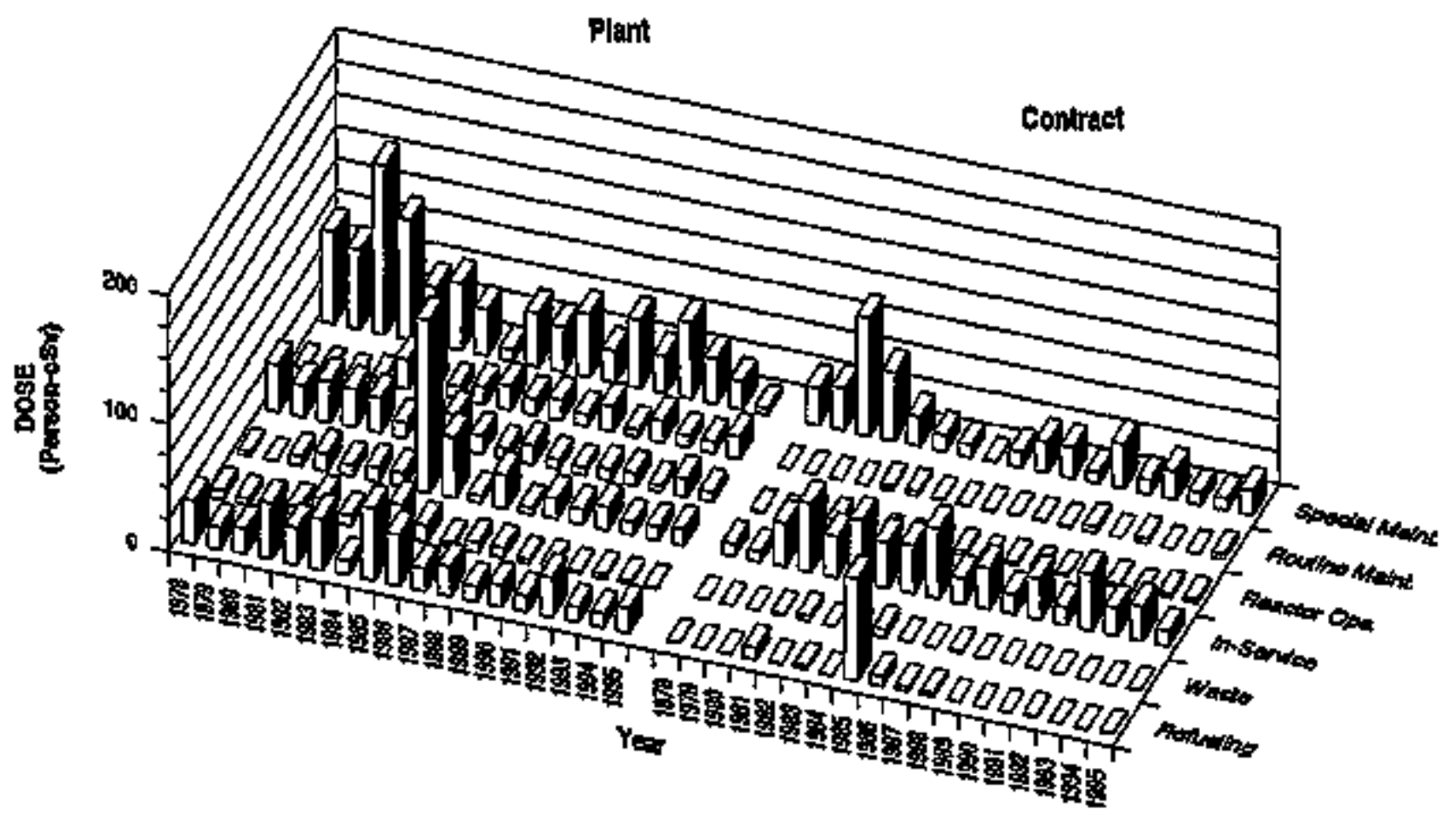


APPENDXX (continued)

OUAD CITES 1, 2

Dase-Perfomance hdieations

BWR

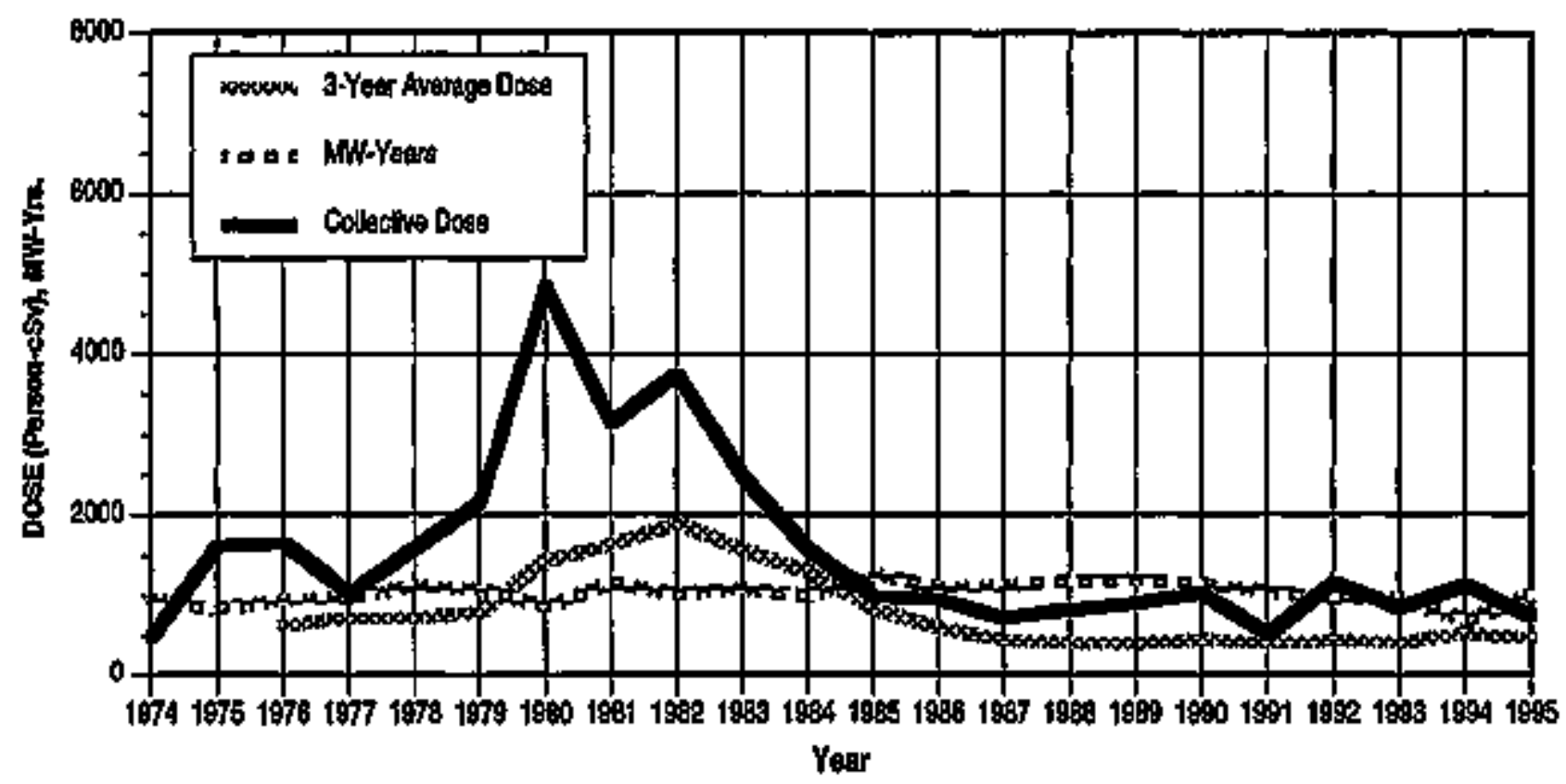

Breakdown by Job Function

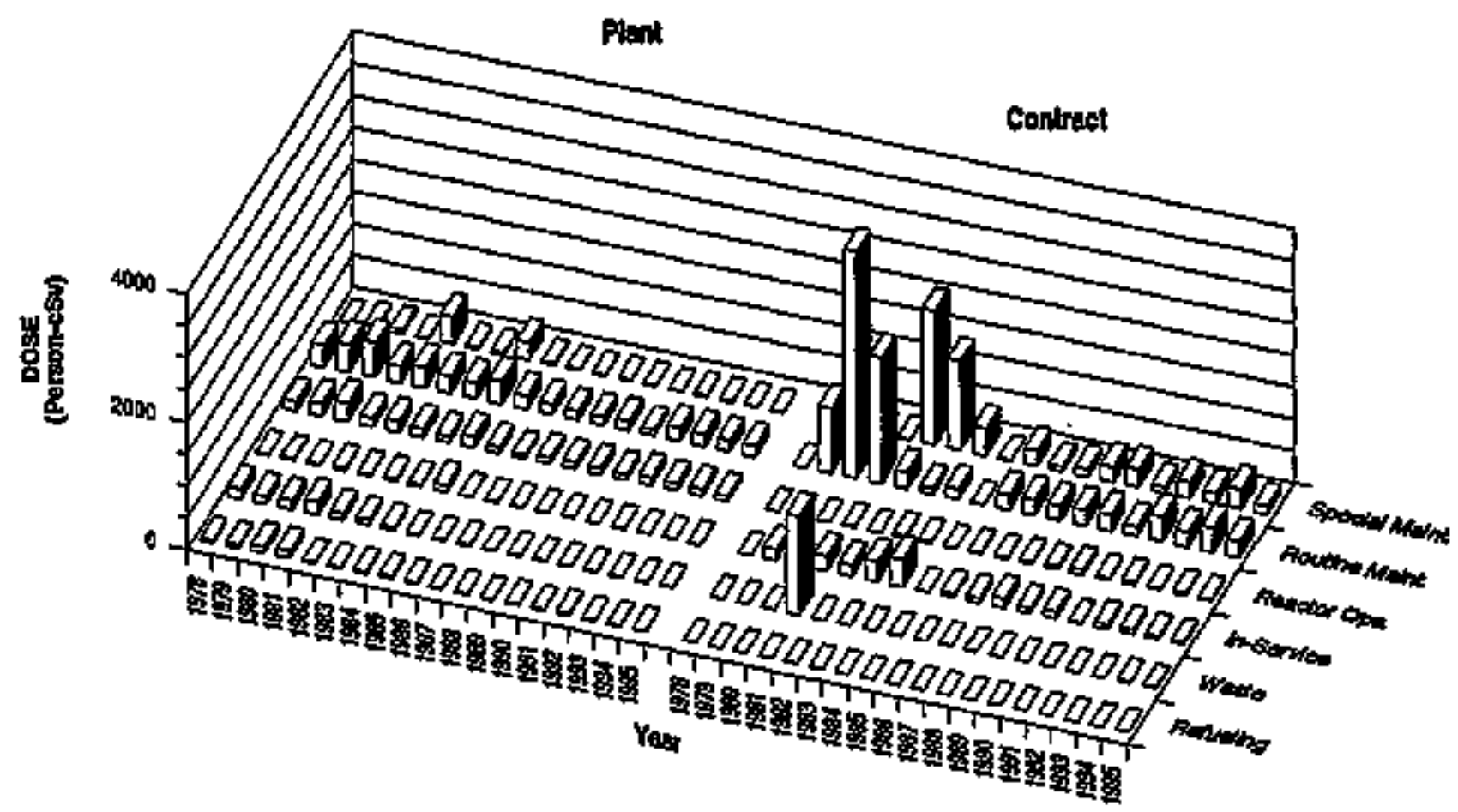


APPENDIX E (continued)

RANCHO SECO

Dose-Performance indtcalors

PWR

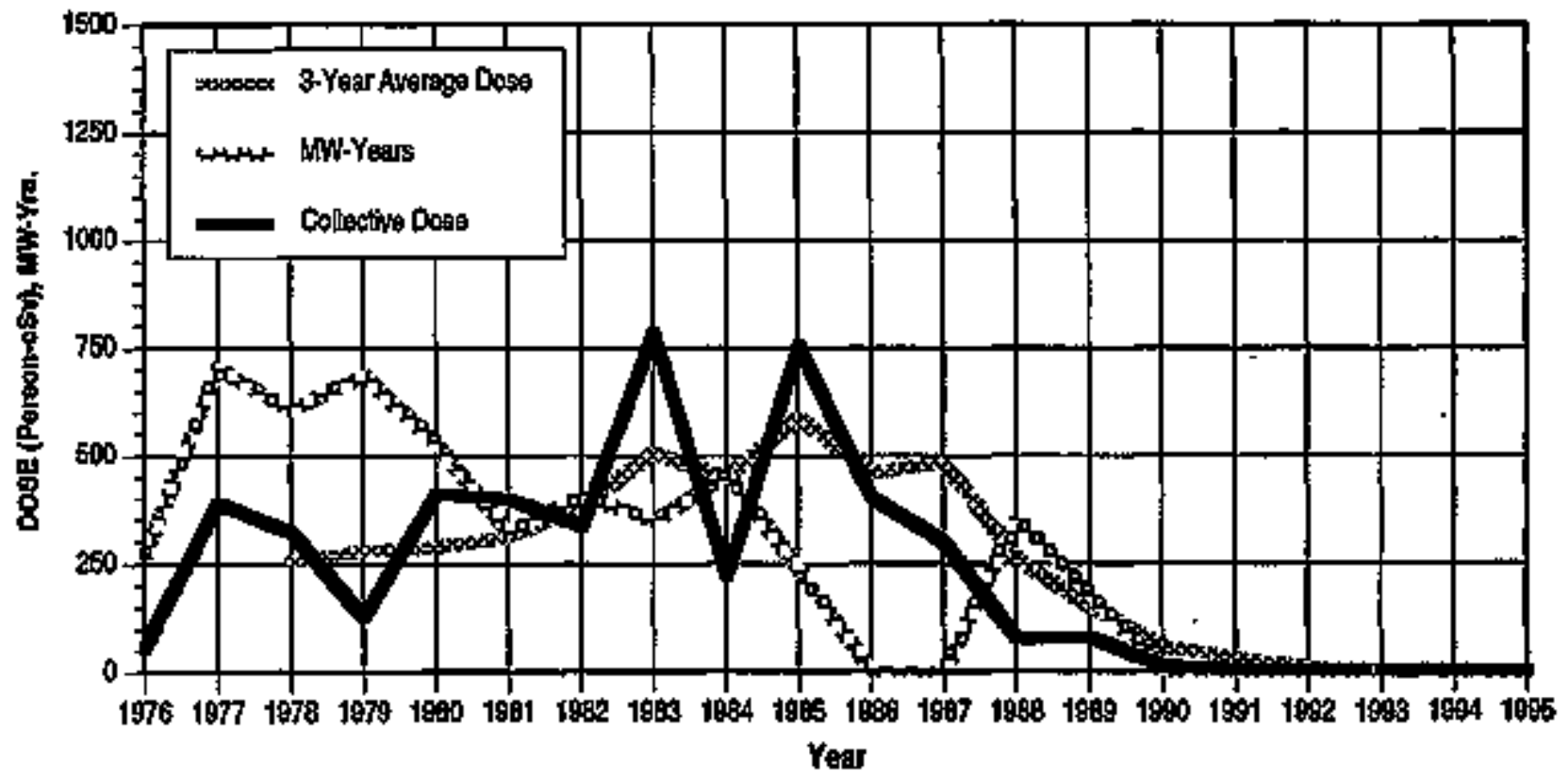

Breakdown by Job function

Plant

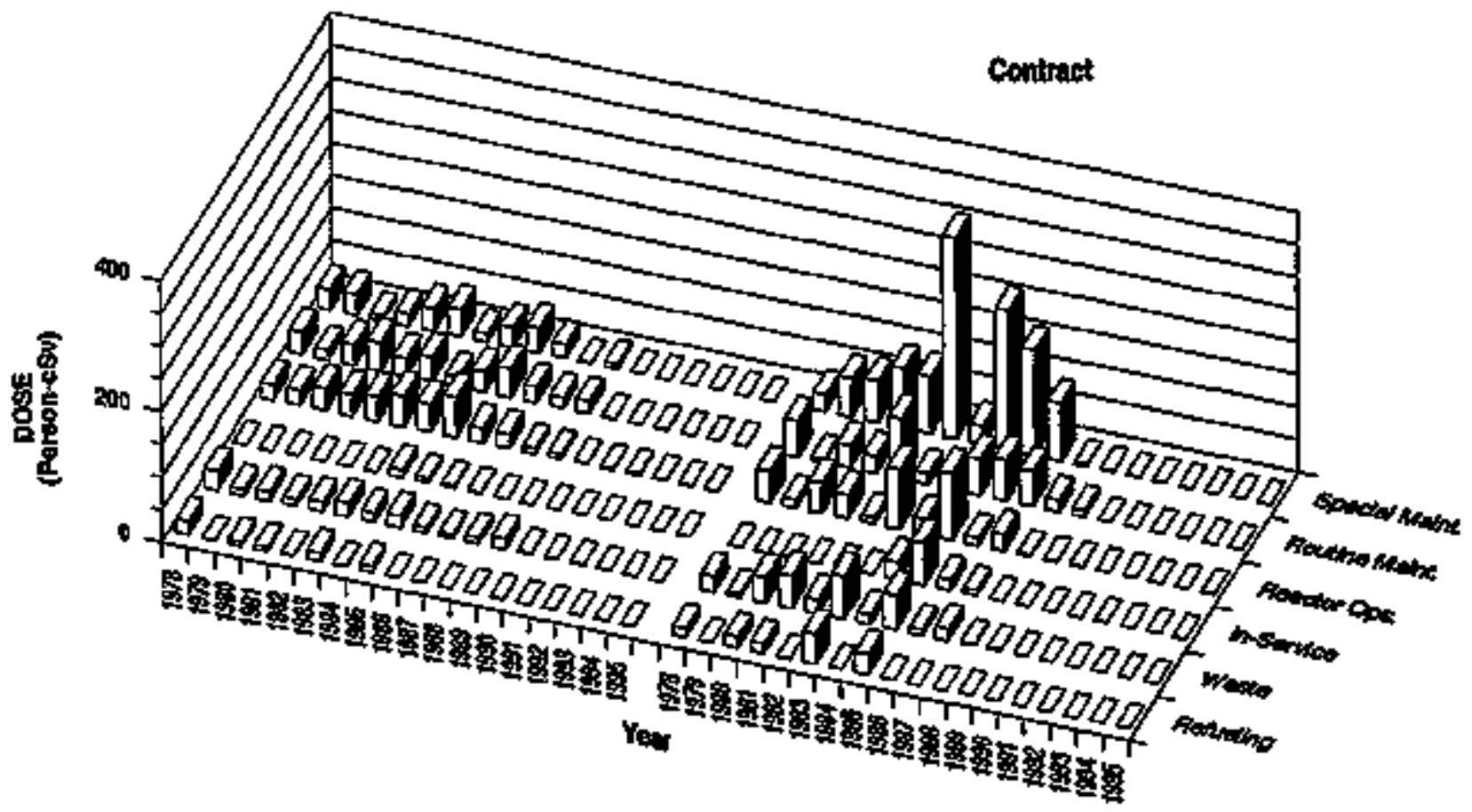

NUREG-0713 
APPENDIX E (continued)

\section{RWER BEND I}

Dose-Partomanks Indicaters

BWR

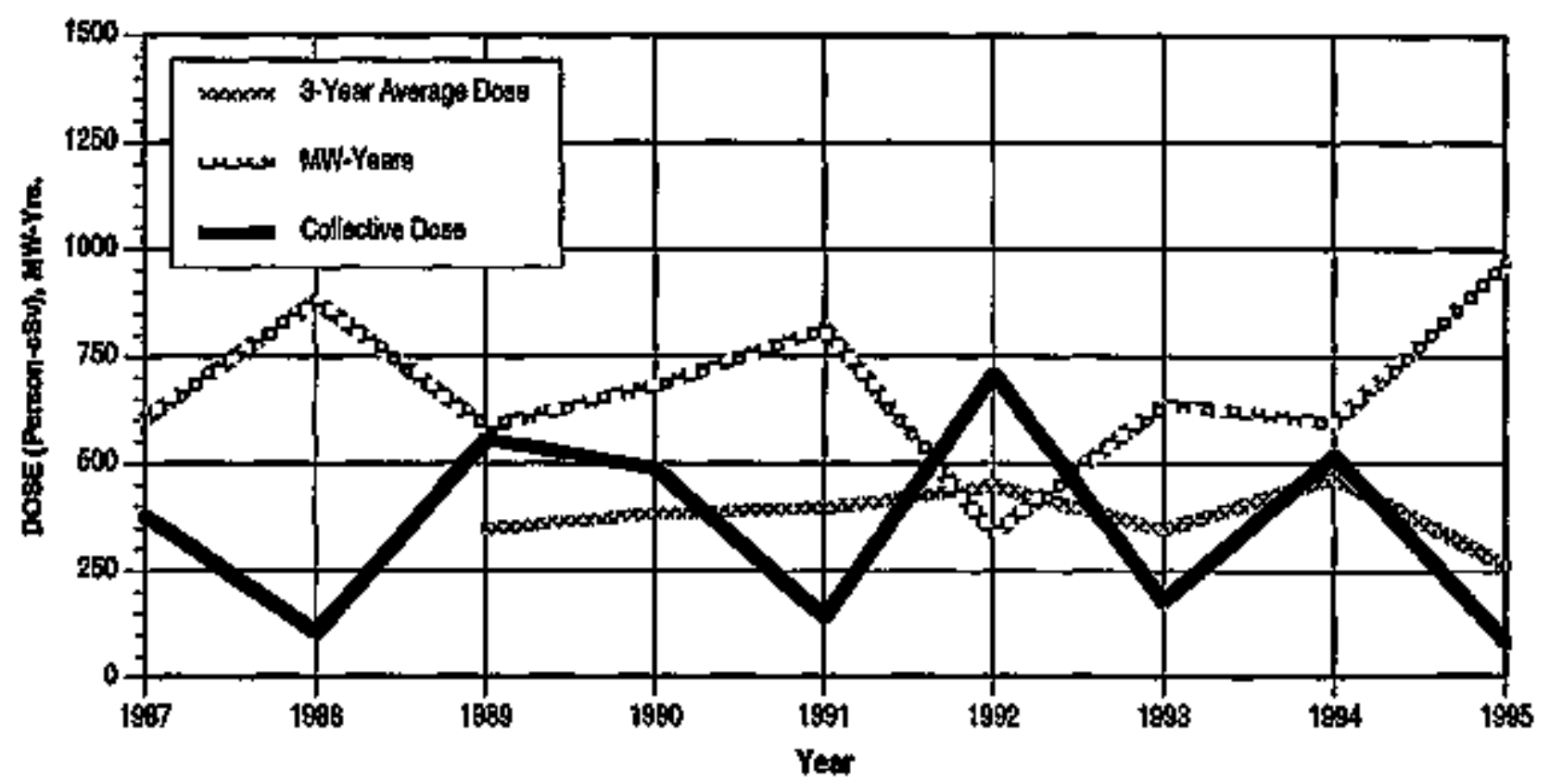

Ereakdown by Job Funclion

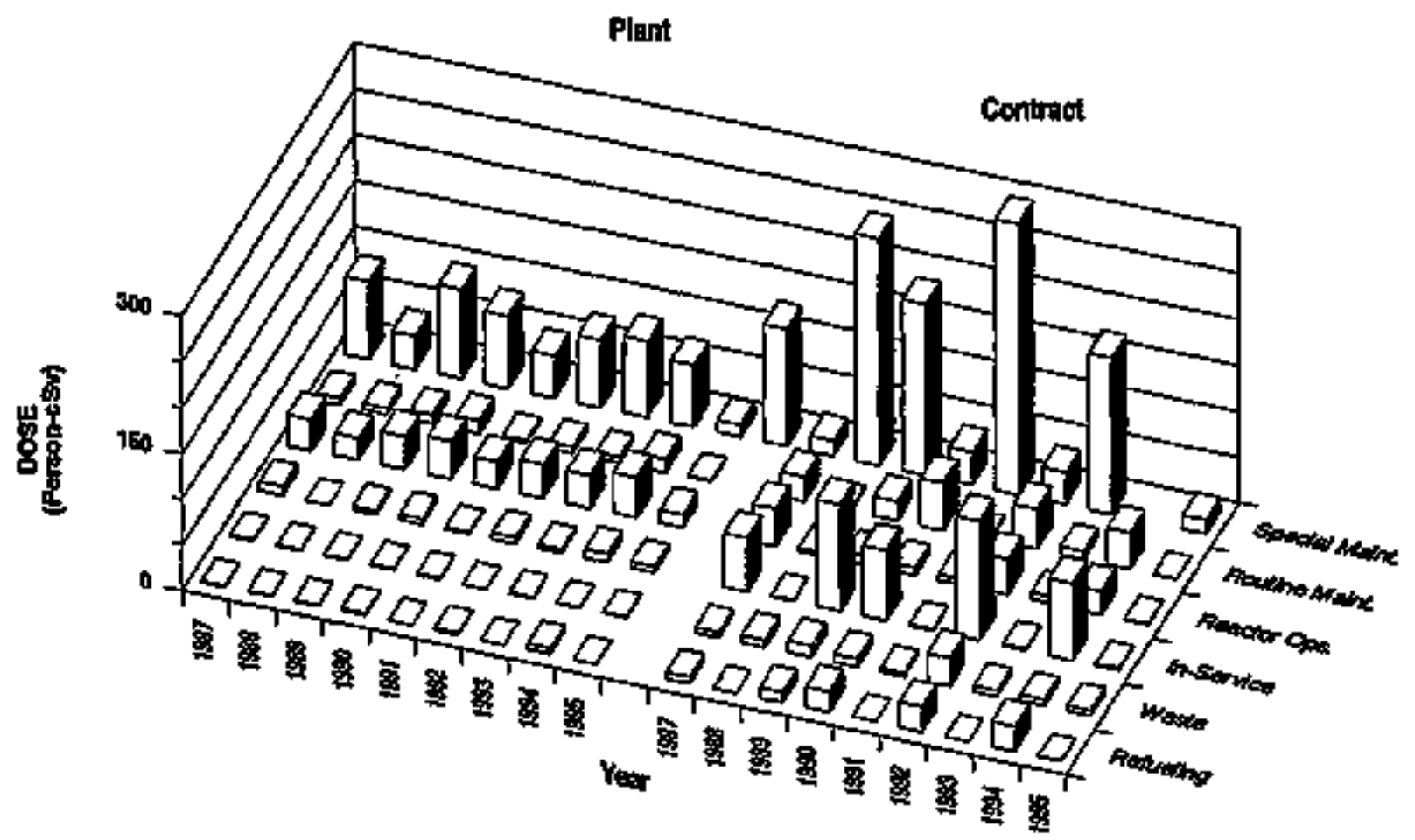


APPENDIX E (continued)

ROBINSON 2

Dose-Perfomence Incileators

PWA

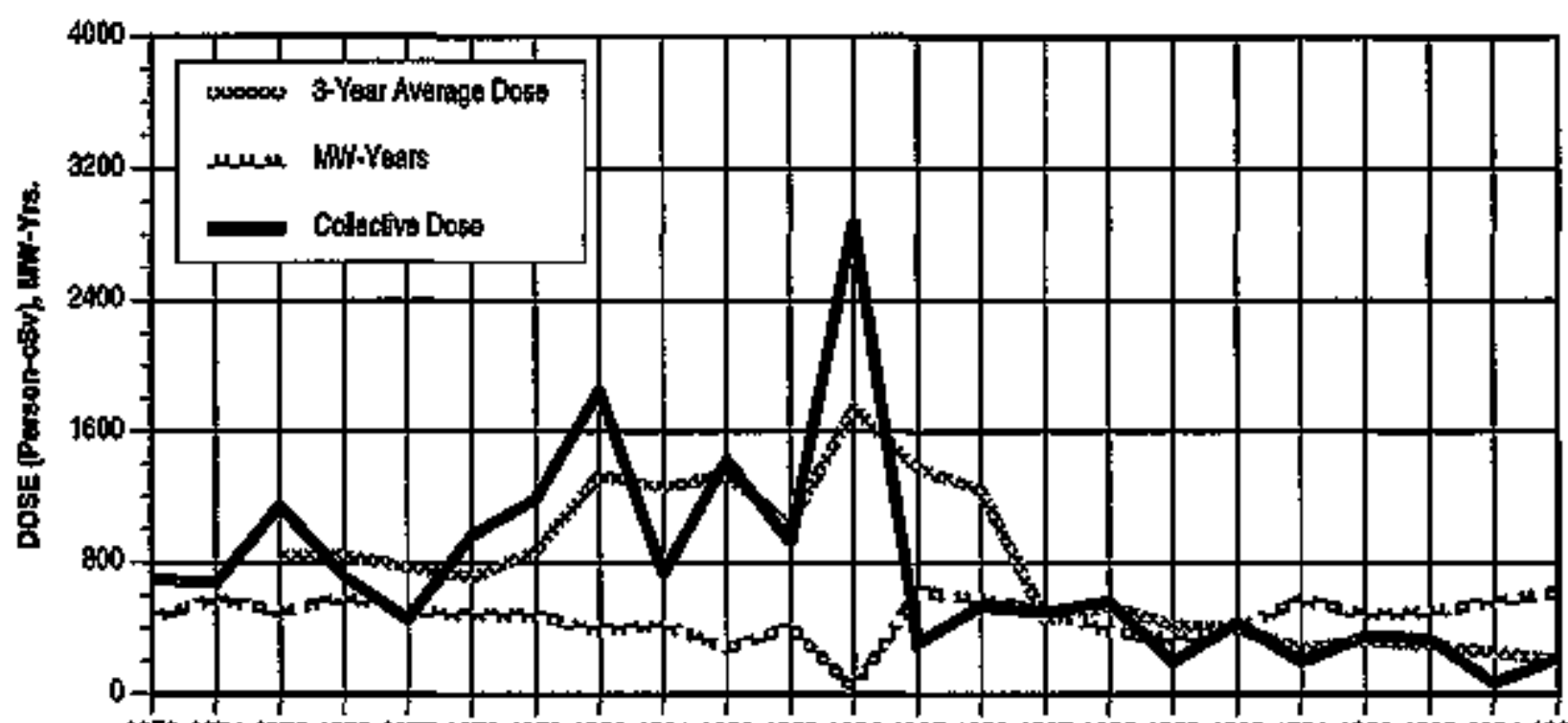

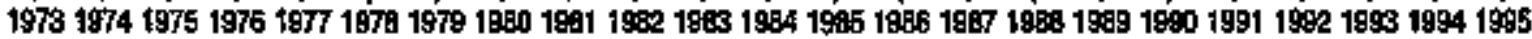
Year

Breaktiown by Job Function

PJant

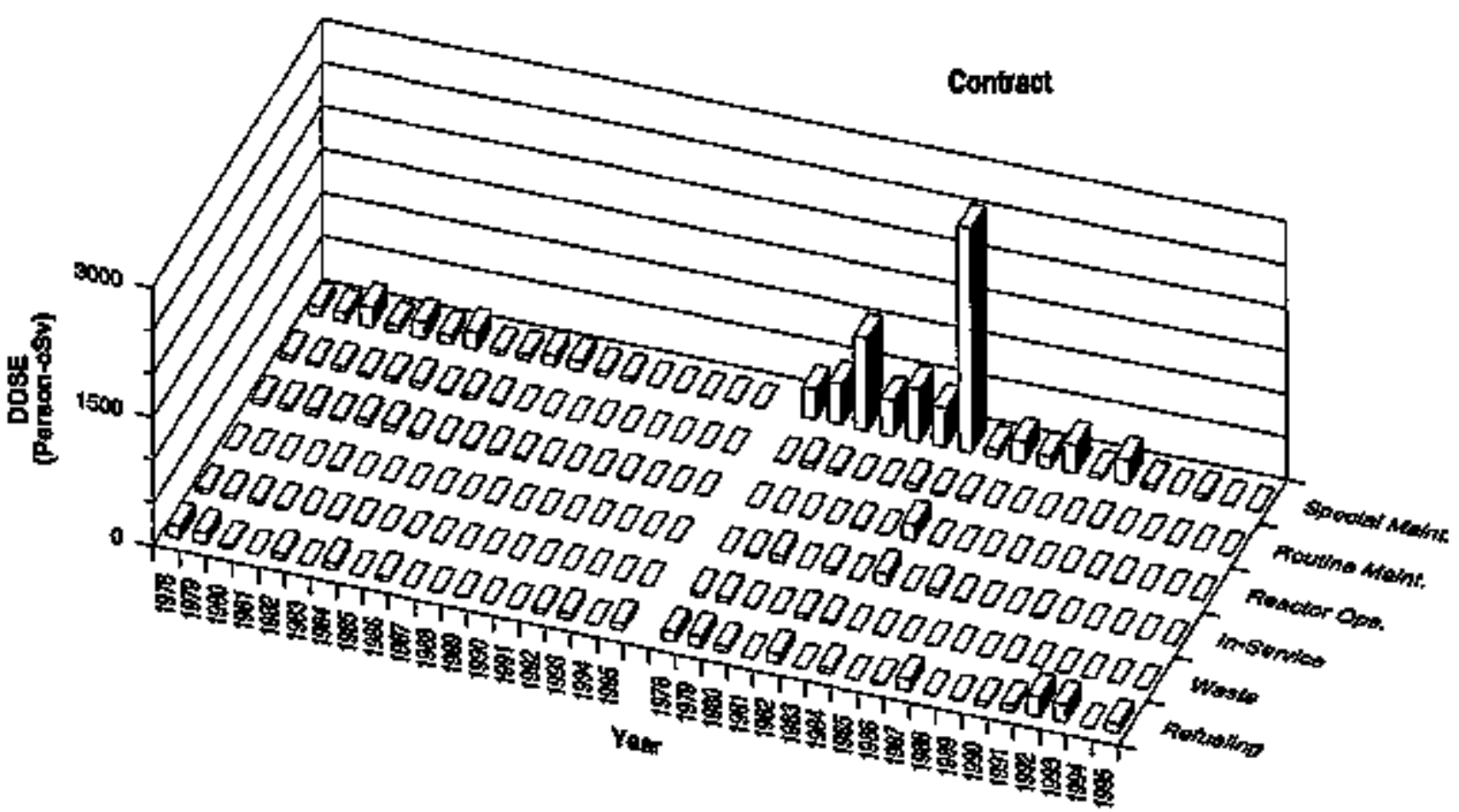


APPENDIX E (continued)

SALEM 1,2

Dose-Perfornance Indtifators

PWR

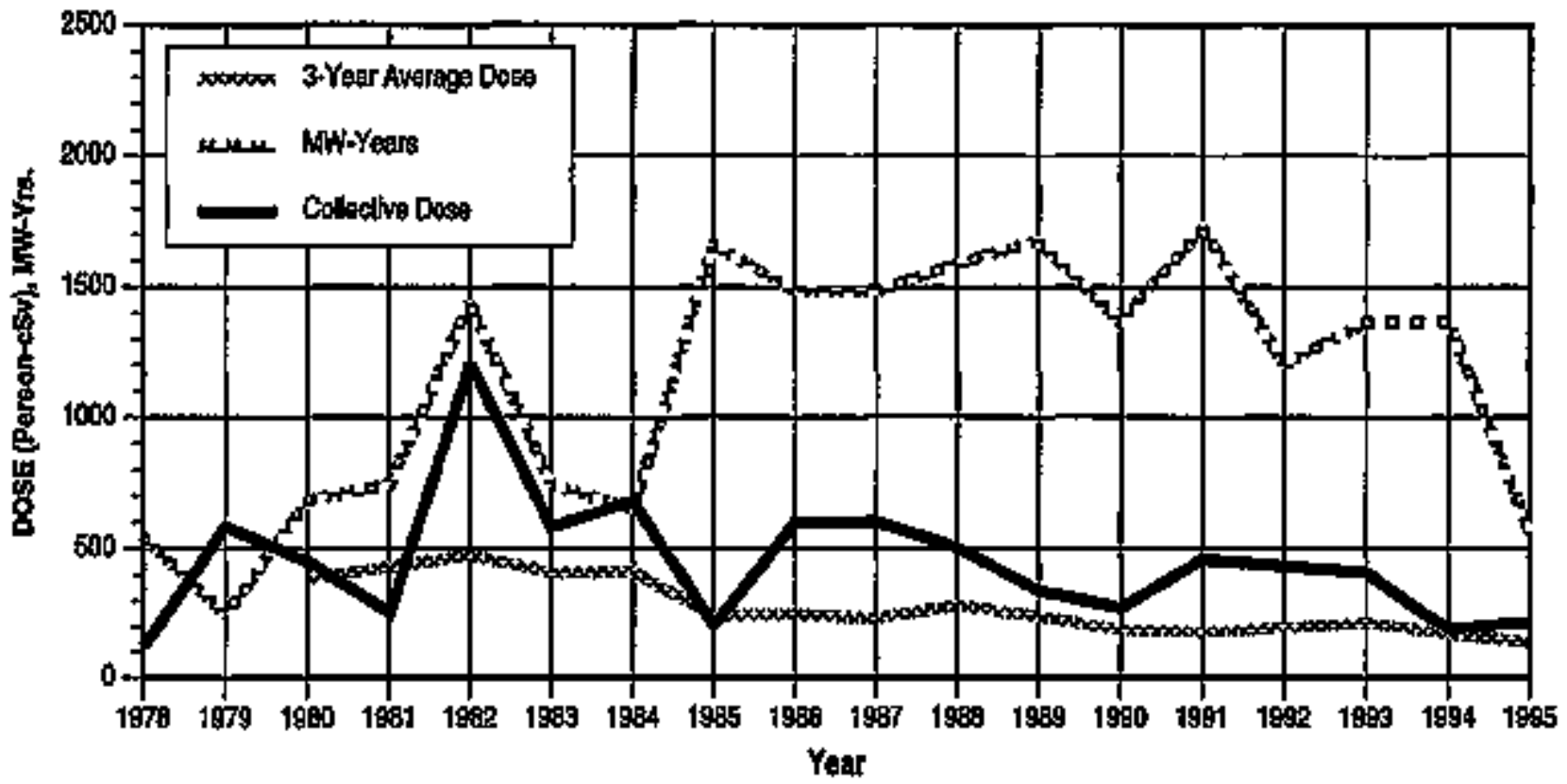

Breakdown by Job Function

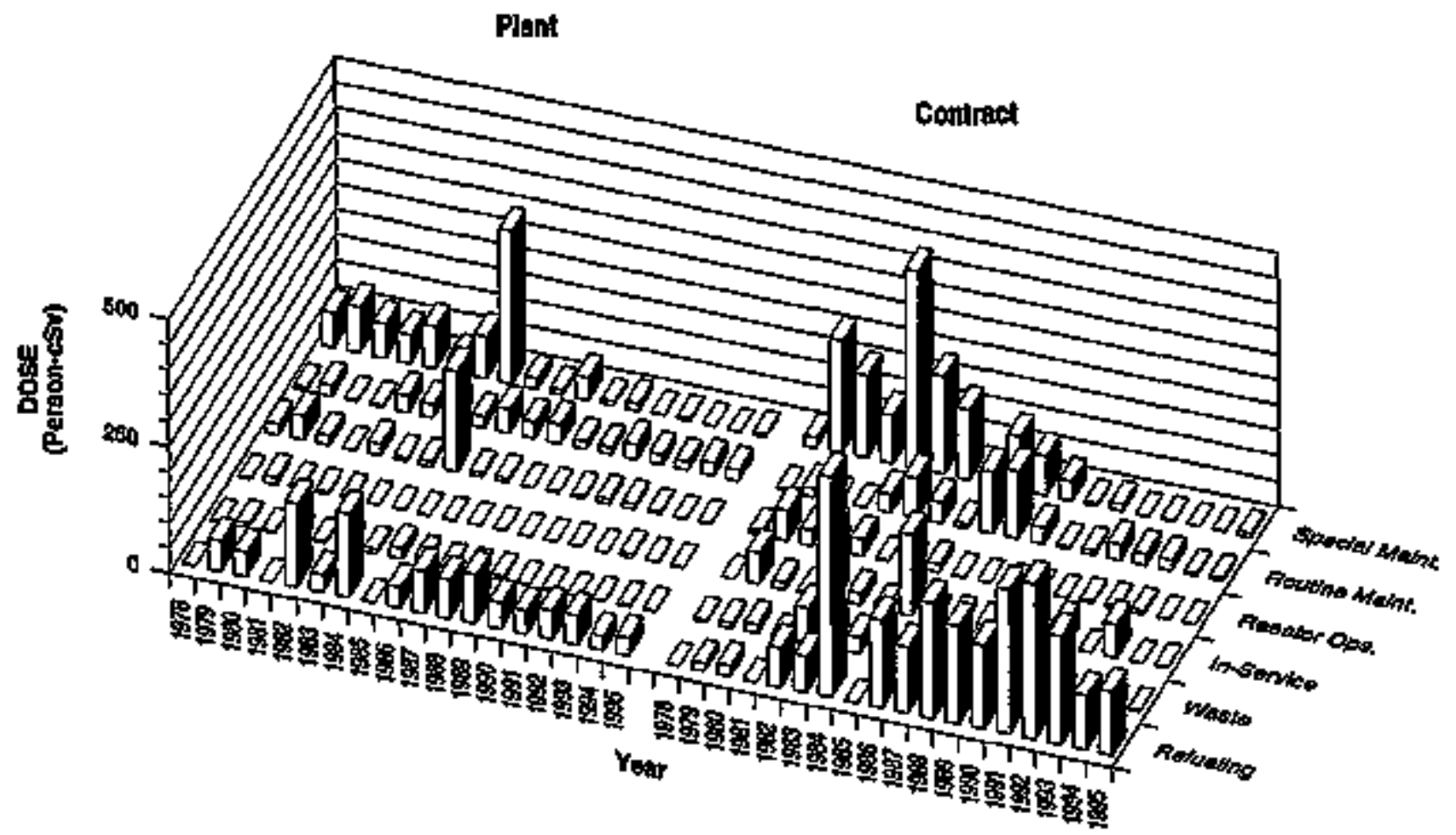




\section{APPENDIX E (continued)}

SAN OHOFAE 1, 2,3

Dose-Periormance indicators

PWR

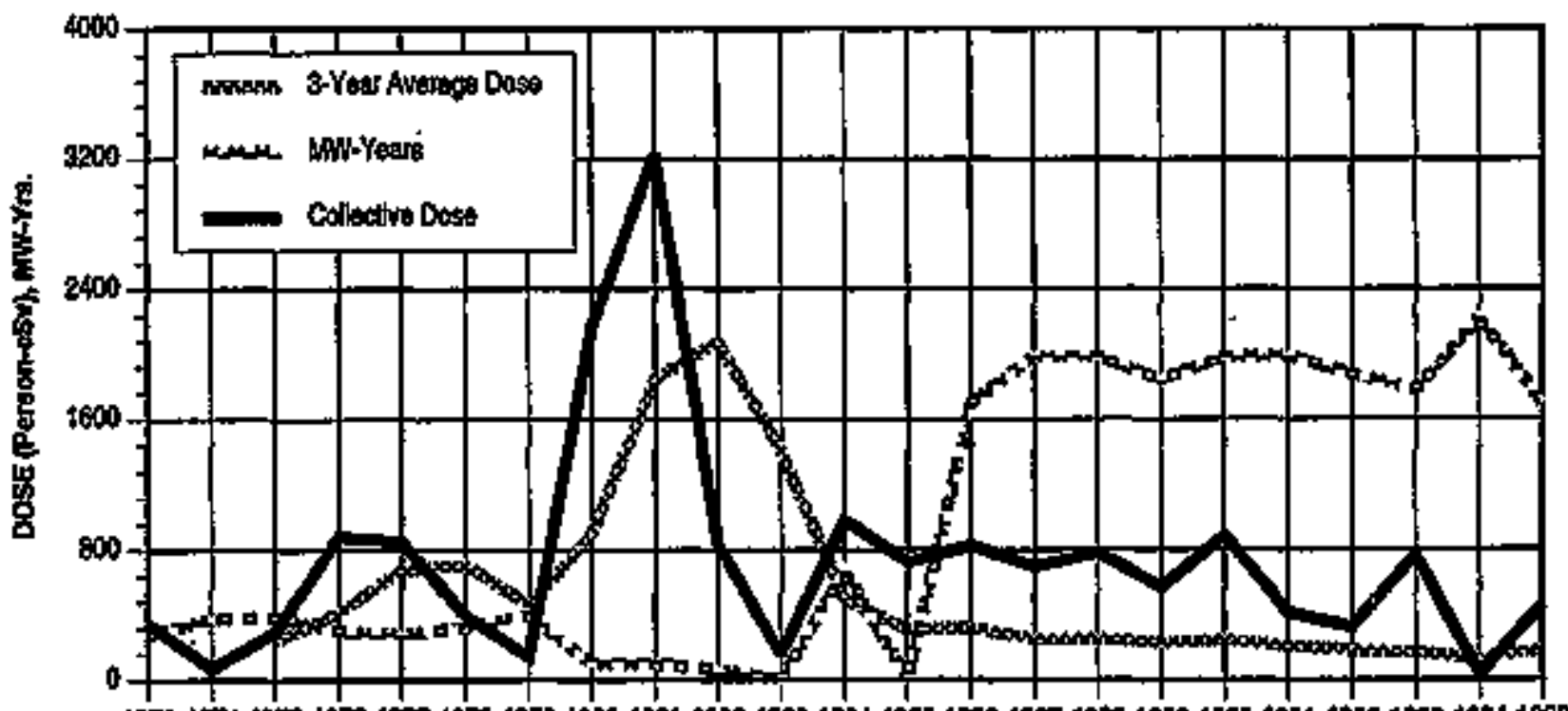

Yecr

Breakciomn ty Job Furetion

Plant

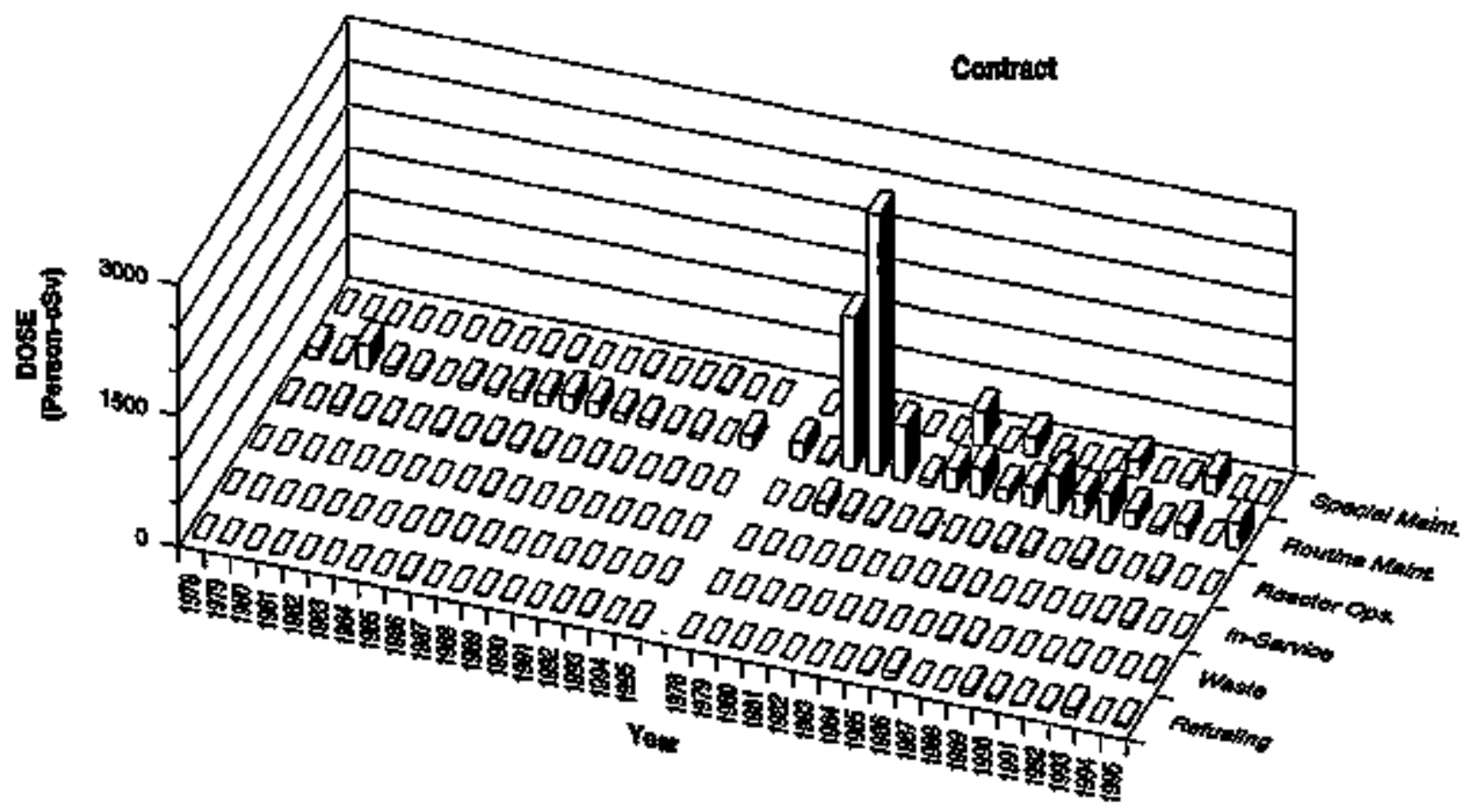




\section{APPENDIX E (continued)}

\section{SEABROOK}

DosaPefformance ind [ealors

PWA

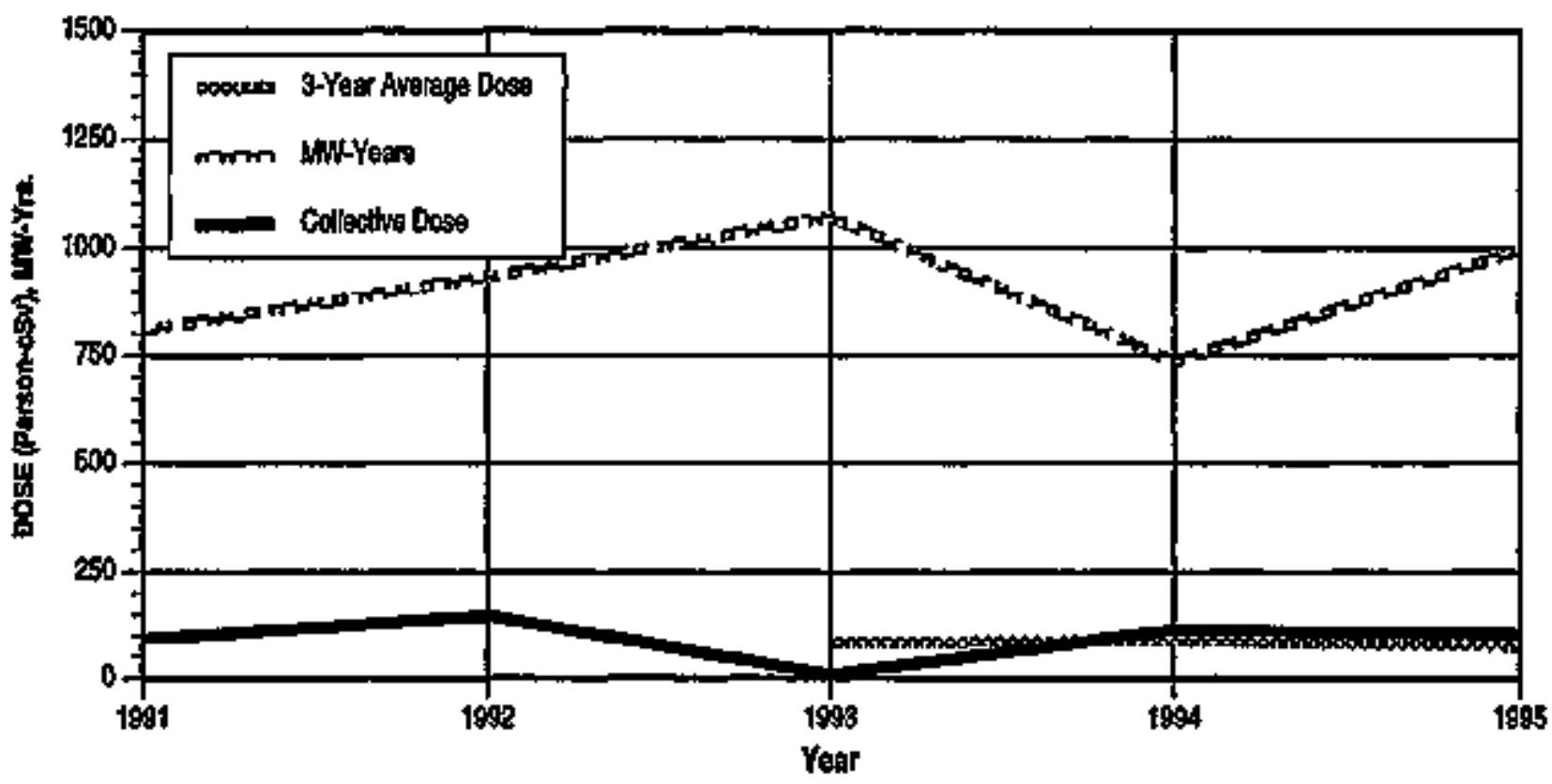

Breakdown by Job Fungtion

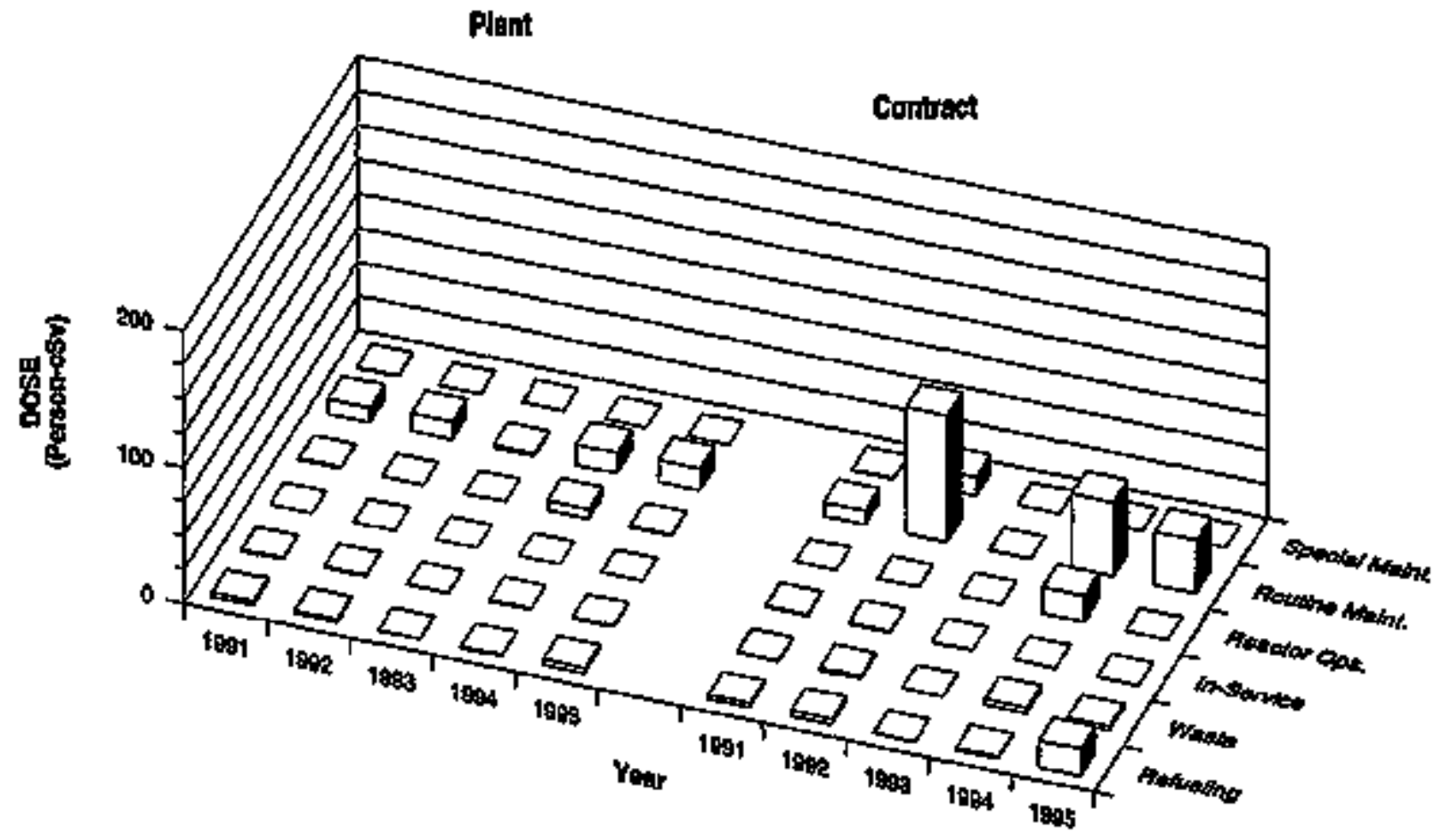




\section{APPENDIX E (contlnued) \\ SEQLOYAH 1,2}

Dose-Pariontrance Indicators

PWR

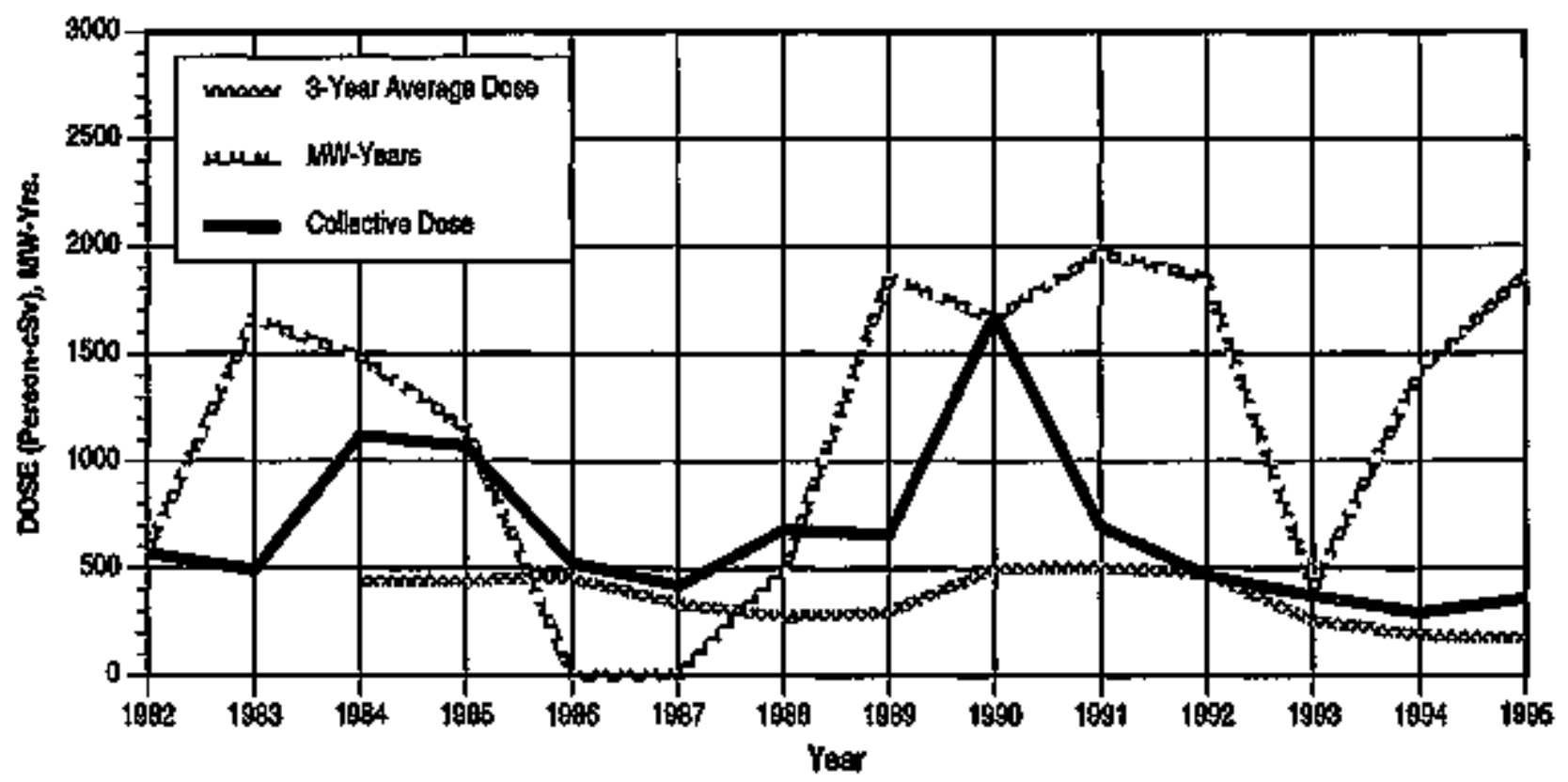

Breakdown by Job Function

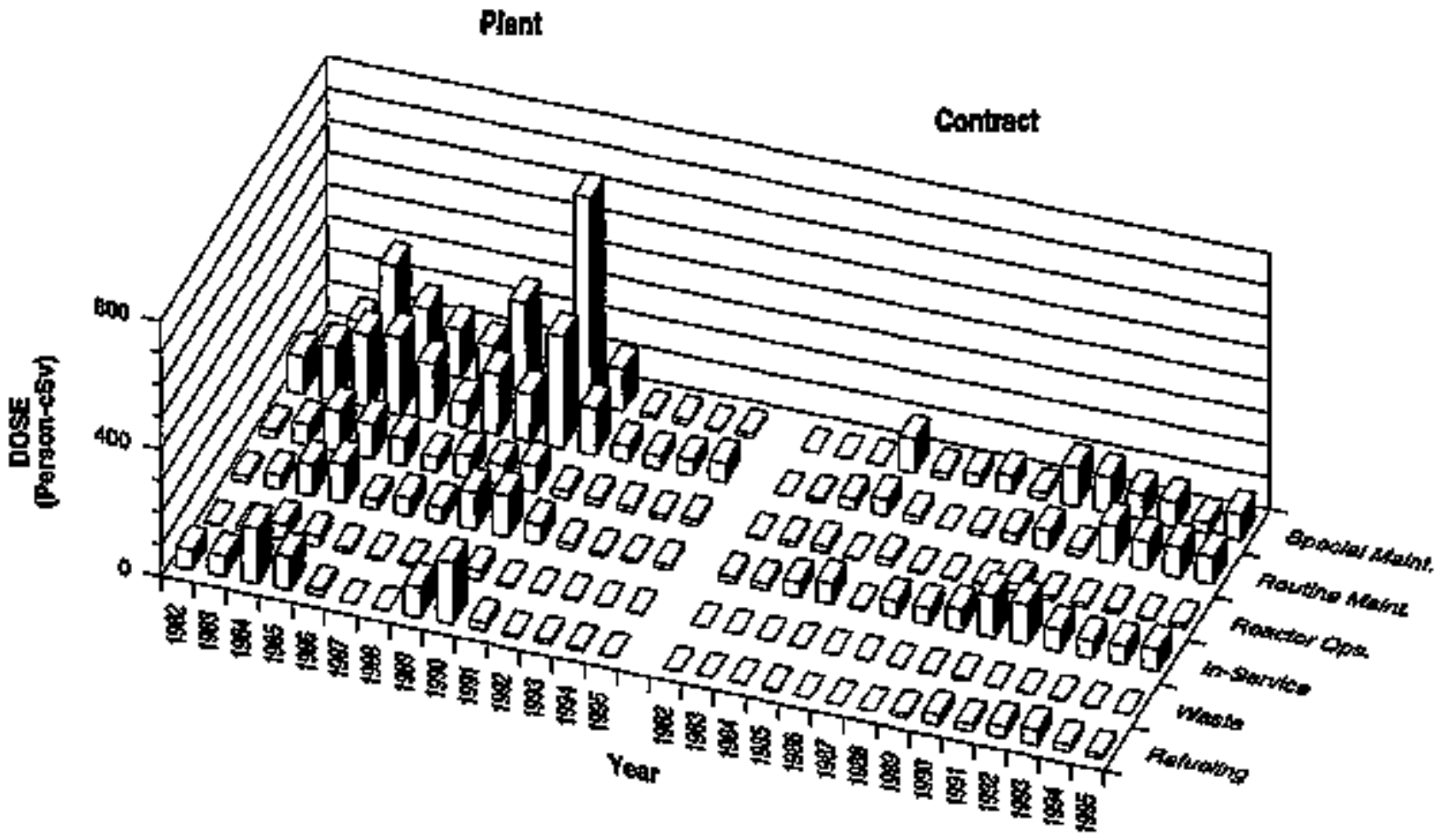

NUREG-0713 


\section{APPENDDX E (conthued) \\ SOUTH TEXAS 1, 2 \\ Dosefefformarice hdicalors}

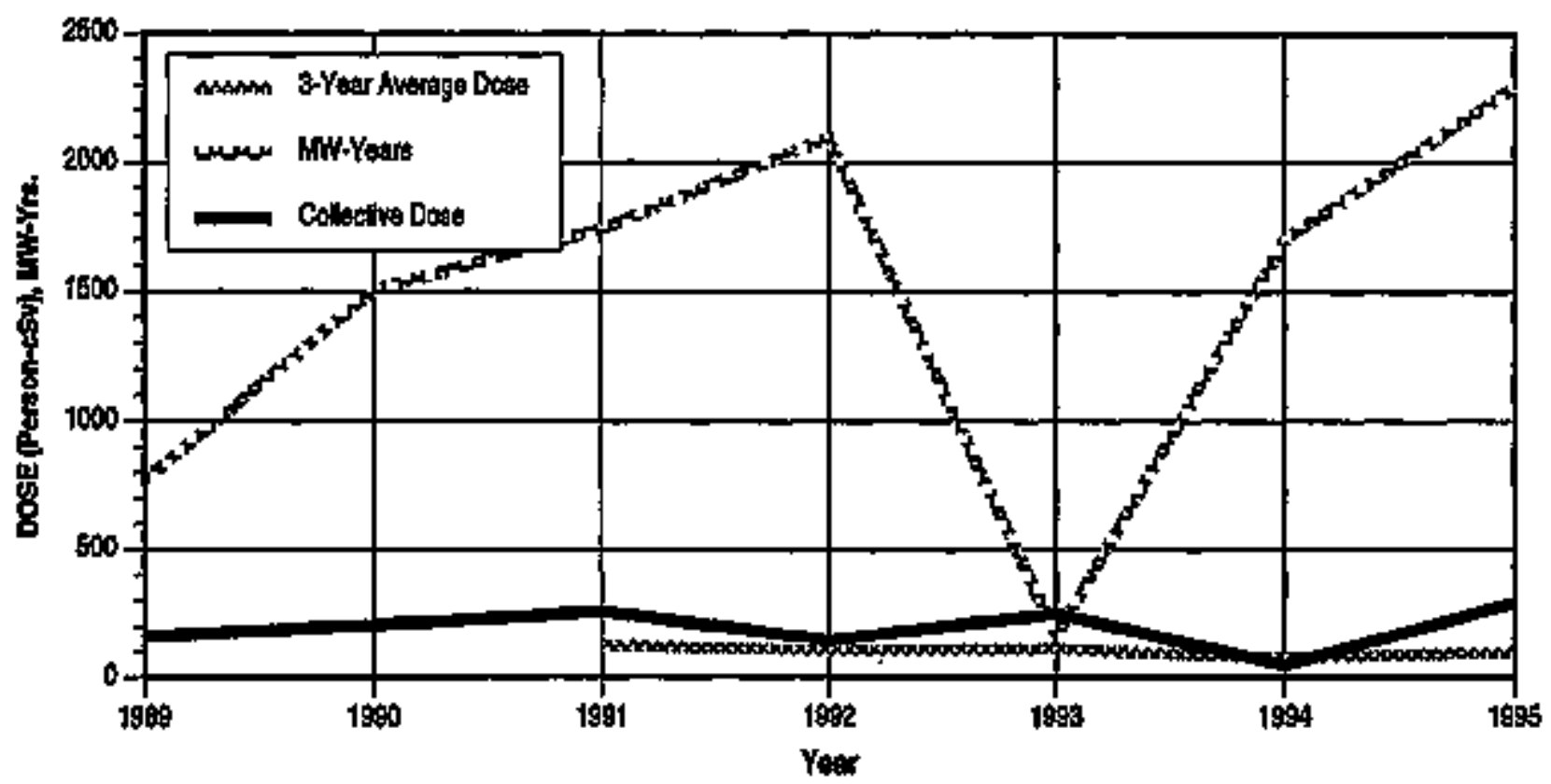

Breakdoun by Job Function

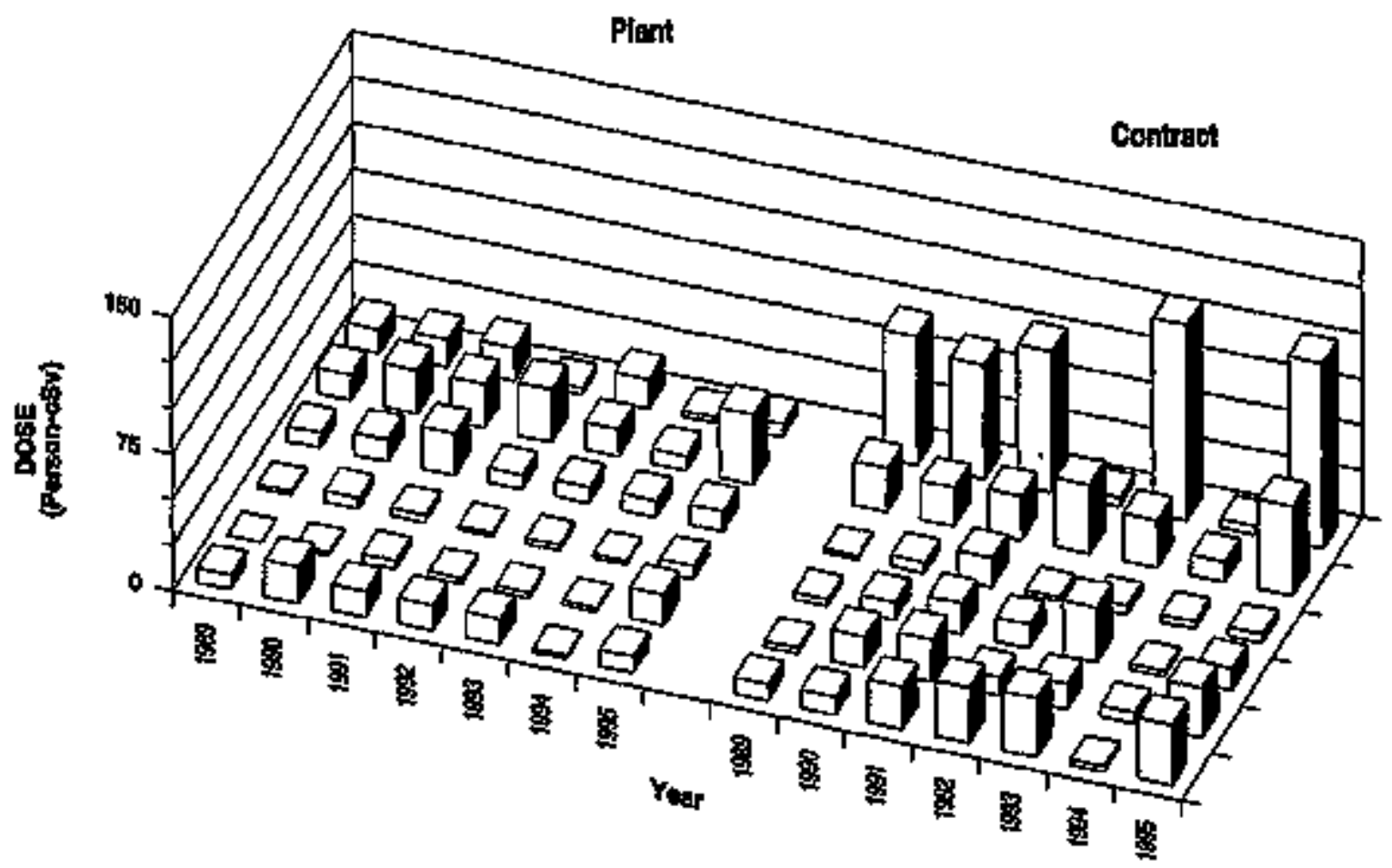




\section{APPENDXX E (continued)}

ST. LUCE 1,2

Doss-Performance hdicators

PNR

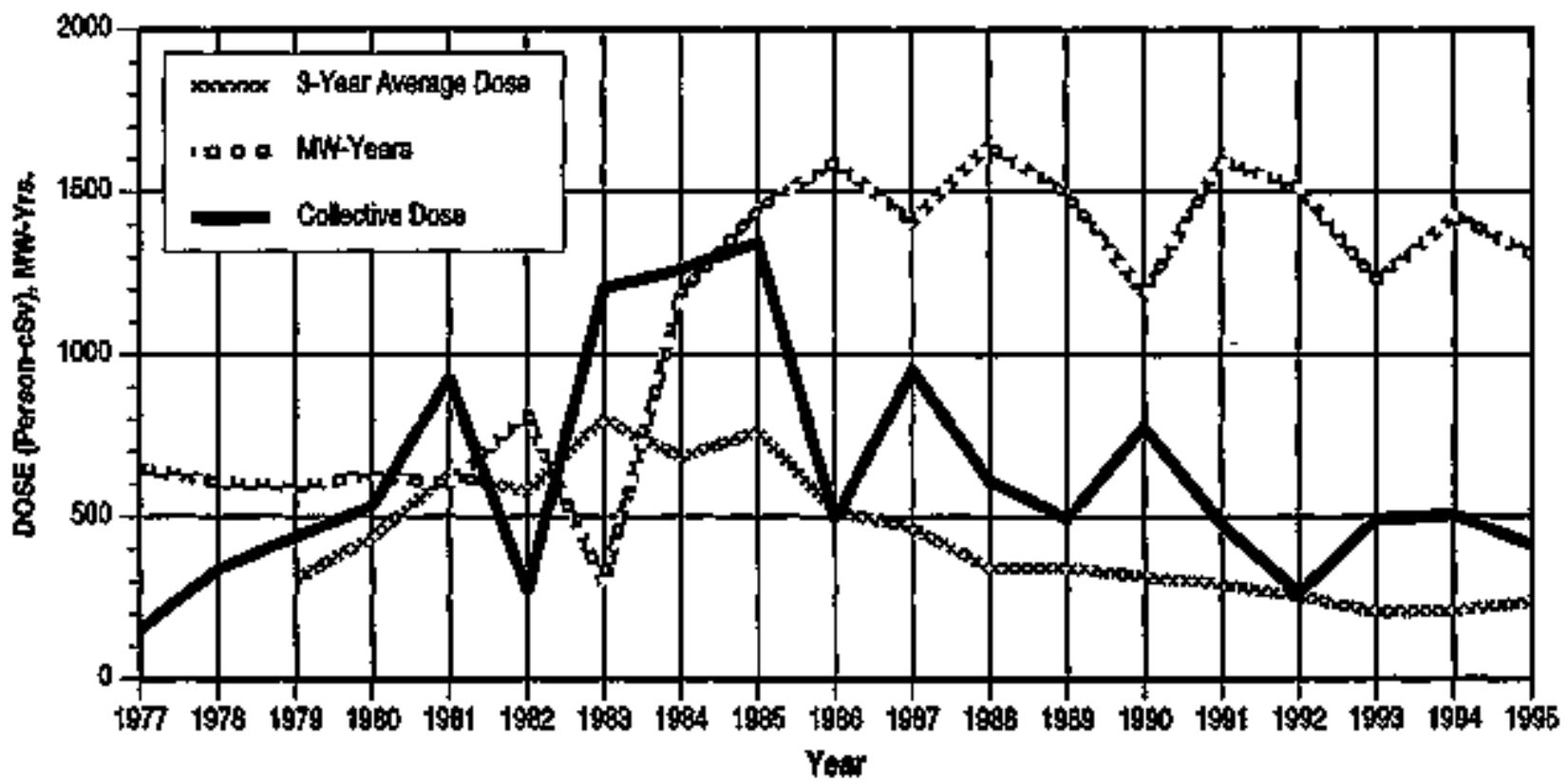

Areakdown by Jab Function

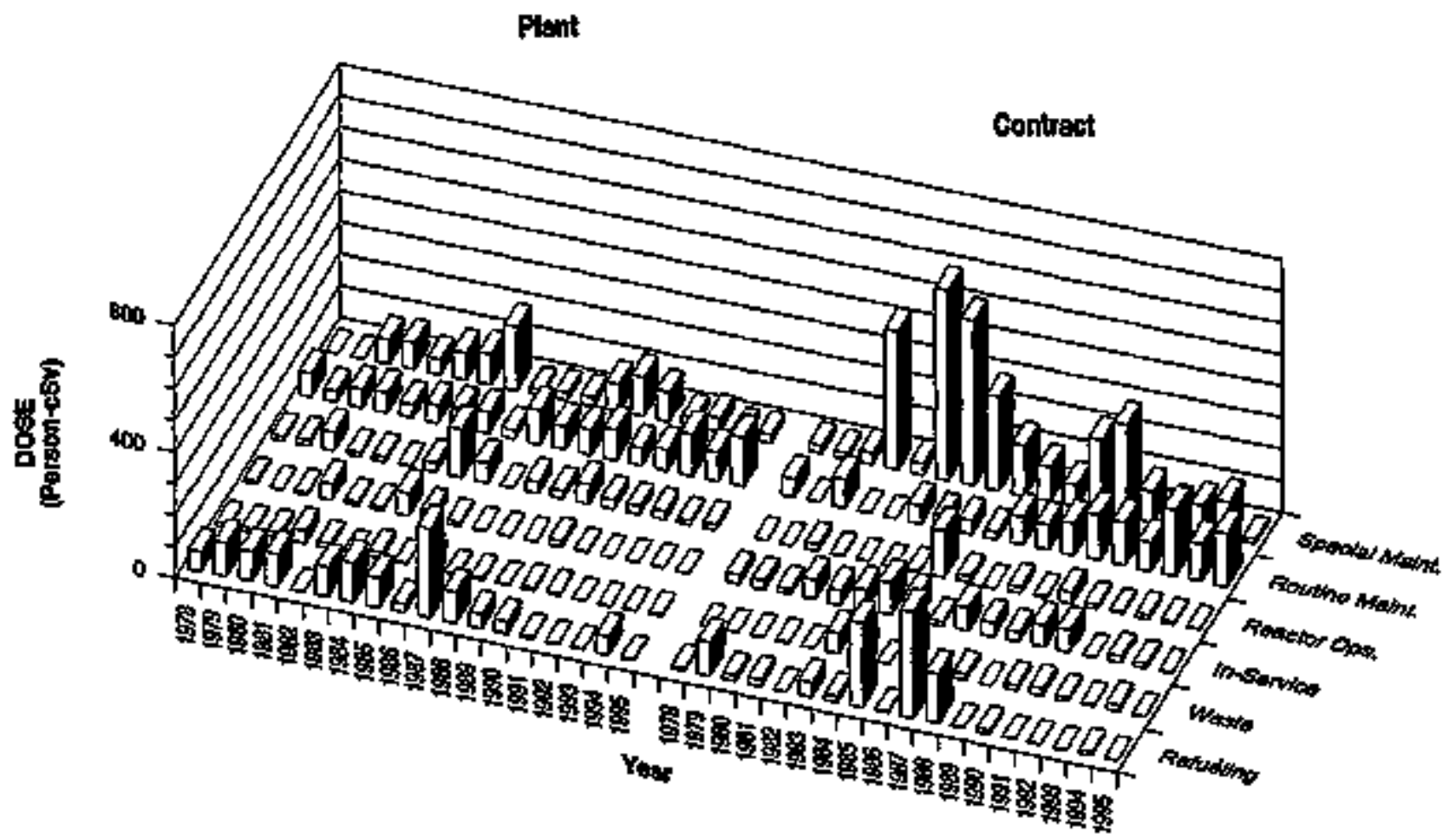


APPENDIX E (contloued)

SUMAMER 1

DosePerformance Indicaloss

PWR

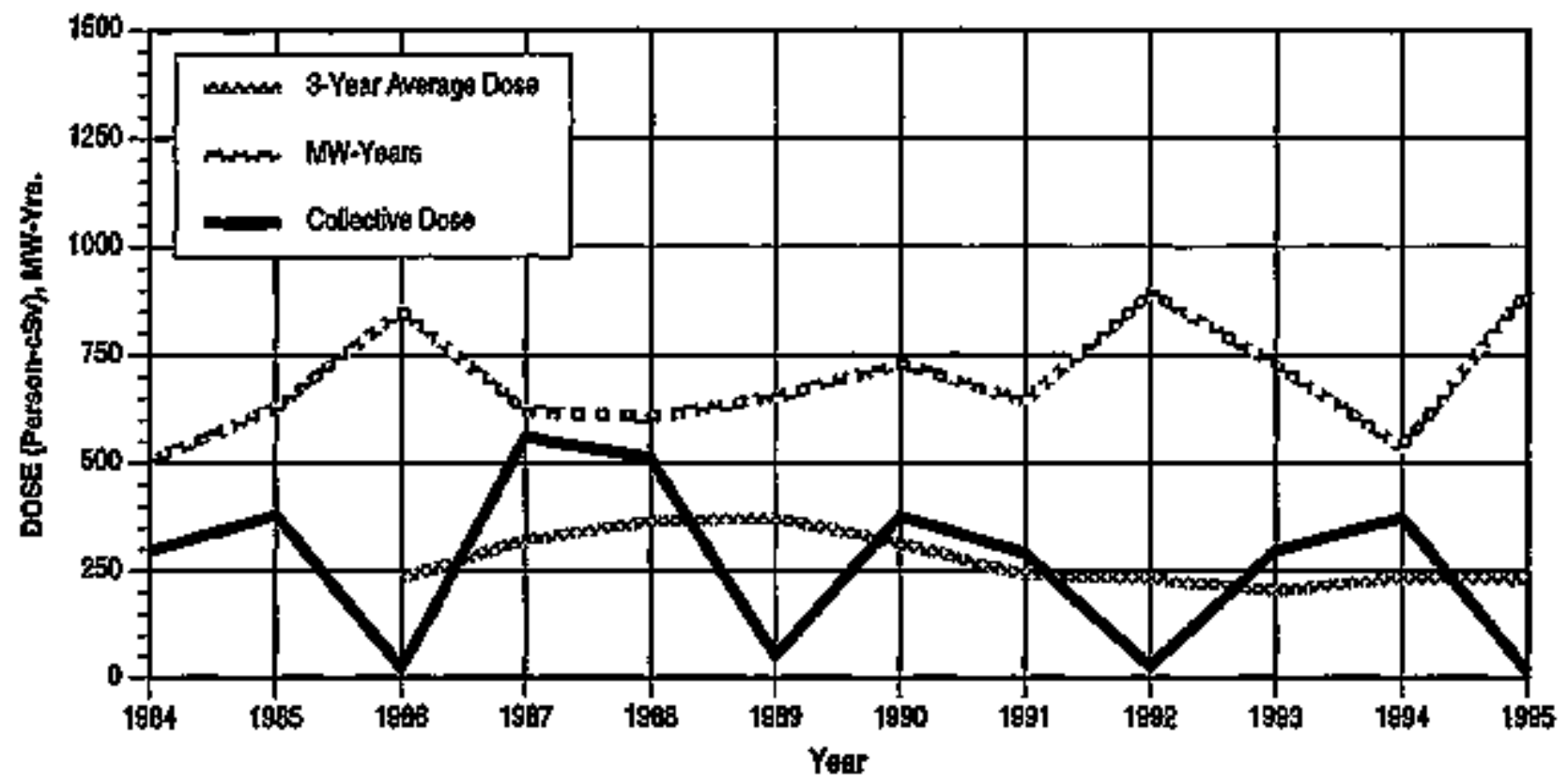

Beakdown by Job Function

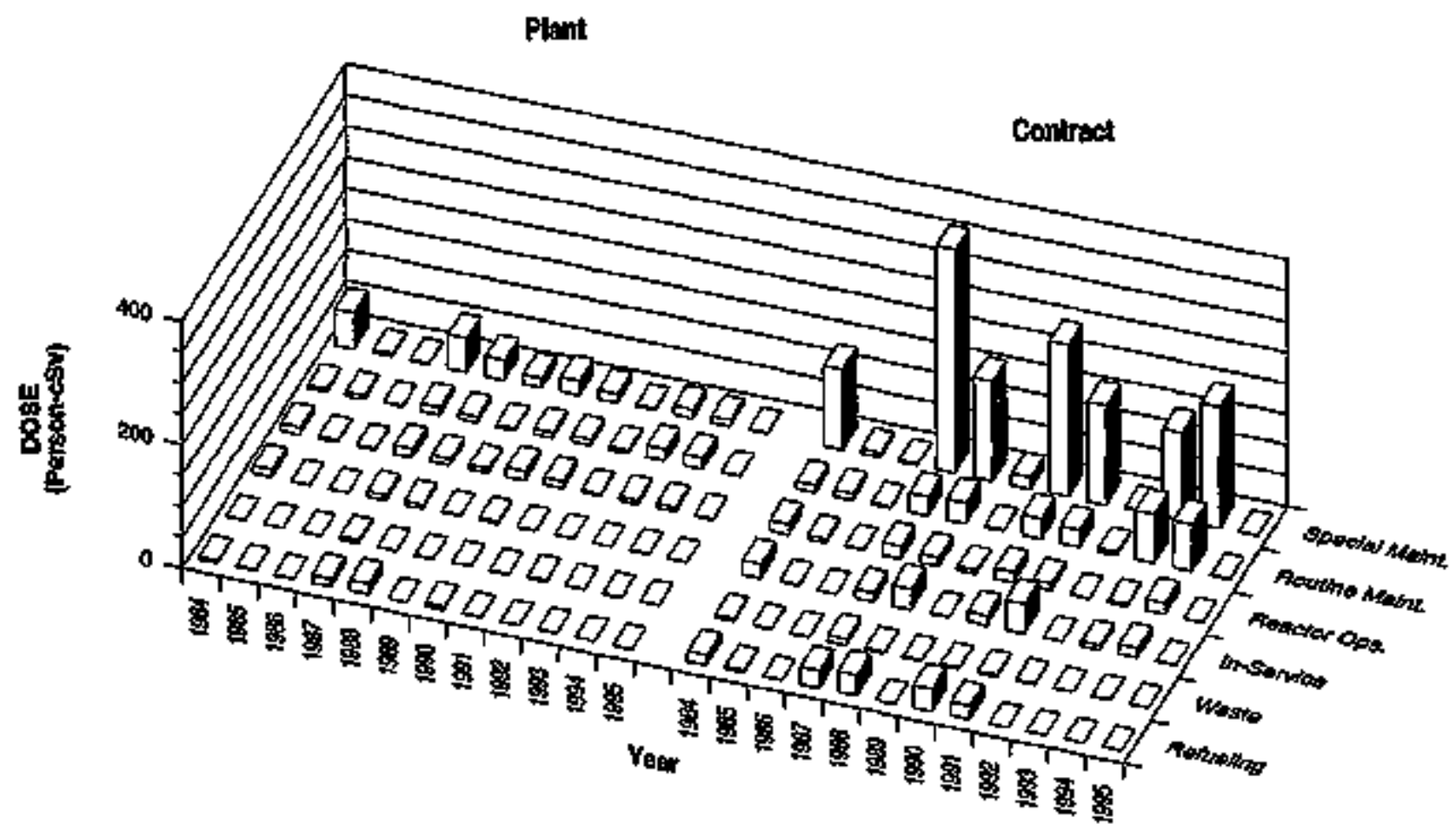




\section{APPENDX E (continued)}

SURAY 1, 2

Dose Pentomanice budicators

PUR

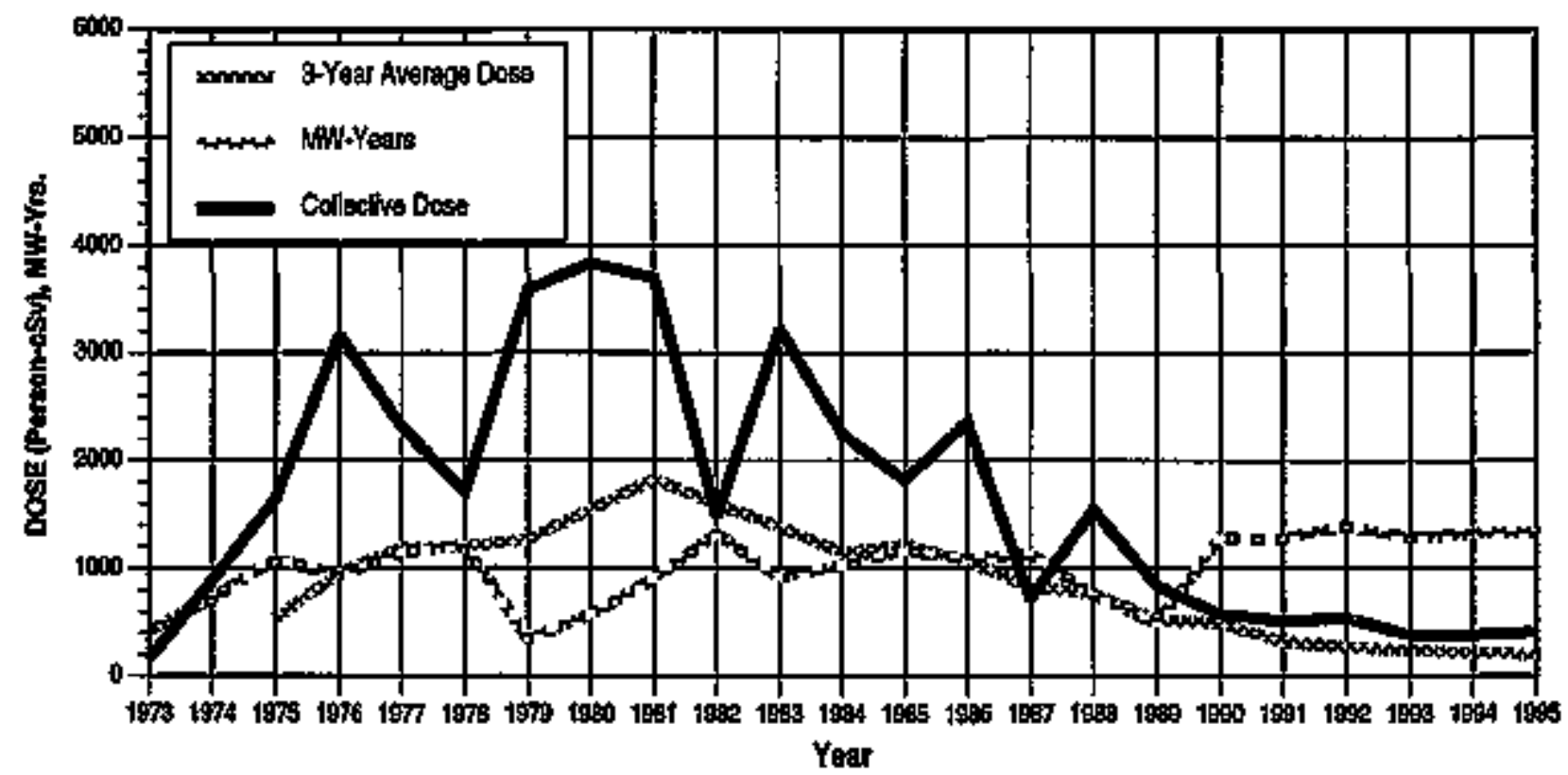

Breakdown by Jow Function

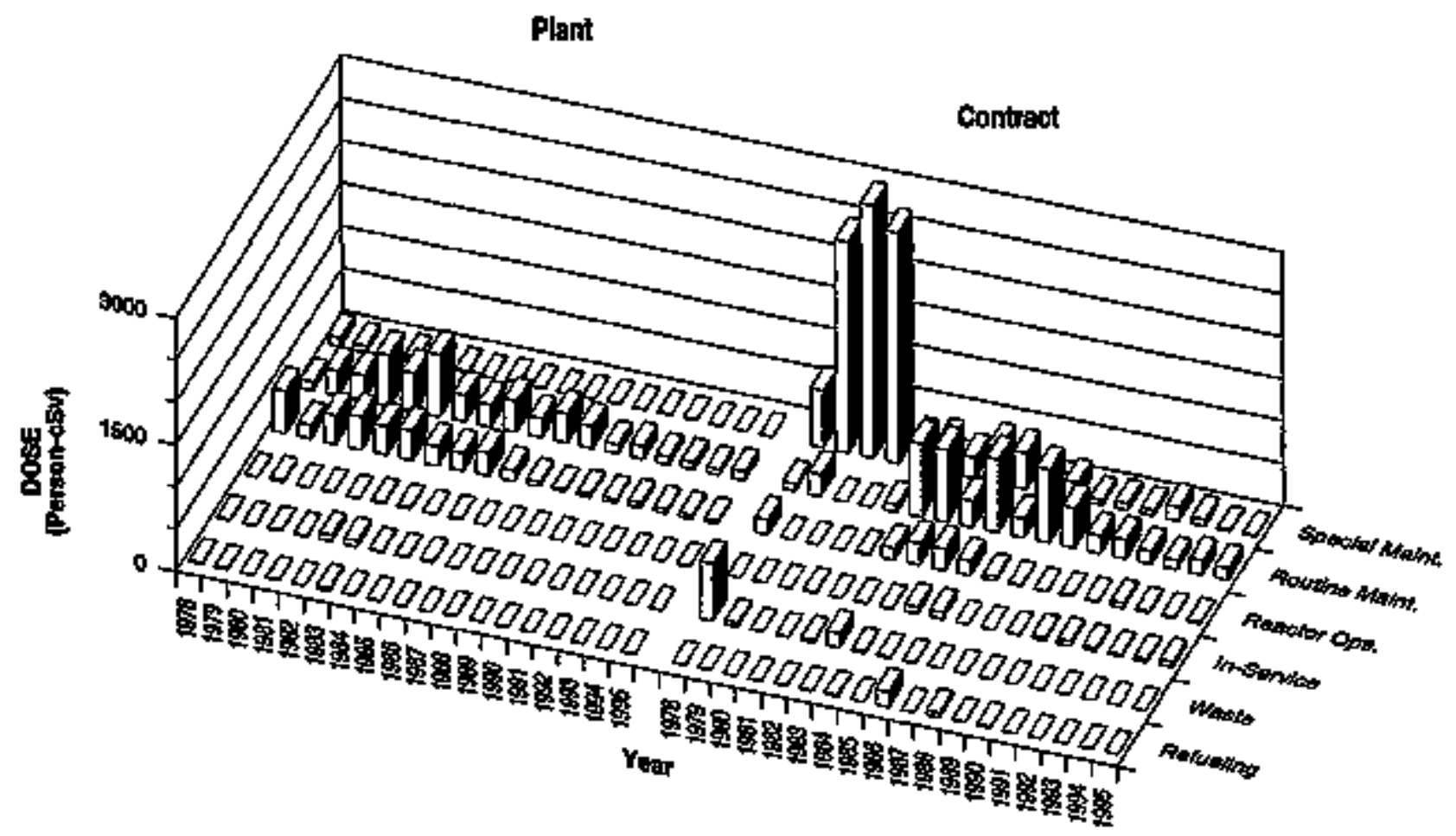




\section{APPENDIX E (cont/nued) \\ SUSQUEHAMNA 1, 2}

Dose-Periannance Indicators

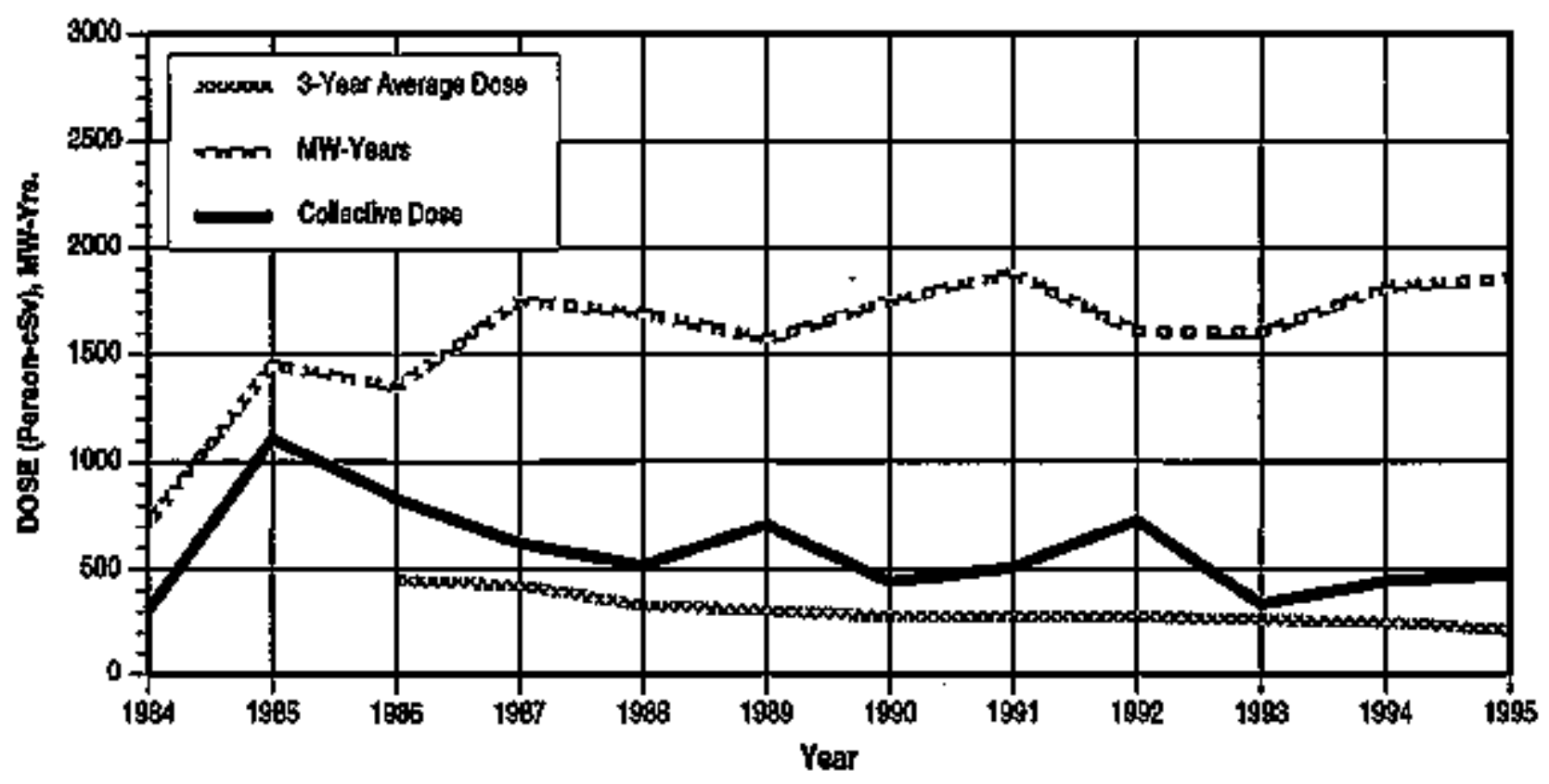

Breakdomn by Job Funtion

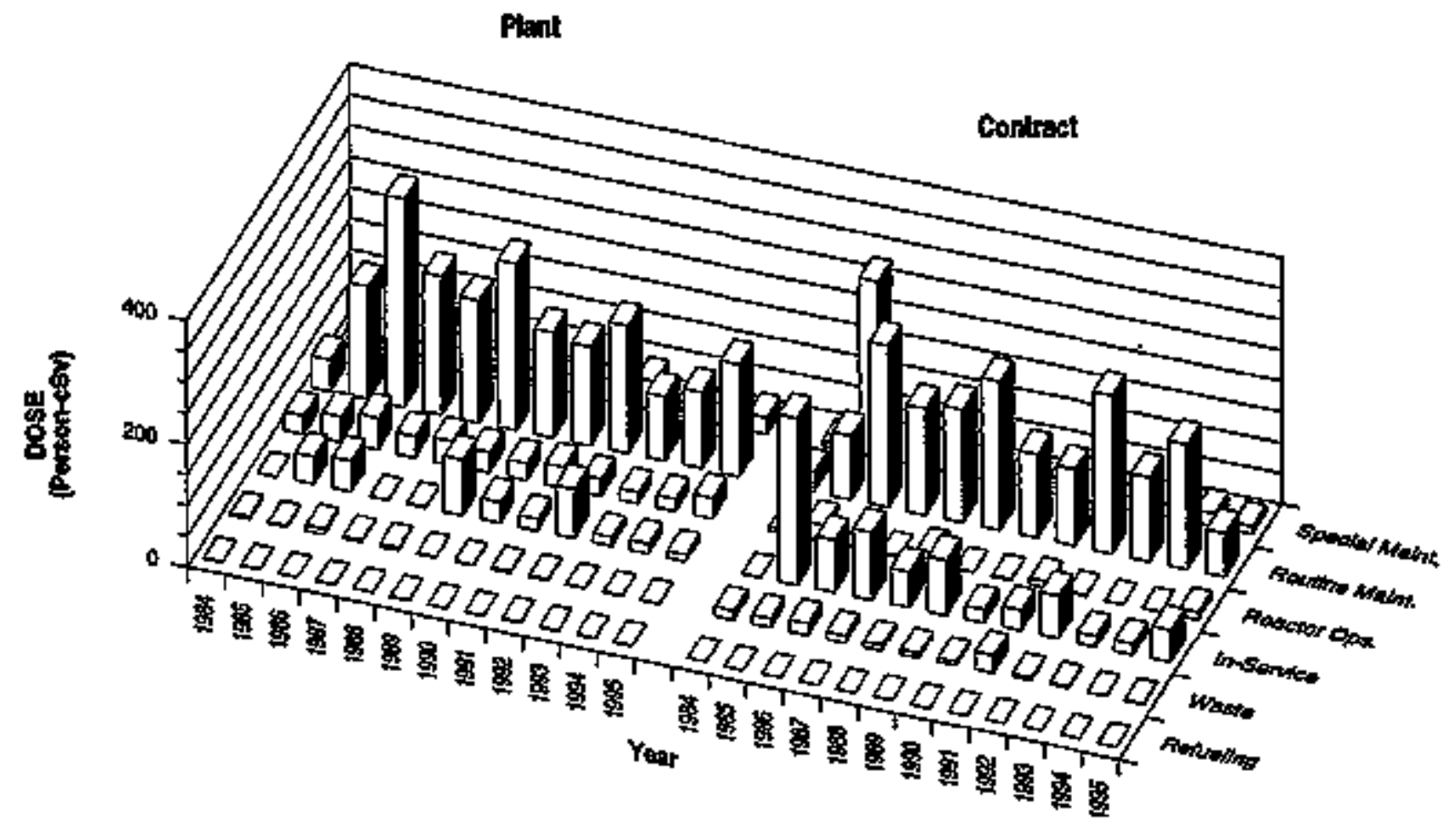


APPENDIX E (continued)

THREE MILE ISLAMD 1

Doso-Perfommance indicators

PWR

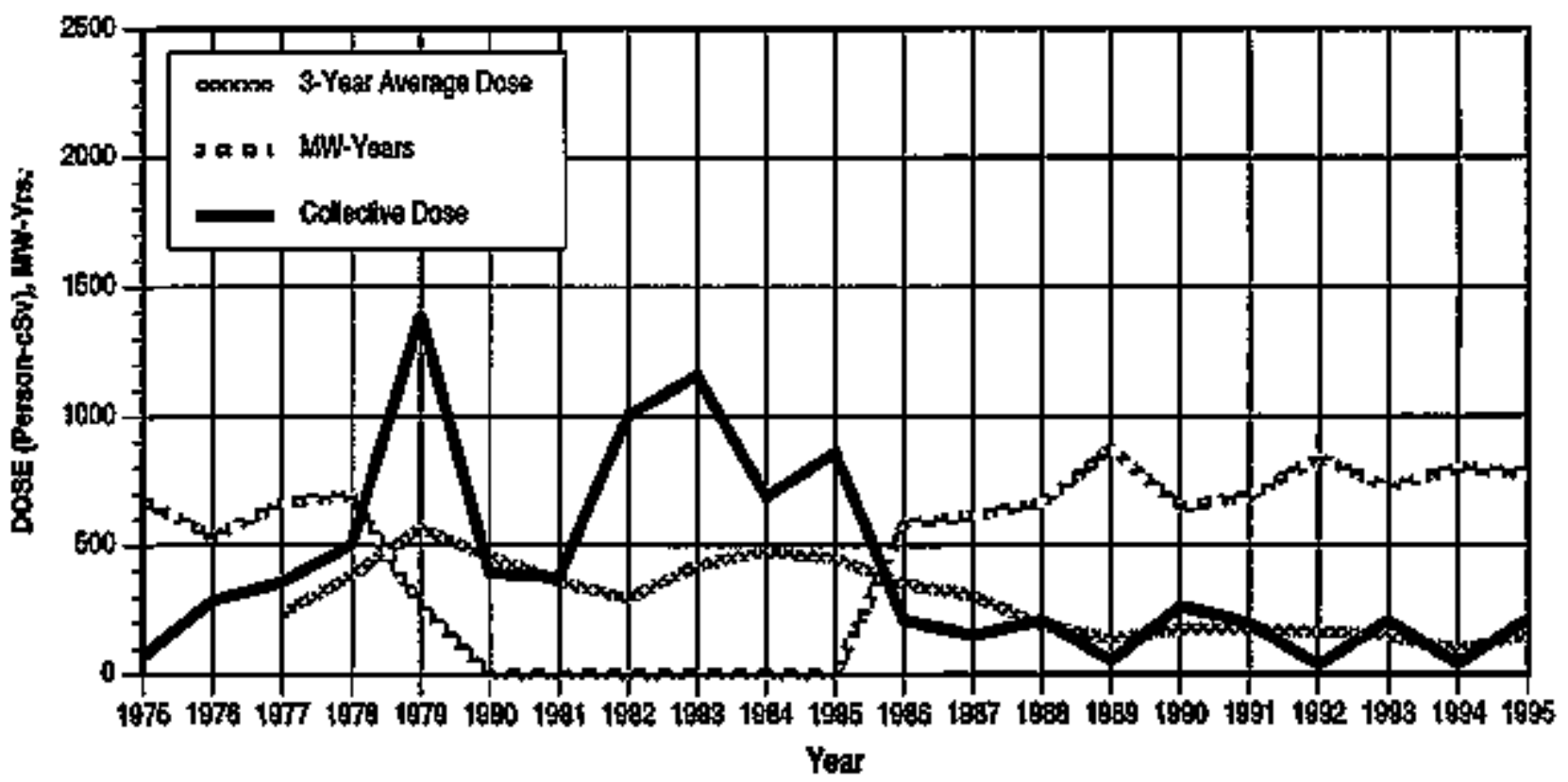

Breakdown by Job Funtion

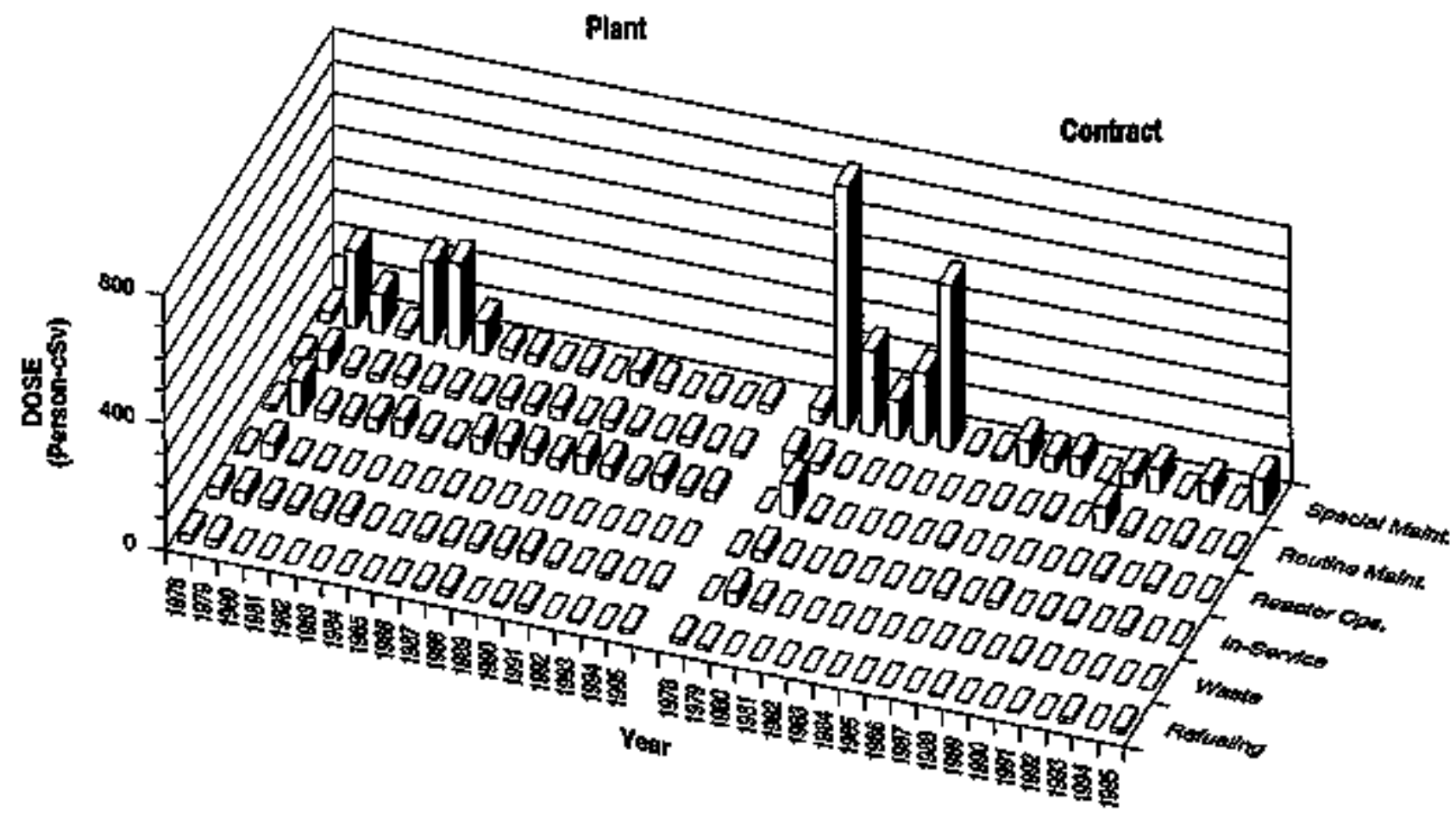




\section{APPENDIX E(continued) \\ THAEE MILE JSLAND 2}

Dose-Performance hodicators

PWR

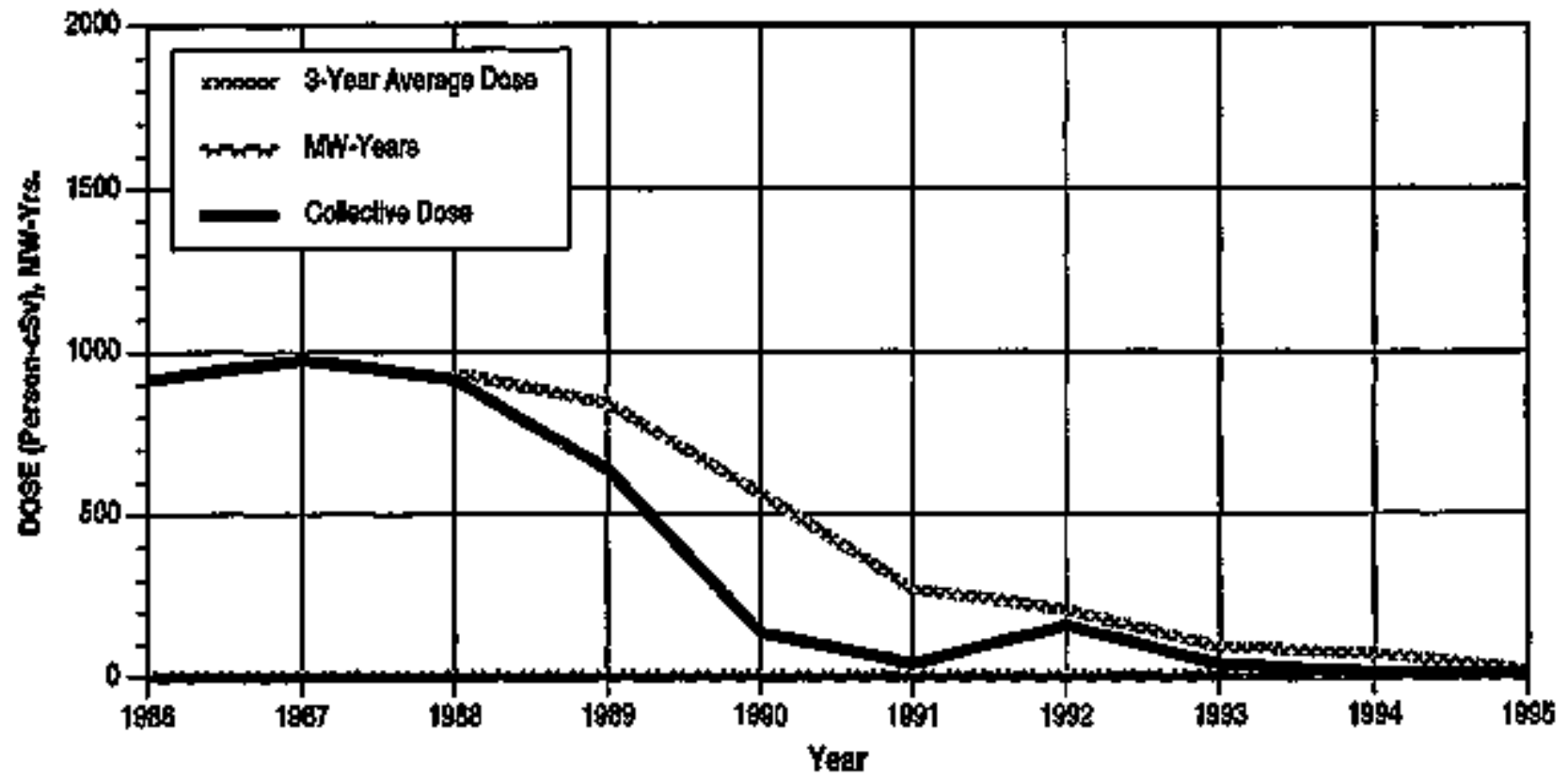

Breakdown by Joo Function

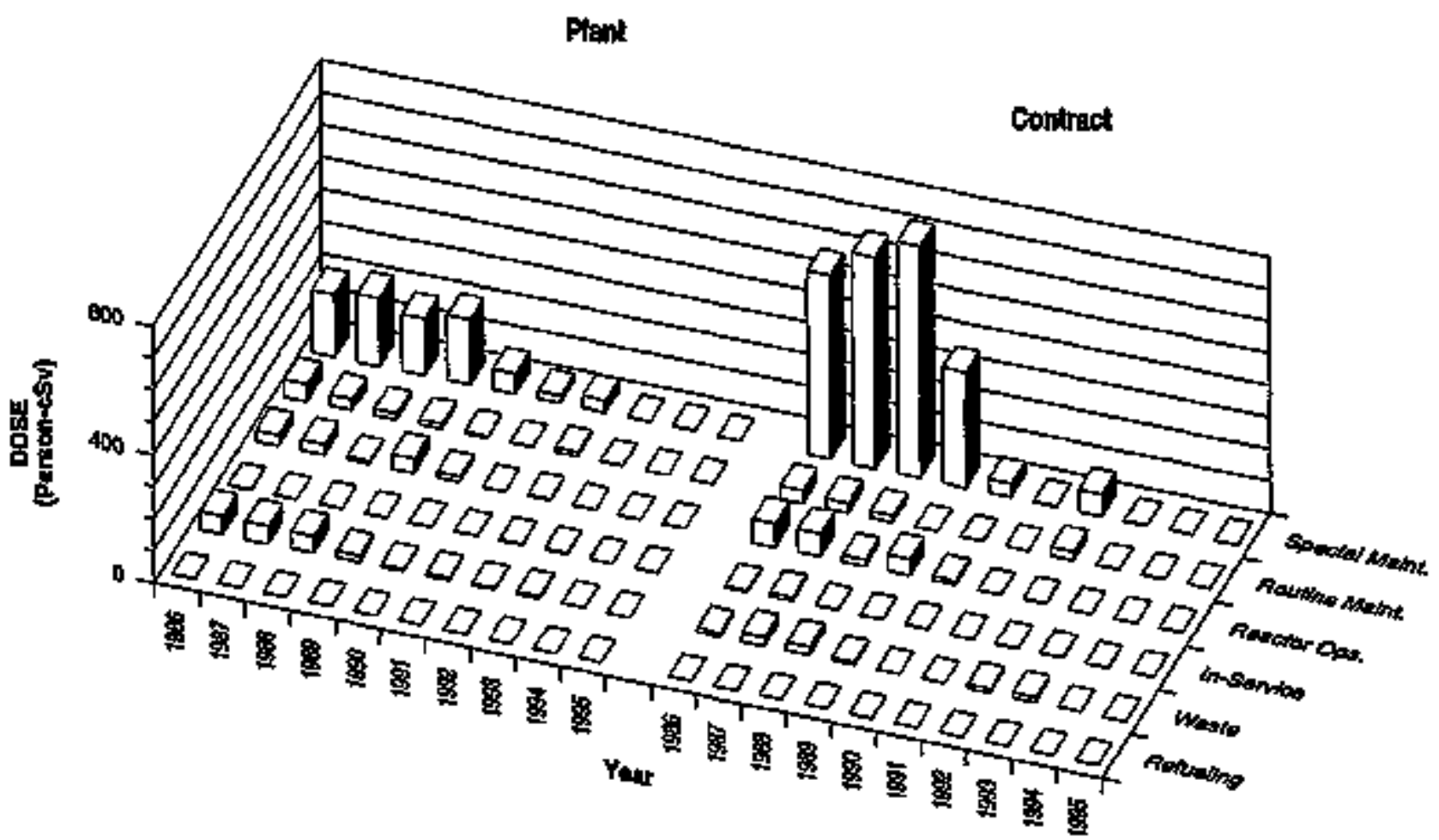


APPENOIX (continted)

TROIAN

DosePerformance Indleators

PWR

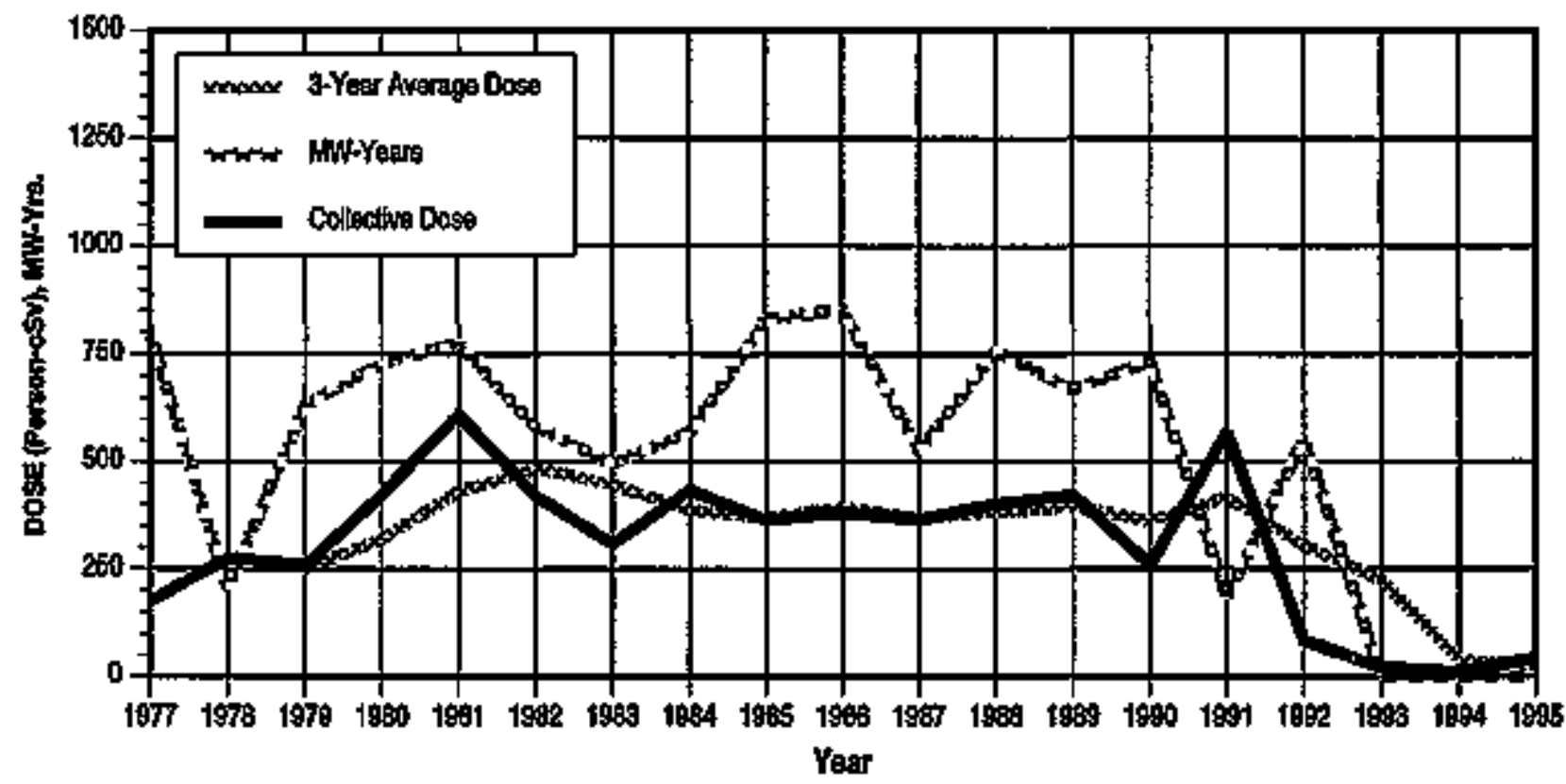

Bxeakdonin by Job Function

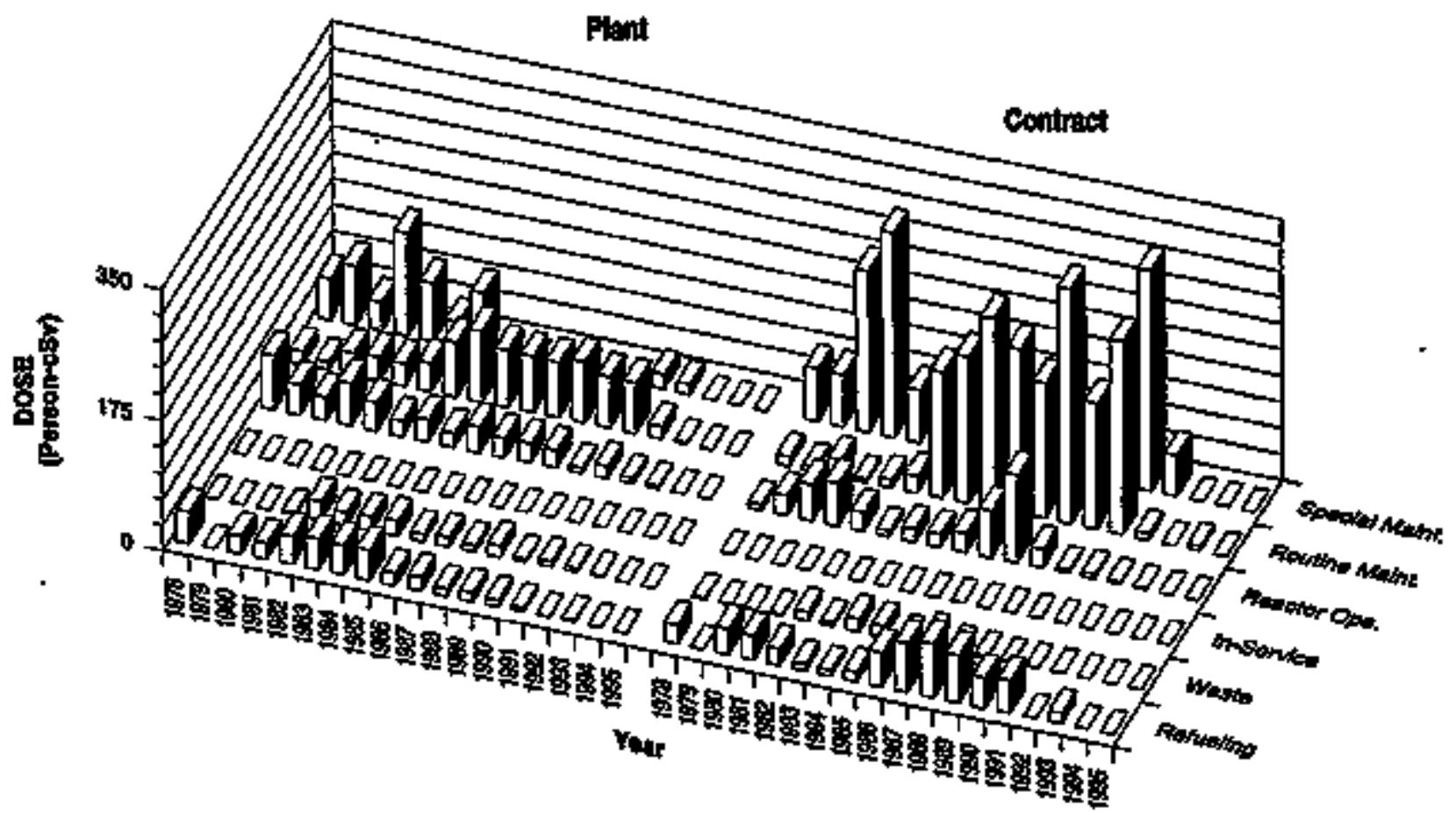




\section{APPENDIX E (continuted)}

\section{TUAKEY PONT 3, 4}

DosePeriomance indicators

PWR

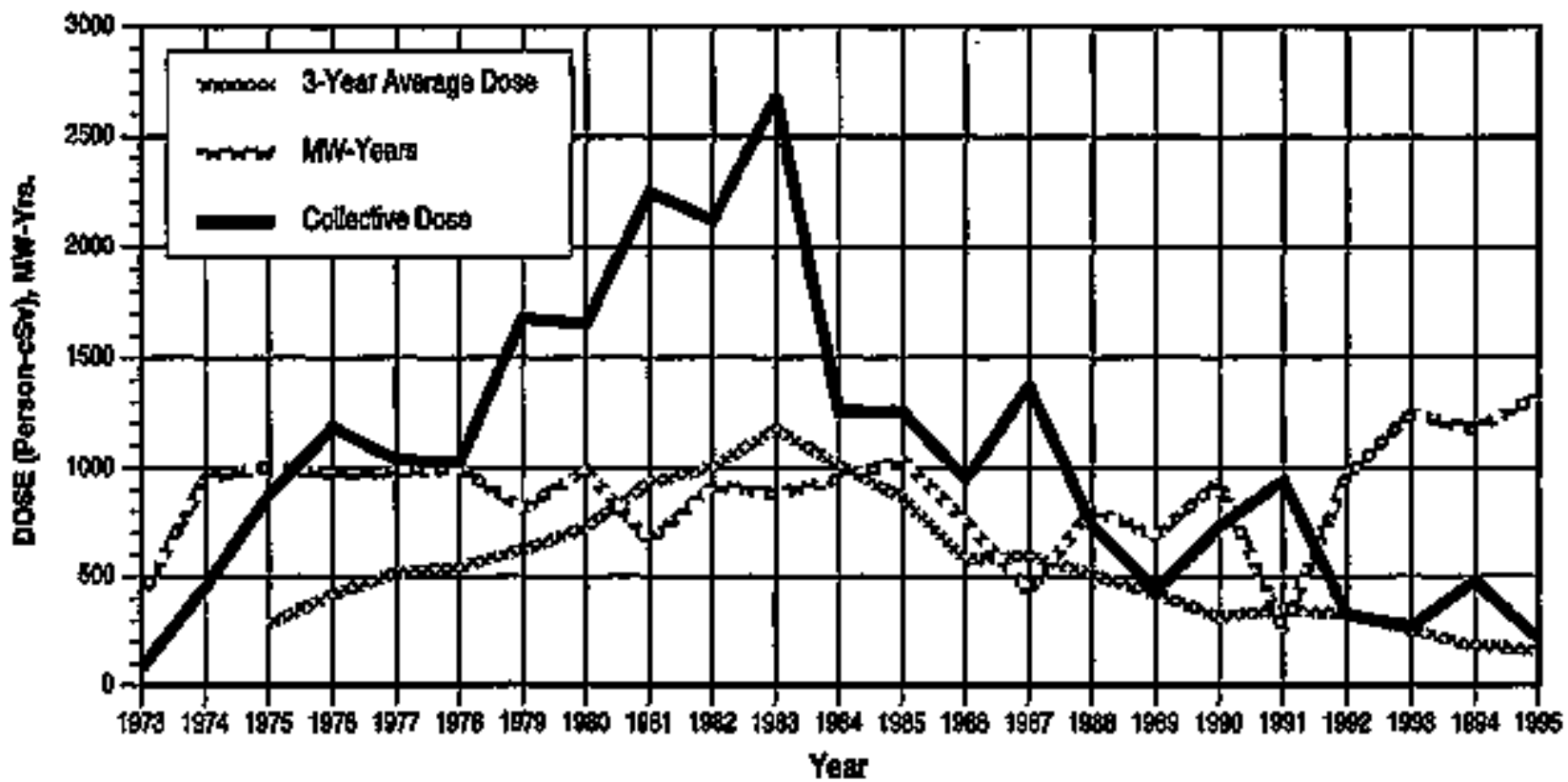

Bralidoun by dob Funotion

Plant

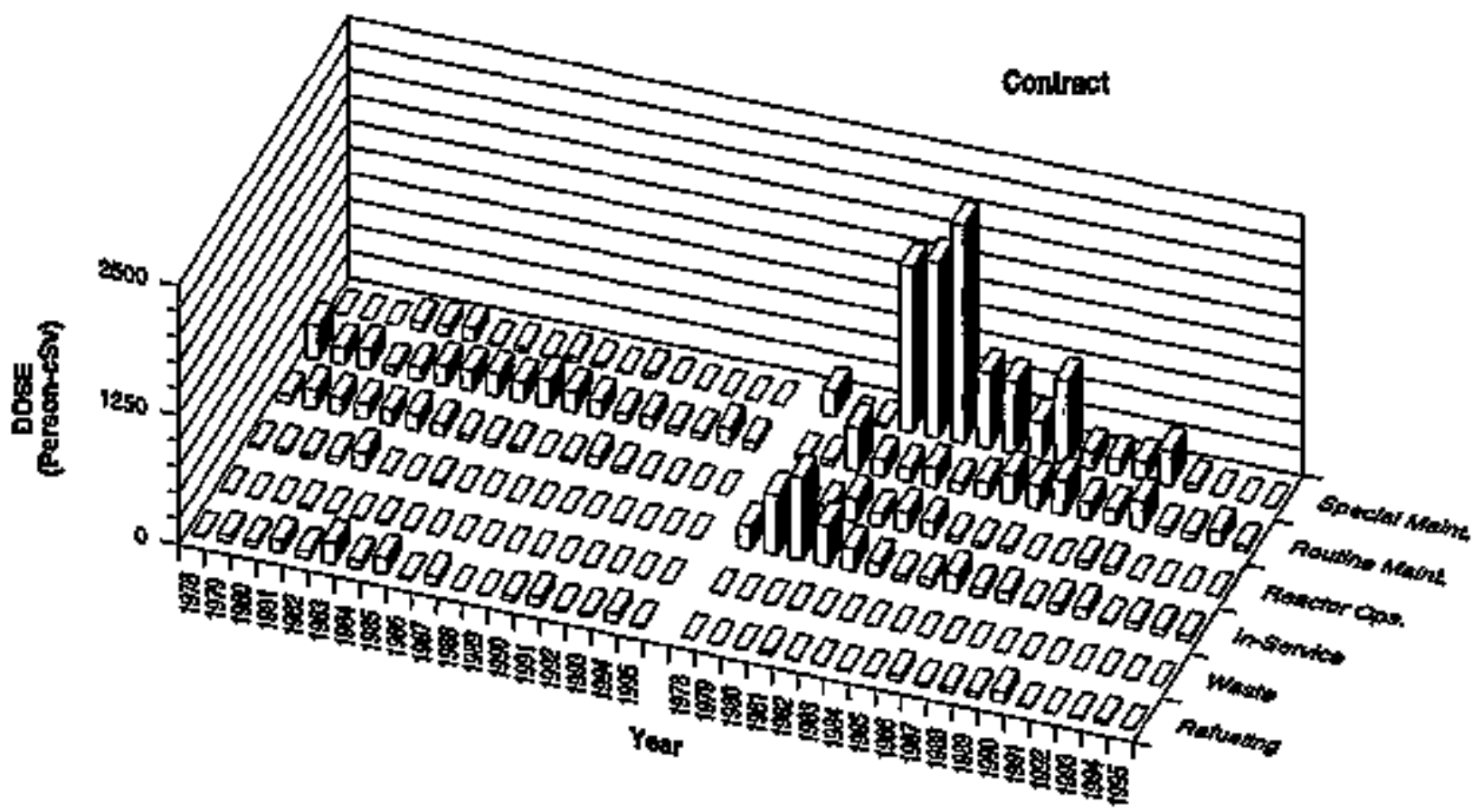




\section{APPENDXX (continued) \\ VEFMONT YANKEE}

Dose-Perfornence Indicalors

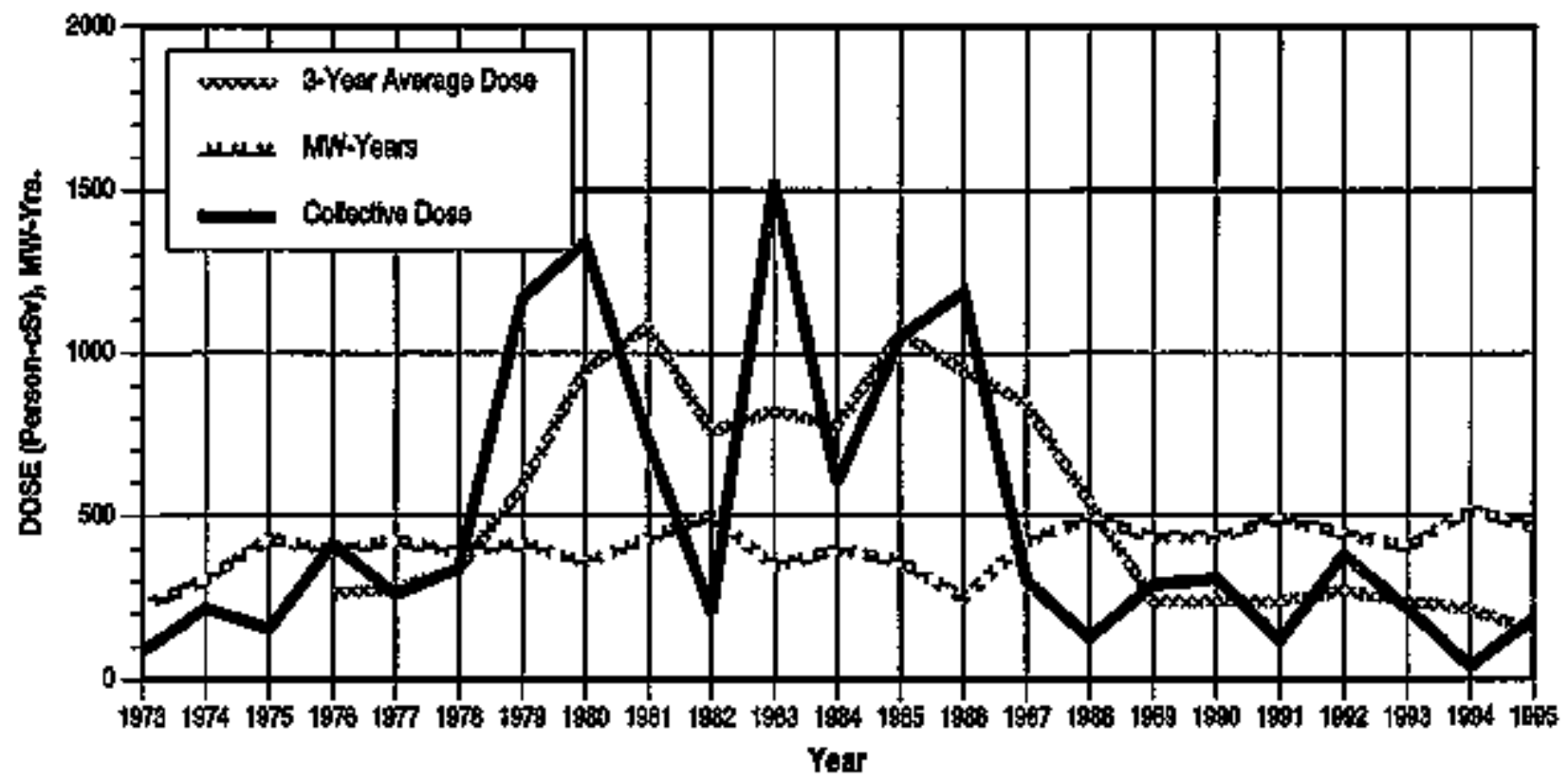

Breakdown by Job Funition

Plant

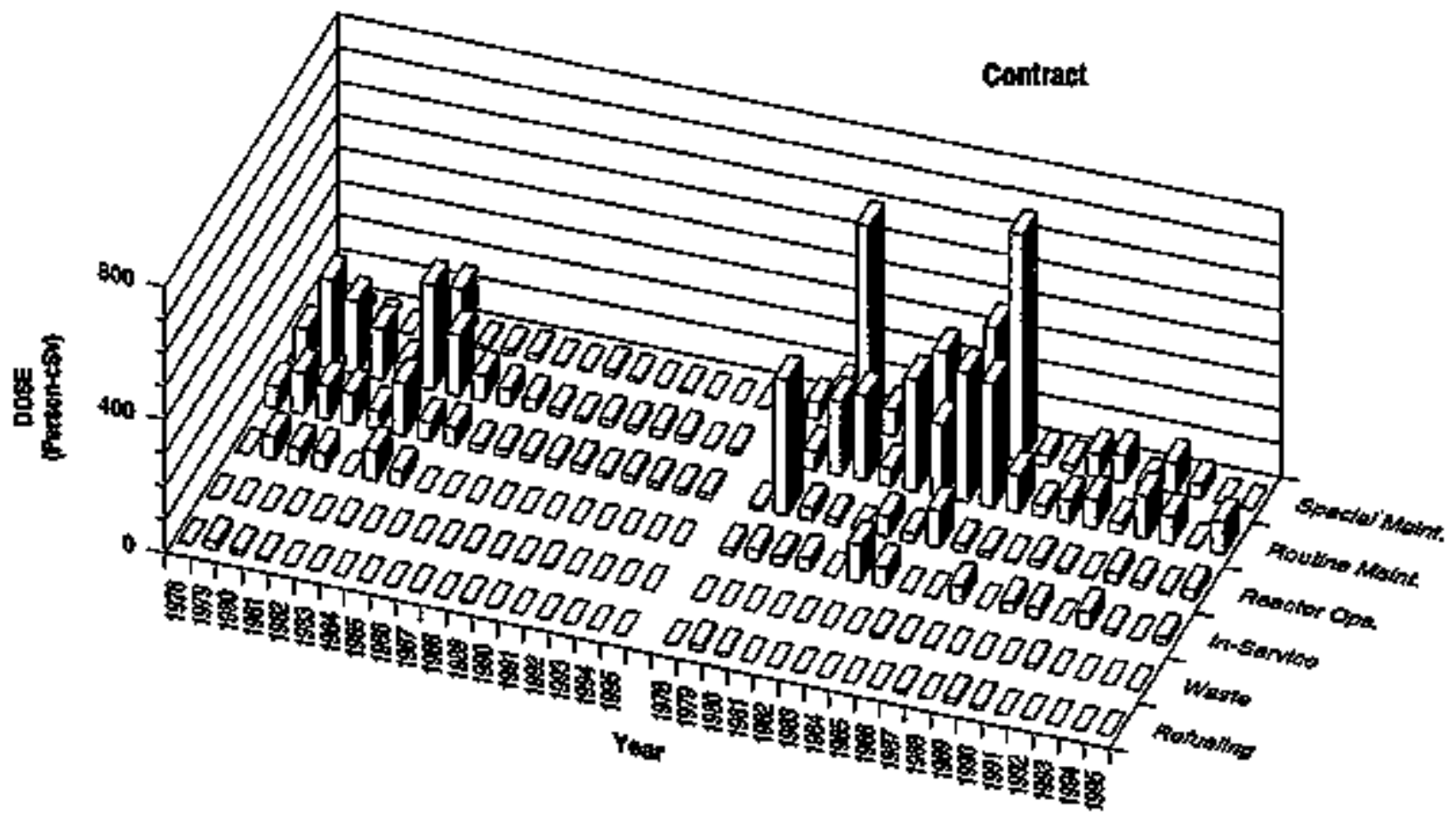


APPENDLX E (continued)

VOGTLE 1,2

Dose.Fetommance Indicators

PWA

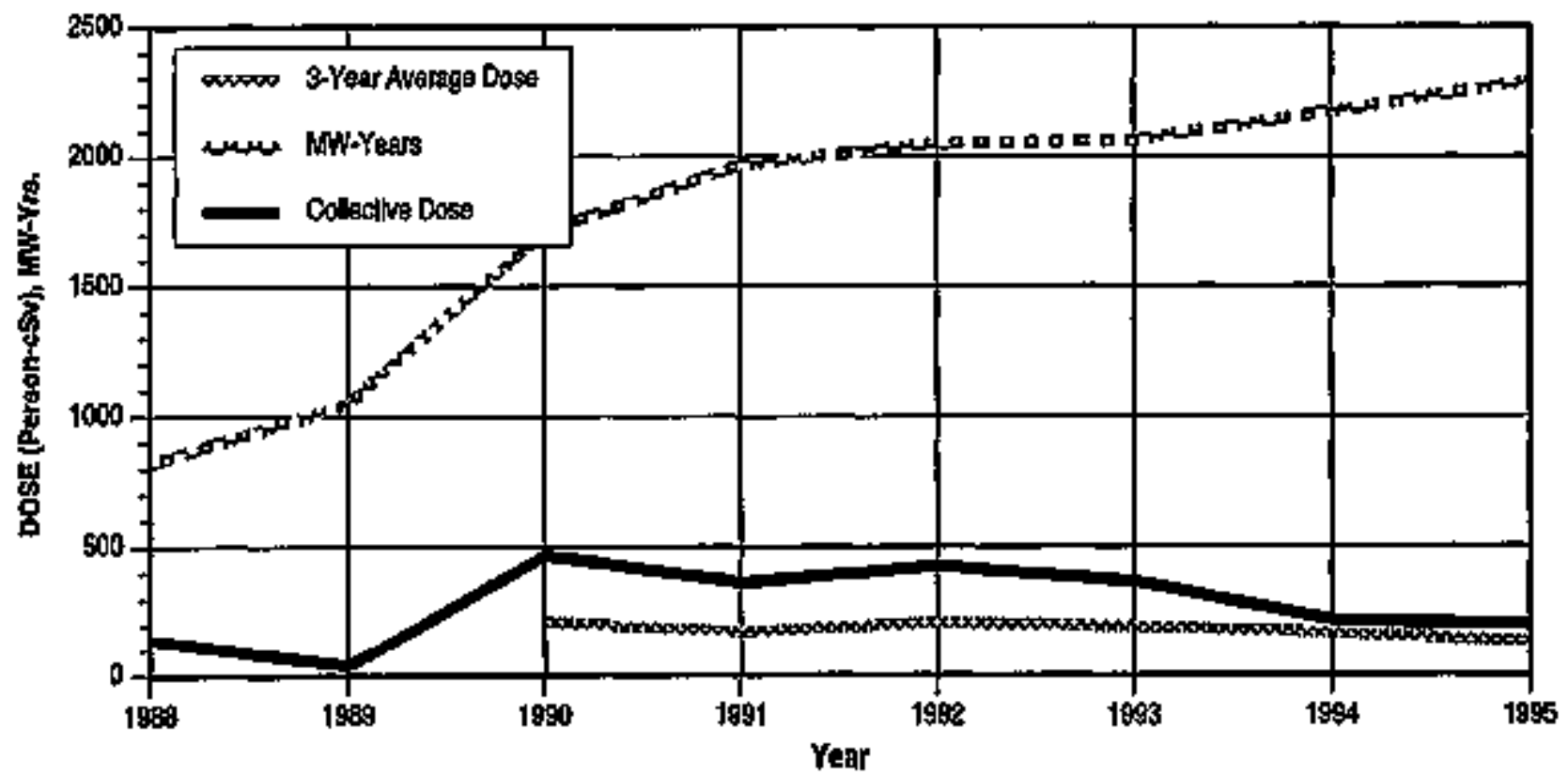

Breakdown by Jab Function

Plant

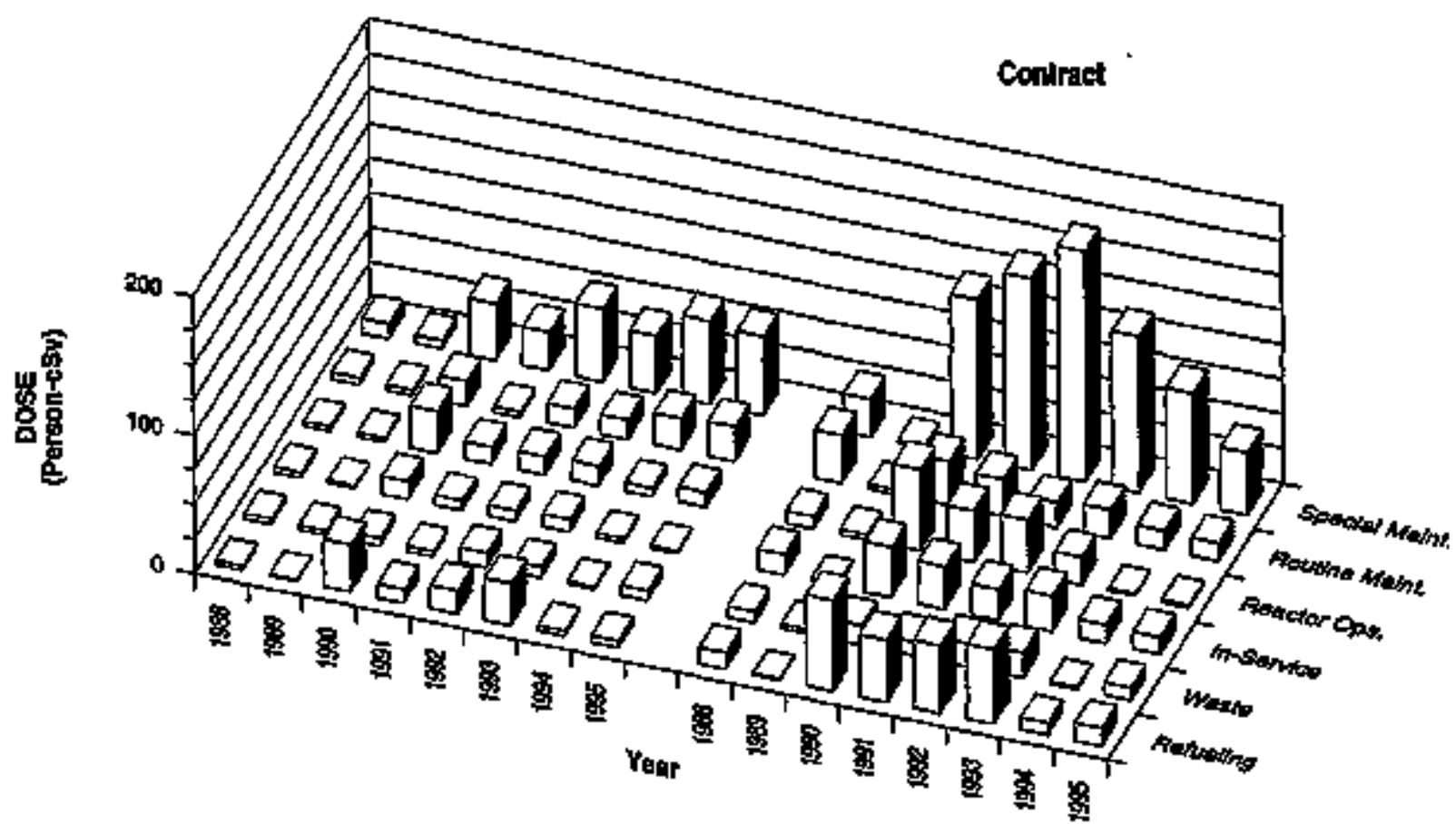


APPENDIX E (continued)

WASHINGTONNUCLEAR 2

Dose-Perlemnence Indcators

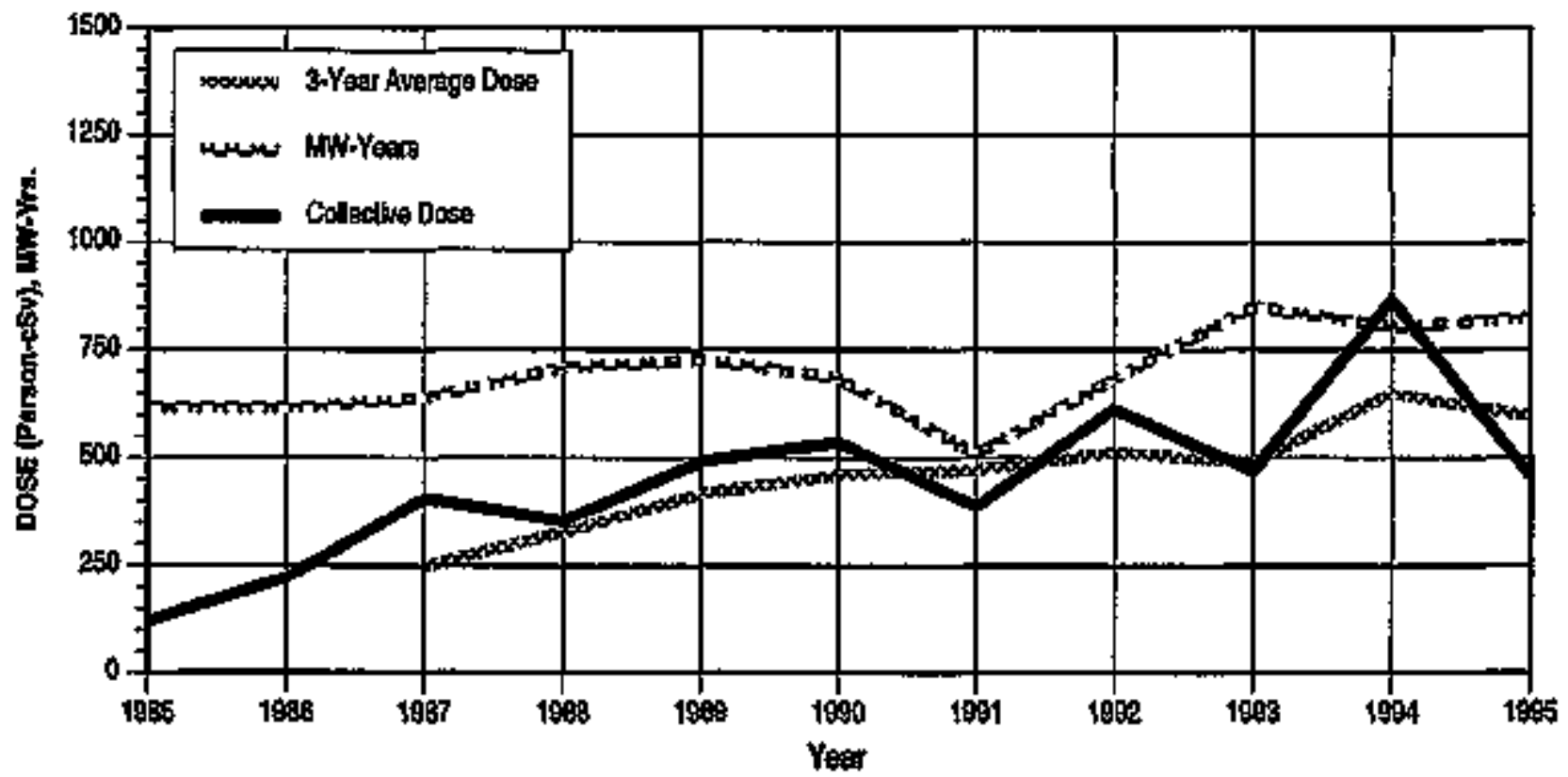

Breakdawn by Job Function

Plat

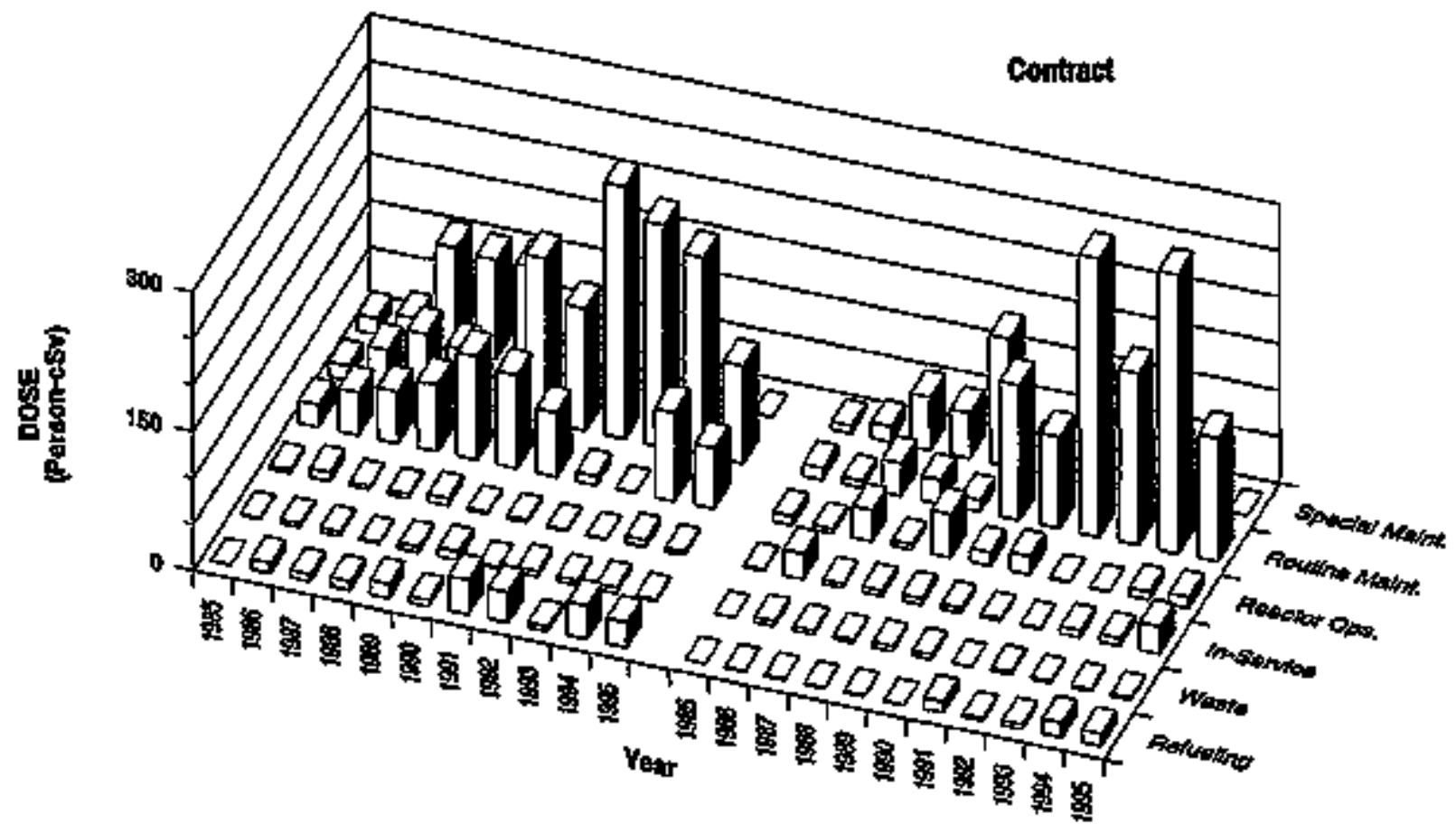

NUREG-0713 


\section{APPENOIX E (continued) \\ WATERTORD 3 \\ Dose Perfonmance hodicators}

PWF

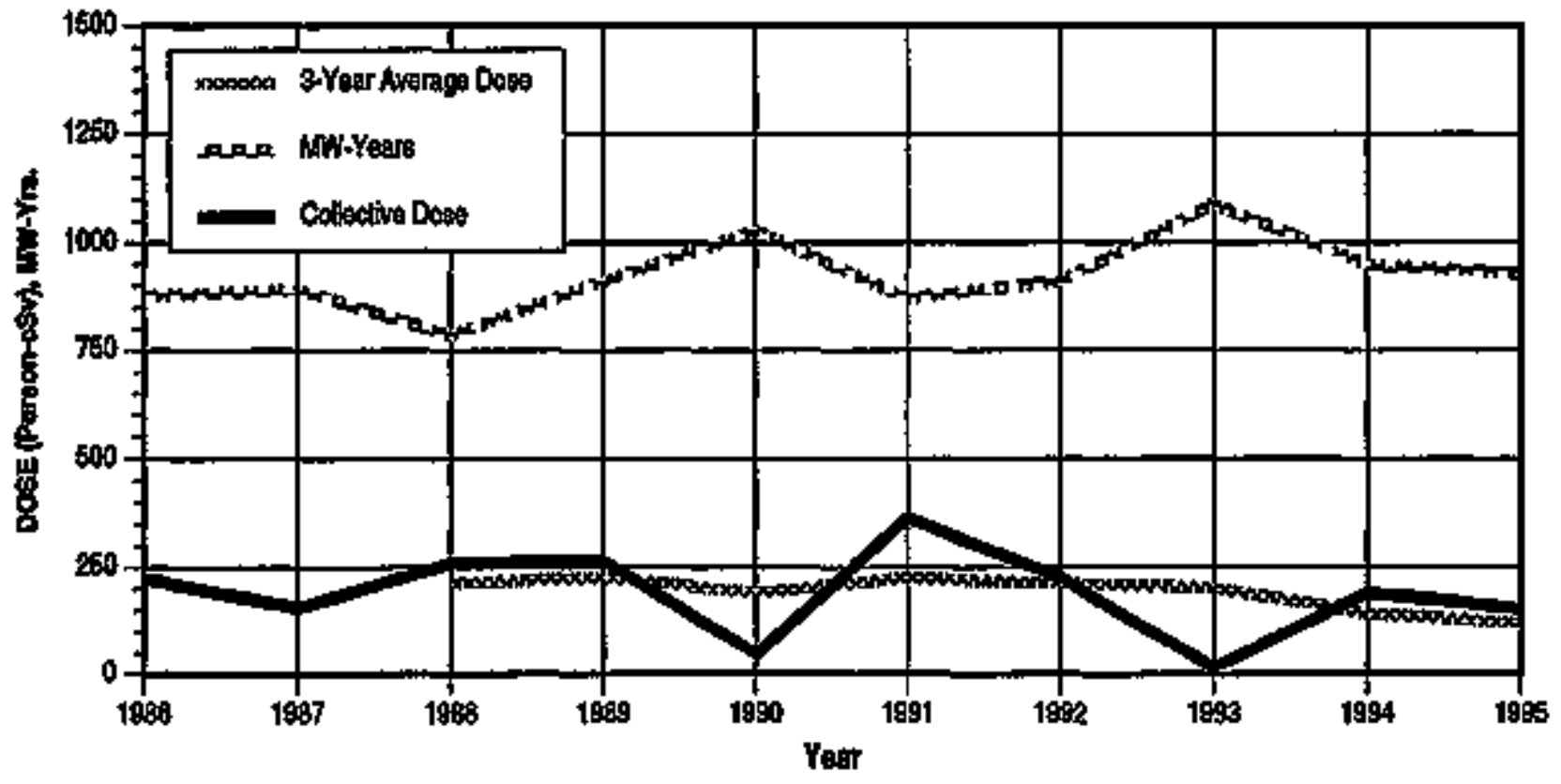

Breekstionn by Jab Function

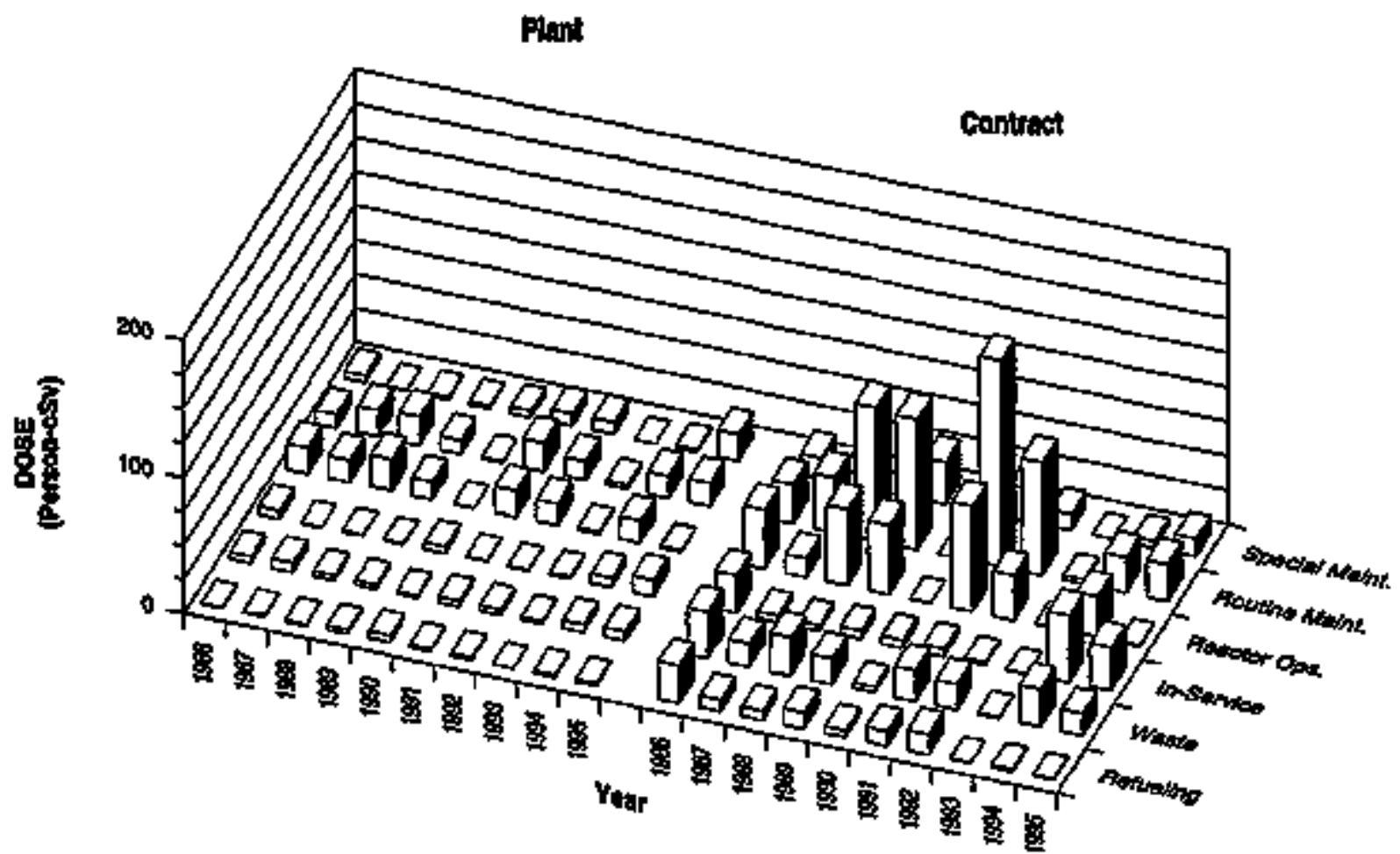

E-73

NUREG-0713 
APPENDIX E (continued)

WOLF CFEEK 1

Dase-Performence Inditalors

PWR

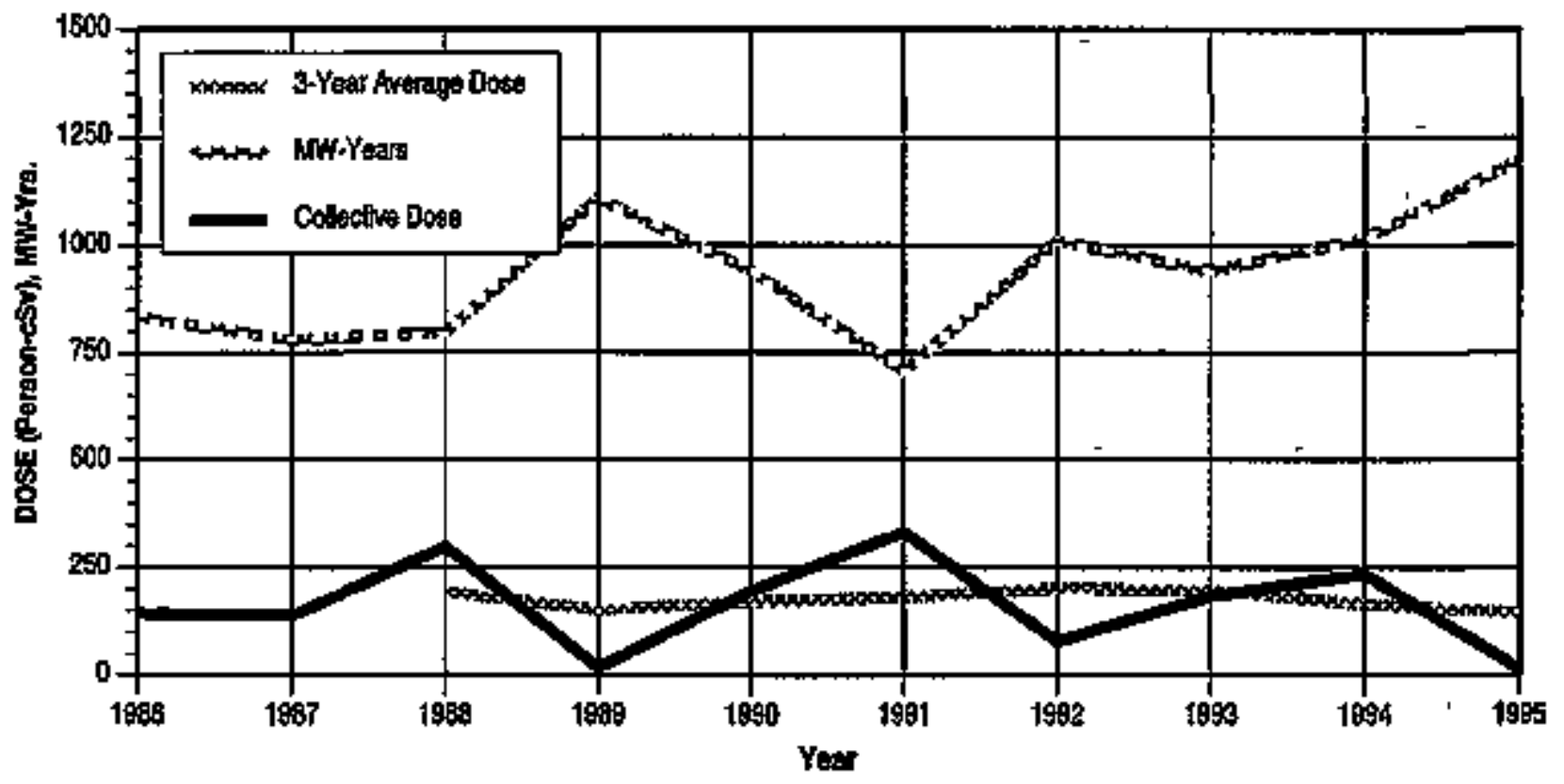

Breaktions by Job Function

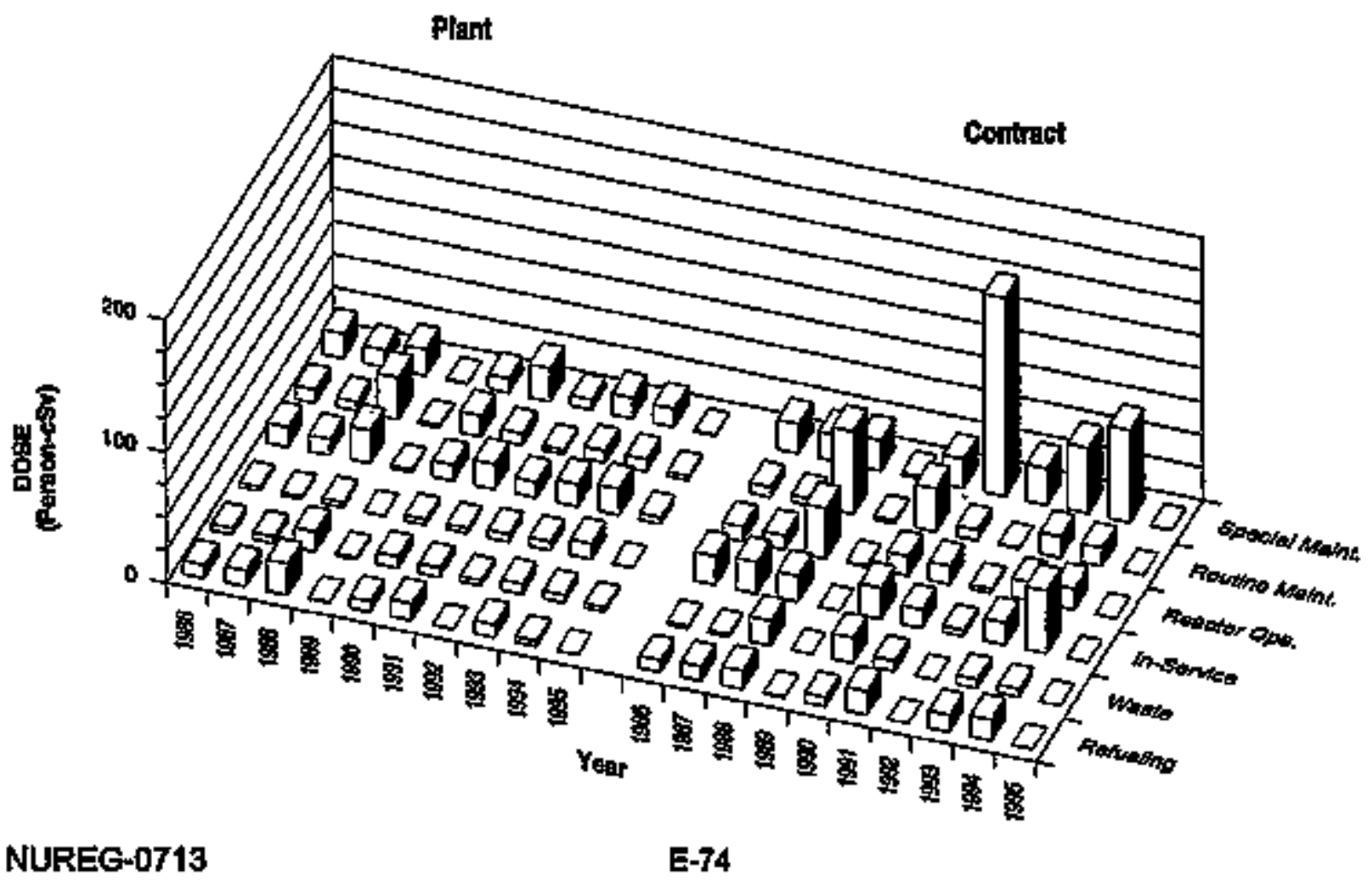




\section{APPENDIX E (continuod) \\ YANKEE-ROWE}

Dose-Pentomance Indicaltors

PWR

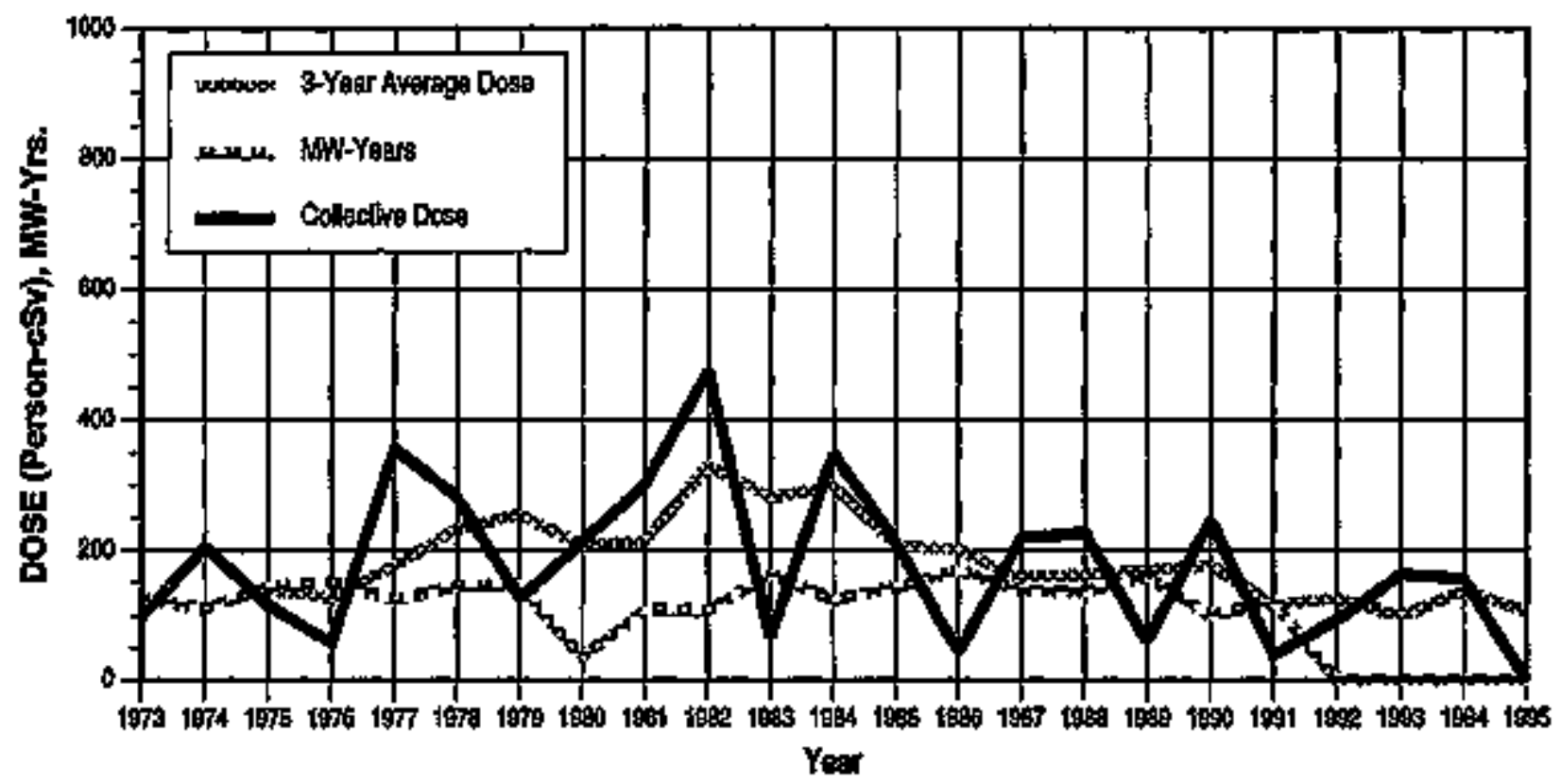

Brealustown by dab Function

Plant

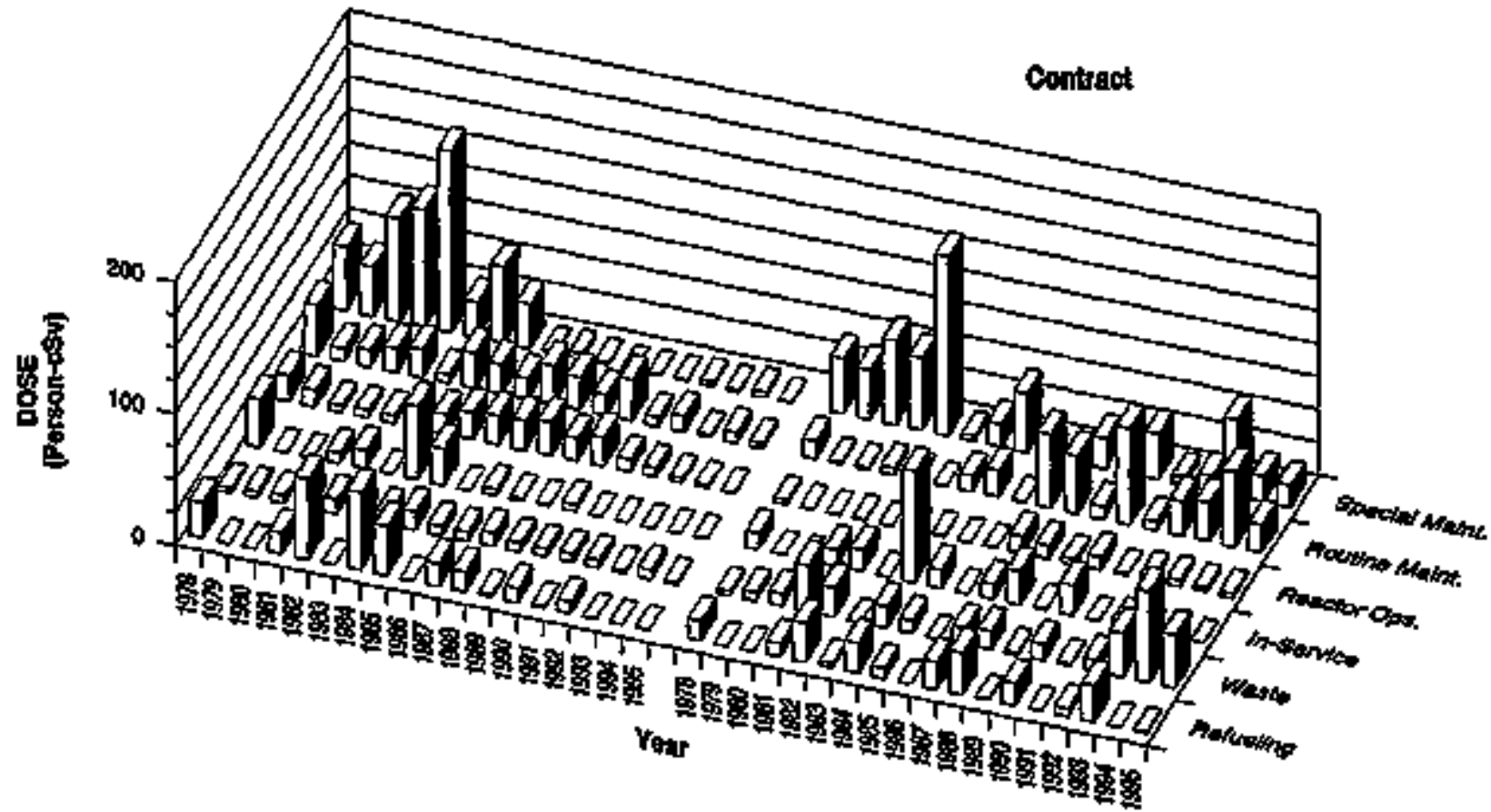


APPEKDIX E (continued)

ZiON 1,2

Dose-Perifomance Indicaters

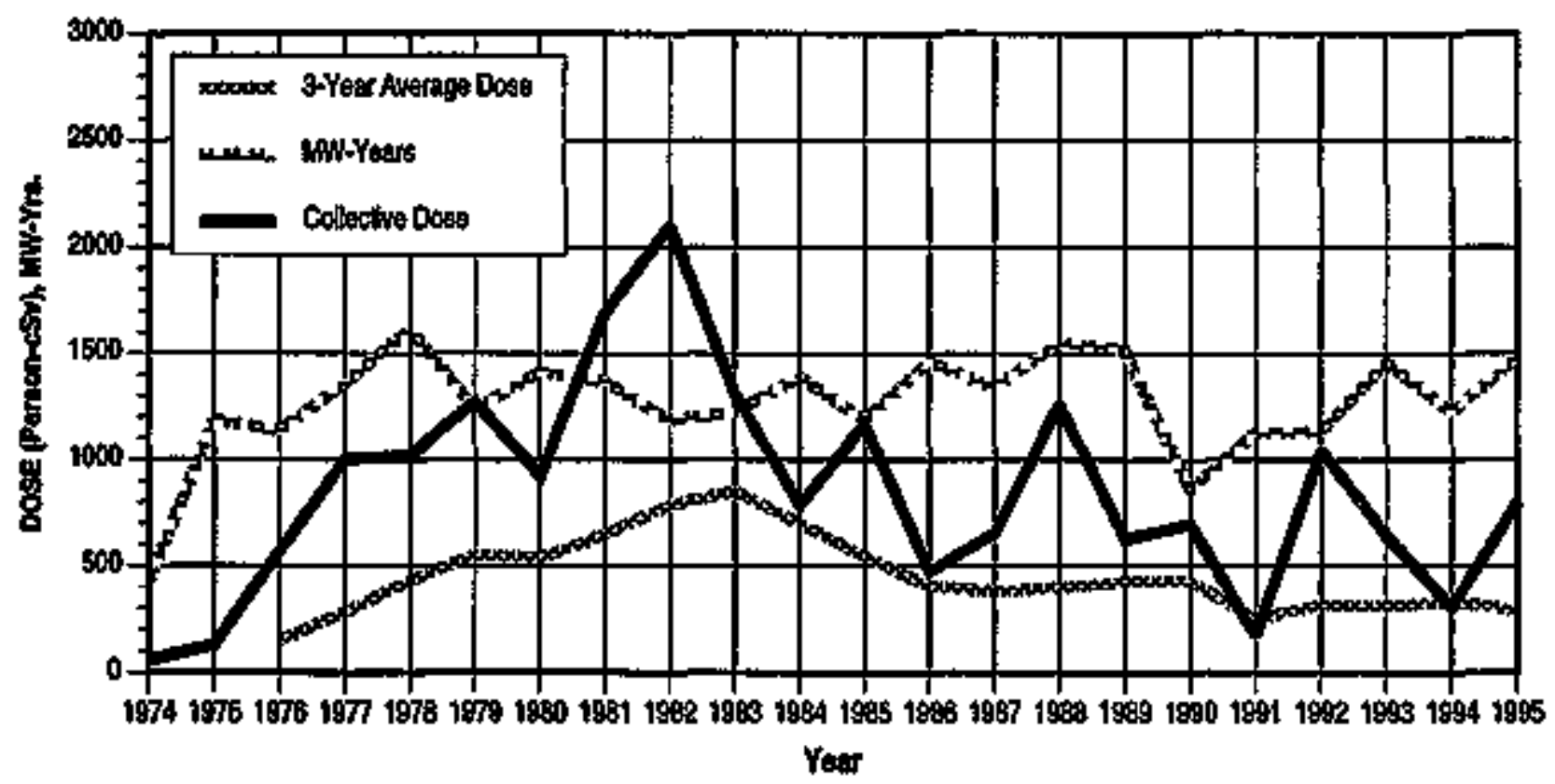

Breakdown by Job Function

Pink

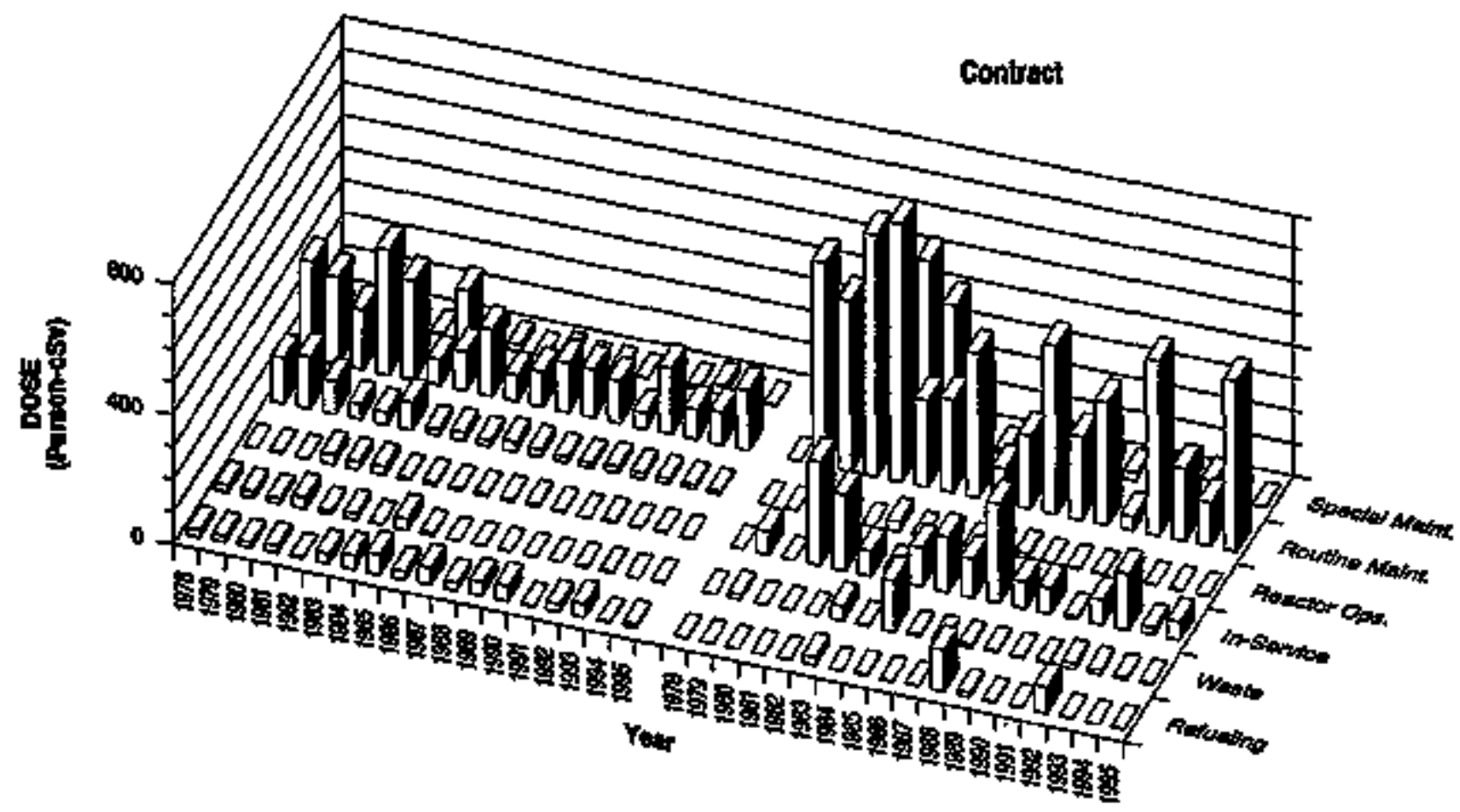




\section{APPENDIX $F$ \\ Stunmary of Annual Whole Body Dose Distributions by Year and Reactor Type \\ 1987-1985}




\section{APPENDIX F*}

\section{SUMMARY OF ANNUAL WHOLE BODY DOSE DISTRIBUTIONS BY YEAR AND REACTOR TYPE}

1987- 1995

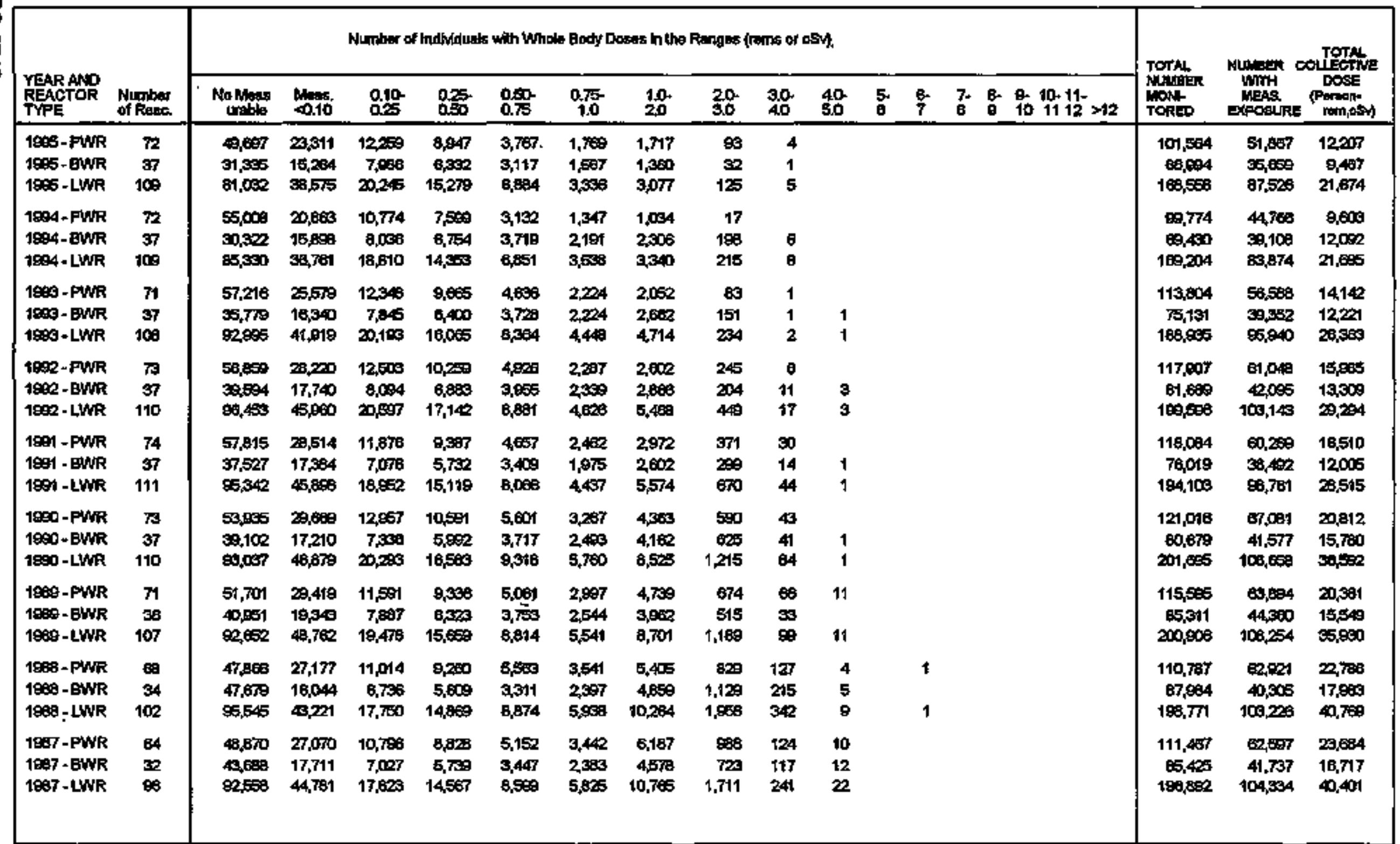

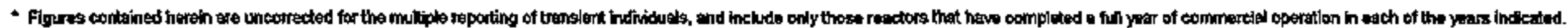




\section{TMLE ANO SLETML}

NUREG-0713, Volume 17

Oecupational Radtation Exposure at Commerical Nuctear Power Reactors and Othes Facilities 1995 .

Twenty-eighth Annual Report

\section{3.}

3. DATE REPOAT FU⿴LISHED

MCNIM

Jararary 1997

4. FIN OR GRANT GUNGER Wooge

5. AUTHOA(5)

6. TYPE OF REPORT

M.L' Thomas

D. Hagemeyer

Annual

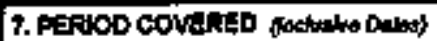

$01 / 01 / 95-12 / 31 / 95$

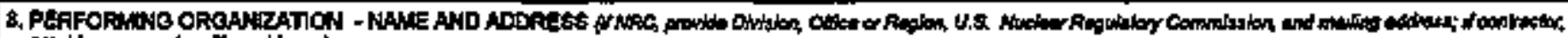

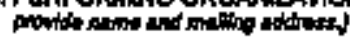

Dhision of Regulatory Applications *SAIC

Otilce of Nuclear Regulatory Applications 301 Laboratory Road U.S. Nuclear Regulatory Comrrission Oak Ridge, TN 37830 Washington, DC 2055s.0001

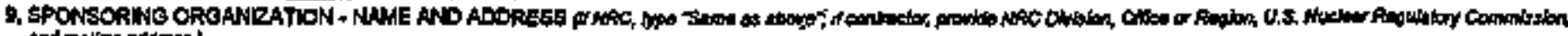
ind (nowis adidur)

Same as above

10, SUPPLAMFNARY NOTES

M.L. Thomas, NRC Project thanager

11. AESTRACT Z200 words aringy

This report summerizes the occupational exposure data that are maintained in the U.S. Nuclear Regulatory Cominission's Radiation Exposure Information and Reperting System (REIRS). The bulk of the information conteined in the repout was compiled thom the 1985 anneal reports subnitted by the classes of NRC ilcensees subject to the reporting requirements of 10 CFR 20.2206.

Anmual reports for 1995 ware received fiom a total of 294 NRC licensees, of which 109 wist aporators of nuclear power reactors In commercial operation. Campllations of the reports stubmitted by the 294 licensens indlcoted that 142,518 individuats were monitored, 76,822 of whom received a measurable dose. The collective dose incurred by these indlviduals wras 24,636 person-csv (person-rem) which replesents a 1\% decreese from the 1994 valug. The number of workers receiving a measurable dose also deareased, resulting in the average measurable dose of 0.32 cSv (rem) for 1995 . The everage measurable dose is defined to be the total collective dose divided by the number of workers feceiving a measturable dose. The figures have been adjusiled to accounk for transient reactor workers. In 1995, the annual collective tose per reactor for tight water reactor licensees was 19 person-sSv (person-rem). This is the samb value that was reported for 1994. The annual oollective dose per reactor for boiling water reactors was 256 person-c5v (person-rem) and, for pressurized water reactors it was 170 person-c5v (person-Fem). Analyses of translent worker data indicated that 17,153 individusts completed work assignments at two or more lioensebs during the moniforing year. The dose distributions are adjusted each year to account for the duplicate reporting of transient wotkers by multiple licensees. In 19g5, the average measurable dose calculated from reported data was 0.26 csv (rem). The corrected dose distribution resulted in an average measurable dose of $0.32 \mathrm{cSv}$ (rem).

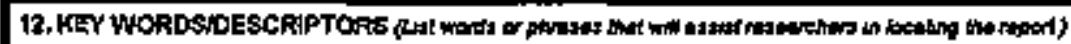

accupational

radiation expostire

nucloar

reactor

dose

transient

\begin{tabular}{|c|}
\hline 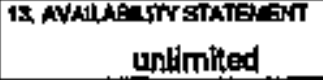 \\
\hline 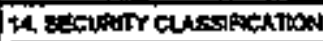 \\
\hline $\begin{array}{l}\text { (Ris Paph } \\
\text { unclassified }\end{array}$ \\
\hline $\begin{array}{l}\text { romk Rapors } \\
\text { Unxlasslined }\end{array}$ \\
\hline 15. NLTEER OF PAG \\
\hline 16. PRSCE \\
\hline
\end{tabular}

